
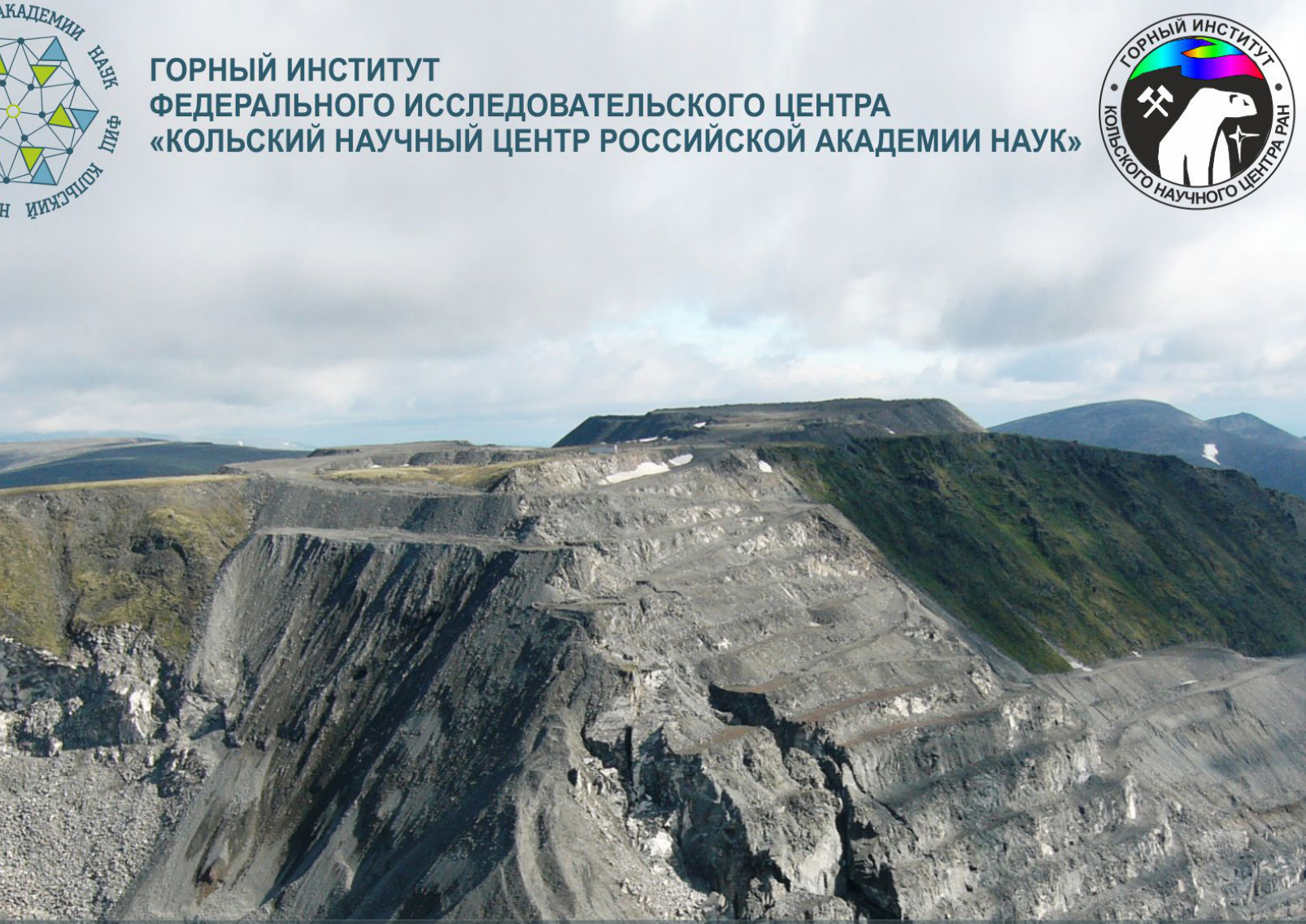

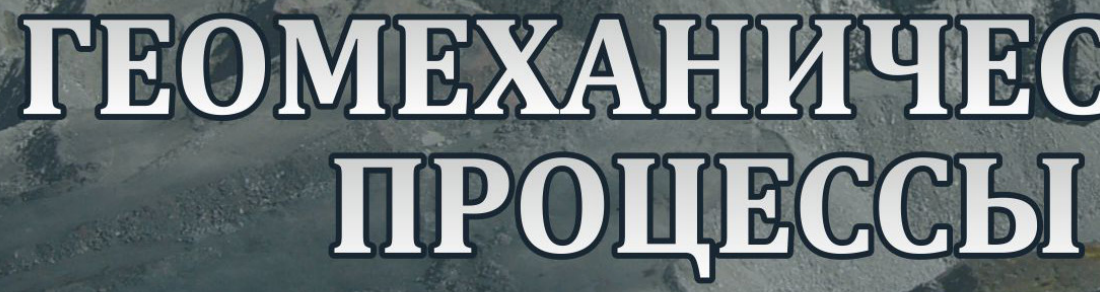 В ГЕОЛОГИЧЕСКОЙ СРЕДЕ ГОРНОТЕХНИЧЕСКИХ СИСТЕМ
} И УПРАВЛЕНИЕ ГЕОДИНАМИЧЕСКИМИ РИСКАМИ
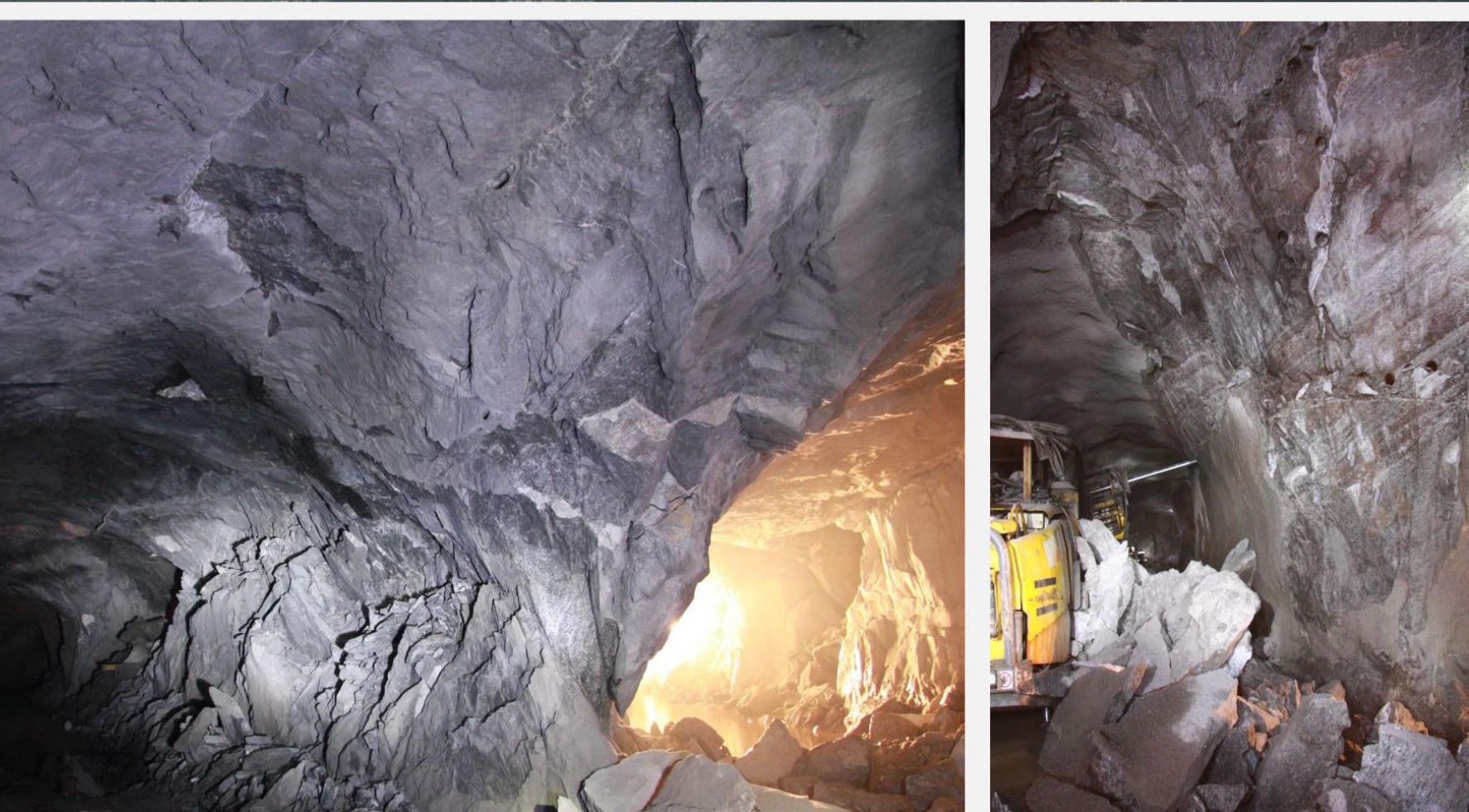
МИНИСТЕРСТВО НАУКИ И ВЫСШЕГО ОБРАЗОВАНИЯ РОССИЙСКОЙ ФЕДЕРАЦИИ

ФЕДЕРАЛЬНЫЙ ИССЛЕДОВАТЕЛЬСКИЙ ЦЕНТР

«КОЛЬСКИЙ НАУЧНЫЙ ЦЕНТР РОССИЙСКОЙ АКАДЕМИИ НАУК»

ГОРНЫЙ ИНСТИТУТ

\section{ГЕОМЕХАНИЧЕСКИЕ ПРОЦЕССЫ \\ В ГЕОЛОГИЧЕСКОЙ СРЕДЕ \\ ГОРНОТЕХНИЧЕСКИХ СИСТЕМ \\ И УПРАВЛЕНИЕ \\ ГЕОДИНАМИЧЕСКИМИ РИСКАМИ}


DOI: $10.37614 / 978.5 .91137 .391 .7$

УДК 622.831.1:550.34

ББК 33

Г35

Печатается по решению ученого совета Федерального исследовательского центра «Кольский научный центр Российской академии наук»

\section{Рецензенты:}

доктор технических наук, профессор Д. В. Яковлев;

доктор технических наук, профессор В.Л. Шкуратник

Геомеханические процессы в геологической среде горнотехнических систем и управление геодинамическими рисками: монография / А. А. Козырев, ГЗ5 С. Н. Савченко, В. И. Панин, И. Э. Семенова, В. В. Рыбин, Ю. В. Федотова, С. А. Козырев и др. - Апатиты: КНЦ РАН, 2019. - 431 с.: ил. ISBN 978-5-91137-391-7

В монографии отражены результаты аналитических и экспериментальных исследований закономерностей геомеханических процессов в геологической среде горнотехнических систем. Предложены объяснительные модели эволюции энергии в геологической среде в процессе ведения горных работ, показаны механизмы деформирования и разрушения пород в массиве с различными параметрами трещиноватости. Численным моделированием показана трансформация напряженного состояния массива пород, а также взаимодействие открытых и подземных технологий на примере Хибинских апатит-нефелиновых месторождений.

Достаточно подробно изложена методика геомеханического мониторинга геологической среды в горнотехнических системах, включающая в себя геодинамическое районирование, инструментальные определения параметров напряженного состояния пород в массиве, контроль деформаций методами традиционной и спутниковой геодезии, регистрацию сейсмической эмиссии в широком частотном диапозоне.

Разработана методология управления геодинамическими рисками при ведении горных работ в высоконапряженных массивах скальных пород, основанная на прогнозе и профилактике кризисной области, опасной по геодинамическим проявлениям горного давления, приведены примеры управления стратегическими, тактическими и оперативными рисками.

Монография может быть полезной специалистам по геомеханике и геофизике, сотрудникам научно-исследовательских и проектных организаций, инженерно-техническим работникам горнорудных предприятий, а также студентам старших курсов и аспирантам горных, инженерно-геологических и строительных специальностей.

УДК 622.831.1:550.34

ББК 33

Фото на обложке - Алексей Пантелеев

Научное издание

Редактор Е. Н. Еремеева

Технический редактор В. Ю. Жиганов

Подписано в печать 17.12.2019. Формат бумаги 70×108 1/16.

Усл. печ. л. 37.63. Заказ № 33. Тираж 500 экз.

ISBN 978-5-91137-391-7

(C Горный институт ФИЦ КНЦ РАН, 2019

(с) ФГБУН ФИЦ «Кольский научный центр

Российской академии наук», 2019 


\section{ОГЛАВЛЕНИЕ}

ВВЕДЕНИЕ

\section{1. ОБЩИЕ ЗАКОНОМЕРНОСТИ ЭВОЛЮЦИИ СЛОЖНЫХ}

1.1. Системные законы и закономерности в горнотехнических системах..........

1.2. Самоорганизация и организация геологической среды в геомеханических пространствах рудников

1.3. Техногенная сейсмичность как отражение эволюции напряженно-деформированного состояния геологической среды в горнорудной природно-технической системе.

1.4. Основные задачи математического и численного моделирования эволюции природных и техногенных полей напряжений в геологической среде

2. НЕЛИНЕЙНЫЕ ЭФФЕКТЫ В ПРОЦЕССАХ ДЕФОРМИРОВАНИЯ

И РАЗРУШЕНИЯ ГОРНЫХ ПОРОД

2.1. Эволюция двухпараметрической динамической системы.

2.2. Некоторые возможные варианты эволюции двухпараметрической динамической системы

2.3. Модель эволюции энергии в геологической среде природно-технических систем

2.4. Сейсмичность массива горных пород при ведении массовых взрывов.....

2.5. Влияние крупноблочного строения и рельефа на напряженное состояние Хибинского и Ловозерского массивов.

2.6. Изменение удельной энергии деформирования в процессе отработки блока-целика Кировский рудник - Саамский карьер в период с 2002 по 2015 годы

2.7. К вопросу о тектонических напряжениях в скальных массивах вблизи дневной поверхности.

8. Тектонические напряжения в Ловозерской интрузии....

2.9. Распределение горизонтальных тектонических напряжений в Ковдорском рудном районе

2.10. Напряженное состояние пород в окрестности трещины на границе раздела геологических блоков.

2.11. Напряженное состояние массива горных пород вблизи трещины, пересекающей границу раздела двух блоков

2.12. Напряженное состояние горных пород в окрестности радиальных ветвящихся трещин

2.13. Напряженное состояние массива пород при сдвижении блоков по шероховатой поверхности.

2.14. Наклонный разлом в гравитационно-тектоническом силовом поле...........

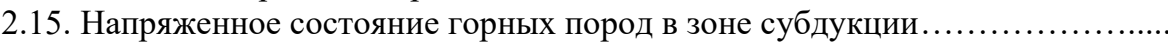

3. ТРАНСФОРМАЦИЯ НАПРЯЖЕННОГО СОСТОЯНИЯ МАССИВА

В РАЙОНЕ КРУПНОМАСШТАБНЫХ ГОРНЫХ РАБОТ.

3.1. Взаимовлияние открытых и подземных горных работ

(на примере Хибинских апатитовых месторождений).

3.1.1. Трансформация напряженного состояния массива при отработке комплекса сближенных месторождений Хибинской апатитовой дуги

3.1.2. Прогнозная оценка коэволюции напряженно-деформированного состояния восточной части апатитовой дуги при разработке месторождений «Олений ручей» и Ньоркпахкское. 
3.2. Воздействие подземной отработки подкарьерных запасов на устойчивость борта карьера в конечном положении (на примере Ковдорского местрождения)...

3.2.1. Разработка геомеханических моделей Большого Ковдора с учетом прочностных и упругих характеристик массива, его геолого-структурных особенностей и прогнозируемыхпараметров действующего поля напряжений

3.2.2. Результаты моделирования напряженно-деформированного состояния массива пород Ковдорского месторождения с помощью мелкомасштабной модели

. Напряженно-деформированное состояние массива пород

в окрестности фактической карьерной выемки.

. Напряженно-деформированное состояние массива пород

в окрестности проектной карьерной выемки до отметки $-660 \mathrm{M}$

3.2.5. Напряженно-деформированное состояние массива пород в окрестности выемки подкарьерных запасов подземным способом до отметки -760 м.

. Напряженно-деформированное состояние массива пород

в окрестности выемки подкарьерных запасов подземным способом до отметки -1200 м.

3.2.7. Напряженно-деформированное состояние массива пород при отработке запасов апатит-штаффелитов на юго-западе месторождения. ....

3.3. Динамика параметров разрушения горных выработок в зависимости от глубины и типа напряженно-деформированного состояния массива пород....

3.3.1. Описание расчетных вариантов....

3.3.2. Размеры зон разрушения вокруг горной выработки....................................

3.3.3. Анализ полученных результатов .................................... 149

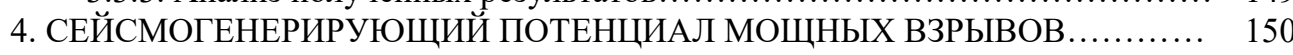

4.1. Закономерности проявлений техногенной сейсмичности и оценка сейсмоопасных участков при ведении горных работ на подземных рудниках Кировского филиала акционерного общества «Апатит».

4.1.1. Выявление закономерностей проявлений техногенной сейсмичности при производстве массовых взрывов на подземных рудниках.

4.1.2. Развитие методики и выявление закономерностей проявлений техногенной сейсмичности для определения сейсмоопасных участков и улучшения временной локализации периодов повышенного риска в различных зонах ведения крупномасштабных горных работ.

Выявление опасных состояний в массиве горных пород в различных

зонах ведения крупномасштабных горных работ за 2013-2015 годы.

4.1.4. Оценка проявления сейсмичности до и после проведения массовых взрывов.

4.2. Закономерности проявления техногенной сейсмичности при производстве массовых и технологических взрывов на апатитовых подземных рудниках

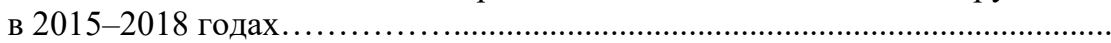

4.2.1. Проявление общей сейсмичности на подземных рудниках.................

4.3. Оценка выделяемой энергии при различных видах воздействия по кумулятивным кривым закаченной и выделенной энергии............... 182

4.3.1. При производстве массовых взрывов .................................. 182

4.3.2. При производстве торцевых взрывов ............................ 183

4.4. Выявление закономерностей проявлений техногенной сейсмичности для определения сейсмоопасных участков и улучшения временной локализации периодов повышенного риска в различных зонах ведения крупномасштабных горных работ. 
4.5. Использование теории динамических систем и недетерминированного хаоса для описания техногенного сейсмического процесса................... 4.5.1. Общие положения

4.6. Кинематические и динамические характеристики инициируемых массовыми взрывами колебаний в различных горно-геологических условиях.....

5. ГЕОМЕХАНИЧЕСКИЙ МОНИТОРИНГ ГЕОЛОГИЧЕСКОЙ СРЕДЫ ГОРНОТЕХНИЧЕСКИХ СИСТ

5.1. Уточнение понятийного аппарата геомеханического мониторинга

5.2. Современные представления о характерных особенностях и геомеханическом состоянии массива горных пород как среды функционирования горнотехнических систем....

3. Концепция единой комплексной системы геомеханического мониторинга геологической среды природно-техногенных и горнотехнических систем... 5.3.1. Методология и программное обеспечение совместного анализа разнородной геофизической и геомеханической информации.....

5.4. Геодинамическое районирование отрабатываемых месторождений

в Хибинском и Ковдорском массивах

5.4.1. Тектоника Кольского полуострова.

5.4.2. Реконструкция палеонапряжений по данным структурной нарушенности Хибинского и Ковдорского массивов.

5.4.2.1. Хибинский массив.

5.4.2.2. Ковдорский массив

5.4.3. Новая информация о современном напряженном состоянии геологической среды горнотехнических систем по данным натурных определений 5.4.3.1. Ковдорская горнотехническая система

5.4.3.2. Хибинская горнотехническая система

5.4.4. Индикаторы геодинамической активности основных разломов, их ранжирование и характер взаимодействия выделенных блоков, оценка их напряженного состояния

5.4.4.1. Факторы контроля геодинамической опасности.....................

5.4.4.2. Индикаторы геодинамической активности.

5.4.5. Карты (схемы) пострудного тектогенеза и геодинамическое районирование отрабатываемых и перспективных месторождений и горизонтов.

5.4.6. Электронные 3D-модели иерархично-блочного строения и геодинамического районирования отрабатываемых месторождений в координатных сетках рудников.

5.4.6.2. Ковдорская горнотехническая система.

5.5. Результаты экспериментальных исследований процессов деформирования геологической среды под влиянием природных и техногенных факторов....

5.5.1. Совершенствование методики выполнения и обработки результатов натурных измерений.

5.5.2. Объекты контроля на апатитовых рудниках и развитие существующих полигонов для измерений методами спутниковой геодезии, лазерной дальнометрии и прецизионного нивелирования.

5.5. Характер деформирования геологической среды в Хибинских горнотехническах системах

5.5.4. Наклономерно-деформометрический комплекс на Кировском руднике... 5.5.4.1. Архитектура комплекса.

5.5.4.2. Результаты контроля деформаций наклономерно-деформометрическим комплексом 
5.6. Изучение геомеханических процессов в геологической среде горнотехнических систем по параметрам сейсмической эмиссии

5.6.1. Современная сейсмологическая активность Фенноскандии и природно-техногенных систем центральной части Кольского полуострова 5.6.1.1. Текущий анализ сейсмической активности прородно-техногенных систем центральной части Кольского полуострова.

5.6.1.1.1. Сейсмическая сеть Кольского филиала федерального исследовательского центра «Единая геофизическая служба Российской академии наук» и ее регистрационные возможности.

5.6 .1 .1 .2 . Региональная сейсмичность тектонической и техногенной природы.

5.6.1.1.3. Сейсмичность в пределах Хибинской, Ловозерской, Ковдорской и Оленегорской горнотехнических систем в 1988-2014 годах.

5.6.2. Пространственно-временные закономерности эволюции параметров сейсмичности в геомеханическом пространстве апатитовых рудников...... 5.6.2.1. Месторождения «Апатитовый Цирк» и «Плато Расвумчорр»......... 5.6.2.2. Кукисвумчоррское месторождение................................ 5.6.2.3. Юкспорское месторождение.

5.6.3. Пространственно-временные закономерности кластеризации сейсмической эмиссии в Хибинских горнотехнических системах........ 5.6.3.1. Кукисвумчоррское месторождение.............................. 5.6.3.2. Юкспорское месторождение.

5.6.4. Влияние метеорологических факторов на процессы трещинообразования в массиве горных пород.

5.6.4.1. Месторождения «Апатитовый Цирк» и «Плато Расвумчорр»...

5.6.4.2. Кукисвумчоррское и Юкспорское месторождения.................

5.6.4.3. Методика комплексной оценки данных метео- и гидромониторинга для прогноза периодов повышенной сейсмической активности на апатитовых рудниках и реализация ее в виде программной системы 5.7. Методические подходы к оценке геодинамической ситуации в геологической среде в горнотехнической системе по параметрам сейсмической эмиссии...

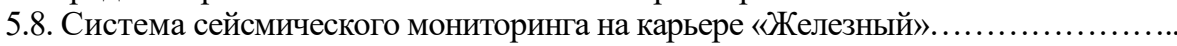

5.8.1. Предыстория и текущее состояние.................................

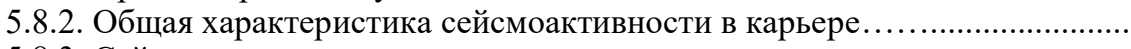

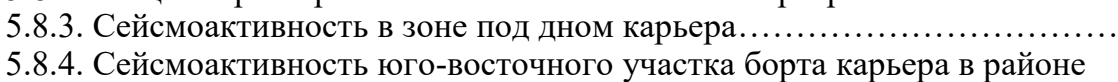
ослабленной зоны.

5.8.5. Оценка геомеханического состояния участка юго-восточного борта карьера по результатам сейсмического мониторинга.

5.8.6. Методические подходы к оценке устойчивости бортов карьеров по данным микросейсмического мониторинга.

\section{6. УПРАВЛЕНИЕ ГЕОДИНАМИЧЕСКИМИ РИСКАМИ В ГОРНОТЕХНИЧЕСКИХ}

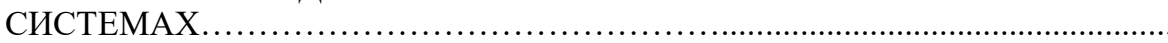

6.1. Основные понятия и терминология в управлении геодинамическими рисками в горнотехнических системах................................ 327

6.2. Классификация и количественная оценка рисков......................... 330

6.3. Оценка уровня геодинамической безопасности на апатитовых рудниках...... 333

6.4. Основные принципы управления геодинамическими рисками в геологической среде горнотехнических систем.

6.5. Управление стратегическими геодинамическими рисками.................... 339

6.5.1. Закономерности динамики параметров геомеханического состояния массива пород по данным численного моделирования при отработке запасов на апатитовых рудниках. 
6.5.1.1. Особенности формирования поля напряжений на глубоких горизонтах Кукисвумчоррского месторождения при применении систем разработки с этажным и подэтажным обрушением руды (на примере блока 7-10 горизонта +170 м).

6.5.1.2. Оценка устойчивости элементов геотехнологии при различных вариантах систем с принудительным обрушением руды....

6.5.1.3. Геомеханическая ситуация в стыковочной зоне между подземными горными работами Расвумчоррского рудника и Центральным карьером.

6.5.1.4. Обеспечение безопасной отработки блока-целика горизонтов +530 и +470 м при приближении подземных горных работ к Центральному карьеру.

6.5.2. Управление геодинамическими рисками на месторождении «Олений ручей»

6.5.2.1. Прогноз напряженно-деформированного состояния при выемке верхней части подземных запасов по данным численного моделирования.

$$
\text { моделирования..... }
$$

6.5.2.2. Управление геодинамическими рисками в процессе развития подземных работ.

6.5.2.2.1. Геомеханическое обоснование размеров камер и целиков...

6.5.2.2.2. Оценка необходимых параметров обнажений для перехода к системе с обрушением подработанных пород.

6.5.2.2.3. Оценка вероятности обрушения налегающей толщи до поверхности.

6.5.2.2.4. Прогноз устойчивости выработок в процессе отработки запасов в отметках $+180-0$ м.

6.5.2.2.5. Определение оптимальных параметров набрызг-бетонной крепи.

6.5.2.3. Предрасчет зоны обрушения и сдвижения при отработке запасов перспективного месторождения «Эвеслогчорр»

6.5.3. Управление тактическими рисками на основе экспертных систем выбора оптимальных технических решений по обеспечению геодинамической безопасности.

6.5.3.1. Развитие методических подходов экспертной оценки геомеханического состояния массива горных пород.

6.5.3.2. Разработка и совершенствование геомеханических моделей месторождений и актуальных участков..

6.5.4. Управление оперативными рисками.................................. 386

6.5.4.1. Результаты расчета рейтинга RL юго-восточной части месторождения «Олений Ручей».

6.5.4.2. Оценка геомеханического состояния массива пород месторождений Мурманской области методом рейтинговых классификаций с учетом новых данных.....

6.5.5. Управление рисками при открытой геотехнологии...................

6.5.5.1. Методика расчета и результаты оценки устойчивости борта карьера «Железный» с учетом инженерно-геологических особенностей массива горных пород.

6.5.5.2. Оценка устойчивости участка борта Оленегорского карьера со стороны лежачего бока рудного тела.

6.5.5.3. Подходы к оценке устойчивости борта и уступов карьера «Олений ручей».

6.5.5.4. Развитие комплексной методики прогноза устойчивости бортов карьеров. 


\section{ВВЕДЕНИЕ}

Важное значение горнодобывающей промышленности как огромной отрасли народного хозяйства, связанного с добычей и переработкой минерального сырья, сохранится на ближайшие десятилетия. При этом, несмотря на значительный прогресс в технологии и технике разработки месторождений, по своему воздействию на природу оно является наиболее масштабным и агрессивным [1]. «Горнодобывающая промышленность жестко воздействует на природную среду...» [2]. Возрастающие потребности в различных видах минерального сырья приводят к углублению горных работ на эксплуатируемых месторождениях и вовлечению в разработку месторождений, неблагоприятных по климатическим или горно-геологическим условиям, а снижение бортового содержания полезных компонентов обусловливает рост объемов извлекаемой и перемещаемой горной массы. Все это приводит к нарушению геодинамического режима геофизической среды, что влечет за собой снижение технико-экономической эффективности и безопасности горных работ. Под геофизической средой здесь понимается любая композиция твердых, жидких и газообразных тел, взаимодействующих между собой при механическом движении в силовых полях Земли. В этих условиях возрастает роль геомеханики как науки о прочности, устойчивости и деформируемости массивов горных пород, горнотехнических объектов и сооружений в поле природных и техногенных воздействий.

Ухудшение горно-геологических условий ведения горных работ вызывает и усложнение геомеханических задач. Эволюцию геомеханических исследований для обеспечения безопасной и эффективной разработки месторождений полезных ископаемых можно проиллюстрировать несколькими монографиями Горного института Кольского научного центра Российской академии наук (ГоИ КНЦ РАН) [3].

В начале 1960-х гг. при отработке Хибинских апатитонефелиновых и Ловозерских редкометалльных месторождений на сравнительно малых глубинах (200-300 м) стали активно проявляться динамические формы горного давления в виде «стреляния» пород, интенсивного заколообразования и отдельных горных ударов. Под руководством чл.-корр. АН СССР И. А. Турчанинова были организованы и проведены теоретические и экспериментальные исследования на стыке основных наук о Земле: геомеханики, тектоники, сейсмологии и горного дела, в результате которых получили развитие методика и техника изучения напряженного состояния массивов горных пород, полагалаясь на идеи М. В. Гзовского [4], была предложена и обоснована гипотеза о действии в массиве тектонических субгоризонтальных напряжений, значительно превышающих напряжения от веса вышележащей толщи пород. Полученные результаты позволили сформулировать новые представления о природе и закономерностях распространения тектонических напряжений в верхней части земной коры, которые в дальнейшем прошли апробацию в других отечественных и зарубежных научных школах. Новые концепции и модели напряженно-деформированного состояния пород в массиве имели большую практическую ценность, поскольку позволили разработать нетрадиционные подходы к обеспечению устойчивости горных выработок и конструктивных элементов систем разработки, что нашло отражение в монографиях [5-7]. В 1984 г. опубликована монография [8], в которой приведена концепция формирования напряженного состояния пород в массиве под влиянием тектонических процессов в верхней части земной коры, а также дан ряд аналитических решений и описаний напряженного состояния массива для некоторых условий залегания пород при гористом рельефе. 
В настоящее время действие тектонических напряжений установлено во многих районах мира, особенно в тектонически активных регионах [9].

После опубликования упомянутых монографий исследования по геомеханическому обеспечению разработки месторождений Кольского полуострова продолжались, актуальность их подтверждалась большими объемами горных работ и активизацией геодинамических процессов в рудниках. Были получены новые знания о закономерностях формирования напряженно-деформированного состояния пород в массиве: изучено влияние ряда естественных и техногенных факторов на распределение напряжений, проведено ранжирование полей напряжений, выявлены потенциально опасные элементы конструкций горных выработок и систем разработки, предложены нетривиальные представления об условиях реализации горных ударов и техногенных землетрясений в тектонически напряженных массивах и разработаны методы их прогноза и профилактики. Все эти результаты изложены в двухтомной монографии [10].

Между тем проблема техногенной сейсмичности при разработке месторождений полезных ископаемых продолжала обостряться и стала актуальной для многих стран с развитой горнодобывающей промышленностью, о чем свидетельствуют материалы нескольких международных конференций. При этом стало очевидным, что наиболее продуктивным методом исследования этой проблемы является метод системного синергетического анализа эволюции сложных открытых нелинейных систем, a, следовательно, развития опасных природных и техноприродных процессов. Результаты такого изучения техногенной сейсмичности в горнорудных природно-технических системах (ПТС) приведены в опубликованной в 2002 г. монографии [11].

C позиций синергетики рассмотрены общие закономерности эволюции ПТС. На основе изучения процессов энергообмена в геологической среде предложена модель реализации катастрофы в ПТС при горных работах. Разработаны методические положения прогноза критических состояний в геологической среде ПТС, чреватых мощными динамическими явлениями в рудниках.

По данным численного моделирования и экспериментальных определений напряжений в массиве пород построена карта напряжений на территории Кольского полуострова, на которой выделены наиболее энергонасыщенные зоны, удовлетворительно согласующиеся с палео- и современной сейсмичностью. По результатам геодинамического мониторинга геологической среды в ПТС установлены взаимосвязи некоторых параметров сейсмичности и деформирования пород в массиве с процессами подготовки и реализации сильных динамических явлений в рудниках.

Показано влияние мощных технологических взрывов на процессы деформирования блочной геологической среды и сейсмический режим в рудниках. Определены предвестники сильных геодинамических явлений, инициированных массовыми взрывами, а также предложены способы оптимизации параметров взрывной отбойки для снижения сейсмической опасности.

Численным моделированием и экспериментальными исследованиями в рудниках выполнена оценка напряженно-деформированного состояния стыковочных зон между подземными и открытыми горными работами, на основе которой разработаны методические рекомендации по оптимальному порядку отработки стыковочных зон между подземными рудниками и карьерами, устраняющие или существенно снижающие вероятность реализации мощных динамических явлений типа горных ударов или техногенных землетрясений. 
И все-таки решение проблемы техногенной сейсмичности при разработке месторождений полезных ископаемых остается незавершенным, что подтверждается материалами международного совещания по техногенной сейсмичности в апреле 2004 г. в г. Кировске [12], а также материалами международных симпозиумов по горным ударам и шахтной сейсмичности, например, в 2005 г. в Австралии [13] и в 2013 г. в России [14].

Необходимо отметить, что состояние проблемы техногенной сейсмичности теснейшим образом связано с состоянием проблемы сейсмичности природной (тектонической), где в последние годы четко обозначился кризис, обусловленный нерешенностью вопросов средне- и краткосрочного прогноза землетрясений. «К сожалению, в настоящее время уровень развития науки пока не позволяет решить проблему краткосрочного и оперативного прогноза землетрясений, что дало бы возможность своевременного предупреждения людей о сейсмической опасности и осуществления эвакуации населения, прежде всего, из несейсмостойких зданий. Некоторые страны (например, США) вообще отказались от ее решения, хотя, с нашей точки зрения, эти исследования необходимо продолжать» [15]. Трудности надежного краткосрочного прогноза землетрясений объясняются крайне сложной природой сейсмического процесса [16]. «Число опробованных предвестников уже перевалило за 1000. Из них более 140 зарегистрированы как открытия, а примеров удачного оперативного прогноза землетрясений фактически нет» [17]. Поэтому «постепенно во всем мире работы по прогнозу землетрясений свертываются, прекращается финансирование как теоретических исследований, так и наблюдений на геодинамических полигонах, а высвобождающиеся научные силы переключаются на более надежные работы по оценке сейсмического риска и сейсмического районирования, что ставит своей конечной целью определение, с каким запасом прочности надо строить сооружения в сейсмоактивных районах» [18]. Апогеем этого кризиса стало признание Международной комиссии в составе десяти экспертов из разных стран, созданной по просьбе и поддержке Правительства Италии после разрушительного землетрясения 6 апреля 2009 г. в Л'Акуиле, в том, «...что из-за сложности самого процесса подготовки землетрясения и недостаточности наших знаний об этом процессе высоконадежный прогноз (будет землетрясение или не будет) в обозримом времени не достижим» [19]. Одной из фундаментальных причин, накладывающих ограничения на возможность краткосрочных прогнозов как естественных, так и техногенных землетрясений является то, что геологическая среда представляет собой открытую нелинейную диссипативную систему, в которой, при условии притока энергии, постоянно идут процессы трансформации в условиях динамического равновесия с образованием новых структур и диссипацией энергии [20-22]. При этом энергия внешних воздействий может быть на несколько порядков меньше самого динамического явления, то есть момент и место реализации этого явления определяется триггерами, которых в геологической среде горнотехнической системы может быть достаточно много [22].

Другим важным фактором является то, что в сейсмологии убедительно доказано, что большинство вариаций параметров геофизических полей, принимавшихся за предвестники землетрясений, не порождено в очаге землетрясения, а обусловлено метеорологическими, космическими и другими факторами, имеет мозаичное распределение на больших территориях и не указывает на местоположение очага. «При разнообразии триггеров неизбежны как ложные тревоги, так и пропуски некоторых разрушительных землетрясений. В этих условиях ни в одной стране мира краткосрочные прогнозы не строятся 
на регулярной основе» [22]. Поэтому одной из самых насущных задач в проблеме прогноза землетрясений является изучение возможных триггеров и механизмов их влияния на сейсмоактивные разломы [23].

Таким образом, на современном этапе развития сейсмического прогноза предпочтение должно быть отдано определению участков, где наиболее вероятно проявление сильных сейсмических событий, хотя задача пространственно-временного прогноза этих событий также должна оставаться в числе приоритетных направлений соответствующих исследований [24-26]. Аналогичная ситуация складывается и в решении проблемы горных ударов и техногенных землетрясений. Кстати, материалы упомянутых международных симпозиумов вышли под общим названием «Управление сейсмическим риском» (Controlling Seismic Risk).

Подобные подходы к оценке геодинамической опасности в рудниках разрабатываются в Горном институте КНЦ РАН. На основе моделей эволюции сложных нелинейных систем предлагается сосредоточить основное внимание не на пространственно-временном прогнозе каждого мощного динамического события, в том числе и горного удара, а на оценке пороговых значений параметров эволюции напряженно-деформированного состояния (НДС) геологической среды в ПТС, определяющих адаптационные возможности среды и уровень геодинамической опасности [27]. На основе результатов многолетних исследований вопросов прогноза и профилактики горных ударов предложена методология управления геодинамическими рисками при ведении горных работ в высоконапряженных массивах скальных пород, отличающаяся тем, что осуществляется прогноз и профилактика не отдельного динамического события, а кризисной области, опасной по динамическим явлениям типа горных ударов и техногенных землетрясений, что позволяет сделать более надежным геодинамический прогноз и существенно повысить безопасность горных работ. Этой методологии и посвящена настоящая монография, являющаяся логическим продолжением монографии [11].

Результаты проведенных исследований показывают, что техногенная сейсмичность является отражением процессов самоорганизации геологической среды в природно-технических системах, в то время как сейсмичность природная (тектоническая) характеризует эволюционные процессы в земной коре. Эволюция любого фрагмента природной и природно-технической системы сопровождается рядом больших и малых катастроф, а каждая катастрофа является следствием разрушения старых подсистем (структур) и возникновения новых.

Таким образом, процессы структурной перестройки в геологической среде проявляются в виде сейсмичности, энергетический спектр которой определяется энергией эволюционных процессов. Отсюда следует и большое значение знания о поведении блочно-иерархической геологической среды, которая «...не только арена, на которой разворачиваются геодинамические процессы, но и активный участник этих процессов» [28]. Поэтому продолжены аналитические исследования напряженно-деформированного состояния иерархично-блочной геологической среды, установлены и обоснованы закономерности, описывающие эволюцию ее НДС в горнотехнической системе с учетом прямых и обратных связей, а также кооперативных эффектов, позволяющих проследить развитие среды до момента катастрофы.

Поскольку сейсмичность неразрывно связана со всеми геомеханическими процессами в геологической среде, продолжены исследования параметров сейсмической эмиссии в природно-техногенной системе «Хибины», показана их тесная взаимосвязь с видимыми проявлениями горного давления 
и продемонстрированы прогностические параметры, отражающие характер напряженного состояния контролируемых участков пород в массиве.

Впервые в России на карьере «Железный» АО «Ковдорский ГОК» обоснована и реализована система сейсмического контроля устойчивости его бортов в режиме реального времени, позволяющая на основе анализа пространственно-временного распределения сейсмических событий в геомеханическом пространстве карьера прогнозировать местоположение опасных сдвиговых деформаций и оценивать геодинамический риск.

Разработана система анализа сейсмических сигналов для геодинамического мониторинга геологической среды в горнотехнических системах, обладающая значительными преимуществами по сравнению с существующими аналогами по способам визуализации, обработки и хранения сейсмологической информации.

Поскольку наиболее наблюдаемыми отражениями геомеханических процессов в геологической среде горнотехнических систем являются деформации, продолжены наблюдения за техногенным деформированием в геомеханическом пространстве апатитовых рудников и Ковдорского карьера методами традиционной и спутниковой геодезии. Разработаны теоретические основы деформационного мониторинга блочной среды и сформулированы основные принципы расположения наблюдательных сетей на дневной поверхности и в горных выработках.

Так как геологическая среда является главным субъектом всех геомеханических процессов и основным объектом изучения, представляется целесообразным привести некоторые замечания, касающиеся некоторых непреложных истин, но не нашедших до настоящего времени четких определений.

Во-первых, геологическая среда постоянно находится в условиях механического стресса, как об этом упомянуто в монографии [29]. «Можно полагать, что в коре всестороннее обжатие (скалярная величина) обеспечивает упрочнение минеральной среды и условия, требующие приложения больших усилий для нарушения ее равновесия (деформации). А главным фактором преобразования геосистем в тектонически активных областях является механическая энергия ориентированного давления, или напряжение механического стресса. Малые значения стресса не нарушают состояния равновесия, а превышающие пределы устойчивости определяют характер деформаций и взаимодействий. Эта энергия структурирует среду по принципу принудительности с элементами адаптивности» [29]. Таким образом, механический стресс, то есть напряжения, определяют энергонасыщенность геологической среды [30] и являются основным фактором всевозможных трансформаций в геологической среде в природно-техногенных и горнотехнических системах, что и определяет наше первостепенное внимание вопросам изучения закономерностей напряженного состояния геологической среды ПТС.

Представляется интересным провести некоторую аналогию с широким употреблением термина «стресс» в живых организмах, впервые введенным в медицинскую практику известным канадским ученым Гансом Селье. «Тогда мы в первый раз употребили слово «стресс» в его теперешнем значении, то есть для обозначения состояния неспецифического напряжения в живом организме, проявляющегося в реальных морфологических изменениях в различных органах...» [31]. Проявление стресса в живом организме во временном развитии включает три четких стадии: реакцию тревоги, стадию резистентности и стадию истощения. С позиций универсального эволюционизма академика Н. Н. Моисеева [32] эволюция напряженного состояния в геологической среде природно-техногенных систем также проходит в три стадии: стадия адаптации, стадия изменчивости и стадия отбора 
(бифуркации) [33]. Как в живых организмах, так и в геологической среде опасен не сам стресс, а его уровень, который является основным фактором развития как живой, так и неживой, косной материи, что является еще одним свидетельством некоторой общности законов эволюции материального мира в целом. «Природа использует стресс, чтобы призвать к выживанию самых мудрых и способных к адаптации» [34]. Поэтому при решении всех геомеханических задач первостепенное значение всегда уделяется изучению всех аспектов НДС геологической среды.

Однако, прежде чем перейти к вопросам изучения НДС, необходимо уделить внимание фундаментальному свойству геологической среды - eе иерархично-блочному строению, особенно в массивах скальных пород. Поэтому в первую очередь в монографии рассмотрены вопросы детального структурного картирования тектонических зон и блоков, уделено внимание выявлению и прослеживанию, в пределах изучаемых массивов, пород основных структурных неоднородностей; исследованию кинематических признаков разрывных нарушений; обоснованию индикаторов активности выделенных разломов; ранжированию и оценке их напряженного состояния; построению карт пострудного тектогенеза и геодинамического районирования разрабатываемых и перспективных месторождений; созданию и пополнению электронных 3D-моделей основных структур, блочного строения и геодинамического районирования $\mathrm{c}$ использованием координатной сетки рудников, предусматривающих возможность в интерактивном режиме вносить необходимые изменения по мере накопления и получения новой информации.

При исследовании напряженно-деформированного состояния геологической среды широко используется математическое и численное моделирование, результаты которого верифицируются материалами натурных определений различными методами. Прежде чем обсуждать задачи и результаты моделирования, представляется целесообразным сделать некоторые замечания.

Самая совершенная модель никогда не сможет учесть все особенности реального объекта, и тем не менее моделирование давно и успешно применяют во многих областях науки и техники, а также в обыденной жизни, потому что, получаемые при этом даже качественные результаты могут представлять неоценимое значение. Для подтверждения этого положения достаточно и полезно сослаться на мнения известных российских ученых академиков В. И. Арнольда и Ю. Н. Работнова.

«Теория доставляет также количественные модели, но качественные выводы представляются более важными и в то же время более надежными: они мало зависят от деталей функционирования системы, устройство которой и численные параметры могут быть недостаточно известными...». Не требуется, однако, специальной математической теории, чтобы понять, что пренебрежение законами природы и общества (будь то закон тяготения, закон стоимости или необходимость обратной связи) падение компетентности специалистов и отсутствие личной ответственности за принимаемые решения приводят рано или поздно к катастрофе» [35].

«Поверхностное понимание физики процесса весьма полезно и необходимо для конструирования механических моделей и для выбора предположительной структуры определяющих уравнений, вопрос об их аналитической форме второстепенен и сводится к вопросу о выборе наилучшей в том или ином смысле аппроксимации. Углубленное понимание может быть даже опасно, поскольку истина в последней инстанции неизвестна, а фиксация внимания на деталях может отвлечь механика от сути дела. Исторический опыт убеждает нас в том, что лучшие 
достижения механики связаны с довольно грубыми моделями, которые описывают явления с той степенью приближения, которая разумна и необходима» [36].

В настоящей монографии приведены объяснительные и прогностические модели эволюции и динамики энергетического состояния иерархично-блочной геологической среды по мере развития горных работ, способствующие пониманию процессов формирования напряженного состояния геологической среды в различных условиях. Также выполнена оценка взаимодействия крупномасштабных открытых и подземных горных работ, необходимая для прогноза геомеханической ситуации в сложных горнотехнических условиях.

Как уже упоминалось выше, одним из основных геомеханических процессов в геологической среде природно-техногенных систем является самоорганизация, представляющая собой чередование стадий концентрации и релаксации напряжений с образованием новых «диссипативных» структур, конечной целью которой, является достижение динамического равновесия. Визуализация этих процессов находит отражение в параметрах деформирования и сейсмической эмиссии, результаты экспериментальных исследований которых приведены в настоящей монографии.

Поскольку геологическая среда в горнотехнической системе находится в состоянии динамического равновесия, то большое значение в этой ситуации имеют триггерные эффекты, наибольшее значение среди которых имеют мощные технологические взрывы при очистных работах. Поэтому вопросам поствзрывной сейсмики посвящена отдельная глава.

Поскольку динамическое равновесие достигается чередованием стадий концентрации и релаксации напряжений, а в крепких скальных породах релаксация происходит или проскальзыванием по границам блоков, или в виде хрупкого разрушения, энергия которого определяется размерами вовлекаемых в этот процесс блоков, то в геологической среде природно-техногенных систем всегда имеют место динамические явления различного энергетического уровня от акустического шума (микросейсмики) до горных ударов и техногенных землетрясений, то есть в геологической среде природно-техногенных, особенно горнотехнических систем, всегда присутствует геодинамический риск. Кстати, риск - это второе после стресса состояние, которое всегда присутствует как в живых, так и в «неживых» технических системах, поскольку «полная безопасность со времен первородного греха в принципе не достижима, и уже с тех пор можно, по крайней мере, выбирать между добром и злом, несмотря на сложность каждый раз верно идентифицировать их» [37].

«...Риск пронизывает все стороны нашей жизни: семейные отношения и состояние здоровья, полеты на самолете и пребывание в загрязненной окружающей среде.... Риск связан с наиболее сложными аспектами психологии, математики и истории. Литература о нем оказалась необозримой» [38].

В настоящее время по проблеме риска действительно имеется обширная отечественная и зарубежная литература, в Российской Федерации создано «Российское научное общество анализа риска», издается специальный журнал «Проблемы анализа риска». Разработаны и действуют ряд стандартов по оценке риска в промышленности, о некоторых из которых будет упомянуто далее. С 1991 г. Научный совет РАН по проблеме геоэкологии, инженерной геологии и гидрогеологии совместно с МЧС России регулярно раз в три года проводит конференции по проблеме анализа, прогноза и управления природными и техногенными рисками.

Имеется некоторый наш собственный опыт по оценке и управлению геодинамическими рисками [39-44]. При этом во всех случаях базовой 
концепцией является допущение о невозможности полного предотвращения аварий и катастроф, которые оказались неустранимыми в прошлом и не могут быть исключены в будущем (концепция не нулевого риска аварий и катастроф) [45].

Необходимо еще раз подчеркнуть, что стресс и риск являются фундаментальными понятиями в геомеханике, поэтому без учета этих двух главных факторов невозможно надежное геомеханическое обоснование современных горнотехнических проектов различного назначения, о чем еще более 40 лет тому назад писал проф. А. И Арсентьев: «Применительно к проектированию и планированию работы горных предприятий понятие и количественная оценка риска не разработаны. В то же время очевидно, что подавляющее большинство исходных данных, используемых при принятии решений по разработке месторождения имеет вероятностный характер, а поэтому и принятые решения могут быть реализованы с большими или меньшими отклонениями. Иными словами, в принятых решениях всегда имеет место определенный уровень риска. Умение оценивать и сознательно использовать риск повышает результативность и глубину наших решений и позволяет правильно реагировать на получающиеся количественные результаты от реализации проектных решений» [46].

В основу монографии положены результаты работ по программам фундаментальных исследований Отделения наук о Земле РАН и по интеграционным междисциплинарным проектам Сибирского отделения РАН, которые нашли частичное отражение в монографиях, подготовленных и изданных головными организациями: Институтом проблем комплексного освоения недр РАН [44, 47-50] и Институтом горного дела Сибирского отделения РАН [51-55].

Значительная часть исследований, результаты которых приведены в настоящей монографии, выполнена при поддержке Российского фонда фундаментальных исследований по грантам 03-05-65258, 06-05-64681, 09-05-00007, 12-05-00507, а также Российского научного фонда по проекту № 14-17-00751.

Структура монографии построена в соответствии с состоянием проблемы и конечной целью настоящих исследований - разработкой методологии управления геодинамическими рисками при ведении горных работ в высоконапряженных массивах скальных пород.

Для понимания процессов, происходящих в геологической среде горнотехнических систем, рассмотрены общие закономерности эволюции сложных открытых систем, а также нелинейные эффекты в процессах деформирования и разрушения горных пород.

Поскольку напряженное состояние массива горных пород является основным фактором геомеханической ситуации в горнотехнических системах, представляется логичным и необходимым рассмотреть основные закономерности трансформации напряженного состояния пород в массиве при открытой и подземной разработке месторождений в условиях гравитационно-тектонических полей напряжений. При этом, поскольку основным технологическим процессом при добыче полезных ископаемых в крепких скальных породах являются взрывные работы, несомненный интерес представляют результаты исследования сейсмогенерирующего потенциала мощных взрывов.

Основой всех оптимальных решений по управлению горным давлением является надежная информация о параметрах свойств и состоянии пород в массиве, которая может быть обеспечена только геомеханическим мониторингом, описание методов и результатов которого приведены в следующей главе.

И, наконец, результирующей является глава, посвященная управлению геодинамическими рисками при ведении горных работ в высоконапряженных 
массивах крепких скальных пород, в основном при разработке Хибинских апатито-нефелиновых месторождений.

Монография написана авторским коллективом в составе: д. т. н. А. А. Козырев (главы 3,5,6); д. т. н. С. Н. Савченко (глава 2); к. т. н. В. И. Панин (главы 1,5,6); к. т. н. И. Э. Семенова (главы 3,6, раздел 1.2); д. т. н. В. В. Рыбин (главы 3,6); к. т. н. Ю. В. Федотова (главы 5,6); д. т. н. С. А. Козырев (глава 4).

Отдельные разделы написаны: д. т. н. Э. В. Каспарьян (разделы 5.2, 5.3, 5.5); к. т. н. О. Г. Журавлева (разделы 5.6.2, 5.6.3, 5.7), к. т. н. С. А. Жукова (разделы 5.6.4.2, 5.6.4.3, 5.6.4.4); к. т. н. А. В. Земцовский (раздел 3.3.); М. М. Каган (раздел 5.5.4, 5.5.5, 5.8); И. Г. Панасенко (раздел 5.5.5); Д. В. Жиров (5.4.1, 5.4.2, 5.4.4, 5.4.5, 5.4.6), д. г.-м. н. Л. И. Сим (5.4.2).

В написании некоторых разделов приняли участие: к. т. н. А. В. Земцовский (3.1.2, 5.4.3.2, 6.5.1.1, 6.5.1.2, 7.5.2); к. т. н. И. М. Аветисян (3.1.1, 3.2, 6.5.1.3, 6.5.1.4, 6.5.3.2); К. Н. Константинов (5.4.3.1, 5.5.5, 5.5.6); А. С. Калюжный (6.5.4, 6.5.5); И. Г. Панасенко (раздел 5.5.4), Д. С. Чернобров (5.8.5, 5.8.6, 5.8.7, 5.8.8); Е. А. Усачев $(4.1,4.2)$.

В монографии использованы результаты большого объема натурных, лабораторных и модельных исследований, в выполнении которых приняли участие: М. И. Потокин, И. В. Данилов, Ю. А. Старцев, А. А. Самсонов, Д. Н. Мельников, Н. Н. Кузнецов, М. А. Кузнецов, Ю. Г. Смагина, Р. Н. Достовалов, С. В. Потемковский, А. Ю. Веремеев, В. П. Гуменников, А. К. Пак, А. А. Шестов, С. В. Дмитриев.

Все шахтные наблюдения и опытно-промышленные испытания проведены при участии инженерно-технических работников и при активном содействии руководства АО «Апатит», ЗАО «СЗФК», АО «Ковдорский ГОК» и ООО «Ловозерский ГОК», которым авторы выражают искреннюю благодарность.

Авторы признательны официальным рецензентам - проф. д. т. н. Д. В. Яковлеву и проф. д. т. н. В. Л. Шкуратнику, сделавшим ряд ценных замечаний и пожеланий по рукописи, которые были учтены в ее окончательной редакции.

Мы не претендуем на истину «в последней инстанции», мы изложили наше понимание техногенного сейсмического процесса и наш опыт обеспечения геодинамической безопасности при ведении горных работ в высоконапряженных массивах скальных пород. Исследования по проблеме техногенной сейсмичности продолжаются, поэтому мы с благодарностью примем все замечания и конструктивные предложения по решению этой актуальной проблемы современной горной науки и практики.

Несмотря на некоторые спорные моменты и недочеты, которые могут встретиться в книге, авторы надеются, что она будет полезна не только научным сотрудникам, но и инженерно-техническим работникам горнопромышленных предприятий, a также аспирантам и студентам горно-геофизических и геологических специальностей. 
Наука есть систематизированное знание.

Л. С. Берг

\section{1. ОБЩИЕ ЗАКОНОМЕРНОСТИ ЭВОЛЮЦИИ СЛОЖНЫХ ОТКРЫТЫХ СИСТЕМ}

\section{1. Системные законы и закономерности в горнотехнических системах}

Наблюдения показывают, что функционирование всех систем подчиняется общесистемным законам и закономерностям, действующим в природе и обществе [56]. Под закономерностью в данном случае понимается более «узкий» закон, который в отличие от закона не распространяется на все без исключения области определения.

1. Принцип компенсации энтропии: снижение энтропии в одной части изолированной системы обязательно сопровождается повышением энтропии в другой ее части или в окружающей среде. По балансу энтропии в системах можно определить рациональные пути развития системы. В реальных системах, в том числе и в природно-технических системах, как правило, протекают два противоположных процесса: изменение Э и НЭ (Э — энтропия (количественная мера беспорядка в системе); НЭ - негэнтропия (количественная мера упорядоченности системы или информация)). С ростом $Э$ в системе растет ее неопределенность и беспорядок, для этого чтобы уменьшить неопределенность системы и ее беспорядок, в систему необходимо ввести НЭ (информацию, знание, упорядоченность). Например, техногенная сейсмичность увеличивает Э ПТС, чтобы уменьшить эту энтропию, необходимы знания о структуре, свойствах и состоянии геологической среды, методах прогноза и профилактики сейсмичности, что и определяет НЭ системы.

2. Закономерность энтропийного равновесия системы - закономерность возрастания и убывания энтропии или негэнтропии в открытой системе. Она определяет состояние беспорядка и степени организованности и дезорганизованности системы различной природы. Чем больше информации о геологии и тектонике месторождения, чем качественнее сделан проект рудника и чем строже он исполняется, чем лучше организован геодинамический мониторинг и качественно выполняется противоударная профилактика, тем более стабильно работает предприятие и тем меныше вероятность возникновения чрезвычайных ситуаций, в том числе горно-тектонических ударов и техногенных землетрясений.

3. Закономерность зависимости потенциала системы от характера взаимодействия ее структурных элементов или степени организованности системы. Очевидно, что технический и экологический потенциал ПТС зависит от того, насколько целенаправленно, взаимно согласованно и рационально взаимодействуют все ее элементы между собой и насколько рационально организована сама система.

4. «Фоновый принцип» и фоновая общесистемная закономерность позволяют при определенных условиях по изменению фона судить о состоянии ПТС. Этот принцип широко применяется в технике, биологии, медицине и т. д. Как электрокардиограмма в медицине свидетельствует о состоянии сердечнососудистой системы, так и параметры сейсмичности определяют геомеханическую ситуацию в ПТС. 
5. Трехэтапное развитие системы на каждом витке эволюционной спирали: адаптация, изменчивость, отбор (бифуркация).

6. Причинно-следственная закономерность систем, или принцип причинности, является обобщением практического опыта на уровне здравого смысла. Можно сказать, что причинно-следственные связи представляют собой общесистемную закономерность, а не закон, поскольку не всегда справедливы. На определенном уровне развития системы, например, когда образуются новые системы, обладающие свойствами, не вытекающими из свойств предыдущих, это означает, что в момент образования новой системы жесткая взаимообусловленность, или причина-следствие, терпит разрыв, и происходит скачкообразное изменение энтропии (в момент катастрофы).

7. Закономерность объединения противоположностей является отражением диалектического единства и борьбы противоположностей. В каждой системе присутствуют минимум две противоположности, которые образуют устойчивую подсистему в виде балансного гомеостазиса. Все сложные системы различной природы гомеостатические. Принцип гомеостазиса, или динамического равновесия, выражается в принципе Ле Шателье, который в обобщенной форме формулируется следующим образом: всякая система подвижного равновесия стремится измениться таким образом, чтобы свести к минимуму эффект внешнего воздействия, вследствие чего формируется структура или область, в пределах которой система стремится поддерживать устойчивое равновесие [57].

Под влиянием возмущающего воздействия среды в такой системе динамического равновесия возникают всевозможные изменения, из которых менее благоприятные для системы отбором устраняются, а более благоприятные сохраняются. В результате чего возникает уравновешивающая структурная тенденция, изменяющая эффект внешнего воздействия. Таким образом, принцип Ле Шателье логически следует из принципа отбора.

8. Колебательный и циклический характер функционирования систем, в частности, геологической и геофизической среды как неотъемлемой части любой природно-технической системы, является на сегодня аксиомой. На эту тему имеется достаточное число публикаций на основе обширного экспериментального материала [57-59]. По результатам наблюдений методами спутниковой геодезии отмечены знакопеременные деформации на различных иерархических уровнях как форме существования геологической среды [60].

9. Иерархическая структура характерна для многих систем, особенно для литосферы Земли, где геофизики выделяют более тридцати иерархических уровней от тектонических плит протяженностью в тысячи километров до отдельных минеральных зерен миллиметрового размера [61]. «Таким образом, земная кора представляет собой не сплошную среду, а дискретную систему блоков и, как любой синергетический дискретный ансамбль, обладает свойствами иерархичности и самоподобия» [62]. Иерархичность структуры определяет иерархичность полей напряжений, поэтому подготовка землетрясения происходит посредством каскада передачи нагрузок с нижних уровней иерархии на верхние. Таким образом, поведение иерархических систем можно наблюдать только на верхних уровнях иерархии (землетрясения, результаты голосования, исполнение распоряжений и законов).

10. Диалектический принцип всеобщей взаимосвязи находит отражение BO

внутрисистемной и межсистемной конвергенции во взаимовлиянии, 
взаимопроникновении между собой разных частиц или систем и разных открытых подсистем внутри одной системы. Самый простой и наглядный пример такой конвергенции - влияние систем разработки на геодинамический режим геологической среды в геомеханическом пространстве рудника.

11. Закономерность «наиболее слабых мест» или «принцип наименьших» означает, что устойчивость всей системы зависит от наиболее слабых мест в системе, другими словами - «где тонко, там и рвется». Закономерность настолько очевидная, что не нуждается в дополнительных комментариях.

12. Закономерность расхождения темпов жизненных функций системы проявляется в различии циклов по темпам жизни, по силе относительного сопротивления среде, что ведет к дезорганизации всей системы, а затем и к ее гибели. В случае системной дезорганизации возникает слабое звено и вступает в силу «принцип наименьших». Принцип системной дезорганизации является основной причиной неполадок или гибели многих биологических, технических и социальных систем.

13. Закономерность перевода системы из одного качественного состояния в другое минимальным воздействием в критической точке фазового перехода можно назвать принципом «ахиллесовой пяты» или триггерным эффектом. Перевод системы из одного состояния в другое минимальным воздействием возможен только в том случае, если система находится в критическом состоянии - вблизи точки бифуркации (сход снежной лавины от громкого крика, провоцирование горного удара или техногенного землетрясения взрывом небольшого заряда взрывчатых веществ (BВ)). Эта закономерность является следствием диалектического закона перехода количества в качество.

14. Диалектическому принципу развития соответствует закономерность прохождения всех этапов эволюционного развития или закономерность эволюции, которая утверждает, что любая развивающаяся система должна обязательно пройти определенный эволюционный путь. Ни в одной из систем нельзя совершить «большой скачок» и пропустить одну или несколько эволюционных стадий, хотя длительность каждого эволюционного этапа может быть по различным причинам замедленна или ускоренна, но «перепрыгивать» через отдельные этапы невозможно.

15. Закон системности утверждает, что любой объект есть объект-система и любой объект-система принадлежит хотя бы одной системе объектов одного и того же рода. Во всех системах можно выделить следующие системные атрибуты:

- первичные, неделимые на данном уровне исследования элементы системы;

- связи между элементами, объединяющие их в единую систему;

- законы композиций отношений, представляющие аксиомы связи, порядка и т. п.

Применительно к горнорудной ПТС и проблеме техногенной сейсмичности одной из реализаций закона системности можно представить цепочку: горная порода - горная выработка - система разработки - горнотехническая система (система подземный рудник - карьер $[63,64]$ ) - ПТС.

16. Закон системных преобразований является основным законом общей теории систем, указывает силы (в том числе внутренние) и внешние факторы среды, вызывающие изменения и развитие объектов-систем [65].

Эволюция горнорудной ПТС определяется качеством природной среды и количеством антропогенных воздействий, например, объемами и темпами 
развития добычи полезного ископаемого и т. д., а также структурой, свойствами и изменением НДС геологической среды. Законы и закономерности этой эволюции в значительной мере определяют безопасность и технико-экономическую эффективность горных работ.

17. Закономерность неравномерного развития элементов системы свидетельствует о том, что чем сложнее система, тем более неравномерно развиваются ее составные части. Эта закономерность по своему содержанию перекликается с закономерностью «наименьших сопротивлений или наиболее слабых мест в системе».

18. Закон «жизненной кривой» системы определяет характер изменения во времени ее основных параметров и имеет для всех систем периоды: «детство», «зрелость», «старость» и «смерть». При этом у разных систем соотношениямежду участками на жизненной кривой разные, что соответствует специфическому фазовому портрету системы.

19. Закономерность триггерной роли случайных событий (принцип Пуанкаре) может играть существенную и даже решающую роль как в возникновении и уничтожении систем, так и в резком изменении направления их эволюции. Особенно велика роль случайных событий в состоянии неустойчивого равновесия вблизи точки бифуркации, когда «совершенно ничтожная причина, ускользающая от нас по своей малости, вызывает значительное действие, которого мы не можем предусмотреть, и тогда мы говорим, что это явление представляет собой результат случая» [66]. Велика роль случайности в геофизике и в геодинамике [67]. «Случайность способна порождать качественно новые режимы эволюции системы «почти из ничего» (из очень малых внешних возмущений) подобно тому, как в калейдоскопе возникают разнообразные картины при его вращении. Таким образом, случайность и хаос, возникающие в результате неустойчивости по-новому ставят вопрос об изучении некоторых неустойчивых геофизических процессов. Точный долгосрочный прогноз для таких явлений в принципе невозможен. Поэтому в этих ситуациях для проверки каких-либо теорий неизбежно использование статистических методов» [67].

Однако необходимо подчеркнуть, что роль случая может быть значительной только в сильно неравновесных системах, поэтому не стоит придавать большого значения упоминаемому в различных публикациях «эффекту бабочки» (butterfly effect). «Мир квантован и системы, в той или иной степени, отделены некими энергетическими барьерами, для преодоления которых необходимо перейти определенный критический барьер. Ничтожная причина может вызвать крупные изменения в системе только в качестве триггера. Искра только тогда может вызвать пламя, когда она тригтерирует неравновесную систему, готовую к взрывной реакции» [57]. Поэтому триггерную роль случая, несмотря на его большую роль в различных системах, следует считать закономерностью, а не законом.

Наряду с перечисленными выше общесистемными законами и закономерностями, существуют и другие, которые для настоящей тематики представляются несущественными, поэтому они не нашли отражения в настоящем разделе. Знание законов, известных в общей теории систем, позволяет понять эволюционные процессы, происходящие в горнорудных ПТС, определить основные закономерности самоорганизации геологической среды в геомеханических пространствах рудников и разработать безопасные и экономически эффективные способы обеспечения геодинамической безопасности горных работ в сложных горно-геологических условиях. 


\section{2. Самоорганизация и организация геологической среды в геомеханических пространствах рудников}

В соответствии с законом системных преобразований эволюция геологической среды в геомеханических пространствах рудников осуществляется за счет как внешних, так и внутренних факторов. Поскольку все ПТС являются открытыми, то всегда имеет место внешнее воздействие, которое в значительной мере определяет процессы самоорганизации в эволюционирующей среде. При этом иногда возникает дискуссия по вопросу о различии между процессами самоорганизации и организации. Вследствие того, что все открытые системы всегда находятся под внешним воздействием, то различие это не является четко выраженным. Наиболее удачным и полезным для наших дальнейших рассуждений представляется определение самоорганизации, которое дал один из основателей синергетики Г. Хакен: «Мы называем систему самоорганизующейся, если она без специфического воздействия извне обретает какую-то пространственную, временную или функциональную структуру. Под специфическим внешним воздействием мы понимаем такое, которое навязывает системе структуру или функционирование. В случае же самоорганизации система испытывает извне неспецифическое воздействие. Например, жидкость, подогреваемая снизу, совершенно равномерно обретает в результате самоорганизации макроструктуру, образуя шестиугольные ячейки» [68]. С позиций такого определения рассмотрим несколько примеров самоорганизации и организации геологической среды в горнотехнической системе.

Самым наглядным примером самоорганизации геологической среды в горнотехнической системе является процесс формирования зон растягивающих деформаций и напряжений в подрабатываемых породах.

На рисунке 1.1 представлены изолинии распределения максимальных растягивающих напряжений $\varepsilon_{3} E$, значения которых сравнивали с пределом прочности пород на разрыв (от 5 до 10 МПа в зависимости от степени нарушенности массива), и ориентация вероятных трещин отрыва в слое элементов непосредственно под дневной поверхностью.

Следует отметить, что сформировавшаяся новая трещина проходит в области своего наибольшего удаления от предыдущей бровки обрушения в зоне концентрации растягивающих напряжений, где абсолютные значения приближаются к пределу прочности пород на растяжение и составляют 8-10 МПа.

При анализе результатов моделирования в вертикальных сечениях вкрест простирания рудной залежи выявлено наличие в толще подработанных пород зоны с пониженными абсолютными значениями деформаций, что, видимо, является одним из сдерживающих факторов для полного самообрушения пород. На рисунке 1.2 показано это сечение.

Пунктирной линией нанесено место выхода трещины на дневную поверхность, которая находится в зоне субвертикальной ориентировки площадок действия $\varepsilon_{3} E$, абсолютные величины которых достигают предела прочности пород на растяжение. На рисунке 1.2 б выделена красным цветом зона вероятного частичного обрушения пород. Область с пониженными значениями растягивающих деформаций показана на рисунке 1.2 a синими и фиолетовыми тонами, здесь же наблюдается и выполаживание площадок $\varepsilon_{3} E$, что тормозит развитие трещины отрыва на всю высоту подработанной толщи пород, мощность которой в этом сечении составляет около 300 м. 
Результаты численного моделирования удовлетворительно согласуются с данными визуального обследования и фототеодолитной съемки, поэтому предложенный подход может быть использован для прогноза развития самоорганизующихся процессов деформирования подработанной толщи.

В результате такой самоорганизации происходит образование зон различного деформирования пород и их самообрушение в выработанное пространство (рис. 1.3) [69].

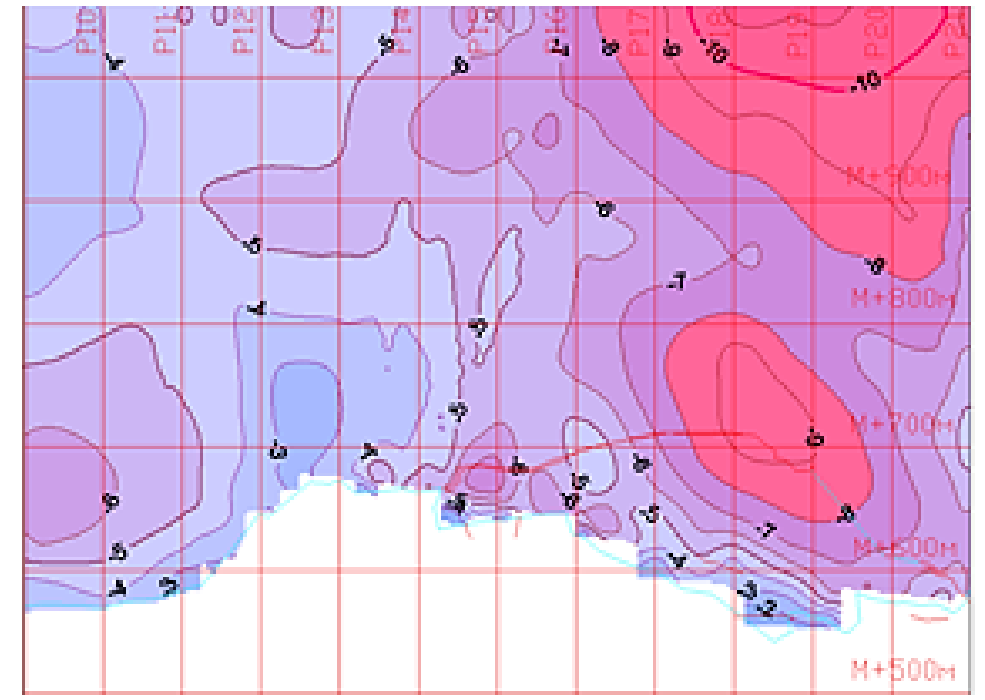

$a$

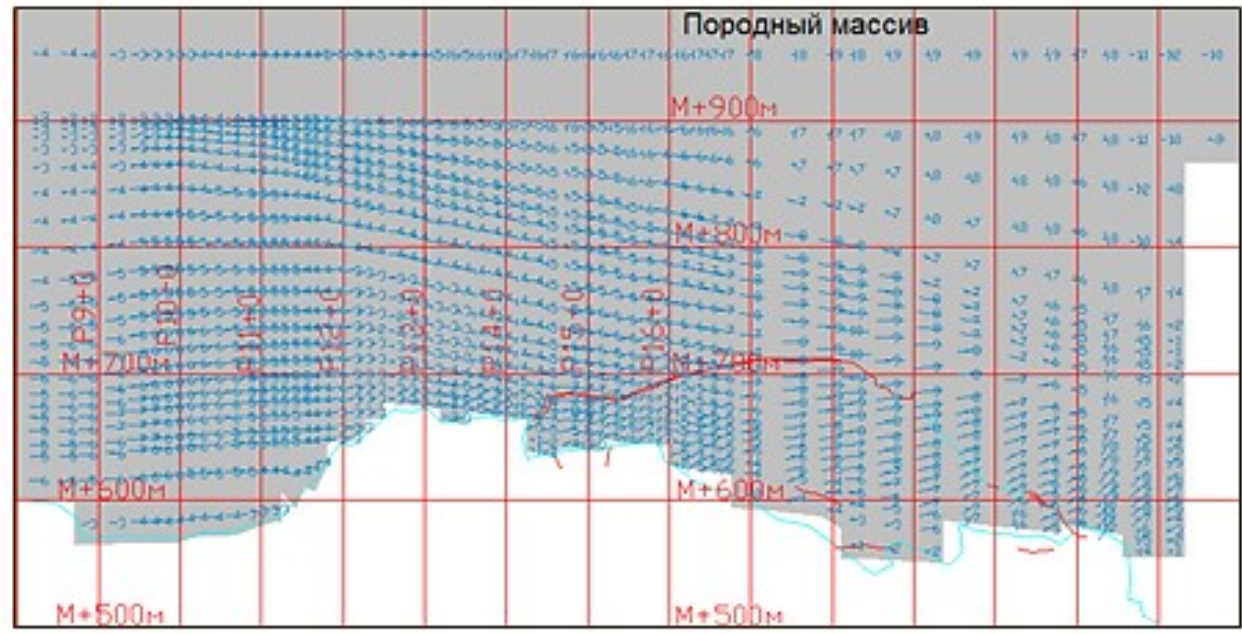

6

Рис. 1.1. Распределение максимальных растягивающих напряжений в горизонтальном сечении у дневной поверхности: $a$ - изолинии $\varepsilon_{3} E ; \sigma-$ ориентация вероятных трещин отрыва 

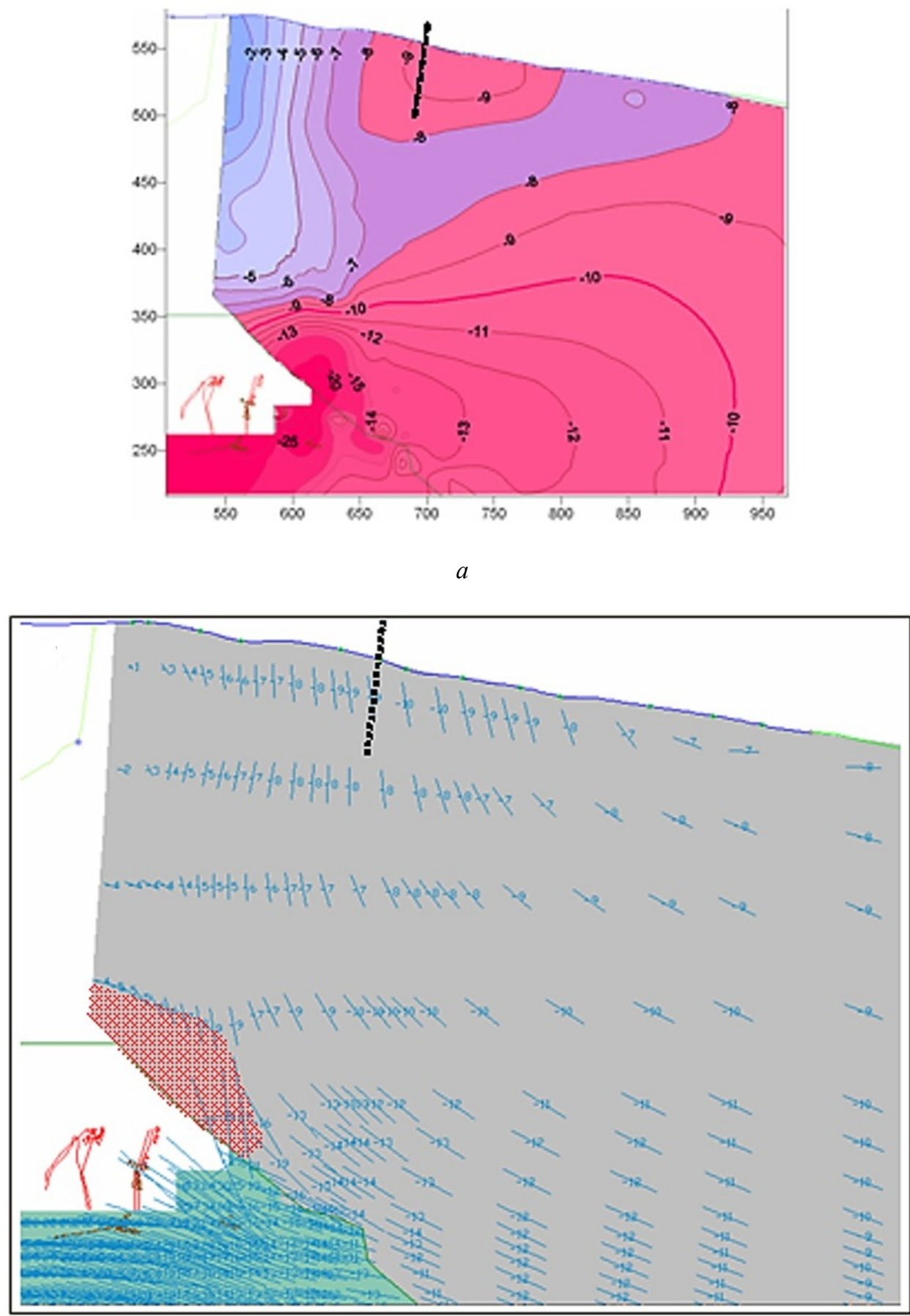

6

Рис. 1.2. Распределение максимальных растягивающих напряжений в вертикальном сечении: $a$ - изолинии $\varepsilon_{3} E ; \sigma-$ ориентация вероятных трещин отрыва 


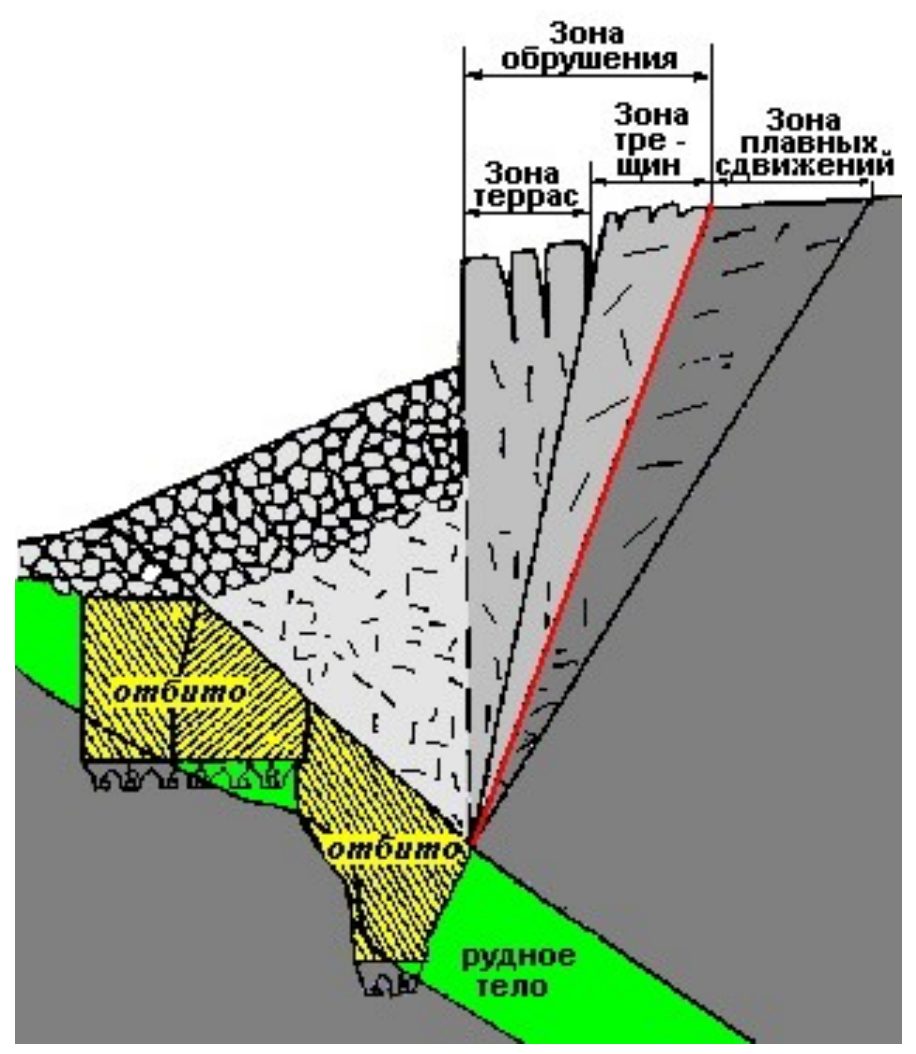

Рис. 1.3. Зоны различного деформирования массива и земной поверхности (в условиях апатитовых рудников)

Такие зоны образуются при подработке налегающих пород на многих пластовых месторождениях, используя для предотвращения внезапных обрушений принудительное обрушение, в этом случае имеет место процесс организованного деформирования геологической среды.

Используется и «пассивное» управление самообрушением подрабатываемых пород, для чего определяют такие параметры подработки, при которых растягивающие деформации в определенных сечениях подрабатываемой толщи достигают критических величин, и процесс самообрушения становится прогнозируемым, что существенно для безопасности горных работ.

В качестве примера можно привести процессы самоорганизации и организации в системе разработки с самообрушением руды и вмещающих пород, различные варианты систем с принудительным обрушением [70]. Системы с самообрушением используются при разработке слабых сильнотрещиноватых руд, где возникающие при подработке растягивающие напряжения превышают прочность руд и пород, поэтому происходит их самообрушение. Из-за сравнительно высоких потерь полезного ископаемого системы с самообрушением применяют не только в условиях низких прочностных параметров руд и пород, но и для разработки малоценных руд.

Так же примером самоорганизации геологической среды в окрестности горных выработок является их характерное (феноменологическое) разрушение в условиях действия высоких тектонических напряжений (рис. 1.4) [7]. Поэтому для управления процессом разрушения пород на контуре горных 
выработок и обеспечения их устойчивости используют специальные формы поперечного сечения (рис. 1.5) [10], где в зависимости от параметров поля напряжений в массиве переносят концентрацию напряжений вглубь массива от контура выработок.

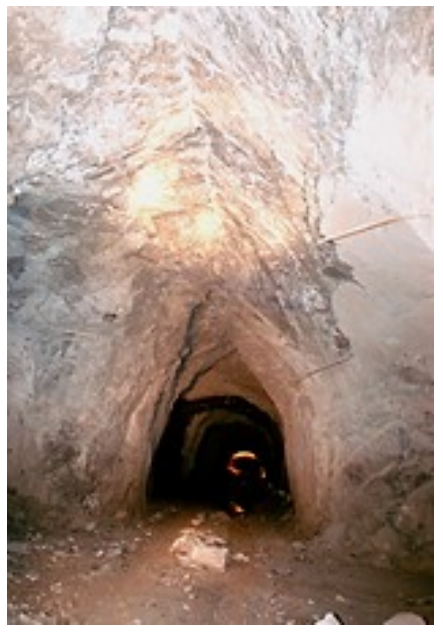

$a$

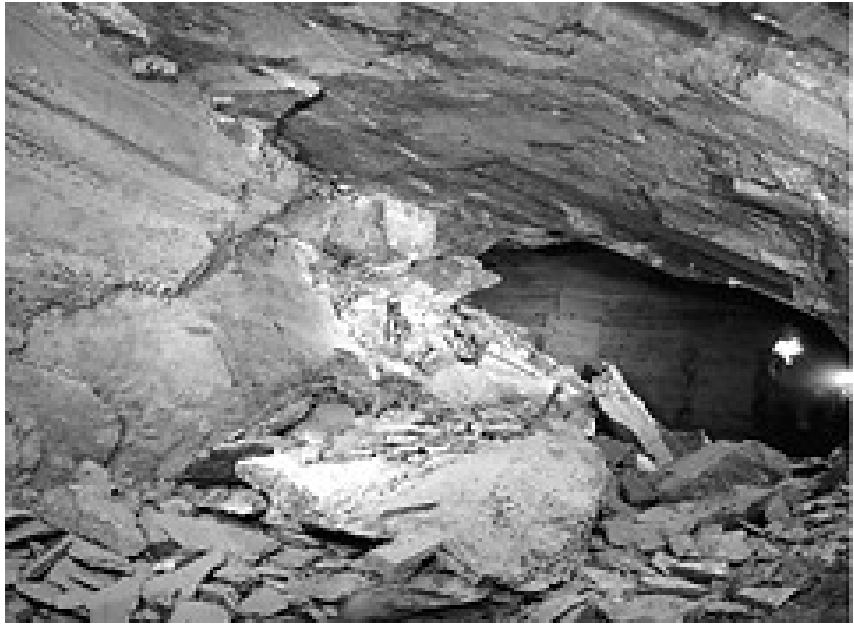

$\sigma$

Рис. 1.4. Характер разрушения пород вокруг выработок на апатитонефелиновых рудниках Хибин за счет стреляния и плитчатого расслаивания $(a)$ и отслаивания по плоскостям трещин (б)

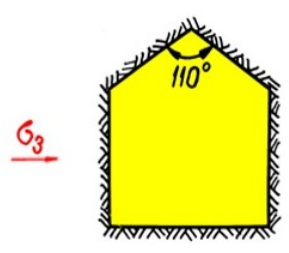

$a$

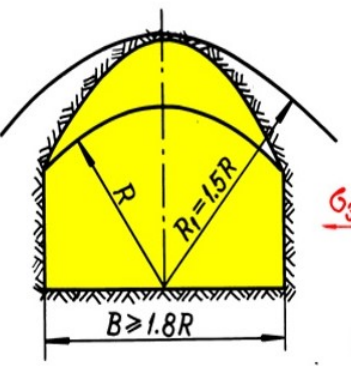

$\sigma$

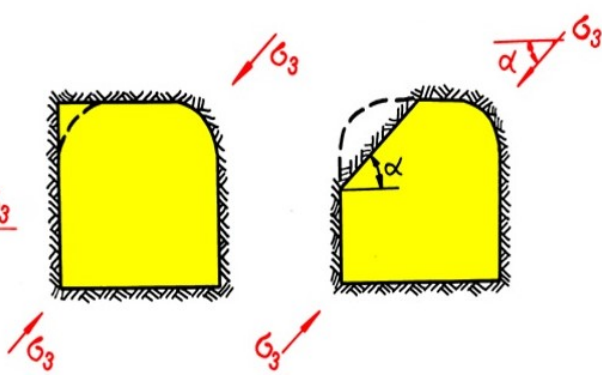

B

Рис. 1.5. Рациональные формы поперечного сечения выработок при действии горизонтальных напряжений

И, наконец, самым выразительным явлением геомеханической самоорганизации геологической среды представляется сейсмичность, которая является отражением эволюционных процессов в литосфере. «Горная порода, в которой происходит сейсмический процесс, далее рассматривается как самоорганизующаяся система, находящаяся в состоянии динамического равновесия, а сами землетрясения - малые ее колебания около положения равновесия» [71]. 


\section{3. Техногенная сейсмичность как отражение эволюции напряженно-деформированного состояния геологической среды в горнорудной природно-технической системе}

Как известно, деформирование геологической среды в природно-технических системах определяется взаимодействием главным образом тектонических и техногенных полей напряжений. При этом в горнорудных ПТС существенное влияние на геомеханические процессы в геологической среде оказывают техногенные нагрузки. Выемка и перемещение значительных объемов горных пород нарушают геодинамический режим геологической среды, однако вследствие гомеостатических механизмов (принцип Ле Шателье) среда постоянно стремится к устойчивому состоянию в определенных временных интервалах. При этом деформирование дискретной геологической среды сопровождается диссипацией энергии, определяемой размерами вовлекаемых в процесс деформирования блоков [72]. Аналитическими и экспериментальными исследованиями установлено [21], что изменение энергии деформирования пород в процессе эволюции геологической среды в ПТС под влиянием естественных и техногенных силовых полей имеет нелинейный характер, а реализация динамического явления обусловлена превышением критической величины накопленной энергии в некотором объеме геологической среды, определяемой параметрами упругих и прочностных свойств горных пород.

По аналогии с предложенной М. В. Гзовским моделью скорости роста и сейсмичности тектонического разрыва с позиций универсального эволюционизма эволюцию НДС геологической среды в ПТС можно представить в виде триады адаптация - изменчивость - отбор (рис. 1.6). В точке бифуркации разрядка напряжений может произойти либо в виде медленных деформаций, либо быстрым сбросом в виде динамического явления, энергия которого определяется размерами вовлекаемых в процесс блоков.

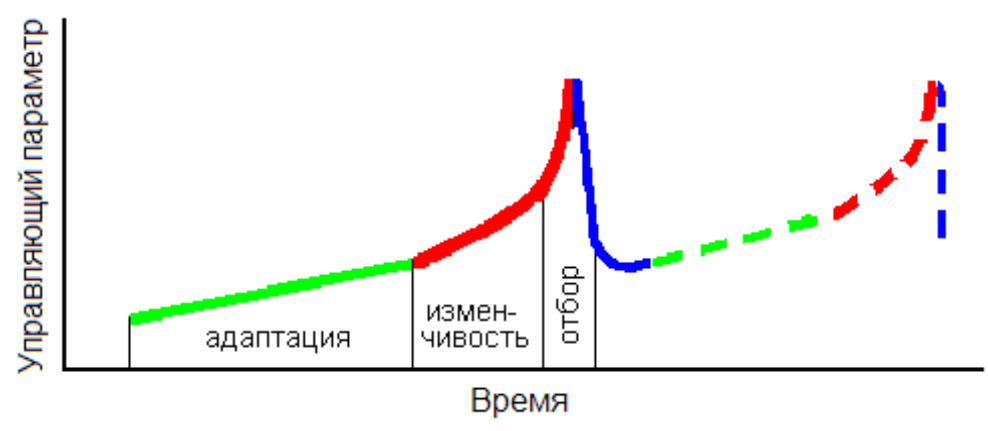

Рис. 1.6. Модель эволюции геологической среды в ПТС

На эволюцию геологической среды в ПТС оказывают влияние множество случайных (принцип Пуанкаре) и детерминированных факторов [71, 72], однако в процессе эволюции любой сложной системы выделяют несколько главных параметров, называемых параметрами порядка, или управляющими параметрами. В качестве внутренних управляющих параметров геологической среды в ПТС, определяющих ее геомеханическую эволюцию, следует принимать показатели ее НДС, в качестве внешних - параметры горных работ. 
Эволюция любой системы преследует определенные цели: стабильность и развитие. При этом развитие возможно только потому, что эта стабильность имеет характер динамического равновесия. Кстати, анализ процесса естественной (тектонической) и техногенной сейсмичности дает основание считать геологическую среду «живой», которая эволюционирует, чутко реагируя на все происходящие в ней природные и техногенные процессы $[73,74]$. «Можно думать, что похожесть геолого-геофизических и биологических ритмов не случайна и ее оправдывают часто встречающиеся в науке термины, подобные «жизни Земли», «здоровью Земли» и т. п. Действительно, многообразие процессов, протекающих в различных средах нашей планеты, их взаимосвязанность и непредсказуемость заставляют подходить к экологическим задачам с позиций, свойственных, скорее, медицине, чем с привычных и распространенных инженерно-технических. Невозможность строгого описания природных процессов требует от ученого-эколога огромного опыта и тонкой интуиции, не меньших, чем опыт и интуиция хорошего врача, диагностирующего болезнь, основываясь на ряде симптомов, часто не имеющих прямой связи с самой болезнью, ни друг с другом» [71].

Предложена еще одна не менее интересная модель Земли, свидетельствующая об активности протекающих в ней эволюционных процессов: «Земля оказывается подобной тепловой машине, в которой мантия соответствует паровому котлу, океанические плиты - движущимися деталями, а континенты - плавающим регулирующим клапанам. В результате работы такой машины тепловая энергия превращается в механическую работу деформации и разрушений литосферы, формируется лик современной Земли и ее прошлая и будущая геологические истории» [75].

Поскольку эволюция живой системы может быть управляемой (в некоторых пространственно-временных интервалах), основной целью эволюции НДС геологической среды в ПТС является обеспечение стабильной и безопасной работы горнодобывающего предприятия. Для этого необходимо контролировать все стадии эволюции этой системы. Самой благоприятной для работающего предприятия является стадия адаптации, в которой необходимо поддерживать систему как можно дольше. Но изменения в геологической среде работающего рудника неизбежны и иногда они могут иметь катастрофический характер. Самой опасной является стадия отбора, где вследствие бифуркационных механизмов возможны кризисные состояния, опасные, в том числе и по динамическим проявлениям типа горных ударов и техногенных землетрясений, как в пределах рабочей зоны рудников, так и в границах их геомеханических пространств.

Следуя медицинской аналогии М. А. Садовского и В. Ф. Писаренко, можно сказать, что в стадии отбора геологическая среда испытывает стресс - «совокупность всех неспецифических изменений, возникающих под влиянием любых сильных воздействий и сопровождающихся перестройкой защитных систем организма» [31]. Как стресс постоянно испытывают все живые существа, так и сейсмический процесс является неотъемлемой частью эволюции геологической среды, поскольку он является самоподобным, что подтверждается законом повторяемости землетрясений Гуттенберга-Рихтера. При этом, как в медицине, важен не сам стресс, а его уровень, так и в сейсмологии определяющее значение имеют энергия землетрясения и расстояние от его очага до рабочей зоны или объектов инфраструктуры.

Стадия отбора является не только самой опасной, но и самой трудной для понимания процессов самоорганизации, поскольку необходимо выявлять 
законы или закономерности, определяющие эволюцию НДС геологической среды. «Изменчивость (стохастичность), влияние прошлого на настоящее и будущее (наследственность) и «берега канала» допустимого (принципы отбора) - первые и основные понятия теории универсального эволюционизма, без которых нельзя объяснить ни один процесс развития, происходящий в нашем Мире» [32].

Таким образом, закономерности эволюции НДС геологической среды в ПТС определяют характер геомеханической эволюции всей горнотехнической системы и являются основой управления геомеханическими процессами в таких системах для обеспечения безопасности и технико-экономической эффективности горных работ.

Эволюция геомеханической ситуации в геологической среде ПТС осуществляется в соответствии с общесистемными законами и закономерностями, которые в определенной степени детерминируют методологию решения проблемы техногенной сейсмичности. В частности, они указывают на бесперспективность поисков методов временного прогноза отдельных сейсмических событий, но в то же время свидетельствуют о реальности оценки геодинамической опасности определенных зон и разработки соответствующих профилактических мероприятий.

Самоорганизация является неотъемлемой частью всех геомеханических процессов в геологической среде горнотехнической системы, и для обеспечения безопасности и технико-экономической эффективности горных работ самоорганизация должна быть контролируемой или заменена, по возможности, организацией.

Техногенная сейсмичность, как и сейсмичность тектоническая, является отражением эволюции НДС иерархично-блочной геологической среды, поэтому определение закономерностей изменения напряжений и деформаций во всех элементах горнотехнических систем является первоосновой для разработки способов оценки геодинамической опасности в ПТС и ее профилактики.

Для изучения закономерностей формирования и эволюции НДС геологической среды в горнотехнических системах наиболее информативным представляется использование аналитических и численных моделей, верифицируемых результатами геодинамического мониторинга.

\section{4. Основные задачи математического и численного моделирования эволюции природных и техногенных полей напряжений в геологической среде горнотехнических систем}

Характерными особенностями современной горнодобывающей промышленности являются большие объемы извлекаемых и перемещаемых масс горных пород, достигающие нескольких миллиардов кубических метров; глубины свыше тысячи метров; образование очистных пространств с огромными площадями обнажений; обрушение и самообрушение пород в несколько миллионов кубических метров, приводящие к значительным изменениям естественного рельефа поверхности. Все это сопровождается перераспределением исходных полей напряжений, способствует возникновению значительных концентраций упругой энергии массива на отдельных участках, которая, высвобождаясь, может приводить к горным ударам и техногенным землетрясениям. Как правило, это происходит вблизи границ блоков различных масштабных уровней в результате их перемещений.

Блочное строение массивов горных пород теснейшим образом связано с его трещиноватостью. Собственно, трещиноватость и блочность - это две грани одного и того же явления, порожденного, на наш взгляд, в некоторой мере неоднородностью НДС геологической среды. 
Если рассматривать движение удельной энергии деформирования как явление природы, то его можно представить в виде «борьбы двух противоположностей» - накопления энергии в процессе изменения НДС и ее диссипации (перехода в другие виды энергии).

В связи с этим научный и практический интерес представляет исследование НДС неоднородных массивов, его изменение в процессе развития (роста) неоднородностей, выяснение возможных причин, порождающих эти изменения.

Как известно, геологическая среда представляет собой сложную открытую нелинейную систему со всеми вытекающими отсюда последствиями. А в среде горнотехнической системы возникают дополнительные факторы, основными из которых (определяющими геодинамическое состояние системы) являются техногенные напряжения. Свойства системы определяются большим числом динамических переменных, характеризующихся нелинейными взаимодействиями, прямыми и обратными связями. Для понимания геодинамических процессов в геологической среде геотехнических систем, разработки способов прогноза и профилактики динамических явлений представляется целесообразным воспользоваться модельной методологией, получившей широкое распространение в современной науке и технике [76]. В решении геомеханических задач в Горном институте КНЦ РАН наибольшее применение находят методы математического и численного моделирования, многолетний опыт применения которых позволил получить ряд новых и практически ценных результатов.

Главной целью математического и численного моделирования эволюции техногенных полей напряжений в геологической среде горнотехнических систем является изучение закономерностей их формирования и разработка модельных представлений о миграции очагов критических ситуаций в геомеханическом пространстве рудников. При этом необходимо отметить большое значение модельных исследований в проблеме техногенной сейсмичности. Именно отсутствие адекватных моделей подготовки и реализации динамических явлений в геологической среде объясняет невозможность до настоящего времени надежного краткосрочного прогноза землетрясений. Однако это не умаляет значений модельных исследований в решении познавательных и практических задач, примеры решения которых приведены в настоящей работе.

Следует отметить, что в современной науке используют четыре вида моделей: описательные, объяснительные, прогностические и модели принятия решений [77].

Описательные модели отображают реальные явления, при этом описание может быть качественным или количественным, то есть в виде статистических данных распределений, а также их эмпирических корреляций.

Объяснительные модели разъясняют, с одной стороны, закономерности, установленные в описательных моделях, а с другой, - причинно-следственные связи между явлениями.

Прогностические модели используют результаты, полученные при описательном или объяснительном анализе фактов. Они опираются преимущественно на экстраполяцию прошлого в будущее, которая, в свою очередь, основывается на постулате о структурном постоянстве явлений.

Модели принятия решений определяют, какие технические и организационные мероприятия должны быть использованы для обеспечения условий безопасного ведения горных работ. Здесь речь идет в основном об объяснительных и частично прогностических моделях.

Установлено, что одним из механизмов реализации горно-тектонических ударов и техногенных землетрясений является разрушение барьерных зон между 
двумя разломами в геомеханическом пространстве рудника [78]. Механизм такого разрушения показан в задачах о разрушении барьерных зон между двумя трещинами и в модели эволюции напряженного состояния пород в массиве с ветвящимися трещинами. Известным фактом является то, что подавляющее большинство мощных динамических явлений приурочено к крупным тектоническим структурам. Почему и как это происходит показано в моделях формирования напряженного состояния геологической среды в окрестности наклонного разлома в гравитационно-тектоническом поле напряжений, а также в задаче о влиянии трещин, располагаемых на границе раздела геологических блоков. На основании этих моделей показано возможное влияние Главного разлома в районе карьера Центрального рудника АО «Апатит» на геодинамическую ситуацию в этом районе, что имеет большое значение в обеспечении безопасности и эффективности открытых горных работ.

Для геодинамического прогноза могут быть весьма полезными закономерности эволюции энергоемкости в иерархично-блочной (реальной) геологической среде на различных масштабных уровнях, а также формирования напряженного состояния пород с учетом размеров неоднородностей.

Важное прогностическое значение имеют исследования методом численного моделирования особенностей трансформации НДС Хибинского и Ловозерского массивов. Все перечисленные результаты дают новые знания о геодинамических процессах в геологической среде горнотехнических систем и имеют большое практическое значение для решения проблем техногенной сейсмичности при ведении горных работ. 


\section{2. НЕЛИНЕЙНЫЕ ЭФФЕКТЫ В ПРОЦЕССАХ ДЕФОРМИРОВАНИЯ И РАЗРУШЕНИЯ ГОРНЫХ ПОРОД}

\section{1. Эволюция двухпараметрической динамической системы}

Говоря об эволюции, мы подразумеваем развитие некоторой незамкнутой системы, состояние которой зависит от внешнего воздействия и времени.

В работах $[21,79]$ исследованы вопросы эволюции динамических систем, где рассмотрены системы с одним управляющим параметром. Из всего множества факторов можно выделить несколько так называемых ведущих параметров. Нас будут интересовать системы с двумя ведущими параметрами. $\mathrm{C}$ математической точки зрения такие динамические системы независимо от их природы могут быть описаны системой дифференциальных уравнений:

$$
\left.\begin{array}{l}
\frac{d N}{d t}=\varphi_{1}(t) N+\varphi_{2}(t) S+f_{1}(t, N, S) \\
\frac{d S}{d t}=\varphi_{3}(t) N+\varphi_{4}(t) S+f_{2}(t, N, S)
\end{array}\right\},
$$

где $N$ и $S$ - ведущие параметры; $t$ - время; $\varphi_{i}-$ некоторые известные функции, которые могут быть как постоянными, так и зависящими от времени.

В случае постоянных коэффициентов решения системы (2.1) достаточно хорошо изучены [80, 81].

Решением системы (2.1) с нулевыми функциями $f_{1}(t, N, S)$ и $f_{2}(t, N, S)$ являются выражения:

$$
\begin{aligned}
& N=\exp \left(\int\left(\varphi_{1}+\frac{\varphi_{2}}{\psi}\right) d t+C_{1}\right), \\
& S=\exp \left(\int\left(\varphi_{3} \psi+\varphi_{4}\right) d t+C_{2}\right)
\end{aligned}
$$

где постоянные интегрирования $C_{1}$ и $C_{2}$ определяются из начальных условий, а функция $\psi(t)=N(t) / S(t)$ должна удовлетворять уравнению Риккати:

$$
\frac{d \psi}{d t}=-\varphi_{3} \psi^{2}+\left(\varphi_{1}-\varphi_{4}\right) \psi+\varphi_{2} .
$$

Рассмотрим несколько частных случаев.

Пример 1. Пусть $\varphi_{2}=0$, тогда система (1.1) принимает вид:

$$
\left.\begin{array}{l}
\frac{d N}{d t}=\varphi_{1} N \\
\frac{d S}{d t}=\varphi_{3} N+\varphi_{4} S
\end{array}\right\} .
$$


Из первого уравнения (2.4) получаем решение для $N$, подставив которое во второе уравнение, имеем линейное неоднородное уравнение $\frac{d S}{d t}-\varphi_{4} S=N_{0} \varphi_{3} \exp \left(\int \varphi_{1} d t\right)$, следовательно, решение системы (2.4) запишется в виде:

$$
\begin{aligned}
& N=N_{0} \exp \left(\int \varphi_{1} d t\right) \\
& \left.S=\exp \left(\int \varphi_{4} d t\right)\left\{S_{0}+N_{0} \int \varphi_{3} \exp \left(\int\left(\varphi_{1}-\varphi_{4}\right) d t\right) d t\right\}\right\} .
\end{aligned}
$$

Для конкретности расчета полагаем $\varphi_{1}=\cos t ; \quad \varphi_{3}=\cos 2 t$; $\varphi_{4}=\cos t+0,1$, тогда (2.5) принимает вид:

$$
\begin{aligned}
& N=N_{0} \exp (\sin t) \\
& S=\exp (\sin t+0,1 t)\left\{S_{0}+N_{0}\left[\frac{e^{-0,1 t}(2 \sin 2 t-0,1 \cos 2 t)}{4,01}\right]\right\}
\end{aligned}
$$

На рисунке 2.1 приведены графики этих зависимостей для начальных значений $S_{0}=N_{0}=1$. Этот пример описывает движение колеблющейся динамической системы, причем параметр $S$ оказывается резонирующим.

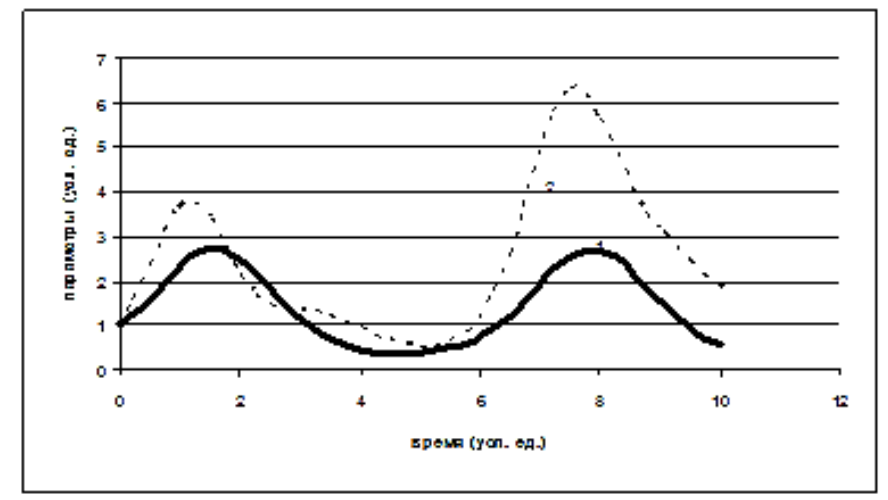

Рис. 2.1. Графики зависимостей $N$ и $S$ от времени для решения (2.5): 1 - параметр $N$; 2 - параметр $S$

Пример 2. Полагаем $\varphi_{1}=0$, тогда система (1.1) приобретает вид:

$$
\left.\begin{array}{l}
\frac{d N}{d t}=\varphi_{2} S \\
\frac{d S}{d t}=\varphi_{3} N+\varphi_{4} S
\end{array}\right\} .
$$

Отсюда $S=\frac{1}{\varphi_{2}} \frac{d N}{d t} ; \frac{d S}{d t}=\frac{1}{\varphi_{2}}\left(\frac{d^{2} N}{d t^{2}}-\frac{d \varphi_{2}}{\varphi_{2} d t} S\right)$. С учетом этого второе уравнение системы (2.6) представляется следующим образом: 


$$
\frac{d^{2} N}{d t^{2}}=A(t) \frac{d N}{d t}+B(t) N
$$

где $A(t)=\varphi_{4}+\frac{1}{\varphi_{2}} \frac{d \varphi_{2}}{d t} ; \quad B(t)=\varphi_{2} \varphi_{3}$. Полагая $B(t)=\frac{d A}{d t}$, что равносильно условию взаимосвязи функций $\varphi_{2} \varphi_{3}=\frac{d \varphi_{4}}{d t}+\frac{1}{\varphi_{2}} \frac{d^{2} \varphi_{2}}{d t^{2}}-\frac{1}{\varphi_{2}^{2}}\left(\frac{d \varphi_{2}}{d t}\right)^{2}$, получаем решение системы (2.6) в следующем виде:

$$
\left.\begin{array}{l}
N=N_{0} \exp \left(\int A d t\right) \\
S=S_{0}+\frac{A N_{0}}{\varphi_{2}} \exp \left(\int A d t\right)
\end{array}\right\} .
$$

Пусть для конкретности расчетов по формулам (2.6) $\varphi_{2}=\frac{t}{\sin ^{2} t}$, $\varphi_{4}=\frac{0,01}{\cos ^{2} t}-\frac{1}{t}+\frac{2 \cos t}{\sin t}$, тогда решение (2.8) представится в виде:

$$
\begin{aligned}
& N=N_{0} \exp (0,1 t \cdot \operatorname{tg} t+\ln |\cos t|) \\
& \left.\begin{array}{l}
S=S_{0}+0,01 N_{0} \operatorname{tg}^{2} t \exp (0,01 t \cdot \operatorname{tg} t+\ln |\cos t|)
\end{array}\right\} .
\end{aligned}
$$

На рисунке 2.2 приведены графики этих зависимостей с начальными значениями $S_{0}=N_{0}=1$, где график 1 показывает изменение во времени параметра $N$, а график 2 - параметра $S$. В моменты времени $t_{1}, t_{2}, t_{3}$ динамическая система находится в состоянии обострения. Очевидно, что такой (или аналогичный) характер изменения параметров $N$ и $S$ можно наблюдать в геологической среде в моменты зарождения и развития трещин в результате внешнего силового воздействия, если трактовать параметры как накопление и диссипацию внутренней энергии, деформирование массива горных пород в некотором объеме.

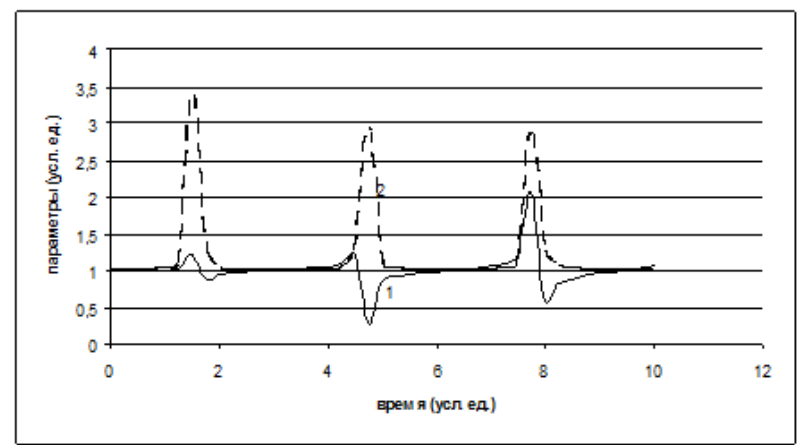

Рис. 2.2. Графики изменения параметров $N$ и $S$ при $\varphi_{1}=0$ для решения (2.9): 1 - параметр $N$; 2 - параметр $S$ 
Пусть $\varphi_{1} \neq \varphi_{4} ; \quad \varphi_{2} \neq 0 ; \quad \varphi_{3} \neq 0 . \quad$ Введем обозначение $\mu(t)=\int\left(\varphi_{4}-\varphi_{1}\right) d t$, тогда выражение

$$
\psi(t)=e^{-\mu} \sqrt{\int \varphi_{2} e^{\mu} d t} / \sqrt{\int \varphi_{3} e^{-\mu} d t}
$$

является частным решением уравнения Риккати (2.3), в чем нетрудно убедиться при непосредственном дифференцировании (2.10). При этом должно быть соблюдено условие:

$$
1=2 \sqrt{\int \varphi_{2} e^{\mu} d t} \sqrt{\int \varphi_{3} e^{-\mu} d t}
$$

В соответствии с этим решение исходной системы уравнений (2.1) имеет вид:

$$
\begin{aligned}
& N=N_{0} \sqrt{\int \varphi_{2} e^{\mu} d t} \cdot \exp \left(\int \varphi_{1} d t\right) \\
& S=S_{0} \sqrt{\int \varphi_{3} e^{-\mu} d t} \cdot \exp \left(\int \varphi_{4} d t\right)
\end{aligned}
$$

Если функции $\varphi_{2}(t)$ и $\varphi_{3}(t)$ произвольны, то выражение (2.10) не будет удовлетворять уравнению Риккати, а (2.12) не будет являться решением системы (2.1).

Выражение (2.10) не является единственным условием совместности системы (2.1), то есть уравнение Риккати (2.3) может иметь и другие частные решения. Все зависит от того, какая установлена (существует) взаимосвязь между функциями $\varphi_{1}, \varphi_{2}, \varphi_{3}, \varphi_{4}$. Например, полагая

$$
\left(\varphi_{1}-\varphi_{4}\right)=\varphi_{3} \psi
$$

и учитывая (2.3), получаем $\varphi_{2}=\frac{\left(\varphi_{1}-\varphi_{4}\right) \varphi_{3}-\left(\varphi_{1}-\varphi_{4}\right) \varphi_{3}}{\varphi_{3}^{2}}$, где точка над функцией означает дифференцирование по времени.

$$
\begin{aligned}
& \text { Отсюда следует, что } \frac{\varphi_{2}}{\psi}=\frac{\dot{\varphi}_{1}-\dot{\varphi}_{4}}{\varphi_{1}-\varphi_{4}}-\frac{\dot{\varphi}_{3}}{\varphi_{3}} \text { и тогда имеем: } \\
& \left.\begin{array}{l}
N=N_{0} \exp \left[\int \varphi_{1} d t\right] \cdot\left|\frac{\varphi_{1}-\varphi_{4}}{\varphi_{3}}\right| \\
S=S_{0} \exp \left[\int \varphi_{1} d t\right]
\end{array}\right\} .
\end{aligned}
$$

Уравнение Риккати (2.3) при замене переменной $\psi=\dot{u} / \varphi_{3} u$ сводится к однородному уравнению второго порядка $\frac{d^{2} u}{d t^{2}}+A \frac{d u}{d t}+B u=0$, где $A=\varphi_{4}-\varphi_{1}-\frac{\dot{\varphi}_{3}}{\varphi_{3}}, B=-\varphi_{2} \varphi_{3}$. 
Если потребовать $B=\frac{d A}{d t}$, что равносильно условию $\varphi_{2}=\frac{\dot{\varphi}_{1}-\dot{\varphi}_{4}}{\varphi_{3}}+\frac{\ddot{\varphi}_{3}}{\varphi_{3}^{2}}-\frac{\dot{\varphi}_{3}^{2}}{\varphi_{3}^{3}}$, то получим $\frac{d}{d t}\left(\frac{d u}{d t}\right)=-\frac{d}{d t}(A u)$. Отсюда имеем $u=\exp \left(-\int A d t\right)$. После подстановки в исходное представление функции $\psi$ получаем $\psi=\frac{\varphi_{1}-\varphi_{4}}{\varphi_{3}}+\frac{\dot{\varphi}_{3}}{\varphi_{3}^{2}}$. Решение системы уравнений (2.1) в этом случае имеет вид:

$$
\left.\begin{array}{l}
S=S_{0}\left|\varphi_{3}\right| \exp \left(\int \varphi_{1} d t\right) \\
\left.N=N_{0}\left|\varphi_{1}-\varphi_{4}+\frac{\dot{\varphi}_{3}}{\varphi_{3}}\right| \exp \left(\int \varphi_{1} d t\right)\right\}
\end{array}\right\}
$$

Пример 3. Пусть $\varphi_{1}=\cos t, \varphi_{3}=\frac{1}{t-t_{0}}, \varphi_{4}=\frac{-1}{t+t_{0}}+\cos t$.

На рисунке 2.3 приведены графики зависимостей параметра $\mathrm{S}$ для системы (2.1), рассчитанные по формулам (2.14) - график 1, (2.15) - график 2 и $(2.15)$ - график 3 , где $t_{0}$ - некоторый момент времени, для конкретности расчетов полагаем его равным 5. Аналогично выглядят и графики для параметра $N$.

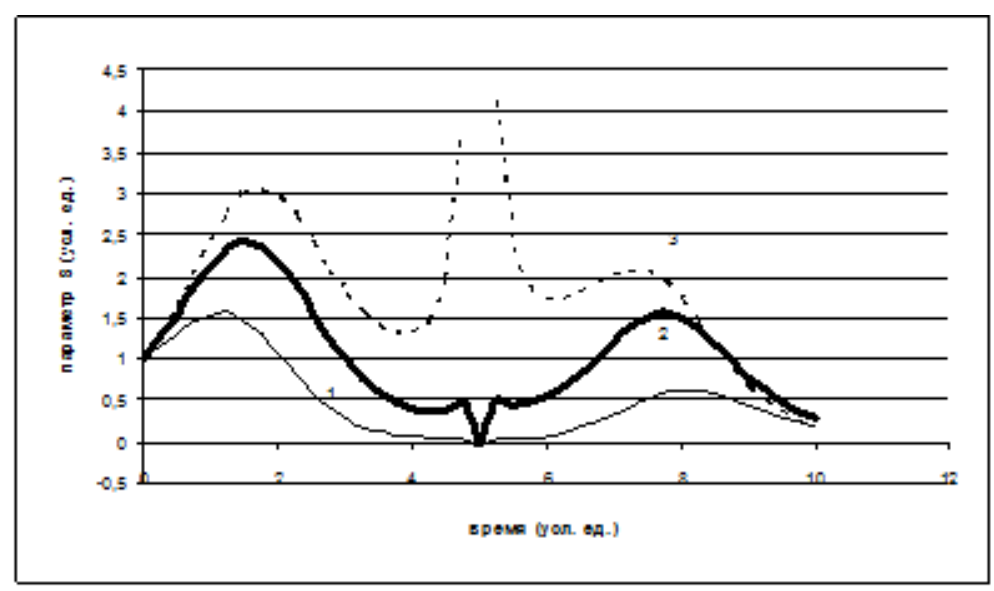

Рис. 2.3. Различные варианты эволюции двухпараметрической динамической системы при одинаковых исходных функциях и с различными связями между ними: 1 - параметр $S_{1}$; 2 - параметр $S_{2} ; 3$ - параметр $S_{3}$

Анализ, приведенных в этом разделе рисунков, свидетельствует о том, что даже при одних и тех же функциях, входящих в (2.1), эволюция двухпараметрической динамической системы может происходить по любому сценарию не только потому, что в уравнения (2.1) могут входить различные функции $\varphi_{1}, \varphi_{2}, \varphi_{3}, \varphi_{4}$, но и потому, какая существует взаимосвязь между этими функциями, определяемая решением уравнения Риккати, которое имеет бесконечное число частных решений. 


\section{2. Некоторые возможные варианты эволюции двухпараметрической динамической системы}

Изменение во времени самоорганизующейся динамической системы, определяемое двумя ведущими параметрами, может быть описано системой дифференциальных уравнений:

$$
\left.\begin{array}{l}
\frac{d N}{d t}=\varphi_{1}(t) N+\varphi_{2}(t) S \\
\frac{d S}{d t}=\varphi_{3}(t) N+\varphi_{4}(t) S
\end{array}\right\} .
$$

Частный вид системы уравнений (2.16) можно представить следующим образом:

$$
\left.\begin{array}{l}
\frac{d N}{d t}=\varphi_{1}(t)(N-S) \\
\frac{d S}{d t}=\varphi_{2}(t)(N-S)
\end{array}\right\} .
$$

Более того, предположим, что скорость диссипации энергии составляет некоторую постоянную часть, зависящую от скорости накопления полной энергии в любой момент времени, то есть $\varphi_{2}(t)=\frac{1}{n} \varphi_{1}(t)$. Тогда (2.17) принимает вид:

$$
\left.\begin{array}{l}
\frac{d N}{d t}=\varphi(t)(N-S) \\
\frac{d S}{d t}=\frac{\varphi(t)}{n}(N-S)
\end{array}\right\} .
$$

Вычитая из первого уравнения (2.18) второе, получаем:

$$
\frac{d(N-S)}{d t}=\frac{n-1}{n} \varphi(t)(N-S) \text {. }
$$

Отсюда после интегрирования имеем:

$$
N-S=\left(N_{0}-S_{0}\right) \exp \left[\frac{n-1}{n} \int \varphi(t) d t\right],
$$

где $N_{0}$ и $S_{0}$ - значения параметров в начальный момент времени $t=0$.

Подставив уравнение (2.20) в первое и второе (2.18) после интегрирования, получим решение системы в виде:

$$
\begin{aligned}
& N=\left(N_{0}-S_{0}\right) \int \varphi(t) \exp \left[\frac{n-1}{n} \int \varphi(t) d t\right] d t \\
& \left.S=\frac{1}{n}\left\{\left(N_{0}-S_{0}\right) \int \varphi(t) \exp \left[\frac{n-1}{n} \int \varphi(t) d t\right] d t\right\}\right\} .
\end{aligned}
$$


Рассмотрим несколько примеров эволюции динамической системы для различных функций $\varphi(t)$, полагая, что $n=10$.

Пример 4. Пусть $\varphi(t)=1 / t^{2}, N_{0}=1, S_{0}=0,1$ условных единиц. С учетом этого из (2.21) имеем:

$$
N=\exp (-0,9 / t) ; S=0,1 N
$$

На рисунке 2.4 приведены графики изменения параметров $N$ и $S$, а также $(N-S)$ для этого случая.

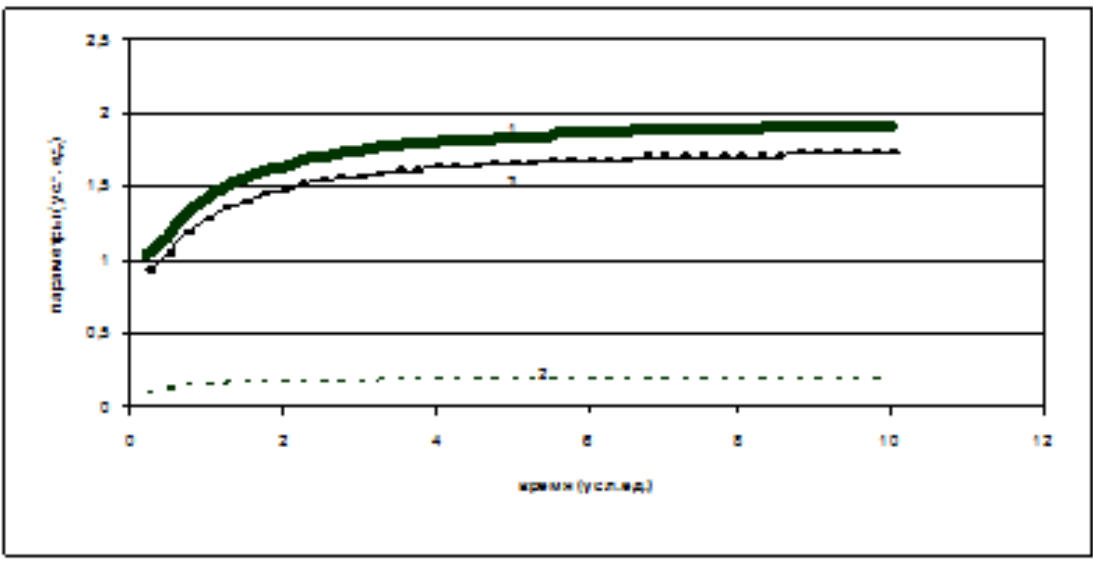

Рис. 2.4. Изменение параметров $N, S$ и $(N-S)$ для функции $\varphi(t)=1 / t^{2}: 1-$ параметр $N$; 2 - параметр $S ; 3$ - полная энергия $(N-S)$

Здесь приведен пример системы, энергия которой в течение некоторого времени нарастает, а затем стабилизируется на определенном уровне. Такая ситуация в геологической среде может наблюдаться, например, при ведении горных работ с последующей их остановкой и консервацией рудника.

Пример 5. Полагаем $\varphi(t)=\cos ^{2} t$ при тех же начальных условиях. В этом случае решение (2.22) представляется в виде:

$$
N=\exp \left[0,9\left(\frac{t}{2}+\frac{\sin 2 t}{4}\right)\right] ; \quad S=0,1 N
$$

На рисунке 2.5 показаны графики изменения соответствующих параметров.

Здесь наблюдается система с неуклонным нарастанием полной энергии. При этом в некоторые моменты времени скорость нарастания параметров и полной энергии замедляется, но в конечном итоге система приходит в критическое состояние. Например, при циклическом ведении горных работ c некоторыми периодами «затишья» энергия деформирования массива то возрастает, то несколько замедляется, но при дальнейшем ведении горных работ может произойти горный удар, или техногенное землетрясение. Изменение порядка ведения горных работ с целью предотвращения катастрофы с математической точки зрения означает изменение вида функции $\varphi(t)$. 


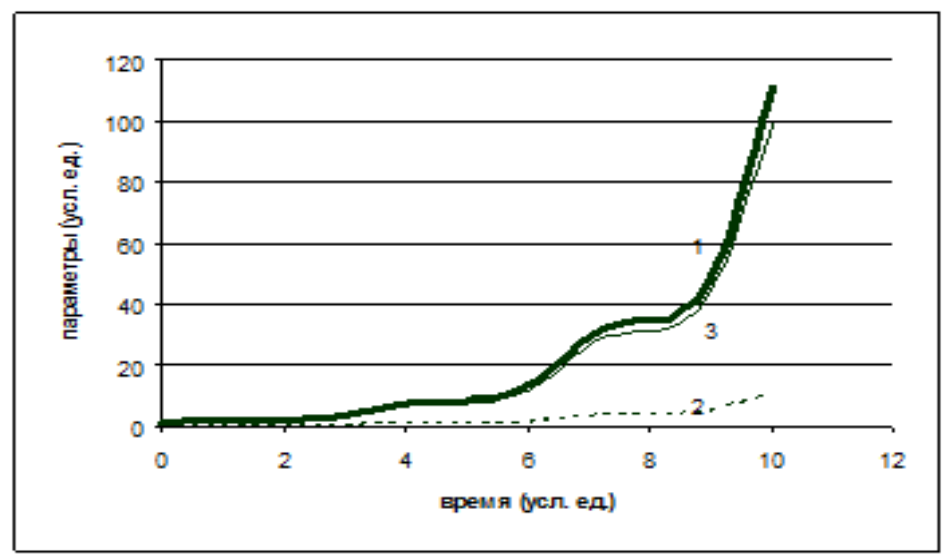

Рис. 2.5. Изменение параметров $N, S$ и $(N-S)$ для функции $\varphi(t)=\cos ^{2} t: 1-$ параметр $N$; 2 - параметр $S ; 3$ - полная энергия $(N-S)$

Пример 6. Рассмотрим случай динамической системы с обострением. Пусть $\varphi(t)=1 /\left(t_{0}-t\right)$, где $t_{0}-$ время обострения, которое для конкретности расчетов полагаем равным 5 условным единицам. Выполнив расчеты по формулам (2.21) при прежних начальных условиях, получим:

$$
N=\left(\frac{5}{5-t}\right)^{0 . .9}, \quad S=0,1 N
$$

На рисунке 2.6 приведены графики зависимостей (2.24) и величины $(N-S)$.

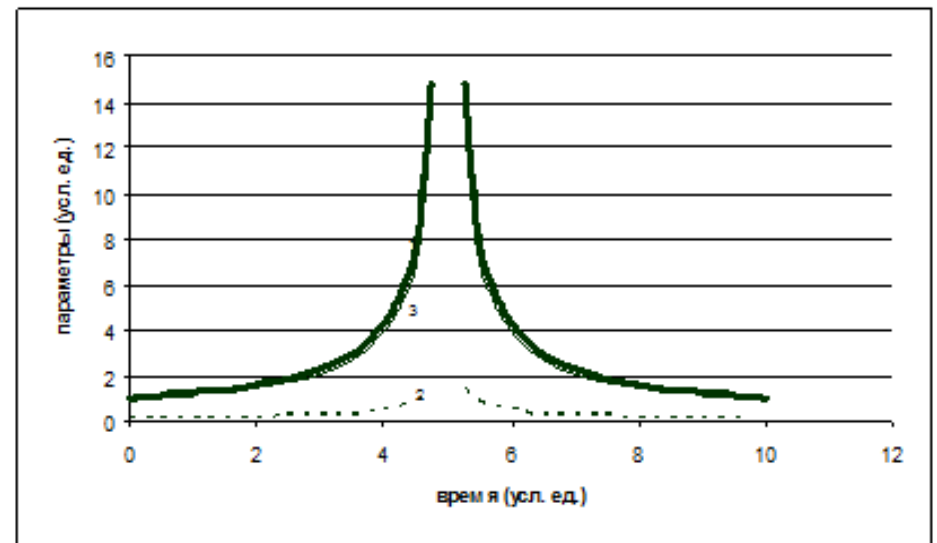

Рис. 2.6. Изменение параметров $N, S$ и $(N-S)$ для функции $\varphi(t)=1 /\left(t_{0}-t\right): 1-$ параметр $N$; 2 - параметр $S ; 3$ - полная энергия $(N-S)$

Отсюда видно, что при $t \rightarrow t_{0}=5$ и слева, и справа скорости роста параметров системы стремятся к бесконечности. В первом случае (при стремлении слева) происходит рост параметров, а после времени обострения снижение. Такая ситуация в массиве горных пород может наблюдаться в некотором объеме, например, в окрестности трещин при разрушении барьера, разделяющего их. 


\section{3. Модель эволюции энергии в геологической среде природно-технических систем}

Пусть эволюция НДС некоторого участка массива горных пород (ПТС) зависит от ее энергии деформирования, которая накапливается и диссипирует. Рассмотрим систему уравнений:

$$
\left.\begin{array}{l}
\frac{d N}{d t}=\varphi_{1}(N-S)+f_{1}(t, N, S) \\
\frac{d S}{d t}=\varphi_{2}(N-S)+f_{2}(t, N, S)
\end{array}\right\},
$$

где $N$ - накопление энергии деформирования; $S-$ диссипация; $(N-S)-$ полная энергия деформирования; $\varphi_{1}, \varphi_{2}-$ некоторые функции времени $t$; $f_{1}, f_{2}$ - функции внешнего силового воздействия.

Вычтя из первого уравнения (2.25) второе, получим:

$$
\frac{d(N-S)}{d t}=\left(\varphi_{1}-\varphi_{2}\right)(N-S)+\left(f_{1}-f_{2}\right)
$$

Если обозначить $(N-S)=W,\left(\varphi_{1}-\varphi_{2}\right)=p,\left(f_{1}-f_{2}\right)=q$, то (2.26) можно представить в виде:

$$
\frac{d W}{d t}=p W+q
$$

Это линейное дифференциальное уравнение, решение которого представляется зависимостью:

$$
W=e^{\int p d t}\left(C+\int q e^{-\int p d t} d t\right) .
$$

Исследуем несколько частных случаев. Из (2.28) получаем:

$$
W=u+u v,
$$

где $u=C e^{\int p d t}, v=\frac{1}{C} \int q e^{-\int p d t} d t$. Следовательно, $e^{\int p d t}=\frac{u}{C}$, или $\int p d t=\ln \frac{u}{C}$ после интегрирования последнего выражения получаем: $p=\frac{1}{u} \frac{d u}{d t}$.

Будем считать, что функция $\boldsymbol{u}$ пропорциональна времени плюс некоторая функция времени, то есть:

$u=t+g(t)$.

При этом имеем:

$$
p=\frac{1+\dot{g}}{t+g} \text {. }
$$


Здесь и далее точка над функцией означает производную по времени.

Полагаем также, что функция $v=\frac{e^{-g}}{C}$, тогда $v=\frac{1}{C} \int q e^{-\int p d t} d t=$ $\int \frac{q}{t+g} d t=\frac{e^{-g}}{C} \cdot$ Отсюда находим:

$$
q=-(t+g) i \quad .
$$

Таким образом, окончательно:

$$
W=(t+g)\left(1+e^{-g}\right) \text {. }
$$

Рассмотрим ПТС, энергия которой с начала ее существования и до последнего момента имела «взлеты» и «падения».

Пусть функции, входящие в (2.25), имеют вид:

$$
\left\{\begin{array}{l}
\varphi_{1}=\frac{1}{t+\arcsin (\sin t)} ; \\
\varphi_{2}=\frac{-\cos t}{\sqrt{1-\sin ^{2} t}(t+\arcsin (\sin t))} \\
f_{1}=t \frac{\cos t}{\sqrt{1-\sin ^{2} t}} e^{-\left(\frac{\pi}{2} \arcsin (\sin t)\right)} ; \\
f_{2}=-\arcsin (\sin t) \frac{\cos t}{\sqrt{1-\sin ^{2} t}} e^{-\left(\frac{\pi}{2}+\arcsin (\sin t)\right)}
\end{array} .\right.
$$

Тогда, после преобразований приведенных выше уравнений, получаем:

$$
W=(t+\arcsin (\sin t))\left[1+\exp \left(-\frac{\pi}{2}-\arcsin (\sin t)\right)\right] .
$$

График этой зависимости представлен на рисунке 2.7.

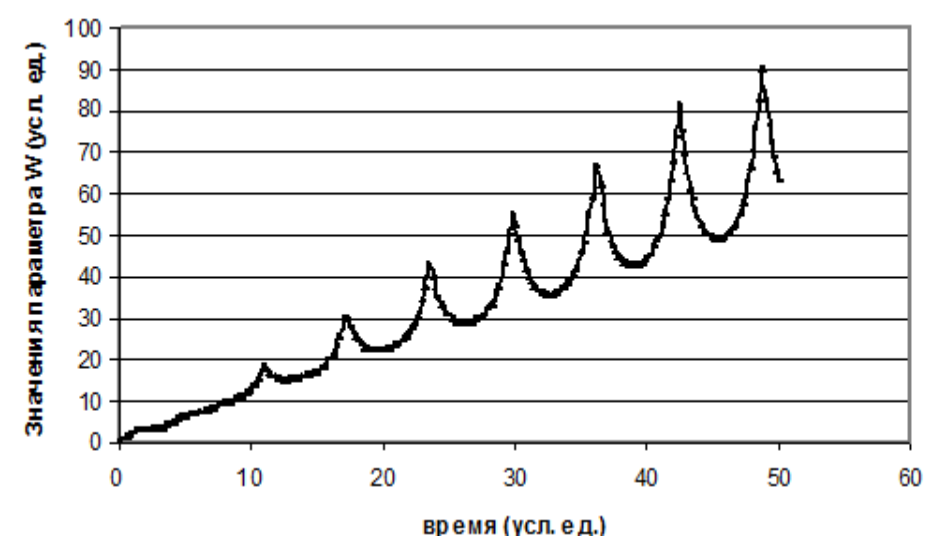

Рис. 2.7. Периодическое изменение энергии ПТС 
Если при каком-то значении времени $t_{0}$ выражение (2.35) дополнить зависимостью

$$
W_{1}=\left[\left(2 t_{0}-t\right)+\arcsin (\sin t)\right][1+\exp (-(\pi / 2)-\arcsin (\sin t))],
$$

то график суммарного выражения (2.35) и (2.36) будет иметь вид, приведенный на рисунке 2.8 .

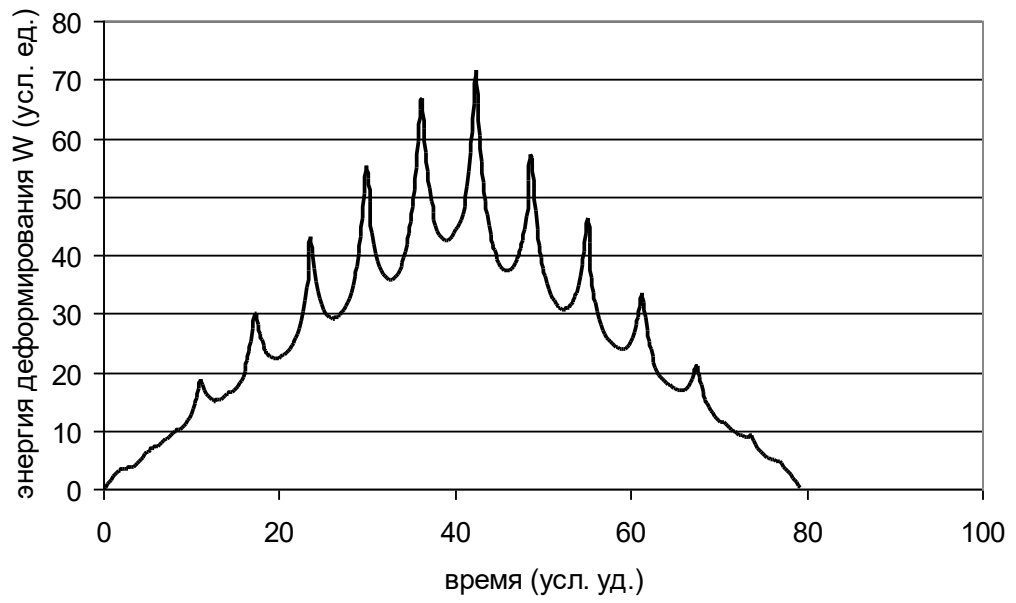

Рис. 2.8. График изменения удельной энергии деформирования ПТС $\mathrm{c}$ «взлетами» и «падениями»

Пример 7. Пусть функции, входящие в (2.25), имеют вид:

$$
\begin{aligned}
& \varphi_{1}=1+\frac{1}{\pi}+\sin t \quad \varphi_{2}=\frac{2}{\pi}\left(\cos \frac{2 t}{3}+\cos \frac{4 t}{15}\right), \\
& f_{1}=-t \dot{g} \exp (-g) \quad f_{2}=g \dot{g} \exp (-g) g=\varphi_{1}-\varphi_{2} .
\end{aligned}
$$

После необходимых преобразований (2.37) получаем:

$$
\begin{aligned}
& u=t+\left(1,31831+0,5 \sin t-\frac{2}{\pi}\left(\cos \frac{2 t}{3}+\cos \frac{4 t}{15}\right),\right. \\
& v=\exp \left(\frac{\pi}{2}-\left(1,31831+0,5 \sin t-\frac{2}{\pi}\left(\cos \frac{2 t}{3}+\cos \frac{4 t}{15}\right)\right)\right), \\
& W=u(1+v) .
\end{aligned}
$$

График этой функции представлен на рисунке 2.9, на котором видно, что энергия системы имеет различные величины подъемов и падений в зависимости от способов накопления и диссипации ее. Эта зависимость напоминает экспериментальные данные по изменению акустической эмиссии при нагружении образца горных пород [82], а также характер изменения энергии в геологической среде горнотехнической системы в процессе развития горных работ. 


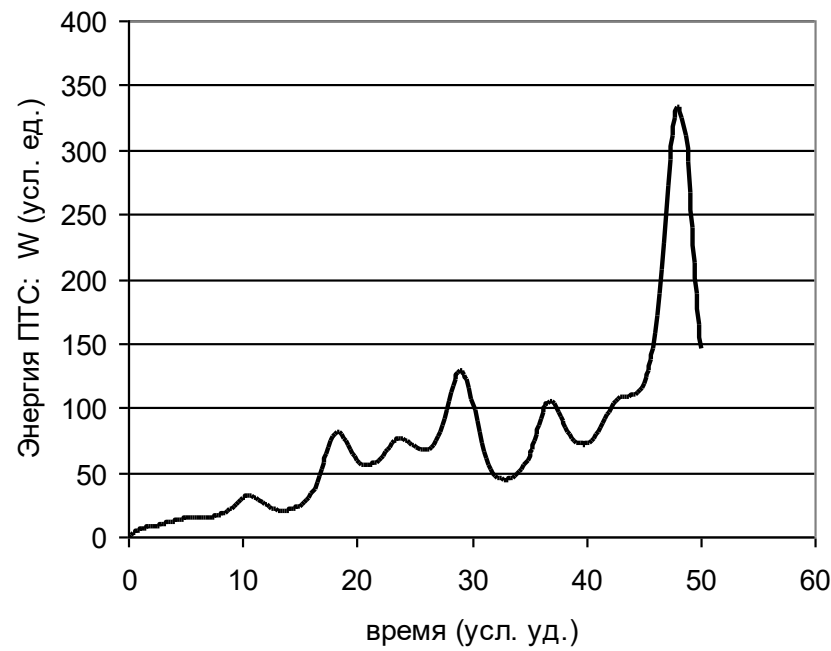

Рис. 2.9. Зависимость $W(t)$ по (2.38)

\section{4. Сейсмичность массива горных пород при ведении массовых взрывов}

Закономерность изменения энергии сейсмических событий в массиве горных пород после проведения в нем массового взрыва представим дифференциальным уравнением:

$$
\frac{d S}{d t}+b(t) S=F(t)
$$

где $S-$ энергия сейсмических событий; $b(t)-$ коэффициент пропорциональности; $F(t)$ - функция энергетического отклика массива на массовый взрыв, выражающаяся в виде серии сейсмических событий (образование новых трещин, подвижка блоков друг относительно друга и т. п.). Представим ее следующим образом:

$$
\begin{aligned}
& F(t)=\sum_{k=1}^{n} a_{k} e^{-\delta \beta_{k}\left(t-t_{k}\right)} \\
& \delta=\left\{\begin{array}{llll}
0 & \text { при } & t \prec t_{k}, & 1
\end{array} \text { при } t \geq t_{k} .\right.
\end{aligned}
$$

здесь $a_{k}, \beta_{k}, t_{k}$ начальная амплитуда, декремент затухания и момент времени $k$-го сейсмического события, являющегося откликом массива на массовый взрыв соответственно.

Подставив (2.40) в (2.39), после интегрирования получим:

$$
S=e^{-\int b(t) d t}\left(\sum_{k=1}^{n} \int a_{k} e^{-\delta \beta_{k}\left(t-t_{k}\right)} e^{\int b(t) d t} d t+C\right) .
$$


В случае, когда $b=$ const (2.41) имеет вид:

$$
S=C_{0} e^{-b t}+\sum_{k=1}^{n} \frac{a_{k}}{b-\delta \beta_{k}} e^{-\delta \beta_{k}\left(t-t_{k}\right)} .
$$

Величина $C_{0}$, характеризующая начальный сейсмический эффект после массового взрыва, зависит не только от энергии взрыва, места взрыва, но и от состояния массива горных пород (напряжений, наличия трещин, прочности и многих других факторов).

Рассмотрим примеры.

На рисунке 2.10 показано изменение сейсмической энергии после массового взрыва, произведенного на гор. +252 м на Кировском руднике $\mathrm{AO}$ «Апатит» (график 1) и его аппроксимация функцией вида (2.42) - график 2, где $C_{0}=52$ МДж, $b=0,1755$, а величины $a_{k}$ и $\beta_{k}$ для различных значений времени $t_{k}$ приведены в таблице 2.1

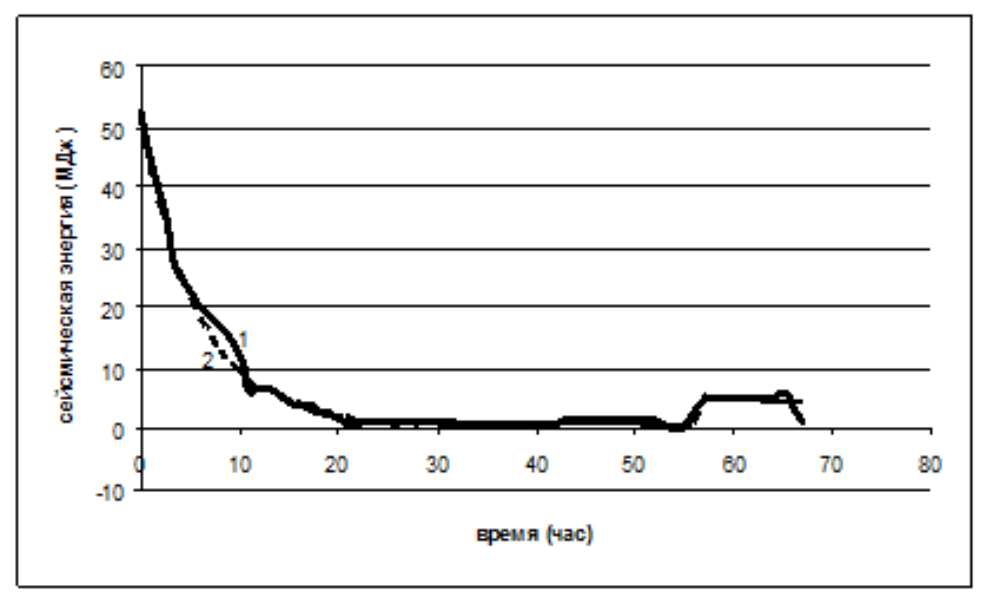

Рис. 2.10. Изменение сейсмической энергии после массового взрыва на гор. +252 м Кировского рудника АО «Апатит» 09.04.1989 г.

Таблица 2.1

Значения параметров $a_{k}$ и $\beta_{k}$ для графика 2 на рисунке 2.10

\begin{tabular}{|c|r|r|r|r|r|r|}
\hline$t_{k}$ (чac) & 13 & 25 & 27 & 29 & 36 & 41 \\
\hline$a_{k}$ & 0,02 & 0,02 & 0,02 & 0,02 & 0,02 & 0,02 \\
\hline$\beta_{k}$ & 0,1605 & 0,06 & 0,1 & 0,08 & 0,02 & 0,02 \\
\hline$t_{k}$ (4ac) & 43 & 44 & 45 & 46 & 47 & 57 \\
\hline$a_{k}$ & 0,02 & 0,02 & 0,02 & 0,02 & 0,02 & 0,75 \\
\hline$\beta_{k}$ & 0,155 & 0,07 & 0,02 & 0,02 & 0,02 & 0,001 \\
\hline
\end{tabular}

На рисунке 2.11 приведены аналогичные данные для другого массового взрыва. Здесь $C_{0}=36$ МДж, $b=0,18$, а параметры $a_{k}$ и $\beta_{k}$ для различных значений времени $t_{k}$ приведены в таблице 2.2 . 


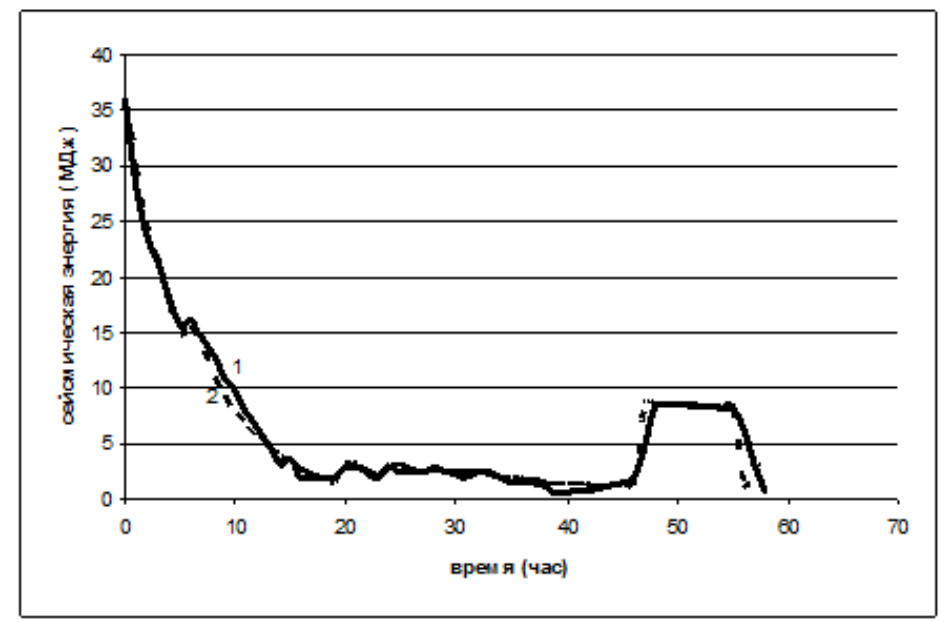

Рис. 2.11. Изменение сейсмической энергии после массового взрыва на гор. +252 м Кировского рудника АО «Апатит» 06.12.1987 г.

Таблица 2.2

Значения параметров $a_{k}$ и $\beta_{k}$ для графика 2 на рисунке 2.11

\begin{tabular}{|c|r|r|r|r|r|r|r|r|}
\hline$t_{k}$ (чac) & 6 & 20 & 24 & 25 & 28 & 32 & 47 & 56 \\
\hline$a_{k}$ & 0,0175 & 0,06 & 0,0375 & 0,0895 & 0,0895 & 0,0025 & 1,3125 & 0,21 \\
\hline$\beta_{k}$ & 0,175 & 0,15 & 0,15 & 0,001 & 0,001 & 0,175 & 0,005 & 0,21 \\
\hline
\end{tabular}

На рисунке 2.12 показано изменение сейсмической энергии после массового взрыва на гор. +252 м Кировского рудника 23.10.2011 г. $C_{0}=30,867$ МДж, $b=2,127$, а параметры $a_{k}$ и $\beta_{k}$ для различных значений времени приведены в таблице 2.3 .

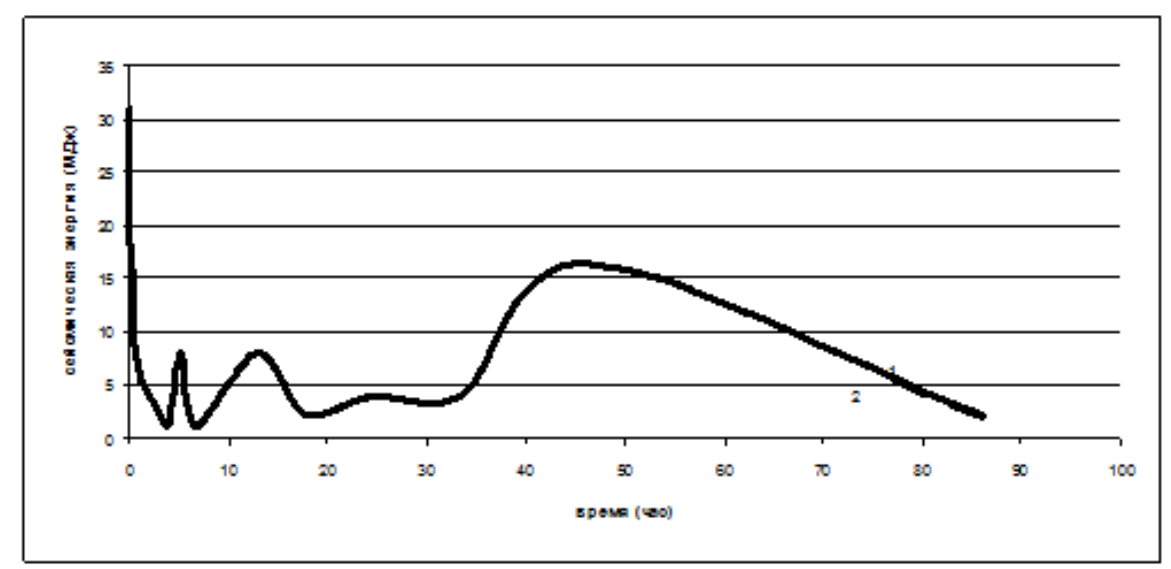

Рис. 2.12. Изменение сейсмической энергии после массового взрыва на гор. +252 м Кировского рудника АО «Апатит» 23.10.2011 г. 
Значения параметров $a_{k}$ и $\beta_{k}$ для графика 2 на рисунке 2.12

\begin{tabular}{|c|r|r|r|r|r|}
\hline$t_{k}$ (час) & 3,758 & 4,135 & 5,092 & 6,671 & 12,917 \\
\hline$a_{k}$ & 144,857 & 226,857 & 1132,143 & 105,571 & 1170,286 \\
\hline$\beta_{k}$ & 2,12 & 2,12 & 2,12 & 2,12 & 2,12 \\
\hline$t_{k}$ (час) & 17,505 & 24,52 & 33,39 & 46,258 & 86,117 \\
\hline$a_{k}$ & 292,571 & 585,143 & 584,857 & 2340 & 292,571 \\
\hline$\beta_{k}$ & 2,12 & 2,12 & 2,12 & 2,12 & 2,12 \\
\hline
\end{tabular}

По величине энергии, высвободившейся в результате сейсмического события, можно определить размеры разрыва (трещины), образовавшейся при этом. Если воспользоваться зависимостью [83]

$$
\operatorname{LgL}=0,244 \operatorname{LgS}-2,266 \text {, }
$$

где $L$ - длина разрыва, $S$ - величина сейсмической энергии, то для максимальных значений сейсмической энергии равных 1 МДж, какие наблюдаются в двух первых приведенных выше примерах, величина разрыва получается равной примерно (15-16) см. На рисунках 2.10-2.12, в конце эксперимента наблюдается значительное повышение сейсмической энергии. Это, очевидно связано с тем, что после серии мелких сейсмических событий (как результат их суммарного влияния) образуется более крупный разрыв (трещина). В первом случае получается $L=23,3$ см, во втором $-L=25,8$ см.

Аналогичным образом можно описать афтершоковые явления, происходящие после сильного землетрясения. На рисунке 2.13 приведена аппроксимация магнитуд афтершоков, происходивших в первые 4 ч после землетрясения 25 марта 2002 г. в Таджикистане [84]. Всего менее чем за двое суток произошло 49 афтершоков.

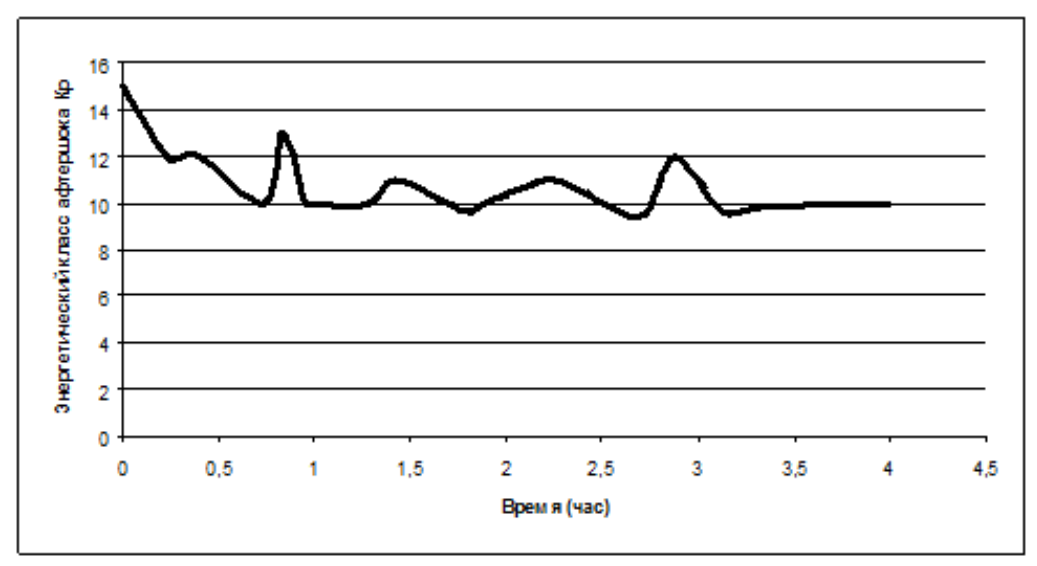

Рис. 2.13. Энергетический класс афтершоков (Кp) в первые 4 ч после землетрясения в Таджикистане 25марта 2002 г. [84] 
Результаты расчетов по формуле:

$$
K p=C_{0} e^{-b t}+\sum_{k=1}^{n} a_{k} \exp \left(-\delta \beta_{k}\left(t-t_{k}\right)\right)
$$

где $C_{\mathrm{o}}=15 ; b=1,5 ;$ величины $a_{k}$ и $\beta_{k}$ для различных моментов времени приведены в таблице 2.4 .

Таблица 2.4

Значения параметров $a_{k}$ и $\beta_{k}$ для графика 2 на рисунке 2.13

\begin{tabular}{|c|r|r|r|r|r|r|}
\hline$t_{k}$ (час) & 0,233 & 0,4 & 0,733 & 0,833 & 0,983 & 1,283 \\
\hline$a_{k}$ & 1,43 & 2,65 & 2,73 & 4,39 & 0,72 & 4,2 \\
\hline$\beta_{k}$ & 1,5 & 1,5 & 1,5 & 4 & 0,1 & 0,1 \\
\hline$t_{k}$ (час) & 1,417 & 1,7 & 2,25 & 2,883 & 3,35 & 4 \\
\hline$a_{k}$ & 2,15 & 0,73 & 2,84 & 3,15 & 1,53 & 1,7 \\
\hline$\beta_{k}$ & 0,1 & 0,1 & 0,75 & 3,75 & 0,1 & 0,1 \\
\hline
\end{tabular}

Необходимо отметить, что расчетные и фактические данные в последних двух примерах совпадают с точностью до второго знака после запятой.

\section{5. Влияние крупноблочного строения и рельефа на напряженное состояние Хибинского и Ловозерского массивов}

В работе [10] рассмотрено напряженное состояние массивов горных пород Кольского полуострова с учетом главных глубинных разломов, прослеживающихся на глубину до 30-40 км. Помимо глубинных разломов, разъединяющих крупные геоблоки, верхняя часть земной коры Балтийского щита разбита более мелкими разломами, глубина которых значительно меныше первых. Так, Б. И. Кошечкин [85] указывает, что «ряд локально развивающихся на голоценовом этапе блоковых структур (Печенгские, Хибинские, Ловозерские тундры) не находят связи с элементами глубинного строения на рассматриваемых уровнях (10-15 км), что, естественно, объясняется их принадлежностью к элементам структуры более высоких горизонтов земной коры». Тем не менее эти образования, особенно сохранившие сейсмодинамическую активность, представляют практический и первоочередной интерес для геомеханики и горного дела. В сравнении с древними глубинными разломами, находящимися в большинстве своем в состоянии тектонического покоя, приповерхностные тектонические элементы имеют рельефообразующее значение, подвержены более интенсивным движениям, в том числе из-за наличия дополнительной степени свободы в виде земной поверхности, отвечают за блочное строение и динамику смещений и деформаций (рис. 2.14). Современная блочная структура верхней части земной коры определяется преимущественно разрывными нарушениями небольшой и средней глубины распространения (от десятков метров до первых километров). При этом дешифрированные линеаменты могут достигать значительной протяженности на поверхности, так как трещиноватость носит системный характер, и их суммарная длина формируется за счет трещин близкой ориентировки. Таким образом, большая протяженность линеамента не всегда свидетельствует о глубинном статусе разлома. С другой стороны, корректно дешифрированные разрывные нарушения характеризуют область практической деятельности горнорудных предприятий и поэтому максимально полезны им. 


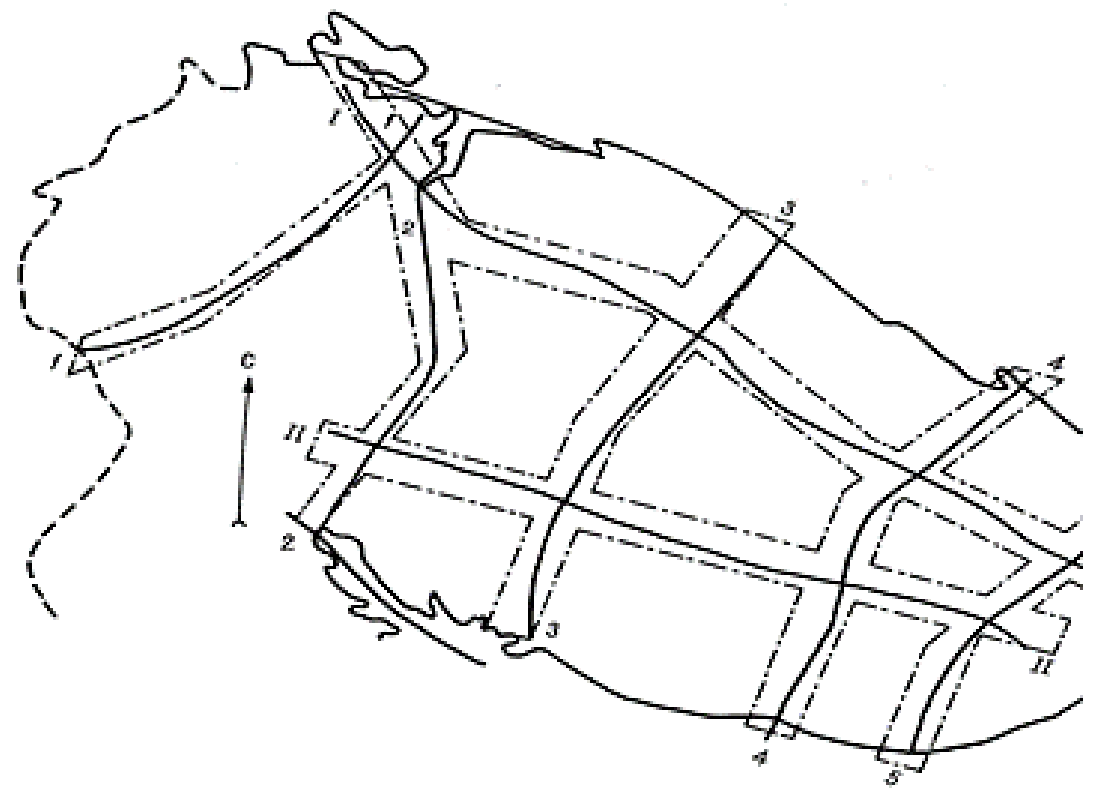

Рис. 2.14. Схема наиболее протяженных разрывных нарушений Кольского региона, выделенных по дешифрированию рельефа

Хибинские и Ловозерские горные системы представляют собой вскрытые эрозией девонские интрузии щелочно-ультраосновных пород, расположенные в срединном поясе гор Кольского полуострова [86]. Положение обеих интрузий в тектонической структуре северо-востока Фенноскандинавского щита, установленной по геологическим и геофизическим данным [87], не обнаруживает связи с тектоническими границами основных геоблоков. По геофизическим данным, западный контакт Хибинской интрузии в целом падает к востоку под углом $\sim 30^{\circ}$, а восточный - к западу под углом $\sim 70-80^{\circ}$, тогда как для Ловозерской интрузии при таких же направлениях падения контактов углы падения составляют $\sim 35^{\circ}$ и $\sim 75-85^{\circ}$ соответственно [88]. В целом обе интрузии имеют воронкообразную форму со сложной изгибающейся поверхностью контакта при погружении оси «воронок» к востоку под углом $\sim 45^{\circ}$ для Хибин и $\sim 60^{\circ}$ для Ловозера. Эти интрузии принадлежат к массивам центрального типа с хорошо выраженными кольцевыми структурами, образованными внедрением разных интрузивных фаз и осложненными радиальными разломами $[89,90]$. В современном рельефе к западу от Хибинской горной системы располагается оз. Имандра, к востоку от Ловозерской - оз. Ловозеро, а сами системы разделены оз. Умбозеро, глубина которого достигает 60-115 м. Осевые линии озер совпадают с протяженными разрывными структурами субмеридионального простирания (рис. 2.15). Влияние кольцевых геологических структур на напряженное состояние пород Хибинского массива исследовано в работах $[10,91]$. В Хибинском и Ловозерском интрузиях расположены крупнейшие месторождения апатитовых и редкометалльных руд [86], поэтому с практической точки зрения особый интерес представляют закономерности распределения современных горизонтальных тектонических напряжений с учетом реального геологического и крупноблокового строения интрузий. 


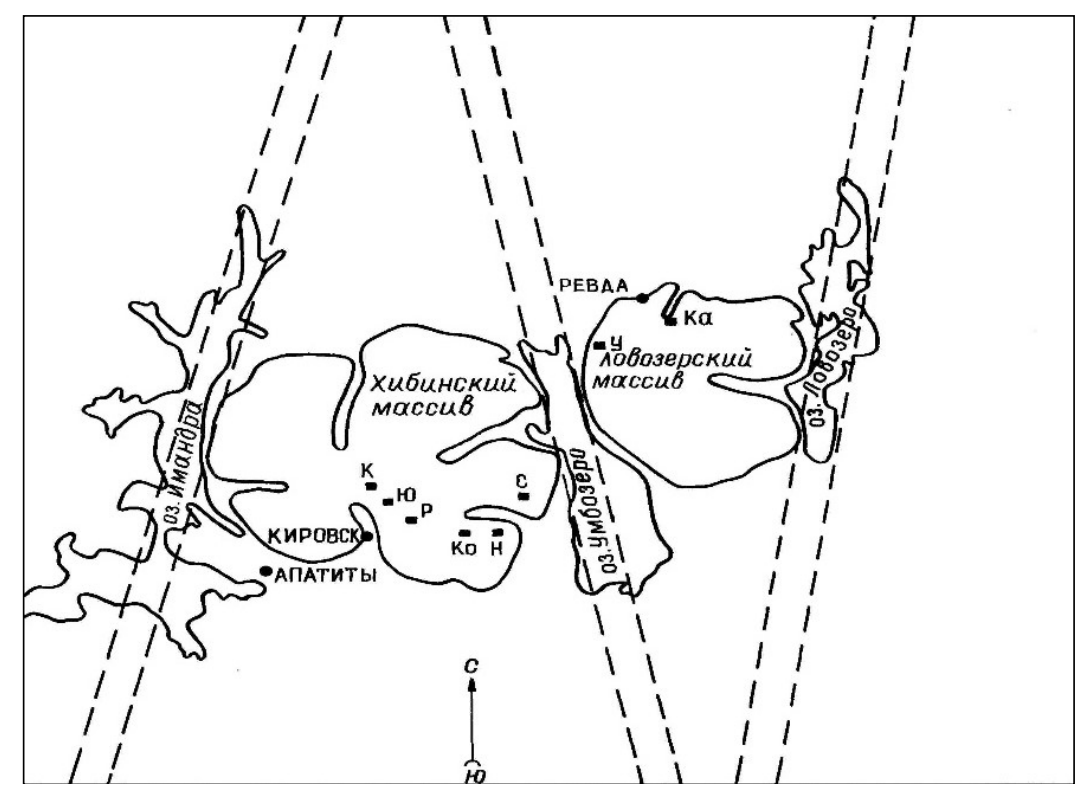

Рис. 2.15. Хибинский и Ловозерский массивы; разделяющие их озера и трассы протяженных нарушений; - - действующие рудники

Окружающие Хибинский и Ловозерский массивы породы представлены гнейсами, для которых среднее значение модуля упругости $E=5,10^{4}$ МПа, а коэффициента Пуассона $v=0,25$. Разломные зоны, как правило, характеризуются системами оперяющих и субпараллельных трещин, о чем свидетельствует изрезанность береговых линий озер. В связи с этим породы разломных зон, имеющих большую нарушенность сплошности, обладают меньшей интегральной несущей способностью. При расчетах модуль упругости пород в разломных зонах принят равным $E=5,10^{3}$ МПа, $v=0,3$. Породы западной части Хибинского массива представлены хибинитами, для которых $E=4,210^{4} \mathrm{MПа,} v=0,25$; восточная часть Хибинского массива сложена более прочными породами (рисчорриты, йолит-уртиты, фойяиты), для которых приняты средние значения $E=7,10^{4} \mathrm{MПа,} v=0,2$. Для пород Ловозерского массива (луявриты, фойяиты, уртиты) значения модуля Юнга и коэффициента Пуассона в расчетах приняты такими же, как и для восточной части Хибин.

В качестве граничных условий использованы результаты предыдущих исследований [92], согласно которым для этого региона $T_{x}=0,82 T, T_{y}=0,87 T$, где $T=-50$ МПа - величина тектонических напряжений, действующих на границе Евразийской литосферной плиты. Необходимо отметить, что рассматриваемые в этой задаче граничные условия, геометрические формы разломных зон и значения параметров физико-механических свойств их пород осреднены. Кроме того, здесь не учтены и такие факторы, как динамическое взаимодействие блоков (движение их друг относительно друга). Однако даже такая картина квазистатического состояния Хибинского и Ловозерского массивов, не учитывающая нарушения более мелкого порядка, дает возможность сделать вполне определенные выводы об особенностях формирования тектонического напряженного состояния руд и пород на эксплуатируемых в настоящее время месторождениях. 
На рисунке $2.16 a, \sigma$ приведены изолинии относительных главных напряжений $\sigma_{1} / T$ и $\sigma_{2} / T$, полученные при решении задачи методом граничных элементов в двухмерной постановке для горизонтального разреза на глубине, исключающей влияние рельефа (2-3 км). По результатам расчетов можно указать на следующие основные закономерности распределения напряжений в Хибинском и Ловозерском массивах.

1. В основной части Хибинского массива, имеющего большую блочнность и соответственно различия упругих свойств пород по сравнению с Ловозерским, диапазон изменения напряжений $\sigma_{1}$ гораздо шире $\left(\sigma_{1}=(0,6-1,1) T\right)$, чем в Ловозерском $\left(\sigma_{1}=(0,7-0,95) T\right)$.

2. В разломных зонах величины напряжения $\sigma_{1}$ значительно меньше, чем в окружающих массивах и изменяются от $0,35 T$ до $0,5 T$.

3. За пределами Хибинского и Ловозерского массивов меньшие по величине сжимающие напряжения $\sigma_{1}$ находятся в диапазоне значений $(0,8-0,85) T$.

4. В районе действующих рудников Хибинского массива Кировского (К), Юкспорского (Ю) и Расвумчоррского (Р) $\sigma_{1} \approx 0,95 T$; Коашвинского (Ко) и Ньюорпахкского $(\mathrm{H}) \sigma_{1} \approx 0,8 T$; Суолуайвского $(\mathrm{C}) \sigma_{1} \approx 0,72 T$. Для рудников Ловозерского массива У мбозерского (У) и «Карнасурта» $\left(\right.$ Ка) $\sigma_{1} \approx 0,8 T$.

5. Максимальные по величине сжимающие напряжения б и Ловозерском массивах находятся в пределах от $0,8 T$ до 1,4T и выше, причем в западной части Хибин они не превышают $T$, а в центре восточной части они достигают значений $1,8 T$. В центральной части Ловозерского массива также $\sigma_{2} \approx 1,8 T$.

6. В разломных зонах $\sigma_{2}$ изменяются от $0,6 T$ до $1,0 T$, имея преимущественное значение $0,8 T$.

7. За пределами Хибинского и Ловозерского массивов в большинстве случаев $\sigma_{2}=(0,85-0,95) T$ и лишь южнее Ловозерского массива $\sigma_{2}=(0,9-1,1) T$.

8. На участках действующих рудников напряжения $\sigma_{2}$ имеют следующие значения (табл. 2.5): Кировского - 1,18T; Юкспорского - 1,15T; Расвумчоррского $-1,11 T$; Коашвинского $-1,02 T$; Ньюорпахкского $-0,96 T$; Суолуайвского - 0,93T; Умбозерского - 1,16T; «Карнасурта» - 1,0T.

На величины напряжений и характер их распределения существенное влияние оказывает рельеф дневной поверхности, так как отрабатываемые месторождения располагаются на глубине $+250-+500$ м при превышении гор над уровнем дна долин до 800-1000 м [8]. В связи с этим характер распределения горизонтальных тектонических напряжений мы будем исследовать в зависимости от рельефа. Для этих целей рассмотрим вертикальные сечения по простиранию и вкрест простирания рудных тел основных месторождений Хибинского и Ловозерского массивов. На рисунках 2.17, 2.18 показано распределение напряжений в зависимости от рельефа по простиранию и вкрест простирания рудного тела в разрезах Кировского, Юкспорского и Расвумчоррского апатитовых месторождений в Хибинах. Аналогичные данные получены для остальных месторождений.

На рисунках видно, что в нагорных участках, где располагаются действующие рудники, коэффициент концентрация тектонических напряжений меньше единицы.

Абсолютные значения главных тектонических напряжений для рассматриваемых месторождений с учетом этих двух факторов (блочного строения и рельефа) можно рассчитать по формуле: $\sigma_{i}=K_{1 i} K_{2 i} T$, где $i=1,2 ; K_{1 i}, K_{2 i}$ - коэффициенты концентрации напряжений от влияния блочности и рельефа соответственно. В таблице 2.5 приведены значения коэффициентов концентрации, а также величины расчетных и измеренных напряжений. 


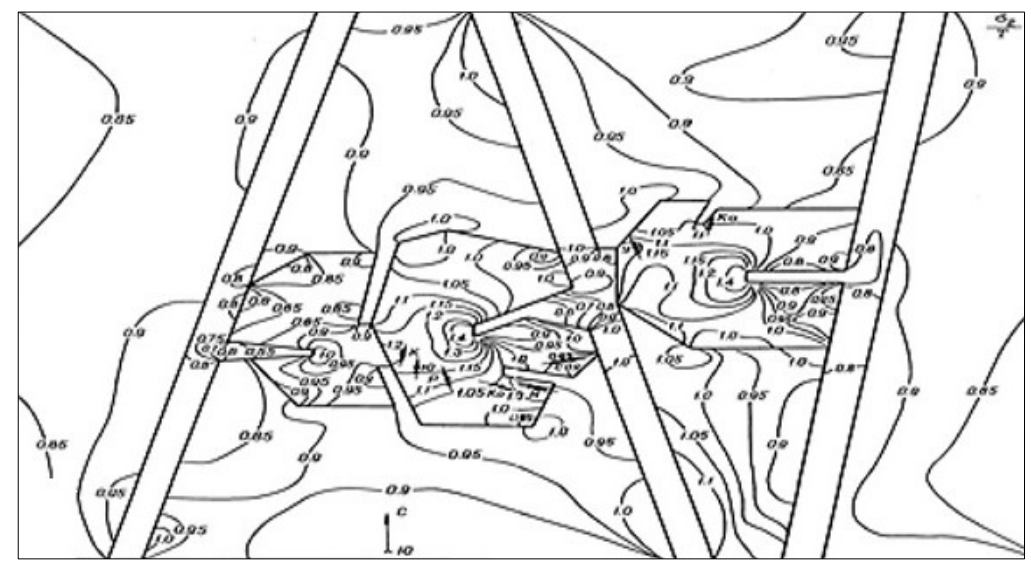

$a$

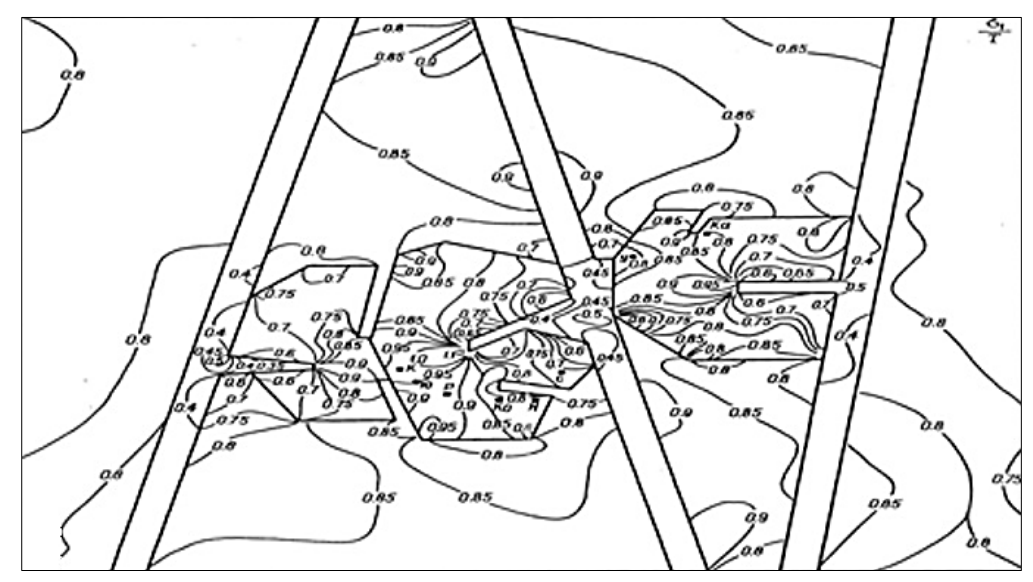

$\sigma$

Рис. 2.16. Распределение минимальных (a) и максимальных (б) горизонтальных тектонических напряжений

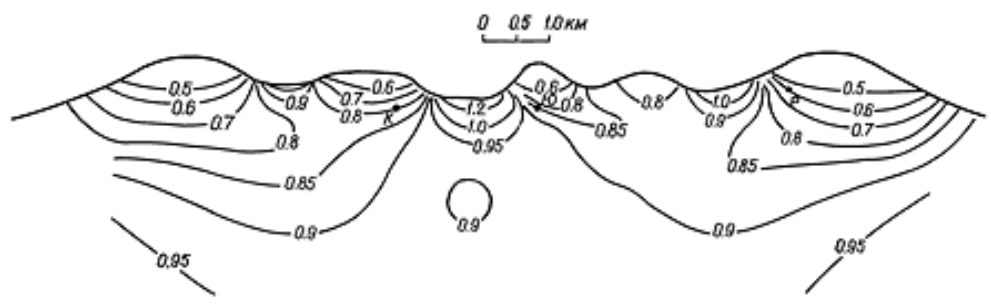

по просткранкю рудного тета Кнровского, Юкспорского и Расвумчоррского руднкков

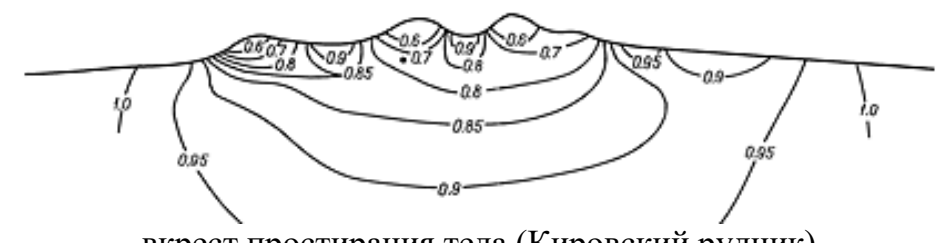

вкрест простирания тела (Кировский рудник)

Рис. 2.17. Распределение тектонических напряжений в зависимости от рельефа в районе Хибинских апатитовых месторождений 


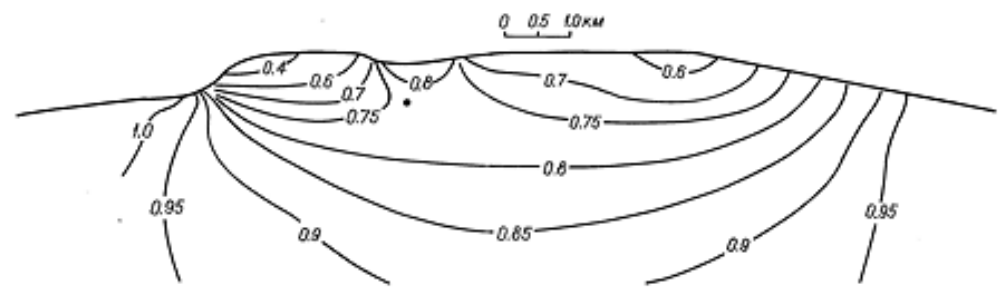

Юкспорский рудник

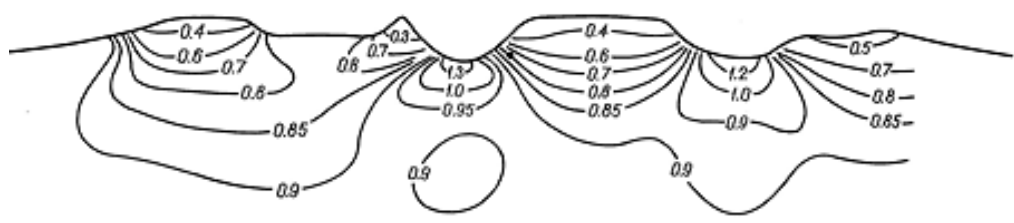

Расвумчоррский руднкк

Рис. 2.18. Распределение тектонических напряжений в зависимости от рельефа вкрест простирания рудного тела

Таблица 2.5

Расчетные и измеренные величины напряжений на действующих рудниках Хибинского и Ловозерского массивов

\begin{tabular}{|c|c|c|c|c|c|c|c|c|c|}
\hline Рудни & \multirow{2}{*}{$K_{11}$} & \multirow{2}{*}{$K_{21}$} & \multirow{2}{*}{$K_{12}$} & \multirow{2}{*}{$K_{22}$} & \multicolumn{3}{|c|}{ Расчетные } & \multicolumn{3}{|c|}{ Измеренные } \\
\cline { 7 - 11 } & & & & & $\sigma_{1}, \mathrm{MПа}$ & $\sigma_{2}, \mathrm{MПа}$ & $\sigma_{1}, \mathrm{MПа}$ & $\sigma_{2}, \mathrm{MПа}$ & $H, \mathrm{M}$ \\
\hline $\mathrm{K}$ & 0,98 & 1,18 & 0,75 & 0,8 & 36,8 & 47,3 & $6-42$ & $15-60$ & $200-450$ \\
\hline Ю & 0,93 & 1,15 & 0,77 & 0,85 & 36,0 & 48,8 & $4-40$ & $10-50$ & $100-480$ \\
\hline $\mathrm{P}$ & 0,92 & 1,11 & 0,7 & 0,8 & 32,0 & 44,5 & $4-48$ & $20-80$ & $150-640$ \\
\hline $\mathrm{Ko}$ & 0,81 & 1,02 & 0,7 & 0,82 & 28,4 & 41,8 & & & \\
\hline $\mathrm{H}$ & 0,82 & 0,96 & 0,8 & 0,85 & 32,8 & 40,8 & & & \\
\hline $\mathrm{C}$ & 0,73 & 0,93 & 0,8 & 0,85 & 29,2 & 39,5 & & & \\
\hline $\mathrm{У}$ & 0,78 & 1,16 & 0,91 & 0,95 & 35,5 & 55,0 & $15-25$ & 50 & 300 \\
\hline $\mathrm{Ka}$ & 0,81 & 1,00 & 0,85 & 0,92 & 34,5 & 45,8 & $10-25$ & $20-50$ & $250-400$ \\
\hline
\end{tabular}

Сравнительный анализ расчетных и измеренных данных показывает удовлетворительное совпадение величин главных напряжений.

Направление действия максимальных сжимающих напряжений в большей степени зависит от более мелких структур, чем рассматриваемые здесь. В работе [91] показано, что в Хибинском массиве ориентация главных напряжений зависит от кольцевых геологических структур. В частности, в апатитовой дуге максимальные сжимающие напряжения действуют вкрест простирания рудного тела, а во вмещающих породах, обладающих большими значениями модуля упругости, они действуют вдоль кольцевых геологических структур.

Таким образом, в Хибинском и Ловозерском массивах за счет их блочного строения и различия упругих свойств горных пород концентрация минимальных по величине сжимающих горизонтальных тектонических напряжений $\sigma_{1}$ изменяется от $0,6 T$ до $1,1 T$, а максимальных $\sigma_{2}-$ от $0,8 T$ до $1,8 T$. В районе действующих рудников $\sigma_{1}=(0,7-1,0) T, \sigma_{2}=(0,9-1,2) T$.

В нагорных участках гористого рельефа тектонические напряжения по величине меньше, а на участках под долинами, располагаемыми ниже 
нулевой отметки, больше действующих на бесконечности усилий. Влияние рельефа распространяется на глубину 2-3 максимальных превышений гор над долинами. Абсолютные величины главных напряжений можно определять произведением соответствующих коэффициентов влияния блочности и рельефа на величину действующих на бесконечности усилий. Учет блочного строения массивов горных пород и их рельефа позволяет оценивать величины главных напряжений с достаточной для практических целей точностью.

\section{6. Изменение удельной энергии деформирования}

\section{в процессе отработки блока-целика Кировский рудник - Саамский карьер} в период с 2002 по 2015 годы

Для организации безопасного ведения горных работ и обоснования противоударных мероприятий важную роль играет долгосрочный прогноз напряженного состояния и изменения удельной энергии деформирования массива в процессе отработки месторождения. Рассмотрим с этой точки зрения отработку блока-целика между Кировским рудником и Саамским карьером в период 2002-2015 гг.

На рисунке 2.19 показана схема расчетной модели отработки этого участка на гор. +252 м. Согласно ранее выполненным исследованиям [8] в районе Кировского рудника вкрест простирания рудного тела действуют горизонтальные сжимающие напряжения $T_{y}=-50 \mathrm{MПа,} \mathrm{а} \mathrm{по} \mathrm{простиранию}-T_{x}=-30 \mathrm{MПа}$.

Исследования выполнены методом граничных элементов в двухмерной постановке задачи. Предполагалось, что отрабатывается только Кировский рудник, а на Юкспорском руднике горные работы не выполняются, при этом за один год производится выемка руды из 3-4 секций. Порядок ведения горных работ показан на рисунке 2.20, номера отрабатываемых по годам секций даны в таблице 2.6.

Распределение главных напряжений $\sigma_{1}$ и $\sigma_{2}$ в исходном состоянии (к началу 2002 г.) показано на рисунке 2.21, а к концу 2015 г. — на рисунке 2.22.

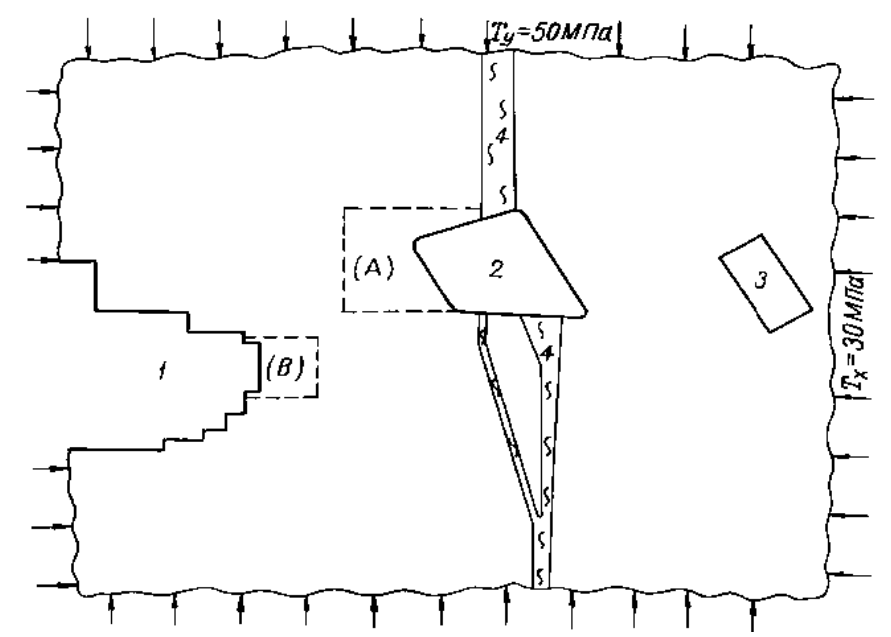

Рис. 2.19. Схема расчетной модели отработки блока-целика между Кировским рудником и Саамским карьером: 1 - очистное пространство подземного Кировского рудника; 2 - контур Саамского карьера; 3 - Юкспорский подземный рудник; 4 - разломная зона; $A, B$ - области, для которых рассчитывали удельную энергию деформирования 


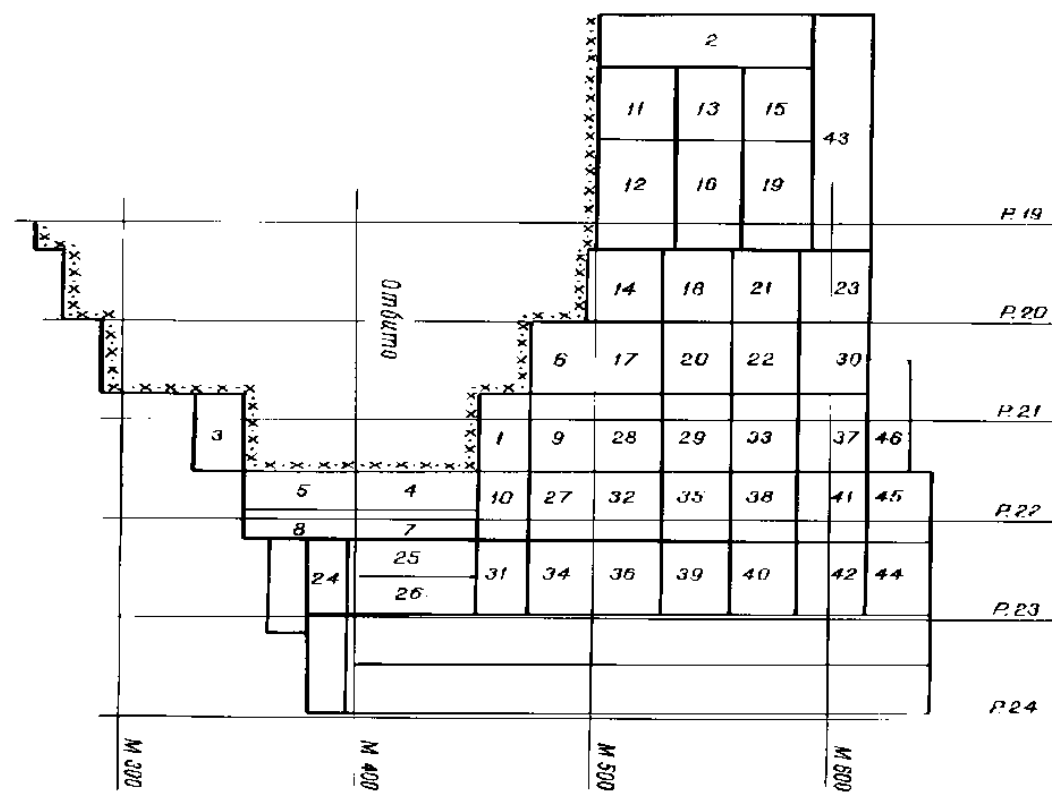

Рис. 2.20. План ведения горных работ на гор. +252 м Кировского рудника: $1,2, \ldots 46-$ отбиваемые секции

Таблица 2.6

Порядок выемки руды по годам

\begin{tabular}{|c|c|c|c|c|c|c|c|}
\hline Год & 2002 & 2003 & 2004 & 2005 & 2006 & 2007 & 2008 \\
\hline Секции & $1-3$ & $4-6$ & $7-10$ & $11-13$ & $14-16$ & $17-19$ & $20-22$ \\
\hline Год & 2009 & 2010 & 2011 & 2012 & 2013 & 2014 & 2015 \\
\hline Секции & $23-26$ & $27-29$ & $30-32$ & $33-35$ & $36-38$ & $39-41$ & $42,44,45$ \\
\hline
\end{tabular}
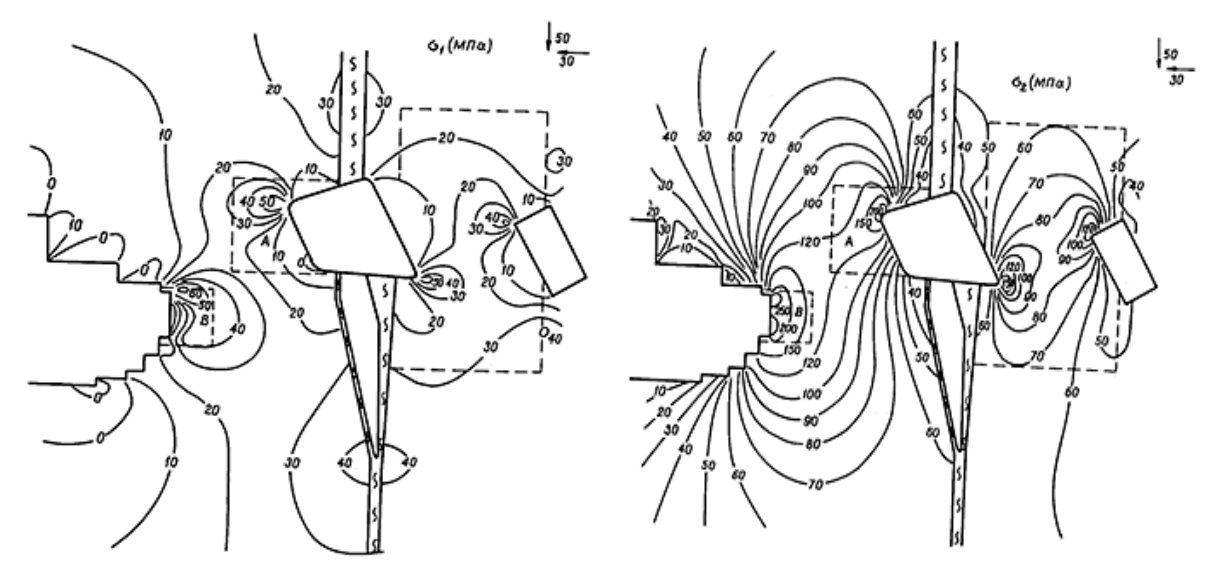

Рис. 2.21. Распределение главных напряжений в блоке-целике на начало ведения горных работ 2002 г. 


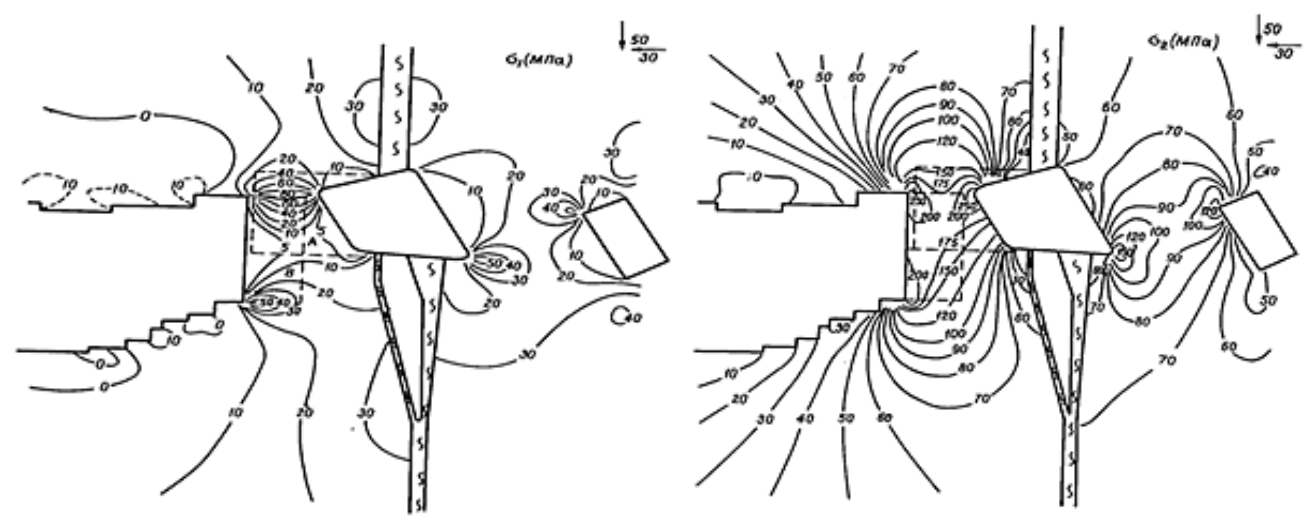

Рис. 2.22. Распределение главных напряжений в блоке-целике на 2015 г.

На рисунках видно, что в блоке-целике между Саамским карьером и Юкспорским рудником напряженное состояние пород осталось фактически неизменным. Существенные изменения напряженного состояния происходят в отрабатываемом блоке-целике между Кировским рудником и Саамским карьером, а также в непосредственной близости к нему.

Результаты определения удельной энергии деформирования существенным образом зависят от объема той области, для которой производятся расчеты. Так как вдали от зон концентрации напряжения стабилизируются и по величине приближаются к действующим на «бесконечности», то, взяв для расчета большую область, уловить изменения энергии практически невозможно. Для этих целей необходимо выбирать либо неизменную область вблизи некоторого концентратора, либо зону определенной протяженности вблизи подвижного фронта очистных работ. На рисунках 2.21 и 2.22 пунктиром выделена неизменная область $A$ вблизи Саамского карьера, для которой рассчитывали удельную энергию деформирования по мере отработки гор. +252 м Кировского рудника. Кроме того, расчет энергии проводили для 100-метровой зоны $B$ блока-целика вблизи кромки очистного пространства, обращенной в сторону Саамского карьера. На отдельных этапах отработки области $A$ и $B$ частично перекрывают друг друга.

На рисунке 2.23 приведены результаты расчета удельной энергии деформирования в зоне $A-$ график 1. Пунктиром график 2 показывает аппроксимацию графика 1 зависимостью

$$
w=w_{0}\left(1+\frac{a}{0,1752 t^{2}+1} \operatorname{sh} t\right)
$$

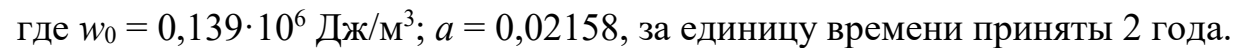

В работе [21] нами показано, что для большинства руд и пород Хибинского массива среднее значение критической удельной энергии деформирования $w_{*}=0,27 \cdot 10^{6}$ Дж/м ${ }^{3}$ (прямая 3). Из рисунка 2.23 следует, что в зоне $A$ удельная энергия деформирования к концу 2015 г. достигнет критического значения. Вместе с тем в зоне $B$ она имеет запредельные значения в течение всего времени отработки (график 4). Необходимо отметить, что зоны $A$ и $B$ начинают перекрывать друг друга с начала 2013 г. 


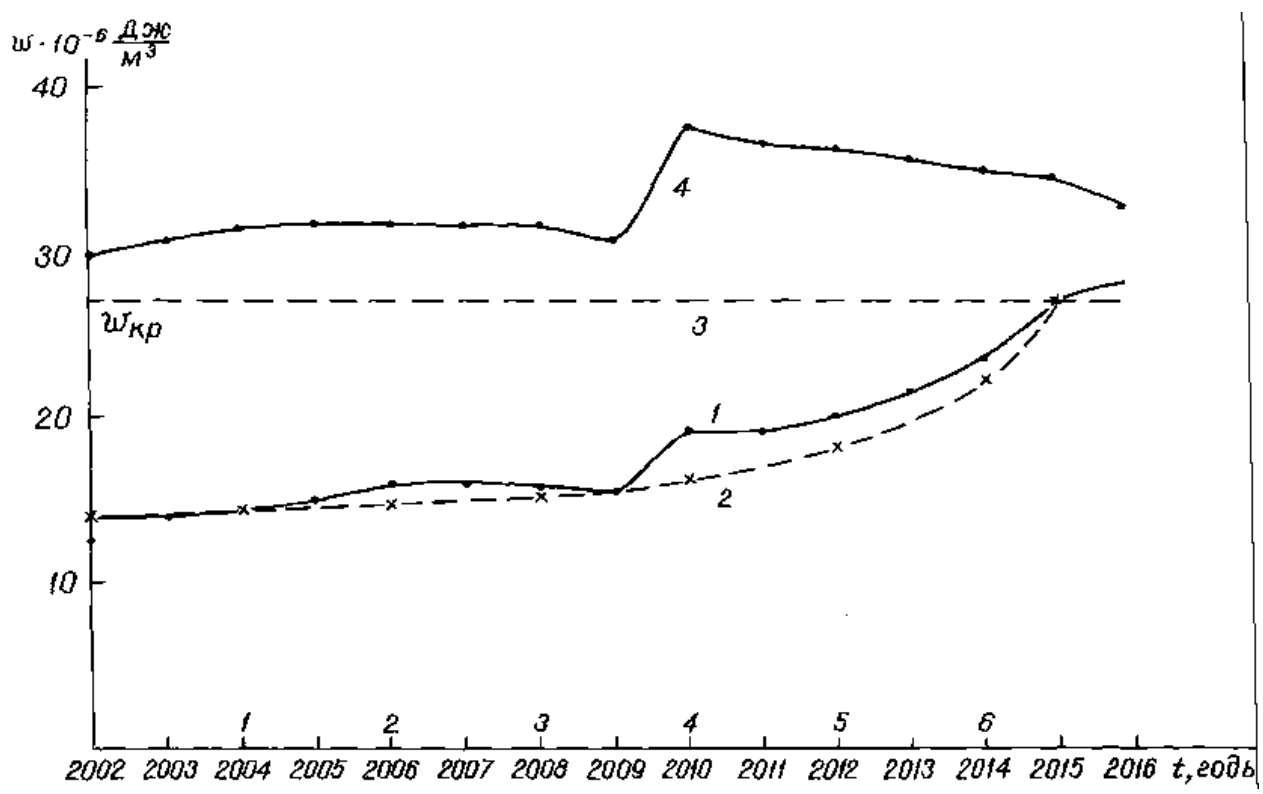

Рис. 2.23. Изменение удельной энергии деформирования: 1 - в зоне $A ; 2$ - аппроксимация зависимостью (2.45); 3 - критическое значение удельной энергии; 4 - в зоне $B$

Таким образом, из выше сказанного следует, что в 100-метровой зоне вблизи кромки очистного пространства возможны динамические проявления горного давления на всем протяжении отработки блока-целика между Кировским рудником и Саамским карьером. Начиная с 2013 г., отработка блока-целика может быть сопряжена с серьезными осложнениями по фактору горного давления. При этом надо учесть то обстоятельство, что эта задача решена в двухмерной постановке. Очевидно, что на нижележащих горизонтах (откатки и т. п.) ситуация может оказаться еще хуже, так как вблизи сопряжений стенок и почвы очистного пространства концентрация тектонических напряжений будет еще выше.

\section{7. К вопросу о тектонических напряжениях в скальных массивах вблизи дневной поверхности}

Существование субгоризонтальных тектонических напряжений в верхней части земной коры в настоящее время является общепризнанным фактом, доказательством которого служат многочисленные результаты измерений напряжений на всех континентах Земли. Их величины и направление действия в различных регионах изменяются в широких пределах и зависят от многих факторов геолого-исторического происхождения и современных эволюционных процессов [93]. Для специалистов горнодобывающей промышленности наиболее важными являются параметры тектонических напряжений: их величина и направление в местах проведения горных работ.

По результатам обработки материалов кернового бурения Кольской сверхглубокой скважины СГ-3, пройденной до глубины 12261 м, можно сказать, что до 6 тыс. м изменение тектонических напряжений отвечает почти линейной закономерности, а на больших глубинах эта зависимость существенно 
нелинейна [94, 95]. Весьма интересным представляется вопрос о том, на какой глубине от дневной поверхности начинают действовать тектонические напряжения и какова их величина вблизи поверхности. Так, например, для Хибинского и Ловозерского массивов установлено, что на глубине около 300 м от дневной поверхности величина горизонтальных сжимающих тектонических напряжений составляет от -30 до -70 МПа в зависимости от формы рельефа [11].

Уникальными, на наш взгляд, являются те участки земной коры, где у дневной поверхности практически на ровном месте за слоем осадочных пород толщиной 3-5 м обнаруживаются тектонические напряжения такой же величины. Об одном из таких участков, расположенном на Карельском перешейке в Ленинградской области, пойдет речь ниже.

Месторождение гранитов, приуроченное к юго-западной части Выборгской интрузии, сложено розово-серыми трахитоидными гранитами рапикави. Оно отрабатывается карьером с начала прошлого века, однако наиболее интенсивно с 1960-х гг. (годовое понижение работ в последний период составляло до $0,5 \mathrm{~m} /$ год). В орографическом отношении район расположения месторождения представляет собой холмистую местность. Основное направление гряд холмов и разделяющих их долин - северо-западное, перепад высот до 35 м. Отрабатываемый участок месторождения - карьер, вытянутый в северо-западном направлении с размерами (в среднем): длина -500 м (C-3); ширина -300 м (Ю-В); глубина -2025 м. В наиболее глубокой северной части карьера в настоящий момент выемка достигла уровня окружающих озер и долин. Месторождение представлено гранитами со следующими физическими свойствами:

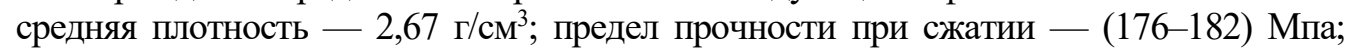
пористость $-1,6 \%$, то есть относительно высокая сплошность [96]. Граниты разбиты системой горизонтальных трещин с углом падения $0-2^{\circ}$, расстояние между которыми по вертикали - 0,1-8 м; а также двумя системами вертикальных трещин с азимутами падения 150 и $238^{\circ}$ (азимут простирания $240+180^{\circ}$ и $328+180^{\circ}$ соответственно), расстояние между вертикальными трещинами - 0,8-25 м. Таким образом, гранитный массив месторождения по характеристикам прочности и сплошности можно отнести к однородной, прочной скальной геологической среде [97].

Основная задача добывающего предприятия состоит в том, чтобы вынимать из карьера гранитные блоки максимально больших размеров длиной до 20 м с минимальными нарушениями сплошности пород. Однако в последние годы предприятие стало испытывать затруднение в подготовке блоков нужных размеров из-за их разрушения, одной из причин которого являются высокие горизонтальные напряжения.

Формы проявления горного давления следующие.

1. Зажим бурового инструмента при бурении вниз вертикальных шпуров и рядов шпуров, которыми по технологии оконтуриваются добываемые гранитные блоки. Глубина шпуров в карьере достигает 6 м.

2. Самопроизвольное смыкание стенок подготовленных буровых щелей, оконтуривающих добываемые гранитные блоки, и подвижки по ним (рис. 2.24). Характер разрушения стенок шпуров и их ориентация (borehole breakout) свидетельствует о том, что максимальные сжимающие напряжения действуют в направлении B-3. 


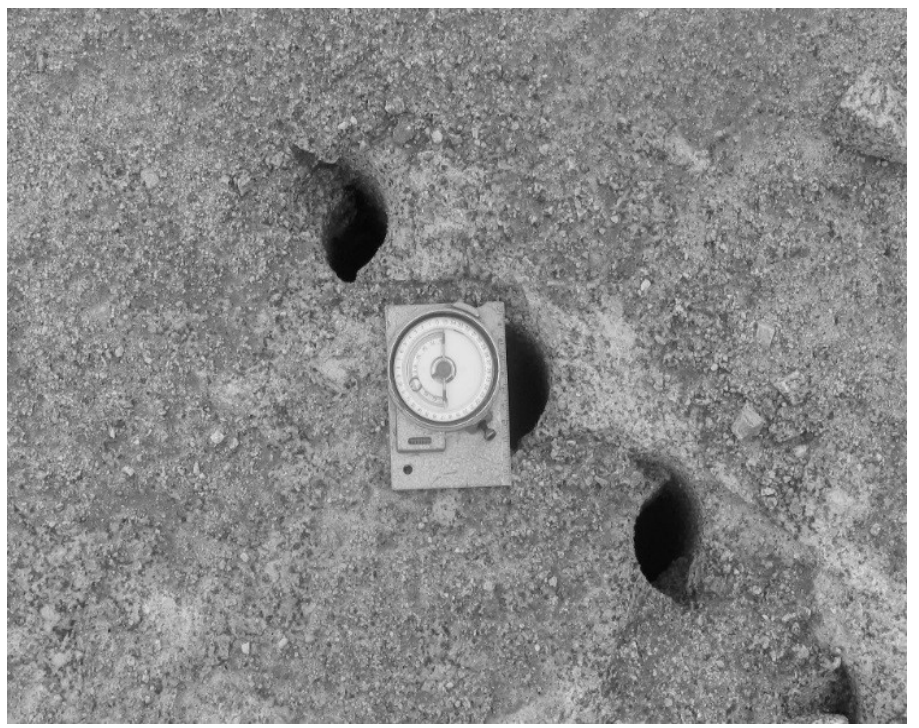

Рис. 2.24. Вид «сдавленных» скважин в дне карьера, стрелка компаса показывает направление С-Ю

3. Разрушение подготавливаемых к выемке блоков вертикальными трещинами (рис. 2.25).

4. Глухие удары и трески в почве карьера, свидетельствующие об образовании трещин в массиве. На рисунке 2.26 показано отслоение горизонтальной плиты в дне карьера.

5. В процессе бурения разведочных скважин на отметках от $+3,0$ до $-16,0$ м наблюдалось дискование керна.

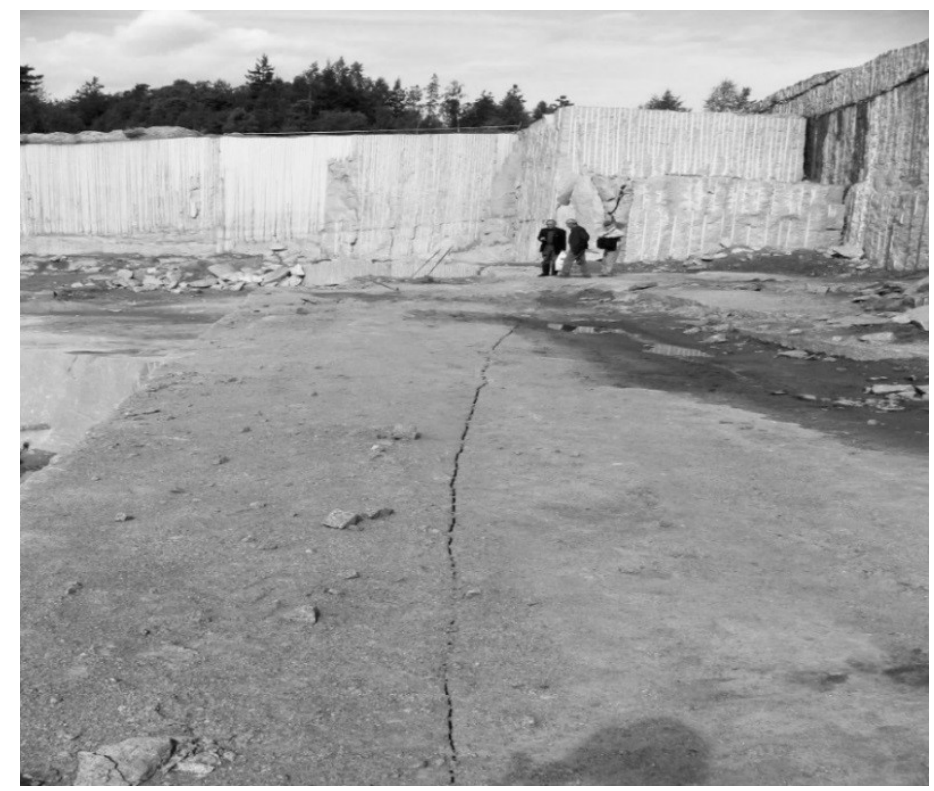

Рис. 2.25. Вертикальная 30-метровая трещина, проросшая вблизи поверхности нижнего уступа в северном торце карьера 


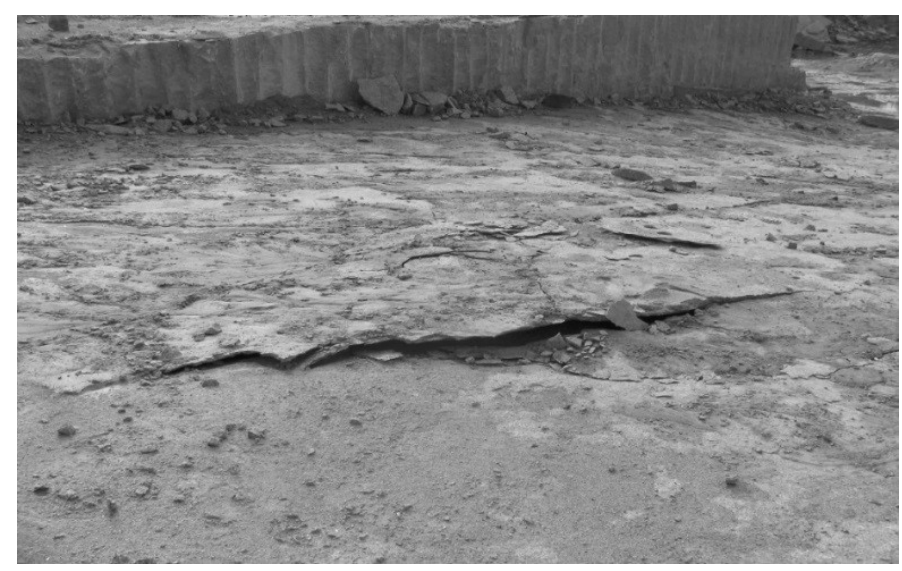

Рис. 2.26. Вид отслаивающихся породных пластин в дне карьера

Попытаемся на основании этих данных оценить величину действующих горизонтальных напряжений.

1. На контуре кругового отверстия концентрация тангенциальных напряжений $\sigma_{\theta}$ составляет $3 \sigma_{3}-\sigma_{2}, \quad$ где $\sigma_{2}$ и $\sigma_{3}-$ действующие на «бесконечности» горизонтальные напряжения. Считаем, что $\sigma_{1}>\sigma_{2}>\sigma_{3}$ алгебраически, сжимающие напряжения $\sigma<0$, то есть максимальными по абсолютной величине являются напряжения бз. Предел прочности пород при одноосном сжатии $\approx-180$ МПа. Пусть $\sigma_{2}=0$ (при больших значениях абсолютной величины, сжимающего $\sigma_{2}$ значение $\sigma_{3}$ будет увеличиваться). Отсюда по условию разрушения стенок скважин получаем $\sigma_{3} \approx-60$ МПа.

2. Для большинства горных пород предел прочности при одноосном растяжении $\left(\sigma_{\mathrm{p}}\right)$ составляет величину $(0,1-0,15) \sigma_{\text {сж. }}$ В нашем случае $\sigma_{\mathrm{p}}=(18-27)$ МПа. Предельная деформация при одноосном растяжении $\varepsilon_{p}=\frac{\sigma_{p}}{E}$, где $E$ - модуль Юнга. Из условия образования горизонтальных трещин (вблизи поверхности пренебрегаем весом вышележащих пород) имеем:

$$
\varepsilon_{2}=\frac{\sigma_{p}}{E}=\frac{-v}{E}\left(\sigma_{3}+\sigma_{2}\right)
$$

а для образования вертикальной трещины получаем:

$$
\varepsilon_{6}=\frac{\sigma_{p}}{E}=\frac{\left(\sigma_{2}-v \sigma_{3}\right)}{E},
$$

где $v$ - коэффициент Пуассона.

Решая совместно (2.46) и (2.47), при $v=0,25$, находим: $\sigma_{3}=-72 \mathrm{MПа,}$ $\sigma_{2}=0$ и $\sigma_{3}=-108 \mathrm{MПа,} \sigma_{2}=0$ соответственно при $\sigma_{p}=18$ МПа и $\sigma_{p}=27$ МПа.

3. В процессе бурения сжатого массива у основания керна возникают растягивающие напряжения по величине равные [95] 


$$
\sigma_{\mathrm{p}}=-0,32 \exp \left(-0,2 \frac{d}{t}\right) \sigma_{3},
$$

где $d$ - диаметр керна; $t$ - толщина диска.

Принимая в (2.48) для простоты рассуждений $\frac{d}{t}=1$, получаем $\sigma_{\mathrm{p}}=-0,26 \sigma_{3}$.

То есть величина действующих напряжений, достаточная для образования дисков при бурении, должна быть в нашем случае $\sigma_{3}=-69$ МПа при $\sigma_{p}=18$ МПа или $\sigma_{3}=-104$ МПа при $\sigma_{p}=27$ МПа. Таким образом, эти оценки дают величину действующих на «бесконечности» напряжений бз $\approx-(60-100)$ МПа.

Теперь изучим более детально закономерности распределения напряжений в окрестности карьерной выемки. На рисунке 2.27 приведено распределение главных тектонических напряжений в блочной структуре Фенноскандии. Здесь точкой $A$ показано местоположение исследуемого участка массива, величина $T=-50 \mathrm{MПа} \mathrm{-} \mathrm{это} \mathrm{действующие} \mathrm{на} \mathrm{границе} \mathrm{Евразийской} \mathrm{литосферной}$ плиты сжимающие напряжения, вызванные взаимодействием Африканской и Евразийской плит и раздвигом в районе срединно-океанической рифтовой зоны Атлантики. Более подробно эти результаты освещены в работах $[11,92,98]$. На рисунке 2.27 видно, что в окрестности точки $A$ действуют напряжения $\sigma_{2} \approx 0,6 T=-30$ МПа, $\sigma_{3} \approx 1,1 T=-55$ МПа, направление действия наибольших сжимающих напряжений В-3, что соответствует расчетным данным, приведенным в $[92,98]$ и согласуется с $[7,99]$.

Рассмотрим распределение горизонтальных напряжений в плане карьера, предполагая, что его глубина повсеместно составляет 20 м, задавшись действующими на «бесконечности» напряжениями в направлении В-3 $\sigma_{x}^{\infty}=-55$ МПа и С-Ю $\sigma_{y}^{\infty}=-30$ МПа. Вблизи сопряжений бортов и дна карьера с учетом объемности напряженного состояния на этих участках величины напряжений будут составлять 0,7 от расчетных. К этому результату приводит, например, рассмотрение напряженного состояния в окрестности кругового отверстия и сферической полости в условиях одноосного сжатия [100].
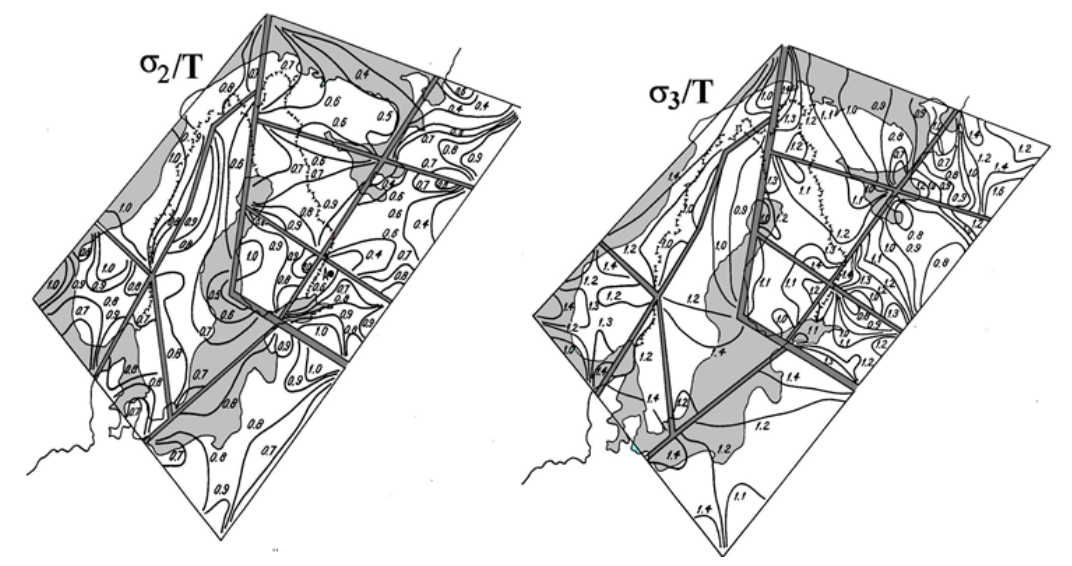

Рис. 2.27. Распределение главных напряжений в блочной структуре Фенноскандии: $(\bullet) A$ - место расположения исследуемого участка массива

На рисунке 2.28 приведены изолинии распределения квазиглавных напряжений $\sigma_{2}$ и $\sigma_{3}$ в плане, а на рисунке 2.29 показана их ориентация. Из этих 
рисунков следует, что оба напряжения в массиве вблизи восточного и западного бортов карьера изменяются в пределах от 0 до -40 МПа. В северном и южном бортах $\sigma_{2} \approx-(30-40)$ МПа, а $\sigma_{3} \approx-(80-125)$ МПа, при этом такие высокие концентрации напряжений распространяются в массив на расстояние около 150 м от кромки бортов.

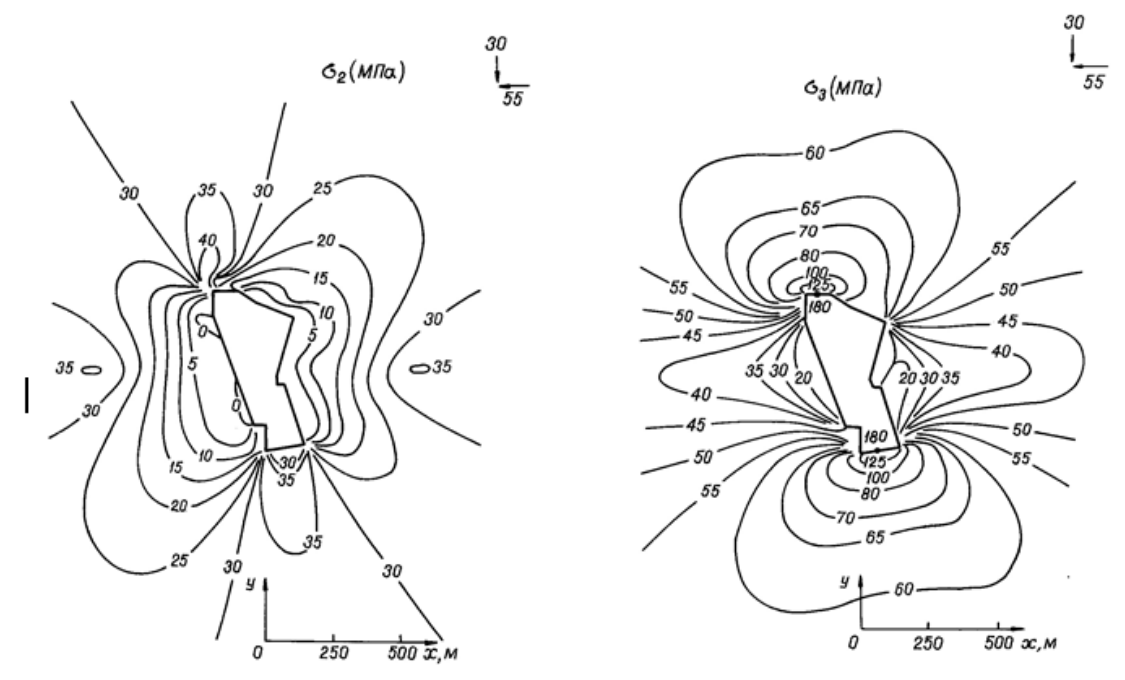

Рис. 2.28. Распределение квазиглавных напряжений $\sigma_{2}$ и $\sigma_{3}$ вблизи карьерной выемки в плане

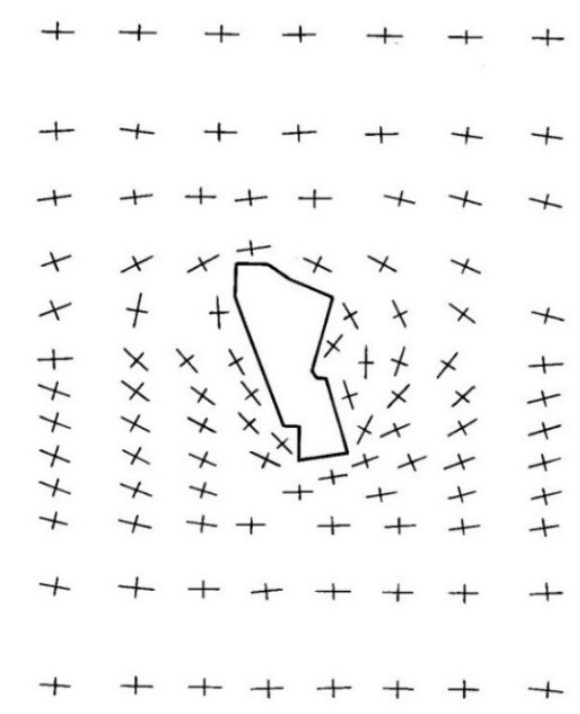

Рис. 2.29. Ориентация квазиглавных напряжений в окрестности карьера

Наибольшая величина сжимающих напряжений $\sigma_{3}=-180$ МПа наблюдается на границе карьера с северной и южной сторон, при этом вторая составляющая напряжений равна нулю. Максимальные сжимающие напряжения в окрестности карьера направлены вдоль бортов (рис. 2.30). Это означает, что вблизи северного и южного бортов северные и южные стенки скважин могут разрушаться так, как показано на рисунке 2.24. В результате образования свободной поверхности 
массивы пород вблизи северного и южного бортов находятся практически в условиях одноосного сжатия в направлении В-3, что приводит к возникновению вертикальных трещин на нижних уступах (рис. 2.25). Фактически эти явления наблюдаются в северном торце карьера, где глубина достигла 20 м от поверхности, в южном торце, в котором глубина меньше, их проявления менее отчетливы.

На рисунке $2.30 a$, б приведено распределение напряжений $\sigma_{1}$ и $\sigma_{3}$ в нетронутом массиве (рис. 2.30 a), в дне карьера и в его бортах для самого узкого сечения восточно-западного направления в вертикальной плоскости. Здесь, помимо тектонических напряжений $\sigma_{x}^{\infty}=-55$ Мпа, учтено и влияние собственного веса пород. В массивах пород, примыкающих к восточному и западному бортам, напряжения $\sigma_{1}$ (близкие к вертикальным) являются растягивающими и по величине не превышают 5 МПа. В бортах карьера $\sigma_{3}$ изменяются от 0 до -40 МПа, а в дне - от -60 до -90 МПа.

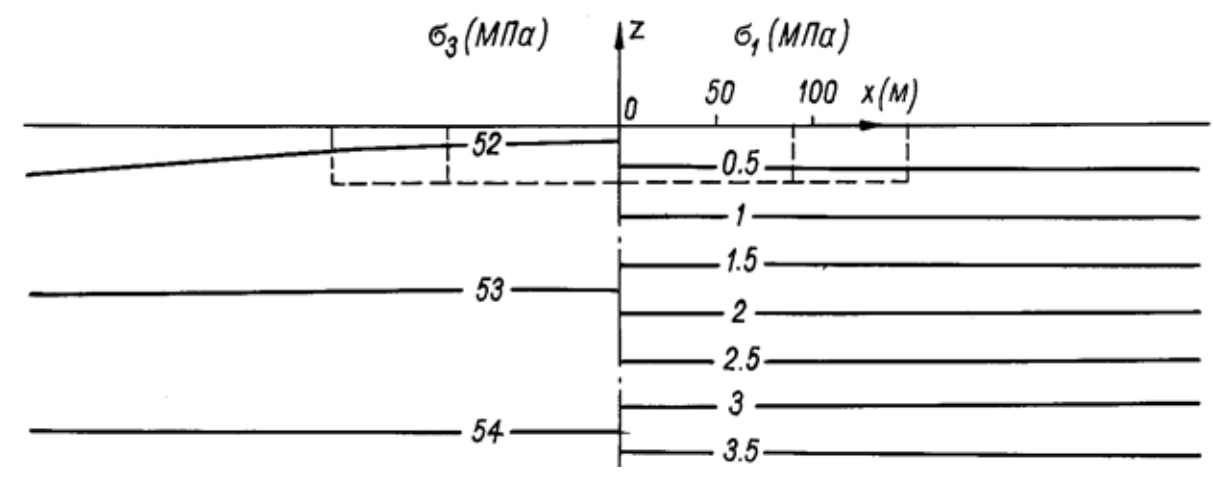

$a$

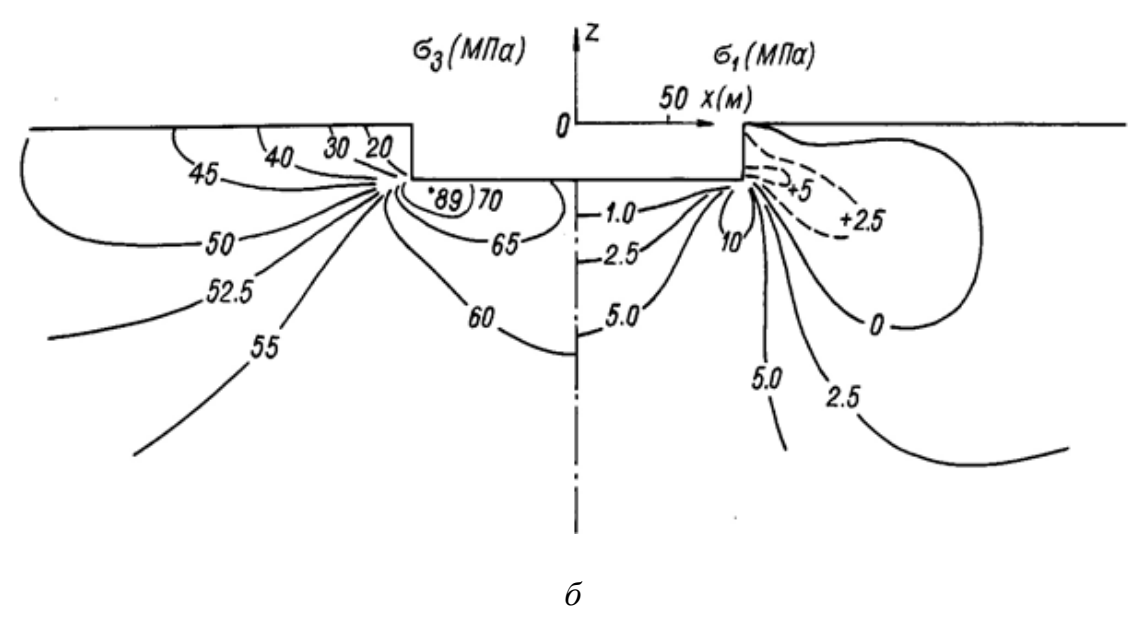

Рис. 2.30. Распределение главных напряжений б (справа от оси симметрии) и бз (слева): $a$ - в вертикальном сечении ненарушенного массива ( - - - - контур карьера); $\sigma$ - в вертикальном сечении наиболее узкой части карьера в направлении В-3 («+»- растяжение)

Рассмотрим возможность разрушения стенок скважин вблизи поверхности в нетронутом массиве и в дне карьера вблизи бортов и в центральной части. 
В нетронутом массиве $\sigma_{3}=-52$ МПа, $\sigma_{2}=-30$ МПа. Максимальная концентрация тангенциальных напряжений на стенке скважины при этом будет $\sigma_{\theta}=-126 \mathrm{MПа}=0,7 \sigma_{\text {сж. }}$ В дне карьера на расстоянии приблизительно 30 м от борта $\sigma_{\theta}=-126 . \sigma_{\theta}=-126, \sigma_{3} \approx-70 \mathrm{MПа,} \sigma_{2}=-30 \mathrm{MПа,} \mathrm{что} \mathrm{дает} \mathrm{на} \mathrm{стенке} \mathrm{скважины}$ $\sigma_{\theta} \approx-180 \mathrm{MПа,} \mathrm{то} \mathrm{есть} \mathrm{фактически} \mathrm{имеем} \mathrm{достижение} \mathrm{предела} \mathrm{прочности} \mathrm{при}$ одноосном сжатии. Здесь же возможно и образование горизонтальных трещин. В вертикальном направлении согласно (2.46) получаем $\varepsilon_{z}=\frac{v}{E}(70+30)=\frac{25}{E} \approx \frac{\sigma_{p}}{E}$, то есть вполне возможно образование горизонтальных трещин в дне карьера и отслаивание плит. В средней части карьера на рассматриваемой глубине также возможно разрушение стенок скважин и образование горизонтальных трещин. Здесь при $\sigma_{3} \approx-65$ МПа, $\sigma_{2} \approx-30$ МПа получаем $\sigma_{\theta} \approx-165$ МПа, $\varepsilon_{z} \approx \frac{24}{E} \approx \frac{\sigma_{p}}{E}$.

Сопоставление рисунка $2.30 a$ и $\sigma$ показывает, что сооружение карьера глубиной 20 м, повышает абсолютную величину напряжений в некоторых участках массива (дне карьера, сопряжениях дна с торцами) в 1,5-1,8 раз по сравнению с существовавшим ранее. Углубление карьера вызывает проявления горного давления в его нижней части, которое должно усиливаться с глубиной.

\section{8. Тектонические напряжения в Ловозерской интрузии}

Ловозерский щелочной массив располагается в центре Кольского полуострова и отделен от Хибин озером Умбозеро. В его пределах отрабатывается Ловозерское редкометалльное месторождение, горные работы на котором велись двумя рудниками: «Карнасурт» (с 1951 г.) и «Умбозеро» (с 1984 г). При этом на руднике «Умбозеро» в 1999 г. произошло сильное техногенное землетрясение, в результате которого он прекратил свое существование [10, 101, 102]. Рудник «Карнасурт», расположенный от рудника «Умбозеро» на расстоянии около 10 км, продолжает работать. В связи с этим практический интерес представляет вопрос о характере распределения напряжений в этом массиве.

В работе [10] показано, что в массивах горных пород Кольского полуострова действуют горизонтальные сжимающие тектонические напряжения, вызванные раздвигом тектонических плит в районе Атлантической рифтовой зоны и давлением Африканской плиты на Европейскую. Величина тектонических напряжений $T=-50$ МПа изменяется в зависимости от блочного строения Европейской плиты от $0,6 T$ до $1,2 T$. При этом в окрестности Ловозерского массива в направлении $\mathrm{C}-$ Ю действуют локальные тектонические напряжения $\sigma_{y}=0,7 T=-35 \mathrm{MПа}$, а в направлении В -3 напряжения $-\sigma_{x}=0,9 T=-45$ МПа.

Рассмотрим влияние геологического строения массива горных пород и глубинных тектонических блоков, разделенных протяженными разломами, на НДС массива. На рисунке $2.31 a$ приведена схематизированная геологическая карта Ловозерского массива, опубликованная в [86], а на рисунке 2.31 б представлена его упрощенная расчетная модель с добавлением блока, окружающего массив. Характеристики упругих свойств геологических блоков представлены в таблице 2.7, из которой следует, что породы Ловозерского массива достаточно крепкие, упругие и лишь блок 5 , состоящий из четвертичных отложений, является слабым включением в этом ансамбле. 


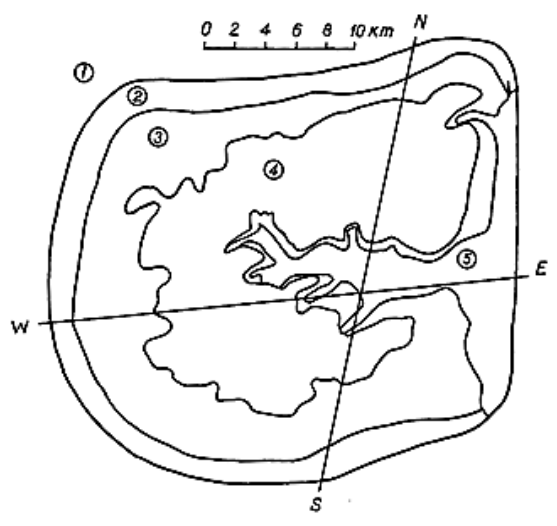

$a$

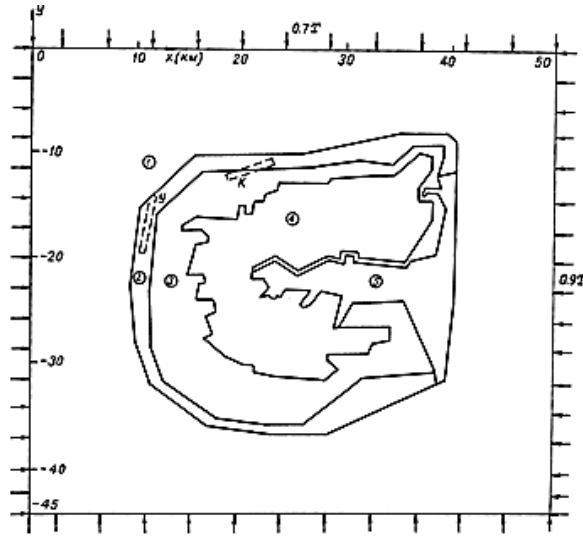

$\sigma$

Рис. 2.31. Схематизированная геологическая карта Ловозерского массива [86] (a) и расчетная модель с учетом геологических блоков (б): $1-5$ - геологические блоки

Таблица 2.7

Упругие свойства пород в геологических блоках Ловозерского массива

\begin{tabular}{|c|l|c|c|}
\hline $\begin{array}{c}\text { № } \\
\text { блока }\end{array}$ & \multicolumn{1}{|c|}{ Основные породы } & $\begin{array}{c}\text { Модуль Юнга, } \\
\text { МПа }\end{array}$ & $\begin{array}{c}\text { Коэффициент } \\
\text { Пуассона } v\end{array}$ \\
\hline 1 & Гнейсы & $5,2 \cdot 10^{4}$ & 0,25 \\
\hline 2 & Биотитовые гнейсы, гнейсо-граниты, гнейсо-диориты & $6,5 \cdot 10^{4}$ & 0,2 \\
\hline 3 & Луявриты, фойяиты и уртиты & $6,1 \cdot 10^{4}$ & 0,24 \\
\hline 4 & Эвдиалитовые луявриты & $5,1 \cdot 10^{4}$ & 0,27 \\
\hline 5 & Четвертичные отложения, породы Ловозерской свиты & $5,0 \cdot 10^{3}$ & 0,3 \\
\hline
\end{tabular}

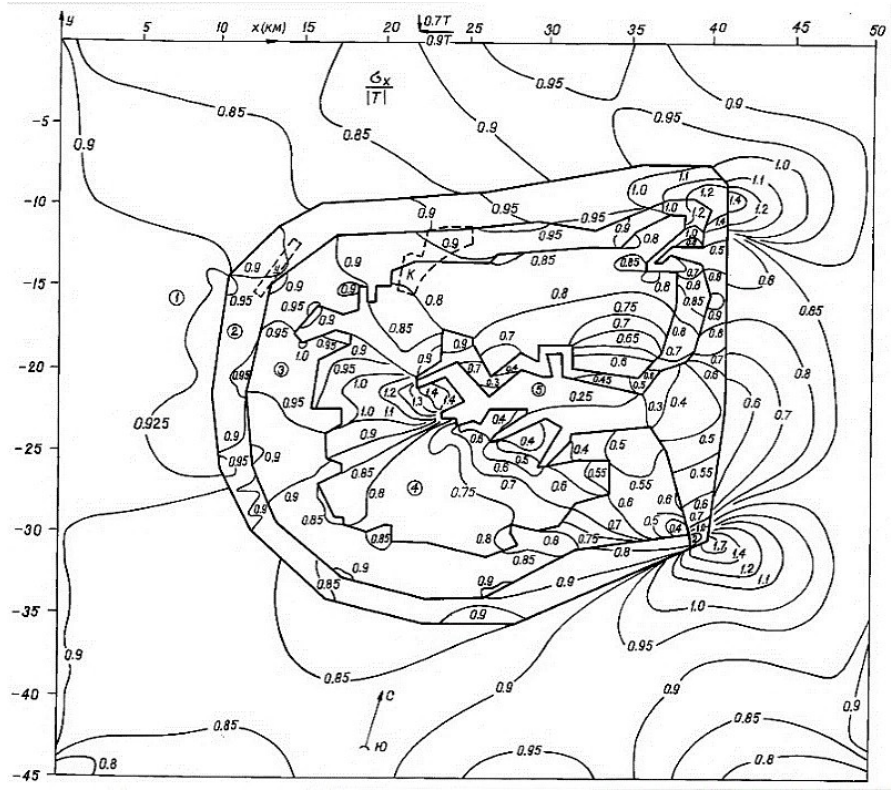

Рис. 2.32. Распределение относительных горизонтальных напряжений $\sigma_{x} / T \mid$ в Ловозерском массиве с учетом геологического строения: 1-5 - модели геологических блоков; $\mathrm{У}, \mathrm{K}$ - расположение рудников «Умбозеро» и «Карнасурт» 
На рисунке 2.32 приведены изолинии относительных напряжений $\sigma_{x} / T$. Во всей исследуемой области напряжения $\sigma_{x}$ сжимающие. В основной части блока пород, окружающих Ловозерский массив (блок 1) с северной, западной и южной сторон, напряжения $\sigma_{x}$ изменяются в пределах от $0,85|T|$ до $0,95|T|$. В районе восточного направления, где блок 1 контактирует с блоком 5 , концентрация напряжений $\sigma_{x}$ находится в пределах от $0,6|T|$ до $1,4|T|$, а вблизи угловых зон контакта блоков - до $1,7|T|$. При этом вблизи протяженного контакта этих блоков напряжения $\sigma_{x}<|T|$, а вблизи угловых зон $-\sigma_{x}>|T|$ по абсолютной величине. Такие же значения напряжений $\sigma_{x}\left(0,8|T| \leq \sigma_{x} \leq 0,95|T|\right)$ наблюдаются в блоках 2 и 3 . В блоке 4 , имеющем значительные участки угловых контактов с блоками 3 и 5 , напряжения $\sigma_{x}$ изменяются в пределах от $0,4|T|$ до $1,4|T|$. Наибольшее изменение величины $\sigma_{x}$ наблюдается в районах контактных соединений блоков 4 и 5 . В основной части блока 5 напряжения $\sigma_{x}$ находятся в интервале от $0,25|T|$ до $0,6|T|$ с увеличением их значений до $(0,8-0,9)|T|$ в угловых зонах контакта блоков 5 и 4 с восточной стороны. В зонах отработки месторождений рудником «Умбозеро» $\sigma_{x}=0,9 T=-45 \mathrm{MПа}$, а в окрестности рудника «Карнасурт» - $\sigma_{x}=(0,8-0,9) T=-(40-45)$ МПа.

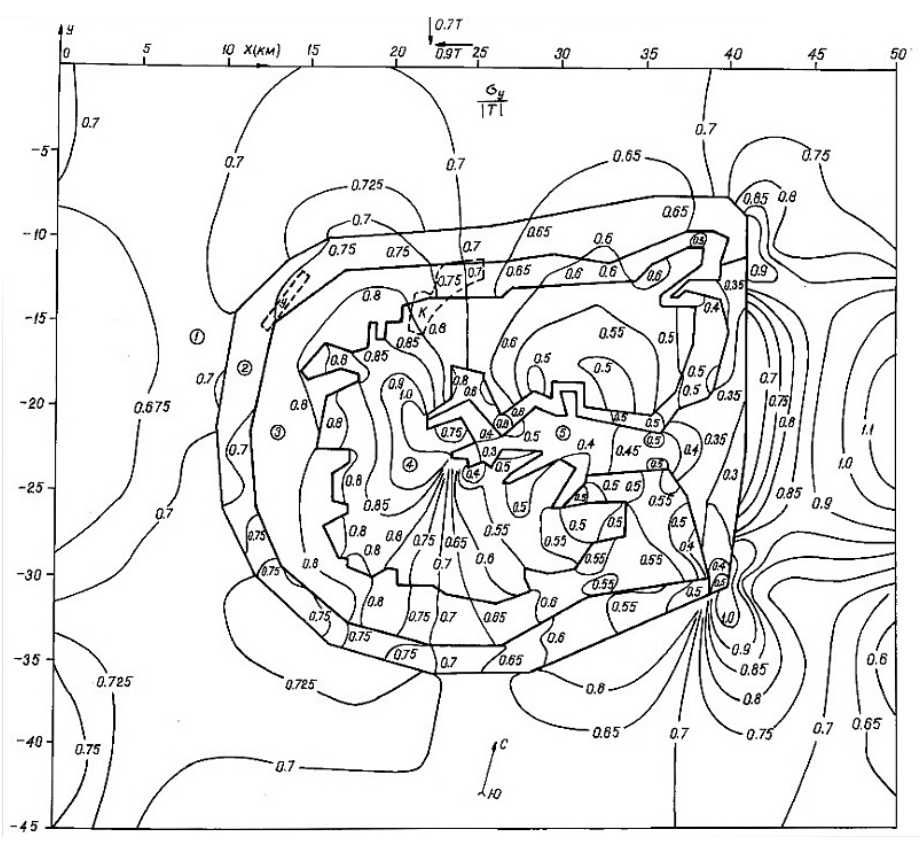

Рис. 2.33. Распределение относительных горизонтальных напряжений $\sigma_{y} /|T|$ в Ловозерском массиве с учетом геологического строения

Распределение напряжений $\sigma_{y} /|T|$ показано на рисунке 2.33. Оно также характеризуется значительной неравномерностью. С северной, западной и южной сторон в блоке 1 преобладают напряжения $\sigma_{y}$, изменяющиеся в интервале $0,6|T| \leq \sigma_{y} \leq 0,75|T|$. С восточной стороны $\sigma_{y}$ находится в пределах $(0,6-1,0) T$. При этом наибольшая неравномерность изменения напряжений $\sigma_{y}$ приурочена к угловым зонам контакта блоков 1 и 5 . В основной части блоков 2 и 3 напряжения $\sigma_{y}$ имеют величины от $0,5 T$ до 0,75T. Наибольшей неравномерностью распределения напряжений $\sigma_{y}$ отличается блок 4, граница которого имеет много угловых зон. Здесь напряжения $\sigma_{y}$ изменяются от $0,5 T=-25$ до $1,0 T=-50$ МПа. В блоке 5 напряжения $(0,3-0,5) T=-(15-25)$ МПа. 
В окрестности рудника «Умбозеро» $\sigma_{y}=0,75 T=-37,5$ МПа, а рудника «Карнасурт» - $0,65|T| \leq \sigma_{y} \leq 0,8|T|$.

Оценим возможности разрушения горных пород при отработке месторождений на этих рудниках. Протяженные наклонные горные выработки 30-50 м с нормальной мощностью 1-2 м, какие используются на рудниках Ловозерского ГОКа, можно трактовать как некоторые трещины. Согласно исследованиям [103] наличие трещин в массиве в условиях сдвига в значительной степени снижает его прочностные свойства. При отработке параллельных пластов формируются зоны растягивающих напряжений, по которым нормально к исходным выработкам, развиваются трещины. В процессе дальнейшей эволюции напряженно-деформированного состояния они образуют поверхности скольжения, выходящие на дневную поверхность. Для этого на границе области может быть приложена всего лишь третья или четвертая часть усилий, составляющих предел прочности на разрушение при одноосном сжатии $T=(0,25-0,3) \sigma_{\mathrm{c}}$. В прочных породах с пределом $\sigma_{\mathrm{c}}=160 \mathrm{MПа}$ эти усилия составляют величину $T=-(40-50)$ МПа. Массив с наклонной дневной поверхностью при действии гравитационных и тектонических напряжений находится в условиях сдвига. На глубинах 300 м от дневной поверхности максимальные касательные напряжения в окрестности выработок определяются выражением:

$$
\tau_{\max }=\frac{\gamma H-\left(\sigma_{\max }+\lambda \gamma H\right)}{2},
$$

где $\sigma_{\max }-$ наибольшее из горизонтальных тектонических напряжений; $\lambda=v /(1-v)$ - боковой отпор; $\gamma$ - удельный вес горных пород.

В рассматриваемых вариантах модели наибольшие сжимающие напряжения в районе рудника «Умбозеро» $\sigma_{\max }=-45$ МПа, а рудника «Карнасурт» $\sigma_{\max }=-(40-45)$ МПа. Следовательно, разрушение горных пород в окрестности обоих рудников вполне возможно.

Таким образом, с учетом геологического строения Ловозерского массива разрушение пород в окрестности выработок рудника «Умбозеро» возможно, вблизи выработок рудника «Карнасурт», располагаемых в блоке 3, потеря устойчивости пород наблюдается, а для выработок, располагаемых в блоке 4, разрушений нет. В действительности сильных горных ударов на руднике «Карнасурт» не наблюдается. Иначе говоря, разрушения связаны не только с неравномерным распределением напряжений, возникающим в окрестности геологических блоков, но и за счет разницы упругих свойств блоков и разломных зон.

Для более детального уточнения характера распределения напряжений в массиве используем информацию, касающуюся блочного тектонического строения. Известно, что Ловозерский массив разделен на 8 крупных геолого-структурных блоков разломами радиальной ориентации (рис. 2.34) [11]. Блоки 3 и 4, а также 5-7 для дальнейших исследований можно объединить в два отдельных блока, что не сможет существенно отразиться на характере распределения напряжений в остальных блоках, так как они (объединенные блоки) находятся на достаточно большом расстоянии от рудников «Умбозеро» и «Карнасурт».

С целью уменьшения исходной информации для численного моделирования объединим упругие свойства геологических блоков, учитывая их пропорциональное отношение в каждом радиальном блоке. Упругие свойства вновь образованных блоков приведены в таблице 2.8 . 


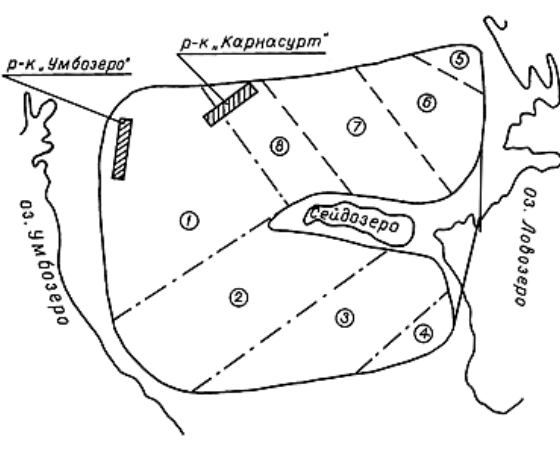

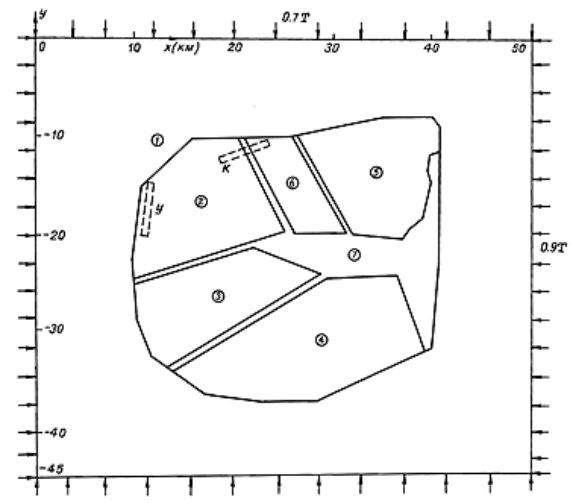

б

Рис. 2.34. План структурно-блочного строения Ловозерского массива (a) [11] и расчетная модель с учетом тектонических блоков (б): 1-7— модели тектонических блоков

Таблииа 2.8

Упругие свойства пород тектонических блоков радиальной ориентации

\begin{tabular}{|l|c|c|c|c|c|c|c|}
\hline \multicolumn{1}{|c|}{ № блока } & 1 & 2 & 3 & 4 & 5 & 6 & 7 \\
\hline Модуль Юнга, МПа & $5,2 \cdot 10^{4}$ & $5,9 \cdot 10^{4}$ & $5,6 \cdot 10^{4}$ & $6,0 \cdot 10^{4}$ & $5,8 \cdot 10^{4}$ & $5,5 \cdot 10^{4}$ & $5,0 \cdot 10^{3}$ \\
\hline Коэффициент Пуассона $v$ & 0,25 & 0,236 & 0,252 & 0,237 & 0,241 & 0,252 & 0,3 \\
\hline
\end{tabular}

На рисунке 2.34 б показана схема этого массива для численного моделирования. Здесь блок 1 , окружающий Ловозерский массив, остался таким же, как и в предыдущих расчетах. Граничные условия на внешнем краю блока 1 такие же, как и раньше.

Блок 7 и разломные зоны, разделяющие блоки, имеют свойства блока четвертичных отложений. Граничные условия на контактах блоков и разломных зон также заключаются в непрерывности нормальных напряжений и перемещений:

$$
\sigma_{n}^{+}=\sigma_{n}^{-} ; u_{n}^{+}=u_{n}^{-} ; \quad \sigma_{t}^{+} \neq \sigma_{t}^{-} ; u_{t}^{+} \neq u_{t}^{-},
$$

где индексы «+» и «-» относятся к элементам пород по разные стороны контакта; «n» и «t» - индексы нормальных и касательных напряжений и перемещений.

На рисунке 2.35 приведено распределение относительных напряжений $\sigma_{x} / \mid T$. Распределение этих напряжений в блоке 1 данной модели от ранее рассмотренного отличается лишь некоторой их концентрацией вблизи концевых зон разломов. Так, в районе концевых областей разломов северной ориентации максимальные значения напряжений $\sigma_{x}$ увеличились на $40 \%$, a y разломов западной ориентации - на $20 \%$. Напряжения $\sigma_{x}$ в блоке 2 , где располагаются рудник «Умбозеро» и частично «Карнасурт», изменяются в пределах от $0,75 T$ до $0,9 T$. При этом в окрестности рудника «Умбозеро» $\sigma_{x}=0,9 T=-45$ МПа, а вблизи рудника «Карнасурт» - $\sigma_{x}=0,75 T=-37,5$ МПа. В блоке 6 напряжения $\sigma_{x}$ находятся в интервале от $0,7 T$ до $0,9 T$. В блоке 3 распределение напряжений $\sigma_{x}$ достаточно равномерное, в основном $\sigma_{x}=(0,75-0,85) T$. Особо неравномерное распределение этих напряжений наблюдается в блоках 4 и 5 , имеющих наибольшую часть элементов, контактирующих с блоком 7. В этих блоках $\sigma_{x}$ изменяется от $0,6 T$ до $(1,0-1,4) T$. В блоке 7 и разломных зонах $\sigma_{x}$ находится в интервале $(0,3-0,6) T$. 


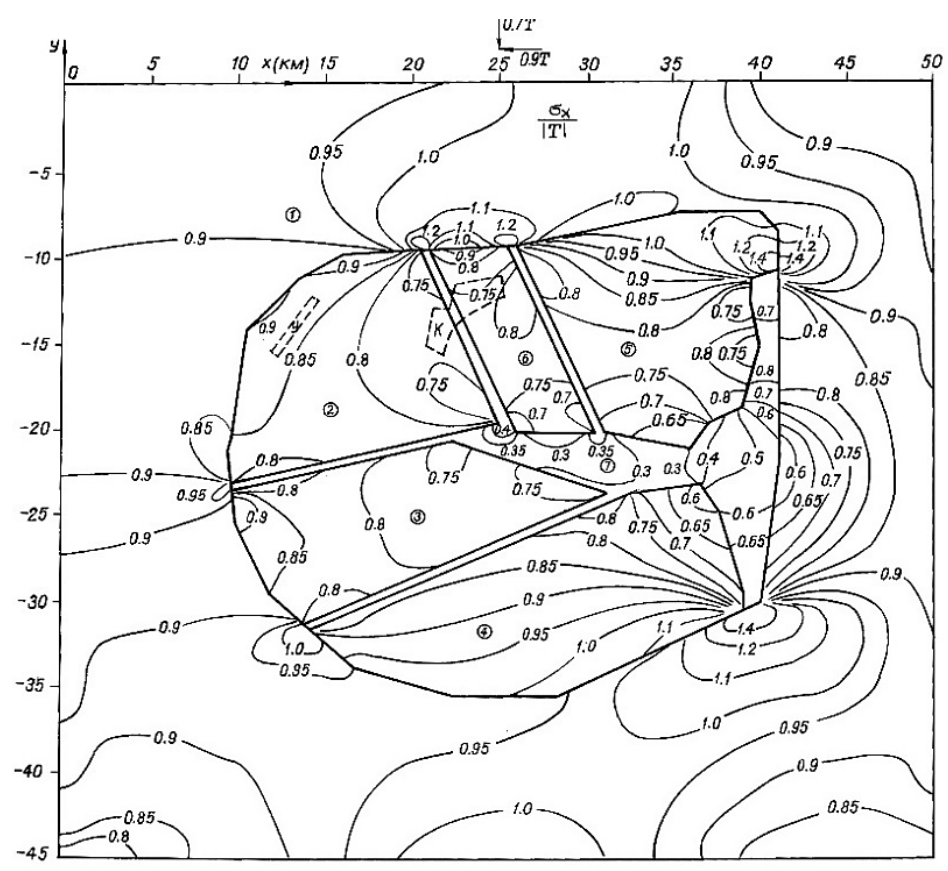

Рис. 2.35. Распределение относительных горизонтальных напряжений $\sigma_{x}|T|$ в Ловозерском массиве с учетом тектонических блоков: 1-7 - модели тектонических блоков; У, К — расположение рудников «Умбозеро» и «Карнасурт»

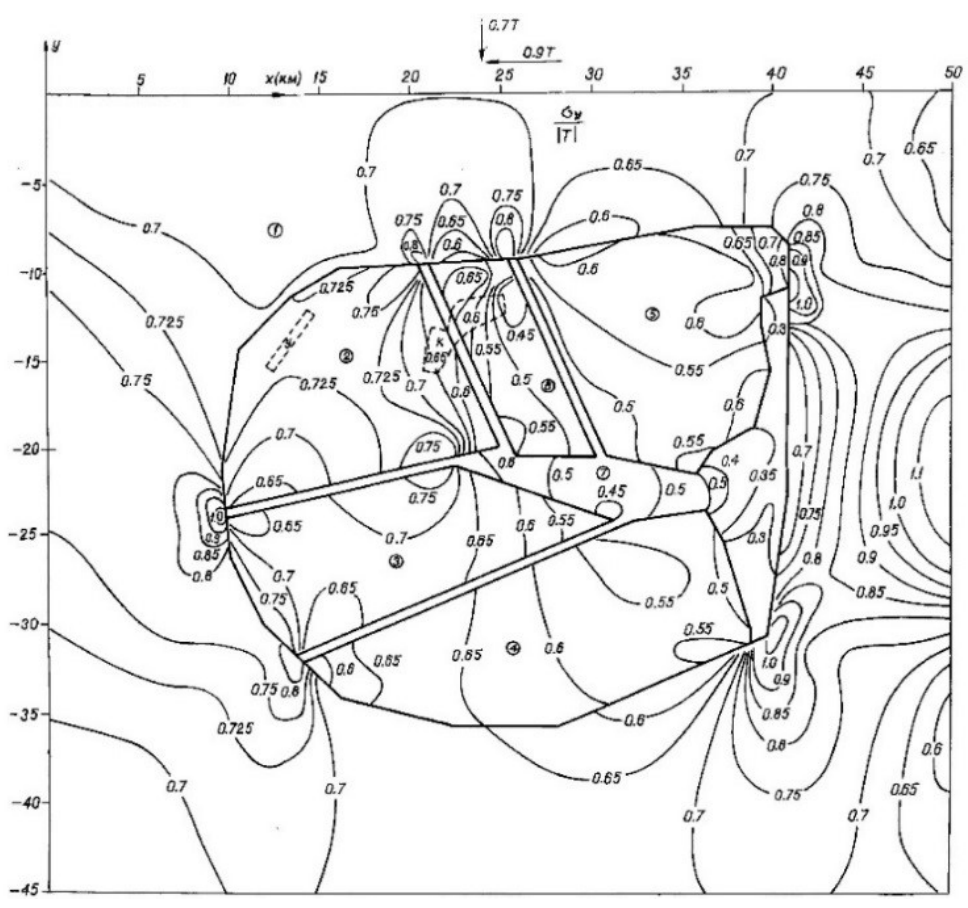

Рис. 2.36. Распределение относительных горизонтальных напряжений $\sigma_{y} /|T|$ в Ловозерском массиве с учетом тектонических блоков 
Распределение напряжений $\sigma_{y}$ в блоке 1 для модели с радиальными разломами (рис. 2.36) характеризуется концентрацией их в окрестности концов разломов, контактирующих с другими блоками. Значения напряжений в окрестности разломов северной ориентации составляют от $0,6 T$ до $0,8 T$, а вблизи разломов западной ориентации - от $0,8 T$ до $1,0 T$. В блоке $2 \sigma_{y}$ находится в интервале $0,65 T-0,75 T$. При этом в районе расположения рудника «Умбозеро» $\sigma_{x}=0,9 T=-45$ МПа; $\sigma_{y}=0,725 T=-36,25$ МПа, а в окрестности рудника «Карнасурт» $\sigma_{y}=0,65 T=-36,5 \mathrm{MПа;} \sigma_{y}=0,725 T=-36,25$ МПа. В блоке 6 напряжения $\sigma_{y}$ изменяются в пределах от $0,45 T$ до $0,65 T$, увеличиваясь с востока на запад. В окрестности рудника «Карнасурт» $0,5 T \leq \sigma_{y} \leq 0,6 T$. В остальных блоках $\sigma_{y}$ изменяется от $0,5 T$ до $0,75 T$.

Рассмотрим возможность разрушения пород при отработке месторождений. Из приведенного выше анализа распределения напряжений следует, что в данном модельном представлении массива в районе рудника «Умбозеро» по-прежнему $\sigma_{\max }=-45 \mathrm{MПа,} \mathrm{а} \mathrm{в} \mathrm{окрестности} \mathrm{рудника} \mathrm{«Карнасурт»} \sigma_{\max }=-37,5 \mathrm{MПа,} \mathrm{что} \mathrm{меньше}$ $0,25 \sigma_{\text {c. }}$ В связи с этим вероятность разрушения пород на руднике «Карнасурт» значительно меньше, чем на руднике «Умбозеро».

Таким образом, в условиях влияния радиальных тектонических разломов на напряженное состояние Ловозерского массива разрушения пород в окрестности рудника «Умбозеро» подтверждается однозначно, а в окрестности рудника «Карнасурт» таких разрушений нет, чем и объясняется более чем 60-летний срок успешной эксплуатации этого рудника, в то время как рудник «Умбозеро» разрушен техногенным землетрясением.

Существенный вклад в неравномерность распределения напряжений в Ловозерском горном массиве при действии горизонтальных сжимающих силовых полей оказывает его тектоническое блочное строение.

Разрушение горных пород рудника «Умбозеро» во время землетрясения 1999 г. связано не только с ведением широкомасштабных горных работ, но и с особым расположением его в системе блочного строения Ловозерского массива.

\section{9. Распределение горизонтальных тектонических напряжений в Ковдорском рудном районе}

Интересными с практической и научной точек зрения представляются закономерности распределения тектонических напряжений в Ковдорской интрузии в целом, в различных местах которой производится добыча полезных ископаемых и, в частности, бадделит-апатит-магнетитового месторождения рудником «Железный» АО «Ковдорский ГОК». В работе [98] показано, что массив горных пород Ковдорского рудного района находится практически в однородном тектоническом поле напряжений. При этом в меридиональном направлении действуют напряжения $\sigma_{\min }=0,8 T=-40$ МПа, а в широтном $-\sigma_{\max }=0,85 T=-42,5$ МПа. Однако надо понимать, что это средние значения напряжений, формируемые блочно-геологическим строением тектонических структур более высокого порядка. Рассмотрим, каким образом изменится характер распределения этих напряжений за счет сложного геологического строения этого участка массива и какие величины локальных напряжений будут при строительстве и эксплуатации горнодобывающих предприятий. 
В работе [86] приведена геологическая карта Ковдорского массива, на основании которой создана упрощенная расчетная модель (рис. 2.37), где учтены 9 основных разновидностей горных пород, буквой $A$ обозначено место отработки месторождения карьером «Железный». Физико-механические характеристики пород Ковдорской интрузии, полученные на основе работ [96, 104], приведены в таблице 2.9. На внешней границе модели заданы равномерно распределенные напряжения $\sigma_{y}^{\infty}=0,8 T$ и $\sigma_{x}^{\infty}=0,85 T$. На границах контактов блоков с различными механическими свойствами представлено непрерывное изменение нормальных напряжений и перемещений.

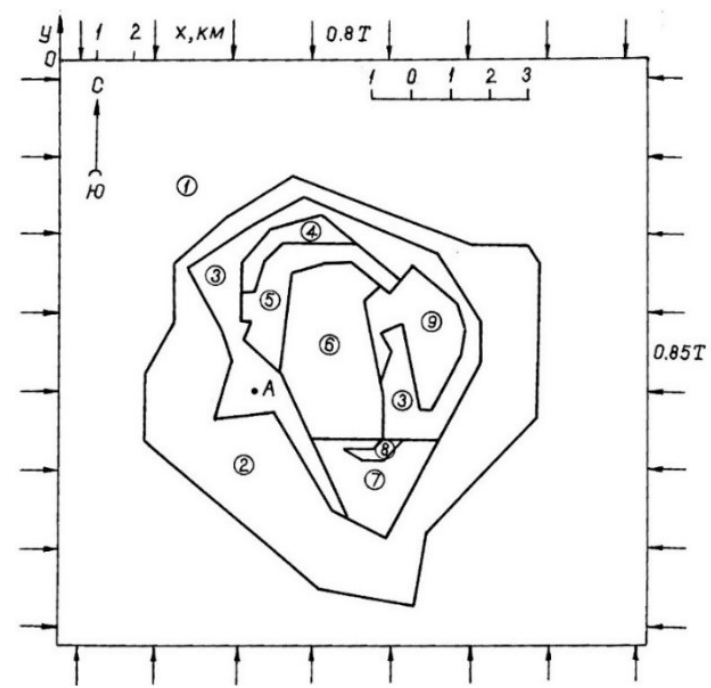

Рис. 2.37. Расчетная модель для численного моделирования напряженного состояния Ковдорской интрузии: $1-9$ - геологические блоки; $A$ - место расположения карьера «Железный»

Таблица 2.9

Упругие свойства горных пород Ковдорской интрузии

\begin{tabular}{|c|l|c|c|}
\hline $\begin{array}{c}\text { № } \\
\text { блока }\end{array}$ & \multicolumn{1}{|c|}{$\begin{array}{c}\text { Наименование } \\
\text { породы }\end{array}$} & $\begin{array}{c}\text { Модуль Юнга } E \cdot 10^{-4}, \\
\text { МПа }\end{array}$ & $\begin{array}{c}\text { Коэффициент } \\
\text { Пуассона } v\end{array}$ \\
\hline 1 & Гнейсы & 5,2 & 0,25 \\
\hline 2 & Фениты & 7,75 & 0,23 \\
\hline 3 & Ийолиты & 10,5 & 0,24 \\
\hline 4 & Монтичеллитовые породы & 8,0 & 0,25 \\
\hline 5 & Пироксиниты & 7,4 & 0,11 \\
\hline 6 & Оливиниты & 10,0 & 0,23 \\
\hline 7 & Пегматоидные рудные пироксениты & 8,02 & 0,16 \\
\hline 8 & Ослюденелые метаоливиниты & 9,0 & 0,25 \\
\hline 9 & Четвертичные породы & 5,03 & 0,3 \\
\hline
\end{tabular}

На рисунке 2.38 приведено распределение относительных минимальных напряжений $\sigma_{x} / T$, действующих в широтном направлении. Все эти напряжения сжимающие и их величины во всей интрузии изменяются в пределах от $0,2 T$ до $1,8 T$. Наибольшая концентрация $\sigma_{x}$ наблюдается в правой части блока 3 (наиболее крепкие породы); под южной частью блока 9, представленного 
слабыми породами четвертичных отложений, имеют место наименьшие величины $\sigma_{x} \approx 0,2 T$. В остальной части интрузии $\sigma_{x}$ распределены неравномерно, их величины находятся в интервале от $0,8 T$ до $T$. Средняя величина $\sigma_{x} \approx 0,85 T$ относится к району отработки месторождения карьером «Железный».

Напряжения $\sigma_{y}$ (рис. 2.39), величины которых во всей интрузии изменяются от $0,16 T$ до $1,5 T$, также распределены неравномерно. Наибольшие их концентрации приурочены к контактам более крепких пород с четвертичными породами с запада и востока. В районе отработки месторождения $\boldsymbol{\sigma}_{y}=1,05 T$.

Исследованию напряженного состояния пород в окрестности карьера «Железный» численными методами в трехмерной постановке задачи методом конечных элементов в последнее время посвящено много работ [104-106]. В исследовании [105] изучено распределение напряжений при действии на границе переменных по глубине тектонических сил, когда $\sigma_{\max }$ направлены вдоль длинной и короткой осей карьера. При этом предполагается, что в другом (ортогональном) направлении на границе модели действуют $\sigma_{\min }=0,5 \sigma_{\max }$. В качестве пород, слагающих массив, учтены три вида: вмещающие породы $E_{n}=1 \cdot 10^{5} \mathrm{MПа,} v_{n}=0,2$; рудное тело $E_{m}=0,5 \cdot 10^{5} \mathrm{MПа}, v_{m}=0,35$; разломные структуры I порядка и ослабленная зона в юго-восточном борту карьера $E_{\mathrm{o}}=0,1 \cdot 10^{5} \mathrm{MПа,} v_{\mathrm{o}}=0,4$. Рассмотрены области вблизи карьера, где действуют деформации растяжения.

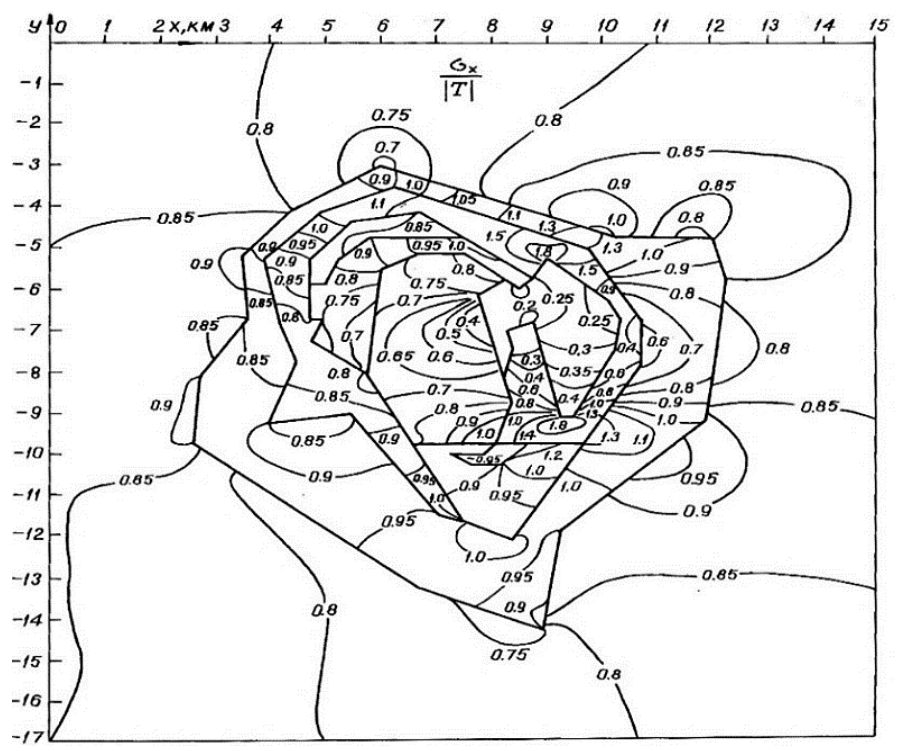

Рис. 2.38. Распределение относительных минимальных напряжений $\sigma_{x} / T$ в районе Ковдорской интрузии

С учетом изложенных выше особенностей распределения напряжений в массиве Ковдорской интрузии определены их закономерности вблизи карьера на глубине 200 м от дневной поверхности. В расчетной модели учтены 8 разновидностей горных пород, выделенных в структурно-геологических секторах, в которых нет четкой разницы между слагающими их породами, но по механическим свойствам их все-таки разделить можно, исходя из их пропорционального соотношения в каждом секторе. В таблице 2.10 приведены их упругие характеристики. 


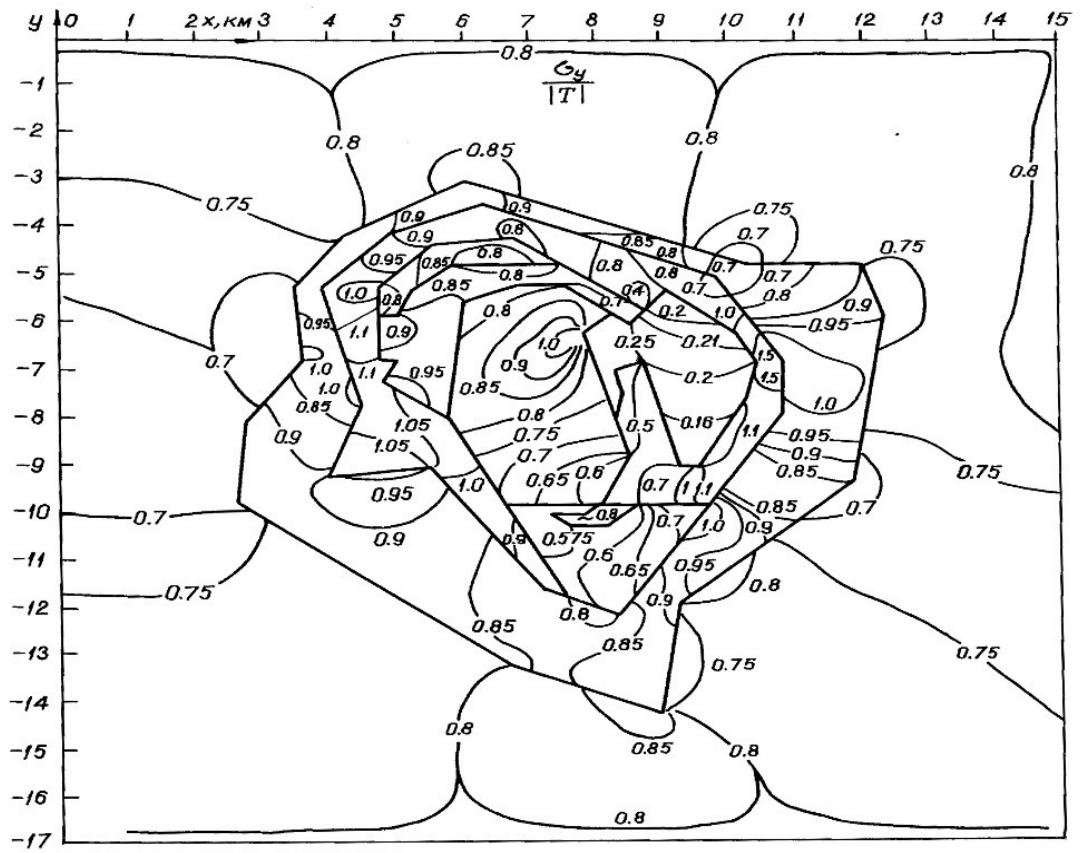

Рис. 2.39. Распределение относительных максимальных напряжений $\sigma_{y} / T$ в районе Ковдорской интрузии

Таблица 2.10

Упругие свойства пород в структурно-геологических секторах в районе карьера «Железный»

\begin{tabular}{|c|c|c|c|c|c|c|}
\hline $\begin{array}{c}\text { № } \\
\text { сектора }\end{array}$ & Породы & $\begin{array}{c}\text { Модуль } \\
\text { Юнга } \\
E \cdot 10^{-4}, \\
\text { МПа }\end{array}$ & $\begin{array}{l}\text { Коэффициент } \\
\text { Пуассона } v\end{array}$ & $\begin{array}{c}\text { Предел } \\
\text { прочности } \\
\text { при } \\
\text { сжатии бс, } \\
\text { МПа } \\
\end{array}$ & $\begin{array}{c}\text { Предел } \\
\text { прочности } \\
\text { при } \\
\text { растяжении } \\
\text { бр, МПа } \\
\end{array}$ & $\begin{array}{c}\text { Предел } \\
\text { растягивающих } \\
\text { деформаций } \\
\varepsilon_{\mathrm{p}} \cdot 10^{3}\end{array}$ \\
\hline 1 & $\begin{array}{l}\text { Пироксенит } 70 \text { \%, } \\
\text { карбонатит } 30 \text { \% }\end{array}$ & 6,9 & 0,1 & -63 & 8 & 0,12 \\
\hline 2 & Пироксенит $100 \%$ & 7,4 & 0,11 & -88 & 10 & 0,13 \\
\hline 3 & $\begin{array}{l}\text { Ийолит } 70 \text { \%, } \\
\text { пироксенит } 30 \text { \% }\end{array}$ & 8,9 & 0,18 & -142 & 10 & 0,11 \\
\hline 4 & $\begin{array}{l}\text { Фенит } 70 \% \text {, } \\
\text { ийолит } 30 \%\end{array}$ & 8,25 & 0,224 & -150 & 11 & 0,13 \\
\hline 5 & $\begin{array}{l}\text { Фенит } 70 \text { \%, } \\
\text { пироксенит } 30 \%\end{array}$ & 7,65 & 0,194 & -127 & 11 & 0,14 \\
\hline 6 & $\begin{array}{l}\text { Фенит } 70 \text { \%, } \\
\text { карбонатит 30 \% }\end{array}$ & 7,1 & 0,185 & -117 & 9 & 0,13 \\
\hline 7 & $\begin{array}{l}\text { Ийолит } 70 \text { \%, } \\
\text { карбонатит 30 \% }\end{array}$ & 8,26 & 0,17 & -132 & 8 & 0,1 \\
\hline 8 & $\begin{array}{l}\text { Фенит } 70 \%, \\
\text { ийолит } 30 \%\end{array}$ & 8,25 & 0,224 & -150 & 11 & 0,13 \\
\hline
\end{tabular}


На рисунке 2.40 приведено распределение относительных минимальных напряжений $\sigma_{\min } / T$ в соответствующих секторах $1-8$ при действии на границе $\sigma_{x}^{\infty}=0,85 T$ и $\sigma_{y}^{\infty}=1,05 T$. Характерной особенностью этого распределения является то, что напряжения $\sigma_{\min }$, являясь нулевыми на границе карьера (карьер свободен от внешних усилий), по величине возрастают до значений $\sigma_{\min }=\sigma_{x}^{\infty}$, оставаясь сжимающими. Очевидно, что характер их изменения в каждом секторе различный и зависит не только от механических свойств пород в рассматриваемом секторе, но и от того, каковы свойства пород в соседних секторах.

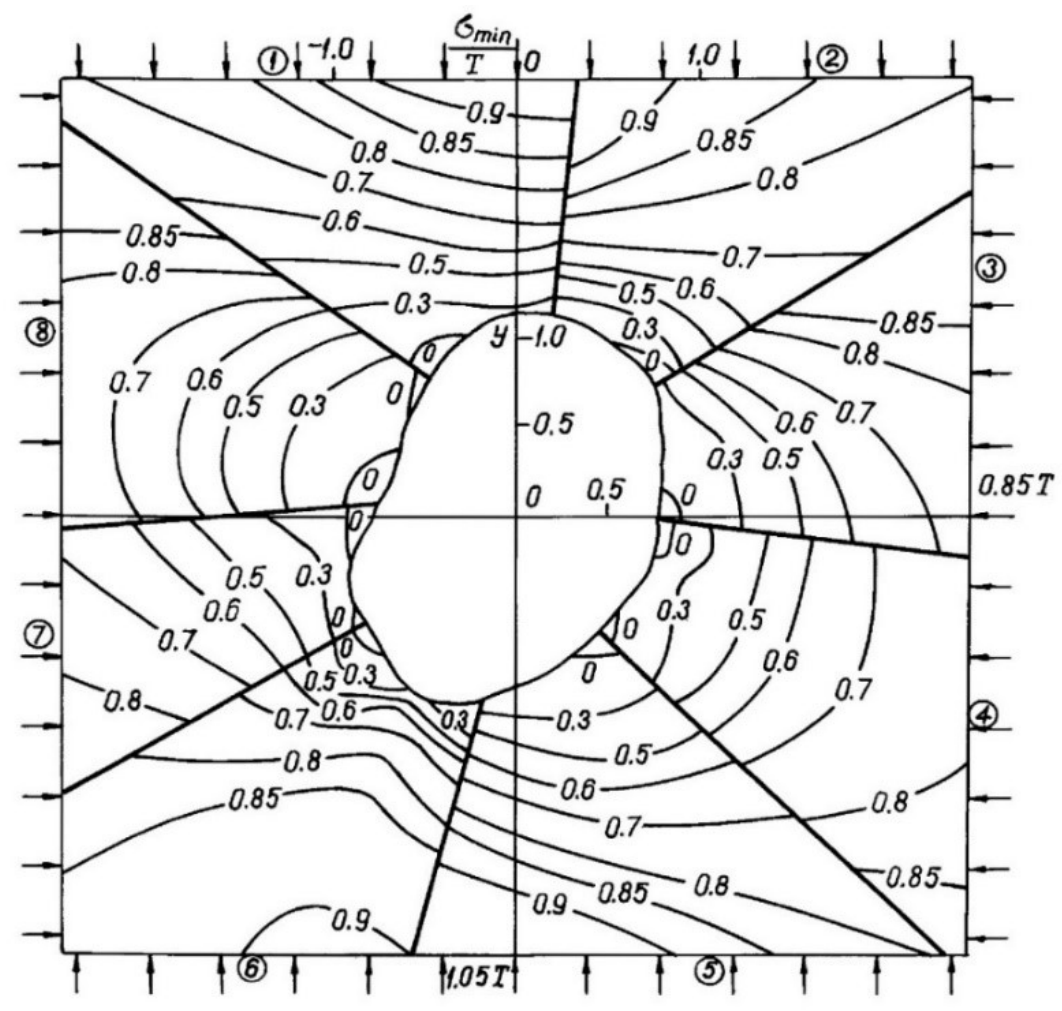

Рис. 2.40. Распределение относительных минимальных напряжений $\sigma_{\min } / T$ вблизи карьера «Железный»: 1-8- структурно-геологические сектора

На рисунке 2.41 показано распределение относительных максимальных напряжений $\sigma_{\max } / T$. Здесь очевидна следующая закономерность: вблизи контура карьера $\sigma_{\max }$ имеют максимальное по величине значение $1,3 T \leq \sigma_{\max } \leq 2 T$, которое уменьшается по мере удаления от контура в массив до $\sigma_{\max }=\sigma_{y}^{\infty}$. 


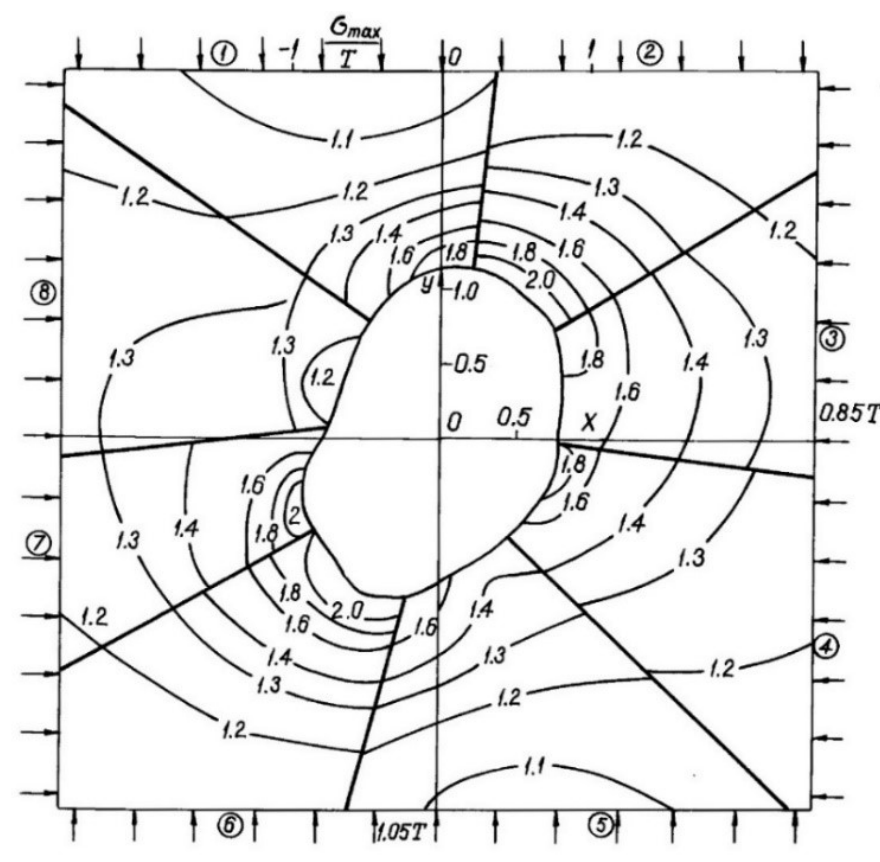

Рис. 2.41. Распределение относительных максимальных напряжений $\sigma_{\max } / T$ вблизи карьера «Железный»

Исходя из этих закономерностей распределения минимальных и максимальных напряжений, становится очевидной возможность формирования растягивающих деформаций $\varepsilon_{1}$ вблизи карьера до тех пор, пока $\sigma_{\min }<-v \sigma_{\max }$.

На рисунке 2.42 показаны зоны, где действуют деформации растяжения в исследуемых секторах при заданных граничных условиях и механических свойствах пород. Это достаточно протяженные зоны, величина которых достигает размеров $0,2 L$ и более, где $L$ - наибольший диаметр карьера. Растягивающие деформации для устойчивости горных пород весьма опасны, так как для не нарушенных трещинами пород предел прочности на растяжение

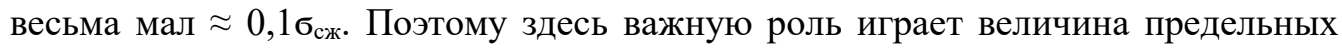
деформаций удлинения, которую можно оценить зависимостью:

$$
\varepsilon_{\mathrm{p}}=\sigma_{\mathrm{p}} / E
$$

где $\sigma_{p}$ - предел прочности пород при растяжении.

На рисунке 2.42 пунктирной линией показана область предельных деформаций растяжения. Эта область подобна области предельных значений удельной энергии деформирования при растяжении:

$$
w=\varepsilon_{\mathrm{p}} \sigma_{\mathrm{p}} / 2,
$$

На рисунке 2.42 видно, что величина предельных деформаций растяжения формируется вблизи разломов, разделяющих структурные блоки. Это связано с тем, что по границам раздела структурно-геологических сегментов происходит их сдвижение друг относительно друга наряду с возникновением растягивающих деформаций параллельно границе карьера. 


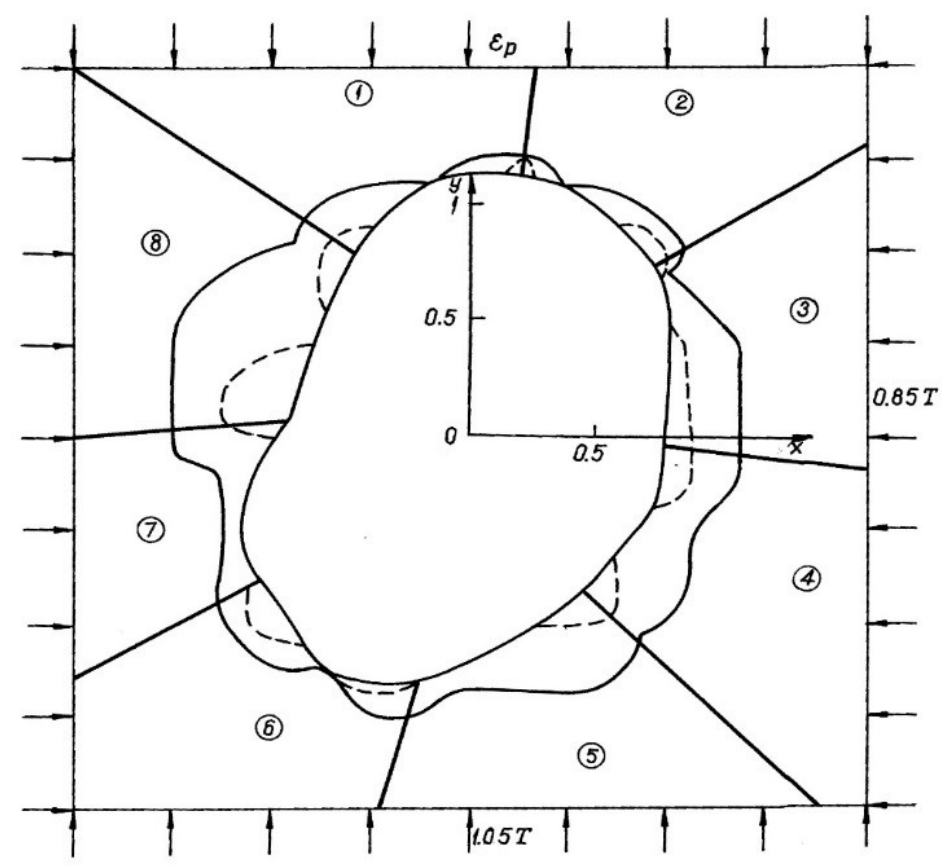

Рис. 2.42. Зоны действия деформаций растяжения вблизи карьера «Железный»:- — - граница действия растягивающих деформаций; - - - - - граница действия предельных растягивающих деформаций

Для выяснения причин сдвижения блоков необходимо определить величину предельных напряжений, при которых происходит сдвиг, то есть необходимо знать $|\tau|_{\text {пр. }}$ В соответствии с теориями прочности для хрупких материалов [107] на практике используется зависимость:

$$
|\tau|_{\text {пр }}=(0,8-1,0)\left|\sigma_{\mathrm{p}}\right| .
$$

Очевидно, что сдвиг по какой-либо поверхности ослабления может произойти тогда, когда минимальные величины касательных напряжений будут равны $|\tau|_{\text {пр, то }}$ есть условие (2.53) будет выполняться в любой точке этой поверхности. В нашем случае вблизи границ контактов структурно-геологических секторов действуют главные напряжения: $\sigma_{1}=(0-0,85) T$ и $\sigma_{2}=(2,0-1,05) T$. Следовательно, наименьшим касательным напряжением на границе раздела секторов будет:

$$
|\tau|_{\text {пр }}=\left|\frac{0,85-1,05}{2} \mathrm{~T}\right|=0,1|\mathrm{~T}|=5 \text { МПа. }
$$

Учитывая то обстоятельство, что для горных пород $\left|\boldsymbol{\sigma}_{\mathrm{p}}\right| \approx(10-15) \mathrm{MПа,}$ можно сделать вывод о выполнении условий (2.53).

Таким образом, установлены следующие закономерности распределения тектонических напряжений в Ковдорской интрузии: 
1. Величины относительных минимальных и максимальных тектонических напряжений, а также характер их распределения существенным образом зависят от наличия области ослабленных пород четвертичного отложения, располагаемой на северо-востоке массива. Окружающие ее участки крепких пород воспринимают на себя большую часть нагрузок аналогично тому, как располагаются зоны повышенных напряжений вблизи горных выработок. В окрестности отработки апатит-магнетитового месторождения карьером «Железный» в направлении восток-запад действуют напряжения $\sigma_{x_{x}}^{\infty} \approx 0,85 T=-42,5$ МПа, а в направлении север-юг $-\sigma_{y}^{\infty}:=1,05 T=-52,5$ МПа.

2. Вблизи карьера за счет образования техногенной, свободной от внешних усилий, поверхности и существующих природных структурно-геологических секторов происходит дальнейшее перераспределение тектонических напряжений, минимальная величина которых вблизи границы карьера $\sigma_{\min }=0$, а максимальная $\sigma_{\max }=(1,8-2,0) T=-(90-100)$ МПа.

3. Неравномерное распределение тектонических напряжений вблизи карьерной выемки приводит к возникновению зон растягивающих деформаций, предельные величины которых приурочены к зонам контактов структурно-геологических секторов вблизи границы карьера. Зоны предельных деформаций растяжения подобны зонам концентрации предельных величин упругой энергии деформирования при растяжении.

4. Вблизи границы карьера в зоне контактов структурно-геологических секторов при действии в массиве пород предельных касательных напряжений происходит смещение секторов друг относительно друга, что увеличивает размеры зон неблагоприятных деформаций.

\subsection{0. Напряженное состояние пород в окрестности трещины на границе раздела геологических блоков}

В работах [108-111] даны аналитические решения задачи о взаимодействии трещиноподобных дефектов с распределенными силами сцепления по всей поверхности берегов, расположенных на границе раздела двух упругих сред под действием растягивающих усилий. Получены системы интегро-дифференциальных уравнений для определения напряжений в связях в концевой области трещины. В работе [112] изучено НДС в окрестности двух жестких остроконечных включений, располагаемых на границе раздела двух полуплоскостей с различными упругими свойствами. Одно из включений жестко соединено с окружающей средой, а другое отсоединено от среды и контактирует с ней, подобно гладкому жесткому штампу. В качестве граничных условий рассмотрены растяжение верхней и нижней полуплоскостей в горизонтальном направлении, сжатие в вертикальном направлении и действие касательных напряжений на бесконечности. В результате решения задачи определены комплексные потенциалы составной упругой плоскости, коэффициенты интенсивности напряжений вблизи вершин включений и углы их поворота.

Однако в этих работах не приводятся картины распределения напряжений в окрестности рассматриваемых дефектов. На основании аналитических 
зависимостей невозможно получить общее представление о характере распределения и величинах напряжений, что имеет весьма важное практическое значение. С другой стороны, решения получены при действии растягивающих силовых полей, что в горно-геологических условиях встречается чрезвычайно редко.

В настоящем разделе изучен характер распределения главных напряжений в геологической блочной среде, прямолинейная граница раздела блоков с различными упругими свойствами ориентирована под углом $\alpha$ к направлению действия сжимающих на бесконечности усилий интенсивности $T_{x}$, схема модели показана на рисунке 2.43 .

На границе раздела блоков располагается трещина длины $L$, граница которой свободна от внешних усилий. Величина раскрытия трещины $h=0,02 L$, а угол раскрытия ее берегов $\beta \approx 5^{\circ}$. Контактные условия на границе раздела геологических блоков следующие:

$$
\sigma_{n 1}=\sigma_{n 2} ; \sigma_{t 1}-\sigma_{t 2} \neq 0 ; V_{n 1}=V_{n 2} ; V_{t 1}-V_{t 2} \neq 0 .
$$

где $\sigma_{n 1}, \sigma_{n 2}, \sigma_{t 1}, \sigma_{t 2}-$ нормальные и тангенциальные напряжения в первом и втором блоках соответственно; $V_{n 1}, V_{n 2}, V_{t 1}, V_{t 2}$ - нормальные и тангенциальные перемещения на разных сторонах границы раздела блоков.

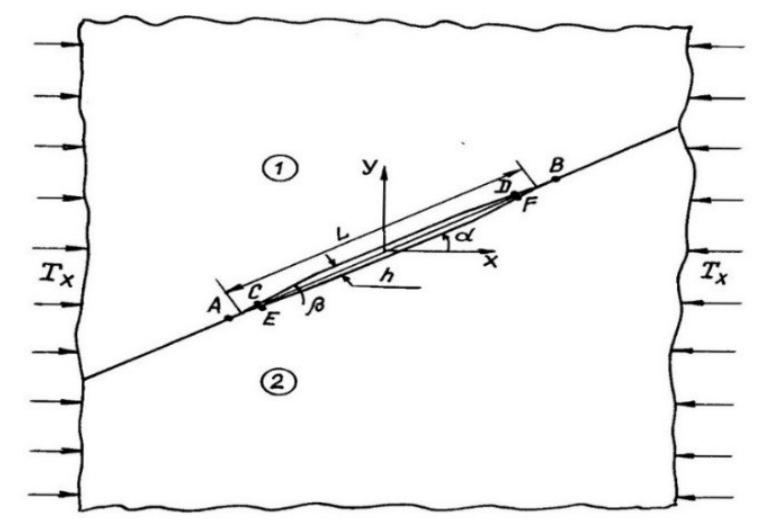

Рис. 2.43. Схема расчетной модели и граничные условия

Иначе говоря, рассматривается случай непрерывности нормальных напряжений и нормальных перемещений на границе раздела двух упругих сред. Рассчитаны варианты углов ориентации $\alpha=0,30,45,60,90^{\circ}$ для отношений модулей Юнга $E_{1} / E_{2}=1,5,10,25,50$. Коэффициент Пуассона для обоих блоков принят одинаковым $v_{1}=v_{2}=0,25$. На рисунке 2.43 показаны точки $A$ и $B$, располагаемые на границе раздела блоков на расстоянии $0,025 L$ от кончиков трещины, и точки $C, D, E, F$ на контуре трещины, находящиеся на таком же расстоянии от кончиков. В этих точках проводится анализ изменения главных напряжений для всех рассматриваемых вариантов.

На рисунке 2.44 показано распределение главных напряжений $\sigma_{1} / T_{x}$ и $\sigma_{2} / T_{x}$ для варианта $\alpha=0^{\circ}, E_{1} / E_{2}=10$. Ввиду того, что расположение границы раздела блоков относительно направления действующих усилий при $\alpha=0$ симметрично, на рисунке приводится симметричная часть распределения напряжений. 


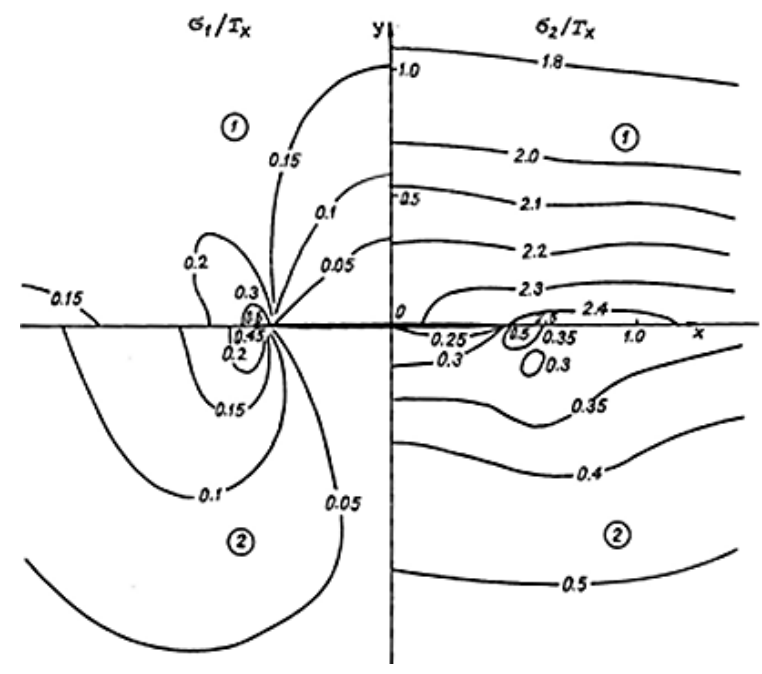

Рис. 2.44. Распределение относительных главных напряжений $\sigma_{1} / T_{x}$ и $\sigma_{2} / T_{x}$ при $\alpha=0^{\circ}$, $E_{1} / E_{2}=10$

На рисунке 2.44 видно, что оба главных напряжения являются сжимающими. При этом в блоке 1 , более жестком по сравнению с блоком 2 , оба главных напряжения по абсолютной величине больше, чем в блоке 2. Величины главных напряжений в точках, располагаемых вблизи кончиков трещины, приведены в таблице 2.11. Здесь и далее знак «+» соответствует растягивающим напряжениям, а знак «-» - сжимающим. Очевидно, что при $E_{1}=E_{2}$, то есть когда упругие характеристики блоков одинаковы, в точках $A$ и $B, C$ и $D, E$ и $F$ главные напряжения по величине одинаковы.

Таблица 2.11 Изменение коэффициентов концентрации главных напряжений в исследуемых точках в зависимости от отношения $E_{1} / E_{2}$ при ориентации границы раздела относительно действующих напряжений $\alpha=0^{\circ}$

\begin{tabular}{|c|c|c|c|c|c|c|c|}
\hline № блока & Точка & Напряжение & $E_{1} / E_{2}=1$ & $E_{1} / E_{2}=5$ & $E_{1} / E_{2}=10$ & $E_{1} / E_{2}=25$ & $E_{1} / E_{2}=50$ \\
\hline \multirow{8}{*}{1} & \multirow{2}{*}{$A$} & $\sigma_{1} / T_{x}$ & $+0,01$ & $-0,389$ & $-0,637$ & \begin{tabular}{|l|}
$-0,869$ \\
\end{tabular} & \begin{tabular}{|l|}
$-0,967$ \\
\end{tabular} \\
\hline & & $\overline{\sigma_{2} / T_{x}}$ & $-0,928$ & $-2,054$ & $-2,556$ & $-3,019$ & $-3,218$ \\
\hline & \multirow{2}{*}{$B$} & $\sigma_{1} / T_{x}$ & $+0,01$ & $-0,389$ & $-0,637$ & $-0,869$ & $-0,967$ \\
\hline & & $\sigma_{2} / T_{x}$ & $-0,928$ & 02,054 & $-2,556$ & $-3,019$ & $-3,218$ \\
\hline & \multirow{2}{*}{$C$} & $\sigma_{1} / T_{x}$ & 0 & 0 & 0 & 0 & 0 \\
\hline & & $\sigma_{2} / T_{x}$ & $-0,935$ & $-1,853$ & $-2,194$ & $-2,490$ & $-2,614$ \\
\hline & \multirow{2}{*}{$D$} & $\sigma_{1} / T_{x}$ & 0 & 0 & 0 & 0 & 0 \\
\hline & & $\sigma_{2} / T_{x}$ & $-0,935$ & $-1,853$ & $-2,194$ & $-2,490$ & $-2,614$ \\
\hline \multirow{8}{*}{2} & \multirow{2}{*}{$A$} & $\sigma_{1} / T_{x}$ & $+0,01$ & $-0,385$ & $-0,471$ & $-0,456$ & $-0,449$ \\
\hline & & $\overline{\sigma_{2} / T_{x}}$ & $-0,928$ & $-0,546$ & $-0,691$ & $-0,950$ & $-1,066$ \\
\hline & \multirow{2}{*}{$B$} & $\sigma_{1} / T_{x}$ & $+0,01$ & $-0,385$ & $-0,471$ & $-0,456$ & $-0,449$ \\
\hline & & $\sigma_{2} / T_{x}$ & $-0,928$ & $-0,546$ & $-0,691$ & $-0,950$ & $-1,066$ \\
\hline & \multirow{2}{*}{$E$} & $\sigma_{1} / T_{x}$ & 0 & 0 & 0 & 0 & 0 \\
\hline & & $\sigma_{2} / T_{x}$ & $-0,935$ & $-0,405$ & $-0,316$ & $-0,263$ & $-0,246$ \\
\hline & \multirow{2}{*}{$F$} & $\sigma_{1} / T_{x}$ & 0 & 0 & 0 & 0 & 0 \\
\hline & & $\sigma_{2} / T_{x}$ & $-0,935$ & $-0,405$ & $-0,316$ & $-0,263$ & $-0,246$ \\
\hline
\end{tabular}


По мере уменьшения жесткости второго блока (увеличения отношения $E_{1} / E_{2}$ ) все напряжения в первом блоке по абсолютной величине возрастают, а во втором блоке в точках $A$ и $B$ напряжения $\sigma_{1}$ изменяются незначительно. На контуре трещины (в точках $C, D, E, F$ ) напряжение $\sigma_{1}=0$ везде. Напряжения $\sigma_{2}$ в точках $E$ и $F$ уменьшаются от $0,94 T_{x}$ до $0,25 T_{x}$, а в точках $A$ и $B$ сначала уменьшаются от $0,93 T_{x}$ до $0,55 T_{x}$ при $E_{1} / E_{2}=5$, а затем возрастают до $1,07 T_{x}$.

Существенным образом изменяется характер распределения главных напряжений в окрестности трещины в случаях, когда $\alpha \neq 0^{\circ}$.

На рисунке $2.45 a$ приведено распределение напряжений $\sigma_{1} / T_{x}$ для случая $\alpha=30^{\circ}, E_{1} / E_{2}=10$. Здесь и далее пунктирными линиями показаны изолинии растягивающих, а сплошными - изолинии сжимающих напряжений. Необходимо отметить, что в окрестности трещины в массиве менее жесткого блока (блок 2) и зона растягивающих напряжений $\sigma_{1}$, и их величина больше, чем в жестком блоке. При этом в окрестности левого кончика трещины над нею в жестком блоке действуют растягивающие напряжения, а вблизи продолжения трещины в окрестности границы контакта блоков - сжимающие. В мягком блоке наоборот: под трещиной формируются сжимающие, а в зоне контакта - растягивающие напряжения. Величины и тех, и других напряжений находятся в пределах $0 \leq\left|\sigma_{1}\right| \leq 0,3 T_{x}$. В окрестности правого (верхнего) кончика трещины в жестком блоке действуют сжимающие напряжения $\sigma_{1}$, а в мягком блоке - растягивающие. Здесь растягивающие напряжения достигают величины порядка $T_{x}$, а на контуре трещины и более. Напряжения $\sigma_{2}$ (рис. 2.45 б) всюду сжимающие, причем в мягком блоке, в окрестности левого кончика, они по величине больше, чем в жестком, а в окрестности верхнего кончика наоборот - в жестком блоке больше, чем в мягком. Изменение величин концентрации напряжений в зависимости от отношения $E_{1} / E_{2}$ в анализируемых точках приведено в таблице 2.12 .

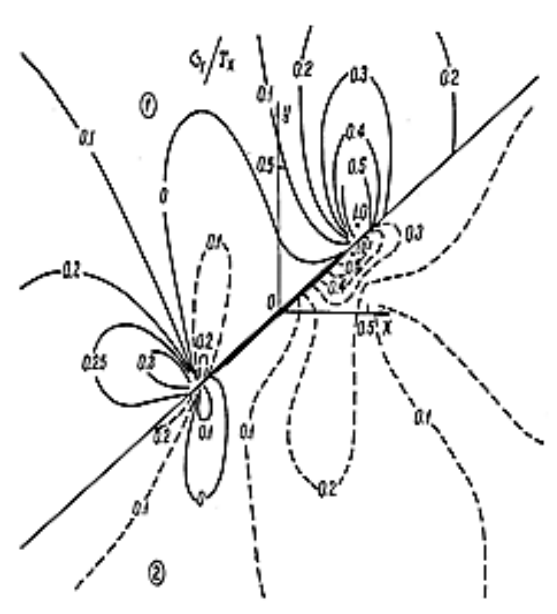

$a$

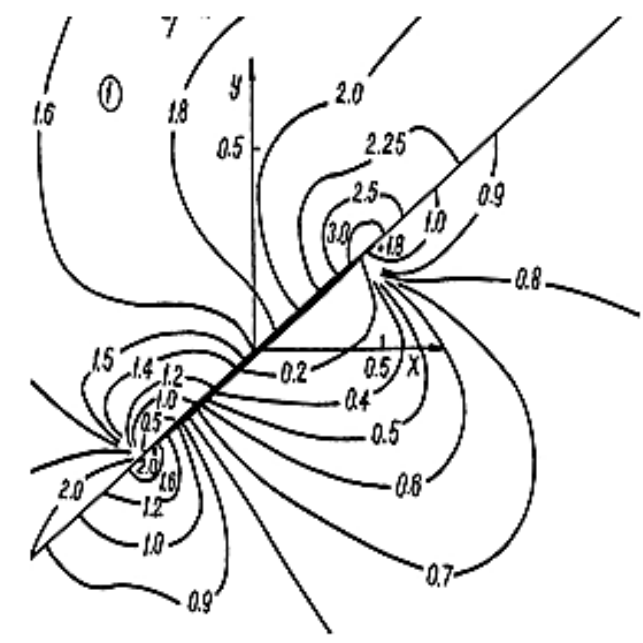

6

Рис. 2.45. Распределение относительных главных напряжений: $a-\sigma_{1} / T_{x} ; \sigma-\sigma_{2} / T_{x}$, при $\alpha=30^{\circ}, E_{1} / E_{2}=10$ 
Таблица 2.12

Изменение коэффициентов концентрации главных напряжений в исследуемых точках в зависимости от отношения $E_{1} / E_{2}$ при ориентации границы раздела относительно действующих напряжений $\alpha=30^{\circ}$

\begin{tabular}{|c|c|c|c|c|c|c|c|}
\hline № блока & Точка & Напряжение & $E_{1} / E_{2}=1$ & $E_{1} / E_{2}=5$ & $E_{1} / E_{2}=10$ & $E_{1} / E_{2}=25$ & $E_{1} / E_{2}=50$ \\
\hline \multirow{8}{*}{1} & \multirow{2}{*}{$A$} & $\sigma_{1} / T_{x}$ & $+1,418$ & $+1,466$ & $+1,330$ & $+1,076$ & $+0,906$ \\
\hline & & $\sigma_{2} / T_{x}$ & $-2,449$ & $-2,741$ & $-2,968$ & $-3,227$ & $-3,358$ \\
\hline & \multirow{2}{*}{ B } & $\sigma_{1} / T_{x}$ & $+0,194$ & $-0,685$ & $-1,055$ & $-1,419$ & $-1,586$ \\
\hline & & $\sigma_{2} / T_{x}$ & $-3,681$ & $-4,384$ & $-4,710$ & $-5,000$ & $-5,115$ \\
\hline & \multirow{2}{*}{ C } & $\sigma_{1} / T_{x}$ & $+1,392$ & $+0,964$ & $+0,665$ & $+0,258$ & $+0,014$ \\
\hline & & $\sigma_{2} / T_{x}$ & 0 & 0 & 0 & 0 & 0 \\
\hline & \multirow{2}{*}{$D$} & $\sigma_{1} / T_{x}$ & 0 & 0 & 0 & 0 & 0 \\
\hline & & $\sigma_{2} / T_{x}$ & $-2,789$ & $-3,479$ & $-3,845$ & $-4,237$ & $-4,435$ \\
\hline \multirow{8}{*}{2} & \multirow[b]{2}{*}{$A$} & $\sigma_{1} / T_{x}$ & $+0,193$ & $+0,728$ & $+0,802$ & $+0,800$ & $+0,769$ \\
\hline & & $\sigma_{2} / T_{x}$ & $-3,681$ & $-3,585$ & $-3,605$ & $-3,582$ & $-3,541$ \\
\hline & \multirow{2}{*}{$B$} & $\sigma_{1} / T_{x}$ & $+1,418$ & $+1,151$ & $+1,003$ & $+0,809$ & $+0,693$ \\
\hline & & $\sigma_{2} / T_{x}$ & $-2,449$ & $-2,634$ & $-2,717$ & $-2,751$ & $-2,74$ \\
\hline & \multirow{2}{*}{$E$} & $\sigma_{1} / T_{x}$ & 0 & 0 & 0 & 0 & 0 \\
\hline & & $\sigma_{2} / T_{x}$ & $-2,789$ & $-2,614$ & $-2,567$ & $-2,471$ & $-2,397$ \\
\hline & \multirow{2}{*}{$F$} & $\sigma_{1} / T_{x}$ & $+1,392$ & $+1,597$ & $+1,613$ & $+1,565$ & $+1,512$ \\
\hline & & $\sigma_{2} / T_{x}$ & 0 & 0 & 0 & 0 & 0 \\
\hline
\end{tabular}

В случае однородной среды с трещиной, располагаемой под углом $\alpha$ к направлению действия сжимающих на бесконечности усилий, величины напряжений на контуре трещины в окрестности кончиков на левом верхнем берегу и нижнем правом, а также на левом нижнем и правом верхнем совпадают $[113,114]$. Аналогичным образом в случае блоков с одинаковыми упругими свойствами $E_{1}=E_{2}$ имеем совпадение значений напряжений в точках $A_{1}$ и $B_{2}, B_{1}$ и $A_{2}$, а также в точках $C$ и $F, D$ и $E$. Здесь индексы 1 и 2 у точек $A$ и $B$ соответствуют первому и второму блокам.

По мере снижения жесткости второго блока величины растягивающих напряжений $\sigma_{1}$ в точках $A_{1}$ и $B_{2}$ уменьшаются, а величины сжимающих напряжений б увеличиваются. Сжимающие напряжения $\sigma_{1}$ в точке $B_{1}$ и растягивающие в точке $A_{2}$ увеличиваются, а сжимающие напряжения $\sigma_{2}$ в точке $B_{1}$ увеличиваются от $3,7 T_{x}$ до $5,1 T_{x}$; в точке $A_{2}$ напряжения $\sigma_{2}$ при этом остаются практически на одинаковом уровне $\sigma_{2}=-(3,54-3,68) T_{x}$. На контуре трещины одно из главных напряжений равно нулю. Растягивающие напряжения $\sigma_{1}$ в точке $C$ уменьшаются, а в точке $F$ сначала возрастают, а затем убывают в пределах $\sigma_{1}=(1,39-1,61) T_{x}$. Сжимающие напряжения $\sigma_{2}$ в точке $D$ возрастают, а в точке $E$ убывают.

Аналогичное распределение напряжений в окрестности трещины наблюдается и при угле $\alpha=45^{\circ}$ (рис. 2.46), а также характер изменения главных напряжений в зависимости от отношения $E_{1} / E_{2}$ (табл. 2.13).

Характер распределения напряжений для углов $\alpha>45^{\circ}$ изменяется таким образом, что теперь и величины растягивающих напряжений $\sigma_{1}$, и зоны их влияния значительно больше в более жестком блоке. На рисунке 2.47 приведено распределение главных напряжений для случая $\alpha=60^{\circ}$ и $E_{1} / E_{2}=10$.

Здесь в окрестности нижнего кончика трещины в блоке 1 (окрестность точки $C$ ) напряжение $\sigma_{1}=1,8 T_{x}$, а вблизи верхнего кончика в блоке 2 (окрестность точки $F$ ) $\sigma_{1} \approx T_{x}$. Изменение величин концентрации напряжений в исследуемых точках в зависимости от $E_{1} / E_{2}$ приведено в таблице 2.14 . В точке $A_{1}$ по мере роста $E_{1} / E_{2}$ растягивающие напряжения $\sigma_{1}$ возрастают, а сжимающие $\sigma_{2}$ остаются примерно 
на одном уровне $\sigma_{2} \approx-4,3 T_{x}$. В точке $A_{2}$ напряжение $\sigma_{1}$ от сжимающих значений переходит к растягивающим, а б $\sigma_{2} \approx-5,4 T_{x}$. В точках $B_{1}$ и $B_{2}$ оба главных напряжения сжимающие, за исключением случая $E_{1}=E_{2}$. Растягивающие напряжения $\sigma_{1}$ в точке $C$ по мере роста $E_{1} / E_{2}$ увеличиваются, а в точке $F-$ уменьшаются. При этом в точке $C$ они в 2 и более раза выше, чем в точке $F$. Напряжения $\sigma_{2}$ в точках $D$ и $E$ сжимающие, причем в точке $D$ они уменьшаются, а в точке $E$ увеличиваются.

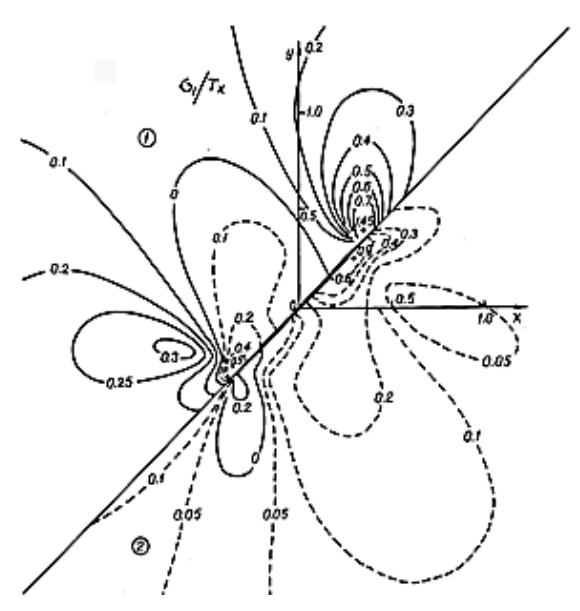

$a$

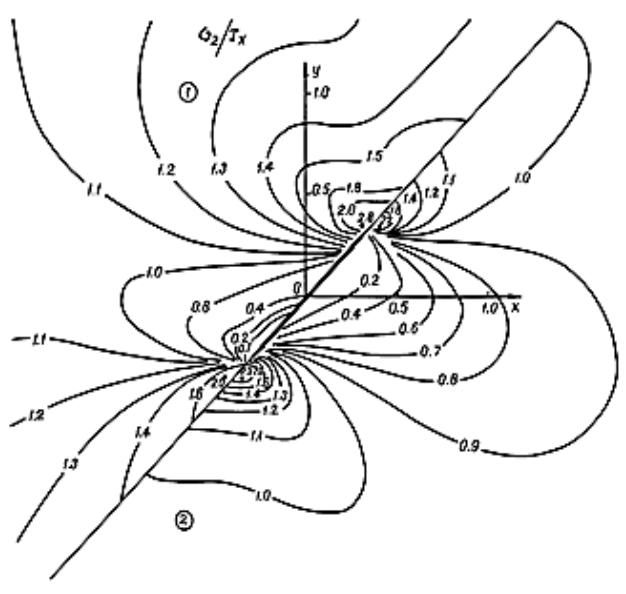

6

Рис. 2.46. Распределение относительных главных напряжений: $a-\sigma_{1} / T_{x} ; \sigma-\sigma_{2} / T_{x}$, при $\alpha=45^{\circ}, E_{1} / E_{2}=10$

Таблииа 2.13

Изменение коэффициентов концентрации главных напряжений в исследуемых точках в зависимости от отношения $E_{1} / E_{2}$ при ориентации границы раздела относительно действующих напряжений $\alpha=45^{\circ}$

\begin{tabular}{|c|c|c|c|c|c|c|c|}
\hline № блока & Точка & Напряжение & $E_{1} / E_{2}=1$ & $E_{1} / E_{2}=5$ & $E_{1} / E_{2}=10$ & $E_{1} / E_{2}=25$ & $E_{1} / E_{2}=50$ \\
\hline \multirow{8}{*}{1} & \multirow[b]{2}{*}{$A$} & $\sigma_{1} / T_{x}$ & $+1,504$ & $+2,032$ & $+2,081$ & $+2,075$ & $+2,060$ \\
\hline & & $\sigma_{2} / T_{x}$ & $-3,747$ & $-3,788$ & $-3,853$ & $-3,944$ & $-3,994$ \\
\hline & \multirow{2}{*}{$B$} & $\sigma_{1} / T_{x}$ & $-0,321$ & $-1,450$ & $-1,804$ & $-2,101$ & $-2,225$ \\
\hline & & $\sigma_{2} / T_{x}$ & $-5,009$ & $-4,997$ & $-5,013$ & $-5,050$ & $-5,074$ \\
\hline & \multirow{2}{*}{$C$} & $\sigma_{1} / T_{x}$ & $+2,056$ & $+2,119$ & $+2,054$ & $+1,960$ & $+1,910$ \\
\hline & & $\sigma_{2} / T_{x}$ & 0 & 0 & 0 & 0 & 0 \\
\hline & \multirow{2}{*}{$D$} & $\sigma_{1} / T_{x}$ & 0 & 0 & 0 & 0 & 0 \\
\hline & & $\sigma_{2} / T_{x}$ & $-3,028$ & $-3,026$ & $-3,074$ & $-3,144$ & $-3,183$ \\
\hline \multirow{8}{*}{2} & \multirow{2}{*}{$A$} & $\sigma_{1} / T_{x}$ & $-0,321$ & $+0,509$ & $+0,665$ & $+0,764$ & $+0,797$ \\
\hline & & $\sigma_{2} / T_{x}$ & $-5,009$ & $-5,005$ & $-5,024$ & $-5,058$ & $-5,078$ \\
\hline & \multirow{2}{*}{$B$} & $\sigma_{1} / T_{x}$ & $+1,504$ & $+0,754$ & $+0,548$ & $+0,389$ & $+0,327$ \\
\hline & & $\sigma_{2} / T_{x}$ & $-3,747$ & $-3,729$ & $-3,731$ & $-3,743$ & $-3,751$ \\
\hline & \multirow{2}{*}{$E$} & $\sigma_{1} / T_{x}$ & 0 & 0 & 0 & 0 & 0 \\
\hline & & $\sigma_{2} / T_{x}$ & $-3,028$ & $-3,071$ & $-3,078$ & $-3,082$ & $-3,084$ \\
\hline & \multirow{2}{*}{$F$} & $\sigma_{1} / T_{x}$ & $+2,056$ & $+1,771$ & $+1,683$ & $+1,614$ & $+1,587$ \\
\hline & & $\sigma_{2} / T_{x}$ & 0 & 0 & 0 & 0 & 0 \\
\hline
\end{tabular}




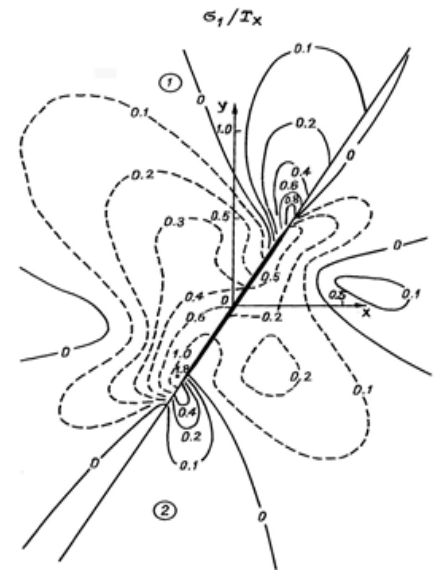

$a$

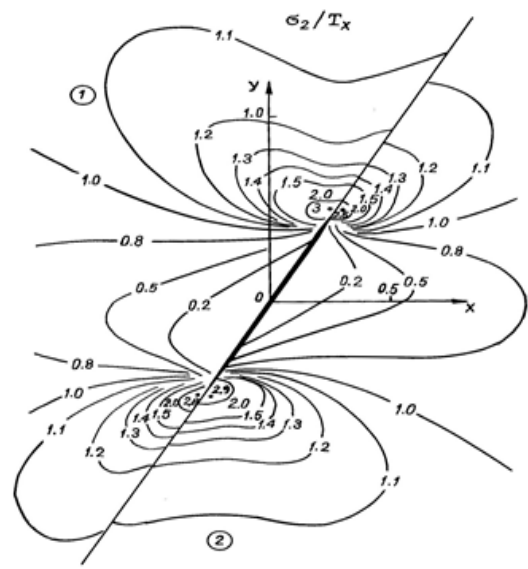

$\sigma$

Рис. 2.47. Распределение относительных главных напряжений: $a-\sigma_{1} / T_{x} ; \sigma-\sigma_{2} / T_{x}$, при $\alpha=60^{\circ}, E_{1} / E_{2}=10$

Таблица 2.14

Изменение коэффициентов концентрации главных напряжений в исследуемых точках в зависимости от отношения $E_{1} / E_{2}$ при ориентации границы раздела относительно действующих напряжений $\alpha=60^{\circ}$

\begin{tabular}{|c|c|c|c|c|c|c|c|}
\hline № блока & Точка & Напряжение & $E_{1} / E_{2}=1$ & $E_{1} / E_{2}=5$ & $E_{1} / E_{2}=10$ & $E_{1} / E_{2}=25$ & $E_{1} / E_{2}=50$ \\
\hline \multirow{8}{*}{1} & \multirow{2}{*}{$A$} & $\sigma_{1} / T_{x}$ & $+0,581$ & $+1,570$ & $+1,810$ & $+1,978$ & $+2,037$ \\
\hline & & $\sigma_{2} / T_{x}$ & $-4,257$ & $-4,330$ & $-4,305$ & $-4,276$ & $-4,263$ \\
\hline & \multirow{2}{*}{$B$} & $\sigma_{1} / T_{x}$ & $-1,214$ & $-2,150$ & $-2,343$ & $-2,469$ & $-2,512$ \\
\hline & & $\sigma_{2} / T_{x}$ & $-5,077$ & $-4,489$ & $-4,316$ & $-4,185$ & $-4,135$ \\
\hline & \multirow{2}{*}{$C$} & $\sigma_{\sigma_{1}} / T_{x}$ & $+1,911$ & $+2,549$ & $+2,695$ & $+2,797$ & $+2,836$ \\
\hline & & $\sigma_{2} / T_{x}$ & 0 & 0 & 0 & 0 & 0 \\
\hline & \multirow{2}{*}{$D$} & $\sigma_{1} / T_{x}$ & 0 & 0 & 0 & 0 & 0 \\
\hline & & $\sigma_{2} / T_{x}$ & $-2,292$ & $-1,736$ & $-1,589$ & $-1,479$ & $-1,435$ \\
\hline \multirow{8}{*}{2} & \multirow[b]{2}{*}{$A$} & $\sigma_{1} / T_{x}$ & $-1,214$ & $-0,217$ & $+0,011$ & $+0,167$ & $+0,221$ \\
\hline & & $\sigma_{2} / T_{x}$ & $-5,077$ & $-5,400$ & $-5,434$ & $-5,446$ & $-5,447$ \\
\hline & \multirow[b]{2}{*}{$B$} & $\sigma_{\sigma_{1}} / T_{x}$ & $+0,581$ & $-0,247$ & $-0,403$ & $-0,504$ & $-0,539$ \\
\hline & & $\sigma_{2} / T_{x}$ & $-4,257$ & $-3,978$ & $-3,898$ & $-3,840$ & $-3,818$ \\
\hline & \multirow{2}{*}{$E$} & $\sigma_{1} / T_{x}$ & 0 & 0 & 0 & 0 & 0 \\
\hline & & $\sigma_{2} / T_{x}$ & $-2,292$ & $-2,747$ & $-2,836$ & $-2,893$ & $-2,911$ \\
\hline & \multirow{2}{*}{$F$} & $\sigma_{1} / T_{x}$ & $+1,911$ & $+1,248$ & $+1,089$ & $+0,975$ & $+0,932$ \\
\hline & & $\sigma_{2} / T_{x}$ & 0 & 0 & 0 & 0 & 0 \\
\hline
\end{tabular}

При $\alpha=90^{\circ}$ в жестком блоке зона растягивающих напряжений достигает размеров порядка $2 L$, в то время как в более мягком блоке она не превышает $0,5 L$. На рисунке 2.48 приведено распределение главных напряжений для варианта $E_{1} / E_{2}=10$. Здесь в силу симметрии расположения границы раздела блоков относительно действующих на бесконечности усилий окрестности точек $A_{1}$ и $B_{1}, A_{2}$ и $B_{2}, C$ и $D, E$ и $F$ идентичны. В таблице 2.15 даны величины концентрации напряжений в рассматриваемых точках в зависимости от отношения $E_{1} / E_{2}$. В точках 
$A_{1}, B_{1}$ и $A_{2}, B_{2}$ (на продолжении трещины) оба главных напряжения являются сжимающими. При этом в обоих блоках $\sigma_{1}$ по величине убывают, а $\sigma_{2}$ находятся примерно на одинаковом уровне $\sigma_{2} \approx-(4,5-4,8) T_{x}$. В точках $C$ и $D$ растягивающие напряжения $\sigma_{1}$ по мере роста $E_{1} / E_{2}$ увеличиваются от $0,05 T_{x}$ при $E_{1}=E_{2}$ до $1,73 T_{x}$ для $E_{1} / E_{2}=50$. Напряжения $\sigma_{2}$ при этом равны нулю. В точках $E$ и $F \sigma_{1}=0$, а напряжения $\sigma_{2}$ сжимающие и также возрастают по абсолютной величине.

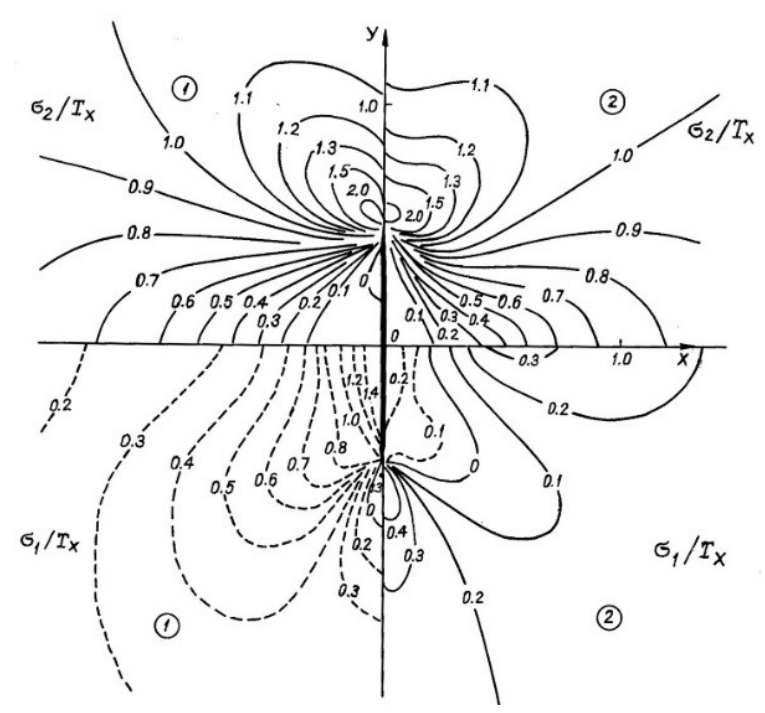

Рис. 2.48. Распределение относительных главных напряжений $\sigma_{1} / T_{x} \quad$ и $\quad \sigma_{2} / T_{x}$ при $\alpha=90^{\circ}, E_{1} / E_{2}=10$

Таблица 2.15

Изменение коэффициентов концентрации главных напряжений в исследуемых точках в зависимости от отношения $E_{1} / E_{2}$ при ориентации границы раздела относительно действующих напряжений $\alpha=90^{\circ}$

\begin{tabular}{|c|c|c|c|c|c|c|c|}
\hline $\begin{array}{c}\text { № } \\
\text { блока }\end{array}$ & Точка & Напряжение & $E_{1} / E_{2}=1$ & $E_{1} / E_{2}=5$ & $E_{1} / E_{2}=10$ & $E_{1} / E_{2}=25$ & $E_{1} / E_{2}=50$ \\
\hline \multirow{8}{*}{1} & \multirow{2}{*}{$A$} & $\sigma_{1} / T_{x}$ & $-2,019$ & $-1,096$ & $-0,729$ & $-0,432$ & $-0,315$ \\
\hline & & $\sigma_{2} / T_{x}$ & $-4,715$ & $-4,720$ & $-4,661$ & $-4,583$ & $-4,544$ \\
\hline & \multirow{2}{*}{$B$} & $\sigma_{1} / T_{x}$ & $-2,019$ & $-1,096$ & $-0,729$ & $-0,432$ & $-0,315$ \\
\hline & & $\sigma_{2} / T_{x}$ & $-4,715$ & $-4,720$ & $-4,661$ & $-4,583$ & $-4,544$ \\
\hline & \multirow{2}{*}{$C$} & $\sigma_{1} / T_{x}$ & $+0,050$ & $+1,117$ & $+1,415$ & $+1,645$ & $+1,734$ \\
\hline & & $\sigma_{2} / T_{x}$ & 0 & 0 & 0 & 0 & 0 \\
\hline & \multirow{2}{*}{$D$} & $\sigma_{1} / T_{x}$ & $+0,050$ & $+1,117$ & $+1,415$ & $+1,645$ & $+1,734$ \\
\hline & & $\sigma_{2} / T_{x}$ & 0 & 0 & 0 & 0 & 0 \\
\hline \multirow{8}{*}{2} & \multirow{2}{*}{$A$} & $\sigma_{1} / T_{x}$ & $-2,019$ & $-1,830$ & $-1,661$ & $-1,525$ & $-1,473$ \\
\hline & & $\sigma_{2} / T_{x}$ & $-4,715$ & $-4,806$ & $-4,810$ & $-4,789$ & $-4,774$ \\
\hline & \multirow[b]{2}{*}{$B$} & $\sigma_{1} / T_{x}$ & $-2,019$ & $-1,830$ & $-1,661$ & $-1,525$ & $-1,473$ \\
\hline & & $\sigma_{2} / T_{x}$ & $-4,715$ & $-4,806$ & $-4,810$ & $-4,789$ & $-4,774$ \\
\hline & \multirow{2}{*}{$E$} & $\sigma_{1} / T_{x}$ & $+0,050$ & 0 & 0 & 0 & 0 \\
\hline & & $\sigma_{2} / T_{x}$ & 0 & $-0,838$ & $-1,024$ & $-1,150$ & $-1,194$ \\
\hline & \multirow{2}{*}{$F$} & $\sigma_{1} / T_{x}$ & $+0,050$ & 0 & 0 & 0 & 0 \\
\hline & & $\sigma_{2} / T_{x}$ & 0 & $-0,838$ & $-1,024$ & $-1,150$ & $-1,194$ \\
\hline
\end{tabular}


Приведенный анализ распределения напряжений свидетельствует о том, что разрушение массива (рост трещины), возможное при наличии растягивающих напряжений, превышающих предел прочности пород, будет происходить следующим образом (рис. 2.49):

1) для углов ориентации границы раздела блоков $\alpha<45^{\circ}$ начнет развиваться трещина отрыва ортогонально границе исходной трещины, в ее верхнем (правом) кончике, со стороны менее жесткого блока;

2) при угле ориентации $\alpha=45^{\circ}$ возможно разрушение ортогонально границе исходной трещины в нижнем (левом) кончике в сторону жесткого блока, а в верхнем - в сторону мягкого блока. Какое разрушение произойдет в первую очередь, зависит от прочностных свойств пород, слагающих блоки;

3) для углов $\alpha>45^{\circ}$ трещина отрыва начнет развиваться ортогонально границе исходной трещины в нижнем кончике в сторону более жесткого блока;

4) при угле ориентации границы раздела блоков $\alpha=90^{\circ}$ разрушение, вероятнее всего, произойдет в центре исходной трещины в сторону более жесткого блока;

5) при угле ориентации границы раздела блоков $\alpha=0^{\circ}$ с исходной трещиной на ней разрушение маловероятно, так как в окрестности такой трещины формируются зоны концентрации сжимающих главных напряжений и $\sigma_{1}$ и $\sigma_{2}$.
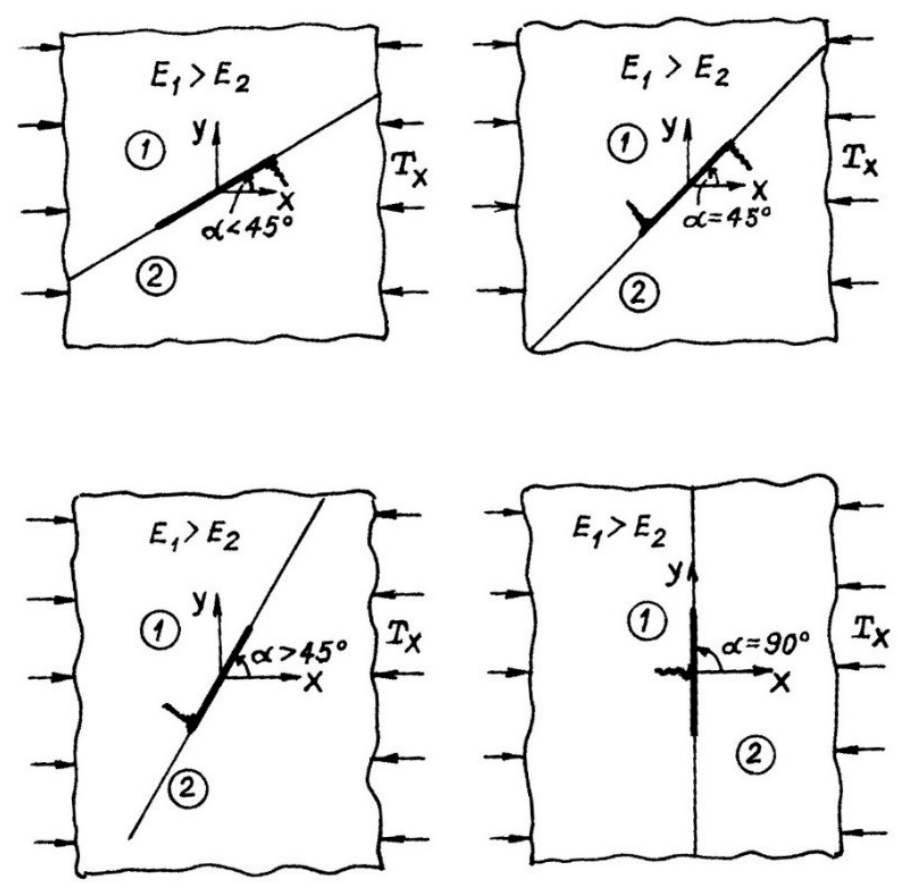

Рис. 2.49. Характер возможного разрушения (развитие трещин отрыва) вблизи исходной трещины, располагаемой на границе блоков с различными упругими свойствами

Характер распределения этих напряжений и способы разрушения массива горных пород в таких условиях определяют возможность образования «кирпичной кладки», наблюдаемой в некоторых участках геологической среды. 


\subsection{1. Напряженное состояние массива горных пород вблизи трещины, пересекающей гранищу раздела двух блоков}

Иерархично-блочное строение массива горных пород обусловлено формой и размерами слагающих его составных частей, а также их взаимным расположением. Изучение процессов разрушения горных пород позволило установить особую роль трещиноватости массива. Под трещиноватостью следует понимать наличие плоскостей ослабления, образованных в результате различных природных и техногенных причин.

Вопросам исследования НДС хрупких тел с трещинами и их разрушению посвящено много работ, например, А. А. Грифитса [115]. Более широкое развитие теория трещин получила в работах советских ученых [116-118]. Интересным представляется то обстоятельство, что в деформируемом теле в условиях действия на его границе сжимающих усилий в концевой зоне трещины возникают растягивающие главные напряжения. Этим во многом и определяется характер разрушения, например, горных пород, у которых предел прочности при растяжении составляет первые десятки МПа. Разрушение барьерных зон между трещинами в однородном массиве горных пород рассматрено в [114]. В предыдущем разделе показано НДС и разрушение горных пород с трещинами, располагаемыми на границе раздела двух сред [119].

В иерархично-блочной геологической среде трещины могут пересекать границу раздела блоков с различными свойствами. Это могут быть как раскрытые трещины, так и протяженные заполненные включения. Научный и практический интерес представляют закономерности формирования НДС таких массивов.

Рассмотрим напряженное состояние сжатой плоскости с горизонтальной границей раздела двух блоков, которую пересекает раскрытая трещина (рис. 2.50). В качестве условий пересечения примем углы $\alpha=30^{\circ}, 45^{\circ}, 60^{\circ}$, а механические свойства верхнего блока приведены в таблице 2.16. При этом модуль Юнга и коэффициент Пуассона нижнего блока остаются неизменными $E_{2}=5 \cdot 10^{4} \mathrm{MПа,} v_{2}=0,25$.

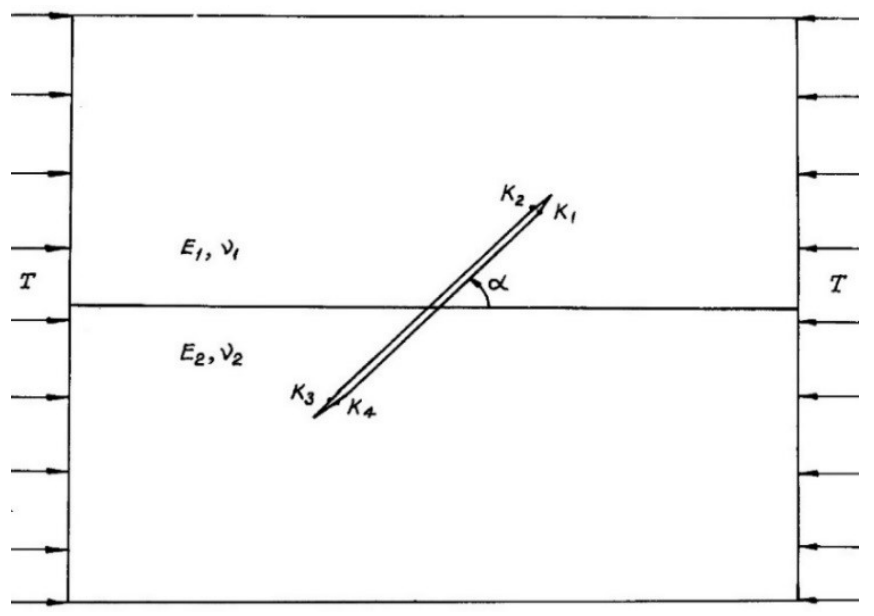

Рис. 2.50. Схема расчетной модели и граничные условия: $K_{1}-K_{4}-$ граничные точки трещины, в которых производится определение напряжений 
Модуль Юнга и коэффициент Пуассона для верхнего блока

\begin{tabular}{|c|c|c|c|r|r|c|}
\hline$E_{1} \mathrm{M \Pi а}$ & $5 \cdot 10^{4}$ & $2,5 \cdot 10^{4}$ & $1,43 \cdot 10^{4}$ & $1 \cdot 10^{4}$ & $6,67 \cdot 10^{3}$ & $5 \cdot 10^{3}$ \\
\hline$v_{1}$ & 0,25 & 0,26 & 0,27 & 0,3 & 0,325 & 0,35 \\
\hline$E_{2} / E_{1}$ & 1 & 2 & 3,5 & 5 & 7,5 & 10 \\
\hline
\end{tabular}

Для сопоставления результатов оценки распределения напряжений вблизи раскрытой трещины и мягкого включения показан характер распределения напряжений возле протяженного включения с модулем Юнга и коэффициентом Пуассона $E_{3}=5 \cdot 10^{3} \mathrm{MПа,} v_{3}=0,35$, пересекающего под углом $\alpha=30^{\circ}$ границу раздела блоков с отношением $E_{2} / E_{1}=2$. Закономерности формирования напряженного состояния изучены методом граничных элементов. На границе контактирующих блоков и мягкого включения предполагается непрерывность нормальных напряжений и перемещений (рис. 2.50).

Распределение напряжений в окрестности трещины (рис. 2.51) характеризуется тем, что:

- в массиве, ниже контурной точки $K_{1}$ (в более мягком блоке), формируются растягивающие главные напряжения $\sigma_{1}$ (пунктирные линии на рис. 2.51 a);

- в массиве, выше контурной точки $K_{2}$, действуют сжимающие главные напряжения $\sigma_{1}$;

- в массиве пород, располагаемом выше точки $K_{3}$ (в более жестком блоке), — растягивающие $\sigma_{1}$;

- ниже точки $K_{4}$ - сжимающие;

- второе главное напряжение $\sigma_{2}$ в окрестности трещины является сжимающим повсюду (рис. 2.51 б).

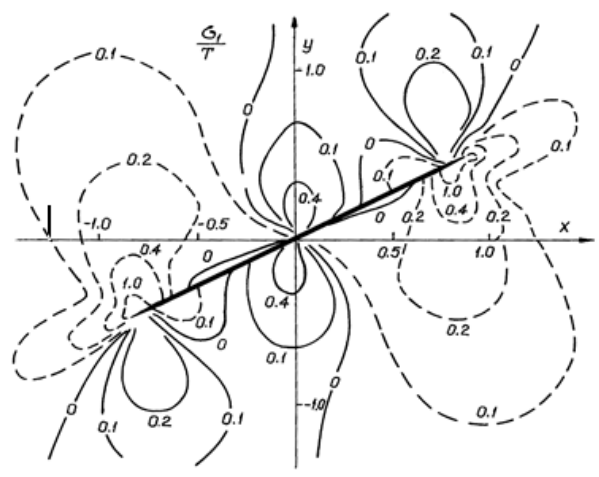

$a$

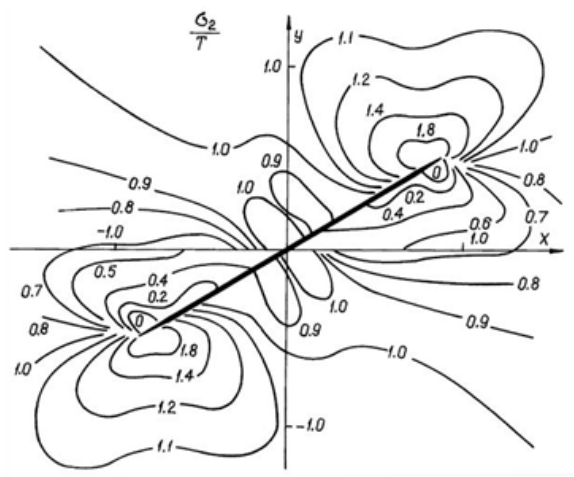

$\sigma$

Рис. 2.51. Распределение относительных главных напряжений $6_{1} / T(a)$ и относительных главных напряжений $\sigma_{2} / T$ при $\alpha=30^{\circ}, E_{2} / E_{1}=1$ (б)

Когда отношение $E_{2} / E_{1}=1$ (оба блока одинаковые), распределение напряжений в обоих блоках относительно трещины «диагонально» симметричные. Изменение упругих свойств блоков нарушает эту симметрию по величине действующих напряжений, оставляя характерные особенности формирования зон сжимающих и растягивающих напряжений неизменными (рис. 2.52). При этом величины растягивающих $\sigma_{1} / T$ и сжимающих $\sigma_{2} / T$ до некоторого значения $E_{2} / E_{1}$ в мягком (верхнем) блоке уменьшаются, а в жестком (нижнем) блоке - увеличиваются. 


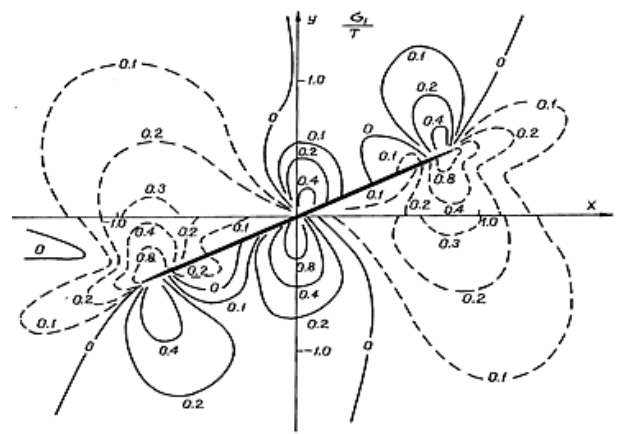

$a$

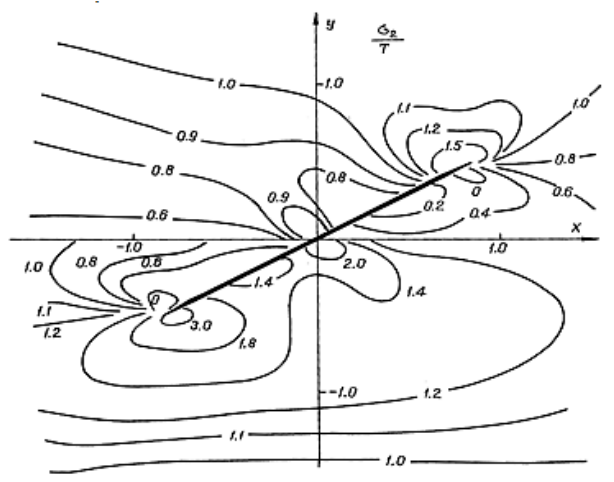

$\sigma$

Рис. 2.52. Распределение относительных главных напряжений б/ $/ T(a)$ и распределение относительных главных напряжений б $/ T$ при $\alpha=30^{\circ}, E_{2} / E_{1}=2$ (б)

Изменение угла наклона трещины относительно границы раздела блоков приводит к увеличению зоны растягивающих напряжений $\sigma_{1} / T$ в массиве пород выше точки $K_{2}$ и ниже точки $K_{4}$. Размеры зон растягивающих напряжений $\sigma_{1} / T$ ниже точки $K_{1}$ и выше точки $K_{3}$ уменышаются, но абсолютные значения напряжений в окрестности этих точек увеличиваются. На рисунке 2.53 показано распределение главных напряжений для угла наклона $\alpha=45^{\circ}, E_{2} / E_{1}=1$.

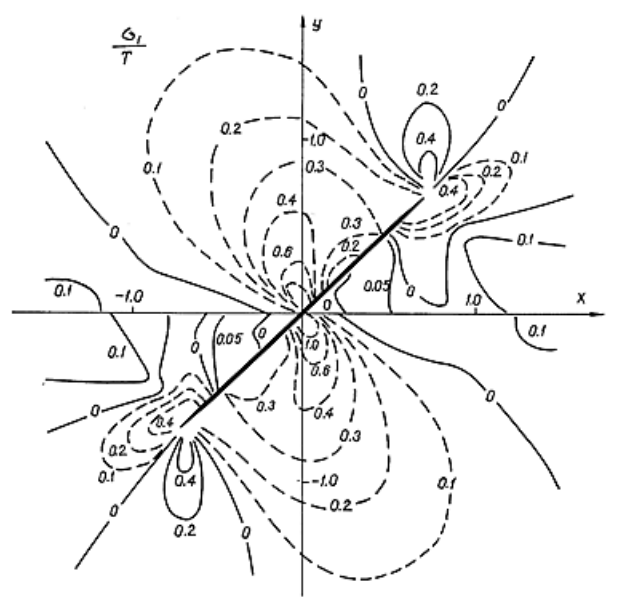

$a$

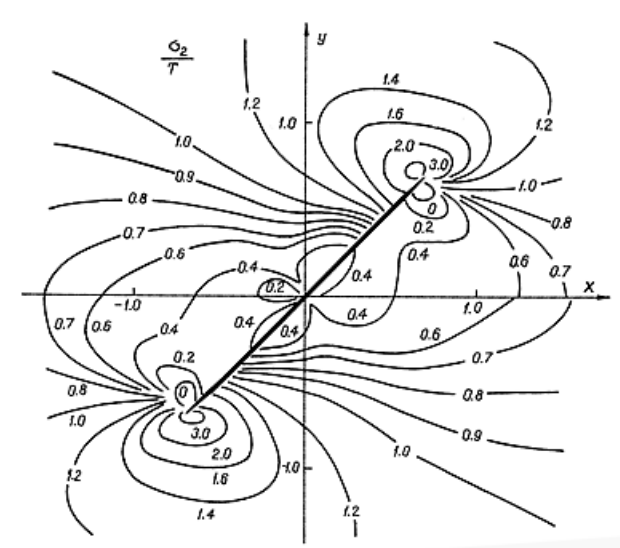

6

Рис. 2.53. Распределение относительных главных напряжений $\sigma_{1} / T(a)$ и относительных главных напряжений $\sigma_{2} / T$ при $\alpha=45^{\circ}, E_{2} / E_{1}=1$ (б)

Аналогичные изменения (рис. 2.54 для $\alpha=60^{\circ}, E_{2} / E_{1}=1$ ) в характере распределения главных напряжений наблюдаются и в других случаях изменения угла наклона и отношений $E_{2} / E_{1}$. 


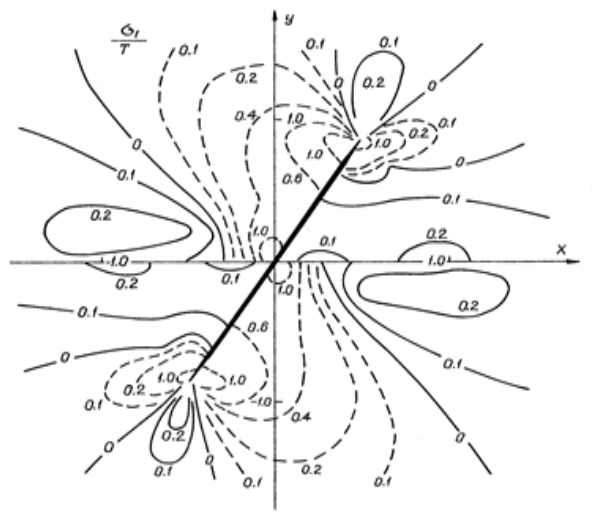

$a$

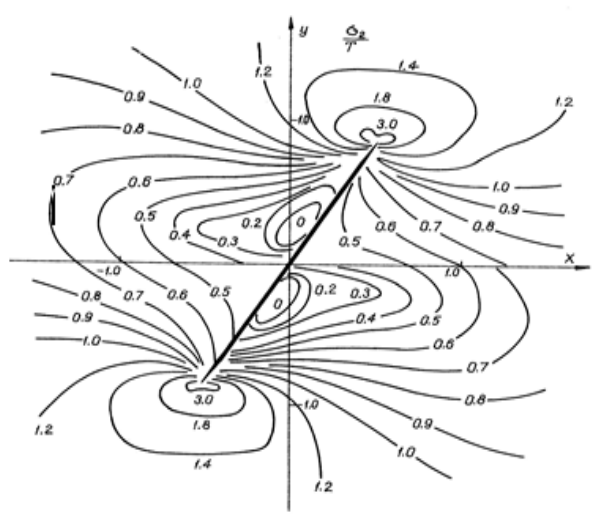

6

Рис. 2.54. Распределение относительных главных напряжений $\sigma_{1} / T$ при $\alpha=60^{\circ}(a)$ и относительных главных напряжений $\sigma_{2} / T$ при $\alpha=60^{\circ}, E_{2} / E_{1}=1$ (б)

С целью более детального анализа изменения напряжений в окрестности контурных точек в таблице 2.17 приведены значения главных напряжений в точках $K_{1}-K_{4}$ для 18 вариантов исследуемой модели. Здесь первое число - отношение главного напряжения $\sigma_{1} / T$, второе $-\sigma_{2} / T$.

Таблица 2.17

Величины главных напряжений в контурных точках

\begin{tabular}{|c|c|c|c|c|}
\hline \multicolumn{5}{|c|}{$\alpha=30^{\circ}$} \\
\hline$E_{2} / E_{1}$ & $K_{1}$ & $K_{2}$ & $K_{3}$ & $K_{4}$ \\
\hline 1 & 7,$027 ;-0,001$ & 0,$001 ;-7,177$ & 7,$03 ; 0,006$ & $-0,006 ;-7,779$ \\
\hline 2 & 5,$822 ; 0$ & 0,$001 ;-5,927$ & 9,$377 ; 0,001$ & $-0,01 ;-9,546$ \\
\hline 3,5 & 5,$456 ;-0,001$ & 0,$001 ;-5,747$ & 12,$897 ; 0,022$ & $-0,021 ;-13,24$ \\
\hline 5 & 5,$795 ; 0,001$ & $-0,003 ;-6,289$ & 17,$007 ; 0,042$ & $-0,038 ;-17,721$ \\
\hline 7,5 & 7,$905 ; 0,041$ & $-0,021 ;-9,703$ & 30,$382 ;-0,183$ & $-0,16 ;-32,781$ \\
\hline 10 & 14,$14 ; 0,215$ & 1,$681 ;-21,473$ & 74,$571 ; 1,691$ & $-1,386 ;-83,053$ \\
\hline$E_{2} / E_{1}$ & \multicolumn{5}{|c|}{$\alpha=45^{\circ}$} \\
\hline 1 & 10,$966 ; 0,027$ & $-0,052 ;-6,118$ & 10,$954 ;-0,031$ & 0,$056 ;-6,076$ \\
\hline 2 & 8,$06 ; 0,08$ & $-0,091 ;-4,077$ & 14,$502 ;-0,024$ & 0,$028 ;-8,249$ \\
\hline 3,5 & 5,$982 ;-0,069$ & 0,$106 ;-2,747$ & 17,$428 ;-0,019$ & 0,$026 ;-10,143$ \\
\hline 5 & 5,$689 ; 0,077$ & $-0,077 ;-1,681$ & 19,$428 ;-0,002$ & 0,$001 ;-11,445$ \\
\hline 7,5 & 5,$115 ;-0,052$ & 0,$09 ;-0,527$ & 21,$743 ; 0,007$ & $-0,015 ;-12,895$ \\
\hline 10 & 5,$031 ;-0,235$ & 0,$529 ; 0,111$ & 23,$727 ; 0,015$ & $-0,037 ;-14,274$ \\
\hline$E_{2} / E_{1}$ & \multicolumn{5}{|c|}{$\alpha=60^{\circ}$} \\
\hline 1 & 9,$192 ; 0,016$ & $-0,012 ;-3,85$ & 9,$236 ; 0,002$ & 0,$002 ;-3,793$ \\
\hline 2 & 6,$595 ; 0,059$ & $-0,016 ;-2,139$ & 12,$267 ; 0,008$ & 0,$009 ;-5,616$ \\
\hline 3,5 & 4,$932 ; 0,088$ & $-0,053 ;-1,156$ & 14,$554 ; 0,011$ & 0,$023 ;-7,081$ \\
\hline 5 & 4,$706 ;-0,022$ & 0,$083 ;-0,045$ & 16,$02 ; 0,022$ & 0,$026 ;-8,13$ \\
\hline 7,5 & 4,$369 ;-0,104$ & 0,$993 ; 0,108$ & 17,$678 ; 0,026$ & 0,$031 ;-9,274$ \\
\hline 10 & 4,$73 ; 0,016$ & 2,$201 ;-0,104$ & 19,$228 ; 0,024$ & 0,$04 ;-10,396$ \\
\hline
\end{tabular}


Из этой таблицы следует, что одно из главных напряжений близко к нулю (для точек $K_{1}$ и $K_{3}-\sigma_{2} / T$, а для точек $K_{2}$ и $K_{4}-\sigma_{1} / T$ ). Таким образом, в контурных точках одно из главных напряжений (близкое к нулю) является нормальным к границе трещины (она свободна от внешних нагрузок), а другое - тангенциальное, то есть действует параллельно границе. Учитывая то обстоятельство, что предел прочности горных пород при растяжении [бр] много меньше предела прочности при сжатии $\left[\sigma_{c}\right]$, получаем области начала разрушений - точки $K_{1}$ и $K_{3}$, где в первую очередь (в каком блоке) начнется разрушение, зависит от величин [б $]$ этих блоков.

На рисунке 2.55 показано распределение главных напряжений в окрестности мягкого включения.

Сопоставляя рисунки $2.52 a$ и $2.55 a, 2.52 \sigma$ и $2.55 \sigma$ видим, что закономерности распределения главных напряжений аналогичны по зонам расположения растягивающих и сжимающих напряжений. Величины их вблизи контурных точек существенным образом зависят от материала, цементирующего включения и геометрических параметров включения. В нашем случае (заполненная широкая трещина) имеем: в точке $K_{1} \sigma_{1} / T=1,167, \sigma_{2} / T=-0,52$; в точке $K_{2} \sigma_{1} / T=0,139, \sigma_{2} / T=-1,291$; в точке $K_{3} \sigma_{1} / T=1,382, \sigma_{2} / T=-1,23$; в точке $K_{4} \sigma_{1} / T=-0,451, \sigma_{2} / T=-3,5$. При этом также можно констатировать, что разрушения могут начаться в точках $K_{1}$ и $K_{3}$, так как в них действуют большие растягивающие напряжения.

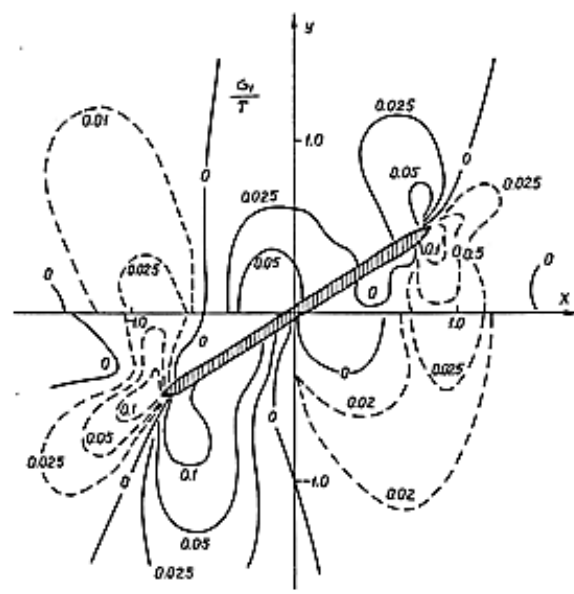

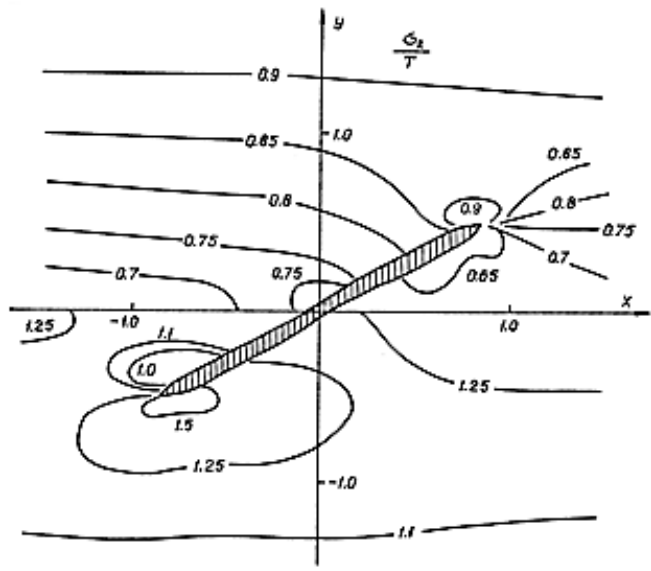

$\sigma$

Pис. 2.55. Распределение относительных главных напряжений $\sigma_{1} / T(a)$ и относительных главных напряжений $\sigma_{2} / T$ при $\alpha=30^{\circ}, E_{2} / E_{1}=2, E_{3} / E_{1}=10$ (б)

\subsection{2. Напряженное состояние горных пород в окрестности радиальных ветвящихся трещин}

Прочность горных пород определяется не только их механическими характеристиками (модуль Юнга, коэффициент Пуассона), но и их строением. В структурах массивов горных пород всегда присутствуют 
неоднородности - различного рода включения, границы зерен и блоков, микро- и макротрещины и т. д. В окрестности таких неоднородностей возникают концентрации напряжений (не только сжимающих, но и растягивающих), что приводит к образованию новых и развитию существующих трещин в массиве.

Начиная со второй половины прошлого столетия, широкое развитие получила динамика хрупкого разрушения твердых деформируемых сред $[117,120]$. Особую актуальность это направление приобретает в связи с частым использованием в народном хозяйстве взрывных работ, которые достигли наибольшего объема в горнодобывающей промышленности (взрывная отбойка, вскрытие месторождений, сейсморазведка и т. д.) Взрывные работы используются также в строительстве, водном хозяйстве, металлургической промышленности.

В процессе взрывания в результате действия высокого давления продуктов детонации, усиливающегося вблизи естественных концентраторов (неоднородностей), возникают и эволюционируют трещины, следствием чего является локальное или полное разрушение горных пород в некотором объеме.

Изучение закономерностей распределения напряжений в окрестности трещин при различных граничных условиях имеет важное практическое значение в вопросах понимания процесса разрушения, например, разрушения барьерных перемычек между разрывами [103], горных ударов, техногенных и естественных землетрясений $[102,121]$ образования блочных структур [122] и др.

Рассмотрена упругая изотропная плоскость с системой одинаковых радиальных трещин единичной длины $(L)$, располагаемых симметрично относительно осей декартовой системы координат под углом $45^{\circ}$ между трещинами. Максимальное раскрытие трещин на протяжении $80 \%$ их длины составляет $d=0,02 L$, угол смыкания берегов трещин в их концевых областях $\alpha \approx 6^{\circ}$. На границах трещин действует равномерно распределенное нормальное давление $(P)$, имитирующее давление продуктов взрывания. Такая ситуация может возникнуть, например, при взрывании одиночного скважинного заряда.

Далее предположено, что в некоторый момент времени магистральные радиальные трещины разветвляются. Разветвление начинается в кончиках магистральных трещин, и каждая трещина имеет три ветви, одна из которых является продолжением магистральной, а две другие располагаются под углами $45^{\circ}$ симметрично относительно первой. Длина каждой ветви $l=L / 2$. Раскрытие ветвей и магистральной трещины остается прежним $-d=0,02 L$, угол смыкания берегов ветвей также составляет $\alpha \approx 6^{\circ}$, а на границах магистральных трещин и их ветвей действует равномерно распределенное нормальное давление $P$.

Таким образом, рассмотрено распределение напряжений в некоторые два мгновения идеального процесса развития трещин в результате взрыва одиночного заряда.

Решение задачи о распределении напряжений в бесконечной плоскости, ослабленной круговым отверстием, на контуре которого приложено равномерное нормальное давление, имеет вид [123]:

$$
\sigma_{r}=-\frac{P R^{2}}{r^{2}}, \quad \sigma_{\theta}=\frac{P R^{2}}{r^{2}}, \quad \tau_{r \theta}=0,
$$


где $\sigma_{r}, \sigma_{\theta}, \tau_{r \theta}$ - радиальные, тангенциальные и касательные напряжения соответственно; $R$ - радиус кругового отверстия; $r$ - радиальное расстояние от центра отверстия до исследуемой точки; $P$ - величина нормального давления, приложенного к обводу кругового отверстия; «-» - сжатие, а «+» - растяжение.

Из (2.56) следует, что на контуре кругового отверстия действуют растягивающие тангенциальные напряжения, а это в свою очередь означает то, что любая, даже незначительных размеров неоднородность, может послужить причиной возникновения трещины отрыва, как только растягивающие напряжения превысят предел прочности пород при одноосном растяжении.

Предположено, что на контуре кругового отверстия изначально были созданы условия (при бурении скважин для размещения ВВ) для возникновения и развития радиальных симметрично расположенных трещин, и в процессе роста они достигли одинаковой длины $L$.

На рисунке 2.56 а приведено распределение относительного главного напряжения $\sigma_{1} / P$. Так как модель симметрична относительно осей декартовой системы координат, то на рисунке показана лишь четвертая часть расчетной области. Расчеты свидетельствуют о том, что в концевых областях трещин действуют растягивающие напряжения (пунктирные изолинии), величина которых достигает значений $\sigma_{1}=P$, а в непосредственной близости к концевой области их интенсивность составляет $(1,7-1,8) P$. При этом растягивающие напряжения распространяются на расстояния порядка $(2,5-3) L$, где $\sigma_{1} \leq 0,1 P$. В основной части массива между магистральными трещинами напряжения $\sigma_{1}$ сжимающие (сплошные изолинии), и лишь вблизи центра взрывания на расстоянии (3-4) радиусов заряда действуют растягивающие $\sigma_{1}$.

Главные напряжения $\sigma_{2}$ всюду сжимающие (рис. 2.56 б). Их величина изменяется от $(1,25-1,5) P$ вблизи концевых областей до $0,75 P$ в массиве между трещинами, а вдали от концевых областей, на расстоянии $(2-2,5) L$, они уменьшаются до $0,1 P$. В малой зоне $(\approx 0,1 L)$ на продолжении трещин напряжения $\sigma_{2}$ растягивающие и их величина не превышает $0,5 P$.

В работе [120] показано, что «для всех значений нагрузок ветвление наступает при одном и том же значении энергии разрушения». Динамический коэффициент интенсивности напряжений определяется выражением:

$$
K \approx \sigma_{n} \sqrt{\pi L},
$$

где $\sigma_{n}$ - величина действующей нагрузки (в наших обозначениях $\sigma_{n}=P$ ); $L$ - длина магистральной трещины до начала ветвления.

Полагая $L=1$, получаем: $K=P \sqrt{\pi}=1,77 P$.

Следовательно, согласно этому критерию в нашем случае ветвление вполне возможно, так как величина растягивающих напряжений вблизи кончика трещины, полученная на основании численного моделирования, $\sigma_{1}=(1,7-1,8) P$. 


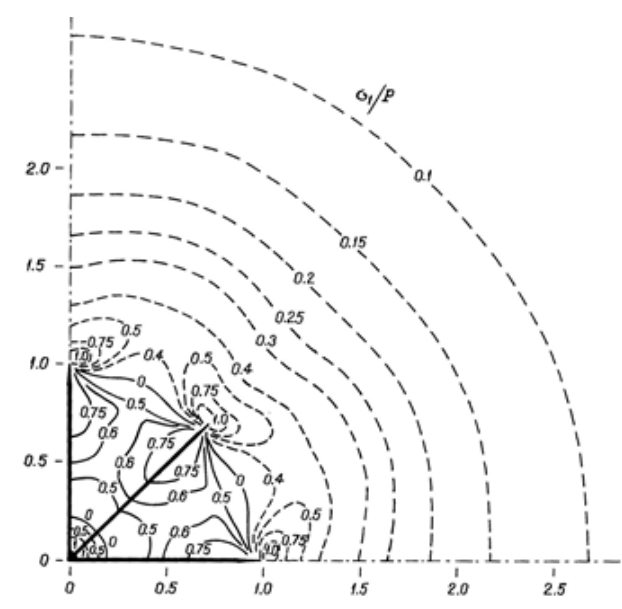

$a$

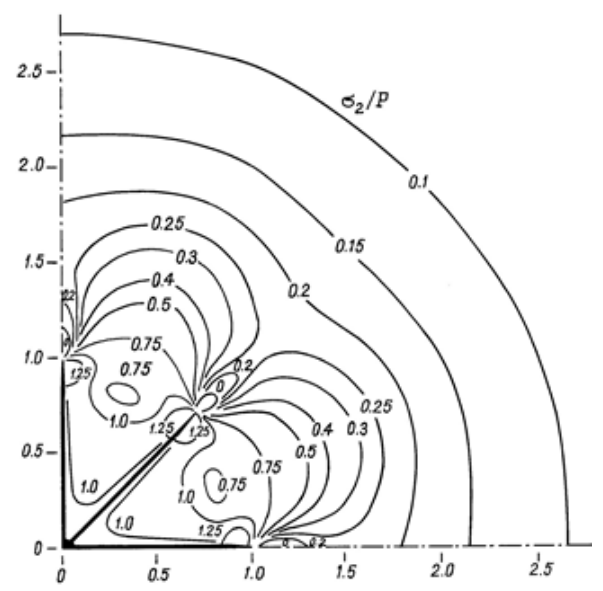

6

Рис. 2.56. Распределение относительных главных напряжений $\sigma_{1} / P(a)$ и $\sigma_{2} / P(б)$ в окрестности радиальных трещин единичной длины

На рисунке 2.57 показана ориентация растягивающих главных напряжений в области действия их максимальных величин. Здесь же пунктирными линиями изображены траектории наиболее вероятного распространения ветвей при условии неизменности величины и направления напряжений в процессе роста ветвей. В реальной ситуации эволюционный процесс ветвления достаточно сложный и зависит от множества факторов, а окончательная форма ветвей также неоднозначна.

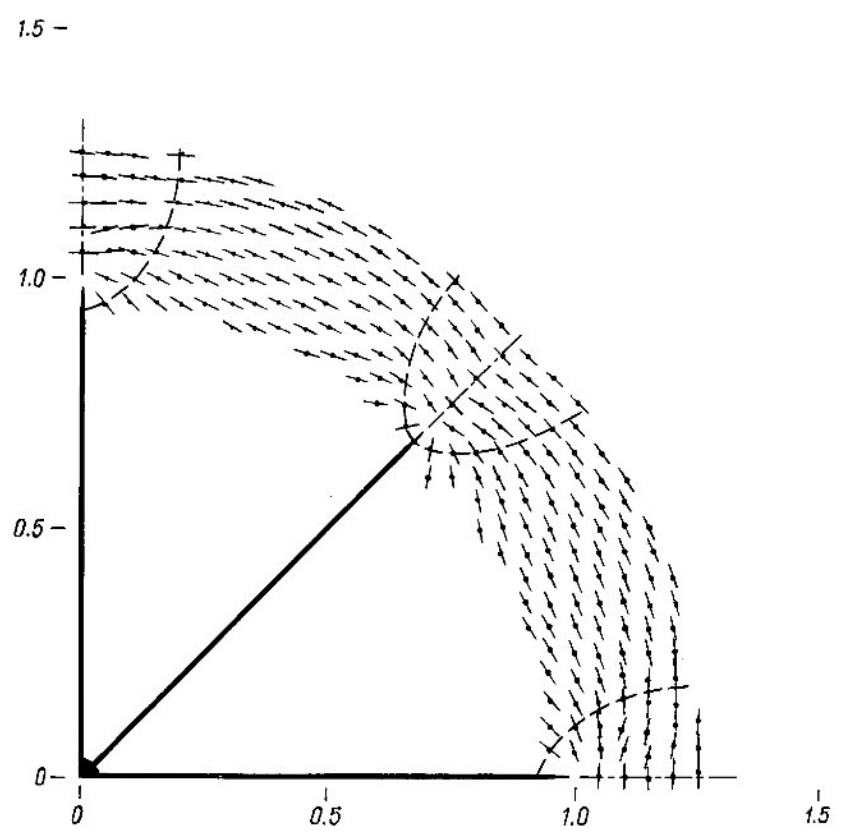

Рис. 2.57. Ориентация главных напряжений $\sigma_{1} / P$ в окрестности радиальных трещин 
Для простоты подготовки исходной информации в целях дальнейших исследований предположено, что форма ветвей прямолинейна, ветвление состоит их трех ветвей, одна из которых является продолжением магистральной трещины, а две другие ветви располагаются симметрично относительно первой под углом $45^{\circ}$.

На рисунке 2.58 a показано распределение относительных главных напряжений, где $\sigma_{1} / P$ для варианта модели, когда длина ветвей составляет половину длины магистральных трещин. Из этого рисунка следует, что в зонах перед ветвями напряжения $\sigma_{1}$ растягивающие, причем в окрестности кончиков ветвей, являющихся продолжением магистральных трещин, их величина наибольшая и достигает значений $\approx(1,25-1,5) P$. В окрестности кончиков двух других ветвей величины растягивающих напряжений $\sigma_{1}$ значительно меньше $\approx(0,5-0,7) P$. В массиве между ветвями и магистральными трещинами напряжения $\sigma_{1}$ сжимающие от 0 до $0,75 P$. Напряжения $\sigma_{2}$ во всей исследуемой области являются сжимающими (рис. 2.58 б). В малой окрестности кончиков ветвей, являющихся продолжением магистральных трещин, $\sigma_{2}$ растягивающие и по величине не превосходят 0,25P. Вблизи кончиков двух других ветвей при этом напряжения $\sigma_{2}$ сжимающие и близки к нулю.

Таким образом, следует, что, если дальнейшее ветвление возможно, то оно, наиболее вероятно, произойдет на ветвях, являющихся продолжением магистральных трещин.

Начало роста трещин при взрыве происходит в результате действия растягивающих напряжений, возникающих вблизи естественных (или техногенных) трещин и других неоднородностей. Вследствие высоких концентраций этих напряжений в окрестности кончиков трещин и ряда других благоприятных (для развития трещин) условий возможно ветвление магистральных трещин.

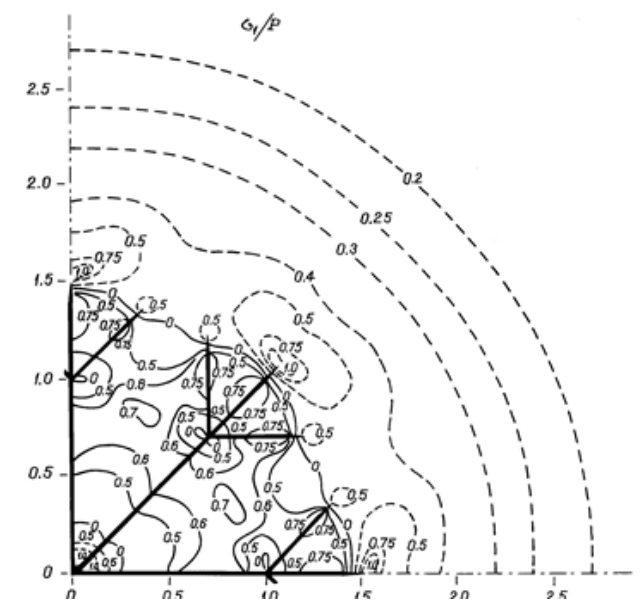

$a$

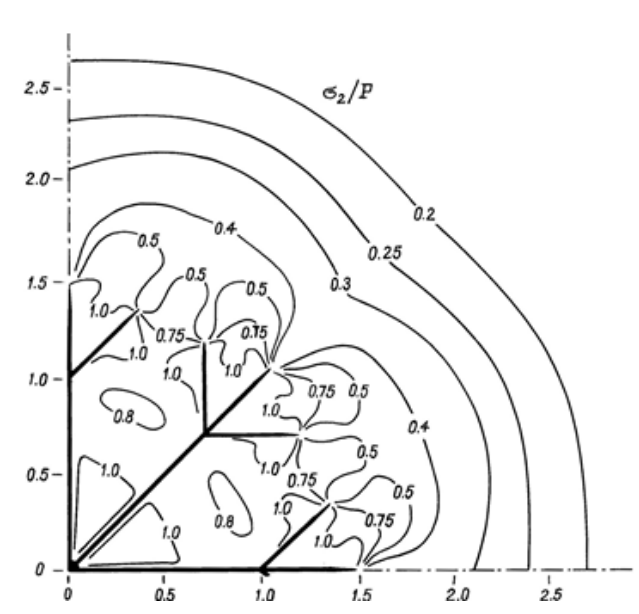

б

Pис. 2.58. Распределение относительных главных напряжений $\sigma_{1} / P(a)$ и $\sigma_{2} / P(\sigma)$ в окрестности радиальных ветвящихся трещин

Взаимодействие ветвящихся трещин (смыкание ветвей в результате разрушения барьеров между ними) приводит к дроблению горной породы. 


\subsection{3. Напряженное состояние массива пород при сдвижении блоков по шероховатой поверхности}

Иерархично-блочное строение земной коры является общепризнанным фактом. Напряженно деформированное состояние блоков различного масштабного уровня определяется не только механическими свойствами пород, слагающих блоки, их геометрией, но и характером их взаимодействия, то есть граничными и контактными условиями. В работе [12] по схеме вложенных блочных структур исследовано напряженное состояние европейской части Евразийской литосферной плиты, блоков, включающих Фенноскандию и Северо-Запад России, геологических блоков Кольского полуострова. Исследования выполнены в двухмерной постановке задачи теории упругости при действии горизонтальных сжимающих усилий. Границы блоков и разломных зон при этом принимались прямолинейными. В действительности в большинстве случаев разделяющие блоки границы имеют неровности. Наличие неровностей обусловлено происхождением блоков, например, образование сейсморазрывов при землетрясении [124], разрушение барьерных зон между разрывами [125], трансформные разломы [126] и т. д.

Вопросу моделирования локальных полей тектонических напряжений, связанных с системами конкретных глубинных разломов в условиях действия сжимающих усилий, посвящены работы Д. Н. Осокиной и Н. Ю. Цветковой [127]. Научный и практический интерес представляют исследования массивов блочного строения в условиях сдвига. Термином «сдвиг» тектонофизики и геологи обозначают тип тектонического нарушения. «Сдвиги, от мелких трещин до гигантских разрывных зон, составляют более $80 \%$ всех типов тектонических нарушений, встречающихся в земной коре» [128]. Механики под термином «сдвиг» понимают величину деформации, возникающей при действии касательных напряжений. В соответствии с законом Гука $\tau=\gamma G$, где $\tau$-касательные напряжения; $\gamma$ - относительный сдвиг; $G$ - модуль упругости при сдвиге $[107,123]$. Иногда под термином «сдвиг» подразумевается процесс «сдвижения блоков друг относительно друга». В работе [129] дано теоретическое решение задачи о напряженном состоянии вязкого слоя при действии горизонтального продольного сдвига. Предполагается, что между подошвой слоя и блоками жесткого фундамента осуществляется полное сцепление. Аналогичная задача $\mathrm{c}$ вертикальной и наклонной относительной скоростью движения блоков жесткого фундамента решена в работе [130]. В дальнейшем, чтобы избежать терминологической путаницы, в настоящей работе будем рассматривать процесс «сдвижения» одного блока относительно другого. При этом горизонтальную поверхность, по которой происходит сдвижение блоков, будем рассматривать не ровной, а имеющей регулярную шероховатость в виде треугольных выступов с прямыми углами в вершинах. Упругие характеристики блоков (верхнего и нижнего) одинаковы: модуль Юнга $E=5 \cdot 10^{4}$ МПа, коэффициент Пуассона $v=0,25$. Так как величины напряжений в блоках в процессе их сдвижения существенным образом зависят от усилий на верхней и нижней гранях, то с целью исключения большого числа расчетных вариантов на этих гранях задано шарнирное закрепление. Иначе говоря, $V=0, U \neq 0$ при $y= \pm H$, где $U, V$ - горизонтальные и вертикальные перемещения соответственно; $H$ - мощность блоков. На правой грани верхнего блока действует равномерно распределенное горизонтальное усилие $T$ единичной интенсивности, левая грань верхнего блока свободна от внешних усилий. Левая грань нижнего блока закреплена шарнирно, то есть $U=0, V \neq 0$ 
при $x=0, h / 2 \leq y \leq H$ ( $h-$ высота выступа). Правая грань нижнего блока свободна от внешних усилий. На границе контакта блоков полагаем непрерывные нормальные напряжения и перемещения.

На рисунке 2.59 a приведено распределение относительного главного напряжения $\sigma_{1} /|T|$. Здесь и далее пунктирными изолиниями обозначены растягивающие напряжения, а сплошными - сжимающие. На рисунке видно, что распределение напряжений характеризуется почти диагональным расположением сжимающих и растягивающих напряжений в блоках. При этом в окрестности всех неровностей действуют растягивающие напряжения $\sigma_{1} \approx 0,2|T|$. Исключение составляют основания первого выступа нижнего блока и последнего выступа верхнего блока, где напряжения $\sigma_{1}$ являются сжимающими и по величине резко изменяются от 0 до $|T|$.

Распределение главного напряжения $\sigma_{2} /|T|$ показано на рисунке 2.59 б. Эти напряжения всюду сжимающие. В основной части верхнего блока $\sigma_{2} /|T|$ изменяется слева направо от 0 до $|T|$, а в нижнем блоке такое же изменение происходит справа налево. И это естественно, так как левая грань верхнего и правая грань нижнего блоков свободны от внешних усилий. В окрестности основания первого выступа нижнего блока и в нем $\sigma_{2}$ изменяется от $|T|$ до (3-4) $|T|$. В соседнем справа выступе верхнего блока $|T| \leq \sigma_{2} \leq 1,3|T|$. В остальных выступах $\sigma_{2}$ находится в пределах $(0,8-1,1)|T|$.

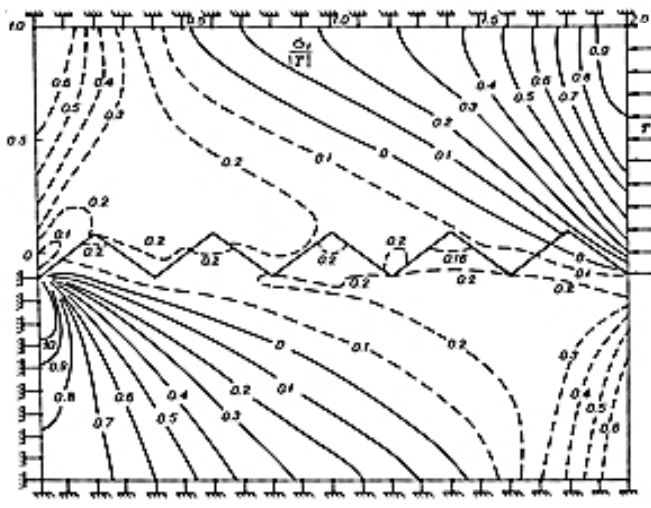

$a$

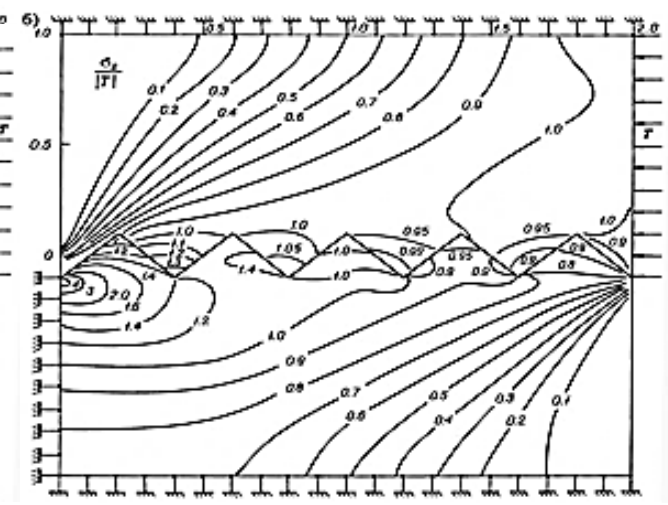

$\sigma$

Рис. 2.59. Распределение относительных главных напряжений $\sigma_{1} /|T|(a)$ и $\sigma_{2} /|T|(б)$ в блоках без прослойка между шероховатостями

Направление действия наибольшего главного напряжения $\sigma_{1}$ в окрестности неровностей поверхности показано на рисунке 2.60 , на котором видно, что вблизи левых граней выступов нижнего блока и правых граней выступов верхнего блока направление действия напряжения $\sigma_{1}$ (а это растягивающие напряжения) почти ортогонально границам неровностей. Вблизи противоположных граней выступов направление этих напряжений почти параллельно им. Следовательно, если величины растягивающих напряжений таковы, что возможно образование трещин отрыва, то они будут возникать параллельно левым граням выступов нижнего блока и правым граням выступов верхнего блока, а вблизи противоположных граней будут прорастать трещины ортогональные к ним. Характер перемещения граней выступов показан пунктирными линиями. Так как для большинства хрупких горных пород предел прочности при одноосном растяжении невелик - $\approx$ (10-15) МПа, 
то при заданных условиях достаточно приложить усилие $|T| \approx(50-70)$ МПа, чтобы возникли соответствующие трещины отрыва в окрестности рассматриваемых неровностей. Такие величины усилий в массиве горных пород встречаются нередко. При этом вблизи выступов образуются зоны ослабленной жесткости.

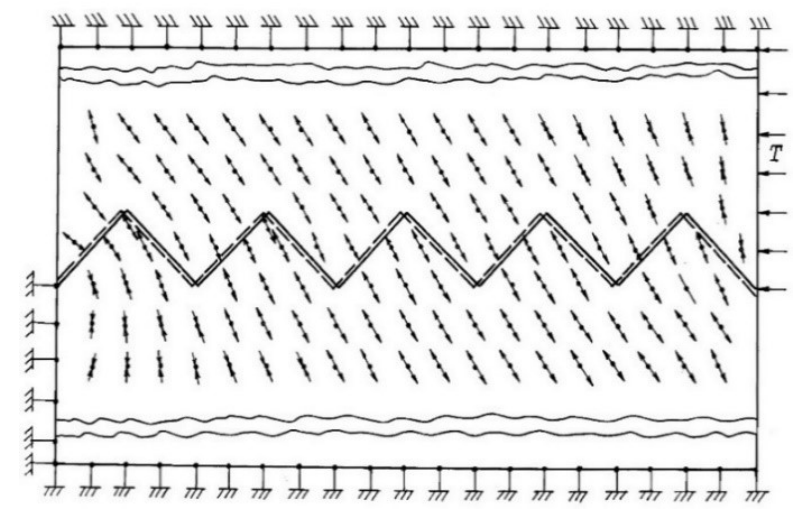

Рис. 2.60. Направление действия главного напряжения $\sigma_{1} /|T|$ вблизи неровностей поверхности сдвижения

На рисунке 2.61 приведен график максимальных касательных напряжений $\tau_{\max }=\left(\sigma_{1}-\sigma_{2}\right) / 2$ на границе контакта блоков, на котором видно, что практически по всей границе контакта блоков $\tau_{\max } \geq 0,5|T|$, и лишь в нижних точках неровностей (слева и справа) наблюдается резкий скачок $\tau_{\max }$. Это означает, что в этой области в первую очередь возможно нарушение сплошности.

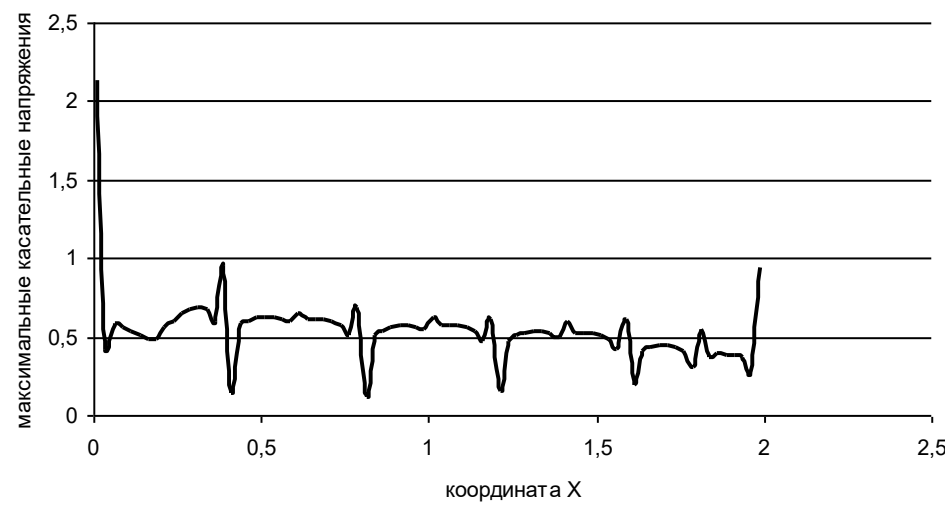

Рис. 2.61. Максимальные касательные напряжения на границе контакта блоков

Рассмотрим задачу о напряженном состоянии блоков, сдвигаемых по шероховатой поверхности при наличии слабого прослойка между выступами. Полагаем для прослойка $E=5 \cdot 10^{3}$ МПа, $v=0,3$. На рисунке 2.62 приведено распределение напряжений $\sigma_{1} /|T|$ и $\sigma_{2} /|T|$ для этого случая. Ориентация главных напряжений аналогична выше рассмотренному варианту. Сравнивая рисунки $2.59 a$ и $2.62 a, 2.59 \sigma$ и $2.62 \sigma$, можно сказать, что характер распределения напряжений в общих чертах изменился незначительно. При этом следует отметить, что величины растягивающих напряжений $\sigma_{1} /|T|$ увеличились в 2 раза. 


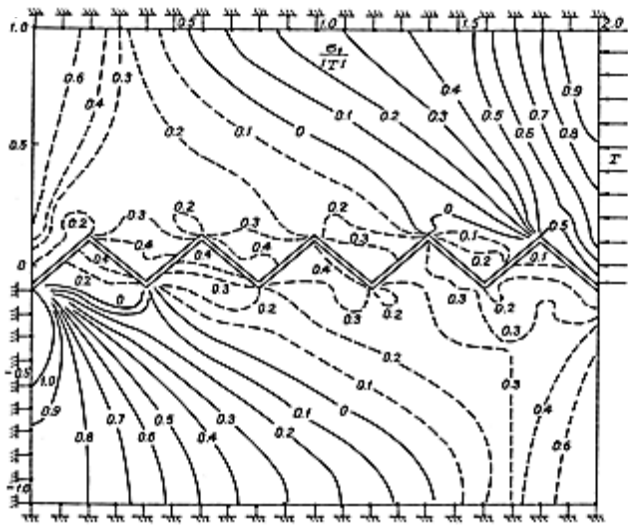

$a$

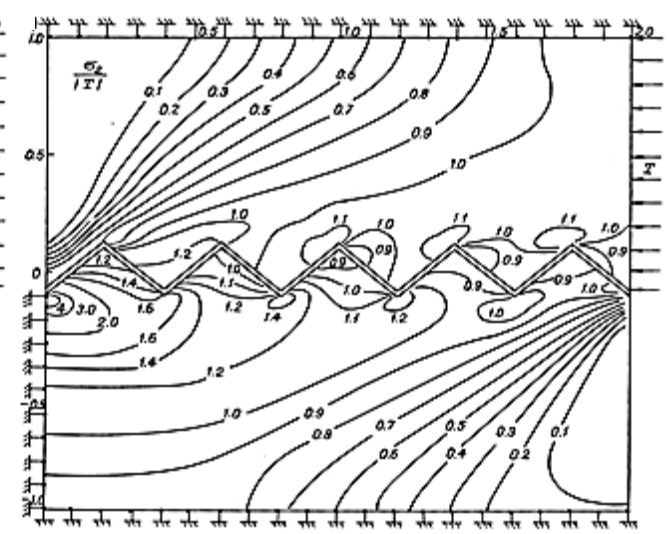

$\sigma$

Рис. 2.62. Распределение относительных главных напряжений $\sigma_{1} / \mid T(a)$ и $\sigma_{2} /|T|($ б) в блоках со слабым прослойком между шероховатостями

Следовательно, интенсивность образования трещин отрыва вблизи границ выступов увеличится. Таким образом, неровности поверхности, по которой происходит сдвижение блоков, постепенно разрушаются. В условиях, когда регулярность шероховатости нарушается (выступы имеют различные геометрические параметры), сдвижение блоков друг относительно друга, возможно, будет происходить скачкообразно: сначала разрушатся выступы одного порядка (произойдет смещение блоков одной величины), затем, в результате перераспределения напряжений, разрушатся выступы другого порядка и т. д. Очевидно, что разрушению мелких неровностей будут соответствовать незначительные перемещения, а для разрушения более крупных неровностей потребуется значительное увеличение напряжений, и, если они достигнут предельных величин, произойдет разрушение крупных неровностей, сопровождаемое значительными подвижками блоков. Таким представляется, на наш взгляд, механизм подготовки и реализации землетрясений.

На рисунке 2.63 приведены графики горизонтальных и вертикальных перемещений граней выступов верхнего и нижнего блоков. Величины горизонтальных перемещений верхнего блока больше таковых для нижнего блока, а величины вертикальных перемещений отличаются незначительно.

Таким образом, при наличии слабого прослойка между шероховатостями поверхности сдвижения возможно (помимо возникновения трещин отрыва в материале блоков) появление нарушений сплошности между прослойком и верхним блоком.

Результаты приведенного анализа показывают, что при сдвижении блоков горных пород по шероховатой поверхности возникают условия для образования трещин отрыва вблизи неровностей, что приводит к образованию слабого прослойка между ними и дальнейшему более интенсивному разрушению неровностей. В естественных условиях, когда поверхность сдвижения обладает неровностями с различными геометрическими параметрами, относительные перемещения блоков могут происходить скачкообразно. 


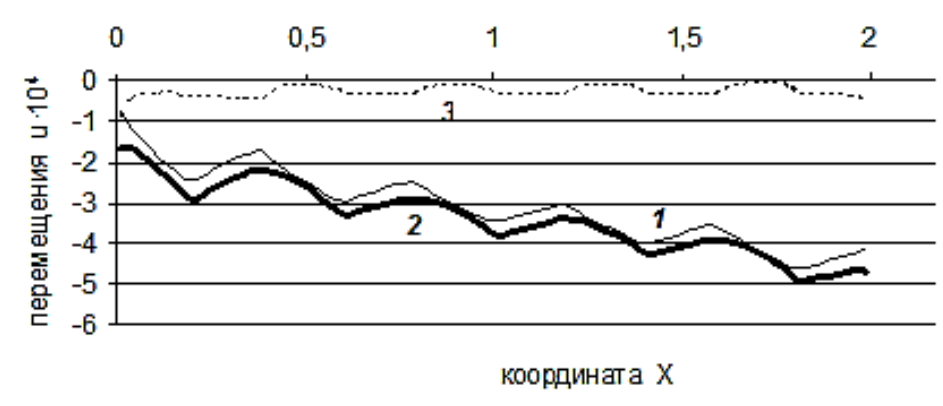

$a$

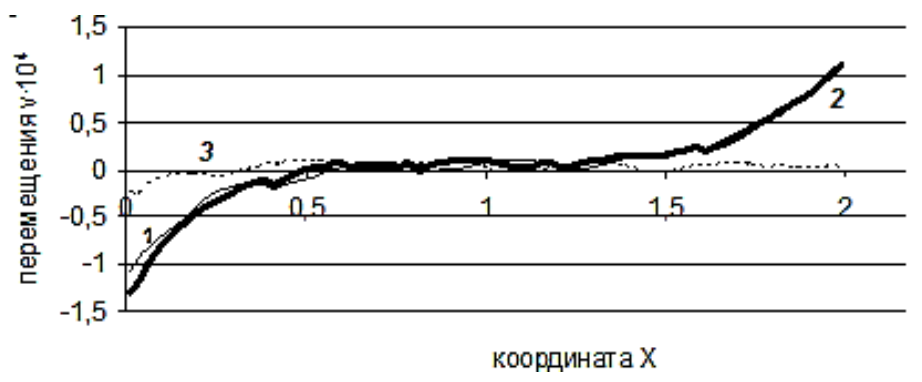

6

Рис. 2.63. Перемещения граней выступов в модели со слабым прослойком между неровностями: $a$ - горизонтальные; $\sigma$ - вертикальные; 1 - нижнего блока; 2 - верхнего блока; 3 - разность перемещений

При наличии слабого прослойка между шероховатостями поверхности, по которой происходит сдвижение блоков, помимо образования трещин отрыва в материале блоков возможно появление нарушений сплошности между прослойком и блоками, о чем свидетельствуют большие величины горизонтальных перемещений верхнего блока.

Результаты настоящих исследований могут быть полезными, например, для оценки возможности обрушения подработанной толщи пород; объяснения форшоковых явлений, предшествующих сильным землетрясениям.

\subsection{4. Наклонный разлом в гравитационно-тектоническом силовом поле}

Ведение крупномасштабных горных работ в условиях гравитационнотектонического силового воздействия сопряжено с опасностью возникновения динамических явлений, сравнимых по мощности с естественными землетрясениями. В ряде случаев реакция геологической среды на техногенное и природное силовые воздействия аналогичны. Поэтому здесь мы будем говорить о землетрясениях в общем, не разделяя их на техногенные и природные.

Землетрясения по количеству человеческих жертв и материальному ущербу занимают одно из первых мест среди катастрофических явлений, хотя, по данным Национального центра информации о землетрясениях США, с 1965 по 1999 гг. они составляют лишь $13 \%$ от общего числа природных катастроф. В прошлое столетие зарегистрировано 2 тыс. землетрясений с магнитудой $M \geq 7,0$, из которых 65 имели $M \geq 8,0[131]$. 
Существуют различные модели подготовки землетрясений: модель лавинно-неустойчивого трещинообразования [132], модель Стюарта [133], модель консолидации [134] и др. Как правило, все эти модели носят чисто гипотетический характер и нуждаются в теоретическом обосновании.

В последнее время многие исследователи, занимающиеся вопросами естественной и техногенной сейсмичности, считают, что существует тесная взаимосвязь между землетрясениями и разломами различных масштабных уровней, разделяющими блоковые структуры земной коры. Такая связь установлена между землетрясениями, происходящими в Калифорнии (США), с разломом Сан-Андреас; землетрясением 1968 г. и разломом в долине Нимблук (Иран); Нефтегорским землетрясением 27(28).05.1995 г. и Верхне-Пильтунским разломом [124] и т. д.

Поэтому весьма интересным представляется вопрос о НДС массива горных пород вблизи наклонного разлома, выходящего на поверхность, в условиях действия гравитационно-тектонических сил.

Исследование выполнено методом граничных элементов в двухмерной постановке третьей (смешанной) задачи теории упругости. На рисунке 2.64 представлена схема модели и граничные условия. Рассматривается часть тяжелой полуплоскости размером $2 a \mathrm{x}$ в с наклонным заполненным разрезом. Пунктиром выделена расчетная область. Упругие характеристики основного массива горных пород приняты следующие: модуль Юнга $E_{0}=10^{4} \mathrm{MПа}$, коэффициент Пуассона $v=0,25$. Свойства материала, заполняющего разлом, таковы: для каждого значения модуля Юнга $E_{3}=1000,100,10$ МПа приняты коэффициенты Пуассона $v_{3}=0,3,0,35,0,4,0,45$.

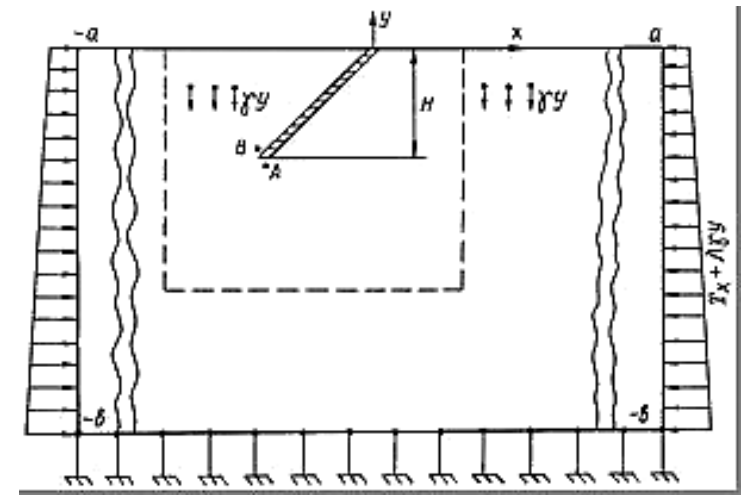

Рис. 2.64. Схема модели и граничные условия. $A, B$ - точки, в которых анализируется напряженное состояние горных пород

Граничные условия:

$$
\left.\begin{array}{llrl}
\sigma_{y}=0 & \text { при } \quad y=0, \quad-a \leq x \leq a \\
\sigma_{y}=\gamma y & \text { всюдy } \\
\sigma_{x}=T_{x}+\lambda \gamma y & \text { nрu } \quad x= \pm a, \quad-8 \leq y \leq 0 \\
V_{y}=0 & \text { при } \quad y=-8, \quad-a \leq x \leq a
\end{array}\right\},
$$

где $\gamma$ - объемный вес пород, $y-$ расстояние от дневной поверхности по вертикали; $\lambda=v /(1-v)-$ коэффициент бокового отпора; $T_{x}$ - равномерно распределенные тектонические силы. 
Для удобства анализа напряженного состояния в относительных величинах рассмотрены случаи $T_{x}=\gamma H, 1,5 \gamma H, 2 \gamma H$, где $H-$ глубина, на которую распространяется разлом. Изучено НДС пород для углов наклона разлома $\alpha=30^{\circ}, 45^{\circ}, 60^{\circ}$. Для точек $A$ и $B$ (рис. 2.64) выполнен детальный анализ результатов расчетов.

На рисунке 2.65 приведено распределение главных относительных напряжений $\sigma_{1} / \gamma H$ и $\sigma_{2} / \gamma H$ для случая $\alpha=30^{\circ}$ и $T_{x}=2 \gamma H$. Считаем растягивающие напряжения положительными, а сжимающие - отрицательными, $\sigma_{1}$ $>\sigma_{2}$ алгебраически. Наибольшие по абсолютной величине главные напряжения $\sigma_{2}$ являются сжимающими и изменяются в пределах от $0,5 \gamma H$ до $5 \gamma H$ и более в зависимости от значений $\alpha$ и $T_{x}$. Максимум концентрации напряжений $\sigma_{2}$ приурочен к нижней части разлома. Над разломом в окрестности левого берега в нижней его части напряжения $\left|\sigma_{2}\right| \prec \gamma H$. В клине, образованном между левым берегом разлома и дневной поверхностью, концентрация сжимающих $\sigma_{2}$ достигает значений $3 \gamma H$. Наибольшая величина градиента напряжений $\sigma_{2}$ наблюдается вблизи заглубленного конца разлома.
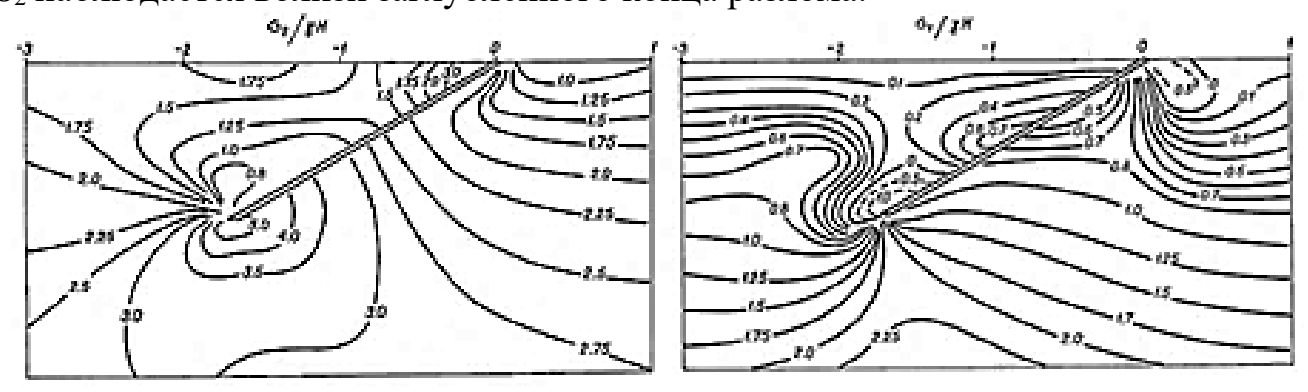

Рис. 2.65. Распределение главных напряжений $\sigma_{1} / \gamma H$ и $\sigma_{2} / \gamma H$ для случая $\alpha=30^{\circ}$ и $T_{x}=2 \gamma H$

Особый интерес представляет распределение главного напряжения $\sigma_{1}$. Оно характерно тем, что в окрестности левого берега разлома, в нижней его части формируется зона растягивающих напряжений, ориентированных параллельно границе разлома, концентрация которых зависит от угла наклона разлома, величины тектонических напряжений и физических свойств материала, заполняющего разлом. Для случая $\alpha=30^{\circ}$ отмечаются растягивающие напряжения $\sigma_{1}$ и в приповерхностной области, в районе правого берега разлома. Но в большей мере нас интересует область растягивающих напряжений в нижней части разлома.

Характер распределения напряжений для случаев $\alpha=45^{\circ}$ и $\alpha=60^{\circ}$ аналогичен приведенному на рисунке 2.65. Отличие заключается лишь в незначительных особенностях расположения этих зон и величинах напряжений.

В таблице 2.18 даны величины напряжений $\sigma_{1} / \gamma H$ (левые значения) и $\sigma_{2} / \gamma H$ (правые) в характерных точках $A$ и $B$ для рассматриваемых 108 вариантов соотношений $E, v, T_{x}, \alpha$. 
Коэффициенты концентрации главных напряжений в точках $A$ и $B$

\begin{tabular}{|c|c|c|c|c|c|c|c|c|c|c|}
\hline \multirow[b]{2}{*}{$\alpha$} & \multirow{2}{*}{$T_{x}$} & \multirow{2}{*}{$\begin{array}{c}E, \\
\text { МПа }\end{array}$} & \multicolumn{4}{|c|}{$A$} & \multicolumn{4}{|c|}{$B$} \\
\hline & & & $v=0,3$ & $v=0,35$ & $v=0,4$ & $v=0,45$ & $v=0,3$ & $v=0,35$ & $v=0,4$ & $v=0,45$ \\
\hline \multirow{9}{*}{30} & \multirow{3}{*}{$\gamma H$} & 10 & $-1,651-4,035$ & $-1,694-4,013$ & $-1,762-3,968$ & $-1,903-3,865$ & $+2,283-1,639$ & $+2,268-1,628$ & $+2,241-1,605$ & $+2,162-1,553$ \\
\hline & & 100 & $-1,679-2,854$ & $-1,727-2,851$ & $-1,782-2,839$ & $-1,844-2,817$ & $+0,615-1,292$ & $+0,625-1,216$ & $+0,618-1,188$ & $+0,573-1,125$ \\
\hline & & 1000 & $-1,134-1,687$ & $-1,146-1,690$ & $-1,156-1,693$ & $-1,162-1,696$ & $-0,833-1,027$ & $-0,811-1,027$ & $-0,779-1,033$ & $-0,728-1,050$ \\
\hline & \multirow{3}{*}{$1,5 \gamma H$} & 10 & $-1,963-5,867$ & $-2,026-5,835$ & $-2,127-5,769$ & $-2,336-5,618$ & $+3,662-2,063$ & $+3,641-2,045$ & $+3,601-2,013$ & $+3,485-1,939$ \\
\hline & & 100 & $-1,998-4,103$ & $-2,068-4,100$ & $-2,150-4,082$ & $-2,241-4,051$ & $+1,170-1,458$ & $+1,186-1,439$ & $+1,180-1,401$ & $+1,119-1,314$ \\
\hline & & 1000 & $-1,178-2,353$ & $-1,197-2,357$ & $-1,214-2,359$ & $-1,226-2,362$ & $-0,775-1,382$ & $-0,742-1,382$ & $-0,694-1,391$ & $-0,617-1,417$ \\
\hline & \multirow{3}{*}{$2 \gamma H$} & 10 & $-2,274-7,701$ & $-2,357-7,659$ & $-2,491-7,571$ & $-2,768-7,371$ & $+5,044-2,490$ & $+5,018-2,467$ & $+4,965-2,425$ & $+4,812-2,328$ \\
\hline & & 100 & $-2,315-5,353$ & $-2,409-5,349$ & $-2,517-5,326$ & $-2,638-5,285$ & $+1,732-1,694$ & $+1,756-1,671$ & $+1,749-1,623$ & $+1,674-1,512$ \\
\hline & & 1000 & $-1,221-3,020$ & $-1,247-3,025$ & $-1,271-3,027$ & $-1,288-3,029$ & $-0,716-1,737$ & $-0,672-1,738$ & $-0,608-1,750$ & $-0,507-1,784$ \\
\hline \multirow{9}{*}{45} & \multirow{3}{*}{$\gamma H$} & 10 & $-2,101-3,937$ & $-2,120-3,909$ & $-2,156-3,856$ & $-2,238-3,727$ & $+0,822-0,977$ & $+0,845-0,962$ & $+0,881-0,933$ & $+0,967-0,870$ \\
\hline & & 100 & $-2,199-3,024$ & $-2,213-2,984$ & $-2,232-2,925$ & $-2,231-2,852$ & $+0,576-0,862$ & $+0,629-0,842$ & $+0,704-0,824$ & $+0,823-0,814$ \\
\hline & & 1000 & $-1,633-2,317$ & $-1,666-2,189$ & $-1,692-2,076$ & $-1,707-1,978$ & $-0,076-1,637$ & $-0,126-1,556$ & $-0,155-1,494$ & $-0,162-1,457$ \\
\hline & \multirow{3}{*}{$1,5 \gamma H$} & 10 & $-2,629-5,728$ & $-2,658-5,687$ & $-2,711-5,608$ & $-2,833-5,416$ & $+1,540-1,139$ & $+1,577-1,119$ & $+1,638-1,082$ & $+1,783-1,003$ \\
\hline & & 100 & $-2,774-4,361$ & $-2,795-4,302$ & $-2,827-4,209$ & $-2,851-4,075$ & $+1,243-1,038$ & $+1,325-1,011$ & $+1,443-0,991$ & $+1,633-0,987$ \\
\hline & & 1000 & $-2,168-3,059$ & $-2,205-2,878$ & $-2,236-2,716$ & $-2,267-2,561$ & $+0,352-2,288$ & $+0,274-2,163$ & $+0,226-2,067$ & $+0,213-2,007$ \\
\hline & \multirow{3}{*}{$2 \gamma H$} & 10 & $-3,158-7,520$ & $-3,195-7,465$ & $-3,265-7,361$ & $-3,427-7,105$ & $+2,268-1,311$ & $+2,319-1,286$ & $+2,404-1,241$ & $+2,607-1,145$ \\
\hline & & 100 & $-3,348-5,699$ & $-3,377-5,619$ & $-3,442-5,494$ & $-3,463-5,304$ & $+1,919-1,223$ & $+2,030-1,188$ & $+2,191-1,165$ & $+2,450-1,166$ \\
\hline & & 1000 & $-2,671-3,831$ & $-2,702-3,610$ & $-2,721-3,416$ & $-2,737-3,234$ & $+0,780-2,940$ & $+0,676-2,771$ & $+0,610-2,641$ & $+0,590-2,560$ \\
\hline \multirow{8}{*}{60} & \multirow{3}{*}{$\gamma H$} & 10 & $-2,205-3,923$ & $-2,214-3,891$ & $-2,231-3,828$ & $-2,274-3,667$ & $+0,449-1,296$ & $+0,460-1,282$ & $+0,479-1,253$ & $+0,535-1,191$ \\
\hline & & 100 & $-2,223-3,129$ & $-2,230-3,019$ & $-2,205-2,878$ & $-2,061-2,732$ & $+0,293-0,884$ & $+0,360-0,919$ & $+0,446-0,949$ & $+0,581-0,999$ \\
\hline & & 1000 & $-1,534-1,785$ & $-1,543-1,767$ & $-1,541-1,748$ & $-1,513-1,743$ & $-0,433-1,070$ & $-0,399-1,080$ & $-0,358-1,099$ & $-0,303-1,143$ \\
\hline & \multirow{3}{*}{$1,5 \gamma H$} & 10 & $-2,784-5,709$ & $-2,797-5,661$ & $-2,823-5,567$ & $-2,886-5,326$ & $+0,979-1,616$ & $+0,998-1,597$ & $+1,032-1,561$ & $+1,133-1,483$ \\
\hline & & 100 & $-2,811-4,518$ & $-2,821-4,354$ & $-2,792-4,133$ & $-2,636-3,857$ & $+0,819-1,071$ & $+0,923-1,128$ & $+1,060-1,181$ & $+1,277-1,271$ \\
\hline & & 1000 & $-1,782-2,497$ & $-1,803-2,461$ & $-1,823-2,412$ & $-1,834-2,350$ & $-0,193-1,429$ & $-0,141-1,445$ & $-0,077-1,475$ & $+0,007-1,530$ \\
\hline & \multirow{2}{*}{$2 \gamma H$} & 10 & $-3,363-7,496$ & $-3,380-7,431$ & $-3,414-7,307$ & $-3,498-6,985$ & $+1,518-1,945$ & $+1,546-1,922$ & $+1,596-1,878$ & $+1,740-1,785$ \\
\hline & & 100 & $-3,398-5,907$ & $-3,411-5,688$ & $-3,377-5,390$ & $-3,197-4,991$ & $+1,356-1,270$ & $+1,496-1,347$ & $+1,682-1,422$ & $+1,980-1,549$ \\
\hline
\end{tabular}


Из таблицы 2.18 следует, что в большинстве случаев зависимость напряжений от коэффициента Пуассона заполнителя $v_{3}$ незначительна, поэтому в расчетах можно использовать средние величины напряжений для каждого рассматриваемого $E_{3}$, а зависимость от величины $T_{x}$ - линейная. Это позволяет аппроксимировать данные в таблице 2.18 следующими однотипными аналитическими выражениями:

$$
\left.\begin{array}{rl}
\sigma_{1}^{A} & =\left(0.2985 T_{x}+0.0080\right) \lg ^{2} E-\left(0.8875 T_{x}+0.0370\right) \lg E-\left(0.131 T_{x}+1.004\right) \\
\alpha=30^{\circ} \sigma_{2}^{A}=\left(0.0185 T_{x}-0.0095\right) \lg ^{2} E+\left(1.0625 T_{x}+0.0405\right) \lg E-\left(4.687 T_{x}+0.395\right) & \\
\sigma_{1}^{B}=\left(0.3210 T_{x}-0.2040\right) \lg ^{2} E-\left(2.5630 T_{x}-0.5820\right) \lg E+\left(4.962 T_{x}-0.860\right) \\
\sigma_{2}^{B}=\left(-0.336 T_{x}+0.2030\right) \lg ^{2} E+\left(1.3960 T_{x}-0.5780\right) \lg E-\left(1.882 T_{x}+0.409\right)
\end{array}\right\},
$$

Образование зоны растягивающих напряжений в окрестности заглубленного конца разлома при определенных граничных условиях является одним из важных факторов, влияющих на процесс подготовки землетрясения. В частности, согласно модели лавинно-неустойчивого трещинообразования в зоне подготовки землетрясения происходит образование трещин и их взаимодействие. Очевидно, что эти процессы могут протекать в условиях действия растягивающих напряжений при превышении ими предела прочности пород на растяжение.

Наличием зоны растягивающих напряжений можно объяснить и явление образования островных дуг (рис. 2.66). Действительно, в результате возникновения растягивающих напряжений в окрестности заглубленного конца разлома в зоне субдукции образуются мощные трещины разрыва на верхнем его берегу, по этим каналам под действием огромного гидростатического давления устремляется магма, расширяя пути своего продвижения, процесс завершается вулканической деятельностью.

Здесь рассмотрены разломы с гладкими берегами. В случае разломов c неровными берегами картина распределения напряжений значительно усложняется. Рассмотрим распределение напряжений в сравнении.

На рисунке 2.67 показано распределение $\sigma_{1} / \gamma H$ и $\sigma_{2} / \gamma H$ для случая $\alpha=45^{\circ}$ с гладкими берегами, а на рисунках 2.68 и 2.69 - распределение напряжений для $\alpha=45^{\circ}$ с различной степенью регулярных неровностей. На этих рисунках видно, что вблизи каждой неровности (выступ, впадина) имеются зоны растягивающих напряжений $\sigma_{1} / \gamma H$, а концентрации сжимающих напряжений 
$\sigma_{2} / \gamma H$ достигают значительных величин - до $7 \gamma H$ и более. Действие растягивающих напряжений и высоких сжимающих ортогонального к ним направления приводит к образованию так называемых «оперяющих» трещин, которые наблюдаются вблизи крупных разломов. В этих зонах массивы горных пород значительно раздроблены, здесь при определенных условиях возможны разрывы барьерных перемычек между трещинами, срывы с неровностей (динамические подвижки берегов друг относительно друга) и прочие явления, вызывающие землетрясения различной мощности.

Возвращаясь к анализу результатов численного моделирования, рассмотрим перемещения берегов разлома. В таблице 2.19 приведены величины горизонтальных $\left(U_{x л}, U_{x n}\right)$ и вертикальных $\left(V_{y л}, V_{y n}\right)$ перемещений берегов разлома в зависимости от глубины для случая $\alpha=45^{\circ}, T_{x}=2 \gamma H, E_{3}=100 \mathrm{MПа,} v_{3}=0,35$, а также модули векторов перемещений $R_{л}=\sqrt{U_{x л}^{2}+V_{y л}^{2}}$ и $R_{n}=\sqrt{U_{x n}^{2}+V_{y n}^{2}}$.

Графики вертикальных и горизонтальных перемещений берегов разлома приведены на рисунке 2.70. Из данных рисунка 2.70 и таблицы 2.19 видно, что вертикальные перемещения (опускание) левого берега на всем протяжении его длины больше, чем опускание правого берега. Горизонтальные перемещения берегов практически одинаковы. Следовательно, относительное перемещение берегов происходит так, как показано на вставке рисунка 2.70. Однако это не означает, что так должно быть всегда. В нашем случае рассмотрен идеальный вариант, когда основной массив пород представлен однородной средой, но на самом деле это не так. Поэтому характер и величины перемещений берегов разрыва в процессе землетрясения зависят от многих факторов, а именно от того, какими физическими свойствами обладают породы вблизи разлома, каковы направление действия и величина тектонических сил и т. д.

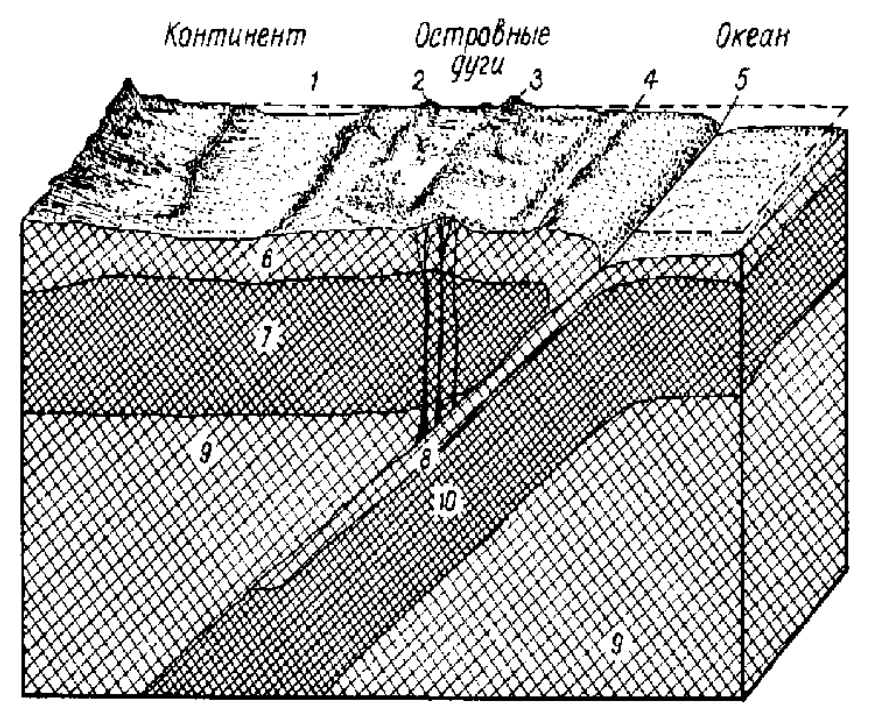

Рис. 2.66. Субдукция под островную дугу: 1 - мелководное море; 2 - потухшие вулканы; 3 - действующие вулканы; 4 - прибрежные острова; 5 - глубоководная впадина; 6 - кора; 7 - континентальная литосфера; 8 - зона плавления; 9 - астеносфера; 10 - опускающаяся океаническая кора 

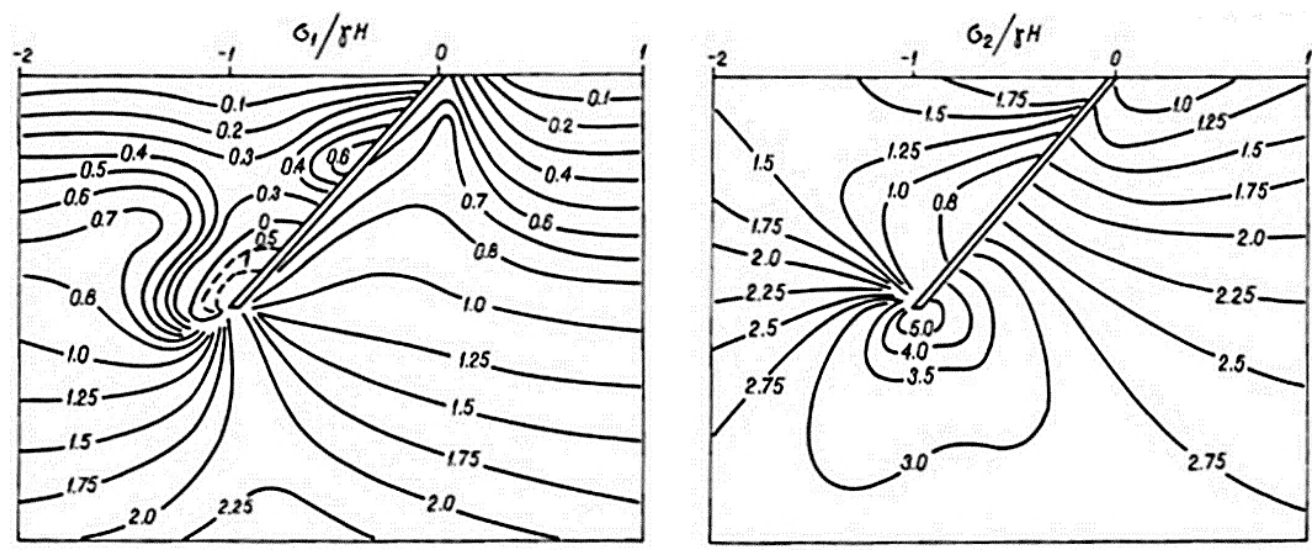

Рис. 2.67. Распределение напряжений $\sigma_{1} / \gamma H$ и $\sigma_{2} / \gamma H$ для $\alpha=45^{\circ}$ и $T_{x}=2 \gamma H$ в случае гладких берегов разлома
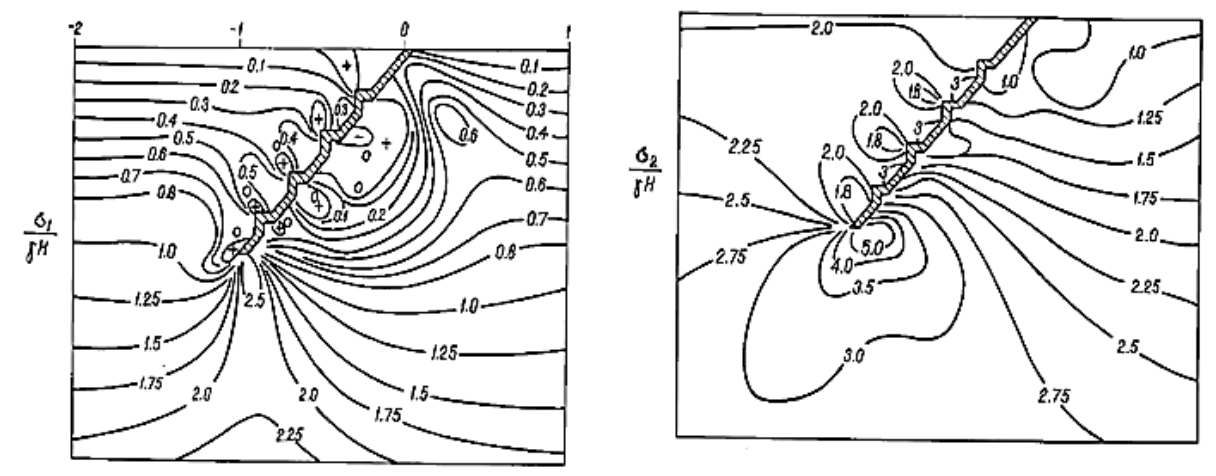

Рис. 2.68. Распределение напряжений $\sigma_{1} / \gamma H$ и $\sigma_{2} / \gamma H$ для $\alpha=45^{\circ}$ и $T_{x}=2 \gamma H$ в случае мелких регулярных неровностей на берегах разлома
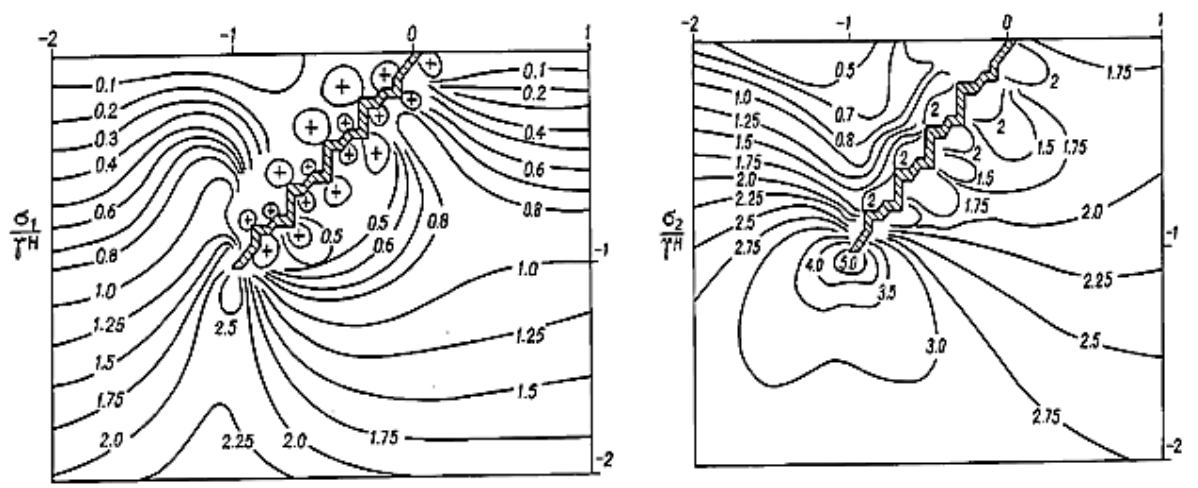

Рис. 2.69. Распределение главных напряжений $\sigma_{1} / \gamma H$ и $\sigma_{2} / \gamma H$ для $\alpha=45^{\circ}$ и $T_{x}=2 \gamma H$ в случае крупных регулярных неровностей на берегах разлома 


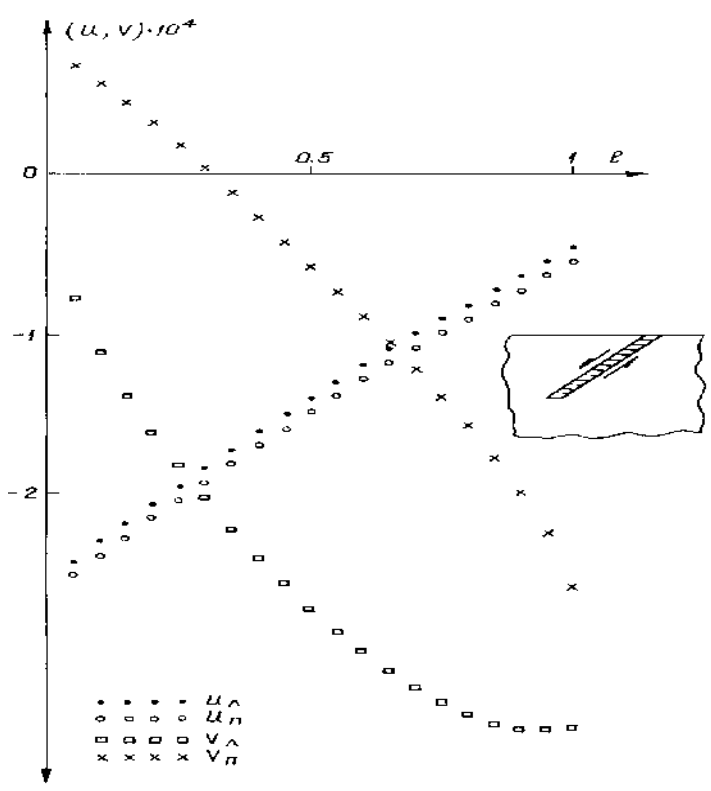

Рис. 2.70. Вертикальные и горизонтальные перемещения берегов разрыва при $\alpha=45^{\circ}$, $T_{x}=2 \gamma H, E_{3}=100 \mathrm{M \Pi а}, v_{3}=0,35$

Таблица 2.19

Перемещения берегов разлома

\begin{tabular}{|c|c|c|c|c|c|c|c|}
\hline $\mathrm{y}$ & $U_{\text {хл }}$ & $V_{\text {ул }}$ & $U_{\text {хп }}$ & $V_{\text {уп }}$ & $R_{\text {л }}$ & $R_{\text {п }}$ & $R_{\text {л }}-R_{\text {п }}$ \\
\hline$-0,025$ & $-2,42 \mathrm{E}-04$ & $-7,74 \mathrm{E}-05$ & $-2,51 \mathrm{E}-04$ & $6,88 \mathrm{E}-05$ & $2,54 \mathrm{E}-04$ & $2,60 \mathrm{E}-04$ & $-6,29 \mathrm{E}-06$ \\
$-0,075$ & $-2,29 \mathrm{E}-04$ & $-1,12 \mathrm{E}-04$ & $-2,39 \mathrm{E}-04$ & $5,67 \mathrm{E}-05$ & $2,55 \mathrm{E}-04$ & $2,45 \mathrm{E}-04$ & $1,04 \mathrm{E}-05$ \\
$-0,125$ & $-2,18 \mathrm{E}-04$ & $-1,38 \mathrm{E}-04$ & $-2,27 \mathrm{E}-04$ & $4,64 \mathrm{E}-05$ & $2,58 \mathrm{E}-04$ & $2,32 \mathrm{E}-04$ & $2,59 \mathrm{E}-05$ \\
$-0,175$ & $-2,06 \mathrm{E}-04$ & $-1,61 \mathrm{E}-04$ & $-2,15 \mathrm{E}-04$ & $3,33 \mathrm{E}-05$ & $2,61 \mathrm{E}-04$ & $2,18 \mathrm{E}-04$ & $4,31 \mathrm{E}-05$ \\
$-0,225$ & $-1,95 \mathrm{E}-04$ & $-1,82 \mathrm{E}-04$ & $-2,04 \mathrm{E}-04$ & $1,91 \mathrm{E}-05$ & $2,67 \mathrm{E}-04$ & $2,05 \mathrm{E}-04$ & $6,16 \mathrm{E}-05$ \\
$-0,275$ & $-1,83 \mathrm{E}-04$ & $-2,03 \mathrm{E}-04$ & $-1,93 \mathrm{E}-04$ & $4,30 \mathrm{E}-06$ & $2,73 \mathrm{E}-04$ & $1,93 \mathrm{E}-04$ & $8,02 \mathrm{E}-05$ \\
$-0,325$ & $-1,72 \mathrm{E}-04$ & $-2,22 \mathrm{E}-04$ & $-1,81 \mathrm{E}-04$ & $-1,08 \mathrm{E}-05$ & $2,81 \mathrm{E}-04$ & $1,82 \mathrm{E}-04$ & $9,86 \mathrm{E}-05$ \\
$-0,375$ & $-1,61 \mathrm{E}-04$ & $-2,40 \mathrm{E}-04$ & $-1,70 \mathrm{E}-04$ & $-2,62 \mathrm{E}-05$ & $2,89 \mathrm{E}-04$ & $1,72 \mathrm{E}-04$ & $1,16 \mathrm{E}-04$ \\
$-0,425$ & $-1,50 \mathrm{E}-04$ & $-2,56 \mathrm{E}-04$ & $-1,60 \mathrm{E}-04$ & $-4,17 \mathrm{E}-05$ & $2,97 \mathrm{E}-04$ & $1,65 \mathrm{E}-04$ & $1,32 \mathrm{E}-04$ \\
$-0,475$ & $-1,40 \mathrm{E}-04$ & $-2,72 \mathrm{E}-04$ & $-1,49 \mathrm{E}-04$ & $-5,73 \mathrm{E}-05$ & $3,06 \mathrm{E}-04$ & $1,60 \mathrm{E}-04$ & $1,46 \mathrm{E}-04$ \\
$-0,525$ & $-1,30 \mathrm{E}-04$ & $-2,86 \mathrm{E}-04$ & $-1,39 \mathrm{E}-04$ & $-7,31 \mathrm{E}-05$ & $3,14 \mathrm{E}-04$ & $1,57 \mathrm{E}-04$ & $1,57 \mathrm{E}-04$ \\
$-0,575$ & $-1,19 \mathrm{E}-04$ & $-2,99 \mathrm{E}-04$ & $-1,29 \mathrm{E}-04$ & $-8,91 \mathrm{E}-05$ & $3,22 \mathrm{E}-04$ & $1,56 \mathrm{E}-04$ & $1,66 \mathrm{E}-04$ \\
$-0,625$ & $-1,09 \mathrm{E}-04$ & $-3,11 \mathrm{E}-04$ & $-1,18 \mathrm{E}-04$ & $-1,05 \mathrm{E}-04$ & $3,29 \mathrm{E}-04$ & $1,58 \mathrm{E}-04$ & $1,71 \mathrm{E}-04$ \\
$-0,675$ & $-1,00 \mathrm{E}-04$ & $-3,21 \mathrm{E}-04$ & $-1,09 \mathrm{E}-04$ & $-1,22 \mathrm{E}-04$ & $3,36 \mathrm{E}-04$ & $1,64 \mathrm{E}-04$ & $1,72 \mathrm{E}-04$ \\
$-0,725$ & $-9,00 \mathrm{E}-05$ & $-3,30 \mathrm{E}-04$ & $-1,00 \mathrm{E}-04$ & $-1,39 \mathrm{E}-04$ & $3,42 \mathrm{E}-04$ & $1,71 \mathrm{E}-04$ & $1,71 \mathrm{E}-04$ \\
$-0,775$ & $-8,10 \mathrm{E}-05$ & $-3,38 \mathrm{E}-04$ & $-9,00 \mathrm{E}-05$ & $-1,57 \mathrm{E}-04$ & $3,48 \mathrm{E}-04$ & $1,81 \mathrm{E}-04$ & $1,67 \mathrm{E}-04$ \\
$-0,825$ & $-7,20 \mathrm{E}-05$ & $-3,44 \mathrm{E}-04$ & $-8,10 \mathrm{E}-05$ & $-1,77 \mathrm{E}-04$ & $3,52 \mathrm{E}-04$ & $1,95 \mathrm{E}-04$ & $1,57 \mathrm{E}-04$ \\
$-0,875$ & $-6,30 \mathrm{E}-05$ & $-3,48 \mathrm{E}-04$ & $-7,30 \mathrm{E}-05$ & $-1,99 \mathrm{E}-04$ & $3,54 \mathrm{E}-04$ & $2,12 \mathrm{E}-04$ & $1,42 \mathrm{E}-04$ \\
$-0,925$ & $-5,40 \mathrm{E}-05$ & $-3,48 \mathrm{E}-04$ & $-6,30 \mathrm{E}-05$ & $-2,24 \mathrm{E}-04$ & $3,52 \mathrm{E}-04$ & $2,33 \mathrm{E}-04$ & $1,20 \mathrm{E}-04$ \\
$-0,975$ & $-4,60 \mathrm{E}-05$ & $-3,46 \mathrm{E}-04$ & $-5,50 \mathrm{E}-05$ & $-2,58 \mathrm{E}-04$ & $3,49 \mathrm{E}-04$ & $2,64 \mathrm{E}-04$ & $8,46 \mathrm{E}-05$ \\
\hline
\end{tabular}

Из таблицы 2.19 следует, что относительное перемещение берегов $R_{л}-R_{n}$ составляет $\approx(1-1,5) \cdot 10^{-4}$ условных единиц. Если в качестве величины заглубления 
разлома взять $H=1$ км, то по нашим расчетам, $R_{л}-R_{n}=(10-15)$ см, для $H=10$ км это будет $(1-1,5)$ м. Такие величины относительных перемещений берегов разрыва вполне реальны. Например, во время Анкашского землетрясения в 1946 г. (Перуанские Анды) вертикальный сброс, образовавшийся вдоль разлома, составил $\approx 3$ м [121]. Величины поперечных сбросов при землетрясении в Нефтегорске в отдельных местах достигали 8 м [124]. В условиях отработки месторождений, когда образуются свободные поверхности (очистные пространства), такие величины перемещений берегов разрывов могут происходить и на значительно меньших глубинах. Например, при техногенном землетрясении, происшедшем на руднике «Умбозеро» 17.08.1999 г. (Кольский полуостров) в результате отработки пологопадающей $\left(17^{\circ}\right)$ залежи на глубине порядка 100-200 м, берега разрыва, образовавшегося под углом $40^{\circ}$, сместились друг относительно друга по вертикали на 9 см, по горизонтали - на 13 см [101]. При этом в массиве пород на этой глубине действуют горизонтальные тектонические напряжения (50-70) МПа.

Таким образом, в условиях действия гравитационно-тектонических силовых полей в массивах горных пород с наклонными разломами, выходящими на поверхность, в окрестности верхнего берега в нижней его части формируется зона растягивающих напряжений, ориентированных параллельно границе разлома. В окрестности нижней части правого берега действуют сжимающие напряжения, концентрация которых может достигать (5-7) $\gamma H$. Вблизи неровностей на берегах разломов формируются зоны с растягивающими напряжениями одного направления и высокими концентрациями сжимающих напряжений ортогонального направления. Вертикальные и горизонтальные перемещения берегов друг относительно друга в зависимости от граничных условий и свойств основных пород массива и материала, заполняющего разлом, могут превысить несколько метров. Наличие зон растягивающих напряжений, формирующихся в концевой области наклонного разлома, является одним из факторов, влияющих на процесс подготовки землетрясения.

\subsection{5. Напряженное состояние горных пород в зоне субдукции}

Вопросам НДС пород в зоне субдукции посвящены работы [135-137], в которых методом конечных элементов в двухмерной постановке задачи исследован характер изменения напряженного состояния литосферных плит в зависимости от свойств пород (упругие, вязкоупругие), слагающих верхнюю часть земной коры и подстилающей ее мантии. При этом в качестве граничных условий рассматривались силы погружения, действующие в вертикальном направлении на некоторой части нижней границы погружаемой плиты, уравновешенные действием вертикальных сил противоположного направления в районе океанической впадины. Показана возможность возникновения локальных горизонтальных напряжений сжатия и растяжения в различных областях как материковой, так и океанической плит в условиях относительного их сдвига и при его отсутствии. Наличие горизонтальных тектонических сил, вызванных раздвигом океанических плит в районе срединноокеанических рифтов, не рассматривалось.

Наши исследования основаны на численном моделировании с применением метода граничных элементов в иной постановке задачи и с иными граничными условиями. 
Рассмотрим погружение океанической плиты под материковую (рис. 2.71) [138]. Пусть мощность материковой плиты $H=80$ км, а мощность океанической в два раза меньше $h=40$ км. Погружение происходит под углом $45^{\circ}$, нормальная мощность разломной зоны, по которой происходит погружение, $h_{p}=1$ км. Перепад высот между верхними границами материковой и океанической плит примем равным $h_{0}=10$ км. Разломная зона в середине океанической плиты (на глубине 40 км) имеет неровность в виде треугольного выступа, горизонтальная и вертикальная грани которого $l_{\mathrm{B}}=h_{\mathrm{B}}=5$ км. Погружение океанической плиты без плавления пород происходит до глубины 120 км. Для определенности расчетов полагаем объемный вес пород и коэффициент Пуассона материковой, океанической плит и разломной зоны одинаковыми $\gamma=3,0 \mathrm{~m} / \mathrm{m}^{3}, v=0,25$, модуль Юнга пород материковой и океанической плит $E=5 \cdot 10^{4}$ МПа, а для разломной зоны $-E_{p}=5 \cdot 10^{3}$ МПа.

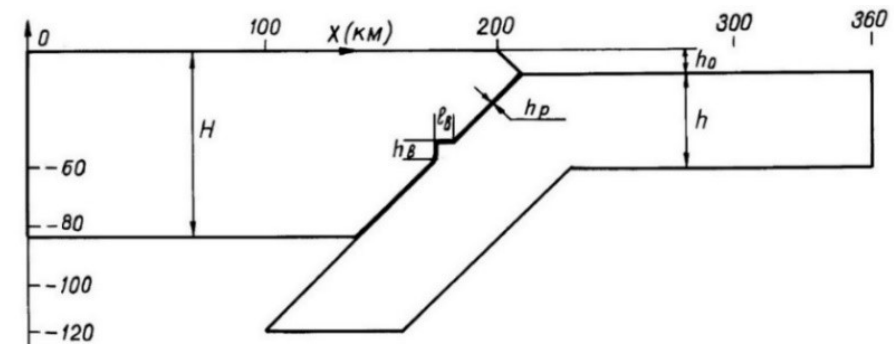

Рис. 2.71. Схема расчетной модели

С целью выяснения влияния различных граничных условий рассмотрены следующие варианты.

1. Действие только гравитационных сил.

В этом случае вертикальные грани модели закреплены шарнирно, что создает боковой отпор горных пород. На верхней части горизонтальной границы океанической плиты задана распределенная нагрузка, имитирующая вес 10-километровой толщи воды. На нижних и наклонных гранях модели заданы силы, уравновешивающие действие вышележащей толщи пород и воды.

2. Действие только тектонических горизонтальных сил.

Полагаем, что действие горизонтальных тектонических сил обусловлено раздвигом океанической плиты в районе срединно-океанического рифта. При этом вертикальная грань материковой плиты закреплена шарнирно, а на вертикальной грани океанической плиты заданы равномерно распределенные по глубине усилия единичной интенсивности. Все остальные части границы свободны от внешнего силового воздействия.

3. Совместное действие гравитационных и тектонических сил.

В этом случае на вертикальной грани океанической плиты заданы силы $\gamma h+\lambda \gamma\left(y-h_{0}\right)$, а на вертикальной грани материковой плиты - силы $\gamma h / 2+\lambda \gamma y$. Здесь $y-$ текущая координата по вертикали; $\lambda=v /(1-v)-$ боковой отпор пород. Для соблюдения условий равновесия на левой грани модели заданы равномерно распределенные тектонические силы $\gamma h / 2$ - в два раза меньше, чем на правой грани. На остальной части границы граничные условия такие же, как и в случае 1.

4. Совместное действие гравитационных, тектонических и касательных сил. 
К граничным условиям третьего варианта добавлено действие конвективных потоков мантийного вещества. Для этого по нижней и на наклонных участках границы модели заданы равномерно распределенные касательные усилия интенсивности $K=400$ МПа. Под материковой плитой конвективный поток направлен по часовой стрелке, а под океанической - против часовой.

5. Совместное действие гравитационных, тектонических и касательных сил для модели с разломной зоной без выступа.

В предположении, что неровность срезана (разрушена), рассмотрен вариант граничных условий 4 .

Во всех случаях рассматриваемых граничных условий, помимо напряженного состояния, во всей исследуемой области получено детальное распределение напряжений в непосредственной близости к выступу на границе разломной зоны.

1. Действие только гравитационных сил.

На рисунке 2.72 показано распределение главных напряжений $\sigma_{1}$ и $\sigma_{2}$ во всей исследуемой области. Будем придерживаться общепринятого положения о том, что $\sigma_{1}>\sigma_{2}$ алгебраически.

На рисунке видно, что главные напряжения $\sigma_{1}$ почти всюду являются сжимающими (сплошные изолинии). В верхней части материковой и океанической плит в районе разломной зоны $\sigma_{1}$ растягивающие (пунктирные изолинии). Величина растягивающих $\sigma_{1}$ на глубине 10-30 км достигает 200 МПа и более, а их ориентация относительно оси $O X$ системы координат $O X У$ составляет (0-45) градусов. Поэтому, если здесь возможно возникновение трещин отрыва, то они будут образовываться нормально к границе разлома. Максимальная величина сжимающих напряжений $\sigma_{1}$ в нижней части материковой плиты $\approx 1000$ МПа, а в нижней части океанической $-\approx 500$ МПа. Это несколько больше, чем $\lambda \gamma H$ и $\lambda \gamma h$, что можно объяснить не вполне равномерным распределением напряжений из-за наличия угловых точек границы.
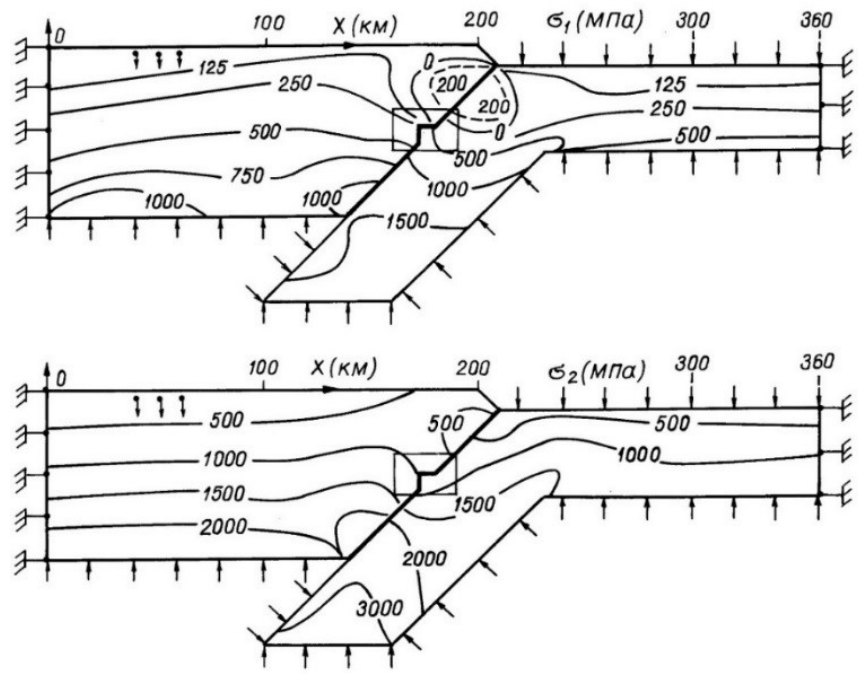

Рис. 2.72. Распределение главных напряжений $\sigma_{1}$ и $\sigma_{2}$ во всей исследуемой области (вариант 1) 

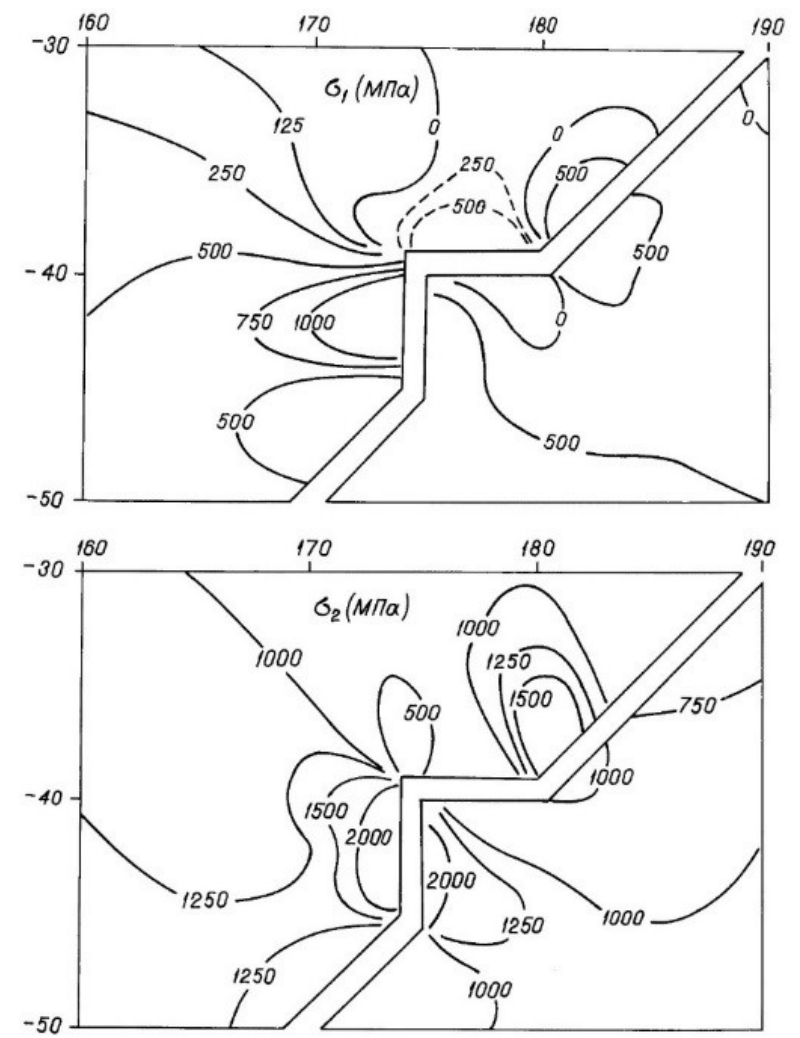

Рис. 2.73. Распределение напряжений $\sigma_{1}$ и $\sigma_{2}$ в окрестности выступа (вариант 1 )

Напряжения $\sigma_{2}$ всюду сжимающие. Это, практически, субвертикальные напряжения. Их величина достигает значений $\approx 3000$ МПа и больше в концевой части погружающейся океанической плиты. На рисунке 2.73 приведено распределение главных напряжений $\sigma_{1}$ и $\sigma_{2}$ в окрестности неровности разломной зоны. Здесь четко прослеживается неравномерность распределения напряжений. Напряжения $\sigma_{1}$ находятся в пределах $\left(-1000 \leq \sigma_{1} \leq+500\right)$ МПа. Растягивающие напряжения $\sigma_{1}$ приурочены к горизонтальной части выступа. Другое главное напряжение $\sigma_{2}$ изменяется в диапазоне $\left(-2000 \leq \sigma_{2} \leq-500\right)$ МПа. Наибольшие сжимающие напряжения концентрируются вблизи вертикальной границы выступа. Максимальные касательные напряжения $\tau_{\max }=\left(\sigma_{1}-\sigma_{2}\right) / 2$ в основании выступа (по линии, соединяющей левый нижний и правый верхний углы выступа) находятся в пределах $\left(200 \leq \tau_{\max } \leq 500\right)$ МПа. Изменение напряжений по длине основания выступа (от левого нижнего угла до правого верхнего) можно аппроксимировать зависимостями:

$$
\left.\begin{array}{l}
\sigma_{1}=(360 l-1750) \mathrm{M \Pi а} \\
\sigma_{2}=(333 l-2470) \mathrm{MПа}
\end{array}\right\}
$$

где $(0 \leq l \leq 7,5)$ км. 
При этом удельная энергия деформирования, вычисленная по формуле

$$
w=\frac{1}{2 E l} \int_{0}^{l}\left(\sigma_{1}^{2}+\sigma_{2}^{2}-2 v \sigma_{1} \sigma_{2}\right) d l
$$

составляет величину $w=22,54$ МДж/ $\mathrm{M}^{3}$. Если предположить, что объем разрушения по основанию выступа составит $(7500 \times 1000 \times 1000) \mathrm{M}^{3}$, то при этом выделится энергия $W=1,69 * 10^{17}$ Дж. Пусть сейсмическая энергия составит $10 \%$ от выделившейся, тогда $W_{\mathrm{c}}=1,69 * 10^{16}$ Дж. Используя зависимость [122]:

$$
\log W_{\mathrm{c}}=5,24+1,44 M_{s}(\text { Дж), }
$$

получаем магнитуду возможного землетрясения $M_{s}=7,6$.

2. Действие только тектонических сил.

Распределение главного напряжения $\sigma_{1}$ (рис. 2.74) в этом случае характеризуется достаточно обширной областью растягивающих значений в окрестности разломной зоны. Эти напряжения достигают в непосредственной близости к выступу $0,2 T$ (рис. 2.75). В основной части материковой и океанической плит $\sigma_{1} \approx 0$. Напряжения $\sigma_{2}$ субгоризонтальные и в большей части материковой плиты равны $(0,5-0,6) T$, а в океанической плите $\sigma_{2}=(0,95-1,05) T$. $\mathrm{B}$ погружающейся части океанической плиты величина $\sigma_{2}$ находится в пределах $0 \leq\left|\sigma_{2}\right| \leq 0,9|T|$. Распределение относительных напряжений $\sigma_{1} / T$ и $\sigma_{2} / T$ в окрестности выступа показано на рисунке 2.75 .
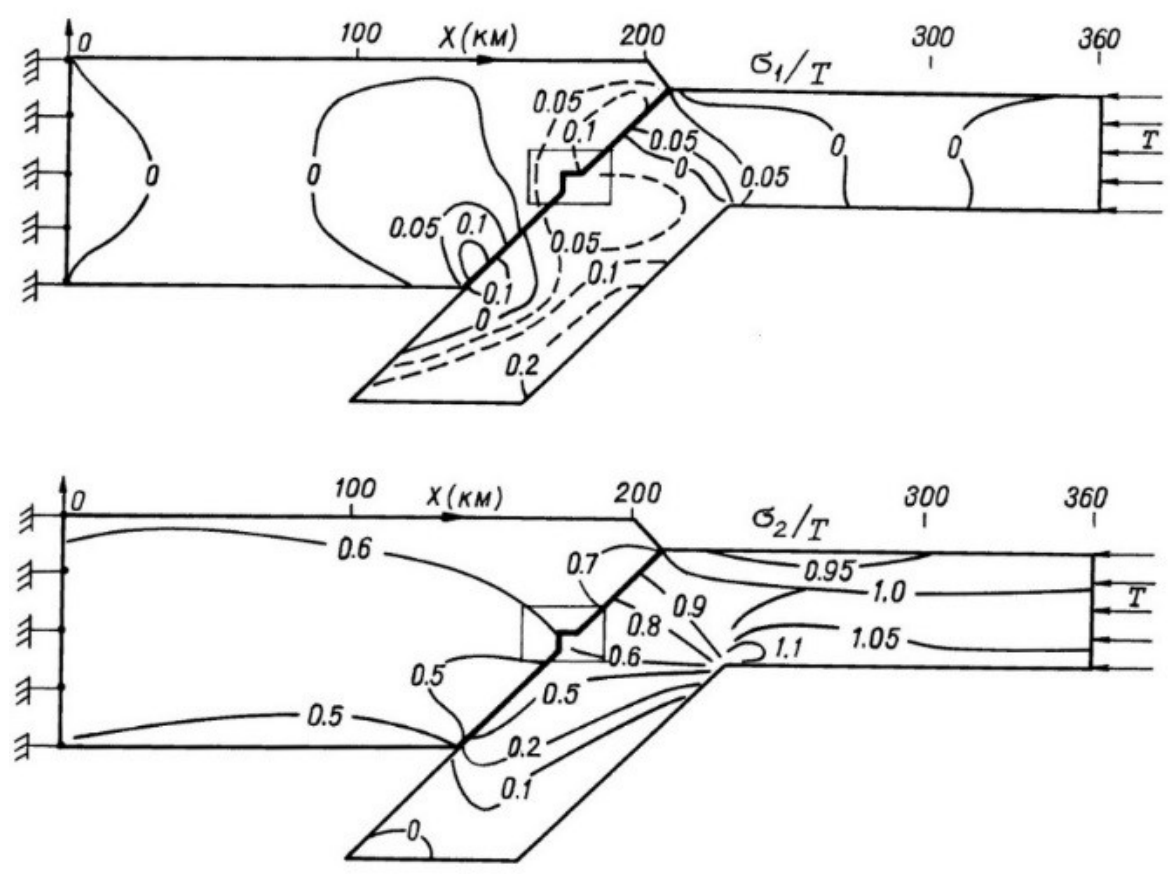

Рис. 2.74. Изолинии относительных напряжений $\sigma_{1} / T$ и $\sigma_{2} / T$ во всей исследуемой области (вариант 2) 

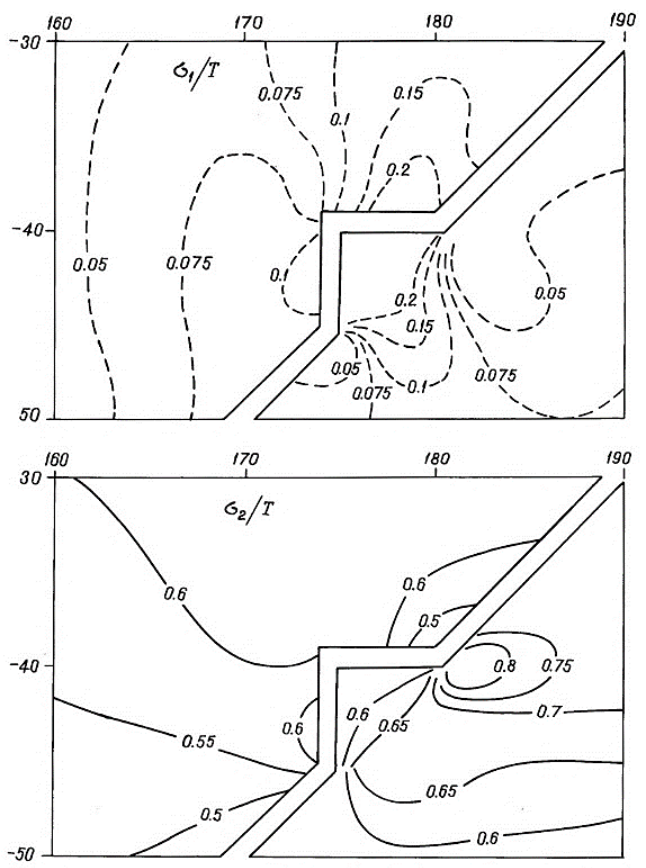

Pис. 2.75. Изолинии относительных напряжений $\sigma_{1} / T$ и $\sigma_{2} / T$ вблизи выступа (вариант 2)

3. Совместное действие гравитационных и тектонических сил.

Предполагаем, что горизонтальные тектонические силы, вызванные раздвигом в срединно-океаническом рифте, равны по величине давлению жидкой магмы на глубине 40 км от дна океана и распределены равномерно по вертикальной границе океанической плиты. В предыдущем случае мы видели, что субгоризонтальные напряжения $\sigma_{2}$ в материковой плите составляют 0,5T. Поэтому, а также из соображения соблюдения условий равновесия, на левой грани модели заданы равномерно распределенные по глубине силы величиной $\gamma h / 2$. Естественно, при этом учитывается и влияние бокового отпора пород.

Распределение напряжений $\sigma_{1}$ и $\sigma_{2}$ для этого варианта граничных условий во всей модели показано на рисунке 2.76. Здесь оба главных напряжения в основном сжимающие, за исключением небольшой области в верхней части материковой и океанической плит в зоне погружения, где $\sigma_{1}$ растягивающие. Напряжения $\sigma_{1}$ находятся в пределах от -2000 МПа до +500 МПа, а $\sigma_{2}$ изменяются в диапазоне $\left(-3500 \leq \sigma_{2} \leq-750\right)$ МПа. В непосредственной близости к выступу (рис. 2.77) $\left(-1270 \leq \sigma_{1} \leq+500\right)$ МПа и $\left(-2000 \leq \sigma_{2} \leq-1000\right)$ МПа. Максимальные касательные напряжения в основании выступа $\left(450 \leq \tau_{\max } \leq 920\right)$ МПа. Главные напряжения в основании выступа можно аппроксимировать зависимостями:

$$
\left.\begin{array}{l}
\sigma_{1}=(358 l-1800) \mathrm{MПа} \\
\sigma_{2}=(406 l-3400) \mathrm{MПа}
\end{array}\right\}
$$

По формуле (2.63) находим удельную энергию деформирования $w=43,38 \mathrm{MДж/ \textrm {M } ^ { 3 }}$. При том же объеме разрушения выделится $W=3,254 \cdot 10^{17}$ Дж, сейсмическая энергия составит $W_{\mathrm{c}}=3,254 \cdot 10^{16}$ Дж, что дает магнитуду возможного землетрясения $M_{s}=7,8$. 

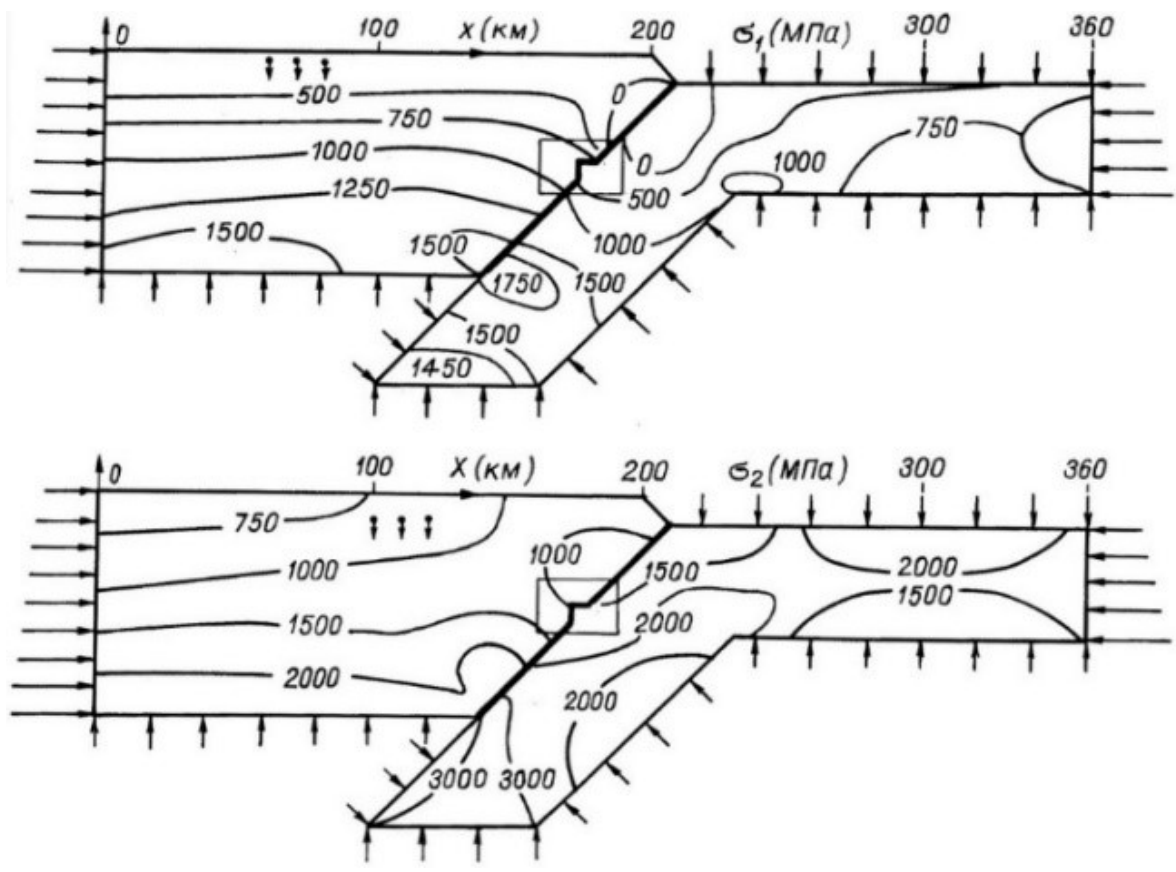

Рис. 2.76. Распределение главных напряжений $\sigma_{1}$ и $\sigma_{2}$ во всей исследуемой области (вариант 3 )
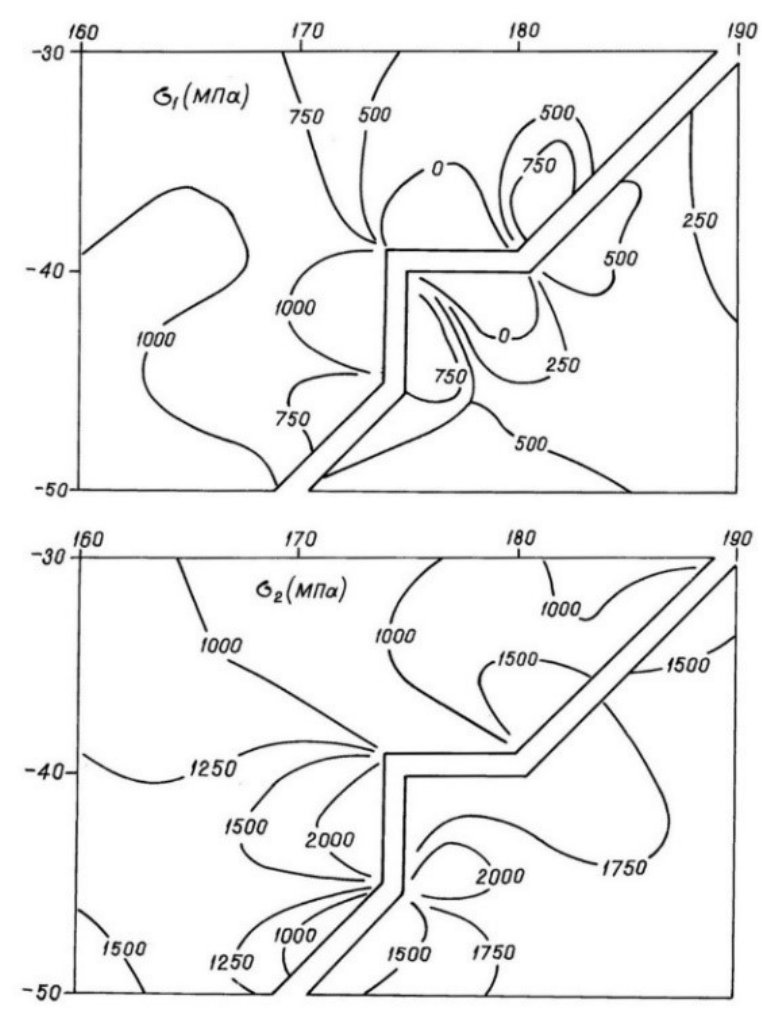

Рис. 2.77. Распределение главных напряжений $\sigma_{1}$ и $\sigma_{2}$ в окрестности выступа (вариант 3 ) 
4. Совместное действие гравитационных, тектонических и конвективных сил. Распределение главных напряжений в этом случае показано на рисунке 2.78.

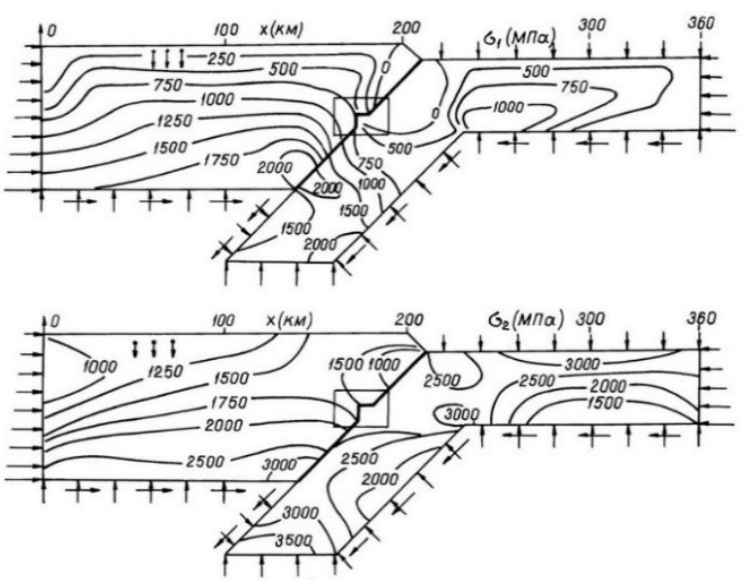

Рис. 2.78. Изолинии главных напряжений $\sigma_{1}$ и $\sigma_{2}$ во всей исследуемой области (вариант 4)
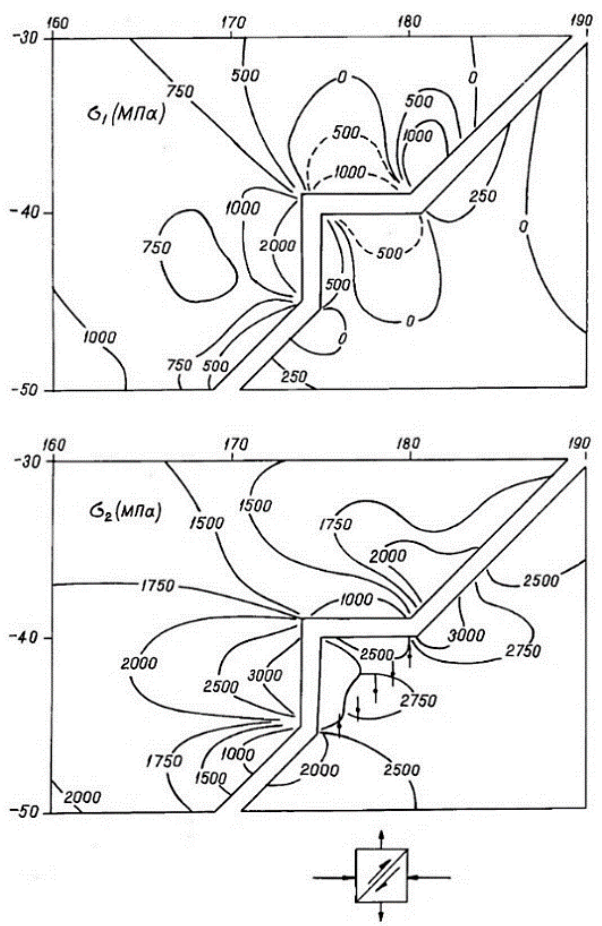

Рис. 2.79. Изолинии главных напряжений $\sigma_{1}$ и $\sigma_{2}$ в окрестности выступа (вариант 4)

Сжимающие напряжения $\sigma_{1}$ в материковой плите здесь достигают 2000 МПа (в правой нижней части плиты). В средней части материковой плиты $\sigma_{1}$ находится в пределах от -500 до -1500 МПа. Как и в предыдущем случае, в верхней части материковой и океанической плит вблизи разломной зоны $\sigma_{1}$ растягивающие до 1000 МПа и более. Напряжения $\sigma_{2}$ всюду сжимающие. В основной части материковой и океанической плит они находятся в диапазоне $-(1500-2500)$ МПа. В верхней части материковой плиты вблизи разломной зоны $\sigma_{2} \approx-1000 \mathrm{MПа,}$ 
а в океанической $\sigma_{2} \approx-2500$ МПа. Распределение напряжений вблизи выступа приведено на рисунке 2.79 , на котором видно, что напряжения $\sigma_{1}$ изменяются от -2000 МПа до +1000 МПа, а $\sigma_{2}-$ от -1000 МПа до -3000 МПа. Это происходит на незначительной (как и в предыдущих случаях) площади $20 \times 30$ км. На рисунке 2.79 показана ориентация главного напряжения $\sigma_{1}$ в основании выступа, a также направление действия максимальных касательных напряжений, которые здесь изменяются от 1200 МПа до 1700 МПа.

Главные напряжения $\sigma_{1}$ и $\sigma_{2}$ у основания выступа аппроксимируются уравнениями:

$$
\left.\begin{array}{l}
\sigma_{1}=(293 l-900) \mathrm{M} \Pi \\
\sigma_{2}=\left(50 l^{2}-300 l-2400\right) \mathrm{M} \Pi \mathrm{a}
\end{array}\right\} .
$$

Расчеты по формуле (2.63) дают значение удельной энергии деформирования $w=74,13 \cdot 10^{5} \mathrm{MДж/ \textrm {M } ^ { 3 }}$. Следовательно, при тех же объемах разрушения должна выделиться энергия $W=5,556 \cdot 10^{20}$ Дж, $10 \%$-я доля сейсмической энергии составит $W_{\mathrm{c}}=5,556 \cdot 10^{19}$ Дж, а магнитуда $M_{s}=10,0$. Такие огромные значения энергии и магнитуды вызваны, очевидно, большой величиной заданных касательных усилий, имитирующих конвективные движения мантийного вещества. Это сделано специально для того, чтобы отразить их влияние на геодинамическую ситуацию.

5. Вариант без выступа в разломной зоне.

Распределение напряжений без неровности в разломной зоне при граничных условиях предыдущего варианта показано на рисунке 2.80. Сравнительный анализ рисунков 2.78 и 2.80 показывает, что в общих чертах и характер распределения напряжений, и их величины изменились незначительно. Это изменение касается в основном части массива, располагаемого в непосредственной близости к неровности (рис. 2.81). Во-первых, распределение напряжений без выступа более равномерное. Во-вторых, диапазон величин напряжений $\sigma_{1}$ и $\sigma_{2}$ значительно меньше: $\left(-750 \leq \sigma_{1} \leq+500\right)$ МПа по сравнению с $\left(-1000 \leq \sigma_{1} \leq+1000\right)$ МПа для разломной зоны с выступом и $\left(-2400 \leq \sigma_{2} \leq 1500\right)$ МПа по сравнению с $\left(-3000 \leq \sigma_{2} \leq-1000\right)$ МПа. Иначе говоря, если считать, что произошло разрушение массива по основанию выступа, то напряжения в массиве «разрядились».

Весьма интересным представляется анализ перемещений точек границы. На рисунке 2.82 представлен фрагмент модели в районе субдукции для 4 варианта граничных условий. Здесь в точках 1-4 показана локальная (следящая) система координат $(\tau, n)$, где $\tau$ - направление касательной, a $n$ - направлений внешней нормали при обходе контуров по часовой стрелке. Здесь же стрелками показано направление перемещений по касательной.

В таблице 2.20 приведены величины перемещений относительно условной единицы $1=100$ км $=10^{5} \mathrm{M}$, из которой следует, что поднятие материковой плиты относительно океанической $\Delta u_{n}=u_{n 1}-u_{n 4}=4.08 \cdot 10^{-4} \cdot 10^{5}=40.8$ м. Пододвигание океанической плиты под материковую составляет $\Delta u_{\tau}=\left|u_{\tau 1}-u_{\tau 4}\right|=7.53 \cdot 10^{-4} \cdot 10^{5}=75.3$ м. Нормальное сближение точек 2 и 3 $\Delta u_{n}=u_{n 2}+u_{n 3}=1.1376 \cdot 10^{-3} \cdot 10^{5}=113.76$ м. Расхождение точек 2 и 3 в касательном направлении $\Delta u_{\tau}=\left|u_{\tau 2}+u_{\tau 3}\right|=3.114 \cdot 10^{-4} \cdot 10^{5}=31.14$ м. 

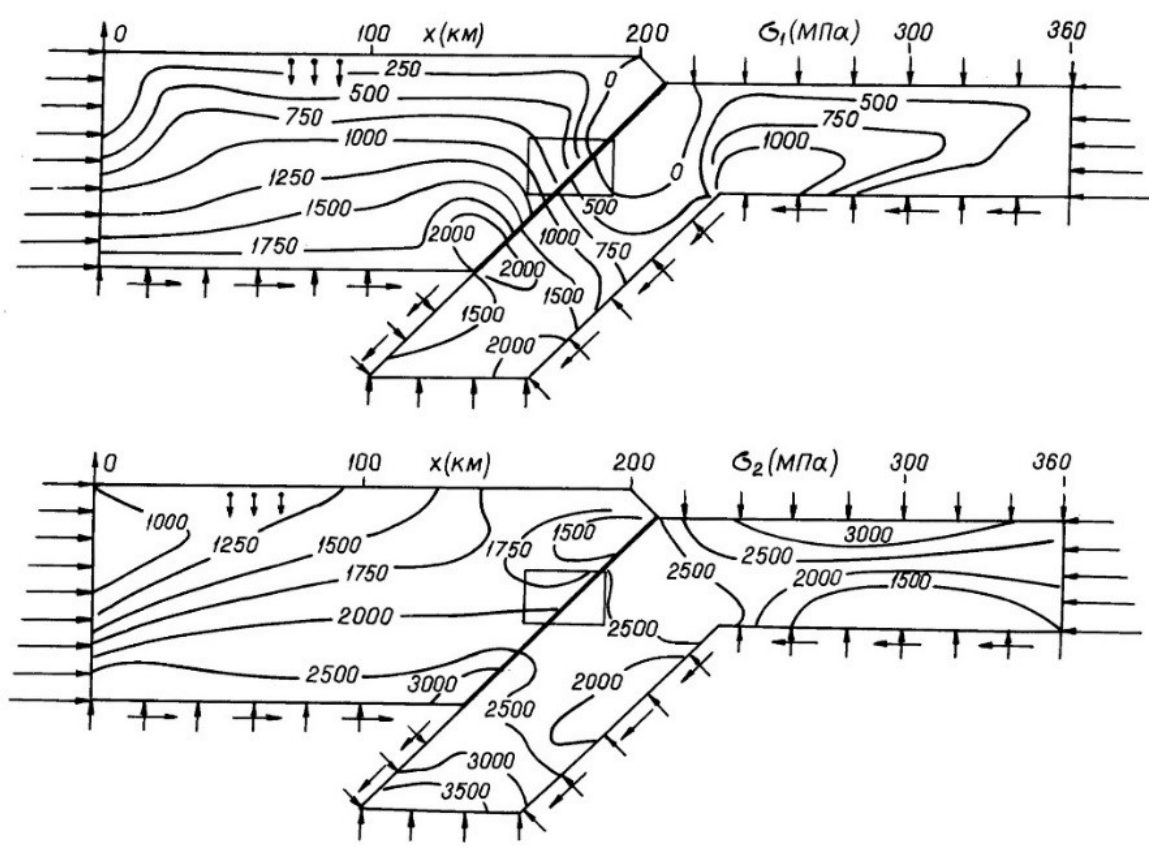

Рис. 2.80. Распределение главных напряжений $\sigma_{1}$ и $\sigma_{2}$ во всей области для модели без выступа (вариант 5)
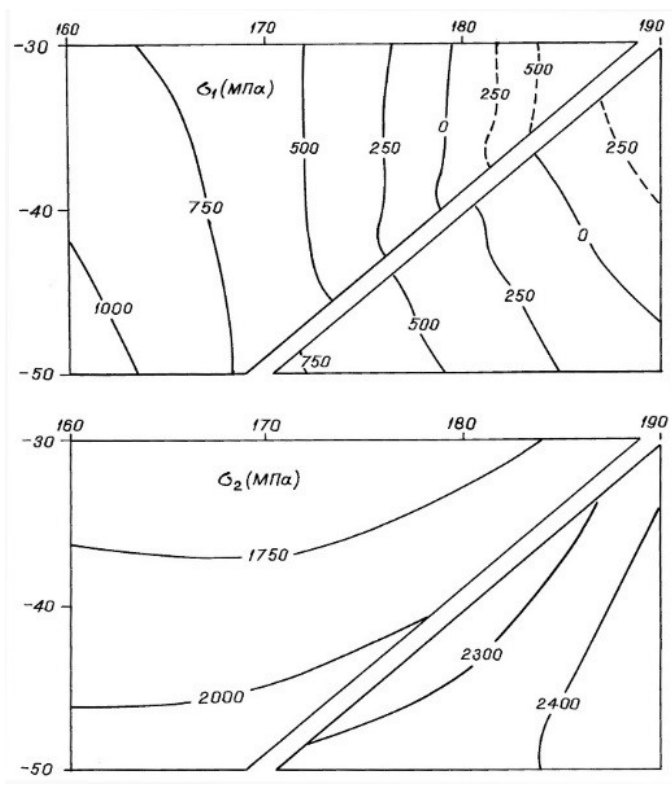

Рис. 2.81. Изолинии главных напряжений $\sigma_{1}$ и $\sigma_{2}$ в окрестности бывшего выступа (вариант 5) 


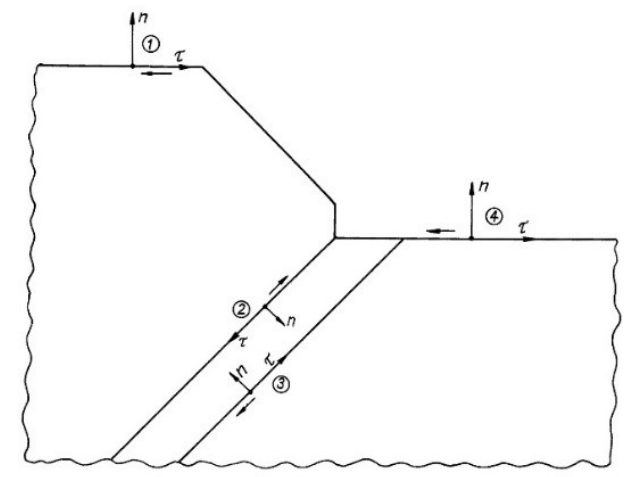

Рис. 2.82. Фрагмент модели с точками, в которых выполнен анализ перемещений

Таблица 2.20

Перемещения точек границы для 4 варианта

\begin{tabular}{|c|c|c|}
\hline Точка & $u_{n}$ & $u_{\tau}$ \\
\hline 1 & $6,073 \cdot 10^{-3}$ & $-1,176 \cdot 10^{-3}$ \\
\hline 2 & $5,801 \cdot 10^{-4}$ & $-1,425 \cdot 10^{-4}$ \\
\hline 3 & $5,575 \cdot 10^{-4}$ & $-1,689 \cdot 10^{-4}$ \\
\hline 4 & $5,665 \cdot 10^{-3}$ & $-1,929 \cdot 10^{-3}$ \\
\hline
\end{tabular}

В таблице 2.21 даны величины перемещений в тех же точках 1-4 для 5 варианта задачи, то есть без неровности на разломе. Из этой таблицы получаем:

- поднятие материковой плиты относительно океанической $\Delta u_{n}=u_{n 1}-u_{n 4}=43.2 \mathrm{M}$;

- пододвигание океанической плиты под материковую составляет $\Delta u_{\tau}=\left|u_{\tau 1}-u_{\tau 4}\right|=78.3 \mathrm{~m}$

- нормальное сближение точек 2 и $3 \Delta u_{n}=u_{n 2}+u_{n 3}=120.77$ м;

- расхождение точек 2 и 3 в касательном направлении $\Delta u_{\tau}=\left|u_{\tau 2}+u_{\tau 3}\right|=25.66 \mathrm{M}$.

Таблица 2.21

Перемещения точек границы для 5 варианта

\begin{tabular}{|c|c|c|}
\hline Точка & $u_{n}$ & $u_{\tau}$ \\
\hline 1 & $6,436 \cdot 10^{-3}$ & $-8,938 \cdot 10^{-4}$ \\
\hline 2 & $6,165 \cdot 10^{-4}$ & $-1,134 \cdot 10^{-4}$ \\
\hline 3 & $5,912 \cdot 10^{-4}$ & $-1,432 \cdot 10^{-4}$ \\
\hline 4 & $6,004 \cdot 10^{-3}$ & $-1,677 \cdot 10^{-3}$ \\
\hline
\end{tabular}

Величины перемещений, приведенные в таблицах 2.20 и 2.21 , надо понимать как перемещения, вызванные мгновенным приложением рассматриваемых сил.

Таким образом, в 5 варианте по сравнению с 4, если их рассматривать как последующее и предыдущее состояния, поднятие материковой плиты относительно океанической увеличилось на 2,4 м; пододвигание океанической плиты под материковую увеличилось на 3 м; нормальное сближение точек 2 и 3 увеличилось на 7,01 м, а их расхождение в направлении касательном к границе разлома - на 5,48 м. 
Здесь рассмотрен вариант, когда в разломной зоне имеется один достаточно большой выступ. В действительности их может быть несколько, но меньших размеров. Характер разрушений при этом, по-видимому, будет идентичным - мгновенный срыв по неровностям.

11 марта 2011 г. в Японии произошло сильнейшее землетрясение $\left(M_{w}=9,0-9,1\right)$, гипоцентр которого располагался на глубине 32 км. Оно породило цунами, волны которого распространились по всему Тихому океану [138]. Как отмечает Л. В. Тарасов [126], наиболее сильные цунами возникают в зонах субдукции, а 85 \% их обусловлены подводными землетрясениями.

Приведенный выше анализ НДС массивов горных пород показывает, что одним из возможных сценариев возникновения землетрясения в районе субдукции, аналогичного японскому, является мгновенное разрушение (срезание) неровностей в разломной зоне.

В зависимости от граничных условий и объемов разрушений магнитуда землетрясения может достигать значений $M_{s}=7,0$ и более.

Перемещения точек материковой и океанической плит в районе субдукции в результате мгновенной «разрядки» напряжений при разрушении неровностей на границе разломной зоны может достигать величин 2-7 м, что может послужить причиной мощных цунами.

Таким образом, в настоящей главе изложены результаты исследований по следующим четырем направлениям:

I. Аналитические решения задач по вопросам эволюци геомеханической ситуации в геологической среде природно-технических систем.

II. Определение закономерностей напряженно-деформированного состояния пород в отдельных актуальных участках Кольского полуострова и изменение удельной энергии деформирования при ведении горных работ.

III. Особенности напряженного состояния горных пород в окрестности трещин.

IV. Характер распределения напряжений в окрестности систем с особенностями границы исследуемой области.

По первому направлению можно сделать следующие основные выводы:

Эволюцию удельной энергии деформирования геологической среды в ПТС с математической точки зрения можно представить в виде решения системы двух дифференциальных уравнений первого порядка, в которую входят некоторые функции $\varphi_{1}, \varphi_{2}, \varphi_{3}, \varphi_{4}$, зависящие от времени и характеризующие физические процессы, происходящие в системе. При этом в большинстве случаев приходится иметь дело с уравнением Риккати, которое не имеет основного решения.

Анализ приведенных в этом разделе результатов свидетельствует о том, что даже при одних и тех же функциях, входящих в исходные уравнения системы, эволюция двухпараметрической динамической системы может происходить по любому сценарию не только потому, что функции $\varphi_{1}, \varphi_{2}, \varphi_{3}, \varphi_{4}$ могут быть различными, но и от частного решения уравнения Риккати.

Энергия эволюции геологической среды в ПТС может иметь различные величины подъемов и падений в зависимости от способов ее накопления и диссипации; по величине энергии, высвободившейся в результате сейсмического события, можно определить размеры разрыва (трещины), образовавшейся при этом.

Результаты исследований по второму направлению показали, что сравнительный анализ расчетных и измеренных данных дает удовлетворительное совпадение величин главных напряжений. Направление 
действия максимальных сжимающих напряжений в большей степени зависит от более мелких структур. В Хибинском массиве ориентация главных напряжений зависит от кольцевых геологических структур. В частности, в апатитовой дуге максимальные сжимающие напряжения действуют вкрест простирания рудного тела, а во вмещающих породах, обладающих большими значениями модуля упругости, они действуют вдоль кольцевых геологических структур.

В Хибинском и Ловозерском массивах за счет их блочного строения и различия упругих свойств горных пород концентрация минимальных по величине сжимающих горизонтальных тектонических напряжений $\sigma_{1}$ изменяется от $0,6 T$ до $1,1 T$, а максимальных $\sigma_{2}-$ от $0,8 T$ до $1,8 T$. В районе действующих рудников - $\sigma_{1}=(0,7-1,0) T, \sigma_{2}=(0,9-1,2) T$.

$\mathrm{B}$ нагорных участках гористого рельефа тектонические напряжения по величине меньше, а на участках под долинами, располагаемыми ниже нулевой отметки, больше действующих на бесконечности усилий. Влияние рельефа распространяется на глубину 2-3 максимальных превышений гор над долинами. Абсолютные величины главных напряжений можно определять произведением соответствующих коэффициентов влияния блочности и рельефа на величину действующих на бесконечности усилий. Учет блочного строения массивов горных пород и их рельефа позволяет оценивать величины главных напряжений с достаточной для практических целей точностью.

В 100-метровой зоне вблизи кромки очистного пространства возможны динамические проявления горного давления на всем протяжении отработки блока-целика между Кировским рудником и Саамским карьером. Начиная с 2013 г. отработка блока-целика может быть сопряжена с серьезными осложнениями по фактору горного давления. Об активизации динамических проявлений горного давления в этом районе свидетельствуют результаты натурных определений сейсмического состояния участка массива, представленные в работе [139], где указывается изменение сейсмической энергии от $E=10^{4}$ Дж до $E=10^{8}$ Дж. При этом надо учесть то обстоятельство, что данная задача решена в двухмерной постановке. Очевидно, что на нижележащих горизонтах (откатки и т. п.) ситуация может оказаться еще более угрожающей, так как вблизи сопряжений стенок и почвы очистного пространства концентрация тектонических напряжений будет еще выше.

В условиях влияния радиальных тектонических разломов на напряженное состояние Ловозерского массива разрушения пород в окрестности рудника «Умбозеро» подтверждаются однозначно, а в окрестности рудника «Карнасурт» таких разрушений нет, чем и объясняется более чем 60-летний срок относительно спокойной его эксплуатации, в то время как рудник «Умбозеро» разрушен тектоническим землетрясением.

Существенный вклад в неравномерность распределения напряжений в Ловозерском массиве при действии горизонтальных сжимающих силовых полей оказывает его тектоническое блочное строение.

Разрушение горных пород рудника «Умбозеро» во время тектонического землетрясения 1999 г. связано не только с ведением широкомасштабных горных работ, но и с особым расположением его в системе блочного строения Ловозерского массива.

Неравномерное распределение тектонических напряжений вблизи карьерной выемки в Ковдорском рудном районе приводит к возникновению зон растягивающих деформаций, предельные величины которых приурочены к зонам контактов структурно-геологических секторов вблизи границы карьера. Зоны предельных 
деформаций растяжения подобны зонам концентрации предельных величин упругой энергии деформирования при растяжении.

Вблизи границы карьера, в зоне контактов структурно-геологических секторов, при действии в массиве пород предельных касательных напряжений происходит смещение секторов друг относительно друга, что увеличивает размеры зон неблагоприятных деформаций.

Исследование напряженного состояния пород в окрестности трещин, располагаемых в неоднородных массивах, показывает, что характер разрушений блочных структур может существенно отличаться от такового в однородном массиве.

1. Для углов ориентации границы раздела блоков $\alpha<45^{\circ}$ начнет развиваться трещина отрыва ортогонально границе исходной трещины в ее верхнем (правом) кончике, со стороны менее жесткого блока.

2. При угле ориентации $\alpha=45^{\circ}$ возможно разрушение ортогонально границе исходной трещины в нижнем (левом) кончике в сторону жесткого блока, а в верхнем - в сторону мягкого блока. Какое разрушение произойдет в первую очередь, зависит от прочностных свойств пород, слагающих блоки.

3. Для углов $\alpha>45^{\circ}$ трещина отрыва начнет развиваться ортогонально границе исходной трещины в нижнем кончике в сторону более жесткого блока.

4. При угле ориентации границы раздела блоков $\alpha=90^{\circ}$ разрушение, вероятнее всего, произойдет в центре исходной трещины в сторону более жесткого блока.

5. Начало роста трещин при взрыве происходит в результате действия растягивающих напряжений, возникающих вблизи естественных (или техногенных) трещин и других неоднородностей. Вследствие высоких концентраций этих напряжений в окрестности кончиков трещин и ряда других благоприятных (для развития трещин) условий возможно ветвление магистральных трещин.

Взаимодействие ветвящихся трещин (смыкание ветвей в результате разрушения барьеров между ними) может приводить к дроблению горной породы.

Результаты исследований по четвертому направлению показали, что при сдвижении блоков горных пород по шероховатой поверхности возникают условия для образования трещин отрыва вблизи неровностей, что приводит к возникновению слабого прослойка между ними и дальнейшему более интенсивному разрушению неровностей.

В естественных условиях, когда поверхность сдвижения обладает неровностями с различными геометрическими параметрами, относительные перемещения блоков могут происходить скачкообразно.

При наличии слабого прослойка между шероховатостями поверхности, по которой происходит сдвижение блоков, помимо образования трещин отрыва в материале блоков, возможно появление нарушений сплошности между прослойком и блоками, о чем свидетельствуют большие величины горизонтальных перемещений верхнего блока.

Результаты этих исследований могут иметь практический интерес, например, для оценки возможности обрушения подработанной толщи пород, объяснения форшоковых явлений, предшествующих сильным землетрясениям.

В условиях действия гравитационно-тектонических силовых полей в массивах горных пород с наклонными разломами, выходящими на поверхность, в окрестности верхнего берега в нижней его части, формируется зона растягивающих напряжений, ориентированных параллельно границе разлома. Вблизи неровностей на берегах 
разломов формируются зоны с растягивающими напряжениями одного направления и высокими концентрациями сжимающих напряжений ортогонального направления.

Вертикальные и горизонтальные перемещения берегов разлома друг относительно друга в зависимости от граничных условий и свойств основных пород массива и материала, заполняющего разлом, могут превысить несколько метров.

Наличие зон растягивающих напряжений, формирующихся в концевой области наклонного разлома, является одним из факторов, влияющих на процесс подготовки землетрясения.

Анализ НДС массивов горных пород в окрестности субдукции показывает, что одним из возможных сценариев возникновения землетрясения является мгновенное разрушение (срезание) неровностей в разломной зоне.

В зависимости от граничных условий и объемов разрушений магнитуда землетрясения может достигать значений $M_{s}=7,0$ и более. Перемещения точек материковой и океанической плит в районе субдукции в результате мгновенной «разрядки» напряжений при разрушении неровностей на границе разломной зоны может составлять 2-7 м. 


\section{3. ТРАНСФОРМАЦИЯ НАПРЯЖЕННОГО СОСТОЯНИЯ МАССИВА В РАЙОНЕ КРУПНОМАСШТАБНЫХ ГОРНЫХ РАБОТ}

\section{1. Взаимовлияние открытых и подземных горных работ (на примере Хибинских апатитовых месторождений)}

Обеспечение безопасной и экономически эффективной разработки месторождений полезных ископаемых невозможно без изучения геомеханических процессов при ведении крупномасштабных горных работ в высоконапряженных массивах, для чего разработана объемная конечно-элементная модель Хибинского массива с учетом основных геологических характеристик: вложенной кольцевой структуры массива, радиальных разломов, рельефа дневной поверхности, параметров рудных тел и горно-технических факторов - геометрии очистных пространств (рис. 3.1 a). Путем задания дополнительных граничных условий в виде горизонтальной пригрузки в субширотном направлении симитировано тектоническое поле напряжений, приближенное к реальному (рис. 3.1 б). Значения горизонтальных напряжений соответствуют результатам многолетних натурных измерений как по абсолютным значениям на различных глубинах, так и по их направлению.

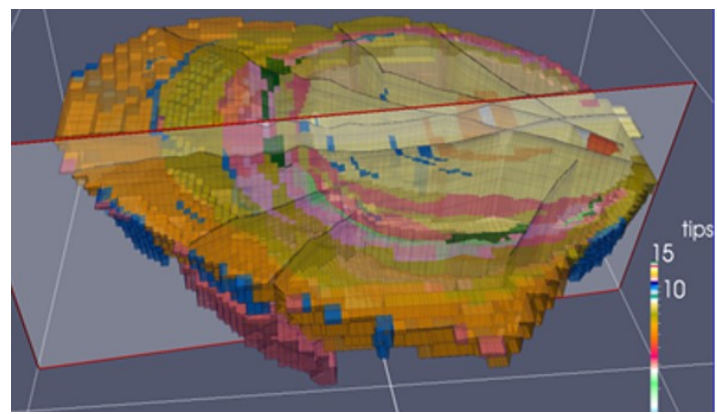

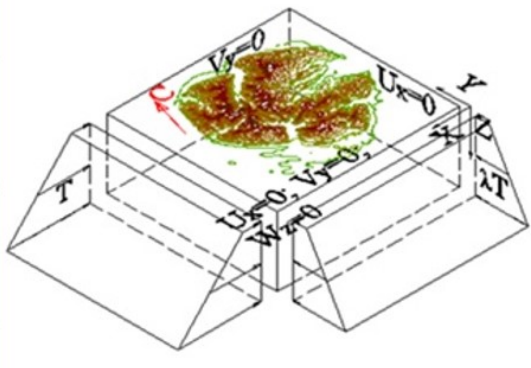

6

Рис. 3.1. Конечно-элементная модель Хибинского массива: $a-$ объемный вид модели; $\sigma$ - схема задания граничных условий

В первую очередь определены параметры поля напряжений для нетронутого массива. Полученные данные сравнивали с полем напряжений без учета тектоники, то есть при учете только собственного веса пород и бокового отпора. Слоистость массива и разломные структуры промоделированы одинаково. На рисунке 3.2 представлено распределение максимальной компоненты главных напряжений $\sigma_{\max }$ в горизонтальном сечении на нулевой отметке, на котором видно, что при учете только собственного веса пород основным фактором, влияющим на распределение напряжений $\sigma_{\max }$, является рельеф дневной поверхности и кольцевая структура массива. В случае же дополнительного учета действующих тектонических сил более значимым становится влияние разломных структур, градиент снижения напряжений в которых увеличивается. 

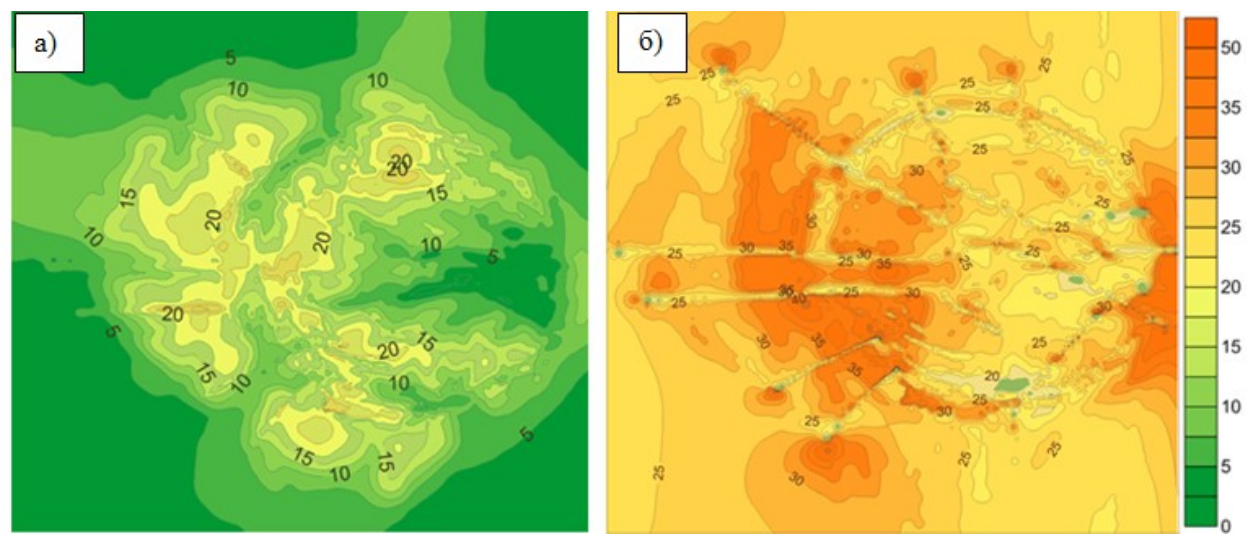

Рис. 3.2. Распределение $\sigma_{\max }$ в горизонтальном сечении на нулевой отметке с учетом: $a$ - собственного веса пород; $\sigma$ - собственного веса пород и тектоники

\subsection{1. Трансформация напряэсенного состояния массива при отработке комплекса сближенных месторождений Хибинской апатитовой дуги}

Основная часть запасов апатитовых руд расположена в южной части Хибинского массива в пределах так называемой Хибинской апатитовой дуги, где разработка проводится как подземным, так и открытым способами. При анализе векторного поля $\sigma_{\max }$ подтверждена гипотеза о переориентировке напряжений в окрестности крупных разломных структур, в том числе разломов Саамского и Гакмана, с чем связаны особенности распределения напряжений на месторождениях Кукисвумчоррское, Юкспорское и «Апатитовый цирк». Направление действия максимальной компоненты напряжений на некоторых участках месторождений - под углом более $45^{\circ}$ и даже вкрест простирания рудного тела при установленном субширотном направлении регионального сжатия (рис. 3.3). При этом наибольшие концентрации сжимающих напряжений приурочены к концам разломных структур и границам разномодульных сред. В самих разломах максимальные напряжения ориентированы перпендикулярно их простиранию и остаются субгоризонтальными даже на больших глубинах.

На следующем этапе модельных исследований имитировали последовательную выемку рудных залежей апатит-нефелиновой дуги. На рисунках 3.4 и 3.5 показано распределение максимальной и минимальной компонент напряжений вблизи дневной поверхности до ведения горных работ, при выемке запасов до абсолютной нулевой отметки и после выемки всех разведанных запасов Хибинской апатитовой дуги. Следует отметить значительное снижение сжимающих напряжений $\sigma_{\max }$ при появлении зон растягивающих напряжений $\sigma_{\min }$ и увеличении площади таких зон, а также росте абсолютных величин растяжений со стороны висячего бока рудной залежи. Так, при полной выемке всех запасов и имитации обрушения подработанных пород размер зоны растяжений в плане достигает размеров самой выемки вкрест простирания (рис. 3.4 в, 3.5 в) с увеличением абсолютных величин напряжений до критических, сопоставимых с пределом прочности пород на растяжение, то есть в породах висячего бока будет происходить активное трещинообразование, что приведет в дальнейшем, в результате процессов разрушения и выветривания, к значительному выполаживанию гористого рельефа в районе апатитовой дуги. 
Анализ полученных данных подтвердил гипотезу о трансформации типа НДС с глубиной. Рассмотрим вертикальное сечение вкрест простирания Кукисвумчоррского месторождения (рис. 3.6, 3.7). Поскольку направление действующих максимальных напряжений на этом участке практически совпадает с направлением сечения, то можно считать показанные на рисунке векторы векторами $\sigma_{\max }$. Как видно, превалирование вертикальных напряжений над горизонтальными начинается с абсолютных отметок $-1000 \div-1200$ м. Так как по данным геологической разведки рудные тела Хибинской апатитовой дуги выклиниваются до абсолютной высотной отметки -500 м, то можно предполагать, что все разведанные на сегодняшний день запасы будут отрабатываться в условиях гравитационно-тектонического поля напряжений с превалированием горизонтальных напряжений над вертикальными. Следует также отметить, что по мере выемки запасов апатитовой руды векторы $\sigma_{\max }$ на больших глубинах выполаживаются, то есть поле напряжений носит еще более выраженный тектонический характер. По прогнозным данным фоновый уровень максимальных сжимающих напряжений на рабочих горизонтах после выемки запасов до нулевой отметки превысит 60 МПа, тогда как в настоящее время фоновые значения бтах не превышают 50 МПа. При таком уровне напряжений подавляющее большинство выработок будет иметь высокую категорию удароопасности, что потребует дополнительных затрат на крепление и будет влиять на удорожание стоимости добычи руды.
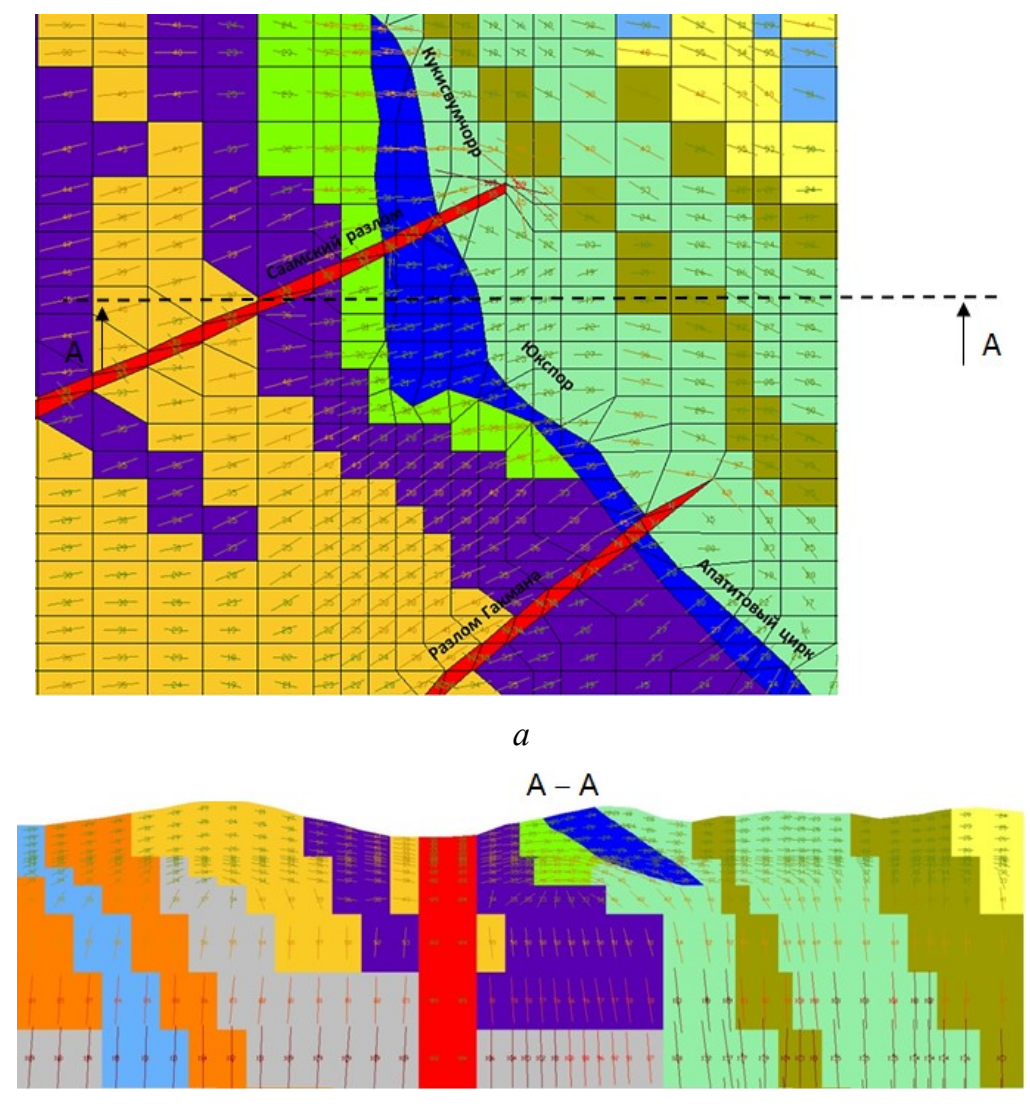

6

Рис. 3.3. Распределение векторов $\sigma_{\max }$ в окрестности апатитовых месторождений: $a$ - в плане; $\sigma$ - в вертикальном сечении по Юкспорскому месторождению 


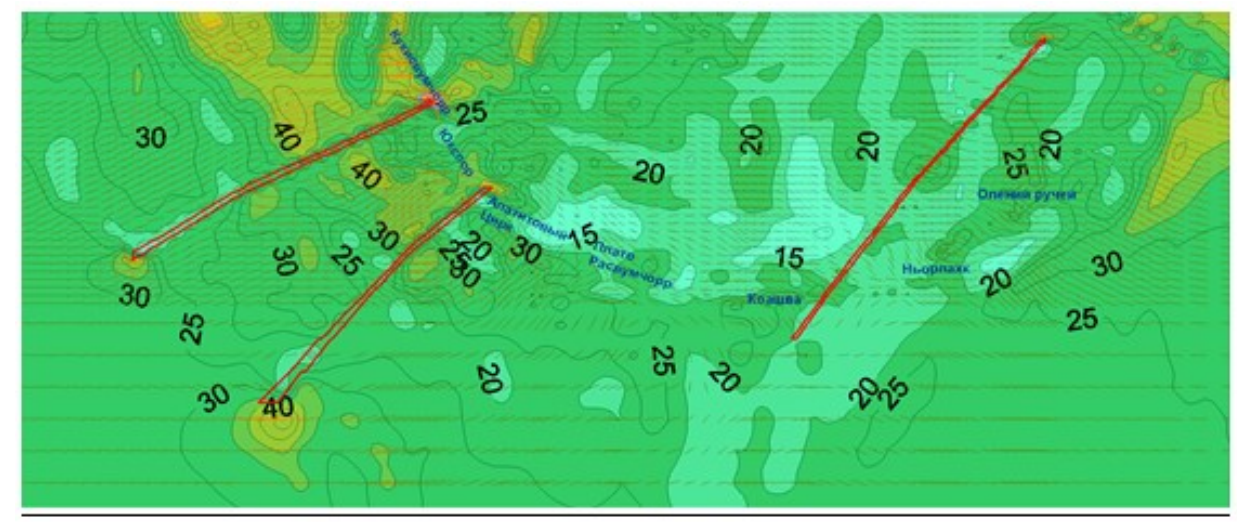

$a$

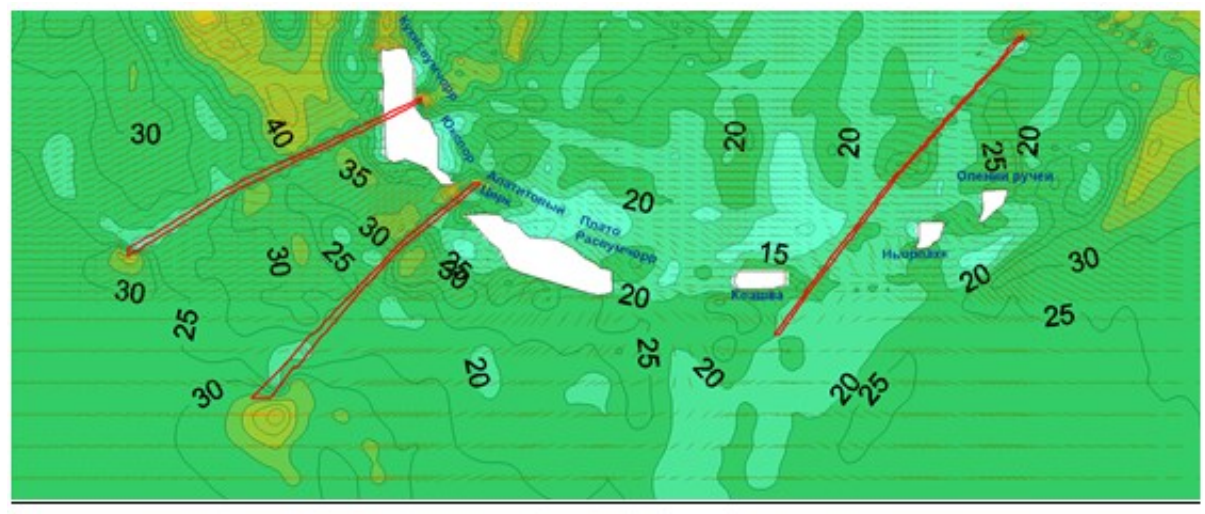

6

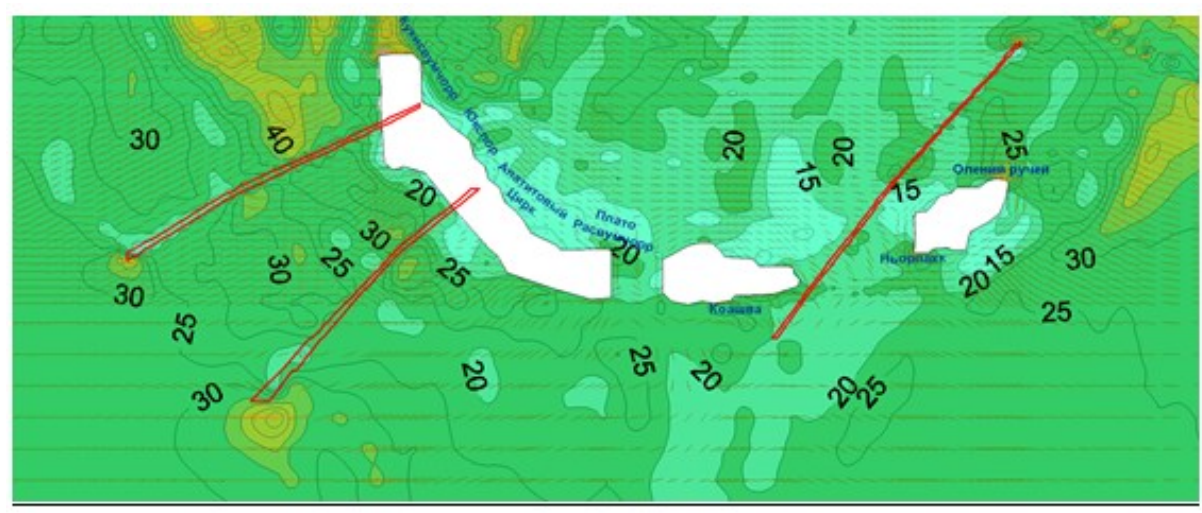

B

Рис. 3.4. Распределение $\sigma_{\max }$ в окрестности сближенных месторождений Хибинской апатитовой дуги в горизонтальном сечении на глубине около 50 м от дневной поверхности: $a-$ нетронутый массив; $\sigma$ - выемка запасов до нулевой отметки; в - полная выемка разведанных запасов 

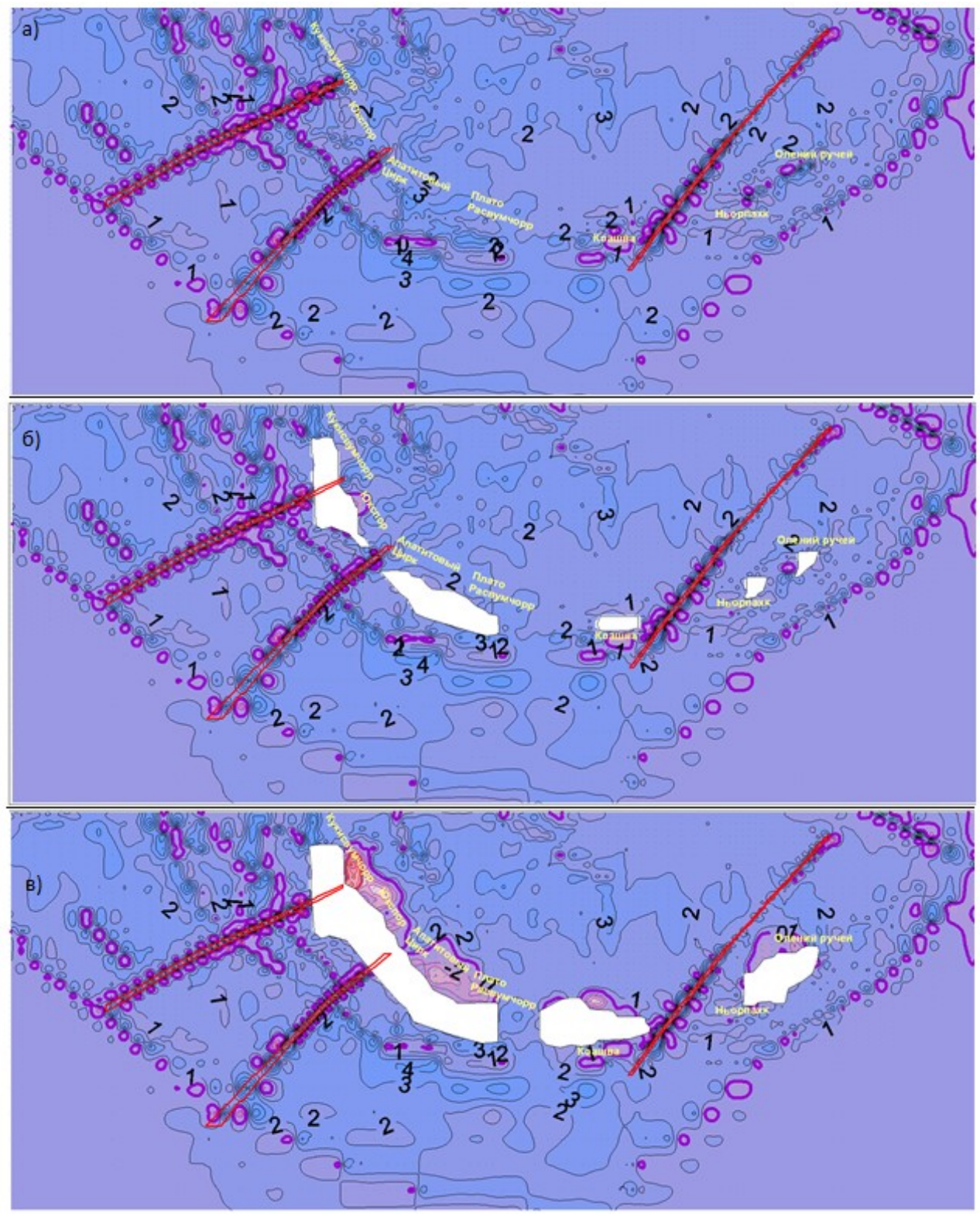

Рис. 3.5. Распределение $\sigma_{\min }$ в окрестности сближенных месторождений Хибинской апатитовой дуги в горизонтальном сечении на глубине около 50 м от дневной поверхности: $a-$ нетронутый массив; $\sigma$ - выемка запасов до нулевой отметки; в - полная выемка разведанных запасов

Участки массива между сближающимися крупномасштабными горными работами, по сути, являются блоками-целиками с повышенной концентрацией сжимающих напряжений. С другой стороны, на таких участках наблюдаются зоны растягивающих напряжений по минимальной компоненте. Такое сочетание одновременного действия сжимающих и растягивающих напряжений является фактором, негативно влияющим на устойчивость массива в целом и отдельных выработок, в частности. 


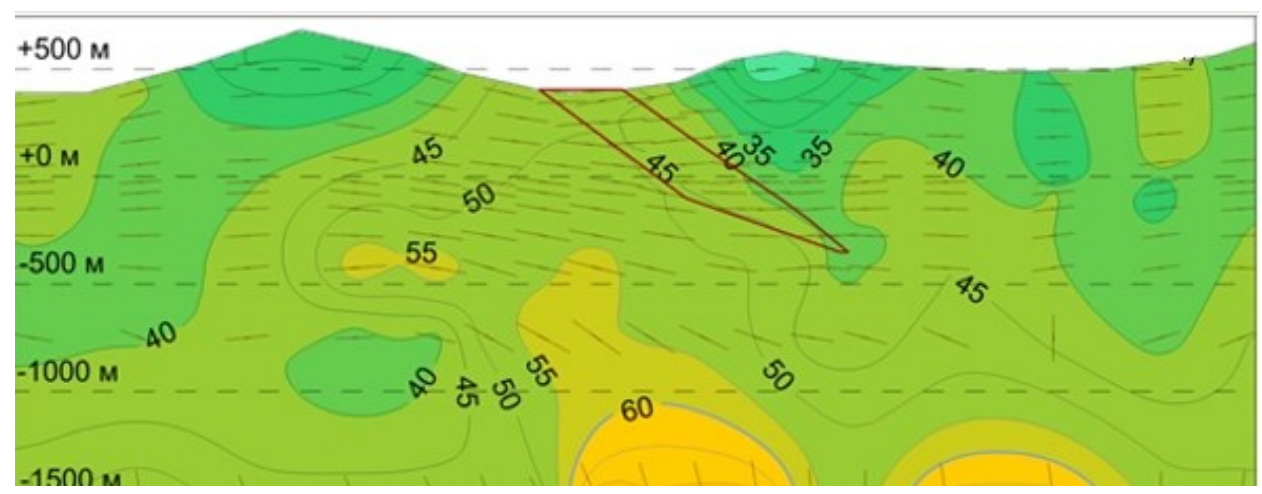

$a$

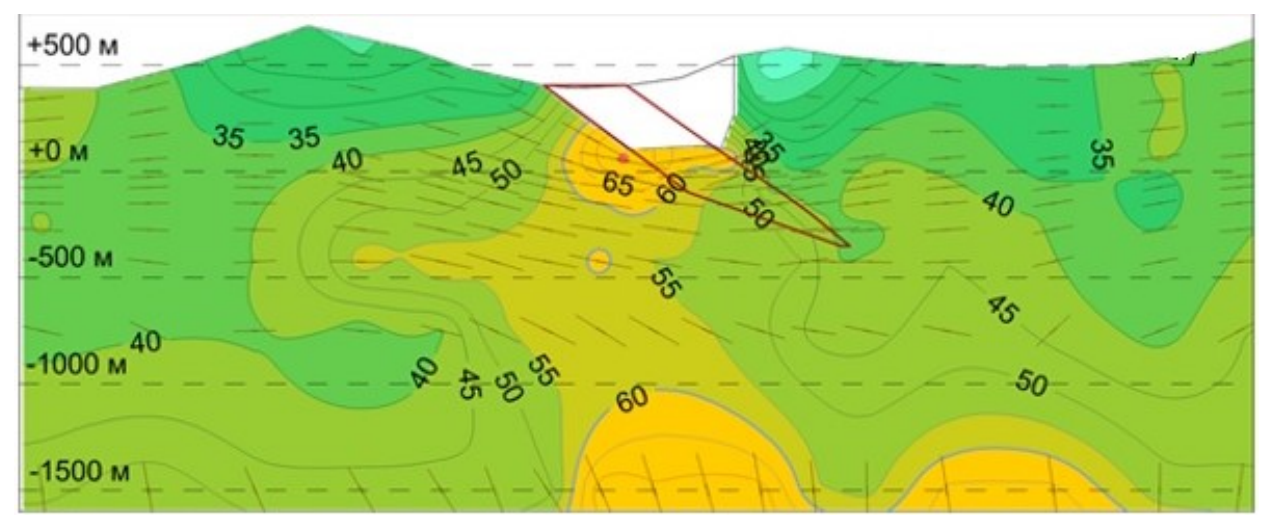

$\sigma$

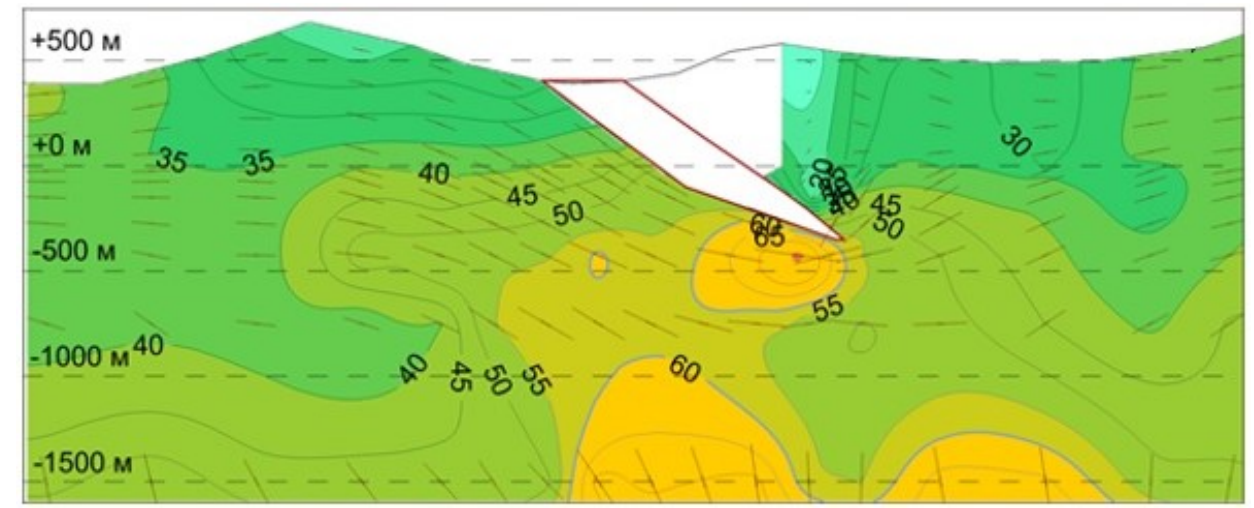

6

Рис. 3.6. Распределение $\sigma_{\max }$ в окрестности Кукисвумчоррского месторождения в вертикальном сечении: $a-$ нетронутый массив; $\sigma-$ выемка запасов до нулевой отметки; 8 - полная выемка разведанных запасов 


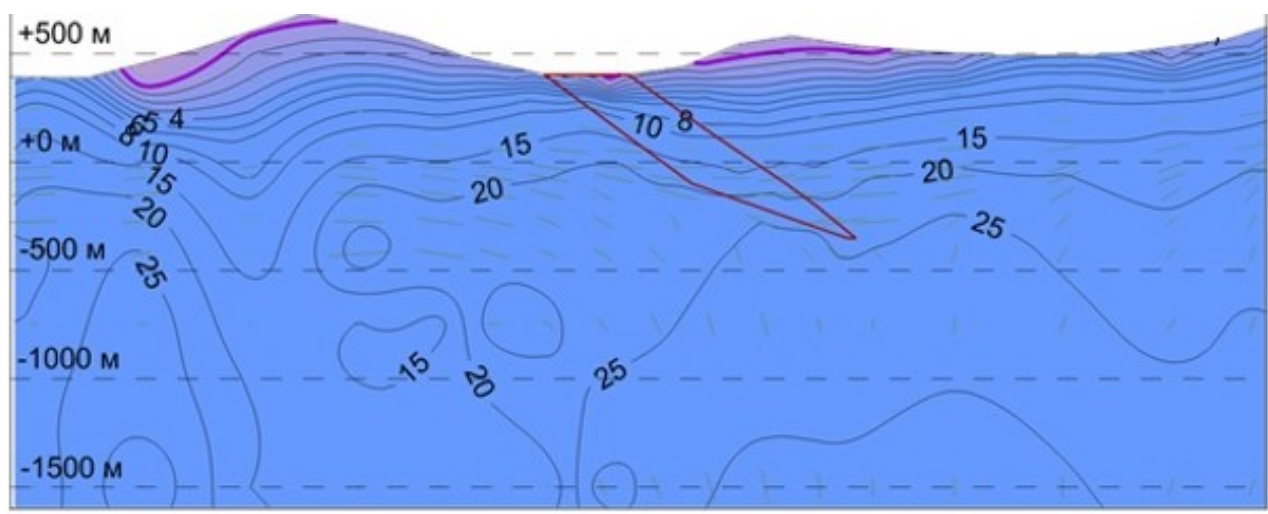

a

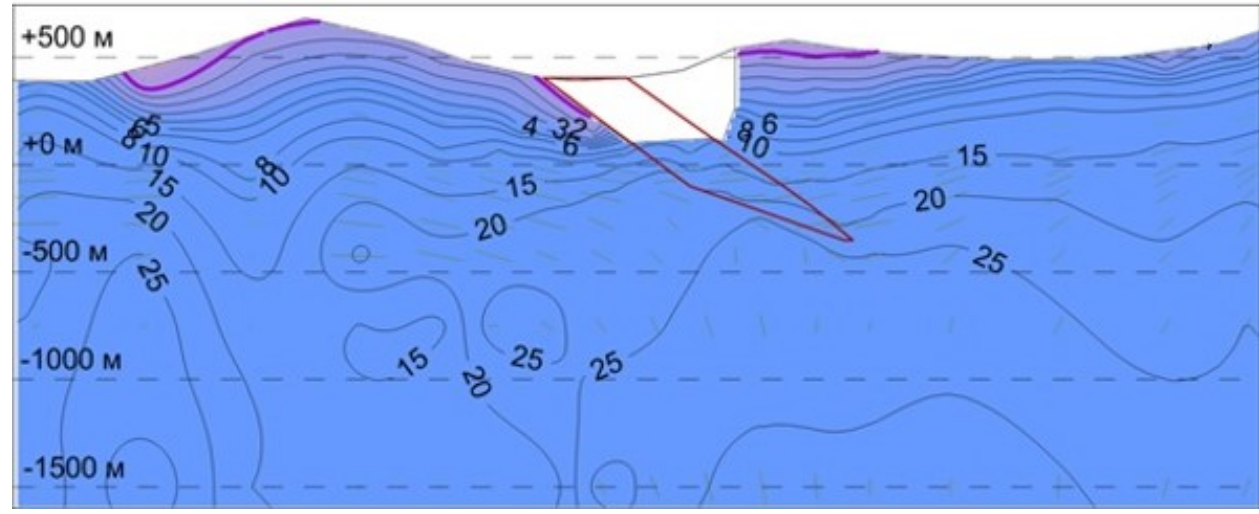

$\sigma$

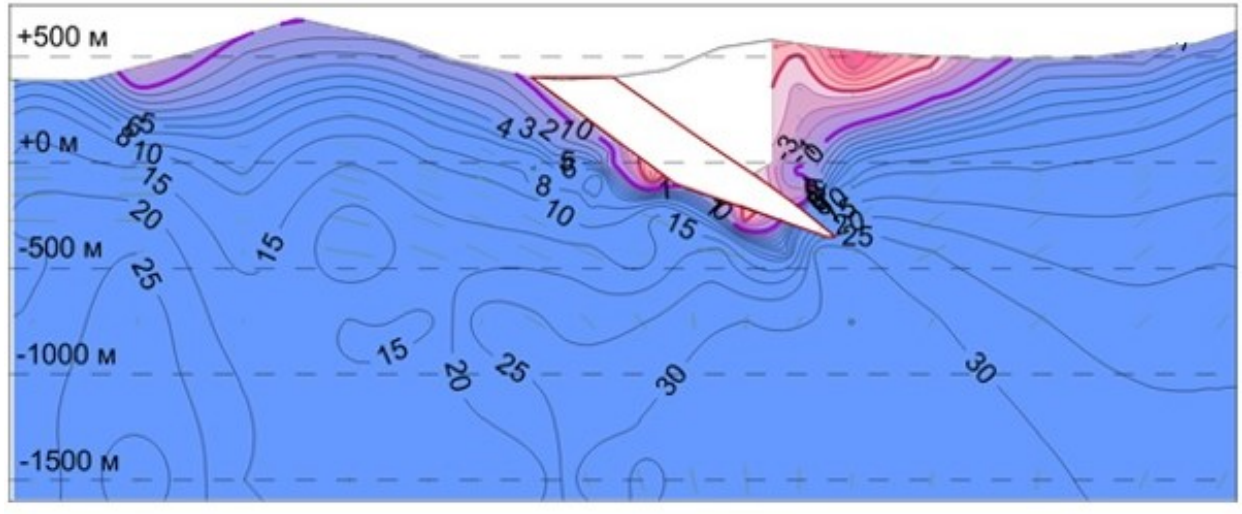

6

Рис. 3.7. Распределение $\sigma_{\min }$ в окрестности Кукисвумчоррского месторождения в вертикальном сечении: $a-$ нетронутый массив; $\sigma$ - выемка запасов до нулевой отметки; в - полная выемка разведанных запасов 
Таким образом, геомеханическая модель Хибинского массива позволяет рассматривать отработку комплекса сближенных месторождений и определять оптимальный порядок, а также направление развития горных работ в удароопасных условиях с учетом вложенных кольцевых структур массива, направления тектонического сжатия, основных радиальных разломов, рельефа дневной поверхности, параметров рудных тел. Установлены особенности НДС Хибинского массива, заключающиеся в следующем:

- подтверждена гипотеза трансформации типа НДС с глубиной, определены абсолютные высотные отметки $-1000 \div-1200$ м, ниже которых горизонтальные напряжения превалируют над вертикальными, из чего следует, что все разведанные запасы Хибинской апатитовой дуги будут отрабатываться в условиях выраженного тектонического сжатия пород;

- установлена переориентация главных напряжений в блоках массива между радиальными разломами;

- полная выемка разведанных запасов обусловливает снижение сжимающих напряжений $\sigma_{\max }$ при появлении зон растягивающих напряжений $\sigma_{\min }$ с увеличением их площади в приповерхностной части массива в висячем боку рудной залежи; здесь возможно активное трещинообразование, что приведет в дальнейшем к значительному выполаживанию гористого рельефа в районе Хибинской апатитовой дуги.

Настоящие результаты могут быть полезными при принятии решений по отработке других сближенных месторождений.

\subsection{2. Прогнозная оценка коэволюции напряэсенно-деформированного состояния восточной части апатитовой дуги при разработке месторождений «Олений ручей» и Ньоркпахкское}

Для оценки НДС восточной части Хибинской апатитовой дуги при отработке запасов месторождений двумя близкорасположенными карьерами и подземным рудником разработана трехмерная конечно-элементная модель [140].

С учетом основных горно-геологических факторов получены данные об исходном НДС юго-восточной части апатитовой дуги. Значения максимальной компоненты главных напряжений $\sigma_{\max }$ во вмещающем массиве изменяются от 20-35 МПа у поверхности, достигая с увеличением глубины на отметке -1000 м 50-55 МПа. Векторы $\sigma_{\max }$ ориентированы субгоризонтально и в направлении, близком простиранию рудной залежи. Области повышенных значений напряжений приурочены к долинам.

Для оценки взаимного влияния открытых и подземных горных работ на месторождениях «Олений ручей» и Ньоркпахкское проведено многовариантное моделирование НДС. Выполнено сравнение результатов для следующих вариантов:

- положение Ньоркпахкского карьера на 2007 г. до начала работ на месторождении «Олений ручей»;

- фактическое положение карьерных выемок;

- варианты с развитием подземных горных работ на месторождении «Олений ручей».

Степень влияния горных работ на состояние массива определяли по относительному изменению максимальной компоненты главных напряжений: 


$$
k=\frac{\left|\sigma_{\max }^{0}-\sigma_{\max }^{k}\right|}{\sigma_{\max }^{0}}=100 \%,
$$

где $\sigma_{\max }^{0}-$ значения напряжений для ненарушенного горными работами массива; $\sigma_{\max }^{k}-$ состояние массива после отработки той или иной части запасов полезного ископаемого. Критерием значимого влияния горных работ считали более чем $5 \%$ изменение величин напряжений.

Сравнение исходного напряженного состояния с фактическим показало, что зоны, в которых $\sigma_{\max }$ изменяется больше чем на $5 \%$, приурочены к двум участкам массива (рис. 3.8 ):

- участок в окрестности дна и бортов карьеров;

- нагорный участок, находящийся между месторождениями Ньоркпахкое и «Олений ручей».

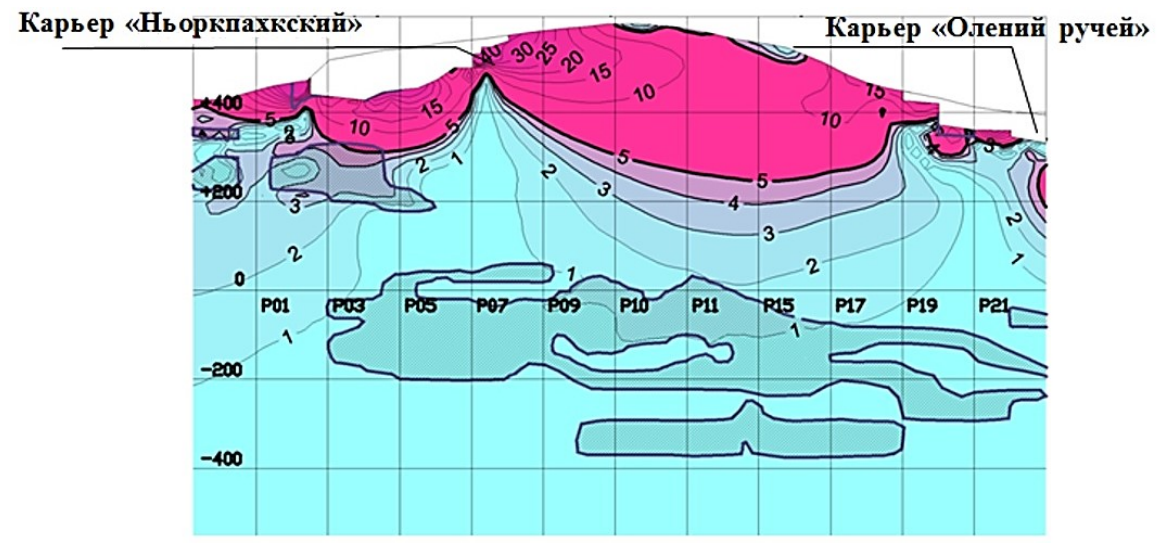

Рис. 3.8. Относительное изменение максимальной компоненты главных напряжений (в \%) в сечении по магистрали $\mathrm{M}+400$

При этом влияние открытых горных работ в области между карьерами распространяется примерно до абсолютной отметки +250 м. Нижний ярус рудных тел месторождения «Олений ручей» находится вне зоны влияния открытых горных работ. Нижний ярус рудных тел Суолуайвского участка Ньоркпахкского месторождения частично попадает в зону влияния карьера, особенно западная его часть.

Для оценки влияния подземных горных работ на НДС массива рассчитаны варианты, моделирующие отработку запасов рудных тел нижнего яруса в разрезах 10-25 до отметки -200 м. Отработку запасов моделировали как поэтапное развитие подземных горных работ от места разрезки (разрез 12) с шагом, равным одному разрезу с учетом геометрии карьерных выемок.

На рисунке 3.9 приведено значение параметра $k(\%)$ в вертикальном сечении по простиранию рудных тел на различных этапах отработки запасов: развитие фронта подземных горных работ в сторону Ньоккпахкского карьера (левая часть рисунка) до разрезов 9 и 8 соответственно и в сторону карьера «Олений ручей» (правая часть рисунка) до разрезов 22 до 25 соответственно. 


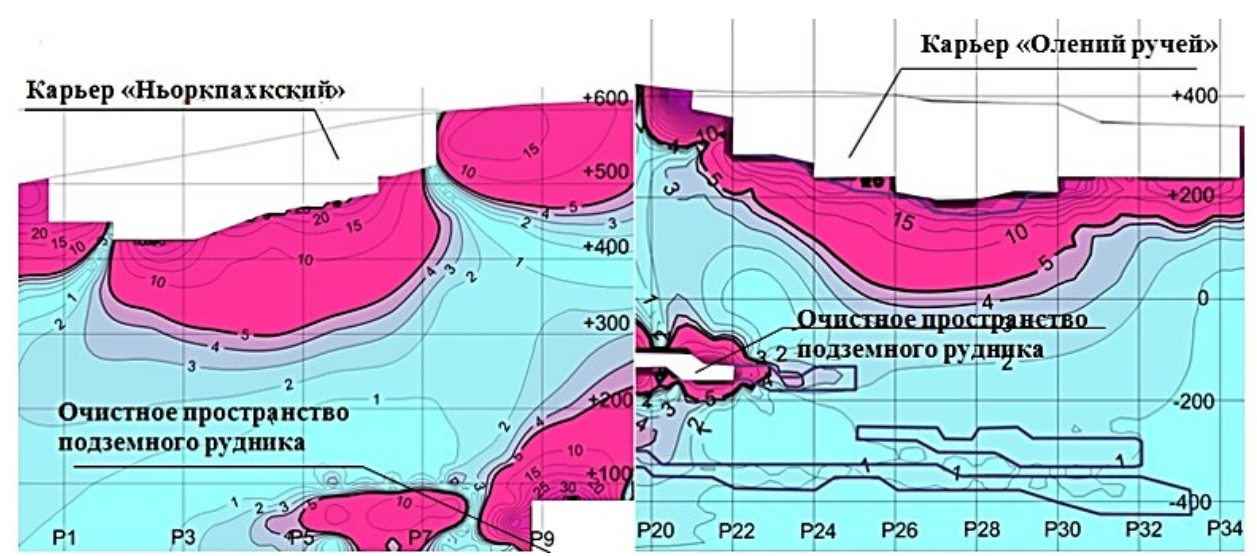

$a$

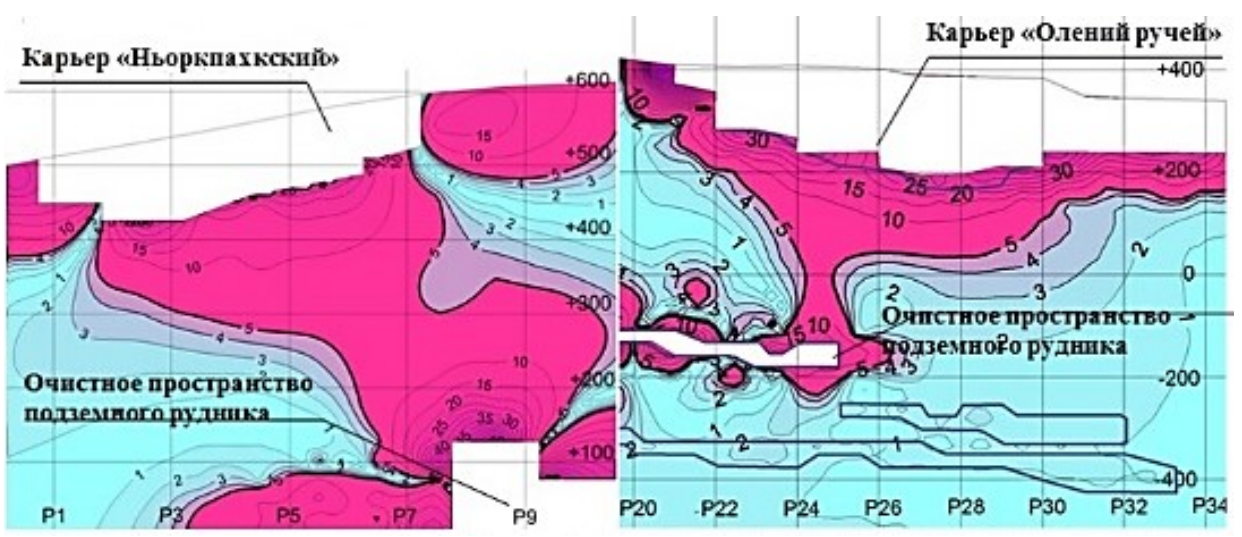

6

Рис. 3.9. Относительное изменение максимальной компоненты главных напряжений (в \%) в вертикальном сечении по простиранию рудных тел при развитии подземных горных работ

Зоны, в которых напряжения изменились больше чем на $5 \%$, располагаются в массиве, прилегающем к очистным пространствам карьера и подземного рудника. При развитии подземных горных работ с увеличением размеров очистного пространства увеличивается также и зона $5 \%$-го изменения максимальной компоненты главных напряжений. При достижении очистным пространством подземного рудника (разрезов 8 и 25 соответственно) отмечается слияние зон влияния на НДС массива открытых и подземных горных работ.

Таким образом, в результате исследования коэволюции напряженного состояния массива восточной части апатитовой дуги определены границы взаимного влияния подземных и открытых очистных выемок и установлено, что оно начинается при достижении фронтом подземных горных работ подкарьерного массива. Такой вывод дает основание для пересмотра границ охранных целиков в сторону их уменьшения, что обеспечит прирост отрабатываемых подземным способом запасов и повысит эффективность подземных горных работ. 
Для более детальной оценки влияния подземных горных работ на НДС массива пород Ньоркпахкского месторождения разработана модель Суолуайвского участка месторождения, который располагается в юго-восточном борту Ньоркпахкского карьера и включает в себя 8 пологопадающих рудных тел линзовидной формы, мощность которых изменяется от 8 до 50 м (средняя мощность 20 м). Запасы руды в основном представлены пологими рудными телами с углом падения $\alpha$ до $25^{\circ}$ и наклонными рудными телами $\alpha=25 \div 45^{\circ}$.

Граничные условия заданы в виде узловых перемещений и рассчитаны путем интерполяции из данных предыдущего этапа моделирования. То есть, опосредованно учтены результаты натурных измерений напряжений на месторождениях Ньоркпахкское и «Олений ручей». Таким образом, сформирована объемная геомеханическая модель Суолуайвского участка Ньоркпахкского месторождения, учитывающая контуры рудных тел, упругие свойства массива, рельеф дневной поверхности, различные положения Ньоркпахкского карьера, а также НДС массива при фактическом состоянии открытых и подземных горных работ. На рисунке 3.10 показан план модели с проекцией рудных тел Суолуайвского участка, границей проектного контура Ньоркпахкского карьера, линиями рудничной сетки координат, контуром прибортового целика на отметке +200 м, а также сечениями модели.

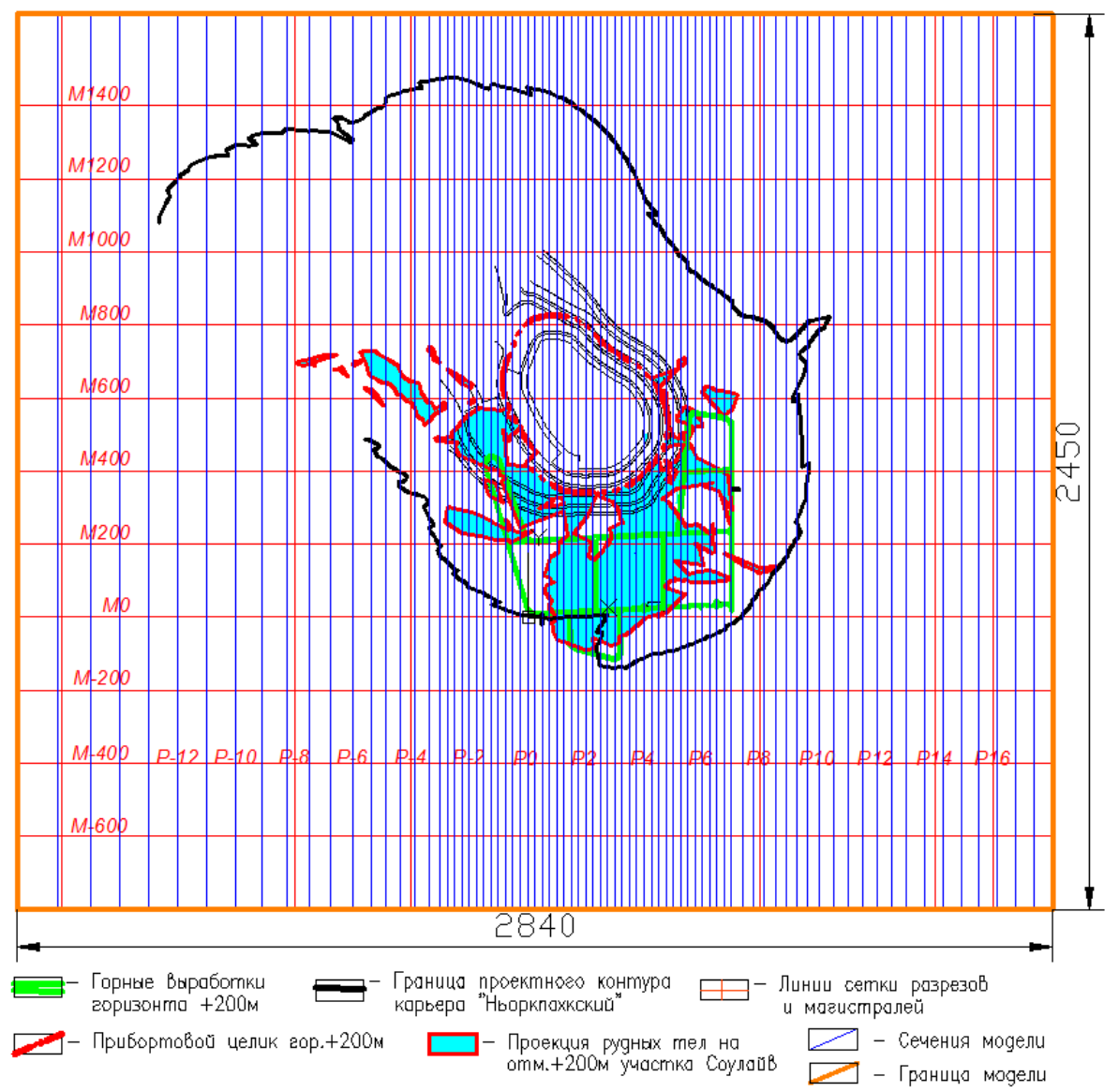

Рис. 3.10. План модели Суолуайвского участка 
С использованием конечно-элементной модели просчитаны варианты развития открытых и подземных горных работ на Ньоркпахкском месторождении. Открытые горные работы моделировали в соответствии с проектными проработками ООО «Горно-химический инжиниринг», подземные горные работы - в соответствии с предложениями ГоИ КНЦ РАН, суть которых сводится к возможности выемки подкарьерных запасов Суолуайвского участка со стороны подземного рудника «Олений ручей». Определяли влияние горных работ на напряженное состояние массива в границах охранного целика. Расчеты проводили в несколько этапов.

В первую очередь рассчитано НДС при фактическом положении Ньоркпахкского карьера $(2014$ г.). В результате установлено, что зона концентрации максимальной компоненты главных напряжений приурочена к нижней части карьерной выемки и максимальна по площади и величине в разрезах $0 \div 1$ (рис. 3.11), где глубина восточной части карьерной выемки наибольшая. Величины $\sigma_{\max }$ достигают 50 МПа во вмещающих породах при среднем уровне на глубине будущей подземной отработки $35 \div 40$ МПа. В рудных телах значения $\sigma_{\max }$ несколько ниже и колеблются в пределах $30 \div 35$ МПа. Также следует отметить субгоризонтальное направление действия $\sigma_{\max }$, с некоторой переориентировкой векторов в окрестности уступов карьера. Растягивающие напряжения в пределах охранного целика практически отсутствуют, что говорит о низкой вероятности образования трещин отрыва в массиве.

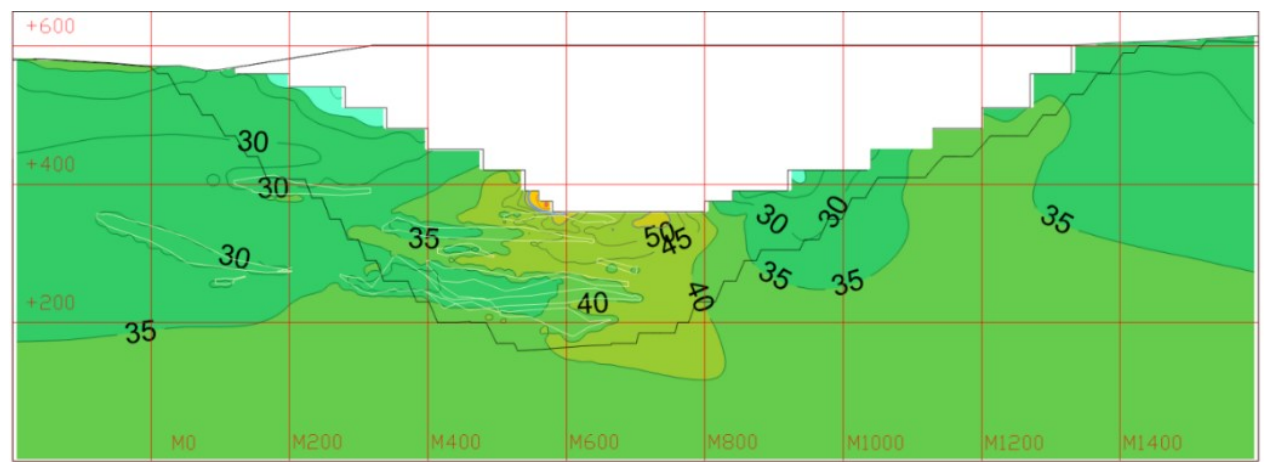

Рис. 3.11. Распределение $\sigma_{\max }$ в вертикальном сечении по разрезу 1 при фактическом положении Ньоркпахкского карьера в районе Суолуайвского участка

Далее анализировали перераспределение напряжений при имитации отработки подземных запасов месторождения Суолуайв в отметках $220 \div 320$ м за бортом проектного карьера с оставлением 50-метрового целика (рис. 3.12). При этом НДС в окрестности уступов карьера меняется незначительно. Увеличение максимальной компоненты сжимающих напряжений не превышает $5 \%$, минимальная компонента в массиве охранного целика также практически неизменна.

Одной из важнейших задач при геомеханическом обосновании комбинированной отработки недр является определение безопасных параметров предохранительного целика между открытыми и подземными горными работами. Для решения этой задачи сравнивали напряженное состояние в окрестности проектной карьерной выемки без подземных очистных пространств с имитацией подземной выемки запасов до отметки +200 м при различных размерах прибортового целика. 


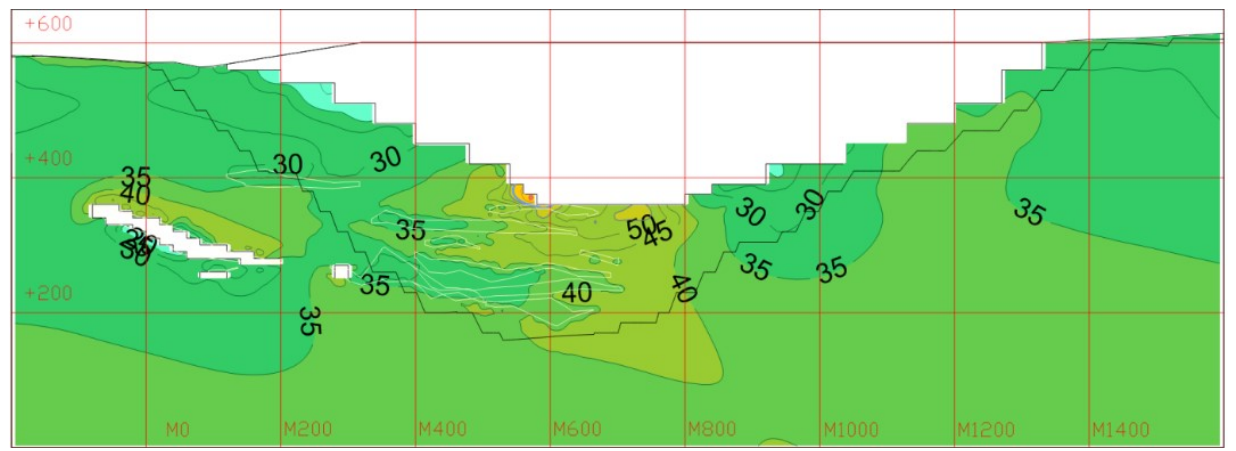

Рис. 3.12. Распределение $\sigma_{\max }$ в вертикальном сечении по разрезу 1 при фактическом положении Ньоркпахкского карьера и имитации выемки запасов в отметках $+220 \div+320$ м, не попадающих в границы проектного карьера с оставлением 50-метрового целика

На рисунке 3.13 показано распределение минимальной компоненты главных напряжений в окрестности проектируемых горных работ при размере целика 50 м по разрезу 3, в котором влияние подземной выемки на борт карьера максимально. Как видно, изменения $\sigma_{\min }$ в приповерхностной зоне незначительны, увеличение локальной зоны растяжений у дневной поверхности не наблюдается. Наибольшее влияние на массив отмечено в окрестности подземной выемки, где формируются зоны растягивающих напряжений в кровле создаваемых подземных обнажений и в межрудных целиках, при этом абсолютные величины растягивающих напряжений близки к нулю, а направление вероятных трещин отрыва субгоризонтальное, что снижает вероятность их прорастания к борту карьера.

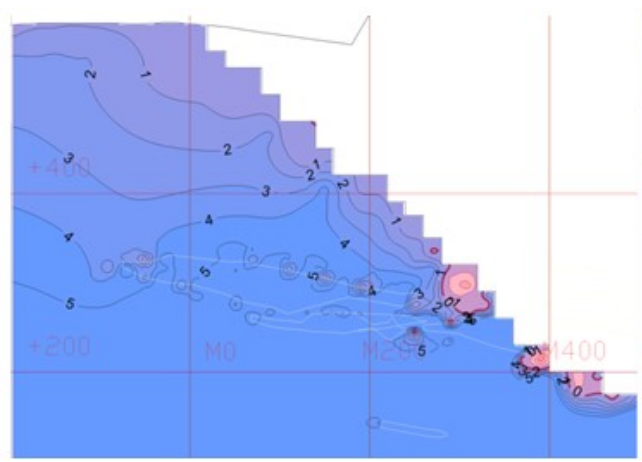

$a$

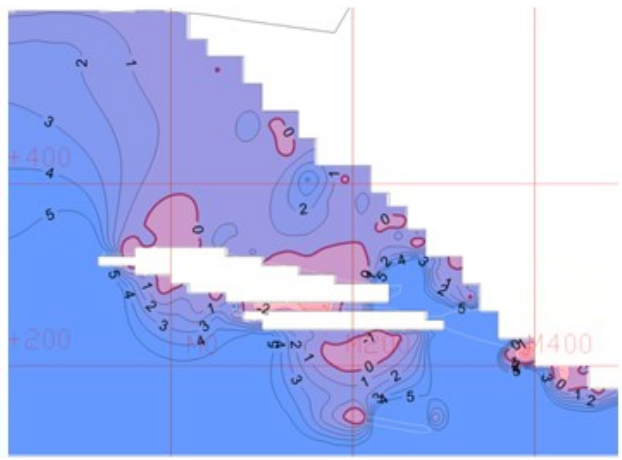

$\sigma$

Рис. 3.13. Распределение $\sigma_{\min }$ в окрестности борта карьера по разрезу 3: $a$ - при проектном положении карьерной выемки и отсутствии подземных горных работ; $\sigma$ - при подработке борта с оставлением целика 50 м

При действии в массиве пород умеренных сжимающих напряжений развитие трещин отрыва и разрушение массива маловероятно. Что касается состояния участка борта вблизи подземных горных работ, то в массиве уступов в диапазоне $260 \div 430$ м происходит незначительное некритичное для устойчивости уступов и участка борта в целом уменьшение $\sigma_{\min }$. На более низких отметках распределение $\sigma_{\min }$ в прибортовом массиве практически не меняется. 
При моделировании комбинированных горных работ с уменьшением целика между открытыми и подземными горными работами результаты расчета НДС показали превышение критических величин как по уровню сжимающих, так и по уровню растягивающих напряжений. Поэтому минимально возможное расстояние между подземными очистными работами и бортом карьера до завершения открытых горных работ принято равным 50 м.

Таким образом, в результате проведенных исследований установлено, что взаимное влияние открытых и подземных работ при отработке запасов месторождений «Олений ручей» и «ьоркпахкское начинается при достижении фронтом подземных горных работ подкарьерного массива. Такой вывод дает основание для пересмотра границ охранных целиков в сторону их уменьшения, что обеспечит прирост отрабатываемых подземным способом запасов и увеличит эффективность подземных горных работ. Определен минимальный размер целика между подземными очистными выемками и восточной частью Ньоркпахкского карьера, равный 50 м.

\section{2. Воздействие подземной отработки подкарьерных запасов на устойчивость борта карьера в конечном положении (на примере Ковдорского местрождения)}

\subsection{1. Разработка геомеханических моделей Больчого Ковдора с учетом прочностных и упругих характеристик массива, его геолого-структурных особенностей и прогнозируемых параметров действующего поля напряжений}

При проектировании совместной отработки Ковдорских месторождений бадделеит-апатит-магнетитовых, апатит-штаффелитовых и апатит-карбонатных руд необходимо геомеханическое обоснование параметров открытых и подземных выемок и их конструктивных элементов, для чего следует определить закономерности перераспределения напряжений в массиве пород в окрестности этих выемок. Одним из методов, позволяющим учесть влияние основных геологических и горнотехнических факторов на распределение напряжений в массиве пород, является трехмерное численное моделирование НДС.

Расчеты НДС выполняли с использованием программного комплекса SigmaGT, разработанного в ГоИ КНЦ РАН.

Достоверные результаты расчетного поля напряжений получены методикой последовательных приближений, в соответствии с которой в первую очередь осуществляют постановку и решение трехмерных мелкомасштабных задач, отражающих основные геологические и горно-технологические особенности моделируемого массива, а затем проводят крупномасштабное моделирование путем «вырезания» локальных областей из мелкомасштабной модели и задания граничных условий в виде узловых перемещений. Подобная вложенность моделей позволяет осуществлять ретроспективные, текущие и, что особенно важно, перспективные прогнозы изменения НДС в сложных ПТС.

На основе анализа геологической и геомеханической информации разработаны две численные модели для расчета НДС массива горных пород на разных масштабных уровнях. 
Геомеханическая мелкомасштабная модель бадделеит-апатит-магнетитовых, апатит-штаффелитовых и апатит-карбонатных руд включает в себя рельеф местности, объекты геологической среды (рудные тела, тектонические нарушения, ослабленные зоны), поле тектонических напряжений, фактические и проектные карьерные и подземные очистные пространства.

Границы расчетной области должны быть удалены от развивающихся горных работ на расстояние, устанавливаемое в соответствии с принципом Сен-Венана. Для определения местоположения границ в плане найдены размеры зоны планируемого ведения горных работ. В результате размер модели составил $10300 \times 8500 \times 3300 \mathrm{~m}^{3}$ (рис. 3.14). Общее количество узлов модели -209952 , количество элементов - 198 800. Типовое вертикальное сечение приведено на рисунке 3.15 Общий вид трехмерной модели представлен на рисунке 3.16.

Алгоритмы конечно-элементого моделирования дают возможность расчета НДС в рамках упругой, упругопластической, пластической и вязкой постановки задачи. Для обоснования физической модели среды выполнен анализ имеющихся данных о прочностных и упругих характеристиках руд и пород, слагающих Ковдорский массив. На основании анализа как абсолютных значений показателей, так и их изменений при нагрузке для большинства пород можно сделать вывод об упругом их деформировании вплоть до разрушения. На основании этого в качестве модели среды принята упругая модель. После необходимой формализации при моделировании приняты величины упругих и плотностных параметров, приведенные в таблице 3.1

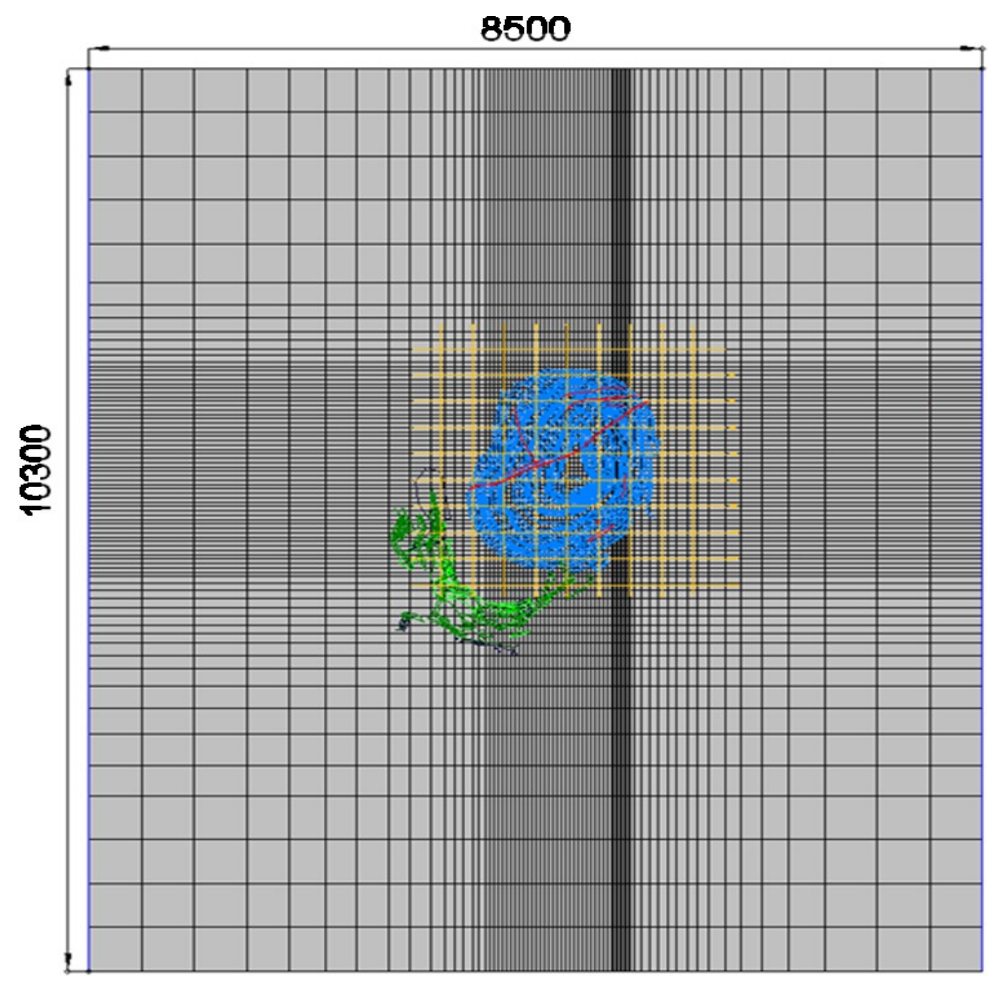

Рис. 3.14. Параметры региональной модели в плане 


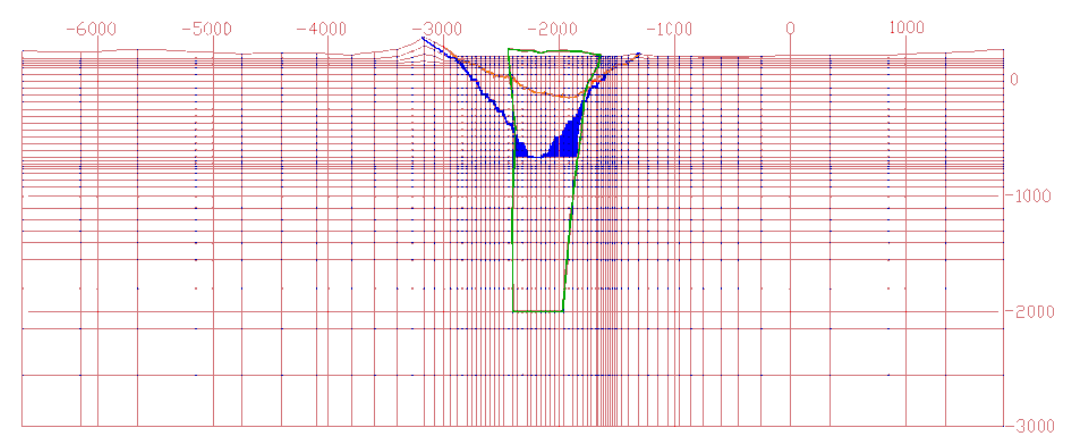

Рис. 3.15. Типовое вертикальное сечение региональной модели

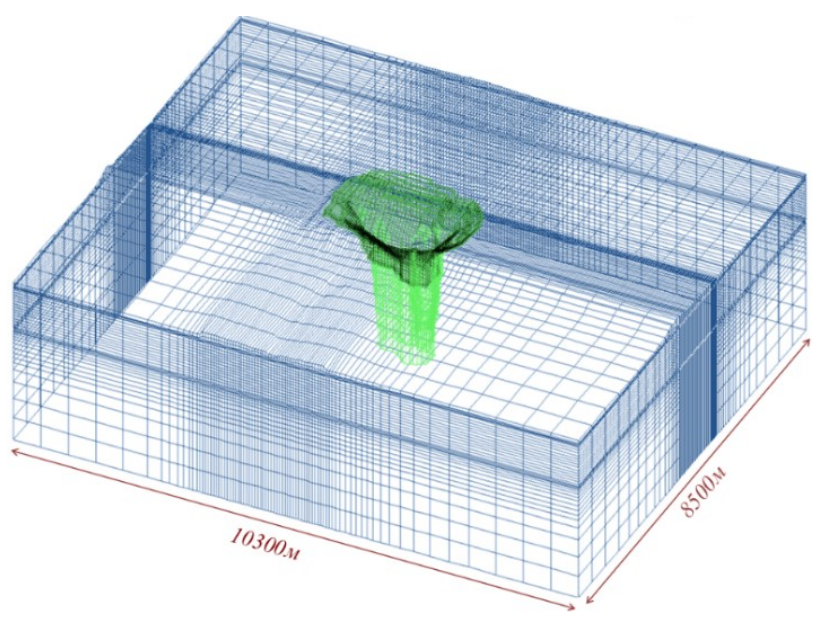

Рис. 3.16. Общий вид трехмерной модели Большого Ковдора

Физические свойства основных типов пород, принятые в геомеханической модели Ковдорского массива

\begin{tabular}{|l|c|c|c|c|c|}
\hline \multicolumn{1}{|c|}{ Название пород } & $\begin{array}{c}\text { Модуль } \\
\text { упругости } E, \\
\text { МПа }\end{array}$ & $\begin{array}{c}\text { Коэффициент } \\
\text { Пуассона } v\end{array}$ & $\begin{array}{c}\text { Объемный } \\
\text { вес } \gamma, \\
\Gamma / \mathrm{cm}^{3}\end{array}$ & $\begin{array}{c}\sigma_{\text {сж, }} \\
\text { МПа }\end{array}$ & $\begin{array}{c}\sigma_{\mathrm{p}}, \\
\text { МПа }\end{array}$ \\
\hline Вмещающие породы & $1 \cdot 10^{5}$ & 0,2 & 3,0 & 280 & 16 \\
\hline Рудное тело & $0,5 \cdot 10^{5}$ & 0,35 & 3,5 & 91 & 10 \\
\hline Ослабленная зона & $0,1 \cdot 10^{5}$ & 0,4 & 3,0 & 80 & 5 \\
\hline Разломные структуры 1-2 ранга & $0,1 \cdot 10^{5}$ & 0,4 & 3,0 & 80 & 5 \\
\hline
\end{tabular}

Решение задач теории упругости методом конечных элементов проводится с заданными на границе усилиями. В этом случае минимизируется дополнительная работа системы. Полная потенциальная энергия упругой системы может быть разделена на две части, одна из которых соответствует энергии деформаций в теле, а другая определяется потенциальной энергией массовых сил, то есть $\Pi=\Lambda+W_{p}$, где $\Lambda$ - энергия деформаций, а $W_{p}$ - потенциальная энергия приложенных сил. Работа внешних сил противоположна по знаку их потенциальной энергии $W=-W_{p}$, тогда $\Pi=\Lambda-W$. 
Граничные условия в модели задавали с учетом проведенных на месторождении натурных измерений напряжений методом разгрузки, а также параметров исследований искривления геологоразведочных скважин на Ковдорском месторождении [141]. Результаты выполненных исследований подтвердили наличие в массиве Ковдорского месторождения тектонических сил, действующих в направлении субпараллельном длинной оси глубокого карьера.

В результате модельных исследований определены параметры НДС массива пород, которые могут быть использованы в качестве граничных условий на последующих этапах моделирования.

\subsection{2. Результаты моделирования напряженно-деформированного состояния массива пород Ковдорского месторождения с помощью мелкомасштабной модели}

C помощью мелкомасштабной геомеханической модели Большого Ковдора было рассчитано НДС массива для следующих вариантов конфигурации горных работ:

- фактическая карьерная выемка;

- проектная карьерная выемка до отметки -660 м;

- полная выемка подкарьерных запасов подземным способом до отметки $-760 \mathrm{M}$;

- полная выемка подкарьерных запасов подземным способом до отметки $-1200 \mathrm{M}$.

\subsection{3. Напряэенно-деформированное состояние массива пород в окрестности фактической карьерной выемки}

Первый этап расчетов НДС массива пород проведен для карьера с фактической конфигурацией. По результатам расчетов определены величины и направления векторов максимальной компоненты главных напряжений $\left(\sigma_{\max }\right)$ и минимальной компоненты главных напряжений $\left(\sigma_{\min }\right)$. Анализ проводили по двум перпендикулярным сечениям: по магистрали М -2100 (длинная ось карьера) и по разрезу Р -500 (короткая ось карьера).

Результаты расчетов показали, что в верхней части северного и южного бортов карьера значения $\sigma_{\max }$ составляют 12-30 МПа (рис. $3.17 a$ ). В нижней части этих бортов значения $\sigma_{\max }$ составляют 30-40 МПа, достигая 50 МПа на сопряжениях бортов и дна карьера. Направления векторов $\sigma_{\max }$ в районе карьерной выемки ориентированы вдоль бортов.

В верхней части западного борта значения $\sigma_{\max }$ составляют 25-30 МПа, в нижней его части значения $\sigma_{\max }$ достигают 40-45 МПа (рис. 3.17 б). Значения $\sigma_{\max }$ в восточном борту карьера практически по всей высоте борта составляют 35-45 МПа.

При этом в сопряжении дна и длинных бортов карьера (западного и восточного) не наблюдается такой ярко выраженной концентрации напряжений, как в сопряжении дна и коротких бортов (северного и южного). Разница в расположении зон концентрации и разгрузки напряжений в бортах карьера связана с вытянутой формой карьера по одной из его осей, которая ориентирована по направлению действия в массиве тектонических сил. 
Анализ распределения векторов минимальной компоненты напряжений $\sigma_{\min }$ показал, что в бортах карьера в основном действуют сжимающие напряжения со значениями 1-5 МПа. Зоны растяжений возникают лишь в локальных областях бортов карьера. Величины растягивающих напряжений не превышают 1 МПа (рис. 3.17 в, г).

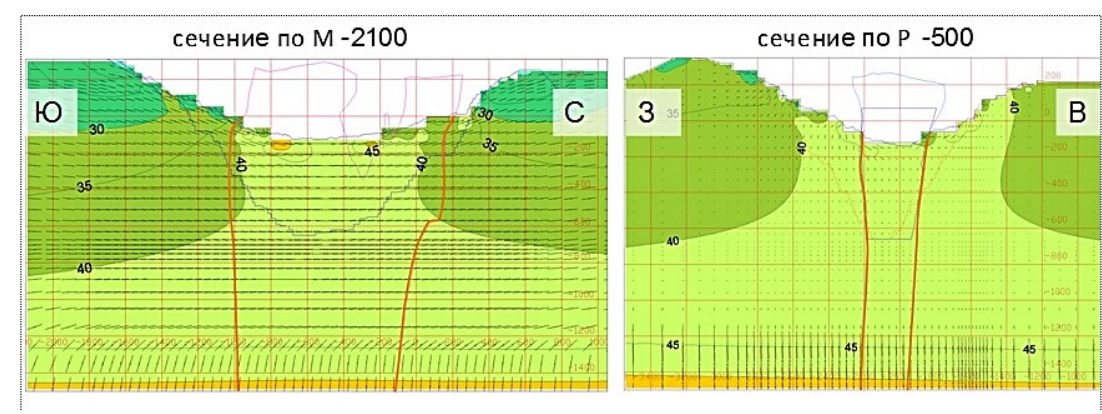

$a$

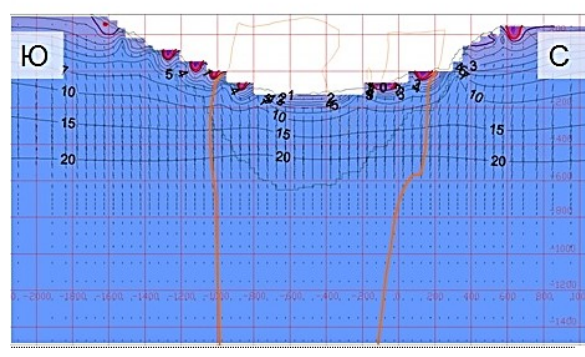

$\sigma$

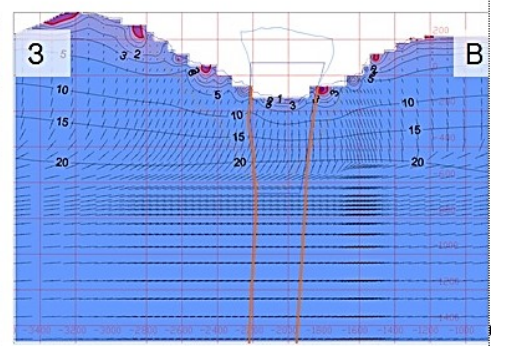

Рис. 3.17. Распределение напряжений в окрестности фактической карьерной выемки в вертикальных сечениях: $a, \sigma-\sigma_{\max } ; 6,2-\sigma_{\min }$

\subsection{4. Напряэенно-деформированное состояние массива пород в окрестности проектной карьерной выемки до отметки -660 м}

Следующий этап расчетов НДС массива пород проведен для проектной карьерной выемки до отметки -660 м, результаты которых показали, что в верхней части коротких бортов (северного и южного) возникает зона разгрузки, где значения $\sigma_{\max }$ составляют $12-25$ МПа. С увеличением глубины напряжения растут и достигают 60 МПа на сопряжении коротких бортов и дна карьера (рис. 3.18 a). В длинных бортах карьера напряжения $\sigma_{\max }$ остаются практически постоянными по всей высоте борта и составляют 30-35 МПа в западном и 40-45 МПа в восточном. На сопряжении длинных бортов и дна значения $\sigma_{\max }$ достигают 55 МПа (рис. 3.18 б). Анализ распределения векторов $\sigma_{\min }$ показал, что в коротких бортах растягивающих напряжений практически не возникает. Напряжения $\sigma_{\min }$ являются сжимающими и принимают значения от 1 МПа вблизи поверхности до 20 МПа на сопряжении короткого борта и дна карьера. Растягивающие напряжения $\sigma_{\min }$ возникают лишь в локальных областях коротких бортов со значениями, не превышающими 1 МПа (рис. 3.18 в). 
В длинных бортах карьера растягивающие напряжения возникают также в локальных областях борта, их значения не превышают 1 МПа (рис. 3.18 г). При этом следует заметить, что векторы напряжений $\sigma_{\min }$ направлены перпендикулярно длинным бортам, а значит, в этом случае будут возможны трещины отрыва в борту карьера. Такое направление возможных трещин отрыва является неблагоприятным с точки зрения обеспечения устойчивости борта, так как при этом существует опасность его оползания по раскрывшимся трещинам отрыва. Однако при этом следует учесть, что величины растягивающих напряжений малы и на порядок меньше предела прочности на растяжение, также на этом участке борта действуют высокие сжимающие напряжения величиной 35-45 МПа, которые будут препятствовать раскрытию трещин.

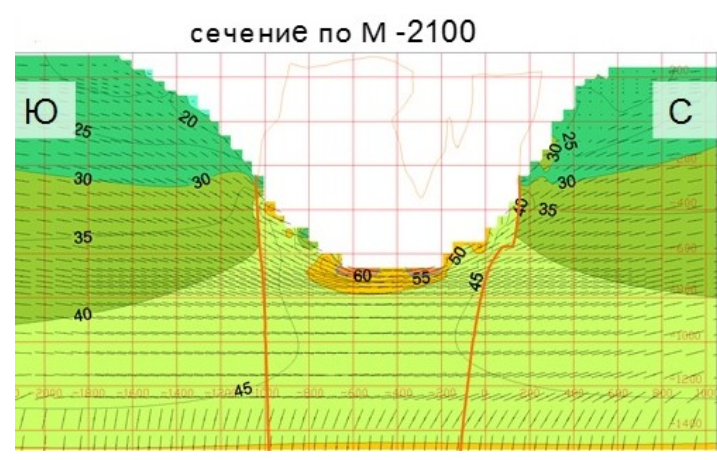

a

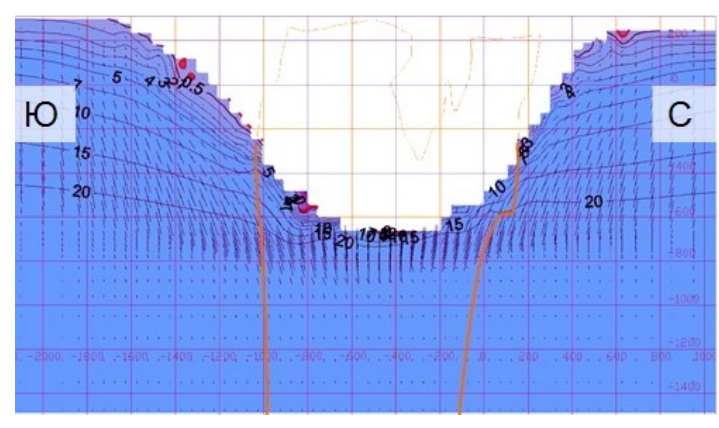

B

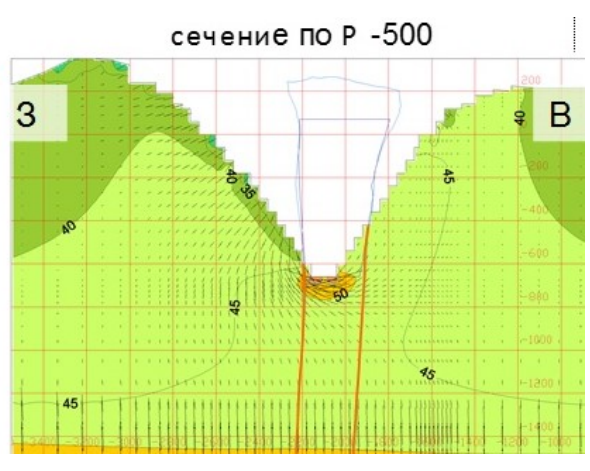

6

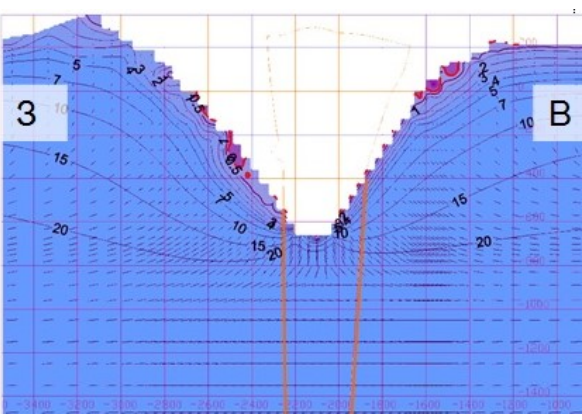

Рис. 3.18. Распределение напряжений в окрестности проектной карьерной выемки до отметки -660 м в вертикальных сечениях: $a, \sigma-\sigma_{\max } ; b, 2-\sigma_{\min }$

В целом можно констатировать, что при углублении карьера до отметки 660 м не наблюдается увеличения зон и абсолютных значений растягивающих напряжений $\sigma_{\min }$, то есть вероятность формирования и раскрытия трещин отрыва не повышается при гравитационно-тектоническом поле напряжений. 


\subsection{5. Напряэенно-деформированное состояние массива пород в окрестности выемки подкарьерных запасов подземным способом до отметки $-760 \mathrm{M}$}

На третьем этапе рассчитан вариант с полной выемкой подкарьерных запасов до отметки -760 м, который показал, что в коротких бортах карьера формируется зона разгрузки напряжений $\sigma_{\max }$ со значениями $15-20$ МПа. В нижней части северного борта значения $\sigma_{\max }$ повышаются до 35-55 МПа. На сопряжениях дна и стенок выемки значения $\sigma_{\max }$ достигают $60 \mathrm{MПа} \mathrm{(рис.} 3.19 a$ ).

В длинных бортах карьерной выемки значения $\sigma_{\max }$ составляют 40-50 МПа. В стенках очистной выемки, образованной при отработке подкарьерных запасов, образуются зоны разгрузки со значениями $\sigma_{\max } 25-30$ МПа (рис. 3.19 б).

Анализ распределения векторов $\sigma_{\min }$ показал, что в коротких бортах растягивающие напряжения практически отсутствуют (рис. 3.19 в).

В сечении по короткой оси карьера в стенках очистной выемки формируются зоны концентрации растягивающих напряжений, достигающих по абсолютной величине 3 МПа (рис. 3.19 г).

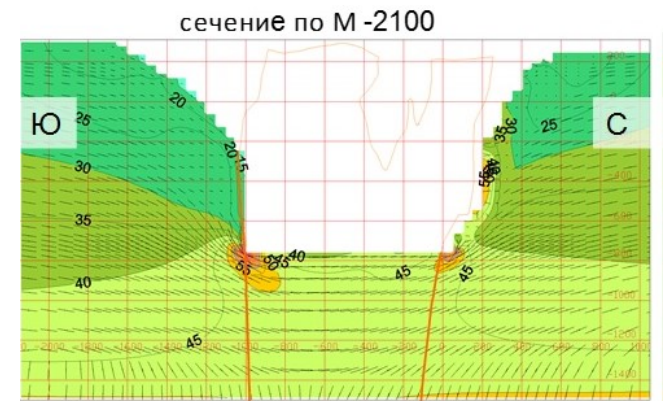

$a$

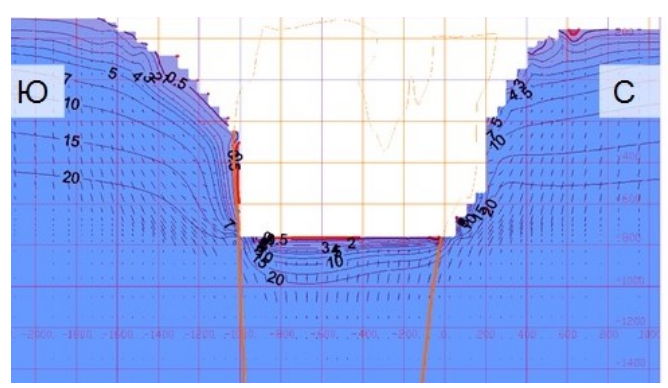

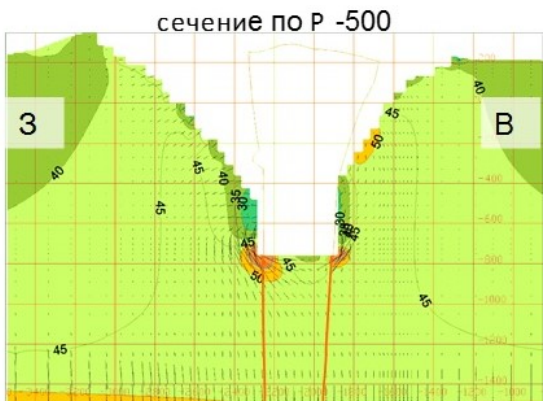

6

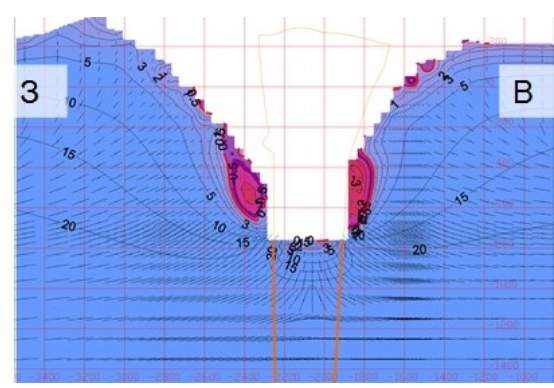

2

Рис. 3.19. Распределение напряжений при выемке подкарьерных запасов подземным способом до отметки -760 м в вертикальных сечениях: $a, \sigma-\sigma_{\max } ; 8,2-\sigma_{\min }$

Таким образом, анализ НДС в окрестности выемки подкарьерных запасов подземным способом до отметки -760 м показал, что зона обрушения формируется в нижней части карьерной выемки (ниже отметки -200 м). В приповерхностной же части карьера геомеханическая ситуация практически не меняется, локальные разрушения возможны только в ослабленных трещинами участках борта и не выходят на дневную поверхность за пределами контура карьера. 


\subsection{6. Напряженно-деформированное состояние массива пород в окрестности выемки подкарьерных запасов подземным способом до отметки -1200 м}

На четвертом этапе рассчитан вариант с полной выемкой подкарьерных запасов до отметки -1200 м, который показал, что углубление выемки до этой отметки приводит к увеличению значений сжимающих напряжений $\sigma_{\max }$ на сопряжении дна и стенок выемки до $70 \mathrm{MПа} \mathrm{(рис.} 3.20 a$, б).

Распределение напряжений $\sigma_{\min }$ аналогично варианту $\mathrm{c}$ выемкой запасов до отметки -760 м: зона возможных обрушений формируется ниже отметки -200 м. Абсолютные значения растягивающих напряжений в зоне достигают $5 \mathrm{MПа} \mathrm{(рис.} 3.20$ г).

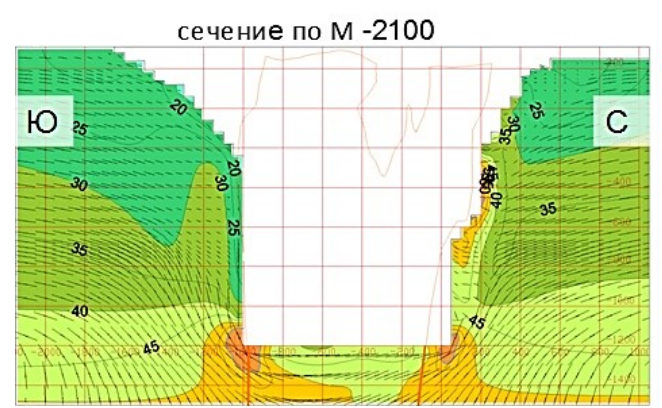

$a$

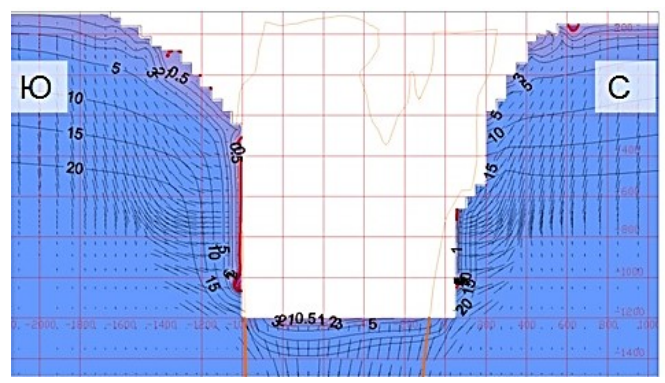

B

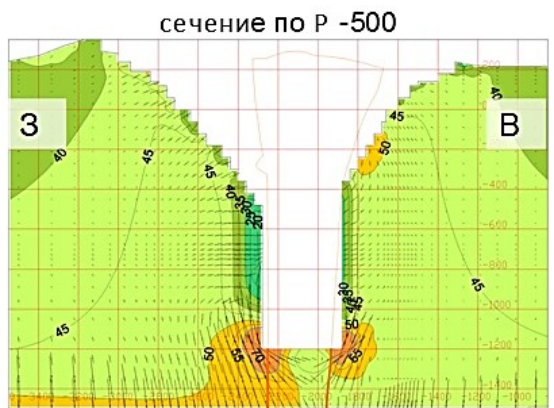

6

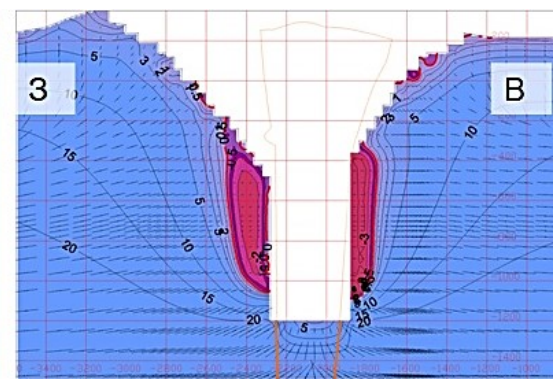

2

Рис. 3.20. Распределение напряжений при выемке подкарьерных запасов подземным способом до отметки -1200 м в вертикальных сечениях: $a, \sigma-\sigma_{\max } ; 8,2-\sigma_{\min }$

Таким образом, в результате расчетов параметров НДС массива пород в окрестности Большого Ковдора установлено, что при выемке запасов открытым способом до проектной глубины -660 м:

- потенциально опасными по динамическому разрушению будут являться уступы, находящиеся ниже отметки -400 м, причем более высокий уровень сжимающих напряжений $\sigma_{\max }$ фиксируется на этих глубинах в восточной части борта;

- не увеличение зон и абсолютных значений растягивающих напряжений $\sigma_{\min }$, то есть вероятность формирования и раскрытия трещин отрыва не повышается;

- за основу для разработки технологических вариантов конечного контура карьера могут быть взяты данные таблицы 3.1. 
При выемке подкарьерных запасов подземным способом до отметки -760 м, а также до отметки $-200 \mathrm{M}$ :

- зона обрушения формируется в нижней части карьерной выемки (ниже отметки -200 м);

- в приповерхностной части карьера геомеханическая ситуация практически не меняется, локальные разрушения возможны только в ослабленных трещинами участках борта и не выходят на дневную поверхность за пределами контура карьера.

\subsection{7. Напряэсенно-деформированное состояние массива пород при отработке запасов апатит-итаффелитов на юго-западе месторождения}

На заключительном этапе оценено влияние отработки апатит-штаффелитового месторождения на НДС прибортового массива.

Анализ результатов моделирования показал, что выемка апатитштаффелитовых руд вызывает образование зоны разгрузки в целике между глубоким и мелким карьерами. Здесь значения $\sigma_{\max }$ составляют 15-20 МПа (рис. 3.21 a). В этом же целике формируются зоны растяжений со значениями $\sigma_{\min } 0,5-1 \mathrm{MПа.}$

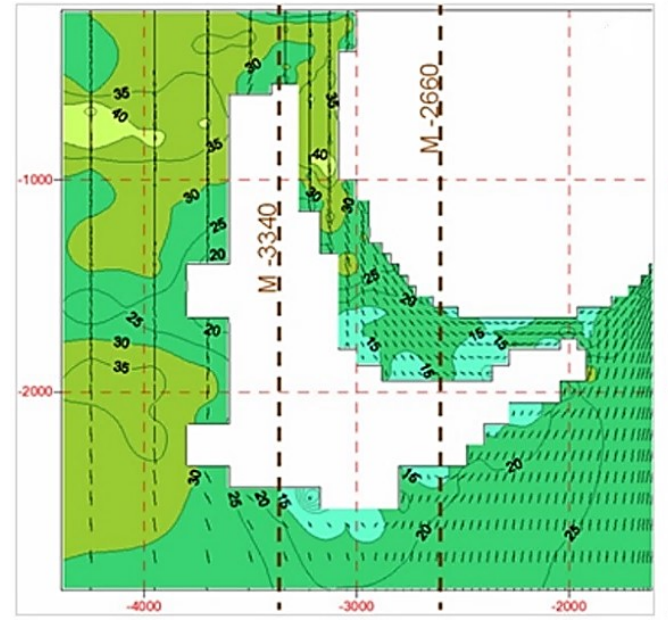

$a$

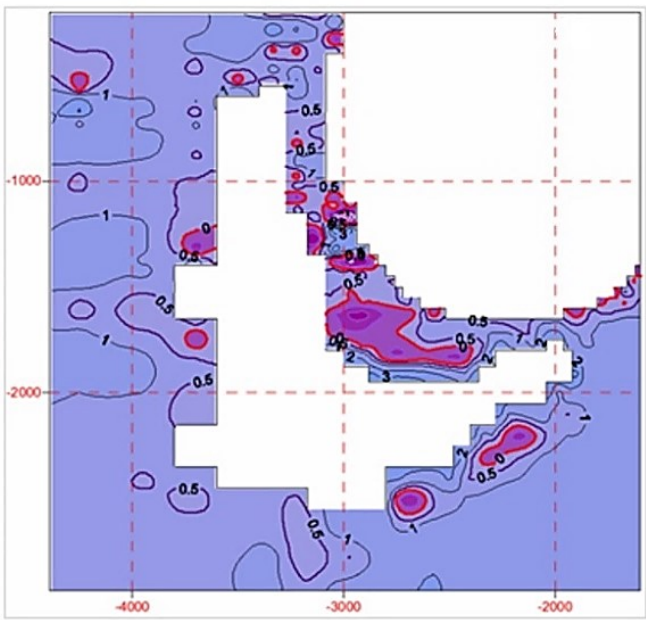

$\sigma$

Рис. 3.21. Распределение напряжений в окрестности апатит-штаффелитового карьера на уровне дневной поверхности: $a-\sigma_{\max } ; \sigma-\sigma_{\min }$

На рисунке 3.22 видно, что выемка апатит-штаффелитовых руд практически не влияет на НДС в бортах глубокого карьера.

Таким образом, результаты расчетов параметров НДС в окрестности двух карьеров показали, что влияние отработки апатит-штаффелитового месторождения на НДС прибортового массива глубокого карьера минимально. В случае оставления целика между глубоким и мелким карьерами в его приповерхностной части возникают зоны растягивающих напряжений, где возможны его разрушения. 


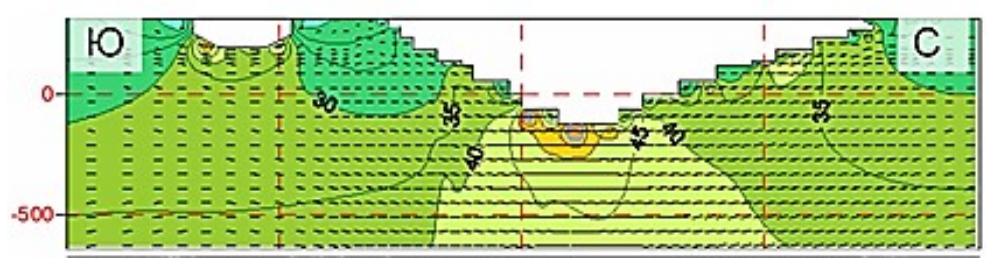

$a$

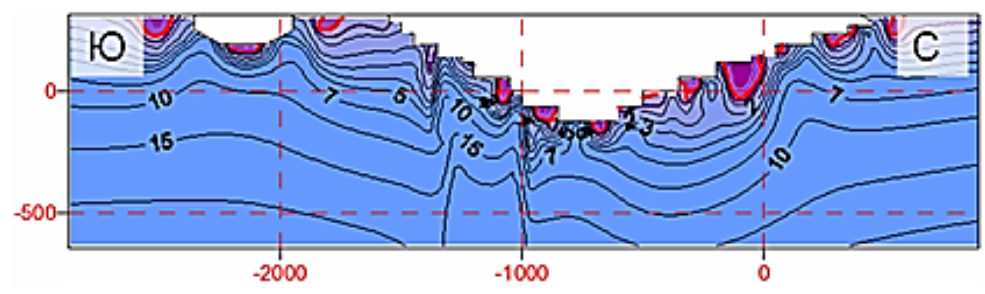

$\sigma$

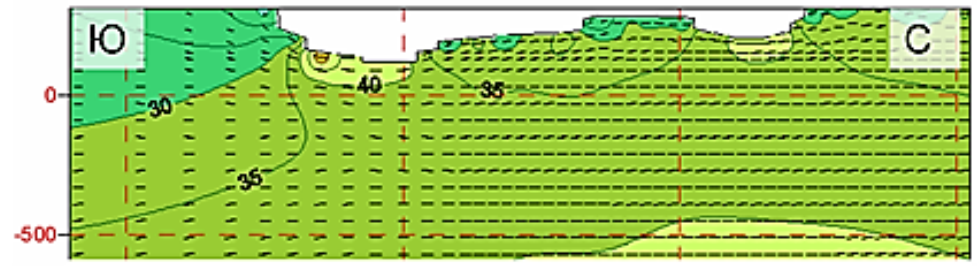

B

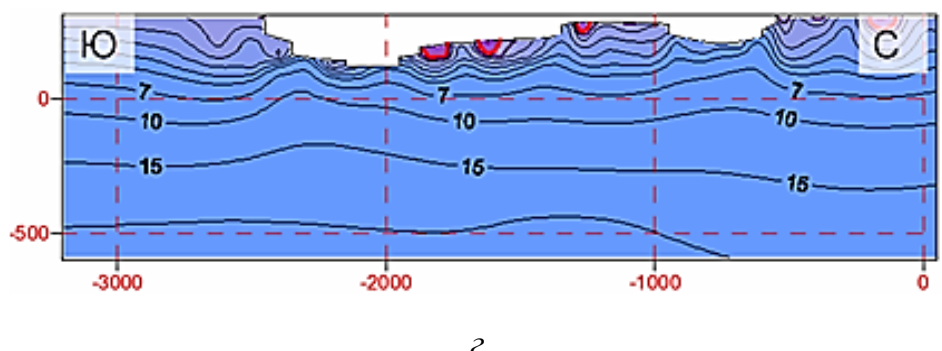

Рис. 3.22. Распределение напряжений в окрестности апатит-штаффелитового карьера: $a-\sigma_{\max }$ по $\mathrm{M}-2660 ; \sigma-\sigma_{\min }$ по $\mathrm{M}-2660 ; \varepsilon-\sigma_{\max }$ по $\mathrm{M}-3340 ; 2-\sigma_{\min }$ по M -334

\section{3. Динамика параметров разрушения горных выработок в зависимости от глубины и типа напряженно-деформированного состояния массива пород}

Как известно, одним из главных факторов, определяющим состояние выработки, является НДС массива горных пород. Для оценки значения этого фактора проведено исследование полей напряжений, действующих в массиве вокруг выработки, а также параметров разрушения контура выработки методами численного моделирования. Исследование проводили для незакрепленной выработки, пройденной в упругом изотропном массиве. Моделирование выполнено с помощью метода граничных элементов в двухмерной упругой постановке в свободно распространяемом программном продукте Examine2D, разработанном фирмой Rocscience Inc. [142]. 


\subsection{1. Описание расчетных вариантов}

Проведено численное моделирование трех различных состояний массива горных пород. В варианте № 1 моделировали НДС массива, определяемое только действием собственного веса горных пород. В варианте № 2, кроме действия собственного веса горных пород, моделировали действие тектонических напряжений равных $50 \mathrm{MПа} \mathrm{и} \mathrm{неизменяющихся} \mathrm{с} \mathrm{глубиной.} \mathrm{В} \mathrm{варианте} \mathrm{№} 3$ моделировали тектонические напряжения, увеличивающиеся с глубиной, характерные для месторождения «Олений ручей». Информация о величинах действующих в массиве тектонических напряжениях была взята из работы [10].

Для всех вариантов величину вертикальной составляющей $P$ определяли по формуле $P=\gamma H$, где $\gamma-$ плотность породы, $H-$ глубина расположения выработки. Горизонтальная составляющая $Q$ зависела от типа моделируемого поля напряжений.

Для варианта № 1 величину горизонтальной составляющей $Q$ определяли по формулам:

$$
\begin{aligned}
& Q=\xi \gamma H, \\
& \xi=v /(1-v),
\end{aligned}
$$

где $\xi$ - коэффициентом бокового отпора, $v-$ коэффициент Пуассона.

На рисунке 3.23 показана схема модели для варианта № 1. В центре модели располагается выработка шириной 5,1 м и высотой 4,5 м. Цифрами обозначены участки приконтурного массива для которых проводили анализ значений напряжений, изменяющихся с глубиной: цифрой 1 обозначена кровля выработки, цифрой 2 - стенка выработки.

Граничные условия задавали следующим образом: на правую и левую границу действовали усилия $Q$ в соответствии с формулой (3.2), а на верхнюю границу задавали усилия $P=\gamma H$. Нижняя граница модели закреплена. На рисунке 3.24 показана схема модели для вариантов № 2 и 3.

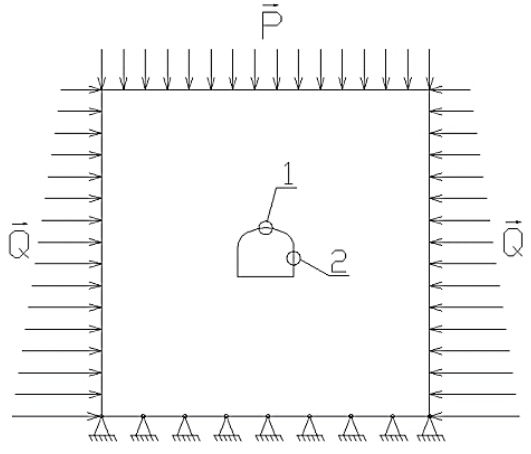

Рис. 3.23. Схема модели для варианта № 1

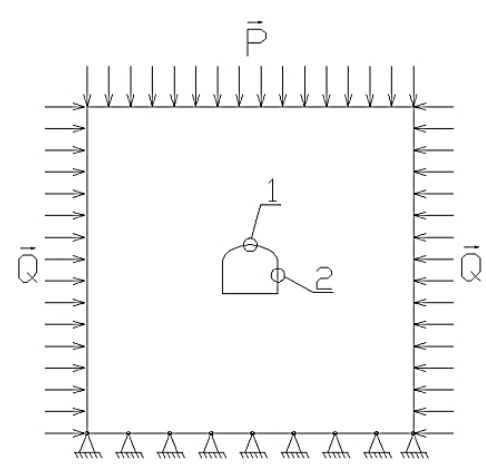

Рис. 3.24. Схема модели для вариантов № 2 и 3

При моделировании НДС массива приняты параметры физико-механических и прочностных свойств пород, характерных для пород, слагающих массив месторождения «Олений ручей», которое представлено прочными скальными породами, склонными к хрупкому разрушению и динамическим проявлениям горного давления. В таблице 3.2 приведены значения параметров свойств пород, использованные при моделировании. 
Характеристики основных свойств пород

\begin{tabular}{|l|c|}
\hline \multicolumn{1}{|c|}{ Наименование параметра } & Величина параметра \\
\hline Модуль упругости, МПа & 70000 \\
\hline Коэффициент Пуассона & 0,2 \\
\hline Плотность, т/м ${ }^{3}$ & 3 \\
\hline Предел прочности на сжатие, МПа & 120 \\
\hline Предел прочности на растяжение, МПа & 10 \\
\hline
\end{tabular}

\subsection{2. Размеры зон разрушения вокруг горной выработки}

Для более детального анализа параметров разрушения горной выработки с увеличением глубины при различных режимах нагружения применяли следующие критерии разрушения: критерий Кулона-Мора [9], критерий Хука-Брауна [143] и критерий Хука-Брауна с параметрами хрупкого разрушения [144].

Определим размеры зон разрушения выработки для каждого рассчитанного варианта НДС массива. Под размером разрушения принимали расстояние $L$ (рис. 3.25) от начального контура выработки до контура, который образовался бы в результате разрушения. Размеры зон разрушения определяли на двух участках контура выработки - в кровле и в стенке.

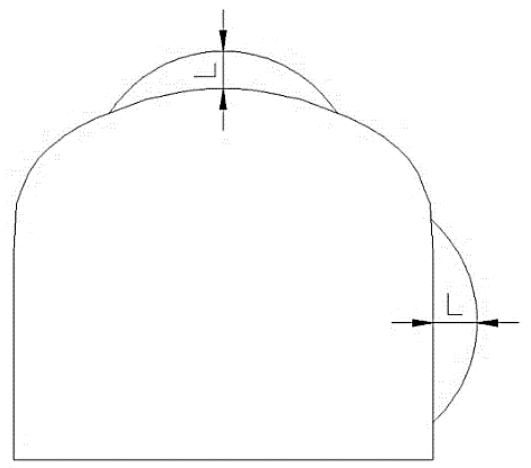

Рис. 3.25. Размер зоны разрушения

Для анализа параметров разрушения использовали показатель устойчивости пород $K_{\mathrm{y}}$, который определяли по перечисленным выше критериям. В тех областях массива, где значения $K_{\mathrm{y}} \leq 1$, возможны разрушения горных пород при их обнажении, а там где $K_{\mathrm{y}}>1$, разрушений нет.

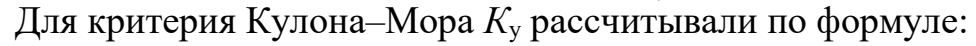

$$
K_{\mathrm{y}}=\frac{\left(2 C+\operatorname{tg} \varphi\left(\sigma_{1}+\sigma_{2}\right)\right) \cos \varphi}{\sigma_{1}-\sigma_{2}} .
$$

Для расчетов размеров разрушенной зоны по критерию Кулона-Мора параметры $C$ и $\operatorname{tg} \varphi$ определяли по следующим формулам:

$$
\begin{aligned}
& \operatorname{tg} \varphi=\frac{\sigma_{\text {сж }}-\sigma_{\mathrm{p}}}{2 \sqrt{\sigma_{\mathrm{cж}} \sigma_{\mathrm{p}}}}, \\
& C=0,5 \sqrt{\sigma_{\text {сж }} \sigma_{\mathrm{p}}} .
\end{aligned}
$$


Подставив средние значения для пород Хибинского массива $\sigma_{\text {сж }}=120 \mathrm{MПа}$ и $\sigma_{\mathrm{p}}=10$ МПа, получим $C=17,32$ МПа и $\operatorname{tg} \varphi=1,588\left(\varphi=57,8^{\circ}\right)$.

Для критерия Хука-Брауна $K_{\text {у }}$ рассчитывали по формуле:

$$
K_{\mathrm{y}}=\frac{\sqrt{m_{b} \sigma_{2} \sigma_{\text {сж }}+s \sigma_{\text {сж }}^{2}}}{\sigma_{1}-\sigma_{2}},
$$

где $m_{b}, s, a$ - параметры, характеризующие массив, причем

$$
\begin{aligned}
& m_{b}=m_{i} \cdot \exp \left(\frac{G S I-100}{28-14 D}\right), \\
& s=\exp \left(\frac{G S I-100}{9-3 D}\right),
\end{aligned}
$$

где $m_{i}$ - безразмерная постоянная, определяющая тип нетронутой породы; $G S I$ - коэффициент геологической прочности связных пород; $D$ - параметр, зависящий от степени нарушенности массива вследствие взрывных работ.

Чаще всего для прочных скальных пород параметр $a$ критерия Хука-Брауна принимают равным примерно 0,5 [144].

При визуальном осмотре поверхности незакрепленных выработок подземного рудника «Олений ручей», пройденных на момент выполнения настоящей работы, было установлено, что в соответствии с работой [143] параметр GSI находится в пределах 70-90. Для расчетов принято наименьшее значение $G S I=70$.

Для расчетов примем $D=0$, что соответствует согласно работе [144] хорошему качеству взрывных работ при проходке выработки.

При анализе литературы для определения параметра $m_{i}$ было установлено, что для пород месторождения «Олений ручей» данный параметр не расчитывался. Однако была определена справочная информация по породам со сходными свойствами - сиениты и нефелиновые сиениты, для которых $m_{i}=22$.

После подстановки значений $G S I, D$ и $m_{i}$ в (3.8) и (3.9), получим значения параметров $m_{b}=8,56$ и $s=0,037$. Таким образом, для расчетов размеров разрушенной зоны по критерию Хука-Брауна примем: $a=0,5 ; m_{b}=8,56 ; s=0,037$.

В работе [144] проведен всесторонний анализ зарубежного опыта проходки выработок различной формы в породах, склонных к хрупкому разрушению. Авторы исследования [10] отмечают, что разрушение контура выработки начинается при достижении величин напряжений на контуре выработки 50 \% в направлении, перпендикулярном действию максимальной компоненты главных напряжений.

Сравнение расчетных данных в работе [145] с параметрами разрушений, полученными опытным путем, показало, что лучше всего хрупкое разрушение контура выработки описывает упругая модель с применением параметра $m_{b}=0$.

Подставим $m_{b}=0$ в формулу критерия прочности, выраженный через $\sigma_{1}$ и $\sigma_{2}$ :

$$
\sigma_{1}=\sigma_{2}+\sigma_{\text {сж }}\left(m_{b} \frac{\sigma_{2}}{\sigma_{\text {сж }}}+S\right)^{0,5}=\sigma_{2}+\sigma_{\text {сж }} \sqrt{S} .
$$


Известно, что на контуре выработки действует тангенциальная компонента напряжений, которая в этой точке будет являться максимальным значением напряжений, то есть $\sigma_{\theta}=\sigma_{1}$, а минимальная компонента в данной точке $\sigma_{2}$ будет равна нулю. С учетом этих рассуждений преобразуем выражение (3.10) следующим образом:

$$
\sigma_{1}=\sigma_{\text {сж }} \sqrt{S} .
$$

В работе [7] было показано, что в условиях Хибинского массива при достижении действующими напряжениями значений, равных примерно 0,5

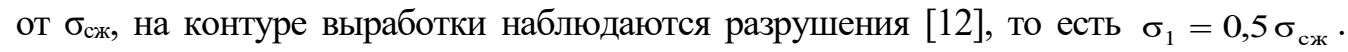
Приняв в качестве условия разрушения массива на контуре выработки выражение

$$
\sigma_{1}=0,5 \sigma_{\mathrm{c} ж}
$$

и сравнив его с выражением (3.11), можно утверждать, что параметр $s$ критерия Хука-Брауна для пород Хибинского массива равен 0,25. Необходимо также учесть, что он изначально характеризует трещиноватость пород и при наличии естественной трещиноватости в массиве будет только уменьшаться, то есть значение $s=0,25$ будет являться максимальным значением при анализе размеров хрупкого разрушения контура выработки в условиях Хибинского массива.

Таким образом, для определения размеров разрушения выработки также будем использовать следующие параметры критерия разрушения Хука-Брауна: $a=0,5 ; m_{b}=0 ; s=0,25$, характеризующие хрупкое разрушение массива.

Оценив зону возможных разрушений, определим размеры этой зоны в кровле и в стенке выработки, как показано на рисунке 3.26. Причем, при размерах зон разрушения, превышающих максимальный размер выработки, будем считать ее полностью разрушеной, и, следовательно, дальнейшее определение размеров будет нецелесообразно.

Ниже представлены результаты расчетов размеров зон разрушений выработок в виде графиков зависимости размеров разрушений от глубины заложения выработки (рис. 3.26-3.28).

На рисунке 3.26 видно, что размеры зоны разрушения контура выработки увеличиваются с глубиной по всем критериям. Однако, если по критерию Хука-Брауна выработка имеет разрушения уже на глубине 100 м (рис. 3.26 a), то по критерию с хрупкими параметрами она начнет разрушаться с глубины $1000 \mathrm{M}$ (рис. 3.26 б), а по критерию Мора-Кулона - только с глубины 2000 м (рис. 3.26 в).

Также есть различия в расположении зон разрушений. Критерий Мора-Кулона показывает, что разрушения будут наблюдаться и в кровле, и в стенке выработки, при этом размер разрушения в кровле будет больше размера разрушения в стенке выработки примерно в два раза. Критерий Хука-Брауна показывает, что разрушения в кровле выработки будут преобладать примерно до глубины 750 м, а ниже размер разрушения в стенке будет больше. Данные, полученные с помощью параметров хрупкого разрушения, показывают, что разрушения будут наблюдаться только в стенке выработки, причем, если до глубины 1000 м их нет, то после этой глубины размеры разрушения в стенке растут быстрее, чем по остальным критериям. 
При рассмотрении результатов о размерах зон разрушения, полученных по критериям для варианта № 2, можно выделить общие закономерности развития разрушения с изменением глубины залегания выработки. По всем критериям размер зоны разрушения в стенке выработки уменьшается до определенной глубины, которая будет отличаться для различных критериев, а при дальнейшем увеличении глубины величина разрушения будет расти. Такое же поведение характерно и для развития разрушения в кровле выработки по критериям Мора-Кулона и Хука-Брауна. Критерий с параметрами хрупкого разрушения показывает, что размер разрушения в кровле с увеличением глубины будет постепенно расти. Если на графики (рис. 3.27) добавить аппроксимирующую функцию, то можно заметить, что зависимость размера зоны разрушения от глубины залегания выработки описывается квадратичной функцией с достаточно высоким коэффициентом аппроксимации $R^{2}$.

На рисунке 3.28 видно, что все критерии показывают увеличение размеров зоны разрушений выработки с определенной глубины, которые будут отличаться для разных критериев. По критерию Мора-Кулона и критерию с параметрами хрупкого разрушения наибольшие разрушения будут происходить в кровле выработки. Результаты, полученные с помощью критерия Хука-Брауна, не позволяют выявить каких-либо особых закономерностей, кроме развития разрушения контура выработки с увеличением глубины ее залегания.

Вариант № 1

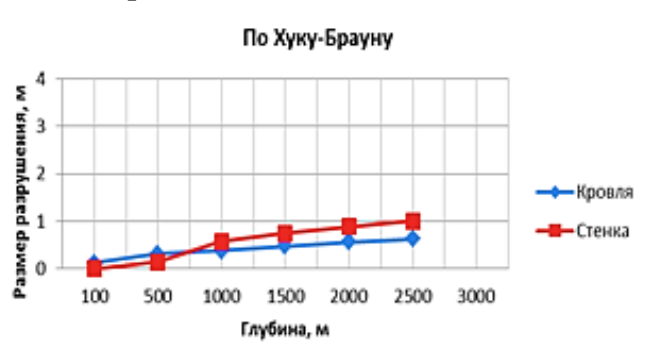

$a$

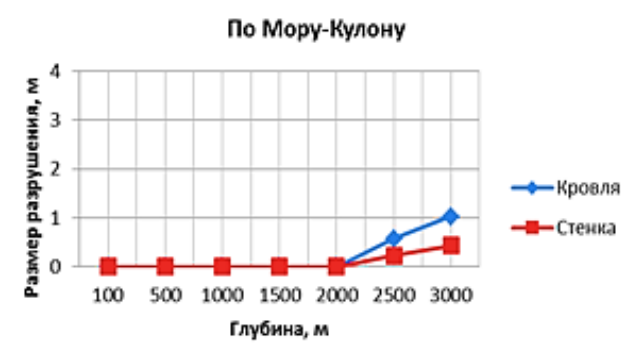

б

Хрупкое разрушение

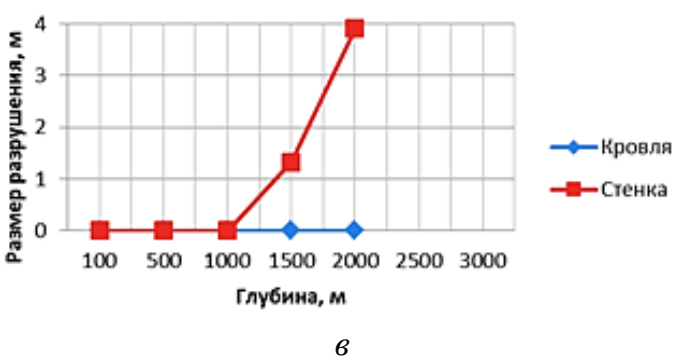

Рис. 3.26. Зависимость размера зоны разрушения контура выработки от глубины залегания для варианта № 1: $a$ - по критерию Мора-Кулона; $\sigma$ - по критерию Хука-Брауна; в - по критерию Хука-Брауна хрупкого разрушения для условий гравитационного типа поля напряжений 
Вариант № 2

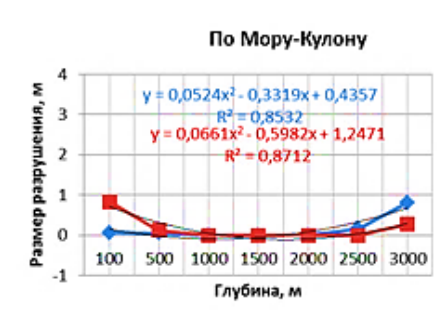

$a$

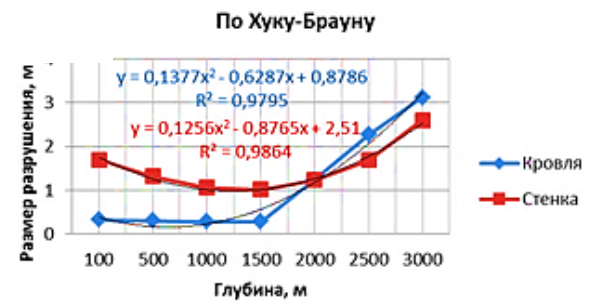

6

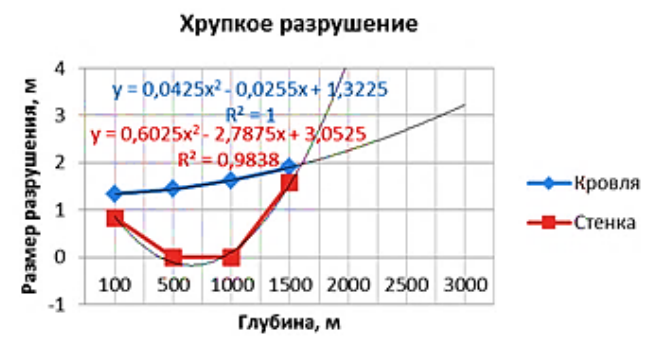

B

Рис. 3.27. Зависимость размера зоны разрушения контура выработки от глубины залегания для варианта № 2: $a$ - по критерию Мора-Кулона; $\sigma-$ по критерию Хука-Брауна; $в$ - по критерию Хука-Брауна хрупкого разрушения для условий действия тектонических напряжений, не изменяющихся с глубиной

Вариант № 3

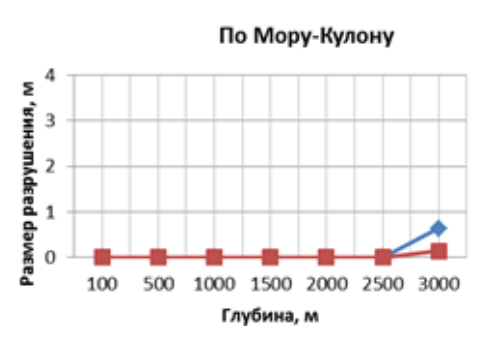

$a$

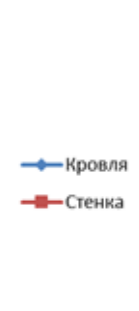

Хрупкое разрушение

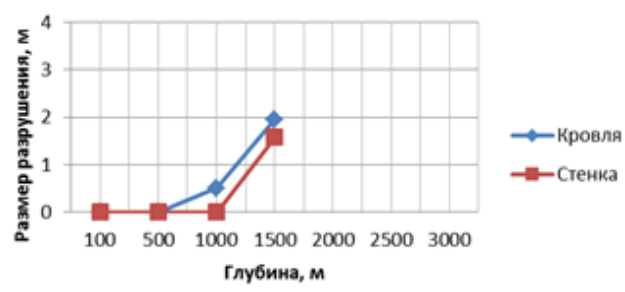

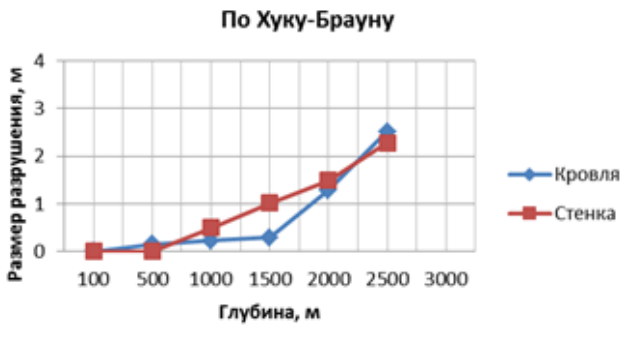

$\sigma$

Рис. 3.28. Зависимость размера зоны разрушения контура выработки от глубины залегания для варианта № 3: a - по критерию Мора-Кулона; б - по критерию Хука-Брауна; в - по критерию Хука-Брауна хрупкого разрушения для условий месторождения «Олений ручей» 


\subsection{3. Анализ полученных результатов}

Анализ результатов расчета размеров зоны разрушения для всех вариантов показал, что критерий Хука-Брауна с параметрами хрупкого разрушения лучше всех остальных критериев определяет расположение зон разрушений. В варианте № 1, где вертикальная компонента напряжений превышает горизонтальную, критерий с хрупкими параметрами предсказывает разрушения в стенке выработки (рис. 3.26 в). А для вариантов № 2 и 3 при превышении горизонтальной компоненты напряжений над вертикальной этот критерий показывает преобладание разрушений в кровле выработки (рис. 3.27 в и 3.28 в), что подтверждается натурными наблюдениями в работе [6].

Данные о параметрах разрушения для варианта № 2, полученные с помощью различных критериев, показали наличие некоторой глубины (рис. 3.27), на которой выработка будет иметь минимальные разрушения. Появление такой глубины можно объяснить тем, что на этой отметке горизонтальная и вертикальная компоненты напряжений будут примерно одинаковы. Такое состояние будет способствовать уменьшению концентрации напряжений на контуре, что приведет к уменьшению размеров зон разрушений выработки.

Таким образом, анализ результатов о размерах зон разрушений в стенке и кровле на основе различных критериев разрушения показал, что в массиве c гравитационно-тектоническим типом поля напряжений, когда значения тектонических напряжений не изменяются, с увеличением глубины заложения выработки происходит уменьшение размеров зон разрушения. Такое явление можно объяснить снижением концентрации сжимающих напряжений в кровле и выравниванием тангенциальных напряжений по всему контуру выработки. После достижения некоторой глубины размеры зон разрушения начнут расти с увеличением глубины заложения выработки. Установлена зависимость размеров зоны разрушения вокруг выработки от глубины ее заложения в тектонически напряженном массиве с минимумом на глубине 1500 м, которая может быть аппроксимирована квадратичной функцией $L=a H^{2}+b H+c$, где $L-$ размер зоны разрушения; $H$ - глубина заложения выработки; $a, b, c$ - коэффициенты, зависящие от рассматриваемого критерия разрушения и его параметров (значения коэффициентов для рассматриваемых критериев даны в таблице 3.3 ).

Таблица 3.3

Значения коэффициентов для различных критериев разрушения

\begin{tabular}{|c|c|c|r|r|r|r|}
\hline \multirow{2}{*}{ Коэффициент } & \multicolumn{2}{|c|}{ По Мору-Кулону } & \multicolumn{2}{c|}{ По Хуку-Брауну } & \multicolumn{2}{c|}{ Хрупкое разрушение } \\
\cline { 2 - 7 } & стенка & кровля & стенка & \multicolumn{1}{c|}{ кровля } & стенка & \multicolumn{1}{c|}{ кровля } \\
\hline$a$ & 0,0661 & 0,0524 & 0,1256 & 0,1377 & 0,6025 & 0,0425 \\
\hline$b$ & $-0,5982$ & $-0,3319$ & $-0,8765$ & $-0,6287$ & $-2,7875$ & $-0,0255$ \\
\hline$c$ & 1,2471 & 0,4357 & 2,51 & 0,8786 & 3,0525 & 1,3225 \\
\hline
\end{tabular}

Полученные результаты о размерах и положений зон разрушений контура выработки при различном соотношении тектонических и гравитационных напряжений могут быть использованы при выборе и расчете параметров крепи. 


\section{4. СЕЙСМОГЕНЕРИРУЮЩИЙ ПОТЕНЦИАЛ МОЩНЫХ ВЗРЫВОВ}

\section{1. Закономерности проявлений техногенной сейсмичности и оценка сейсмоопасных участков при ведении горных работ на подземных рудниках Кировского филиала акционерного общества «Апатит»}

В последние годы проблема техногенной сейсмичности в рудниках и шахтах приобрела особую актуальность в мире и, в частности, в нашей стране. Интенсивная добыча полезных ископаемых на подземных рудниках и постоянное воздействие мощных технологических взрывов сопровождается сейсмическими явлениями с катастрофическими последствиями. Реакция горных пород на техногенные воздействия зависит не только от интенсивности и вида воздействия, но и от характера естественного деформационного процесса, энергонасыщенности структур коры, распределения и величины напряженного состояния, которая отражается как в динамических проявлениях горного давления (горные и горно-тектонические удары, техногенные землетрясения), так и в деформировании массива пород (крип по структурным нарушениям и дезинтеграция массива, обусловленная релаксацией напряжений) [146, 147]. Практика отработки глубоких горизонтов апатитовых рудников свидетельствует о том, что основная доля динамических проявлений приходится на участки с тектоническими нарушениями.

Вопросам поведения блочной среды при динамических воздействиях ГоИ КНЦ РАН занимается довольно длительное время и накоплены некоторые знания о проявлениях техногенной сейсмичности при производстве массовых взрывов $[11,148]$.

Но в связи с углублением горных работ, увеличением масштабов добычи и изменением технологии ведения взрывных работ реакция массива горных пород на взрывные воздействия может проявляться совершенно по другому, чем в предшествующие периоды.

Поэтому изучение кинетики техногенного сейсмического процесса и установление взаимосвязи параметров сейсмических событий с параметрами динамического воздействия должно производиться постоянно.

Массовые взрывы, осуществляемые на Хибинских рудниках для отбойки руды, значительно влияют на активизацию сейсмичности массива пород. Непосредственно после массового взрыва количество сейсмических событий возрастает в 10-50 раз по сравнению с фоновым значением. Многие мощные сейсмические события, в том числе тектонические горные удары и техногенные землетрясения, происходят в момент проведения взрыва или непосредственно после него. Массовый взрыв, являясь мощным энергетическим воздействием на окружающий массив пород, с одной стороны, может привести к подготовке опасного сейсмического события, a c другой, - явиться спусковым механизмом уже подготовленного ранее сейсмического события. Поэтому, вероятно, управляя параметрами массовых взрывов, можно управлять процессами подготовки и реализации сейсмических событий большой энергии. Для этого, в качестве первого шага, необходимо изучить закономерности изменения параметров сейсмичности массива пород после проведения массовых взрывов на руднике.

В настоящем разделе приведены результаты изучения закономерностей проявлений техногенной сейсмичности для определения сейсмоопасных участков и улучшения временного прогноза периодов повышенного риска в различных зонах ведения крупномасштабных горных работ.

Проявление техногенной сейсмичности изучали на основе базы данных системы геодинамического мониторинга Кировского филиала акционерного 
общества «Апатит» (КФ АО «Апатит») с помощью разработанного программного комплекса ACS, позволяющего оперативно, по мере поступления сейсмической информации, оценивать ситуацию в районе ведения горных работ.

Оценку сейсмической опасности проводили для шахтных полей Кукисвумчоррского и Юкспорского месторождений, отрабатываемых Объединенным кировским рудником (ОКР) за период 2013-2018 гг.

Проявление техногенной сейсмичности изучали в два этапа:

1 этап - 2013-2015 гг., когда производились массовые взрывы в системе разработки с этажным обрушением;

2 этап - 2015-2018 гг., когда производились в основном технологические взрывы в системе разработки с подэтажным обрушением и торцевым выпуском руды.

\subsection{1. Выявление закономерностей проявлений техногенной сейсмичности при производстве массовых взрывов на подземных рудниках}

Для установления взаимосвязи техногенной сейсмичности с режимом ведения взрывных работ были проанализированы все взрывы, проведенные в 2013-2015 гг. (табл. 4.1.).

Таблица 4.1

Взрывы, проведенные в 2013-2015 гг. на Кировском руднике

\begin{tabular}{|c|c|c|c|}
\hline Дата & Время & № участка & Bec BB \\
\hline \multicolumn{4}{|c|}{ Взрывы на Кировском крыле ОКР } \\
\hline 23.02 .2013 & $7: 23$ & 4 & 110000 \\
\hline 08.03 .2013 & 4:01 & 8 & 40000 \\
\hline 14.04 .2013 & $9: 25$ & 14 & 76000 \\
\hline 02.06 .2013 & $9: 50$ & 4 & 36000 \\
\hline 28.07 .2013 & $11: 30$ & 4 & 51000 \\
\hline 15.09.2013 & $6: 41$ & 14 & 72000 \\
\hline 22.09 .2013 & $7: 15$ & 8 & 38000 \\
\hline 27.10 .2013 & $8: 36$ & 4 & 35000 \\
\hline 01.12 .2013 & $11: 00$ & 4 & 30000 \\
\hline 15.12 .2013 & $10: 40$ & 14 & 58000 \\
\hline 20.04 .2014 & 7:00 & 8 & 35000 \\
\hline 22.06 .2014 & - & 8 & 28000 \\
\hline 02.11 .2014 & $11: 51$ & 8 & 37000 \\
\hline 28.12.2014 & 11:00 & 8 & 28000 \\
\hline 13.01 .2015 & $11: 57$ & 8 & 16000 \\
\hline 15.02 .2015 & - & 8 & 38000 \\
\hline 06.09 .2015 & - & 8 & 83000 \\
\hline \multicolumn{4}{|c|}{ Взрывы на Юкспорском крыле ОКР } \\
\hline 27.01 .2013 & $0: 50$ & 6 & 16000 \\
\hline 10.02 .2013 & $0: 53$ & 6 & 14000 \\
\hline 17.03 .2013 & $1: 45$ & 6 & 11000 \\
\hline 24.03 .2013 & $7: 10$ & 6 & 160000 \\
\hline 01.05 .2013 & $6: 50$ & 1 & 120000 \\
\hline 09.06 .2013 & $9: 15$ & 1 & 82000 \\
\hline 01.09 .2013 & $10: 10$ & 9 & 82000 \\
\hline 13.10 .2013 & $7: 22$ & 6 & 180000 \\
\hline 26.01 .2014 & $7: 25$ & 6 & 136000 \\
\hline 16.02 .2014 & $6: 34$ & 9 & 95000 \\
\hline 30.03 .2014 & - & 6 & 228000 \\
\hline 18.05 .2014 & $11: 15$ & 1 & 119000 \\
\hline 05.10 .2014 & 11:00 & 3 & 40000 \\
\hline 08.02 .2015 & $10: 48$ & 1 & 95000 \\
\hline 27.09 .2015 & $9: 55$ & 3 & 300000 \\
\hline
\end{tabular}


Взаимосвязь проявления техногенной сейсмичности с режимом ведения взрывных работ для Кировского крыла представлена на рисунках 4.1 и 4.2, а для Юкспорского крыла — на рисунках 4.3 и 4.4.
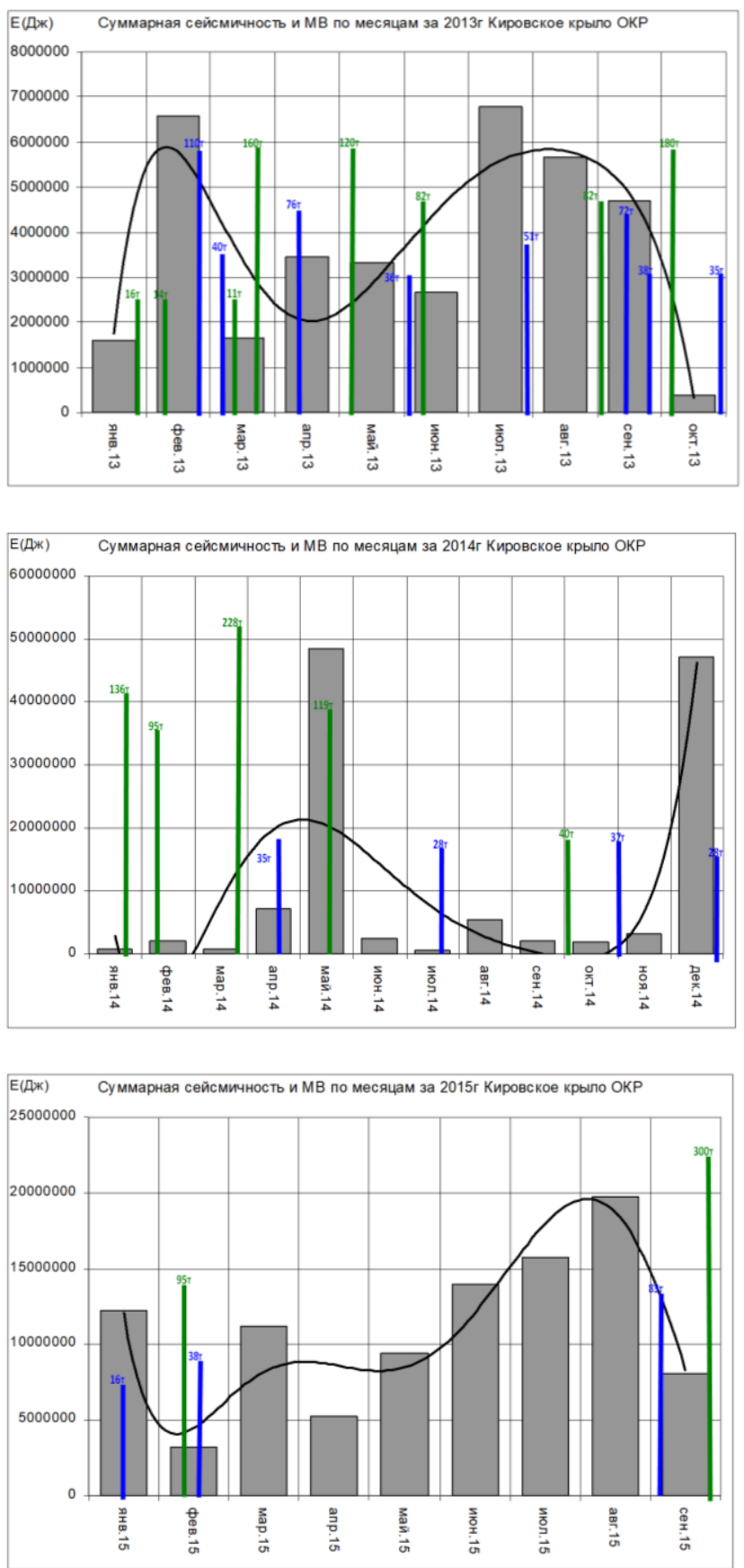

Рис. 4.1. Взаимосвязь проявления месячной техногенной сейсмичности с режимом ведения взрывных работ для Кировского крыла ОКР в 2013-2015 гг. Синим цветом обозначены взрывы, производимые на Кировском крыле ОКР, а зеленым — на Юкспорском крыле 

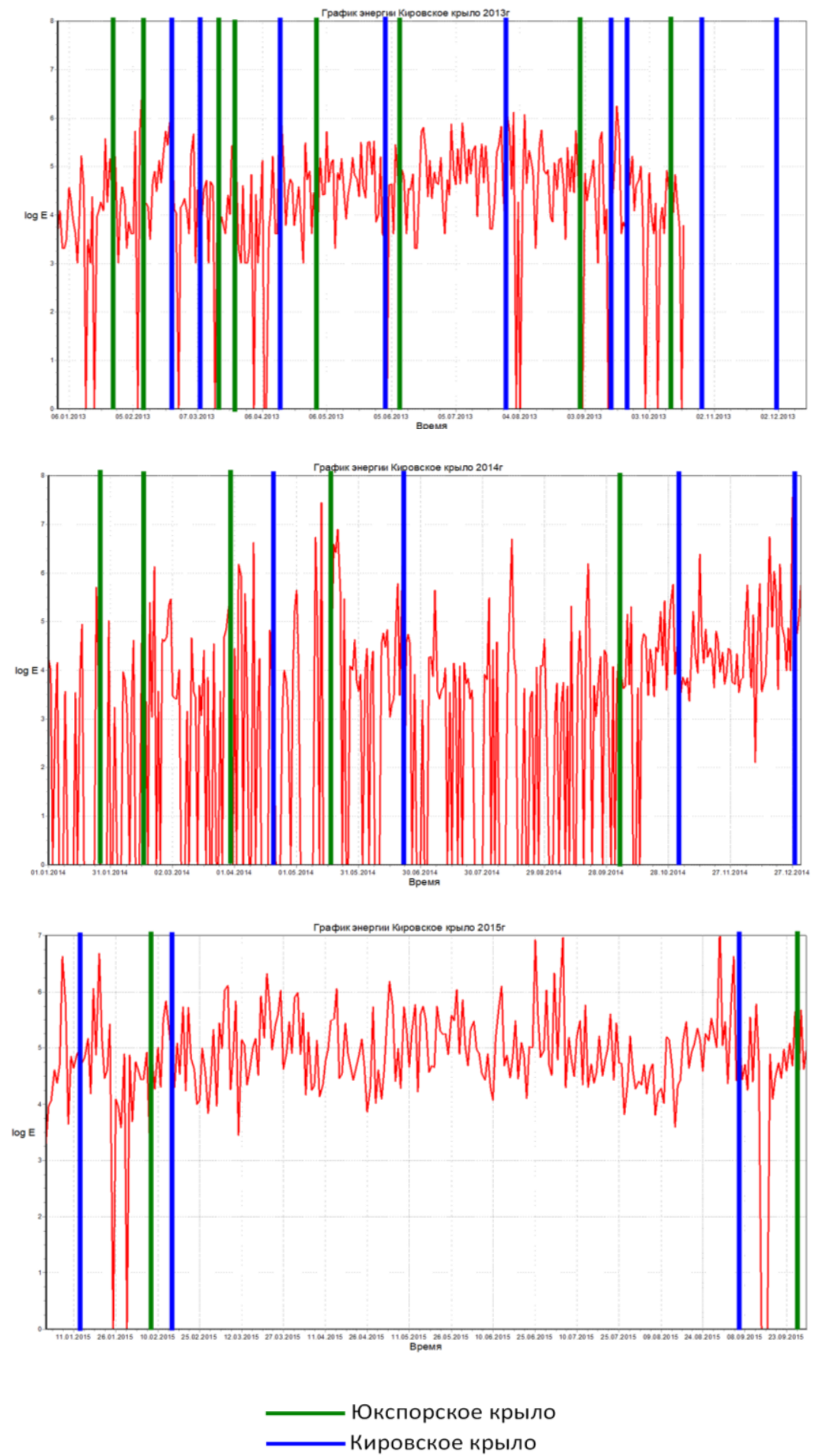

Рис. 4.2. Взаимосвязь проявления суточной техногенной сейсмичности с режимом ведения взрывных работ для Кировского крыла ОКР в 2013-2015 гг. 

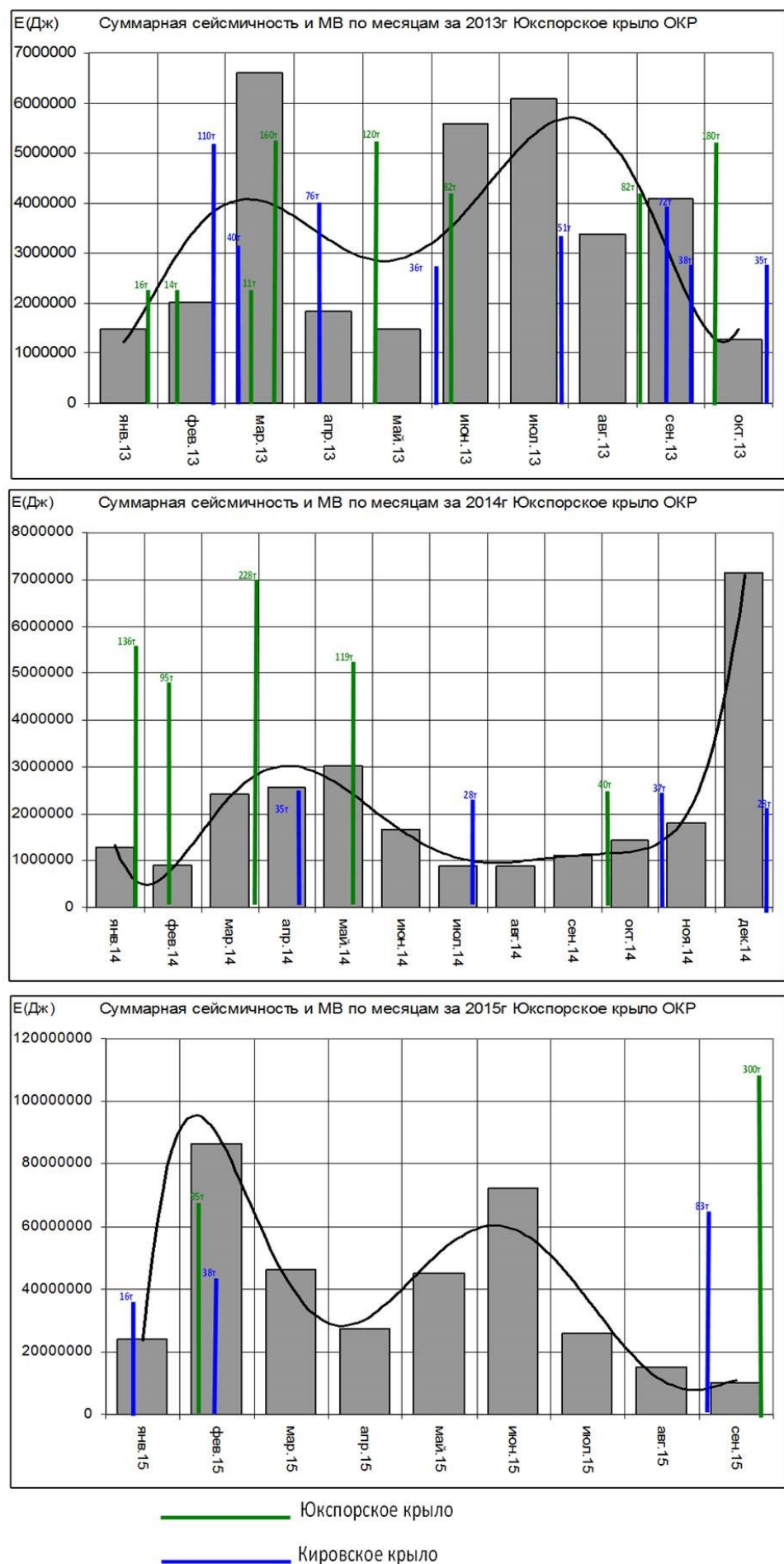

Рис. 4.3. Взаимосвязь проявления месячной техногенной сейсмичности с режимом ведения взрывных работ для Юкспорского крыла ОКР в 2013-2015 гг. Синим цветом обозначены взрывы, производимые на Кировском крыле ОКР, а зеленым - на Юкспорском крыле 

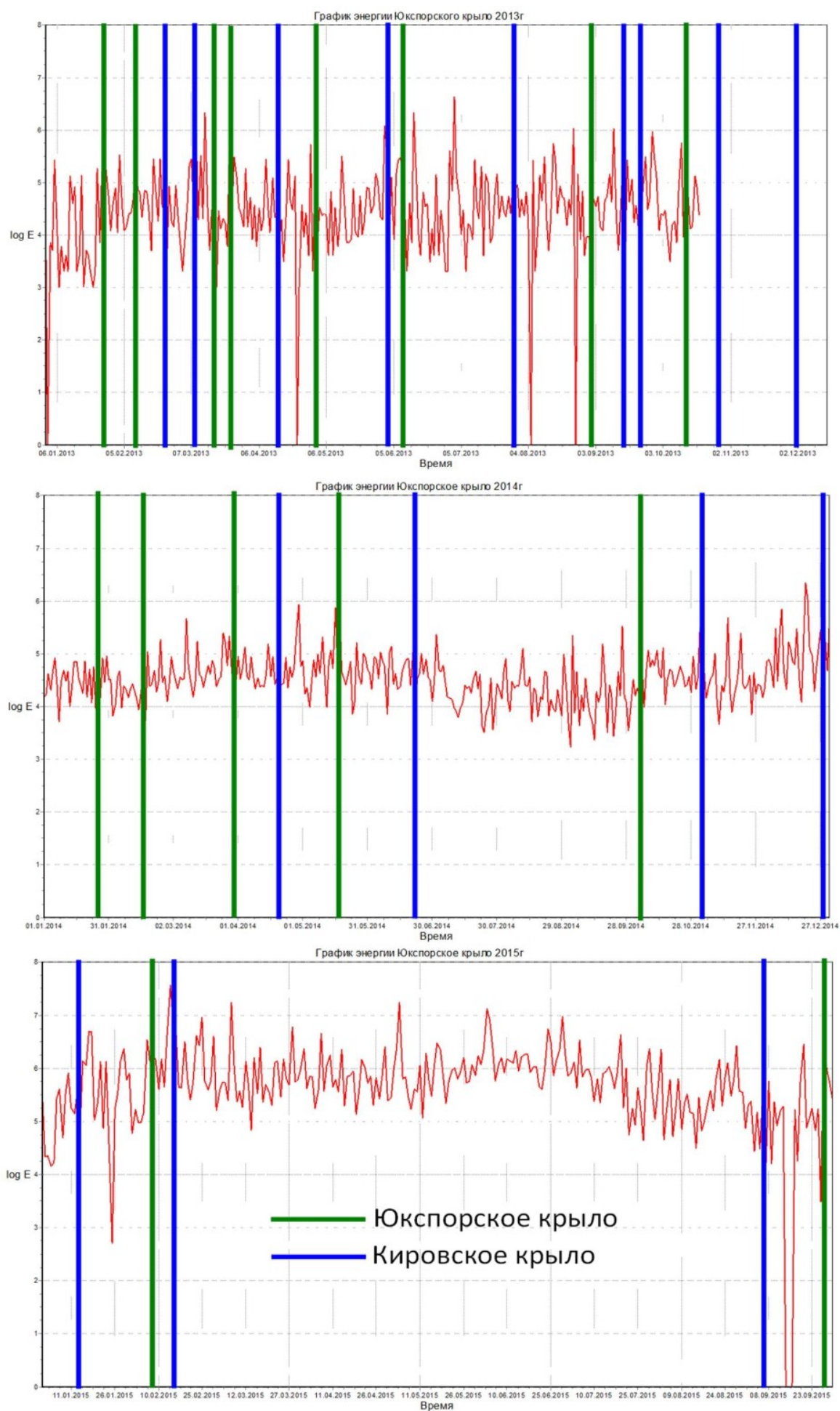

Рис. 4.4. Взаимосвязь проявления суточной техногенной сейсмичности с режимом ведения взрывных работ для Юкспорского крыла ОКР в 2013-2015 гг. 
Из представленных данных следует, что на проявление техногенной сейсмичности в массиве горных пород шахтных полей оказывают влияние массовые взрывы, производимые на обоих подземных рудниках, а также выявлено, что с уменьшением количества массовых взрывов происходит увеличение общего количества сейсмических событий (табл. 4.2).

Таблийа 4.2

Количество массовых взрывов и сейсмических событий по годам для объединенного Кировского рудника

\begin{tabular}{|l|c|c|c|}
\hline & 2013 г. & 2014 г. & 2015 г. \\
\hline Кировское крыло & $10 \mathrm{MB}-1379 \mathrm{CC}$ & $3 \mathrm{MB}-977 \mathrm{CC}$ & $3 \mathrm{MB}-4170 \mathrm{CC}$ \\
\hline Юкспорское крыло & $8 \mathrm{MB}-1955 \mathrm{CC}$ & $5 \mathrm{MB}-9054 \mathrm{CC}$ & $2 \mathrm{MB}-10752 \mathrm{CC}$ \\
\hline
\end{tabular}

За рассматриваемый период было произведено всего 30 массовых взрывов (табл. 4.2), из них в 2013 г. - 18, 2014 г. - 8, 2015 г. - 5. При этом средний массовый взрыв составил на Кировском крыле - 47,7 т ВВ, а на Юкспорском - 112 т ВВ. Такой режим ведения взрывных работ не мог не сказаться на проявление техногенной сейсмичности.

Для рассматриваемых условий при регулярном проведении массовых взрывов происходит более равномерное проявление техногенной сейсмичности на обоих рудниках. Уменьшение числа массовых взрывов на Кировском крыле в 2014 г. привело к снижению количества сейсмических событий, а после пятимесячного отсутствия массовых взрывов сейсмическая активность массива горных пород значительно увеличилась, и в октябре 2015 г произошло техногенное землетрясение. В данный период зарегистрировано большое количество крупных событий (4 энергетического класса и выше): в 2013 г. - 88 сейсмических событий (СС) (всего - 1379 СС), в 2014 г. - 72 (всего - 977 СС) и в 2015 г. — 94 (всего - 4170 СС). Местоположение сейсмических событий в пределах шахтного поля Кировского крыла представлено на рисунке 4.5.

Из рисунка следует, что все крупные сейсмические события приурочены к консоли необрушенных пород и разломным зонам

На Юкспорском крыле с уменьшением числа массовых взрывов, наоборот, происходило увеличение количества сейсмических событий. Уровень выделившейся суточной сейсмической энергии, средней в 2013-2014 гг., составляет приблизительно $5 \cdot 10^{4}$ Дж. Следует отметить, что несмотря на четырехкратное увеличение сейсмических событий в 2014 г. средний уровень суточной сейсмичности находился примерно на одном уровне, то есть ее увеличение происходило за счет более мелких событий. В 2015 г. сейсмическая активность значительно активизировалась и достигла уровня $3 \cdot 10^{6}$ Дж. При этом сейсмические события концентрировались в основном в блоке-целике и в консоли необрушенных пород. На Юкспорском крыле за этот период было зарегистрировано следующее количество крупных событий (4 энергетического класса и выше): в 2013 г. - 96 событий (всего - 1955 СС), в 2014 г. - 108 (всего - 9054 СС) и в 2015 г. - 91 сейсмическое событие (всего - 10752 СС) (рис. 4.6).

Распределение сейсмических событий в пределах шахтного поля за указанный период приведено на рисунке 4.7 , а на рисунке 4.8 - количество выделенной суточной сейсмической энергии за этот же период. 
Сейсмическая обстановка на Кировском крыле ОКР за рассмотренный период характеризуется довольно неравномерным распределением сейсмических событий. Так, в 2013 г. они распределены практически по всему шахтному полю. Уровень выделившейся суточной сейсмической энергии в среднем составляет $5 \cdot 10^{4}$ Дж. В 2014 г. уровень выделившейся суточной сейсмической энергии несколько снизился и составлял в среднем $10^{3}$ Дж, а в 2015 г. сейсмическая активность значительно активизировалась и достигла уровня $3 \cdot 10^{5}$ Дж. При этом сейсмические события концентрировались в основном в пределах разрезов 8-14 и приурочены к границам отработки и разлому в консоли необрушенных пород. За этот период было произведено 15 массовых взрывов на Юкспорском крыле и 17 - на Кировском.

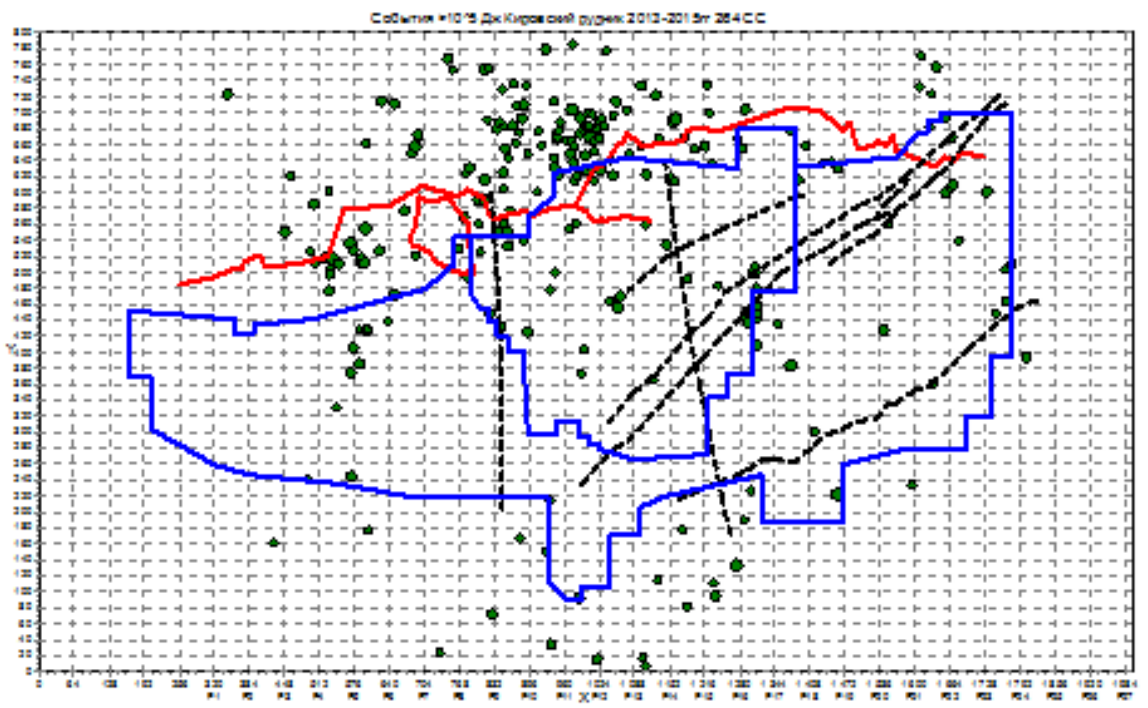

Рис. 4.5. Местоположение крупных сейсмических событий с энергией $10^{5}$ и более Дж в пределах шахтного поля Кировского крыла ОКР

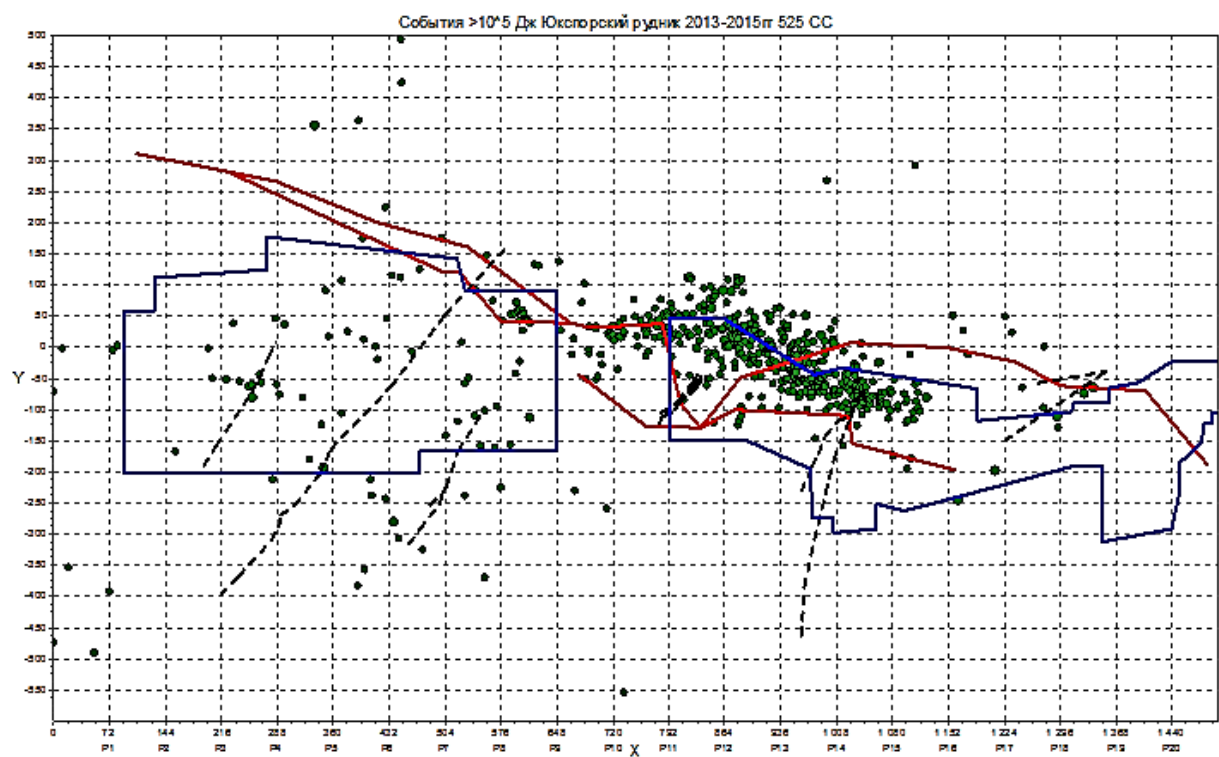

Рис. 4.6. Местоположение крупных сейсмических событий с энергией 105 и более Дж в пределах шахтного поля Юкспорского крыла ОКР 

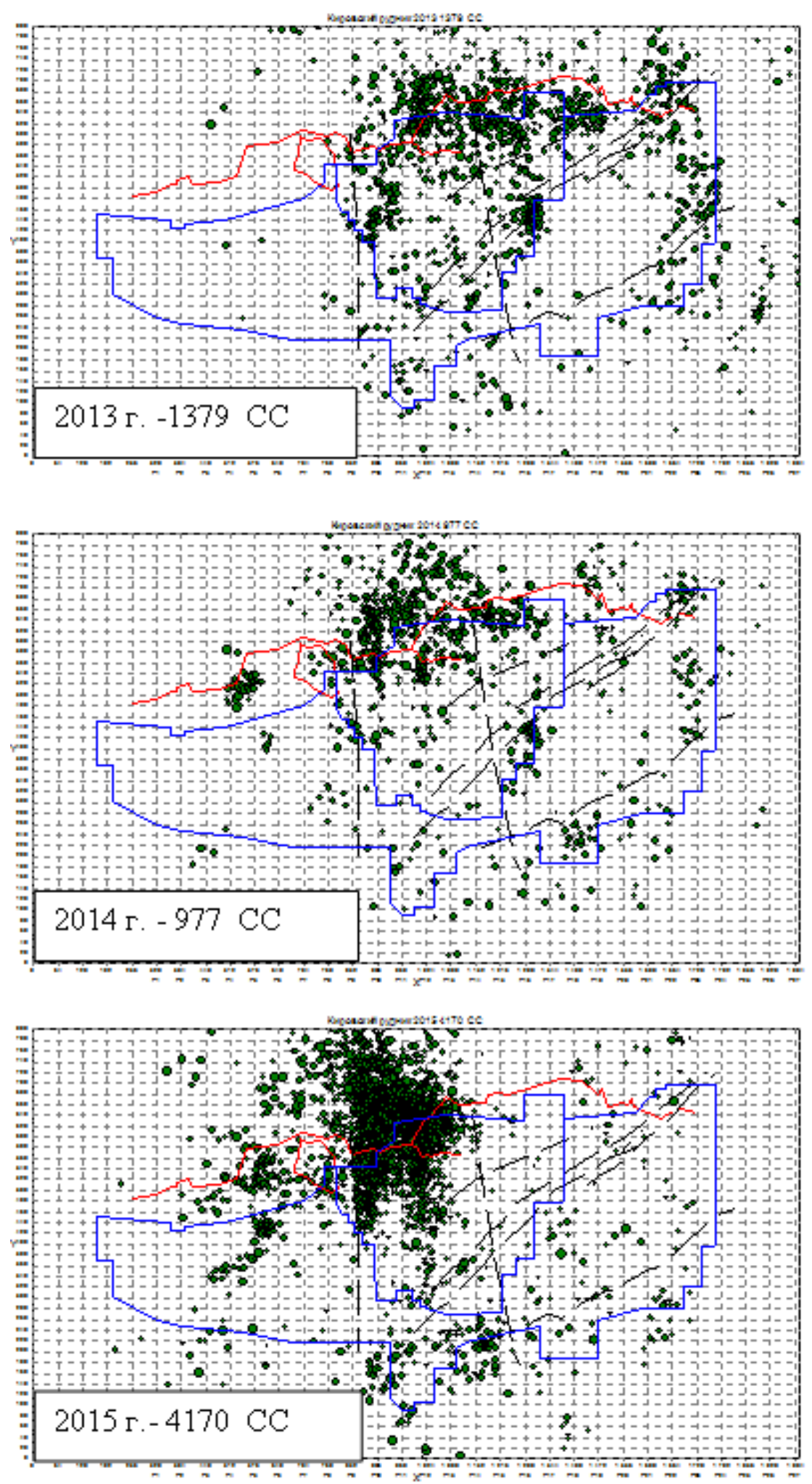

Рис. 4.7. Сейсмические события (СС) на Кировском крыле ОКР в 2013-2015 гг. 


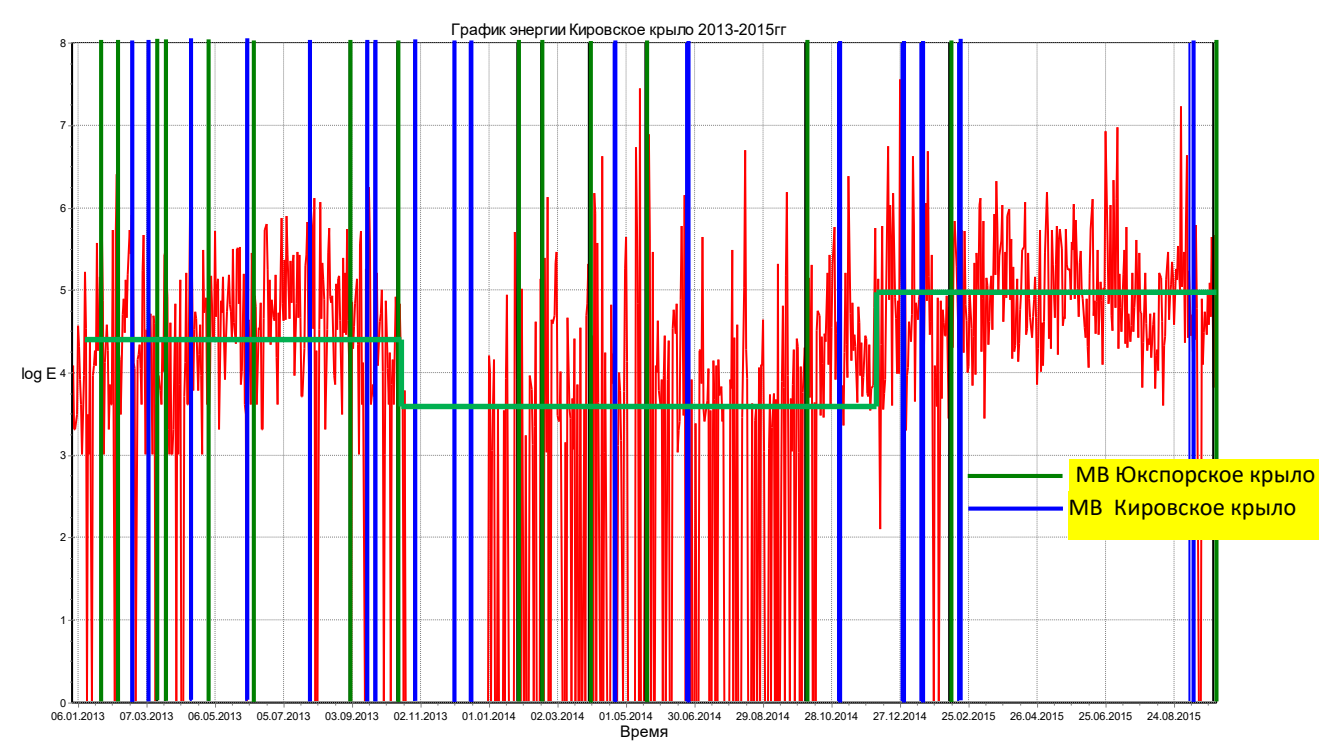

Рис. 4.8. Соотношение выделившейся суточной сейсмической энергии на Кировском крыле ОКР в 2013-2015 гг. и времени производства массовых взрывов (обозначены вертикальными линиями зеленого и синего цветов)

\subsection{2 Развитие методики и выявление закономерностей проявлений техногенной сейсмичности для определения сейсмоопасных участков и улучщения временной локализации периодов повыщенного риска в различных зонах ведения крупномасштабных горных работ}

Горные работы на рудниках Хибин достигли таких объемов, которые обусловили существенное увеличение техногенного воздействия на тектонически напряженный массив, что проявляется в подвижках блоков, формировании на поверхности больших зон обрушения, трещин отрыва и других проявлений.

Проявление крупных сейсмических событий, горных ударов и техногенных землетрясений зависит от подготовки их очагов к естественной разрядке. С приближением к моменту выброса накопленной энергии очаговая зона становится более чувствительной к внешним воздействиям. Поэтому в первую очередь необходимо выявить подготовленный очаг, после чего следует принимать меры по его разрядке либо искусственным воздействием, либо применять профилактические мероприятия по защите объектов, попадающих в зону действия того или иного события [11].

За последние десятилетия разработано множество физических методов и моделей прогноза землетрясений и горных ударов, основанных на сеймологических, деформационных, геомеханических, электромагнитных, гидрогеологических, метеорологических и других данных. Количественные результаты прогноза землетрясений при этом в основном вероятностные. Неопределенность и недостаточная точность этих прогнозов не позволяет правомерно их применять [148]. Поэтому определение степени сейсмической опасности тех или иных участков шахтных полей до сих пор остается весьма сложной задачей. 
Региональный прогноз удароопасности шахтных полей осуществляют с помощью микросейсмического районирования. Одним из наиболее распространенных параметров сейсмического режима шахтного поля, по которому производят микрорайонирование, является уровень сейсмической активности $A_{\triangle E}$, под которым понимается количество сейсмических событий $N$ определенного диапазона энергии $\Delta E$, происшедших за фиксированный промежуток времени $\Delta T$ в определенном объеме горных пород $V$. Количественные значения параметров сейсмической активности при районировании и критериальные значения границ оконтуриваемых зон удароопасности выбирают эмпирическим путем в процессе непрерывных наблюдений, при этом они являются специфическими для каждого конкретного месторождения [149].

Подход к прогнозу горно-тектонических ударов и техногенных землетрясений по анализу микросейсмичности массива основан на кинетической концепции прочности твердых тел или ее модификации для землетрясений в виде модели лавинно неустойчивого трещинообразования. В соответствии с этой концепцией процесс разрушения твердых тел протекает в несколько стадий — от возникновения мелкомасштабных трещин (микротрещин длиной миллиметры и сантиметры) до крупномасштабных разрывов (горно-тектонические удары и землетрясения с разрывами от десятков метров до километров).

Процесс разрушения развивается в пространстве и во времени, поэтому критерии прогноза сейсмических событий должны в первую очередь учитывать именно пространственно-временные параметры потока микросейсмичности. Однако в одном критерии учесть обе стороны процесса сложно. Поэтому в качестве первого шага к осуществлению прогноза принят подход одновременного рассмотрения однопараметровых критериев, отражающих какую-либо одну из особенностей процесса разрушения. В настоящее время применяют в основном два критерия прогноза: вариации временных интервалов (ВВИ) между сейсмическими событиями и изменения фрактального размера пространственного распределения сейсмических событий FD $[150,151]$. Особенностью этих методик является то, что они рассчитаны на прогноз в квазисплошном массиве при естественном ходе подготовки мощного сейсмособытия.

Включение в анализ всех событий с различными механизмами их реализации таких, как в результате подвижек по разломам или трещин отрыва в консоли зависающих пород, отличающихся от развития процесса разрушения в квазисплошном массиве, снижает эффективность прогноза по рассмотренным критериям [21]. Кроме того, производство на подземных рудниках мощных массовых взрывов может ускорить процесс реализации крупных сейсмических событий, а деформирование блочной структуры реальной геологической среды в результате внешних воздействий приводит к пространственному распределению энергии на значительных площадях и, как следствие, к интенсификации релаксационных процессов (локальные разрушения и взаимная подвижка блоков) [152]. В таких условиях поведение системы не предсказуемо.

Поэтому изыскание дополнительных физических методов и моделей прогноза является весьма актуальной задачей. Для ее решения нами была адаптирована к условиям подземных рудников Хибин теория количественного описания сейсмических процессов в реальной среде, основанная на законе производства сейсмической энтропии [148], создан программный комплекс ACS и рассмотрена кинетика техногенного сейсмического процесса при ведении горных работ на рудниках. 
Теория количественного описания - это установление в течение некоторого временного интервала $T$ (сейсмического цикла) закономерностей между параметрами крупных сейсмических событий и кумулятивными параметрами событий индикаторов, которые позволяют с некоторой точностью предсказать поведение системы. Состояние сейсмической системы внутри сейсмических циклов (между двумя крупными событиями) $t_{\mathrm{cj}-1}<t<t_{\mathrm{cj}}$ описывается кумулятивными параметрами $E_{\mathrm{c}}$ и $S_{\mathrm{c}}$ :

$$
E_{\mathrm{c}}=\sum_{i=1}^{N_{\mathrm{ct}}} E_{i}, S_{\mathrm{c}}\left(E_{\mathrm{c}}, t\right)=\left(t-t_{\mathrm{c} j-1}\right) * E_{\mathrm{c}}-\sum_{i=1}^{N_{\mathrm{c} t}}\left\{\left(t_{i}-t_{\mathrm{c} j-1}\right)\right\},
$$

где $t_{i}-$ время излучения событий-индикаторов; $E_{i}-$ сейсмическая энергия событий-индикаторов; $N_{\mathrm{ct}}$ - число всех событий-индикаторов внутри сейсмического цикла на момент времени $t ; S_{\mathrm{c}}$ - функция плотности состояния сейсмической системы. Эта функция одновременно содержит в себе пространственно-временную и энергетическую информацию о сейсмическом событии.

По результатам вычислений строятся трековые диаграммы в плоскости $W \mathrm{~K}\left(W_{a}\right.$ - энтропия, $\mathrm{K}_{c j}$ - класс сейсмического события).

По аналогии с определением физической энтропии в термодинамике, величина $W_{a}$ определяется как энтропия очаговой области:

$$
W_{\mathrm{c}}=\lg S_{\mathrm{c}}=\lg \left(S_{\mathrm{c}} \cdot t_{\mathrm{c}}-\Sigma E_{i} t_{i}\right) .
$$

Функция $S_{\mathrm{c}}$ является неубывающей и имеет размерность (энергия·время),

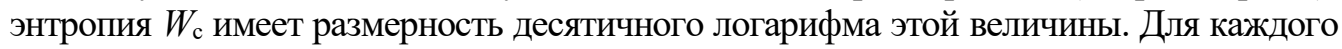
завершившегося сейсмического цикла на основе событий-индикаторов можно рассчитать два параметра, которые описывают состояние системы:

$$
\mathrm{K}_{\mathrm{cj}}=\lg E_{\text {с } i} \text { и } W_{\mathrm{c} i}=\lg S_{\mathrm{c} i} .
$$

Состояние системы описывается двумя независимыми контролирующими параметрами - энтропией $W_{\mathrm{c}}$ и кумулятивным энергетическим классом $\mathrm{K}_{\mathrm{c}}$.

Форма трека отражает механизм неустойчивости и подвижек в массиве, а по областям, в которых концентрируются похожие по форме треки, можно определить состояние массива. Чем продолжительней и многоступенчатей трек, тем более спокойная обстановка в массиве.

В связи с тем, что процесс расчета сейсмически опасных зон достаточно трудоемкий и занимает много времени, возникла необходимость создания программного обеспечения этой методики.

Программа ACS предназначена для мониторинга сейсмической обстановки по имеющимся сейсмическим данным формата DB и DBF.

На рисунках 4.9 и 4.10 показан внешний вид и описание меню программы ASC.

Использование этой программы позволяет оперативно оценивать сейсмическую обстановку на подземных рудниках, определять местоположение сейсмоопасных зон и степень их готовности к потере устойчивости. 


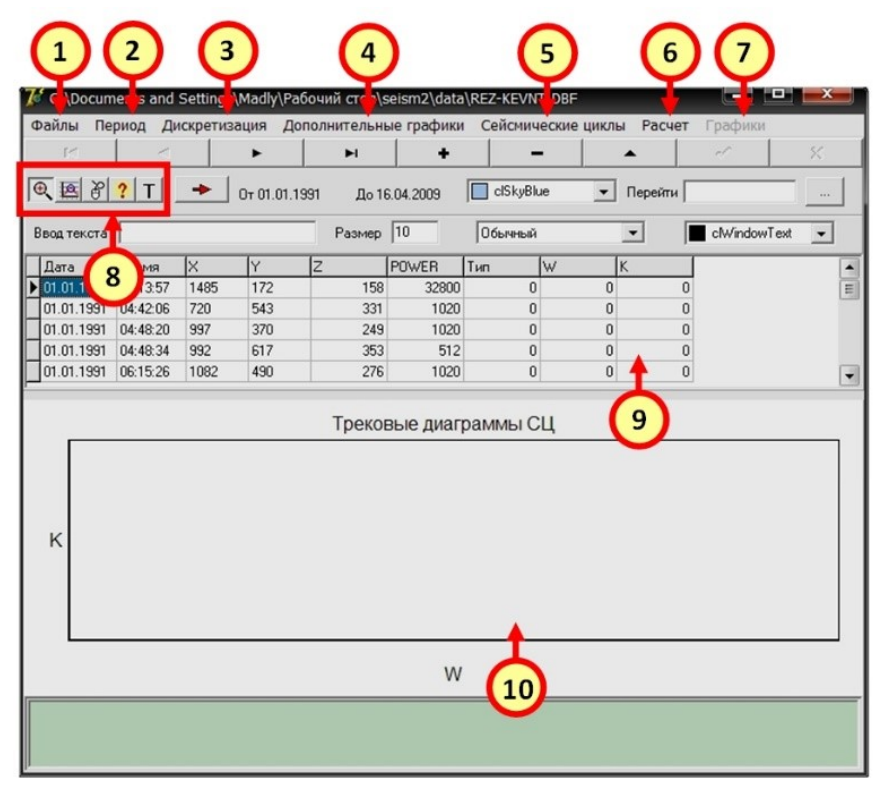

Pис. 4.9. Внешний вид первого модуля программы ASC: 1 - открытие базы данных (БД) с СС на рудниках (БД с крупными СС, БД по массовым взрывам (МВ)); 2 - определение временного промежутка для расчета; 3 - проведение дискретизации данных; 4 - отображение всех СС в плоскости $X Y$ и построение графика энергии; 5 - определение класса цикла; $6-$ расчет $W$ и $\mathrm{K} ; 7$ - отображение сейсмических циклов в новом окне, сохранение и редактирование информации, настройки; 8 - инструменты для работы с сейсмическим циклом СЦ; 9 - область редактирования БД; 10 - область отображения трековых диаграмм

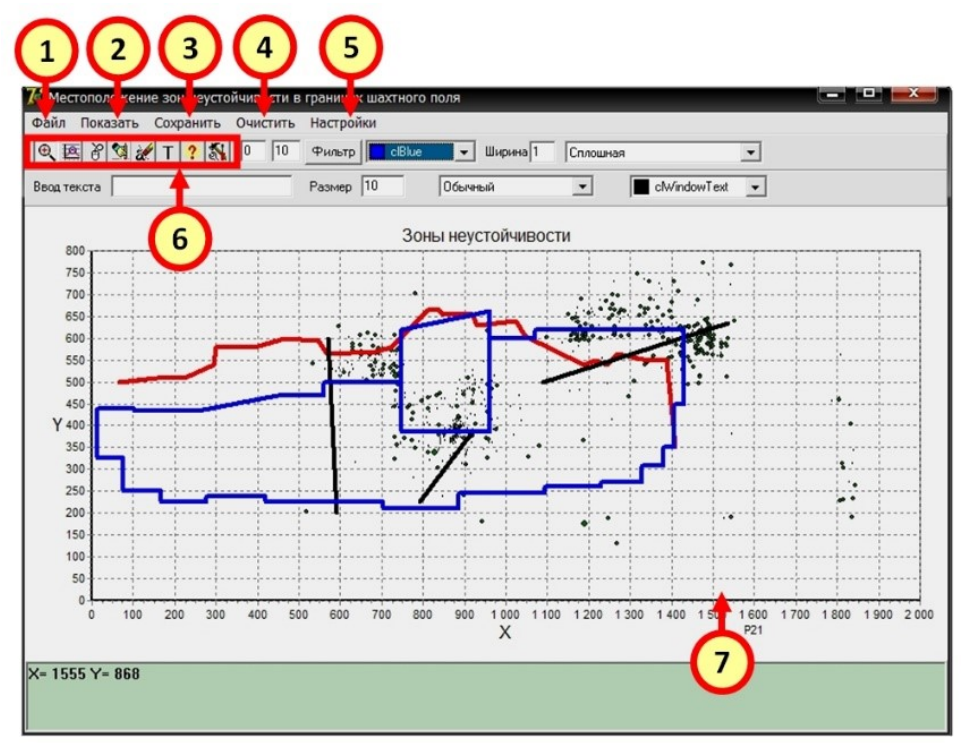

Рис. 4.10. Внешний вид второго модуля программы ASC: 1 - создание и редактирование элементов разработки и геологических нарушений; 2 - показать/убрать элементы разработки; 3 - сохранение результатов; 4 - очистить введенные линии и области; 5 - настройки рабочей области; $6-$ инструменты редактирования; 7 - область сейсмических циклов и сейсмических событий 


\subsection{3. Выявление опасных состояний в массиве горных пород в различных зонах ведения крупномасштабных горных работ за 2013-2015 годы}

Рассмотрена возможность применения данной методики к количественному описанию техногенного сейсмического процесса при ведении горных работ на Хибинских подземных рудниках. За сейсмическую систему принята площадь горного отвода Кировского рудника (ОКР), которая включает в себя все сейсмические события в энергетическом диапазоне $E=10^{2}-10^{7}$ Дж, зарегистрированные системой сейсмического мониторинга КФ АО «Апатит».

В качестве сейсмического цикла принимался временной интервал между двумя крупными сейсмическими событиями с энергией $E>10^{5}$ Дж, а в качестве индикаторов принимали сейсмические события с энергией $E=10^{2}-10^{4}$ Дж.

\section{Кировское крыло ОКР}

С целью выявления опасных состояний в массиве горных пород были рассчитаны сейсмические циклы, построены трековые диаграммы и аттракторы, которые представлены на рисунке 4.11, а на рисунке 4.12 отражены наиболее опасные зоны в границах шахтного поля.

Из рисунка 4.11 следует, что в 2013-2014 гг. имело место примерно одинаковое количество длинно-, средне- и короткоживущих циклов, что соответствует стационарному выделению энергии из массива горных пород.

В 2015 г. количество длинноживущих циклов значительно уменьшилось, но возросло количество средне- и короткоживущих, что говорит о переходе системы в новое неустойчивое состояние. Такая последовательность проявления зон неустойчивости связана как с технологией ведения горных работ, так и с воздействием на массив массовых взрывов.

Для выявления зон неустойчивости в конкретных условиях на план горных работ Кировского крыла переносились сейсмические события, завершающие циклы из каждой выделенной зоны (рис. 4.12), с отображением границ обрушения покрывающих пород и фронта горных работ.

Из представленных данных следует, что в 2013 г. зона неустойчивого состояния с незначительным уровнем сейсмичности была приурочена к границам обрушения покрывающих пород и простиралась от 10 разреза до Саамского карьера. Это вызвано тем, что вблизи зон концентрации сейсмических событий за год было произведено 11 массовых взрывов, не считая технологических (с промежутками между ними примерно 1 раз в месяц) и массив не успел накопить упругую энергию, что и обеспечило равномерное выделение энергии.

В 2014 г. зоны неустойчивости с еще меньшим уровнем сейсмичности несколько уменьшились в размере и их местоположение осталось в тех же границах отработки. Снижение размеров указанных зон и уровня сейсмичности связано с уменьшением количества производимых в этом месте взрывов до 5 .

В 2015 г. в связи с увеличением количества взрывов при расширении фронта очистных работ вдоль висячего бока активизировалась северная часть рассматриваемого участка, и образовалась вторая зона неустойчивости. Обе зоны примыкают к пересекающему рудное тело разлому, что и привело к его активизации с увеличением сейсмической активности.

Таким образом, количество закачанной в массив горных пород энергии от массовых взрывов существенным образом влияет на его сейсмоактивность. 

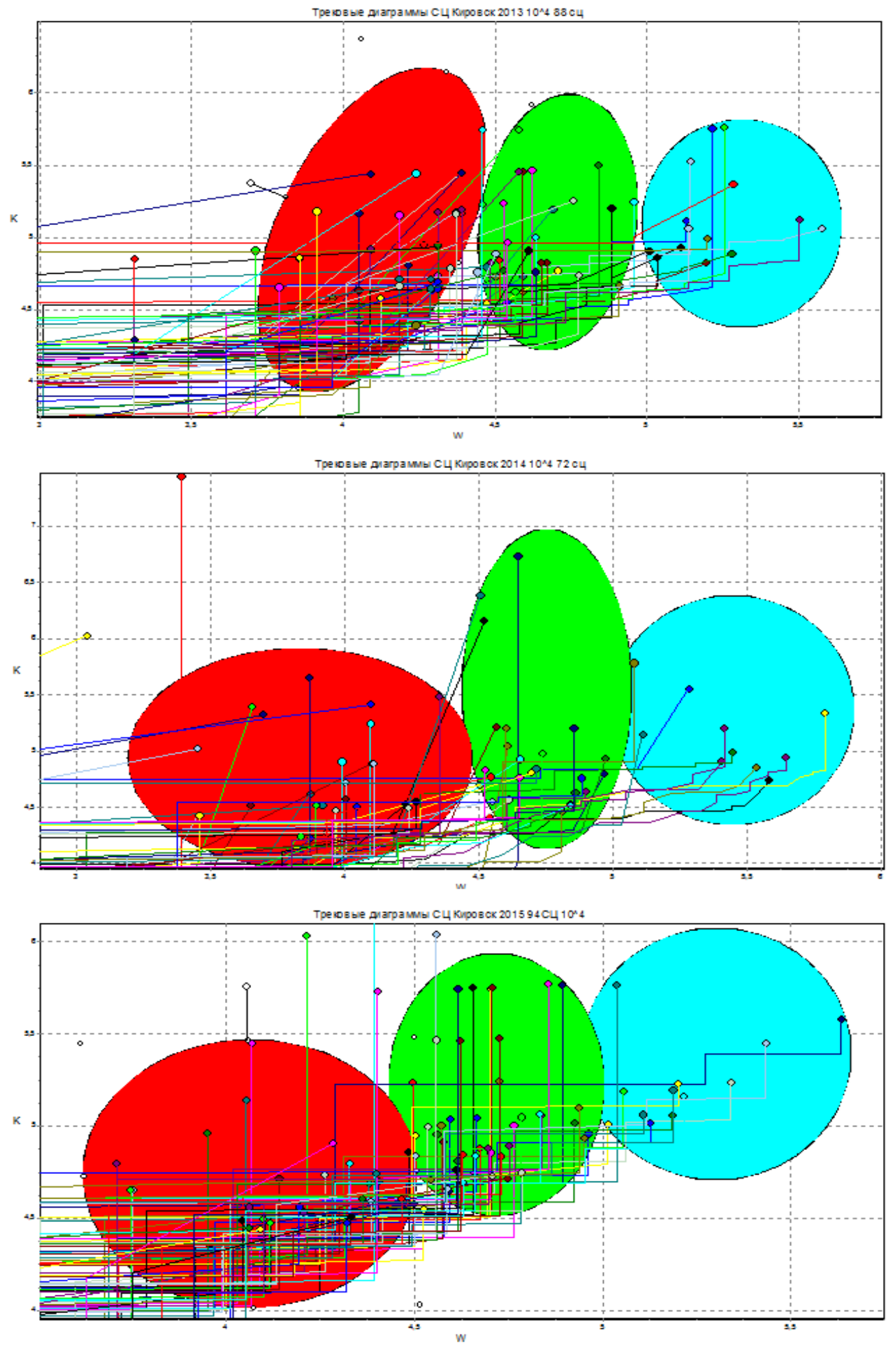

Рис. 4.11. Трековые диаграммы сейсмических циклов и аттракторы для Кировского крыла за 2013-2015 гг. (красный, зеленый и синий цвета соответствуют коротко-, средне- и длинноживущим циклам соответсвенно) 

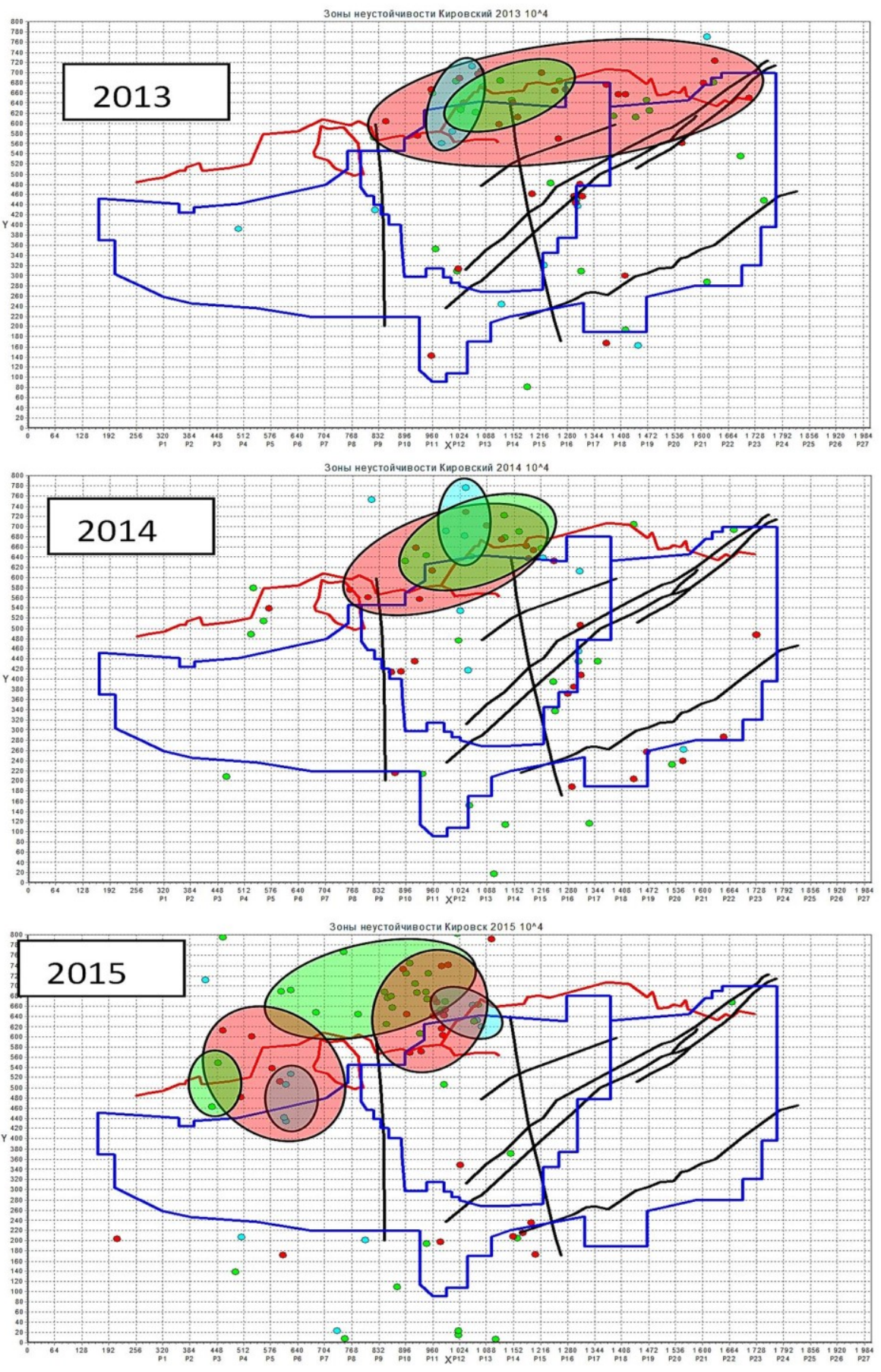

Рис. 4.12. Местоположение зон неустойчивого состояния в границах шахтного поля Кировского крыла ОКР в 2013-2015 гг. по циклам 5 энергетического класса

Юкспорское крыло ОКР

Для Юкспорского крыла ситуация с техногенной сейсмичностью несколько иная. За исследуемый период (рис. 4.13) характерно значительное увеличение количества сейсмических событий по годам: в 2013 г. - 1955 СС, 2014 г. — 9054 СС, 
2015 г. - 10752 СС. Особенно сильное увеличение сейсмичности произошло в 2014 г, когда интенсивно стали отрабатывать блок-целик, а в 2015 г. количество сейсмических событий увеличилось в 5 раз по сравнению с 2013 г.
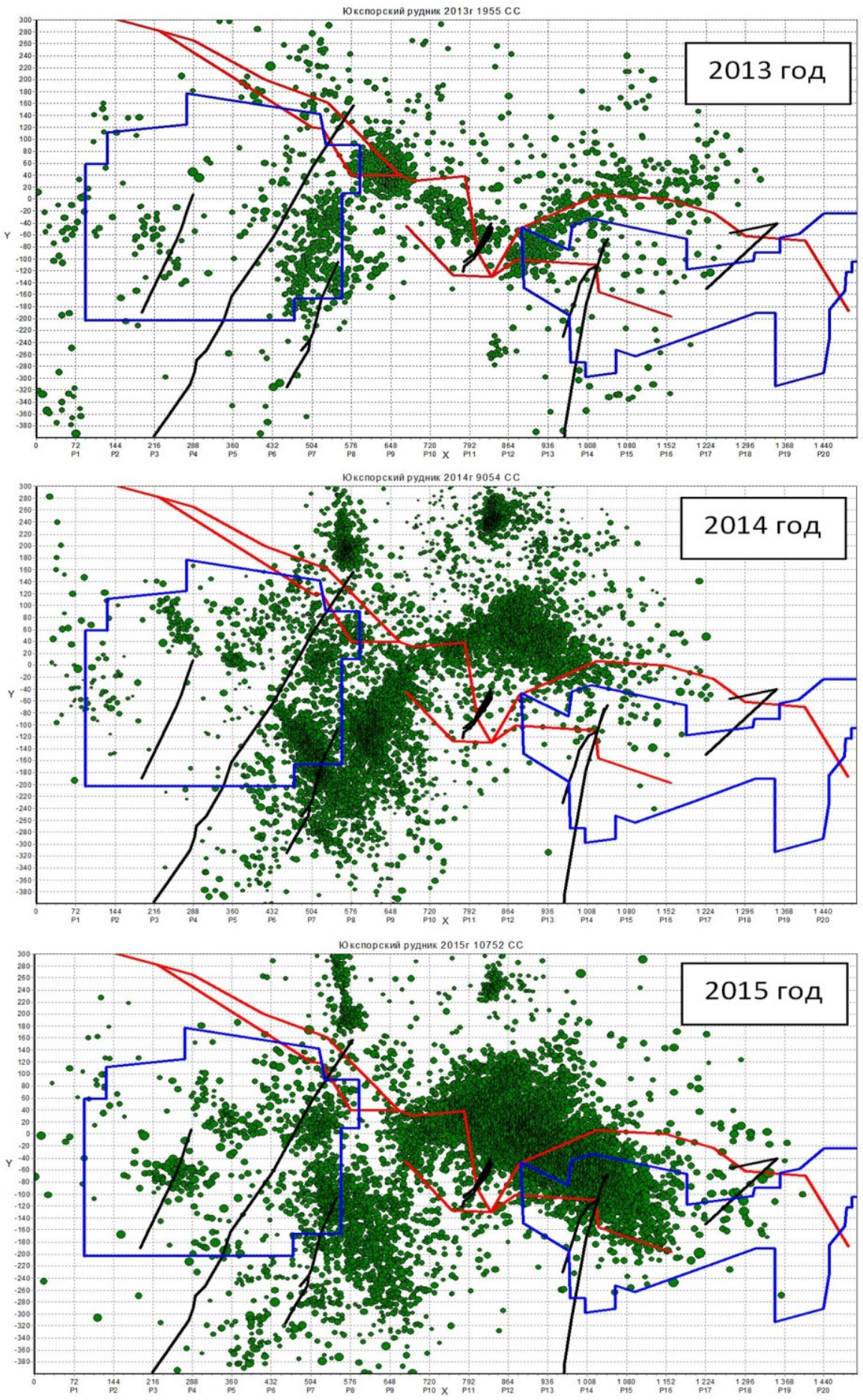

Рис. 4.13. Распределение сейсмических событий на Юкспорском крыле ОКР в 2013-2015 гг. 
Количество выделенной суточной сейсмической энергии за этот период представлено на рисунке 4.14.

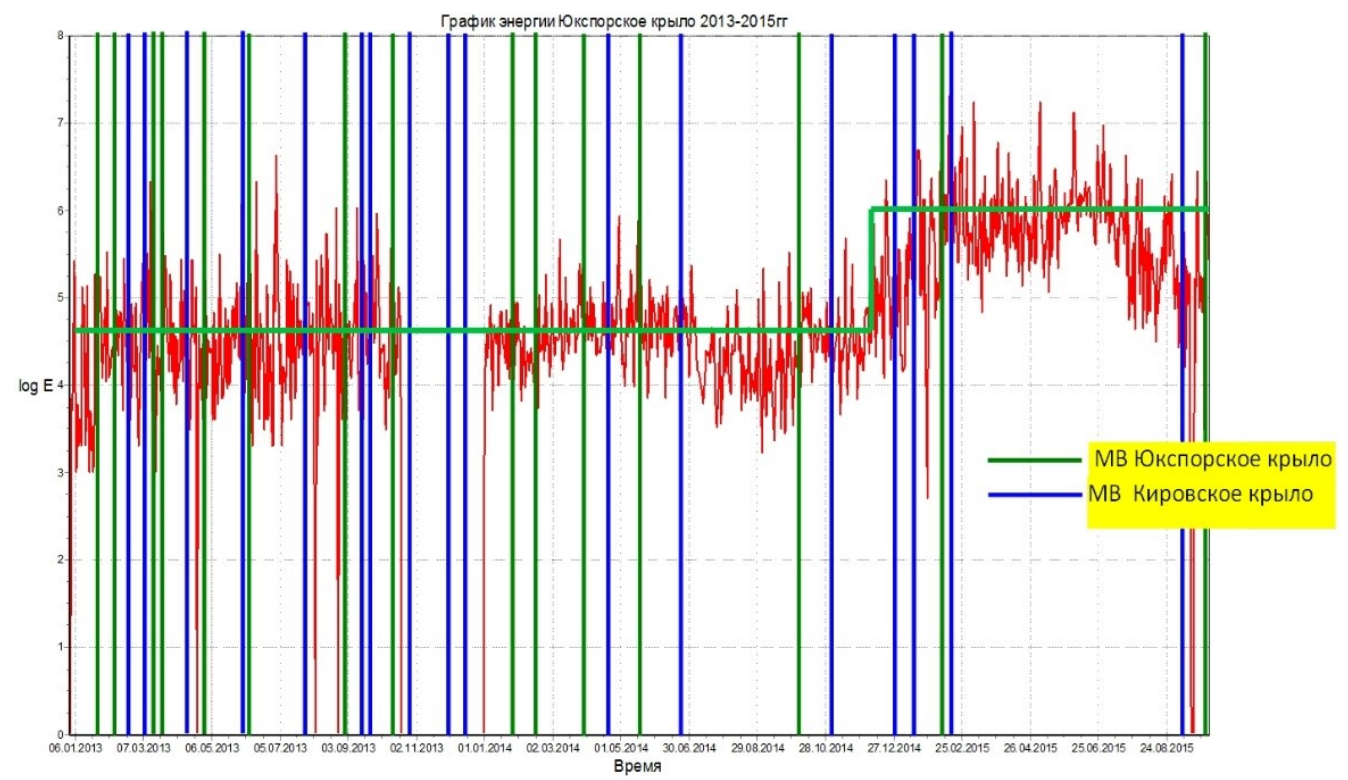

Рис. 4.14. Сопостовление выделившейся суточной сейсмической энергии на Юкспорском крыле ОКР в 2013-2015 гг. со временем производства массовых взрывов (обозначены вертикальными линиями зеленого и синего цветов)

Уровень выделившейся средней суточной сейсмической энергии

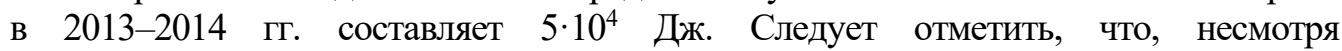
на четырехкратное увеличение сейсмических событий в 2014 г., средний уровень суточной сейсмичности находился примерно на одном уровне, то есть увеличение сейсмичности происходило за счет более мелких событий. В 2015 г. сейсмическая активность значительно активизировалась и достигла уровня $3 \cdot 10^{6}$ Дж. При этом сейсмические события концентрировались в основном в блоке-целике и в консоли необрушенных пород.

С целью выявления опасных состояний в массиве горных пород были рассчитаны сейсмические циклы, построены трековые диаграммы и аттракторы, которые представлены на рисунке 4.15, а на рисунке 4.16 отражены наиболее опасные зоны в границах шахтного поля.

В 2013 г. зоны неустойчивого состояния концентрировались в трех областях. Первая область - разрезы Р8-P10, вторая область - разрезы Р10-P11 и третья область - разрезы Р12-Р14. Области приурочены к границам обрушения и к границам отбойки правого и левого фронта горных работ. В 2014 г. ситуация изменилась. Из трех локальных областей образовалась одна большая область неустойчивого состояния по разрезам Р9-P15 и одна область подготовки по разрезам Р5-P9. В 2015 г. осталась одна область неустойчивого состояния по разрезам Р11-P15, приуроченная к консоли необрушенных пород. 

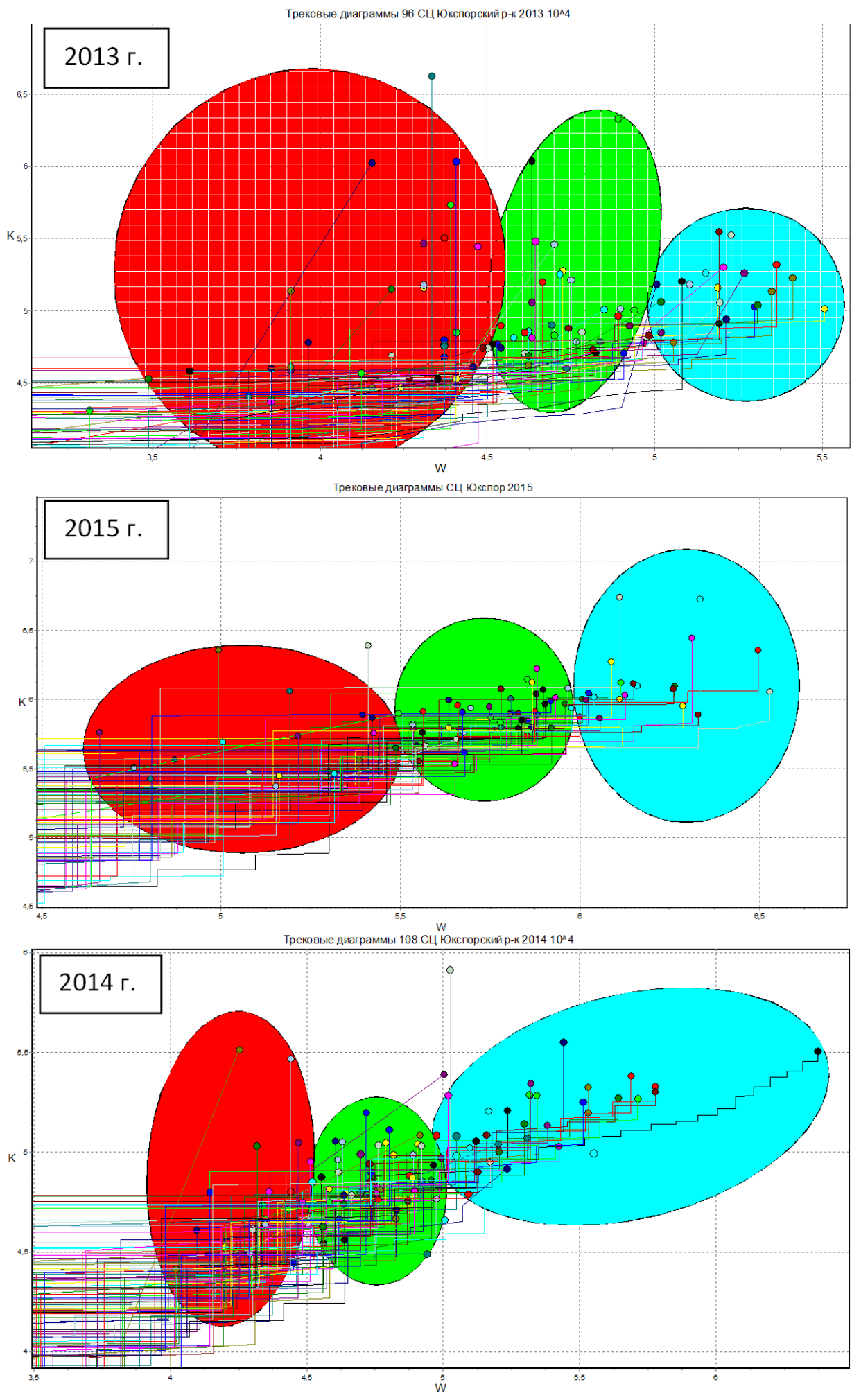

Рис. 4.15. Трековые диаграммы сейсмических циклов и аттракторы для Юкспорского крыла за 2013-2015 гг. 

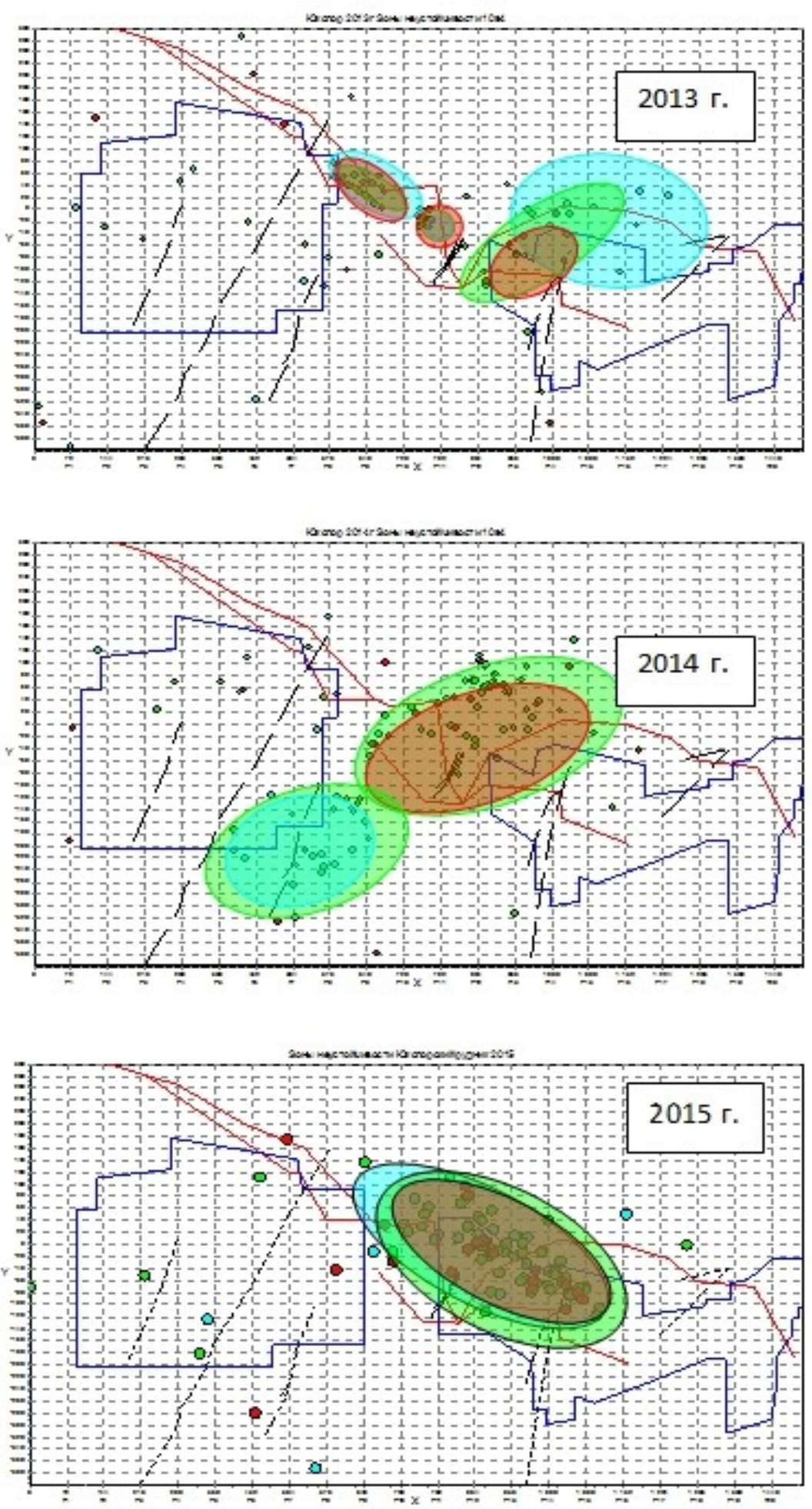

Рис. 4.16. Местоположение зон неустойчивого состояния в границах шахтного поля Юкспорского крыла ОКР в 2013-2015 гг. по циклам 4 энергетического класса 


\subsection{4. Оценка проявления сейсмичности до и после проведения массовых взрывов}

Проведена оценка проявления сейсмичности до и после массовых взрывов и установлено, что после массового взрыва увеличивается общее количество сейсмических событий, но уменьшается суммарная энергия. Причем чем больше разница в общем количестве сейсмических событий, тем больше понижается энергия сейсмической активности (рис. 4.17). При этом общее количество сейсмических событий после массовых взрывов зависит от места их проведения и массы $\mathrm{BB}$, а наиболее крупные события проявляются как в первые сутки, так и в последующие дни после взрыва. Выявить общую закономерность взаимосвязи этих параметров для данных горно-геологических условий довольно сложно.
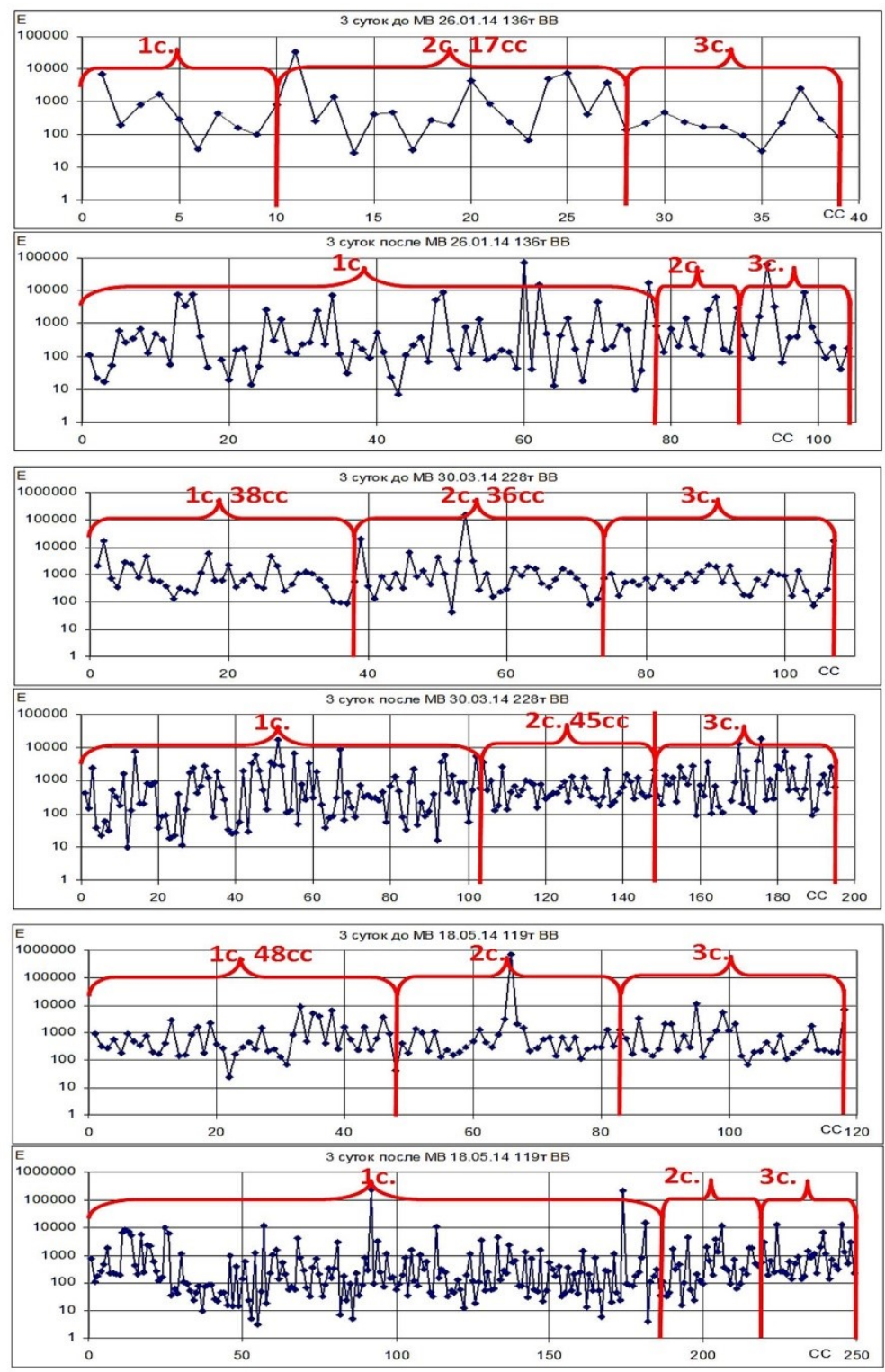

Рис. 4.17. Проявление техногенной сейсмичности за трое суток до и после массовых взрывов на Юкспорском крыле ОКР 
Рассмотрим проявление техногенной сейсмичности при проведении специального взрыва по отбойке стыковочной секции на Юкспорском крыле ОКР (рис. 4.18 и 4.19).
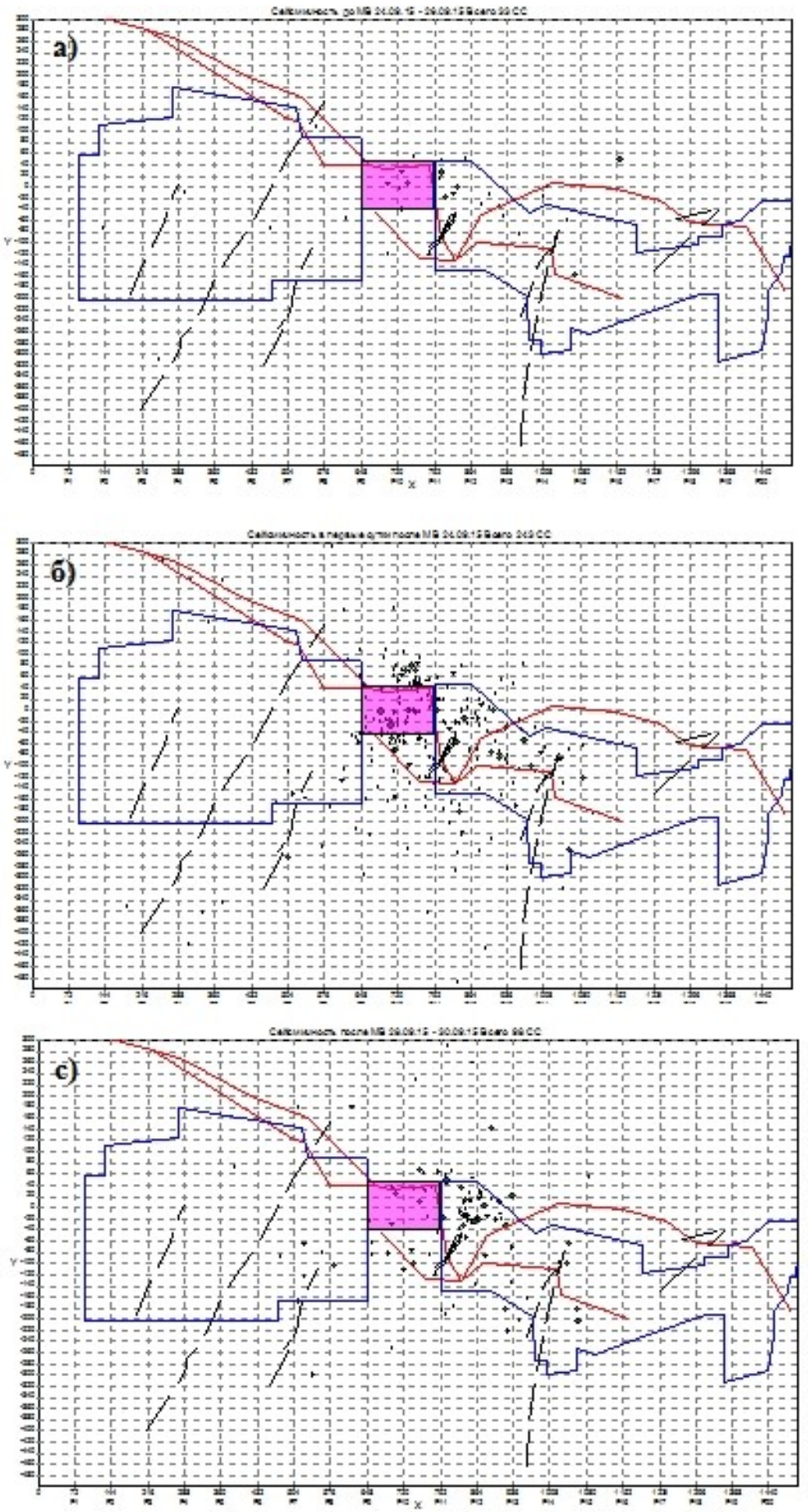

Рис. 4.18. Проявление техногенной сейсмичности за трое суток до взрыва $(a)$, непосредственно в первые сутки после взрыва (б) и в последующие двое суток (c) 


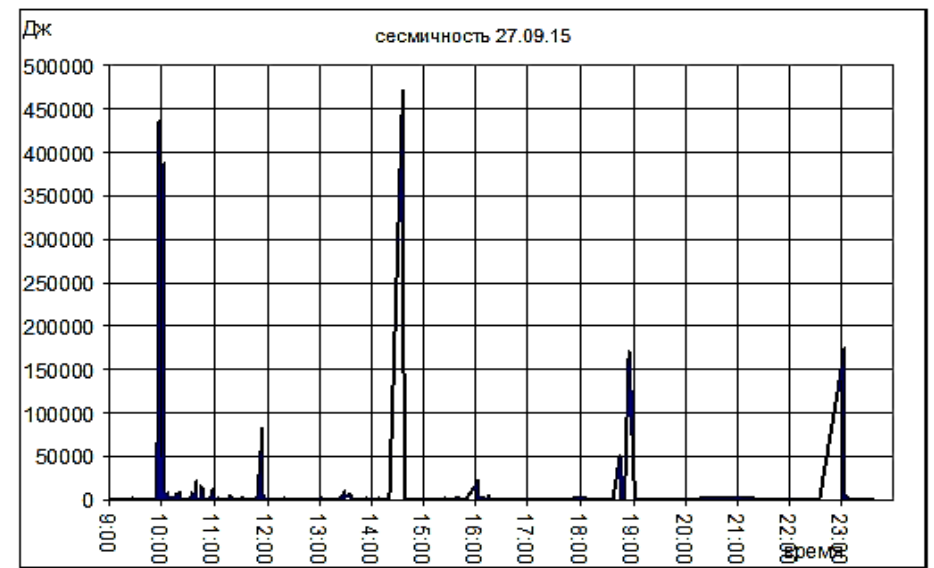

Рис. 4.19. Энергия сейсмических событий в первые сутки после массового взрыва

Как следует из представленных данных, наиболее крупные сейсмические события проявлялись с периодичностью в среднем через 4 ч. Первое крупное событие произошло сразу же после массового взрыва (рис. 4.20).

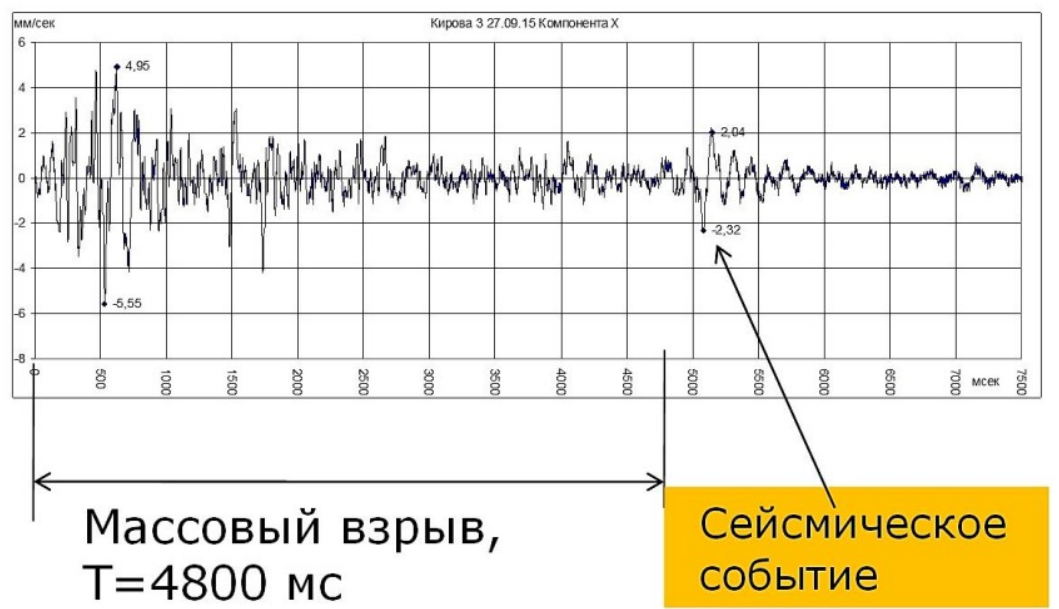

Рис. 4.20. Сейсмограмма колебаний массива от массового взрыва

Очередность проявления сейсмических событий при отбойке стыковочной секции представлена на рисунке 4.21.

Проявление сейсмичности после массового взрыва носит цикличный характер. Первая область приурочена непосредственно к границам отбойки и предыдущего обрушения консоли, в которой произошли практически все крупные сейсмические события, вызванные обрушением покрывающих пород. Вторая область расположена на некотором удалении от границы обрушения. В последующие дни сейсмичность проявлялась вокруг этих очаговых зон, связанных с развитием трещин отрыва в консоли.

Первое обрушение произошло непосредственно после массового взрыва, а второе, наиболее крупное, в 14 ч 30 мин. В дальнейшем обрушения происходили и в последующие сутки. Общий график изменения сейсмичности до и после проведения массового взрыва представлен на рисунке 4.22. 


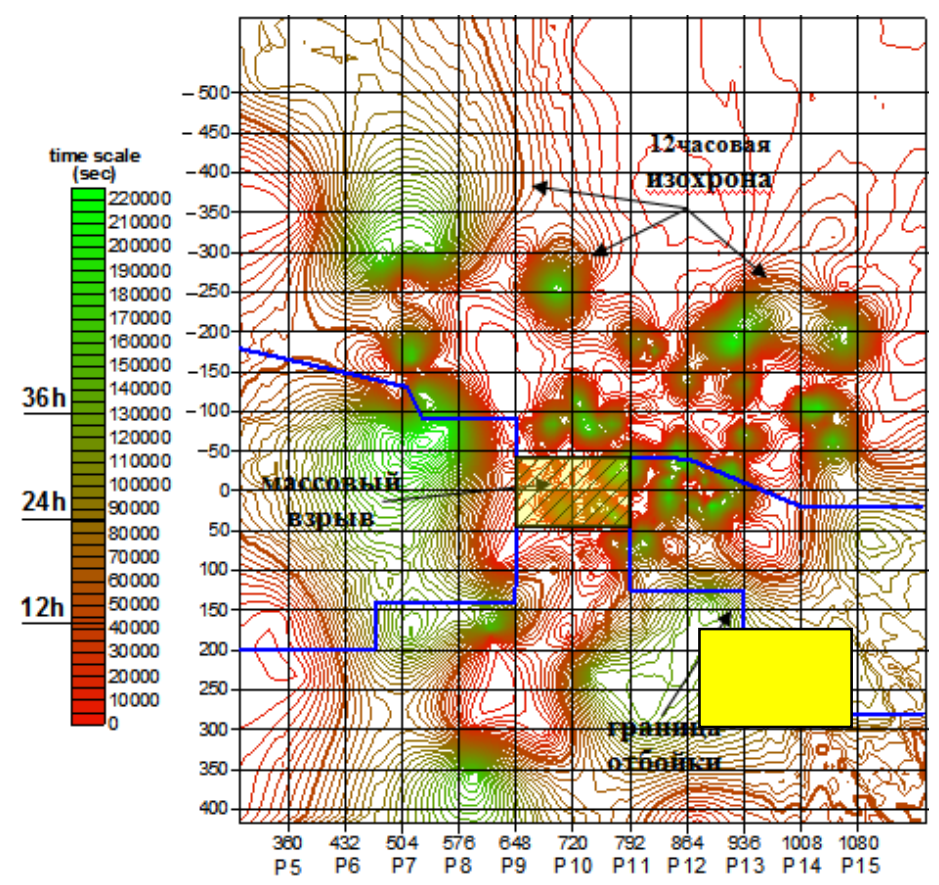

Рис. 4.21. Изохроны очередности проявления сейсмических событий после массового взрыва
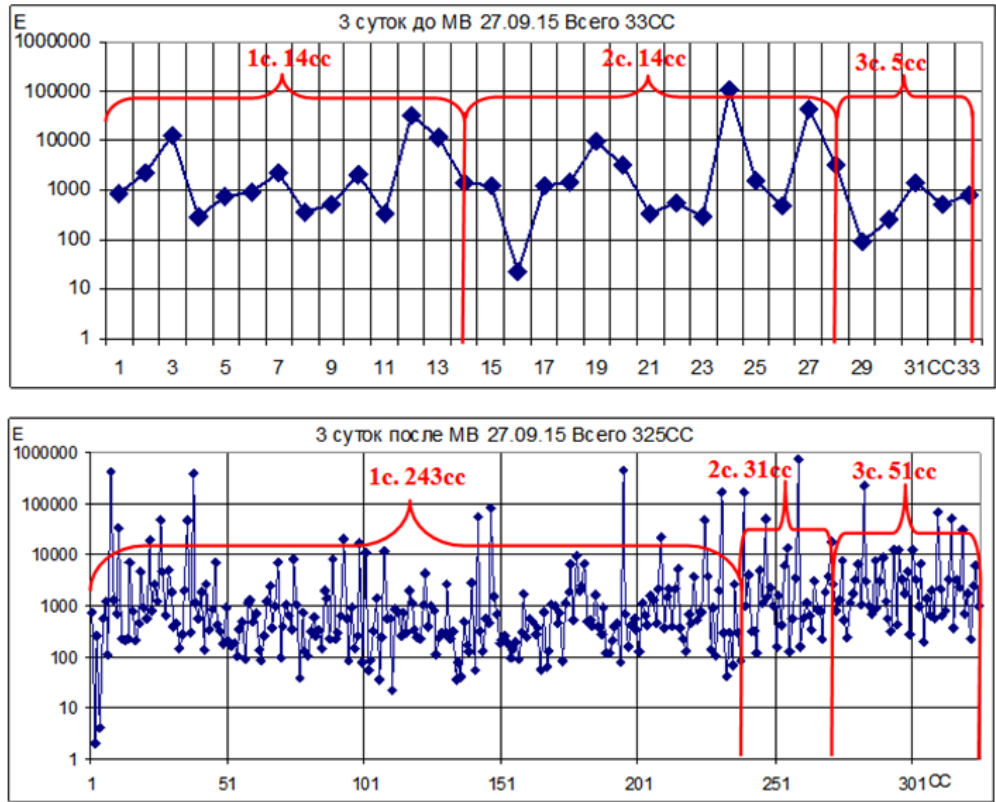

Рис. 4.22. Проявление техногенной сейсмичности за трое суток до и после отбойки стыковочной секции

Таким образом, по результатам исследований для условий отработки Кукисвумчоррского и Юкспорского месторождений установлена взаимосвязь режима ведения взрывных работ с проявлением техногенной сейсмичности и развитием зон с неустойчивым состоянием и показано, что массовые взрывы существенно влияют на проявление сейсмичности в ПТС. 
4.2. Закономерности проявления техногенной сейсмичности при производстве массовых и технологических взрывов на апатитовых подземных рудниках в 2015-2018 годах

В последние годы на подземных рудниках КФ АО «Апатит» добычу руды в полном объеме осуществляют с применением системы разработки с подэтажным обрушением и торцевым выпуском руды.

Отбойку руды массовыми взрывами практически не производят за исключением погашения один раз в год блока-целика на Юкспорском месторождении. Всего за последние четыре года было произведено 9 массовых взрывов, из них 4 - при отбойке стыковочной секции (табл. 4.3).

Таблица 4.3

Взрывы, проведенные в 2015-2018 гг. на ОКР

\begin{tabular}{|c|c|c|c|}
\hline Дата & Время & № участка & Вес ВВ, кг \\
\hline \multicolumn{4}{|c|}{ Взрывы на Кировском крыле ОКР } \\
\hline 13.01 .2015 & $11: 57$ & 8 & 16000 \\
\hline 15.02 .2015 & - & 8 & 38000 \\
\hline 06.09 .2015 & - & 8 & 83000 \\
\hline 21.08 .2016 & $7: 30$ & 14 & 57000 \\
\hline Всего & \multicolumn{3}{|c|}{} \\
\hline \multicolumn{4}{|c|}{ Взрывы на Юкспорском крыле ОКР } \\
\hline 08.02 .2015 & $10: 48$ & 1 & 95000 \\
\hline 27.09 .2015 & $9: 55$ & 3 & 300000 \\
\hline 21.08 .2016 & \multicolumn{3}{|c|}{} \\
\hline 20.03 .2017 & & 3 & 99750 \\
\hline 28.05 .2018 & & 3 & 131000 \\
\hline
\end{tabular}

За рассматриваемый период произведено всего 9 массовых взрывов, из них в 2015 г. - 7, в 2016 г. — 2, в 2017 г. - 1, в 2018 г. - 1. Общее количество взорванного массовыми взрывами ВВ составило на Кировском крыле 194 тыс., а на Юкспорском крыле - 754 тыс. кг. При этом средний массовый взрыв составил на Кировском крыле 64,6, а на Юкспорском - 150,0 т ВВ. Из таблицы 4.3 следует, что в 2015 г. было произведено 5 массовых взрывов, а в 2016 г. - 2 (по одному на Кировском и Юкспорском крыле), в 2017 и 2018 гг. произведено по одному взрыву при погашении подэтажей в стыковочной секции. Весь остальной объем отбойки осуществляется торцевыми взрывами. Максимальное количество ВВ при отбойке руды в системе подэтажного обрушения на один взрыв не превышает 5 тыс. кг. Торцевые взрывы на рудниках производятся ежедневно около трех раз в сутки (в 7:00, 15:00 и 23:00).

Такой режим ведения взрывных работ не мог не сказаться на проявлении техногенной сейсмичности в пределах шахтного поля рудника.

\subsection{1. Проявление общей сейсмичности на подземных рудниках}

Проявление общей сейсмичности на Кукисвумчоррском месторождении

Распределение сейсмических событий в пределах шахтного поля за указанный период приведено на рисунке 4.23 , а на рисунке 4.24 - количество выделенной суточной сейсмической энергии за этот же период. 

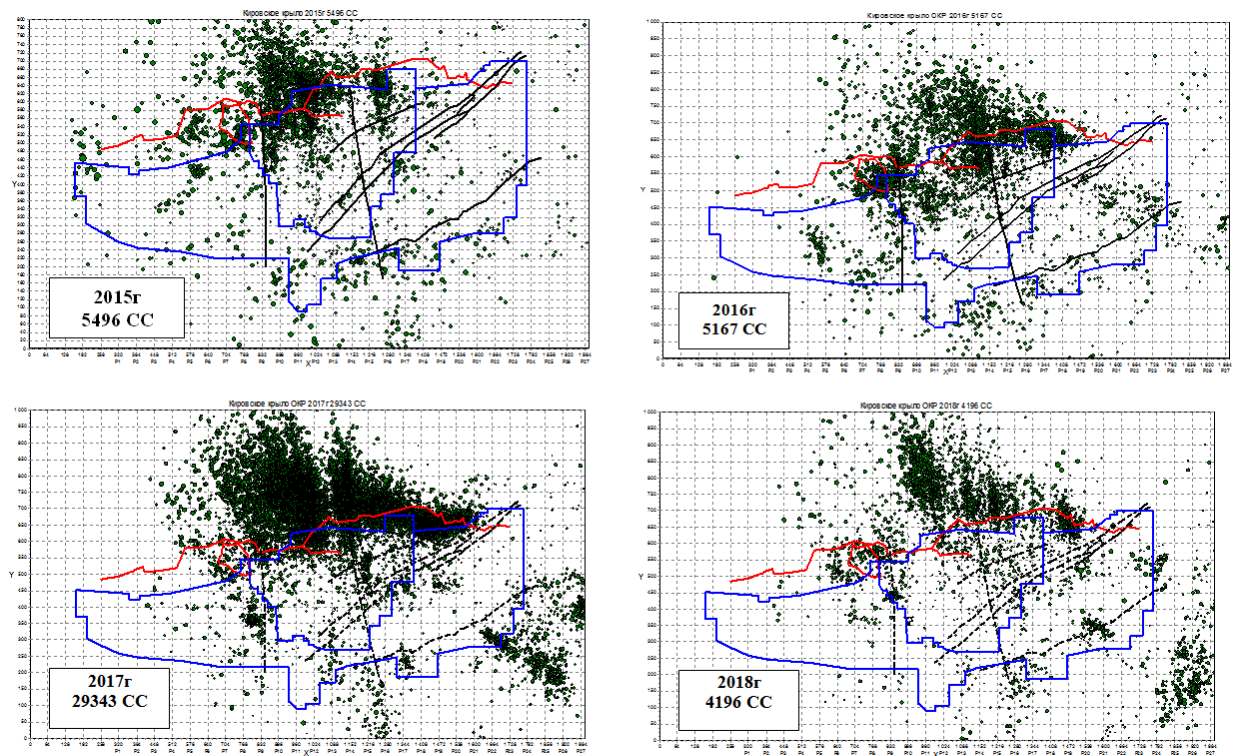

Рис. 4.23. Сейсмические события (СС) в пределах шахтного поля на Кукисвумчоррском месторождении в 2015-2018 гг.
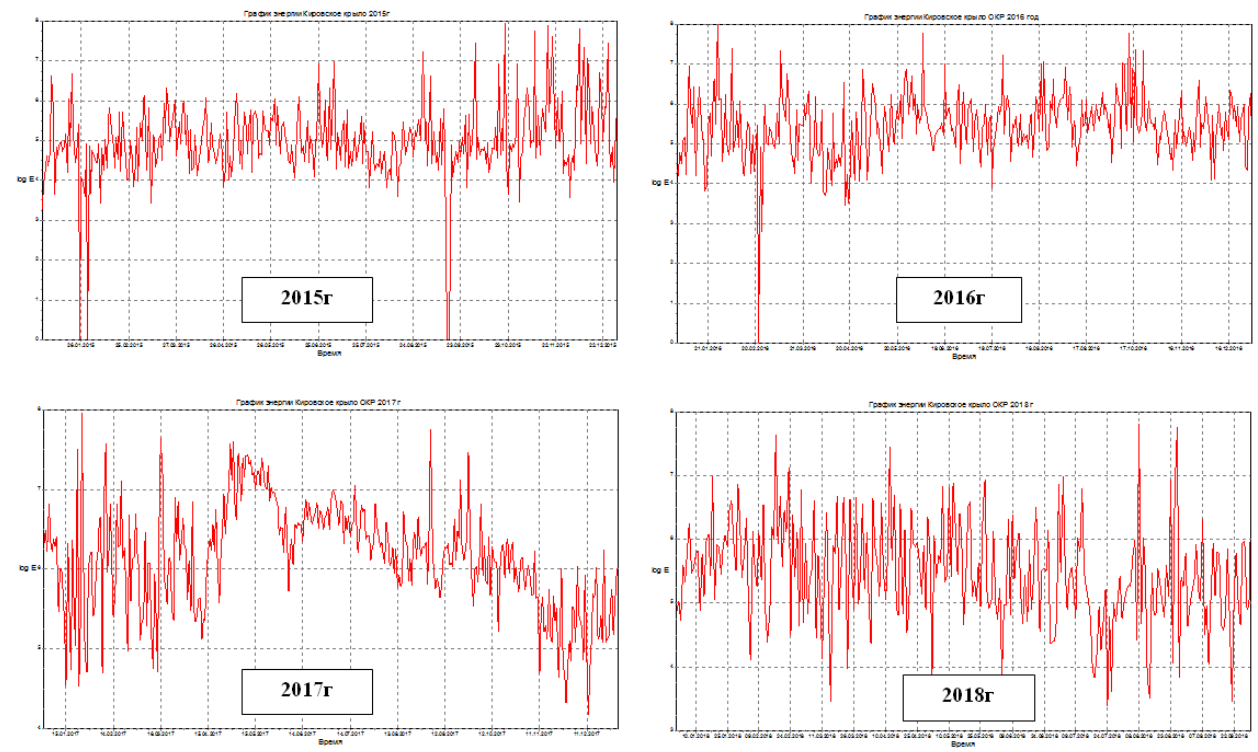

Рис. 4.24. График выделившейся суточной сейсмической энергии в пределах шахтного поля на Кукисвумчоррском месторождении в 2015-2018 гг.

Сейсмическая обстановка в пределах шахтного поля на Кукисвумчоррском месторождении за рассмотренный период характеризуется неравномерным распределением сейсмических событий. В 2015 г. их количество составило 5496 СС. В пределах шахтного поля события приурочены к двум областям: разрез 4-14 и разрез 15-17. В 2016 г. общее количество событий осталось практически одинаковым - 5167 СС. Область распределения СС несколько расширилась и находится в пределах 6-10 и 11-19 разреза. 2017 г. характеризуется резким увеличением техногенной сейсмичности, в этот период произошло 
29343 сейсмических событий. В пространственном отношении проявление сейсмичности также увеличилось и находилось в пределах 6-12 и 13-21 разреза. В 2018 г. техногенная сейсмичность соответствовала уровню 2015-2016 гг., количество произошедших СС составило 4196. Область распространения также уменьшилась и находится в пределах разрезов 9-16 и 18-20. Большинство зафиксированных сейсмических событий приурочено к границам отработки и разлому в консоли необрушенных пород.

Энергетические характеристики техногенной сейсмической активности в пределах шахтного поля на Кукисвумчоррском месторождении за исследуемый период также неравномерны. Так, уровень средней выделившейся

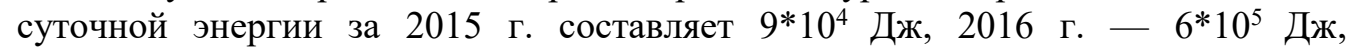

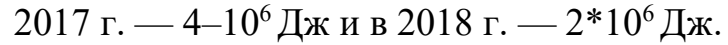

С целью выявления опасных состояний в массиве горных пород была использована представленная выше методика и рассмотрена кинетика техногенного сейсмического процесса при ведении горных работ на рудниках.

По имеющимся сейсмическим данным были рассчитаны сейсмические циклы, построены трековые диаграммы и аттракторы, которые представлены на рисунке 4.25 , а на рисунке 4.26 отражены наиболее опасные зоны в границах шахтного поля.

На представленных рисунках видно, что в 2015 г. количество длинноживущих циклов значительно меньше, чем средне- и короткоживущих, что говорит о том, что система находится в неустойчивом состоянии. В 2016 г. количество длинно-, средне- и короткоживущих циклов было примерно одинаковым, что свидетельствует о том, что массив горных пород находится в равновесном состоянии. В 2017 г. количество долгоживущих циклов значительно превосходит количество средне- и короткоживущих, что соответствует равномерному выделению энергии из массива горных пород. В 2018 г. наблюдается увеличение средне- и короткоживущих циклов и уменьшение количества длинноживущих, что свидетельствует о переходе системы в неустойчивое состояние. Количество сейсмических циклов (СЦ) в 2015-2018 гг. было примерно одинаковым и составило: 132 СЦ в 2015г., 126 СЦ в 2016 г., 135 СЦ в 2017 г. и 100 СЦ в 2018 г.
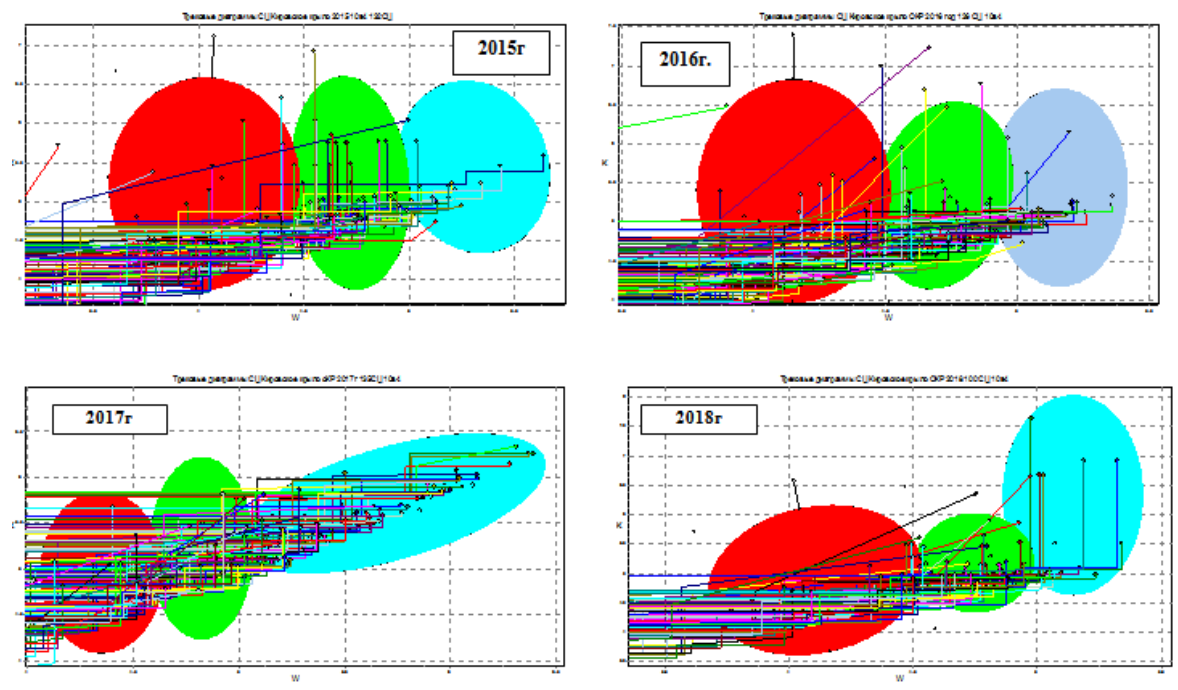

Рис. 4.25. Трековые диаграммы сейсмических циклов и аттракторы для шахтного поля Кукисвумчоррского месторождения за 2015-2018 гг. 

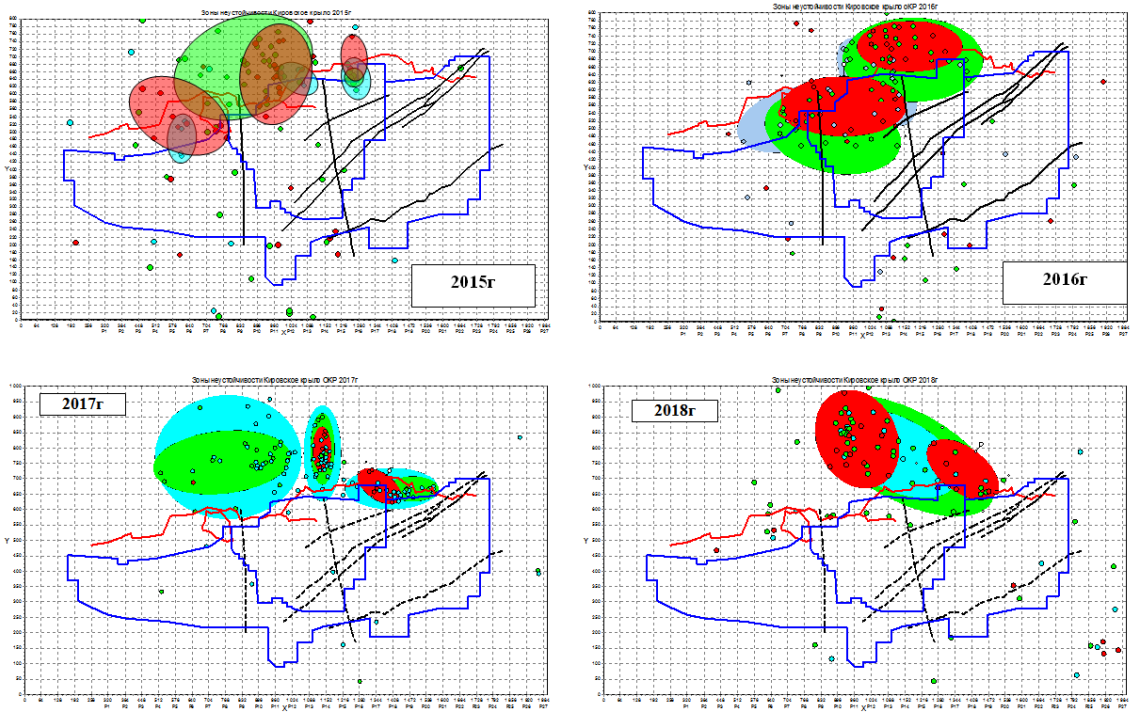

Рис. 4.26. Местоположение зон неустойчивости в переделах шахтного поля Кукисвумчоррского месторождения за 2015-2018 гг.

Расположение зон выделения техногенной сейсмической энергии в пределах шахтного поля Кукисвумчоррского месторождения носит переменчивый характер и заключается в следующем. В 2015 г. существовало три области неустойчивого состояния: 1 область - разрезы 3-8, 2 область - разрезы 9-13 и 3 область - разрезы 15-16. В 2016 г. произошло преобразование областей неустойчивости, в результате образовалось две области неустойчивого состояния: 1 область - разрезы 7-14 и 2 область - разрезы 12-17. В 2017 г. области неустойчивого состояния значительно уменьшились и находились в пределах 13-14 разреза (первая область) и 16-18 разреза (вторая область). В 2018 г. данные зоны неустойчивости увеличились и находились в пределах 9-13 разреза (первая область) и 15-18 разреза (вторая область). Таким образом, за исследуемый период (2015-2018 гг.) произошло многократное изменение пространственного расположения областей неустойчивого состояния. Так, в 2015 г. массив горных пород находился в неустойчивом состоянии, существовало 3 опасные области; в 2016 г. выделение техногенной сейсмической энергии носило равновесный характер, и образовались 2 опасные области; далее, в 2017 г. происходило равномерное выделение сейсмической энергии, а опасные области значительно уменьшились. В 2018 г. массив горных пород опять перешел в неустойчивое состояние, и образовались две обширные области неустойчивости.

Таким образом, установлено, что состояние массива горных пород определяется продолжительностью коротко- и длинноживущих сейсмических циклов (за сейсмический цикл принят временной интервал между сейсмическими событиями с энергией более $10^{5}$ Дж). Чем больше короткоживущих сейсмических циклов, тем быстрее массив переходит в критическое состояние и, наоборот, чем больше длинноживущих циклов, тем меньше вероятность проявления зон неустойчивости.

Проявление общей сейсмичности на Юкспорском месторождении

Техногенная сейсмичность в пределах шахтного поля на Юкспорском месторождении характеризуется бо́льшим количеством произошедших сейсмических событий, чем на Кукисвумчоррском. Так, в 2015 г. произошло 18376 СС, в 2016 г. - 41175 CС, в 2017 г. - 24787 СС, в 2018 г. - 14643 СС. Расположение 
сейсмических событий в пределах шахтного поля Юкспорского крыла ОКР показано на рисунке 4.27. Количество выделенной суточной сейсмической энергии по годам представлено на рисунке 4.28.
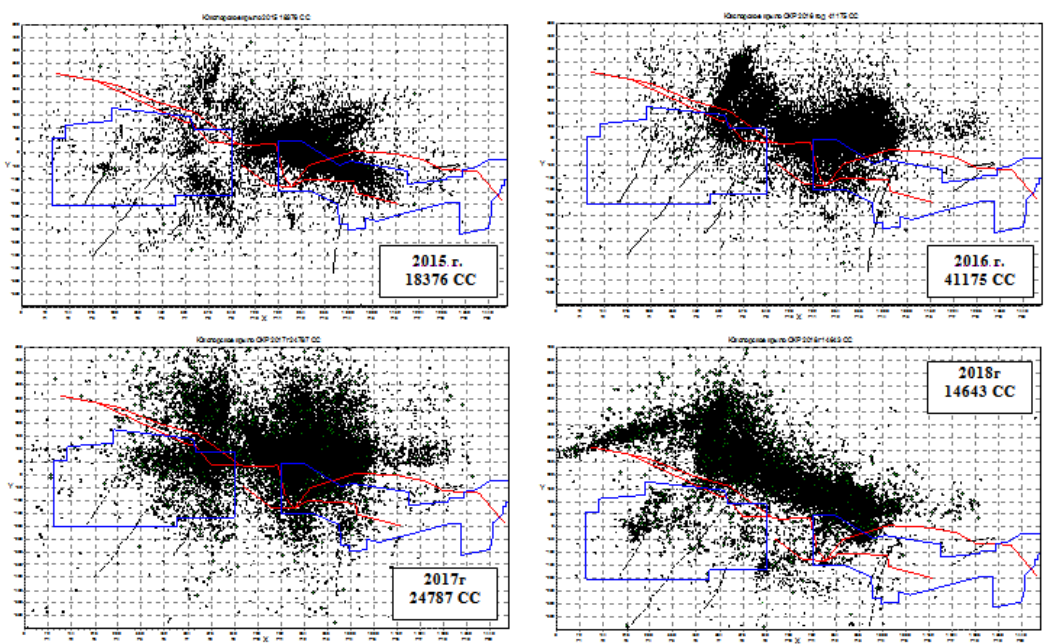

Рис. 4.27. Сейсмические события (СС) в пределах шахтного поля Юкспорского месторождения в 2015-2018 гг.

Сейсмическая обстановка на Юкспорском месторождении за рассмотренный период характеризуется расширением области проявления сейсмических событий. В 2015 г. они распределены в области 8-15 разреза. В 2016 г., одновременно с более чем двукратным увеличением количества сейсмических событий, увеличилась и область их распределения, которая находится в пределах 6-15 разреза. В 2017 г. область распространения техногенной сейсмичности увеличилась и охватила площадь с 5 до 15 разреза. В 2018 г. сейсмические события были зафиксированы в пределах 0-15 разреза, и область их концентрации приобрела вытянутую форму вдоль кромки обрушения в висячем боку месторождения. Уровень выделившейся суточной сейсмической энергии также изменился и составил: $5^{*} 10^{5}$ Дж в 2015 г., $2 * 10^{6}$ Дж в 2016 г., $7 * 10^{6}$ Дж в 2017 г. и $3 * 10^{6}$ Дж в 2018 г.
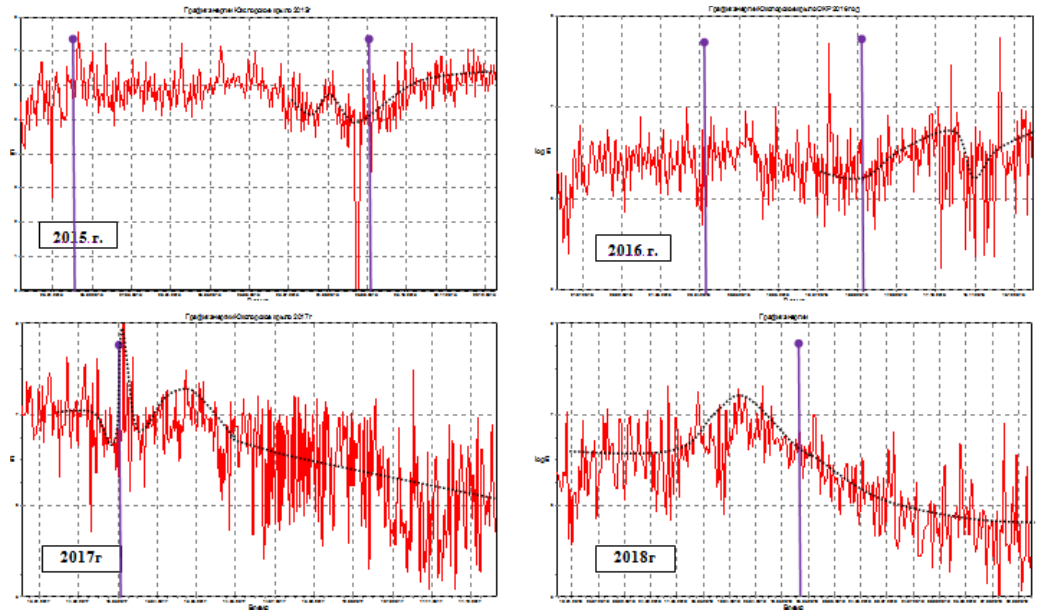

Рис. 4.28. Графики выделившейся суточной сейсмической энергии в пределах шахтного поля Юкспорского месторождения в 2015-2018 гг. (вертикальными линиями обозначено время проведения массовых взрывов) 
С целью выявления опасных состояний в массиве горных пород были рассчитаны сейсмические циклы, построены трековые диаграммы и аттракторы, которые представлены на рисунке 4.29, а на рисунке 4.30 отражены наиболее опасные зоны в границах шахтного поля.
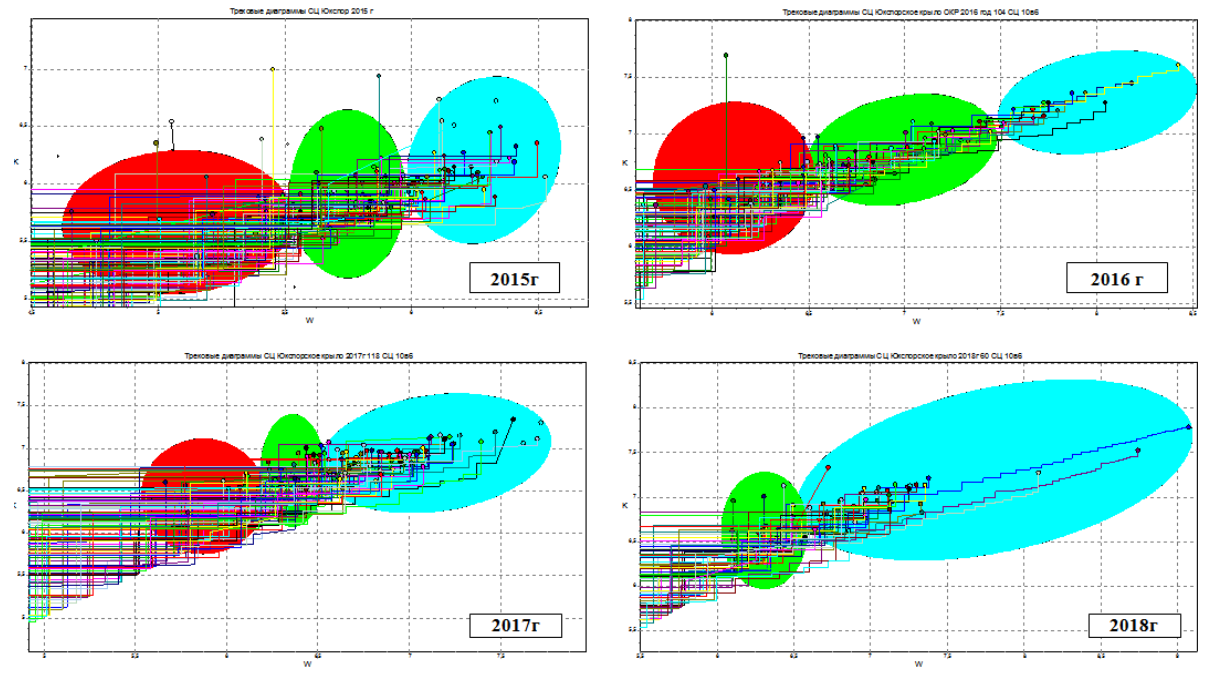

Рис. 4.29. Трековые диаграммы сейсмических циклов и аттракторы для Юкспорского крыла за 2015-2018 гг.
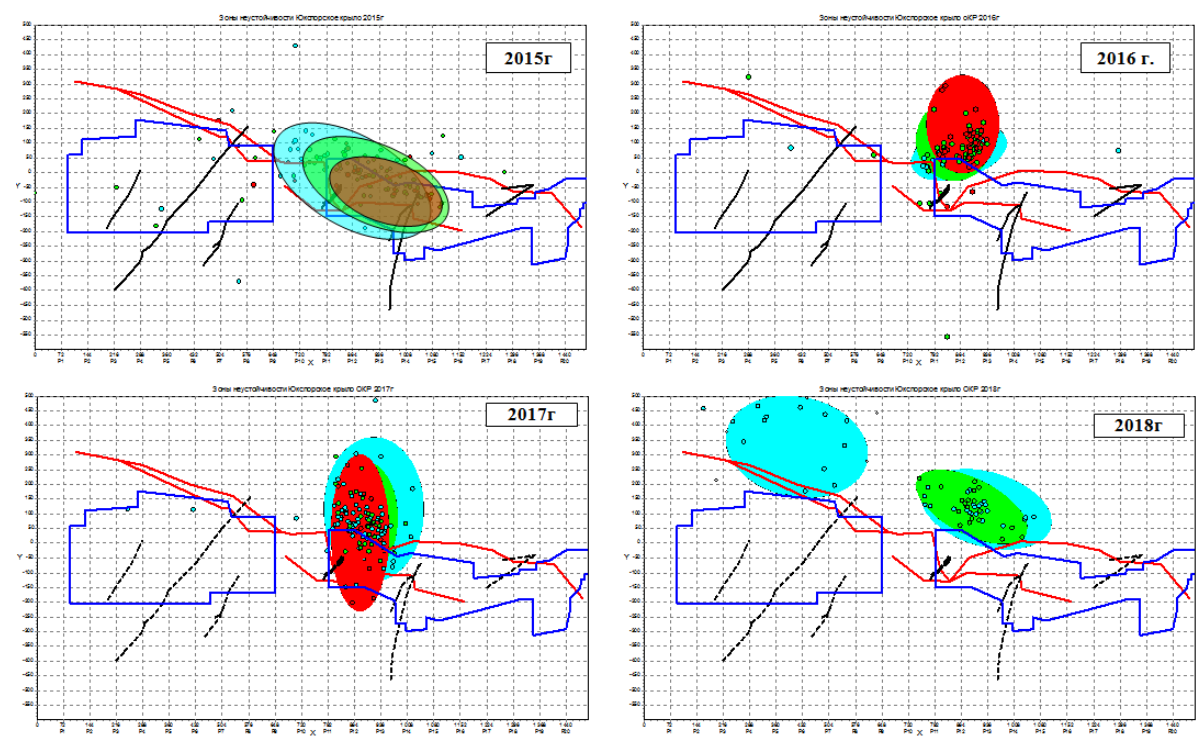

Рис. 4.30. Местоположение зон неустойчивости на Юкспорском месторождении в 2015 и 2018 гг. по циклам 5 энергетического класса

На представленных рисунках видно, что в 2015 г. количество короткоживущих циклов превосходило количество длинноживущих, что способствовало образованию зон неустойчивости вдоль кромки обрушения (рис. 4.29). В 2016 г. количество коротко-, средне- и длинноживущих циклов было примерно одинаковым, что приводило к более равномерному выделению энергии в массиве горных 
пород. При этом сформировалась одна зона неустойчивости. В 2017 г. количество долгоживущих циклов уменьшилось, но при этом увеличилось количество короткоживущих, что привело к расширению зоны неустойчивого состояния в сторону блока-целика. В 2018 г. количество длинноживущих циклов преобладает над среднеживущими, причем короткоживущие циклы отсутствуют. Данный факт свидетельствует о том, что горный массив находился в состоянии равномерного выделения сейсмической энергии. Количество сейсмических циклов в 2015-2018 гг. составило 124 СЦ в 2015 г., 104 СЦ в 2016 г., 118 СЦ в 2017 г. и 60 СЦ в 2018 г.

На такой характер проявления сейсмичности существенное влияние оказывало производство массовых взрывов при отбойке стыковочной секции (рис. 4.28). Всего было произведено 4 массовых взрыва по отбойке подэтажей в стыковочной секции — 27.09.2015 г., 21.08.2016 г., 20.03.2017 г., и 28.05.2018 г. (рис. 4.28).

Так, до взрыва в 2015 г., имело место равномерное выделение энергии из массива горных пород. После производства взрыва, в течение двух месяцев, происходило нарастание сейсмичности с увеличением количества короткоживущих циклов. В последующее время выделение энергии стабилизировалось, несмотря на производство взрыва вдали от стыковочной секции. После отбойки второго подэтажа в стыковочной секции 21.08.2016 г. также в течение 2 месяцев происходило нарастание сейсмичности. Количество коротко-, средне- и длинноживущих циклов было примерно одинаковым, что приводило к более равномерному выделению энергии в массиве горных пород. После отбойки третьего подэтажа 20.03.2017 г. резкое нарастание сейсмичности происходило сразу же после взрыва, далее выделение энергии происходило с небольшим нарастанием в течение одного месяца, после чего в течение полугода происходило снижение сейсмичности. Это связано, по всей видимости, с тем, что из-за заглубления границы отбойки в сторону висячего бока в консоли произошло раскрытие трещин отрыва. В 2018 г. еще до отбойки четвертого подэтажа 28.05.2018 г. начало происходить снижение сейсмичности, после его отбойки процесс снижения происходил еще более интенсивно. Это говорит о том, что в консоли уже полностью сформировалась трещина отрыва и уменьшилось количество источников формирования сейсмических событий.

Рассмотрим, какое воздействие оказывают сами взрывы на проявление сейсмичности в зоне их влияния.

Взрыв 20 марта 2017 года

На рисунке 4.31 представлены графики выделения суточной сейсмической энергии за трое суток до и после массового взрыва, а на рисунке 4.32 изохроны очередности проявления сейсмических событий до и после массового взрыва.
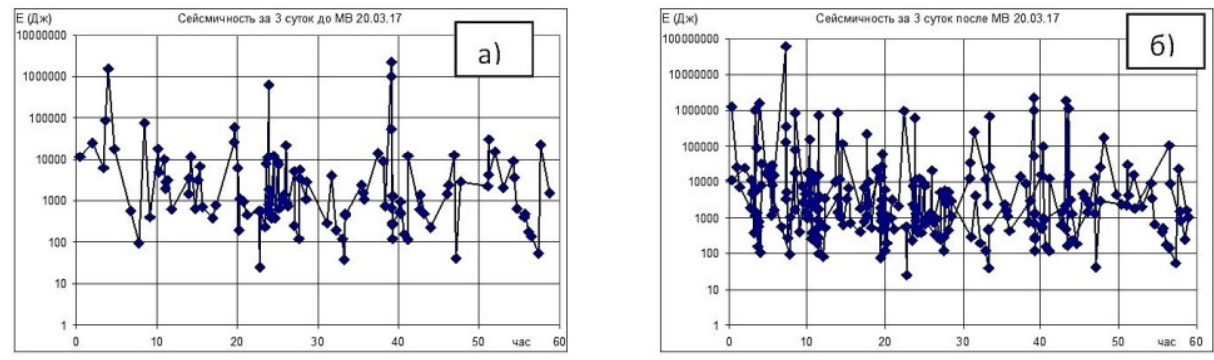

Рис. 4.31. Графики выделения суточной сейсмической энергии за трое суток до (a) и после (б) массового взрыва 20.03.2017 г. 

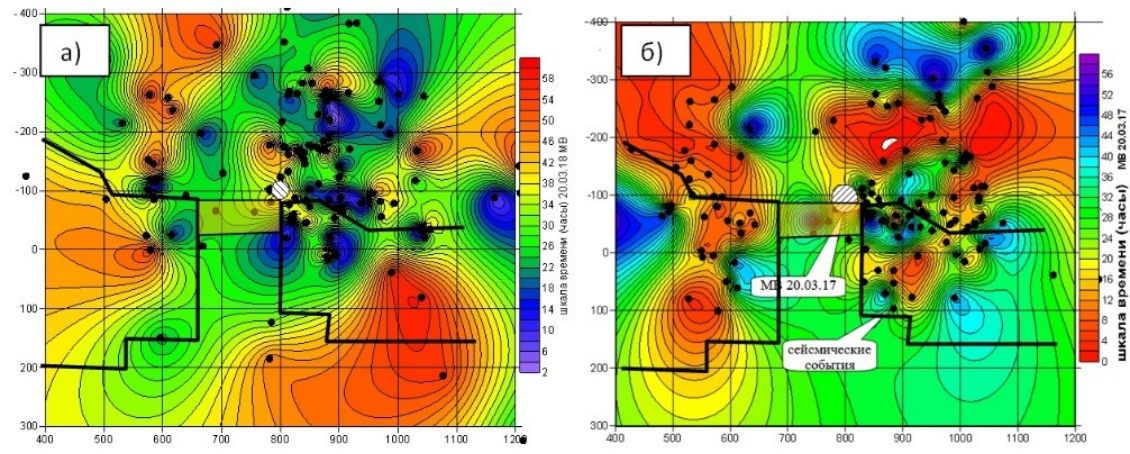

Рис. 4.32. Изохроны очередности проявления сейсмических событий до $(a)$ и после (б) проведения массового взрыва 20.03.2017 г.

Из рисунка 4.32 следует, что до производства массового взрыва в первые сутки сейсмические события развивались в основном в угловых зонах стыковочной секции и в консоли необрушенных пород, а непосредственно перед массовым взрывом - уже на удалении от МВ. После производства МВ, в первые 12 ч, практически все события произошли в консоли необрушенных пород и в угловых зонах отбиваемой секции, то есть наиболее активные участки еще более активизировались взрывом, а на ранних участках сейсмические события проявлялись практически через двое суток.

Рассматривая динамику выделения сейсмической энергии за трое суток до и после проведения МВ (рис. 4.31) можно видеть, что после его проведения увеличивается как общее количество сейсмических событий, так и более крупных событий, которые проявлялись в течении двух суток.

Таким образом, можно константировать, что в процессе производства MB в первую очередь активизируются наиболее сейсмогенные участки со значительным увеличением их размеров.

\section{Взрыв 28 мая 2017 года}

Рассматривая динамику выделения сейсмической энергии за трое суток до и после проведения МВ (рис. 4.33) можно видеть, что до и после его проведения общее количество сейсмических событий остается примерно на одном уровне как по количеству, так и по энергии без проявления крупных сейсмических событий. Можно предположить, что после предыдущего МВ в консоли уже полностью сформировалась трещина отрыва и уменьшилось количество источников формирования сейсмических событий.
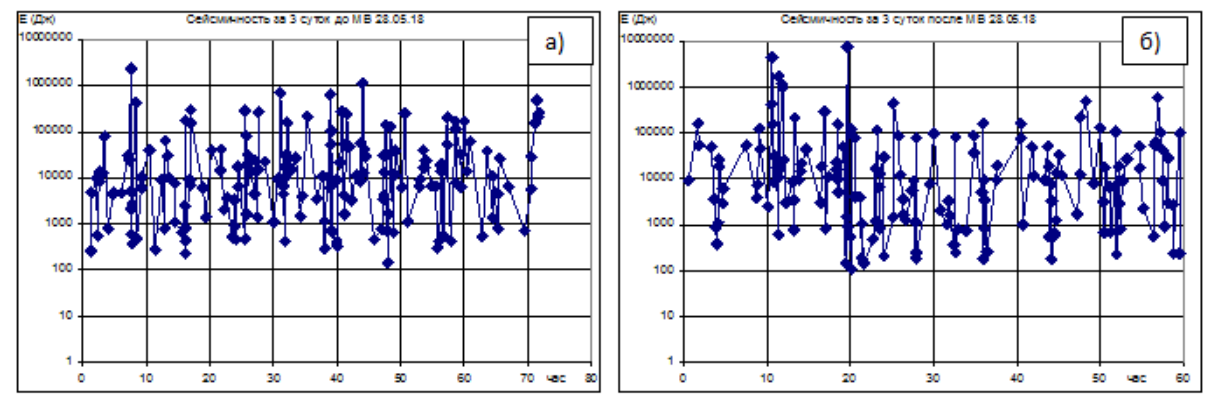

Рис. 4.33. Графики выделения суточной сейсмической энергии за трое суток до (a) и после (б) проведения массового взрыва 28.05.2018 г. 
При рассмотрении очередности проявления сейсмических событий до проведения МВ можно видеть (рис. 4.34), что непосредственно перед взрывом очаги событий проявлялись разрозненно в консоли необрушенных пород. Размер этой зоны после взрыва несколько расширился, но очаги также остались разрозненными. По этой причине уменьшилось количество коротко- и среднеживущих циклов, в результате массив горных пород перешел в метастабильное состояние, что и отразилось на проявление неустойчивых зон (рис. 4.30).

Таким образом, проведенный анализ показал, что проявления сейсмических событий после производства массовых взрывов при поэтапной отбойке стыковочной секции происходят в наиболее подготовленных зонах. При этом, в зависимости от состояния массива, эти зоны могут или увеличиваться в размере, или оставаться на прежнем уровне.

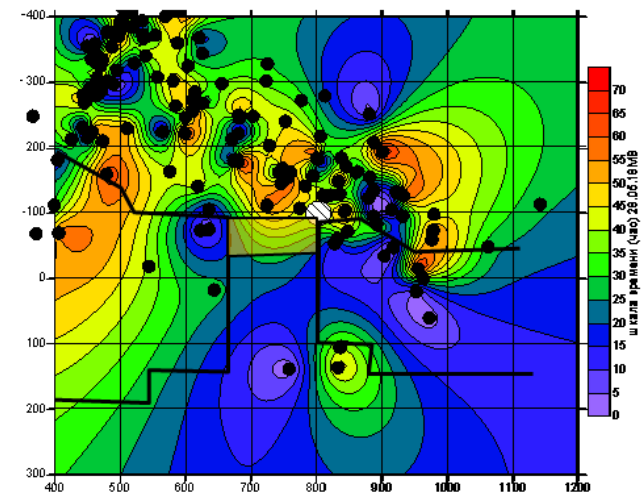

a

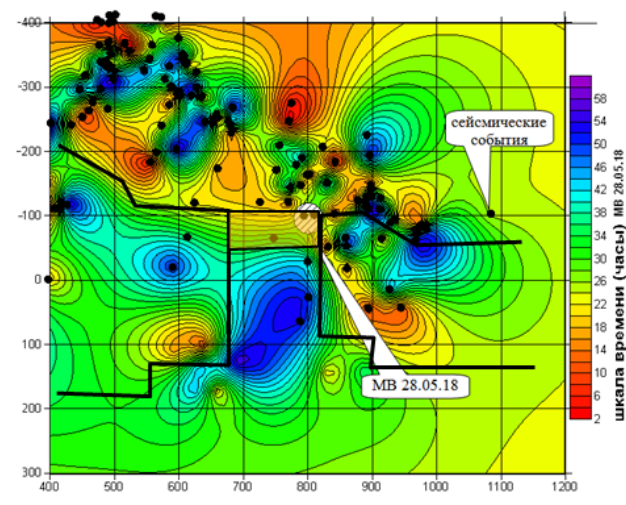

6

Рис. 4.34. Изохроны очередности проявления сейсмических событий до (a) и после (б) массового взрыва 28.05.2018 г.

\section{3. Оценка выделяемой энергии при различных видах воздействия по кумулятивным кривым закаченной и выделенной энергии}

\subsection{1. При производстве массовых взрывов}

Из рисунка 4.35 следует, что количество выделившейся энергии значительно меньше закаченной от массовых взрывов. Это объясняется тем, что при производстве МВ образуется зона необратимых локальных деформаций, в пределах которой и проявляются основные сейсмические события различного уровня продолжительностью до 1-3 сут, но с учетом большого количества мелких событий они по энергии не превышают закаченную в массив энергию от МВ, что не соответствует общепризнанному положению о том, что при тригтерной сейсмичности интенсивность сейсмических событий и выделяемая энергия должны превышать соответствующие величины от техногенного воздействия. Но и массовый взрыв, являясь мощным энергетическим воздействием на окружающий массив пород, с одной стороны, может привести к подготовке опасного сейсмического события, а с другой, - явиться спусковым механизмом уже подготовленного ранее сейсмического события. 

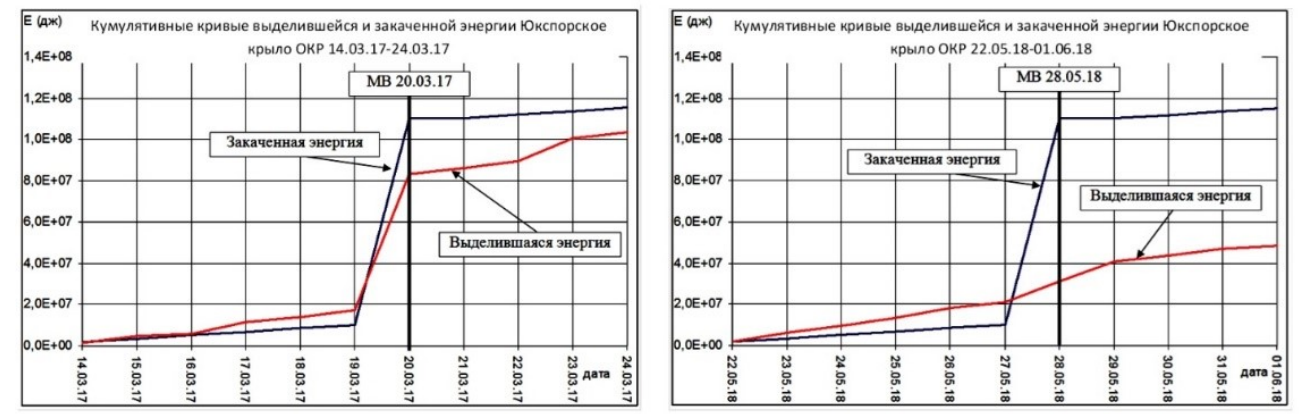

Рис. 4.35. Кумулятивные кривые закаченной и выделенной энергии при производстве массовых взрывов

\subsection{2. При производстве торцевых взрывов}

Торцевые взрывы на рудниках производятся ежедневно около трех раз в сутки (в 7:00, 15:00 и 23:00) и, воздействуя на массив, способствуют краткосрочному (до 3 ч) всплеску выделяемой энергии (рис. 4.36).
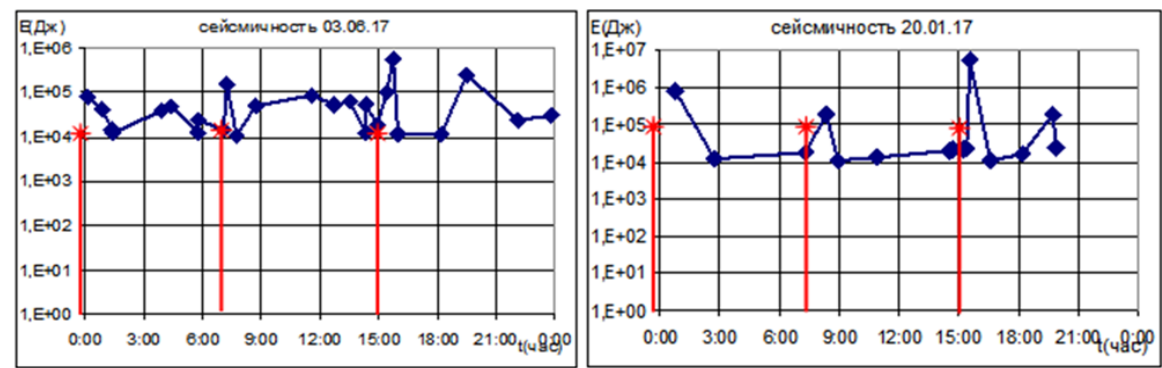

Рис. 4.36. Примеры проявления сейсмичности после производства торцевых взрывов (вертикальными красными линиями обозначено время проведения торцевых взрывов)

Из кумулятивных кривых (рис. 4.37) следует, что при равномерном (стационарном) ходе суточного сейсмического процесса количество выделившейся энергии во всех случаях превосходит закаченную энергию от взрывов. То есть проведение торцевых взрывов является триггером высвобождения собственных запасов энергии в геологической среде.

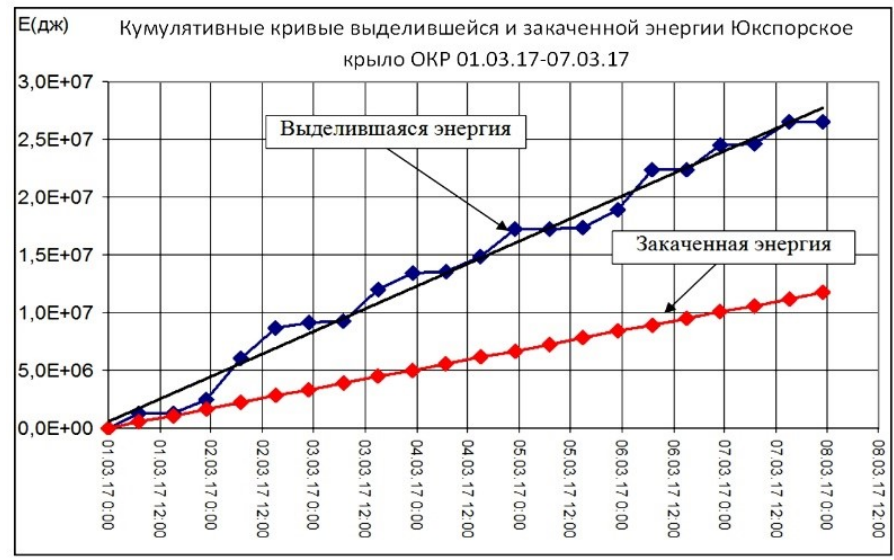

Рис. 4.37. Кумулятивные кривые закаченной и выделенной энергии при производстве торцевых взрывов 
При нарушении стационарного деформационного режима в геологической среде торцевые взрывы только ускоряют или запускают высвобождение накопленной упругой энергии и формирование очагов сейсмических событий в неустойчивых зонах, подготовленных к переходу к неустойчивой стадии (рис. 4.38). В данном случае и сами сейсмические события способствуют формированию более крупных событий, приводят к изменению геодинамической ситуации в зоне перехода массива к неустойчивой стадии (рис. 4.39).

Из рисунков следует, что в первоначальный момент времени СС (1) формировались несколько в стороне от крупных сейсмических событий (2), затем непосредственно вблизи СС (3) и в последнюю очередь в первоначальных зонах (4 и 5) с последующей стабилизацией сейсмического режима (рис. 4.39).
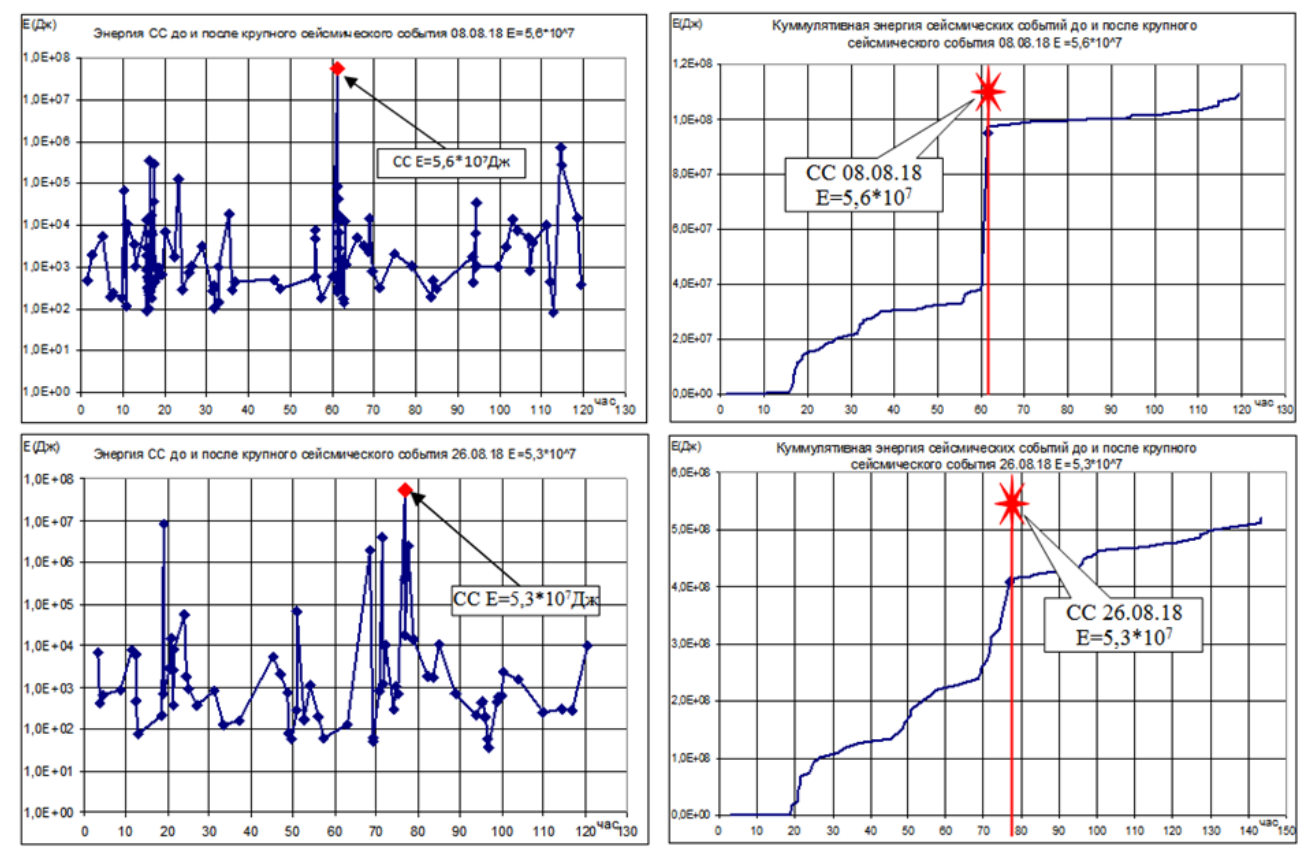

Рис. 4.38. Распределение сейсмических событий во времени и их кумулятивная энергия до и после крупных сейсмических событий
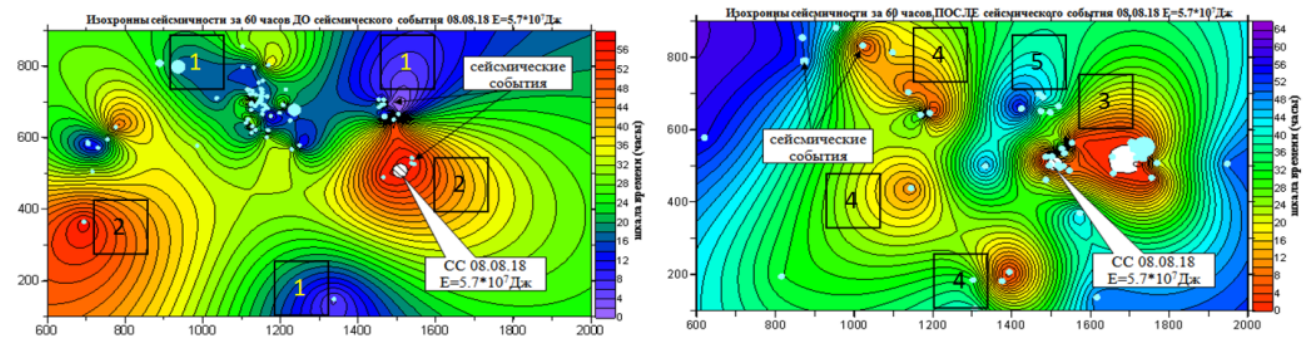

Рис. 4.39. Изохроны сейсмичности до и после крупного сейсмического события 08.08.2018 г. 


\section{4. Выявление закономерностей проявлений техногенной сейсмичности для определения сейсмоопасных участков и улучшения временной локализации периодов повышенного риска в различных зонах ведения крупномасштабных горных работ}

В вышеприведенных разделах рассматривались сейсмические циклы между событиями 5 энергетического класса, а в качестве событий-индикаторов использовались сейсмические события 2-4 энергетических классов. Это было вызвано тем, что в исследуемой сейсмической системе преобладали в основном события 4 и 5 энергетического класса. Данный подход позволял определить зоны неустойчивого состояния массива горных пород с определенной точностью. Для повышения локализации зон неустойчивости было предложено рассчитать трековые диаграммы используя события-индикаторы иных энергетических классов. В качестве исходных данных была использована информация по техногенной сейсмичности за 2018 г. на Кировском крыле ОКР. На рисунках 4.40-4.42 представлены трековые диаграммы для сейсмических циклов 3-6 энергетического класса с использованием событий-индикаторов низших классов, а также расположение полученных областей в пределах шахтного поля.

При использовании сейсмических циклов 3 класса (рис. 4.40) сейсмически опасная зона находится на обширной площади - в пределах 9-17 разреза, поэтому судить о потере ее устойчивости довольно затруднительно, так как события 3 класса могут вызвать длину разрыва в пределах $0,2-1,2$ м, что не приведет к существенному изменению системы.
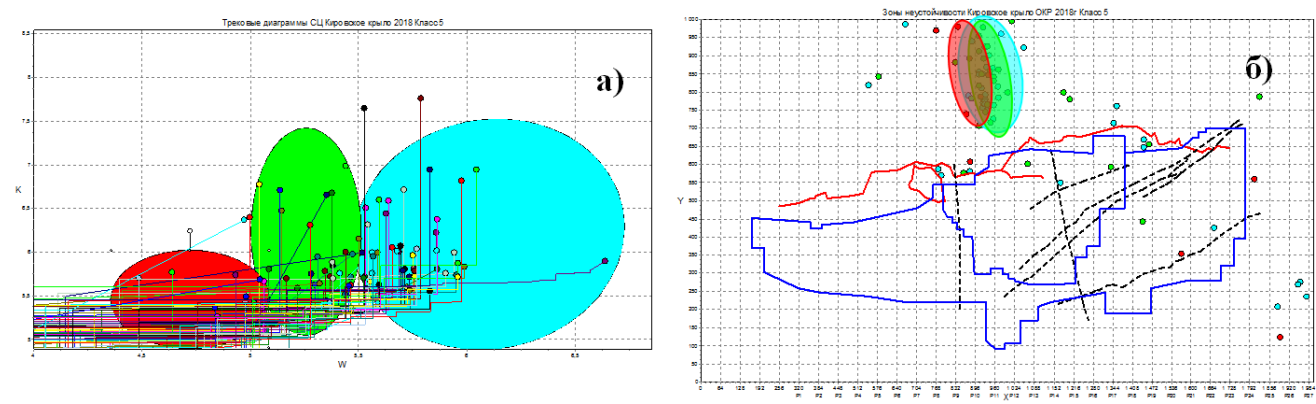

Рис. 4.40. Трековые диаграммы сейсмических циклов 3 класса $(a)$ и зоны неустойчивости в пределах шахтного поля (б)
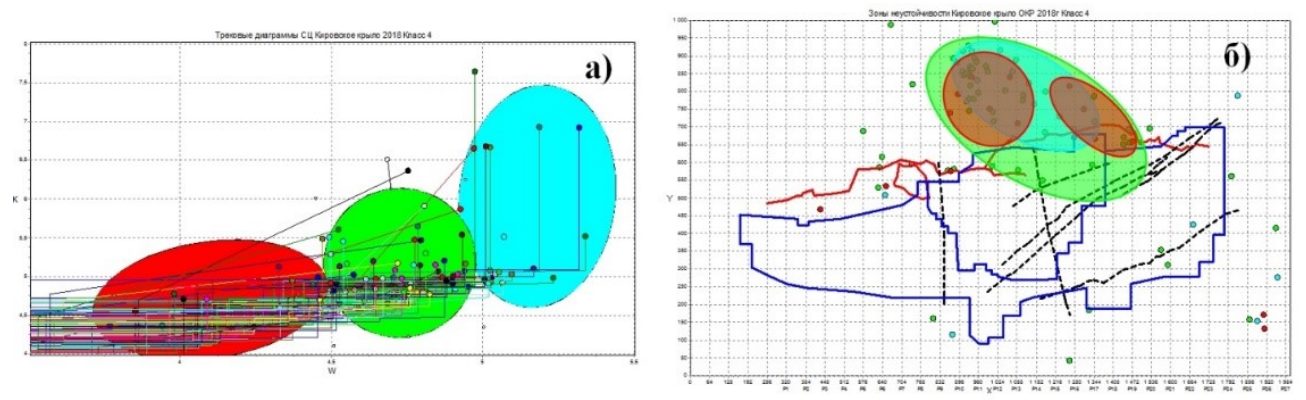

Рис. 4.41. Трековые диаграммы для сейсмических циклов 4 класса $(a)$ и зоны неустойчивости в пределах шахтного поля (б) 

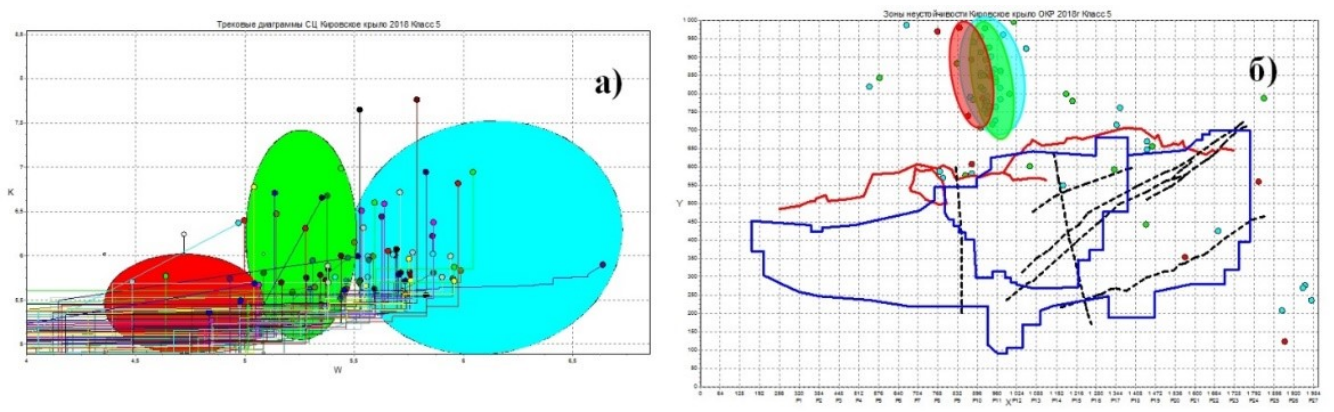

Рис. 4.42. Трековые диаграммы для сейсмических циклов 5 класса $(a)$ и зоны неустойчивости в пределах шахтного поля (б)

Так как в сейсмическом процессе присутствуют сейсмические события и более высокого класса необходимо рассматривать все сейсмические циклы.

Результат расчета трековых диаграмм для сейсмических циклов 4 класса событий-индикаторов представлен на рисунке 4.41. В данном случае произошло разделение зон неустойчивого состояния, которые находятся в пределах 9-13 и 15-18 разрезов.

При сейсмических циклах с энергией между событиями 5 класса (рис. 4.42) наблюдается локализация зоны неустойчивости в одной определенной области всех зон сейсмического состояния массива горных пород (зоны устойчивого состояния, зоны подготовки и зоны неустойчивости) с уменьшением ее размера по сравнению с предыдущими. Данная область находится в пределах 8-12 разреза, она переместилась от фронта горных работ в сторону висячего бока.

При сейсмических циклах с энергией между событиями 6 класса (рис. 4.43) наблюдается еще большая точность определения зон сейсмического состояния массива горных пород. Так, зона неустойчивого состояния в пространственном отношении совпадет с зоной подготовки и зоной устойчивости и находится в пределах 10-12 разреза.

Применительно к проведенным исследованиям при расчете трековых диаграмм по сейсмическим циклам 3 класса и при переносе их в пределы шахтного поля рудника рассчитывается некоторая область мелкого трещинообразования (рис. 4.40). Далее увеличение класса между сейсмическими циклами до 4 позволяет определить области формирования более крупных трещин (рис. 4.41). Дальнейшее увеличение классности событий (5-6 класс) позволяет рассчитать области значительных тектонических нарушений в исследуемом массиве горных пород (рис. 4.42 и 4.43). С физической точки зрения происходит переход от системы мелкого трещинообразования с энергией $10^{3}$ Дж к другой более энергоемкой системе с энергией $10^{4}$ Дж и далее к высокоэнергетическим событиям с энергиями $10^{5}$ и $10^{6}$ Дж.

Таким образом, зная пороговые значения энергии сейсмических событий, при которых происходит нарушение сплошности массива, можно выбрать сейсмические циклы с определенной энергией между событиями и определить состояние массива, что приводит к более точному пространственному определению опасных зон в пределах шахтного поля рудника и их классификации по энергетическим параметрам. 

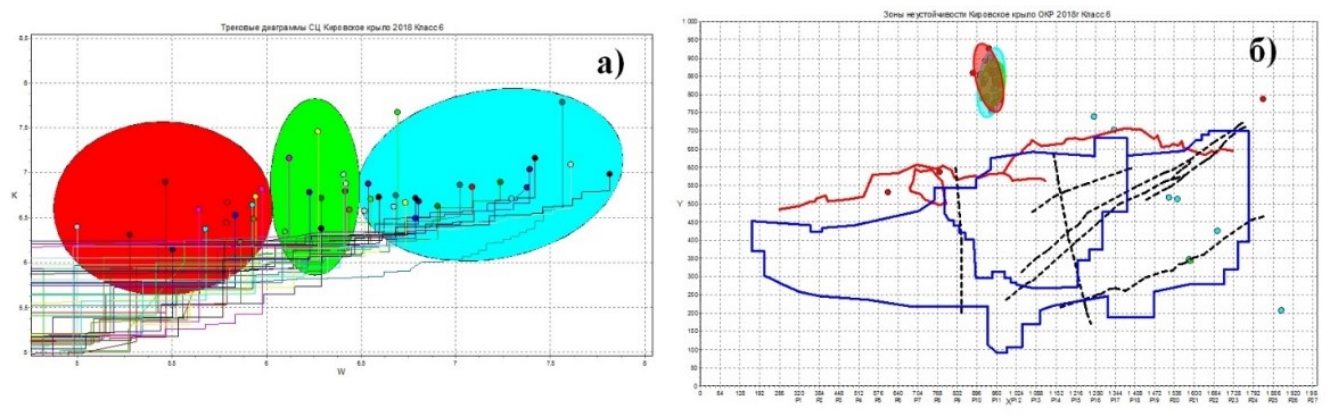

Рис. 4.43. Трековые диаграммы от событий-индикаторов 6 класса ( $a$ ) и зоны неустойчивости в пределах шахтного поля (б)

\section{5. Использование теории динамических систем и недетерминированного хаоса для описания техногенного сейсмического процесса}

\subsection{1. Общцие положения}

Тектонически напряженный массив горных пород является открытой, неравновесной, нелинейной, диссипативной динамической системой взаимодействующих между собой отдельностей (блоков), которая (система) постоянно эволюционирует во времени. Производство массовых и технологических взрывов обеспечивает подпитку энергией извне, которая распределяется среди блоков различного ранга, накапливая и сбрасывая излишки энергии, которые, в свою очередь, поглощаются другими блоками. Другими словами, постоянная подпитка энергией от взрывов обеспечивает самоорганизацию отдельностей в диссипативную структуру, имеющую самоподобный характер. Данный процесс происходит до момента достижения массивом горных пород равновесного состояния. Однако любое изменение (даже самое незначительное) в системе приводит к новому перераспределению энергии. Таким образом, процесс перераспределения энергии в массиве является хаотическим и тесным образом связан с нелинейностью в поведении динамической системы в процессе ее эволюции.

Нелинейность динамической системы характеризуется следующими факторами [153]:

- неустойчивое и хаотическое поведение системы;

- малые изменения в величинах параметров или внешних условий могут приводить к необратимым качественным изменениям;

- нелинейные системы, наряду с детерминированным хаосом, могут содержать высококогерентные, стабильные, локализованные структуры или импульсы, которые сохраняют свою форму неизменной даже при взаимодействии с другими импульсами.

Массив горных пород шахтного поля Объединенного Кировского рудника КФ АО «Апатит» является нелинейной детерминированной динамической системой, так как отвечает всем признакам нелинейных динамических систем, а характер выделения сейсмичности носит хаотический характер. Для описания техногенной сейсмичности является логичным применение методов, используемых при описании нелинейных динамических систем - теории аттракторов и фазового пространства. 
Фазовое пространство - это абстрактное пространство, в котором координатами служат компоненты состояния. Оно представляет поведение динамической системы в геометрической форме.

Траектории в фазовом пространстве представляют собой графическое отображение эволюции системы, а область, к которой притягиваются точки в фазовом пространстве называются аттракторами.

Существует несколько типов аттракторов. Самый простой тип - неподвижная точка (рис. 4.4 a), он характеризуется возвращением в одно и то же положение покоя независимо от предыдущего движения. Более сложный тип аттрактора - предельный цикл (рис. 4.44 б), который описывает устойчивые колебания. Сложному колебанию или квазипериодическому движению соответствует аттрактор в виде тора (рис. 4.44 в). Данные аттракторы являются предсказуемыми.

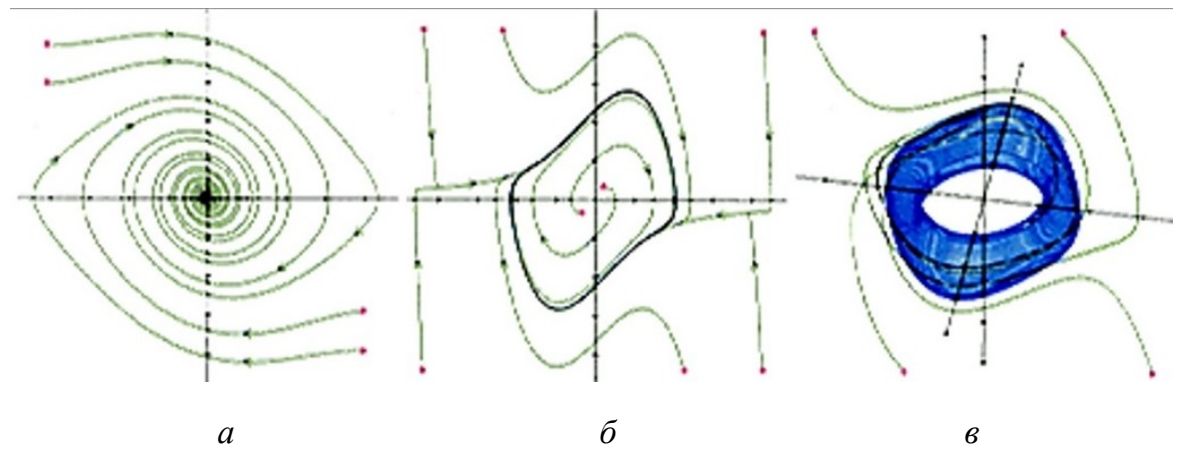

Рис. 4.44. Виды простых аттракторов: $a$ - неподвижная точка; $\sigma$ - предельный цикл; 6 - тор

Хаотические (странные) аттракторы соответствуют непредсказуемому движению и имеют более сложные геометрическую форму. Примеры хаотических аттракторов показаны на рисунке 4.45. Они имеют более сложное строение, чем предсказуемые аттракторы. В крупном масштабе хаотический аттрактор являет собой неровную поверхность со складками [154].

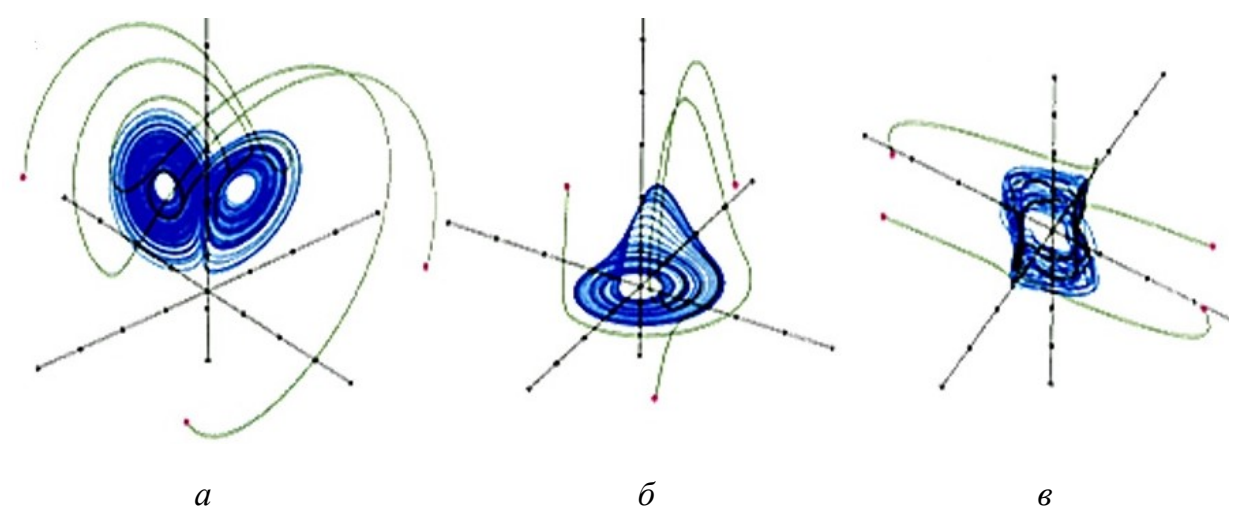

Рис. 4.45. Примеры хаотических аттракторов: $a$ - аттрактор Лоренца; $\sigma$ - аттрактор Ресслера; 8 - аттрактор Шоу

Для хаотического (странного) аттрактора характерно то, что траектория его эволюции начинается из начальной точки и постепенно заполняет некоторую область фазового пространства. 
Для описания сейсмического процесса с помощью фазового пространства необходимо преобразовать имеющиеся координаты $A(t)$ к фазовым координатам $(A(t), d A(t) / d t)$, то есть от координат сейсмическая активность - время к координатам сейсмическая активность - скорость изменения активности.

До преобразования сейсмической активности в фазовый портрет необходимо провести операцию нормирования по отношению к среднему значению ряда и операцию сглаживания методом скользящего среднего. Данные операции необходимы для того, чтобы устранить или уменьшить случайную составляющую.

После проведения данных операций производится переход к фазовым координатам, что дает следующее:

1) две характеристики сейсмического процесса (активность и скорость активности) рассматриваются и преобразуются как независимые величины;

2) фазовый портрет более чувствителен к таким процедурам как сглаживание и удаление тренда, что облегчает выбор интервала времени для расчета активности, степени сглаживания, преобразования координат;

3) в фазовом пространстве возрастание амплитуды колебаний до некоторой постоянной величины будет выглядеть, как внешний предельный цикл, убывание амплитуды, — как аттрактор типа точки;

4) после подбора процедур, приводящих фазовый портрет к виду, который допускает математическое описание, можно, выполнив обратное преобразование, получить математическое описание регулярной составляющей исходного сейсмического процесса, что дает возможность оценки дальнейшего развития сейсмичности.

В частности, были рассчитаны фазовые портреты для наиболее крупных сейсмических циклов за период 2017-2018 гг. Данные о циклах приведены в таблице 4.4, а на рисунке 4.46 приведены трековые диаграммы исследуемых сейсмических циклов (СЦ).

Полученные в результате расчетов фазовые портреты представлены на рисунке 4.47, а на рисунке 4.48 показаны пространственные расположения сейсмических событий для каждого исследуемого цикла.

В результате анализа полученных фазовых портретов и пространственного расположения сейсмических событий установлено, что все фазовые портреты имеют форму раскручиваемой спирали, это свидетельствует о высокой сейсмической активности в исследуемый период. Степень скручиваемости фазового портрета зависит от продолжительности выбранного периода. Так, фазовые портреты 4 и 6 сейсмического цикла менее закручены по сравнению с остальными. Это связано с тем, что продолжительность этих СЦ намного меньше, чем продолжительность остальных, так как меньше зарегистрированных событий.

Таблица 4.4

Информация по сейсмическим циклам

\begin{tabular}{|c|c|c|c|}
\hline № СЦ & Дата начала СЦ & Дата окончания СЦ & Энергия СЦ, Дж \\
\hline 1 & $16.01 .2017 ; 01: 18$ & $22.03 .2017 ; 21: 09$ & 8389000 \\
\hline 2 & $01.04 .2017 ; 08: 21$ & $10.05 .2017 ; 18: 56$ & 4194000 \\
\hline 3 & $14.05 .2017 ; 07: 13$ & $02.02 .2018 ; 05: 11$ & 2097000 \\
\hline 4 & $02.02 .2018 ; 05: 11$ & $24.02 .2018 ; 10: 51$ & 2097000 \\
\hline 5 & $24.02 .2018 ; 10: 51$ & $03.08 .2018 ; 12: 12$ & 2097000 \\
\hline 6 & $03.08 .2018 ; 12: 12$ & $24.08 .2018 ; 22: 22$ & 2097000 \\
\hline 7 & $24.08 .2018 ; 22: 22$ & $20.12 .2018 ; 21: 44$ & 1049000 \\
\hline
\end{tabular}




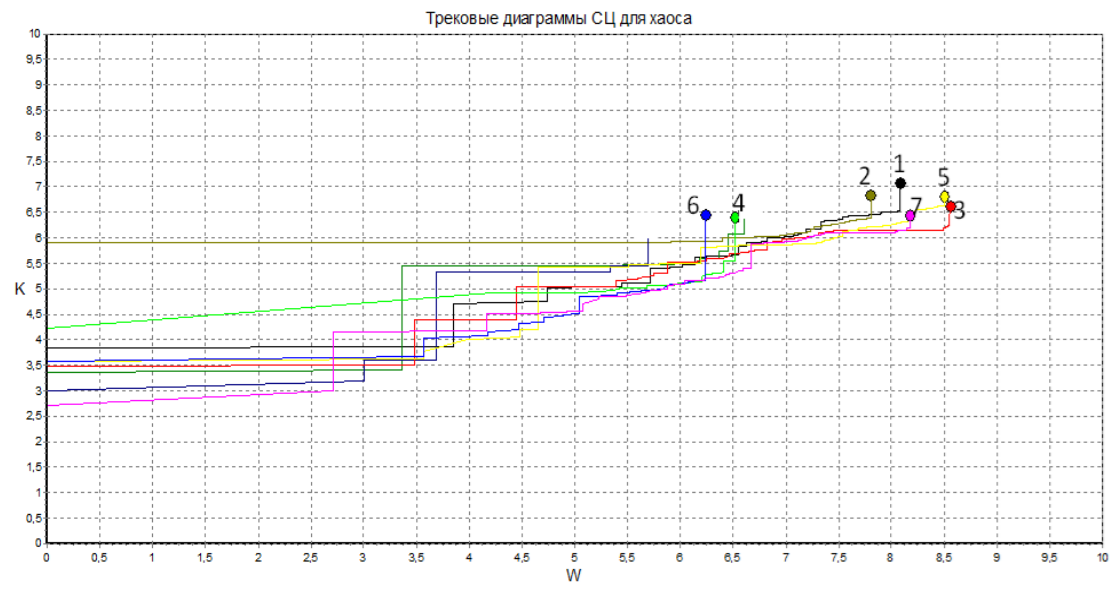

Рис. 4.46. Трековые диаграммы исследуемых сейсмических циклов для Кировского крыла ОКР

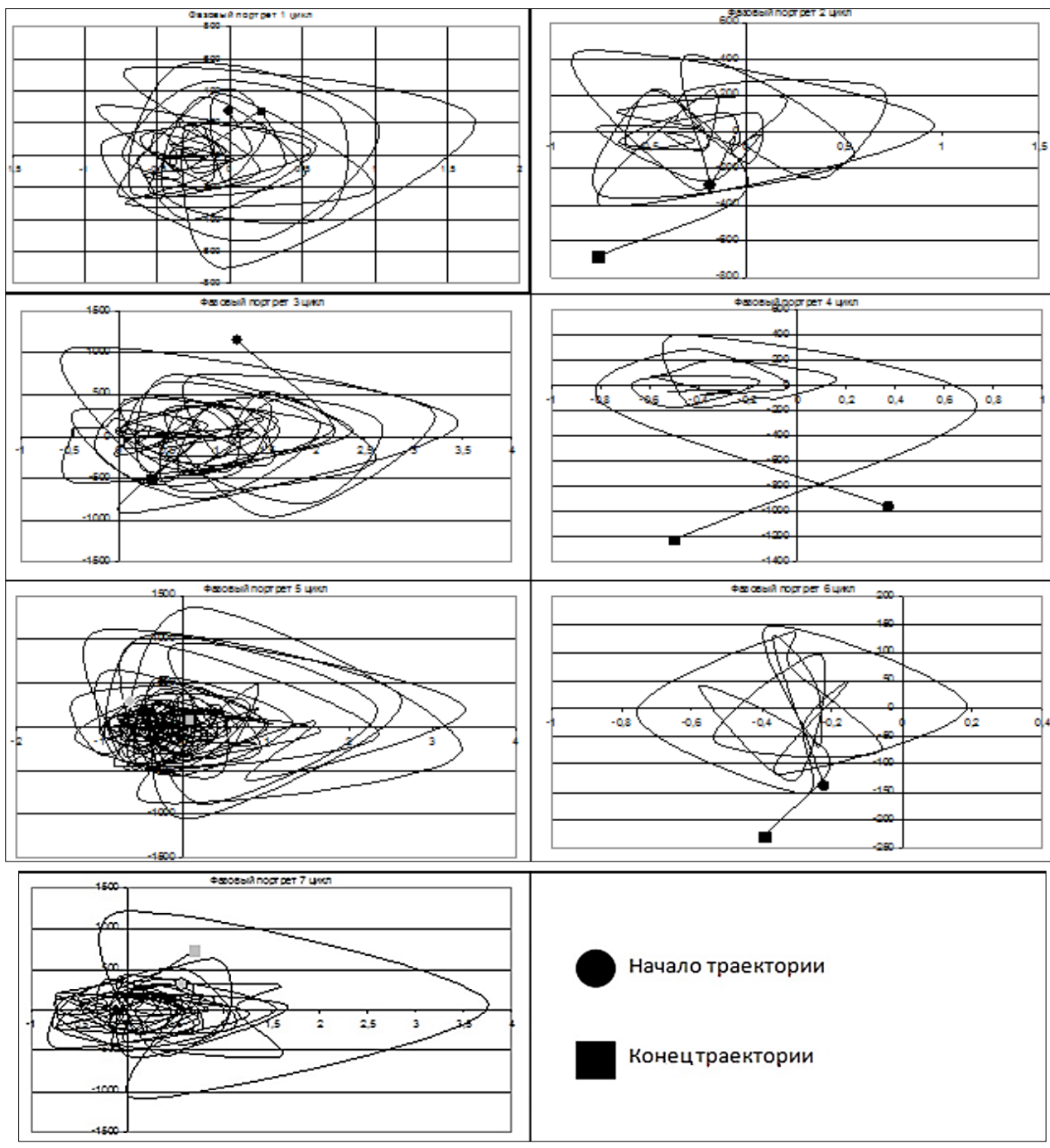

Рис. 4.47. Фазовые портреты исследуемых сейсмических циклов для Кировского крыла ОКР 

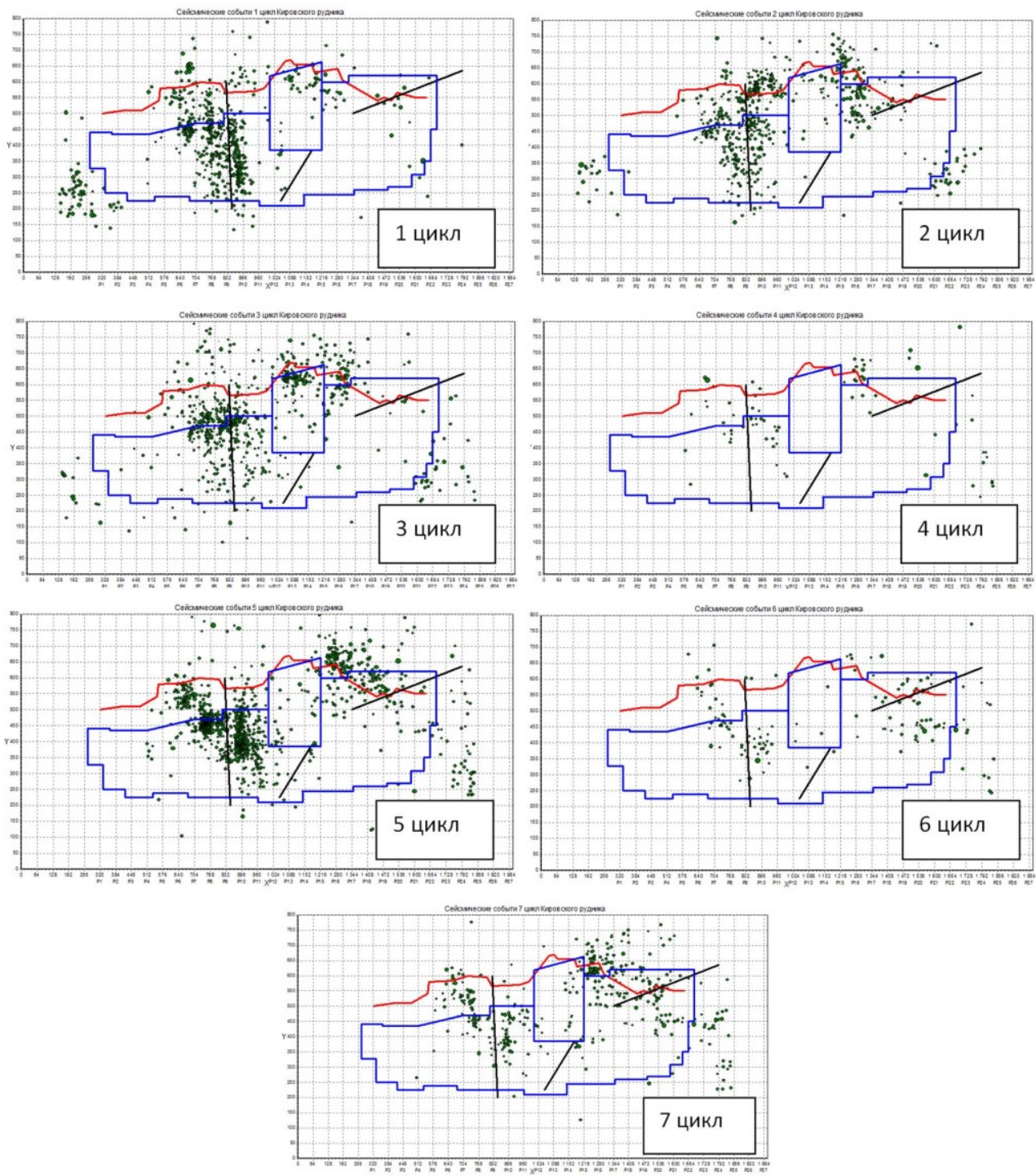

Рис. 4.48. Пространственное расположение сейсмических событий исследуемых сейсмических циклов в пределах шахтного поля Кировского крыла ОКР

\section{Детальный анализ сейсмоопасных зон}

С целью детального анализа сейсмической обстановки с помощью фазовых портретов был проведен расчет аттракторов по выделенным ранее областям сейсмической активности за 2018 г. для Кировского крыла ОКР с помощью программного комплекса ASC. Данные области находятся по следующим координатам (рис. 4.49, 4.50):

1) область - разрез 5 (576 м) - разрез 11 (960 м) (рис. 4.49);

2) область - разрез $13(1088 \mathrm{м})$ - разрез 21 (1600 м) (рис.4.50).

На рисунках $4.51(a, \sigma, b)$ и $4.52(a, \sigma, b)$ представлены изменения значений энергий, трековые диаграммы и зоны неустойчивости для первой и второй выделенной области. 
Для первой и второй выделенных областей характерно как плавное, так и скачкообразное выделение энергии из одной и той же зоны. Для того, чтобы определить временные промежутки данных состояний, было предложено проанализировать полученные результаты с помощью теории динамических систем, в частности, построить фазовые траектории (аттракторы).

На приведенных ниже рисунках представлены фазовые траектории для выбранных областей и определен тип аттрактора (раскручивающийся или скручивающийся). На рисунке 4.53 представлены фазовые траектории для первой выбранной области, а на рисунке 4.54 —для второй.

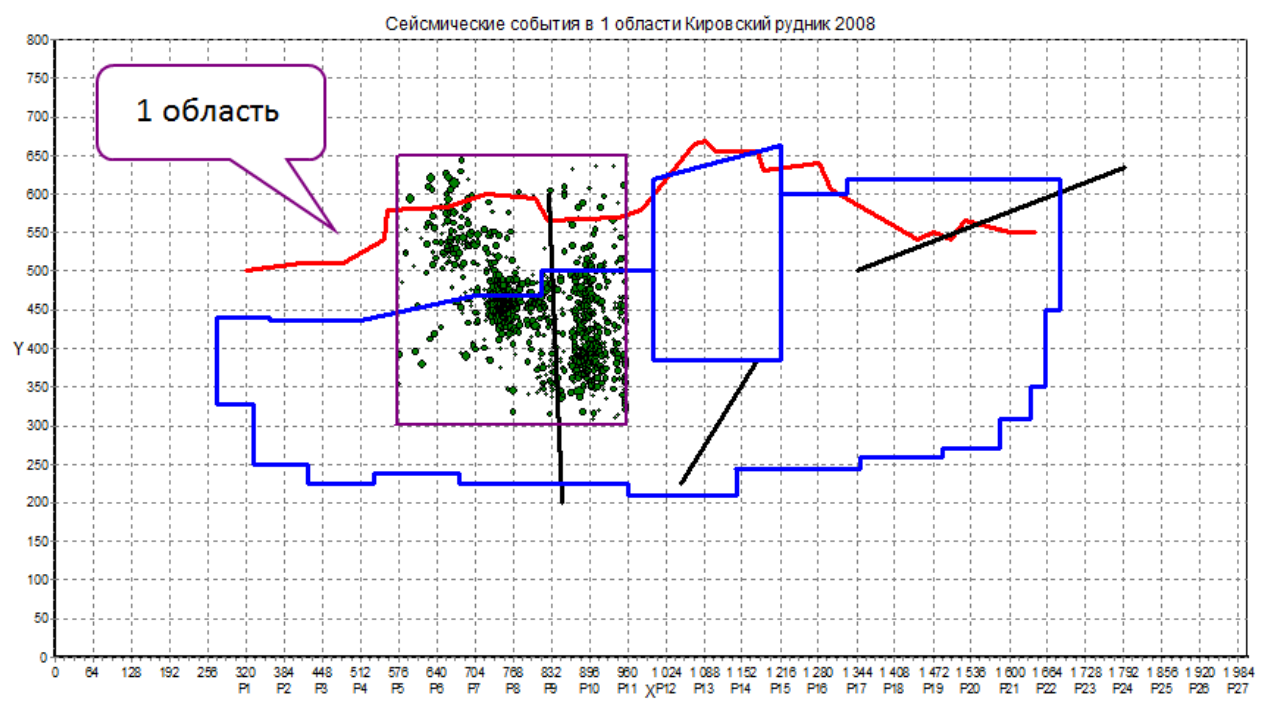

Рис. 4.49. Расположение сейсмических событий за 2018 г. на Кировском крыле ОКР в первой выбранной области

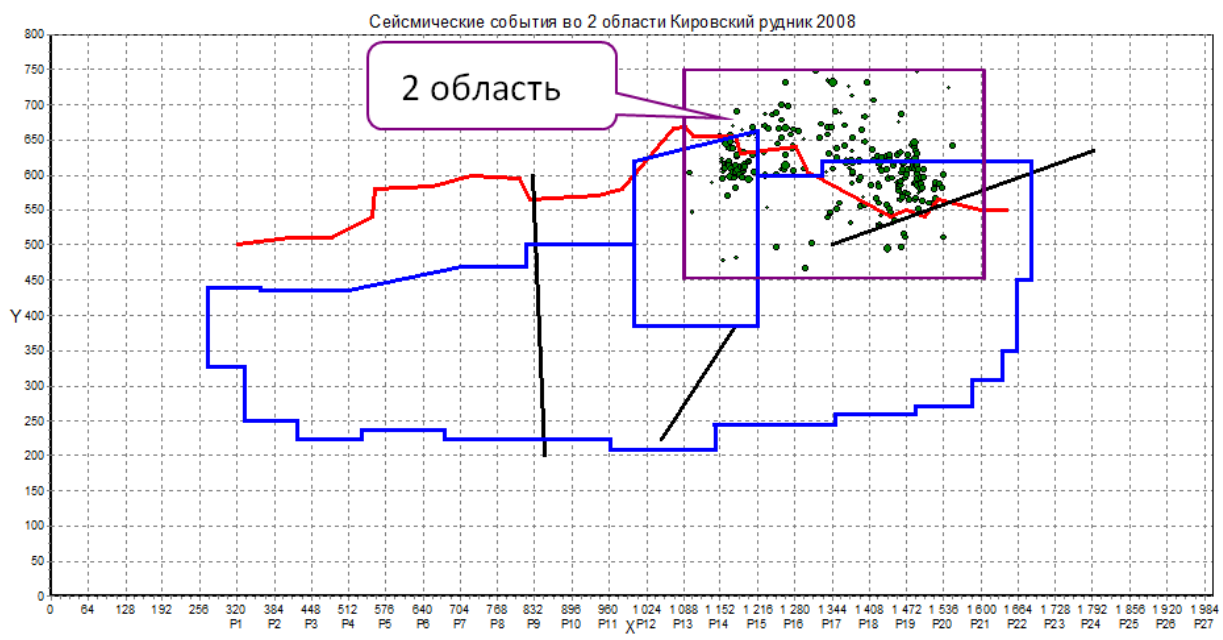

Рис. 4.50. Расположение сейсмических событий за 2018 г. на Кировском крыле ОКР во второй выбранной области 

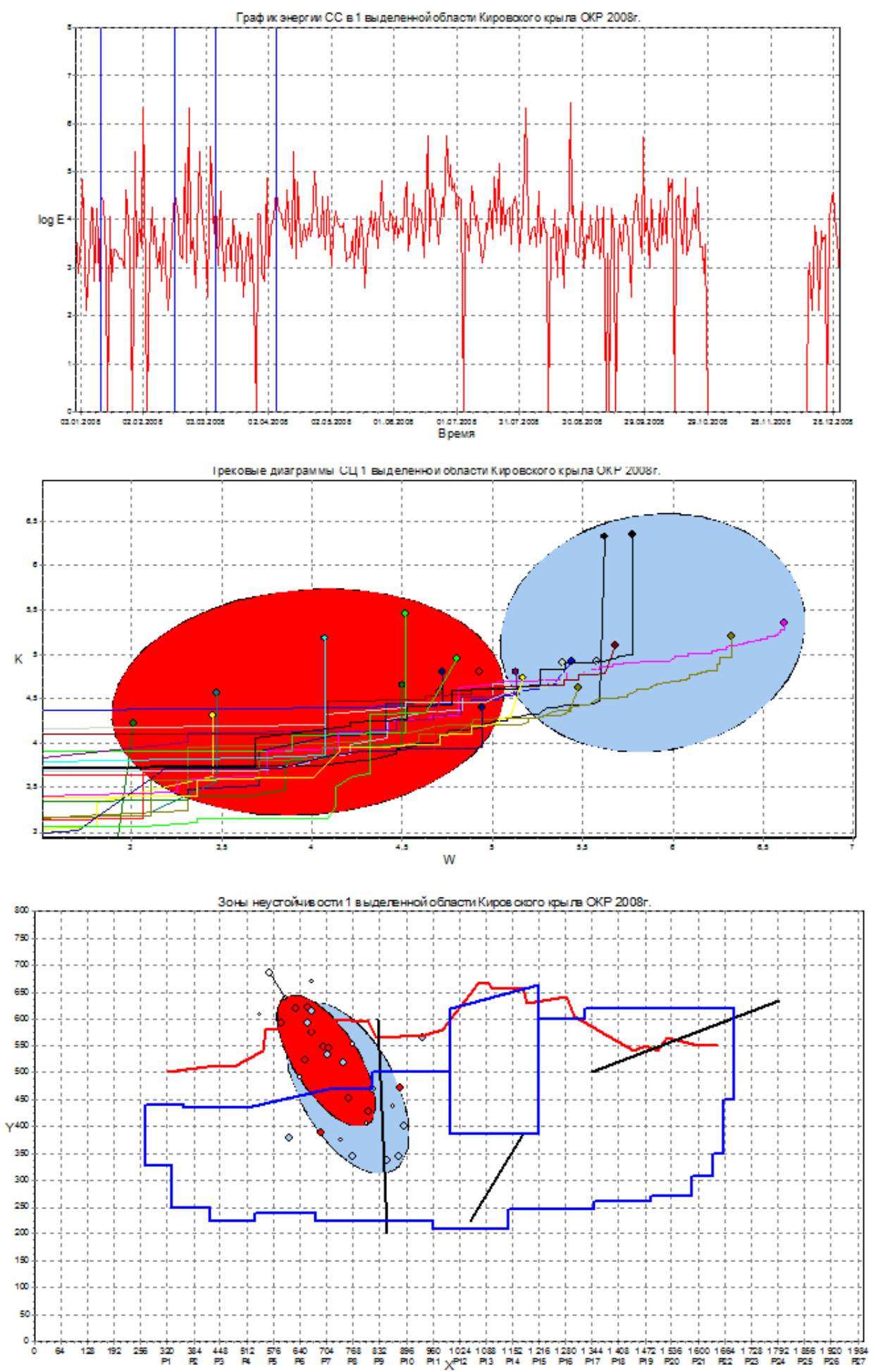

Рис. 4.51. График энергии СС, трековые диаграммы и зоны неустойчивости в первой выделенной области 

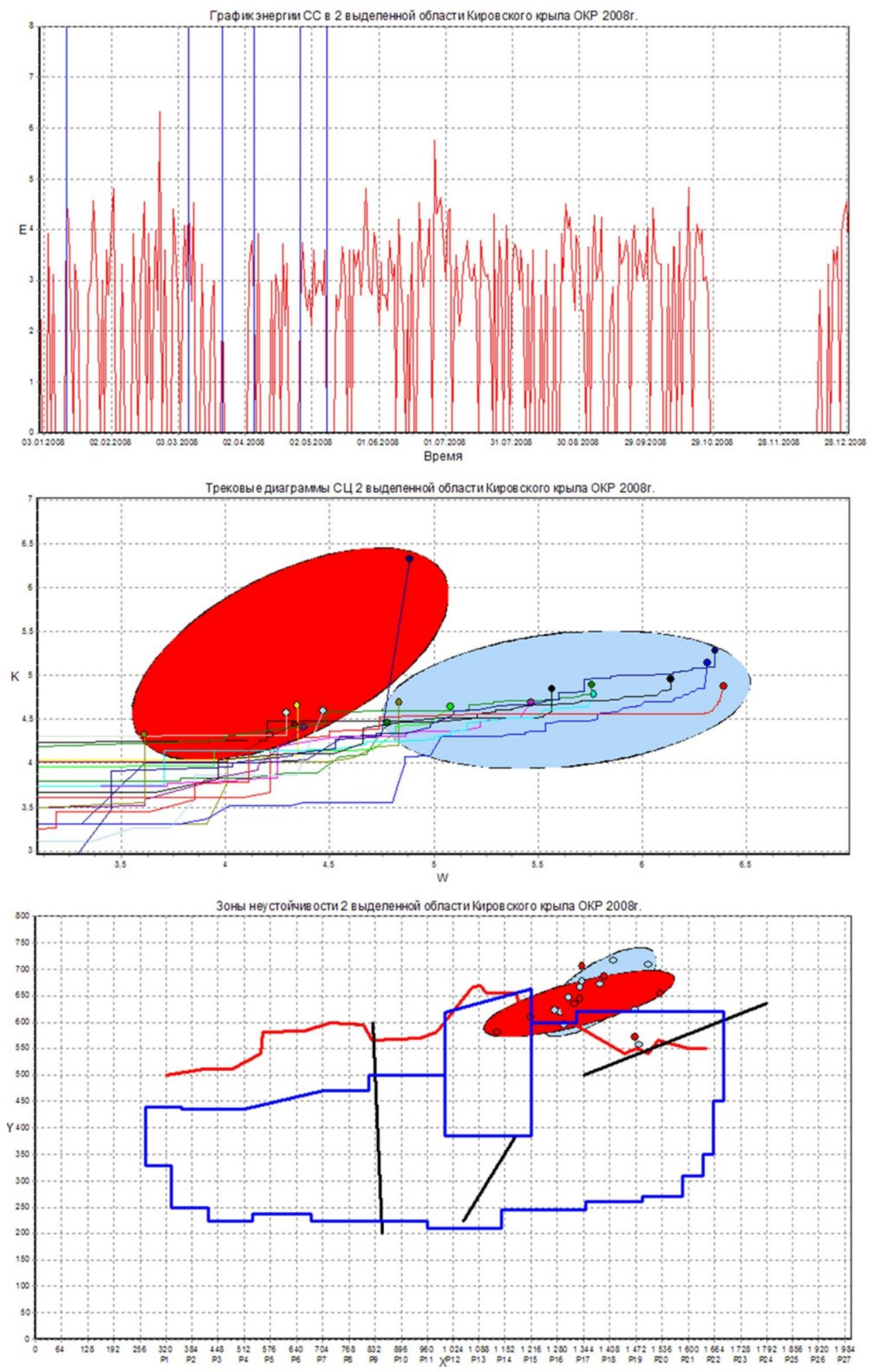

Рис. 4.52. График энергии СС, трековые диаграммы и зоны неустойчивости во второй выделенной области 


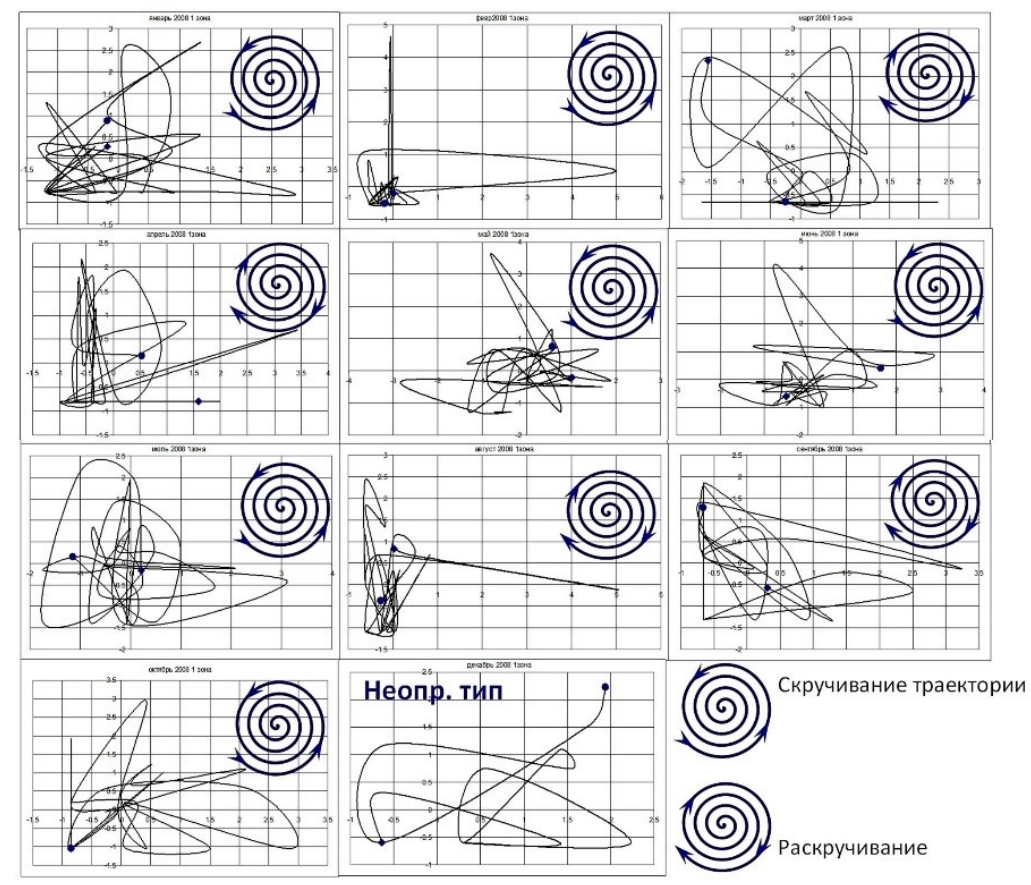

Рис. 4.53. Фазовые траектории первой области за период январь - декабрь 2018 г. для Кировского крыла ОКР

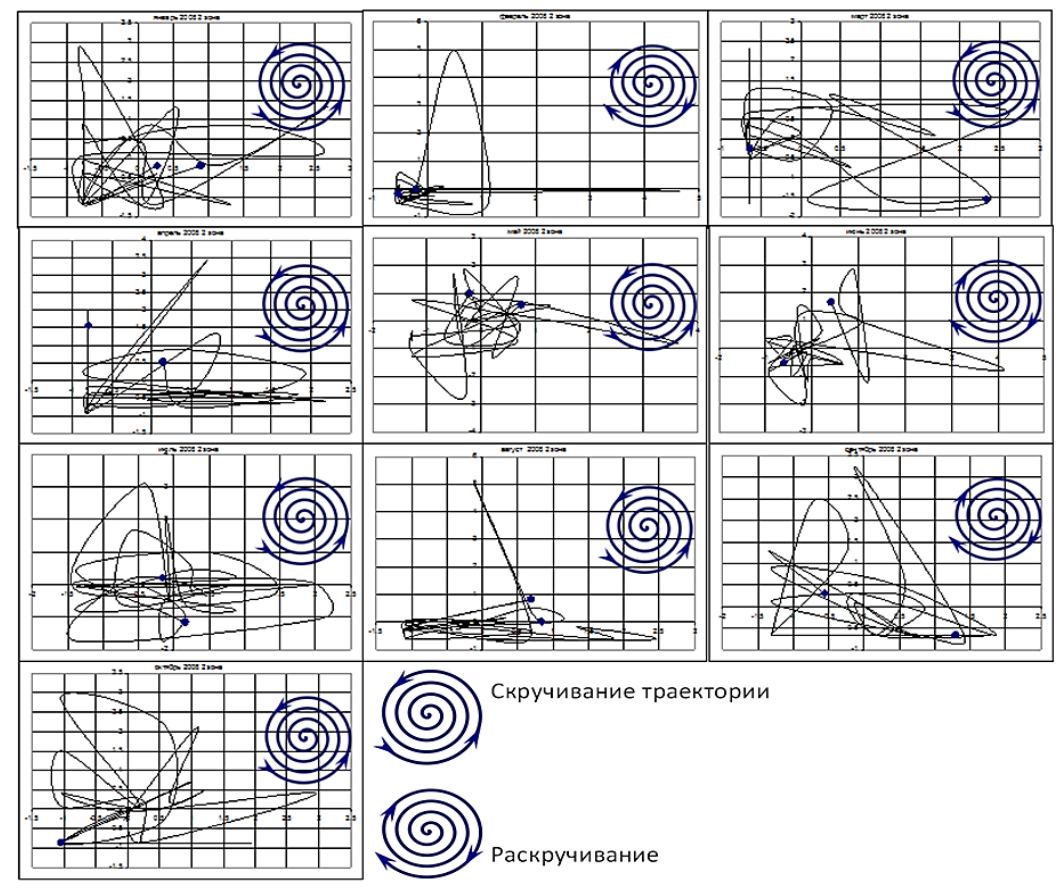

Рис. 4.54. Фазовые траектории второй области за период январь - декабрь 2018 г. для Кировского крыла ОКР

В таблице 4.5 типы полученных аттракторов для выделенных областей за период 2018 г. для Кировского крыла ОКР обобщены по месяцам. 
Типы аттракторов для первой и второй выделенных областей

\begin{tabular}{|l|l|l|l|}
\hline \multicolumn{1}{|c|}{ Область 1 } & \multicolumn{1}{c|}{ Тип аттрактора } & \multicolumn{1}{c|}{ Область 2 } & \multicolumn{1}{c|}{ Тип аттрактора } \\
\hline Январь & Скручивание & Январь & Скручивание \\
\hline Февраль & Скручивание & Февраль & Раскручивание \\
\hline Март & Раскручивание & Март & Скручивание \\
\hline Апрель & Раскручивание & Апрель & Скручивание \\
\hline Май & Скручивание & Май & Скручивание \\
\hline Июнь & Скручивание & Июнь & Раскручивание \\
\hline Июль & Скручивание & Июль & Скручивание \\
\hline Август & Раскручивание & Август & Скручивание \\
\hline Сентябрь & Раскручивание & Сентябрь & Раскручивание \\
\hline Октябрь & Скручивание & Октябрь & Скручивание \\
\hline Ноябрь & Нет данных & Ноябрь & Нет данных \\
\hline Декабрь & Неопределенный тип & Декабрь & Нет данных \\
\hline
\end{tabular}

По приведенным в таблице 4.5 данным распределения типов аттракторов по месяцам видно, что в марте, апреле, августе и сентябре сейсмическая обстановка на Кировском крыле ОКР в первой выделенной области характеризовалась активным выделением сейсмической энергии, а во второй выделенной области сейсмически активными месяцами явились февраль, июнь и сентябрь.

Анализ результатов показал, что в выделенных областях проявление сейсмичности может происходить по-разному. В половине рассмотренных случаях наблюдается следующая закономерность: один аттрактор раскручивается, второй скручивается и наоборот, а в другой половине случаев первый и второй одинаковы (данный факт еще не нашел своего объяснения). Перестройка системы происходит не только в отдельных областях, но и в пределах всего шахтного поля.

Таким образом, теория хаоса и динамических систем позволяет по-новому взглянуть на процессы, протекающие в тектонически напряженном массиве горных пород. По характеру аттрактора можно судить о том, в каком состоянии находится система тектонически напряженный массив - массовые взрывы - техногенная сейсмичность (ТНМ - MB - ТС). Так, если аттрактор имеет правильную и законченную форму, то система находится в состоянии динамического равновесия, если аттрактор начинает раскручиваться, то данный факт свидетельствует о потери системой равновесия и переходу к состоянию динамического хаоса, который характеризуется хаотическим аттрактором на фазовой траектории. Другими словами, раскручивание спиралевидной траектории свидетельствует об увеличении амплитуды колебаний сейсмического процесса, скручивание - уменьшении амплитуды колебаний.

\section{6. Кинематические и динамические характеристики, инициируемых массовыми взрывами колебаний в различных горно-геологических условиях}

Эту задачу решали при оценке сейсмической уязвимости борта карьера «Железный» АО «Ковдорский ГОК» по данным кинематических и динамических характеристик колебаний от массовых взрывов.

В настоящее время для экспериментальной оценки состояния прибортового массива основными являются геофизические и геодезические методы, которые требуют проведения длительных наблюдений в условиях действующего карьера и могут дать характеристику массива только в период этих наблюдений. 
В последние годы новым направлением в комплексе исследований, способствующих повышению безопасности и эффективности открытых горных работ, становится микросейсмический мониторинг.

На сегодняшний день микросейсмический мониторинг бортов карьеров применяется на ряде предприятий, ведущих открытые горные работы в Австралии, Намибии и ЮАР. Уже получен ряд новых интересных результатов подобного мониторинга [155].

Положение очагов микросейсмических событий и их деформационные характеристики позволяют оценить сейсмическую составляющую смещения борта. Подобная оценка, выполненная в рамках упругой модели породного массива, выявила интересную особенность [155]. Оказалось, что рассчитываемая по сейсмическим данным деформация борта опережает реально фиксируемое (по результатам маркшейдерских измерений) сдвижение на 1-2 мес.

На рисунке 4.55 показано сопоставление величин смещений одного из маркшейдерских реперов на карьере Navachab по геодезическим и микросейсмическим данным [155].

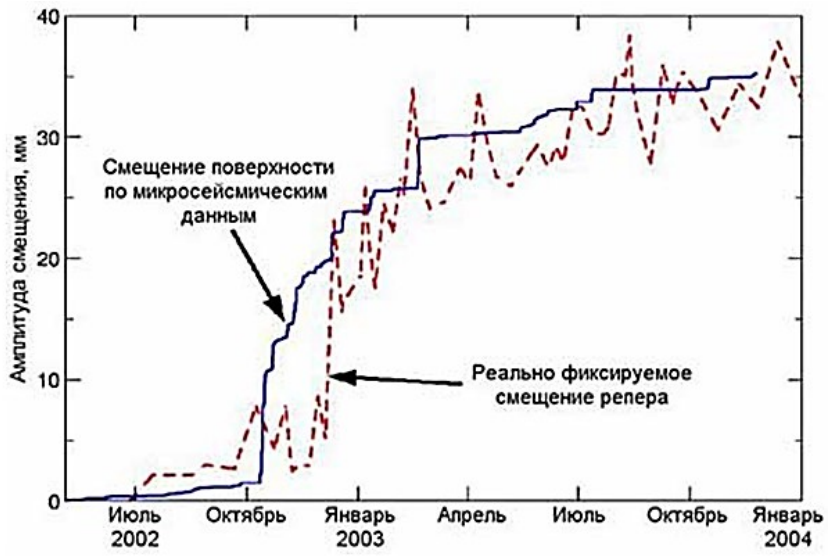

Рис. 4.55. Сопоставление величин смещений одного из маркшейдерских реперов на карьере Navachab по геодезическим и микросейсмическим данным [155]

Следует отметить, что все наблюдения за состоянием борта карьера основаны на интерпретации микросейсмических событий. Обработка материалов сейсмомониторинга включает выделение сейсмических сигналов и оценку параметров их очагов: координат $x$; времени инициации очагового процесса $t$; сейсмической энергии $E_{s}$; сейсмического момента (меры неупругой деформации в очаге) $M_{o}$.

Для определения $x$ и $t$ используются кинематические параметры сигналов - времена вступлений продольных $(P)$ и поперечных $(S)$ волн. Расчет выделившейся сейсмической энергии и сейсмического момента выполняется по амплитудным характеристикам этих волн. Для более достоверной оценки $E_{s}$ и $M_{o}$ используют трехкомпонентные сейсмоприемники. Интерпретация и анализ этих характеристик позволяют выполнить:

- оценку влияния интенсивности горных работ на макроскопическую устойчивость пород борта;

- идентификацию сейсмически активных геологических структур;

- оценку связанной с сейсмическими событиями деформации бортов. 
В России впервые система микросейсмического мониторинга создана на руднике «Железный» $\mathrm{AO}$ «Ковдорский ГОК», которая позволяет регистрировать не только техногенные сейсмические события, но и колебания массива от массовых взрывов. При этом весь комплекс работ по контролю над работоспособностью оборудования и оперативной обработке материалов наблюдений производится дистанционно из головного офиса Горного института КНЦ РАН, что позволяет оперативно анализировать текущее состояние. Более подробно об этой системе будет сказано в главе 5.

Отличительной особенностью этой системы является то, что сейсмоприемники установлены в скважинах на различной глубине от поверхности уступов. Такое расположение позволяет оценить реакцию массива горных пород на мощные динамические воздействия при производстве массовых взрывов как внутри массива, так и вблизи поверхности уступов. В настоящее время динамические характеристики колебаний оценивают по общепризнанным критериям - скорости смещения, ускорению и смещению, но в дальней зоне, ввиду их малости, трудно предсказать поведение какого-либо участка массива в карьере при динамическом воздействии.

Для решения настоящей задачи была положена ранее успешно применявшаяся методика, предложенная японским сейсмологом Ю. Накамурой [156], которая позволяет с использованием трехкомпонентной регистрации микросейсмического природного фона просвечивать толщу грунтов с целью получения амплитудно-частотной характеристики разреза и оценивать его основные геотехнические параметры.

Метод Ю. Накамуры, основанный на регистрации микросейсм природного и техногенного происхождения, довольно широко применяется в геофизических исследованиях, a также для оценки конструктивной устойчивости и уязвимости общественно важных зданий — архитектурные памятники (Колизей, Пизанская башня), множество административных зданий и сооружений (виадуков, скоростных автомагистралей), которые успешно выполняются в Японии и ряде стран Евросоюза [157].

Метод Накамуры использует в первом приближении прямую связь частотной характеристики передаточной функции с амплитудами возможных сдвиговых деформаций в сооружении. Отсюда следует, что резонансы (пики) частотной характеристики свидетельствуют о наличии резонансов при сдвиговых деформациях на заданных частотах и их повышенной чувстветильности к повреждениям на этих частотах под действием прилагаемых внешних нагрузок.

Суть метода Накамуры выражается следующей зависимостью:

$$
U(f)_{i, o}=\left(H_{N-S}+H_{E-W}\right) / 2 V_{Z},
$$

где $U(f)_{i, o}$ - максимальные значения характерных зависимостей на исследуемом участке; $H_{N-S}$ и $H_{E-W}$ - спектры колебаний по горизонтальным компонентам (север-юг, восток-запад соответственно); $V_{Z}-$ спектр колебаний на вертикальной компоненте.

Отношение спектральных характеристик горизонтальных компонент к спектру вертикальной компоненты характеризует так называемую передаточную функцию, которая строго зависит от тонкой структуры изучаемого объекта, то есть позволяет определить резонансные частоты на исследуемом участке. 
На основе построенных спектральных графиков усиления сотрясений на наиболее доминирующих частотах можно вычислить значения коэффициентов уязвимости $(K)$ :

$$
K=a^{2} / F,
$$

где $a$ - максимальное значение коэффициента усиления; $F$ - соответствующая этому значению частота.

Этот метод адаптирован применительно к оценке уязвимости бортов карьеров при производстве массовых взрывов. Основной целью исследований первоначально было оценить влияние каскадного массового взрыва на состояние борта карьера, а затем проследить во времени изменение состояния прибортового массива при производстве массовых взрывов в карьере.

Местоположение каскадного взрыва относительно точек наблюдения представлено на рисунке 4.56 .

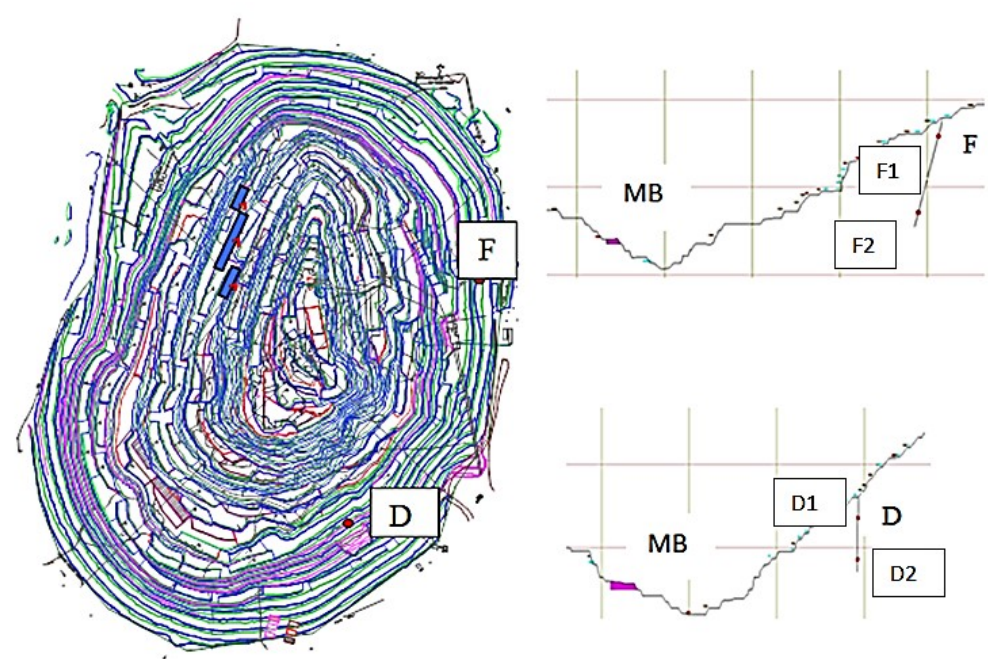

Рис. 4.56. Местоположение взрывов относительно точек наблюдения в плане и по разрезам на взрыв

На рисунке 4.57 приведены сейсмограммы от взрыва 08.06.2013 г. для точек D1, D2, а на рисунке 4.58 для точек F1, F2.

Анализ сейсмограмм и спектров колебаний в точках $\mathrm{D}$ и $\mathrm{F}$ показал, что вблизи поверхности (точка D1) основная доля энергии переносится на частотах 10-20 Гц и 30-40 Гц, в то время как в нижней точке D2 - на частотах 30-40 Гц. В точке F1 преобладающими являются частоты 10-20 Гц, а в точке $\mathrm{F} 2-40-70$ Гц. То есть в нижней части массива преобладают более высокочастотные колебания, чем в верхней.

Построенные по методу Ю. Накамуры передаточные функции показали (рис. $4.57,6,4.58,6$ ), что на определенных частотах происходит существенное увеличение горизонтальных колебаний (до 10 раз) по сравнению с вертикальными. Причем, если в точках D1, D2 имеется насколько резонансных частот, то в точках F1, F2 в основном выделяется две резонансные частоты -5 и 40 Гц. Это отличие обусловлено, по всей видимости, структурными 
особенностями каждого участка. Вычисленные по этому же методу коэффициенты уязвимости (отношение квадрата коэффициента усиливаемости к частоте колебаний на этом уровне) (рис. $4.57,2$ и 4.58, г) показали, что наиболее уязвимым к динамическим воздействиям является восточный борт (точка F), где возможно образование сдвиговых деформаций в сторону выработанного пространства, что приводит к повышенной способности к повреждениям на этих частотах под действием прилагаемых внешних нагрузок.

Точка регистрации $\mathrm{D}_{1}$
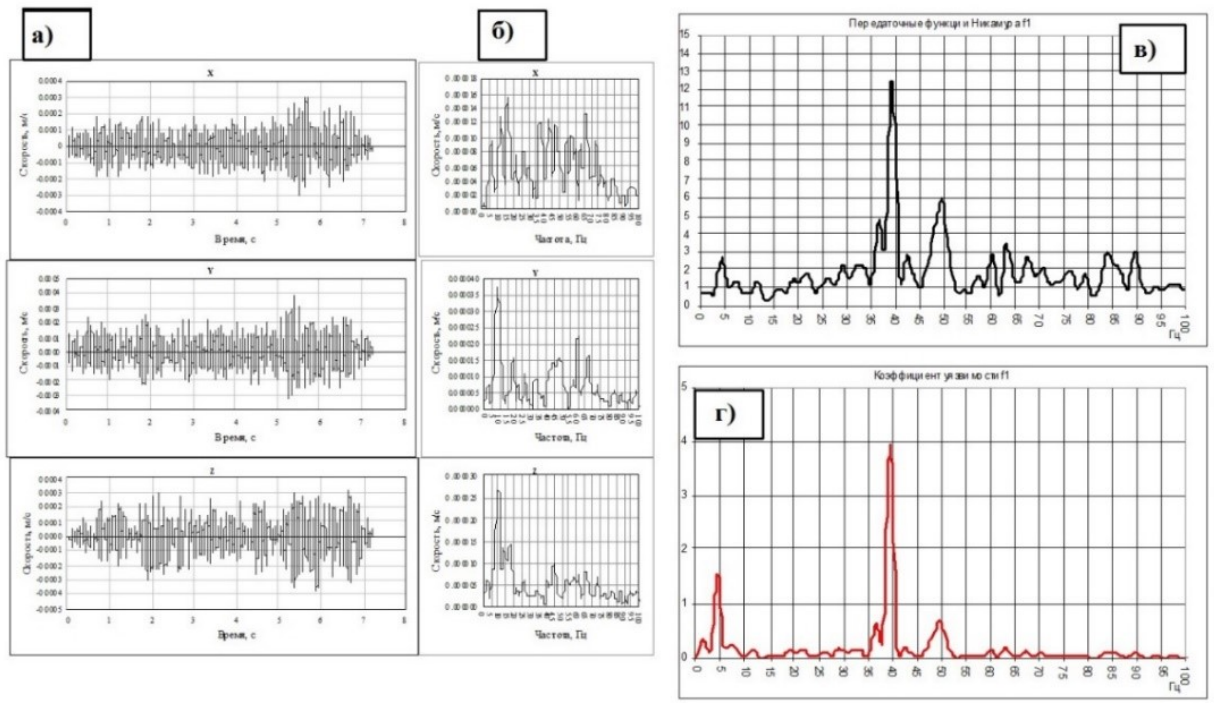

Точка регистрации $\mathrm{D}_{2}$
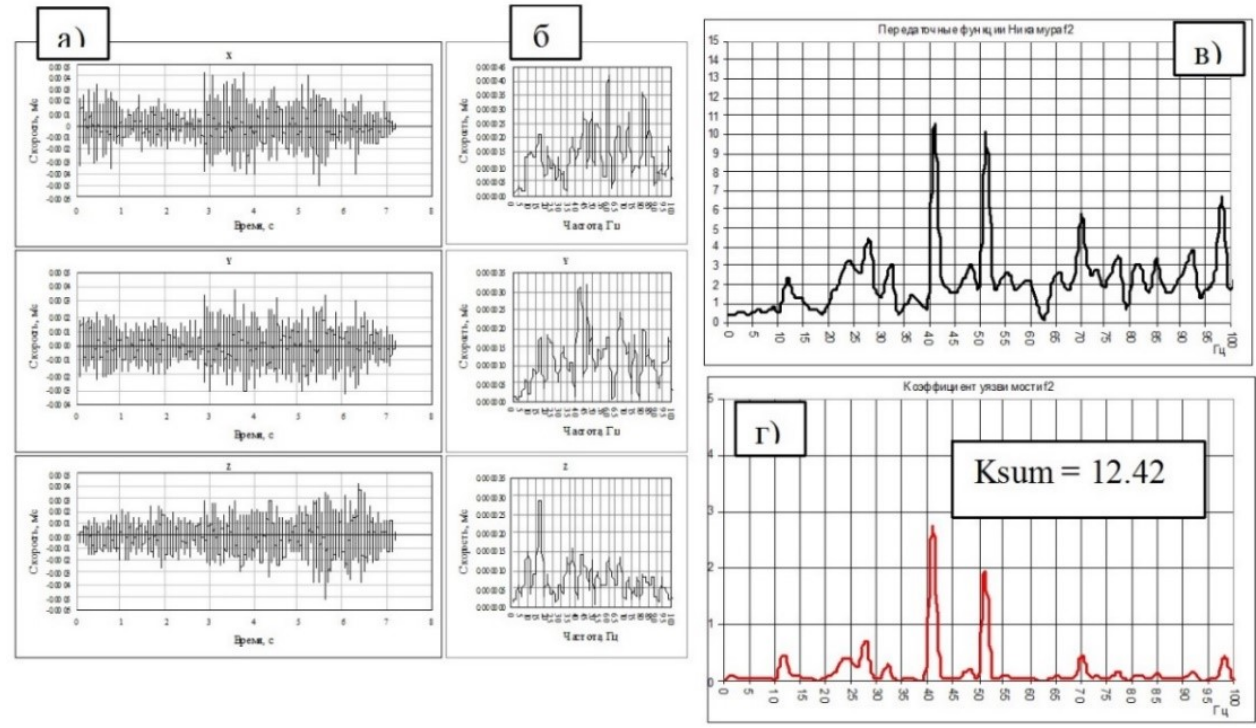

Рис. 4.57. Сейсмограммы колебаний по трем компонентам (a), их спектры (б), передаточная функция Накамуры (в) и коэффициент уязвимости (2) в точках D1-D2 (рис. 4.56). Взрыв 08.06.2013 
Точка регистрации $\mathrm{F}_{1}$
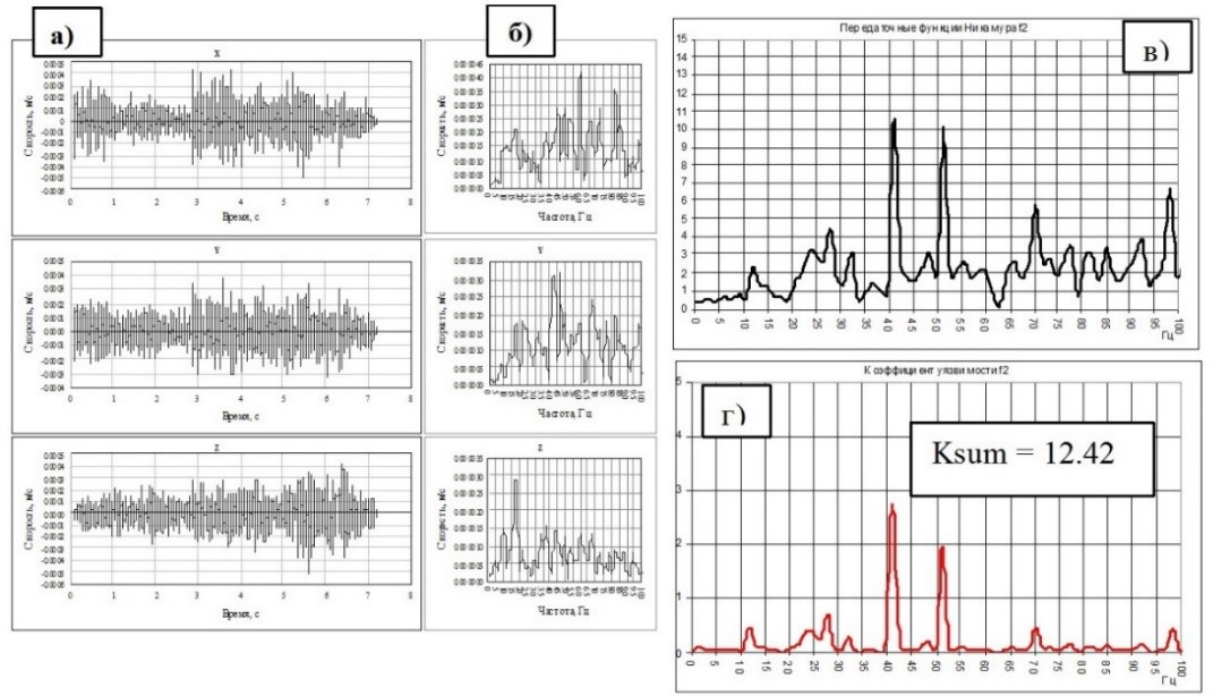

Точка регистрации $\mathrm{F}_{2}$

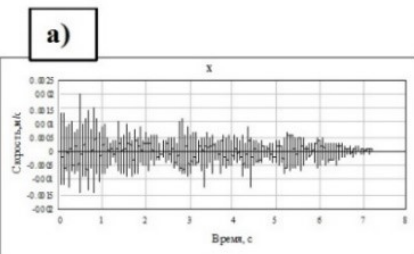

б)
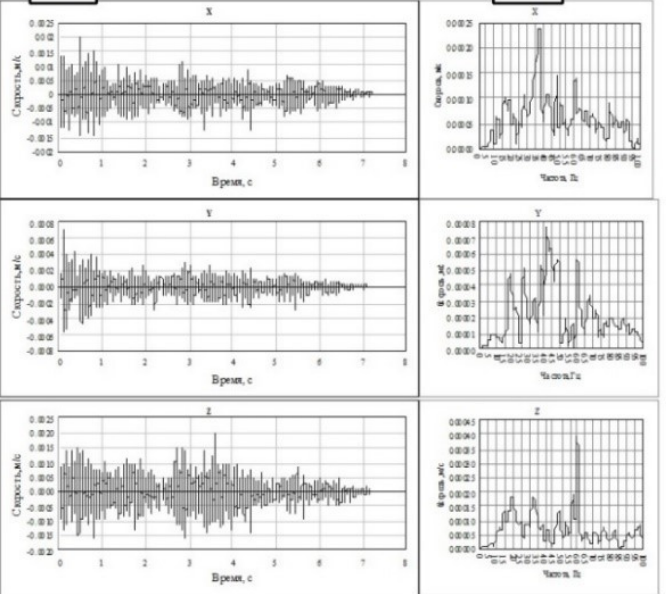

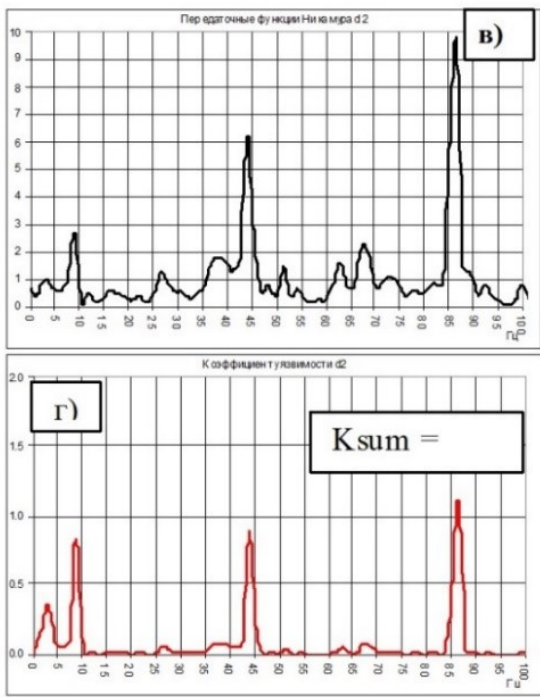

Рис. 4.58. Сейсмограммы колебаний по трем компонентам (a), их спектры (б), передаточная функция Накамуры (в) и коэффициент уязвимости (2) в точках F1-F2 (рис. 4.56)

Работы в этом направлении были продолжены именно на восточном борту карьера (рис. 4.59) с целью проследить во времени изменение состояния прибортового массива при производстве массовых взрывов в карьере.

Анализ сейсмограмм и спектров колебаний в точке F показал (рис. 4.60), что вблизи поверхности (F1) преобладающими являются частоты 8-12 Гц, а в точке $\mathrm{F} 2-10-30$ Гц. То есть в нижней части массива преобладают более высокочастотные колебания, чем в верхней.

На рисунке 4.61 показаны передаточные функции от 12 взрывов, произведенных в 2012-2014 гг., для точки F1, находящейся вблизи поверхности борта карьера. 


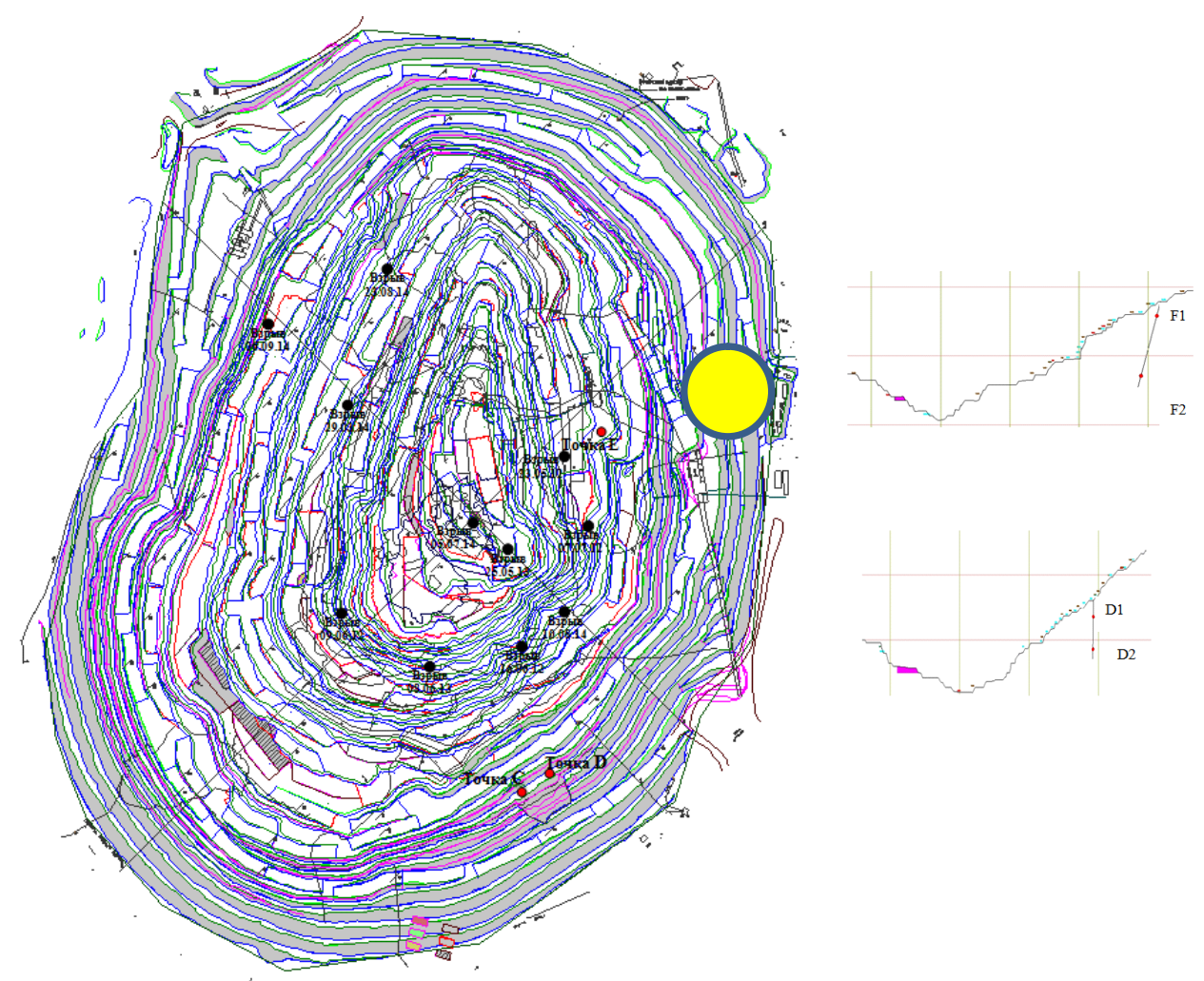

Рис. 4.59. Местоположение взрывов относительно точек наблюдения в плане и по разрезам на взрыв

Построенные по методу Ю. Накамуры передаточные функции показали (рис. 4.61), что на определенных частотах в точке F1 происходит существенное увеличение горизонтальных колебаний (до 10 и более раз) по сравнению с вертикальными. При этом выделяются несколько резонансных частот, а наибольшее усиление сотрясений происходит на резонансных частотах 1-10 и 20-30 Гц, что совпадает с преобладающими частотами колебаний от массовых взрывов. Увеличение периода колебаний и длительности их воздействия усиливает влияние динамических нагрузок на устойчивость бортов карьеров.

Сравнивая передаточные функции от различных взрывов можно видеть их существенное различие, что обусловлено как их местоположением в карьере относительно точки наблюдения, так и направленностью их воздействия. Наиболее благоприятными являются взрывы, произведенные по направлению с точкой наблюдения, которые вызывают усиление колебаний в низкочастотном диапазоне и которые наиболее опасны с точки зрения развития деформаций.

В целях выявления большей достоверности предложенного подхода по оценке сейсмической уязвимости рассматриваемого участка борта карьера была сделана попытка увязать воздействие взрывов с наведенной сейсмичностью на этом участке. Но, к сожалению, это сделать не удалось, в связи с тем, что вблизи точки наблюдения расположен рудный 
дробильно-конвейерный комплекс (РДКК), при работе которого возникают периодические колебания, амплитудные значения которых значительно выше сейсмических событий в массиве. Поэтому сейсмические события не удается выделить из общей базы данных.
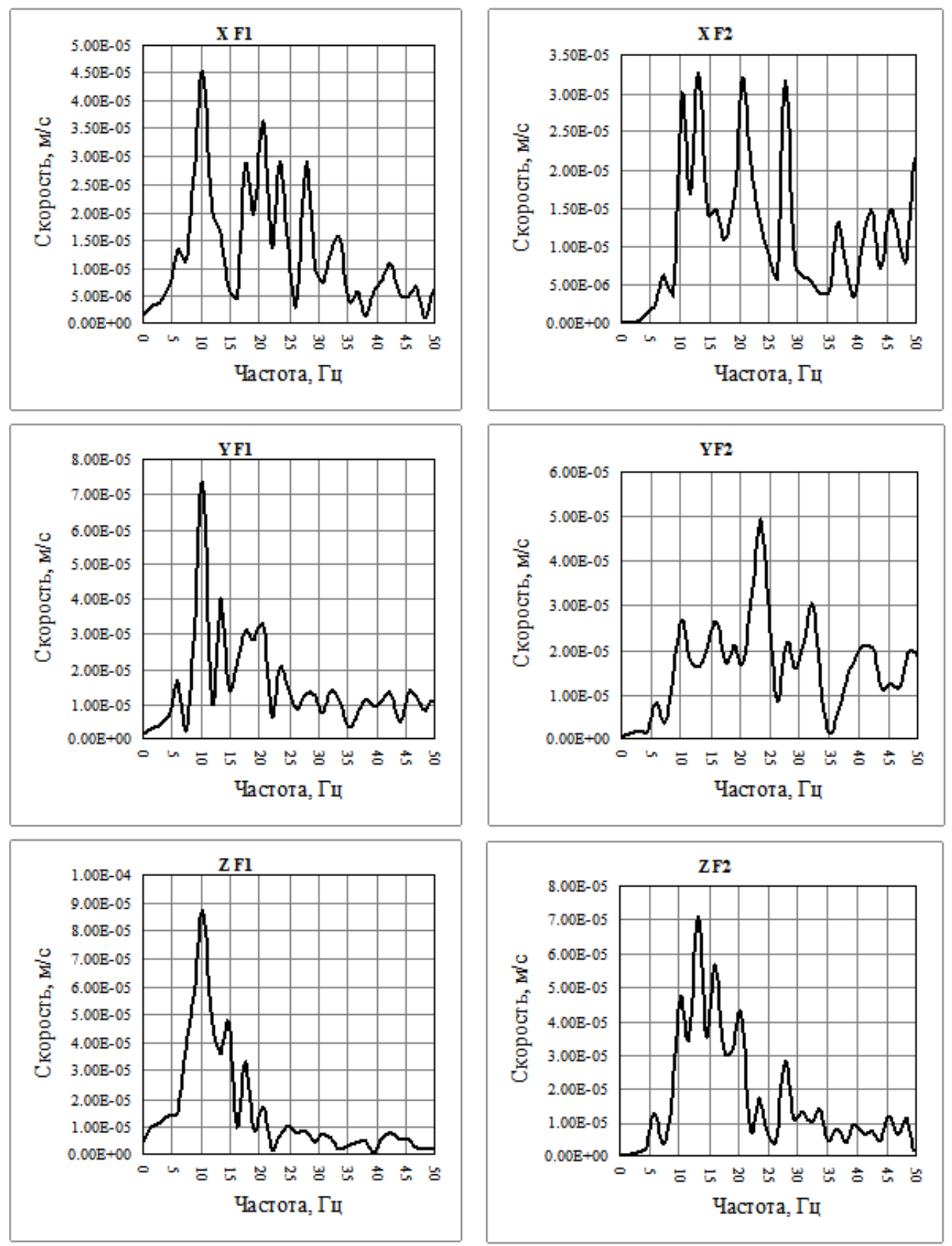

Рис. 4.60. Наиболее характерные спектры колебаний в точках F1 и F2 при производстве массовых взрывов в карьере 

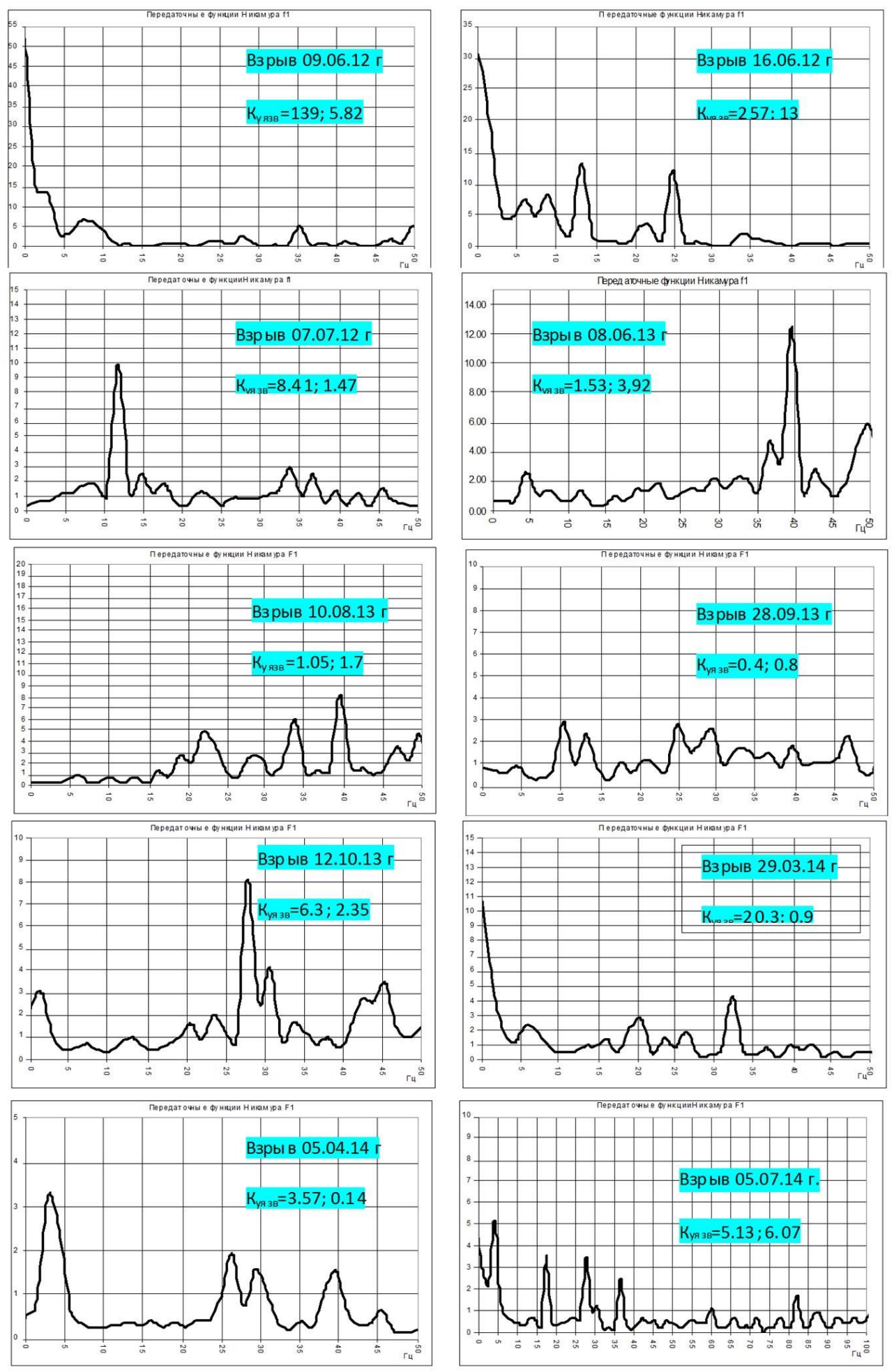

Рис. 4.61. Коэффициенты усиления колебаний в точке F1 для разных взрывов 
Таким образом, в результате изучения закономерностей проявления техногенной сейсмичности при производстве взрывных работ на объединенном Кировском руднике КФ АО «Апатит» получены следующие результаты.

1. Установлена взаимосвязь проявления сейсмичности с режимом ведения взрывных работ. Показано, что регулярное проведение массовых взрывов способствует более равномерному выделению накопленной энергии в массиве горных пород и позволяет избежать создания критических состояний на обоих месторождениях. С уменьшением числа массовых взрывов происходит снижение общего количества сейсмических событий, а после пятимесячного отсутствия массовых взрывов сейсмическая активность массива горных пород возрастает. При этом растет количество крупных сейсмических событий.

2. Для изыскания дополнительных физических методов и моделей прогноза проявлений техногенной сейсмичности к условиям подземных рудников Хибин адаптирована теория количественного описания сейсмических процессов в реальной среде, основанная на законе производства сейсмической энтропии, создан программный комплекс ACS и рассмотрена кинетика техногенного сейсмического процесса при ведении горных работ на рудниках.

3. С целью выявления опасных состояний в массиве горных пород рассчитаны сейсмические циклы, построены трековые диаграммы и аттракторы, на основании которых выявлены наиболее опасные зоны в границах шахтного поля. В результате проведенного анализа установлено, что сейсмически опасные зоны относительно фронта горных работ могут существовать довольно длительное время. Они также могут как расширяться за счет их объединения, так и в отдельные временные отрезки не проявлять сейсмической активности, то есть исчезать, а при определенных условиях могут появляться и новые зоны с неустойчивым состоянием.

4. Оценены проявления сейсмичности до и после проведения массового взрыва. В результате анализа установлено, что после массовых взрывов общее количество сейсмических событий увеличивается, но их суммарная энергия уменьшается, что свидетельствует о релаксации напряжений в массиве горных пород после их производства. Причем чем больше разница в общем количестве сейсмических событий до и после взрыва, тем больше понижается энергия сейсмической активности.

5. На основе изучения сейсмического режима на подземных рудниках КФ АО «Апатит» выявлены зоны неустойчивого состояния массива и показано, что их формирование определяется продолжительностью коротко- и длинноживущих сейсмических циклов. Показано, что при производстве массовых взрывов проявление сейсмических событий определяется в основном уровнем воздействия в зоне действия массового взрыва, а количество выделившейся энергии не превосходит закачанную энергию от взрывов.

6. Рассмотрено проявление техногенной сейсмичности при переходе на отбойку руды технологическими взрывами в системе разработки подэтажного обрушения с торцевым выпуском руды и дано ее сравнение с условиями проведения массовых взрывов. При проведении торцевых взрывов и равномерном (стационарном) ходе суточного сейсмического процесса количество выделившейся энергии во всех случаях превосходит закачанную энергию от взрывов, а сами взрывы являются триггером высвобождения собственных запасов энергии в геологической среде. При нарушении стационарного деформационного режима в среде торцевые взрывы только ускоряют или запускают высвобождение накопленной в среде упругой энергии и формирование очагов сейсмических событий в зонах, подготовленных к переходу к неустойчивой стадии. 
7. Показано, что сами сейсмические события после производства торцевых взрывов способствуют формированию более крупных событий и приводят к изменению геодинамической ситуации в зоне перехода массива к неустойчивой стадии.

8. Для повышения точности локализации зон неустойчивости было предложено рассчитать трековые диаграммы, используя сейсмические циклы различных энергетических классов. Применительно к проведенным исследованиям при расчете трековых диаграмм по сейсмическим циклам 3 класса выделяются в основном области мелкого трещинообразования. С увеличением класса между сейсмическими циклами до 4 позволяет определить области формирования более крупных трещин. Дальнейшее увеличение классности событий (5-6 класс) позволяет рассчитать области значительных тектонических нарушений в исследуемом массиве горных пород. С физической точки зрения происходит переход от системы мелкого трещинообразования с энергией $10^{3}$ Дж к другой более энергоемкой системе с энергией $10^{4}$ Дж и далее, к высокоэнергетическим событиям с энергиями $10^{5}$ и $10^{6}$ Дж.

9. Массив горных пород является нелинейной детерминированной динамической системой, так как отвечает всем признакам нелинейных динамических систем, а характер выделения сейсмичности носит хаотический характер. Для описания техногенной сейсмичности предложено применять методы, используемые при описании нелинейных динамических систем - теорию аттракторов и фазового пространства.

10.Получены экспериментальные данные о сейсмическом действии массовых взрывов на прибортовой массив горных пород карьера «Железный» Ковдорского ГОКа по данным системы микросейсмического мониторинга.

11.Рассмотрена возможность применения метода Накамуры для оценки сейсмической уязвимости бортов карьера. Построенные по методу Накамуры передаточные функции показали, что на определенных частотах происходит существенное увеличение горизонтальных колебаний (до 10 раз) по сравнению с вертикальными. Вычисленные по этому же методу коэффициенты уязвимости (отношение квадрата коэффициента усиливаемости к частоте колебаний на этом уровне) показали, что наиболее уязвимым к динамическим воздействиям является восточный борт карьера, где возможно образование сдвиговых деформаций в сторону выработанного пространства, что приводит к повышенной повреждаемости на этих частотах под действием прилагаемых внешних нагрузок. 


\section{5. ГЕОМЕХАНИЧЕСКИЙ МОНИТОРИНГ ГЕОЛОГИЧЕСКОЙ СРЕДЫ ГОРНОТЕХНИЧЕСКИХ СИСТЕМ}

\section{1. Уточнение понятийного аппарата геоеханического мониторинга}

В настоящее время уже общеизвестно, что геологическая среда является сложной открытой динамической нелинейной системой, что существенно усложняет прогнозирование происходящих в ней процессов, о чем свидетельствует многолетняя история прогноза землетрясений. Поэтому единственной возможностью контролировать ее состояние и обеспечить качественный прогноз развития геодинамических процессов во времени является детальный и комплексный мониторинг [158].

Необходимость надежной информации о параметрах свойств и состоянии горных пород в массиве сегодня ни у кого не вызывает сомнений, поэтому постоянно и повсеместно ведутся поиски эффективных и технологичных соответствующих экспериментальных методов. Однако иногда возникает путаница в терминологии и в определениях измеряемых параметров. В связи с этим представляется целесообразным напомнить некоторые простейшие элементы теории измерений, в соответствии с которой каждый объект характеризуется внешними измеряемыми величинами и внутренними ненаблюдаемыми параметрами [159]. Первые для краткости названы индикаторами, вторые - латентами, по-видимому, производным от латинского слова latentis - скрытый, что является, по нашему мнению, весьма удачным определением.

Для формализации связей между индикаторами и латентами к настоящему времени наработано великое множество уравнений, которые в работе [159] названы метрическими моделями. Соотношения между латентами, индикаторами и метрическими моделями применительно к задачам геомеханического мониторинга в первом приближении представлены в таблице 5.1 .

Любая по-настоящему полезная классификация содержит от трех до шести категорий [160].

Адекватность метрических моделей физической сущности исследуемых процессов определяет надежность оценки изучаемой ситуации и соответствующего прогноза. Поэтому наиболее корректными и надежно определяемыми in situ (то есть, натурными методами непосредственно в массиве горных пород) геомеханическими параметрами геологической среды на сегодня являются напряжения, измеряемые методами разгрузки и гидроразрыва; деформации и перемещения, измеряемые геодезическими и сейсмическими методами.

Метод разгрузки - в настоящее время общепризнанный и наиболее доступный способ получения количественной информации о параметрах поля напряжений в массиве пород, в то время как метод гидроразрыва имеет некоторые ограничения как по условиям его применения, так и, главным образом, по сложности технического обеспечения, хотя для определений на больших глубинах (например, в скважинах глубиной до 5000 м [161]) он является практически незаменимым.

Разделение геодинамических опасностей на удароопасность и сейсмоопасность является довольно условным, поэтому в последней редакции «Правил безопасности...» [162] упоминается только удароопасность. 
Классификация геомеханических параметров геологической среды в природно-технических системах

\begin{tabular}{|c|c|c|c|}
\hline \multicolumn{2}{|c|}{ Латенты } & Индикаторы & Метрические модели \\
\hline \multirow{3}{*}{\multicolumn{2}{|c|}{ Напряжения }} & $\begin{array}{l}\text { Деформации } \\
\text { (методы разгрузки) }\end{array}$ & $\begin{array}{l}\text { Формулы теории } \\
\text { упругости + эмпирические } \\
\text { коэффициенты } \\
\end{array}$ \\
\hline & & $\begin{array}{l}\text { Давление гидроразрыва } \\
\text { скважины (метод гидроразрыва) }\end{array}$ & $\begin{array}{l}\text { Формулы теории } \\
\text { упругости }\end{array}$ \\
\hline & & $\begin{array}{l}\text { Параметры упругих волн } \\
\text { и электромагнитного излучения } \\
\text { (геофизические методы) }\end{array}$ & $\begin{array}{l}\text { Эмпирические } \\
\text { статистические связи }\end{array}$ \\
\hline \multirow[t]{2}{*}{$\begin{array}{l}\text { Горные удары } \\
\text { (геодинамические } \\
\text { опасности) }\end{array}$} & удароопасность & $\begin{array}{l}\text { Разрушения контура горных } \\
\text { выработок и скважин, } \\
\text { шелушение и стреляние пород, } \\
\text { параметры свойств пород и поля } \\
\text { напряжений в массиве } \\
\text { (геомеханические методы) }\end{array}$ & $\begin{array}{l}\text { Эмпирические } \\
\text { статистические связи }\end{array}$ \\
\hline & сейсмоопасность & \begin{tabular}{|l} 
Параметры сейсмического \\
режима, параметры полей \\
напряжений и деформации \\
в геологической среде \\
(сейсмологические методы)
\end{tabular} & $\begin{array}{l}\text { Эмпирические } \\
\text { статистические связи }\end{array}$ \\
\hline
\end{tabular}

Однако уже давно известно, что горные удары и землетрясения имеют одинаковую физическую природу, а характер проявления их в горных выработках определяется энергией динамического события и расстоянием от очага этого события до горных выработок. Поэтому все совещания по этой тематике в последние годы как в России, так и за рубежом идут под флагом техногенной сейсмичности и горных ударов, а сам горный удар (например, в Австралийском центре геомеханики [163]) определяется как сейсмическое событие, результатом которого стало видимое разрушение горных пород в массиве, что в общем виде в большей степени соответствует физической природе процесса и горнотехнической практике.

Из таблицы 5.1 следует, что и удароопасность, и сейсмоопасность зависят от многих факторов, что объясняет отсутствие до настоящего времени адекватных метрических моделей и трудности, в частности, надежного прогноза землетрясений [19], как, впрочем, и сложности с прогнозом других многофакторных явлений [164, 165].

Таким образом, становится очевидным, что надежный геодинамический прогноз не может быть сделан на основании какого-либо одного геофизического параметра. Решение задачи геодинамического прогноза должно базироваться на всестороннем анализе текущего состояния геологической среды в горнотехнических системах по комплексу факторов таких, как: параметры физических свойств пород и полей напряжений в массиве, сейсмический режим геологической среды, результаты деформационных наблюдений методами традиционной и космической геодезии [166], а также высокоточными наклономерами и деформометрами. 


\section{2. Современные представления о характерных особенностях \\ и геомеханическом состоянии массива горных пород как среды функционирования горнотехнических систем}

По современным представлениям любой реальный массив горных пород представляет собой сложную иерархически блочную среду, каждой структурной единице которой присущи свои деформационные характеристики. Степень изученности общих закономерностей деформирования и разрушения подобных сред не достаточна. Однако определенная ясность в этих вопросах уже есть благодаря последним результатам исследований, полученным в связи с организацией и анализом длительных наблюдений за состоянием различных ответственных сооружений. Кроме того, последний период характеризуется интенсивным развитием новых методов контроля состояния массива, к которым в первую очередь следует отнести физические методы измерения расстояний и методы космической геодезии, имеющие существенные преимущества перед традиционными методами и поэтому позволившие уже на данном этапе получать качественно новую информацию.

В целом современные представления о геомеханическом состоянии и основных закономерностях деформирования и разрушения иерархически блочных массивов горных пород сводятся к следующему.

1. Для массивов горных пород в пределах верхней мантии и земной коры характерна общая схема иерархически блочного строения, которую можно проследить от планетарных структур типа литосферных плит, континентов и рифтов до микроструктур на уровне отдельных минеральных зерен и кристаллов.

2. Массивы горных пород отличаются наличием начального (естественного) напряженного состояния, обусловленного действием главным образом двух считающихся независимыми полей напряжений. Одно из них - обусловлено действием гравитационных сил, оно повсеместно; другое - обусловлено действием условно называемых «тектонических» сил и характерно для 60 \% скальных массивов и $20 \%$ массивов, сложенных осадочными породами.

3. На начальное напряженное состояние массивов накладываются различные воздействия, обусловленные как естественными (природными) причинами, так и результатом деятельности человека, в частном случае, строительством и эксплуатацией каких-либо сооружений или разработкой месторождений полезных ископаемых. В результате наложения указанных полей в массиве пород создается сложное неравномерное в пространстве и во времени результирующее поле напряжений, которое на отдельных участках реализуется в виде деформаций, разрушений и перемещений элементов общей системы массива пород.

4. Неоднородность результирующих полей напряжений взаимосвязана и взаимообусловлена неоднородностью (иерархичностью) структуры и свойств массива пород, это определяет особенности их деформирования и разрушения.

5. Явления деформирования и разрушения в массивах пород носят пространственно-дискретный характер. Внутренние части блоков деформируются сравнительно однородно, в то время как на их границах наблюдаются концентрации деформаций. При этом в зависимости от вида, мощности и области воздействий процессы деформирования и разрушения проявляются на различных уровнях структурных неоднородностей массива и охватывают различные его объемы.

6. Пространственная дискретность развития процессов деформирования и разрушения массивов пород дополняется дискретностью развития их во времени. На настоящий момент установлено, что все ранги и типы структурных неоднородностей проявляют подвижность, которая носит направленный, достаточно постоянный (трендовый) характер и в то же время сопровождается существенными динамическими колебаниями. 
Отмеченные общие закономерности деформирования и разрушения иерархически блочных сред в полной мере справедливы для скальных высокопрочных и высоконапряженных массивов пород Хибинских апатит-нефелиновых и Ковдорского железорудного месторождений. В соответствии с этими общими закономерностями выполнялись все работы по организации и проведению наблюдений на специально оборудованных геомеханических полигонах в подземных выработках и карьерах по известным методикам $[167,168]$.

\section{3. Концепция единой комплексной системы геомеханического мониторинга геологической среды природно-техногенных и горнотехнических систем}

Многолетний опыт выполнения наблюдений и измерений на рудниках и карьерах $\mathrm{AO}$ «Апатит» и $\mathrm{AO}$ «Ковдорский ГОК» позволил сформулировать основные положения единой комплексной системы геомеханического мониторинга геологической среды природно-техногенных и горнотехнических систем [139, 169]. При этом главная конечная цель подобных работ представляется в виде создания общей геомеханической модели исследуемой ПТС, а мониторинг геомеханических процессов в массивах различных ПТС является одним из основных методов решения этой общей проблемы. Задачи контроля состояния отдельных элементов, применяемых систем разработки, являются весьма существенными практическими применениями организуемых систем мониторинга.

Вопросы организации мониторинга геомеханического состояния массива горных пород представляют собой новейшее направление геомеханики как науки, которое сейчас достаточно бурно развивается и которое пока еще, с точки зрения общих подходов и применяемых терминов, не является полностью сформированным. В настоящее время существуют различные мнения о задачах, методах проведения, общей организации и последовательности этапов выполнения отдельных видов работ при создании систем мониторинга массива.

Постепенно все большее распространение среди специалистов получает идея о том, что общая концепция организации геомеханического мониторинга должна предусматривать выполнение следующих обязательных этапов:

1) разработка моделей массивов пород и контролируемых процессов, выполнение геодинамического районирования территории рассматриваемых объектов и составление общей геомеханической модели исследуемой ПТС;

2) выбор приоритетных контролируемых параметров;

3) измерение этих параметров в натурных условиях;

4) сопоставление расчетных и измеренных величин с целью верификации принятых моделей;

5) расчет на моделях критических значений параметров, соответствующих переходу участков массива в опасное состояние;

6) оценка текущего состояния контролируемого объекта путем сопоставления измеренных и критических значений наблюдаемых параметров;

7) разработка технических мер по обеспечению эффективности и безопасности горных работ;

8) контроль реализации разработанных технических мер и их корректировка.

Относительно большая степень проработанности вопросов мониторинга характерна для предприятий атомной и нефтегазовой промышленности. В частности, в качестве единичного положительного примера полной реализации комплексного подхода можно указать организацию системы мониторинга на Астраханском газоконденсатном месторождении [170]. 


\subsection{1. Методология и программное обеспечение совместного анализа разнородной геофизической и геомеханической информации}

Изучение геомеханических процессов в геологической среде горнотехнических систем опирается на результаты геодинамического мониторинга, методы которого отражают различные аспекты поведения среды и отличаются реализацией, а также структурой, физическим смыслом и другими характеристиками производимой информации. При этом у них имеется общее свойство - большие объемы информации. Для воспроизводства полной картины текущего состояния контролируемой среды собранная информация должна обрабатываться комплексно, результаты этой обработки должны отображаться в сводном виде на одном рабочем месте. Крайне желательна возможность одновременного доступа к территориально разнесенным базам данных, не ограниченная рамками локальной сети.

Система комплексного геофизического мониторинга состоит из следующих компонентов.

1. База данных хранения, извлечения, корректировки, ассоциирования и распространения всей имеющейся информации, которая может быть использована в вопросах оценки состояния конструктивных элементов геотехнологии, а также других объектов мониторинга.

2. Программные продукты, позволяющие визуализировать пространственную информацию всех используемых типов и форматов о текущем состоянии горных выработок и других объектов мониторинга, а именно:

- карты горного и земельного отводов, в том числе трехмерные модели;

- планы горных работ;

- геолого-структурная, инженерно-геологическая и гидрогеологическая информация;

- фотоснимки, графическая и эскизная информация;

- результаты сканирования и радарной съемки в виде облаков точек, наложенных на трехмерные модели поверхности бортов карьеров, отвалов и других объектов мониторинга.

3. Средства, способные обеспечить согласованный экспресс-анализ информации по вопросам прогнозирования процессов деформирования массива пород, элементов зданий и сооружений, а также своевременное качественное принятие решений, способствующее минимизации негативных последствий таких событий.

4. Набор технических устройств, позволяющий в полевых условиях автоматически и в ручном режиме вводить в базу данных оперативную информацию в виде фотографий и эскизов о геолого-структурных особенностях массива пород, состоянии строений и других свойствах объектов мониторинга.

5. Программно-аппаратный комплекс, позволяющий контролировать текущее положение уступов и бортов карьеров, состояние подземных выработок, отвалов, дамб и других объектов мониторинга, а также отображать результаты контроля в реальном времени в цифровой модели территории горнодобывающего предприятия.

6. Программно-аппаратный комплекс, привлекаемый к более детальному контролю ранее выявленных областей с целью дальнейшего обоснованного принятия решений по снижению возможных рисков возникновения неблагоприятных ситуаций, связанных с потерей устойчивости уступов и бортов карьеров, подземных выработок и других опасных производственных объектов и их конструктивных элементов повышенного уровня ответственности. 
7. Программно-аппаратный комплекс выполнения прогноза состояния объектов мониторинга (карьер, подземная выработка, дамба и др.) на кратко-, средне- и долгосрочном уровне.

Объектами мониторинга являются: поверхности бортов карьеров и отвалов; стены и своды подземных выработок; гидротехнические сооружения; инфраструктурные сооружения (мосты, дорожные насыпи и выемки, трубопроводы, опоры ЛЭП и т. п.); здания.

Следует отметить, что мониторингу подлежат объекты, расположенные не только на территории горнодобывающего предприятия, но и на прилегающих территориях.

Информация о состоянии объектов поступает как результат различных методов наблюдений:

- геологические (визуальный);

- геофизические методы (датчики перемещения (наклономеры, деформометры); локальные геомеханические (анализ керна, контроль разрушения скважин, ультразвуковое прозвучивание и профилирование); региональные геомеханические; пассивные сейсмические (мониторинг естественной сейсмической активности); активные сейсмические);

- методы маркшейдерии (геодезические (нивелирование, светодальнометрия, GPS-геодезия, интерферометрия спутниковых снимков); наземное лазерное сканирование; радарное сканирование; лидарные системы; аэрофотосъемка).

В таблице 5.2 показана применимость различных методов наблюдения к различным видам объектов мониторинга.

Таблийа 5.2

Методы мониторинга объектов горнорудного предприятия

\begin{tabular}{|c|c|c|c|c|c|}
\hline $\begin{array}{c}\text { Тип объекта / } \\
\text { методы }\end{array}$ & $\begin{array}{c}\text { Борта } \\
\text { карьеров } \\
\text { и отвалов }\end{array}$ & $\begin{array}{c}\text { Стены } \\
\text { и своды } \\
\text { подземных } \\
\text { выработок } \\
\end{array}$ & $\begin{array}{c}\text { Гидротехнические } \\
\text { сооружения }\end{array}$ & $\begin{array}{c}\text { Инфраструктурные } \\
\text { сооружения }\end{array}$ & Здания \\
\hline Визуальный & - & a & - & घ & - \\
\hline Датчики перемещения & - & ! & ! & ! & ! \\
\hline $\begin{array}{l}\text { Локальные } \\
\text { геомеханические }\end{array}$ & - & - & & & \\
\hline $\begin{array}{l}\text { Региональные } \\
\text { геомеханические }\end{array}$ & - & - & & & \\
\hline $\begin{array}{l}\text { Пассивные } \\
\text { сейсмические }\end{array}$ & - & - & & & \\
\hline $\begin{array}{l}\text { Активные } \\
\text { сейсмические }\end{array}$ & घ & - & & & \\
\hline Нивелирование & - & - & $\square$ & $\square$ & ! \\
\hline Светодальнометрия & - & ! & - & - & - \\
\hline GPS-геодезия & - & & - & - & - \\
\hline $\begin{array}{l}\text { Интерферометрия } \\
\text { спутниковых снимков }\end{array}$ & - & & - & - & - \\
\hline $\begin{array}{l}\text { Наземное лазерное } \\
\text { сканирование }\end{array}$ & - & & & & \\
\hline $\begin{array}{l}\text { Радарное } \\
\text { сканирование }\end{array}$ & - & & घ & & \\
\hline Лидарные системы & - & & 口 & - & - \\
\hline Аэрофотосъемка & - & & - & ! & a \\
\hline
\end{tabular}


Наиболее естественной является организация потоков по методам наблюдения. Это обусловлено общностью специфики собираемых данных, используемой аппаратуры, технологии и алгоритмов сбора, а также структур хранения данных. Результаты по каждому методу наблюдения собираются в одну тематическую базу данных. Далее собранные данные, находящиеся в различных тематических базах, логически могут быть сгруппированы любым удобным для обработки образом в зависимости от специализации их потребителя.

Функционально система является одной из подсистем корпоративной геоинформационной системы, что и определяет схему ее организации, представленную на рисунке 5.1 .

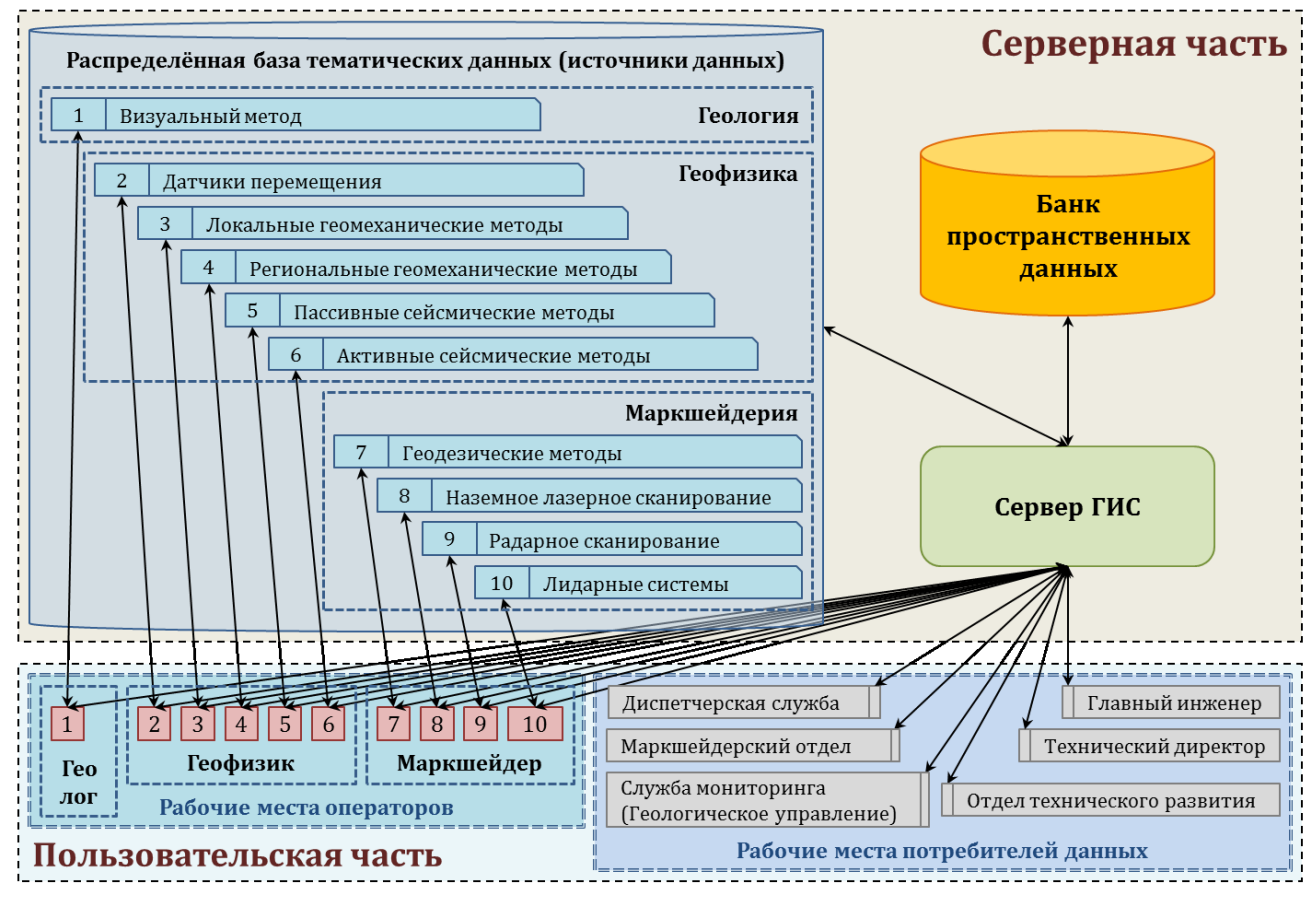

Рис. 5.1. Схема организации системы мониторинга состояния объектов горнодобывающего предприятия

В качестве базовой платформы для построения системы комплексного геофизического мониторинга наилучшим выбором представляется горногеологическая информационная система MINEFRAME, используемая на различных горнодобывающих предприятиях России, в том числе и на Крайнем Севере. В частности, ГГИС MINEFRAME успешно применяется в ПАО «ППГХО» (Забайкальский край) именно как платформа для сопоставления и визуализации данных, поступающих из различных источников.

Одним из источников тематических данных для системы комплексного мониторинга является наклономерно-деформографический комплекс (НДК), функционирующий в течение более десяти лет на Кировском руднике АО «Апатит», о чем будет сказано ниже [171]. 


\section{4. Геодинамическое районирование отрабатываемых месторождений в Хибинском и Ковдорском массивах}

\subsection{1. Тектоника Кольского полуострова}

Тектоника региона определяется строением литосферы и отдельных ее составных частей, а также историей формирования, вещественных преобразований и деформации земной коры. Поэтому в конечном итоге строение земной коры обуславливает характер, параметры и основные закономерности делимости (блочного строения), деформирования и распределения современных напряжений в верхней части коры - области деятельности горнорудного комплекса.

Кольский полуостров вместе с материковыми районами Мурманской области представляет собой северо-восточную часть Балтийского щита, который граничит на востоке и юго-востоке с платформенным осадочным чехлом Восточно-Европейской платформы, а на западе - с надвинутым комплексом каледонид (рис. 5.2).

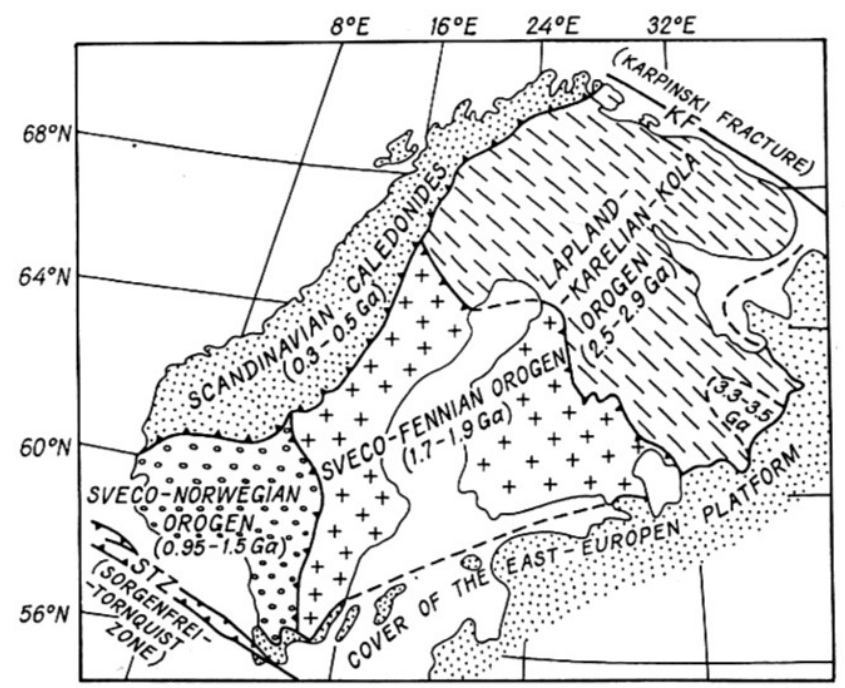

Рис. 5.2. Упрощенная тектоническая схема Балтийского щита по [86]

Наиболее крупными геоблоками являются архейский ЛапландскоКольско-Карельский, палеопротерозойский Свекофеннский и мезопротерозойский Свеко-Норвежский орогены, на которые с запада надвинуты скандинавские каледониды (рис. 5.2). Эти тектонические единицы в рамках рассматриваемой территории являются структурами докембрийского фундамента наивысшего (надрегионального) ранга и характеризуются разными временами становления и (или) консолидации коры, включая образование структурно вещественных комплексов, проявлениями первичных и наложенных геологических процессов, а также тектонической эволюцией в целом.

В пределах Кольского региона (северо-восточной части ЛапландскоКольско-Карельского орогена) выделяются следующие тектонические единицы второго (регионального) ранга (рис. 5.3) [87, 172]: Мурманский составной террейн; Центрально-Кольский составной террейн, включающий КольскоНорвежский, Кейвский и Сосновский террейны; составной террейн Инари; Печенгская и Имандра-Варзугская палеорифтовые зоны осадочно- 
вулканогенного пояса Полмак-Пасвик-Печенга-Имандра-Варзуга; Лапландский гранулитовый террейн; Беломорский составной террейн, Карельский составной террейн; Умбинский составной террейн; Терский террейн; Стрельницкий террейн; Лапландско-Кольская, Северо-Карельская и Печенга-Имандра-Варзугская сутуры (шовные зоны, маркирующие предполагаемую зону коллизии / столкновения литосферных плит или крупных блоков земной коры); меланжи Колвицкий и Танаэлв (шовные пояса с интенсивным тектоническим перемешиванием горных пород из различных геоблоков). Все перечисленные тектонические элементы первого и второго ранга масштабности обособляются друг от друга глубинными разломами и тектоническими зонами различного залегания, имеют принципиальные отличия в современном геологическом строении и реологии пород. Внутри каждого террейна тектоническое районирование может быть продолжено с разбиением на несколько рангов масштабности вплоть до отдельных геологических тел и структур.

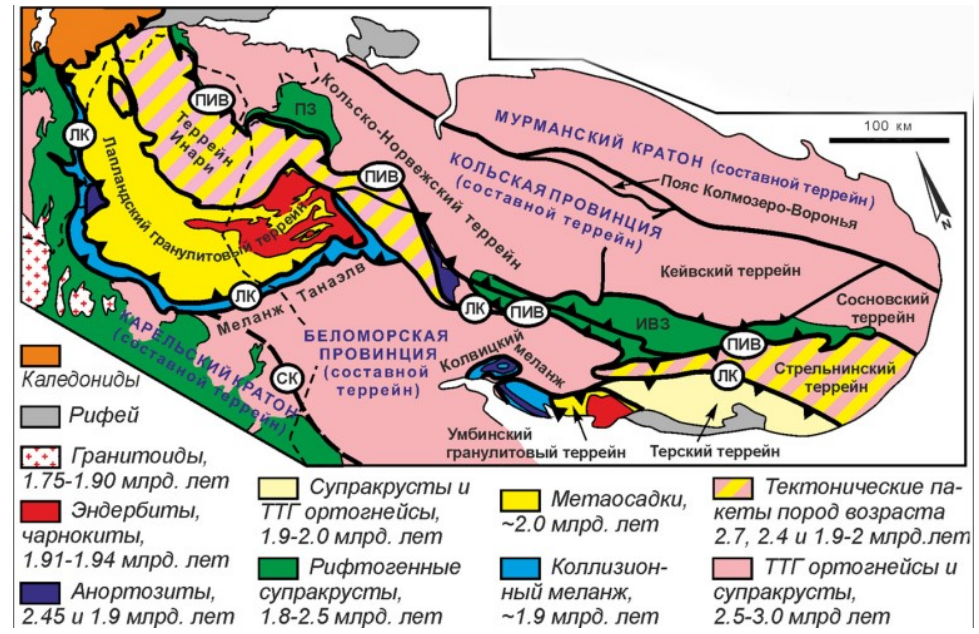

Рис. 5.3. Тектоническая схема Кольского региона (по [87,172]): ПЗ и ИВЗ - Печенгская и Имандра-Варзугская палеорифтовые зоны осадочно-вулканогенного пояса Полмак-Пасвик-Печенга-Имандра-Варзуга; ЛК - Лапландско-Кольская; СК и ПИВ - Северо-Карельская и Печенга-Имандра-Варзугская сутуры с возрастом около 1,9 млрд лет

Для раннего докембрия региона была характерна горизонтальная тектоника со значительными (десятки километров и более) латеральными смещениями геоблоков друг относительно друга. Относительные движения и деформации террейнов в современной системе координат происходили вдоль линии северо-восточного простирания, а приращение коры осуществлялось в юго-западном направлении. Масштабные горизонтальные движения и формирование континентальной коры завершились в конце палеопротерозоя (около 1,8 млрд лет), после чего консолидированный фундамент региона испытывал только вертикальные дифференцированные смещения. Достоверных данных о каких-либо значимых латеральных деформациях северо-восточной части Балтийского щита после палеопротерозоя не известны, а развитие региона осуществлялось в основном за счет накопления и эрозии осадочного чехла. Осадочные толщи рифейских отложений есть на севере (полуострова Рыбачий и Средний, остров Кильдин) и юге (Терские песчаники), а мощная толща фанерозойского осадочного чехла обнаружена в кальдере проседания Контозерского массива [86]. 
Завершающим этапом магматической эволюции докембрийского фундамента Балтийского щита стала тектономагматическая активизация, обусловленная воздействием палеозойского плюма [173], в результате которой сформировалась Кольская щелочная крупная изверженная провинция (Kola Alkaline LIP). Она включает многочисленные щелочно-ультраосновные массивы с карбонатитами (ЩУКМ) центрального типа с большим набором месторождений стратегических полезных ископаемых и индустриальных минералов. Большинство массивов, включая крупнейшие в мире Хибинскую и Ловозерскую щелочные интрузии, расположены в Кольском регионе и имеют девонский возраст 380-360 млн лет $[174,175]$. Однако на Балтийском щите известны и другие палеозойские интрузии, которые пространственно увязываются прямолинейной широкой зоной Кухаренко [176] северо-восточного простирания, начинающейся на юге Норвегии в районе г. Осло, идущей через Швецию и Финляндию в Кольский регион, а далее плавно переходящей в зону развития Восточно-Баренцевоморского рифта. Примечательно, что при движении вдоль зоны Кухаренко в северо-восточном направлении молодеет возраст интрузий: карбонатиты Фен вблизи Осло - 565 млн лет, массив Альне, Швеция - 537 млн лет и магматизм в Финляндии и РФ - 380-360 млн лет. Помимо северо-восточного тренда, существуют и субширотные до юго-восточного простирания структуры, контролирующие размещение ЩУКМ, с аналогичной тенденцией омоложения в восточном направлении (рис. 5.4). Линейные контролирующие структуры и направления омоложения могут отражать либо траектории как конвективных потоков палеозойского плюма (наиболее вероятно), так и движения литосферной плиты относительно неподвижного головы плюма, либо формирование линейных структурных неоднородностей в результате плюм-литосферного взаимодействия.

В неотектонический и современный этапы развития доминирующую роль играли экзогенные процессы и дифференцированные вертикальные движения, которые в целом отвечают за имеющийся рельеф и блочное строение верхней части земной коры. Из огромного числа разновозрастных разломов различного масштаба (глубинные надрегиональные и региональные разломы, многочисленные внутриформационные и межформационные разломы, а также зоны трещиноватости) геодинамической (сейсмодинамической) активностью характеризуется лишь весьма малая часть. Остальные находятся в законсервированном состоянии или испытывают медленные деформации, заметные только в геологическом масштабе времени и не имеющие значения в практической деятельности горнорудных предприятий. Большинство активных ныне тектонических структур имеют приповерхностное в масштабе земной коры залегание (глубины от сотен метров до первых километров). При выполнении геодинамического районирования в первую очередь выделяются современные активные структуры рангов интрузива и (или) района работ (рис. 5.5), затем шахтного поля и далее, - имеющие значение для групп или отдельных выработок.

В рамках настоящей работы наибольший акцент в проводимых исследованиях был поставлен в отношении анализа тектонических структур Хибинского и Ковдорского интрузивов, в которых эксплуатируется целый ряд месторождений мирового класса (Кукисвумчоррское, Юкспорское, «Апатитовый цирк», «Плато Расвумчорр», «Коашва», «Олений ручей» и Ковдорское). Архейские метаморфические породы окружают Хибинский щелочной массив с севера, северо-востока и юго-востока, а протерозойские вулканогенно-осадочные толщи 
имандра-варзугского комплекса - с юга и запада. Этот массив представляет собой многофазный плутон центрального типа с признаками расслоенности некоторых субинтрузий. На сегодня сложилось следующее представление о геологическом строении Хибинского массива. Это эллипсовидный в плане многофазный плутон, слегка вытянутый в субширотном направлении по азимуту $82^{\circ}$ с осями эллипса длиной 45 и 35 км со смещенной к востоку корневой частью [88]. Морфологически он близок асимметричному лополиту с крутыми восточным, южным и северным контактами и более пологим западным (рис. 5.6). Согласно работе [89], западный контакт до глубины 5-6 км в целом падает на восток под углом $70^{\circ}$, а южный, северный и восточный контакты крутые вплоть до вертикальных (рис. 5.5). По геофизическим данным [88] западный контакт Хибинского массива в целом падает к востоку под углом $\sim 30^{\circ}$, а восточный — к западу под углом $\sim 70-80^{\circ}$. Внутреннее строение массива концентрически-зональное [89]. Большинство выделенных концентрических зон не являются непрерывными. Контакты между субинтрузиями выражены неотчетливо.

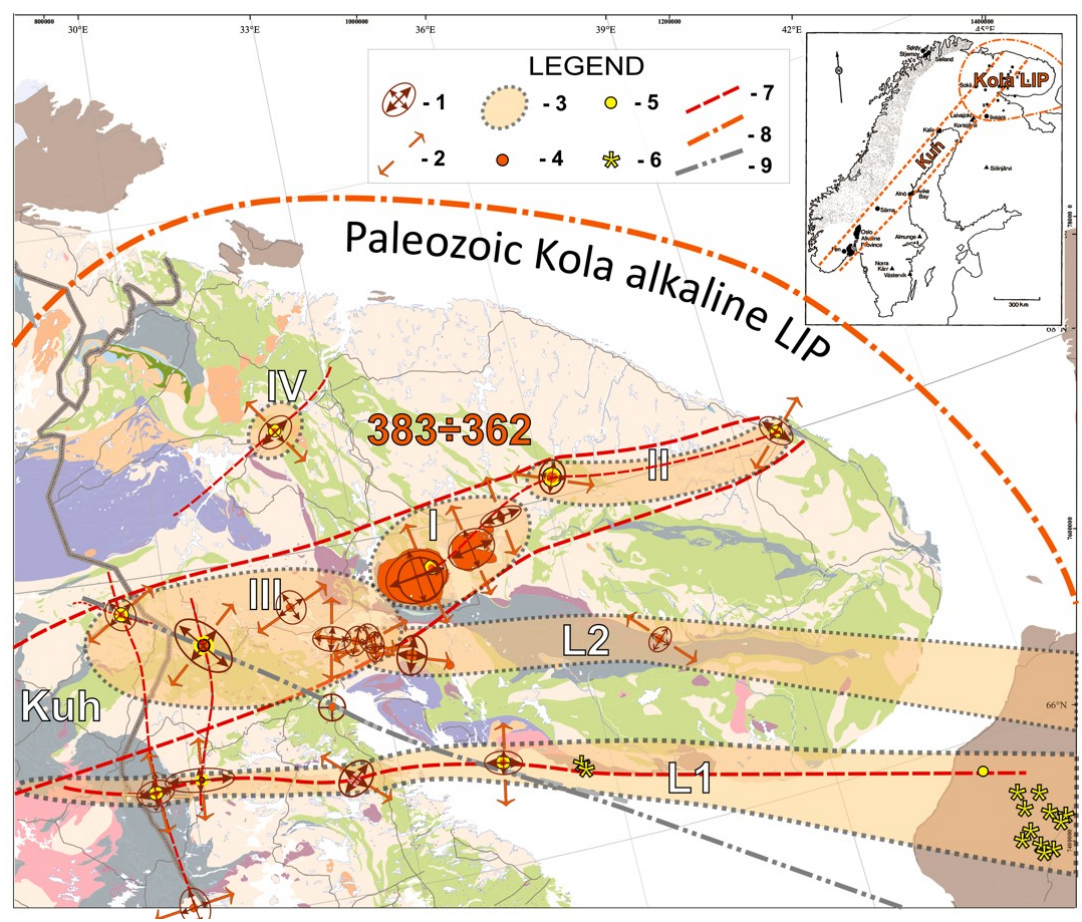

Рис. 5.4. Контролирующие размещение ЩУКМ Кольского региона структуры (по [177]): 1 - соотношение длинной и короткой стороны интрузива по очерченному эллипсу; 2 - направление максимального растяжения; 3 - зоны группировки интрузивов площадного типа: $I$ - Хибинско-Ловозерская, II - Контозеро-Ивановка, III - Сокли-Ковдор-Нива-Салмагора, $I V$ - Себльявр; 4 - ЩУК интрузив; 5 - карбонатиты; 6 - трубки взрыва (кимберлиты); 7 - линейные зоны с вариантами интерпретации: структурные неоднородности или траектории конвекцивных тепловых потоков палеозойского плюма, или траектории перемещения литосферной плиты: Kuh - зона Кухаренко, $L 1$ - зона / разлом Салланлатва-Вуориярви-Турий-Мела/Золотица, L2 - зона Африканда-Озерная Варака-Ингозеро-Песочный-Зимний Берег; 8 - приблизительные границы Кольской щелочной LIP; 9 - осевая линия Кандалакшского грабена 


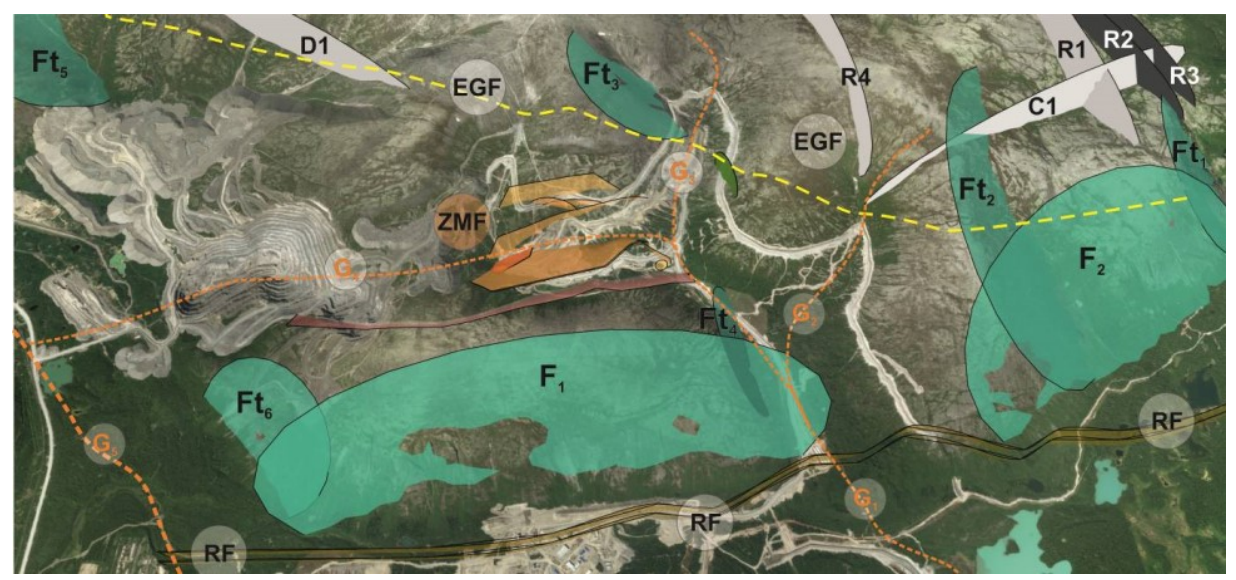

Рис. 5.5. Пример схемы геодинамического районирования восточной части Хибинского массива: $R F$ — Ring Fault внешний кольцевой разлом; группа $F$ - Fault сбросы / псевдосбросы; группа $F t$ - Transverse Fault поперечные сбросы; $E G F$ - южная граница Эвеслогчоррской группы разломов / зоны смятия; $Z M F$ - зона Главного разлома; группа $R$ - радиальные разломы; $D$ - диагональные разломы; $C$ - концентрические разломы; группа $G$ - границы блоков, дешифрированные по орогидрографической сети

Возраст массива и его интрузивных фаз многократно определен различными геохронологическими методами и варьирует в пределах 366-376 млн лет, что в целом подтверждает впервые полученные датировки $[174,175]$. В отношении последовательности внедрения различных фаз существуют разночтения, однако все исследователи отмечают тесную связь апатитовых руд с ийолит-уртитовым комплексом (фоидолитами), образующим незамкнутое кольцо по простиранию с центриклинальным падением к центру массива вдоль Главного конического разлома [178]. Все промышленные месторождения были открыты в пределах этой рудоконтролирующей структуры, при этом наиболее крупные из них сосредоточены в южной (юго-западной) ее части. Соответственно, большинство рудников также находятся здесь.

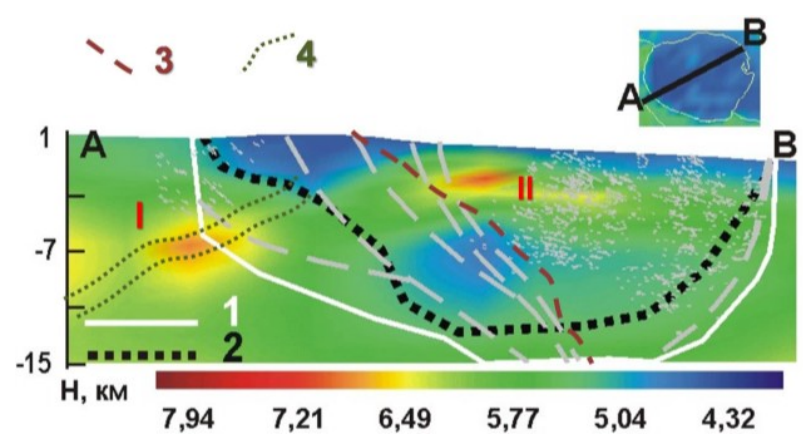

Рис. 5.6. Сравнение результатов сейсмоплотностного моделирования с предшествующей моделью строения Хибинского плутона: 1 - границы массива по компиляционной модели по А. В. Галахову и др. [89]; 2 - границы массива по результатам сейсмоплотностного моделирования по [88, 179]; 3 - проекция осевой линии ийолит-уртитового (фоидолитового) комплекса; 4 - вероятный коридор контакта осадочно-вулканогенного комплекса Имандра-Варзуга с вмещающим комплексом архейского основания и аномалия, интерпретируемая слепым палеопротерозойским расслоенным мафит-ультрамафитовым интрузивом 
Для наиболее крупных и продуктивных месторождений Юго-Западного рудного поля (рис. 5.7) характерна линзовидно-пластовая форма рудных тел с выраженной поперечной (вкрест мощности) и вертикальной зональностью, наиболее проявленной в направлении от лежачего крыла к висячему со следующей последовательностью: массивные уртиты $\rightarrow$ апатитсодержащие уртиты $\rightarrow$ массивные и сетчатые руды $\rightarrow$ линзовидно-полосчатые руды (до $50 \%$ от общего объема) $\rightarrow$ блоковые руды $\rightarrow$ богатые пятнистые и пятнисто-полосчатые руды (до $30 \%$ от общего объема) $\rightarrow$ титанит-апатитовые руды [178]. Как правило, содержание апатита увеличивается от подошвы рудного тела к его кровле.

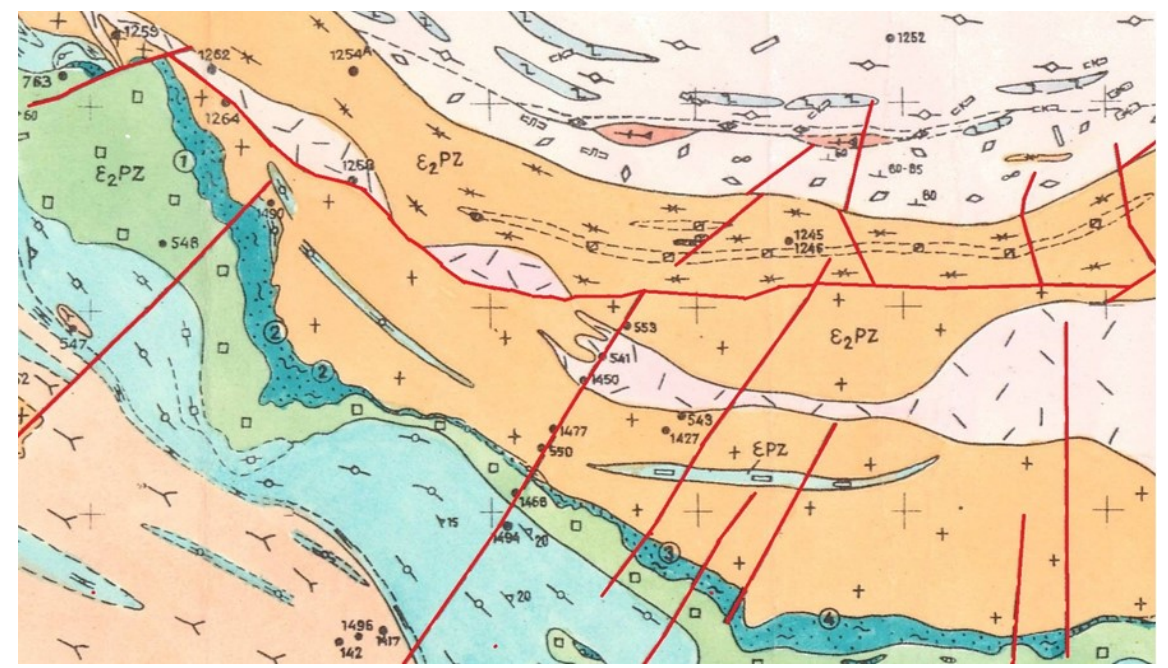

Рис. 5.7. Геологическая схема месторождений Юго-Западного рудного поля: 1 - Кукисвумчоррское; 2 - Юкспорское; 3 - «Апатитовый цирк»; 4 - «Плато Расвумчорр». Красным цветом выделены разрывные нарушения 2-3 рангов

Хибинский массив разбит на сеть разломов различных рангов (III-VII порядков по СНиП 2.02.02-85). Наибольшее значение играют конические и радиальные разломы, основные из которых, по результатам обобщения геолого-геофизических материалов, были выделены и геометризованы Ф. М. Онохиным [90]. По его мнению, на ранних этапах постмагматической стадии развития Хибинского массива были заложены конические и радиальные разломы, по которым позднее он оказался разбит на грабены и горсты. Местоположение большинства радиальных и конических разломов для южной части массива заверено многолетними и многочисленными геологоразведочными, геофизическими и горными работами. Нашими исследованиями принципиальная схема разломной тектоники Хибинского массива постоянно детализируется и уточняется.

Основные радиальные разломы южной части Хибин (Северный, Саамский, Гакмановский, Юкспорлакский, Расвумчоррский и «Дразнящее эхо») отстоят друг от друга на 2-2,5 км, а концентрические - на 3-3,5 км. Разломы представляют собой систему параллельных трещин, нередко ветвящихся как в плане, так и по вертикали. Часто разломы характеризуются наличием в них зон изменения пород (шпреуштейнизации) различной интенсивности вплоть до полной переработки первичных минералов. Мощность таких зон составляет от нескольких сантиметров до первых десятков метров [180-182]. 
Апатитовые месторождения юго-западного рудного поля представляют собой непрерывную пластообразную залежь протяженностью около 11 км, осложненную раздувами (линзами) и пережимами (резким уменьшением мощности) между ними (рис. 5.7). Одна линза объединяет Кукисвумчоррское и Юкспорское месторождения, а вторая - «Апатитовый Цирк» и «Плато Расвумчорр» (рис. 5.7). Оба линзообразных тела сходны по их морфоструктуре.

В пределах юго-восточного рудного поля (к востоку от разлома «Дразнящее эхо») апатитовые месторождения (Коашвинское, Ньоркпахкское, Суолуайвское и «Олений ручей») представлены отдельными линзами или группами линз.

Блочное строение, высокие горизонтальные напряжения, прочные, но хрупкие породы и динамические формы проявления горного давления позволили отнести отрабатываемые месторождения к склонным и опасным по горным ударам. Под воздействием техногенной деятельности, связанной с их разработкой, с одной стороны, и естественных геологических процессов в земной коре, с другой, происходят либо внезапные подвижки блоков по разломам относительно друг друга, либо образование новых и разрастание старых трещин как внутри блоков, так и в приконтурной части выработок. Это выражается в виде сейсмических событий различного энергетического уровня, приводящих к разрушению горных выработок и целиков (от микроударов до техногенных землетрясений).

Ковдорский щелочно-ультраосновной с карбонатитами массив (КМ) представляет собой интрузию концентрически-зонального строения, имеющую в плане овальную форму, несколько вытянутую в меридиональном направлении и образующую в плане S-образную дугу. Бурением он вскрыт до глубин немногим более 2 км, но геофизические данные позволяют предполагать, что его тело имеет веретенообразную форму и прослеживается, постепенно сужаясь, до глубины 20 км [183]. В свою очередь, массив прорывает биотитовые гнейсы и гранитогнейсы, содержащие незначительное количество амфиболитов, архейского кольско-беломорского комплекса, имеющих общее падение на северо-восток и осложненных в юго-восточной части района складчатостью второго и более высоких порядков [86].

Ковдорский массив имеет прямую зональность, то есть в целом он был образован последовательным внедрением магматических фаз от центра к периферии, при этом месторождение фоскоритов с карбонатитами образовано в результате проявления магматических импульсов поздних фаз. На структуру массива в большей или меньшей степени оказали влияние унаследованные в различной степени элементы строения архейской рамы, зона Кухаренко палеозойской тектонической активизации северо-восточного простирания, постмагматическая тектоническая эволюция самого КМ, а также усложнение строения на неотектоническом этапе. Каждый из перечисленных этапов характеризуется своим парагенетическим комплексом структурных элементов, образующих в сочетании и наложении друг на друга сложнейшую картину хрупких деформаций и других структурных неоднородностей массива пород.

Нашими исследованиями выявлена закономерная тенденция в тектономагматической эволюции КМ. Каждая магматическая фаза приводила к образованию комплекса пород, в первом приближении имеющего в плане форму эллипса, при этом эллипс каждой последующей магматической фазы изменял ориентацию осей в горизонтальной плоскости и местоположение геометрического центра. Это изменение выражалось во вращении эллипса каждой последующей магматической фазы по часовой стрелке от 10 до 20-25, при этом вертикальная ось (геометрический центр) 
вращения незначительно смещалась, описывая траекторию движения против часовой стрелки (рис. 5.8). Изменялась не только ориентировка осей эллипса и его центра, но и отношения короткой стороны эллипса к длинной. Приведенные в совокупности данные позволяют нам принять за наиболее вероятный сценарий вариант тектономагматического развития КМ в рамках региональной сводово-купольной структуры над палеозойским мантийным плюмом, испытывавшей общую обстановку растяжения при изгибе. Внедрение щелочно-ультраосновных массивов осуществлялось, вероятно, в узлах пересечения зоны Кухаренко с глубинными разломами в обстановке субгоризонтального растяжения с косым сдвигом или транстенсии. В ходе дальнейшего раскрытия узла инъецировались последующие порции магматических расплавов и высокотемпературных гидротермальных растворов. Изменение кинематики и тектонофизических параметров вокруг камеры отражалось на морфологии и положении субинтрузий.

В пределах КМ в настоящее время одним карьерным полем эксплуатируются Ковдорское бадделеит-апатит-магнетитовое месторождение (магнетитовых и апатитовых руд) и Ковдорское месторождение франколитовых (штаффелитовых) руд. Первое из них представляет собой вертикальный шток длиной около 1500 м при ширине в плане 300-800 м, а второе является останцом коры выветривания в приповерхностной части рудного штокверка. Начиная с 2000 г., ведутся комплексные исследования по обоснованию возможности строительства и безопасной эксплуатации сверхглубокого карьера (более 800 м от поверхности), что позволит пролонгировать экономически эффективную деятельность градообразующего предприятия до 2043-2048 гг. [184]. В этих условиях достоверные знания о неотектонических и современных полях напряжений, сформировавших сеть разно ориентированных дизъюнктивов и трещин, предопределяющих устойчивость действующих и проектируемых инженерных сооружений, уступов и бортов карьера, приобретают особое значение.

Инженерно-геологические условия отработки этих месторождений неблагоприятные, что обусловлено сложным тектоническим строением массива, которое определяется основными тектоническими нарушениями северо-восточного и северо-западного простирания с углами, близкими к вертикальным. Местоположение и направленность тектонических зон устанавливается в основном по линейным структурам и зонам развития внутриформационных брекчий и милонитизации. Зоны неотектонических преобразований унаследовали ориентировку основных тектонических нарушений.

На месторождении выделяется несколько крупных разрывных субвертикально залегающих нарушений первого порядка, из которых наиболее мощным является разлом R1 (рис. 5.9). Кроме того, для массива пород характерно широкое распространение разрывных нарушений центриклинального (в сторону отработанного пространства) залегания. Совокупность этих элементов на участках реактивации поздними тектоническими движениями представляет наибольшую опасность для устойчивости уступов и борта в целом. Наложенный тектогенез в пределах массива пород проявился неоднородно, что отражает избирательность активизации в конкретной тектонофизической обстановке только структур определенной ориентировки.

В массиве пород установлена вертикальная зональность. Верхняя зона интенсивной дезинтеграции характеризуется переходом первичных скальных пород в глинисто-суглинистую и супесчано-дресвяную массу, включающую многочисленные реликты слабо выветрелых скальных пород. Ниже развита зона частичной 
дезинтеграции, в которой практически невыветрелые породы местами раздроблены до щебня и дресвы, но сохранили первоначальную структуру и текстуру. Переход к скальным породам в среднем происходит на глубине 80-120 м от поверхности, а вдоль субвертикальных разломов глубины увеличиваются до 180-230 м.

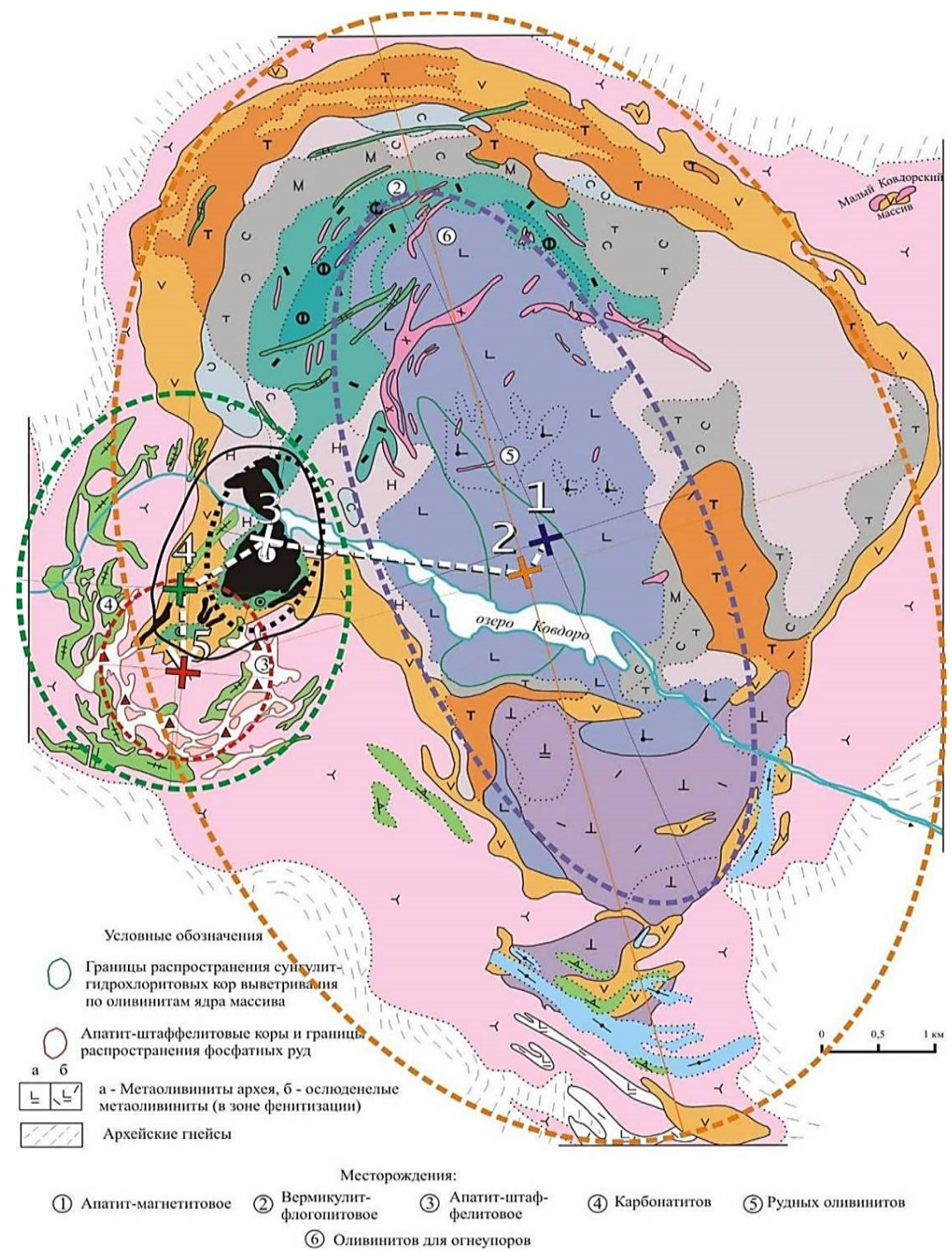

Рис. 5.8. Схема Ковдорского щелочно-ультраосновного массива и его магматической эволюции. Центр пересечения внутри эллипса (пунктирные контуры) - геометрический центр соответствующей магматической фазы. Белый пунктир показывает последовательное смещение («миграцию») центров тектономагматической активности от наиболее древних к молодым образованиям. Сплошная линия - текущий контур карьера рудника «Железный», черная заливка - рудный шток месторождения. (По [185] с авторскими дополнениями)

Несмотря на сравнительно большую мощность основных тектонических нарушений, характер и интенсивность проявлений оперяющей трещиноватости уменьшаются с глубиной. Это отражается в блочности пород. В породах поздних фаз формирования месторождения (в основном в карбонатитах) размеры отдельных тектонических блоков составляют 15-20 м, в ийолитах и фенитах - 5-10 м, а в зонах, сопряженных с тектоническими нарушениями, - $1-2$ м. 
По результатам инженерно-геологического районирования выделены 8 секторов с относительно однородной тектонической структурой и свойствами пород (рис. 5.9). В зависимости от сложности строения и количества представленных опасных тектонических элементов по каждому из секторов построено от 2 до 6-8 инженерно-геологических разрезов, использующихся для расчетов устойчивости и проектирования.

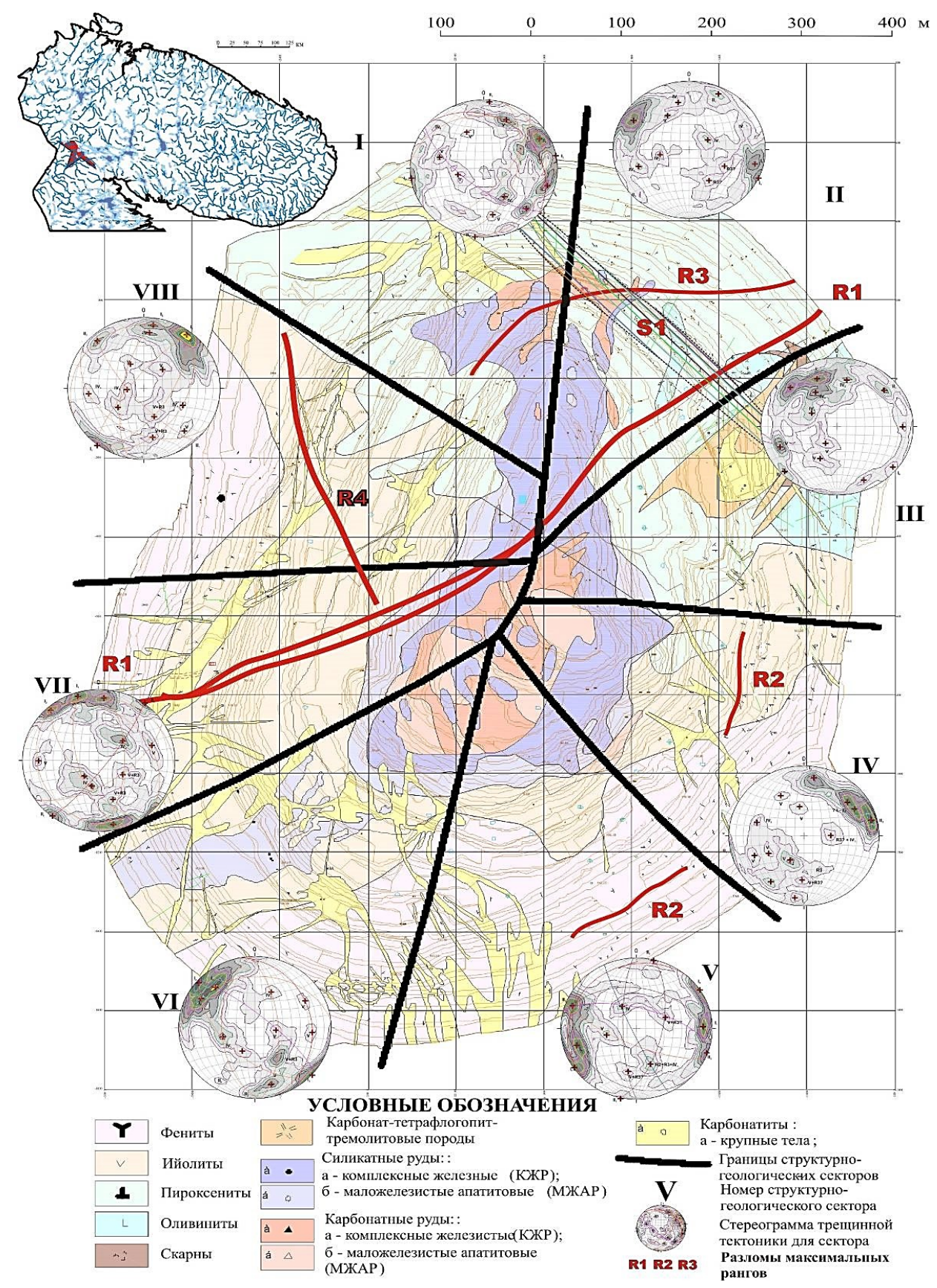

Рис. 5.9. Уточненная карта-схема инженерно-структурного районирования Ковдорского месторождения магнетитовых и апатитовых руд (по $[186,187])$ 


\subsection{2. Реконструкция палеонапряжений по данным структурной нарушенности Хибинского и Ковдорского массивов}

В тектонофизике, сейсмологии, инженерной геологии и геомеханике напряженное состояние массива горных пород оценивается методами: реконструкции напряжений по трещиноватости; дискованию керна, по разрушению поперечного сечения скважин, сейсмологическим; разгрузки; визуально.

Визуальная оценка напряжений по состоянию горных выработок возможна, когда напряжения на контуре обнажений превышают определенный предел. Возникновение трещин и последующие отслоения по ним происходят в местах, где хотя бы одно из главных сжимающих напряжений превышает половину прочности пород на одноосное сжатие. Формы, размеры, ориентировка в пространстве участков разрушения пород на контуре выработок закономерно связаны с ориентировкой наибольших напряжений и могут быть использованы для качественной оценки поля напряжений.

Метод разгрузки - наиболее разработанный и теоретически обоснованный способ измерений в массиве. Он основан на измерении упругих деформаций элемента породного массива при разгрузке этого элемента от действовавших в нем напряжений и упругом восстановлении им первоначальных размеров. По измеренным деформациям и упругим свойствам пород вычисляют действующие напряжения.

Результаты измерений напряжений в нетронутых массивах показали, что теоретические представления о формировании силовых полей практикой подтверждаются не всегда. Особенности распространения и перераспределения напряжений являются индивидуальной характеристикой массивов, определяющих геомеханические условия разработки месторождений.

Величины измереннего напряжения не соответствуют геостатическому закону распределения. При разнообразии горно-геологических условий установлено:

- вертикальная составляющая гравитационно-силового поля нередко отличается от расчетной;

- главные нормальные напряжения, действующие в горизонтальной плоскости, превосходят вертикальную составляющую в несколько раз.

Резкие и незакономерные изменения величины и знака напряжений объясняются тем, что гравитационные и тектонические силы реализуются в условиях структурных неоднородностей. Невозможность однозначной корреляции напряжений с глубиной делает весьма приближенными расчеты, направленные на обеспечение безопасности горных работ.

В результате техногенного воздействия в массиве горных пород развивается комплекс явлений, изменяющих его напряженно-деформированное состояние:

- изменение поля напряжений вокруг выработок;

- изменение свойств пород на контуре выработок;

- перемещение, взаимоконтактирование, деформирование и разрушение пород в зависимости от напряжений и свойств пород.

В крепких породах в допредельном состоянии упругие деформации вокруг одиночной выработки остаются незамеченными. В слабых или весьма нарушенных породах возникают квазипластические деформации.

Системы разломов придают массивам тектоническую блочность. Тектонические блоки еще более усложняют гравитационное поле. В крыльях крупных и средних размеров блоков вслед за зоной концентрации напряжений формируются зоны разгрузки. 
У крутых разломов отмечены зоны концентрации напряжений в 2-6 раз превышающие мощность самого разлома. Зона разгрузки напряжений более широкая, но степень разгрузки напряжений меньше, чем в предыдущей зоне. Для наклонных и пологих разломов характерна широкая зона пониженных напряжений с невысокой степенью разгрузки. В висячих крыльях разломов максимальными являются горизонтальные напряжения, перпендикулярные разлому, вертикальные напряжения в 1,5-3,0 раза меньше горизонтальных и больше гравитационных. В лежачих крыльях максимальными являются вертикальные напряжения.

В краевых частях тектонических блоков формируются зоны повышенной напряженности, во внутренних частях, захватывающих большую часть, - области пониженных напряжений.

На формирование зон напряжений в массиве с разломной структурой оказывают влияние:

- масштаб и ориентировка разломов;

- размеры, конфигурация тектонических блоков и их взаимоположение и положение относительно массива;

- свойства пород, слагающие зоны разломов и тектонические блоки.

В массивах с блочностью структур на однородном участке массива напряженность характеризуется среднеарифметическим значением напряжений по плоскостям структурного блока.

$\mathrm{C}$ середины прошлого века в тектонофизике, сейсмологии и структурной геологии получили широкое развитие методы расчета (реконструкции) природных напряжений по совокупностям разрывных нарушений, информацию о которых получают сейсмологическими или геологическими методами. В это же время, фактически параллельно без взаимной связи, происходило создание методов расчета остаточных деформаций, формирующихся в массивах горных пород за счет смещений по совокупностям сколовых трещин.

Все методы реконструкции природных напряжений можно разделить на две группы в соответствие с принципами, лежащими в основе перехода от структурно-кинематических данных о разрывах и трещинах к тектоническим напряжениям.

В методах структурного анализа (МСA) такой переход обосновывается закономерностями механики разрушения (теория Кулона-Мора или теория максимальных касательных напряжений), а в методах дислокационного анализа - положениями теории скольжения Батдорфа-Будянского, созданной для описания пластического течения за счет дислокаций и микротрещин, которые были адаптированы к описанию процесса образования макроскопических разрывов и трещин. В первой группе методов, как правило, используются данные только о плоскостях залегания трещин, а во второй, на равноправной основе, используются также и данные о направлениях относительного смещения бортов разрывов. Результатом применения МСА являются данные об ориентации главных природных напряжениях (три угла Эйлера, определяющие ориентацию трех ортогональных осей), а использование методов дислокационного анализа позволяет определять, помимо этих параметров напряженного состояния, также и значение коэффициента Лоде-Надаи, характеризующего вид тензора напряжений и соотношение его главных значений.

Методы расчета квазипластических (трещинных) деформаций также используют некоторые положения теории дислокаций. Исходными здесь являются сейсмологические данные о механизмах очагов землетрясений или геологическая информация о залеганиях плоскостей трещин и о направлениях скольжения их бортов. 
Метод катакластического анализа (МКА) разрывных нарушений использует общие энергетические положения современной теории пластичности и позволяет в едином режиме производить расчет как параметров тензора напряжений, так и тензора квазипластических деформаций. Этот метод дает возможность определять относительные величины шаровой и девиаторной компонент тензора напряжений, а также с некоторым приближением оценивать сами величины напряжений и флюидного давления.

Представленные методы позволяют рассчитывать только четыре компоненты тензора напряжений (ориентация главных осей и коэффициент вида тензора напряжений). Сами величины напряжений (максимальные касательные напряжения и шаровая компонента тензора - среднее напряжение) остаются неизвестными. В настоящее время существует несколько подходов к оценке величин напряжений в различных блоках массива горных пород. Как правило, они базируются на результатах лабораторных экспериментов по разрушению образцов горных пород либо на измерениях методом разгрузки, проведенных непосредственно в массиве.

В рамках настоящей работы проводили реконструкции параметров палео- и современных напряжений и структурной эволюции участков массивов горных пород Хибинского и Ковдорского интрузивов. При этом использовали следующие методы исследований:

- картирование и многопараметрическая документация in situ (в обнажениях, природных откосах, уступах карьеров, в стенках подземных горных выработок, керна разведочных и инженерно-геологических скважин), структурных и геомеханических (проявления горного давления, деформации, обрушения и др.) пространственно-распределенных данных с использованием традиционных (горный компас, геодезические рулетки, нивелир, теодолит и др.) и новых высокотехнологичных инструментов (лазерные дальномеры, тахеометры, горные лидары, радарные интерферометры и др.), в том числе оригинальных авторских разработок;

- специальные исследования состояния массива пород (замеры параметров НДС in situ, сейсмотомографическое просвечивание в поверхностном и скважинном исполнении, георадарное и сейсмическое профилирование и съемка, сейсмомониторинг с помощью трехкомпонентных станций);

- дифференцированная обработка и анализ многопараметрических замеров с использованием: математической статистики и анализа; кинематического метода (КМ) [188-190] и МКА [191] для обработки и анализа борозд скольжения; модифицированного метода поясов анализа трещиноватости $[192,193]$; методов 3D- и 4D-моделирования и обработки пространственно распределенных данных [194].

Перечисленный комплекс исследований отвечает требованиям полноты и достаточности для решения поставленных задач (реконструирования эволюции НДС во взаимосвязи с тектоникой и геологической структуктурой массива). Ниже приведены некоторые результаты таких исследований.

\subsubsection{1. Хибинский массив}

Обработка замеров борозд скольжения в Хибинском массиве выполнена с использованием МКА и КМ совместно с сотрудниками лаборатории «Тектонофизики» ИФЗ РАН. Результаты реконструкций локальных палео- и современных напряжений для единичных участков массовых замеров приведены в таблице 5.3. 
Таблииа 5.3

Результаты реконструкции КМ локальных палео- и современных напряжений для южной части Хибинского массива

\begin{tabular}{|c|c|c|c|c|c|c|c|c|}
\hline \multirow{2}{*}{$\begin{array}{l}\text { № } \\
\text { ППா }\end{array}$} & \multirow{2}{*}{$\begin{array}{l}\text { Внутренний } \\
\text { номер точки }\end{array}$} & \multirow{2}{*}{$\begin{array}{c}\text { Координаты, } \\
\text { N }\end{array}$} & \multirow{2}{*}{$\begin{array}{c}\text { Координаты, } \\
\text { E }\end{array}$} & \multicolumn{2}{|c|}{$\begin{array}{c}\text { Положение } \\
\sigma_{1}, \text { град. }\end{array}$} & \multicolumn{2}{|c|}{$\begin{array}{c}\text { Положение } \\
\sigma_{3}, \text { град. }\end{array}$} & \multirow{2}{*}{$\begin{array}{c}\text { Характер } \\
\text { НДС }\end{array}$} \\
\hline & & & & аз. п. & $\angle$ & аз. п. & $\angle$ & \\
\hline \multicolumn{9}{|c|}{ Поверхностные измерения: } \\
\hline 1 & 10519 & N 6740,822 & E 3410,150 & 270 & 66 & 116 & 22 & Взбросовый \\
\hline 2 & 10525 & N 6741,470 & E 3411,090 & 44 & 55 & 152 & 12 & Взбросовый \\
\hline 3 & 10526 & N 6741,314 & E 3411,378 & 316 & 55 & 103 & 30 & Взбросовый \\
\hline 4 & $10527 \mathrm{a}$ & N 6740,854 & E 3413,778 & 288 & 0 & 198 & 6 & Сдвиговый \\
\hline 5 & 10528 & N 6737,693 & E 3352,082 & 127 & 11 & 222 & 22 & Сдвиговый \\
\hline 6 & 10529 & N 67 38,598 & E 3401,019 & 144 & 6 & 240 & 45 & Сбрососдвиг \\
\hline 7 & 10530 & N 6738,329 & E 3400,500 & 191 & 15 & 96 & 18 & Сдвиговый \\
\hline 8 & $10532-10534$ & N 6737,543 & E 3352,184 & 47 & 11 & 308 & 40 & Сбрососдвиг \\
\hline 9 & 2 этап & N 6737,543 & E 3352,184 & 144 & 6 & 53 & 17 & Сдвиговый \\
\hline 10 & 10535 & N 6737,696 & E 3352,111 & 151 & 6 & 248 & 53 & Сбрососдвиг \\
\hline \multicolumn{9}{|c|}{ Измерения в подземных выработках Расвумчоррского рудника } \\
\hline 11 & 2 & \begin{tabular}{|l|} 
Привязка \\
по карте \\
\end{tabular} & $\begin{array}{l}\text { Привязка } \\
\text { по карте } \\
\end{array}$ & 63 & 77 & 161 & 2 & Взбросовый \\
\hline 12 & $2 \Gamma$ & $-\backslash-\backslash-$ & $-\backslash-\backslash-$ & 90 & 60 & 339 & 14 & Взбросовый \\
\hline 13 & TH 12 & $-\backslash-\backslash-$ & $-\backslash-\backslash-$ & 243 & 77 & 349 & 4 & Взбросовый \\
\hline
\end{tabular}

Напряженное состояние определено не только для различных участков, но и в целом для южной части Хибинского массива, где сосредоточены основные горнодобывающие предприятия.

Таким образом, для южной части Хибинского массива в результате проведенной реконструкции определен взбросовый тип общего поля напряжений. Возраст восстановленных по бороздам скольжения полей напряжений принимается за неотектонический и современный, так как в определении общего поля напряжений участвуют и локальные палео- и современные напряжения в четвертичных породах. Полученное поле напряжений для южной части Хибинского массива согласуется с его общим воздыманием в неотектонический этап.

\subsubsection{2. Ковдорский массив}

Сбор исходных пространственно-распределенных данных по признакам кинематических смещений проведен в период 2013-2015 гг. в ходе полевых исследований в карьере рудника «Железный». Обработка замеров борозд скольжения в Ковдорском массиве выполнена аналогично с обработкой данных по Хибинскому массиву. Результаты реконструкций локальных палео- и современных напряженных состояний для отдельных массовых замеров приведены в таблице 5.4.

Проведенные исследования подтвердили результат реконструкции эволюции НДС отрабатываемого Ковдорского месторождения, полученный ранее [195], и общую со всем Ковдорским интрузивом трехстадийную историю тектонического развития после завершения карбонатитовой стадии магматизма со сменой обстановок: сдвиговое поле с осью сжатия северо-восточного простирания $\rightarrow$ взбросовое поле с осью сжатия северо-западного простирания $\rightarrow$ сдвиговое поле с осью сжатия северо-западного простирания (см. $B, C$ и $D$ на рис. 5.10). 
Таблича 5.4

Результаты реконструкции КМ локальных палео- и современных напряженных состояний массива пород Ковдорского массива

\begin{tabular}{|c|c|c|c|c|c|c|c|c|}
\hline \multirow{2}{*}{$\begin{array}{l}\text { № } \\
\text { ПП }\end{array}$} & \multirow{2}{*}{$\begin{array}{c}\text { Номер точки } \\
\text { внутренний }\end{array}$} & \multirow{2}{*}{$\begin{array}{c}\text { Координаты, } \\
\text { N }\end{array}$} & \multirow{2}{*}{$\begin{array}{c}\text { Координаты, } \\
\text { Е }\end{array}$} & \multicolumn{2}{|c|}{ Положение $\sigma_{1}$} & \multicolumn{2}{|c|}{ Положение $\sigma_{3}$} & \multirow{2}{*}{$\begin{array}{c}\text { Характер } \\
\text { НДС }\end{array}$} \\
\hline & & & & а3. п. & $\angle$ & аз. п. & $\angle$ & \\
\hline & $12403-12405$ & N 6734,777 & E 3230,596 & 350 & 25 & 254 & 10 & Не определено \\
\hline & 12407 & N 6736,497 & E 3201,266 & 233 & 35 & 70 & 50 & Не определено \\
\hline & $12408-12409$ & N 6736,497 & E 3201,266 & 155 & 5 & 62 & 40 & Не определено \\
\hline & 12415 & N 6733,122 & E 03024,922 & 50 & 65 & 270 & 20 & Взбросовое \\
\hline & 12415 & N 6733,122 & E 03024,922 & 170 & 15 & 270 & 20 & Сдвиговое \\
\hline & 12416 & N 6733,136 & E 03024,848 & 192 & 20 & 82 & 40 & Сбросо-сдвиговое \\
\hline & 12420 & N 6728,040 & E 03225,629 & 334 & 20 & 140 & 70 & Сбросовое \\
\hline & $12420^{*}$ & N 6728,040 & E 03225,629 & 245 & 40 & 106 & 40 & Сдвиго-взбросовое \\
\hline & 12421 & N 6728,040 & E 03225,629 & 26 & 20 & 292 & 5 & Сдвиговое \\
\hline & 12422 & N 6730,615 & E 03220,732 & 216 & 35 & 113 & 20 & Сдвиговое \\
\hline 11 & $12422 *$ & N 6730,615 & E 03220,732 & 216 & 35 & 0 & 50 & Сбросовое \\
\hline
\end{tabular}

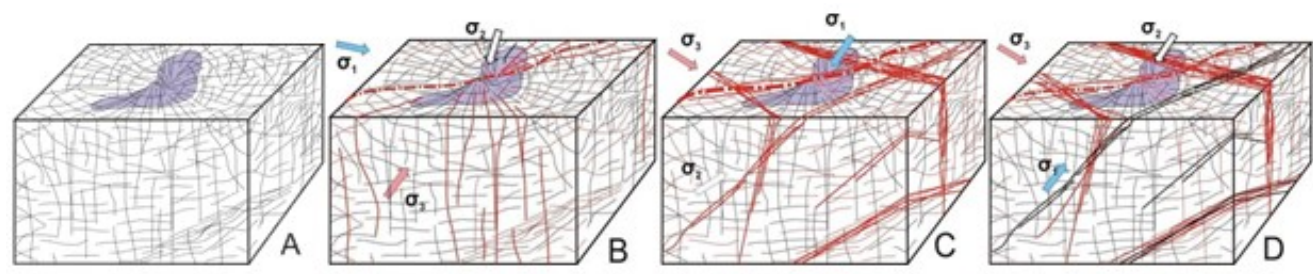

Рис. 5.10. Основные этапы деформирования с трещинообразованием массива пород Ковдорского интрузива и реактивации мультикинематических дизъюнктивов [204] [196]: $A, B, C, D$ - последовательность этапов / стадий разрывной тектоники с переиндексацией (транспозицией) осей главных напряжений, $\sigma_{1} \geq \sigma_{2} \geq \sigma_{3}$ (max сжимающее)

Такая последовательность в упрощенном виде соответствует универсальному эволюционному циклу НДС, предложенному Васильевым [197], согласно которому изменение состояния поля происходит методом переиндексации главных осей: после разгрузки максимального напряжения $\sigma_{3}$ за счет трещинообразования и смещения крыльев вдоль плоскостей промежуточное $\sigma_{2}$ становится максимальным и так далее, пока диссипация упругой энергии не приведет систему в устойчивое состояние.

Заполнение трещин и разрывов, образовавшихся на этапах $B, C$ (рис. 5.10), поздними карбонатитами и высокотемпературной гидротермальной минерализацией позволяет отнести время их возникновения к ранним стадиям эволюции массива пород по упругохрупкому типу. В отношении этапа $D$ прямые и косвенные данные указывают на неизменность НДС до настоящего времени и что его можно принять за современное общее поле напряжений в естественном (антропогенно неизмененном) виде.

Полученные результаты реконструкции локальных палео- и современных напряженных состояний Хибинского и Ковдорского массивов, проведенной с помощью МКА, хорошо согласуются с данными, полученными с помощью КМ. 


\subsection{3. Новая информация о современном напряженном состоянии геологической среды горнотехнических систем по данным натурных определений}

\subsubsection{1. Ковдорская горнотехническая система}

Исследования НДС Ковдорского массива, устойчивости борта и отдельных уступов карьера рудника «Железный» $\mathrm{AO}$ «Ковдорский ГОК» являются неотъемлемой частью разработанной в ГоИ КНЦ РАН концепции геомеханического обоснования рациональных конструкций бортов карьеров в скальных породах, основывающейся на их представлении как иерархически блочной среды, в которой действует поле напряжений гравитационно-тектонической природы.

На рисунке 5.11 показана схема расположения наблюдательных станций (н/с) по исследованию НДС массива пород в пределах карьера. Каждая наблюдательная станция состоит из одной колонковой скважины диаметром 76 мм и длиной 50 м, пробуренной под углом $+3^{\circ}$ к горизонту.

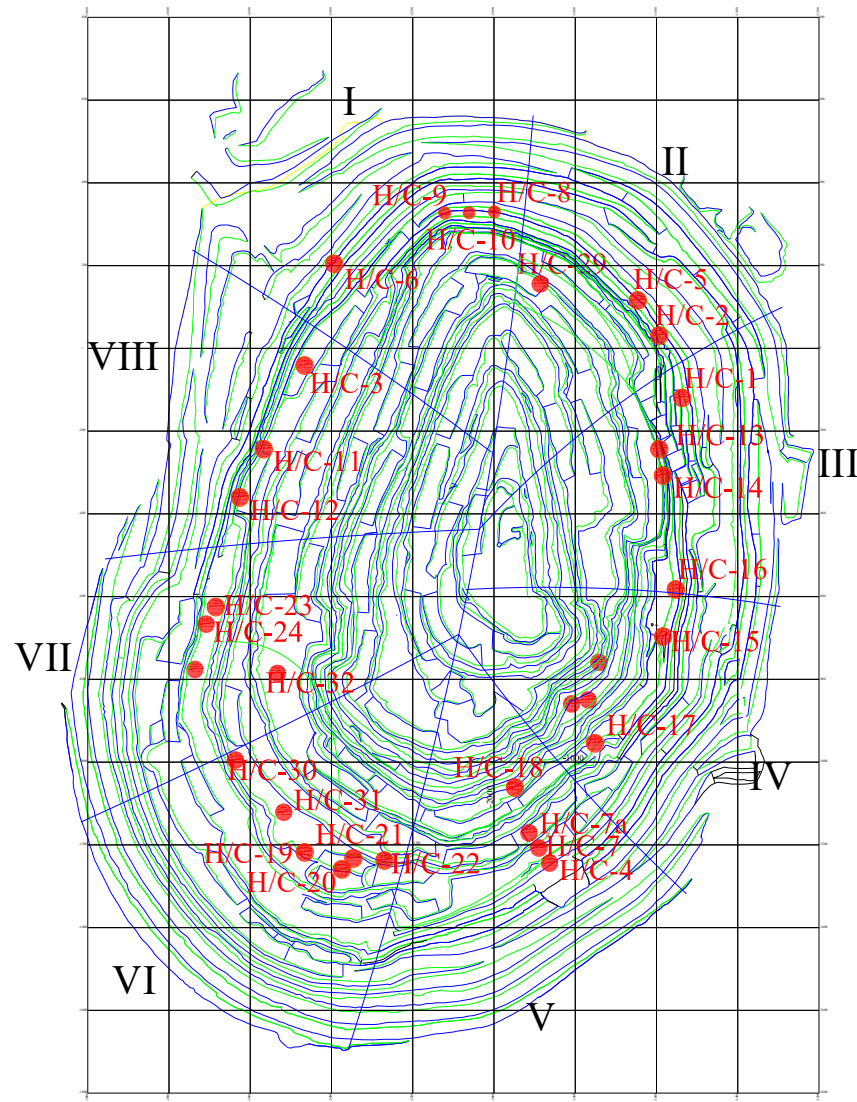

Рис. 5.11. Схема расположения наблюдательных станций в пределах карьера рудника «Железный» АО «Ковдорский ГОК»: • - расположение наблюдательных станций и их номер; — — границы инженерно-геологических секторов и их номер

В таблице 5.5 приведены обобщенные результаты измерений параметров напряженного состояния массива пород карьера, сгруппированные по участкам (рис. 5.11). Также в таблице для сравнения приведены расчетные параметры напряженного состояния массива пород исходя только из собственного веса вышележащих пород. 
Таблииа 5.5

Результаты измерений параметров напряженного состояния пород методом разгрузки в карьере рудника «Железный» $\mathrm{AO}$ «Ковдорский ГОК»

\begin{tabular}{|c|c|c|c|c|c|c|c|}
\hline \multirow[t]{2}{*}{ ИГС } & \multirow{2}{*}{$\begin{array}{c}\text { Абсолютная отметка } \\
\text { измерительной станции, } \\
\text { место измерений, } \\
\text { участок борта карьера }\end{array}$} & \multirow{2}{*}{$\begin{array}{c}H_{\text {cp. }}, \\
\text { M }\end{array}$} & \multicolumn{3}{|c|}{$\begin{array}{c}\text { Параметры } \\
\text { НДС }\end{array}$} & \multicolumn{2}{|c|}{$\begin{array}{c}\text { Расчетные напряжения в массиве } \\
\text { исходя из собственного веса } \\
\text { вышележащих пород }\end{array}$} \\
\hline & & & $\begin{array}{c}\sigma_{\max } \\
\text { МПа }\end{array}$ & $\begin{array}{l}\sigma_{\min }, \\
\text { МПа }\end{array}$ & $\begin{array}{l}B_{\text {бахах, }} \\
\text { град. }\end{array}$ & $\sigma_{\text {верт }}^{\text {cp }}$, МПа & $\sigma_{\text {гор }}^{\text {cp }}$, МПа \\
\hline \multirow[t]{4}{*}{ I } & H/C-6: +118 м, 2005, C3 & 132 & 5 & -1 & 6 & 2,7 & 0,9 \\
\hline & H/C-8: +10 м, 2007, СБ & 247 & 20 & 3 & -24 & 7,4 & 2,5 \\
\hline & H/C-9: +10 м, 2008, СБ & 247 & 27 & 8 & -17 & 7,4 & 2,5 \\
\hline & H/C-10: +25 м, 2007, C3 & 237 & 24 & 14 & -15 & 7,1 & 2,3 \\
\hline \multirow[t]{3}{*}{ II } & H/C-2: +94 м, 2000, CB & 163 & 22 & 9 & -14 & 5 & 1,6 \\
\hline & H/C-5: +40 м, 2005, CB & 217 & 13 & 4 & 18 & 6,5 & 2,2 \\
\hline & $\mathrm{H} / \mathrm{C}-29:-45,2014, \mathrm{CB}^{*}$ & 285 & 21 & 8 & -10 & 8,5 & 2,8 \\
\hline \multirow[t]{4}{*}{ III } & H/C-1: +94 м, 2000, CB & 163 & 20 & 4 & 18 & 5 & 1,6 \\
\hline & H/C-13: +15 м, 2009, В & 190 & 16 & 12 & 32 & 6 & 3 \\
\hline & H/C-14: +15 м, 2009, В & 190 & 22 & 12 & 15 & 6 & 3 \\
\hline & H/C-16: +55 м, 2010, B & 160 & 11 & 0,5 & -11 & 5 & 2 \\
\hline \multirow[t]{5}{*}{ IV } & H/C-15: +40 м, 2010, В & 175 & 10 & 9 & -20 & 5 & 2 \\
\hline & H/C-17: +24 м, 2011, ЮB & 240 & 8 & 6 & 107 & 7 & 3 \\
\hline & H/C-26: -67 м, 2014, B & 290 & 18 & 13 & -2 & 9 & 3 \\
\hline & H/C-27: -59 м, 2014, B & 290 & 29 & 19 & 7 & 9 & 3 \\
\hline & H/C-28: - 35 м, 2014, В & 270 & 26 & 21 & 5 & 8 & 2,6 \\
\hline \multirow[t]{4}{*}{$\mathrm{V}$} & H/C-4: +166 м, 2003, ЮB & 130 & 3 & -1 & 13 & 1,2 & 0,4 \\
\hline & H/C-7: +154 м, 2005, ЮB & 140 & 11 & 3 & 88 & 1,6 & 0,5 \\
\hline & H/C-7a: +142, 2006, ЮB & 64 & 12 & 2 & -125 & 3 & 0,5 \\
\hline & H/C-18: +15 м, 2011, ЮB & 190 & 10 & -1 & -45 & 6 & 2 \\
\hline \multirow[t]{6}{*}{ VI } & $\mathrm{H} / \mathrm{C}-19:+40$ м, 2011, Ю3 & 175 & 13 & 7 & 89 & 5 & 2 \\
\hline & H/C-20: +40 м, 2011, Ю3 & 175 & 8 & 5 & -27 & 5 & 2 \\
\hline & H/C-21: +10 м, 2012, Ю & 250 & 28 & 4 & -22 & 8 & 3 \\
\hline & H/C-22: +10 м, 2012, Ю & 250 & 20 & 5 & -44 & 8 & 3 \\
\hline & H/C-30: -16 м, 2014, Ю3 & 330 & 13 & 6 & 41 & 10 & 3,3 \\
\hline & H/C-31: -16 м, 2014, Ю3 & 330 & 15 & 1 & 5 & 10 & 3,3 \\
\hline \multirow[t]{4}{*}{ VII } & H/C-23: +70 м, 2012, Ю3 & 250 & 24 & 9 & -30 & 5 & 2 \\
\hline & H/C-24: +70 м, 2012, Ю3 & 250 & 6 & 4 & -16 & 5 & 2 \\
\hline & H/C-25: +40 м, 2013, Ю3 & 270 & 8 & 4 & 23 & 8 & 2,6 \\
\hline & H/C-32:-63 м, 2014, Ю3 & 370 & 12 & 5 & 5 & 11 & 3,6 \\
\hline \multirow[t]{3}{*}{ VIII } & H/C-3: +142 м, 2001, C3 & 110 & 8 & -2 & 43 & 2 & 0,6 \\
\hline & H/C-11: +99 м, 2009, 3 & 157 & 23 & 13 & -80 & 5 & 2 \\
\hline & H/C-12: +109 м, 2009, 3 & 160 & 31 & 25 & -89 & 5 & 2 \\
\hline
\end{tabular}

Из данных в таблице видно, что во всех случаях имеет место превышение абсолютных значений измеренных максимальных компонент главных напряжений $\sigma_{\max }$ над расчетными параметрами вертикальных напряжений $\sigma_{\text {верт, }}$ обусловленных собственным весом пород.

На основе многолетних исследований НДС прибортового массива пород Ковдорского месторождения выполнено районирование карьера по величинам действующих напряжений и структурной нарушенности массива, что позволяет дифференцировать устойчивость уступов и участков борта карьера с учетом геологоструктурных особенностей массива и выбирать рациональные параметры уступов и бортов карьера по геомеханическим условиям (рис. 5.12). 


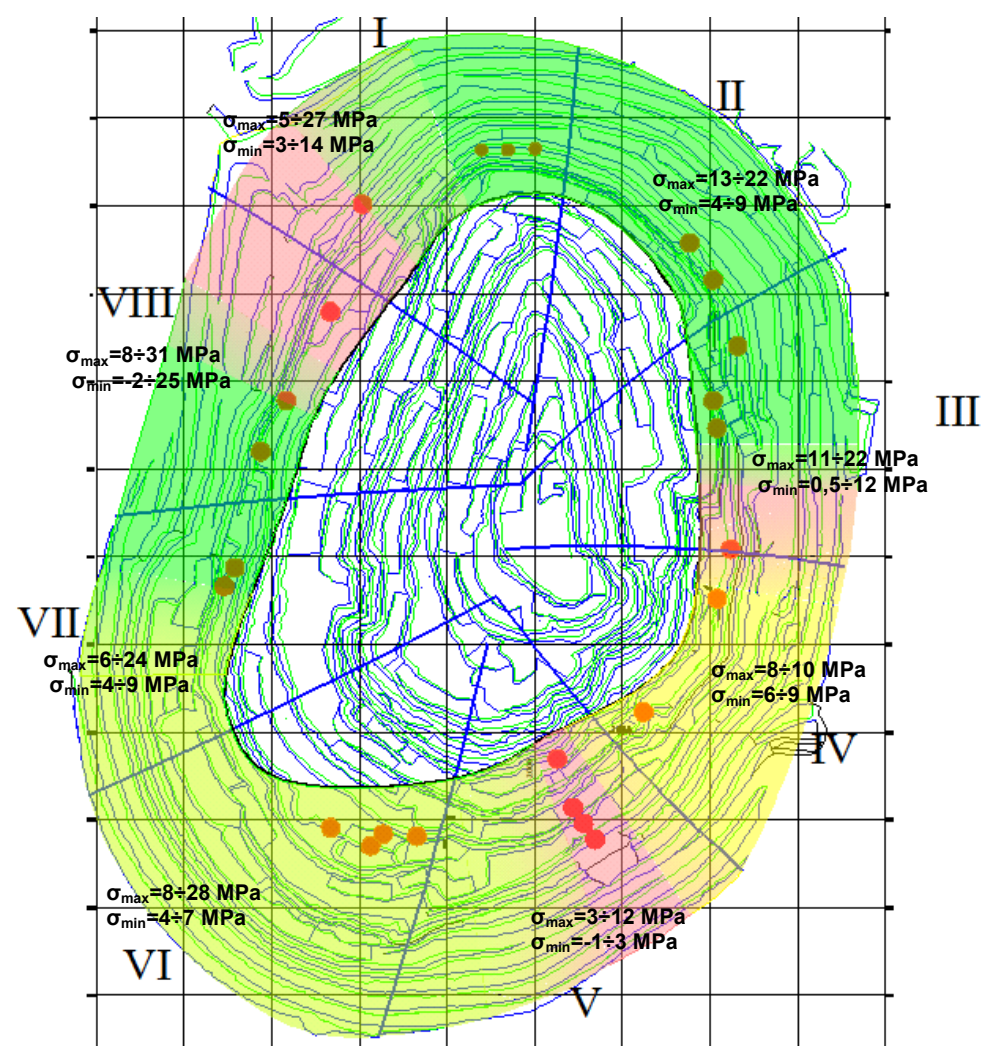

Рис. 5.12. Районирование карьера рудника «Железный» по величинам действующих напряжений с учетом геолого-структурных особенностей строения массива горных пород: I-VIII - инженерно-геологические секторы; - места заложения наблюдательных станций; — наиболее благоприятные зоны с точки зрения действующих в массиве пород напряжений; — менее благоприятные зоны; — - наименее благоприятные зоны

Учитывая большой объем накопленных к настоящему времени данных, можно спрогнозировать увеличение абсолютных значений действующих напряжений с глубиной, что должно приводить к большей устойчивости борта карьера до того момента, пока действующие напряжения не начнут разрушать сами горные породы. При этом локальные потенциально неустойчивые зоны в приконтурном массиве могут быть выявлены с помощью комплексного анализа параметров залегания структурных нарушений относительно формируемого конечного контура карьера и контрастности действующих напряжений, а также геомеханическим мониторингом.

В результате рассмотрения всей совокупности данных об исследовании НДС массива пород Ковдорского месторождения установлено, что напряженное состояние массива пород в окрестности рудника «Железный» относится к гравитационно-тектоническому типу. При этом действие в массиве горных пород повышенных горизонтальных напряжений оказывает неоднозначное влияние на устойчивость борта карьера.

При анализе результатов измерений следует обращать особое внимание на участки массива пород, в пределах которых отмечается действие растягивающих напряжений, а также на соотношение максимальной и минимальной компонент главных напряжений, которые могут быть индикаторами потенциально недостаточной устойчивости участка массива в приконтурной зоне. 


\subsubsection{2. Хибинская горнотехническая система}

Кукисвумчоррское и Юкспорское месторождения

В 2014-2015 гг. выполнены измерения напряжений методом разгрузки на трех двухскважинных станциях. Местоположение определяли необходимостью уточнения параметров напряженного состояния отдельных участков глубоких горизонтов Кировского рудника: две станции (№ 105, 106) на гор. +92 м (рис. 5.13 a), одна станция (№ 104) на гор. +250 м Юкспорской прирезки (рис. 5.13 б).

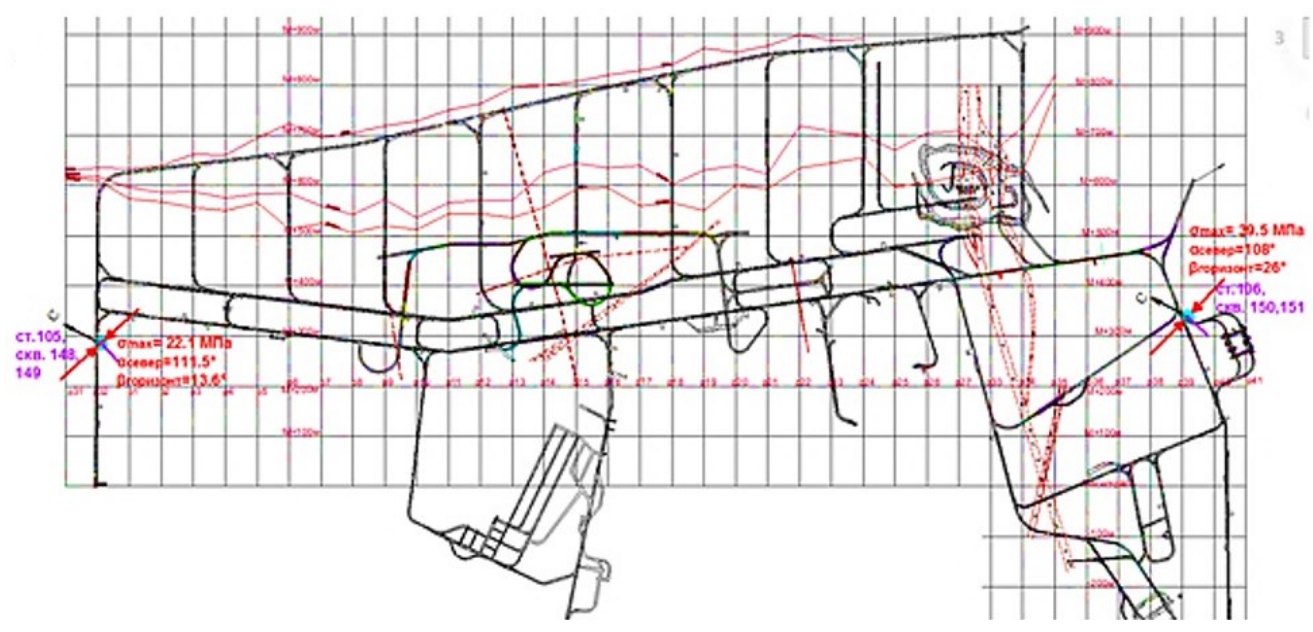

$a$

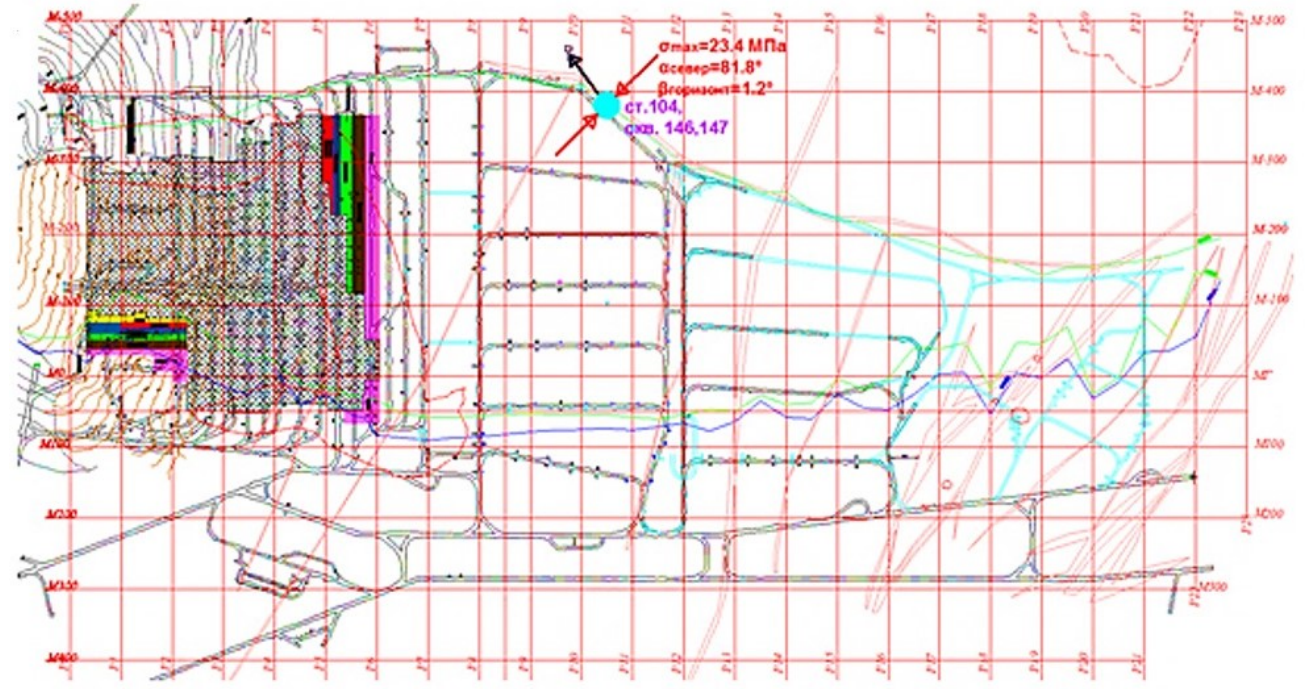

6

Pис. 5.13. Местоположение станций разгрузки с векторами и абсолютными величинами $\sigma_{\text {max: }}$ : $a$ - гор. +92 м Кукисвумчоррского крыла; 6 - гор. +250 м Юкспорского крыла

Все показатели сведены в итоговую таблицу (табл. 5.6). Следует отметить, что однозначное определение всех трех компонент напряжений возможно только в случае проведения измерений на трехскважинных станциях. 
Результаты измерений напряжений методом разгрузки на Кировском руднике

Таблийа 5.6

\begin{tabular}{|c|c|c|c|c|c|c|c|c|c|c|c|c|}
\hline \multirow{2}{*}{$\begin{array}{l}\text { № } \\
\text { п/п }\end{array}$} & \multirow{2}{*}{ Дата } & \multirow{2}{*}{$\begin{array}{c}\text { № } \\
\text { станции }\end{array}$} & \multicolumn{3}{|c|}{ Рудничные координаты } & \multirow{2}{*}{$\begin{array}{c}\text { Глубина } \\
\text { от дневной } \\
\text { поверхности }\end{array}$} & \multicolumn{3}{|c|}{$\begin{array}{c}\text { Главные напряжения, } \\
\text { МПа }\end{array}$} & \multirow{2}{*}{\begin{tabular}{|c|} 
Отношение \\
промежугочного \\
напряжения \\
к главному
\end{tabular}} & \multirow{2}{*}{$\begin{array}{c}\text { Азимут вектора } \\
\text { максимальных } \\
\text { напряжений, } \\
\text { град. }\end{array}$} & \multirow{2}{*}{$\begin{array}{c}\text { Наклон вектора } \\
\text { максимальных } \\
\text { напряжений } \\
\text { к горизонту, град }\end{array}$} \\
\hline & & & разрез & магистраль & $\begin{array}{c}\text { высотная } \\
\text { отметка }\end{array}$ & & $\sigma_{\text {max }}$ & $\sigma_{\text {пр }}$ & $\sigma_{\text {min }}$ & & & \\
\hline 1 & 02.2015 & 104 & $10 Ю+35 \mathrm{M}$ & $\mathrm{M}+384$ & $+252 \mathrm{M}$ & $550 \mathrm{M}$ & 23,4 & 13,9 & 1,8 & 0,59 & 81,8 & 1,2 \\
\hline 2 & 03.2015 & 105 & $32+12 \mathrm{M}$ & $\mathrm{M}+284$ & $+92 \mathrm{M}$ & $360 \mathrm{M}$ & 22,1 & 8,2 & 7,1 & 0,37 & 111,5 & 13,6 \\
\hline 3 & 08.2015 & 106 & $39+12 \mathrm{M}$ & $\mathrm{M}+336$ & $+92 \mathrm{M}$ & $350 \mathrm{M}$ & 39,5 & 18,4 & 5,7 & 0,47 & 108,1 & 26,1 \\
\hline
\end{tabular}


Низкая величина $\sigma_{\max }$ на станции № 105 связана, вероятно, с наличием в нескольких десятках метрах нарушенной зоны. Значения, полученные на станции № 104, значительно отличаются от величин $\sigma_{\max }$, замеренных на близлежащих станциях, где $\sigma_{\max }>30$ МПа.

Явное дискование керна получено только на станции № 106, где уровень максимальной компоненты главных напряжений близок к 40 МПа (рис. 5.14). Здесь же выявлена также содовая минерализация.

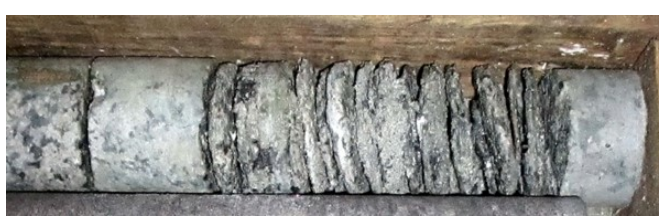

$a$

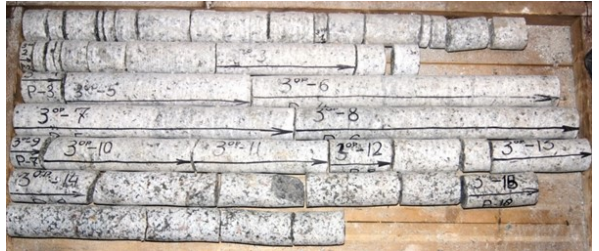

$\sigma$

Pис. 5.14. Состояние керна на станции № 106 по скважине 150 к (вертикальная): $a$ - дискование керна (0,84-0,99 м); 6 - выход керна по скважине 3 (0-6 м)

В целом результаты определений подтверждают действие в массиве пород тектонических напряжений. Соотношения промежуточной и максимальной компоненты находятся в интервале $0,4 \div 0,6$.

\section{Месторождение «Олений ручей»}

В 2012-2013 гг. проведены измерения методом разгрузки в торцевом варианте на двух станциях подземного рудника «Олений ручей ЗАО “СЗФК”». Обе станции расположены на гор. +240 м. На рисунке 5.15 приведен план гор. +240 м с пройденными на момент измерений выработками; геологическими нарушениями (мончекитовые дайки), зафиксированными геологической службой рудника; местоположением станций разгрузки и векторами максимальной компоненты напряжений $\sigma_{\max }$ с указанием их величин и азимута.

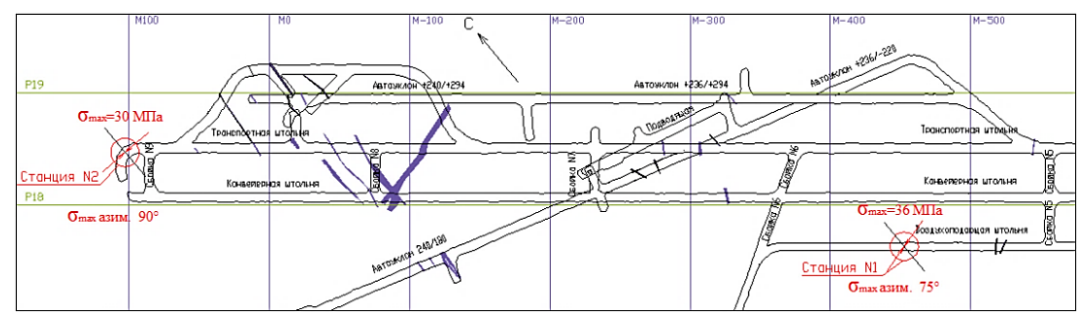

Рис. 5.15. План гор. +240 м с расположением измерительных станций и определенными векторами $\sigma_{\max }$

Состояние керна, полученного при бурении измерительных скважин, свидетельствует о малой нарушенности массива в месте проведения измерений, a дискование керна в пределах первых метров указывает на наличие концентрации напряжений вблизи контура выработок (рис. 5.14).

На рисунке 5.16 приведены графики изменений напряжений с увеличением глубины измерительных скважин. Значения главных компонент напряжений, а также ориентировка проекции векторов $\sigma_{\max }$ на горизонтальную плоскость по двум измерительным станциям приведены в таблице 5.7 . В результате измерений не удалось получить достоверные данные о минимальной компоненте главных напряжений. 


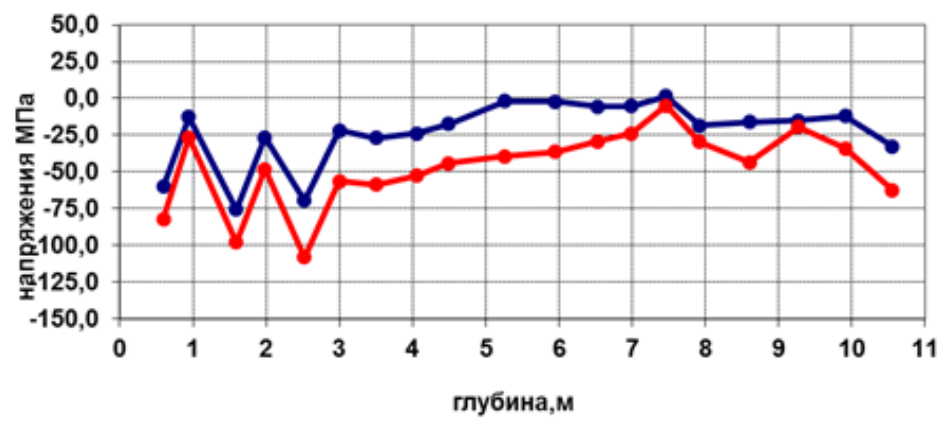

$a$

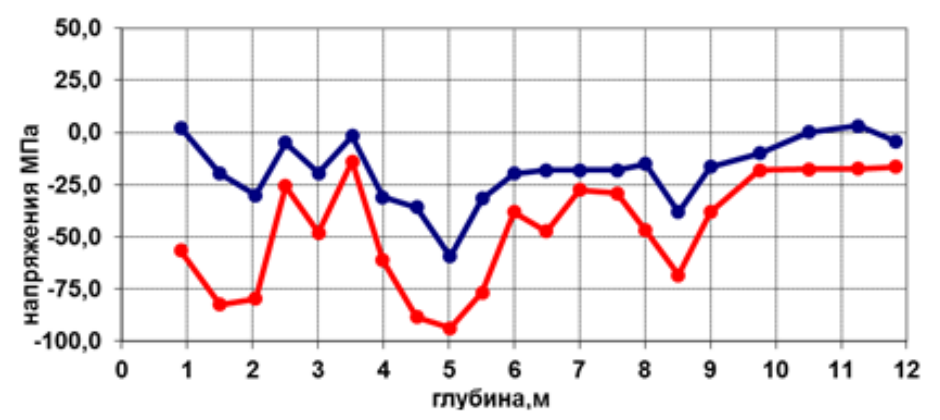

$\sigma$

Рис. 5.16. Изменение напряжений по скважинам станции № 2: $a$ - вертикальная; 6 - горизонтальная скважины

Таблица 5.7

Результаты измерений напряжений методом разгрузки на гор. +240 м рудника «Олений ручей»

\begin{tabular}{|c|c|c|c|c|c|c|c|c|}
\hline \multirow[b]{2}{*}{ Станция } & \multirow[b]{2}{*}{ Дата } & \multicolumn{3}{|c|}{ Рудничные координаты } & \multirow[b]{2}{*}{$\begin{array}{l}\sigma_{\max }, \\
\text { МПа }\end{array}$} & \multirow[b]{2}{*}{$\begin{array}{l}\sigma_{\text {пр }} \\
\text { МПа }\end{array}$} & \multirow{2}{*}{$\begin{array}{l}\sigma_{\min }, \\
\text { МПа }\end{array}$} & \multirow{2}{*}{$\begin{array}{c}\text { Азимут } \sigma_{\max }, \\
\text { град. }\end{array}$} \\
\hline & & разрез & магистраль & $\begin{array}{c}\text { высотная } \\
\text { отметка }\end{array}$ & & & & \\
\hline № 1 & 12.2012 & $17+60 \mathrm{M}$ & $-450 \mathrm{M}$ & $+240 \mathrm{M}$ & 36 & 10 & -2 & 75 \\
\hline № 2 & 12.2013 & $18+50 \mathrm{M}$ & $+105 \mathrm{M}$ & $+240 \mathrm{M}$ & 30 & 16 & 12 & 90 \\
\hline
\end{tabular}

Визуальный осмотр выработок на начальном этапе проходки не выявил каких-либо признаков проявлений горного давления. Состояние выработок характеризовалось как устойчивое. Разрушения крепи отсутствовали. Однако в дальнейшем, при проходке штолен после сбойки № 6 и автоуклона $+234 /-220$, а также после проходки узла перегрузки № 2, были отмечены проявления горного давления в виде шелушения, стреляния, динамического заколообразования. Разрушение контура выработки происходило преимущественно в кровле выработки, реже на сопряжении кровли со стенкой. Пример выработки, в которой происходило разрушение, показан на рисунке 5.17 .

Форма разрушения выработки говорит о том, что вектор максимальной компоненты главных напряжений является субгоризонтальным. Также по характеру разрушений можно приблизительно оценить величину напряжений на контуре выработки. 


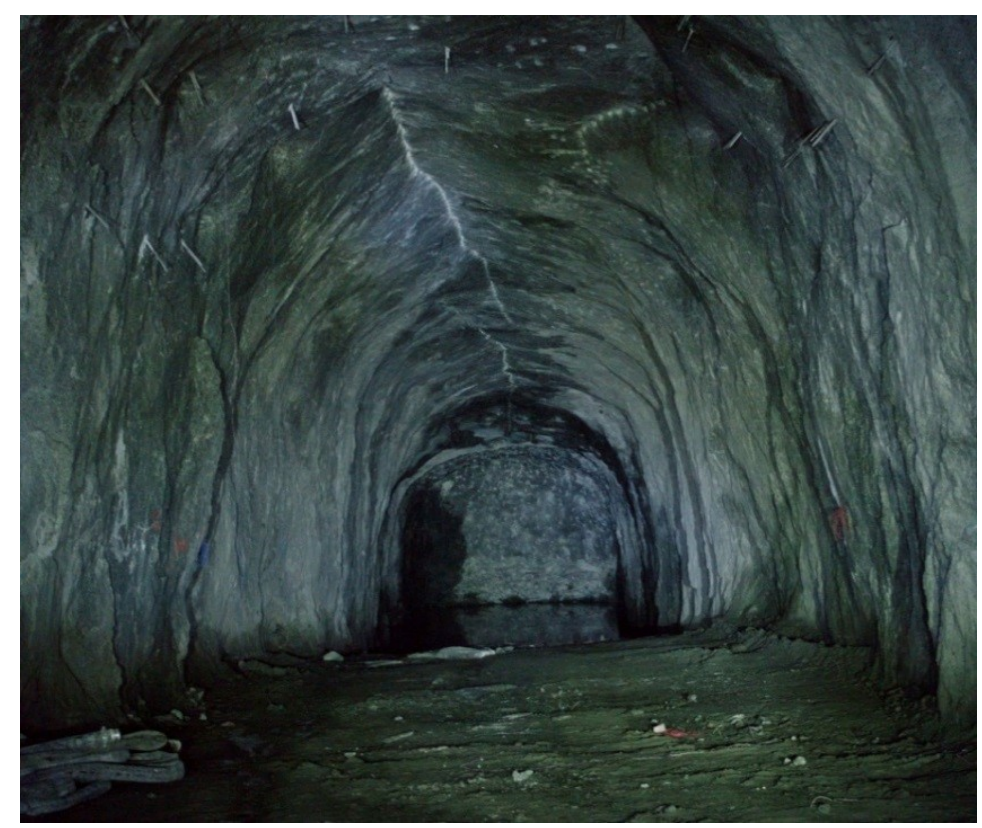

Pис. 5.17. Характер разрушения контура выработки (автоуклон - +234/-220 м)

Увеличение проявлений горного давления в динамической форме может быть обусловлено следующими факторами:

- геологическими особенностями массива - после сбойки № 6 выявлены мончекитовые дайки различной мощности, разрушение вмещающих пород между подобными жесткими включениями может проходить более интенсивно;

- изменением рельефа дневной поверхности, участки с динамическими проявлениями горного давления находятся под толщей пород более 400 м;

- усложнением горнотехнической ситуации, а именно одновременной проходкой в массиве разнонаправленных большепролетных выработок;

- неотлаженной технологией проведения разгрузочных мероприятий.

Комплексом натурных исследований получены следующие результаты.

1. Методом сейсмической томографии определены скорости продольных и поперечных волн: $V_{p}=6 \mathrm{\kappa m} / \mathrm{c}$ и $V_{s}=3 \mathrm{\kappa m} / \mathrm{c}$. Скорости $V_{p}$ в массиве превышают скорости в образце, что свидетельствует о повышенном уровне напряжений в массиве.

2. Ультразвуковым каротажом скважин определены размеры нарушенной зоны, которые на устойчивых участках составляют 0,4 м, для выработок с проявлениями горного давления - 0,8 м.

3. Измерениями методом разгрузки на гор. +234 м установлено, что $\sigma_{\max }=30 \div 36 \mathrm{MПа,} \mathrm{азимут} \mathrm{вектора} \sigma_{\max }-75 \div 90^{\circ}$, при этом значения $\sigma_{\max }$ более чем в 3 раза превышают уровень напряжений от собственного веса пород, что подтверждает наличие тектонических напряжений в массиве.

4. Значительное влияние на устойчивость выработок оказывают особенности геологического строения (наличие мончекитовых даек), увеличение глубины работ, усложнение горнотехнической ситуации.

5. Характер разрушения выработок, а именно проявления горного давления в кровле, подтвердили действие высоких горизонтальных напряжений в массиве пород месторождения. 


\subsection{4. Индикаторы геодинамической активности основных разломов, их ранжирование и характер взаимодействия выделенных блоков, оценка их напряженного состояния}

\subsubsection{1. Факторы контроля геодинамической опасности}

Обеспечение геодинамической безопасности является важнейшим, ключевым требованием при производстве горных работ, особенно в ПТС с накопленными масштабными антропогенными преобразованиями исходной геологической среды.

Геодинамическая безопасность контролируется многочисленными факторами, которые влияют на трансформацию современного поля напряжений, одним из результатов которого могут быть геодинамические явления (табл. 5.8).

\section{Таблица 5.8}

Основные факторы геодинамического риска при горных работах

\begin{tabular}{|c|c|c|}
\hline № & Факторы & Агенты влияния и механизмы реализации \\
\hline \multicolumn{3}{|r|}{ Природные } \\
\hline 1 & $\begin{array}{l}\text { Физико-механические } \\
\text { свойства и агрегатное } \\
\text { состояние пород }\end{array}$ & $\begin{array}{l}\text { Физико-механические свойства пород определяют локализацию } \\
\text { проявлений горного давления и других опасных геолого-геофизических } \\
\text { явлений. Агрегатное состояние (рыхлое, слабосвязанное, } \\
\text { дезинтегрированное, скальное и т. п.) определяет модель поведения } \\
\text { под нагрузкой или под собственным весом }\end{array}$ \\
\hline 2 & $\begin{array}{l}\text { Разрывная тектоника, } \\
\text { структурные } \\
\text { неоднородности } \\
\text { и трещиноватость }\end{array}$ & $\begin{array}{l}\text { Разломы, разрывные нарушения, трещины, зоны катаклаза } \\
\text { милонитизации и пр. являются проводниками для поверхностных / } \\
\text { подземных вод, а также глубинных газово-жидких фаз, концентраторами } \\
\text { напряжений и разграничительными поверхностями / зонами } \\
\text { относительных смещений блоков }\end{array}$ \\
\hline 3 & НДС & $\begin{array}{l}\text { Высокие значения и анизотропия (неравнокомпонентность) полей } \\
\text { напряжений. Разгрузка напряжений (стресс состояний) вызывает } \\
\text { геодинамические явления и интенсивные деформационные процессы }\end{array}$ \\
\hline 4 & $\begin{array}{l}\text { Гидрогеология } \\
\text { и гидрология }\end{array}$ & $\begin{array}{l}\text { Повышенные водопритоки в выработки, как правило, существенно } \\
\text { снижают прочностные свойства и повышают вероятность опасных } \\
\text { геолого-геофизических явлений }\end{array}$ \\
\hline 5 & Метеоусловия & $\begin{array}{l}\text { Обильные осадки и интенсивное снеготаяние изменяют } \\
\text { гидрогеологический режим. Циклы «замерзание- оттаивание» } \\
\text { и «прогрев - охлаждение» способствуют физическому выветриванию } \\
\text { приповерхностных пород. Вариации атмосферного давления могут } \\
\text { служить триггером для систем с неустойчивым равновесием }\end{array}$ \\
\hline 6 & $\begin{array}{l}\text { Природные } \\
\text { физические } \\
\text { (геофизические) } \\
\text { поля }\end{array}$ & $\begin{array}{l}\text { Флуктуации природных геофизических полей, включая геомагнитные } \\
\text { возмущения, солнечно-лунные приливы и др., воздействуют на НДС } \\
\text { и могут служить триггерами для геосистем в неустойчивом равновесии. } \\
\text { Неоднородность теплового потока приводит к перераспределению } \\
\text { и концентрации напряжений }\end{array}$ \\
\hline \multicolumn{3}{|r|}{ Антропогенные (техногенные) } \\
\hline 7 & $\begin{array}{l}\text { Выемка, перемещение } \\
\text { и складирование } \\
\text { горных пород }\end{array}$ & $\begin{array}{l}\text { Выемка из мест первичного залегания, перемещение и складирование } \\
\text { горных пород в огромных объемах (десятки-сотни миллионов тонн) } \\
\text { существенно изменяет состояние геологической среды, включая } \\
\text { гидрогеологический и гидрологический режимы, НДС и др. }\end{array}$ \\
\hline 8 & Взрывные работы & $\begin{array}{l}\text { Массовые взрывы активизируют геодинамические явления } \\
\text { и деформационные процессы в геомеханическом пространстве рудников }\end{array}$ \\
\hline 9 & $\begin{array}{l}\text { Геометрия горных } \\
\text { выработок, способ } \\
\text { и направление } \\
\text { развития горных работ }\end{array}$ & $\begin{array}{l}\text { Геометрия, способ и направление развития горных работ определяют } \\
\text { локализацию и характер проявления горного давления. В зависимости } \\
\text { от применяемых параметров может достигаться как положительный } \\
\text { рффект (разгрузка горного давления), так и негативный } \\
\text { (активизация геодинамических явлений) }\end{array}$ \\
\hline
\end{tabular}

Любое геодинамическое проявление имеет интегральную природу, то есть является результатом взаимодействия ряда причин, что делает актуальным исследования по их ранжированию и оценке весового вклада. 


\subsubsection{2. Индикаторы геодинамической активности}

Под геодинамически активными структурами в геодинамике понимаются прорастающие в современный период разрывные нарушения, отличающиеся более активным развитием деформаций и связанных с ними структурных изменений (малоамплитудных разрывов, флексур, послойных нарушений, раздувов и пережимов пластов и т. д.) участков геологической среды, прилегающих к нарушениям, высокой концентрацией напряжений и повышенной проницаемостью массива вдоль их простирания [180, 198, 199].

По природе своего образования все геодинамически активные структуры в реальной геологической среде находятся в соподчиненном положении. Они ранжируются по масштабному признаку на структуры различного иерархического уровня (обычно с I по VII), при этом каждая из них находится в иерархической подчиненности от структур более крупного ранга. Наиболее активными движениями обычно отличаются структуры самых крупных масштабных рангов, однако максимальная концентрация напряжений чаще приурочена к структурам среднего или самого мелкого масштабного ранга (более «молодым» в ряду иерархической подчиненности).

При производстве горных работ наличие геодинамически активных структур в пределах отрабатываемого месторождения приводит к рискам возникновения горных ударов регионального и локального происхождения, внезапных выбросов или обрушений кровли и других опасных событий и явлений геодинамической природы или геодинамическим рискам, которые, в свою очередь, подразделяются на риски возникновения сейсмической опасности и удароопасности. При этом зоны сопряжения геодинамически активных структур представляют собой наиболее опасные участки недр, характеризующиеся самыми высокими рисками развития опасных геодинамических процессов и явлений.

Для геодинамического районирования в настоящее время применяют ряд геологических и геофизических индикаторов геодинамической активности геологической среды в пределах шахтных полей разрабатываемых месторождений.

\section{Геологические индикаторы}

В ряду перечисленных факторов геодинамической опасности (табл. 5.8) разрывная тектоника и трещиноватость занимает особое место, что акцентируется во всех без исключения нормативно-технических и научных источниках [199-204]. Индикаторами геодинамической опасности разрывных нарушений служат прежде всего следы свежих геодинамических событий, которые на поверхности, как правило, выражаются в рельефе (линейные ступенеобразные поднятия и зияющие трещины/разломы, сильно расчлененные долины и склоны), а в горных выработках - в виде деформаций и их обрушений. Универсальным признаком служат зеркала и борозды скольжения, которые показывают «молодую» активность разлома и позволяют определить относительное смещение блоков, тип и параметры локального и общего поля напряжений.

Реконструкция перемещений основывается на кинематических индикаторах, под которыми понимаются структуры, зафиксированные при геологических наблюдениях, с одной стороны, и указывают направление тектонических перемещений, с другой. В процессе ранее проведенных исследований было выявлено четыре типа индикаторов. Для массивов горных пород в пределах шахтных 
полей, отрабатываемых месторождений Ковдорского и Хибинского массивов, основными геологическими индикаторами активности разрывных нарушений являются наличие зон расщепления участков приоткрывания, смещения полосчатости и штрихов скольжения.

Структура типа зон расщепления образуется чаще всего при сжатии. Подвижка ориентирована «в тупой угол» структуры (рис. 5.18 a), причем линия подвижки перпендикулярна линии расщепления (смыкания плоскостей основной и оперяющей структур). Участки приоткрывания образуются при любом виде напряженного состояния (сжатие - растяжение). На изучаемых месторождениях они представлены пустотами, причем направление удлинения пустот обычно перпендикулярно направлению перемещения (рис. 5.18 б). Смещение полосчатости по разрыву - традиционный объект изучения в структурной геологии. Перемещение определяется геометрическим построением по результатам наблюдений в двух сечениях (рис. 5.18 в). Штрихи (или борозды) скольжения - также обычный кинематический индикатор (рис. 5.18 г). В случае разведуемых месторождений штрихи скольжения мелкие, заметны часто только при отмывке фрагмента плоскости зоны. Определить направление подвижки по ним (сброс - взброс, правый сдвиг - левый сдвиг) весьма затруднительно. Для этой цели необходимо дополнительно выявить какой-либо из вышеописанных индикаторов.

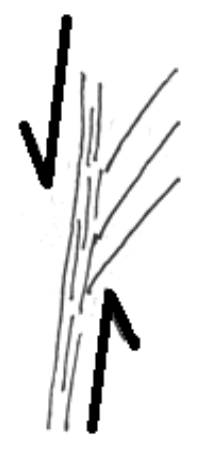

$a$

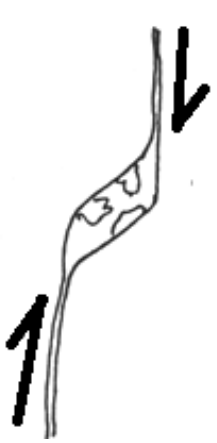

6

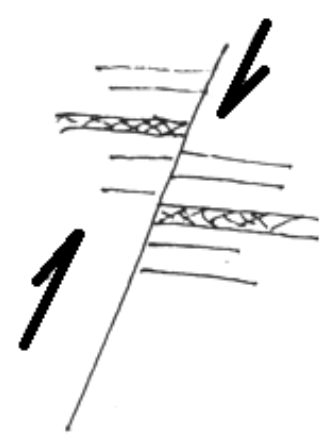

$B$

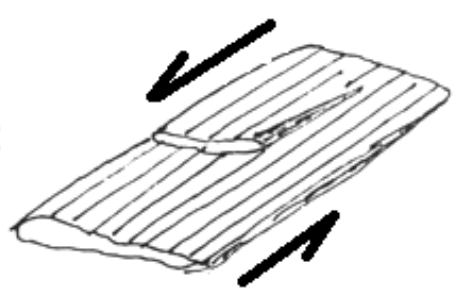

2

Рис. 5.18. Геологические индикаторы: $a-$ расщепление зон; $\sigma-$ участки приоткрывания; в - смещение полосчатости; 2 - штрихи скольжения

При изучении структурных неоднородностей в законтурном пространстве используют также ориентированный керн.

\section{Деформаиионные индикаторь}

К деформационным индикаторам обычно относят предвестники, выявленные по данным наблюдений за медленными движениями земной поверхности. Такие наблюдения представляют собой один из основных методов поиска предвестников различных геодинамических явлений, в том числе землетрясений. Это объясняется тем, что они позволяют фактически непосредственно контролировать процесс изменения напряженного состояния и деформирования земной коры. 


\section{Геофизические индикаторы}

Геофизические методы (сейсмо-, акусто- и др. профилирование и томография) дают общую сглаженную картину и выявление только наиболее крупных и контрастных объектов. При наличии достаточно густой сети сейсмических станций для целей геолого-картировочного плана могут быть привлечены данные сейсмологических наблюдений $[191,199,203]$. В этом случае в качестве критериев для выделения границ блоковых структур используют:

- уровень сейсмической активности, характеризующий сейсмический режим данного района - флуктуацию уровня во времени и пространстве;

- корреляцию периодов, соответствующих максимальным амплитудам на записях местных и удаленных землетрясений, зависящих от геологического строения региона в районе расположения сейсмостанций.

Проведение более детального многоэтапного анализа (при фильтрации событий, приуроченных к отрабатываемым блокам) позволяет выделять облака кластеров событий, соответствующих имеющимся и формирующимся структурным неоднородностям. Таким образом, количество событий, находящихся в кластере, приуроченном к определенному разрывному нарушению, также характеризует степень его активности.

\section{Гидрогеологические индикаторы}

В формировании гидрогеологической обстановки в зоне активного водообмена ведущими являются состояния структурно-геологических условий и неотектонических движений. Действие еe установлено для различных регионов мира [196]. В качестве расчетных показателей для построения структурно-гидрогеологических схем используются показатели: подземного стока, подземного химического стока и углеводородного стока, которые позволяют с высокой точностью картировать локальные положительные структуры и выделять геодинамические активные зоны.

\section{Радиогенные индикаторы}

Одним из перспективных направлений является оценка возможности прогноза опасных геодинамических явлений на основе анализа результатов мониторинговых наблюдений за эманацией радиогенных газов. Из радиогенных газов, которые образовались в процессе распада природных радиоактивных веществ и используются для изучения геодинамических процессов, в основном изучаются водород, аргон-40 и изотопы радона. Анализ их содержаний и вариаций во времени несет информацию о процессах, протекающих непосредственно в горных породах, и позволяет получить информацию о свойствах среды, в которой происходит миграция радиогенных газов. Рождаясь в горных породах и мигрируя по ним, они несут информацию о тех геодинамических процессах и их изменениях, которые на эти породы воздействуют. Наиболее полную информацию о характере геодинамических процессов можно получить, используя долговременные ряды наблюдений за их концентрацией [205].

Таким образом, все рассмотренные выше индикаторы геодинамической активности (в той или иной степени) применяются для регионального геодинамического районирования, при котором границами блоков являются линеаментные разрывные нарушения. То есть речь идет о масштабах оценки влияния от литосферных плит (где границами служат трансформные разломы) 
до структурных блоков, разделяемых разрывными нарушениями 1-3 рангов (первые десятки км). При проведении детального геодинамического районирования шахтных полей горнодобывающих предприятий приходится иметь дело со структурными блоками, ограниченными разрывными нарушениями 5-6 рангов, что предъявляет свои требования к выбору методов анализа геодинамической активности участков массива горных пород.

При визуальном осмотре выработок основными индикаторами активности разрывных нарушений являются смещения берегов нарушений друг относительно друга с явно выделяемыми бороздами скольжения; увеличение водопритока по данному разрывному нарушению; нарушение или смещение элементов крепи, если нарушение находится за ней.

\subsection{5. Карты (схемы) пострудного тектогенеза и геодинамическое районирование отрабатываемых и перспективных месторожндений и горизонтов}

Геодинамическое районирование предназначено для выявления тектонической структуры месторождений, характеристики их НДС, на основании которого оптимизируются способы и параметры недропользования (в частности, выбор систем разработки, определение оптимального порядка отработки месторождений, способы поддержания горных выработок и др.). В первую очередь выделяют тектонически напряженные зоны (ТНЗ), в которых могут быть реализованы геодинамические явления, опасные при строительстве и эксплуатации рудника. Далее в ТНЗ выделяют геодинамически опасные зоны (ГОЗ) - ТН3 с размещенными или планируемыми к размещению в них горными выработками, в пределах которых повышается вероятность горных ударов и других динамических проявлений горного давления из-за сложения первичных тектонических и вторичных техногенных напряжений, вызванных ведением горных работ. Исходя из этого создаваемые модели, отражающие эти характеристики, по цели исследования относятся к моделям процессов и явлений, по особенностям представления - к сложным, неоднородным, закрытым, динамическим и вероятностным. Адекватность моделей определяется учетом наиболее важных характеристик, количеством и качеством исходных данных.

Геодинамическое районирование заключается в последовательном формировании трех эвристических информационных структурных моделей процесса с многократным их уточнением по мере получения новой информации о строении и свойствах массива горных пород, ведения горных работ, напряжениях и деформациях (рис. 5.19).

Первая модель строится на основании данных, полученных при ведении геологоразведочных работ, морфометрическому анализу земной поверхности, дешифрирования аэро- и космоснимков, геофизических методов выделения структур. Она является визуализацией данных по блочной структуре месторождений, шахтных полей и внутриблоковых тектонических нарушений.

Вторая модель строится на основе данных, полученных при проведении аналитических расчетов, экспериментальных измерений и оценке результатов различных методов (экспериментальные методы определения НДС, тектонофизический анализ НДС, математическое моделирование НДС, анализ современных тектонических движений и сейсмической активности). Фактически она является визуализацией данных по свойствам, естественному НДС блоков массива горных пород. 
Третья модель создается по информации, полученной при анализе горнотехнической и горно-геологической ситуации, результатов измерений параметров состояния массива различными локальными методами и результатов мониторинга. Она является визуализацией данных по расположению выработок и свойствам массива горных пород в подготавливаемых к отработке блоках, соответствующей информации имеющихся геологических карт, тектонических схем, разрезов по разведочным линиям, данным геофизических измерений, а также инструментальных измерений и наблюдений в скважинах и горных выработках.

\begin{tabular}{|c|c|c|c|c|c|c|c|c|c|}
\hline \multicolumn{4}{|c|}{ Исходные данные } & \multicolumn{2}{|c|}{ Исходные данные } & \multicolumn{4}{|c|}{ Исходные данные } \\
\hline 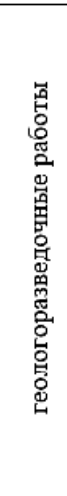 & 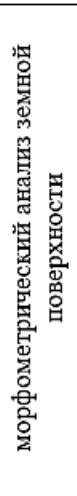 & 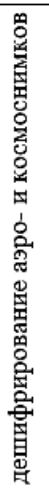 & 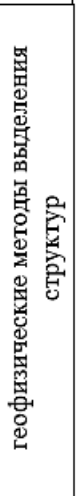 & 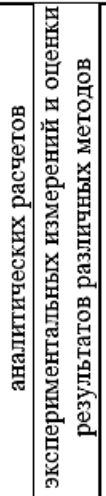 & $\begin{array}{l}\text { экспериментальные } \\
\text { методы опредетения } \\
\text { НДС, } \\
\text { тектонофизический } \\
\text { анапиз НДС, } \\
\text { математическое } \\
\text { моделирование НДС, } \\
\text { оценка напряженности } \\
\text { блоков по смещениям } \\
\text { на граничных } \\
\text { разрьвах, анатиз } \\
\text { современных } \\
\text { тектонических } \\
\text { движеннй, анализ } \\
\text { сейсмиической } \\
\text { активности }\end{array}$ & 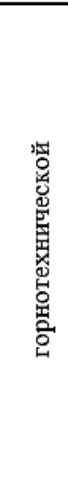 & 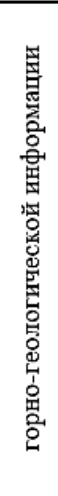 & 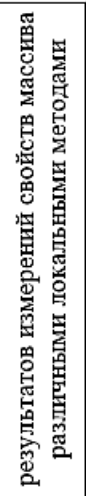 & 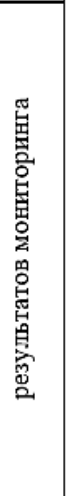 \\
\hline \multicolumn{4}{|c|}{$\begin{array}{c}\text { Блочная } \\
\text { геолого-структурная } \\
\text { (геометрическая) модель }\end{array}$} & \multicolumn{2}{|c|}{$\begin{array}{c}\text { Геодинамическая модель } \\
\text { месторождения }\end{array}$} & \multicolumn{4}{|c|}{$\begin{array}{c}\text { Горно-геодинамическая } \\
\text { модель рудника и участков }\end{array}$} \\
\hline \multicolumn{4}{|c|}{$\begin{array}{c}\text { визуализацией данных } \\
\text { по блочной структуре } \\
\text { месторождений, шахтных } \\
\text { полей и внутриблоковых } \\
\text { тектонических нарушений }\end{array}$} & $\begin{array}{r}\text { визуал } \\
\text { по } \\
\text { естес } \\
\text { блоков }\end{array}$ & $\begin{array}{l}\text { Iизацией данных } \\
\text { свойствам, } \\
\text { твенному НдС } \\
\text { массива горных } \\
\text { пород }\end{array}$ & \multicolumn{4}{|c|}{ 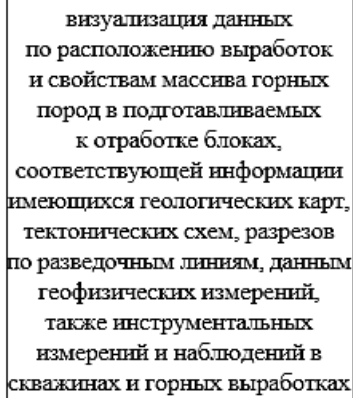 } \\
\hline
\end{tabular}

Рис. 5.19. Структура процесса геодинамического районирования

Таким образом, для построения геодинамической модели разрабатываемого месторождения необходимо провести оценку напряженного состояния массива горных пород, на основании которой, определяются прогнозные границы ТНЗ и ГОЗ. Прогнозные зоны вносят в геолого-маркшейдерскую модель, что позволяет получить исходную геодинамическую модель части отрабатываемого месторождения в пределах шахтного поля.

Горно-геодинамическая модель рудника дает возможность установить ГОЗ на протяжении всего периода отработки месторождения. Данные о местоположении этих $30 н$ должны учитываться при проведении инструментальных измерений для определения категории удароопасности. В качестве примера на рисунке 5.20 приведена блочная модель для гор. +92 м Кукисвумчоррского крыла Кировского рудника (КР). 


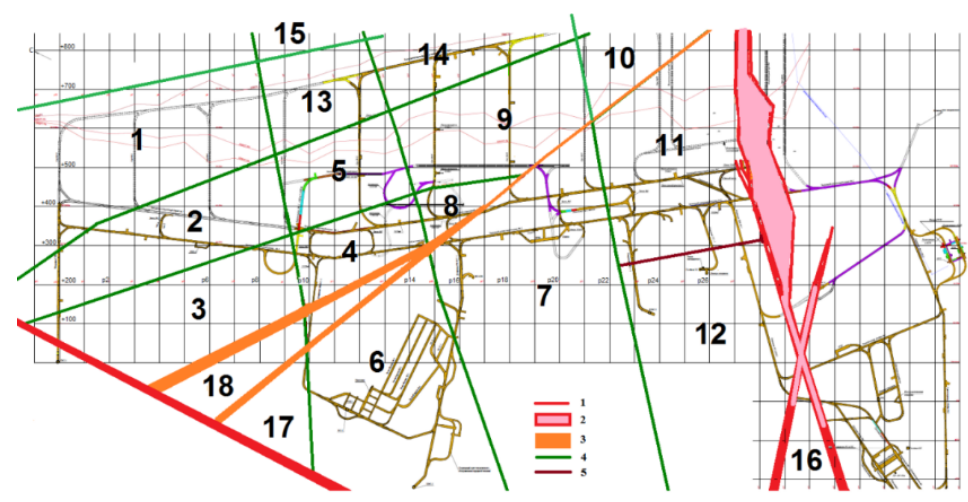

Рис. 5.20. Схема блочного строения Кукисвумчоррского крыла КР (гор. +92 м): 1 - разрывное нарушение 4 ранга; 2 - заполнитель мощного разрывного нарушения, представленный зонами шпреуштейнизации; 3 - блок, ограниченный двумя близкорасположенными разрывными нарушениями 5 ранга; 4 - разрывное нарушение 5 ранга; 5 - разрывное нарушение 6 ранга. Большими цифрами пронумерованы выделенные геодинамические блоки

Отображение на блочной модели результатов измерений НДС для гор. +92 м Кукисвумчоррского крыла приведено на рисунке 5.21 .

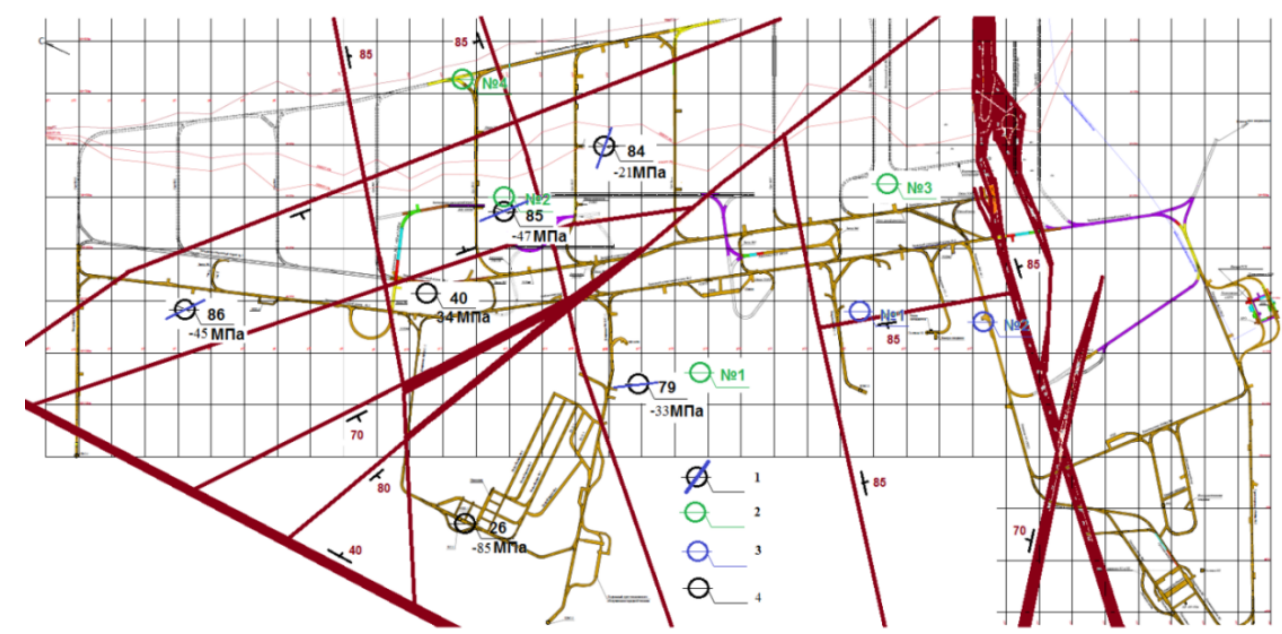

Рис. 5.21. Результаты проведения измерений НДС массива на Кукисвумчоррском крыле (для гор. +92 м): 1 - место проведения измерений методом разгрузки (сверху номер станции, снизу - значения максимальных напряжений и направление действия максимальных сжимающих напряжений); 2 - место расположения опережающей скважины и ее номер; 3 - место отбора керна опережающих скважин для определения физико-механических свойств; 4 - место проведения измерений методом разгрузки для станций, проведенных ранее

На рисунке 5.22 в качестве примера показаны выделенные ТНЗ и ГОЗ для гор. +92 м Кукисвумчоррского крыла КР.

Для анализа динамики разрушения массива горных пород под техногенным воздействием в процессе отработки месторождения в геодинамическую модель включаются данные о сейсмических событиях. Визуальное представление сейсмических событий в геодинамической модели месторождения дает наглядное представление об активности разрывных нарушений и блоковых структур, образованных ими. 


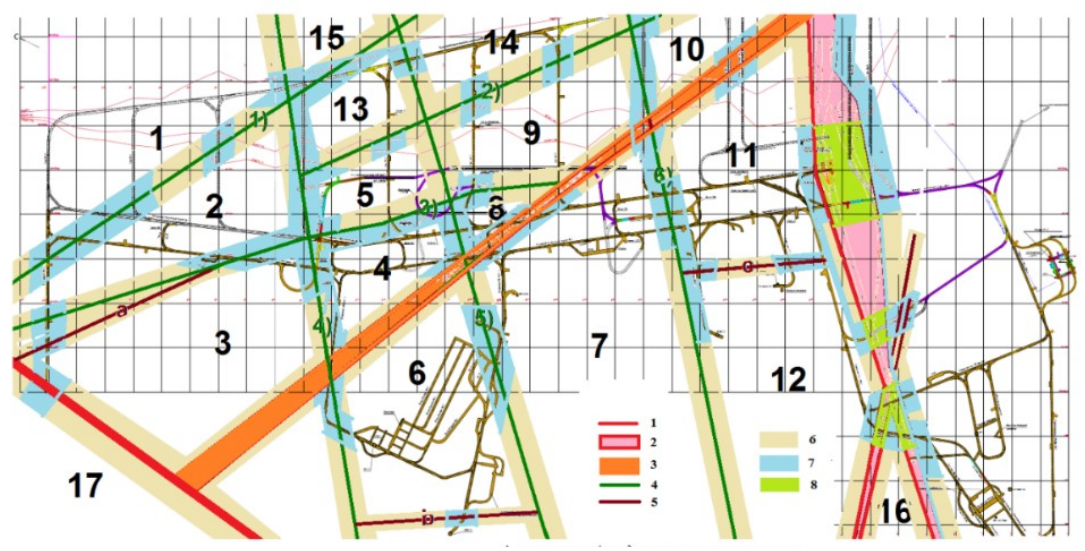

Рис. 5.22. Схема ТНЗ и ГОЗ гор. +92 м Кукисвумчоррского месторождения: 1 - разрывное нарушение 4 ранга; 2 - заполнитель мощного разрывного нарушения, представленный зонами шпреуштейнизации; 3 - блок, ограниченный двумя близкорасположенными разрывными нарушениями 5 ранга; 4 - разрывное нарушение 5 ранга; 5 - разрывное нарушение 6 ранга; 6 - ТН3; 7 - ГОЗ (зона, опасная по геодинамическим проявлениям в выработках); 8 - разгруженная зона, в которой высока вероятность вывалов. Большими цифрами пронумерованы выделенные геодинамические блоки

На рисунке 5.23 показаны выделенные активные и пассивные границы блоков для гор. +92 м Кукисвумчоррского крыла на основе совместной оценки результатов кластерного анализа сейсмической базы данных и горнотехнической обстановки.

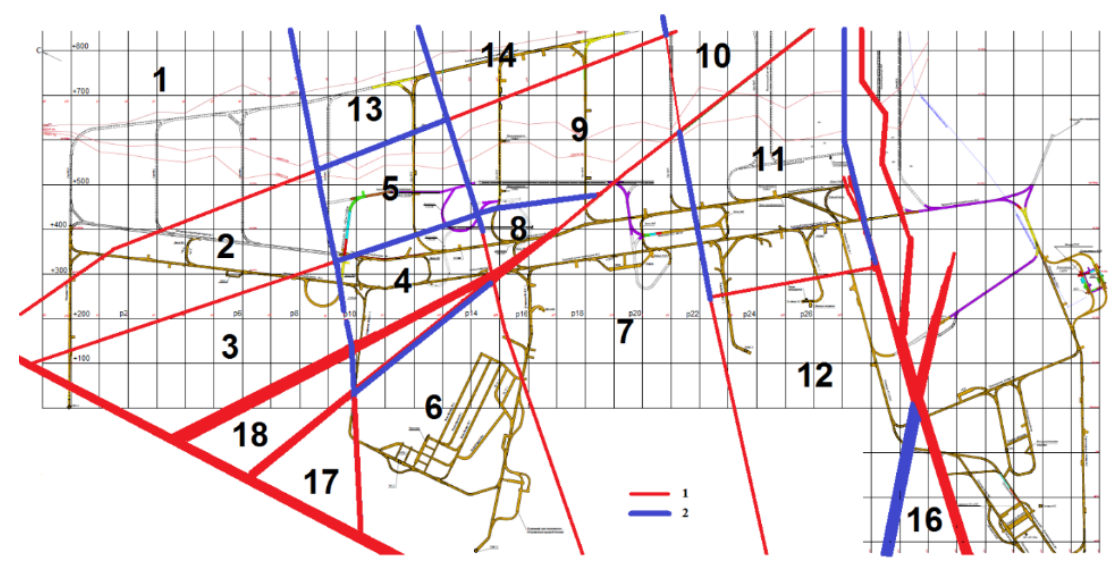

Рис. 5.23. Расположение активных и пассивных границ блоков на гор. +92 м Кукисвумчоррского месторождения: 1 - пассивные; 2 - активные границы

Регулярное пополнение геодинамической модели месторождения новой информацией делает ее актуальной и способствует принятию обоснованных решений на разных стадиях освоения месторождения.

Вся информация, полученная в результате мониторинга, используется для пополнения и корректировки горно-геодинамической модели как основы прогноза ГОЗ в условиях движения фронтов очистной выемки и разработки рекомендаций и профилактических мер для безопасного ведения горных работ. 


\subsection{6. Электронные 3D-модели иерархично-блочного строения и геодинамического районирования отрабатываемыхместорождений в координатных сетках рудников}

\subsubsection{1. Хибинская горнотехническая система}

С целью создания единой фактографической базы данных и визуализации результатов исследований разработана пилотная 3D-модель геомеханического пространства Расвумчоррского рудника АО «Апатит», включающая месторождения «Апатитовый цирк» и «Плато Расвумчорр» Хибинского массива, которая представляет собой базу пространственно распределенных данных, сгруппированную в тематические слои и группы объектов, а также средства визуализации и фильтрации.

С использованием этой модели выполнен пространственный анализ для выявления закономерностей и основных управляющих геодинамических факторов, а также их геометризации в целях районирования (рис. 5.24)

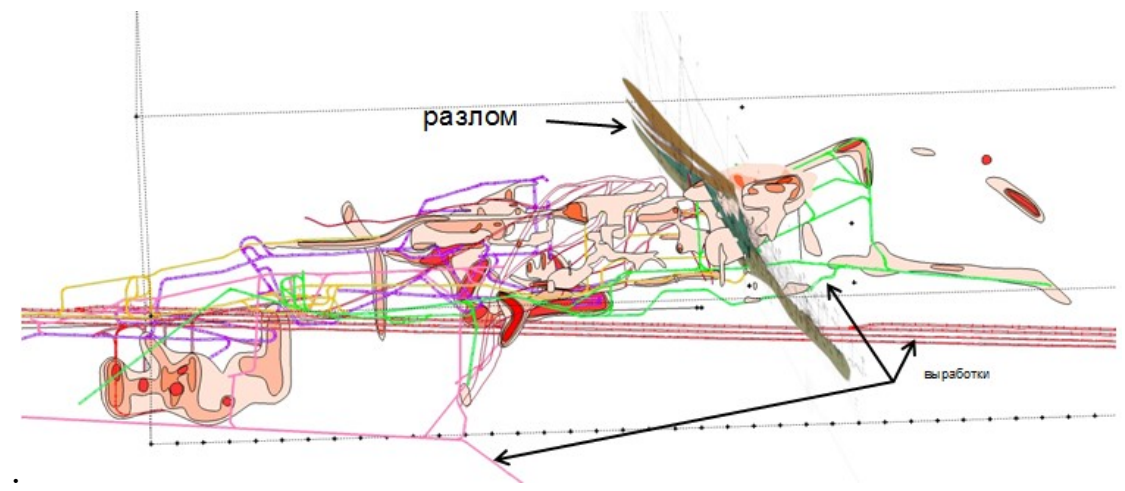

Рис. 5.24. 3D-модель зон проявления горного давления. Интенсивность окраски зон соответствует интенсивности проявления горного давления

Полученные результаты позволили сделать следующие выводы.

1. Очевидное превалирование техногенного фактора в качестве триггера сейсмической активности. Все центры выделенных зон увязываются с местами максимально интенсивного антропогенного изменения геологической среды.

2. Наиболее выдержанный и интенсивный центр сейсмоактивности массива горных пород - южное лежачее крыло вмещающих пород (южный борт карьера Центральный на глубине 50-150 м от поверхности). Все крупные события находятся именно в этой зоне. Второй центр (в районе стыковки подземных выработок и северо-западного борта карьера) имеет несколько временных максимумов в своем развитии.

3. Долговременная зона минимума энерговыделения (наиболее спокойная) приходится на центральную и левую нижнюю области модели, где образуется относительно устойчивое поле, которое год от года незначительно меняет свою форму и локализацию.

4. Пространственный анализ результатов многолетних визуальных обследований проявлений горного давления в выработках позволил представить главное сжимающее напряжение в векторной (на верхней полусфере пространства) и тензорной формах. При этом установлено, что техногенный фактор (геометрия и положение выработанных пространств и консоли обрушения), а также фактор времени значительно изменяют ориентацию и структуру (контрастность и неоднородность) поля напряжений. 
Таким образом, моделирование позволило наглядно визуализировать и геометризовать в целях геодинамического районирования несколько контролирующих геодинамическую безопасность факторов.

\subsubsection{2. Ковдорская горнотехническая система}

Инженерно-геологическая модель части отрабатываемого Ковдорского месторождения карьером рудника «Железный» предоставляет возможность интерпретации внутренней структуры массива пород (делимости и блочной иерархии) и его катакластической тектонической эволюции на принципиально новом качественном уровне, с одной стороны, и является частью системы поддержки управленческих решений в области проектирования, планирования и обеспечения геодинамической безопасности горных работ, с другой. C ее помощью можно оперативно осуществлять ситуационный анализ инженерно-структурных условий применительно к конкретному участку недр и во взаимосвязи с вариантами проектируемых решений по отстройке рабочих и конечных контуров глубокого/сверхглубокого карьера.

На рисунке 5.25 показан результат подобного ситуационного анализа в отношении опасного разлома № 62 в восточной части карьера. Полноценная инженерно-структурная 3D-модель в отличие от печатных разрезов и планов позволила выявить и спрогнозировать участок, опасный по обрушению в проектируемом контуре карьера (см. участок № 4 на рис. 5.25).

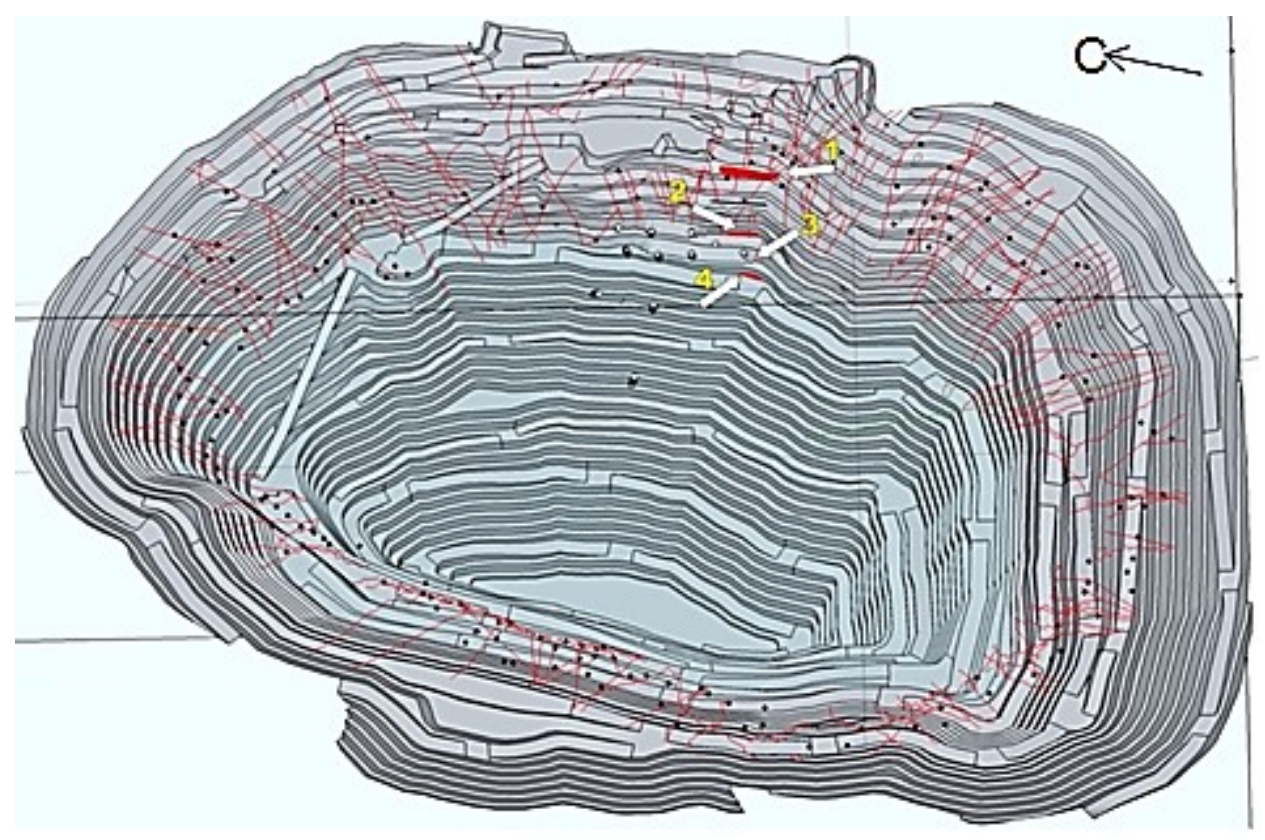

Рис. 5.25. Фактически установленные по состоянию на 1 января 2014 г. и предполагаемые по результатам 3D-моделирования локальные участки выхода разрывного нарушения № 62 (заливка жирным красным) в проектируемый контур восточного борта: 1 - деформация на уступах гор. $+142 \div+70$ м; 2 - деформация от 15 мая 2013 г. на гор. $+10 \div-20$ м; 3 - деформация от 5 октября 2013 г. на уступе между гор. $-20 \div-50$ м; 4 - ожидаемая деформация на уступе между гор. $-50 \div-70$ м (над путепроводом) 
Таким образом, инженерно-структурное районирование позволяет определить следующие важнейшие параметры для проектирования и перепроектирования глубоких карьеров:

- локализованные и геометризованные на печатной карте и разрезах, a также в 3D-модели разломы, разрывные нарушения с опасным залеганием для устойчивости уступа и борта в целом, зоны ослабления, выветривания, дезинтеграции и другие структурные неоднородности;

- геометризованные структурно-однородные (квазиоднородные) участки массива пород;

- инженерно-геологическая изученность законтурного пространства рудника и потенциально-опасных участков.

Приведенные в настоящей главе результаты продемонстрировали реконструкцию эволюции НДС Хибинского и Ковдорского массивов во взаимосвязи с тектоникой и геологической структурой массива на основе полученных разными методами данных о величинах локальных и региональных палеонапряжений, их последовательности и положению главных осей напряжений на каждом этапе тектогенеза.

Для южной части Хибинского массива в результате проведенной реконструкции определен взбросовый тип общего поля напряжений. Возраст, восстановленных по бороздам скольжения полей напряжений, принимается за неотектонический и современный, так как в определении общего поля напряжений участвуют и локальные палео- и современные напряжения в четвертичных породах. Реставрированное поле напряжений для южной части Хибинского массива согласуется с его общим воздыманием в неотектонический этап.

Результаты реконструкции НДС Ковдорского массива для современного этапа показали, что его можно принять за современное общее поле напряжений в естественном (антропогенно неизмененном) виде.

Анализ показал, что НДС Ковдорского массива в пределах крупной карьерной выемки рудника «Железный» относится к гравитационно-тектоническому типу. При этом действие в массиве горных пород повышенных горизонтальных напряжений оказывает неоднозначное влияние на устойчивость борта карьера. Особое внимание требуют участки, в пределах которых отмечается действие растягивающих напряжений в массиве пород, а также соотношение максимальной и минимальной компонент главных напряжений, которые могут быть индикаторами потенциально недостаточной устойчивости участка массива пород в приконтурной зоне.

Измерения на Кукисвумчоррском и Юкспорском месторождениях Хибинского массива подтвердили превалирующее действие в массиве пород тектонических напряжений. Соотношения величин промежуточной и максимальной компонент находятся в интервале $(0,4-0,6)$.

Исследования на месторождении «Олений ручей» свидетельствуют о малой нарушенности массива в месте проведения измерений, а дискование керна в пределах первых метров связано с наличием концентрации напряжений на контуре выработок. Эти результаты испольозваны при подготовке нормативных документов - «Указаний по безопасному ведению горных работ на месторождениях, склонных и опасных по горным ударам (месторождение “Олений ручей”)» и «Инструкции по креплению горных выработок на месторождении апатит-нефелиновой руды «Олений ручей”». 


\section{5. Результаты экспериментальных исследований процессов деформирования геологической среды под влиянием природных и техногенных факторов}

\subsection{1. Совершенствование методики выполнения и обработки результатов натурных измерений}

Геомеханический контроль состояния массива пород заключается в определении перемещений фундаментальных и рабочих реперов полигонов. Для этих целей возможно применение как традиционных геодезических методов (нивелирование, полигонометрия, триангуляция, трилатерация), так и методов космической геодезии.

На пунктах поверхностных геомеханических полигонов наблюдения выполняют комплексным методом: светодальномерные измерения - для определения расстояний между пунктами, а абсолютные координаты пунктов определяют методами космической геодезии.

Перед началом полевых измерений все применяемые инструменты проходят метрологическую проверку с оформлением соответствующих документов.

До лета 2013 г. расстояния измеряли светодальномером Мекометр-5000 (ME-5000). При этом светодальномер и отражатели устанавливали с принудительным центрированием, поэтому погрешности установки приборов были чрезвычайно малы. Поскольку светодальномер Мекометр-5000 отличается весьма стабильными результатами измерений, для сокращения времени и без снижения точности измерения расстояний выполняли только в одном направлении. На каждом пункте измерения выполняли двумя приемами, в ходе обработки результатов вносили поправки на метеоусловия по данным психрометров и барометров, фиксируемых в момент времени взятия отсчетов измеряемой длины.

Абсолютная величина среднеквадратической погрешности наблюдений находилась в пределах $\left(+0,38\right.$ мм $\left.+0,68 \cdot 10^{-6} D\right)$, где $D$ - измеряемое расстояние в км.

В настоящее время для светодальномерных измерений используют тахеометр Elta S10 фирмы Zeiss. Точность измерения расстояний составляет $1 \mathrm{~mm}+2 \mathrm{ppm}(1+2$ мм на каждый км). Таким образом, точность измерений расстояний между пунктами существенно снизилась, поэтому измерения расстояний выполняют в прямом и обратном направлениях, в дальнейшей обработке используется среднее значение.

На подземных геомеханических полигонах до 2013 г. применяли комплексную методику определения перемещений: для вертикальных компонент - высокоточное нивелирование, а для горизонтальных компонент - светодальномерные измерения расстояний.

Нивелирование выполняли с использованием оптического нивелира В1 (Sokkia). Среднеквадратическая погрешность на 1 км двойного хода с использованием микрометренной насадки составляет $- \pm 0,5$ мм.

Конструкция реперов на подземных полигонах позволяет с помощью специального замка надежно устанавливать на них как нивелирную рейку, так и отражатель для светодальномерных измерений.

Первичная обработка результатов нивелирных наблюдений заключается в вычислении превышений и условных отметок реперов относительно исходного пункта, который считается неподвижным. Результаты представляются в виде ведомостей превышений реперов, графиков относительных смещений реперов или их производных (например, скоростей смещений реперов по всему полигону в целом или для любого отдельно взятого репера на любой момент времени). 
Контроль качества нивелирования заключается в вычислении невязки по ходу, ее величина должна быть не более $\pm 0,3$ мм· $\sqrt{n}$ ( $n$ - число стоянок штативов) - для полигонов протяженностью менее 1 км.

В целом по результатам анализа всех проведенных к настоящему времени измерений можно считать, что точность определения вертикальных и горизонтальных перемещений традиционными геодезическими методами составляет в абсолютном исчислении $\pm 0,5$ мм, что вполне приемлемо для целей геомеханического мониторинга.

Регулярные измерения с применением GPS-технологий выполняются с 2007 г., при этом пока используются спутники только системы GPS (США). В настоящий момент в нашем распоряжении имеются пять комплектов аппаратуры, состоящих из приемника JNS Lexon-GGD и антенны JNS Chock Ring CR3_GGD, разработанных и произведенных фирмой Javad Navigation System.

Процесс GPS-измерений заключается в регистрации с интервалом 30 сек псевдодальностей до спутников системы GPS на двух несущих частотах $L_{1}=1575,42$ МГц и $L_{2}=1227,60$ МГц. Угол минимального возвышения спутников над горизонтом при измерениях принят $10^{\circ}$. Регистрация и слежение за сигналами производится автоматически под управлением микропрограммного обеспечения приемников.

В период проведения измерений приемники в определенной последовательности переставляются с пункта на пункт так, чтобы время одновременной работы инструментов в каждом треугольнике пунктов составляло не менее 2 ч.

Для снижения погрешностей измерений применяют дифференциальную коррекцию с использованием стационарного GPS-приемника, установленного в точке с заранее определенными координатами. Такой приемник - базовая станция (БС) — накапливает данные о погрешностях определений координат в течение всего периода выполнения измерений, которые с помощью специальной программы учитываются при обработке данных мобильных приемников, устанавливаемых на контролируемых пунктах. Кроме того, БС обеспечивает получение информации о глобальных пространственных перемещениях всего региона, где организован геомеханический мониторинг.

Координаты БС определяются с привлечением пунктов международной геодезической сети IGS. В частности, для определения координат БC KOV1 (рудник «Железный» $\mathrm{AO}$ «Ковдорский ГОК») в качестве исходных пунктов были использованы пункты IGS - KIRU (г. Кируна, Швеция), TRO1 (г. Тромсе, Норвегия), SVTL (г. Светлое, Россия), представленные на рисунке 5.26.

Доступ к координатам этих пунктов свободен и осуществляется через интернет-сервисы международных служб, например, через центр сбора и обработки спутниковых данных Scripps Orbit and Permanent Array Center (SOPAC).

Привязка базовой станции к сети международных пунктов осуществляется путем отправки «сырых» данных пункта KOV1 на сервер SOPAC и получения уравненных координат в системе координат ITRF2005. Эта процедура выполняется при постобработке каждой серии наблюдений.

Дальнейшая обработка наблюдений проводится в пакете программ Trimble Business Center версии 3.41 и заключается в вычислении координат фундаментальных пунктов полигона с привлечением высокоточных эфемерид спутников, также получаемых с соответствующих серверов GPS. На заключительном этапе осуществляется преобразование геоцентрических координат фундаментальных пунктов в координаты на плоскости (СК-42) с привлечением параметров эллипсоида EGM2008. 


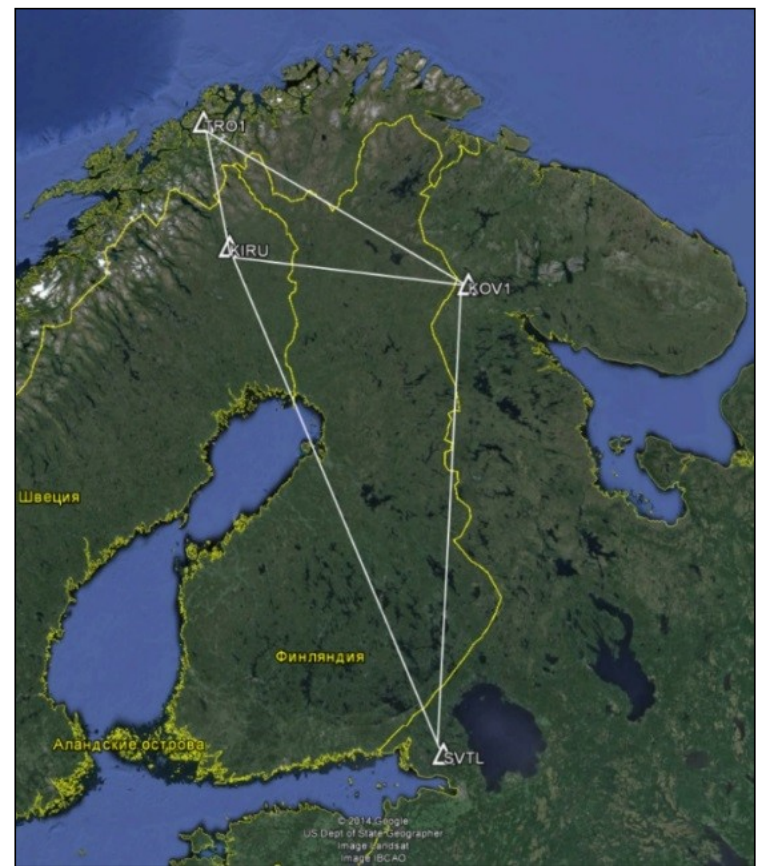

Рис. 5.26. Схема определения координат БС KOV1 (рудник «Железный» АО «Ковдорский ГОК»)

По изменениям плоских координат фундаментальных пунктов между циклами измерений за вычетом изменений соответствующих координат базовой станции определяются смещения фундаментальных пунктов в результате деформирования массива пород во времени, а по ним строятся проекции векторов смещения на планах горных работ.

Точность измерений, получаемая при использовании имеющейся аппаратуры, складывается из приборной точности и влияний различных факторов, например, от месторасположения антенны, ошибок оператора при измерениях и др. Аппаратурная точность, определенная изготовителем для двухчастотных приборов: изонтальная 3 мм + 1 ppm, вертикальная - 5мм +1.5 ppm.

\subsection{2. Объекты контроля на апатитовьх рудниках и развитие \\ существующих полигонов для измерений методами спутниковой геодезии, лазерной дальнометрии и прецизионного нивелирования}

В пределах природно-технической системы «Хибины» геодинамические полигоны оборудованы в выработках Кировского рудника, в карьере Центрального и в транспортном тоннеле Расвумчоррского рудников.

Конкретные практические задачи наблюдений в каждом случае были различными, однако общим направлением при выборе мест заложения полигонов являлось стремление получить максимальную информацию об эволюции геомеханических процессов в условиях сложной горнотехнической обстановки.

В частности, в массиве пород Кировского рудника геодезические полигоны оборудованы в подземных выработках гор. +252 и +172 м и на поверхности в Саамском карьере для контроля НДС массива пород в районе крупной тектонической структуры — Саамского разлома (рис. 5.27). 


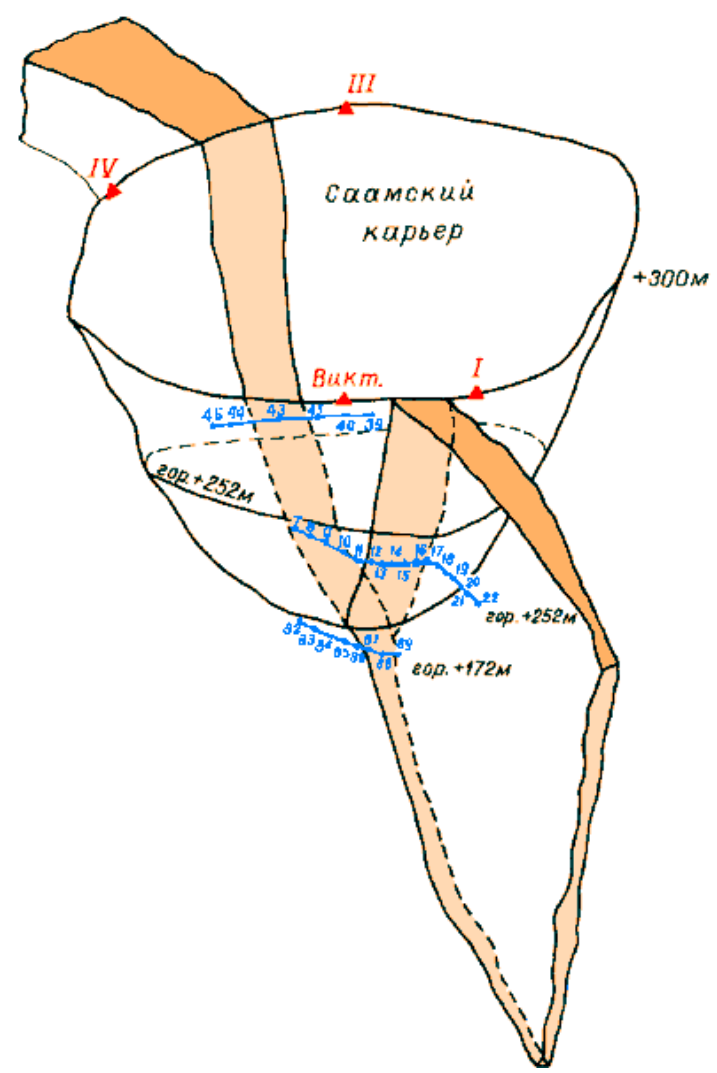

Рис. 5.27. Схема расположения нивелирных и светодальномерных полигонов в районе Саамского разлома (Объединенный Кировский рудник, АО «Апатит»): ^III — пункты наземного светодальномерного полигона в Саамском карьере; 4039 подземных нивелирных полигонов

Саамский разлом (2-й порядок по классификации проф. М. В. Раца) представляет собой зону шпреуштейнизированных пород, залегающую практически вертикально вкрест простирания рудного тела, заполненную окисленными породами и имеющими существенно меньшую прочность по сравнению с вмещающими породами. Мощность зоны на разных участках колеблется в пределах от 1 до 136 м.

Северо-восточная часть разлома является руслом p. Лопарской, юго-западная часть пересекает Саамский карьер.

На горизонте +252 м Кировского рудника нивелирный полигон из 47 пунктов заложен в 1990 г., в 1991 г. начаты регулярные прецизионные наблюдения методом повторных нивелирований, соответствующие по точности наблюдениям на государственных высотных сетях II класса.

В настоящее время полигон представляет собой две ветви (14 и 6 наблюдаемых реперов соответственно), не имеющие связи между собой и расположенные непосредственно на участках Саамского разлома.

Для получения более полной картины изменения НДС контролируемого массива пород нивелирные полигоны в подземных выработках в 1995 г. были дополнены измерительным светодальномерным полигоном из 5 пунктов в Саамском карьере. Наблюдения здесь проводились в период 1996-2003 гг., а затем были прекращены в связи с закрытием в карьере работ и отсутствием в него доступа. 
В 2003 г. на гор. +252 м также непосредственно в районе Саамского разлома заложен подземный светодальномерный полигон из 6 пунктов, место заложения которого определили по результатам нивелирных наблюдений на участке наиболее активного деформирования массива пород.

В 1998 г. начаты наблюдения по 39 пунктам нивелирного полигона гор. +172 м, который пересекает по меньшей мере три блочные структуры, включая Саамский разлом, разделенные геологическими нарушениями с различными элементами залегания. Первые наблюдения на гор. +172 м выполнены до начала массовой отработки блоков (2001 г.), что позволило зафиксировать начальное геомеханическое состояние массива.

Последние циклы наблюдений на полигонах Кировского рудника выполнены в 2013 г.

Геодинамическая ситуация в районе Центрального рудника отличается повышенной сложностью по сравнению с другими рудниками АО «Апатит», что обусловлено высокой напряженностью массива пород в целом и большими объемами изъятой и перемещенной горной массы, а также наличием развитого подземного комплекса транспортных выработок (глубокие рудоспуски и тоннели большого сечения). Ситуация осложняется также подземными работами Расвумчоррского рудника в непосредственной близости от карьера. Эти факторы обусловливают повышенную геодинамическую активность массива пород, что выражается в периодически происходящих в районе Центрального рудника крупных динамических проявлениях горного давления.

Объектом наблюдений в карьере рудника Центральный является крупный разлом А-А (2-й порядок по классификации проф. М. В. Раца) в пределах западного фланга карьера, вблизи которого осуществлялись крупномасштабные работы по формированию отвала пород и одновременно проводилась отработка открытым и подземным способами в пределах стыковочной зоны между Расвумчоррским и Центральным рудниками. При этом решались практические задачи контроля устойчивости северо-западного участка борта карьера при его подработке подземными работами Расвумчоррского рудника.

Для решения поставленных задач и оценки общей геомеханической ситуации в 1999 г. на территории Центрального рудника заложен светодальномерный полигон, который к настоящему времени состоит из 7 фундаментальных пунктов, располагающихся по обе стороны наблюдаемого разлома (А-А) (рис. 5.28). При этом пункт Р6 заложен в 2011 г. вблизи крупного разлома «Дразнящее эхо» в целях общего развития наблюдательной сети в сторону Восточного рудника, поскольку именно в этом районе предполагается дальнейшее развитие горных работ Центральным рудником и, кроме того, здесь было зарегистрировано мощное динамическое событие 25.05.2009 г.

Последние циклы наблюдений на полигонах Центрального рудника выполнены в 2012 г.

Для получения более полной картины развития геомеханических процессов в массивах пород сеть наблюдаемых пунктов должна включать полигоны как на дневной поверхности, так и непосредственно в подземном пространстве. Исходя из чего в 2006 г. в тоннеле (под карьером Центрального рудника) в районе 6-го рудоспуска оборудован измерительный полигон для выполнения высокоточных нивелирных и светодальномерных наблюдений (рис. 5.29). 
a)

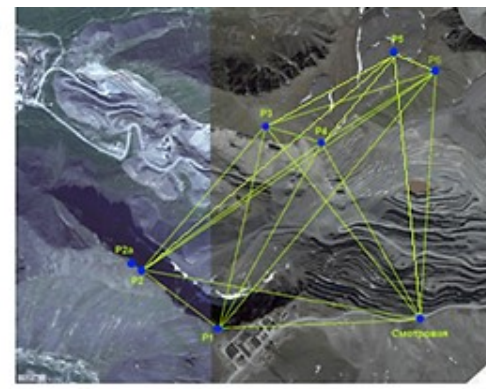

б)

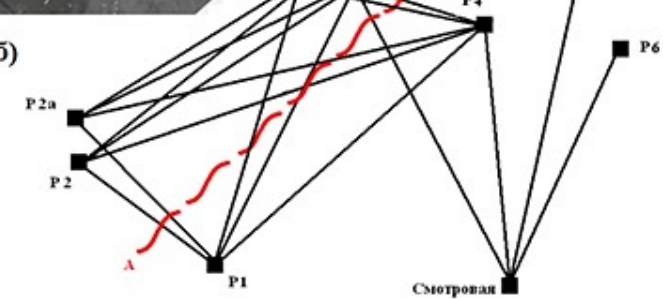

P 4

- опорные пункты ; $\int$ - лшвия разлома

Рис. 5.28. Общая конфигурация сети фундаментальных пунктов в карьере Центрального рудника AO «Апатит»: $a$ - схема GPS-наблюдений; $\sigma$ - схема светодальномерных наблюдений

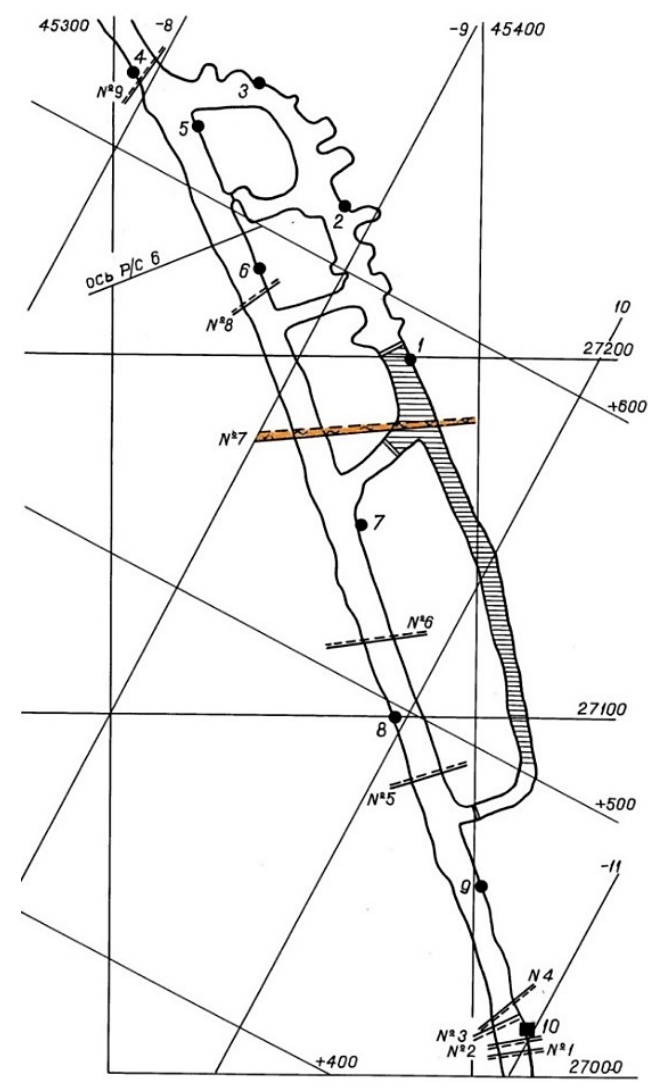

Рис. 5.29. План наблюдательного полигона (тоннель, район 6-го рудоспуска, Центральный рудник АО «Апатит»): - — фундаментальный репер; • — рабочие реперы; Шचл — выработка закрещена; №-7 - крупные трещины 
Цель наблюдений в тоннеле - контроль состояния массива пород, в частности, смещений крупных структурных блоков для прогноза возможных сильных сейсмических событий в районе глубоких рудоспусков.

Дополнительной мотивацией организации этого полигона послужило техногенное землетрясение с магнитудой $M=2,2$, энергией $E=2,15 \cdot 10^{9}$ Дж (по данным Кольского регионального сейсмологического центра), которое произошло в сентябре 2004 г. в районе Центрального рудника. Гипоцентр землетрясения располагался на глубине 140 м от дневной поверхности, действие землетрясения отмечали жители города Кировска и поселка Кукисвумчорр. В подземных выработках это событие проявилось в виде серии толчков, произошедших в районе рудоспуска № 6 и выброса руды в объеме $0,2 \mathrm{~m}^{3}$ по южной стенке рудоспуска и ее сопряжению с кровлей к западу от субвертикальной трещины, залеченной цеолитом.

Необходимо отметить, что и после этого события геодинамическая активность этого участка массива продолжала проявляться. Так, 13 февраля 2008 г. произошел вывал породы в тоннеле на сопряжении Седьмого пути с разворотной нишей (ПК8). 25 мая 2009 г. сейсмостанцией ЦГМ АО «Апатит» зарегистрирован рост сейсмической активности в районе рудоспусков Центрального рудника и крупное сейсмическое событие с энергией 5,0 $10^{9}$ Дж, квалифицируемое как техногенное землетрясение. Источником этого сейсмического события признана подвижка по разлому «Дразнящее эхо», а причинами - длительное техногенное воздействие во время разработки месторождений «Плато Расвумчорр» и «Апатитовый цирк».

Породы этого участка представлены массивными средне-крупнозернистыми полевошпатовыми уртитами, равномернотрещиноватыми (6-10 трещин на 1 погонный метр), с углом падения трещин $30^{\circ}$. Участок пересекает мощная шпреуштейнизированная зона.

Светодальномерный полигон пересекает все структурные блоки, образованные крупными трещинами. Светодальномерные наблюдения выполняли на пунктах, расположенных в пределах прямой видимости от места установки инструмента - фундаментального пункта, который условно считали неподвижным. Репер Rp 5 (рис. 5.29) находится по другую сторону мощной шпреуштейнизированной зоны. Все реперы, кроме Rp 8, расположены на одной стороне выработки.

Последние циклы наблюдений на полигоне в тоннеле Центрального рудника выполнены в 2012 г.

\subsection{3. Характер деформирования геологической среды в Хибинских горнотехническах системах}

При анализе результатов наблюдений на Кировском руднике АО «Апатит» особое внимание было уделено деформированию пород в пределах Саамского разлома (рис. 5.27).

При этом необходимо отметить, что в общем случае геомеханическое состояние массивов горных пород определяется объемом необходимой информации относительно трех компонентов:

- структурных особенностей;

- физико-механических свойств пород, слагающих массив;

- естественного напряженного состояния. 
Массив пород Хибинских месторождений апатитонефелиновых руд изучен весьма детально, поскольку разработка месторождений производится с 30-х годов прошлого столетия и масштабы добычи руд чрезвычайно велики.

Результаты более чем двадцатилетних натурных измерений на полигоне Кировского рудника АО «Апатит» в районе Саамского разлома показали, что основной особенностью здесь является четко зафиксированное поднятие реперов в пределах тела самого разлома по отношению к вмещающему массиву пород при незначительных знакопеременных флуктуациях (рис. 5.30).

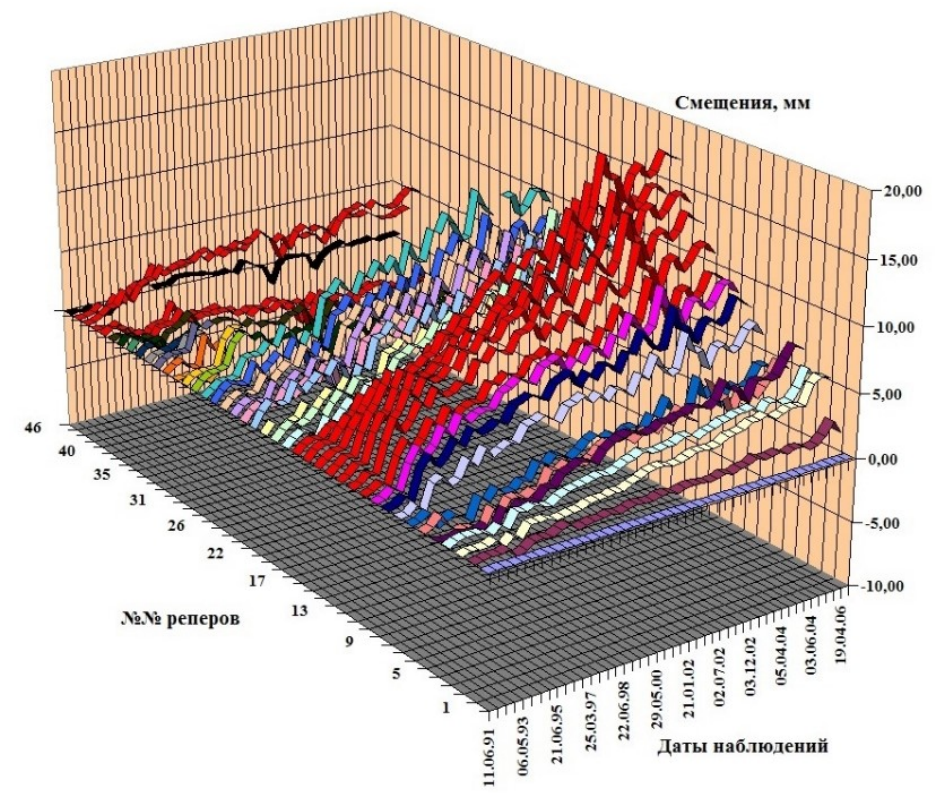

Рис. 5.30. Графики смещений реперов на полигоне гор. +252 м, зафиксированные за весь период наблюдений, начиная с 1991 г. Красным цветом показаны перемещения реперов в зоне Саамского разлома

Накопленное за период наблюдений (1991-2012 гг.) максимальное относительное вертикальное перемещение внутренней части разлома на гор. +252 м составило $+9,47$ мм (07.04.09 г.) для западного участка профиля и +10,98 мм (26.01.06 г.) - для восточного. Следует отметить, что вертикальные смещения реперов и соответственно скорость поднятий увеличиваются по мере приближения к центральной зоне разлома.

На рисунке 5.31 приведены результаты наблюдений для всех реперов полигона гор. +252 м в пределах Саамского разлома (рис. 5.27).

По этим результатам удалось определить кинематические параметры перемещений материала Саамского разлома, в частности, скорости смещений (поднятий) материала-заполнения, которые до мая 2007 г. оказались весьма стабильными и равными для восточной и западной ветвей полигона 0,04 и $0,06 \mathrm{mм} /$ мес или 0,48 и 0,72 мм/год соответственно.

Обращает на себя внимание, что в период 2007-2008 гг. резко изменяется режим деформирования материала-заполнителя разлома: подъем прекращается и наступает некоторая стабилизация перемещений. Скорее всего, это следствие ведения горных работ на нижних горизонтах и вскрытие разлома горными выработками. 

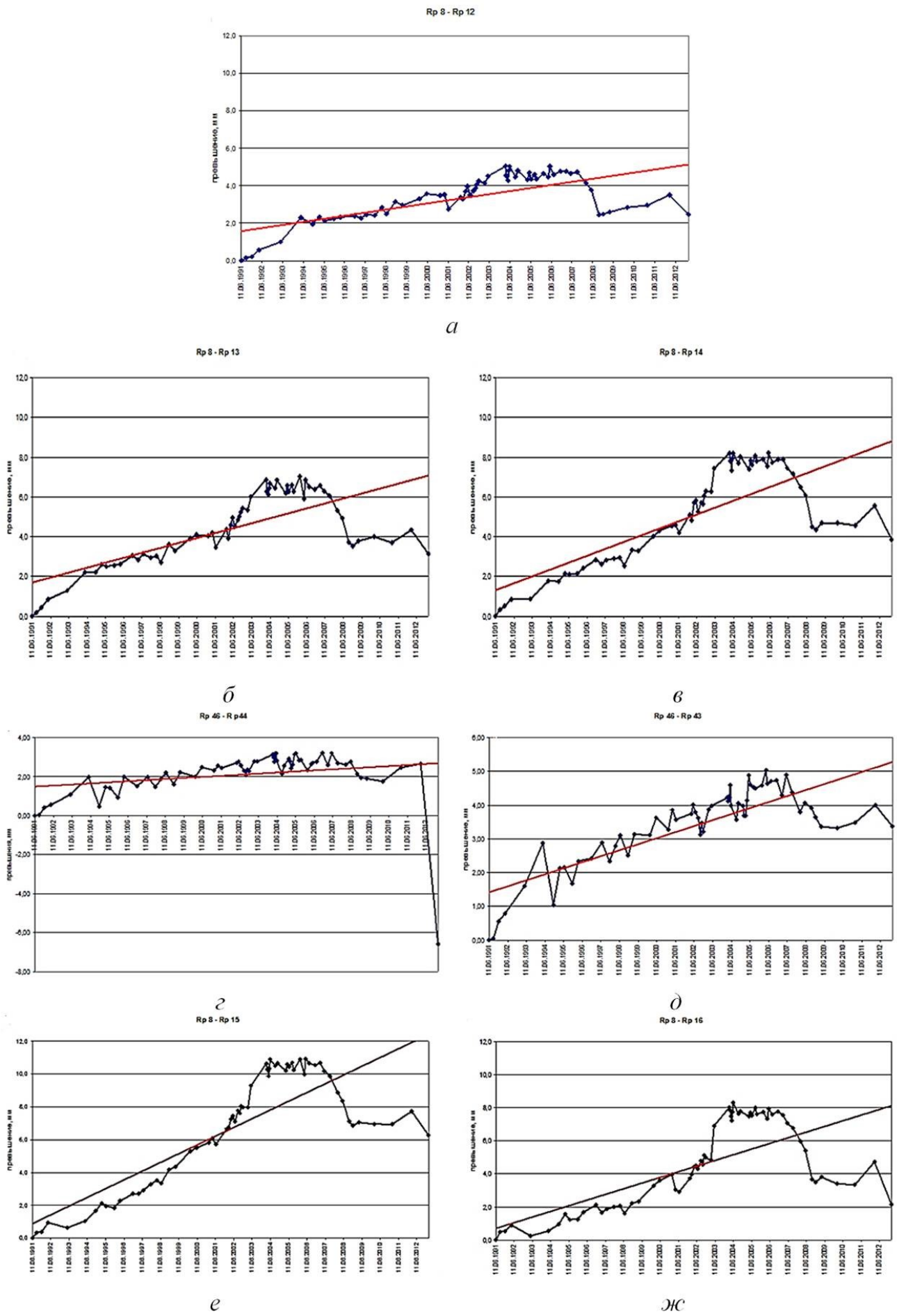

Рис. 5.31. Результаты наблюдений для реперов полигона гор. +252 м в пределах Саамского разлома: $a$ - восточная ветвь полигона - реперы $12,13,14,15$ и $16 ; 6-\partial-$ восточная ветвь полигона (реперы 12, 13, 14, 15 и 16); $е$-ж - западная ветвь полигона (реперы 44 и 43). Красной линией обозначена средняя линия хода накопления превышений, определенная по принципу наименьших квадратов отклонений 
Поднятия материала-заполнения Саамского разлома зафиксированы и на полигоне гор. +172 м (рис. 5.32).

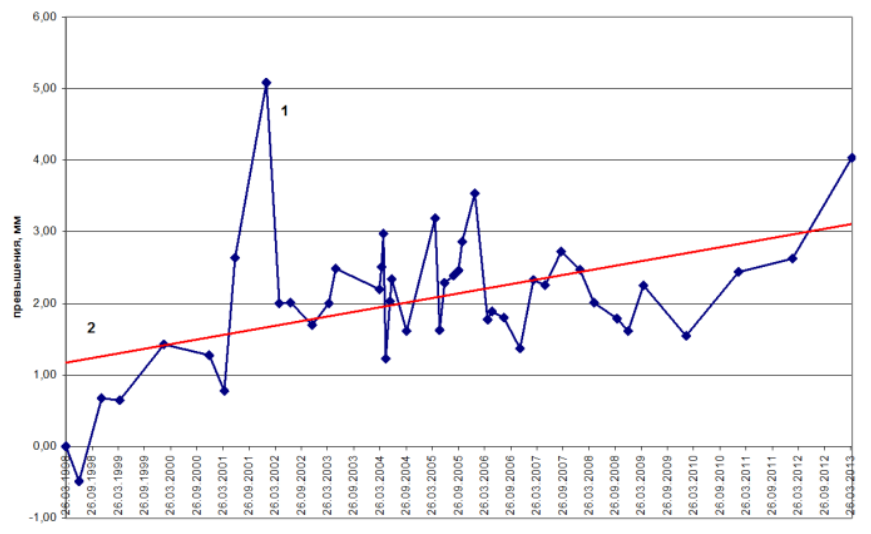

Рис. 5.32. Изменения превышений между реперами подземного нивелирного полигона в районе Саамского разлома на гор. +172 м Кировского рудника $\mathrm{AO}$ «Апатит» за период 1998-2012 гг.

Здесь скорости поднятий до 2007 г. также достаточно стабильны и составляют 0,02 мм/мес или 0,24 мм/год. Меньшая величина скорости по отношению к скоростям поднятия на гор. +252 м может быть обусловлена большей глубиной расположения полигона и, как следствие, большим влиянием веса пород разлома. Здесь также после 2007 г. прекращается подъем реперов и просматривается стабилизация их положения.

Одновременно с этим светодальномерные измерения, проведенные в Саамском карьере в период 1996-2003 гг. (рис. 5.33) и на гор. +252 м (рис. 5.34) выявили очень малые (в пределах нескольких миллиметров, на пределе точности измерений) изменения расстояний между реперами в направлении вкрест простирания разлома.

Влияние структурных неоднородностей на деформирование массива пород проявляется и в результатах наблюдений на геодезических полигонах в карьере рудника «Центральный» и в тоннеле Расвумчоррского рудника.

В частности, в карьере рудника «Центральный» светодальномерные наблюдения выполнялись в период 1999-2012 гг., их основные результаты представлены на рисунке 5.35 .

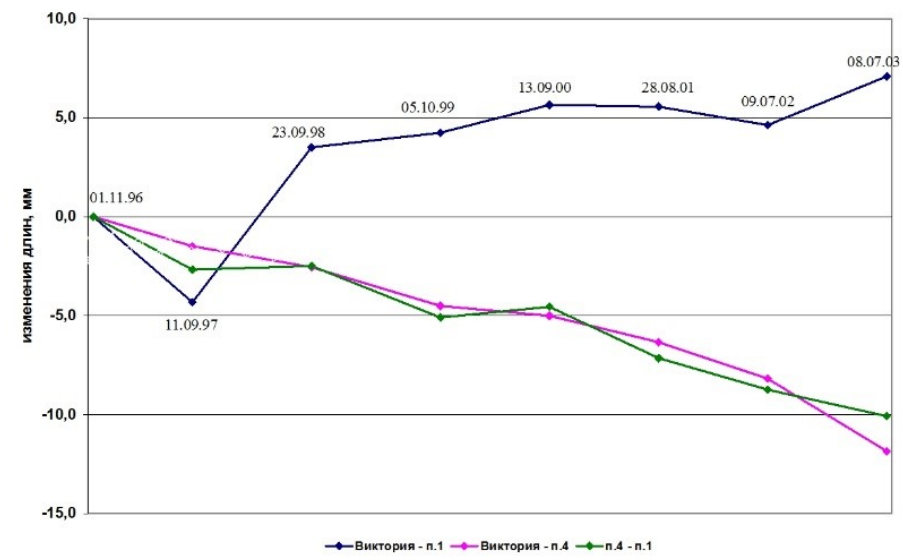

Pис. 5.33. Результаты светодальномерных наблюдений в Саамском карьере 


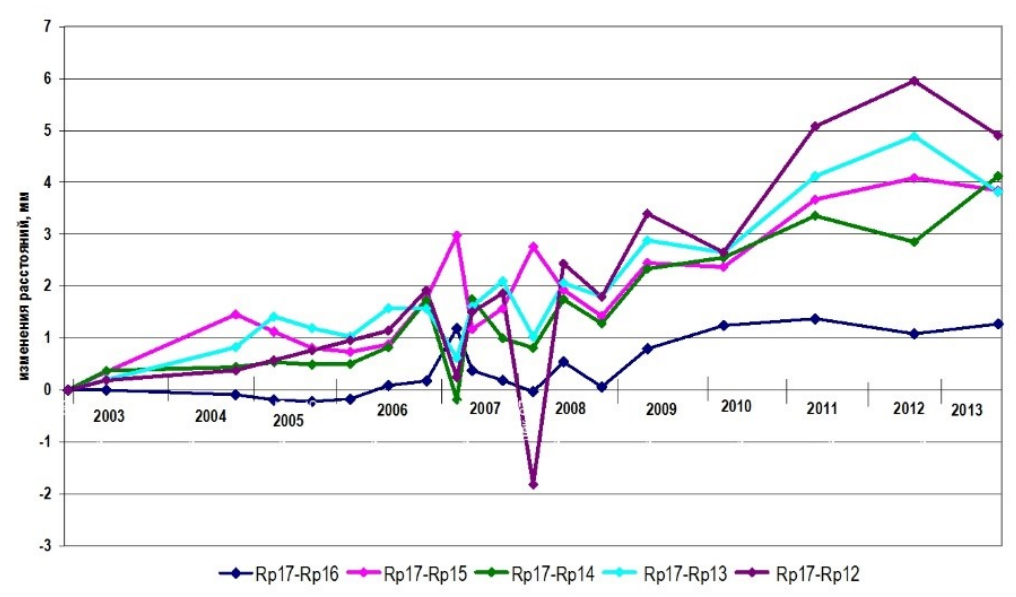

Рис. 5.34. Изменения расстояний между реперами на подземном светодальномерном полигоне гор. +252 м (Кировского рудника АО «Апатит»)

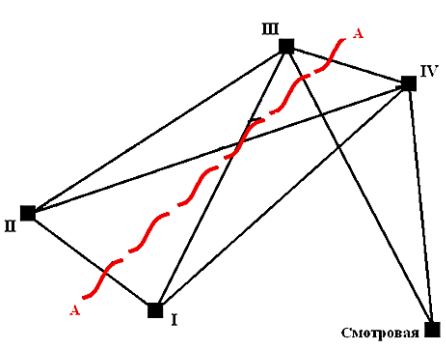

$a$

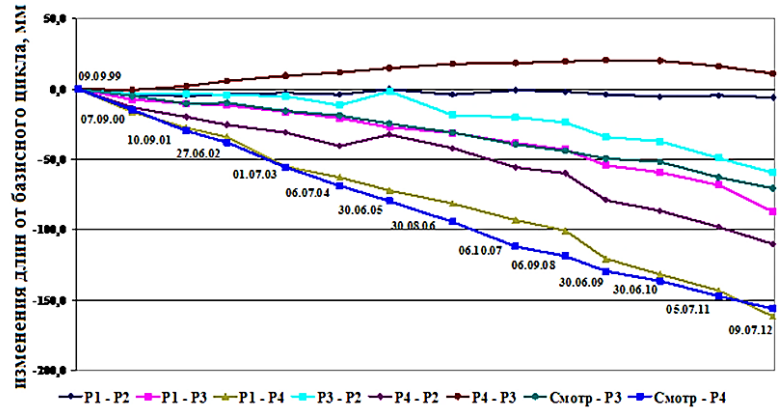

$\sigma$

Рис. 5.35. Схема светодальномерного полигона $(a)$ и изменения расстояний в карьере Центрального рудника от базисного цикла (б)

Весьма показательно, что по результатам наблюдений расстояние между пунктами Р3-P4, нормальное к разлому А-А, единственное из всех остальных проявляет тенденцию к увеличению (с небольшим возрастанием скорости в период 30.08.06-06.10.08). Это свидетельствует о проявлении процессов растяжения (возможно и незначительных) в теле разлома. При этом необходимо учесть, что выход разлома на поверхность (или под поверхность) был сильно пригружен отвалом пород, который формировался здесь в течение многих лет. В то же время незначительные знакопеременные изменения расстояния между пунктами P1 и P2 (тоже нормальное к разлому А-А) показывают, что на этом участке разлом А-А либо уже отсутствует, либо не проявляет заметной активности.

По остальным направлениям наблюдалось устойчивое сжатие массива пород в квазилинейном режиме, что совпадает с общим направлением действия максимальных тектонических напряжений в массиве. Расстояния между пунктами P1-P2, P1-P4, P1-P3, P2-P4, Смотровая-P3 и Смотровая-P4 устойчиво уменьшаются от цикла к циклу практически с постоянной скоростью без видимых признаков затухания.

Практически такие же результаты получены и по результатам GPS-измерений (рис. 5.36). 


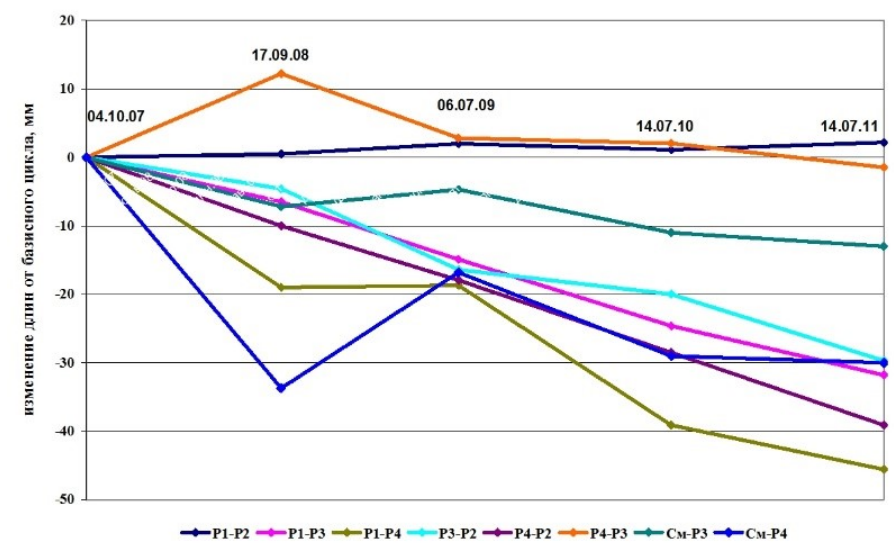

Рис. 5.36. Изменения расстояний между пунктами полигона в карьере Центрального рудника по данным GPS-измерений

На полигоне в тоннеле Расвумчоррского рудника (в районе 6-го рудоспуска) структурная неоднородность № 7 представлена крупной трещиной - зоной шпреуштенизации. Здесь результаты высокоточного нивелирования и светодальномерных измерений свидетельствуют о резком изменении состояния массива и его деформирования по разные стороны от этой зоны.

В частности, на рисунке 5.37 представлена схема полигона и результаты нивелирных наблюдений.

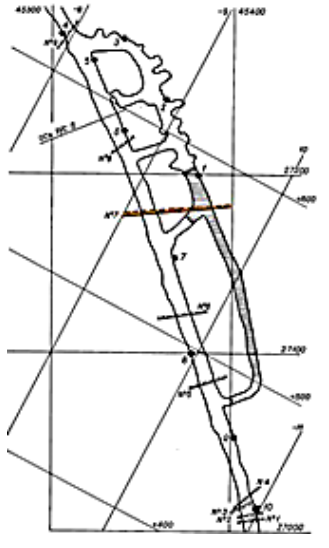

$a$

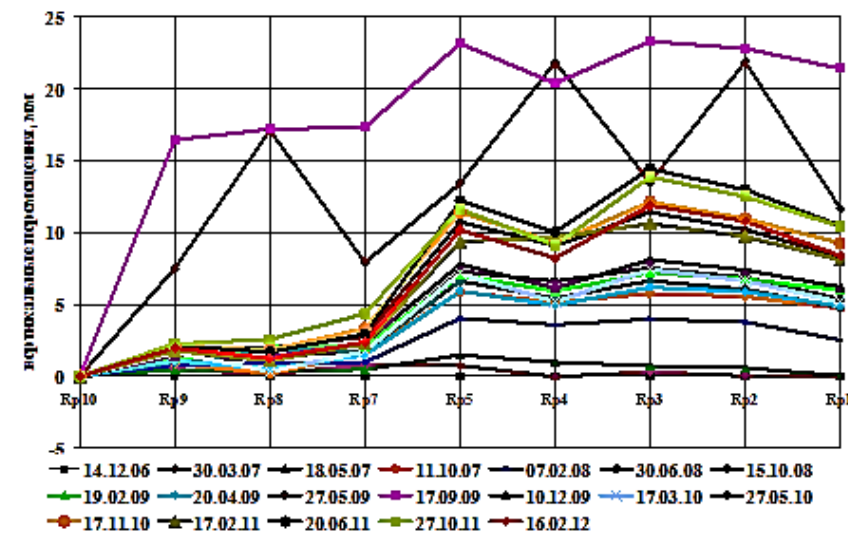

6

Рис. 5.37. Схема полигона $(a)$ и вертикальные перемещения рабочих реперов (б) в тоннеле Расвумчоррского рудника (относительно пункта Rp10)

На графиках рисунка 5.37 видно, что по вертикальным перемещениям наблюдается четкое разделение реперов на две группы: Rp9, Rp8, Rp7 и Rp5, Rp4, Rp3, Rp2, Rp1, которые располагаются по разные стороны от структуры № 7 - зоны шпреуштейнизации. При этом перемещения реперов первой группы во всех циклах остаются меньше вертикальных перемещений реперов второй группы, что свидетельствует о различном характере деформирования участков полигона по разные стороны от структуры № 7. 
Также достаточно четко разделяются вертикальные перемещения контролируемого участка массива по времени - до и после сильного сейсмического события. Непосредственно после события вертикальные перемещения резко возросли (циклы 27.05.09 и 17.09.09), а затем уменьшились до значений, характерных для периода времени до сейсмического события. В последние шесть циклов наблюдается незначительное поднятие реперов.

Еще более отчетливо характер процессов деформирования проявляется при анализе скоростей вертикальных смещений реперов (рис. 5.38).

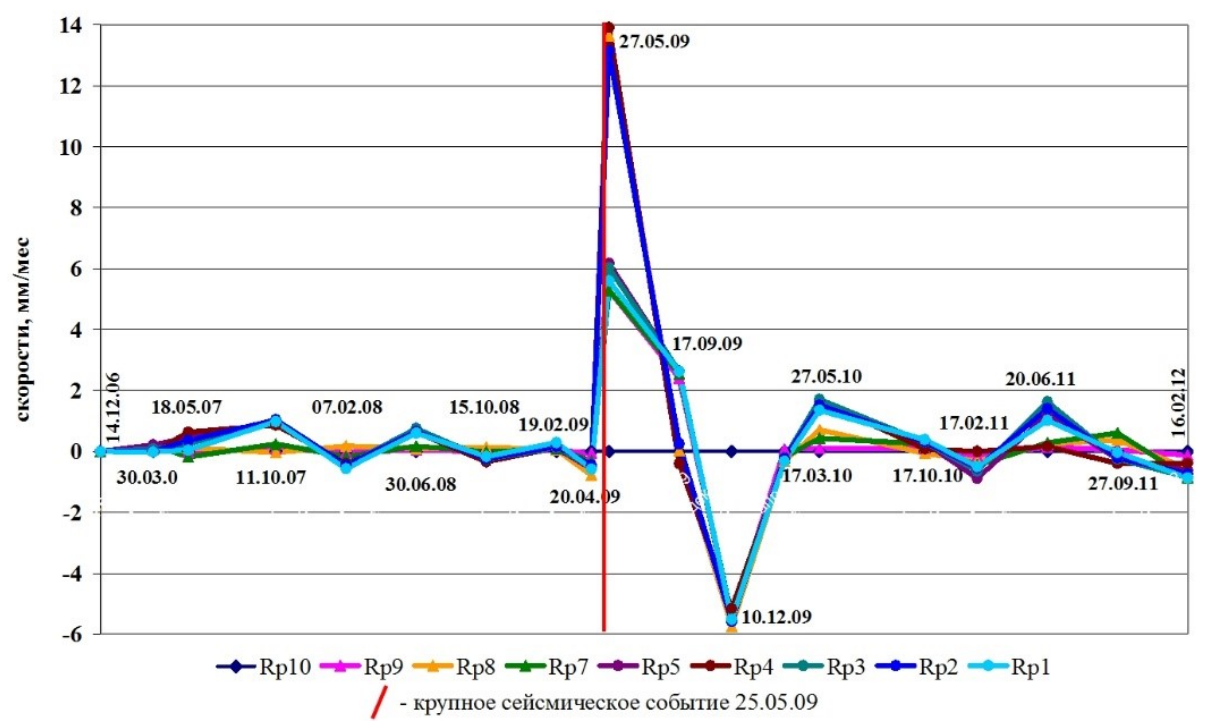

Рис. 5.38. Скорости вертикальных смещений реперов полигона в тоннеле Расвумчоррского рудника

При этом в первых циклах наблюдений численные значения скоростей между группами реперов Rp9-Rp7 и Rp5-Rp1 различались более чем в два раза. Но с октября 2008 г. эта разность постепенно уменьшается, то есть происходит снижение скоростей вертикальных перемещений в группе Rp5-Rp1. В циклах измерений накануне сейсмического события движение всех реперов полигона происходило почти синхронно.

Цикл измерений 27.05.09 г. выполнен через двое суток после сейсмического события, при этом было зафиксировано максимальное значение скорости. Затем в двух последующих циклах отмечалось резкое снижение скоростей вертикальных перемещений реперов (от 6 до 38 раз). В последующих циклах скорости возросли и приблизились к значениям, характерным для периода до сейсмического события.

В двух последних циклах проявляется синхронный характер скоростей вертикальных перемещений реперов на обоих участках полигона.

В отношении светодальномерных измерений расстояний (рис. 5.39) различия в перемещениях реперов, расположенных по разные стороны от структуры № 7, проявляются менее отчетливо. Можно лишь говорить, что если расстояние Rp10-Rp5 всего периода наблюдений постепенно увеличивается, то есть репер Rp5 отдаляется от исходного фундаментального пункта, то изменения расстояний до реперов 7, 8 и 9 имеют знакопеременный характер и существенно меньше по своей величине. При этом наименьшие колебания проявляются у репера Rp7. 


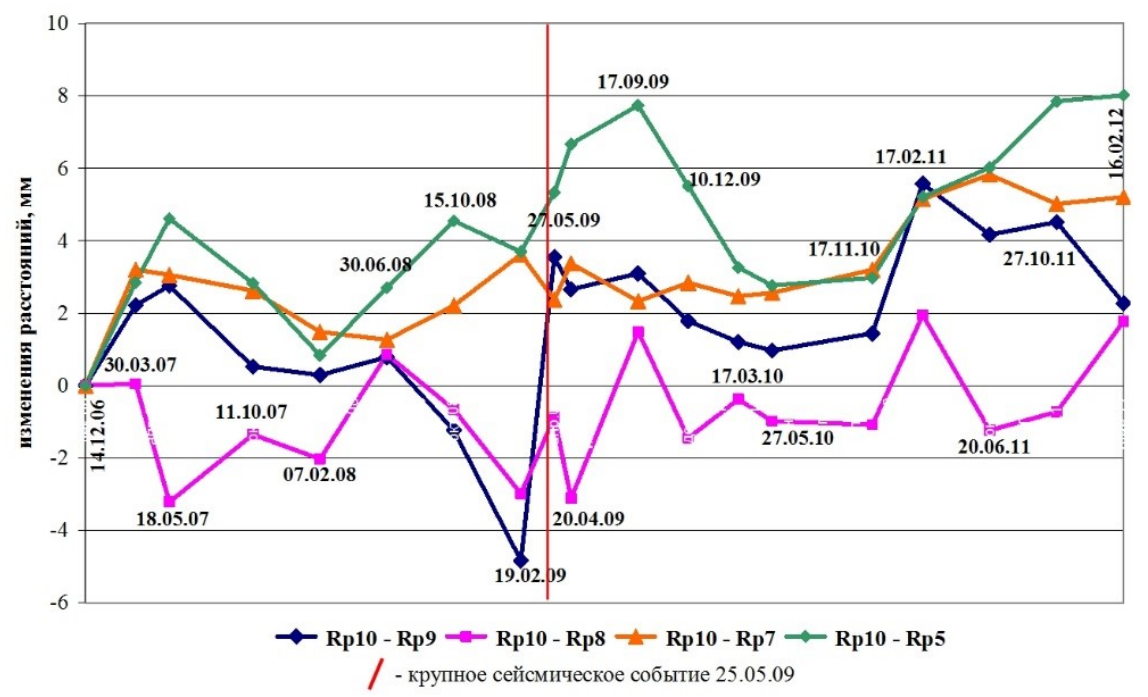

Pис. 5.39. Изменения расстояний от исходного пункта (Rp10) до реперов 5, 7, 8 и 9 полигона в тоннеле Расвумчоррского рудника по результатам светодальномерных измерений

Характер изменения скоростей горизонтальных перемещений рабочих реперов представлен на рисунке 5.40.

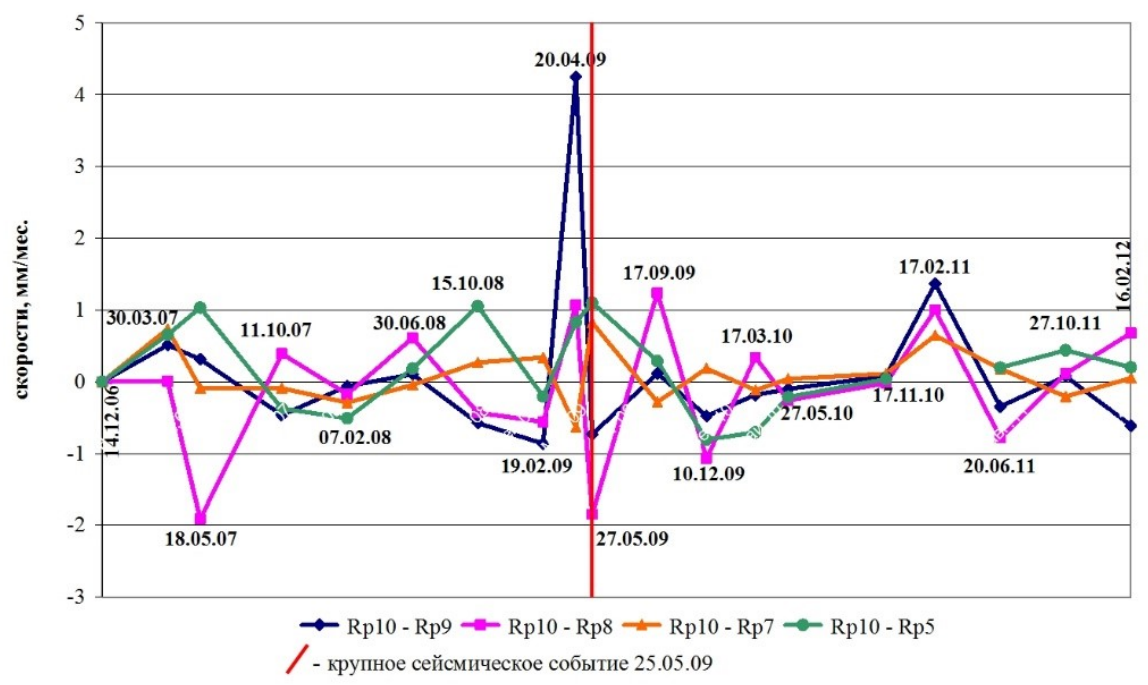

Рис. 5.40. Изменение скоростей горизонтальных перемещений реперов полигона в тоннеле Расвумчоррского рудника

На графиках рисунка 5.40 видно, что скорости горизонтальных перемещений реперов также имеют знакопеременный характер. Максимальное значение скорости наблюдается у репера Rp9 (если исходный репер Rp10 считать неподвижным) в цикле наблюдений 20.04.09 г. за месяц до сейсмического события 25.05.2009 г. В последних циклах скорости перемещения всех реперов близки по значениям друг к другу. 
Результаты геодезических измерений были детально обработаны с помощью специально разработанной методики [206] для разделения перемещений реперов, обусловленных подвижками самих структурных блоков, и перемещений, вызванных их деформированием, а также для оценки изменений степени напряженности выделенных структурных блоков.

Bce данные о деформациях, вращениях и особенно об изменении дополнительной энергии свидетельствуют о том, что расчетный блок Rp8-Rp7 (то есть ближайший к зоне шпреуштейнизации) этого полигона является наиболее подвижным относительно других блоков и в наибольшей степени реагирует на все изменения НДС массива в данном районе.

Таким образом, результаты наблюдений на полигонах Центрального рудника и в тоннеле Расвумчоррского рудника свидетельствуют о существенном отличии деформирования массива пород вблизи крупных структур.

\subsection{4. Наклономерно-деформометрический комплекс на Кировском руднике}

Деформационные процессы в скальных породах происходят медленно, имеют циклический характер и могут продолжаться длительное время. Поэтому для выявления их закономерностей необходимо использовать высокочувствительные и стабильные во времени системы наблюдений. Как показывает опыт изучения таких процессов, в целях контроля состояния горных выработок и других сооружений этим условиям в наибольшей степени соответствует наклономерно-деформометрический комплекс, многолетний положительный опыт использования которого накоплен в сейсмологии. Для контроля за процессами деформирования и прогноза разрушений в массиве под влиянием горных работ в 2010 г. такой комплекс был установлен на гор. -24 м Юкспорского крыла Кировского рудника, включающий в себя подземный пункт регистрации и наземный пункт сбора, накопления и обработки данных [207].

\subsubsection{1. Архитектура комплекса}

В состав подземного пункта входят датчики деформометров (ДКК-3) и наклономеров (НК), регистратор информации Regin-3F-6k и элементы, обеспечивающие бесперебойное питание системы.

Съем информации с датчиков осуществляется с помощью высокочувствительных емкостных дифференциальных преобразователей механических перемещений в изменения частоты выходного сигнала.

Подземный пункт размещен в забое одиночной горной выработки протяженностью 90 м на горизонте - 24 м Юкспорского крыла Кировского рудника.

С целью минимизации теплового и шумового воздействия на чувствительные элементы датчиков подземный пункт изолирован от остальной части подводящей к полигону выработки и квершлага Западного вентиляционного ствола двумя железобетонными перемычками.

На стенке забоя выработки смонтированы два деформометра ДКК-3, сориентированные по сторонам света - восток-запад (далее ДКК В-3) и юг-север (ДКК Ю-С) (рис. 5.41). На постаменте, жестко связанным со скальным массивом, установлен ДКК-Z, контролирующий смещения в вертикальной плоскости и наклономеры, установленные $\mathrm{c}$ ориентировкой осей по направлению запад-восток (НК 3-В) и север-юг (НК С-Ю). 

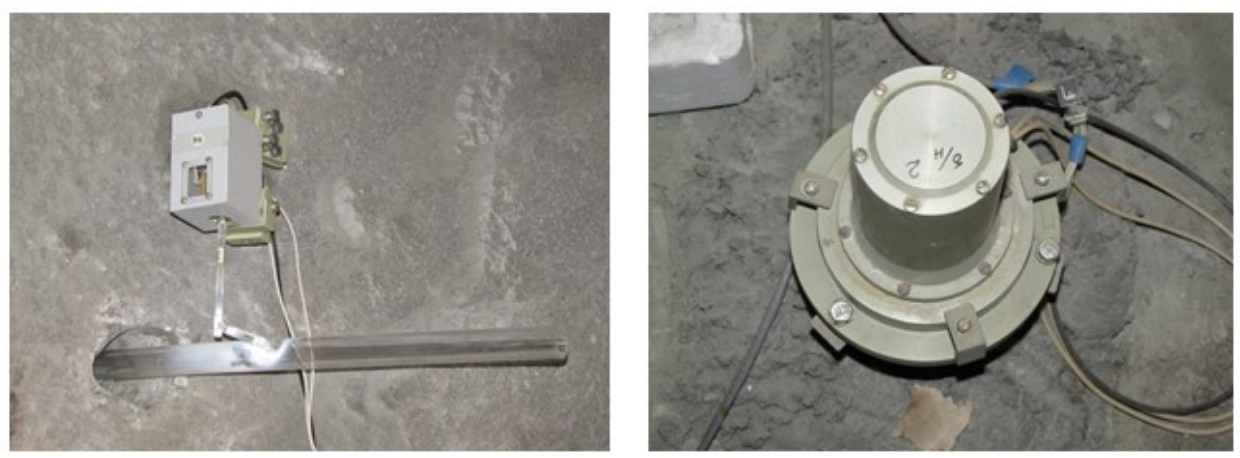

Рис. 5.41. Кварцевые деформометр ДКК-3 (слева) и наклономер НК (справа)

Регистратор информации Regin-3F-6k размещен в этом же забое в непосредственной близости от датчиков (длина сигнальных кабелей не превышает 5 м). Обмен информацией между регистратором информации Regin-3F-6k и наземным пунктом сбора и обработки данных организован посредством удаленного доступа.

На рисунке 5.42 приведена структурная схема геодинамического полигона.

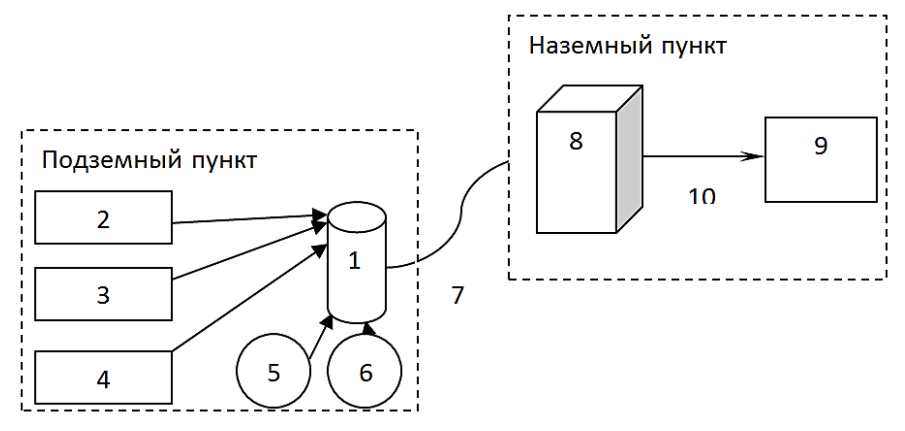

Рис. 5.42. Структурная схема организации геодинамического полигона регистрации деформаций и наклонов: 1 - регистратор информации Regin-3F-6k; 2-4 - кварцевые деформометры ДКК-3; 5, 6 - кварцевые наклономеры НК; 7 - линия связи подземного и наземного пунктов; 8 - коммутационный блок на поверхности рядом с западным вспомогательным стволом 3ВС; 9 - пункт сбора и обработки данных, организованный в ГоИ КНЦ РАН; 10 - удаленный доступ, осуществляемый по каналу Ethernet

\subsubsection{2.Результаты контроля деформаций наклономерно-деформометрическим комплексом}

Информация с комплекса поступает с июля 2010 г. Этот период включает в себя момент реализации техногенного землетрясения с магнитудой 3,5 21 октября 2010 г. в 12 ч 10 мин по московскому времени, гипоцентр которого находился в пределах Кукисвумчорского крыла Кировского рудника примерно на гори. +16 м (360 м от поверхности) на некотором удалении от очистных работ. Выделившаяся энергия составила порядка $7 \cdot 10^{9}$ Дж. Размер зоны подготовки землетрясения составил несколько километров, то есть включал в себя всю промышленную зону рудника и значительную часть продуктивной толщи Хибинского массива. В результате этого события в ряде подземных выработок произошло раскрытие трещин, отслоения бетонной и набрызг-бетонной крепи, обрушение породы. Каких-либо значимых признаков этого землетрясения на поверхности не выявлено. 
По результатам, зарегистрированных комплексом деформаций, визуально выделяются три характерных временных этапа (рис. 5.43):

- от начала регистрации до 06.10.2010 г., когда зафиксировано непрерывное медленное изменение наклона в плоскости север-юг (НК 3-В) при относительно малых изменениях в показаниях остальных приборов;

- c 06.10.2010 г. по 21.10.2010 г. (этап подготовки и реализации техногенного землетрясения) наблюдается резкое изменение показаний всех приборов, за исключением ДКК С-Ю, причем наклон в плоскости север-юг сменил знак приращения, а ДКК 3-В показывал рост отрицательных деформаций (сжатие);

- c 21.10.2010 г. по 31.10.2010 г. (афтершоковый), отражающий уменьшение скоростей наклонов при продолжающемся росте деформаций сжатия в направлении восток-запад.

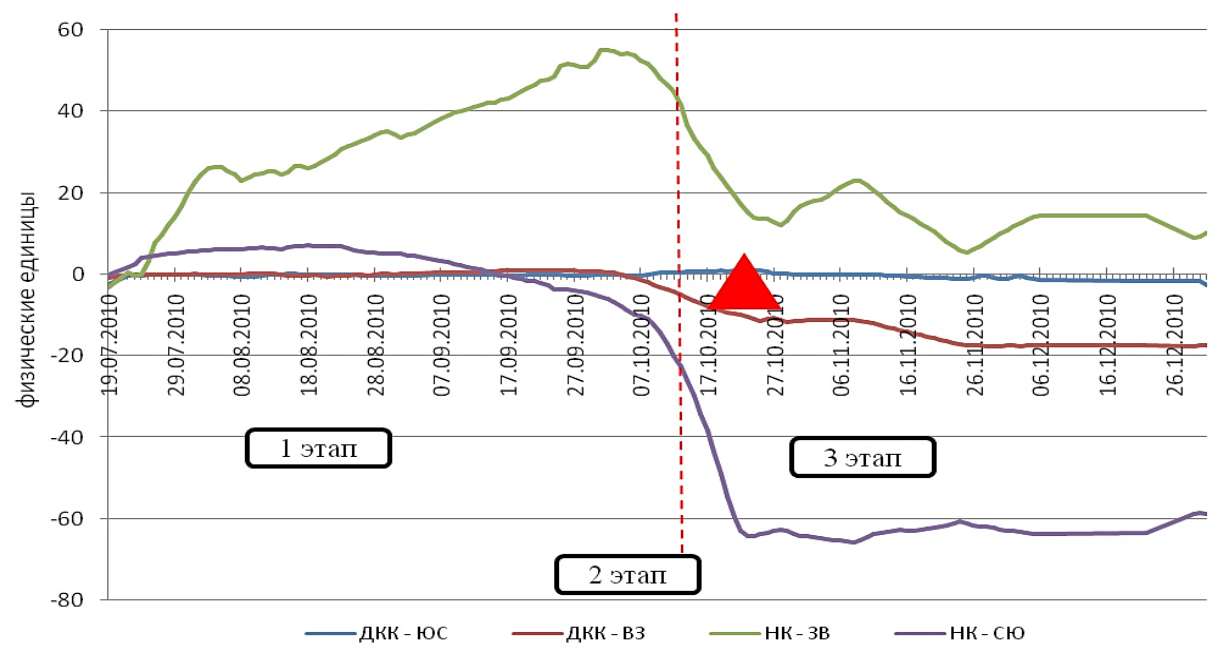

Рис. 5.43. Данные деформационно-наклономерного комплекса в период подготовки и реализации техногенного землетрясения 21.10.2010: 1 этап — период стабильности (22.07.2010-06.10.2010); 2 этап - подготовка землетрясения (06.10.2010-21.10.2010); 3 этап — афтершоковый период (с 21.10.2010); _ _ _ - момент начала развития устойчивых предвестников готовящегося сильного сейсмического события, $\boldsymbol{\Delta}$ - техногенное землетрясение 21.10.2012

Полученные результаты достаточно отчетливо отражают различные стадии подготовки и реализации техногенного землетрясения и позволяют четко определить начало заключительной стадии подготовки - недельного интервала, предшествующего реализации землетрясения (вертикальный красный пунктир на рис. 5.44).

После реализации землетрясения прослеживается уменьшение скоростей наклонов при продолжающемся росте деформаций сжатия в направлении восток-запад.

В течение 2011 г. и в первой половине 2012 г. геодинамический режим геологической среды характеризуется чередованием процессов сжатия-растяжения (опускание-поднятие) по вертикальной компоненте, что иллюстрируется графиком на рисунке 5.44 показаниями ДКК-Z и деформациями наклона вкрест простирания рудного тела в северном, либо южном направлениях, что отражено в показаниях НК 3-B. 


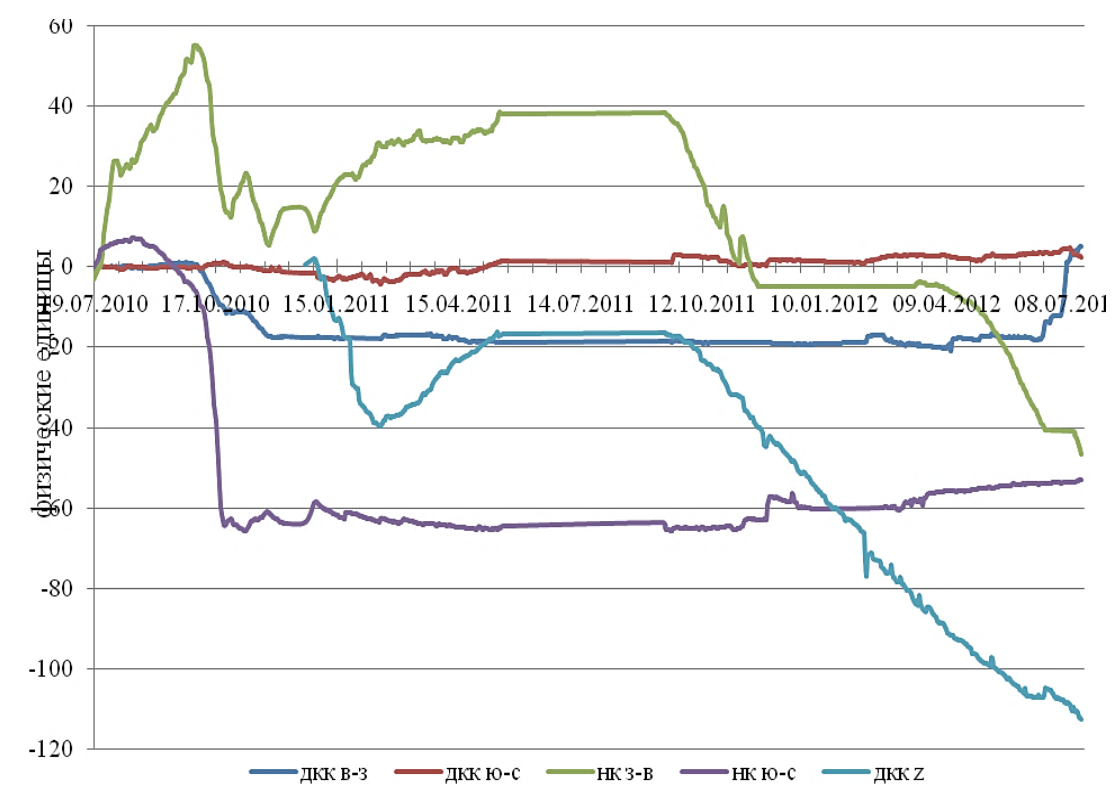

Рис. 5.44. Данные деформационно-наклономерного комплекса с июля 2010 г.

Таким образом, по результатам наблюдений деформационно-наклономерным комплексом установлено, что он достаточно четко реагирует на изменения НДС массива пород в процессе подготовки и реализации мощного динамического события, что позволяет выявлять средне- и краткосрочные предвестники готовящихся техногенных землетрясений. Поэтому есть основания полагать, что организация сети деформационно-наклономерных станций в сочетании с другими методами контроля позволит прогнозировать опасные геодинамические явления в природно-техногенных и горнотехнических системах. Однако для обоснования такой возможности необходимо расширение системы наблюдений и набор достаточно убедительной статистики.

\subsection{5. Система наблюдений в Ковдорской природно-технической системе}

В пределах горнотехнической системы «Ковдорский ГОК» закономерности деформирования массивов горных пород изучали главным образом применительно к вопросам оценки устойчивости бортов и уступов и оптимизации конструкций бортов карьера, устанавливаемых на конечном контуре.

В результате выполненных исследований в период с 1998 по 2003 гг., которые продолжаются по настоящее время, было предложено на отдельных, благоприятных по инженерно-геологическим условиям участках контура карьера увеличить углы откоса уступов до вертикальных, а углы наклона борта карьера в целом - до 45-60 в зависимости от конкретных геомеханических и горно-геологических условий. Рекомендации были реализованы, и в настоящее время около 30 \% контура карьера представлено бортами с вертикальными уступами.

Однако с формированием высоких бортов уступами с повышенными углами откосов возрастает риск потери устойчивости и развития процессов обрушения, поэтому возрастает роль специальных систем геомеханического мониторинга. 
В 2004 г. Горным институтом КНЦ РАН разработан регламент на создание системы контроля состояния прибортового массива и деформаций бортов и откосов уступов карьера рудника «Железный», поставленных на конечный контур, в соответствии с которым в 2005-2006 гг. осуществлены закладка и оборудование измерительного полигона, включающего шесть фундаментальных пунктов (рис. 5.45).

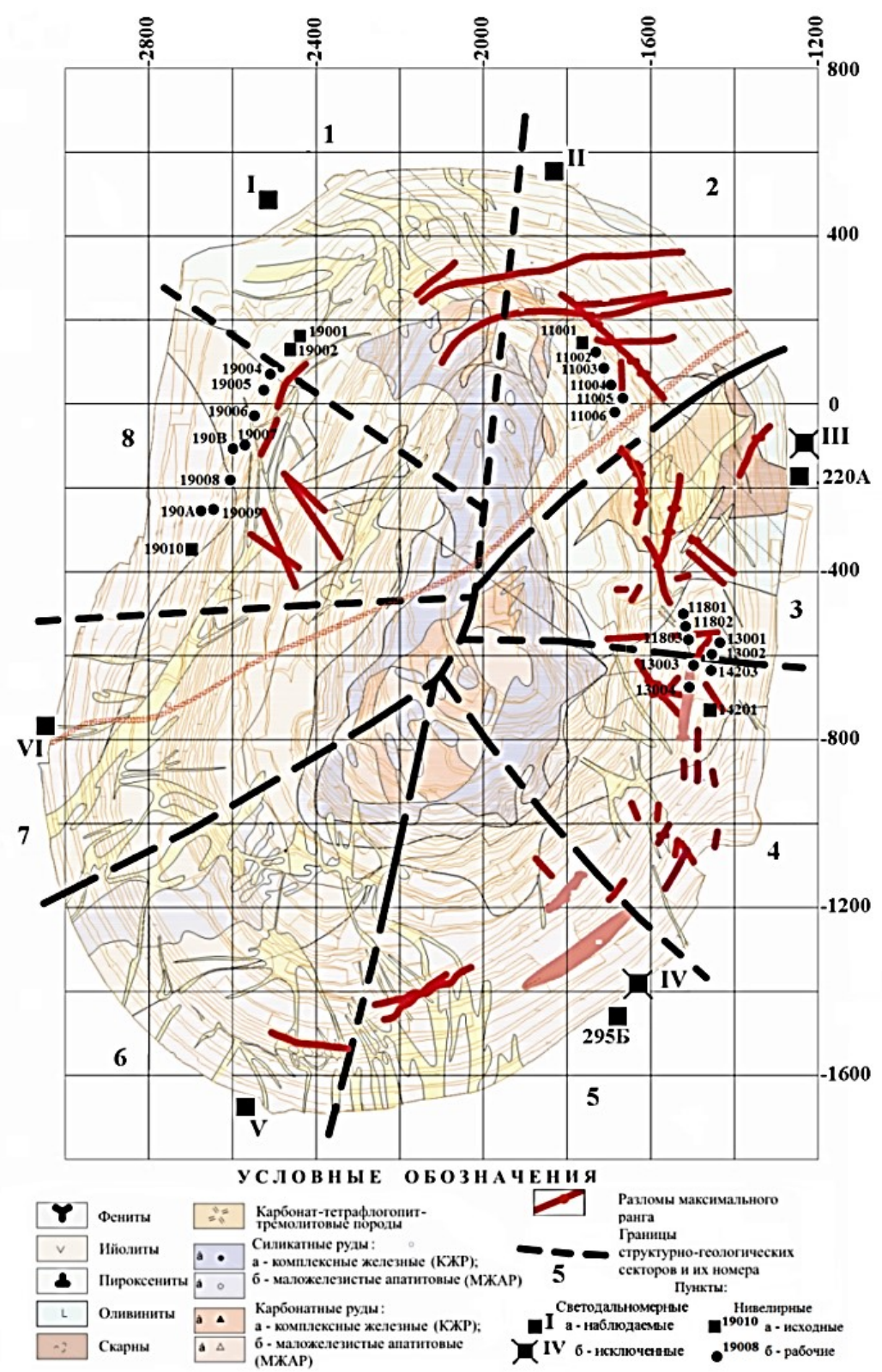

Рис. 5.45. Схема расположения фундаментальных реперов светодальномерного полигонаи нивелирных реперов наблюдательных станций в карьере рудника «Железный» и районирование массива пород карьера по инженерно-геологическим условиям (по Д. В. Жирову, Геологический институт КНЦ РАН) 
Кроме того, в 2014 г. начаты наблюдения по наблюдательным станциям, заложенным службой мониторинга устойчивости уступов АО «Ковдорский ГОК» с целью контроля проблемных участков контура и зданий.

В 2015 г. для уточнения размеров области влияния карьера на состояние окружающего массива и границ, выделяемых структурно-геологических секторов, измерительный полигон дополнен шестью пунктами, которые образуют внешнее кольцо по отношению к основным фундаментальным пунктам (рис. 5.46), на которых предполагалось выполнять определения координат методом GPS-технологий.

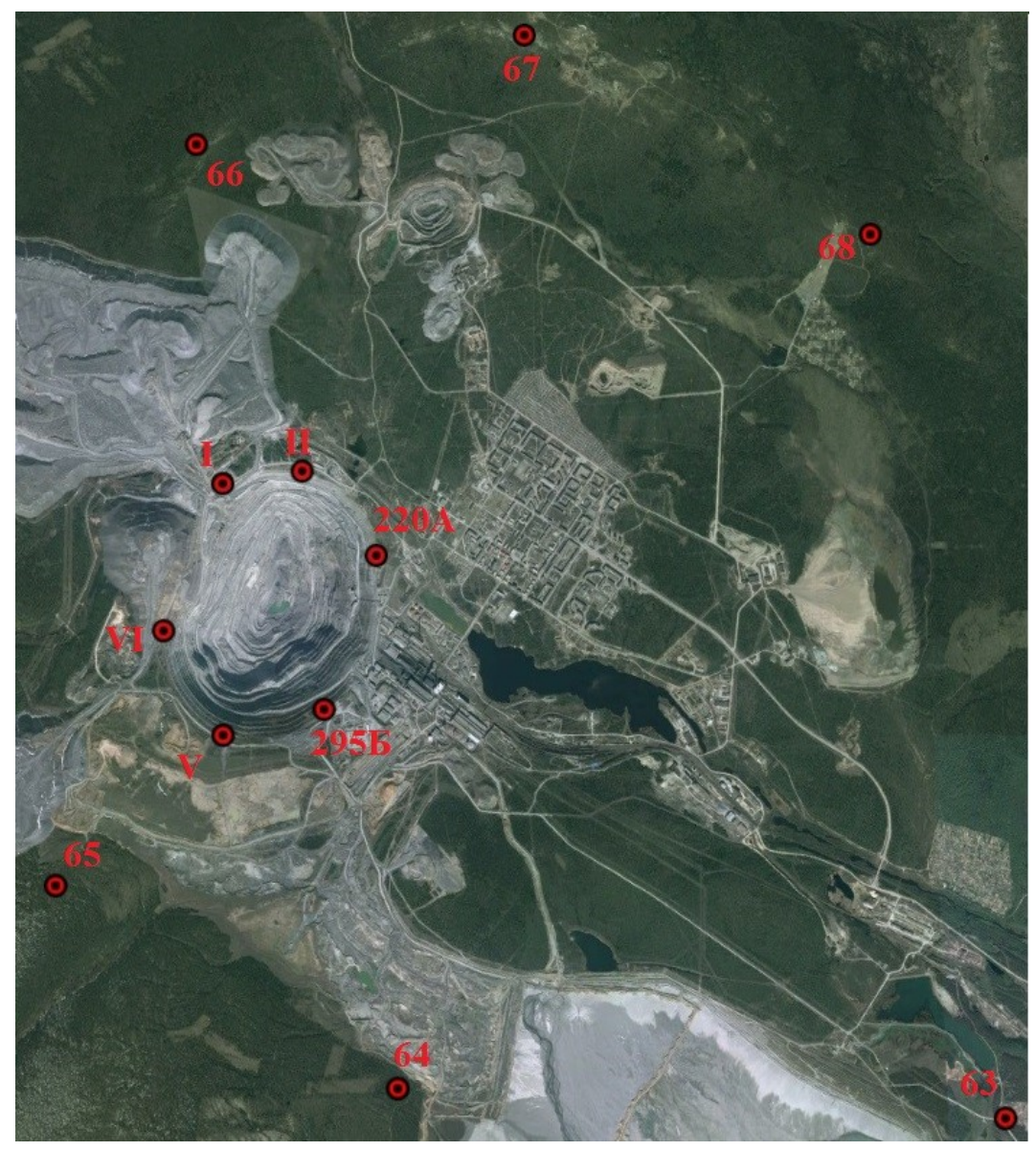

Pис. 5.46. Схема расположения пунктов GPS-наблюдений (внешнее кольцо)

Места расположения фундаментальных пунктов выбраны таким образом, чтобы максимально возможно учесть пространственное расположение самых крупных структурных неоднородностей в пределах карьера. Также при выборе места заложения пунктов учитывали необходимость обеспечения прямой видимости между пунктами, наличие подъездных путей и удобства подхода к ним.

Поскольку для пунктов III и IV из-за большой мощности наносов (до 20-35 м) не удалось обеспечить необходимые требования в части их закладки в скальном массиве, в состав полигона дополнительно были включены маркшейдерские пункты 220А и 295Б. 


\subsection{6. Характер деформирования горных пород в карьере «Железный»}

Для обеспечения безопасности и эффективности открытых горных работ необходимо прогнозировать характер и механизм развития геомеханических процессов и надежно рассчитывать устойчивые конструктивные параметры борта карьера (углы откосов уступов, их высоту, параметры предохранительных и транспортных берм).

При этом борта карьеров можно рассматривать как специфические инженерные сооружения, обладающие особыми свойствами с точки зрения геомеханики. Прежде всего это относится к весьма большим площадям обнажений пород в борту карьера, достигающих часто нескольких квадратных километров. Кроме того, разные уступы борта карьеров имеют различный срок службы, наиболее продолжительные сроки характерны для самых верхних, поставленных в конечное положение.

Поскольку верхние уступы часто располагаются в грунтовых массивах или ослабленных скальных породах, здесь наиболее широко распространенной формой проявления геомеханических процессов являются перемещения частиц в пределах каких-либо объемов массива, а наиболее опасным видом потери устойчивости являются оползни.

В нижележащих уступах, когда они располагаются в массивах прочных скальных пород, основными формами проявления геомеханических процессов являются деформации пород и образование зон неупругих деформаций и разрушений в приконтурном массиве, при этом наиболее распространенными видами потери устойчивости обнажений пород являются отдельные их вывалы. Преобладающие размеры вывалов определяются видом «эффективных» структурных неоднородностей, которые устанавливаются на основании соотношений размеров деформируемых объектов и параметров различных видов структурных неоднородностей [208].

Для борта в целом, с учетом больших площадей и объемов пород, вовлекаемых в процессы деформирования и разрушения, роль «эффективных» структурных неоднородностей обычно выполняют крупные структурные неоднородности, образующие структурные блоки размерами до нескольких десятков и сотен метров. В этом случае одной из основных форм проявления геомеханических процессов являются сближения участков борта карьера вследствие перемещения крупных блоков массива [209].

В условиях Ковдорского месторождения и рудника «Железный» грунтовые массивы представлены приповерхностной зоной интенсивно дезинтегрированных пород мощностью от 10 до 40 м, на юго-западном и юго-восточном участках контура - до 100-200 м от поверхности. Ниже располагаются полускальные и скальные породы с постепенно уменьшающейся степенью дезинтеграции и возрастанием показателей физико-механических свойств.

Результаты инженерно-структурного районирования свидетельствуют о том, что на большей части контура все уступы бортов, за исключением одного-двух самых верхних, располагаются в скальных породах. При этом в качестве «эффективных» структурных неоднородностей по отношению к уступам выступает крупноблоковая трещиноватость, образующая структурные блоки с линейными размерами в первые единицы метров, а для борта в целом - структурные неоднородности первого ранга, образующие структурные блоки с размерами до первых сотен метров. 
С точки зрения масштабов областей деформирования и разрушения массива горных пород иерархично-блочной структуры можно выделить региональный и локальный уровни проявлений геомеханических процессов [208] и, соответственно, рассматривать региональный и локальный уровни организации и проведения мониторинга геомеханических процессов.

В настоящее время для целей локального мониторинга весьма эффективно применение методов площадных съемок с применением лазерного сканирования и радарной технологии. При этом наиболее перспективным являются радарные технологии, поскольку достаточно независимы от погодных условий и по рекламным данным обладают большой дальнобойностью и высокой точностью определения расстояний (до 4 км и точностью до 0,1 мм). Преимуществом подобных технологий является высокая производительность, а недостатками - сложность обработки получаемых данных и высокая стоимость применяемого оборудования и программного обеспечения. Кроме этого, необходимо иметь в виду, что лазеры и радары фиксируют уже свершившиеся результаты образования вывалов, а это может означать и завершение процессов разрушения массива. С этой точки зрения эти технологии при безусловной перспективности требуют еще определенной проработки в части анализа получаемых данных и, что особенно важно, уточнения критических значений измеряемых параметров, свидетельствующих об опасном состоянии уступов.

Из региональных геомеханических явлений в карьере рудника «Железный» наблюдаются перемещения (сближения) борта карьера пока без видимых нарушений сплошности среды.

На рисунке 5.47 показаны результаты светодальномерных наблюдений за сближениями бортов карьера за весь период.

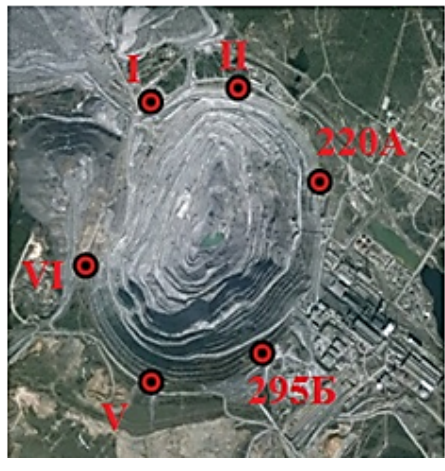

$a$

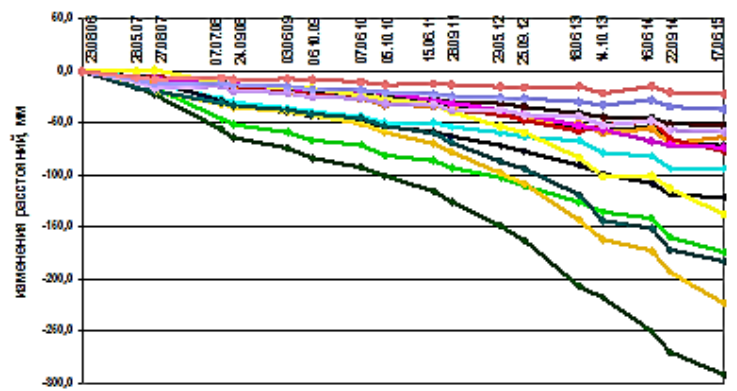

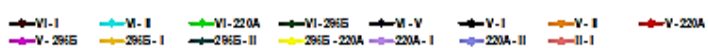
$\sigma$

Рис. 5.47. Схема полигона (a) и графики изменений расстояний (б) между фундаментальными пунктами полигона в карьере рудника «Железный»

Результаты наблюдений свидетельствуют, что общая тенденция изменений расстояний между пунктами практически во всех циклах заключается в их уменьшении, то есть наблюдаются сближения участков борта карьера.

Это подтверждает прежде всего непрекращающееся развитие геомеханических процессов в приконтурном массиве борта карьера, а различие величин сближений по отдельным направлениям говорит о различной динамике отдельных блоков приконтурного массива. При этом характер деформирования пород на северных и северо-западных участках контура карьера резко отличается от характера деформирования массива на юге и юго-востоке. 
С математической точки зрения сближение пунктов представляет собой векторную величину - сумму перемещений двух фиксированных точек массива, которая может быть разложена на составляющие в соответствии с выбранной системой координат.

В качестве начального этапа целесообразно проанализировать сближения фундаментальных пунктов раздельно по направлениям приблизительно перпендикулярно контуру борта (условно по радиальному) и вдоль него (по тангенциальному).

Для северного участка радиальному направлению в наибольшей степени отвечает линия реперов I-220A, а тангенциальному - линия I-II. Для южного участка радиальному направлению соответствуют сближения по линии VI-295Б, а тангенциальному - сближения по линии V-295Б. Развитие сближений по этим линиям приведено отдельно на рисунке 5.48 .

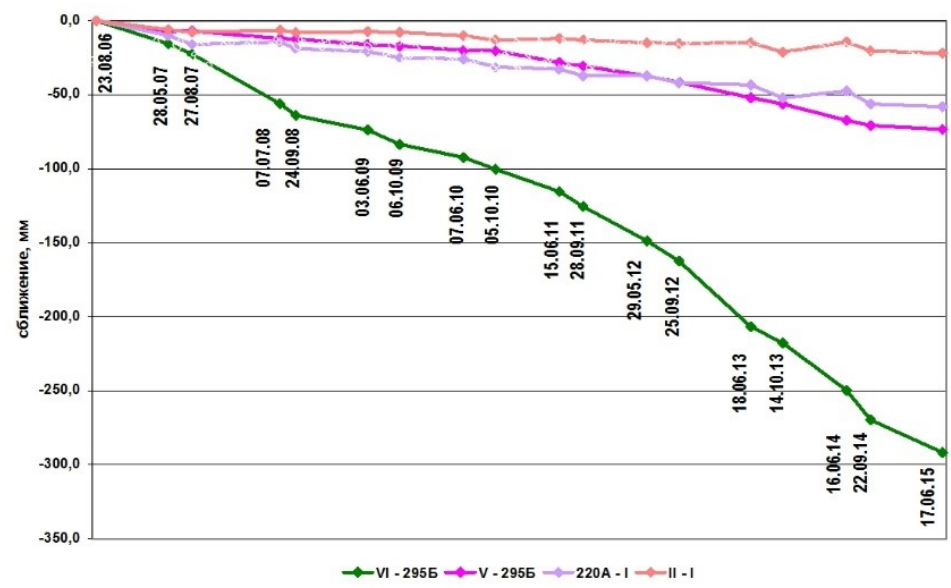

Рис. 5.48. Типичные графики сближений фундаментальных пунктов на северном и южном участках контура карьера рудника «Железный»

На рисунке 5.49 приведены скорости сближения пунктов тех же линий северного и южного участков контура карьера.

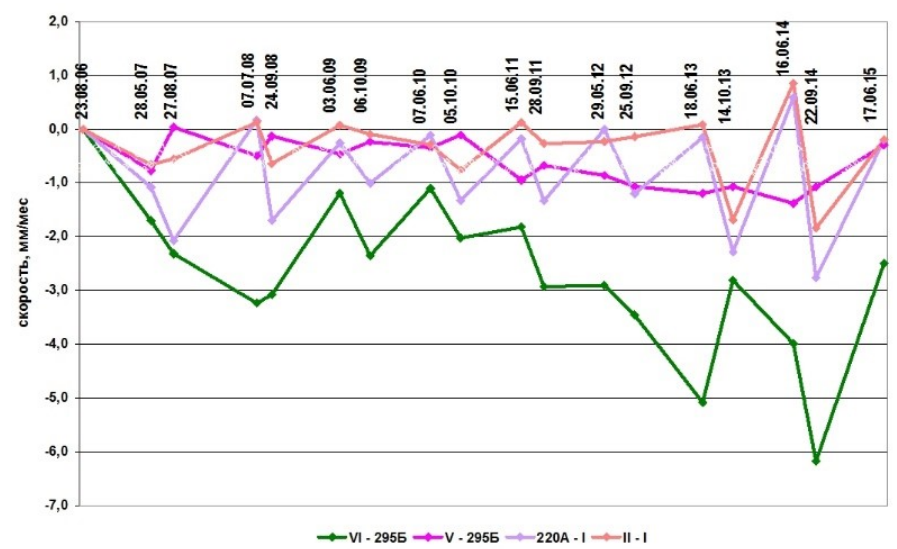

Рис. 5.49. Скорости сближения фундаментальных пунктов по северному и южному участку контура карьера 
Анализ графиков на рисунках 5.48 и 5.49 показывает, что на северном участке контура сближения по тангенциальному направлению (линия I-II) увеличиваются медленно (максимально до 22 мм за 9 лет), скорости составляют доли миллиметров в месяц и колеблются в пределах погрешностей измерений. При этом размах колебаний скоростей сближений в последних циклах существенно увеличился, что, по-видимому, можно объяснить применением тахеометра ELTA S10, у которого точность измерений меньше, чем у ранее применявшегося светодальномера «Мекометр-5000».

По радиальному направлению (линия I-220A) характер развития сближений аналогичен сближениям по тангенциальному направлению, но величины сближений несколько больше и достигают максимально 58,1 мм, а скорости сближений - менее 3 мм/мес.

Существенно иной характер развития сближений наблюдается на южном участке контура карьера. В частности, развитие сближений по тангенциальному направлению похоже на развитие сближений на северном участке, но больше по величине (до 70,8 мм) при постепенно увеличивающихся скоростях сближений, достигающих в настоящее время 1 мм/мес и даже несколько более. В то же время развитие сближений по радиальному направлению резко отличается и по величинам (до 291,8 мм) и по скоростям, которые постоянно возрастают и в настоящее время превышают 6 мм/мес.

Если результаты светодальномерных наблюдений обеспечивают получение общей информации о сближениях фундаментальных пунктов полигона, то по результатам GPS-измерений можно определять индивидуальные подвижки каждого из пунктов и строить векторы перемещений по результатам наблюдений каждого цикла. В качестве примера на рисунке 5.50 приведены векторы перемещений фундаментальных пунктов в период с 26 сентября 2011 г. по 24 сентября 2012 г. и с 24 сентября 2012 г. по 19 июня 2013 г.

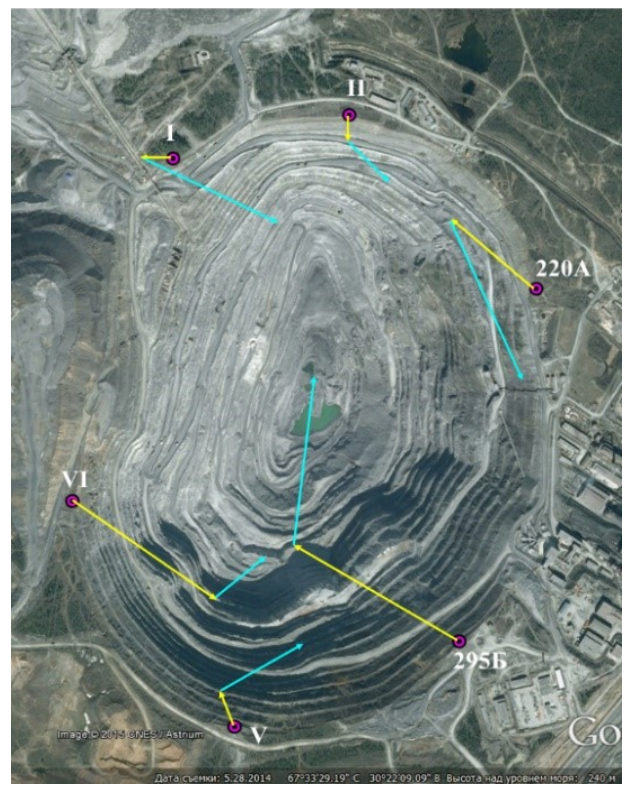

Рис. 5.50. Схема перемещений (в плане) фундаментальных пунктов геомеханического полигона в период с 26.09.2011 г. по19.06.2013 гг. (рудник «Железный»). Желтым цветом показаны векторы смещения за период с 26 сентября 2011 г. по 24 сентября 2012 г., голубым - с 24 сентября 2012 г. по 19 июня 2013 г. 
Все приведенные результаты убедительно подтверждают положение о том, что граница между северным и южным участками месторождения, резко различающимися по геомеханическому состоянию и проявлениям геомеханических процессов, по-видимому, представлена наиболее крупной структурой — главным разломом R1, пересекающем все месторождение, и границы выделенных структурно-геологических секторов в дальнейшем будут скорректированы.

При этом необходимо отметить, что горные работы последнего времени сосредоточены именно на южном и юго-восточном участках месторождения, и это обуславливает особую актуальность проведения здесь дальнейших наблюдений с целью контроля состояния борта карьера. Вместе с тем фиксируемые в настоящее время значения сближений и, главное, значения скоростей сближений (6 мм/мес), по-видимому, еще не являются критическими, поскольку состояние борта в целом пока отвечает условиям безопасности ведения горных работ, а имевшие место неоднократные нарушения устойчивости части уступов носят характер локальных обрушений (хотя и достаточно значительных по объемам), осложняющих ведение горных работ, но не приводящих к нарушениям устойчивости всего борта в целом.

\section{6. Изучение геомеханических процессов в геологической среде горнотехнических систем по параметрам сейсмической эмиссии}

\subsection{1. Современная сейсмологическая активность Фенноскандии и природно-техногенных систем центральной части Кольского полуострова}

5.6.1.1. Текущий анализ сейсмической активности природно-техногенных систем центтральной части Кольского полуострова

\subsubsection{1. Сейсмическая сеть Кольского филиала федерального иссследовательского иентра «Единая геофизическая служба Российской академии наук» и ее регистрационные возможности}

В настоящее время осуществляется непрерывный мониторинг сейсмичности центральной части Кольского полуострова. Основой регистрационной сети являляются три постоянные станции: сейсмическая малоаппертурная группа «Апатиты» (AP0), среднеполосная станция TER и широкополосная станция APA.

Станция «Anamumbl» (APA) расположена в микрорайоне Академгородок города Апатиты в подвале здания № 37А, в котором размещен и региональный центр сбора и обработки сейсмологических данных Кольского филиала Геофизической службы РАН (КоФ ФИЦ ЕГС РАН). Регистрация ведется широкополосным велосиметром Guralp CMG-3ESP (рис. 5.51 a), обладающим плоской амплитудночастотной характеристикой в диапазоне от 0,01 до 50 Гц (рис. 5.51 б).

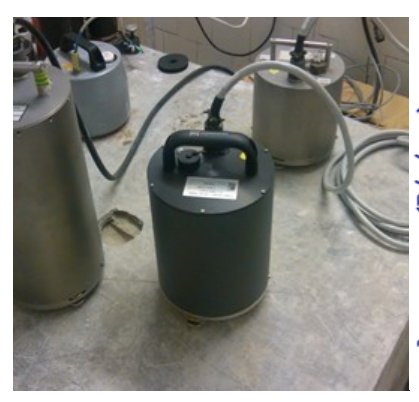

$a$

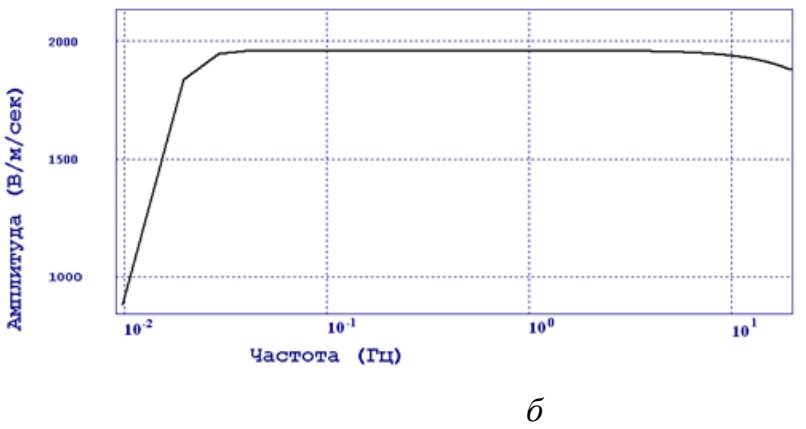

$\sigma$

Рис. 5.51. Место установки сейсмических датчиков (велосиметра Guralp CMG-3ESP) (a) и его амплитудно-частотная характеристика (б) 
Датчик установлен на бетонный постамент, связанный со скальным основанием. Чувствительность сенсора по компонентам: вертикальная - 1980 B/м/c; север/юг - 1956 B/м/с; восток/запад - 1970 В/м/с. Оцифровка аналогового сигнала производится с частотой 40 отсчетов в секунду посредством 24-битного АЦП Е-24 (L-Card), коэффициент преобразования $\left(k_{\text {пр }}\right)$ равен 0,298 мкВ/отсчет.

Сейсмическая станция TER ("Териберка») установлена на побережье Баренцева моря в поселке Териберка на площадке метеорологической станции Мурманского управления по гидрометеорологии и мониторингу окружающей среды Росгидромета. Регистрация проводится трехкомпонентным велосиметром CMG 40T производства фирмы Guralp. Сейсмометр установлен на скальном выходе коренных кристаллических пород (архейских гнейсо-гранитов) и накрыт термостатирующим боксом.

Амплитудно-частотная характеристика прибора столообразная на интервале 0,01-50 Гц (рис. 5.52). Чувствительность датчика по компонентам: вертикальная - 400 В/м/с; север/юг - 406 В/м/с; восток/запад — 400 B/м/с.

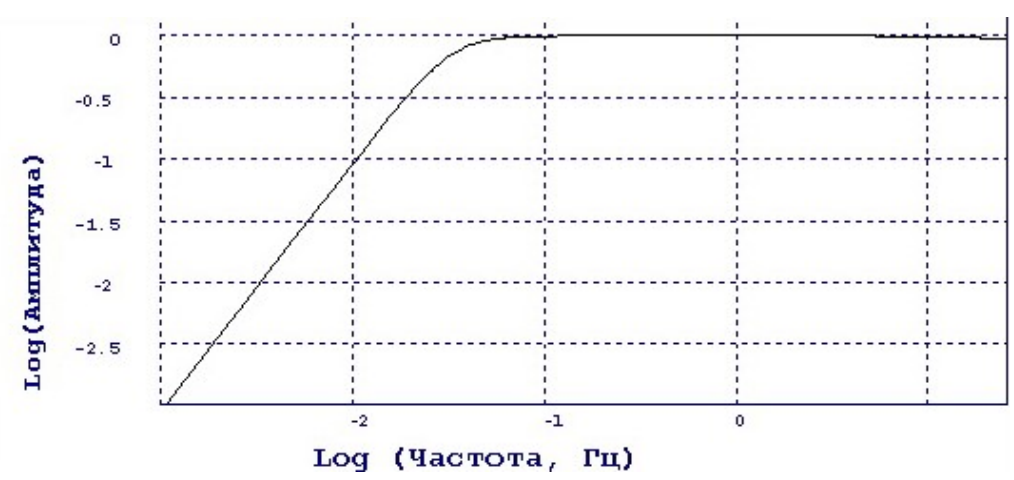

Рис. 5.52. Амплитудно-частотная характеристика велосиметра Guralp CMG-40T

Система сбора данных выполнена на базе 24-битного модуля АЦП LAI-24USB производства ЗАО «Руднев-Шиляев». Частота дискретизации 100 отсчетов в секунду. Коэффициент преобразования $\left(k_{\text {пр }}\right)$ равен 0,298 мкВ/отсчет, коэффициент усиления $\left(k_{\mathrm{y}}\right)$ равен 1.

Передача данных в центр сбора и обработки в городе Апатиты выполняется в режиме близком к реальному времени посредством 3G-модема по сети Интернет.

Сейсмическая группа АРО (Апатитская сейсмическая группа) расположена в 18 км от города Апатиты на территории комплексного эколого-геофизического полигона Кольского научного центра РАН. Группа состоит из 8 вертикальных датчиков и одной трехкомпонентной станции в центре. Схема расположения элементов группы представлена на рисунке 5.53.

Регистрация ведется короткопериодными велосиметрами GS-1, производства OYO Geospace. Датчики имеют столообразную амплитудно-частотную характеристику в диапазоне частот 1-25 Гц (рис. 5.54).

Оцифровка аналогового сигнала производится с частотой 80 отсчетов в секунду для центральной трехкомпонентной станции и 40 отсчетов в секунду для остальных каналов посредством 24-битных АЦП E-24 (L-Card), коэффициент преобразования $\left(k_{\text {пр }}\right)$ равен 0,298 мкВ/отсчет, коэффициент усиления $\left(k_{\mathrm{y}}\right)$ равен 128.

Передача данных в центр сбора и обработки в городе Апатиты осуществляется двумя путями: по сети Интернет и по радиоканалу. 
Все велосиметры установлены на скальное основание (кристаллические сланцы и метагаббро раннепротерозойского метаморфического комплекса) в бункерах, заглубленных в почвенный покров на 1-2,5 м. Чувствительность велосиметра GS-1 - 375 B/м/c.

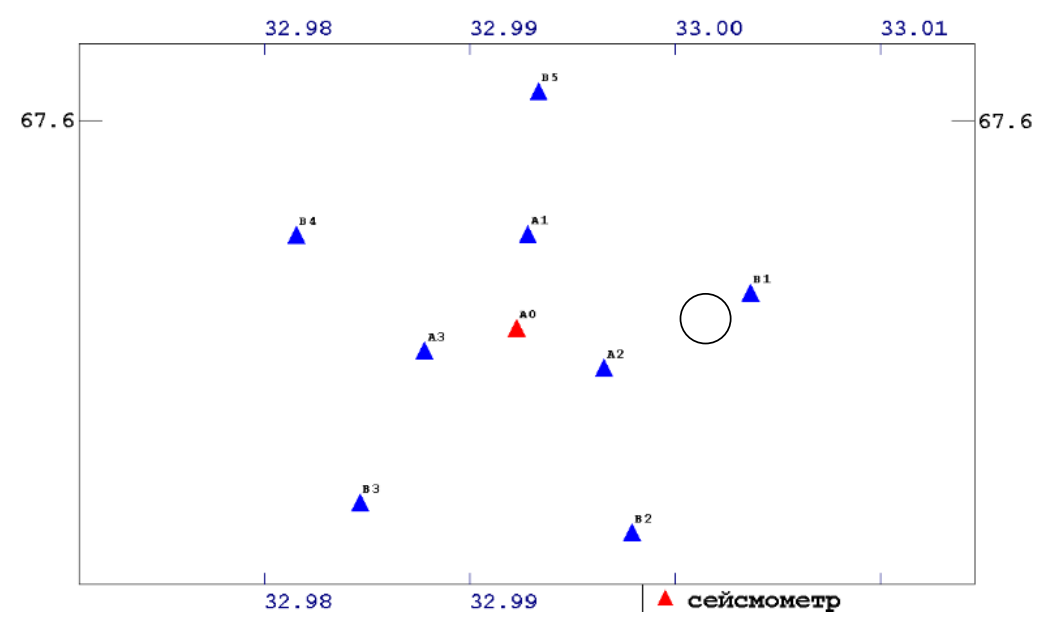

Рис. 5.53. Схема расположения элементов сейсмической группы АР0. Красным треугольником обозначен трехкомпонентный датчик. Синими треугольниками - вертикальные датчики

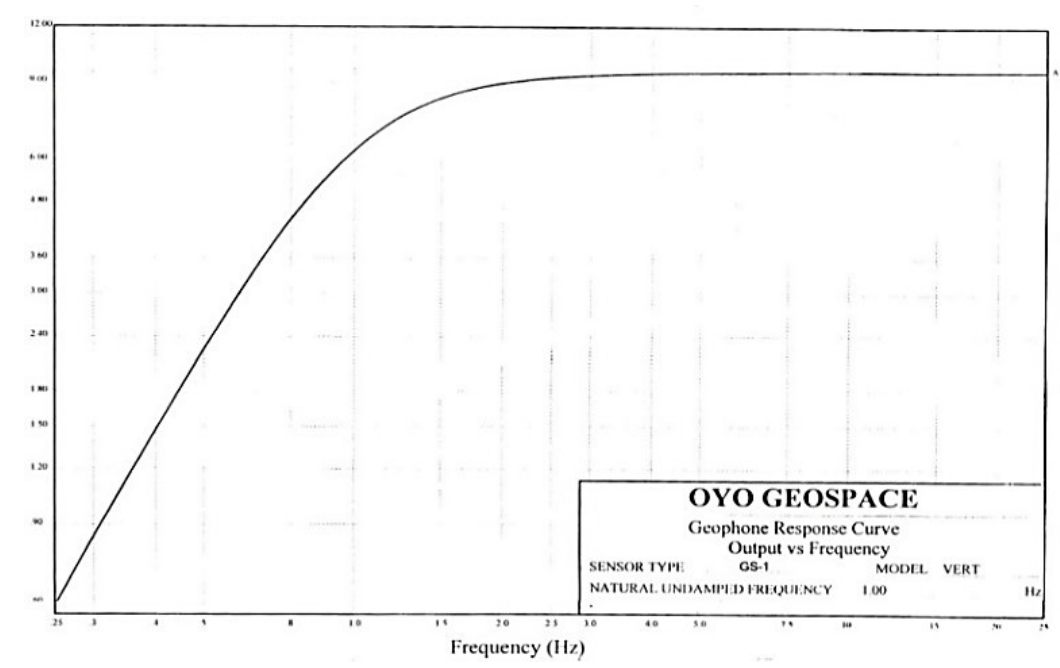

Рис. 5.54. Амплитудно-частотная характеристика велосиметра GS-1

На рисунке 5.55 представлена карта, иллюстрирующая чувствительность сети КФ ГС РАН. Цветами, от ярко зеленого к серому, обозначены области уверенной регистрации сейсмических событий той или иной магнитуды. Красными точками нанесены рудники горнодобывающих предприятий области - $\mathrm{AO}$ «Апатит», $\mathrm{AO}$ «Ковдорский ГОК» (КовдГОК), АО «Оленегорский ГОК» (ОГОК).

На рисунке видно, что различные ПТС контролируются с разными порогами магнитудной представительности. Так, Хибинская ПТС имеет самый низкий магнитудный порог: для всех апатитовых рудников события с магнитудой выше 1 уверенно регистрируются станциями КоФ ФИЦ ЕГС РАН. Рудники АО «Оленегорский ГОК» находятся на границе данного регистрационного порога, 
для них уверенная регистрация сейсмических событий начинается с магнитуды 1.5 , как и для Ловозерской ПТС. Рудники АО «Ковдорский ГОК» находятся в области, для которой уверенная регистрация сейсмических событий начинается с магнитуды 2. Самый высокий порог представительности в такой конфигурации сейсмической сети сложился для рудников Печенгской ПТС (район г. Заполярный). Эти рудники попали на границу областей с магнитудным порогом 2 и 2,5 [210, 211].

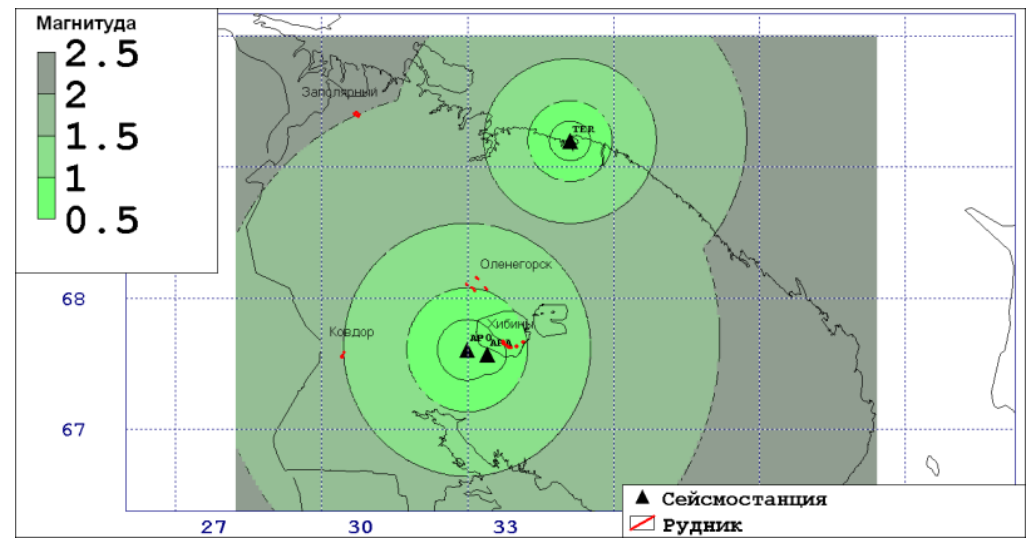

Pис. 5.55. Сеть постоянных сейсмических станций КФ ГС РАН в 2013-2015 гг. и ее регистрирующая способность

Для понижения магнитудного порога регистрации сейсмических событий Печенгской ПТС и мониторинга сейсмичности шельфа Баренцева моря c 2014 г. в тестовом режиме работает сейсмическая станция на полуострове Рыбачий (RYB). Станция оборудована трехкомпонентным короткопериодным сейсмометром и автономной системой энергообеспечения. Установка станции RYB позволяет снизить магнитудный порог регистрации сейсмических событий из Печенгской ПТС с 2-2,5 до 1-1,5 (рис. 5.56).

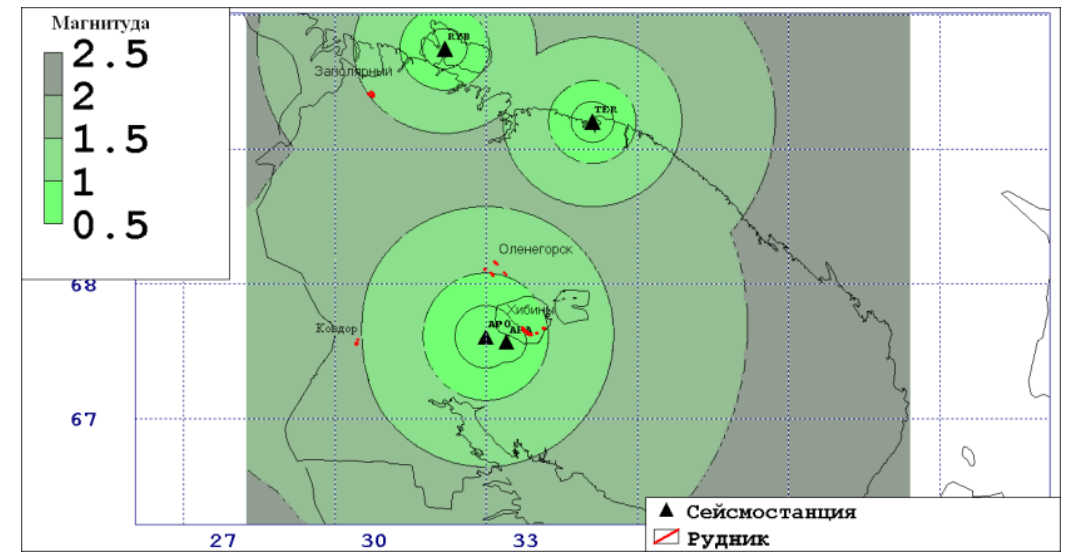

Рис. 5.56. Сеть постоянных сейсмических станций КФ ГС РАН с учетом используемой в тестовом режиме станции RYB и ее регистрирующая способность

Ниже детально рассмотрены результаты анализа сейсмичности
наблюдаемых ПТС.




\subsubsection{2. Региональная сейсмичность тектонической и техногенной природы}

Региональная сеть сейсмического мониторинга КоФ ФИЦ ЕГС РАН регистрирует ежегодно более 3 тыс. сейсмических событий тектонической и техногенной (взрывной) природы, локализованных преимущественно в горнопромышленных узлах Мурманской области, Северной Финляндии и Норвегии (рис. 5.57).

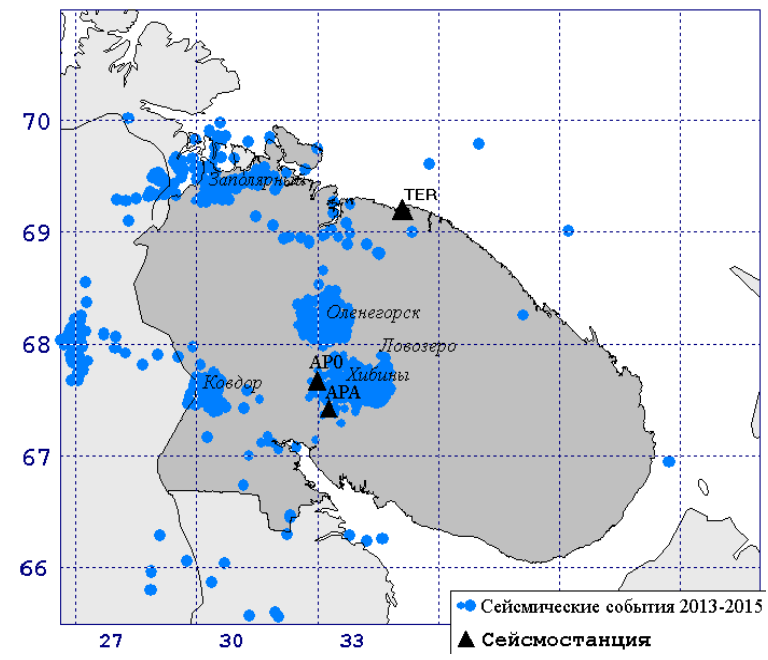

Рис. 5.57. Карта-схема пространственного распределения эпицентров сейсмических событий, обнаруженных сетью КоФ ФИЦ ЕГС РАН за период 2013-2015 гг.

Подавляющее большинство этих событий (более 95 \%) являются техногенными, в основном индуцированными технологическими взрывами. Сильнейшие из них регистрируются сетью КоФ ФИЦ ЕГС РАН, большинство же являются недостаточно мощными и регистрируются лишь внутрирудничными сетями геофизического мониторинга.

Очищенная от техногенного «фона» карта-схема тектонической сейсмичности приведена на рисунке 5.58 .

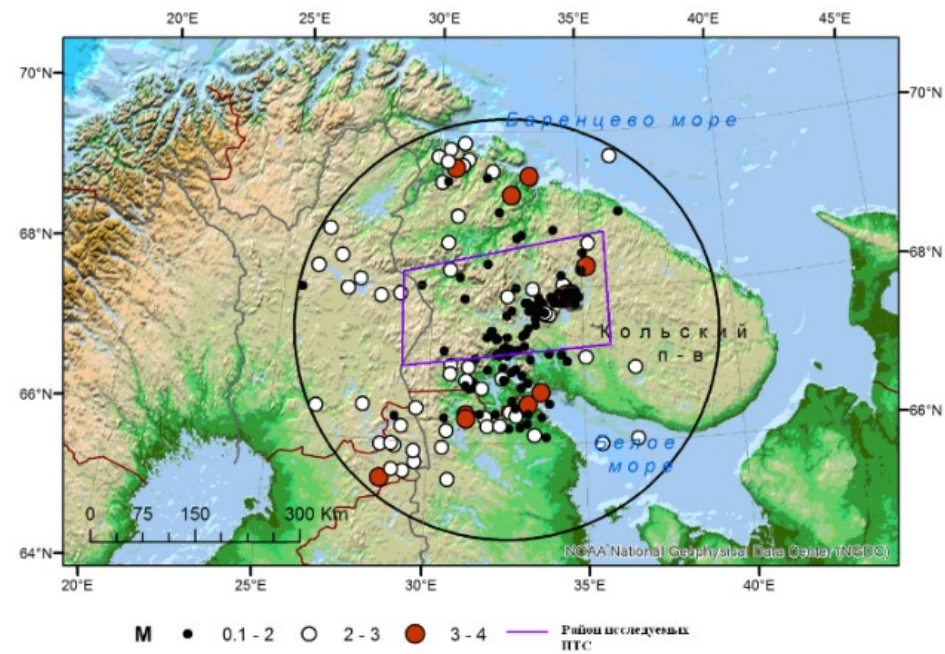

Pис. 5.58. Карта эпицентров землетрясений за 1992-2014 гг. в 300 км зоне от базовой станции АРА по данным КоФ ФИЦ ЕГС РАН. Фиолетовый четырехугольник - район локализации Хибинской, Ловозерской, Оленегорской и Ковдорской ПТС 
За период с ноября 1992 г. по декабрь 2014 г. по данным КоФ ГС РАН на Кольском полуострове и прилегающих территориях в радиусе 300 км от базовой сейсмостанции было зарегистрировано 467 землетрясений с магнитудами от 0,1 до 4,0 (рис. 5.58). Соответствующая гистограмма распределения магнитуд землетрясений изображена на рисунке 5.59. График повторяемости для данной выборки приведен на рисунке 5.60.
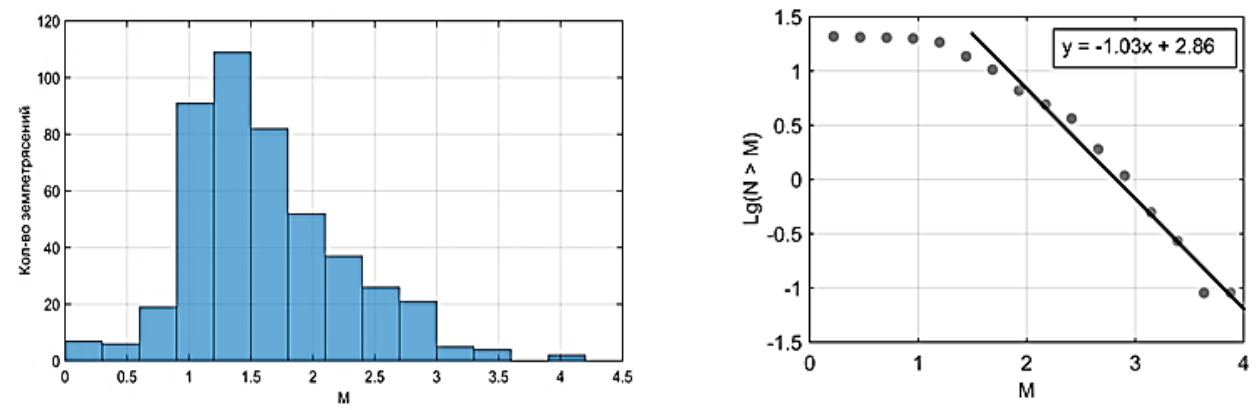

Рис. 5.59. Гистограмма магнитуд Рис. 5.60. График повторяемости землетрясений землетрясений за 1992-2014 гг. по данным за 1992-2014 гг. по данным КоФ ГС РАН КоФ ГС РАН

\subsubsection{3. Сейсмичность в пределах Хибинской, Ловозерской, Ковдорской} и Оленегорской горнотехнических сиситем в 1988-2014 годах

За период с 1988 по 2014 гг. сейсмической сетью КоФ ГС РАН зарегистрировано 704 сейсмических события тектонической природы в контурах площадей Хибинской, Ловозерской, Ковдорской и Оленегорской ПТС. На рисунке 5.61 приведена схема районов наблюдаемых ПТС, принятая в данной работе при анализе локальной сейсмичности в отдельных ПТС.

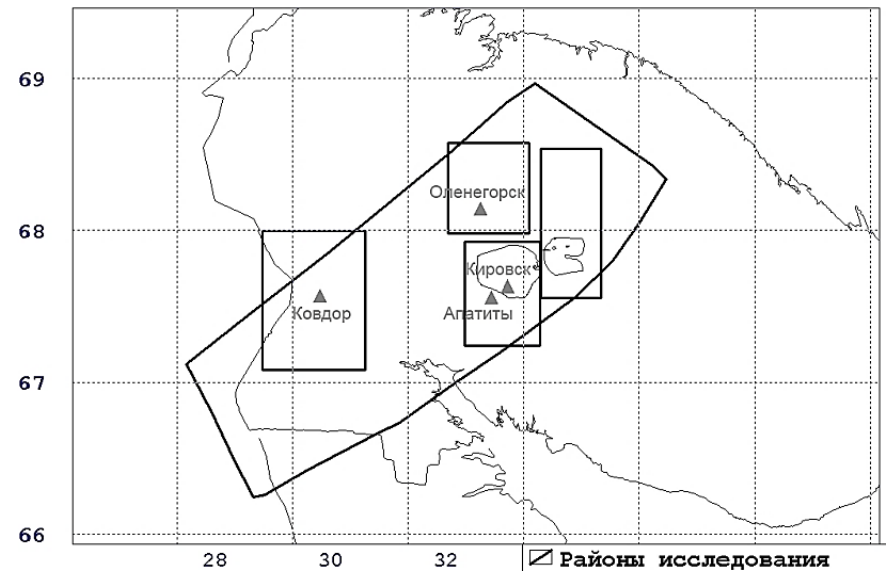

Рис. 5.61. Схема условных контуров площадей Хибинской, Ловозерской, Оленегорской и Ковдорской ПТС

Так как в настоящее время нет универсальных общепринятых методик, позволяющих однозначно различать взрывы и тектонические землетрясения по сейсмическим записям, специалистами КоФ ГС РАН к этому генетическому типу события причислялись как по косвенным диагностическим критериям, 
оцениваемым по атрибутам сейсмограмм, так и на основании официальной информации от горнодобывающих предприятий об отсутствии взрывных работ на момент регистрации события.

На сегодняшний день в КоФ ГС РАН применяется семь основных критериев отличия тектонических землетрясений от событий взрывной природы $[212,213]$.

Отнотение амплитуд $S$-волны/ $P$-волныл. Значение такого параметра выше 3 может свидетельствовать в пользу того, что сейсмическое событие является землетрясением. Низкое значение этого параметра не может быть серьезным аргументом в пользу предположения, что изучаемое событие является взрывом.

Глубина события - параметр, требующий специального анализа в каждом случае; может быть использован в качестве критерия дискриминации при наличии недостаточно большого числа регистрирующих станций только при обработке данных по сейсмической группе, когда высокое значение кажущихся скоростей прихода волн на группу может рассматриваться как свидетельство в пользу естественного происхождения события.

Разность магнитуд по объемным и поверхностным волнам. Критерий хорошо работает для достаточно сильных событий на региональных расстояниях (хотя и здесь существует область перекрытия); для применения критерия необходимо наличие широкополосных записей.

Изменение спектров во времени. Высокие значения параметра $a$, основанного на расчете корреляции между спектральными амплитудами, вычисленными для одной и той же записи, но для разных положений временного окна (выше 0,5$)$ с очень высокой степенью достоверности свидетельствуют об искусственном происхождении сейсмического события.

Сравнение обобщенных трасс событий является достаточно надежным критерием дискриминации событий при условии наличия детальной базы данных о событиях известной природы, полученной в предыдущие годы.

Наличие акустических сигналов - достоверный критерий техногенного происхождения сейсмического события.

Характерная форма сейсмограммы события. Наличие на сейсмограммах отчетливо выраженных цугов низкочастотных поверхностных волн при слабой выраженности или отсутствии сигналов от объемных волн может указывать на принадлежность события к типу оползней или обрушений пород. В тех случаях, когда азимуты этих событий направлены на действующие рудники, события однозначно трактуются как обрушения пород.

Применение перечисленных методов идентификации естественных событий стало возможно при переходе на цифровую регистрацию, которая началась в КоФ ГС РАН в 1992 г. Разумеется, более строгий подход к разделению естественных и техногенных событий не мог не сказаться на количестве отбираемых событий.

Возможно, приведенный в таблице 5.9 перечень 704 событий не полон, однако с большой уверенностью можно утверждать, что он практически не содержит взрывов.

На рисунках 5.62-5.66 показаны диаграммы временного хода вариации количества землетрясений тектонической природы и их суммарного энерговыделения во всем горнопромышленном кластере центральной части Кольского полуострова и раздельно в контурах площадей Хибинской, Ловозерской, Ковдорской и Оленегороской ПТС.

Пересчет магнитуды $M L$ в энергетический класс $K=\operatorname{Lg} E$ (Дж) выполнялся по формуле Ю. Ризниченко: $K=1,8 \bullet M L+4,0$. 
Суммарное энерговыделение и количество землетрясений во всем районе,

Хибинской, Ловозерской, Ководорской и Оленегорской ПТС за период 1988-2014 гг.

\begin{tabular}{|c|c|c|c|c|c|c|c|c|c|c|}
\hline \multirow[b]{2}{*}{ Год } & \multicolumn{2}{|c|}{ Весь район } & \multicolumn{2}{|c|}{ Хибинская ПТС } & \multicolumn{2}{|c|}{ Ловозерская ПТС } & \multicolumn{2}{|c|}{ Ковдорская ПТС } & \multicolumn{2}{|c|}{ Оленегорская ПТС } \\
\hline & количество & $\begin{array}{c}\text { суммарная } \\
\text { энергия (Дж) }\end{array}$ & количество & $\begin{array}{c}\text { суммарная } \\
\text { энергия (Дж) }\end{array}$ & количество & $\begin{array}{c}\text { суммарная } \\
\text { энергия (Дж) }\end{array}$ & количество & $\begin{array}{c}\text { суммарная } \\
\text { энергия (Дж) }\end{array}$ & количество & $\begin{array}{c}\text { суммарная } \\
\text { энергия (Дж) }\end{array}$ \\
\hline 1988 & 20 & $3.62 \cdot 10^{10}$ & 14 & $1.46 \cdot 10^{10}$ & 1 & $8.71 \cdot 10^{9}$ & 1 & $9.08 \cdot 10^{9}$ & 0 & 0 \\
\hline 1989 & 27 & $2.70 \cdot 10^{11}$ & 12 & $2.54 \cdot 10^{11}$ & 0 & 0 & 0 & 0 & 0 & 0 \\
\hline 1990 & 94 & $6.38 \cdot 10^{9}$ & 83 & $6.08 \cdot 10^{9}$ & 1 & $3.24 \cdot 10^{7}$ & 0 & 0 & 0 & 0 \\
\hline 1991 & 82 & $3.71 \cdot 10^{9}$ & 67 & $1.09 \cdot 10^{9}$ & 11 & $2.16 \cdot 10^{9}$ & 0 & 0 & 0 & 0 \\
\hline 1992 & 109 & $3.75 \cdot 10^{9}$ & 89 & $8.97 \cdot 10^{8}$ & 17 & $1.75 \cdot 10^{9}$ & 0 & 0 & 1 & $6.03 \cdot 10^{7}$ \\
\hline 1993 & 38 & $4.48 \cdot 10^{9}$ & 5 & $1.10 \bullet 10^{9}$ & 32 & $3.38 \cdot 10^{9}$ & 0 & 0 & 1 & $6.31 \cdot 10^{5}$ \\
\hline 1994 & 3 & $9.92 \cdot 10^{7}$ & 1 & $4.17 \cdot 10^{5}$ & 2 & $9.88 \cdot 10^{7}$ & 0 & 0 & 0 & 0 \\
\hline 1995 & 6 & $3.24 \cdot 10^{8}$ & 3 & $4.35 \cdot 10^{7}$ & 2 & $2.20 \bullet 10^{8}$ & 0 & 0 & 1 & $6.03 \cdot 10^{7}$ \\
\hline 1996 & 13 & $4.27 \cdot 10^{8}$ & 2 & $2.60 \bullet 10^{6}$ & 10 & $4.22 \cdot 10^{8}$ & 0 & 0 & 0 & 0 \\
\hline 1997 & 44 & $5.15 \cdot 10^{9}$ & 1 & $2.19 \cdot 10^{6}$ & 39 & $4.49 \cdot 10^{9}$ & 1 & $3.98 \cdot 10^{7}$ & 0 & 0 \\
\hline 1998 & 18 & $1.33 \cdot 10^{9}$ & 2 & $4.43 \cdot 10^{6}$ & 16 & $1.33 \cdot 10^{9}$ & 0 & 0 & 0 & 0 \\
\hline 1999 & 46 & $1.09 \cdot 10^{11}$ & 0 & 0 & 44 & $1.09 \cdot 10^{11}$ & 0 & 0 & 0 & 0 \\
\hline 2000 & 14 & $5.87 \cdot 10^{9}$ & 4 & $1.31 \cdot 10^{6}$ & 9 & $5.84 \cdot 10^{9}$ & 1 & $2.63 \cdot 10^{7}$ & 0 & 0 \\
\hline 2001 & 16 & $1.43 \cdot 10^{8}$ & 1 & $2.19 \cdot 10^{6}$ & 12 & $1.13 \cdot 10^{8}$ & 0 & 0 & 0 & 0 \\
\hline 2002 & 21 & $6.68 \cdot 10^{8}$ & 1 & $7.94 \cdot 10^{4}$ & 18 & $6.60 \cdot 10^{8}$ & 0 & 0 & 0 & 0 \\
\hline 2003 & 23 & $1.05 \cdot 10^{8}$ & 1 & $9.55 \bullet 108$ & 21 & $9.27 \cdot 10^{7}$ & 0 & 0 & 0 & 0 \\
\hline 2004 & 13 & $4.66 \cdot 10^{9}$ & 1 & $1.51 \cdot 10^{4}$ & 9 & $3.84 \cdot 10^{9}$ & 0 & 0 & 0 & 0 \\
\hline 2005 & 18 & $1.45 \cdot 10^{8}$ & 4 & $1.05 \cdot 10^{8}$ & 11 & $2.76 \cdot 10^{7}$ & 0 & 0 & 0 & 0 \\
\hline 2006 & 20 & $4.85 \cdot 10^{7}$ & 4 & $1.27 \cdot 10^{6}$ & 12 & $1.28 \cdot 10^{7}$ & 0 & 0 & 0 & 0 \\
\hline 2007 & 16 & $9.31 \cdot 10^{7}$ & 1 & $3.31 \cdot 10^{6}$ & 12 & $7.71 \cdot 10^{7}$ & 0 & 0 & 0 & 0 \\
\hline 2008 & 5 & $4.98 \cdot 10^{8}$ & 0 & 0 & 4 & $1.89 \cdot 10^{7}$ & 0 & 0 & 0 & 0 \\
\hline 2009 & 22 & $6.19 \cdot 10^{8}$ & 1 & $3.16 \cdot 10^{8}$ & 20 & $9.35 \cdot 10^{7}$ & 0 & 0 & 0 & 0 \\
\hline 2010 & 8 & $1.10 \bullet 10^{9}$ & 4 & $1.10 \bullet 10^{9}$ & 4 & $4.26 \cdot 10^{6}$ & 0 & 0 & 0 & 0 \\
\hline 2011 & 7 & $1.54 \cdot 10^{7}$ & 1 & $6.31 \cdot 10^{5}$ & 5 & $3.26 \cdot 10^{6}$ & 0 & 0 & 0 & 0 \\
\hline 2012 & 7 & $9.29 \cdot 10^{7}$ & 0 & 0 & 6 & $8.79 \cdot 10^{7}$ & 0 & 0 & 0 & 0 \\
\hline 2013 & 6 & $2.03 \cdot 10^{7}$ & 3 & $5.78 \cdot 10^{5}$ & 2 & $8.22 \cdot 10^{6}$ & 0 & 0 & 0 & 0 \\
\hline 2014 & 8 & $2.7 \cdot 10^{6}$ & 7 & $2.1 \cdot 10^{6}$ & 1 & $6.32 \cdot 10^{5}$ & 0 & 0 & 0 & 0 \\
\hline Итог & 704 & $4.55 \cdot 10^{11}$ & 312 & $2.79 \cdot 10^{11}$ & 321 & $1.44 \cdot 10^{11}$ & 3 & $9.14 \cdot 10^{9}$ & 3 & $1.21 \cdot 10^{8}$ \\
\hline
\end{tabular}




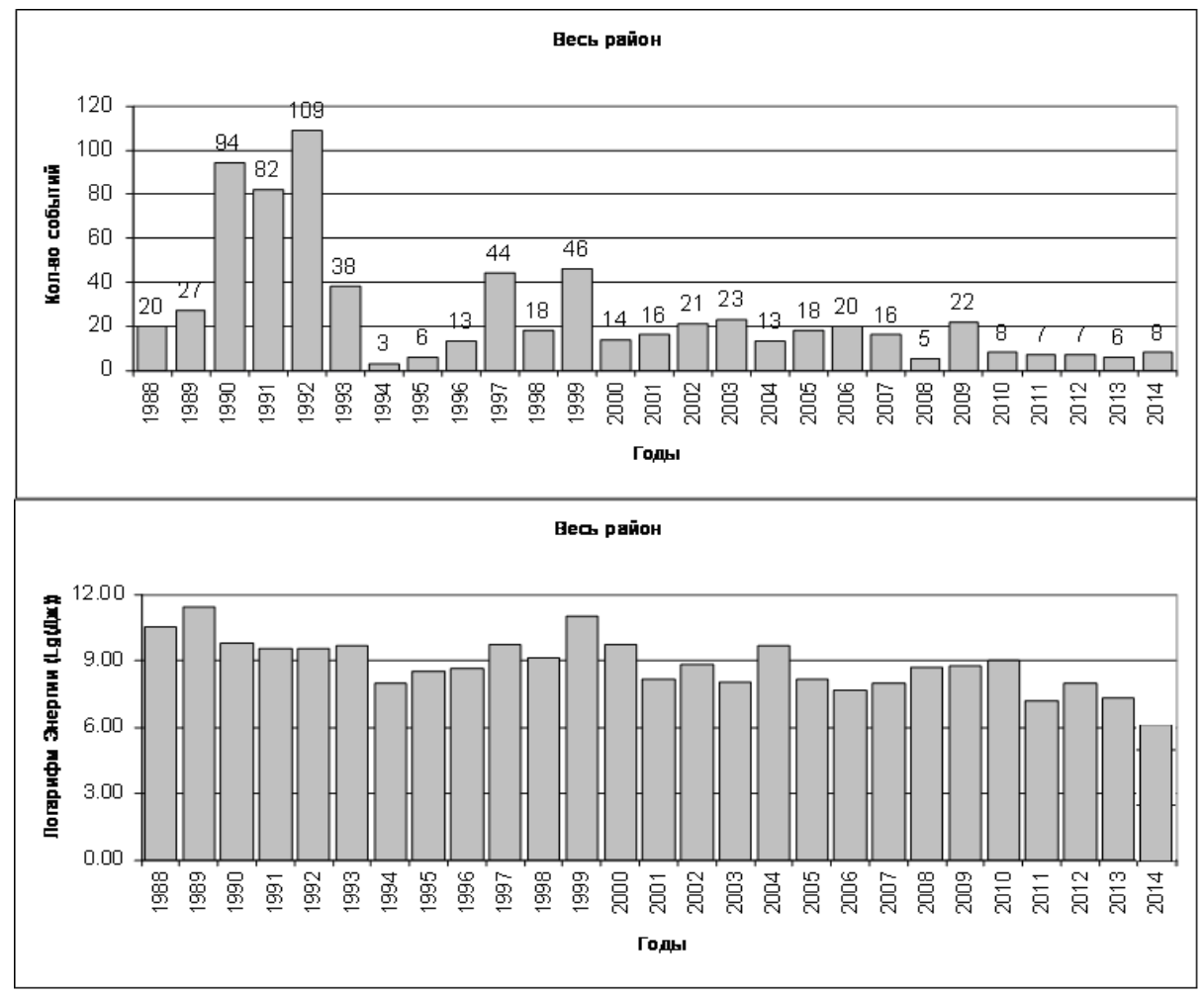

Рис. 5.62. Количество событий и суммарной энергии сейсмической эмиссии, зарегистрированной в пределах всего района наблюдений за 1988-2014 гг.
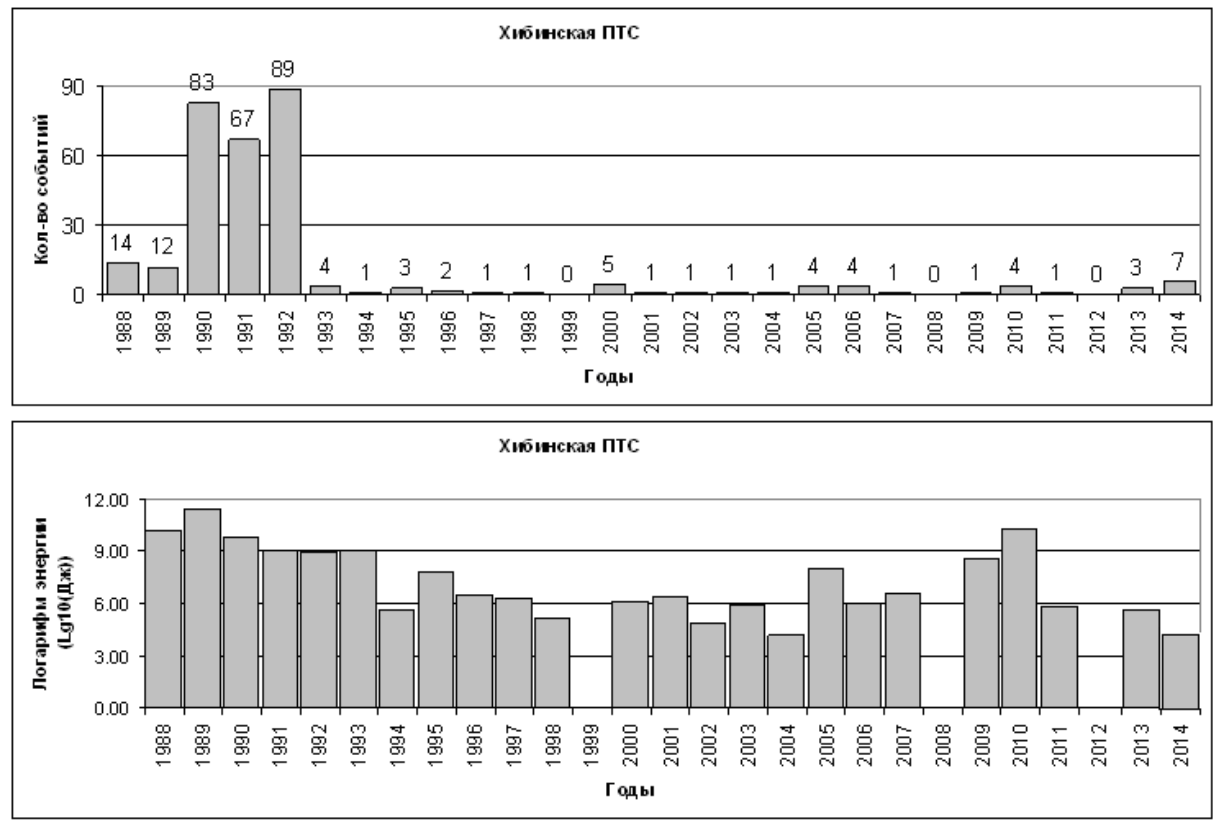

Рисунок 5.63. Количество событий и суммарной энергии сейсмической эмиссии, зарегистрированной в пределах Хибинской ПТС за 1988-2014 гг. 


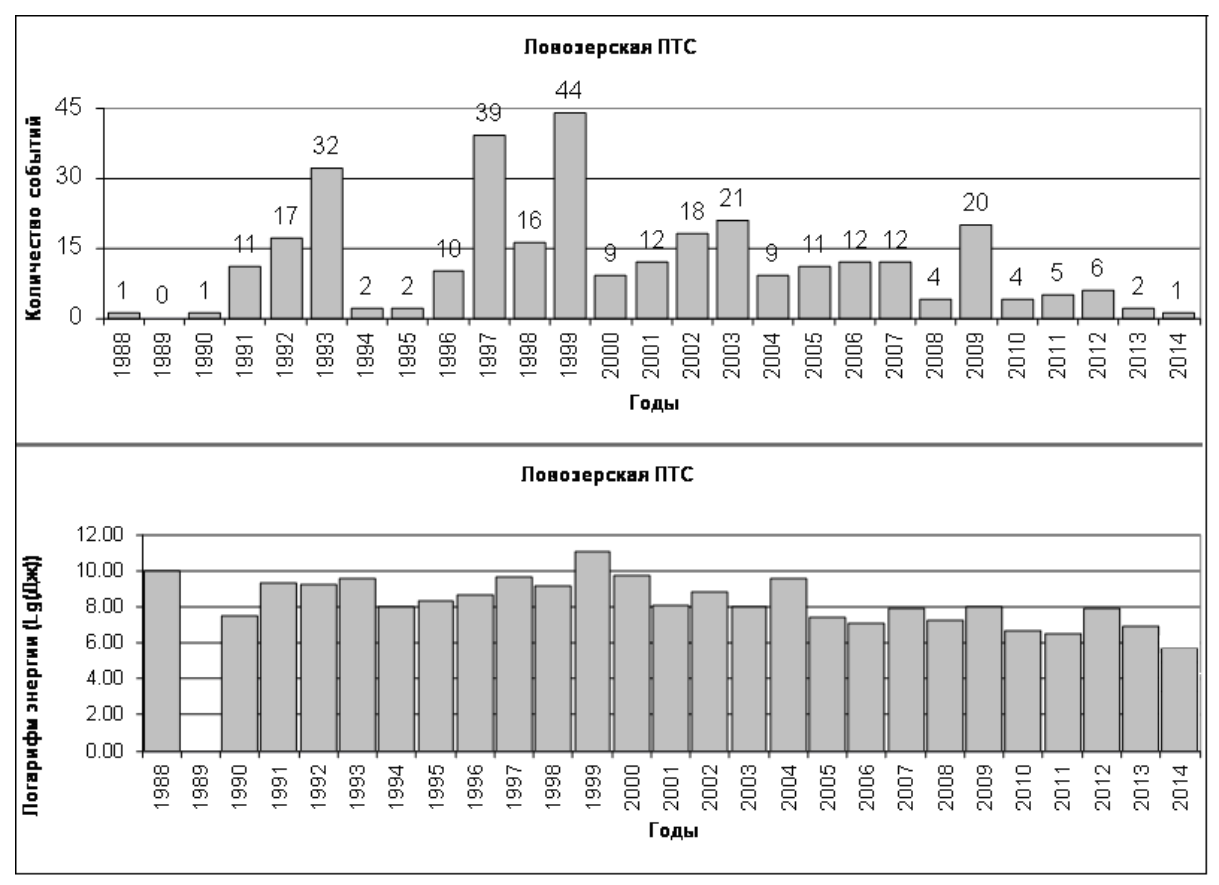

Рис. 5.64. Количество событий и суммарная энергия сейсмической эмиссии, зарегистрированные в пределах Ловозерской ПТС за 1988-2014 гг.
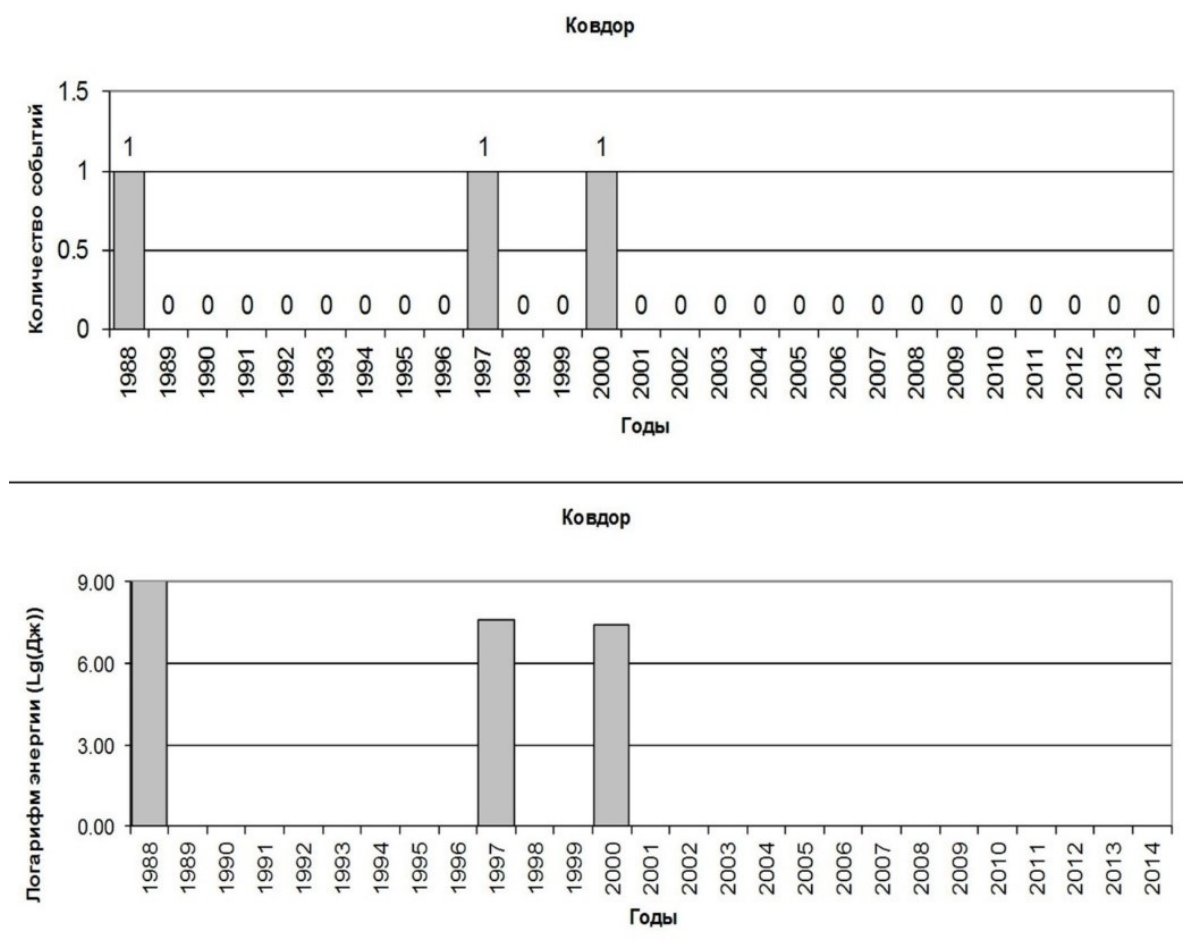

Рис. 5.65. Количество событий и суммарной энергии сейсмической эмиссии, зарегистрированные в пределах Ковдорской ПТС за 1988-2014 гг. 


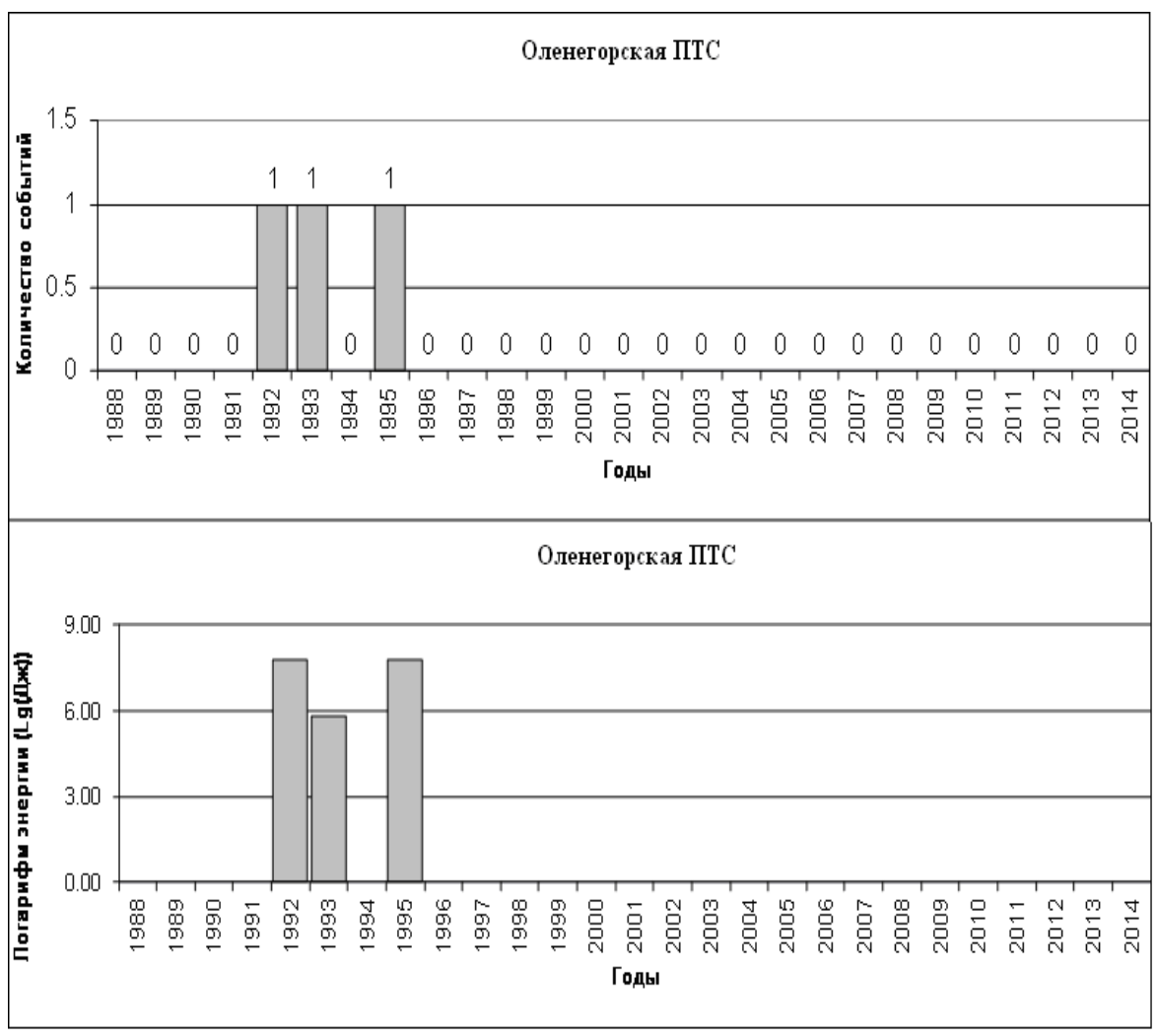

Рис. 5.66. Количество событий и суммарной энергии сейсмической эмиссии, зарегистрированной в пределах Оленегорской ПТС за 1988-2014 гг.

Наибольшей полнотой и надежностью характеризуется выборка данных по Хибинской ПТС, в которой мониторинг в 2012-2015 гг. осуществлялся с помощью объединенной сети КоФ ГС РАН и АО «Апатит» [214]. Результаты совместной обработки двух сетей позволили выявить за период с 01.10.2010 по 01.01.2014 более 2500 событий, 362 из которых идентифицированы как динамические проявления горного давления с магнитудами от 0,6 до 3,2, Распределение по магнитудам выглядит следующим образом: 156 событий с магнитудой от 0,6 до 1; 199 событий с магнитудой от 1 до 2; 7 событий с магнитудой больше 2. Объединенная сеть позволяет разработать дополнительные критерии для дискриминации взрывов и техногенных или тектонических сейсмических событий.

В Ловозерской ПТС контроль геодинамического режима осуществляется сейсмостанцией международной сети IRIS, установленной на руднике «Карнасурт» и станциями региональной сети КоФ ГС РАН, находящимися далеко за пределами ПТС. Поэтому картина пространственно-временной динамики сейсмичности в этой ПТС прорисовывается с гораздо меньшей детальностью, чем в Хибинской. С момента образования Ловозерской ПТС в 1950-е гг. (ввод в эксплуатацию в 1951 г. рудника «Карнасурт» на Ловозерском редкометальном месторождении) и вплоть до 1983 г. не было зарегистрировано ни одного ощутимого сейсмического события [211-213]. После ввода в 1984 г. в эксплуатацию второго подземного рудника «Умбозеро» сейсмичность Ловозерской ПТС резко возросло $[215,216]$. Производительность рудника с начала эксплуатации нарастала и достигла максимума 
в 1991 г. Для выемки рудных тел на руднике применялась камерно-целиковая система без обрушения и закладки выработанного пространства, что привело к постепенному нарастанию объема пустот. «К 1991 году, вследствие изменений напряженного состояния массива, его геодинамическое равновесие было нарушено серией горно-тектонических ударов с магнитудой $M=2,2-2,6$, очаги которых были приурочены к южному флангу рудника. Дальнейшее развитие горных работ, накопление потенциальной энергии в массиве, привело к ее разрядке в виде разрушительного техногенного землетрясения 17.08.1999 г. $(M=4,0) »$ [215]. После него сейсмическая активность в массиве несколько понизилась, однако все равно оставалась на уровне около 10 событий с магнитудой $M \geq 1$ в год, что свидетельствует о неустановившемся геодинамическом состоянии массива. «Характерно, что техногенная сейсмичность, вызванная эксплуатацией рудника «Умбозеро», настолько «раскачала» геологическую блочную структуру северо-западной части Ловозерского массива, что в последние годы произошло несколько землетрясений, очаги которых расположены в западной части шахтного поля рудника «Карнасурт», чего раньше не наблюдалось» [215]. Попытки обнаружить устойчивую периодичность в проявлении техногенной сейсмичности Ловозерского массива не привели к успеху. Также не было обнаружено какой-либо взаимосвязи между проявлением природной и техногенной сейсмичности [210, 217]. Следует также отметить, что в августе 2009 г. эксплуатация рудника «Умбозеро» была полностью остановлена, что привело к его затоплению, вызвав кратковременное резкое увеличение слабых сейсмических событий. В последующие годы их число существенно понизилось.

В Оленегорской ПТС, удаленной от базовых сейсмостанций на сотню километров, статистика зарегистрированных событий в настоящее время недостаточна для надежной реконструкции вариаций временного хода слабой сейсмичности тектонического происхождения.

Поскольку наблюдения в районе Печенгской ПТС начались недавно, накопленная к настоящему времени статистика является недостаточной для соответствующего анализа.

Параметры сейсмического режима при ведении крупномасштабных горных работ по данным локальных сейсмических станций приведены ниже.

\subsection{2. Пространственно-временные закономерности эволюции параметров сейсмичности в геомеханическом пространстве апатитовых рудников}

Хибинская ПТС включает в себя ряд месторождений, отрабатываемых в настоящее время открытым, подземным и комбинированным способами.

Акционерное общество «Апатит» ведет крупномасштабные горные работы на Кукисвумчоррском и Юкспорском месторождениях - Кировским рудником, «Апатитовом Цирке» и «Плато Расвумчорр» - Расвумчоррским, Коашвинском и Ньоркпахкском - Восточным.

Акционерное общество «Северо-Западная Фосфорная Компания» («СЗФК») начало отработку запасов месторождения «Олений ручей» одноименным рудником.

В настоящее время только на Кировском и Расвумчоррском рудниках установлены автоматизированные системы контроля сейсмичности массива, централизованная обработка данных которых осуществляется сотрудниками Центра геофизического мониторинга АО «Апатит» (ЦГМ). 


\subsubsection{1. Месторождения «Апатитовый Цирк» и «Плато Расвумчорр»}

На Расвумчоррском руднике в 2013-2015 гг. наблюдаются как сезонный рост уровня сейсмоактивности, так и рост сейсмоактивности, связанный с технологией ведения горных работ. На рисунке 5.67 видно, что в этот период здесь зарегистрировано малое число событий с энергией от $10^{3}$ Дж. Если раньше ежемесячно регистрировалось до 500, а иногда и более событий, то в этот период их число зачастую не достигает и 100 в месяц.

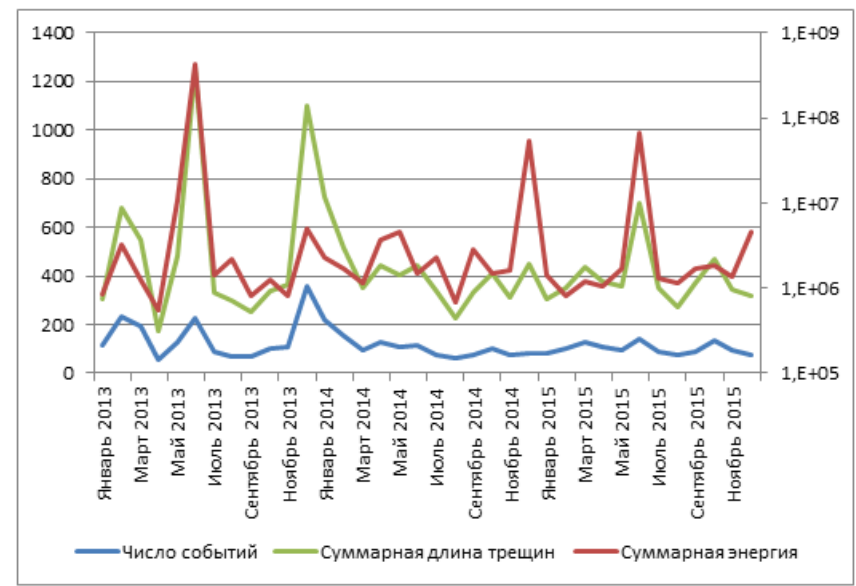

Pис. 5.67. Динамика сейсмической активности месторождений «Апатитовый Цирк» и «Плато Расвумчорр» в течение 2013-2015 гг.

Тем не менее достаточно отчетливо выделяются сезонные повышения показателей сейсмического режима в мае-июне 2013 и 2015 гг., связанные с интенсивным снеготаянием (менее заметен рост показателей в тот же период в 2014 г.). Также отмечается повышение показателей сейсмичности в ноябре-декабре 2013 и 2014 гг.

На рисунке 5.68 представлено распределение по энергии сейсмических событий, зарегистрированных в 2013-2015 гг. Всего было зарегистрировано 38282 сейсмических события. Сейсмический момент определен для 6331 событий, что составляет около $16 \%$ от общего числа.

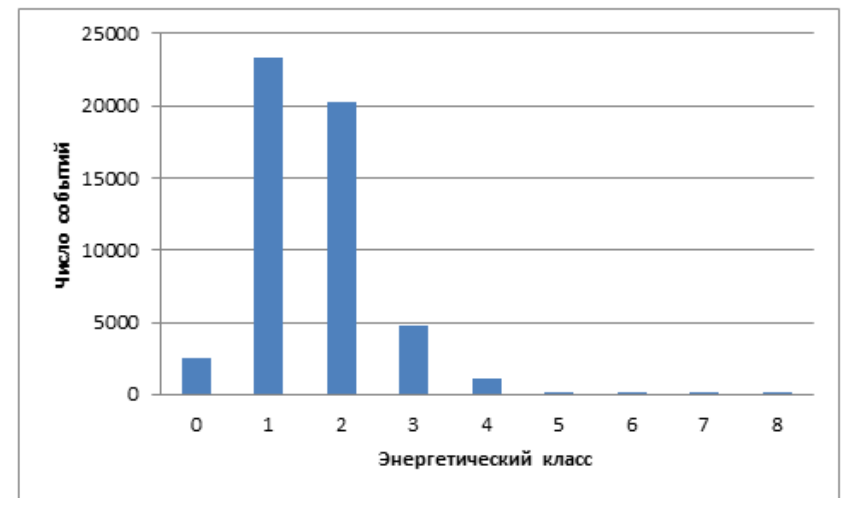

Рис. 5.68. Распределение по энергии сейсмических событий, регистрируемых на месторождении «Апатитовый Цирк» и «Плато Расвумчорр» (Расвумчоррский рудник, 2013-2015 гг.) 


\subsubsection{2. Кукисвумчоррское месторождение}

В этот период на Кукисвумчоррском месторождении в пределах шахтного поля Кукисвумчоррского крыла Кировского рудника (КР) (рис. 5.69) в среднем регистрировалось 150 сейсмических событий в месяц с энергией от $10^{3}$ Дж, что вдвое ниже, чем в предыдущие три года (в 2010-2012 гг. - в среднем до 300 событий в месяц). Наблюдается тенденция роста уровня сейсмоактивности в 2015 г. Максимальное число событий (347) было зарегистрировано в мае 2015 г.

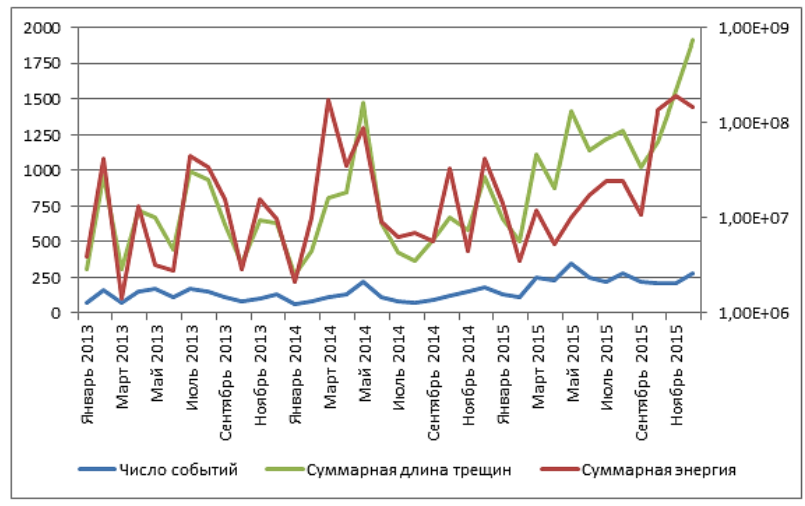

Рис. 5.69. Динамика сейсмической активности Кукисвумчоррского месторождения в течение 2013-2015 гг.

Особенность сейсмической активности в 2013-2015 гг. заключается в следующем: по сравнению с предыдущими периодами наблюдений сложнее выделить сезонную составляющую. В течение последних трех лет, как и в предыдущие годы, наблюдаются сезонные всплески сейсмоактивности (рост числа сейсмических событий), связанные, как правило, с повышенной обводненностью массива, резкой сменой дневного и ночного температурного режимов, характерные в основном для мая-июня (интенсивное снеготаяние).

На рисунке 5.70 представлено распределение по энергии сейсмических событий, зарегистрированных в 2013-2015 гг. Всего было зарегистрировано 14554 сейсмических события. Сейсмический момент определен для 8231 событий (примерно $56 \%$ от общего числа).

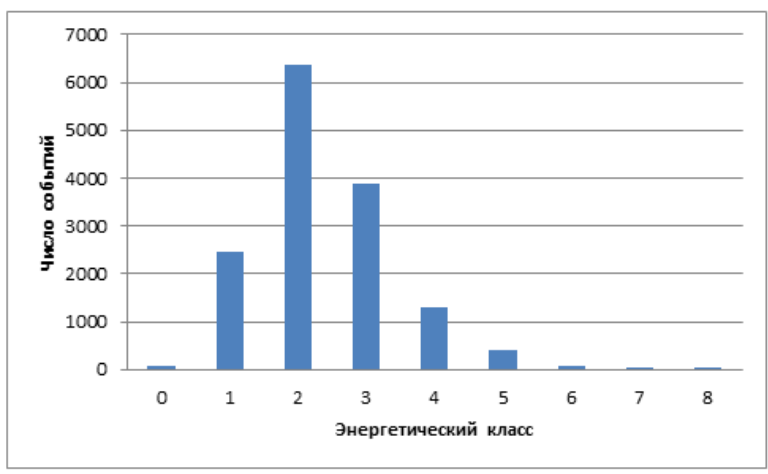

Рис. 5.70. Распределение сейсмических событий по энергии, Кукисвумчоррское крыло КР, 2013-2015 гг. 


\subsubsection{3. Юкспорское месторождение}

На Юкспорском месторождении в пределах шахтного поля Юкспорского крыла КР за анализируемый период наблюдается значительный рост уровня сейсмической активности в 2015 г. (рис. 5.71).

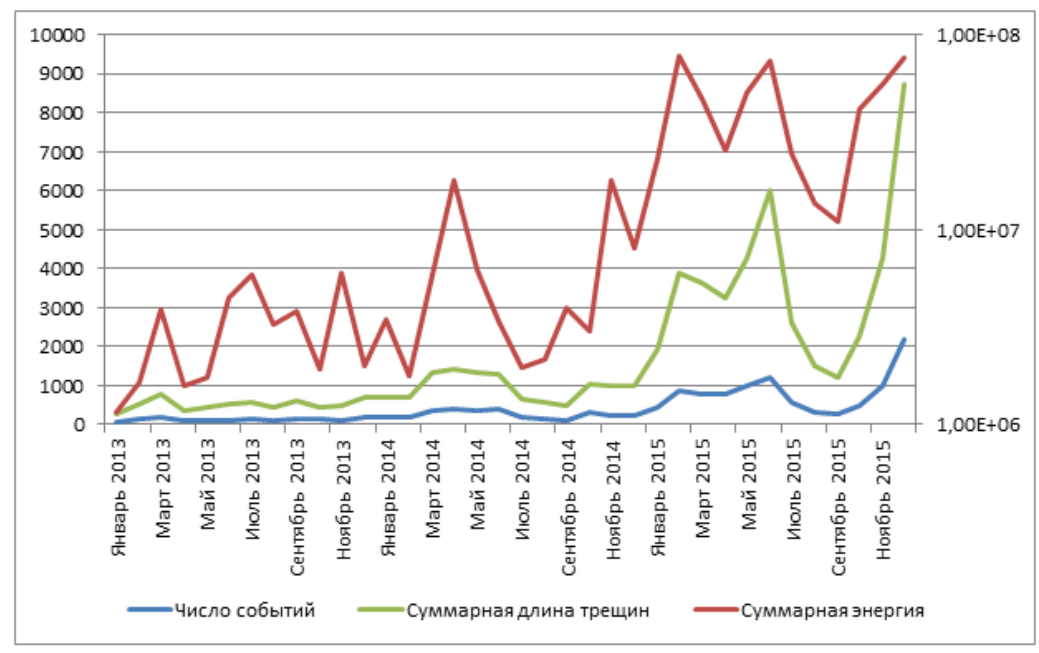

Pис. 5.71. Динамика сейсмической активности Юкспорского месторождения в течение 2013-2015 гг.

На представленных графиках видно, что наблюдается значительный рост уровня сейсмической активности, начиная с октября 2014 г., который закончился спадом с июля по сентябрь 2015 г., а затем начался новый рост, который продолжался до конца 2015 г.

Ниже приведен анализ сейсмической активности Юкспорского месторождения за период наблюдений октябрь 2014 г. — август 2015 г. (табл. 5.10).

Таблииа 5.10

Показатели сейсмического режима Юкспорского месторождения за выбранный период наблюдений

\begin{tabular}{|l|c|c|c|c|c|}
\hline Период & $\begin{array}{c}\text { Число } \\
\text { событий }\end{array}$ & $\begin{array}{c}\text { Суммарное } \\
\text { энерговыделение, Дж }\end{array}$ & $\begin{array}{c}\text { Суммарная } \\
\text { длина трещин, м }\end{array}$ & $\begin{array}{c}\text { Средняя } \\
\text { энергия, Дж }\end{array}$ & $\begin{array}{c}\text { Средняя длина } \\
\text { трещин, Дж }\end{array}$ \\
\hline Окт. 14 & 310 & $3,00 \cdot 10^{6}$ & 1025 & $9,66 \cdot 10^{3}$ & 3,31 \\
\hline Ноя. 14 & 251 & $1,81 \cdot 10^{7}$ & 1011 & $7,20 \cdot 10^{4}$ & 4,03 \\
\hline Дек. 14 & 231 & $8,12 \cdot 10^{6}$ & 994 & $3,52 \cdot 10^{4}$ & 4,30 \\
\hline Янв. 15 & 430 & $2,34 \cdot 10^{7}$ & 1915 & $5,44 \cdot 10^{4}$ & 4,45 \\
\hline Фев. 15 & 851 & $7,85 \cdot 10^{7}$ & 3902 & $9,22 \cdot 10^{4}$ & 4,58 \\
\hline Мар. 15 & 784 & $4,67 \cdot 10^{7}$ & 3638 & $5,96 \cdot 10^{4}$ & 4,64 \\
\hline Апр.15 & 782 & $2,57 \cdot 10^{7}$ & 3257 & $3,29 \cdot 10^{4}$ & 4,16 \\
\hline Май. 15 & 1000 & $5,06 \cdot 10^{7}$ & 4277 & $5,06 \cdot 10^{4}$ & 4,28 \\
\hline Июн. 15 & 1193 & $7,35 \cdot 10^{7}$ & 5998 & $6,16 \cdot 10^{4}$ & 5,03 \\
\hline Июл. 15 & 558 & $2,46 \cdot 10^{7}$ & 2608 & $4,40 \cdot 10^{4}$ & 4,67 \\
\hline Авг. 15 & 307 & $1,36 \cdot 10^{7}$ & 1506 & $4,42 \cdot 10^{4}$ & 4,91 \\
\hline
\end{tabular}


Значительной рост сейсмической активности Юкспорского месторождения в этот период связан со сложной горнотехнической обстановкой: развитие горных работ привело к образованию целиков в районе разрезов Р11, P12 (средняя отметка +400 м), негативно влияющих на устойчивость выработок и безопасность ведения горных работ. На рисунке 5.72 представлено распределение сейсмических событий по энергии.

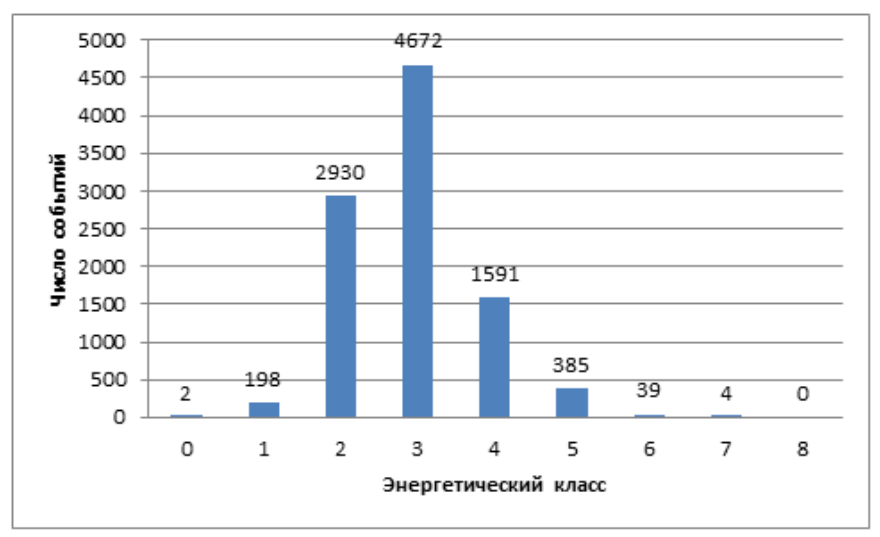

Рис. 5.72. Распределение сейсмических событий по энергии, Юкспорское крыло КР, октябрь 2014 г. - август 2015 г.

Рисунки 5.73-5.83 демонстрируют ежемесячную миграцию сейсмичности в течение рассматриваемого периода.

Представленные рисунки показывают, что значительный рост сейсмической активности в районе отм. +400 м произошел в феврале 2015 г, и до июня 2015 г. уровень сейсмоактивности оставался высоким. В июле и августе на проблемном участке не зарегистрировано ни одного сильного сейсмического события. Хотя число событий с энергией менее $10^{6}$ Дж остается высоким (но меньше, чем в предыдущие месяцы).

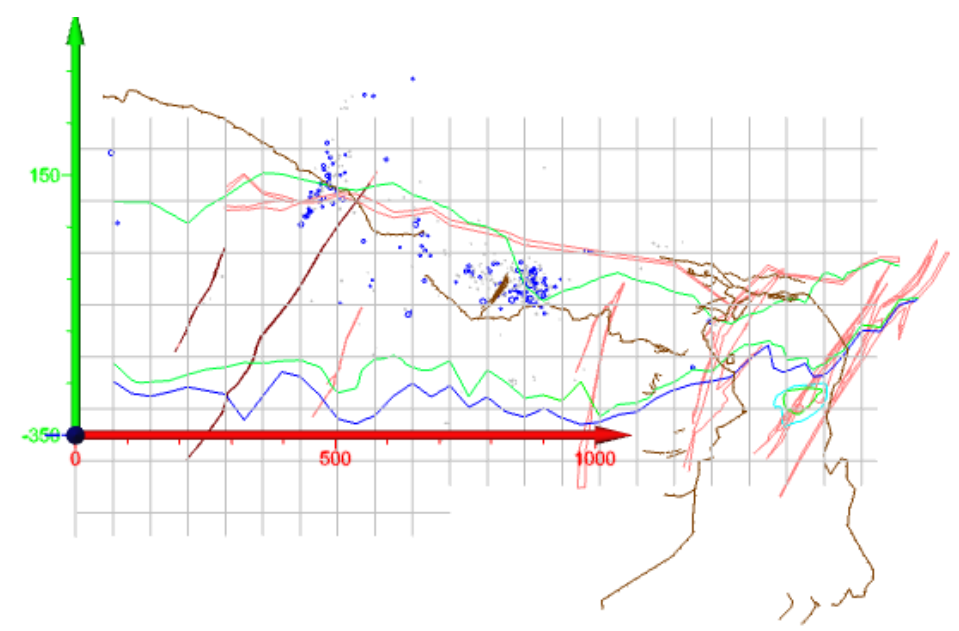

Рис. 5.73. Характер сейсмичности в октябре 2014 г. 


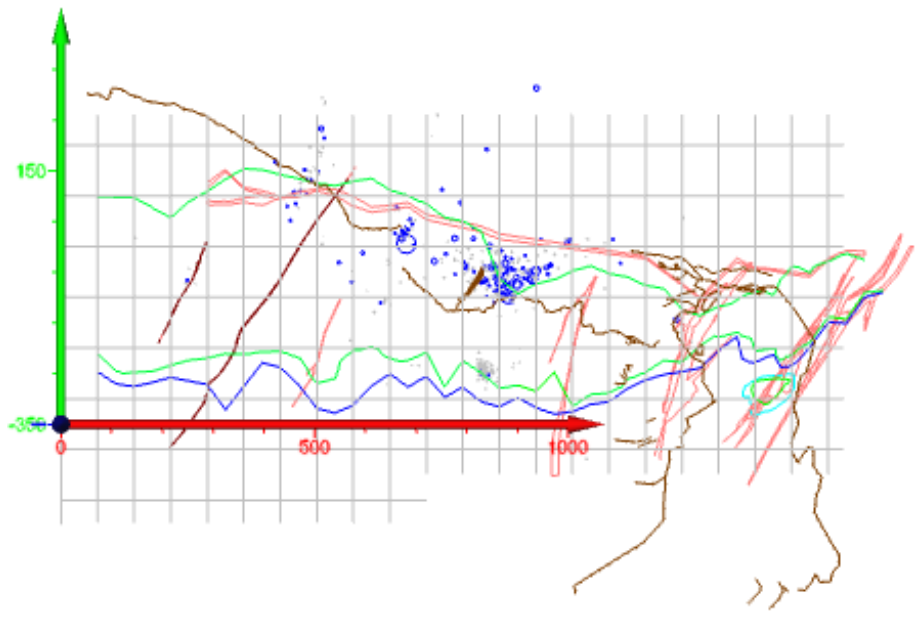

Рис. 5.74. Характер сейсмичности в ноябре 2014 г.

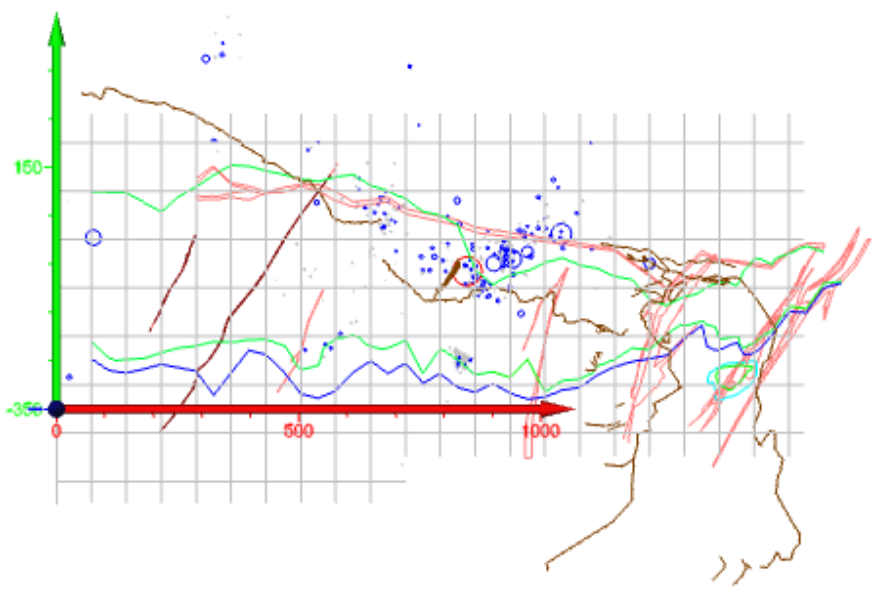

Рис. 5.75. Характер сейсмичности в декабре 2014 г.

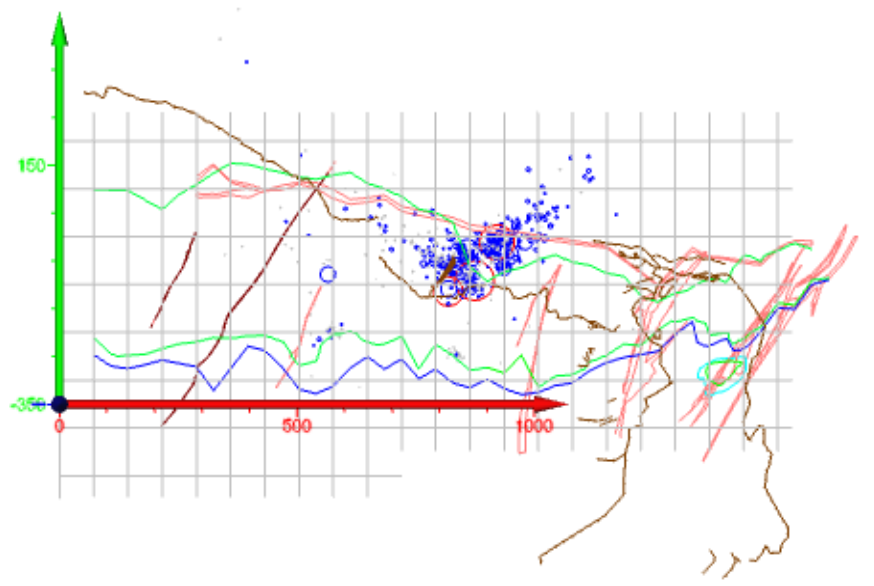

Рис. 5.76. Характер сейсмичности в январе 2015 г. 


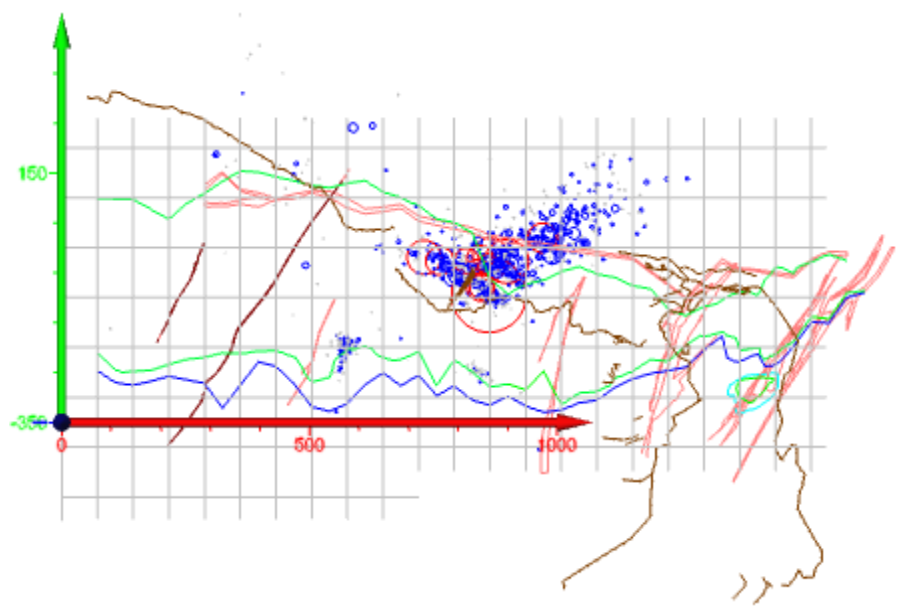

Рис. 5.77. Характер сейсмичности в феврале 2015 г.

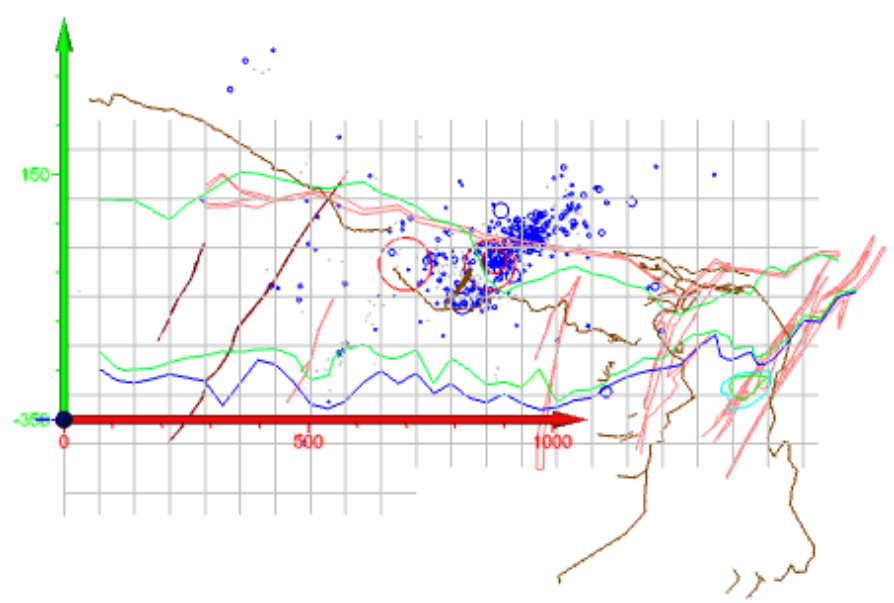

Рис. 5.78. Характер сейсмичности в марте 2015 г.

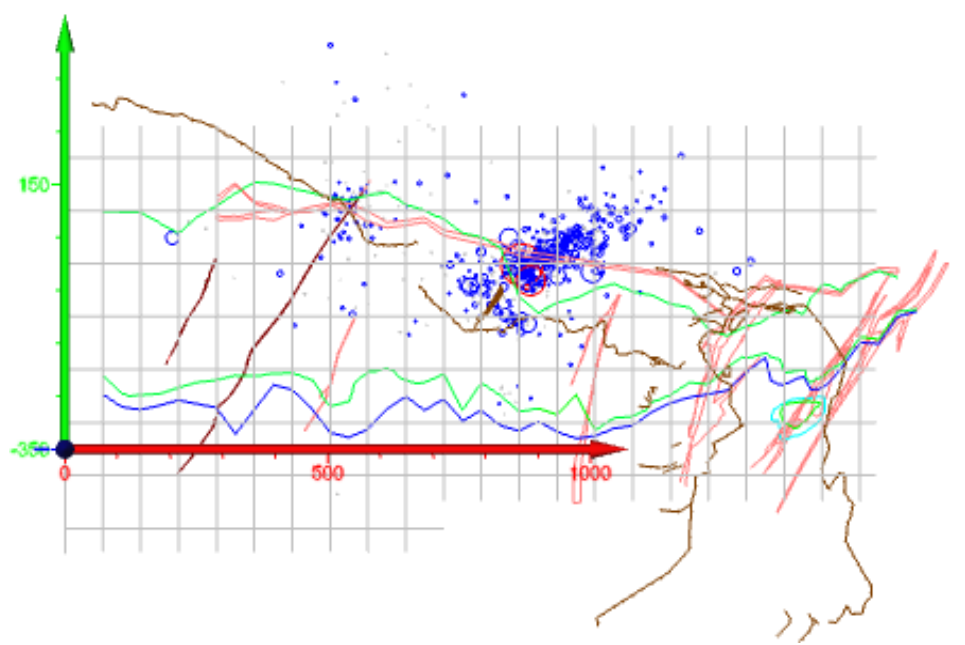

Рис. 5.79. Характер сейсмичности в апреле 2015 г. 


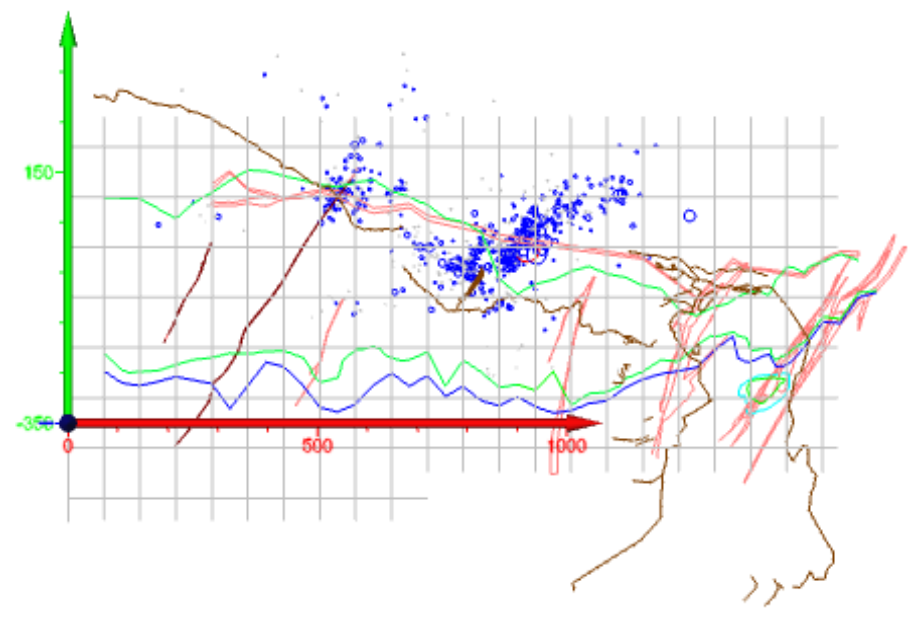

Рис. 5.80. Характер сейсмичности в мае 2015 г.

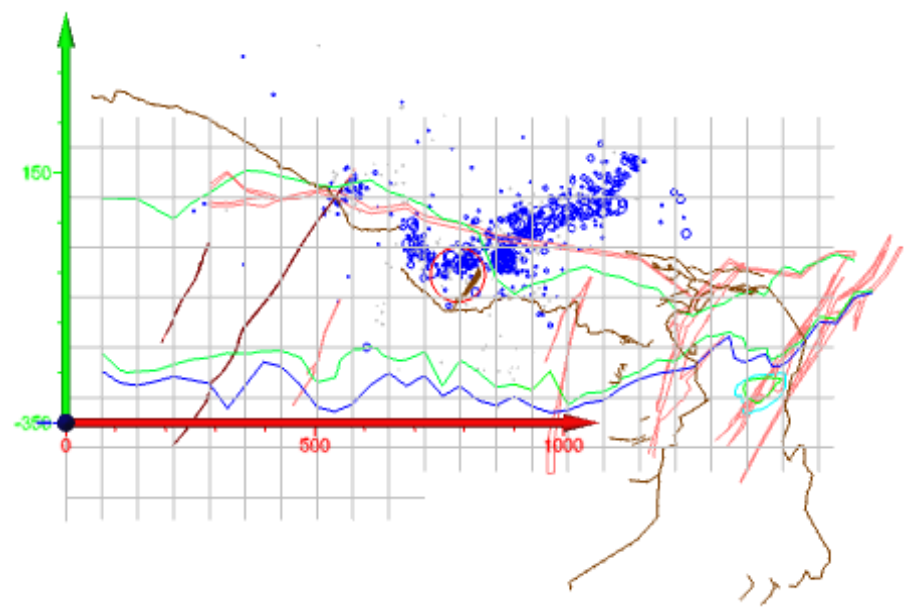

Рис. 5.81. Характер сейсмичности в июне 2015 г.

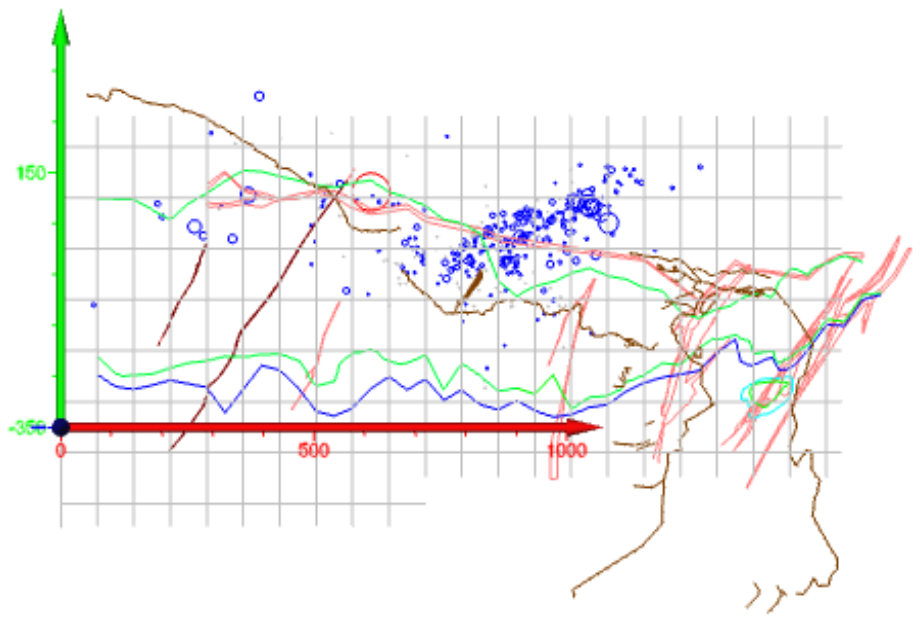

Рис. 5.82. Характер сейсмичности в июле 2015 г. 


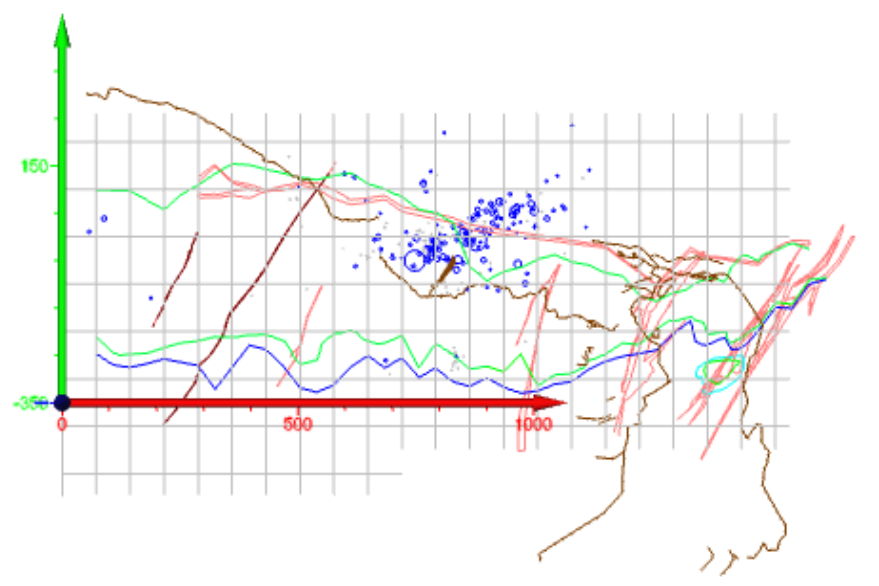

Рис. 5.83. Характер сейсмичности в августе 2015 г.

На проблемном участке (рис. 5.6.84-5.87) развитие горных работ привело к образованию целиков в районе разрезов $\mathrm{P} 11+30 \div \mathrm{P} 12$, негативно влияющих на устойчивость выработок и безопасность ведения горных работ в данной области массива, что подтверждает и высокий уровень сейсмической активности. В сложившейся ситуации ведение очистных работ было существенно затруднено.

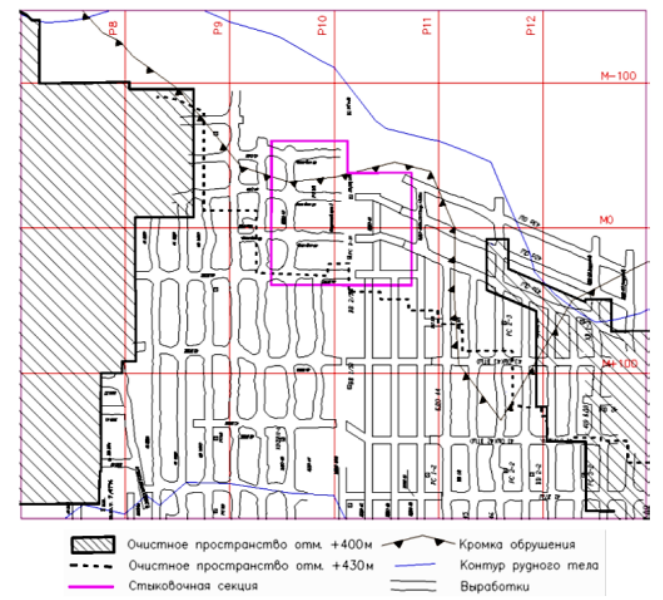

$a$

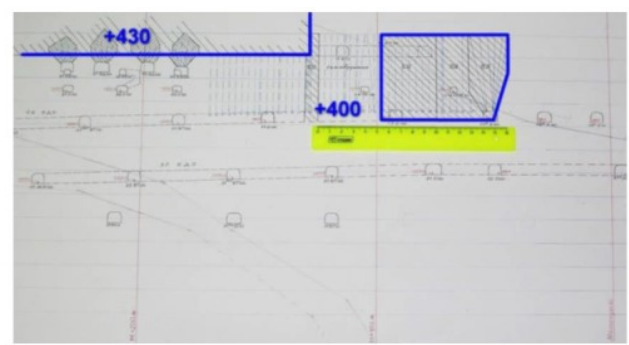

$\sigma$

Рис. 5.84. Горнотехническая ситуация на конец февраля 2015 г.: $a$ - план 4-го буро-доставочного подэтажа средняя отметка +400 м; $\sigma$ - разрез 12 


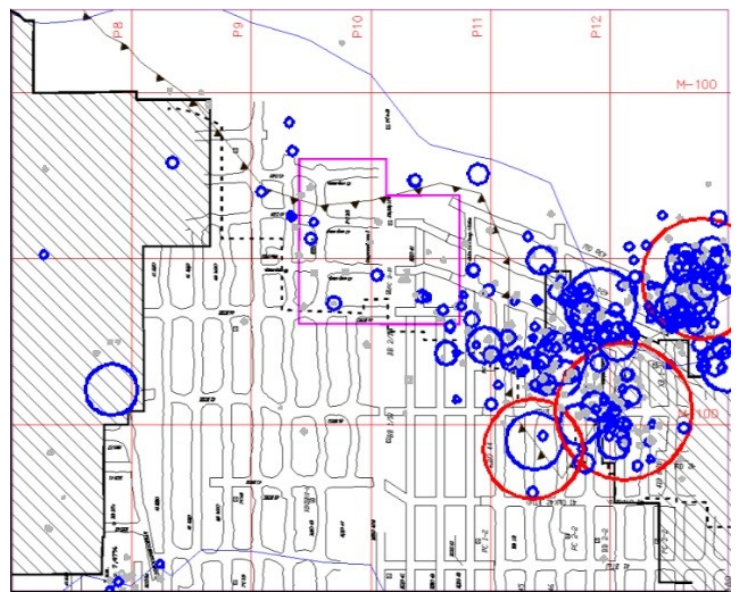

Рис. 5.85. Горнотехническая ситуация на конец февраля 2015 г. и сейсмические события, зарегистрированные в январе 2015 г.

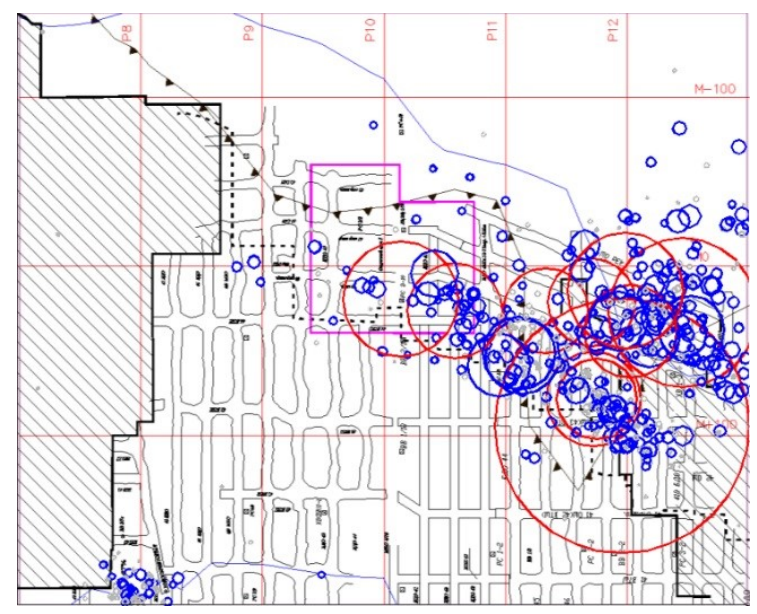

Рис. 5.86. Горнотехническая ситуация на конец февраля 2015 г. и сейсмические события, зарегистрированные в феврале 2015 г.

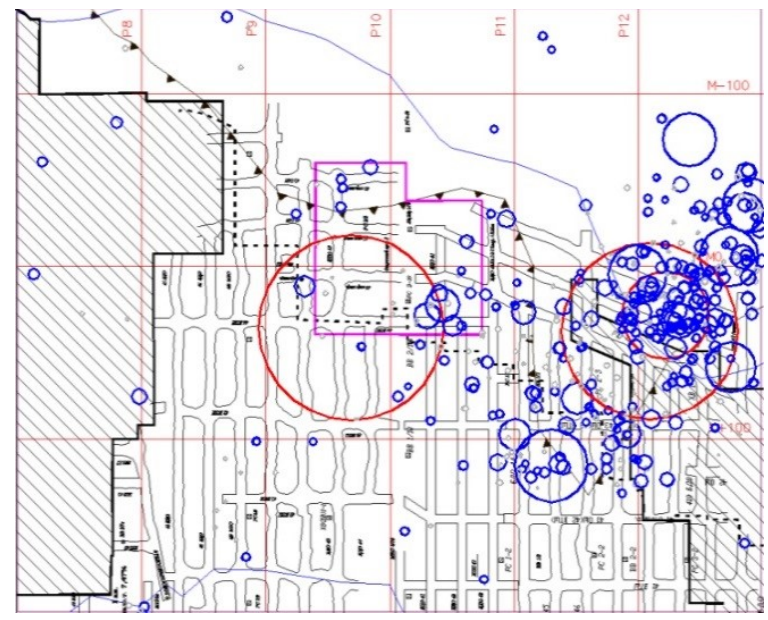

Рис. 5.87. Горнотехническая ситуация на конец февраля 2015 г. и сейсмические события, зарегистрированные в марте 2015 г. 
Таким образом, результаты анализа сейсмических наблюдений на Кировском руднике свидетельствуют о сложной горнотехнической ситуации, обусловленной как ведением горных работ, так активизацией процессов трещинообразования и развитием магистральных разрывов в консоли налегающей толщи висячих пород отрабатываемых Кукисвумчоррского и Юкспорского месторождений. Такое поведение массива свидетельствует о том, что накопленные напряжения в нем достигли величин близких к критическому и дальнейшее развитие очистных работ с использованием массовых взрывов может привести к реализации сильных сейсмических событий в пределах висячего бока. В наибольшей степени это относится к отрабатываемой части Юкспорского месторождения.

\subsection{3. Пространственно-временные закономерности кластеризации сейсмической эмиссии в Хибинских горнотехнических системах}

Многолетними исследованиями установлено, что сейсмические события на рудниках проявляются неравномерно и зачастую представляют собой скопления близкорасположенных событий, которые могут рассматриваться как кластеры событий [218, 219]. Такие кластеры могут быть приурочены к какой-либо геологической структуре, месту ведения горных работ либо могут образовываться под влиянием нескольких факторов как природных, так и техногенных. Важной задачей является не только определение числа кластеров, но и возможность дальнейшего изучения каждого кластера в отдельности [220].

Известно, что кластерный анализ позволяет: разрабатывать классификации объектов; проводить исследования различных схем группирования объектов; формулировать гипотезы возникновения объектов; осуществлять оценку выдвинутых гипотез.

В общем случае кластерный анализ предназначен для объединения некоторых объектов в группы таким образом, чтобы в один класс попадали максимально схожие объекты, а объекты различных классов максимально отличались друг от друга. Количественный показатель сходства рассчитывается в зависимости от параметров, характеризующих объекты. В случае, когда не только известно, что существует некая кластеризация событий, но и можно предположить (например, исходя из числа основных влияющих на сейсмичность факторов) возможное число кластеров, в первую очередь важен четвертый пункт.

Существуют различные методы кластерного анализа групп данных. Исходя из необходимости детального рассмотрения четвертого пункта выбран метод $K$-средних, основанный на том, что уже имеется представление относительно числа кластеров. Для расчета применяется программный комплекс STATISTICA. Целью этого анализа является разбиение событий на группы, каждая из которых соответствует определенному геодинамическому блоку. То есть сейсмические события, попавшие в одну группу, характеризуются одинаковой или схожей причиной возникновения, которая впоследствии изучается более детально при выполнении многоэтапного анализа.

При выполнении кластерного анализа в первом приближении рассматривали сейсмологический каталог, содержащий следующую информацию о каждом зарегистрированном событии: дату, время, координаты, величину энергии. Для кластеризации рассматривается выборка событий за определенный период времени (в зависимости от поставленной задачи, например, один год). 
В качестве переменных при кластеризации используются координаты событий и величина их энергии в виде энергетического класса события $(K)$, для которого введены различные весовые коэффициенты (от 1 до 200). Необходимость использования значений энергетического класса с весовыми коэффициентами обусловлена тем, что при кластеризации вычисляются расстояния как между кластерами, так и между объектами каждого кластера. Если проводить ее с использованием только координат событий, то при вычислении расстояния между кластерами не возникает проблем. При добавлении же в нее четвертой переменной (энергии) возникает проблема масштабов единиц измерения - координаты измеряются десятками, сотнями или тысячами метров, а энергия - от $10^{3}$ Дж до $10^{9}$ Дж. Попытка использовать значения энергии в таком виде привела к неприемлемым результатам, поскольку значение энергии при изменении расстояний между кластерами давало значительно больший вклад, чем координаты. В связи с этим при выполнении расчетов был использован параметр энергетического класса событий $K$, а сами расчеты проведены при разных весовых коэффициентах для этого параметра (от 1 до 200). Координаты учитывались с коэффициентом 1. Другими словами, координаты события оказывают одинаковое влияние на результаты кластеризации, а энергетический класс - различное, в зависимости от выбранного весового коэффициента.

С добавлением в базу данных сейсмичности значений новых параметров стало очевидно, что предложенный метод весовых коэффициентов не будет эффективным, поскольку при учете новых параметров (например, сейсмический момент) снова возникнет проблема масштабов единиц измерения, и придется подбирать весовые коэффициенты не для одного параметра, а уже для нескольких, что значительно усложняет процесс проведения кластерного анализа.

Поэтому был использован метод стандартизации - статистический метод, который приводит все исходные значения к набору сравнимых элементов из распределения с нулевым средним и стандартным отклонением, равным 1. Такой вид преобразования значительно упрощает механизм сравнения переменных.

В дальнейшем проводился кластерный анализ с учетом различных параметров сейсмических событий:

1) координаты $X, Y, Z$;

2) координаты $X, Y, Z$, энергия;

3) координаты $X, Y, Z$, сейсмический момент;

4) координаты $X, Y, Z$, энергия, сейсмический момент.

По изложенной методике были проведены исследования по определению пространственно-временных закономерностей распределения кластеров сейсмических событий в различных зонах ведения горных работ.

\subsubsection{1. Кукисвумчоррское месторождение}

В качестве примера приведены результаты кластерного анализа для Кукисвумчоррского месторождения. Первым этапом являлся анализ структурных блоков месторождения. В пределах шахтного поля Кукисвумчоррского крыла КР выделено 17 структурных блоков, отделенных друг от друга различными разрывными нарушениями. В зависимости от степени влияния горных работ на конкретный структурный блок и геодинамической активности разрывных структур поле напряжений в каждом блоке претерпевает пространственно-временные изменения, формируя зоны концентрации и разгрузки. Так, практика отработки месторождения показала, что наибольшая сейсмическая активность и связанные с ней динамические проявления горного давления приурочены в основном к разрывным нарушениям № 3, 4, 5 и 7 (рис. 5.88). 


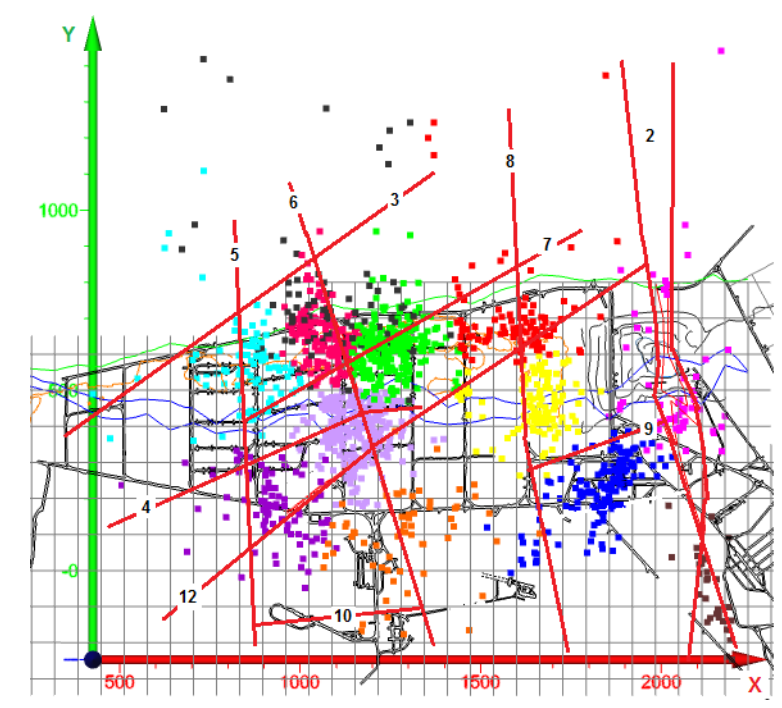

Рис. 5.88. Кластеризация сейсмических событий Кукисвумчоррского месторождения (Кукисвумчоррское крыло КР, гор. +172 м)

На рисунке 5.88 представлены результаты кластеризации зарегистрированных сейсмических событий в течение одного года в пределах шахтного поля Кукисвумчоррского крыла КР (приведена проекция отрабатываемого гор. +172 м).

Проведенный анализ блочного строения массива горных пород и сопоставление расположения отдельных блоков с местами ведения горных работ показал, что оптимальным числом кластеров для Кукисвумчоррского месторождения является 12. Анализ местоположения каждого из выделенных кластеров позволил оценить как приуроченность зарегистрированных событий к разрывным нарушениям (существующим и формирующимся), так и вероятность роста уровня сейсмической активности на проектируемом к отработке гор. +92 м.

В результате проведенного исследования установлено:

- кластеры приурочены к Саамскому разлому;

- 5 кластеров - это события, произошедшие в висячем боку месторождения;

- 5 кластеров расположены в зонах пересечения нескольких разломов, а также в местах ведения горных работ (для этой группы кластеров характерно наличие центра кластера (плотная группа событий) и разброс одиночных событий вокруг центра).

На рисунке 5.89 представлен пример выделенного кластера сейсмических событий № 1. Число событий в кластере с энергией от $10^{3}$ Дж и более составляет 290.

Максимальная энергия - порядка $10^{4}$ Дж. Кластер расположен на пересечении трех разрывных нарушений, которые являются границами блоков. По вертикали события равномерно распределены между рабочими гор. $+172,+252$ и +322 м.

Кластерный анализ также позволяет выделить группы сейсмических событий, приуроченных к каждому горизонту. На рисунке 5.90 представлены кластеры событий, расположенные вблизи гор. +172 м.

Выделяются три кластера с большим числом событий, произошедших плотной группой. Один кластер - на пересечении трех разломов $(4,6,12)$, два кластера разделены разломом 6. В других кластерах распределение событий менее плотное, поэтому определить причину их возникновения сложнее. 


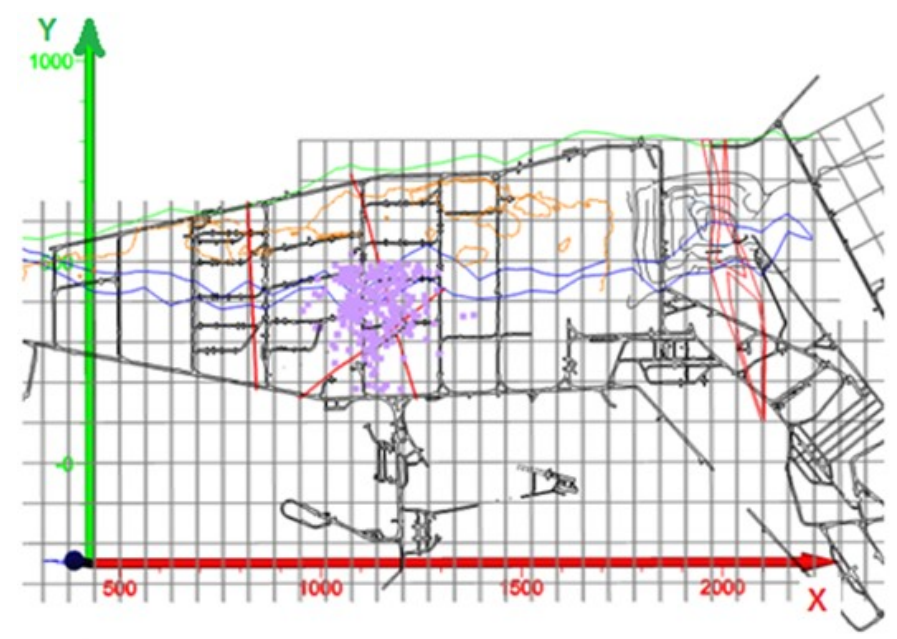

a

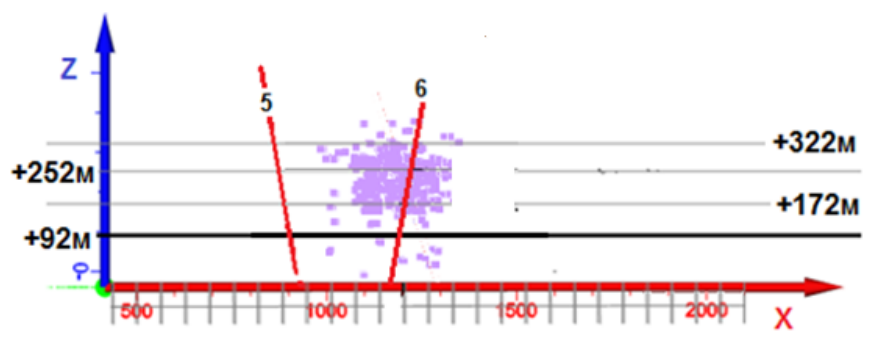

б

Рис. 5.89. Выделенный кластер сейсмических событий: $a-$ в плане (проекция $X Y)$; $\sigma$ - в разрезе (проекция $X Z$ )

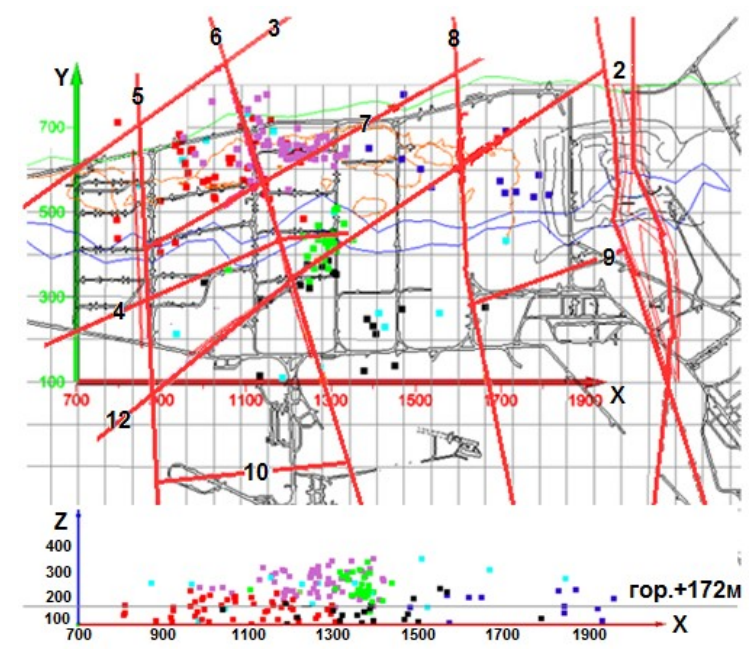

Рис. 5.90. Кластеризация сейсмических событий Кукисвумчоррского месторождения (Кукисвумчоррское крыло КР, отм. +172 м 


\subsubsection{2. Юкспорское месторождение}

Число кластеров сейсмических событий определяли с учетом выделенных структурных блоков в пределах отрабатываемого месторождения. При этом кластерный анализ проводили таким образом, чтобы усилить влияние координаты $Z$ сейсмических событий (рис. 5.91). Для наглядности представлена кластеризация событий для трех кластеров.
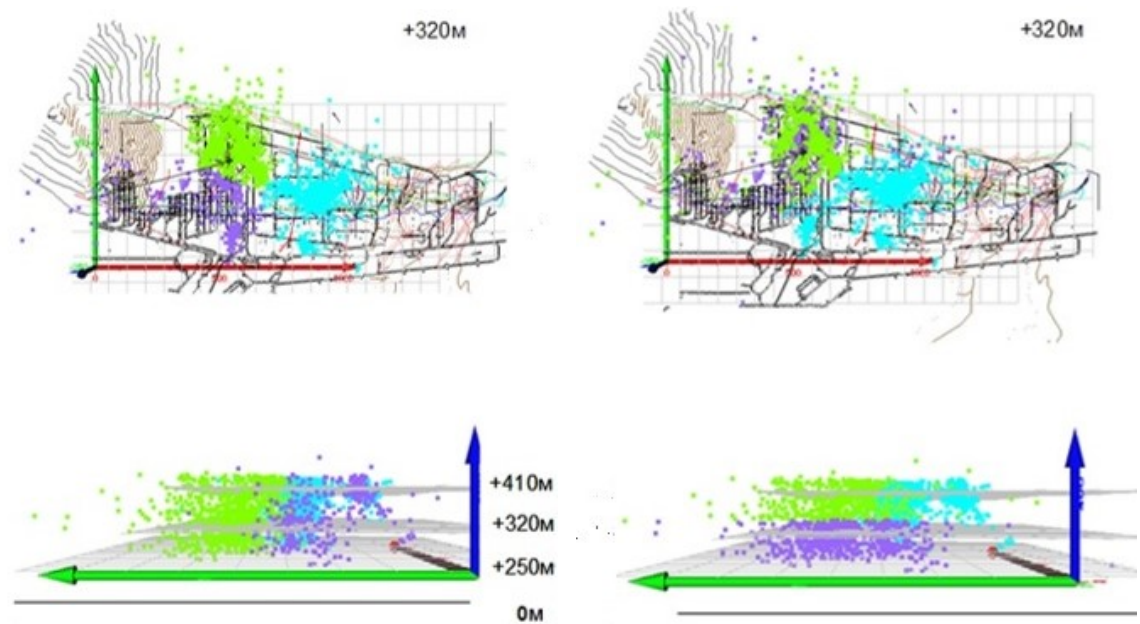

6

Рис. 5.91. Пример двух подходов к проведению кластерного анализа: $a-$ обычная кластеризация; $\sigma$ - усиление влияния координаты $Z$ сейсмических событий

На приведенных на рисунке 5.91 данных видно, что благодаря применению подхода усиления влияния координаты $Z$ сейсмических событий появляется возможность более детального анализа взаимосвязи сейсмических событий и горно-геологических факторов (рис. 5.92).
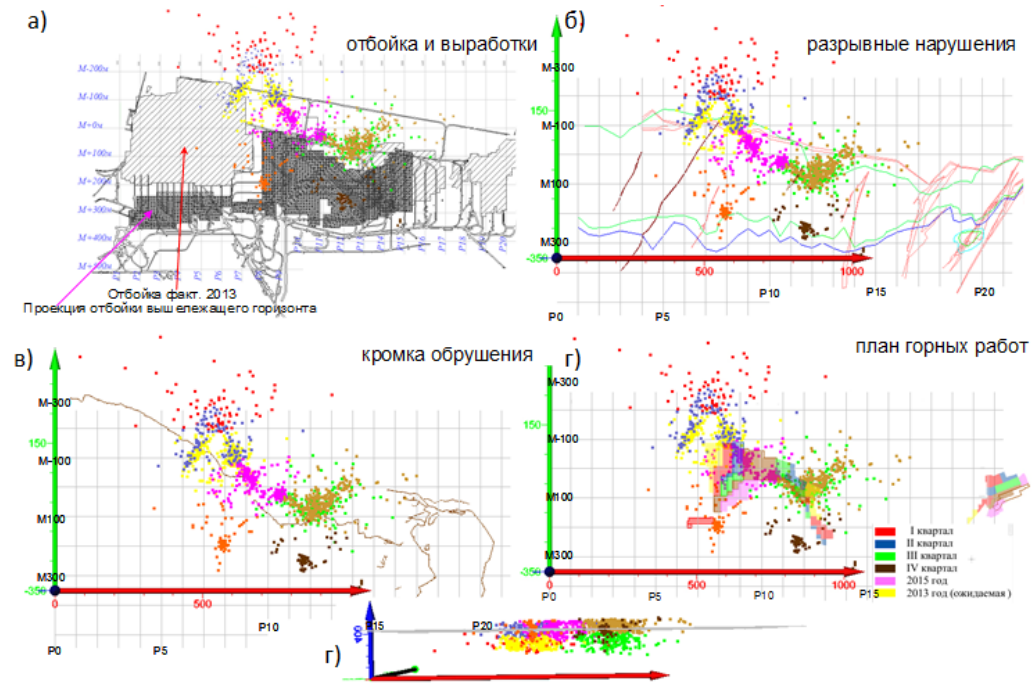

Рис. 5.92. Кластеры сейсмических событий на Юкспорском месторождении (Юкспорское крыло КР, отм. + 410 м, 2014 г.) 
На приведенных на рисунке 5.92 данных видно, что вблизи отрабатываемого гор. +410 м выделены несколько групп кластеров сейсмических событий. Часть кластеров - это события, произошедшие в висячем боку рудного тела (рис. 5.92 в). Другие кластеры событий расположены вблизи разломов (рис. 5.92 б), а также в местах ведения горных работ (рис. $5.92 a, 2$ ).

Ведение горных работ на этом горизонте, наряду с природными факторами (значительная глубина горных работ, действие высоких тектонических напряжений, структурные неоднородности), стали основной причиной высокого уровня сейсмической активности в течение 2014-2015 гг. Кластерный анализ позволил выделить группы событий по степени влияния на уровень сейсмической активности различных горно-геологических факторов. Так, например, прослеживается связь миграции сейсмических событий трех кластеров с поквартальным продвижением горных работ. В первом кластере 185 сейсмических событий с энергией от $10^{3}$ Дж, максимальная энергия $-1,0 \cdot 10^{5}$ Дж, суммарная энергия $-1,2 \cdot 10^{6}$ Дж. В области, где зарегистрированы события данного кластера, нет крупных разрывных нарушений. В составе других двух кластеров 287 и 92 сейсмических события (с энергией от $10^{3}$ Дж), максимальная энергия - $1,1 \cdot 10^{6}$ Дж и $8,8 \cdot 10^{4}$ Дж, суммарная выделившаяся энергия $-3,6 \cdot 10^{6}$ Дж и $4,5 \cdot 10^{5}$ Дж. По-видимому, это связано с тем, что в этой области на уровень сейсмической активности, помимо продвижения фронта горных работ, влияют имеющиеся в массиве мончикитовая дайка и зона шпреуштейнизированных пород.

\subsection{4. Влияние метеорологических факторов на процессы трещинообразования вмассиве горных пород}

Влияние природных факторов установлено при эксплуатации многих месторождений [221-223]. Известны случаи, когда резкие изменения атмосферного давления, связанные с прохождением атмосферных фронтов, совпадали с местными землетрясениями.

Анализ баз данных регистрации сейсмичности в районах крупномасштабных горных работ позволил установить изменчивость сейсмического режима различных ПТС, которая обусловлена наличием возмущающих техногенных и природных факторов.

Результаты анализа влияния природных факторов для различных ПТС Кольского полуострова освещены в работах [224-239].

Поля напряжений в массивах горных пород асейсмичных районов формируются не столько действием современных тектонических процессов (хотя они и присутствуют), сколько крупномасштабными горными работами, которые вносят весомый вклад в процесс перераспределения напряжений. Это приводит к накоплению потенциальной энергии в отдельных участках массива. Когда в них накапливается ее критическое значение, она преобразуется в кинетическую энергию геодинамических процессов (от растрескивания массива до подвижек по тектоническим нарушениям).

Иерархично-блочный массив горных пород, характеризующийся наличием разномасштабной трещиноватости, подвергается перенасыщению жидкостью в периоды интенсивного снеготаяния и обильных дождей в весенний и осенний периоды. Особенно при резких перепадах суточной температуры и атмосферного давления, способствующих интенсивному развитию процессов трещинообразования 
в массиве. В зависимости от пористости и влагопроницаемости пород, слагающих отрабатываемое месторождение, сейсмическая реакция массива на влияющие факторы может быть различной. Поскольку развитие трещиноватости и влагонасыщение массива горных пород приводит к уменьшению сцепления межблоковых связей и, как следствие, нарушению устойчивости пород. При этом вода, проникающая в массив горных пород с поверхности, увеличивает давление в порах и трещинах, является своеобразной «смазкой» на границах между блоками и способствует их смещению друг относительно друга.

\subsubsection{1. Месторождения «Апатитовый Цирк» и «Плато Расвумчорр»}

Проведен сопоставительный анализ сейсмических и метеорологических данных применительно к периодам активизации сейсмической активности, зарегистрированной на месторождениях «Апатитовый Цирк» и «Плато Расвумчорр».

Известно, что наличие поверхностей ослабления в скальном массиве в виде зон окисления горных пород, зон трещиноватости и иных неоднородностей среды в значительной степени снижают прочностные свойства горных пород. Так, например, 23-24 сентября 2004 г. автоматизированной системой контроля сейсмичности массива (АСКСМ) АО «Апатит» был зарегистрирован рост сейсмической активности в районе рудоспуска № 6 Центрального рудника. 24 сентября в 17:29 на Центральном руднике был произведен массовый взрыв. В 19:04 (МСК) АСКСМ было зарегистрировано сейсмическое событие с энергией $2,15 \cdot 10^{9}$ Дж (магнитуда 2,2), которое сопровождалось длительной афтершоковой серией сейсмических событий и классифицировано как техногенное землетрясение.

В результате главного толчка были зафиксированы нарушения крепи нескольких горных выработок в районе рудоспуска № 6. Событие вызвало нарушение целостности торкретбетона, образование трещин по подошве и поднятие бетонного пола, вывал породы и заколообразование. В одной из выработок из образовавшихся трещин на расстоянии 0,5 м от подошвы пошла вода.

Произошедшие разрушения в выработках были вызваны подвижкой блоков массива горных пород по разлому, заполненному водонасыщенными окисленными породами.

Результаты ретроспективного анализа метео- и гидрологических данных показали, что изменение значений атмосферных осадков и скорости водопритока в выработки (рис. 5.93) началось за несколько дней до регистрации техногенного землетрясения, когда наблюдалось увеличение количества осадков и рост обводненности по трем рудоспускам.

Таким образом, массовый взрыв привел к увеличению сейсмической активности, а в напряженном участке обводненного массива - к реализации техногенного землетрясения.

Рассмотрим пример увеличения сейсмической активности в весенний период наблюдений. 17, 21, 23, 26, 27 и 31 мая 2013 г. АСКСМ были зарегистрированы сейсмические события с энергией $E \geq 10^{6}$ Дж, общее количество которых составило 9. Наряду с этим с каждым днем число сейсмособытий с энергией $10^{3}-10^{7}$ Дж увеличивалось: так 18 мая их было зарегистрировано 14; 19 мая - 17; 20 мая - 19 событий. С 26 мая количество регистрируемых событий в этом районе увеличилось до 50 в сут, из них 9 имели энергию $E \geq 10^{5}$ Дж. Так, 1 июня 2013 г. в 11:22:42 в карьере Центрального 
рудника объединенной системой контроля сейсмичности массива было зарегистрировано сейсмическое событие с магнитудой 2,7 , которое сопровождалось длительной серией афтершоков (общее количество составило 162 события за сутки с энергией от $10^{3}$ до $10^{9}$ Дж, из них 5 событий - с энергией более $10^{6}$ Дж, в зоне стыковки и районе рудоспусков зарегистрировано 90 событий из 162). А 2 июня 2013 г. с 01:00 до 02:00 были зарегистрированы сейсмособытия с энергией $10^{5} \div 10^{6}$ Дж в районе рудоспуска № 6, при этом в выработках подземного Расвумчоррского рудника горнорабочие ощутили серию толчков.

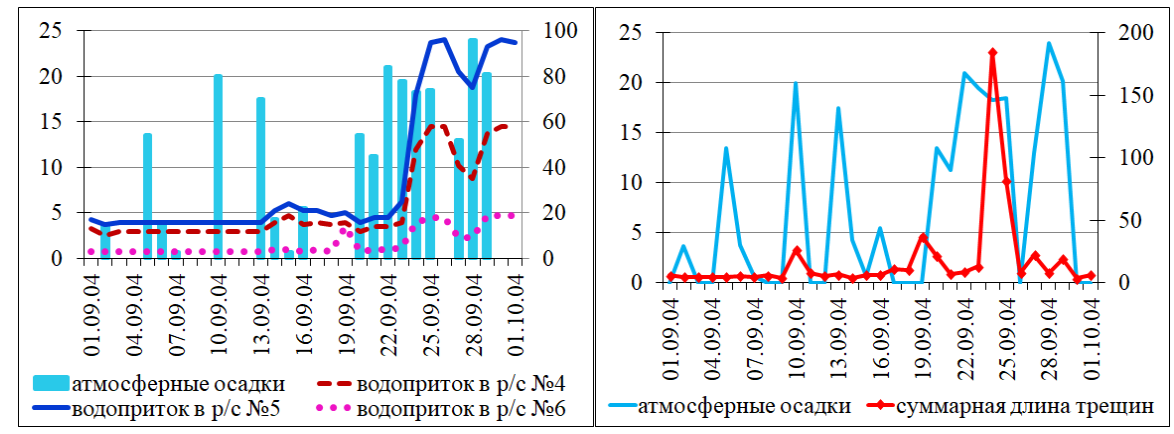

$a$

$\sigma$

Рис. 5.93. Временной ряд распределения данных метеорологического, гидрологического (a) и сейсмического (б) наблюдений за сентябрь 2004 г. На основной вертикальной оси представлены значения по количеству атмосферных осадков (мм), на вспомогательной - данные по объему рудничного водопритока $\left(\mathrm{M}^{3} / \mathrm{y}\right)$ и расчетной длине трещин (м) за сутки

На рисунке 5.94 представлены тренды полученных значений метеорологических данных, количества сейсмических событий и выделившейся энергии.

По изменяющимся линиям графика и уровням гистограмм видно, что рост положительных температурных показателей сопровождался ростом значений по водопритокам, что отразилось на изменении количества регистрируемых событий (рис. 5.94 a) и увеличении выделившейся сейсмической энергии (рис. 5.94 б) в зоне стыковки подземного Расвумчоррского рудника и карьера, а также в районе рудоспусков.

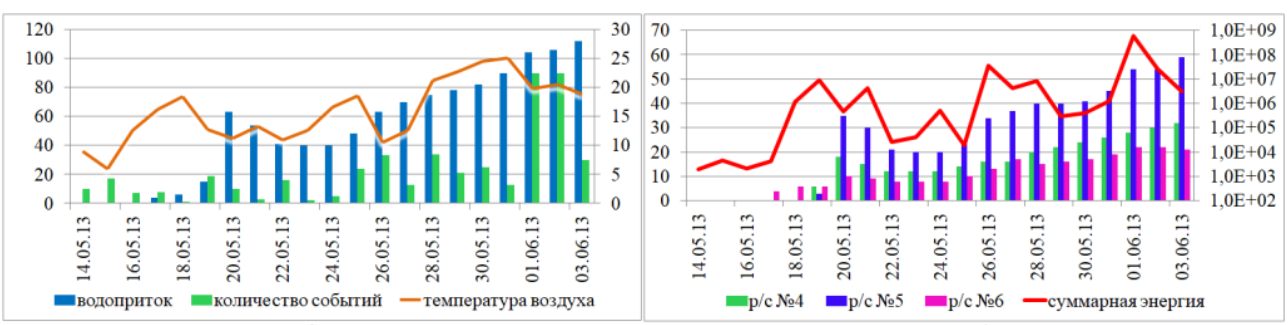

$a$

$\sigma$

Рис. 5.94. Влияние метеорологических и гидрологических факторов на изменение сейсмической активности массива горных пород. На основной вертикальной оси представлены значения по количеству событий, по объему рудничного водопритока (м³), на вспомогательной - данные по средней температуре воздуха $\left({ }^{\circ} \mathrm{C}\right)$ и суммарной энергии (Дж) за сутки 
По результатам наблюдений за температурой снежного покрова, проводимых на горно-лавинной станции «Центральная», представленных в виде сводного графика изменения температуры снежного покрова за 2013 г. (рис. 5.95), видно резкое увеличение значений температур в снежной толще 19 мая 2013 г. Резкое изменение значений свидетельствует о просачивании талых вод в самый нижний слой -0 см от почвы.

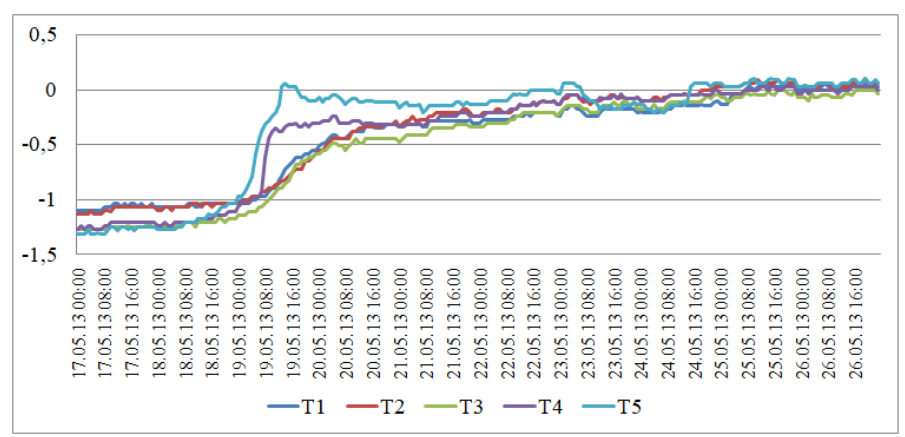

Рис. 5.95. Сводный график изменения температуры снежного покрова, где T1...T5 - номера датчиков измерения температуры $\left({ }^{\circ} \mathrm{C}\right)$, расположенных от нижнего к верхнему через 20 см друг от друга

Значение температуры снежного покрова по показаниям датчика Т1 с 19 мая (с 06:00 ч) по 26 мая (до 08:00 ч) изменилось с $-1{ }^{\circ} \mathrm{C}$ до $+0,06{ }^{\circ} \mathrm{C}$ соответственно. В этот период АСКСМ было зарегистрировано увеличение количества событий и их энергии в исследуемом районе. В 2013 г. после 19 мая максимальный всплеск сейсмической активности зарегистрирован 1 и 2 июня, это объясняется тем, что процесс обильного снеготаяния в связи с погодными условиями данного года происходил дольше.

Анализ энергетических диапазонов всех зарегистрированных сейсмических событий показывает, что суммарная выделившаяся энергия на порядок больше в зонах влияния разрывных нарушений и примерно в три раза превышает энергию, выделившуюся в остальной части района наблюдений несмотря на то, что количество событий в зонах отбитых секций несколько больше. События с энергией более $10^{4}$ Дж в основном происходят вблизи зон нарушений. События, не связанные с тектоникой, приурочены к зоне опорного давления от фронта очистных работ.

Совместный анализ сейсмических и гидрологических данных, полученных для месторождений «Апатитовый Цирк» и «Плато Расвумчорр» за период мониторинга с 2004 по 2014 гг., позволил выявить связь активизации сейсмичности с ростом обводненности пород в периоды обильных осадков (осенью) и интенсивного снеготаяния (весной). Результатом анализа зависимости сейсмической активности, зафиксированной в зоне контролируемых АСКСМ месторождениях, от гидрологической и метеорологической обстановок являются полученные коэффициенты корреляции, значения которых попали в интервал от 0,58 до 0,73, что свидетельствует о хорошей сходимости результатов и доказывает наличие связи роста сейсмической активности в районе отрабатываемых месторождений с сезонной обводненностью пород данного массива.

В результате ретроспективного анализа данных сейсмических, метеорологических и гидрологических наблюдений были определены критические значения спада высоты снежного покрова (табл. 5.11) и критический уровень 
значений по водопритокам (табл. 5.12), после превышения которых, наблюдался всплеск сейсмической активности на отрабатываемых месторождениях (в виде сильного сейсмического события ( $E \geq 10^{7}$ Дж) или серии слабых событий $\left(E \geq 1,0 \bullet 10^{6} \div 9,9 \bullet 10^{6}\right.$ Дж)). При анализе оценивали изменение данных по высоте снега и число совпадений проявления активизации сейсмичности в данном районе. Так, интервалам времени, в течение которых наблюдался спад высоты снежного покрова, соответствовало резкое увеличение количества сейсмических событий с энергией от $10^{6}$ до $10^{9}$ Дж.

Таблииа 5.11

Критический диапазон значений угла наклона по данным высот снежного покрова и временной интервал тревоги

\begin{tabular}{|l|c|c|c|c|}
\hline Диапазоны значений углов спада высоты снежного покрова, град. & $60-70$ & $70-80$ & $80-85$ & $85-90$ \\
\hline Временной период тревоги, дни & 7 & 5 & 4 & 2 \\
\hline
\end{tabular}

Критический уровень значений по водопритоку (мัч)

\begin{tabular}{|c|c|c|c|c|c|}
\hline \multicolumn{3}{|c|}{ Весенний период } & \multicolumn{3}{c|}{ Осенний период } \\
\hline P/С № 4 & P/С № 5 & P/С № 6 & P/C № 4 & P/С № 5 & P/С № 6 \\
\hline 48 & 61 & 29 & 88 & 89 & 34 \\
\hline
\end{tabular}

Временные периоды возможного возникновения сильных сейсмических событий были выявлены на основании статистического анализа базы данных по частоте распределения числа зарегистрированных событий за интервал времени с определенным значением спада высоты снежного покрова (рис. 5.96).

Критический уровень значений по водопритоку установлен в результате ретроспективного анализа событий с энергией более $10^{6}$ Дж за временной диапазон «предыстории» замеров по водопритоку, который был определен опытным путем в ходе статистического анализа данных.

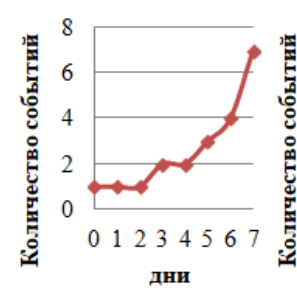

$a$

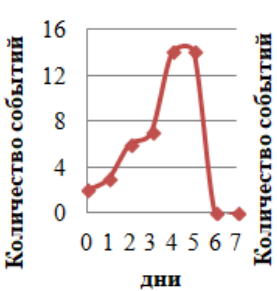

$\sigma$

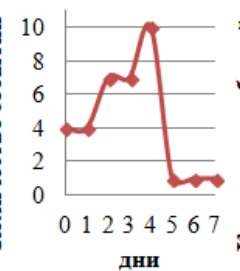

дни

8

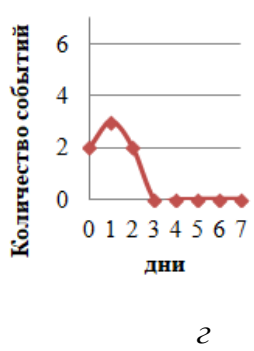

Рис. 5.96. Частота возникновения сейсмических событий, где диапазоны значений углов спада высоты снежного покрова составляют: $a-60^{\circ} \div 70^{\circ} ; \sigma-70^{\circ} \div 80^{\circ}$; в- $80^{\circ} \div 85^{\circ} ; 2-85^{\circ} \div 90^{\circ}$

Из 50 случаев в 46 из них при превышении определенного диапазона значений угла наклона по данным высот снежного покрова сопровождались повышением сейсмической активности (в эти периоды были зарегистрированы сейсмические события с $E \geq 10^{6}$ Дж (серия от 3 и более событий) либо сейсмические события с $E \geq 10^{7}$ Дж). При комплексном анализе, с учетом критических значений по водопритокам, 4 неподтвержденных события по высоте снежного покрова попадают в интервал тревоги по возможному росту сейсмоактивности. 


\subsubsection{2. Кукисвумчоррское и Юкспорское месторождения}

Для Кировского рудника ретроспективно был проведен аналогичный анализ данных, который показал, что из-за неравномерности производимых измерений количества водопритока (раз в пять-семь дней делается один замер) на Кукисвумчоррском и Юкспорском крыльях рудника проследить динамику роста водопритока в условиях решения поставленной задачи представляется затруднительным. Поэтому выделить критические значения и уровень, предшествующие реализации сильного сейсмического события, не удалось, и проводился только качественный анализ.

Сезонное увеличение водопритоков также привело к изменению сейсмического режима участков массива горных пород в пределах отрабатываемых месторождений.

21 октября 2010 г. в 12:10 (МСК) в районе Кукисвумчоррского месторождения было зарегистрировано сейсмическое событие с энергией $E=3,18^{*} 10^{9}$ Дж, которое ощущалось жителями поселка Кукисвумчорр, городов Кировск и Апатиты и сопровождалось длительной афтершоковой серией сейсмических событий. Данное геодинамическое явление классифицировано как техногенное землетрясение. Проведен анализ сейсмических данных, зарегистрированных за период с 1 августа по 20 октября до реализации главного события и 21 октября - в день техногенного землетрясения (рис. 5.97). Можно отметить, что эпицентры событий на Кукисвумчоррском крыле, концентрируются в зонах тектонических нарушений и в районе ведения горных работ. С 19 по 21 октября до 12 ч наблюдается увеличение числа событий на обоих крыльях рудника, но энергетический диапазон данных событий снизился до $10^{3}$ Дж. 21 октября на Кукисвумчоррском крыле после сейсмического события с энергией $10^{9}$ Дж произошла миграция сейсмичности на лежачий бок рудного тела, события приурочены к геологическим разломам. На Юкспорском крыле отмечается снижение сейсмической активности. За четыре дня регистрации сейсмическая обстановка мало изменилась: подавляющее число событий приурочено к районам тектонических нарушений.

Проведен комплексный анализ данных метеорологического, гидрогеологического и сейсмического мониторинга. На рисунке 5.98 a представлены значения по количеству осадков за месяц до сильного события. На графике по пикам максимумов видно, что за месяц до землетрясения были продолжительные дожди. На графике 5.98 б с начала октября наблюдаются колебания положительных значений температуры воздуха, максимум значений по сейсмичности приходится на резкий перепад этих значений.

Анализ водопритоков осеннего периода мониторинга показал, что большое количество осадков и положительные значения температуры воздуха повлияли на увеличение объемов водопритоков, так, значения за сентябрь составили $9204 \mathrm{~m}^{3} /$ ч, в октябре и ноябре значения были ниже - 7193 и $4684 \mathrm{~m}^{3} / \mathrm{\varphi}$ соответственно. Это объясняется наличием отрицательных значений температуры воздуха (ниже $0^{\circ} \mathrm{C}$ ) с конца октября, что привело к оледенению трещин, заполненных водой и, как следствие, повышению сейсмичности района: в этот период наблюдалось разрушение породы за счет сдвиговых микроподвижек по плоскостям трещин и разрывных нарушений. 


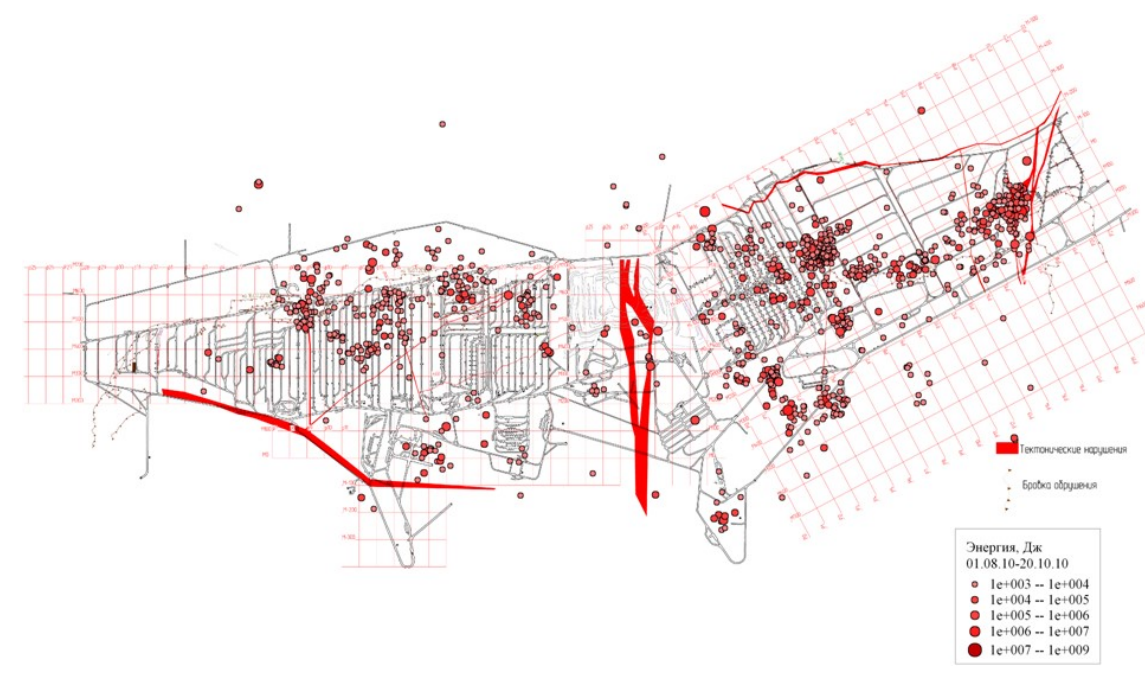

a

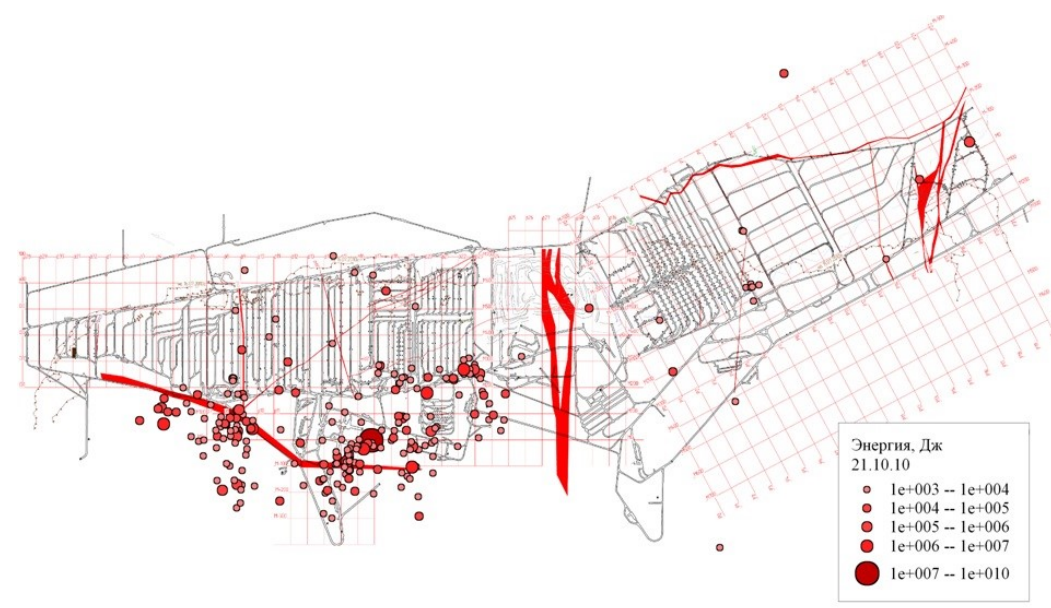

$\sigma$

Рис. 5.97. Карты эпицентров сейсмических событий: $a-$ с 1 августа по 20 октября 2010 г.; б- 21 октября 2010г.

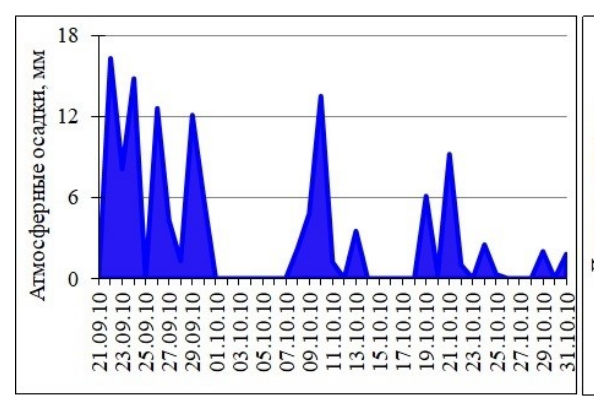

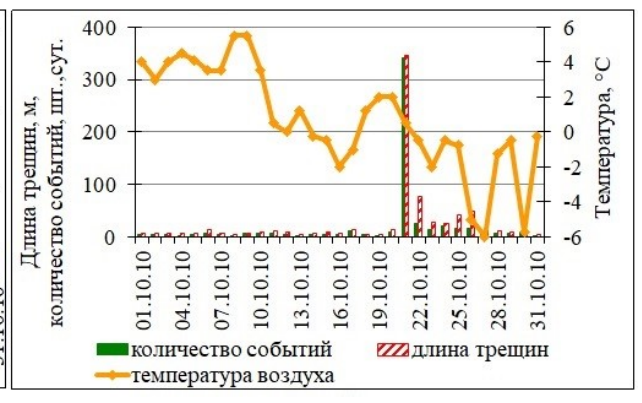

б

Рис. 5.98. Временные ряды метеорологических и сейсмических данных: $a-$ количества атмосферных осадков; $\sigma$ - зависимость сейсмической активности от перепадов температуры воздуха. На основной оси представлены данные по числу событий и суммарной длине трещин (м), на вспомогательной — значения средней температуры воздуха $\left({ }^{\circ} \mathrm{C}\right)$ 
Установлены причины динамического проявления горного давления в этот период: совокупность природных и техногенных факторов. Природными факторами являются: действие в массиве горизонтальных тектонических напряжений, высокие упругие свойства пород и наличие тектонических нарушений. Техногенным фактором является ослабление межблоковых связей массива в сочетании с нарушением устойчивости блоков в результате длительных горных работ. Инициирование источника сейсмического события произошло под воздействием сезонной обводненности пород и резкого изменения температурного режима.

Несмотря на некоторые нюансы, результаты сейсмических наблюдений за 2014 г. принципиально не отличаются от данных, полученных в предыдущие периоды.

Так, на Кировском руднике 27.10.2014 г. в период с 6:30 до 7:00 массив, вмещающий выработки 24, 23 ВТО, 22, 23, 24 БДШ, испытал динамическое воздействие, при котором были зафиксированы характерные признаки: потрескивание породы, хлопки, «схлопывание» разгрузочных строчек с образованием пыли в выработках и после этого - выбросы породы с кровли выработок.

В районе блока 28/1 гор. +250 м 27.10.2014 г. системой АСКСМ зарегистрированы 3 естественных сейсмических события:

- в 6:37- событие с энергией $6,6 \cdot 10^{4}$ Дж, координатами $\mathrm{P} 32+3, \mathrm{M}+425, \mathrm{Z} 288 \mathrm{M}$

- в 6:45 - событие с энергией $3,3 \cdot 10^{4}$ Дж, координатами P 31+1, M+495, Z 196 м.

По данным регистрации сейсмических событий, 27.10.2014 г. в 6:46 в районе ОКР зарегистрировано сейсмическое событие с магнитудой $1,3\left(1,7 \cdot 10^{7}\right.$ Дж), координатами $\mathrm{P} 30+36 \mathrm{M}, \mathrm{M}+403 \mathrm{M}, \mathrm{Z}+227$ м, которое классифицировано как горно-тектонический удар. Реализация его обусловлена совместным воздействием природных и техногенных (антропогенных) факторов:

- природных: высокого напряженного состояния нетронутого массива и направления действия напряжений, обусловленных геологической неоднородностью массива и наличием на этом участке тектонического пологопадающего нарушения, заполненного шпреуштейнизированными породами; сезонной обводненности массива, обусловленной интенсивными осадками и резким изменением температурного фона (рис. 5.99);

- техногенных: наличия повышенной концентрации напряжений в зоне опорного давления от границы очистных работ гор. +320 м; влияние буровзрывных работ;

- нарушения проекта: наличия выработок, пройденных с нарушением проекта (их направление, конфигурация), вследствие чего были образованы межштрековые целики с недостаточной степенью запаса устойчивости; невыполнения или некачественного выполнения мероприятий по обезопашиванию контура выработок; наличия крепи, не соответствующей условиям устойчивости выработок.

По данным метеомониторинга, можно сделать вывод, что до сильного события, произошедшего 27 октября 2014 г., зафиксированы продолжительные дожди и перепады температуры воздуха. Как известно, при замерзании вода расширяется на 1/11 своего объема. Поэтому образовавшийся лед давит на стенки трещин, разрывая скальные породы любой твердости. Частые колебания температуры около $0^{\circ} \mathrm{C}$ отрицательно сказываются на прочности массива горных пород, так как 
периодическое промерзание и оттаивание трещин приводит к изменению порового давления в породах, что в свою очередь отражается на геодинамическом состоянии всего массива. По условиям образования и размерам на Кукисвумчоррском месторождении встречаются: крупные щели (шириной до 2 м), зияющие трещины (с раскрытием от 2-3 мм до 5-10 см) и мелкие трещины.

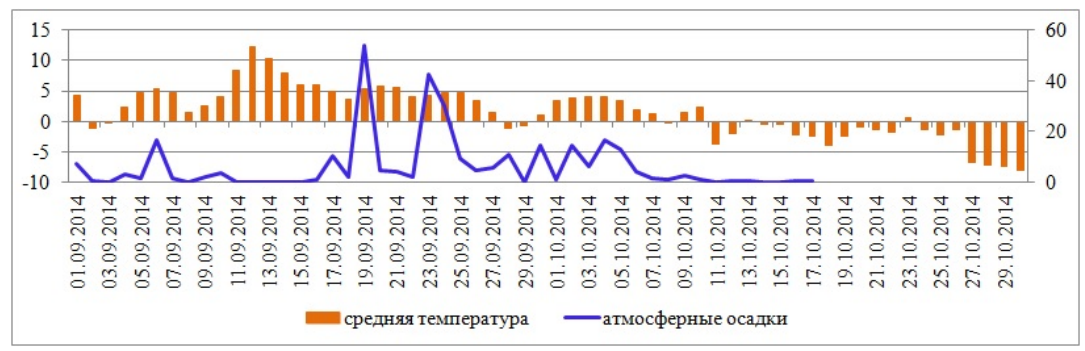

Рис. 5.99. Сводный график метеорологических данных. На основной оси представлены значения температуры воздуха $\left({ }^{\circ} \mathrm{C}\right)$, на вспомогательной — данные по атмосферным осадкам (мм)

\subsubsection{3. Методика комплексной оценки данныхх метео- и гидромониторинга для прогноза периодов повышенной сейсмической активности на апатитовых рудниках и реализаиия ее в виде программной системы}

Изменение метеорологических параметров в ту или иную сторону существенно влияют на обводненность массива горных пород. При этом активизация сейсмичности отмечается в периоды наибольшей обводненности. Поэтому основным предвестником сейсмоактивности выбран критический уровень значений по водопритоку.

Алгоритм методики прогноза опасных периодов сейсмоактивности массива на основе анализа данных метеорологических и гидрогеологических наблюдений на рудниках КФ АО «Апатит» представлены на рисунке 5.100.

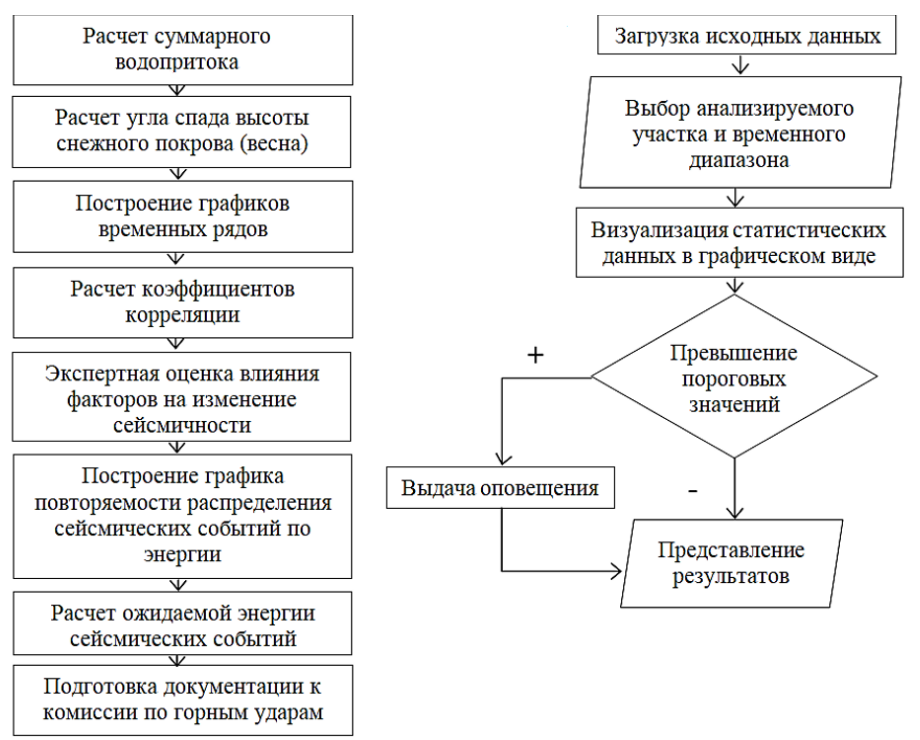

Рис. 5.100. Общая схема методики комплексной оценки данных метео- и гидромониторинга для выявления периодов сейсмической активности на рудниках КФ АО «Апатит» $(a)$ и блок-схема работы программной системы Seasonal Seismic Activity Identification System (AS SSAIS) (б) 
Важнейшим блоком программной системы является блок выбора анализируемого участка массива и временного интервала комплексного анализа. От рационального выбора исходных параметров зависит конечный результат. Для примера рассмотрены два случая активизации сейсмичности, зарегистрированной на месторождении «Плато Расвумчорр»: в 2004 г. - осенний период времени года (рис. 5.101) и в 2005 г. — весенний период времени года (рис. 5.102).

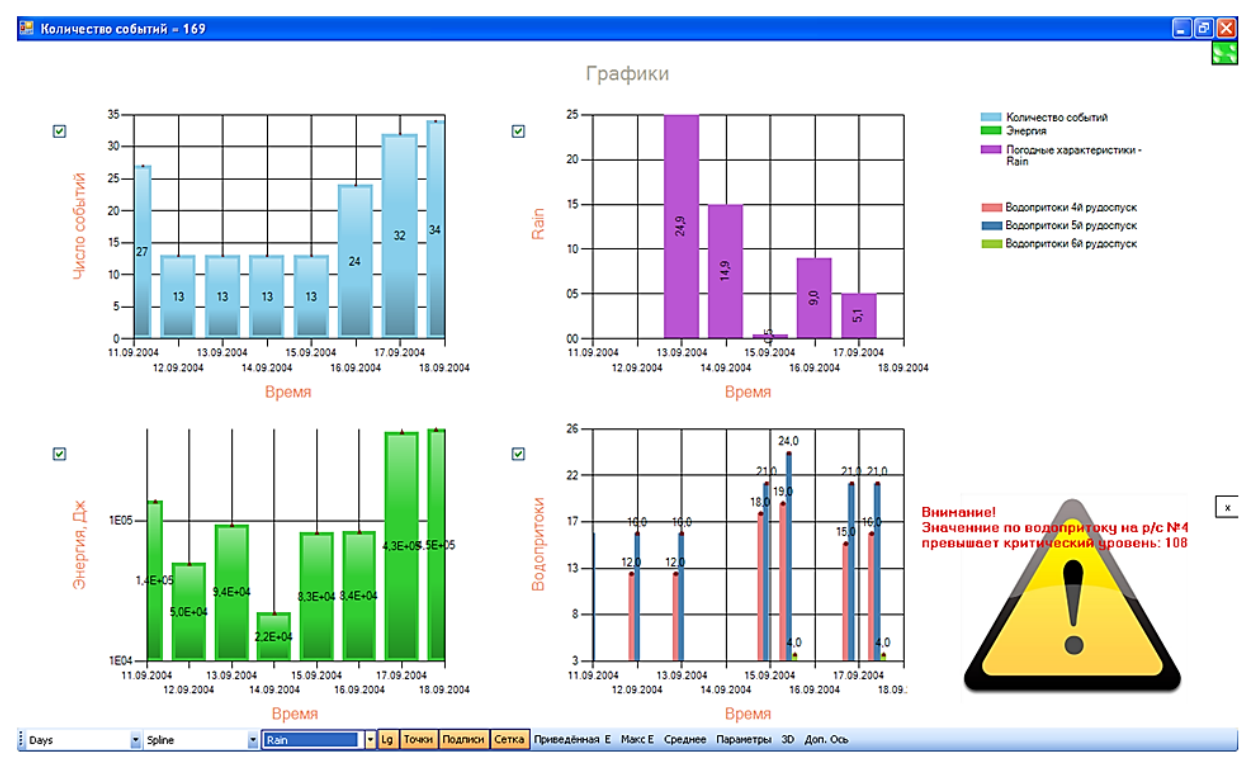

a

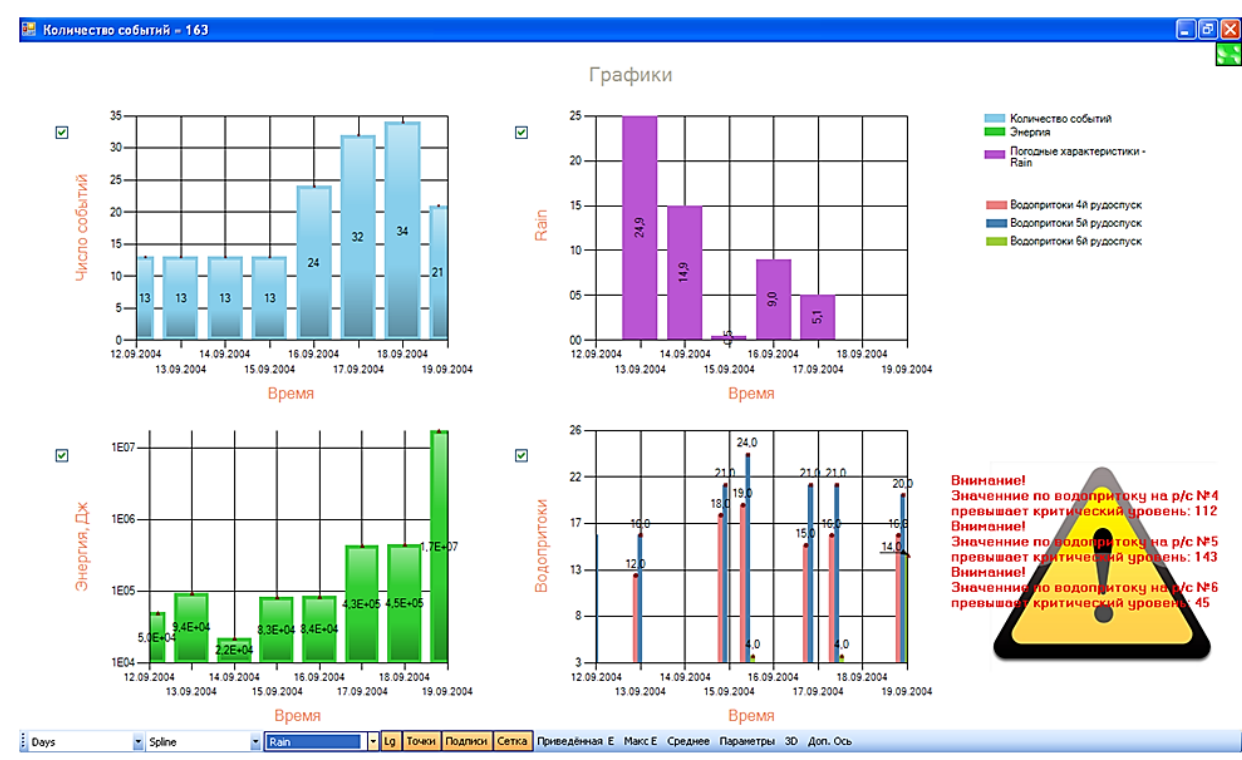

6

Рис. 5.101. Пример результата комплексного анализа данных 2004 г. 


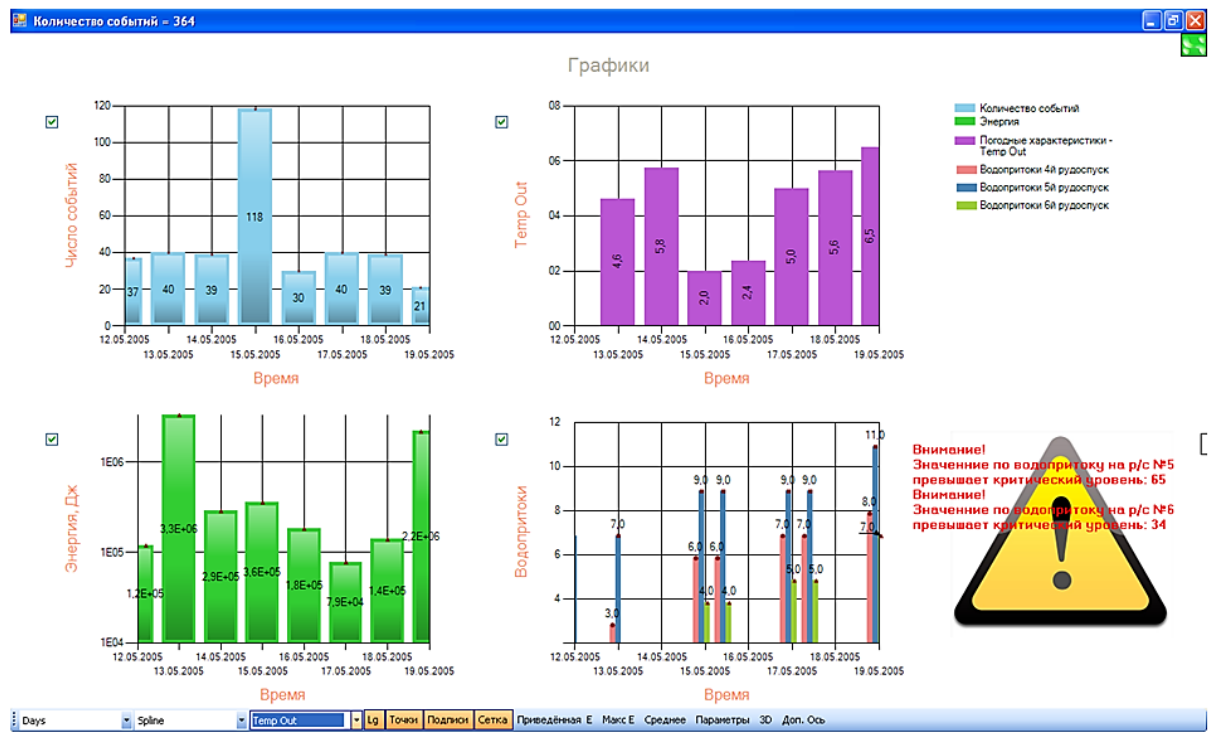

$a$

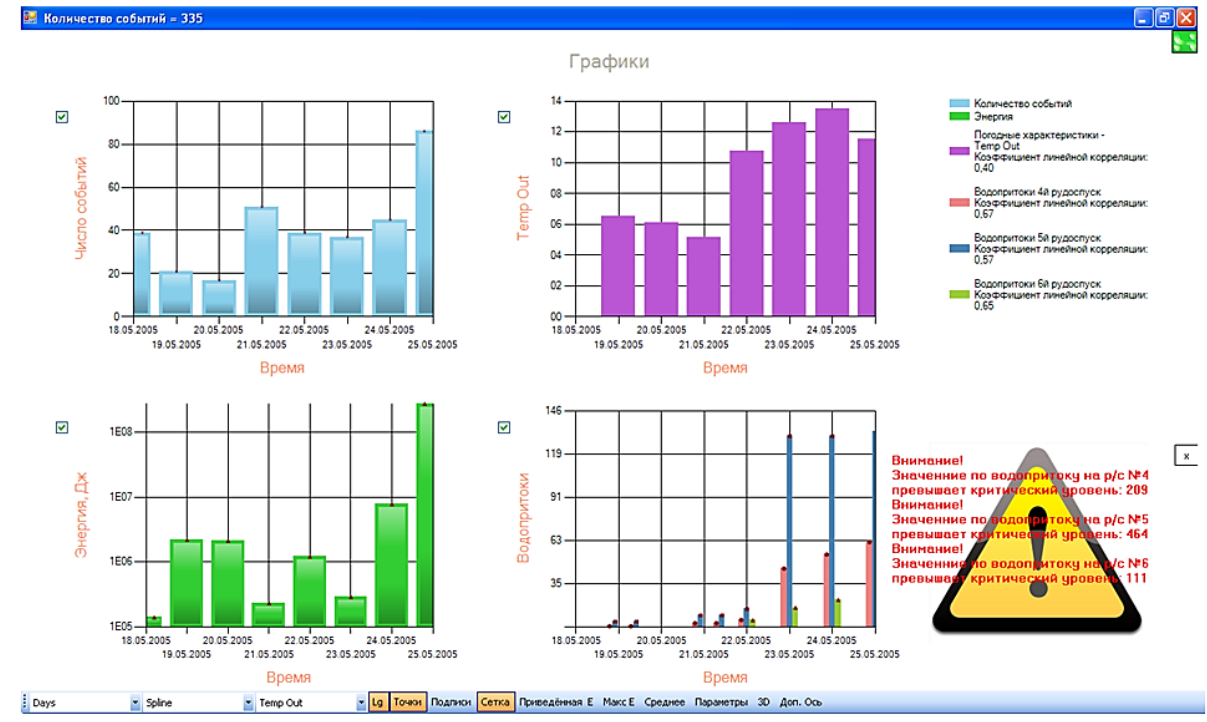

$\sigma$

Рис. 5.102. Пример результата комплексного анализа данных 2005 г.

На рисунке 5.101 a видно, что 18 сентября выявлено превышение значений по водопритоку на рудоспуске № 4 относительно критического уровня, 19 сентября происходит превышение критического уровня значений на рудоспусках № 5 и 6 (рис. 5.101 б). В этот день АСКСМ зарегистрировано сейсмическое событие с энергией $1,7 \cdot 10^{7}$ Дж.

Ретроспективный анализ данных по метео-, гидро- и сейсмомониторингу показал, что в 2005 г. за шесть дней до техногенного землетрясения обнаружено превышение значений по водопритокам на рудоспусках № 5 и 6 относительно 
критического уровня (рис. 5.102 a). 25 мая в 8:47 зарегистрировано событие с энергией 6,7•107Дж, далее в течение того дня было зарегистрировано еще 7 сильных геодинамических явлений с энергетическим диапазоном $1,7 \cdot 10^{7} \div 1,3 \cdot 10^{8}$ Дж. На рисунке 5.102 б справа показаны коэффициенты линейной корреляции между значениями по водопритоку и количеством сейсмических событий.

Информационное сообщение справа (рис. 5.101 и 5.102) позволяет оперативно узнавать о происходящем повышении обводненности массива. При дальнейшем анализе сейсмических данных по временному ряду определяется, происходит ли изменение сейсмической активности - по увеличению энергетического диапазона и количества событий в контролируемом районе.

С 2016 г., согласно акта об использовании материалов диссертационной работы С. А. Жуковой, методика комплексной оценки данных и программная система (ПС) AS SSAIS успешно применяется в службе прогноза и предотвращения горных ударов КФ АО «Апатит», что позволяет автоматизировать анализ баз данных метеорологических, гидрологических параметров и сейсмических событий. По окончании выполнения обобщающего анализа данных предусмотрена передача полученных результатов и разработка рекомендаций (например, тщательный выбор района проведения массовых взрывов в карьере Центральный КФ АО «Апатит»). Ниже приведены результаты комплексного анализа данных оценки влияния метеорологических и гидрологических факторов для установления периодов активизации сейсмической активности в мае 2016 г. для района стыковки Расвумчоррского рудника с карьером Центральный, которые были получены в онлайн-режиме.

На рисунке 5.103 а приведено окно ПС с результатами оценки данных сейсмических, метеорологических и гидрологических наблюдений, в котором можно видеть, что за несколько дней до серии событий программа сообщает о превышении критического уровня значений по водопритокам.

На рисунке 5.103 б представлены результаты оценки возможного возникновения роста сейсмической активности по изменению угла спада высоты снежного покрова.

С 1 мая по 15 мая 2016 г. наблюдается изменение высоты снежного покрова с 68 до 43 см, с 16 мая отмечается резкий спад высоты снежного покрова на 13 см. За данный временной период АСКСМ зарегистрировано 63 события с энергией от $10^{3}$ до $3,4 \cdot 10^{4}$ Дж. 16 мая при анализе программная система выдает сообщение о возможном возникновении сейсмического события с большой энергией в период с 16 до 18 мая (красный столбик указывает на то, что пользователем выбрана временная ступень анализа, и ПС рассчитан временной интервал тревоги с учетом «предыстории» изменения анализируемых параметров, об этом указано в сообщении - вверху окна). При анализе 22 мая 2016 г. ПС предупреждает о возможном возникновении сильного события в период с 22 по 26 мая, и, действительно, в этот период АСКСМ была зарегистрирована серия событий. За временной период обильного снеготаяния и повышенного водопритока с 16 по 31 мая 2016 г. было зарегистрировано около 130 событий с энергией от $10^{3}$ Дж, из них 4 события с энергией от $10^{6}$ до $3,4 \cdot 10^{7}$ Дж. Таким образом, перспективно успешно спрогнозирована серия событий с энергией от $10^{6}$ Дж. 

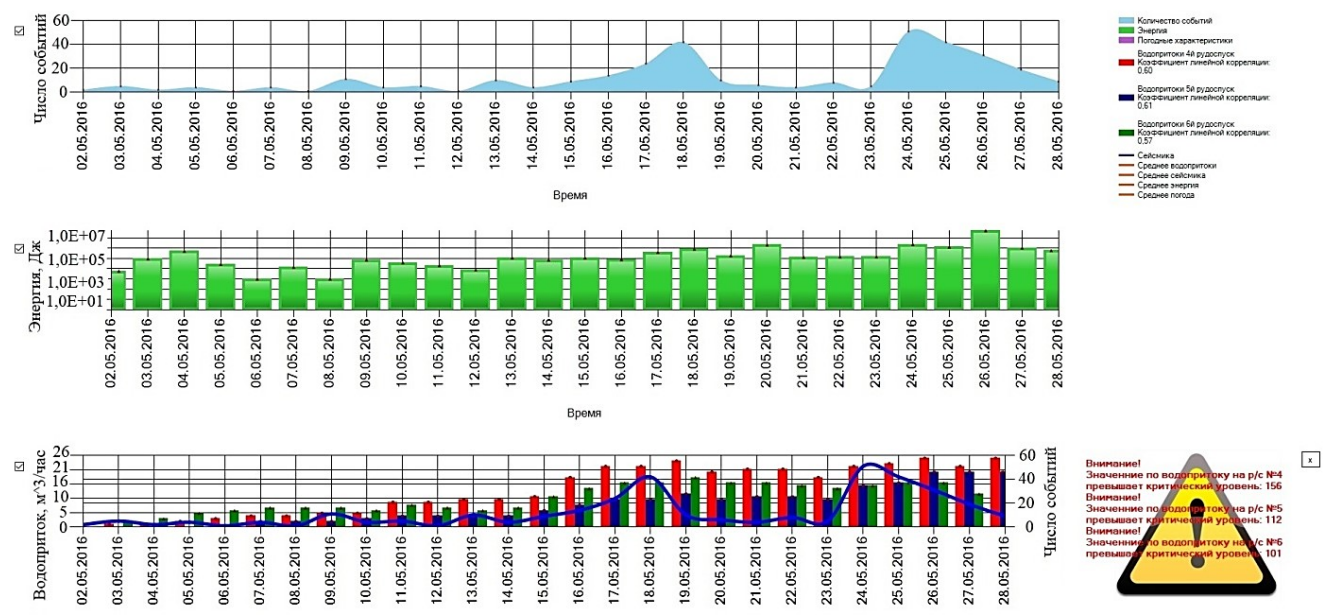

$a$

唱 Оценка возможности возникновения крупного сейсмособытия по данным ОЛБ Внимание! Ожидается сейсмическое событие с большой энергией в период с 16.05.2016 по 18.05.2016 $-\square \times$ Внимание! Ожидается сейсмическое событие с большой энергией в период с 22.05.2016 по 26.05.2016

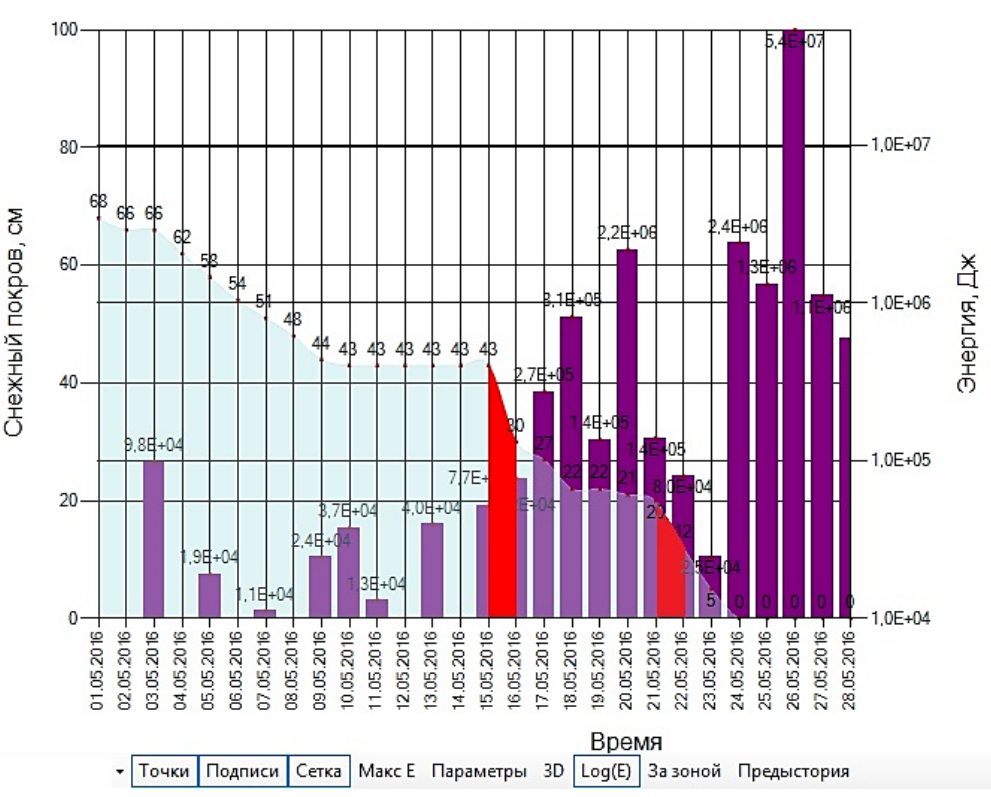

- Энергия Снежный покров

Рисунок 5.103. Результаты перспективной оценки возможного возникновения роста сейсмической активности: $a$ - по превышению пороговых значений водопритоков; $\sigma$ - по превышению критического диапазона значений углов спада высоты снежного покрова (данные замеров отдела лавинной безопасности КФ АО «Апатит») 


\section{7. Методические подходы к оценке геодинамической ситуации в геологической среде горнотехнической системы по параметрам сейсмической эмиссии}

Для оценки геодинамической ситуации в геологической среде горнотехнической системы по результатам сейсмических наблюдений для большинства сейсмических событий определяют дату, время, координаты и величину сейсмической энергии.

Оценка сейсмической активности массива проводится с учетом комплекса прогностических критериев, различных по физическому смыслу и дополняющих друг друга. Для совместного использования критериев, отражающих различные параметры потока сейсмической эмиссии, рассчитываются значения комплексного индикатора:

$$
X^{\prime \prime}=\frac{1}{N} \sum_{j=1}^{N} X_{j}^{\prime},
$$

где $N$ - количество отдельных прогностических критериев; $X_{j}^{\prime}-$ значение каждого прогностического критерия.

Изменения количества, конфигурации и местоположения выделенных сейсмоактивных зон отражают характер перераспределения действующих напряжений в массиве в зависимости от интенсивности ведения горных работ. По степени сейсмоактивности определяются три типа зон: устойчивая, пульсирующая, растущая (рис. 5.104, табл. 5.13). Комплексным индикатором можно учесть поведение отдельных критериев и точнее оценить прогностические параметры сейсмического режима в пространственной ячейке, чем при использовании одного критерия. Детальный анализ структуры множества сейсмических событий с целью выявления закономерностей формирования сейсмоактивных зон и их взаимосвязи с горно-геологическими факторами дает возможность понять природу сейсмической активности.

По результатам расчетов производится временной прогноз (долгосрочный, среднесрочный или краткосрочный). Анализ геологической и горнотехнической информации позволяет в выделенных зонах сейсмоактивности выявлять наиболее опасные участки. На основании результатов прогноза принимаются решения о необходимости проведения мероприятий по профилактике удароопасной ситуации в выработках, попавших в выделенную зону, и проводятся соответствующие мероприятия по обеспечению безопасности горных работ.

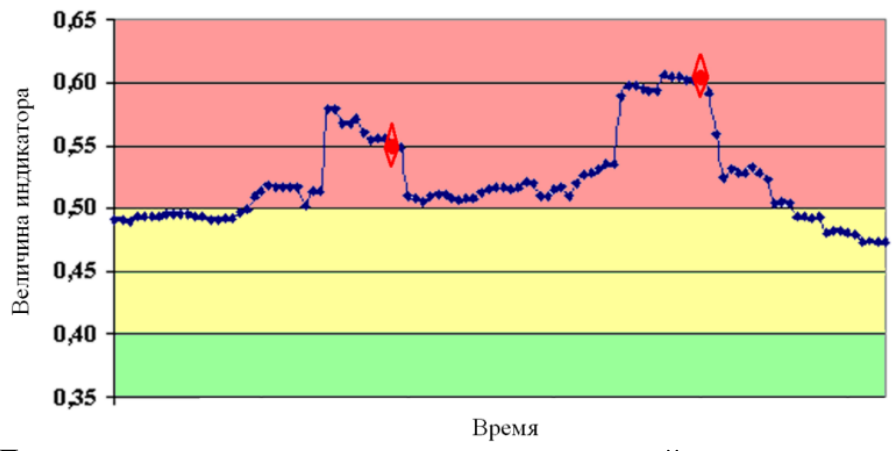

Рис. 5.104. Динамика комплексного критерия на сейсмически опасном участке (произошли два сильных сейсмических события) 
Классификация типов сейсмоактивных зон

\begin{tabular}{|c|c|c|c|}
\hline $\begin{array}{c}\text { Тип } \\
\text { зоны }\end{array}$ & $\begin{array}{c}\text { Величины } \\
\text { комплексного } \\
\text { индикатора } \\
\end{array}$ & $\begin{array}{c}\text { Вероятность } \\
\text { возникновения } \\
\text { события } \\
\end{array}$ & $\begin{array}{c}\text { Требуемые действия } \\
\text { для минимизации разрушений контура } \\
\text { выработок, попадающих в зону }\end{array}$ \\
\hline Растущая & 0,50 и больше & $\begin{array}{l}\text { Высока вероятность } \\
\text { реализации сильного } \\
\text { сейсмического события } \\
\text { или серии событий }\end{array}$ & $\begin{array}{l}\text { Необходимо провести анализ всех } \\
\text { имеющихся данных (локальные методы, } \\
\text { моделирование) по этой зоне } \\
\text { и рассчитать вероятность возникновения } \\
\text { сильного сейсмического события } \\
\text { для определения последовательности } \\
\text { мероприятий по предупреждению } \\
\text { разрушения выработок }\end{array}$ \\
\hline Пульсирующая & От 0,40 до 0,50 & $\begin{array}{l}\text { Реализация сильного } \\
\text { сейсмического события } \\
\text { или серии событий } \\
\text { маловероятна }\end{array}$ & $\begin{array}{l}\text { При учете имеющейся информации } \\
\text { по данному участку (локальные методы, } \\
\text { моделирование) необходимо определить } \\
\text { последовательность проведения } \\
\text { профилактических мероприятий } \\
\text { по поддержанию выработок }\end{array}$ \\
\hline Устойчивая & Менее 0,40 & $\begin{array}{l}\text { За анализируемый период } \\
\text { не зарегистрировано } \\
\text { ни одного сильного } \\
\text { сейсмического события }\end{array}$ & $\begin{array}{l}\text { Осуществляется долгосрочный прогноз, } \\
\text { учитывающийся при ежегодном } \\
\text { планировании профилактических } \\
\text { мероприятий по поддержанию } \\
\text { выработок }\end{array}$ \\
\hline
\end{tabular}

Диапазоны значений комплексного индикатора, параметры анализа и применяемые отдельные прогностические критерии могут уточняться по мере накопления соответствующей информации.

После выявления сейсмоактивных зон, их картирования и определения их типа необходимо провести анализ дополнительной информации.

В зависимости от типа выявленной сейсмоактивной зоны проводится анализ имеющейся дополнительной информации по данному району, на основании которого определяется периодичность контроля каждой из этих зон:

- ежедневно, еженедельно (краткосрочный прогноз);

- ежемесячно (среднесрочный прогноз);

- ежеквартально или ежегодно (долгосрочный прогноз).

Анализ имеющейся дополнительной информации заключается в оценке:

- наличия в выделенной зоне выработок. Если они имеются, то для них определяется тип (капитальные, подготовительные или очистные), оценивается наличие и тип крепи;

- результатов визуального обследования выработок, попадающих в выделенную зону (наличие проявлений горного давления, проводились ли мероприятия по приведению данных выработок в неудароопасное состояние, категории выработок и т. п.);

- результатов измерений локальными методами, а также данных численного моделирования НДС.

Также оценивается близость сейсмоактивных зон к разломам или окисленным зонам, к фронту очистных работ, к бровке обрушения пород висячего бока.

Дополнительным критерием идентификации сейсмоопасных зон является определение вероятности возникновения в них сильного сейсмического события. При этом для зон растущего и пульсирующего типа необходима разработка профилактических мероприятий на краткосрочный и среднесрочный период, а для зон устойчивого типа проводится разработка мероприятий на долгосрочный период. 
Необходимо учитывать, что одним из основных факторов, влияющим на изменение сейсмической активности массива, являются взрывные работы, поскольку они могут активизировать участки нарушений, расположенные в непосредственной близости к отбиваемыми секциями или связанными с ними в силу блочного строения массива. Технологические взрывы обладают мощным триггерным эффектом, существенно изменяющим сейсмический режим рудника, таким образом:

1) чем дальше выявленный сейсмоактивный участок удален от зоны влияния фронта очистных работ, тем меньше вероятность разрушения выработок. Ориентировочно минимальное безопасное расстояние контура незакрепленной выработки от фронта очистных работ равно 50 м, то есть, если выработка находится на расстоянии, большем данной величины, то влияние фронта очистных работ не приведет к возникновению на ее контуре состояния удароопасности, и этот фактор можно не учитывать при дальнейшем анализе. Если выработка находится на расстоянии меньшем 50 м от фронта очистных работ, то под воздействием приближающегося фронта могут создаться условия концентрации напряжений на этом участке, что, в свою очередь, может привести к реализации сейсмических событий вблизи контура выработки, a, соответственно, и к нарушению ее устойчивости;

2) чем дальше выделенный участок удален от зоны влияния разлома, тем меньше вероятность разрушения выработок, находящихся в нем. Ориентировочно минимальное безопасное расстояние контура выработки от разрывного нарушения - 50 м. То есть, если выработка находится на расстоянии, большем данного значения, то наличие разлома в массиве горных пород не приведет к возникновению на ее контуре состояния удароопасности, и этот фактор можно не учитывать при дальнейшем анализе. При приближении горных работ к разлому могут создаться условия концентрации напряжений на этом участке, что может привести к реализации сейсмических событий вблизи контура выработки. Практика отработки апатитовых месторождений свидетельствует о сильном влиянии тектоники на формирование удароопасной обстановки. Анализ горных ударов, зарегистрированных на хибинских рудниках, показал, что все они происходили на удалении от тектонических нарушений не более $50 \mathrm{~m}$, что свидетельствует о большом влиянии тектонических структур на удароопасную ситуацию;

3) чем дальше контур выработки удален от сейсмоактивной зоны, тем меньше вероятность его разрушения в случае динамических проявлений горного давления (ориентировочно минимальное безопасное расстояние гипоцентра сейсмического события от контура незакрепленной выработки для разных энергетических диапазонов равно: $10^{6}$ Дж $-70 \mathrm{~m} ; 10^{7}$ Дж - $160 \mathrm{~m} ; 10^{8}$ Дж - $\left.350 \mathrm{м}\right)$. То есть реализация сильного события в массиве пород на некотором удалении от выработок также может привести к их разрушению.

Наличие нескольких факторов на анализируемом участке позволяет более уверенно оценить уровень геодинамической опасности.

Для выявленных зон сейсмоактивности растущего и пульсирующего типов на этом этапе дополнительно проводится расчет вероятности возникновения сильного сейсмического события. Он проводится на основе ретроспективных данных о проявлении сильных сейсмических событий. Оценивается среднее время ожидания сейсмических событий, вероятность возникновения события и вероятность ложной тревоги (табл. 5.14). 
Вероятностный прогноз сильных сейсмических событий

\begin{tabular}{|l|c|c|c|}
\hline \multicolumn{1}{|c|}{$\begin{array}{c}\text { Параметры } \\
\text { прогноза }\end{array}$} & $\begin{array}{c}\text { Долгосрочный } \\
\text { прогноз }\end{array}$ & $\begin{array}{c}\text { Среднесрочный } \\
\text { прогно3 }\end{array}$ & $\begin{array}{c}\text { Краткосрочный } \\
\text { прогно3 }\end{array}$ \\
\hline Время ожидания события & $>30$ дней & $<30$ дней & $1-5$ дней \\
\hline Вероятность возникновения события & $>0,75$ & $>0,5$ & $>0,5$ \\
\hline Вероятность ложной тревоги & $<0,25$ & $<0,5$ & $<0,5$ \\
\hline
\end{tabular}

\section{8. Система сейсмического мониторинга на карьере «Железный»}

\subsection{1. Предыстория и текущее состояние}

Сейсмический мониторинг в настоящее время имеет широкое применение на карьерах в Австралии, Канаде, Намибии и ЮАР. В опубликованных работах на эту тему делаются выводы, что микросейсмический мониторинг не следует рассматривать как средство объявления тревоги неустойчивого состояния пород бортов, a, скорее, как инструмент, позволяющий понять закономерности деформирования исследуемого массива.

Тем не менее результаты сейсмического мониторинга являются в настоящее время единственным средством для получения представления о глубинных процессах, происходящих в скальном массиве прибортовой зоны карьеров, а главное - в пределах зон сближенных центриклинальных трещин. Отмечается, что интерпретируемые в геомеханических терминах результаты обработки материалов сейсмологических наблюдений на карьерах имеют большие перспективы в плане комплексирования с другими геотехническими методами, к примеру, маркшейдерских наблюдений или геомеханическими расчетами. Еще один вариант использования сейсмических данных предполагает непосредственное использование очаговых параметров сейсмических событий (актов микроразрушения) в геомеханических расчетах.

В 2007 г. на участке юго-восточного борта карьера «Железный» Ковдорского ГОКа, с целью изучения закономерностей деформирования исследуемого массива в геомеханическом пространстве карьера была организована система сейсмических наблюдений в частотном диапазоне 4-3000 Гц (микросейсмическая система), которая состоит из шести трехкомпонентных (14 Гц) и шести однокомпонентных $(3,5$ Гц) сейсмических датчиков фирмы ISS International (ЮАР), расположенных в четырех скважинах (две - глубиной 250 м, две - 180 м), пройденных по периметру контролируемого участка, пунктов предварительного сбора сейсмической информации и центрального пункта сбора и обработки информации.

Система спроектирована таким образом, чтобы обеспечить высокую разрешающую способность регистрации сейсмических событий, происходящих в исследуемом районе, и позволяет контролировать процесс хрупкого разрушения в массиве в диапазоне от $10^{-1}$ до $10^{8}$ Дж.

Для ручной обработки и последующего анализа зарегистрированные данные передаются в Горный институт КНЦ РАН.

Опыт эксплуатации системы показал, что при такой конфигурации сейсмической сети область контроля составляет 20 \% площади карьера, что удовлетворительно согласуется с расчетными данными (рис. 5.105). 


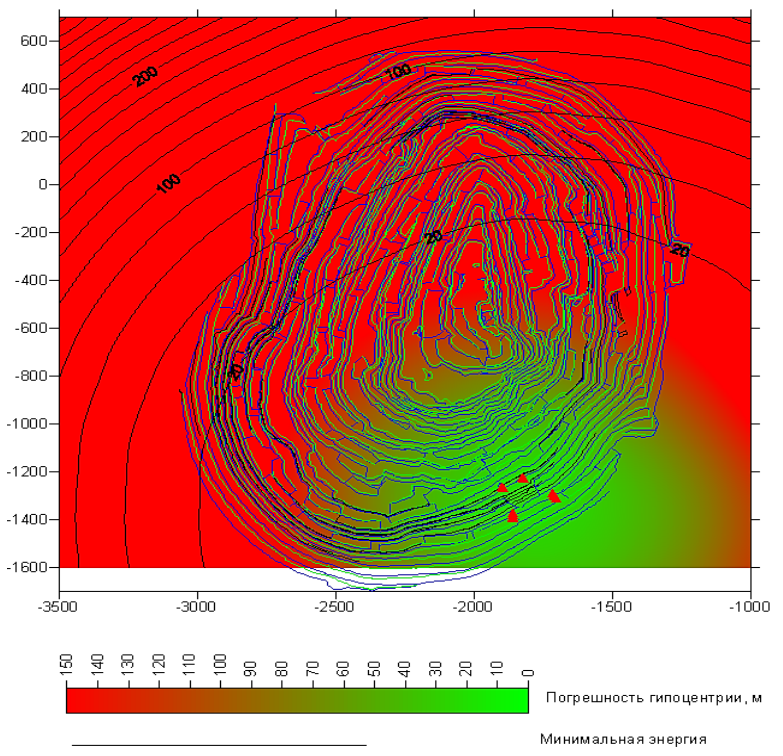

Рис. 5.105. Расчетный район регистрации действующей системы

\subsection{2. Общая характеристика сейсмоактивности в карьере}

За период 2010-2012 гг. системой сейсмического мониторинга карьера «Железный» Ковдорского ГОКа зарегистрировано 2014 сейсмических событий. Общие результаты регистрации с разбивкой по источникам приведены в таблице 5.15 .

Распределение по источникам сейсмических событий, зарегистрированных за период 2010-2012 гг.

\begin{tabular}{|l|c|c|}
\hline Источник сейсмособытия & Число событий & $\%$ \\
\hline Технология & 3058 & 40 \\
\hline Сейсмика & 2014 & 26 \\
\hline Помехи & 2588 & 34 \\
\hline Общий итог & 7660 & 100 \\
\hline
\end{tabular}

Из приведенных данных следует, что для карьера рудника «Железный» доля «естественных» событий, имеющих источником сейсмическую эмиссию массива, составляет порядка $26 \%$ всех регистрируемых системой событий.

Пространственное распределение сейсмических событий, связанных с процессами разрушения породного массива, приведено на рисунках 5.106 и 5.107.

Характерным является концентрация сейсмоактивности в зоне, примыкающей ко дну карьера. События в основном имеют источники, расположенные на глубинах до 200 м от дневной поверхности. Именно здесь зарегистрированы наиболее мощные события. В частности, в начале сентября 2011 г. здесь произошло событие с энергией в $5 \cdot 10^{6}$ Дж (магнитуда 1,2 ). К сожалению, ввиду удаленности очагов событий сложно анализировать механизмы их источников, так как продольные волны от них приходят всегда с одинаковым знаком (примерно в 20-30\% случаев приходят волны растяжения). Вместе с тем зарегистрировано значимое число сейсмических событий в зоне, тяготеющей к борту карьера. 


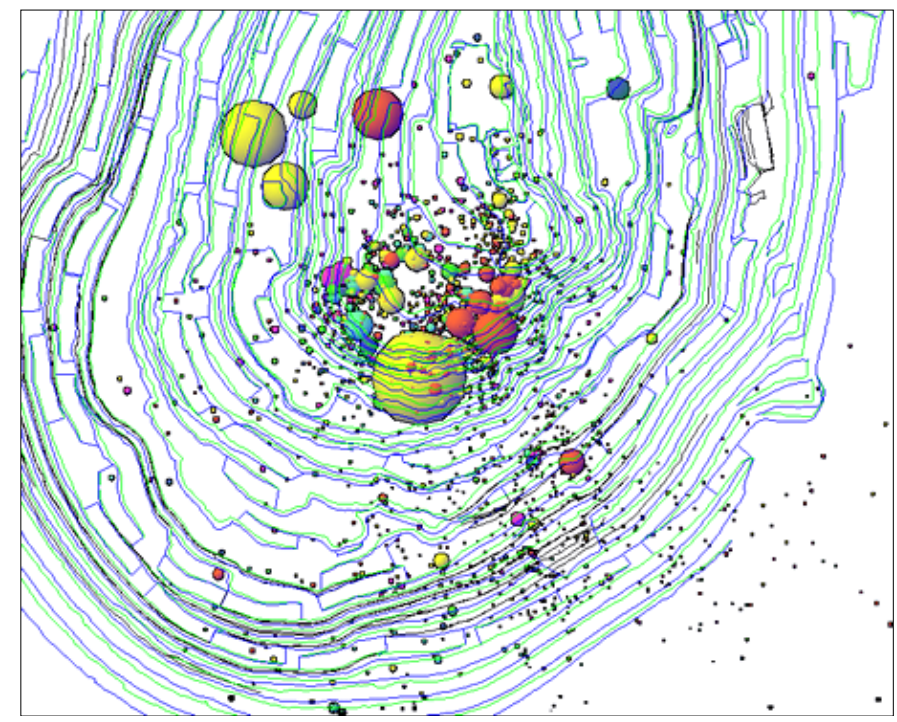

Рис. 5.106. Распределение сейсмособытий, вид сверху (размер значков соответствует линейному размеру зоны разрушения)

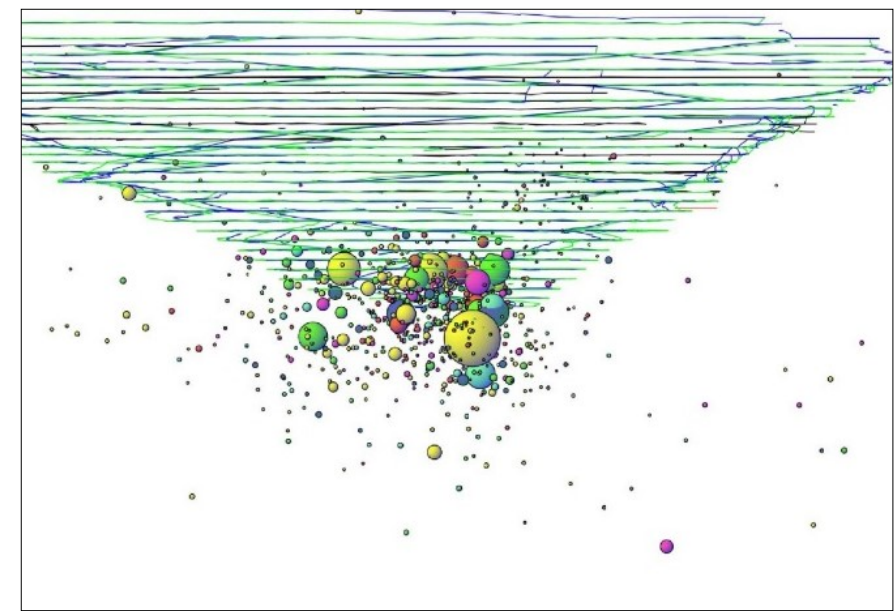

Рис. 5.107. Распределение сейсмособытий, вид с направления юг-север

Так же районирование эффективно реализуется с помощью кластерного анализа распределения очагов сейсмособытий в трехмерном пространстве. Из многочисленных методов кластерного анализа, в этом случае, наиболее точно отвечает физической природе кластеризуемого объекта метод иерархической кластеризации по минимальному расстоянию до объектов в качестве целевой функции, так как данный метод не накладывает никаких ограничений на форму выделяемых кластеров.

В результате кластерного анализа в пространственном распределении очагов сейсмособытий, зарегистрированных в 2016-2018 гг. выявлено 5 кластеров. Распределение событий в кластерах на плане карьера показано на рисунке 5.108, а в таблице 5.16 сведены общие параметры выявленных кластеров. 


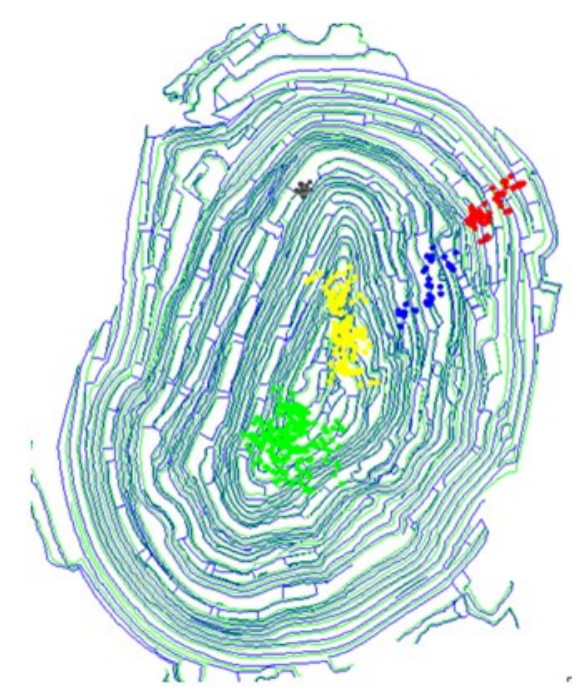

a

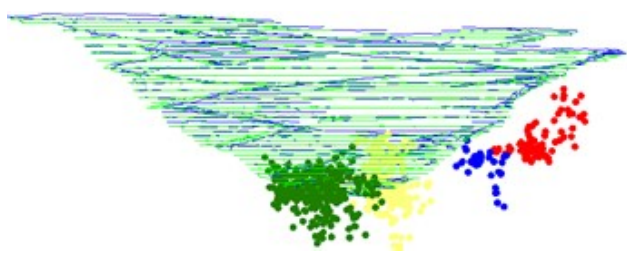

6

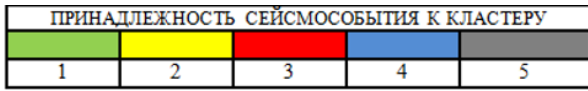

Рис. 5.108. Пространственное распределение очагов сейсмических событий в кластерах (2016-2018 гг.): $a$ - вид сверху; 6 - вид с направления юг-север. Цвета значков сейсмособытий определяются принадлежностью к кластерам

Таблица 5.16

Параметры выделенных кластеров

\begin{tabular}{|c|c|c|c|c|c|c|}
\hline \multirow{2}{*}{ Кластер } & Число событий & \multicolumn{3}{|c|}{ Координаты центра } & \multirow{2}{*}{$\begin{array}{c}\text { Средний } \\
\text { размер, м }\end{array}$} & $\begin{array}{c}\text { Суммарная } \\
\text { энергия, Дж }\end{array}$ \\
\cline { 3 - 5 } & в кластере & $X \longleftarrow$ & $Y_{ц}$ & $Z$ Zц & \\
\hline 1 & 316 & -432 & -1987 & -204 & 430 & $8,3^{*} 10^{5}$ \\
\hline 2 & 329 & -802 & -2196 & -223 & 351 & $3,8^{*} 10^{6}$ \\
\hline 3 & 65 & -236 & -1679 & -135 & 200 & $1,8^{*} 10^{4}$ \\
\hline 4 & 79 & 19 & -1492 & -60 & 254 & $7,1^{*} 10^{4}$ \\
\hline 5 & 20 & 1,8 & -2051 & -308 & 94 & $6,7^{*} 10^{3}$ \\
\hline
\end{tabular}

Распределение сейсмоактивности по месяцам (рис. 5.109 показывает, что максимум сейсмоактивности приходятся на весенние месяцы активного снеготаяния (апрель-июнь)).

Поскольку аналогичные закономерности в распределении сейсмоактивности наблюдались и в предыдущие годы, можно утверждать, что процессы снеготаяния существенным образом влияют на геомеханическую ситуацию в приконтурной зоне карьера. 


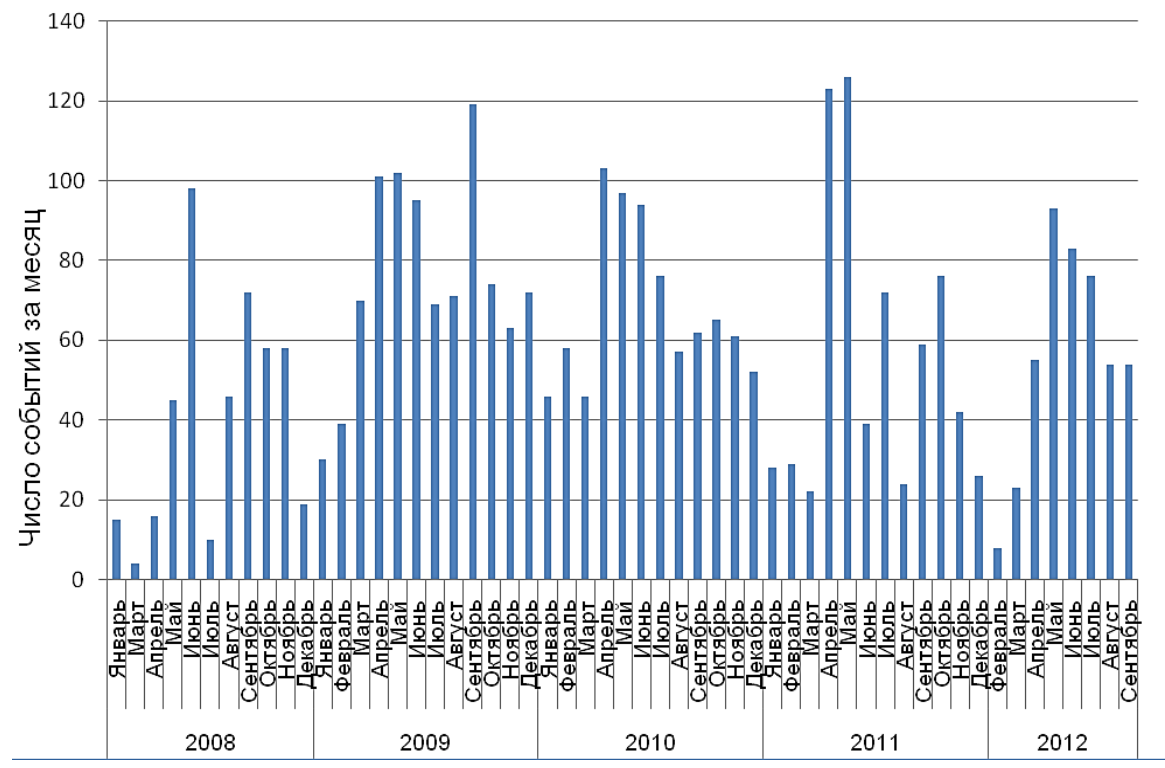

Рис. 5.109. Распределение сейсмособытий по месяцам

Распределение сейсмособытий по дням недели представлено в таблице 5.17 и на рисунке 5.110.

Таблица 5.17

Распределение сейсмоактивности по дням недели

\begin{tabular}{|l|c|}
\hline \multicolumn{1}{|c|}{ День недели } & Число событий \\
\hline Понедельник & 1202 \\
\hline Вторник & 1304 \\
\hline Среда & 1180 \\
\hline Четверг & 980 \\
\hline Пятница & 1100 \\
\hline Суббота & 1300 \\
\hline Воскресенье & 1228 \\
\hline Сумма & 8304 \\
\hline
\end{tabular}

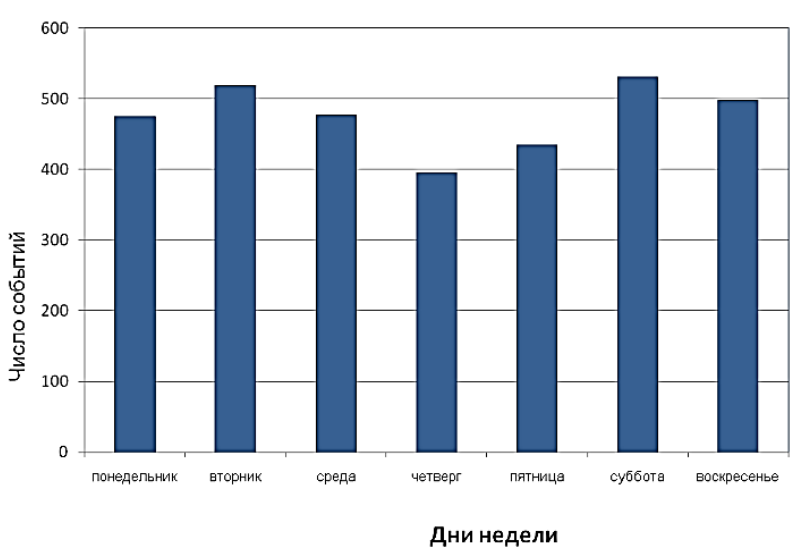

Рис. 5.110. Распределение сейсмособытий по дням недели 
Статистический анализ показал, что колебания сейсмоактивности в течение недельных циклов носят значимый характер. Можно предположить с большой долей вероятности, что в данном случае наблюдается опосредствованная реакция массива горных пород на технологические работы в карьере, а именно бурение скважин, взрывы и транспортировка руды. К сожалению, не удалось выявить главные действующие факторы. По крайней мере, можно отметить, что массовые взрывы, проводимые, как правило, по средам и субботам приводят к существенному повышению уровня сейсмоактивности.

О влиянии технологических процессов на естественную сейсмоактивность массива можно судить по распределению ее по времени суток (рис. 5.111), на котором имеется 3 значимых минимума в 6, 13 и 23 ч. Учитывая трехсменный режим работ по погрузке и вывозу взорванной горной породы, можно предположить, что именно этот вид работ существенно сказывается на общем уровне сейсмоактивности.

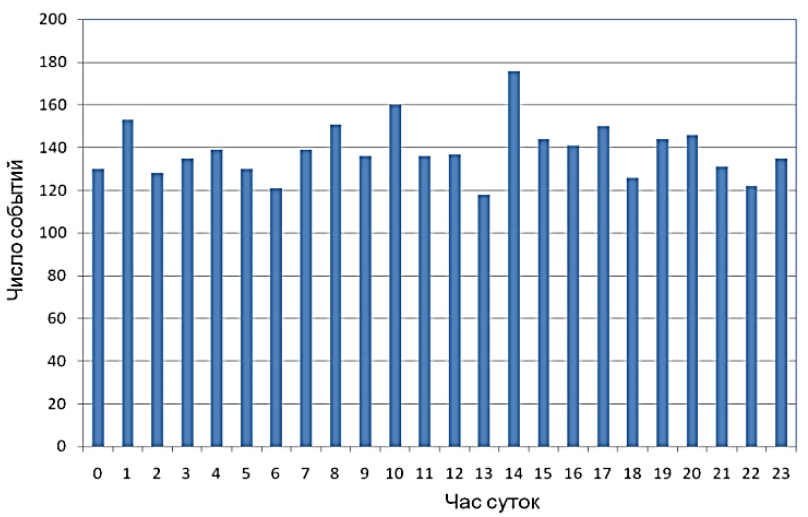

Рис. 5.111. Распределения сейсмособытий по времени суток

\subsection{3. Сейсмоактивность в зоне под дном карьера}

Массив под дном карьера является источником повышенной сейсмической активности, потому что именно в этой зоне были зарегистрированы 47 сейсмических событий с энергией большей $10^{4}$ Дж. Максимальная энергия события составляла порядка 750869 Дж. Событие произошло на глубине 127 м от поверхности, расчетный размер очага порядка - 45 м. Сейсмические события такого энергетического класса представляют непосредственную опасность для технологического оборудования и обслуживающего персонала. В связи с этим представляется важным обеспечить прогноз такой опасности. Для этого проанализировано временное распределение сейсмоактивности в карьере за весь период регистрации (рис. 5.112).

Анализ выполняли для сейсмоактивной зоны вблизи дна карьера. Изменение сейсмоактивности во времени в выделенной зоне оценивалось по изменению значения комплексного критерия $S=E_{\max } \cdot N / T$, где $E_{\max }$ - прогнозная верхняя оценка максимальной энергии сейсмического события на основе распределения событий по энергии в событийном окне фиксированной длины $N$ (график повторяемости), $T$ - временной интервал выборки. При этом распределение событий по энергии выполнялось с учетом весов, которые экспоненциально уменьшались по мере приближения к хронологическому началу выборки. Для обеспечения статистической 
значимости результатов расчетов при сохранении возможности отслеживания динамики процесса размер событийного окна составлял 100 событий. Анализ выполнялся по событиям с энергией меньшей $10^{5}$ Дж. Из представленных данных следует, что сейсмоактивность имеет значительную сезонную зависимость. Это позволяет предположить, что в процессах формирования напряженного состояния массива вблизи поверхности существенно влияние оказывают сезонные явления (например, снеготаяние). На этом же графике отражены зарегистрированные в этой же зоне события с энергией большей $10^{5}$ Дж. Можно видеть, что мощные сейсмические события происходят в периоды малой сейсмической активности и предваряют всплеск сейсмоактивности. Таким образом, можно говорить о том, что зарегистрированная сейсмичность носит афтершоковый характер и является следствием изменений геомеханической ситуации в массиве.

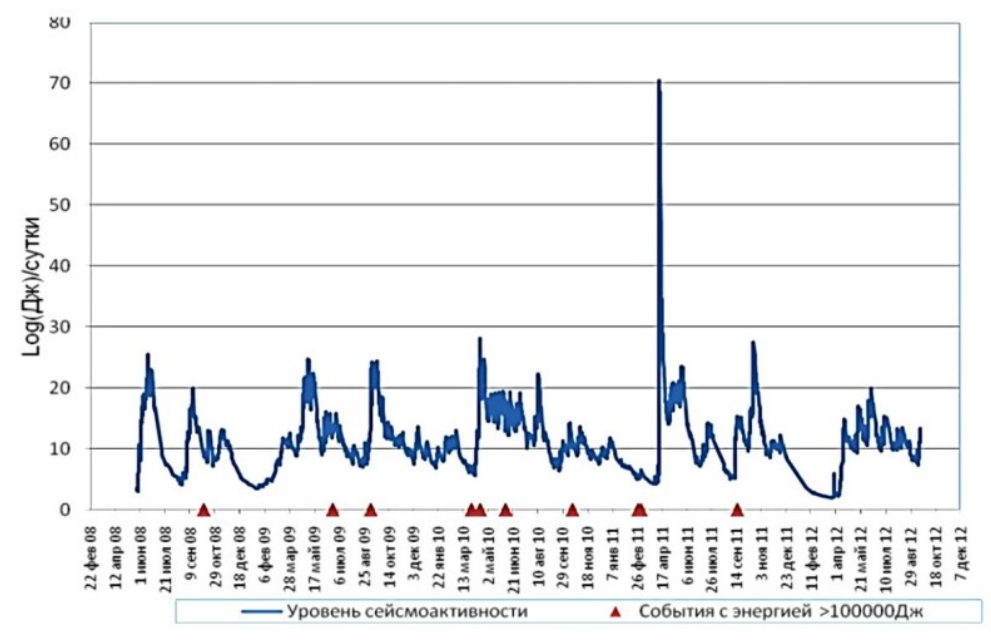

Рис. 5.112. Временное распределение сейсмоактивности

\subsection{4. Сейсмоактивность юго-восточного участка борта карьера в районе ослабленной зоны}

Рассматриваемый участок борта находится в пределах V-структурно-геологического сектора по классификации АО «Мурманская ГРЭ» (при участии Геологического института КНЦ РАН). Ранее на этом участке дважды (в 1994 и 2001 гг.) имели место потери устойчивости уступов после их формирования на проектном конечном контуре. Потеря устойчивости происходила путем сдвига блоков пород по плоскости структурного нарушения R2, подсекающего борт карьера в пределах рассматриваемого участка под углом ориентировочно $43^{\circ}$. В результате к настоящему времени сформировался сплошной откос от отм. +214 до отм. +142 м. Проведенными исследованиями получена достаточно детальная и достоверная информация о структурной нарушенности этого участка. Прежде всего это касается характеристик залегания структурных нарушений, имеющих выход на поверхность карьера или залегающих в непосредственной близости от нее (первые десятки метров). В то же время информации о геомеханическом состоянии и, в частности, характеристиках структурной нарушенности на глубине (в пределах первых сотен метров), явно, недостаточно. Результаты сейсмического мониторинга позволяют судить о геомеханическом состоянии прибортового массива пород в этой зоне. 
Параметры сейсмоактивности в юго-восточном борту карьера (в районе ослабленной зоны) могут быть полезными для своевременного выявления деформационных процессов в массиве пород, приводящих, в конечном счете, к потере устойчивости борта карьера. Следует отметить, что этот район находится в центре зоны регистрации системы, что позволяет с относительно большой точностью определять координаты очагов сейсмических событий даже с малыми энергиями (единицы Джоулей). Кроме того, расположение сейсмических датчиков относительно очагов событий в этом районе позволяет производить оценку механизмов реализации событий.

В течение 2010-2012 гг. в указанной области зарегистрировано 250 сейсмических событий, энергия которых не превышает 15 кДж.

Характерный размер зоны разрушения в очаге сейсмособытия может быть оценен по излученной энергии. В сферическом приближении $L=0,46 E^{1 / 3}$, где $L$ - диаметр сферы разрушения; $E$ - излученная энергия (Дж). Максимальные размеры очагов не превышают единиц метров.

Пространственное распределение сейсмических событий в юго-восточной части карьера показано на рисунках 5.113-5.115 (вид в направлении запад-восток).

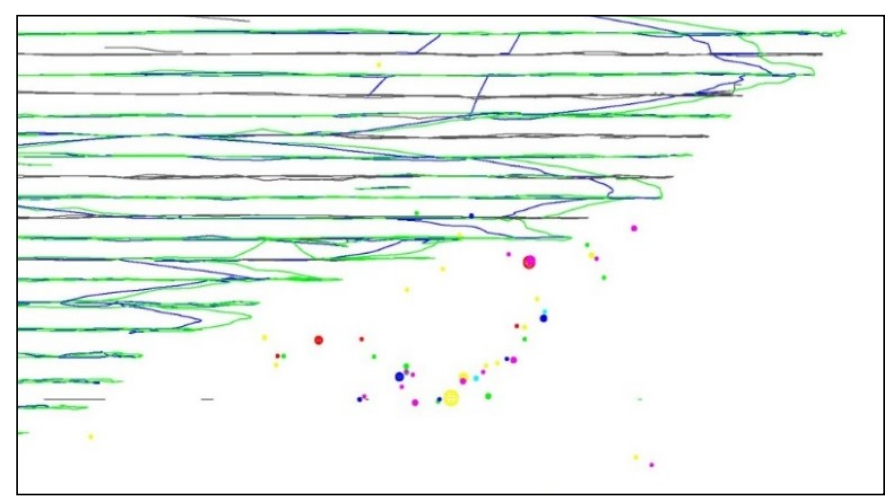

Рис. 5.113. Сейсмособытия на Ю-В борту карьера 2010 г.

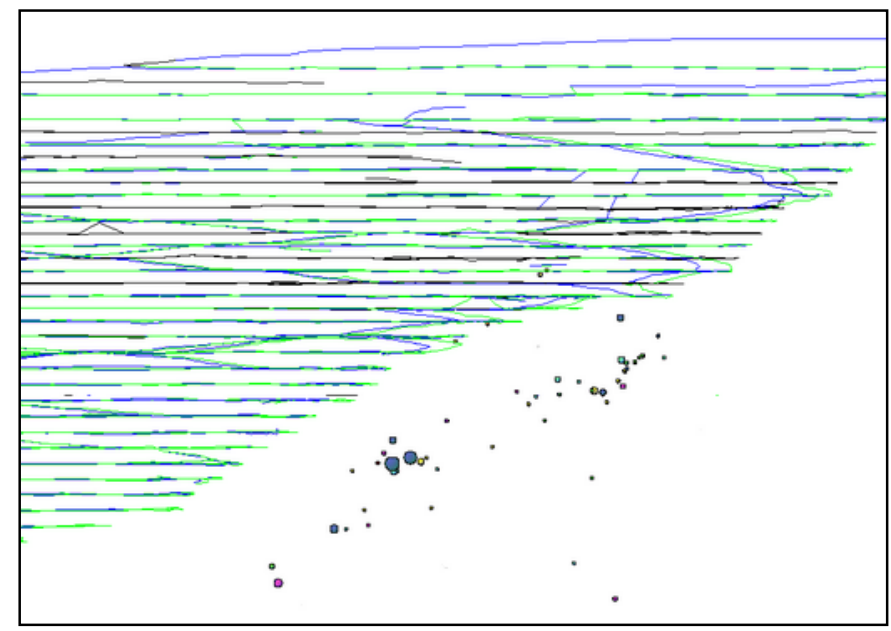

Рис. 5.114. Сейсмособытия на Ю-В борту карьера 2011 г. 


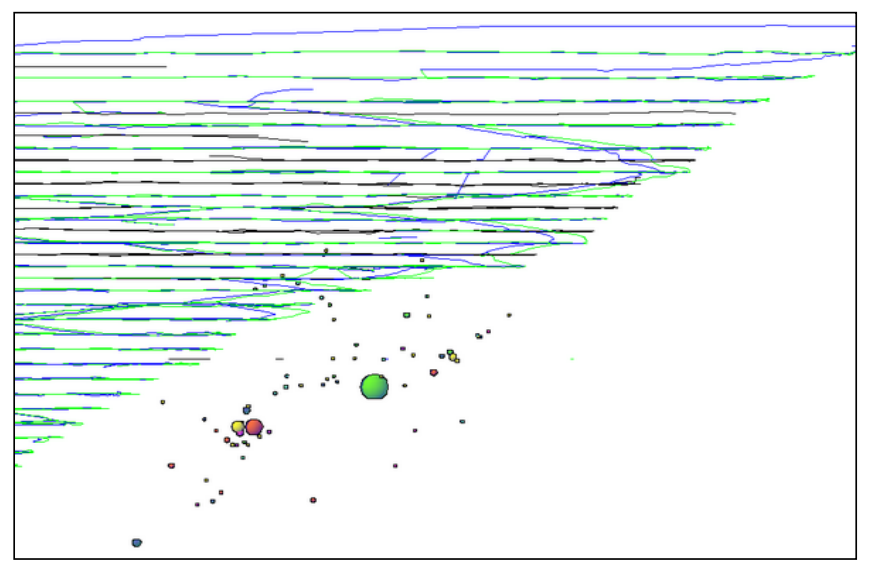

Рис. 5.115. Сейсмособытия на Ю-В борту карьера 2012 г.

На рисунках видно, что сейсмические события локализуются в массиве пород вблизи некоторой внутренней плоской структуры. По данным 2010 г. наклон этой плоской структуры составлял ориентировочно $70^{\circ}$ к вертикали, но как можно видеть на рисунке 5.115 к концу 2012 г. наклон изменился, и структура стала практически параллельной борту карьера.

Сейсмические события в ослабленной зоне относительно выявленных структурных нарушений группируются в направлении, соответствующем зоне сближения субпараллельных трещин центриклинального типа (рис. 5.116).

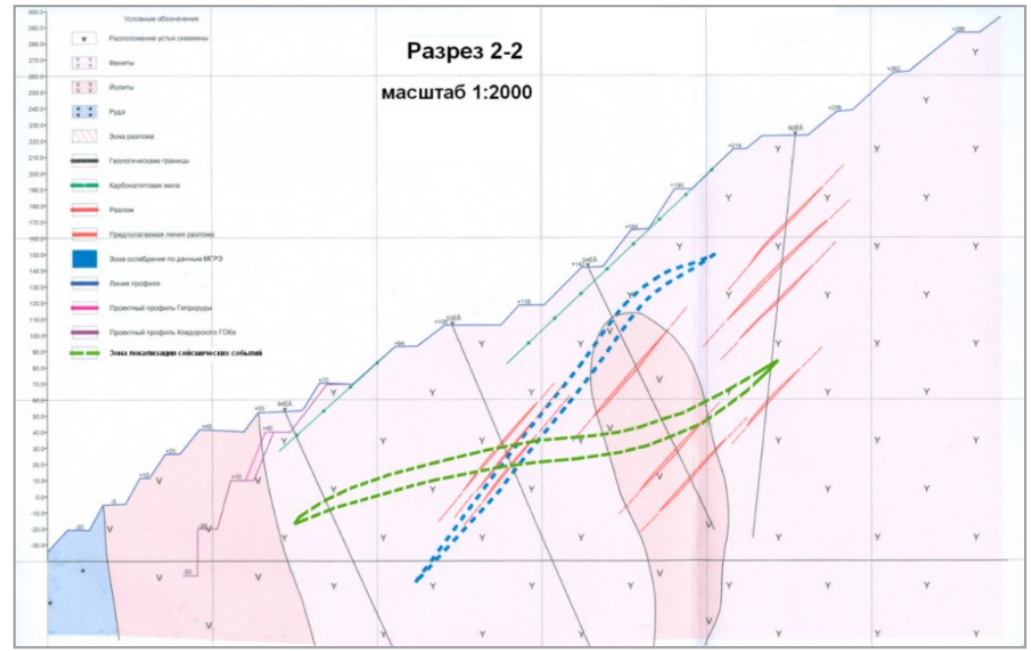

Рис. 5.116. Выделенная зона локализации сейсмических событий относительно структурных нарушений в массиве в ослабленной зоне: ----- - зона локализации сейсмособытий; ---- - зона ослабления по данным геологической службы рудника; — — контуры разломов по результатам бурения разведочных скважин

Выявленная сейсмоактивность в зонах структурных нарушений, явно, свидетельствует о существенном изменении в геомеханическом состоянии массива по мере развития горных работ в карьере. 


\subsection{5. Оценка геомеханического состояния участка юго-восточного борта карьера по результатам сейсмического мониторинга}

Одним из методов оценки изменений геомеханического состояния массива горных пород может использоваться реконструкция механизмов очагов сейсмических событий. Определение механизмов очагов базируется на анализе знаков вступлений продольных волн, зарегистрированных сейсмическими датчиками, окружающими очаг. Механизм очага реконструирован в рамках модели разрушения за счет сдвига для стандартного двухдипольного источника. При этом определяли положение в пространстве нодальных плоскостей, отделяющих области сжатия и растяжения, одна из которых является плоскостью разрыва сплошности в очаге. На основе положения нодальных плоскостей определяли направление осей сжатия и растяжения.

В рамках этой модели проведен анализ механизмов очагов сейсмособытий в исследуемой области.

Данные об ориентации осей напряжений за 2010, 2011, 2012 гг. на вертикальном сечении карьера приведены на рисунке 5.117.

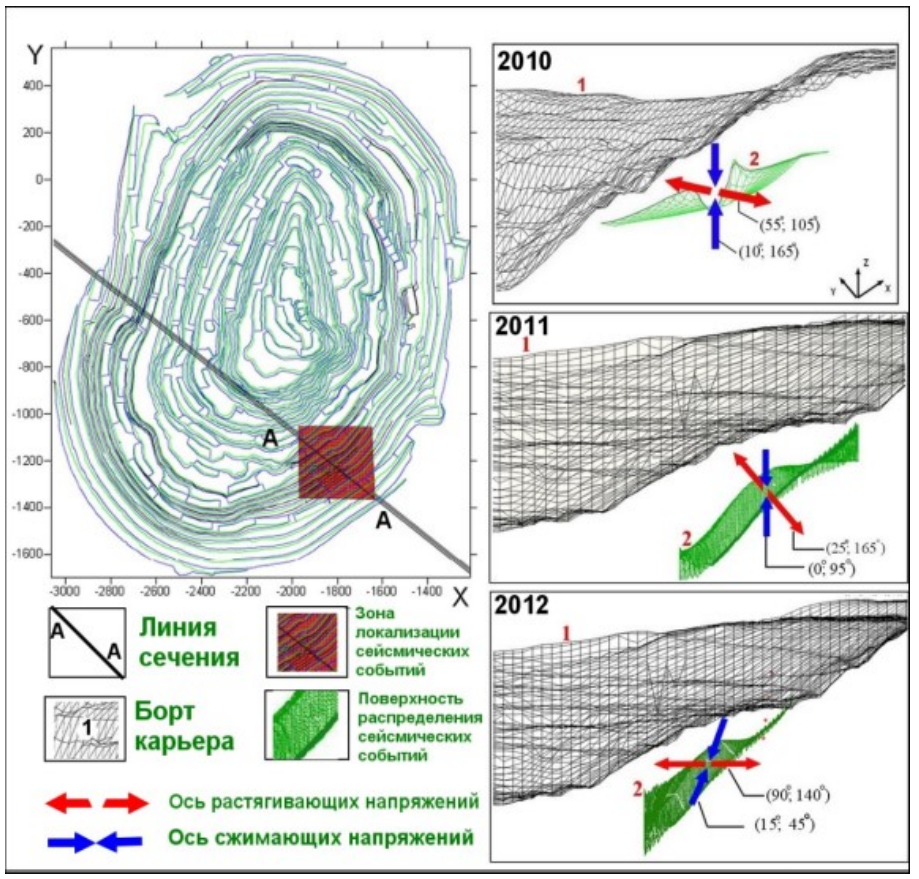

Рис. 5.117. Распределения сейсмособытий и направления преобладающих напряжений в юго-восточной части карьера (по данным 2010-2012 гг.)

Можно видеть, что ось сжимающих напряжений в течение трех лет практически не меняла своего направления, оставаясь близкой к вертикальной, в то же время направление оси растягивающих напряжений изменялось, существенно, меняя наклон от практически перпендикулярного к борту карьера в 2010 г., до горизонтального в 2012 г. Результаты показали, что имеются разрушения как сдвигового, так и надвигового типа. 
Представляет определенный интерес сравнение полученных данных с информацией о геомеханическом состоянии этого участка прибортового массива, полученной ранее другими методами.

Для контроля геомеханического состояния этого участка в 2003-2006 гг. были проведены измерения напряжений методом разгрузки. В 2003 г. на уступе с абсолютной отметкой +166 м были получены следующие результаты: максимальная компонента квазиглавных напряжений $\sigma_{\max }$ составила $3 \mathrm{MПа;}$ минимальная компонента квазиглавных напряжений $\sigma_{\min }=-1 \mathrm{MПа;} \mathrm{наклон}$ $\sigma_{\max }$ К горизонту составил $13^{\circ}$. В дальнейшем по мере постановки этого участка борта карьера на конечный контур были выполнены измерения на гор. +154 м в 2005 г.: $\sigma_{\max }=11 \mathrm{MПа;} \sigma_{\min }=2 \mathrm{MПа;} \mathrm{наклон} \sigma_{\max } \kappa$ горизонту составил $88^{\circ}$. После этого в 2006 г. были выполнены измерения на гор. +142 м: $\sigma_{\max }=12 \mathrm{MПа;}$ $\sigma_{\min }=3 \mathrm{MПа;} \mathrm{наклон} \sigma_{\max }$ к горизонту составил $-125^{\circ}$.

При анализе этих результатов необходимо обратить внимание на следующие обстоятельства. Во-первых, небольшие значения $\sigma_{\min }$ от -1 МПа (растяжение) до 3 МПа (сжатие), что при значениях $\sigma_{\max }$ на гор. +154 и +142 м порядка 11-12 МПа обуславливает действие в массиве пород касательных напряжений порядка 5 МПа. Во-вторых, субвертикальная ориентация $\sigma_{\max }$. В целом на основе выполненных ранее исследований НДС методом разгрузки, можно сделать вывод о том, что в пределах этого участка прибортового массива пород действуют заметные касательные напряжения, что делает возможным сдвиг пород по существующим поверхностям ослабления. Помимо этого, существует некоторая тенденция к распространению растягивающих напряжений, что может приводить к раскрытию существующих и формированию новых трещин в массиве пород.

Сопоставление результатов определения НДС массива пород методом разгрузки и данных по контролю сейсмичности показывает их удовлетворительное качественное соответствие. В обоих случаях субвертикальная компонента напряжений является сжимающей и отмечается наличие растягивающих напряжений.

На основе выполненных исследований сейсмичности прибортового массива пород юго-восточного участка борта карьера можно предположить, что локализация сейсмических событий в законтурном массиве пород по некоей поверхности приурочена, скорее всего, к формирующейся в массиве структуре. При этом наличие в массиве пород растягивающих напряжений, направленных по данным сейсмического контроля нормально к борту карьера, свидетельствует, скорее всего, о реализации этой структуры.

Таким образом, параметры сейсмической эмиссии способны дать достоверную информацию о состоянии контролируемого участка, поэтому этот метод может быть весьма полезным для других проблемных участков борта карьера.

Представленные результаты регистрации и анализа сейсмической эмиссии свидетельствуют об эффективности этого метода для мониторинга геомеханической ситуации в геологической среде карьера. При этом существенное его преимущество перед другими методами (например, геодезическими в их различной технической реализации) являет то, что он дает информацию о динамике геомеханических процессов в самой среде, а не о результатах развития этих процессов, отражением которых является видимые деформации и разрушения на поверхности уступов и борта в целом. 


\subsection{6. Методические подходы к оценке устойчивости бортов карьеров по данным микросейсмического мониторинга}

На основе накопленного опыта эксплуатации микросейсмической системы на карьере рудника «Железный» Ковдорского ГОКа определены принципы построения методики оценки устойчивсоти бортов, реализующих анализ данных сейсмомониторинга, которые отражают различные аспекты состояния прибортового массива карьера (табл. 5.18).

Таблииа 5.18

Процедуры для выявления устойчивости бортов карьера по данным микросейсмического мониторинга

\begin{tabular}{|c|l|}
\hline 1 & Выявление мощных событий, приуроченных к бортам карьера \\
\hline 2 & $\begin{array}{l}\text { Пространственное районирование очагов сейсмических событий, выявление зон } \\
\text { повышенной сейсмоактивности }\end{array}$ \\
\hline 3 & $\begin{array}{l}\text { Анализ пространственного расположения выявленных сейсмоактивных зон относительно } \\
\text { глубины до поверхности, фронта горных работ, имеющихся известных структурных } \\
\text { нарушений массива пород }\end{array}$ \\
\hline 4 & $\begin{array}{l}\text { Определение характера сейсмоактивности по пространственно-временному распределению } \\
\text { параметров очагов сейсмособытий в зонах. Ранжирование выделенных зон по степени } \\
\text { влияния на устойчивость бортов карьера }\end{array}$ \\
\hline 5 & $\begin{array}{l}\text { Соотнесение полученных результатов с хронологически более ранними результатами } \\
\text { анализа, выполнение заключения о состоянии прибортового массива с точки зрения } \\
\text { возможности потери устойчивости борта по данным регистрации сейсмической эмиссии }\end{array}$ \\
\hline
\end{tabular}

Ниже приводится практическая реализация отдельных частных методик.

1. Выявление мощных событий, приуроченных к бортам карьера.

К мощным сейсмическим событиям могут быть отнесены такие, линейные размеры очага которых сопоставимы с характерными размерами элементов, представляющих борт карьера (высота уступов, ширина берм т. п.). Однако далеко не всегда удается из сейсмологических записей достоверно восстановить размер очагов. В таких случаях в качестве оценочного фактора могут использоваться величина излученной сейсмической энергии, сейсмический момент, магнитуда.

2. Пространственное районирование очагов сейсмических событий, выявление зон повышенной сейсмоактивности.

Пространственное районирование очагов сейсмических событий на интервалах времени, достаточных для регистрации статистически значимого для анализа числа событий. Этот период определяется чувствительностью сейсмической системы и интенсивностью сейсмической эмиссии в каждом конкретном случае. Пространственное районирование осуществляется за счет визуального просмотра распределения сейсмособытий в трехмерном пространстве массива пород.

Анализ временного распределения сейсмособытий позволяет выделить некоторые закономерности, которые из года в год остаются неизменными, и связать сейсмичность с процессами, происходящими в прибортовом массиве действующего карьера.

3. Анализ пространственного расположения выявленных сейсмоактивных зон относительно глубины до поверхности, фронта горных работ, имеющихся известных структурных нарушений массива пород. 
Если очаги большого числа сейсмических событий расположены на самой структуре или вблизи нее, тогда вероятно, что по данной структуре происходит проскальзывание. Определенные по сейсмическим событиям плоскости ослабления могут также указывать на ранее неизвестные геологические структуры, которые впоследствии могут быть подтверждены другими геотехническими методами.

4. Соотнесение полученных результатов с хронологически более ранними результатами анализа, выполнение заключения о состоянии прибортового массива с точки зрения возможной потери устойчивости борта по данным регистрации сейсмической эмиссии.

Соотнесение полученных результатов с хронологически более ранними результатами анализа может помочь в выполнении заключения о состоянии прибортового массива по данным регистрации сейсмической эмиссии. Результаты сейсмического мониторинга, по сути, отражают динамику процесса формирования структурной нарушенности массива, что позволяет оценить устойчивость борта карьера на контролируемом участке.

Таким образом, использование результатов сейсмического мониторинга для оценки устойчивости бортов карьеров основано на пространственном районировании очагов сейсмических событий и выявлении зон с характерным пространственно-временным распределением параметров очагов.

Ранжирование выделенных зон по степени влияния на устойчивость бортов карьера должно выполняться на основе их пространственного расположения относительно бортов карьера и имеющихся геологических структур.

Интерпретируемые в геомеханических терминах результаты обработки материалов сейсмологических наблюдений на карьерах имеют определенные перспективы при использовании совместно с другими геотехническими методами. 


\section{6. УПРАВЛЕНИЕ ГЕОДИНАМИЧЕСКИМИ РИСКАМИ В ГОРНОТЕХНИЧЕСКИХ СИСТЕМАХ}

\section{1. Основные понятия и терминология в управлении геоднамическими рисками в горнотехнических системах}

Горнотехническая система представляет собой комплекс технических сооружений (предприятие) и вмещающую его геологическую среду, в процессе эволюции которой могут возникать чрезвычайные ситуации (аварии, несчастные случаи), инициированные техногенными, природными и социальными факторами (а также их сочетаниями). Ущерб от них может быть причинен техносфере, природе, человеку. Это заставляет в качестве объекта анализа выбирать не только предприятие (комплекс технических сооружений), но и окружающую природно-социальную среду, одним словом, промышленно-природно-социальную систему. Окружающая предприятие природно-социальная среда имеет пространственные границы, определяемые возможным (опасным) воздействием на нее негативных факторов, в том числе и геодинамических рисков.

Применительно к управлению геодинамическими рисками в горнотехнических системах представляется целесообразным напомнить определения некоторых основных понятий.

Риск - количественная мера опасности. Опасность - это свойство кого (чего)-либо причинять кому (чему)-либо ущерб (вред). Таким образом, опасность - понятие качественное. Говоря о ней, необходимо указывать как источник, так и объект ее воздействия. Только в этом случае данное понятие имеет конкретный смысл. Источниками и объектами воздействия опасности могут являться элементы горнотехнической системы: промышленные, природные и социальные.

Чрезвычайные ситуации, аварии, несчастные случаи, геодинамические события - это проявления, реализации опасностей, значимость которых определяется уровнем риска.

Риск может быть допустимый (приемлемый) и недопустимый (неприемлемый). Количественные критерии допустимости/недопустимости риска определяются экономическими и социальными факторами и имеют различные значения для разных стран и ситуаций. Риск характеризуется частотой (вероятностью) и тяжестью возможных последствий (ущербом).

Безопасность - это отсутствие недопустимого риска. Выделяются уровни безопасности, определяемые риск-показателями, экономическими и социальными факторами.

Управление рисками - это комплекс организационно-технических мероприятий для обеспечения адекватной ситуации уровня безопасности, то есть приемлемого риска.

Рассматриваются такие опасные геодинамические явления, как шелушение, стреляние, заколообразование, микроудар, горный удар, горно-тектонический удар, техногенное землетрясение. Следует отметить, что геодинамическое явление может и не приводить к разрушениям горных выработок, но наличие таких событий, однозначно, свидетельствует о потенциальной опасности для ведения горных работ.

Совершенно очевидно, что последствия геодинамического явления для рудника будут определяться не только мощностью события, но и координатами очага. При достаточно удаленном от горных работ очаге будет иметь место толчок, звук и сотрясение, от которого будут определяться энергией события; при расположении очага вблизи горных работ будет иметь место горно-тектонический 
удар в его общепринятой формулировке. То есть имеет место влияние различных факторов, которые необходимо учитывать при оценке риска.

В системе Ростехнадзора РФ используются следующие определения рисков и ущерба [240]:

- технический риск - вероятность отказа технических устройств с последствиями определенного уровня (класса) за определенный период функционирования опасного производственного объекта;

- индивидуальный риск - частота поражения отдельного человека в результате воздействия исследуемых факторов опасности аварий;

- потенциальный территориальный риск - частота реализации поражающих факторов аварии в рассматриваемой точке территории;

- коллективный риск - ожидаемое количество пораженных в результате возможных аварий за определенный период времени;

- социальный риск (или $F / N$ - кривая) - зависимость частоты возникновения событий $F$, в которых пострадало на определенном уровне не менее $N$ человек, характеризует тяжесть последствий (катастрофичность) реализации опасностей;

- оценка риска аварии - процесс, используемый для определения вероятности (или частоты) и степени тяжести последствий реализации опасностей аварий для здоровья человека и/или окружающей природной среды;

- приемлемый риск аварии - риск, уровень которого допустим и обоснован исходя из социально-экономических соображений. Риск эксплуатации объекта является приемлемым, если ради выгоды, получаемой от эксплуатации объекта, общество готово пойти на такой риск.

В таблице 6.1 приведен перечень геодинамических явлений, представляющих собой геодинамические риски, различающиеся по масштабу последствий при их реализации. Следует обратить внимание на то, что горно-тектонический удар и техногенное землетрясение по мощности проявления и тяжелым последствиям представляют собой катастрофу [241, 242]. В отечественной литературе не обозначена четкая граница между этими двумя явлениями, но за рубежом отношение к ним в разных странах неоднозначное. Так, например, в материалах Австралийского центра геомеханики есть упоминание о том, что техногенное землетрясение может и не сопровождаться разрушением горных выработок [163].

Представляет некоторый интерес рассмотрение вопросов безопасности в ряде зарубежных публикациях.

Шинзингер и Мартин [243] (Schinzinger and Martin) предлагают следующее определение безопасности: «Процесс считается безопасным, если при известных рисках, эти риски признаются приемлемыми здравомыслящим человеком в свете установленных значимых принципов». Приемлемость риска зависит от того, является ли подвергание риску добровольным или принудительным. Принудительные риски - это риски, которым подвергается обычный человек без выбора, например, смертельные болезни или пожары. С другой стороны, добровольным рискам подвергаются только те, кто сам выбирает опасные занятия.

Что касается профессий, связанных с горным делом и других промышленных профессий, то часто существует разница во мнении, какому риску подвергаются рабочие - добровольному или принудительному. Промышленные риски можно рассматривать как добровольные, если работнику было официально позволено сознательно принять риски за соответствующее вознаграждение [244]. 
Таблица 6.1

Геодинамические явления в рудниках

\begin{tabular}{|c|c|c|c|}
\hline $\begin{array}{l}\text { Геодинамическое } \\
\text { явление }\end{array}$ & $\begin{array}{c}\text { Этап } \\
\begin{array}{c}\text { развития опасной } \\
\text { ситуации }\end{array}\end{array}$ & Сущность процесса & $\begin{array}{l}\text { Уровень } \\
\text { геодинамического } \\
\text { риска }\end{array}$ \\
\hline Шелушение & \multirow{3}{*}{ Угроза } & Постепенное разрушение поверхности породы на отдельные пластинки & \multirow{3}{*}{ Низкий } \\
\hline Стреляние & & Отскакивание с поверхности обнажения массива пластин пород различных размеров со звуком & \\
\hline $\begin{array}{l}\text { Динамическое } \\
\text { заколообразование }\end{array}$ & & $\begin{array}{l}\text { Образование и отделение заколов вслед за оборкой, сопровождаемое треском и звуками, } \\
\text { напоминающими выстрел }\end{array}$ & \\
\hline Микроудар & Инцидент & $\begin{array}{l}\text { Мгновенное хрупкое разрушение целика или части массива горных пород с выбросом породы в горные } \\
\text { выработки без нарушения технологического процесса }\end{array}$ & Низкий \\
\hline Горный удар & Авария & $\begin{array}{l}\text { Внезапное быстропротекающее разрушение предельно напряженной части массива, прилегающего } \\
\text { к горной выработке, проявляющееся в виде выброса руды (породы) в подземные выработки с нарушением } \\
\text { крепи, смещением машин, механизмов, оборудования и вызывающее нарушение технологического процесса }\end{array}$ & Средний \\
\hline $\begin{array}{l}\text { Горно-тектонический } \\
\text { удар }\end{array}$ & \multirow[b]{2}{*}{ Катастрофа } & $\begin{array}{l}\text { Мгновенная подвижка пород по тектоническому нарушению или прорастание крупной трещины в массиве, } \\
\text { в том числе с образованием систем оперяющих трещин, сейсмическое воздействие от которых вызывает } \\
\text { хрупкое разрушение пород на контуре горных выработок в виде горных ударов, вывалов пород, падения } \\
\text { заколов, разрушение целиков и крепи на большой площади или на отдельных удаленных друг от друга } \\
\text { участках выработок }\end{array}$ & \multirow[b]{2}{*}{ Высокий } \\
\hline $\begin{array}{l}\text { Техногенное } \\
\text { землетрясение }\end{array}$ & & $\begin{array}{l}\text { Мгновенная подвижка пород по тектоническому нарушению или прорастание крупной трещины в массиве } \\
\text { геомеханического пространства рудника, в том числе с образованием систем оперяющих трещин. Само } \\
\text { явление или его сейсмическое воздействие вызывает хрупкое разрушение пород на контуре горных выработок } \\
\text { в виде горных ударов, вывалов пород, падения заколов, разрушение целиков и крепи, вспучивание почвы } \\
\text { на значительных площадях в подземных горных выработках, а также приводит к повреждениям и разрушениям } \\
\text { на земной поверхности }\end{array}$ & \\
\hline
\end{tabular}




\section{2. Классификация и количественная оценка рисков}

Общее понятие риска включает в себя два четко различимых компонента.

1. Частота (вероятность) $F(P)$ ожидаемого нежелательного события (аварии). Она выражается числом событий в единицу времени (или безразмерна).

2. Последствия (ущерб) $C$, которые являются мерой серьезности нежелательного события (аварии). Последствия могут быть выражены различными показателями: гибелью или причинением ущерба здоровью людей, а также нарушением технологии производства и соответствующим ущербом.

Таким образом, риск - это функция двух переменных:

$$
\text { Риск }=f(F, C)
$$

где $F$ - частота; $C$ - последствия.

$\mathrm{C}$ позиций геодинамической безопасности может быть полезной классификация рисков по времени актуализации (реализации) динамического события [245]:

- оперативные риски - период реализации не превышает одного, в крайнем случае несколько дней;

- тактические риски - период реализации от нескольких дней до нескольких месяцев, но не более одного года;

- стратегические риски - период реализации превышает несколько месяцев и может иметь продолжительность до нескольких и более лет.

Риск различных видов деятельности. Для сравнения различных видов деятельности риск часто количественно выражается через показатель FAR (Fatal Accident Rate), характеризующий частоту аварий со смертельным исходом. Показатель FAR отражает количество смертельных исходов в течение $10^{8}$ ч воздействия вероятных аварийных факторов на здоровье 1 тыс. человек. Так, если для некоторого предприятия показатель FAR равен 8,0, то это означает, что из 1 тыс. работающих на этом предприятии всю трудовую жизнь при режиме работы в течение 50 недель в год (2 недели на отпуск) и 40 ч в неделю, 8 человек могут погибнуть из-за аварии.

Приемлемость риска. На государственном уровне методология анализа и управления риском, основанная на концепции приемлемого риска, была принята в Нидерландах [246]. Голландский подход в последнее время получил широкое распространение в зарубежной практической деятельности по обеспечению безопасности и управления риском. Согласно этому подходу весь «спектр» риска (индивидуального и социального) разбивают на три области в соответствии с принципом светофора (рис. 6.1., 6.2):

недопустимого (чрезмерного) риска - «красную» область. Любая деятельность, характеризующаяся для какого-либо индивидуума уровнем риска из этой области, недопустима, даже если она выгодна для общества в целом;

приемлемого риска - «желтую» область. Любая деятельности из этой области является объектом контроля для регулирующего органа. Уровень риска, приемлемый для той или иной деятельности, определяется исходя из экономических и социальных аспектов в соответствии с принципами управления риском;

пренебрежимого риска - «зеленую» область. Любая деятельность с уровнем риска из этой области не контролируется регулирующим органом. 


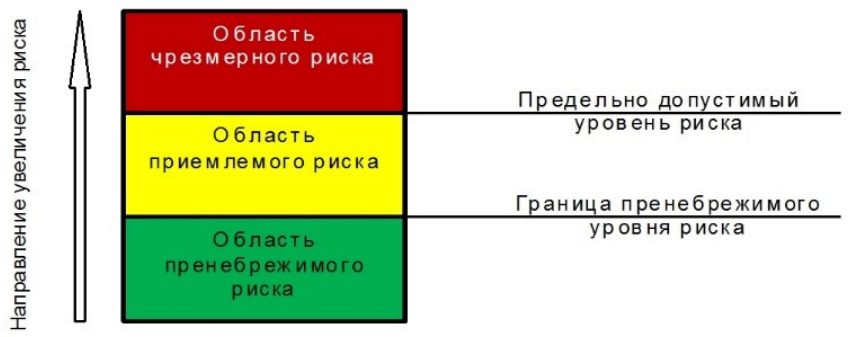

Рис. 6.1. Разбиение диапазона значений индивидуального риска на три области: недопустимого (чрезмерного), приемлемого и пренебрежимого

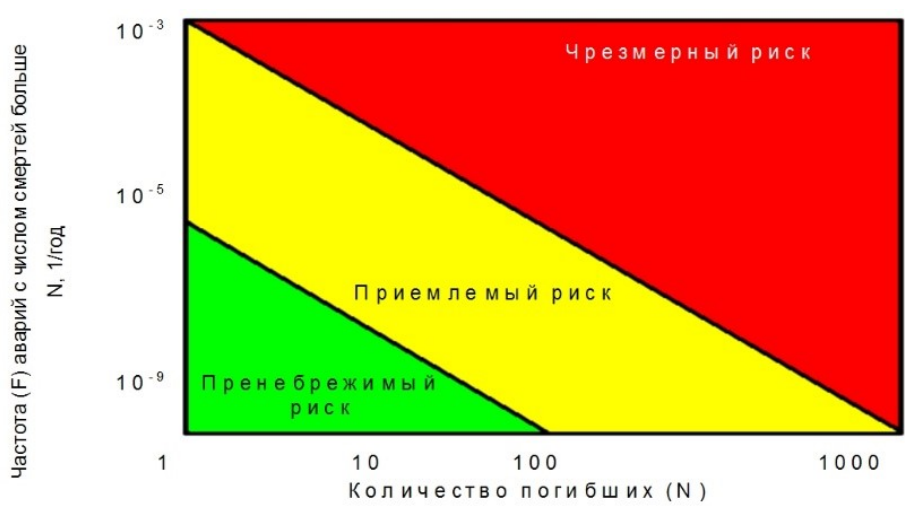

Рис. 6.2. Разбиение диапазона значений социального риска на три области: недопустимого (чрезмерного), приемлемого и пренебрежимого

Предель индивидуального и социального риска. В Нидерландах [247] на законодательном уровне для предельно допустимого уровня (ПДУ) индивидуального риска, обусловленного хозяйственной деятельностью, неприемлемым принято значение риска смерти, равное $10^{-6}$ в год. Что касается численного значения для пренебрежимого риска, то в настоящее время общепринятой является точка зрения, согласно которой риск смерти для индивидуума менее $10^{-8}$ в год можно рассматривать как пренебрежимый.

Для максимально допустимого уровня социального риска в Нидерландах была рекомендована величина $10^{-5}$ в год с максимальным числом погибших, равным 10 .

Рекомендации нормативных уровней риска для России. Различные значения ПДУ индивидуального риска, используемые в разных странах, указывают на то, что уровень риска смерти выше $10^{-4}$ в год в качестве значения для ПДУ однозначно признается неприемлемым (чрезмерным). Экспертные оценки, основанные на обобщении выполненных исследований, в том числе декларирований безопасности, показывают [248-251], что ПДУ индивидуального риска для России должен находиться в диапазоне $10^{-4}-10^{-5}$ в год (табл. 6.2).

Целесообразным представляется применение различных критериальных уровней для вновь строящихся объектов и уже действующих. Для вводимых новых объектов критериальные уровни должны быть установлены ниже тех, которые могут применять в течение определенного периода времени для функционирующих объектов. Для новых объектов ПДУ индивидуального риска может быть установлен на уровне $10^{-5}$ в год, для действующих $-10^{4}$ в год, при условии принятия мер по снижению риска в течение установленного срока (рис. 6.3). 
Сравнение нормативных показателей индивидуального риска, принятых или предлагаемых для использования в практической деятельности в различных странах

\begin{tabular}{|l|c|c|}
\hline \multicolumn{1}{|c|}{ Страна } & Предельно допустимый уровень, 1/год & Пренебрежимо малый уровень, 1/год \\
\hline Нидерланды & $10^{-6}$ & $10^{-8}$ \\
\hline Гонконг (Китай) & $10^{-5}$ & $10^{-7}$ \\
\hline Россия (Москва) & $10^{-5}-10^{-4}$ & $10^{-7}-10^{-6}$ \\
\hline
\end{tabular}

Функционирующий о бъект

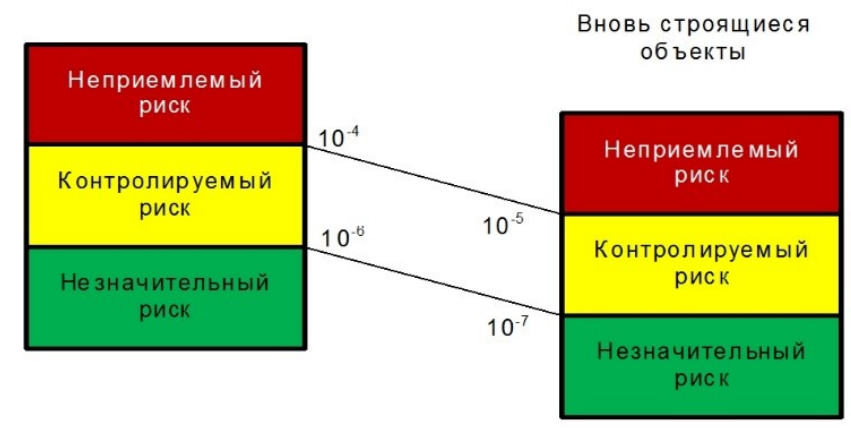

Рис. 6.3. Дифференциация рекомендуемых нормативных уровней индивидуального риска для функционирующих и вновь строящихся объектов — источников техногенного риска

Для России, в качестве критериев индивидуального риска, создаваемого систематическим воздействием на здоровье населения загрязняющих веществ, поступающих в окружающую среду с выбросами и сбросами, действующих в штатном режиме объектов, а также в результате совместного действия загрязняющих веществ, радиационного облучения и других факторов, целесообразно установить значения на порядок более «мягкие», по сравнению с теми критериальными уровнями, которые применяются в Нидерландах (рис. 6.4), а именно:

для систематического воздействия на здоровье населения:

- предельно (максимально) допустимый уровень индивидуального риска $-10^{-5}$ в год;

- пренебрежимый уровень индивидуального риска $-10^{-7}$ в год;

для совместного воздействия на здоровье населения различных факторов:

- предельно (максимально) допустимый уровень индивидуального риска - $10^{-4}$ в год;

- пренебрежимый уровень индивидуального риска $-10^{-6}$ в год.

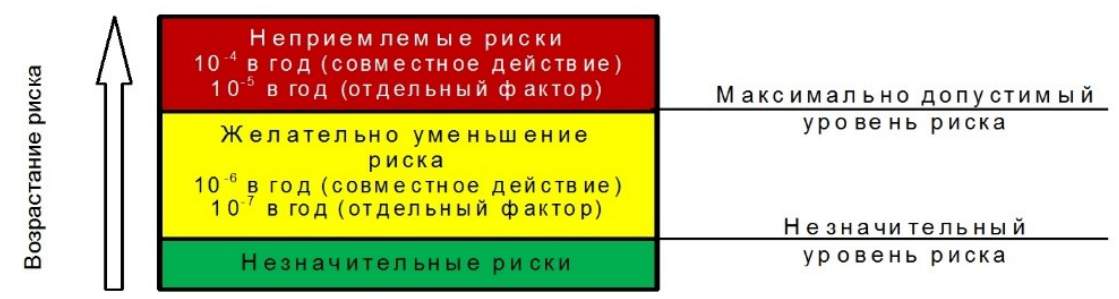

Рис. 6.4. Рекомендации для России по критериям индивидуального риска от систематического и совместного воздействия различных факторов 


\section{3. Оценка уровня геодинамической безопасности на апатитовых рудниках}

Принятые в сфере геодинамической безопасности классификации и показатели риска носят в основном качественный характер. Уровни геодинамического риска в зависимости от возможного геодинамического явления, этапа развития опасной ситуации, описания возможного опасного процесса подразделяются на «низкий», «средний», «высокий».

Это объясняется сложностью физического процесса формирования очага и реализации динамического явления, большим числом взаимно влияющих факторов и трудностью математической формализации для определения количественных параметров уровня опасности. Поэтому вербальные оценки уровня риска достаточно широко применяются в промышленности, например, в [252-255], что разрешено соответствующим ГОСТом [256].

В соответствии с изложенными принципами выполнена оценка геодинамического риска для Хибинских апатитовых рудников на современном уровне технологии горных работ.

Породы и руды апатитовых месторождений в зависимости от предела прочности при сжатии подразделяются на различные категории прочности (степени крепости, от «высшей степени крепких» до «очень слабых»). Также породы и руды классифицируются по интенсивности трещиноватости и (в зависимости от категорий прочности и трещиноватости) по устойчивости. На этой основе разработана классификация состояний горных выработок. Каждой категории состояния поставлен в соответствие качественный (вербальный) показатель уровня геодинамического риска (табл. 6.3).

Основными параметрами количественных показателей опасных геодинамических явлений являются местоположение очага, магнитуда, интенсивность (сила) колебаний, сейсмическая энергия, площадь и/или объем разрушений, экономический ущерб. Существуют различные классификации геодинамических явлений в зависимости от энергии, повторяемости, площади (зоны) разрушений, массы разрушаемой породы, магнитуды.

Для оценки уровня геодинамического риска рассчитана вероятность возникновения геодинамического явления и определена степень последствий по имеющейся базе данных геодинамических явлений, официально зарегистрированных комиссиями по горным ударам на рудниках АО «Апатит» за период 1981-2015 гг. На рисунке 6.5 показано распределение количества этих событий в течение всего рассматриваемого периода.

Представленные данные демонстрируют отклик массива на техногенное воздействие. Провалы в регистрации явлений объясняются различными технологическими (корректировкой технологии отработки месторождений и замедлением ведения горных работ в этот период), социальными и экономическими факторами, которые здесь не учитываются.

За рассматриваемый временной период зарегистрировано 67 различных геодинамических явлений, сопровождавшихся в разной степени разрушением выработок, повреждением оборудования, травмированием людей и случаями, обошедшимися без последствий. Для анализа отобраны 54 явления, по которым имеется исчерпывающая информация по всем актуальным параметрам. На диаграмме (рис. 6.6) приведены результаты анализа процентного содержания последствий геодинамических явлений по этим параметрам. 
Классификация категорий состояния горных выработок

Таблица 6.3

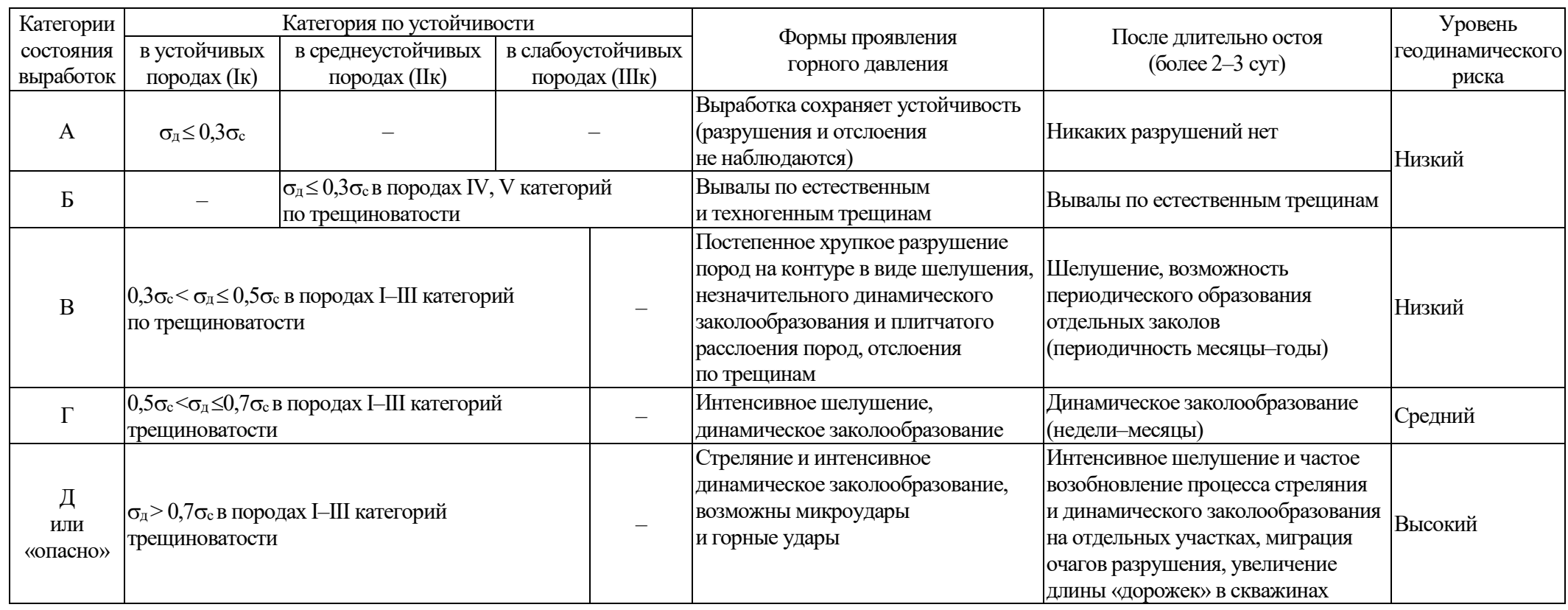




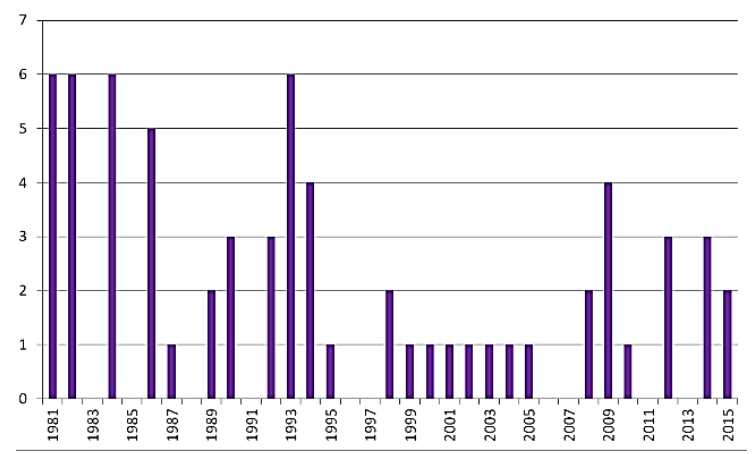

Рис. 6.5. Распределение количества геодинамических событий по годам за период с 1981 по 2015 гг. (официально зарегистрированных комиссиями по горным ударам АО «Апатит)
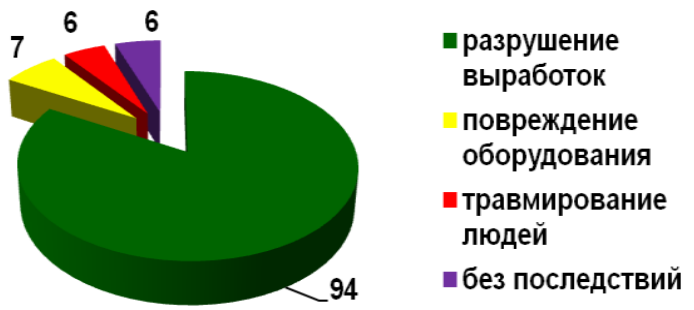

Рис. 6.6. Процентное распределение основных последствий геодинамических явлений, зарегистрированных в период 1981-2015 гг.

Приведенные данные показывают, что основной ущерб от геодинамических явлений заключается в различной степени нарушения горных выработок, при этом на остальные последствия приходится менее 10 \%. То есть, в этом случае геодинамический риск можно классифицировать как технологический.

Более детальный анализ указанных временных периодов показал следующую тенденцию (рис. 6.7): первый двадцатилетний период характеризуется наличием случаев повреждения оборудования и травмирования людей, последние пятнадцать лет - травмирования людей от геодинамических явлений больше не регистрируется, a наряду с ростом количества случаев повреждения оборудования (особенно в последние 5 лет) возросло количество событий без каких-либо последствий, что может свидетельствовать о достаточно высокой эффективности проведения соответствующих профилактических мероприятий.

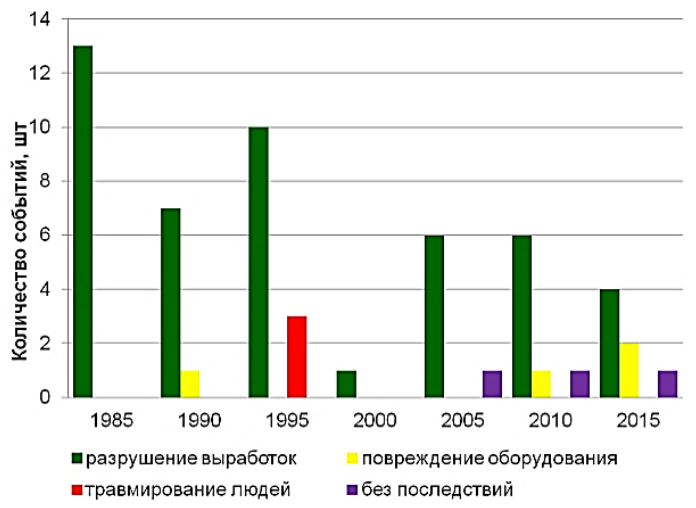

Рис. 6.7. Распределение количества различных последствий геодинамических явлений за рассматриваемый период 
Для этих последствий рассчитаны вероятности $P$ наступления одного события по формуле:

$$
P=N / T,
$$

где $N$ - количество зарегистрированных событий; $T$ - рассматриваемый временной период.

Также рассчитаны риски наступления последствий геодинамического события по следующим формулам:

1) вероятность разрушения выработок $P_{b w}$ :

$$
P_{b w}=\left(N_{b w} \cdot L_{b w}\right) / L_{w}
$$

где $N_{b w}$ - количество зарегистрированных событий; $L_{b w}$ - длина разрушенной зоны; $L_{w}$ - общая длина выработок.

2) вероятность повреждения оборудования $P_{b e}$ :

$$
P_{b e}=N_{b e} /\left(T \cdot N_{e}\right),
$$

где $N_{b e}-$ количество зарегистрированных событий; $T$ - временной период; $N_{e}$ - общее количество оборудования, находящегося в выработках.

3) вероятность травмирования людей $P_{b m}$ :

$$
P_{b m}=N_{b m} /\left(T \cdot N_{m}\right)
$$

где $N_{b m}$ - количество зарегистрированных событий; $T$ - временной период; $N_{m}$ - общее количество людей, находящихся в выработках.

4) вероятность отсутствия последствий $P_{w}$ :

$$
P_{w}=N_{w} / T,
$$

где $N_{w}-$ количество зарегистрированных событий; $T$ - рассматриваемый временной период.

При этом значения вероятностей и рисков наступления последствий события рассчитывались за год, а для последствий в виде разрушения выработок - на $1 \mathrm{~m}^{3}$ выработки в год.

В таблице 6.4 приведены вероятности возникновения определенного класса последствий геодинамических явлений для разных временных диапазонов, где диапазон 5 лет равен временному периоду с 1981 по 1985 гг., 10 лет — с 1981 по 1990 гг. и т. п.

Из представленных в таблице 6.4 расчетных значений видно, что величины вероятностей весьма малы и находятся в диапазоне значений $10^{-7}-10^{-8}$ в год.

В таблице 6.5 для сравнения приведены рассчитанные для рассматриваемого периода вероятности возникновения геодинамических явлений для разных временных диапазонов, а также вероятности возникновения определенного класса их последствий в порядке обратного отсчета, где диапазон 5 лет равен временному периоду с 2015 по 2010 гг., 10 лет — с 2015 по 2005 гг. и т. п. При этом значения вероятности и риска наступления события также рассчитывались за год, а для последствий в виде разрушения выработок — на 1 м³ выработки в год. 
Таблица 6.4

Результаты статистического анализа последствий геодинамических явлений

\begin{tabular}{|c|c|c|c|c|c|c|c|c|c|c|}
\hline 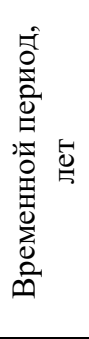 & 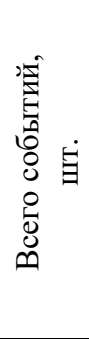 & 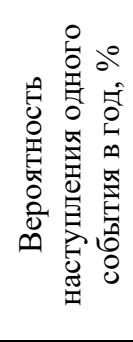 & 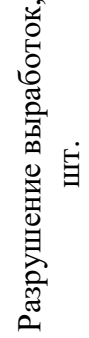 & 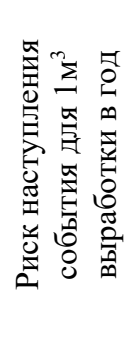 & 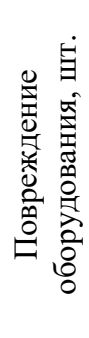 & 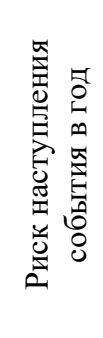 & 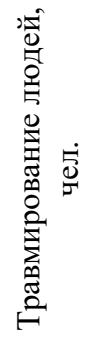 & 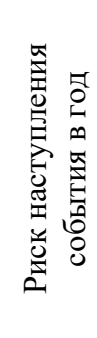 & 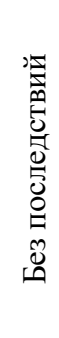 & 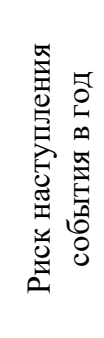 \\
\hline 35 & 54 & $4 \cdot 10^{-3}$ & 51 & $9 \cdot 10^{-8}$ & 4 & $3 \cdot 10^{-7}$ & 4 & $6 \cdot 10^{-8}$ & 4 & $6 \cdot 10^{-8}$ \\
\hline 30 & 49 & $4 \cdot 10^{-3}$ & 43 & $9 \cdot 10^{-8}$ & 2 & $2 \cdot 10^{-7}$ & 3 & $5 \cdot 10^{-8}$ & 2 & $4 \cdot 10^{-8}$ \\
\hline 25 & 41 & $4 \cdot 10^{-3}$ & 37 & $9 \cdot 10^{-8}$ & 1 & $1 \cdot 10^{-7}$ & 3 & $7 \cdot 10^{-8}$ & 1 & $2 \cdot 10^{-8}$ \\
\hline 20 & 34 & $5 \cdot 10^{-3}$ & 31 & $9 \cdot 10^{-8}$ & 1 & $1 \cdot 10^{-7}$ & 3 & $8 \cdot 10^{-8}$ & 0 & 0 \\
\hline 15 & 3 & $5 \cdot 10^{-4}$ & 30 & $1 \cdot 10^{-7}$ & 1 & $2 \cdot 10^{-7}$ & 3 & $1 \cdot 10^{-7}$ & 0 & 0 \\
\hline 10 & 23 & $6 \cdot 10^{-3}$ & 20 & $1 \cdot 10^{-7}$ & 1 & $3 \cdot 10^{-7}$ & 0 & 0 & 0 & 0 \\
\hline 5 & 12 & $7 \cdot 10^{-3}$ & 12 & $1 \cdot 10^{-7}$ & 0 & 0 & 0 & 0 & 0 & 0 \\
\hline
\end{tabular}

Таблица 6.5

Результаты статистического анализа последствий геодинамических явлений (обратный расчет)

\begin{tabular}{|c|c|c|c|c|c|c|c|c|c|c|}
\hline 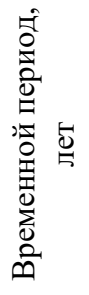 & 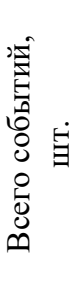 & 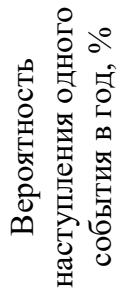 & 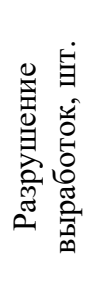 & 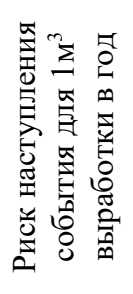 & 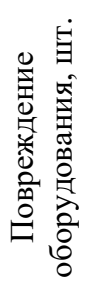 & 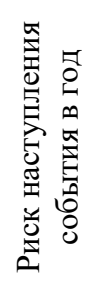 & 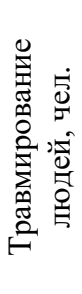 & 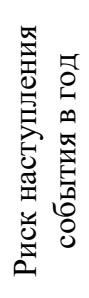 & 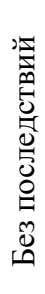 & 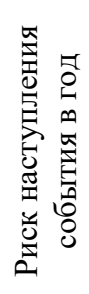 \\
\hline 35 & 54 & $8 \cdot 10^{-7}$ & 47 & $8 \cdot 10^{-8}$ & 4 & $6 \cdot 10^{-8}$ & 3 & $5 \cdot 10^{-8}$ & 3 & $5 \cdot 10^{-8}$ \\
\hline 30 & 42 & $8 \cdot 10^{-7}$ & 34 & $7 \cdot 10^{-8}$ & 4 & $7 \cdot 10^{-8}$ & 3 & $5 \cdot 10^{-8}$ & 3 & $5 \cdot 10^{-8}$ \\
\hline 25 & 31 & $7 \cdot 10^{-7}$ & 27 & $7 \cdot 10^{-8}$ & 3 & $7 \cdot 10^{-8}$ & 3 & $7 \cdot 10^{-8}$ & 3 & $7 \cdot 10^{-8}$ \\
\hline 20 & 21 & $6 \cdot 10^{-7}$ & 17 & $5 \cdot 10^{-8}$ & 3 & $8 \cdot 10^{-8}$ & 0 & 0 & 3 & $8 \cdot 10^{-8}$ \\
\hline 15 & 20 & $7 \cdot 10^{-7}$ & 16 & $6 \cdot 10^{-8}$ & 3 & $1 \cdot 10^{-7}$ & 0 & 0 & 3 & $1 \cdot 10^{-8}$ \\
\hline 10 & 13 & $7 \cdot 10^{-7}$ & 10 & $6 \cdot 10^{-8}$ & 3 & $2 \cdot 10^{-7}$ & 0 & 0 & 2 & $1 \cdot 10^{-8}$ \\
\hline 5 & 5 & $5 \cdot 10^{-7}$ & 4 & $5 \cdot 10^{-8}$ & 2 & $2 \cdot 10^{-7}$ & 0 & 0 & 1 & $1 \cdot 10^{-8}$ \\
\hline
\end{tabular}

При сопоставлении значений рассматриваемых параметров, приведенных в таблицах 6.4 и 6.5 , видно, что обратный анализ дает еще меньшие значения вероятностей, уровень риска при которых находится в диапазоне $10^{-7}-10^{-8}$ в год.

Таким образом, степень риска зависит не только от общего рассматриваемого периода наблюдений, но и от временных диапазонов его слагающих. Но в целом рассчитанный уровень индивидуального риска при возникновении геодинамического явления и реализации его негативных последствий весьма низок и находится в диапазоне значений пренебрежимого уровня индивидуального риска $10^{-6}-10^{-8}$ в год, находящемся в основном в зеленой области «светофора», упомянутом в разделе 6.2. 
Представляется интересным и полезным обратиться к соответствующему зарубежному опыту. Уровень смертельного риска между 1:1000 и 1:10000 соответствует максимальному уровню приемлемого риска, используемого большинством инструкций, а именно: Плановым департаментом Гонконга (the Hong Kong Planning Department), ANCOLD (Австралийским национальным комитетом по крупным дамбам), Американским бюро по восстановлению земель (U.S. Bureau of Reclamation), Великобританскими правилами по технике безопасности и охране труда (the U.K. Health and Safety Guidelines).

Приемлемые уровни индивидуального риска по данным Эриксона (для риска, связанного с хранением взрывчатых веществ в Норвегии) составляют $2 \times 10^{-5} /$ год, $2 \times 10^{-6} /$ год и $2 \times 10^{-7} /$ год для тех работников, которые прямо подвергаются рискам, для тех, кто подвергается риску косвенно, и для тех, кто не подвергаются риску, соответственно [257].

Таким образом, величина индивидуального геодинамического риска на апатитовых рудниках соответствует мировому уровню.

\section{4. Основные принципы управления геодинамическими рисками в геологической среде горнотехнических систем}

Управление геодинамическими рисками при ведении горных работ сводится в основном к управлению НДС геологической среды в горнотехнических системах, основная цель которого - обеспечение безопасности и технико-экономической эффективности горных работ при разработке месторождений полезных ископаемых, а также при различного рода подземного строительства. Основой всякого управления является информация, циркулирующая в системе управления и содержащая в общем случае три составляющие:

1) информацию о фактическом состоянии объекта управления;

2) прогнозную модель условий в объекте управления;

3) организационные и технические средства управления.

Эффективность любого управления определяется адекватностью оценки текущей ситуации и надежностью прогнозной оценки состояния объекта техногенного воздействия. В нашем случае речь идет о геодинамической безопасности, которая может быть обеспечена только надежным геомеханическим прогнозом и эффективной профилактикой.

В результате многолетних исследований по проблеме обеспечения безопасности при ведении горных работ в удароопасных условиях определилась оптимальная методология геомеханического прогноза, которая состоит из следующих этапов:

1) создание инженерно-геологических моделей месторождения или разрабатываемых его участков;

2) построение математических или численных моделей НДС месторождений или актуальных его частей;

3) прогноз геомеханической ситуации и определение оптимального порядка ведения горных работ, выбор и обоснование противоударных профилактических мероприятий.

Первым этапом геомеханического прогноза является создание инженерно-геологической модели месторождения, которая содержит информацию о его геологии и тектонике, основных литотипах руд и пород, их физико-механических свойствах и прогнозную оценку параметров физико-механических свойств пород 
и поля напряжений в массиве. Этот этап выполняется совместно с соответствующими геологическими организациями, взаимодействие с которыми в результате многолетнего сотрудничества хорошо отработано, поэтому здесь не рассматривается.

Продолжением этого этапа является определение уточненных количественных параметров физико-механических свойств руд и пород и поля напряжений в характерных участках горнотехнической системы с использованием комплекса инструментальных методов, основным из которых является метод разгрузки в варианте торцевых измерений. Значительный объем таких работ выполнен на рудниках АО «Апатит» и в карьере «Железный» АО «Ковдорский ГОК», на рудниках АО «Печенганикель», на рудниках Ловозерского ГОКа. Результаты этих определений имеют не только практическую значимость, но и интересны в научном плане как новая дополнительная информация о главных параметрах состояния пород в массиве.

Следующим этапом является построение численных моделей перспективных или локальных участков разрабатываемых месторождений, на основе которых осуществляется прогноз геомеханических условий и разрабатываются рекомендации по конструктивным параметрам систем разработки, регламентам на проектирование или по оптимальным способам отработки проблемных участков.

И последний, наиболее ответственный этап, - верификация моделей. Несомненно, самый надежный критерий истины - практика, однако далеко не всегда следует ждать полного завершения проекта, чтобы убедиться в адекватности моделей, на основе которых этот проект был разработан, поскольку даже самая совершенная модель не может учесть всех особенностей моделируемой среды, в частности, такой сложной, как геологическая среда в горнотехнической системе. Поэтому на самых начальных этапах реализации проекта необходим инструментальный геомеханический мониторинг среды. Наиболее пригодным методом для такого мониторинга является сейсмическая томография и контроль сейсмической активности массива, которые позволяют получить скоростную модель контролируемого участка массива, а также развитие процессов микроразрушений, отражающих все особенности его геологии и тектоники, позволяющие получить интегральную характеристику его состояния и динамики. Сейсмическая томография и сейсмоакустика достаточно давно и успешно используются в Горном институте КНЦ РАН для решения ряда геотехнических задач.

\section{5. Управление стратегическими геодинамическими рисками}

Целью управления стратегическими геодинамическими рисками является разработка такой последовательности строительства и эксплуатации горных предприятий, которая на каждом этапе освоения месторождения позволяет выбирать наиболее эффективные мероприятия, обеспечивающие безопасность горных работ, не снижая при этом эффективности горного производства. Эффективность обеспечения геодинамической безопасности определяется в первую очередь достоверностью оценки свойств и состояния геологической среды и возможностями надежного прогноза развития геодинамической ситуации во времени и пространстве. Ниже, на примере нескольких крупных горнодобывающих предприятий, проиллюстрированы возможности прогноза развития геомеханической ситуации с помощью модельных методов оценки состояния геологической среды, а также даны примеры эффективных способов воздействия на геологическую среду с целью обеспечения геодинамической безопасности горных работ. 


\subsection{1 Закономерности динамики параметров геомеханического состояния массива пород по данным численного моделирования при отработке запасов на апатитовьх рудниках}

Разработка апатитовых руд ведется в удароопасных условиях. Возрастание глубины и объемов горных работ в последние годы приводит к повышению как фонового уровня напряжений, так и увеличению по площади и абсолютным величинам зон концентрации напряжений в окрестности фронтов горных работ и других элементов горной технологии. В связи с этим изучение закономерностей изменения параметров геомеханического состояния массива пород с учетом основных геологических и горнотехнических факторов является актуальной задачей, успешное решение которой возможно только применением комплекса натурных и численных методов, что, в конечном счете, позволяет обосновать профилактические мероприятия по снижению геодинамических рисков.

\subsubsection{1. Особенности формирования поля напряжений на глубоких горизонтах Кукисвумчоррского месторождения при применении систем разработки с этажным и подэтажным обрушением руды (на примере блока 7-10 горизонта +170 м)}

Для Кукисвумчоррского месторождения, как и для других Хибинских апатитовых месторождений, характерно: действие на глубине ведения горных работ тектонических напряжений, фоновый уровень которых в два и более раза превышает уровень напряжений от действия собственного веса пород $\sigma_{m}>2 \gamma H$; крепкие вмещающие породы и руды, склонные к хрупкому разрушению; концентрация напряжений вблизи фронта горных работ с коэффициентом $k=2 \div 3$. Особенностью геомеханического состояния массива пород Кукисвумчоррского месторождения является действие тектонических напряжений практически вкрест простирания рудного тела (рис. 6.8). Еще одним важным фактором, определяющим геомеханическое состояние этого месторождения, является наличие разломных структур и окисленных зон. В блоке 7-10 такой структурой является разломная зона, проходящая вкрест простирания рудного тела по 9 разрезу и имеющая мощность 4-5 м, уменьшающуюся с глубиной.

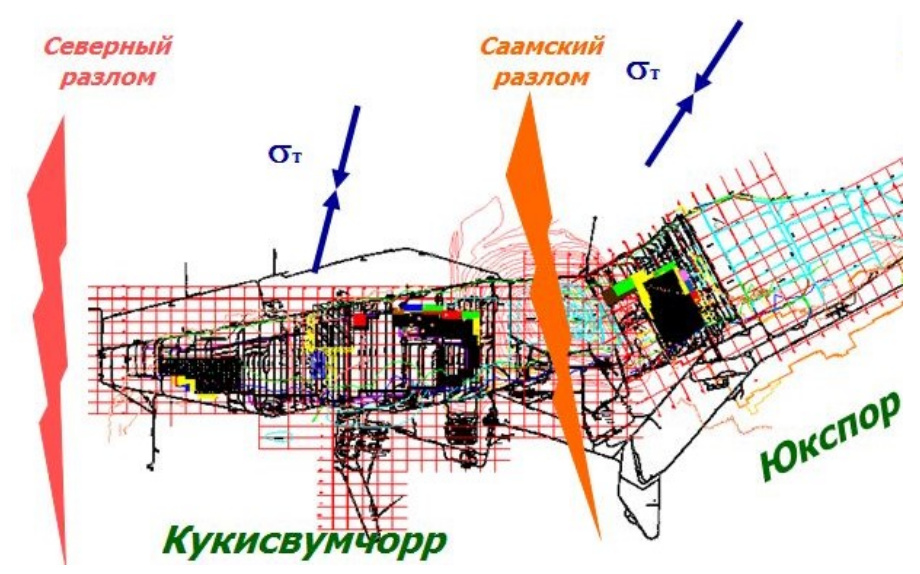

Рис. 6.8. Направление действия тектонических напряжений на месторождениях, отрабатываемых Кировским рудником АО «Апатит» 
На Кировском руднике в настоящее время применяются две системы разработки:

- этажное принудительное обрушение со скважинной отбойкой и площадным выпуском;

- подэтажное принудительное обрушение со скважинной отбойкой с торцевым выпуском и доставкой руды самоходным оборудованием.

В последние годы на рудниках АО «Апатит» в большей мере применялась система подэтажного принудительного обрушения, имеющая большую маневренность при выемке запасов, что позволяет развивать очистную выемку на конкретном участке с учетом геомеханической ситуации. Основным недостатком этого варианта системы является невозможность одновременной отбойки больших объемов руды, что очень важно в свете последних решений по интенсификации выемки запасов на подземных рудниках AO «Апатит». Рассматривали возможность перехода на систему с этажным принудительным обрушением при обеспечении необходимой безопасности горных работ.

Предыдущими исследованиями и практикой ведения горных работ была показана эффективность создания опережающей отбойки по висячему боку рудной залежи при действии максимальных сжимающих напряжений вкрест простирания или под углом более $45^{\circ}$ к элементам залегания рудного тела, что позволяет защитить породы лежачего бока от действия высоких тектонических напряжений и создать условия для снижения удароопасности [258]. Поэтому независимо от выбираемого варианта системы разработки создание такого опережения является необходимым на глубоких горизонтах Кировского рудника АО «Апатит».

При проработке возможных вариантов выемки запасов блока 7-10 гор. +170 м специалистами ГоИ КНЦ РАН было предложено условное разделение запасов блока на три технологические зоны (рис. 6.9):

- участки рудного тела, расположенные в висячем боку в зоне повышенного горного давления (1 Т3);

- центральная (средняя) часть залежи, расположенная под обрушенной толщей пород, с постоянными параметрами выемочных участков и высотой этажа (2 Т3);

- запасы в треугольниках лежачего бока залежи с ограниченной и непостоянной высотой этажа, наличием обрушенных покрывающих пород (3 Т3).

Для первой и второй зоны оценивали плюсы и минусы применения этажной или подэтажной выемки запасов с точки зрения безопасности горных работ.

Для оценки напряженного состояния в зависимости от варианта применяемой системы разработки созданы конечно-элементные модели с учетом проектных параметров элементов горной технологии. На рисунке 6.10 приведено распределение напряжений $\sigma_{\max }$ в разрезе вкрест простирания рудной залежи при фактическом состоянии горных работ и при создании опережающей отбойки по висячему боку рудной залежи с применением систем с этажным и подэтажным обрушением руды.

На рисунке 6.10 видно, что бо́льший эффект разгрузки массива к лежачему боку наблюдается при применении системы с подэтажным обрушением руды, что связано с возможностью продвижения работ по простиранию рудной залежи ступенчатым фронтом с равномерным распределением зон концентрации напряжений по подэтажам. В случае же применения системы с этажным обрушением в висячем боку отбиваются секции на всю высоту подэтажа, создавая дополнительную пригрузку призабойной зоны, особенно нижней ее части, что негативно влияет на состояние выработок траншейного днища и откаточного горизонта. 
Затем рассматривали возможность применения в центральной части рудного тела системы с этажным обрушением руды, что является предпочтительным по производительности в блоке. Полученное распределение напряжений на подэтажах, траншейном днище и откаточных горизонтах (рис. 6.11) показало, что возможно применение и той и другой системы.

При этом рекомендуется ортовая подготовка блока, так как направление действия напряжений на момент проходки выработок вкрест простирания рудного тела, то есть выработки штрекового направления, в таких условиях пригружены больше: для разгрузки массива необходимо вести очистные работы с опережением по висячему боку рудной залежи:

- больший эффект разгрузки массива достигается опережением в висячем боку системой подэтажного обрушения с торцевым выпуском руды;

- выработки откаточного горизонта меньше пригружаются при ведении работ в блоке подэтажной системой с торцевым выпуском руды;

- при применении системы с этажным обрушением более высокая категория удароопасности на траншейном днище прогнозируется у выработок штрекового направления, поэтому предпочтительной является ортовая подготовка блока.
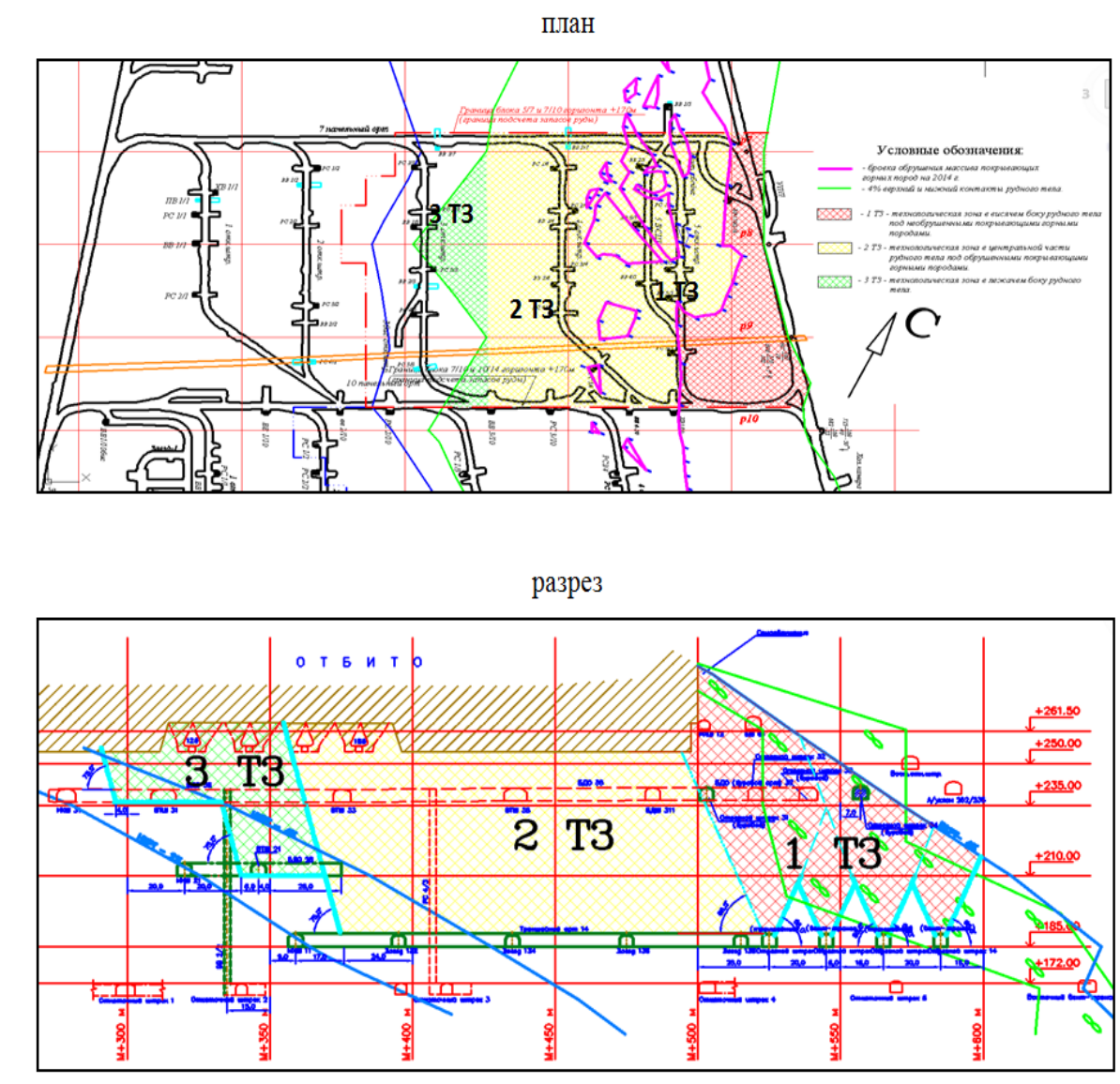

Рис. 6.9. Технологические зоны при отработке гор. +170 м Кукисвумчоррского месторождения 


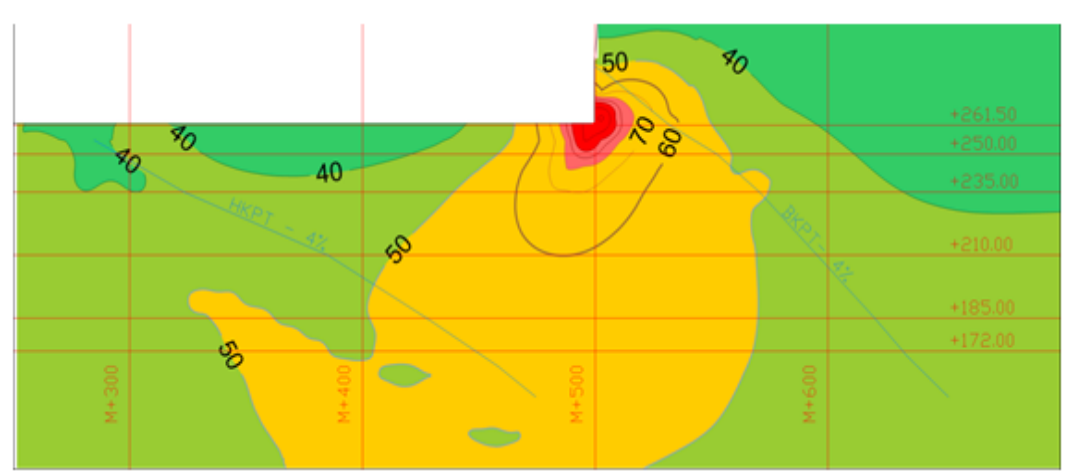

$a$

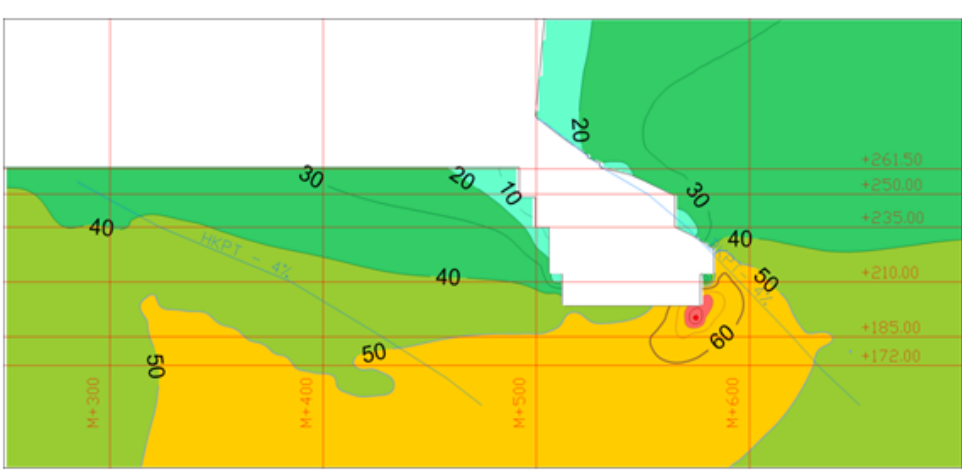

$\sigma$

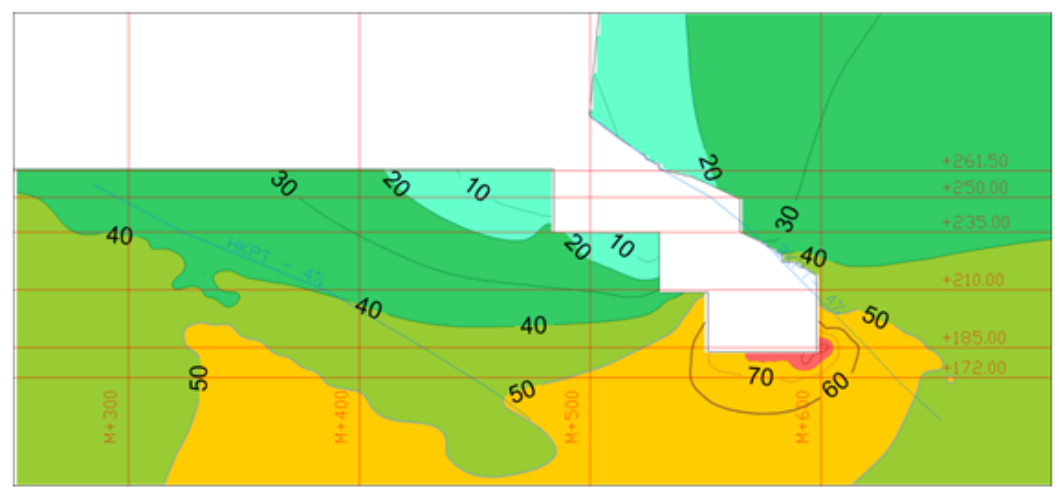

Рис. 6.10. Распределение $\sigma_{\max }$ в разрезе вкрест простирания рудной залежи Р.9: $a$ - при фактическом состоянии горных работ; $\sigma$ - при отрезке 

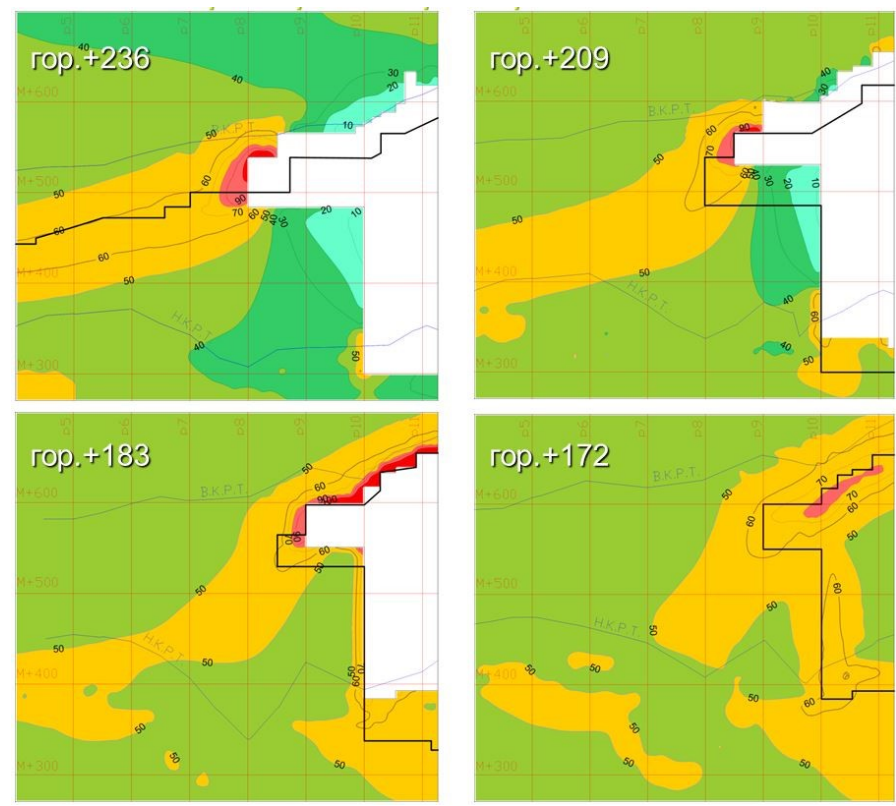

Рис. 6.11. Распределение $\sigma_{\max }$ на подэтажах гор. +170 м при отрезке по висячему боку с применением подэтажной системы с торцевым выпуском руды

\subsubsection{2. Оченка устойчивости элементов геотехнологии при различных вариантах систем с принудительным обрушением руды}

Горизонт +170 м являлся основным рабочим горизонтом на Кукисвумчоррском месторождении. Разрезка была произведена в районе 12 разреза, после чего горные работы развивались к флангам двумя фронтами системой подэтажного обрушения с торцевым выпуском руды. Блок 7-10 предполагалось отрабатывать с применением системы этажного обрушения с траншейным днищем. Для оценки устойчивости элементов геотехнологии и определения оптимального порядка работ разработана серия крупномасштабных конечно-элементных моделей блока с имитацией различной последовательности выемки запасов при учете комплекса влияющих на НДС факторов: тектонические напряжения, гористый рельеф дневной поверхности, положение кромки обрушенных пород, очистные пространства, основные разломные структуры, геометрия элементов геотехнологии. Разработаны два типа сеток конечных элементов (для каждой из систем (рис. 6.12)), граничные условия для которых получали путем интерполяции узловых перемещений из предыдущего этапа моделирования.

В итоге сформированы четыре основные модели для имитации горных работ:

- отрезка по висячему боку с применением системы разработки с подэтажным обрушением;

- отрезка по висячему боку с применением системы разработки с этажным обрушением;

- ведение очистной выемки в технологической зоне 2 с применением системы разработки с подэтажным обрушением;

- очистная выемка в технологической зоне 2 с применением системы разработки с этажным обрушением. 

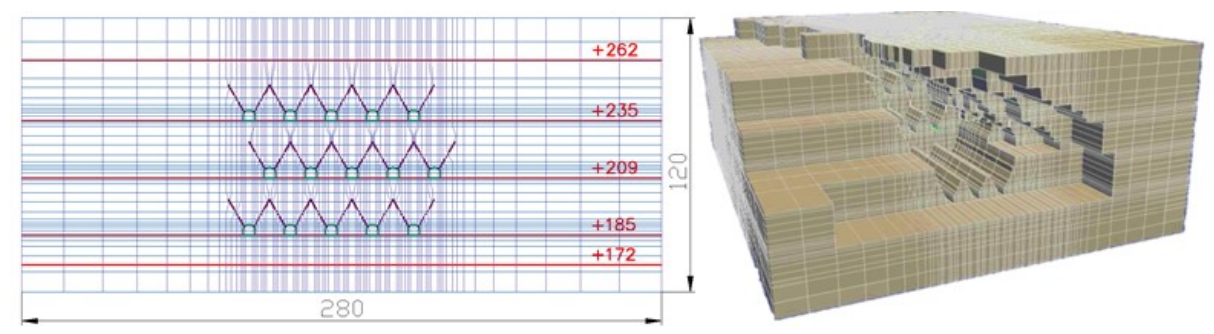

$a$

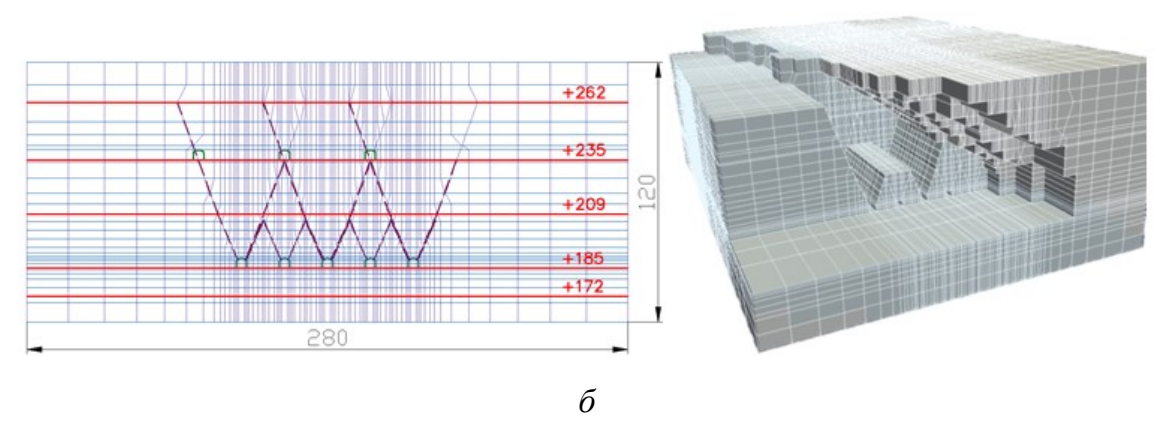

Рис. 6.12. Типовые сечения и модели для: $a$ - системы разработки с подэтажным обрушением; $\sigma$ - системы разработки с этажным обрушением

Решали вопрос о порядке ведения работ при системе разработки с этажным обрушением. С точки зрения технологии очередности работ возможно сначала создать траншеи, а потом формировать отбойку или наоборот.

В случае применения этажной системы разработки в висячем боку рудной залежи по геомеханическим условиям наиболее предпочтительным является вариант с предварительным созданием траншей (рис. 6.13 a), так как при предварительной отбойке руды до гор. +209 м происходит пригрузка массива на отметках траншейного днища (средний уровень $\sigma_{\max }=60-70 \mathrm{MПа)} \mathrm{и} \mathrm{соответственно} \mathrm{выработок} \mathrm{горизонта}$ траншейного днища +185 м (рис. 6.13 б). Наиболее опасными будут зона опорного давления в непосредственной близости от очистной выемки блока 10-14, а также зона вблизи продвигающегося фронта в висячем боку. Также зона разгрузки к лежачему боку рудной залежи не достигает отметок траншейного днища, где уровень напряжений около 50 МПа. То есть выработки днища будут проходиться в удароопасных условиях.

Минимальные напряжения являются сжимающими. При порядке работ с первоначальным созданием траншей локальные зоны растяжений формируются в стенках траншей, что не является критичным. В случае создания очистной выемки до отметки +209 м зоны растяжений формируются в стенках штреков, достигая предельных величин в непосредственной близости от очистной выемки блока 10-14.

Распределение бтах в надштрековом целике неравномерно. Наиболее пригруженными являются участки надштрековых целиков вблизи продвигающегося фронта опережающей очистной выемки. Вблизи очистной выемки блока 10-14 надштрековый целик между траншеями разгружается, а наиболее опасным является состояние штрека, примыкающего к висячему боку рудной залежи (рис. $6.14 a$ ). Растягивающие напряжения наблюдаются в надштрековом целике вблизи очистного пространства и имеют величины до $0,5 \sigma_{\text {p }}$ (рис. 6.14 б). 

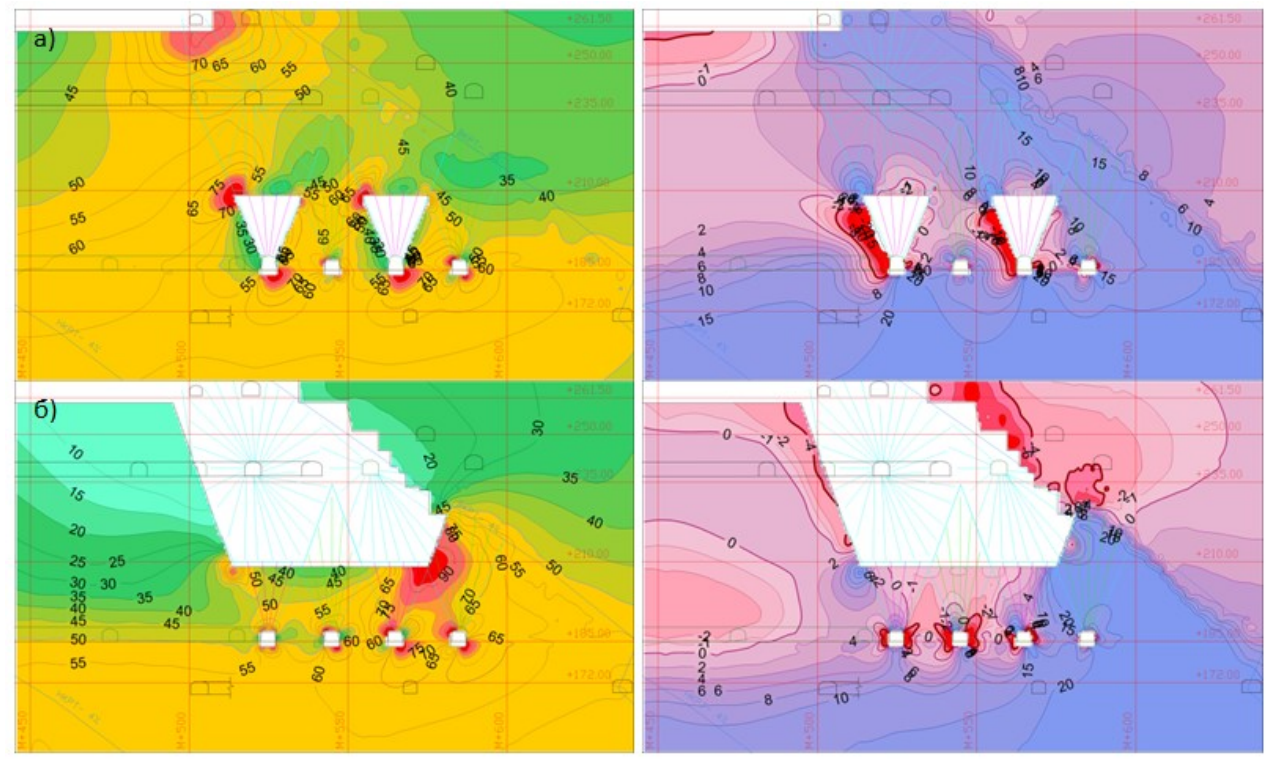

Рис. 6.13. Распределение максимальных $\sigma_{\max }$ и минимальных $\sigma_{\min }$ напряжений по разрезу 8+50 при создании опережающей разгрузочной зоны по висячему боку: $a$ - с траншеями, $\sigma$ - без траншей
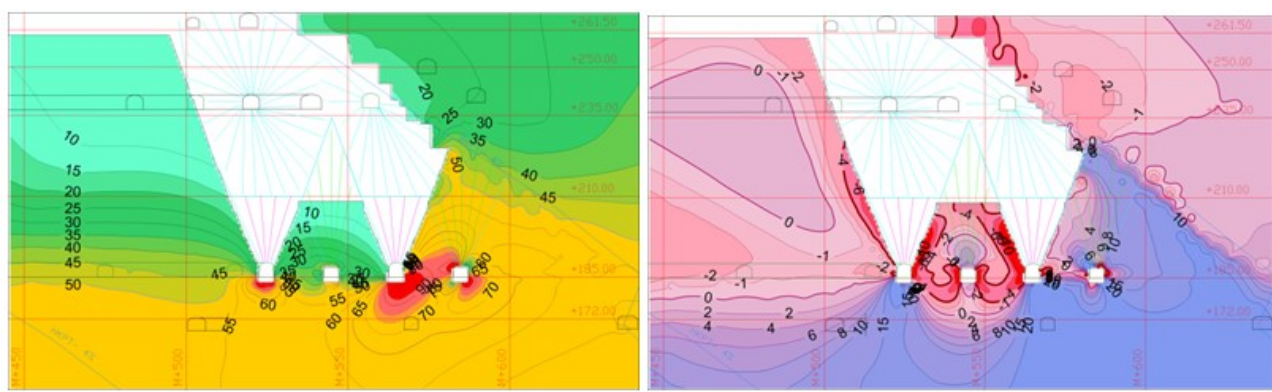

Рис. 6.14. Распределения максимальных $\sigma_{\max }$ и минимальных $\sigma_{\min }$ напряжений по разрезу $9+40$ (состояние надштрекового целика)

Оценивали также состояние заездов по мере развития опережающей очистной выемки в висячем боку (рис. 6.15).

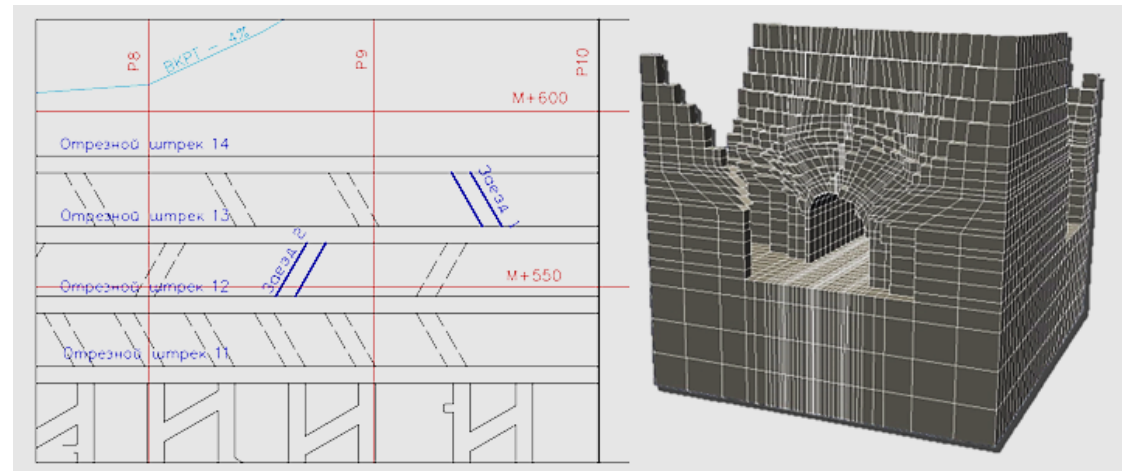

Рис. 6.15. Местоположение локальных моделей заездов и объемный вид модели при выемке запасов висячего бока системой разработки с этажным обрушением 
Приведены результаты уточненных расчетов НДС для двух разнонаправленных заездов при развитии работ в висячем боку рудной залежи (рис. 6.16). Особенностью в распределении напряжений на контуре заезда 1 является концентрация максимальных напряжений на сопряжениях обеих стенок с кровлей. Напряженное состояние на контуре заезда 1 по максимальной компоненте наихудшее до торцевой отбойки массива над заездом 1. Максимальная область растяжений формируется в стенках и кровле заезда 1 после торцевой отбойки массива над заездом 1. Концентрация напряжений на кровле заезда 2 формируется при проходке траншей, и далее напряженное состояние изменяется незначительно. Значения растягивающих напряжений не превышают критических величин. Таким образом, заезды целесообразно проходить до отбойки запасов висячего бока, крепить их необходимо с учетом возрастания удароопасности и развития технологической нарушенности массива по мере развития горных работ.
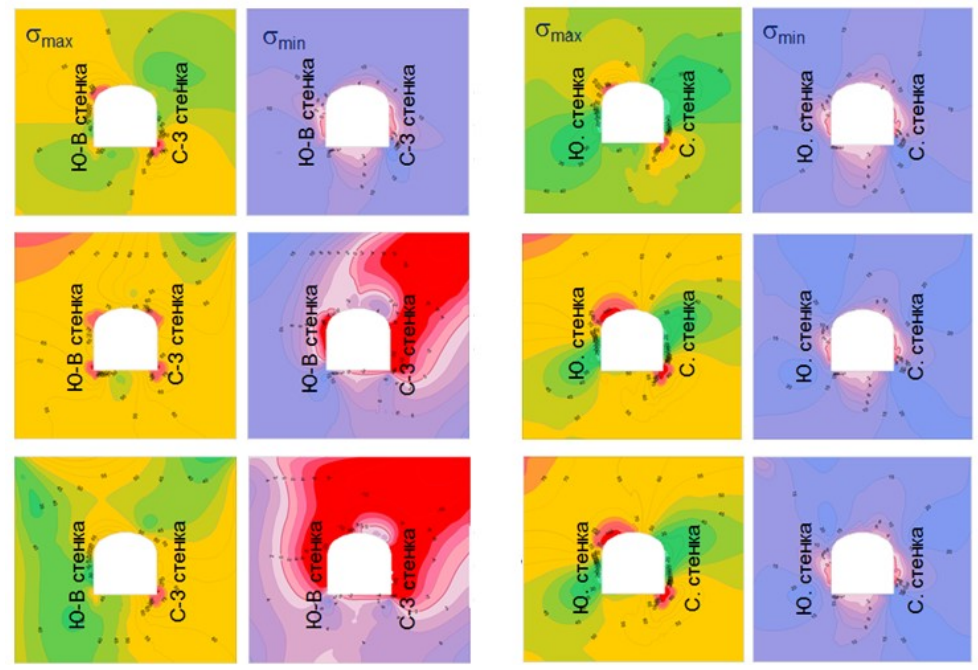

Рис. 6.16. Изменение напряженного состояния в окрестности заездов 1 (слева) и 2 (справа) по мере выемки запасов висячего бока системой разработки с этажным обрушением

Далее моделировали развитие отрезки по висячему боку системой разработки с подэтажным обрушением (рис. 6.17).

При развитии отрезки на 100 м в висячем боку рудной залежи (рис. 6.17) зона разгрузки охватывает большую часть массива в лежачем боку, захватывая все рабочие подэтажи, а также значительную часть массива на откаточном горизонте +172 м. Зона концентрации сжимающих напряжений формируется непосредственно под отрезкой висячего бока.

Результаты сравнения двух систем показали, что при системе разработки с подэтажным обрушением из-за конфигурации очистного пространства значения максимальных сжимающих напряжений распределены более равномерно по подэтажам и размеры зон концентрации и величин $\sigma_{\max }$ в них меньше, чем при системе разработки с этажным обрушением, где зона концентрации $\sigma_{\max }$ с величинами до 120 МПа формируется на горизонте траншейного днища. Эффект защиты массива в средней части рудного тела от действия высоких сжимающих напряжений выше при системе с подэтажным обрушением, причем зона разгрузки в этом случае позволяет защитить не только подэтажи, но и выработки откаточного горизонта. 


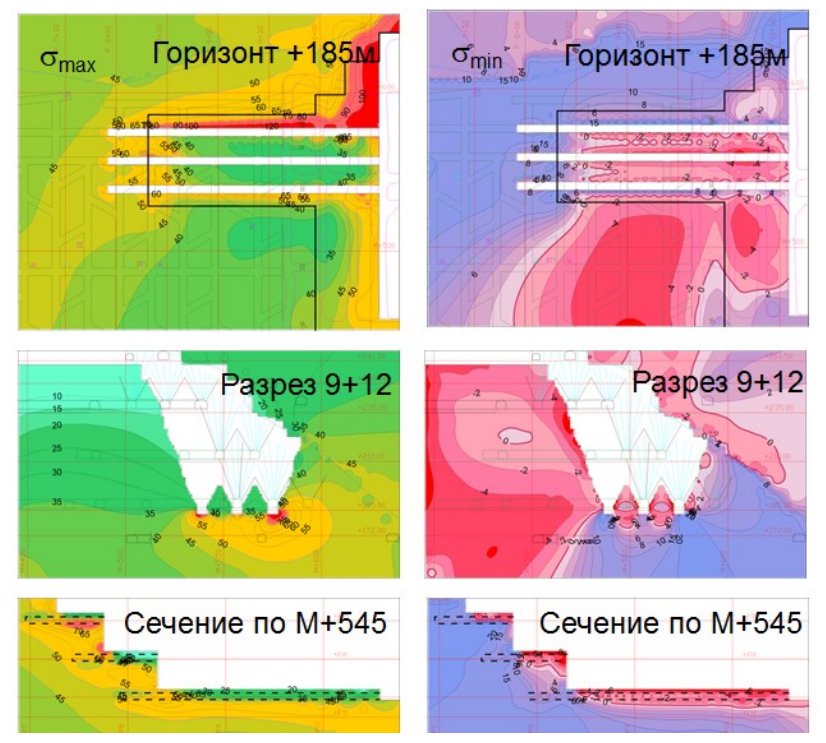

Рис. 6.17. Распределение напряжений при выемке запасов системой с подэтажным обрушением

Применение системы разработки с этажным обрушением руды обуславливает высокую изрезанность массива на горизонте траншейного днища, где наблюдается одновременное действие в массиве высоких сжимающих и критических растягивающих напряжений, что окажет негативное влияние на устойчивость как массива в целом, так и отдельных выработок.

Таким образом, для отработки запасов в висячем боку рудной залежи и создания разгрузочной зоны рекомендуется применение системы с подэтажным обрушением руды.

При применении систем с этажным и подэтажным обрушением руды в центральной части рудного тела очистные работы будут вестись в разгруженном от действия высоких напряжений массиве. Худшее состояние выработок ожидается при системе с этажным обрушением из-за действия растягивающих напряжений, близких к пределу прочности пород на растяжение, то есть возможно прорастание трещин отрыва и разрушение приконтурного массива нединамического характера. При выполнении дополнительных мероприятий по обезопашиванию и креплению горных выработок траншейного днища допускается применение в центральной части рудного тела системы с этажным обрушением.

\subsubsection{3.Геомеханическая ситуация в стыковочной зоне между подземными горными работами Расвумчоррского рудника и Центральным карьером}

Как известно, при разработке удароопасных месторождений не рекомендуется создание целиков, однако в случае сближенных месторождений или месторождений, имеющих лишь условную границу, неизбежно возникает ситуация, когда между очистными пространствами на каждом месторождении остается участок массива, который по сути является блоком-целиком и требует дополнительного обоснования отработки как по технологии, так и с позиций геодинамической безопасности.

Именно такая ситуация создалась на Расвумчоррском руднике, отрабатывающем запасы двух месторождений - «Апатитовый цирк» и «Плато Расвумчорр». Граница между месторождениями является условной и проходит по перегибу рудного тела, меняющего в этом месте свое 
направление в плане приблизительно на $23^{\circ}$. Причем запасы месторождения «Плато Расвумчорр» отрабатывались в основном Центральным карьером, запасы месторождения «Апатитовый цирк» отрабатываются подземным способом. При этом на верхних горизонтах до отметки +600 м уже произошла сбойка с карьерным пространством. В настоящее время очистные работы ведутся на гор. $+530,+470$ и +450 м системой с подэтажным обрушением и торцевым выпуском руды. На гор. +530 и +470 м очистные работы приближаются к борту карьера. Ситуация осложняется тем, что в стыковочных зонах будут находиться запасы месторождения «Плато Расвумчорр», то есть имеет место разворот рудной залежи на $23^{\circ}$. Кроме того, участок массива между подземными и открытыми горными работами характеризуется значительным распространением окисленных разрушенных зон, имеющих изменчивое направление в плане и угол падения, близкий к падению рудного тела (рис. 6.18).

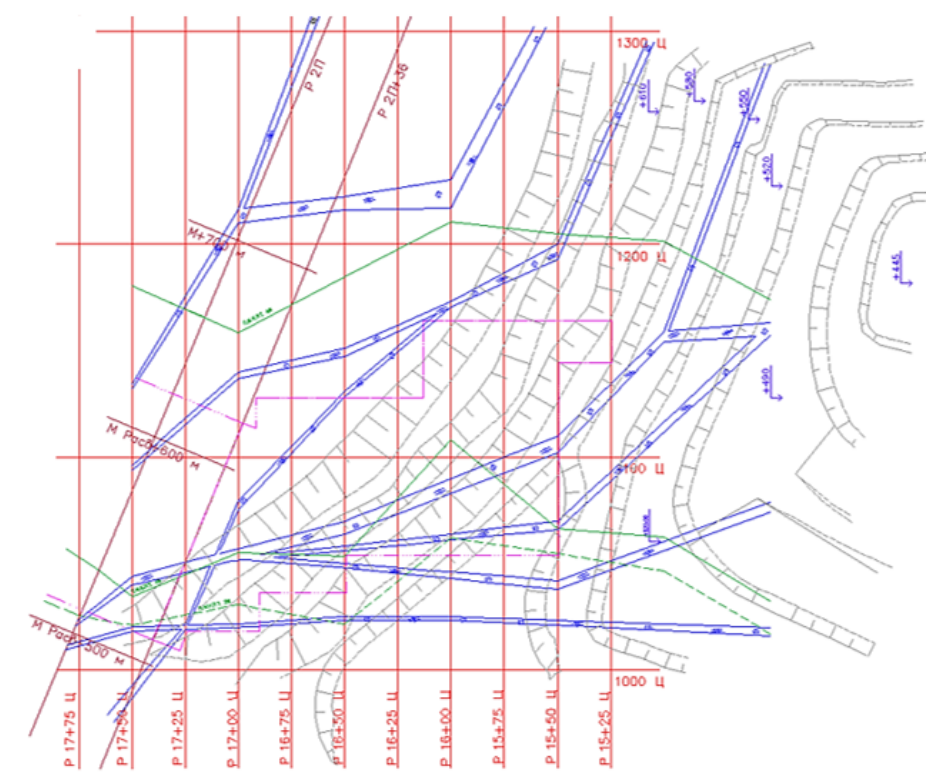

a

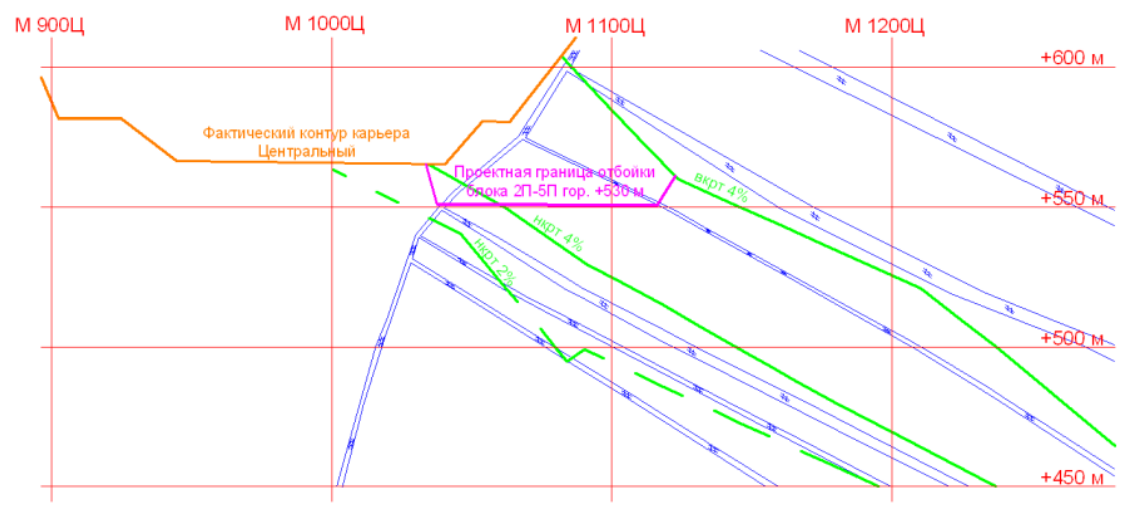

$\sigma$

Рис. 6.18. Геологическая и горнотехническая ситуация в стыковочной зоне: $a-$ в плане гор. +500 м; $\sigma$ - в разрезе вкрест простирания рудного тела Р16Ц 
Положение горных работ на гор. +530 и +470 м по состоянию на III квартал 2015 г., а также их проектное развитие на конец 2016 г представлено на рисунке 6.19.

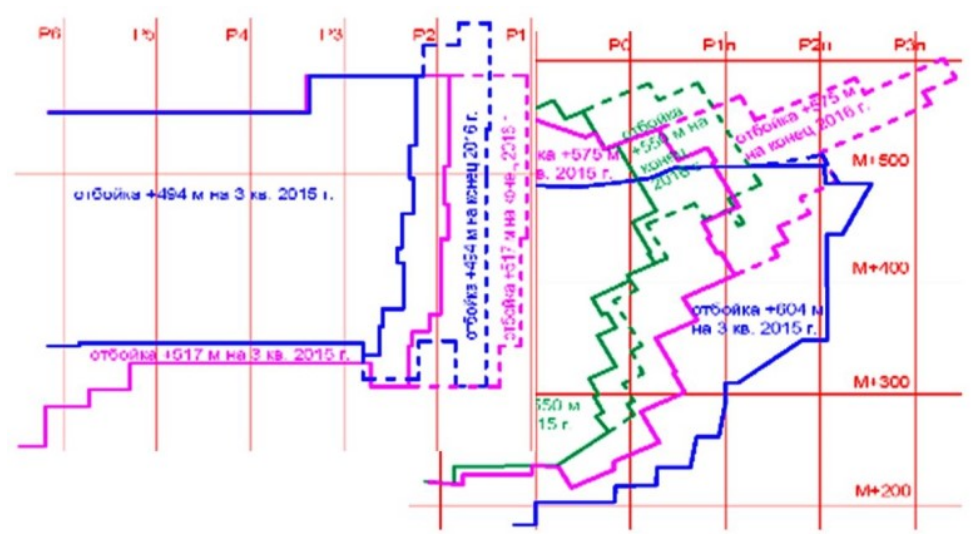

Рис. 6.19. Фактическое и проектное положение горных работ на гор. +530 и +470 м

С учетом всех вышеизложенных факторов, а также фактического рельефа дневной поверхности и мощных разломных структур была разработана модель зоны стыковки (рис. 6.20) для геомеханического обоснования выемки запасов и разработки мер по обеспечению безопасности горных работ.

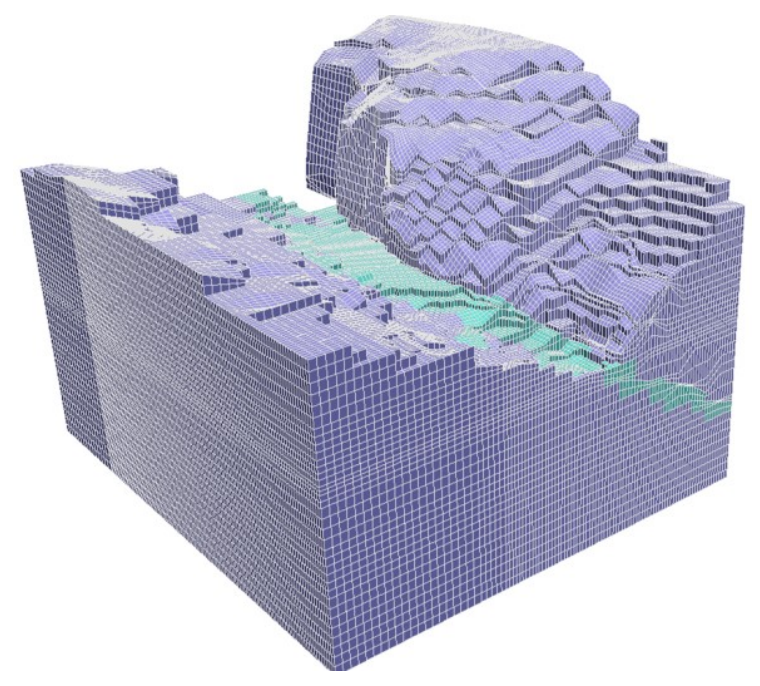

Рис. 6.20. Трехмерное отображение модели зоны стыковки подземной выемки Расвумчоррского рудника с Центральным карьером

На Расвумчоррском руднике в связи с относительно высокими отметками дна Расвумчоррской долины и обширным плато, окружающим с трех сторон рудник, гор. +530 и +470 м относятся к глубинным, поэтому параметры поля напряжений здесь достаточно стабильны по площади и глубине. Исходное направление векторов максимальной компоненты главных напряжений близко к простиранию рудного тела. Однако в зоне стыковки происходит переориентировка максимальных сжимающих напряжений, причем по мере приближения фронта подземных горных работ к борту карьера она становится все более существенной (рис. 6.21), что следует учитывать при планировании горных работ. 


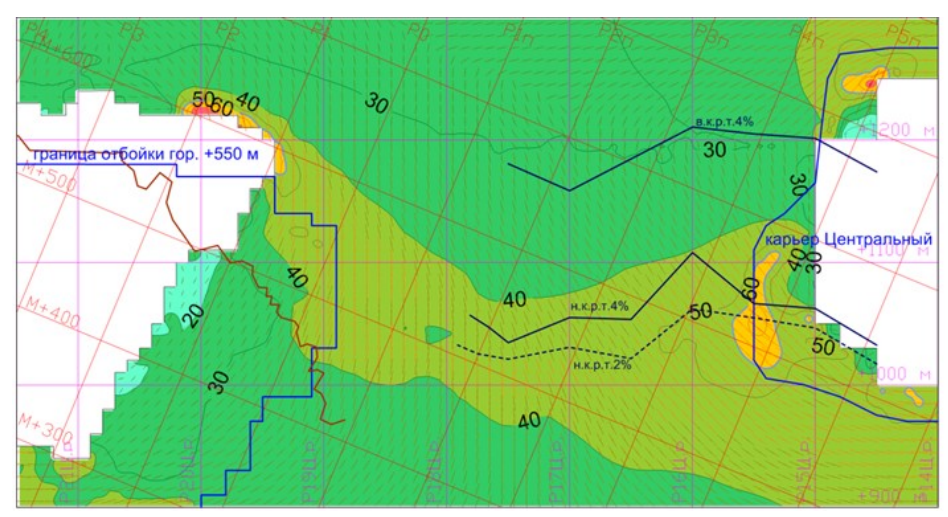

$a$

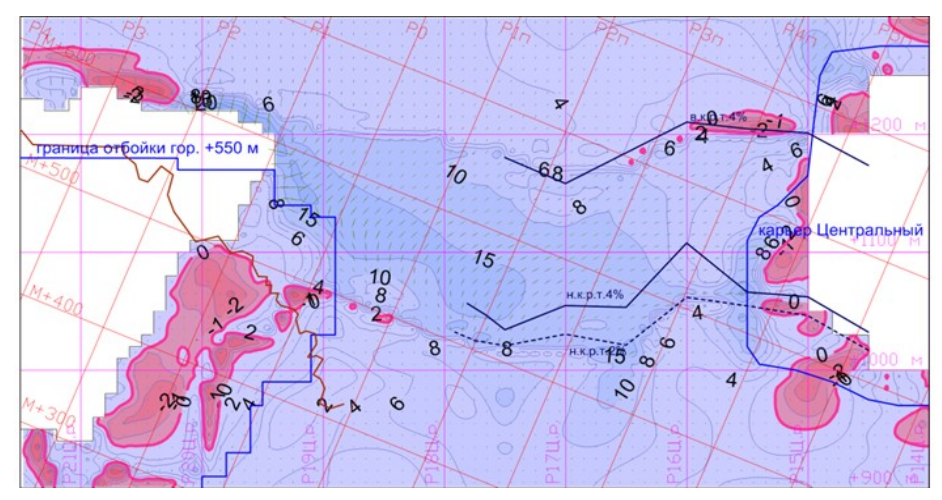

6

Рис. 6.21. Распределение напряжений в зоне стыковки подземных работ Расвумчоррского рудника с Центральным карьером на гор. +500 м: $a-\sigma_{\max } ; \sigma-\sigma_{\min }$

На горизонте +530 м выработки в зоне стыковки уже пройдены, а на гор. +470 м рекомендована ортовая подготовка, что снизит удароопасность выработок. Оптимальный порядок ведения работ - с небольшим опережением по висячему боку рудной залежи. На рисунке 6.22 показана трансформация поля напряжений по мере приближения фронта подземных работ к борту карьера при рекомендуемом порядке отработки блока-целика. Основные зоны концентрации напряжений приурочены к границам вышележащих горных работ, в том числе и уступам карьера, а также к границе очистной выемки в висячем боку рудной залежи в районе перегиба рудного тела.

Таким образом, определены основные параметры поля напряжений в породах блока-целика, которые учтены в регламентах на отработку запасов гор. +530 и +470 м:

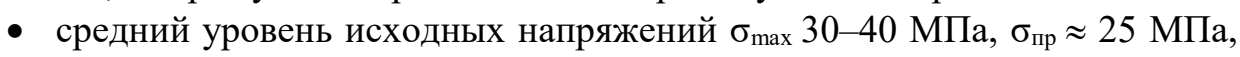
$\sigma_{\min } \approx 10$ МПа соответствует глубине горизонта;

- зоны концентрации $\sigma_{\max }$ под очистной выемкой вышележащего горизонта наиболее выражены на верхнем подэтаже;

- локальные зоны концентрации $\sigma_{\max }$ в висячем (больше) и в лежачем боках в окрестности горных работ на подэтажах; 
- зоны концентрации $\sigma_{\max }$ под уступами Центрального карьера;

- зоны растяжений по минимальной компоненте $\sigma_{\min }$ вдоль продвигающихся фронтов горных работ на подэтажах и под ними на откаточном горизонте при значениях растяжений в 2-3 раза меньше пределов прочности породы на растяжение;

- переориентировка напряжений $\sigma_{\max }$ под углом 40-60 $0^{\circ}$ к элементам залегания рудного тела происходит по мере приближения фронта подземных горных работ к борту карьера.
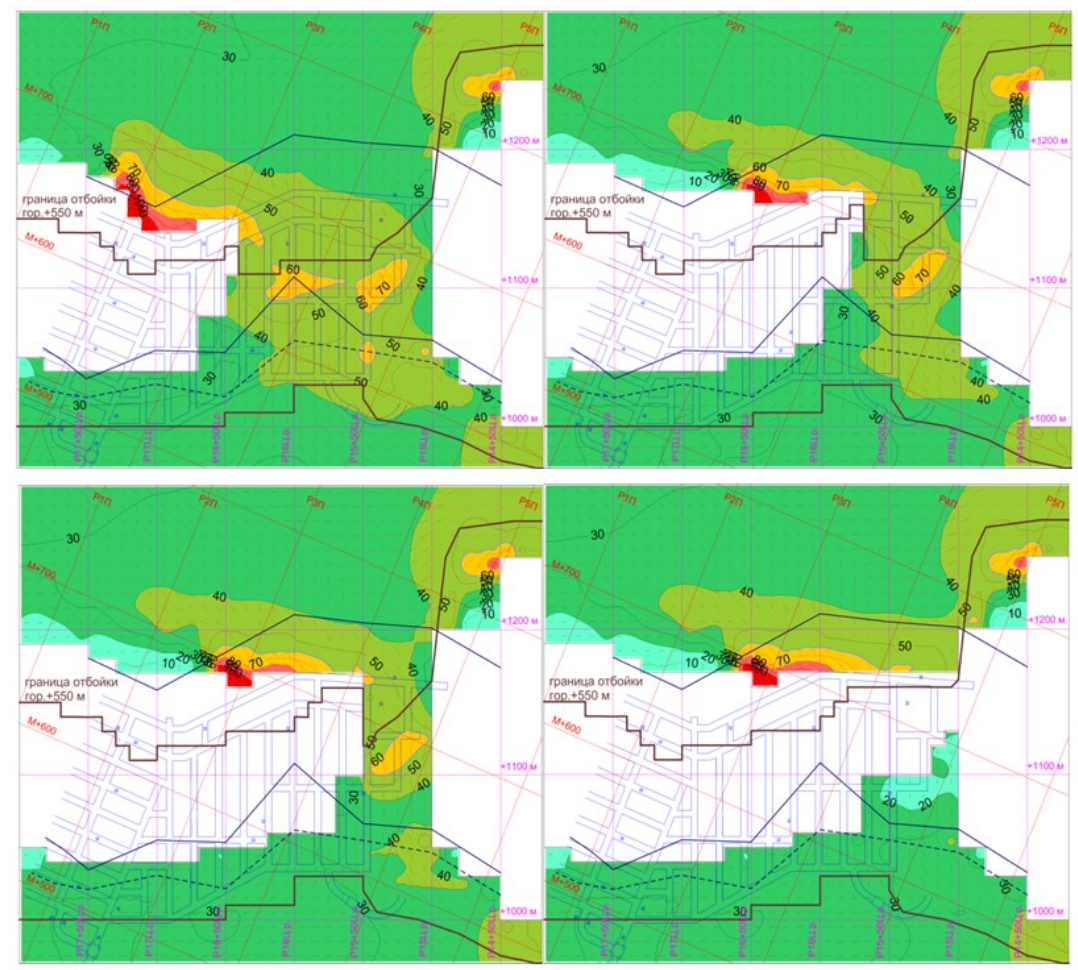

Рис. 6.22. Распределение $\sigma_{\max }$ при последовательной отработке запасов блока-целика

6.5.1.4. Обеспечение безопасной отработки блока-целика горизонтов $+530 u+470 \mathrm{M}$ при приближении подземных горных работ Центральному карьеру

Рекомендации по обеспечению безопасной выемки блока-целика гор. +530 и +470 м разработаны на основе численного моделирования напряженного состояния массива при имитации последовательной выемки запасов стыковочной зоны. При этом учитывали основные геологические, горнотехнические и геомеханические факторы, а именно:

- высокая тектоническая напряженность массива горных пород, усложняющая условия разработки месторождения;

- переориентировка действующих тектонических напряжений в зоне стыковки подземных и открытых горных работ;

- необходимость ведения работ на уменьшающийся целик;

- значительная изменчивость мощности рудного тела по падению и простиранию при выдержанном угле падения;

- изменение ориентировки рудной залежи в плане в районе стыковки подземных и открытых горных работ; 
- выработки на подэтажах и откаточном гор. +470 м в зоне стыковки с карьером еще не пройдены, что дает возможность выбора оптимальной подготовки запасов к выемке по совокупности горнотехнических и геомеханических факторов;

- приостановка открытых горных работ на Центральном карьере в районе зоны стыковки, то есть условие сохранения подработанных уступов карьера не является необходимым.

При развитии горных работ встречными фронтами с определенного расстояния между ними происходит существенное увеличение напряжений за счет взаимного наложения зон концентрации напряжений. Именно при таких параметрах участок массива между очистными пространствами в условиях действия высоких тектонических напряжений становится блоком-целиком и для его отработки необходима разработка мероприятий по предотвращению опасных проявлений горного давления.

В «Указаниях» [241] размер стыковочной зоны $L_{\min }$ рассчитывается по упрощенной формуле:

$$
L_{\min }=\frac{\left(L_{1}+L_{2}\right)}{2},
$$

где $L_{1}$ и $L_{2}$ - характерные размеры сближающихся очистных пространств.

При этом предполагается отсутствие информации о распределении и перераспределении напряжений в породах между сближающимися фронтами. В результате модельных исследований НДС при приближении подземных горных работ к борту карьера на гор. +470 м уточнены параметры поля напряжений в окрестности фактических и планируемых горных работ, поэтому определение параметров блока-целика проводили на основе расчетных значений напряжений и их изменения по мере сближения фронтов горных работ на расстояние 250, 200, 150 и 100 м. Под началом взаимного влияния двух очистных пространств при модельных исследованиях понимается десятипроцентное увеличение концентрации напряжений в целике между ними по сравнению с начальным уровнем, что соответствует точности определений параметров напряженного состояния массива существующими методами. Десятипроцентное изменение напряжений будет являться значимым, так как граничные условия для моделирования НДС определены на основе данных, полученных методом разгрузки.

На рисунке 6.23 приведен график изменения средних по блоку-целику значений напряжений $\sigma_{\max }$ при приближении фронта подземных горных работ к борту карьера. За исходное состояние горных работ принят вариант со сбойкой подземных работ с бортом карьера на гор. +550 м. В этом варианте исходная величина напряжений на гор. +520 м составляет 52 МПа при расстоянии между подземными работами и бортом карьера 260 м. Соответственно, напряжения, увеличенные на $10 \%$, составят примерно 57 МПа. Такие значения напряжений возникают в массиве между подземными и открытыми горными работами горизонта +470 м при расстоянии между их фронтами 150 м. Таким образом, ширина блока-целика, исходя из критерия десятипроцентного увеличения напряжений в центре блока, составляет 150 м.

Аналогично определяли размер блока-целика для гор. +530 м, который составил $120 \mathrm{M.}$ 


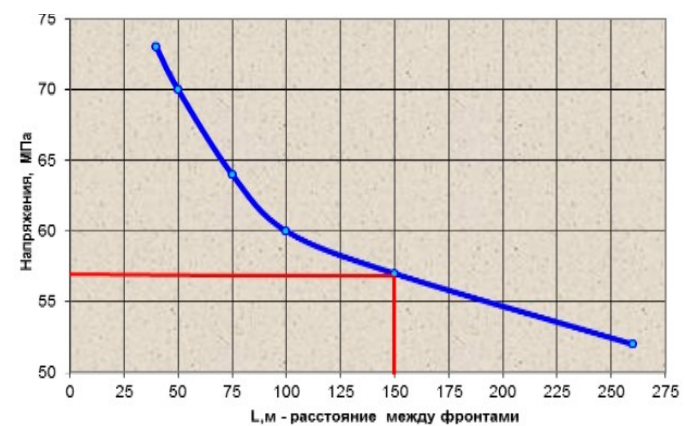

Рис. 6.23. Зависимость максимального главного напряжения от расстояния между очистными фронтами (синий график). Красной линией показан десятипроцентный уровень увеличения напряжений по сравнению с исходным и соответствующий ему размер блока-целика

Начиная с этого расстояния, между фронтами горные работы в блоке должны вестись в соответствии с разработанным регламентом.

Для определения минимальных размеров стыковочной секции проведено численное моделирование НДС при ее размерах 40, 50, 60 м. Прогнозные величины главных компонент напряжений вводили в уравнение предельного состояния пород стыковочной секции:

$$
k_{3} \cdot\left(\sigma_{\max }+\sigma_{\text {ср }}\right)=k_{\text {осл }} \cdot \sigma_{\mathrm{c}}+k \cdot \sigma_{\min },
$$

где $\sigma_{c}-$ прочность породы при одноосном сжатии; $\sigma_{\max }, \sigma_{\mathrm{cp}}, \sigma_{\min }-$ соответственно максимальное, среднее и минимальное сжимающие напряжения, действующие в стыковочной секции; $k-$ коэффициент пропорциональности (для апатит-нефелиновых руд $k=5$ ); $k_{\text {осл }}$ - коэффициент структурного ослабления, равный 0,8 для I категории по интенсивности трещиноватости; $k_{3}-$ коэффициент запаса, равный 2 для секции, существующей не более одного года.

Для левой и правой части уравнения построены линии зависимости от размера секции (соответственно 1 и 2 на рис. 6.24). Точка их пересечения соответствует минимально возможной ширине стыковочной секции - 44 м. Так как на участках неотбитого массива, примыкающих к очистному пространству или к обрушенному массиву, из-за отсутствия со стороны отбитого или обрушенного массива нормальных напряжений достаточной величины возможны нарушения сплошности по существующим плоскостям ослаблений, то необходимо увеличение ширины секции. Таким образом, окончательная ее ширина должна быть не менее 50 м.

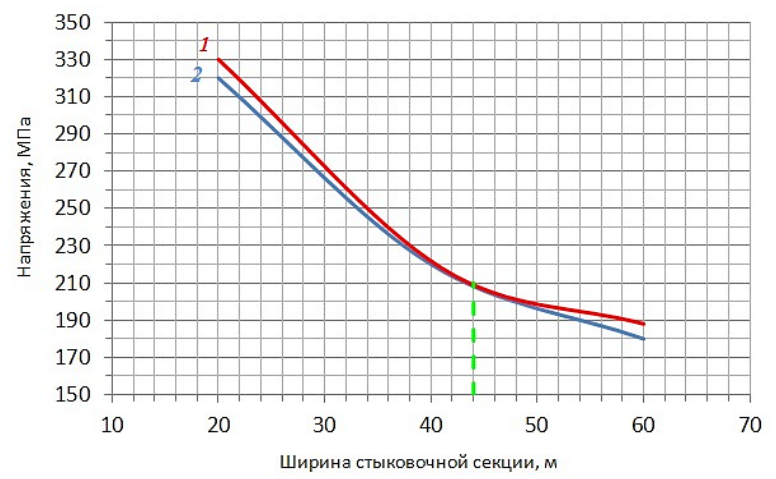

Рис. 6.24. Графическое определение ширины стыковочной секции для уравнения предельного состояния пород: 1 - левая часть уравнения; 2 - правая часть уравнения 
На ширину стыковочной секции вкрест простирания будет влиять гипсометрия контакта рудного тела. На гор. +470 м в районе разрезов Р16Ц.p. - Р14+50Ц.p. угол падения контакта варьирует в пределах $29 \div 36^{\circ}$. При формировании опережения в висячем боку рудной залежи должна быть обеспечена обязательная сбойка с отбитым массивом на вышележащем горизонте.

Ширина стыковочных секций на подэтажах может быть различной, но не менее 40 м.

Взрывание стыковочных секций на каждом подэтаже будет производиться отдельно по мере достижения предельного положения. Важным фактором при стыковке разгрузочной зоны является время, так как при прогнозируемом уровне напряжений в зонах их концентрации, составляющем порядка $0,5 \sigma_{c}$, возможны динамические проявления горного давления и разрушения выработок. Поэтому объем стыковочной секции на подэтаже не должен быть более объема, который можно отбить одним взрывом.

Вследствие переориентировки напряжений в породах блока-целика до $40-60^{\circ}$ к элементам залегания рудного тела выработки штрекового направления будут находиться в худших условиях (рис. 6.25). Выполнение противоударных мероприятий и усиленного крепления выработок в случае штрековой подготовки блока (вариант АО «Апатит») потребуют дополнительных затрат.

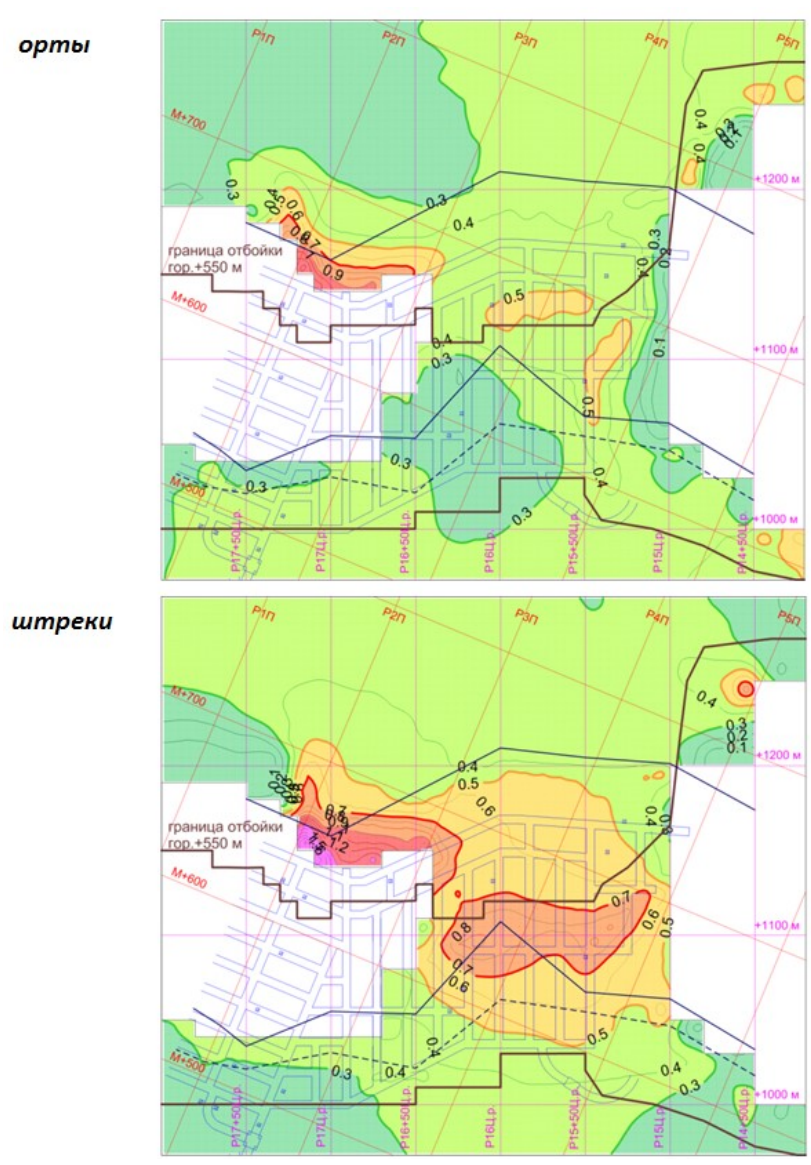

Рис. 6.25. Расчетные категории состояния выработок на верхнем подэтаже гор. +470 м 
С учетом этого фактора технологами ГоИ КНЦ РАН разработан ортовый вариант подготовки блока на гор. +470 м (рис. 6.26), так как на гор. +530 м выработки уже пройдены. Стыковочная секция показана голубым цветом, ее ширина (размер вкрест простирания рудной залежи) может быть уменьшена, размер по простиранию - 50 м.

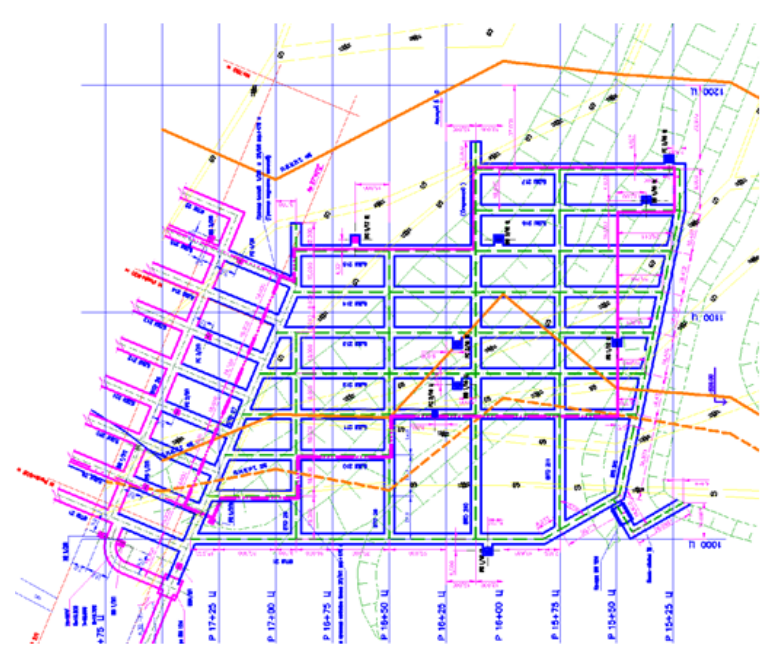

$a$

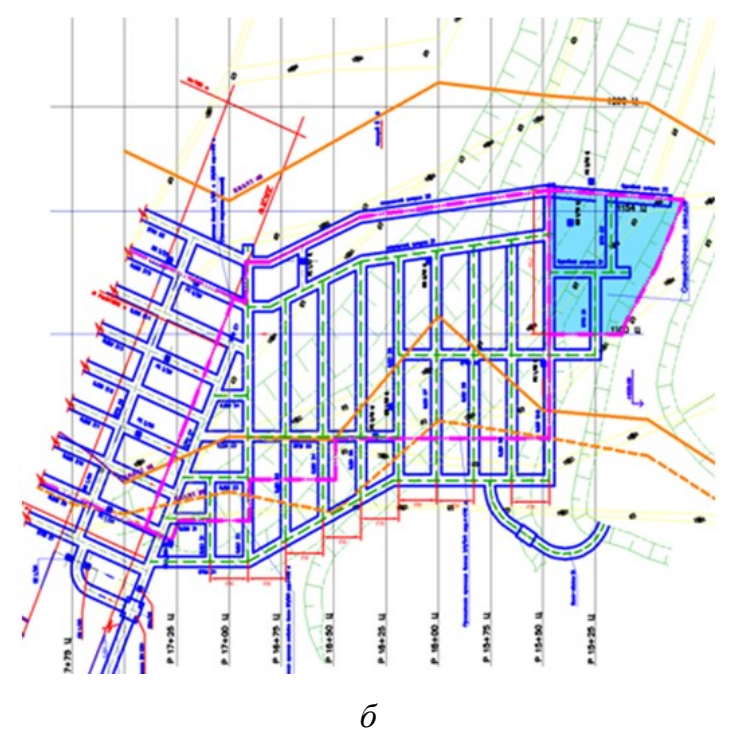

Рис. 6.26. Варианты отработки запасов руды в разрезах в стыковочной зоне гор. +470 м: $a$ - в штрековом направлении (АО «Апатит»); $\sigma$ — в ортовом направлении (ГоИ КНЦ РАН)

Рекомендовано производить опережающую отрезку на 20-30 м по висячему боку месторождения двумя отрезными штреками с частичной подрывкой покрывающих пород; отработку руды на подэтажах гор. +470 м осуществлять лентами вкрест простирания рудного тела в направлении от висячего к лежачему боку месторождения; производить отбойку стыковочных секции на подэтажах с помощью одного массового взрыва. 
При определении оптимальных отставаний нижележащего подэтажа к вышележащему варьировали этот параметр с шагом 10 м. Фактические отставания нижележащего подэтажа на гор. +530 м составляют около 60-80 м. Приведены результаты распределения максимальной компоненты напряжений при имитации отставания нижележащих подэтажей на 40 м (рис. 6.27). При этом существенных изменений в распределении $\sigma_{\max }$ не наблюдается. Положительным фактом является сокращение площади зон концентрации сжимающих напряжений.

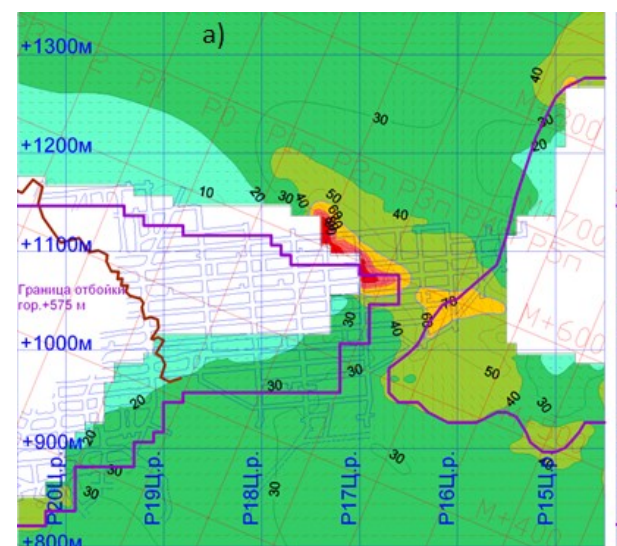

$a$

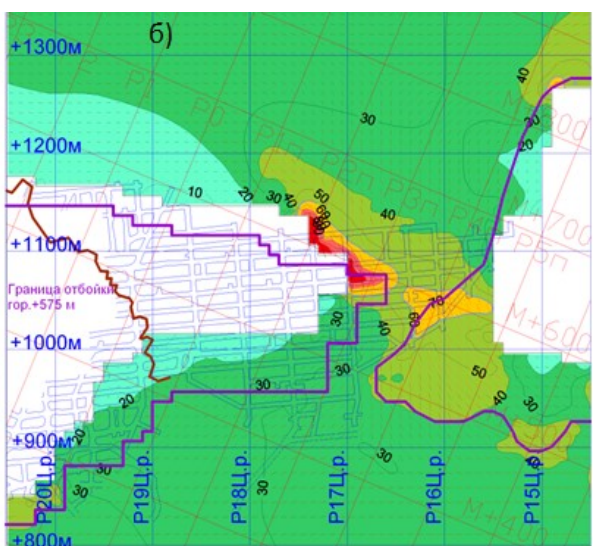

$\sigma$

Рис. 6.27. Распределение напряжений $\sigma_{\max }$ в районе стыковочной зоны на гор. +575 м: $a$ - при опережении по висячему боку 60 м; $\sigma$ - при опережении по висячему боку 30 м

Существенное опережение вышележащего подэтажа по отношению к нижележащему позволяет вести очистные работы на нижележащем этаже в более спокойных геомеханических условиях, что хорошо видно на разрезе по простиранию рудной залежи (рис. 6.28). Однако при этом в висячем боку рудной залежи под фронтом вышележащей очистной выемки формируется более протяженная зона концентрации напряжений, что может привести к разрушениям в выработках (особенно штрекового направления) в динамической форме. Поэтому отставание, рекомендуемое для очистных работ нижележащего подэтажа к вышележащему, составляет 40-50 м.

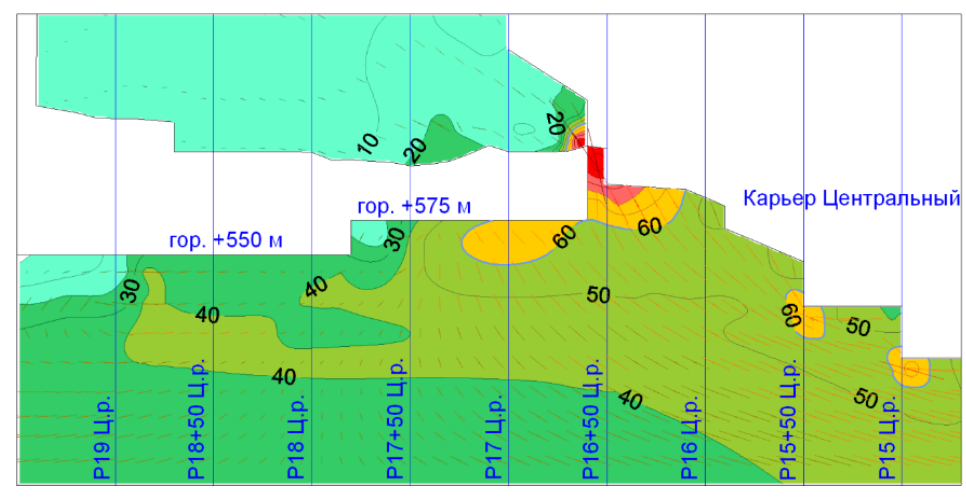

Рис. 6.28. Распределение напряжений $\sigma_{\max }$ в сечении по магистрали +1060 м (сетка Центрального) при формировании стыковочной секции на гор. +575 м и отставании очистных работ нижележащего подэтажа на 80 м 
По результатам прогноза категорий состояния выработок (рис. 6.27) показана целесообразность проходки всех горизонтальных выработок, необходимых для отбойки стыковочных секций, с обязательным применением разгрузочных щелей независимо от степени их устойчивости на момент проходки.

По результатам проведенных исследований разработаны регламенты для гор. +530 и +470 м, обеспечивающие безопасное ведение горных работ.

\subsection{2. Управление геодинамическими рисками на месторождении «Олений ручей»}

\subsubsection{1. Прогноз напряженно-деформированного состояния при выемке верхней части подземных запасов по данным численного моделирования}

На стадии детальной разведки месторождения «Олений Ручей» были установлены параметры поля напряжений:

- I (до глубины 400 м) - слабонапряженная зона, $\sigma_{\max } \leq 20 \mathrm{MПа;}$

- II (с глубиной от 400 м до 1000 м) - средненапряженная зона, 20 МПа $<\sigma_{\max }<40$ МПа;

- III (с глубиной более 1000 м) - сильнонапряженная зона, $\sigma_{\max } \geq 40$ МПа.

Натурными измерениями определен угол наклона вектора максимальной компоненты главных напряжений к горизонту $\approx 5^{\circ}$ и абсолютные значения $\sigma_{\max }$ в зоне II - 30-36 МПа.

Для выявления закономерностей эволюции НДС при отработке верхней части подземных запасов месторождения «Олений ручей» создана трехмерная геомеханическая модель на основе геологической и технологической информации в среде Geotech 3D.

Граничные условия для расчета НДС массива заданы в виде узловых перемещений на гранях модели. Информация о граничных условиях получена путем интерполяции перемещений, полученных в результате моделирования НДС массива горных пород. Исходная модель сгенерирована для геомеханического обоснования подземной выемки запасов месторождения. Результаты распределения напряжений и деформаций, полученные для массива месторождения в исходной модели, соответствуют общим современным представлениям о геомеханическом состоянии массива и удовлетворительно коррелируют с данными натурных определений.

Принятые в модели физико-механические свойства приведены в таблице 6.6. По причине слабой геологической изученности вмещающих пород считали их однородными с усредненными упругими и прочностными характеристиками.

Таблийа 6.6

Физико-механические свойства горных пород

\begin{tabular}{|l|c|c|}
\hline \multicolumn{1}{|c|}{ Показатели } & Вмещающие породы & Породы рудного тела \\
\hline Модуль упругости, ГПа & 70 & 40 \\
\hline Коэффициент Пуассона & 0,2 & 0,35 \\
\hline Плотность, $\mathrm{T} / \mathrm{M}^{3}$ & 2,65 & 3,00 \\
\hline
\end{tabular}

В результате построена объемная геомеханическая модель участка месторождения «Олений ручей», учитывающая параметры рудных тел, упругие свойства массива, рельеф дневной поверхности, а также исходное НДС массива (рис. 6.29). 
С использованием этой модели получено исходное НДС массива в окрестности планируемых на начальном этапе подземных горных работ и промоделированы варианты их развития с различными параметрами систем разработки.

Месторождение «Олений ручей» (нижний ярус рудных тел) находится в условиях трехкомпонентного сжатия с максимальной компонентой, определяемой действием тектонических сил.

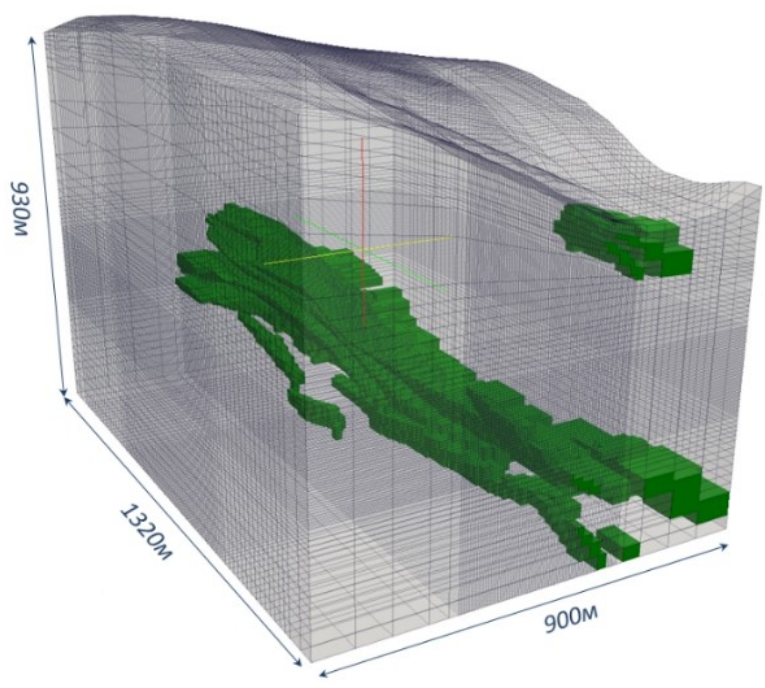

Рис. 6.29. Трехмерная конечно-элементная модель

Поле напряжений в районе планируемых очистных работ $+180-0$ м характеризуется достаточно однородным уровнем максимальных сжимающих напряжений во вмещающих породах $40 \div 42$ МПа, в породах рудного тела - $34 \div 36$ МПа. Направление векторов $\sigma_{\max }$ близко к горизонтальному по простиранию рудного тела, незначительная переориентировка наблюдается на маломощных участках рудных тел и в породах междупластья.

Минимальная компонента главных напряжений определяется в основном действием собственного веса пород и варьирует в пределах $8 \div 16$ МПа во вмещающем массиве, $12 \div 16$ МПа в рудном теле. Области растягивающих напряжений, близких по абсолютным величинам к нулю, приурочены к наиболее низким участкам рельефа дневной поверхности.

Сгенерированная геомеханическая модель адекватно отражает поле напряжений месторождения «Олений ручей» и может быть использована для обоснования параметров систем разработки. Следует отметить, что прогнозный уровень $\sigma_{\max }$ близок $\kappa$ уровню измеренных напряжений на гор. +240 м, где уже фиксируются проявления горного давления в динамической форме [259]. То есть выемка подземных запасов будет проходить в удароопасных условиях, что предопределяет необходимость исследования НДС массива при развитии подземных горных работ. Для решения этой задачи проведена серия прогнозных расчетов НДС по мере отработки рудных тел.

Рассчитана серия вариантов при последовательной выемке запасов. Схема развития моделируемых горных работ по вариантам (разрез по магистрали) показана на рисунке 6.30 . 
Вариант 0 - исходное напряженное состояние при конфигурации карьеров месторождения «Олений ручей» и Ньоркпахкский на начало выемки подземных запасов.

Вариант I - образование первой камеры на промежуточном этаже +100 м.

Вариант II - развитие горных работ с образованием трех камер на промежуточном этаже +100 м и одной камеры на промежуточном этаже 0 м.

Вариант III - развитие горных работ с образованием пяти камер на промежуточном этаже +100 м и трех камер на промежуточном этаже 0 м.

Вариант IV - погашение междукамерных и межэтажного целиков для варианта II.

Вариант $V$ - погашение междукамерных и межэтажного целиков для варианта III.

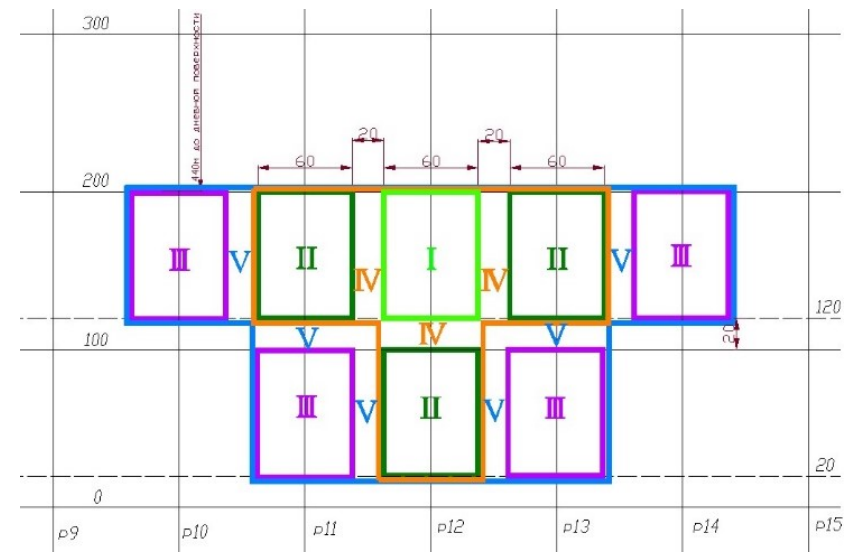

Рис. 6.30. Схема вариантов расчета в разрезе по магистрали (римскими цифрами указаны номера вариантов)

Разрезка, то есть формирование первой камеры, осуществлялась в районе 12 разреза. Исходили из того, что в удароопасных условиях более безопасным по геомеханическим условиям является развитие горных работ от центра к флангам двумя одновременно работающими фронтами, поэтому разрезной блок целесообразно расположить по центру участка месторождения, где отсутствует возможность подработки карьеров (Ньоркпахкский и «Олений Ручей»). Центром такого участка является разрез 12. Здесь рудное тело № 3 достигает максимальной высотной отметки +170 м. Имитировали развитие работ симметрично от центра к флангам с опережением вышележащего горизонта к нижележащему на одну камеру. Начальные размеры камер и целиков были приняты 60 и 20 м соответственно с возможностью варьирования их размеров в зависимости от результатов геомеханического моделирования.

Применение этажно-камерной системы с открытым очистным пространством планируется на двух верхних промежуточных этажах до создания условий для перехода к системе с обрушением. Для геомеханического обоснования размеров камер и целиков оценивали изменение НДС по мере развития работ как в окрестностях камер, так и непосредственно в междукамерных и междуэтажных целиках. Анализ НДС проводили для расчетных вариантов I-III. На рисунках 6.31 и 6.32 показано распределение максимальной компоненты главных напряжений $\sigma_{\max }$ в разрезах вкрест простирания рудной залежи. 
При анализе результатов моделирования исходного напряженного состояния массива установлено, что в районе планируемых очистных работ $+180-0$ м уровень максимальных сжимающих напряжений во вмещающих породах достаточно однородный с величинами $40 \div 42$ и $34 \div 36$ МПа в рудном теле. Направление векторов $\sigma_{\max }$ близко к горизонтальному по простиранию рудного тела, незначительная переориентировка наблюдается на маломощных участках рудных тел и в породах междупластья. Как видно (рис. 6.31), более значительные изменения напряжений происходят в окрестности центральной камеры, что связано прежде всего с увеличением мощности рудного тела и, соответственно, размера камеры в районе 12 разреза. Наибольшая концентрация напряжений приурочена к породам междупластья и кровле камер. Следует отметить также, что более пригруженными являются угловые части камер, причем зона концентрации у торца с меньшим номером разреза (названным «южным») смещена к ребру камеры у верхнего контакта рудного тела (рис. $6.32 a$ ), а зона концентрации $\sigma_{\max }$ У противоположного северного торца смещена к нижнему контакту рудного тела (рис. 6.32 б). Такие особенности НДС определяются тем фактом, что рудное тело расположено в плане в основном под углом к направлению действия тектонических напряжений. Коэффициент концентрации $k$ максимальной компоненты главных напряжений на торцах в узких участках рудного тела выше. В тоже время $k \leq 2$, а зоны концентрации имеют незначительную площадь и находятся во вмещающих породах с более высоким пределом прочности на сжатие (в среднем $200 \mathrm{MПа).}$ При этом в междукамерных и межэтажных целиках уровень напряжений близок к исходному с небольшими участками повышенных и пониженных напряжений. Уровень напряжений в рудных целиках не превышает $50 \mathrm{MПа,} \mathrm{что}$

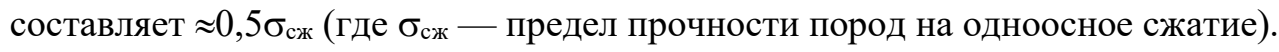
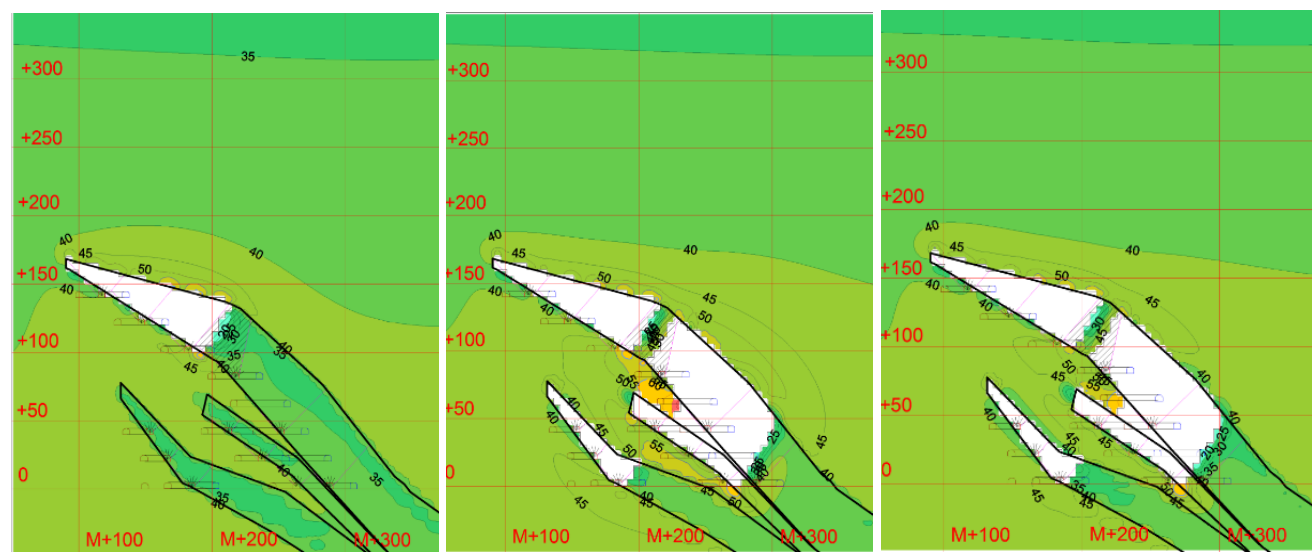

Рис. 6.31. Изменение $\sigma_{\max }$ по мере развития работ для вариантов I-III по разрезу 12 (середина центральной камеры) месторождения «Олений Ручей»

Минимальные напряжения $\sigma_{\min }$ являются сжимающими со значениями от 5 до 10 МПа во вмещающем массиве и до 15-20 МПа в рудных телах (рис. 6.33 и 6.34). Однако в целиках, кровле камер и породах междупластья можно выделить зоны растягивающих напряжений, абсолютные значения которых достигают 1-2 МПа. 


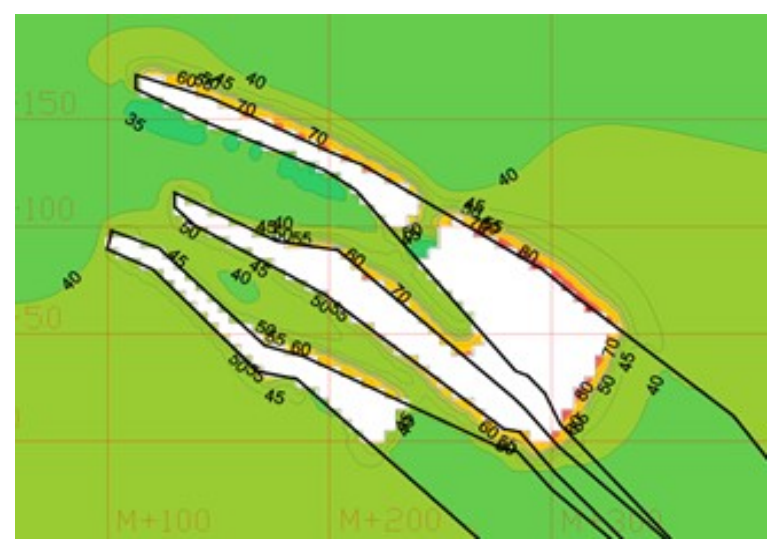

$a$

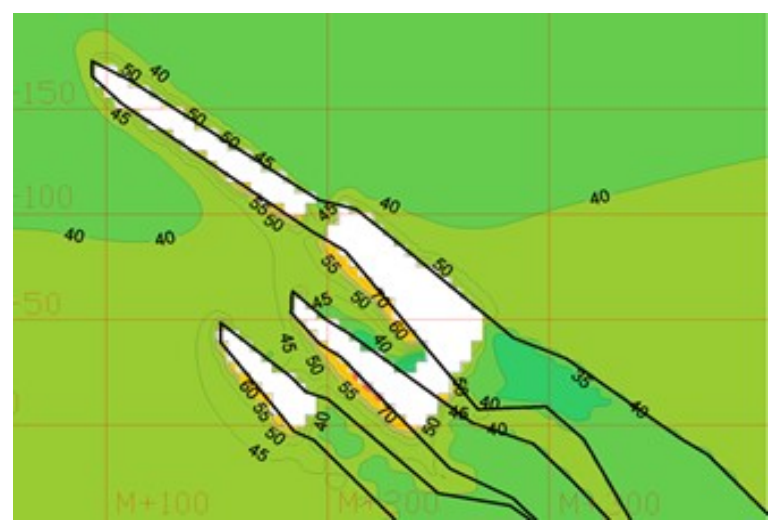

$\sigma$

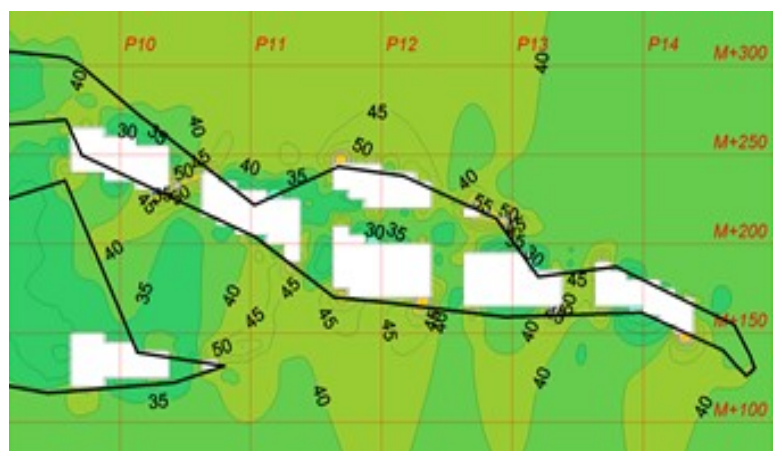

B

Рис. 6.32. Распределение $\sigma_{\max }$ для варианта III: $a$ - разрез $10+60 \mathrm{~m} ; \sigma-$ разрез $13+30 \mathrm{~m}$; в- план гор. +110 м

В результате математического моделирования напряженно-деформированного состояния при отработке подземных запасов в отметках $+180-0$ м установлено:

- исходное поле напряжений в районе месторождения «Олений ручей», которое характеризуется как высоконапряженное со значениями $\sigma_{\text {мах }}$ от 35 до 50 МПа в высотных отметках будущих подземных горных работ; 
- в районе планируемой очистной выемки при отработке верхней части запасов исходный уровень максимальных сжимающих напряжений составляет $40 \div 42$ МПа во вмещающих породах и $34 \div 36$ МПа в рудном теле; направление векторов $\sigma_{\max }$ близко к горизонтальному и ориентировано по простиранию рудного тела, незначительные отклонения наблюдаются на маломощных участках рудных тел и в породах междупластья;

- наибольшая концентрация напряжений приурочена к породам междупластья, коэффициент концентрации напряжений $k \leq 2$, зоны концентрации находятся во вмещающих породах с более высоким пределом прочности на сжатие (в среднем 200 МПа);

- зоны концентрации максимальной компоненты главных напряжений формируются в окрестности торцевых частей камер на узких участках рудного тела;

- на более мощных участках рудного тела пригруженными являются угловые части камер.
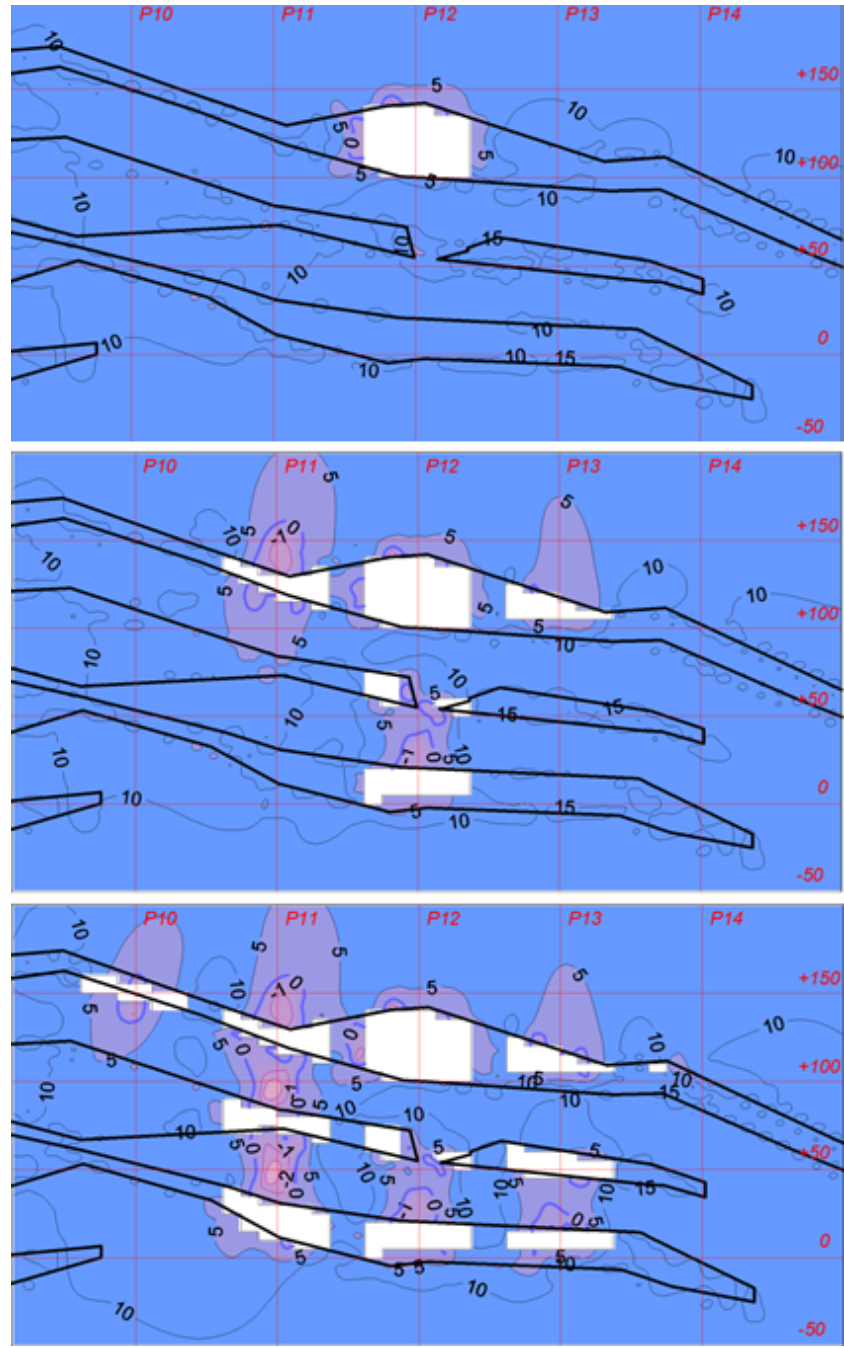

Рис. 6.33. Изменение $\sigma_{\min }$ по мере развития работ для вариантов I-III по магист. +190 м 


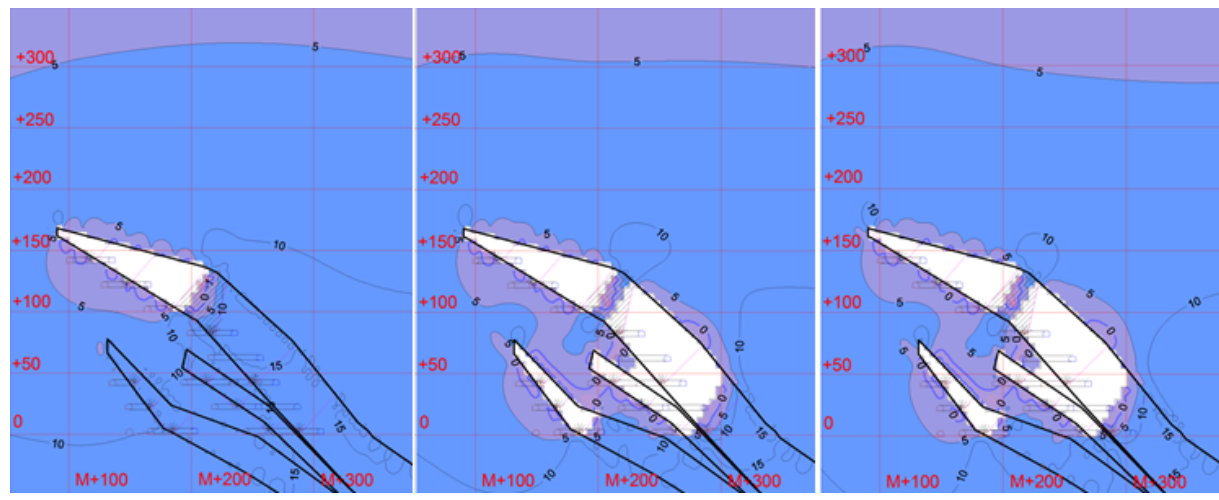

Рис. 6.34. Изменение $\sigma_{\min }$ по мере развития работ для вариантов I-III по разрезу 12 (середина центральной камеры) месторождения «Олений Ручей».

\subsubsection{2. Управление геодинамическими рисками в прочессе развития подземных работ}

Месторождение «Олений ручей» отнесено к опасным по горным ударам с глубины 400 м от дневной поверхности [260]. Рудные тела нижнего яруса месторождения расположены ниже отметки +200 м, при этом высотные отметки рельефа дневной поверхности в этом районе колеблются в пределах $+600 \div+660$ м. Таким образом, отработка подземных запасов будет проходить в удароопасных условиях, что предопределяет необходимость геомеханического обоснования параметров системы разработки, порядка горных работ и разработки мероприятий по обеспечению геодинамической безопасности горных работ. Для решения этих задач проведена серия прогнозных расчетов НДС по мере отработки рудных тел с использованием трехмерной геомеханической модели месторождения.

Выемка подземных запасов на верхних горизонтах предполагается системой с открытым очистным пространством с переходом на более глубоких горизонтах к системе с обрушением руды. В связи с этим требуется решение следующих задач:

- геомеханическое обоснование размеров камер и целиков;

- оценка необходимых параметров обнажений для перехода к системе с обрушением подработанных пород;

- оценка вероятности обрушения налегающей толщи до поверхности;

- прогноз устойчивости этажных выработок в процессе отработки подземных запасов.

\subsubsection{1.Геомеханическое обоснование размеров камер и целиков}

Как было указано ранее, уровень напряжений в рудных целиках не превышает $50 \mathrm{MПа,} \mathrm{что} \mathrm{составляет} \approx 0,5 \sigma_{\text {сж }}$ (где $\sigma_{\text {сж }}$ - предел прочности пород на одноосное сжатие). Таким образом, рассмотренные варианты развития горных работ с применением этажно-камерной системы разработки позволяют сделать вывод о том, что предложенные размеры камер и целиков (60 и 20 м соответственно) являются допустимыми по уровню напряжений. Средняя мощность межэтажных целиков при имитации выемки запасов системой с открытым очистным пространством составляла 15-20 м, что является достаточным с точки зрения прогнозируемого в них уровня действующих максимальных напряжений, которые составляют от 20 до 50 МПа. Однако при этом в межэтажных целиках фиксируются области растягивающих напряжений $\sigma_{\min }$ с абсолютными значениями до 2 МПа, поэтому желательно увеличение размеров межэтажного целика до 25 м. 
Минимальное значение ширины целика определяли также в соответствии с методическими указаниями ВНИМИ [261], ширину МКЦ определяли по следующей формуле:

$$
\frac{K_{H} K_{\alpha} \gamma H\left(\alpha+l_{\mathrm{k}}\right)}{a}=\frac{K_{\text {осл }} K_{\phi 1} K_{\phi 2} K_{\text {д }} \sigma_{\text {сж }}^{0}}{K_{3}},
$$

где $K_{H}$ - коэффициент, учитывающий влияние размеров отрабатываемого участка; $K_{\alpha}$ - коэффициент, учитывающий влияние угла падения рудного тела; $\gamma$ - удельный вес пород; $H$ - глубина разработки; $K_{\text {осл }}$ - коэффициент структурного ослабления; $K_{\phi 1}$ - коэффициент формы, учитывающий влияние отношения длины к ширине целика; $K_{\phi 2}$ - коэффициент формы, учитывающий влияние отношения ширины к высоте целика; $K_{\text {д }}$ - коэффициент, учитывающий влияние времени; $\sigma_{\text {сж }}^{0}$ - прочность породы в образце; $K_{3}-$ коэффициент запаса прочности; $l_{\mathrm{\kappa}}$ - ширина камеры.

После преобразования получаем:

$$
a=\frac{K_{3} K_{H} \gamma H l_{\kappa}}{K_{\text {осл }} K_{\phi 1} K_{\text {中2 }} K_{\text {д }} \sigma_{\text {сж }}^{0}-K_{3} K_{H} K_{\alpha} \gamma H} .
$$

Коэффициент $K_{H}=0,7$, так как ширина отрабатываемого участка $L$ больше глубины отработки $H$, то есть $L / H<0,8$.

Коэффициент $K_{\alpha}$ для ленточных целиков рассчитали по следующей формуле:

$$
K_{\alpha}=\cos ^{2} \alpha+\eta \sin ^{2} \alpha
$$

где угол падения рудного тела $\alpha=35^{\circ} ; \eta=\frac{\mu}{1-\mu}=0,42-$ коэффициент бокового отпора (коэффициент Пуассона $\mu=0,3)$. Тогда:

$$
K_{\alpha}=\cos ^{2} 35^{\circ}+0,42 \sin ^{2} 35^{\circ}=0,81 .
$$

Коэффициент структурного ослабления принимали $K_{\text {осл }}=0,5$ исходя из отсутствия фактических данных по параметрам трещиноватости и по аналогии с другими близлежащими Хибинскими апатит-нефелиновыми месторождениями.

Коэффициент формы $K_{\phi 1}$ рассчитывается по формуле:

$$
K_{\phi 1}=0,8+0,2 \frac{a}{h} .
$$

Длина целика определяется средней мощностью рудного тела и составляет около 40 м. Для условий месторождения предполагаемое отношение длины целика к его ширине $b / a=2$. Тогда:

$$
K_{\phi 1}=0,8+0,2 \cdot 2=1,2 .
$$

Для расчета коэффициента формы $K_{\phi 2}$ отношение ширины целика к его высоте примем равным 0,2, а на контактах с боковыми породами отсутствуют пластичные прослойки, тогда: 


$$
K_{\text {中2 }}=0,6+0,4 \frac{a}{h}=0,6+0,4 \cdot 0,2=0,68 .
$$

Коэффициент запаса рассчитывали по формуле:

$$
K_{3}=K_{31} \cdot K_{32} \cdot K_{33},
$$

где $K_{31}-$ коэффициент, учитывающий изменчивость среднемаксимальной прочности, равный 1,$25 ; K_{32}$ - коэффициент, учитывающий возможное уменьшение площади поперечного сечения целика в натуре по сравнению с проектной, принимали равным 1,$1 ; K_{33}-$ коэффициент, учитывающий сейсмическое воздействие взрывов на целик, принимали равным 1,2. Таким образом, коэффициент запаса $K_{3}$ равен

$$
K_{3}=K_{31} \cdot K_{32} \cdot K_{33}=1,25 \cdot 1,1 \cdot 1,2=1,65 .
$$

Коэффициент, учитывающий влияние времени $K_{\text {д }}$ принят равным 0,7 .

С учетом значений коэффициентов в формуле (6.10), а также известных данных $\left(\sigma_{\text {сж }}^{0}=14000 \mathrm{~T} / \mathrm{M}^{2}, \gamma=2,7 \mathrm{~T} / \mathrm{M}^{3}, H=400 \mathrm{M}, l_{\mathrm{K}}=60 \mathrm{M}\right)$, ширина МКЦ будет равна:

$$
a=\frac{1,65 \cdot 0,7 \cdot 0,81 \cdot 2,7 \cdot 400 \cdot 60}{0,5 \cdot 1,2 \cdot 0,68 \cdot 0,7 \cdot 14000-1,65 \cdot 0,7 \cdot 0,81 \cdot 2,7 \cdot 400}=20,3 \mathrm{M}
$$

Таким образом, двумя методами обоснован минимальный размер междукамерных целиков, составляющий 20 м при максимальном пролете камеры 60 м. Мощность межэтажного целика должна быть не менее 25 м.

\subsubsection{2. Оиенка необходимых параметров обнажений для перехода к системе с обрушением подработанных пород}

Для обоснования перехода к системе с обрушением пород кровли на нижних горизонтах, где рудные тела характеризуются большей мощностью, определяли параметры очистного пространства при отработке двух верхних промежуточных этажей камерно-целиковой системой, при которых создаются условия для достаточного заполнения очистного пространства обрушенными породами. Задача сводилась к нахождению объема пород кровли, вероятность обрушения которых близка к единице. С учетом разрыхления обрушаемой массы этот объем должен быть примерно в 1,5 раза меньше объема очистного пространства.

Обрушение подработанных пород в тектонически нагруженных массивах можно рассматривать на основе теории разрушения отрывом сжатых скальных пород. В наибольшей степени на разрушение подработанного массива влияет максимальная растягивающая компонента деформаций и ее ориентировка по отношению к плоскостям трещин. Методика оценки деформированного состояния подработанного массива и возможности обрушения до поверхности приведена в работах [262, 263].

Анализ объемов пород, склонных к обрушению проводили для двух вариантов (рис. 6.29):

- вариант IV - погашение межкамерных и межэтажного целиков между тремя камерами на промежуточном этаже +100 м и одной камеры на промежуточном этаже 0 м;

- вариант V - погашение межкамерных и межэтажного целиков между пятью камерами на промежуточном этаже +100 м и тремя камерами на промежуточном этаже 0 м. 
На рисунке 6.35 а приведены результаты расчетов при отбойке трех камер на этаже +100 м и одной камеры на этаже 0 м с погашением межкамерных и межэтажных целиков. Показано распределение приведенных напряжений $\left(\varepsilon_{3} E\right)$ в вертикальных сечениях по центру камер (разрез 12). Суммирование объемов вероятных обрушений по слоям модели показало, что для рассматриваемого варианта $V_{\text {обр }}=0,5 V_{\text {к. }}$.

Анализ распределения $\varepsilon_{3} E$ при отбойке пяти камер на этаже +100 м и трех камер на этаже 0 м с погашением межкамерных и межэтажных целиков (рис. 6.35 б)

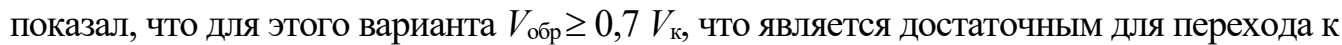
системе с обрушением. При этом ориентировка вероятных трещин отрыва близка к ортогональной по отношению к контакту рудного тела, который в данном случае является кровлей камеры. Кроме того, направление трещин субмагистральное. Такая ориентировка площадок способствует обрушению определенного объема подработанных пород и заполнению очистного пространства.
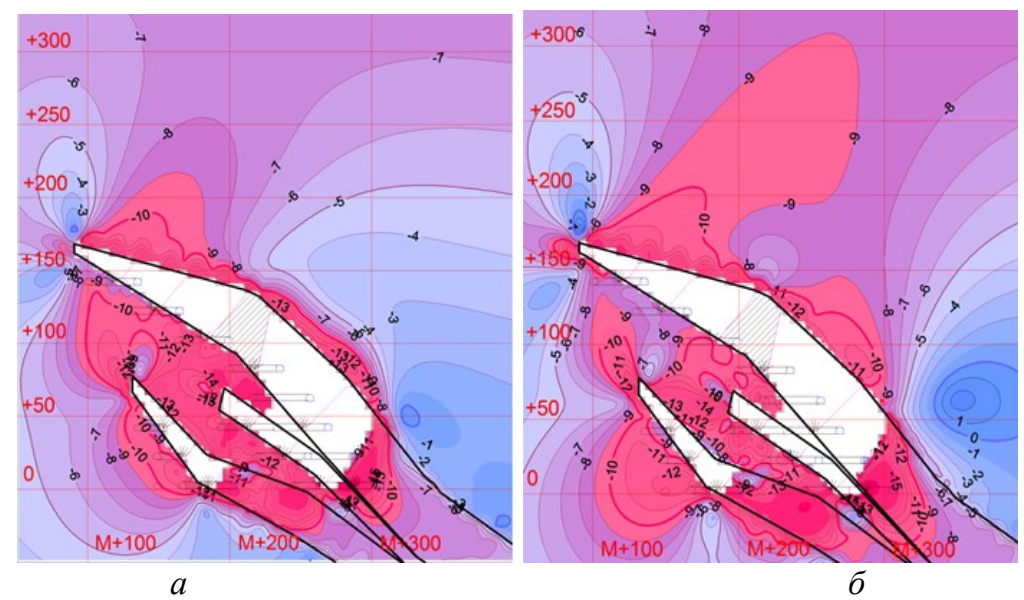

Рис. 6.35. Распределение $\varepsilon_{3} E: a-$ при отбойке трех камер на этаже +100 м и одной камеры на этаже 0 м с погашением межкамерных и межэтажных целиков; $\sigma$ - при отбойке пяти камер на этаже +100 м и трех камер на этаже 0 м с погашением межкамерных и межэтажных целиков

\subsubsection{3. Оченка вероятности обрушения налегающей толщи до поверхности}

Если частичное обрушение пород в очистное пространство обеспечивает безопасность горных работ на данном этапе, то полное обрушение налегающей толщи до поверхности является крайне негативным фактором. Известно, что форма проявления, характер развития и параметры процесса сдвижения горных пород и дневной поверхности зависят от следующих основных факторов: формы и размеров выработанного пространства; физико-механических свойств вмещающих пород; угла падения залежи; структурных особенностей массива (трещиноватость, тектонические разрывы, ослабленные зоны); глубины разработки; рельефа местности; величины и направления действия тектонических сил; сейсмического воздействия массовых взрывов; собственной сейсмичности массива и др.

Выполнен прогноз деформированного состояния всей подработанной толщи в процессе дальнейшей отработки рудной залежи до отметки -100 м. На рисунке 6.36 показано распределение максимальных растягивающих деформаций в сечении по простиранию рудной залежи (магистраль +340 м). 
Следует отметить достаточно высокие абсолютные значения $\varepsilon_{3} E$, близкие к пределу прочности вмещающих пород на разрыв. Зоны, в которых происходит превышение предельной величины, выделены красным цветом. В то же время по мере удаления от очистной выемки к дневной поверхности происходит выполаживание площадок, на которые действуют растягивающие деформации, что будет тормозить процесс развития обрушения и выхода его на дневную поверхность.

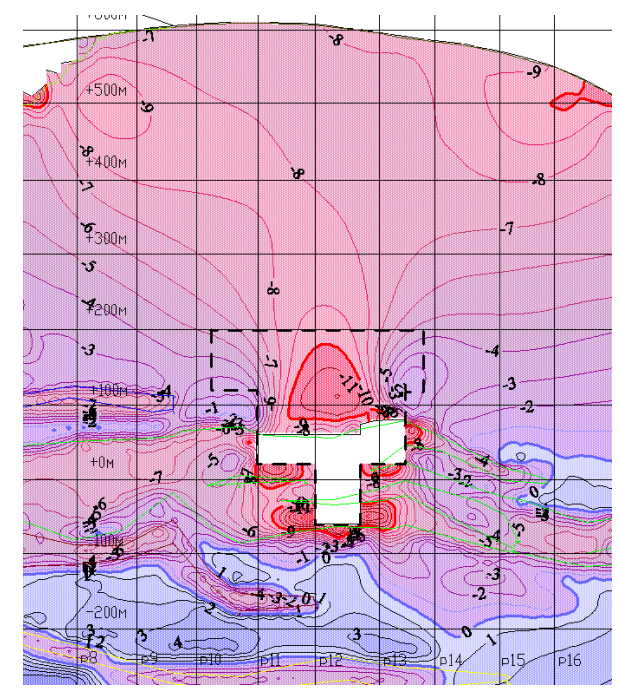

Рис. 6.36. Деформированное состояние пород по магистрали +340 м при отработке запасов до отметки -100 м, изолинии $\varepsilon_{3} E$

По мере углубления горных работ происходит небольшой рост абсолютных величин растягивающих деформаций при сохранении общих тенденций с достижением предельных величин в зоне, примыкающей к кровле, и в локальных зонах у дневной поверхности, приуроченных к карьерным выемкам и долинам.

Таким образом, при формировании условий для частичного самообрушения пород в очистное пространство и возможном появлении локальных зон плавных сдвижений на дневной поверхности вблизи долин и у дна карьеров полное обрушение пород до поверхности маловероятно в силу следующих причин: большая мощность подработанной толщи (минимум 400 м), четырехстороннее опирание подработанных пород, действие в массиве пород месторождения высоких тектонических напряжений. Сумма этих факторов приводит к образованию в подработанных породах обширной зоны с субгоризонтальной ориентировкой предположительных трещин отрыва, тормозящей процесс выхода разрушений на дневную поверхность. По мере уточнения прочностных характеристик руды и вмещающих пород необходимо проводить текущие прогнозы деформированного состояния и оценку параметров зон возможного приповерхностного нарушения массива.

\subsubsection{4. Прогноз устойчивости выработок в прочессе отработки запасов в отметках $+180-0 \mathrm{M}$}

Оценка устойчивости выработок по результатам прогноза напряженного состояния массива пород проведена по показателю отношения действующих напряжений на контуре выработки к прочности пород при одноосном сжатии $\sigma_{д} / \sigma_{\text {сж. }}$ 
Величины напряжений на контуре выработки вычисляли по специально разработанной методике, учитывающей все три компоненты главных напряжений и девять углов их наклона относительно осей выработок. Рассмотрены этажи +100 и +0 м для вариантов последовательного развития очистной выемки.

На рисунках 6.37 и 6.38 представлены изолинии величин отношения $\sigma_{д} / \sigma_{\text {сж }}$ для штреков и ортов, а также показано изменение этого параметра для горизонтов +0 и +100 м при последовательной отработке запасов месторождения: $a$ и $\sigma-$ формирование камеры на горизонте $+100 \mathrm{~m}$; в и 2 - формирование 3 камер на горизонте +100 м и 1 камеры на горизонте +0 м, отбойка всех целиков; $\partial$ и $e$ - формирование 5 камер на горизонте +100 м и 3 камер на горизонте +0 м при отработке всех целиков.

На приведенных картах изолиний по промежуточным этажам цветовая гамма и категории состояния выработок соответствует шкале рисунка 6.39.

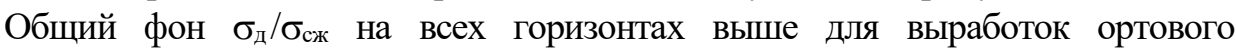
направления, что связано с действием максимальной компоненты напряжений по простиранию рудной залежи. Практически все выработки ортового направления в породах рудного тела при проходке имеют прогнозную категорию Г, что может привести к проявлениям горного давления в динамической форме. Уровень удароопасности для ортов и для штреков растет по мере приближения и увеличения их размеров к очистному пространству, что связано с переориентировкой напряжений в окрестности создаваемых очистных выемок (камер). Для выработок ортового направления категория удароопасности по мере развития работ на отдельных участках снижается; для выработок субмагистрального направления происходит увеличение удароопасности, особенно в междукамерных целиках и в междупластье.

Практически все выработки в породах рудного тела при проходке имеют более

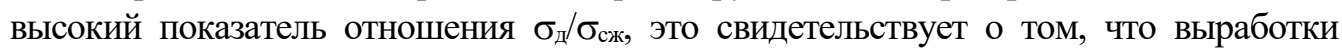
в рудных телах будут в худшем состоянии, чем во вмещающих породах.

Таким образом, по результатам прогноза состояния горных выработок установлено:

- более высокая категория удароопасности характерна для выработок ортового направления;

- в рудных телах выработки будут в худшем состоянии, чем выработки, пройденные во вмещающих породах;

- при приближении к очистному пространству и увеличении его размеров состояние выработок будет ухудшаться, что связано с переориентировкой напряжений в окрестности создаваемых очистных выемок (камер).

В результате проведенного анализа эволюции НДС массива в процессе подземной отработки запасов месторождения установлено:

- в межкамерных целиках уровень напряжений не превышает $50 \mathrm{MПа,}$ что составляет $\approx 0,5 \sigma_{\text {сж }}$ (где $\sigma_{\text {сж }}$ - предел прочности пород на одноосное сжатие); размеры камер и целиков (60 и 20 м соответственно) являются допустимыми по уровню максимальных напряжений;

- рекомендуемый с точки зрения геомеханических условий размер межэтажных целиков должен быть не менее 25 м;

- заполнение очистного пространства обрушенными породами в объеме, достаточном для перехода к системе с обрушением, обеспечивается при отбойке 
пяти камер на этаже +100 м и трех камер на этаже 0 м с погашением межкамерных и межэтажных целиков;

- вероятность полного обрушения пород до поверхности при выемке подземных запасов в отметках +180-0 м в пределах разрезов 9-16 минимальна;

- при подготовительных работах более высокая категория удароопасности будет в выработках ортового направления;

rop. $+0 \mathrm{M}$

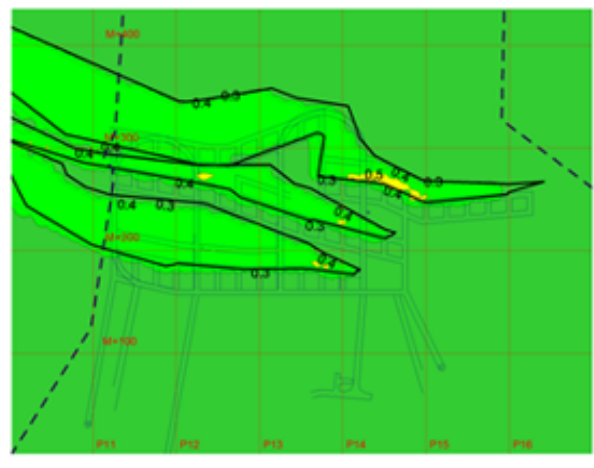

$a$

$$
\text { rop. }+0 \mathrm{M}
$$

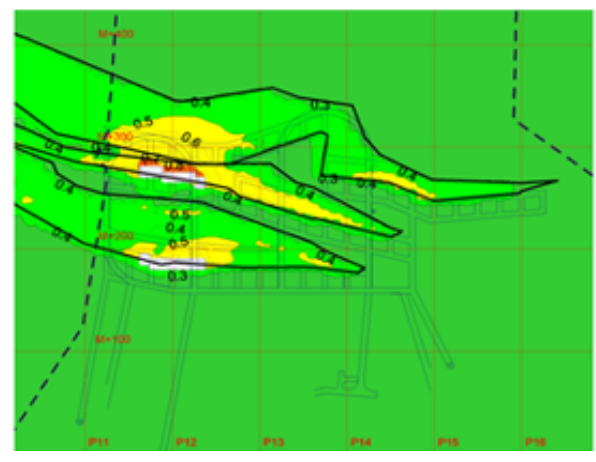

B

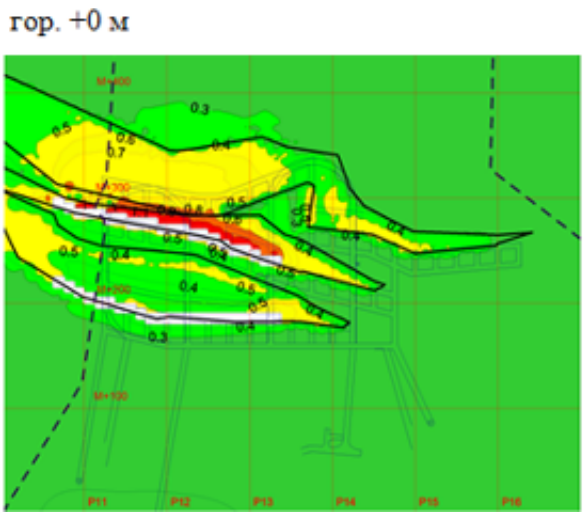

$\partial$

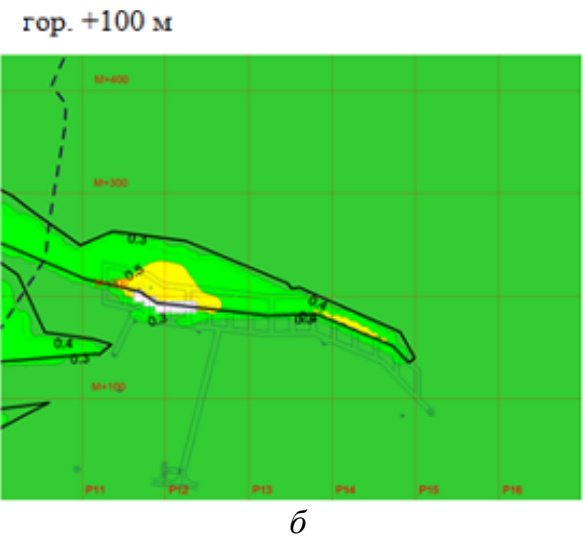

rop. $+100 \mathrm{M}$

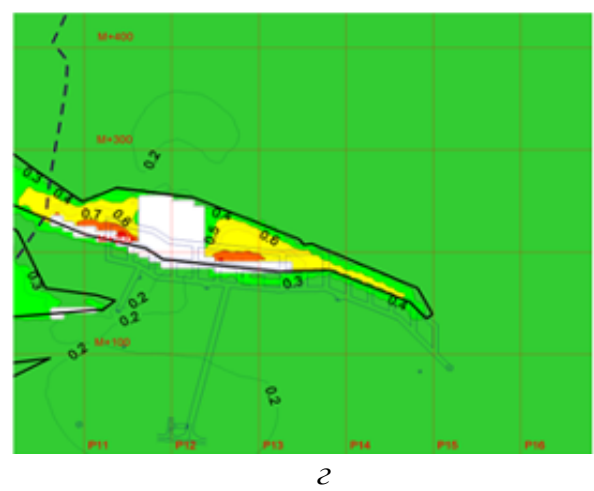

rop. $+100 \mathrm{M}$

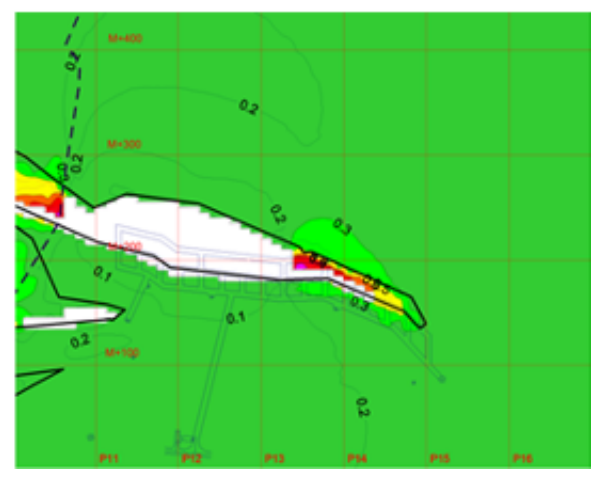

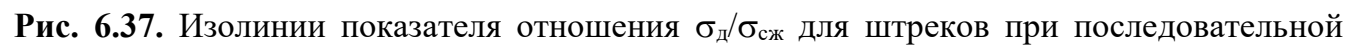
отработке запасов месторождения на гор. +0 и +100 м 


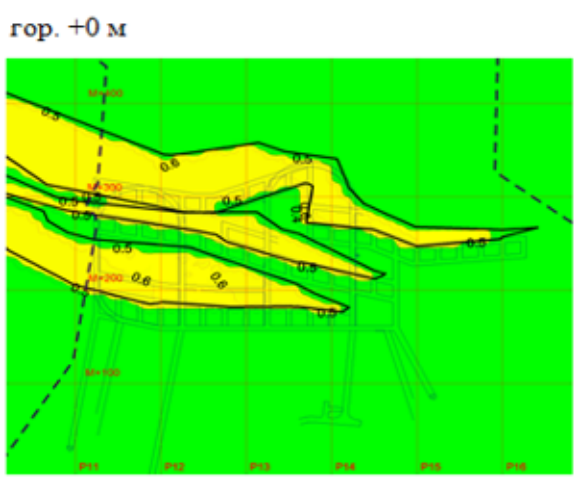

$a$

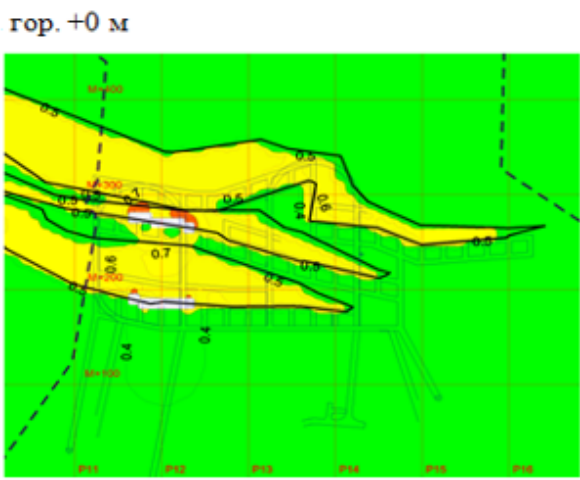

B

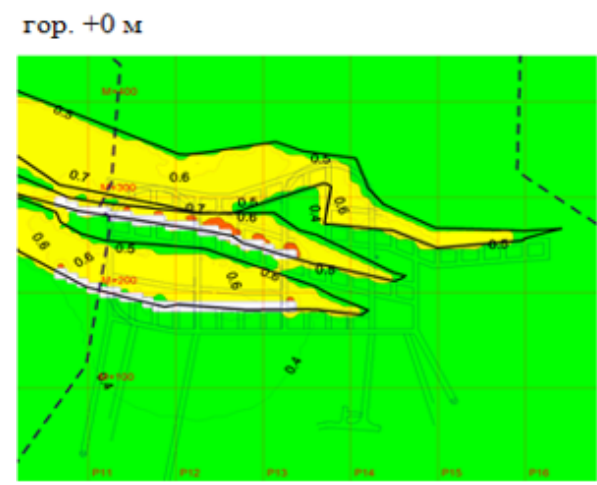

$\partial$

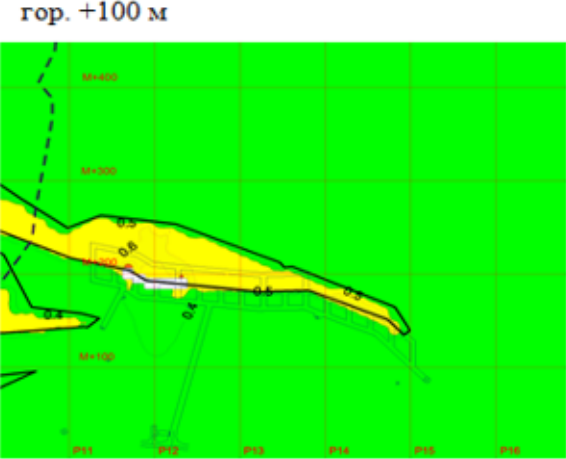

6
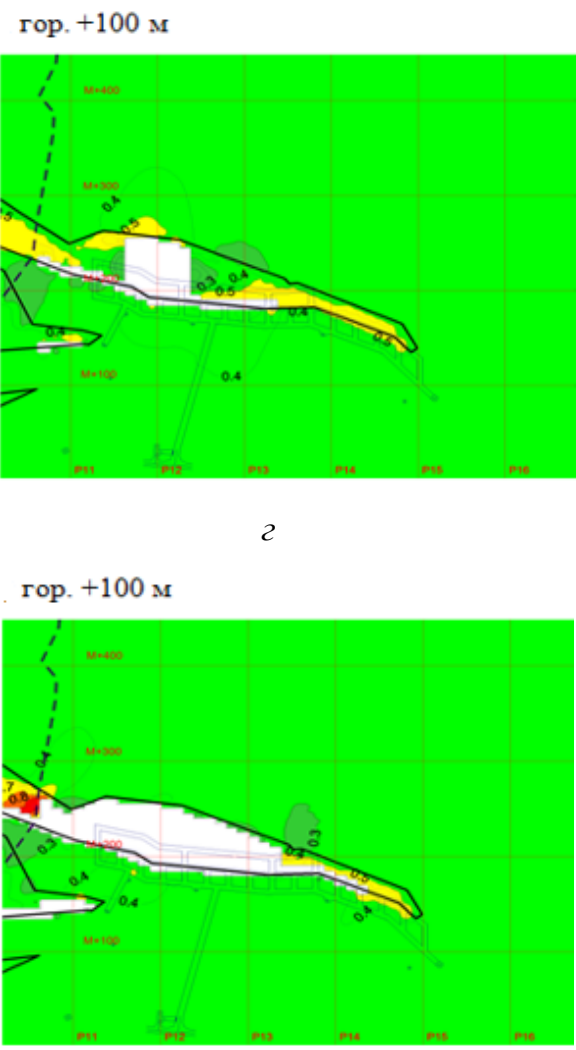

$e$

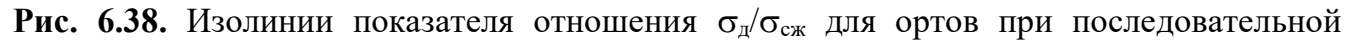
отработке запасов месторождения на горизонта +0 и +100 м

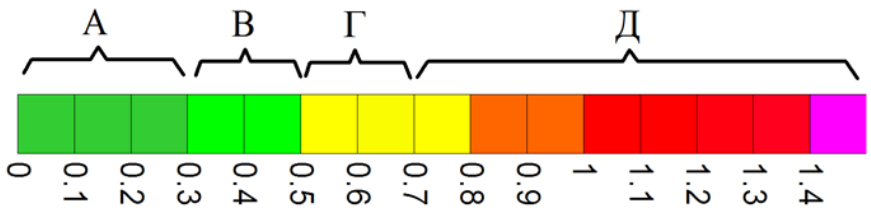

Рис. 6.39. Шкала соответствия отношений $\sigma_{д} / \sigma_{\text {сж }}$ и их цветовой интерпретации на картах изолиний категориям состояния выработок 
- по мере развития очистных работ состояние выработок (особенно магистрального направления) будет ухудшаться, что связано с конщентрацией напряжений и их переориентировкой в окрестности создаваемых очистных выемок (камер).

\subsubsection{5. Определение оптимальных параметров набрызг-бетонной крепи}

Для оценки НДС массива в окрестности подземных горных выработок на руднике «Олений ручей» и определения оптимальных параметров набрызг-бетонной крепи сгенерирована локальная численная модель, разбиение которой позволяет имитировать проходку выработок трех сечений, соответствующих транспортной, конвейерной и воздухоподающей штольне на разных участках гор. +240 м. Кроме того, сгенерированная сетка позволяет промоделировать крепление выработок набрызг-бетоном с толщиной 50 или 100 мм. В качестве граничных условий задавали узловые перемещения, полученные путем интерполяции из модели месторождения «Олений ручей».

В результате, построена объемная модель (рис. 6.40), учитывающая форму контура трех штолен, упругие свойства массива и набрызг-бетона, а также исходное НДС массива до проходки выработок.

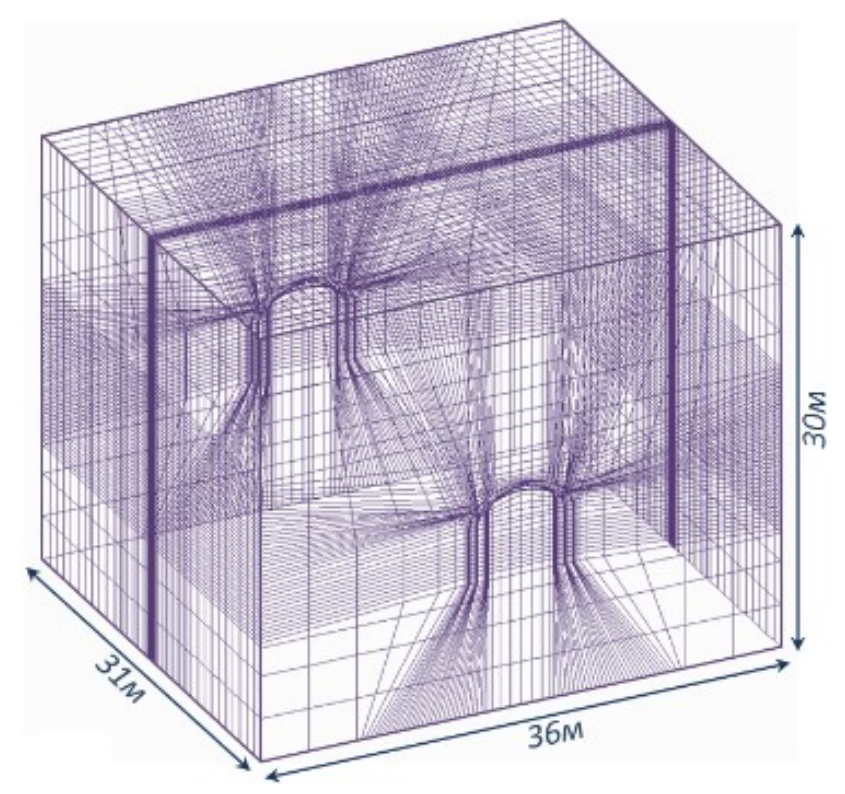

Рис. 6.40. Сетка конечных элементов модели штолен

Локальная модель имеет протяженность 31 м и может встраиваться в любую область мелкомасштабной модели месторождения.

Проведены многовариантные расчеты НДС в окрестности штолен (рис. 6.41). В результате, определена оптимальная мощность набрызг-бетонной крепи, составившая 50 мм. 


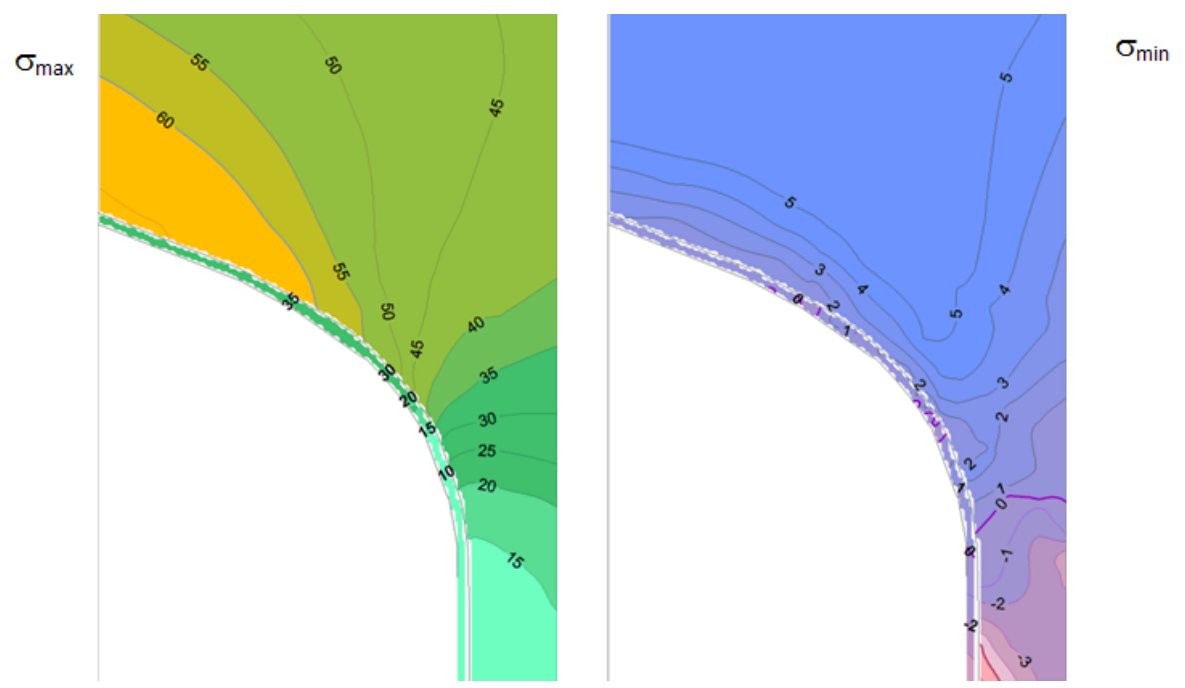

Рис. 6.41. Распределение напряжений в крепи и приконтурном массиве конвейерной штольни с толщиной бетонной крепи 50 мм

\subsubsection{3.Предрасчет зонь обрушения и сдвижения при отработке запасов перспективного месторождения «Эвеслогчорр»}

Перспективное месторождение «Эвеслогчорр» расположено в 12 км восточнее города Кировска в горнодолинной части реки Вуоннемйок. Месторождение локализовано в пределах ийолит-уртитовой дуги Хибинского щелочного массива. Рельеф местности здесь резко пересеченный - высоты окружающих гор близки к 1000 м, превышения над дном долины составляют 370-770 м.

Апатитовая залежь месторождения «Эвеслогчорр», как и всех других Хибинских месторождений, расположена в кровле толщи массивных уртитов и перекрывается породами комплекса гнейсовидных ийолит-уртитов, ювитов и рисчорритов. Месторождение является слепым рудным телом, то есть не выходит на поверхность, являясь наиболее глубинным среди других Хибинских месторождений. Его верхняя граница проходит ниже абсолютной отметки 0 м, а нижний контур опускается до $-1150 \div-1400$ м. Рудная залежь имеет форму уплощенной линзы размером 2,7 × 2,3 км при мощности в центре до 100 м. Простирание рудной залежи широтное, падение на север под углами $25 \div 45^{\circ}$. Месторождение «Эвеслогчорр» на отметке -100 м имеет условную границу с месторождением «Плато Расвумчорр», которое отрабатывалось Центральным рудником. Горная порода из Центрального карьера транспортировалась в отвалы № 11 и 3Ц, расположенные на северном его борту. Большая часть запасов перспективного апатитового месторождения «Эвеслогчорр», отработка которого в будущем планируется подземным способом, расположена под этими отвалами (рис. 6.42).

В связи с необходимостью обеспечения устойчивости отвалов важной является задача по предрасчету зоны обрушения и сдвижения от отработки горизонтов месторождения «Эвеслогчорр».

По шкале крепости профессора Протодьяконова апатит-нефелиновые руды относятся к классу крепких пород III категории, а вмещающие породы - очень крепких пород II категории (табл. 6.7). 


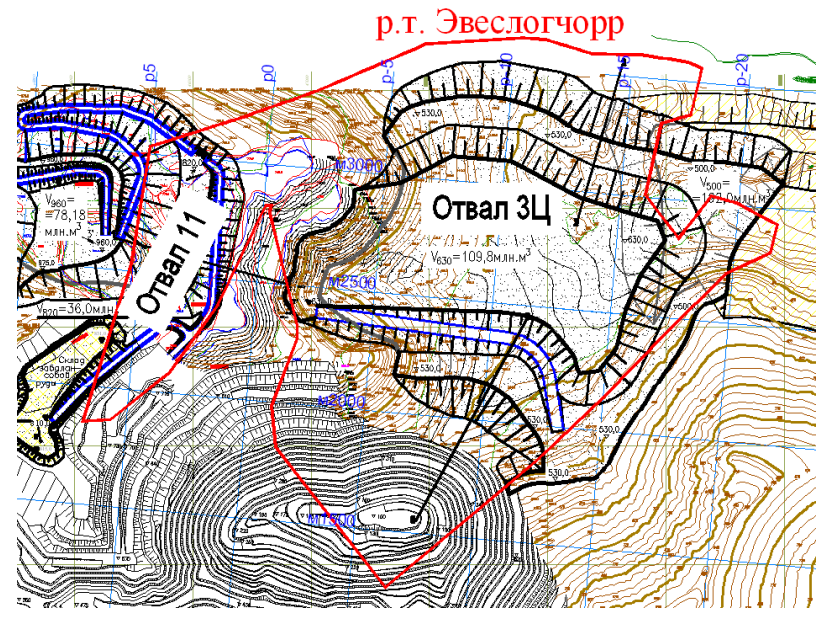

Рис. 6.42. План отвалов на конец отработки месторождения «Плато Расвумчорр» с проекцией рудного тела месторождения «Эвеслогчорр»

Таблица 6.7

Прочностные свойства пород месторождения «Эвеслогчорр»

\begin{tabular}{|c|c|c|c|c|}
\hline \multirow[b]{2}{*}{ Наименование } & \multicolumn{4}{|c|}{ Предельные показатели физических свойств пород } \\
\hline & $\begin{array}{c}\text { прочность } \\
\text { при сжатии, } \\
\text { МПа }\end{array}$ & $\begin{array}{c}\text { прочность } \\
\text { при растяжении, } \\
\text { МПа }\end{array}$ & $\begin{array}{c}\text { коэффициент } \\
\text { крепости }\end{array}$ & 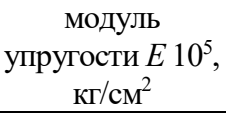 \\
\hline Апатит-нефелиновые руды & $67-166$ & $1,4-5,8$ & $7-13$ & $3,3-7,1$ \\
\hline Вмещающие породы & $147-281$ & $4,4-15,5$ & $12-19$ & $9,0-12,6$ \\
\hline
\end{tabular}

Напряженно-деформированное состояние массива месторождения относится к гравитационно-тектоническому типу с достаточно высоким уровнем горизонтальных сжимающих напряжений. Разработана геомеханическая конечно-элементная модель месторождений «Плато Расвумчорр» и «Эвеслогчорр» (рис. 6.43). Граничные условия задавались на основе сформировавшихся современных представлений о Хибинском массиве в целом и месторождении «Плато Расвумчорр» в частности.

Максимальная компонента напряжений ориентирована субпараллельно простиранию рудной залежи, абсолютные величины напряжений и их изменение с глубиной получены на основе результатов измерений методом разгрузки.

Прогнозные значения максимальной компоненты главных напряжений $\sigma_{\max }$ находятся в пределах от $20 \mathrm{MПа} \mathrm{(в} \mathrm{нагорных} \mathrm{областях)} \mathrm{до} 60 \mathrm{MПа}$ (у дна карьера и отдельных участков северного борта), на глубине залегания запасов месторождения «Эвеслогчорр» уровень $\sigma_{\max }$ около 40 МПа. Минимальная компонента главных напряжений $\sigma_{\min }$ в основном сжимающая, области растяжений с абсолютными величинами в несколько раз ниже предела прочности, приурочены к некоторым участкам борта карьера. В качестве примера приведены результаты моделирования по двум характерным вертикальным сечениям по разрезам Р-4 и Р-8 при формировании проектного карьера «Центральный» до отметки +100 м (рис. 6.44). По полученным результатам моделирования можно предположить, что НДС массива будет в данном случае являться фактором, сдерживающим процесс обрушения подработанных пород до поверхности. 


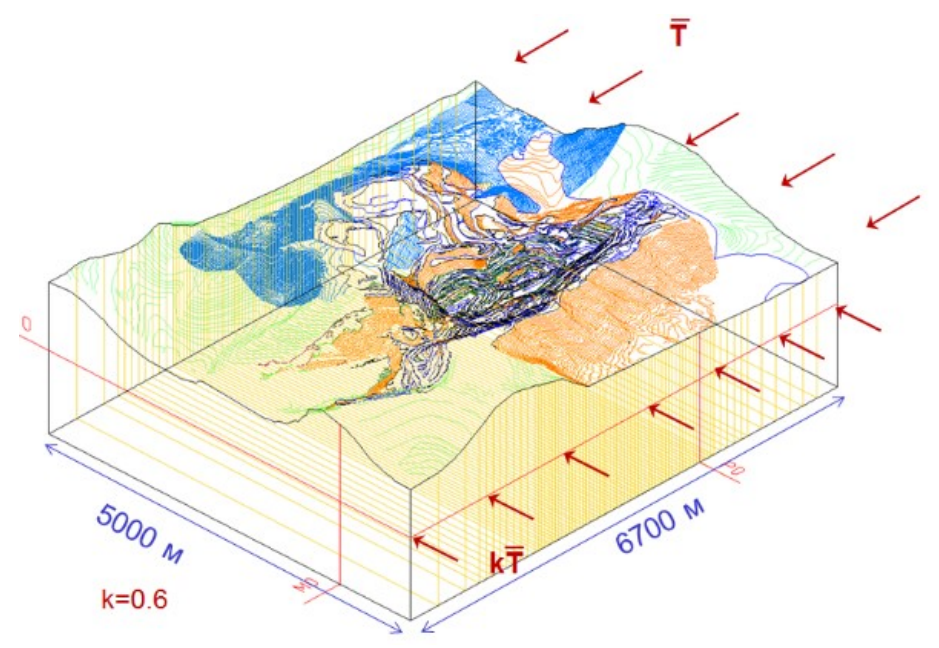

Рис. 6.43. Мелкомасштабная геомеханическая модель месторождений «Плато Расвумчорр» и «Эвеслогчорр» со схемой заданных тектонических сил Т
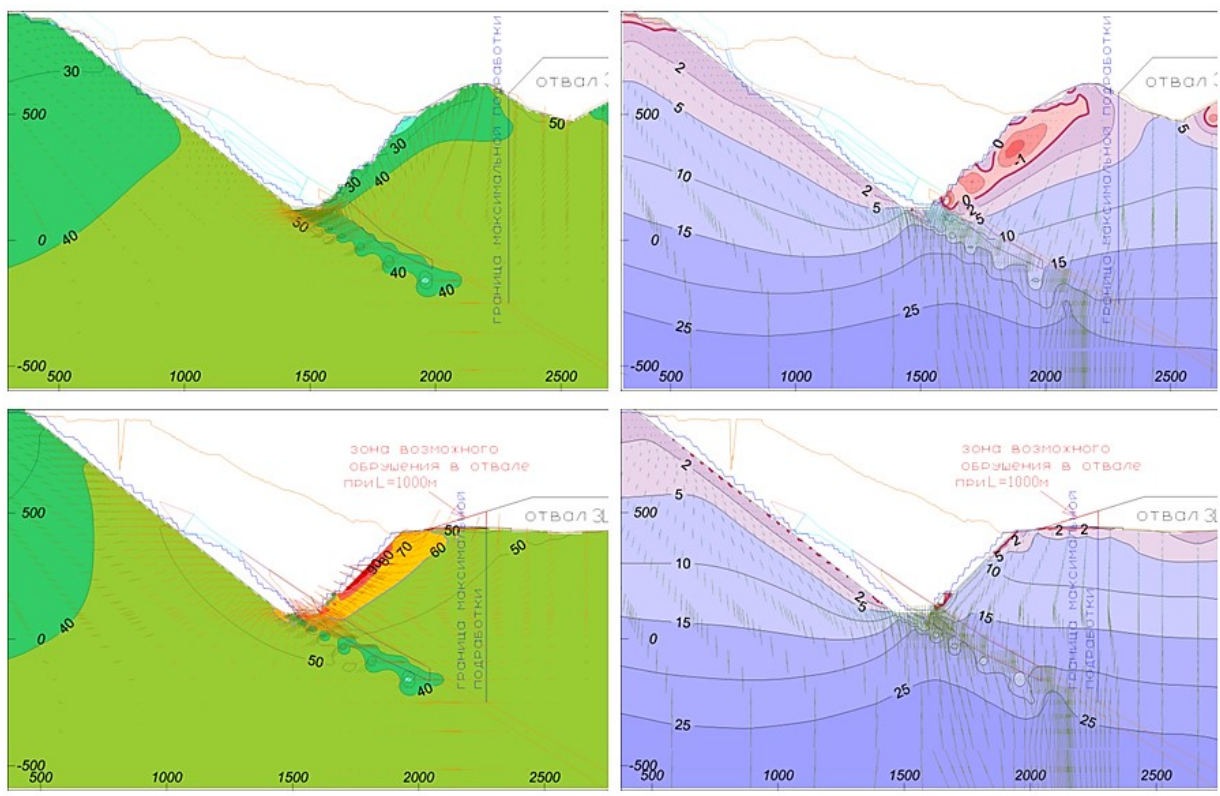

$a$

$\sigma$

Рис. 6.44. Прогнозное распределение $\sigma_{\max }$ и $\sigma_{\min }$ компоненты главных напряжений при формировании проектного контура карьера «Центральный» до отметки +100 м: $a$ - по разрезу Р-4; $\sigma$ - по разрезу Р-8

Средняя глубина залегания рудного тела под отвалами (рис. 6.45) варьирует от 750 м (в районе разреза Р-12 (отвал № 3Ц)) до 1500 м (в районе разреза Р4 (отвал № 11)).

Для оценки зоны сдвижения и обрушения при отработке месторождения определены параметры подработки по простиранию и вкрест простирания рудного тела. Для этого на основе цифровой модели месторождения 
«Эвеслогчорр» построены разрезы вкрест простирания рудного тела по сетке разрезов и магистралей Центрального рудника.

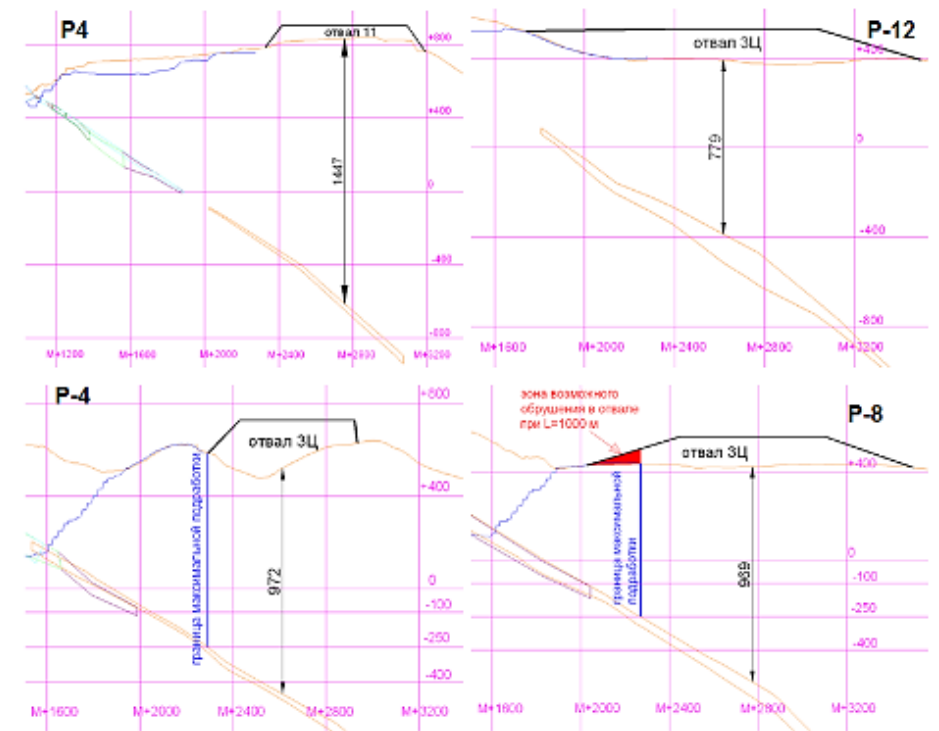

Рис. 6.45. Разрезы вкрест простирания рудного тела месторождения «Эвеслогчорр» со средней глубиной его залегания под отвалами Центрального рудника

Расчет параметров подработки проводился для трех вариантов с различной длиной фронта подработки покрывающих пород по простиранию $L$. При расчетах были сделаны следующие допущения:

- рудное тело, расположенное выше месторождения «Эвеслогчорр», полностью отработано до отметки -100 м глубоким карьером и частично подземными горными работами;

- вследствие этого произошло полное обрушение массива пород под углом сдвижения $\beta=70^{\circ}$ с отставанием по висячему боку, равным 100 м;

- рудное тело месторождения «Эвеслогчорр» отработано в пределах высотных отметок от -100 до -250 м.

Величина подработки налегающего массива вкрест простирания рудной залежи $l$, а также глубина в районе кромки обрушения $H_{1}$ и границы подработки массива $\mathrm{H}_{2}$ определялись геометрически (рис. 6.46).

Далее рассчитывали параметр $H$ как среднее между $H_{1}$ и $H_{2}$, величина подработки по простиранию $-L / H$ и величина подработки вкрест простирания - $l / H$.

Первый вариант соответствует началу отработки месторождения. Так как первые разрезные блоки планируется отрабатывать в центре участка шахтного поля между разрезами Р-5 и Р-7, были рассчитаны параметры подработки для $L=200$ м, что соответствует расстоянию между этими разрезами. Параметры подработки рассчитаны для разрезов Р-5, Р-6, Р-7.

Второй вариант рассчитан для $L=400$ м. Параметры подработки рассчитаны для разрезов Р-4, Р-6, Р-8. 
Третий вариант рассчитан для $L=1000$ м. Параметры подработки рассчитаны для разрезов Р-4, Р-6, Р-8.

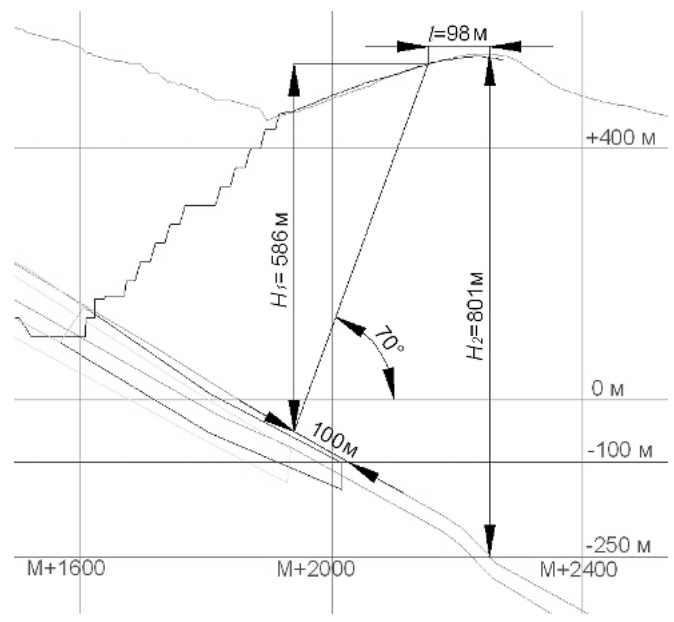

Рис. 6.46. Схема расчета параметров подработки массива по разрезу Р-6

Рассчитанные параметры подработки по трем вариантам представлены в таблице 6.8 .

Таблица 6.8

Параметры подработки месторождения «Эвеслогчорр»

\begin{tabular}{|c|c|r|r|r|r|c|}
\hline № варианта & № разреза & $H, \mathrm{M}$ & $l, \mathrm{M}$ & $L, \mathrm{M}$ & $L / H$ & $l / H$ \\
\hline \multirow{3}{*}{1} & P-5 & 749 & 70 & 200 & 0,27 & 0,09 \\
\cline { 2 - 7 } & P-6 & 693 & 98 & 200 & 0,29 & 0,14 \\
\cline { 2 - 7 } & P-7 & 630 & 143 & 200 & 0,32 & 0,22 \\
\hline \multirow{3}{*}{2} & P-4 & 752 & 83 & 400 & 0,53 & 0,11 \\
\cline { 2 - 7 } & P-6 & 693 & 98 & 400 & 0,58 & 0,14 \\
\cline { 2 - 7 } & P-8 & 591 & 160 & 400 & 0,68 & 0,27 \\
\hline \multirow{3}{*}{3} & P-4 & 752 & 83 & 1000 & 1,33 & 0,11 \\
\cline { 2 - 7 } & P-6 & 693 & 98 & 1000 & 1,44 & 0,14 \\
\hline & P-8 & 591 & 160 & 1000 & 1,69 & 0,27 \\
\hline
\end{tabular}

Месторождение «Эвеслогчорр» имеет схожее геологическое строение с другими апатитовыми месторождениями Хибин и расположено вблизи других апатитовых месторождений, отрабатываемых подземным способом. На основании этого было сделано предположение о том, что характер самообрушения на месторождении «Эвеслогчорр» будет подобен этому процессу на других Хибинских рудниках.

Определение критических параметров подработки покрывающих пород на месторождении выполнено на основе прогнозных графиков критических параметров подработки для подземных рудников ОАО «Апатит» (Расвумчоррского рудника и Юкспорского крыла Кировского рудника (КР)) [264], а также графика для Кукисвумчоррского крыла КР, построенного по результатам исследований, проведенных ГоИ КНЦ РАН в 2009-2010 гг. [265]. Эти три графика, нанесенные на один график, образуют три характерные зоны: зону устойчивых обнажений, зону неопределенности и зону неустойчивых обнажений (рис. 6.47). На график также были нанесены рассчитанные параметры подработки месторождения «Эвеслогчорр» по трем вариантам. 


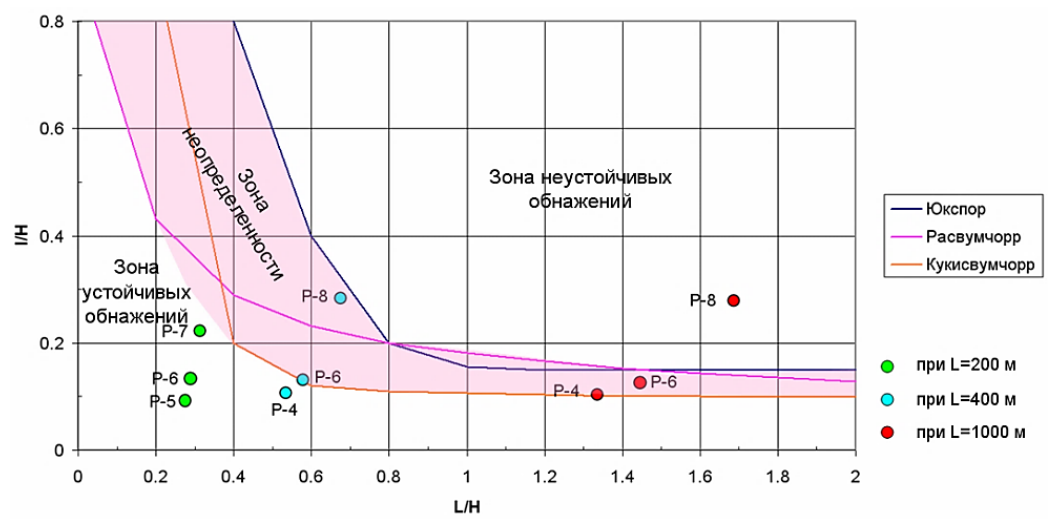

Рис. 6.47. Зоны параметров подработки покрывающих пород для месторождения «Эвеслогчорр»

На рисунке 6.47 видно, что при $L=200$ м (первый вариант) параметры подработки по всем трем разрезам находятся в зоне устойчивых обнажений. Это позволяет предположить, что при такой длине фронта подработки покрывающих пород по простиранию в пределах данных разрезов обрушений не произойдет.

При $L=400$ м (второй вариант) параметры подработки по разрезу P-4 находятся в зоне устойчивых обнажений. Параметры подработки по разрезам Р-6 и Р-8 находятся в зоне неопределенности. При этом параметры по разрезу Р-6 находятся на границе с зоной устойчивых обнажений, в то время как параметры по разрезу Р-8 приближаются к границе с зоной неустойчивых обнажений. Анализ расчетных данных по второму варианту позволяет предположить, что при $L=400$ м обрушения в пределах разрезов Р-4-P-6 не произойдет. В районе разреза Р-8 обрушение возможно.

При $L=1000$ м (третий вариант) параметры подработки по разрезам Р-4 и Р-6 находятся в зоне неопределенности, причем параметры по разрезу Р-4 находятся на границе с зоной устойчивых обнажений, а параметры по разрезу Р-6 расположены в центре зоны неопределенности. Параметры по разрезу Р-8 находятся в зоне неустойчивых обнажений. Анализ расчетных данных по третьему варианту позволяет предположить, что при $L=1000$ м обрушения возможны на промежутке между разрезами P-4-P-8, причем вероятность обрушения в районе разреза Р-4 невелика, а в районе разреза Р-8 весьма велика. Такое увеличение вероятности обрушения от разреза Р-4 до разреза Р-8 в большой мере обусловлено понижением рельефа от разреза Р-4 в сторону разреза Р-8.

При этом стоит отметить, что даже если обрушение произойдет в районе разрезов Р-4 и Р-6, возможная бровка обрушения (совпадающая с границей максимальной подработки) не достигнет границ отвалов. Обрушение в районе разреза Р-8 может достигнуть отвала.

Западнее разреза Р-4 обрушений не произойдет вследствие большой высоты налегающих пород.

В результате проведенных исследований по определению критических параметров подработки покрывающих пород на месторождении «Эвеслогчорр» определена зона обрушения при выемке рудной залежи до отметки -250 м, которая может захватить часть отвалов в районе разреза Р-8, где целесообразен перенос плановых границ отвала ЗЦ к северо-востоку от конечного борта карьера 
«Центральный» приблизительно на 200 м. Полученные результаты вошли в технологический регламент по отработке месторождения «Плато Расвумчорр» Центральным рудником.

\subsection{3. Управление тактическими рисками на основе экспертных систем выбора оптимальных технических рещений по обеспечению геодинамической безопасности}

Развитие экспертных систем выбора технических решений по повышению безопасности и эффективности горных работ в удароопасных условиях тектонически напряженных массивах проводили в нескольких направлениях [266]:

- совершенствование методических подходов экспертной оценки геомеханического состояния геологической среды (ГС);

- разработка новых функций программного обеспечения расчета НДС, обработки и визуализации полученных данных;

- разработка и совершенствование геомеханических моделей месторождений и их участков.

\subsubsection{1.Развитие методических подходов экспертной оченки геомеханического состояния массива горных пород}

При разработке удароопасных месторождений эффективность и безопасность горных работ во многом зависит от своевременного прогноза формирования зон концентрации напряжений, а, следовательно, и удароопасности применительно к конкретным горно-геологическим условиям. Такой прогноз позволяет еще на этапе проектирования оптимизировать конструктивные параметры систем разработки и порядок ведения горных работ. Одним из современных методов прогноза полей напряжений является численное моделирование НДС массива с использованием разработанного и успешно применяемого программного комплекса Sigma GT [267]. Применение численных прогнозов НДС совместно с натурными методами оценки удароопасности позволяет осуществлять геомеханически обоснованный выбор технических решений на разных стадиях освоения месторождения - от проектных проработок до текущих прогнозов, от региональных прогнозов до оценки устойчивости отдельных элементов геотехнологии.

Особенно важным, на наш взгляд, является внедрение подобных систем на самом горном предприятии как инструмента оперативного управления геомеханической ситуацией в том или ином блоке и помощника при разработке ежегодных и перспективных планов горных работ, позволяющего минимизировать геодинамические риски. Такая работа выполнена на двух крупных предприятиях, ведущих горные работы на удароопасных месторождениях. Это АО «Апатит», разрабатывающее апатит-нефелиновые месторождения Хибин, и ПАО «Приаргунское производственное горно-химическое объединение» (ППГХО), отрабатывающее урановые месторождения Стрельцовского рудного поля.

В процессе сопровождения введенного в промышленную эксплуатацию Sigma GT назрела задача комплексирования всего спектра геологических, горнотехнических и геомеханических данных в геоинформационных системах, используемых в настоящее время практически на всех горных предприятиях, а также их визуализации и интерпретации. Если геологические и горнотехнические модели 
используются на горных предприятиях уже около 20 лет, то включение моделей НДС геологической среды и данных ее геомеханического мониторинга - новое направление, позволяющее учитывать особенности трансформации НДС при различном порядке ведения горных работ и выбирать оптимальный по геомеханическим условиям вариант. Модуль прогноза НДС интегрирован в систему геодинамической безопасности ПАО «ППГХО» (рис. 6.48). Для объединения результатов численного прогноза с данными геомеханического мониторинга, технологической и геологической информацией разработаны алгоритм и программа передачи расчетных данных о поле напряжений и категориях состояния выработок из модуля Sigma GT в среду MINEFRAME, используемую на предприятии для проектирования горных работ. Кроме расчетных данных о поле напряжений, отображаются результаты сейсмоакустического и деформационного мониторинга. В итоге, горные инженеры предприятия могут выполнять комплексный анализ текущих и ретроспективных геомеханических данных в автоматизированном режиме, а также вести учет результатов прогноза местоположения удароопасных зон при планируемом порядке ведения горных работ, что позволяет повысить обоснованность принимаемых технических решений и предусмотреть необходимые профилактические мероприятия.

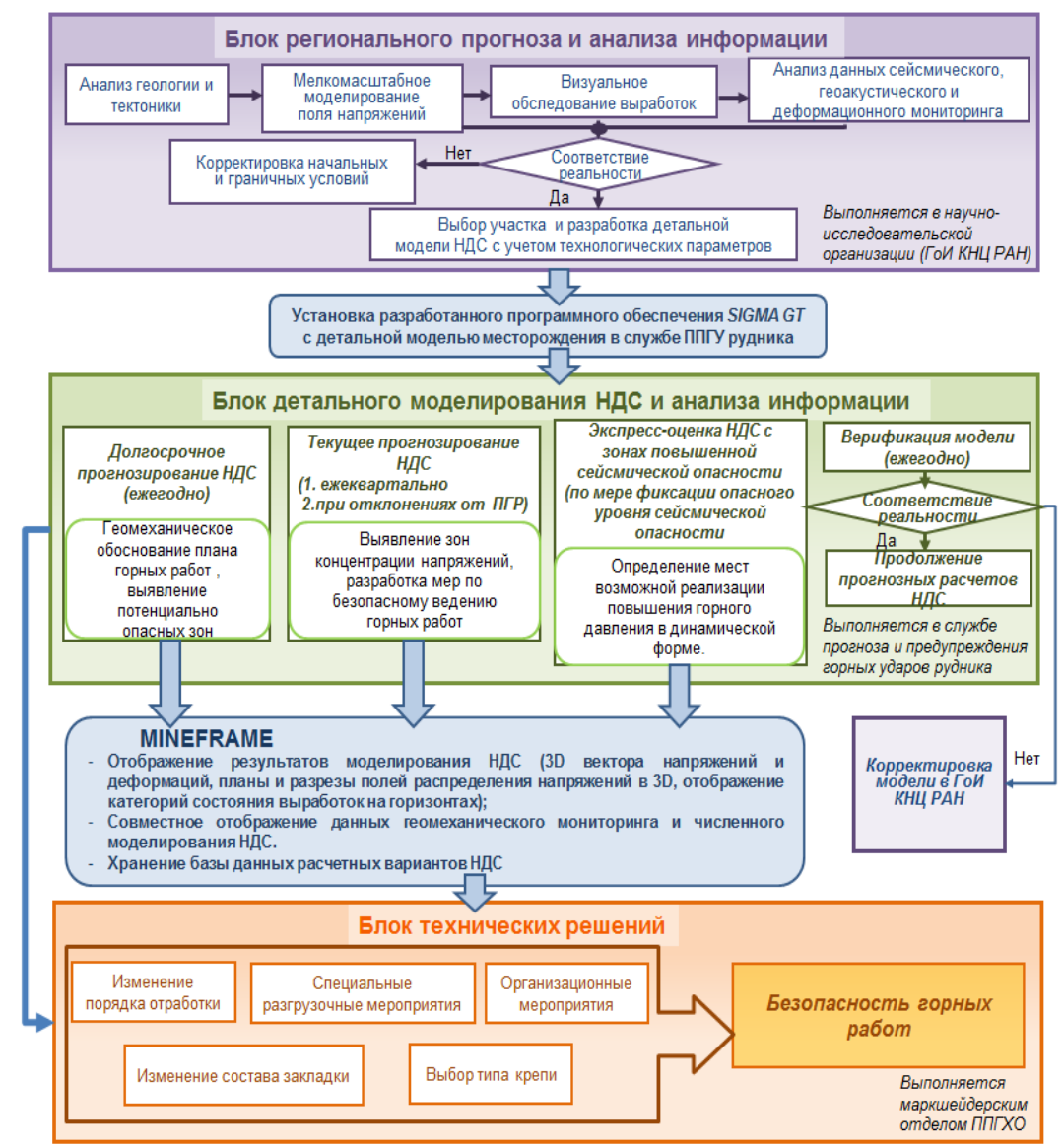

Рис. 6.48. Схема интеграции модуля прогноза НДС в систему обеспечения геодинамической безопасности 
Реализована передача в среду MINEFRAME расчетных данных тензора напряжений и деформаций в центрах тяжести элементов конечно-элементной модели и данные о категориях состояния выработок ортового и штрекового направления. На основе этой информации отдельно или в различных сочетаниях в трехмерном пространстве моделей объектов геотехнологии обрабатываются и визуализируются:

- 3D-векторы напряжений и деформаций, что дает представление об их направлении, величине в любой точке массива и изменчивости в объеме;

- 3D-площадки, на которые действуют растягивающие деформации, являющиеся потенциальными трещинами отрыва;

- поля напряжений на планах и разрезах по и вкрест простирания рудного тела в виде заливки определенным цветом (рис. 6.49);

- категории состояния фактических и проектных выработок любого направления и их сопряжений (рис. 6.50).

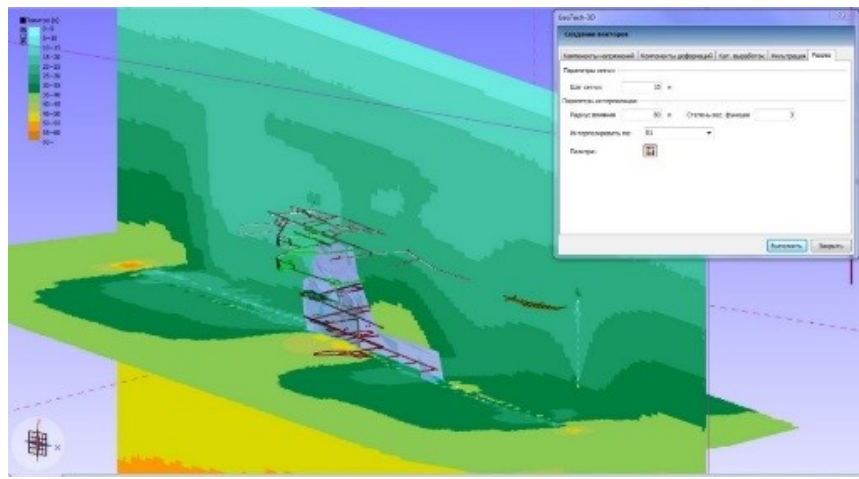

Pис. 6.49. Отображение поля максимальной компоненты главных напряжений в двух взаимно перпендикулярных плоскостях в трехмерной области

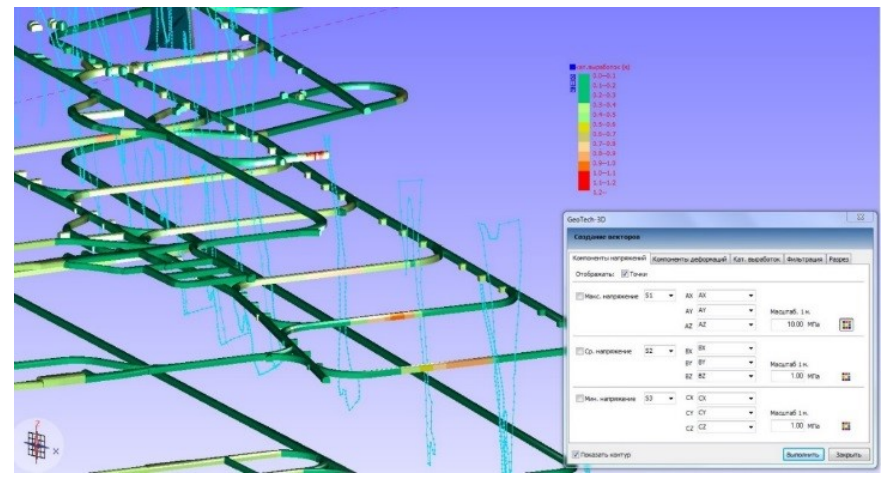

Рис. 6.50. Раскраска выработок по категориям состояния в зависимости от уровня удароопасности

Таким образом, создана геоинформационная система оценки геомеханических условий отработки удароопасных месторождений, базирующаяся на программных средствах моделирования объектов геотехнологии, расчета НДС массива и комплексирование их с результатами микросейсмического и деформационного мониторинга техногенно-нарушенной геологической среды в едином информационном пространстве [268]. 
Дальнейшее развитие системы предусматривает автоматическую интерпретацию комплекса данных с выдачей предложений по необходимым профилактическим мероприятиям и вариантам развития горных работ.

\subsubsection{2. Разработка и совершенствование геомеханических моделей месторождений и актуальных участков}

Публичное акиионерное общество

«Приаргунское производственное горно-химическое объединение»

Разработан комплекс трехмерных геомеханических моделей уранового месторождения «Антей», отрабатываемого ПАО «ППГХО» с учетом основных факторов, влияющих на НДС массива пород Стрельцовского рудного поля (рис. 6.51). Проведен анализ, позволивший выделить наиболее значимые разломные структуры, определяющие ориентировку максимальных сжимающих напряжений в породах месторождения.

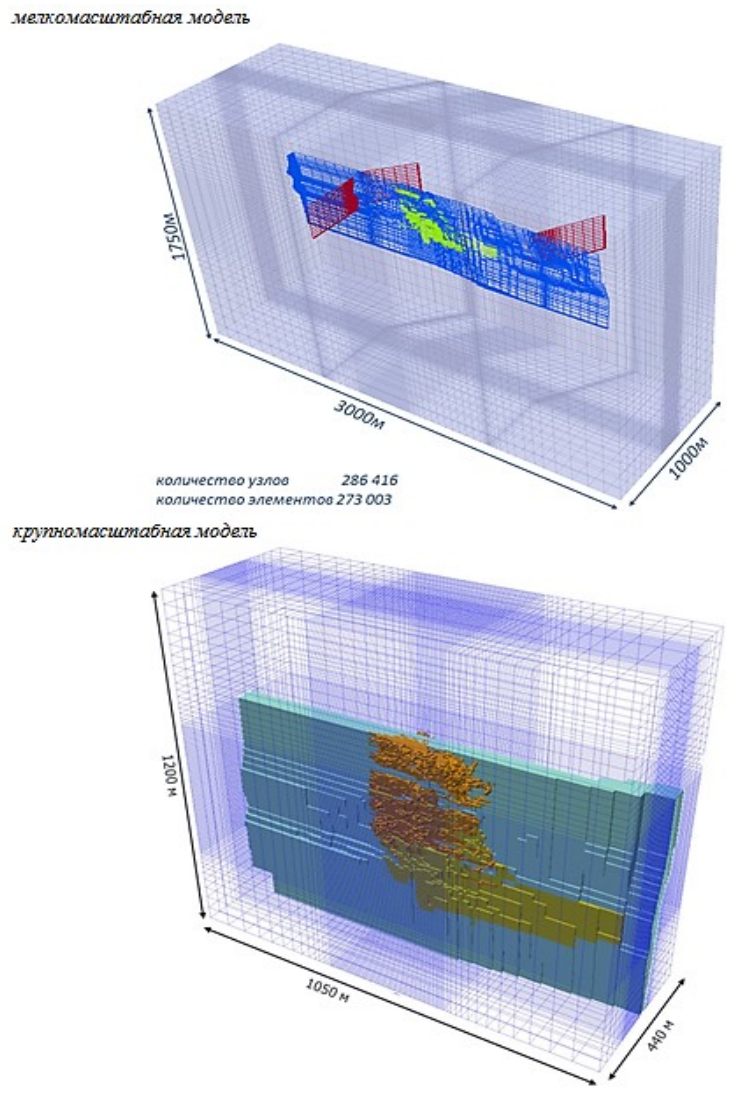

Рис. 6.51. Общий вид трехмерных конечно-элементных моделей месторождения «Антей»: $\square-$ вмещающий массив (граниты); $\square-$ рудосодержая зона (гидрослюдезиты); $\square-$ оперяющие разломные структуры; $\square-$ урановые руды; $\square-$ - закладочный массив

Комплекс включает в себя:

- мелкомасштабную модель всего месторождения «Антей» с определяющими НДС тектоническими нарушениями и рудной зоной; 
- крупномасштабную модель месторождения «Антей» с сеткой, позволяющей имитировать с достаточной точностью выемку полезного ископаемого и закладку очистных пространств;

- модели отдельных (удароопасных) участков;

- модели выработок.

По результатам численного моделирования установлено, что наибольшая концентрация напряжений приурочена к целикам и границам закладочного массива, в наибольшей мере к его нижней границе. Наблюдается постепенный рост напряжений на глубоких горизонтах по мере приближения к ним горных работ. Так, на гор. -120 м при выемке запасов до отметки -95 м прогнозируется увеличение коэффициента концентрации максимальных сжимающих напряжений под закладочным массивом до значения $K_{\text {бтах }}=1,5$ (рис. 6.52). Вследствие этого на нижних горизонтах может возникнуть необходимость проведения дополнительных разгрузочных мероприятий на отдельных участках массива, а также на контуре выработок (особенно штрекового направления) и изменения параметров крепи для повышения их безопасности.

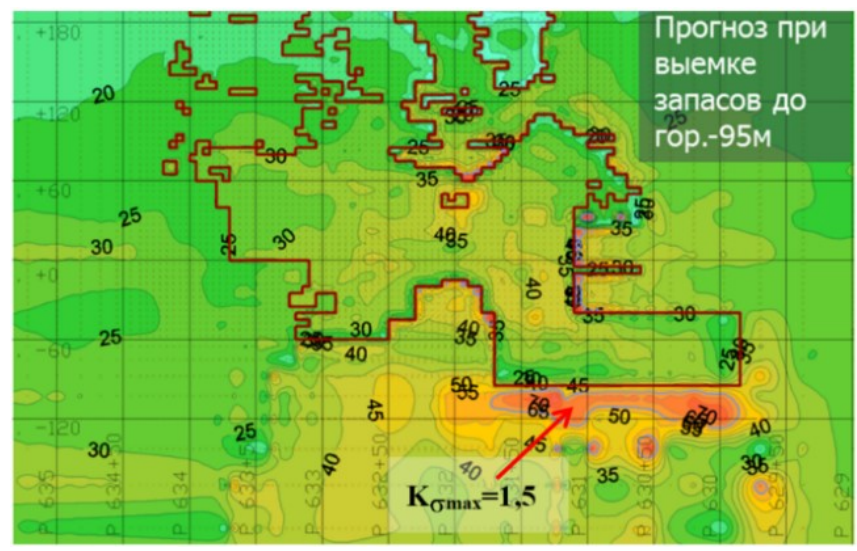

Рис. 6.52. Прогнозное изменение $\sigma_{\max }$ при выемке запасов и закладке массива до отметки -95 м. Бордовыми линиями показаны границы закладочного массива

Проведен сопоставительный анализ результатов численного моделирования с результатами регистрации сейсмоакустической эмиссии за 2013 г. (рис. 6.53). Эпицентр сейсмоакустических событий приурочен к зоне концентрации напряжений, что является подтверждением адекватности модели реальным геомеханическим условиям месторождения «Антей». Сопоставление результатов расчетов НДС с результатами визуального обследования также показало их удовлетворительную схожесть.

Программное обеспечение с комплексом геомеханических моделей месторождения «Антей» передано специалистам ПАО «ППГХО» и используется ими для текущего и перспективного прогноза геомеханической ситуации.

Многоуровневый комплекс трехмерных геомеханических моделей удароопасного месторождения урановых руд «Антей» позволил впервые получить численную оценку параметров зон концентраций напряжений на глубоких горизонтах при отработке с закладкой очистных пространств. Дан перспективный прогноз местоположения опасных зон с углублением горных работ до 1000 м от дневной поверхности. Установлено, что коэффициент концентрации максимальных сжимающих напряжений под закладочным массивом увеличивается с глубиной 
и составляет на гор. -120 м $K_{\sigma \max }=1,5$. Адекватность моделей реальным геомеханическим условиям подтверждена результатами сопоставительного анализа с данными сейсмоакустического мониторинга и визуального обследования выработок.

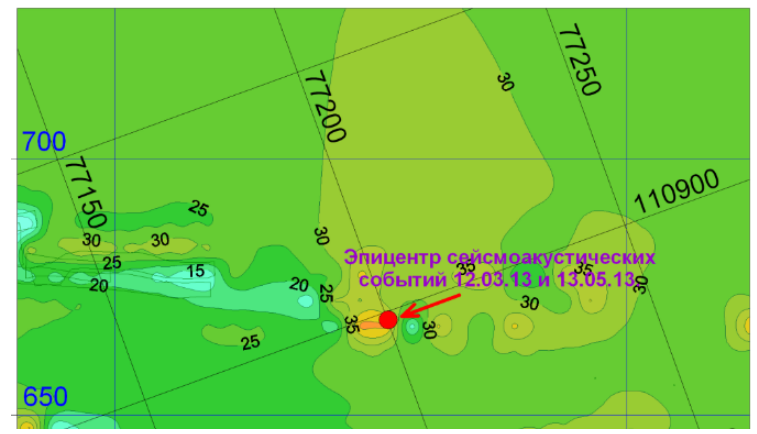

Рис. 6.53. Распределение $\sigma_{\max }$ в окрестности эпицентра сейсмоакустических событий 12.03.2013 и 13.05.2013 (горизонтальное сечение с абсолютной отметкой +115 м)

Кировский филиал акционерного общества «Апатит»

С целью повышения достоверности прогнозных расчетов НДС на Кировском руднике КФ АО «Апатит» разработана новая численная конечно-элементная модель Кукисвумчоррского месторождения, основными отличиями которой являются:

- учет не только региональных разломов, но и разломных структур более низкого ранга, определяющих особенности распределения напряжений в отдельных блоках;

- сетка конечных элементов позволяет имитировать отработку запасов системой с торцевым выпуском как в штрековом, так и в ортовом направлениях на высотных отметках подэтажных выработок до гор. +90 м включительно.

Решение этих задач потребовало увеличения области моделирования и значительной детализации сетки конечных элементов.

В модели учтены следующие разломные структуры: Саамский разлом, разломная зона в окрестности разреза 9, разломная зона в разрезах 14-16, опосредованно (путем соответствующих граничных условий) учтено влияние Северного разлома, также возможен дополнительный учет других неоднородностей.

Размеры модели в плане составляют $2816 \times 2000 \mathrm{~m}^{2}$. Северная граница проходит по разрезу Р28-320 м (Р1-640 м), южная - по Р40. Дно модели располагается на отметке -450 м. Координаты верхней границы модели соответствуют рельефу дневной поверхности (рис. 6.54).

Сгущение сетки конечных элементов приурочено к зоне активного ведения горных работ и разломным структурам. Минимальный размер элемента в зоне сгущения составляет $4 \times 5 \times 4 \mathrm{~m}^{3}$. Количество конечных элементов в модели составляет 1423008.

Граничные условия задавали в виде узловых перемещений из мелкомасштабной модели участка Хибинской апатит-нефелиновой дуги, включающей Кукисвумчоррское и Юкспорское месторождения.

С помощью этой модели проведены расчеты НДС массива пород Кукисвумчоррского месторождения с параметрами очистной выемки на второй квартал 2015 г. в соответствии с планом горных работ (рис. 6.55). Результаты 
расчетов подтверждают общие закономерности распределения напряжений на месторождении, выявленные в процессе многолетних натурных и численных геомеханических исследований. Отмечен более высокий фоновый уровень сжимающих напряжений в северной части месторождения, действие $\sigma_{\max }$ в направлении практически вкрест простирания рудного тела и приуроченность зон концентрации $\sigma_{\max }$ в основном к фронтам горных работ в висячем боку рудной залежи. Зоны растягивающих напряжений локализуются в разломных структурах и на контактах разномодульных сред, а также под очистной выемкой и в зонах, защищенных определенным порядком развития горных работ.

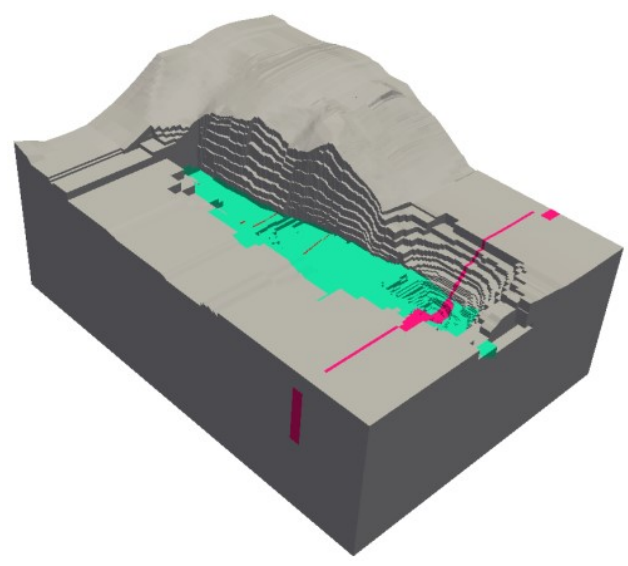

Рис. 6.54. Объемная модель Кукисвумчоррского месторождения
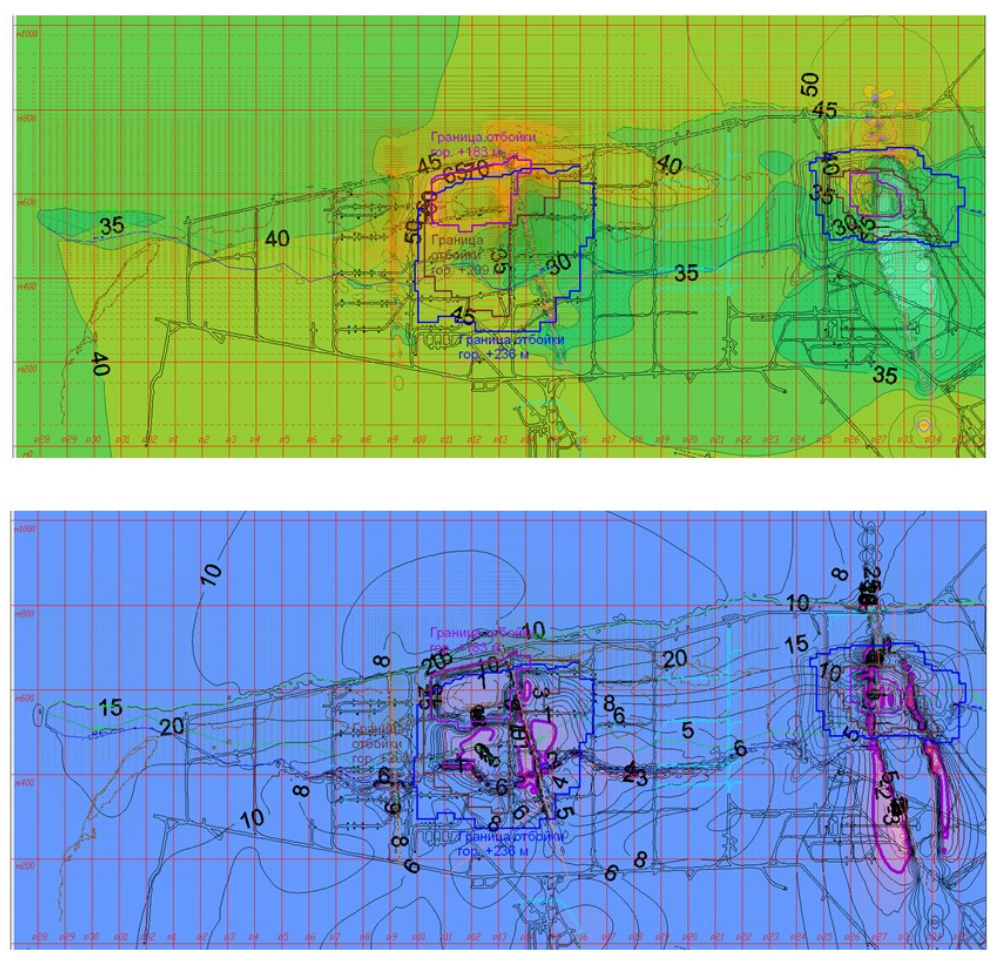

Рис. 6.55. Распределение максимальной и минимальной компонент главных напряжений на откаточном горизонте +170 м 
Проведено сопоставление данных численного моделирования с результатами визуального обследования выработок. Результаты расчетов приведены в виде распределения категорий состояния выработок ортового и штрекового направлений. В целом наблюдается удовлетворительная сходимость результатов численного моделирования и визуального обследования выработок.

Модель вместе с программным обеспечением установлена в службе прогноза и предупреждения горных ударов Кировского рудника и используется при разработке текущих планов горных работ.

\subsection{4. Управление оперативными рисками}

Управление оперативными рисками сводится в основном к обеспечению устойчивости горных выработок в течение всего периода их эксплуатации, способы поддержания которых в сложных горно-геологических условиях, а также вид и параметры крепи определяются степенью устойчивости массива горных пород, то есть его способностью сохранять форму и размеры обнажений, образуемых при разработке месторождений и подземном строительстве. При этом на степень устойчивости влияют как естественные факторы (крепость пород, напряженное состояние и степень нарушенности массива горных пород трещинами, которая зависит от характера блочности (числа систем трещин), раскрытия трещин, шероховатости стенок и материала заполнения трещин, а также от ориентировки трещин относительно выработки), степень обводненности пород, смерзаемость пород), так и технологические (пролет выработки, способ и время проходки и др.).

Для выбора способа поддержания выработанного пространства в настоящее время широко применяются различные классификации скальных массивов, способные учитывать различные горно-геологические и горно-технологические факторы (Q-индекс, GSI, RMR, MRMR b др.). Наиболее полно учитывает совокупность имеющихся факторов рейтинговая классификация профессора Д. Лобшира MRMR (далее $-R_{L}$ ), которая широко применяется как на открытых, так и на подземных отработках в отечественной и зарубежной практике [269]. Ниже приведен пример использования этой классификации применительно к условиям подземной разработки месторождения «Олений ручей».

\subsubsection{1. Результаты расчета рейтинга $R_{L}$ юго-восточной части месторождения «Олений Ручей»}

Расчет рейтинга $R_{L}$ выполнен для участка расположения Главного ствола, где была пробурена структурная инженерно-геологическая скважина для оценки геомеханических условий его проходки.

Величина рейтинга $R_{L}$ определяется формулой:

$$
R_{L}=\left(R \sigma_{б л}+R_{\text {КТ }}+R_{\mathrm{yT}}\right) \times \kappa_{i},
$$

где $R \sigma_{б л}-$ рейтинг прочности породного блока; $R_{\text {Кт }}-$ рейтинг по количеству трещин; $R$ ут - рейтинг условий трещиноватости; $\kappa_{i}-$ коэффициенты, учитывающие выветривание, ориентацию трещин, напряжения в массиве, взрывание, наличие подземных водопритоков. 
Определение рейтинга прочности породного блока $R \sigma_{\text {бл. }}$

Прочность горных пород при одноосном сжатии изменяется от 100 до 240 МПа. В мончикитовой дайке прочностные показатели выше по сравнению с вмещающими горными породами и составляют 300-400 МПа.

Средние значения предела прочности на одноосное сжатие крепкой и слабой породы составляют 230 и 120 МПа соответственно.

Необходимо найти среднее значение $\sigma_{c ж}$ как процент от крепких пород. Установлено, что объем слабых пород составляет $42 \%$.

Величина бсж слабых пород относительно крепких вычисляется по формуле:

$$
\frac{\sigma_{\text {сж }} \text { слабой породы }}{\sigma_{\text {сж }} \text { крепкой породы }} \times 100 \%=\frac{120 \mathrm{MПа}}{230 \mathrm{MПа}} \times 100 \%=52 \% \text {. }
$$

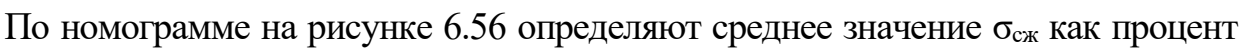
от крепких пород, которое равно $68 \%$.

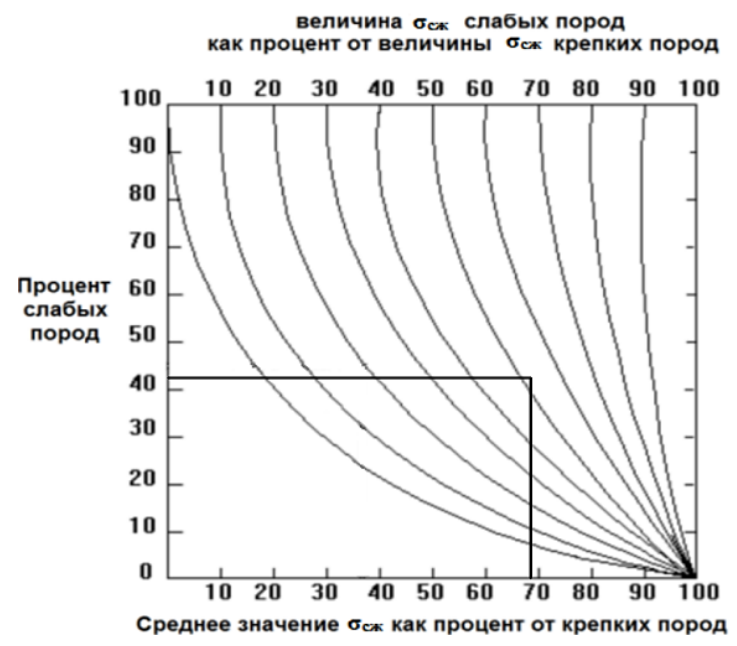

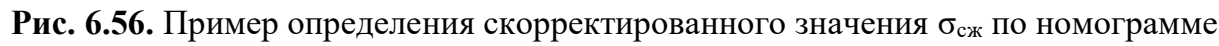

Скорректированное значение прочности пород на сжатие:

$\sigma_{\text {сж кор }}=68 \%$ от $230 \mathrm{MПа}=156$ МПа.

Далее определяют прочность породного блока:

$\sigma_{\text {бл }}=\sigma_{\text {сж кор }} \times 0,8 \times K$,

где $K$ - коэффициент корректировки.

Коэффициент корректировки $K$ определяется умножением инверсии по коэффициенту заполнителя трещины (табл. 6.9) на количество трещин на 1 м - $\mathrm{M}_{\text {TP }}$ (рис. 6.57). Количество трещин на 1 м $\mathrm{M}_{\mathrm{TP}}=3$ тр/м. Трещины заполнены натролитом с крепостью по шкале Мооса равной 5. 
Таблииа 6.9

Таблица к определению показателя инверсии по коэффициенту крепости (по шкале Мооса)

\begin{tabular}{|l|c|c|c|c|c|}
\hline \multicolumn{1}{|c|}{ Заполнитель } & $\begin{array}{c}\text { Тальк, } \\
\text { молибден }\end{array}$ & $\begin{array}{c}\text { Гипс, } \\
\text { хлорит }\end{array}$ & $\begin{array}{c}\text { Кальцит, } \\
\text { ангидрит }\end{array}$ & $\begin{array}{c}\text { Флюорит, } \\
\text { халькопирит }\end{array}$ & Апатит \\
\hline $\begin{array}{l}\text { Коэффициент крепости заполнителя } \\
\text { по Моосу }\left(K_{3}\right)\end{array}$ & 1 & 2 & 3 & 4 & 5 \\
\hline Инверсия $\left(J=1 / K_{3}\right)$ & 1,0 & 0,5 & 0,33 & 0,25 & 0,2 \\
\hline
\end{tabular}

Коэффициент корректировки К

\begin{tabular}{|c|c|c|c|c|c|c|c|c|}
\hline 1,00 & 0,95 & 0,90 & 0,85 & 0,80 & 0,75 & 0,70 & 0,65 & 0,60 \\
\hline 0,1 & 0,2 & 0,4 & 1 & 2 & & 10 & & 40 \\
\hline
\end{tabular}

Рис. 6.57. Номограмма для определения коэффициента корректировки прочности нетронутого массива с учетом крепости руды и густоты трещин

Таким образом, коэффициент $K \approx 0,88$. В результате, прочность породного блока:

$$
\sigma_{\text {бл }}=\sigma_{\text {сж кор }} \times 0,8 \times k=155 \times 0,8 \times 0,88=109 \mathrm{MПа,} \approx 110 \text { МПа. }
$$

Далее по графику на рисунке 6.58 находится составляющая рейтинга $R_{L}-$ рейтинг прочности породного блока $R \sigma_{б л}$.

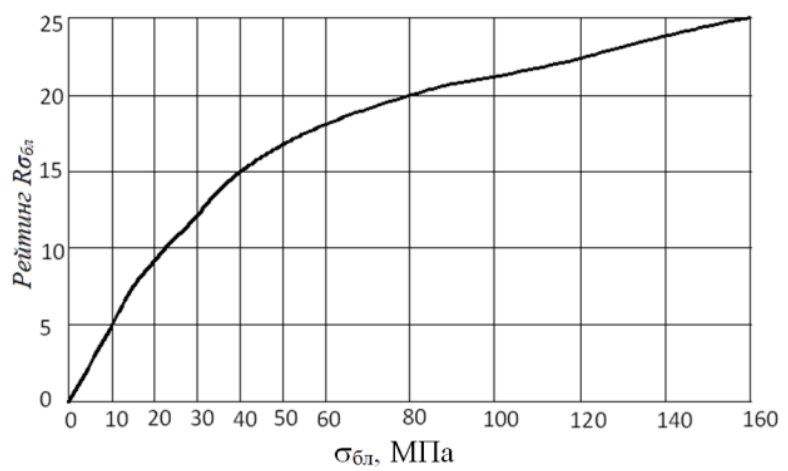

Рис. 6.58. Определение величины частного рейтинга $R \sigma_{б л}$

Для значения $\sigma_{б л}=110$ МПа показатель рейтинга прочности породного блока $R \sigma_{б л}=22$.

Рейтинг трещиноватости массива $R_{K T}$ характеризует только раскрытые трещины, расстояние между которыми в данном примере составляет 0,25 м. По номограмме на рисунке 6.59 рейтинг $R_{K \mathrm{~T}}=10$ (в расчет принимается 3 системы трещин).

Рейтинг условий трещиноватости $R$ ут определяется по следующей формуле:

$$
R_{\mathrm{Y} T}=40 \times \frac{A}{100} \times \frac{B}{100} \times \frac{C}{100} \times \frac{D}{100} \times \frac{E}{100} .
$$

Параметры $A, B, C, D, E$ определяются по таблице 6.10 


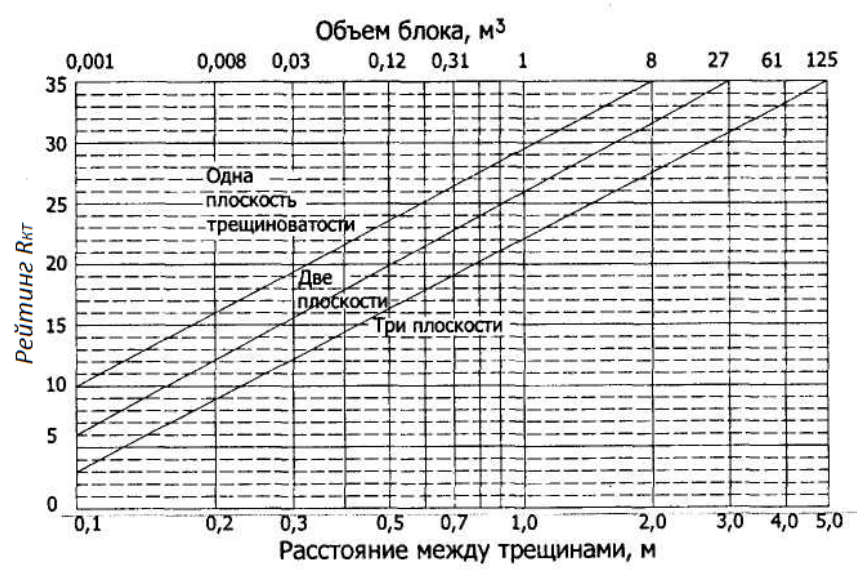

Рис. 6.59. Рейтинг трещиноватости массива $R_{K T}$

Поправочные коэффициенты к показателю $R$ ут

$A$. Крупномасштабное влияние трещин

Разнонаправленные волнообразные

Однонаправленные волнообразные

Кривые

Слегка волнообразные или прямые

$B$. Небольшие расстояния между трещинами $200 \times 200$ мм

Неровные выступы/нерегулярные

Плавные выступы

Гладкие выступы

Шероховатые волнистые

Плавные шероховатые

Гладкие и шероховатые

Шероховатые плоские

Плавные плоские

Гладкие

C. Стенки трещин деформированы и слабее, чем породы и заполнитель

D. Раздувы

Толщина $<$ протяженности

Толщина $>$ протяженности

\begin{tabular}{r|r} 
& 100
\end{tabular}

E. Сцементированные наполненные трещины (порода прочнее заполнителя трещин)

Крепость заполнителя

\begin{tabular}{|c|c|}
\hline Е. Сцементированные наполненные трещины (порода прочнее заполнителя трещин) \\
\hline Крепость заполнителя & Значение \\
5 & коэффициента \\
4 & 95 \\
3 & 90 \\
2 & 85 \\
1 & 80 \\
\hline
\end{tabular}

Для данного участка массива характерны следующие условия: трещины грубоволнистые однонаправленные $(A=95 \%)$, стенки трещин шероховатые волнистые $(B=80 \%)$, заполнены в основном натролитом $(E=95 \%)$.

Показатель $R$ ут имеет следующее значение: 


$$
R_{\mathrm{yT}}=4=40 \times \frac{95}{100} \times \frac{80}{100} \times \frac{95}{100}=31
$$

Далее необходимо определить поправочные коэффициенты по фактору взрывания (табл. 6.11) и влияния подземных вод (табл. 6.12).

Взрывание на участке ведения работ плохое, соответственно, коэффициент равен 0,8. Для месторождения характерны влажные условия, соответственно, коэффициент влияния подземных вод равен 0,9 .

Коэффициенты по фактору взрывных работ

\begin{tabular}{|l|c|}
\hline \multicolumn{1}{|c|}{ Качество взрывания } & Влияние, \% \\
\hline Механическая отбойка & 100 \\
Контурное взрывание & 97 \\
Хорошее стандартное взрывание & 94 \\
Плохое взрывание & 80 \\
\hline
\end{tabular}

Таблий 6.12

Влияние подземных вод

\begin{tabular}{|c|c|c|}
\hline Влажные условия & $\begin{array}{c}\text { Среднее давление 1-5 МПа, } \\
25-125 \text { л/мин }\end{array}$ & $\begin{array}{c}\text { Высокое давление }>5 \text { МПа, } \\
>125 \text { л/мин }\end{array}$ \\
\hline $95-90 \%$ & $90-80 \%$ & $80-70 \%$ \\
\hline
\end{tabular}

Таким образом, подставляя полученные значения в формулу (6.19) получаем:

$$
R_{L}=(23+10+31) \times 0,8 \times 0,9=46 .
$$

В соответствии с таблицей 6.13 полученный результат говорит о том, что горные породы месторождения «Олений Ручей» относятся к III классу и характеризуются средней устойчивостью.

Таблииа 6.13

Классификация пород по устойчивости согласно методике Д. Лобшира

\begin{tabular}{|l|c|c|c|c|c|}
\hline \multicolumn{1}{|c|}{ Рейтинг $R_{L}$} & $5-20$ & $21-40$ & $41-60$ & $61-80$ & $81-100$ \\
\hline Класс & $\mathrm{V}$ & IV & III & II & I \\
\hline Устойчивость пород & Очень низкая & Низкая & Средняя & Высокая & Очень высокая \\
\hline
\end{tabular}

Таким образом, изучение свойств горных пород исследуемого участка массива месторождения «Олений ручей» и оценка их устойчивости являются основанием для предварительного выбора крепления горных выработок.

На основе накопленного опыта по управлению устойчивостью горных выработок, в соответствии с рейтинговой классификацией MRMR и сроком службы выработок, предложена сводная таблица 6.14 по выбору рекомендуемой крепи капитальных выработок для условий отработки месторождения «Олений ручей». Данные таблицы соответствуют рекомендациям Н. С. Булычева [270] и опыту крепления горных выработок [271].

Таким образом, для решения вопросов проектирования необходимо выполнять расчет рейтинга конкретного участка массива горных пород. Для получения адекватного результата необходимо корректно оценивать применяемые поправки и интерпретировать исходные данные, поскольку переход на автоматизированный 
подсчет результатов может привести к серьезным ошибкам при оценке качества геологической среды.

Таблица 6.14

Рекомендуемые виды постоянной крепи горизонтальных капитальных выработок

\begin{tabular}{|c|c|c|c|c|c|c|c|c|c|c|}
\hline \multirow{3}{*}{ Типы крепи } & \multicolumn{10}{|c|}{ Классы устойчивости пород } \\
\hline & \multicolumn{2}{|c|}{$\mathrm{I}$} & \multicolumn{2}{|c|}{ II } & \multicolumn{2}{|c|}{ III } & \multicolumn{2}{|c|}{ IV } & \multicolumn{2}{|c|}{$\mathrm{V}$} \\
\hline & $\leq 5$ & $>5$ & $\leq 5$ & $>5$ & $\leq 5$ & $>5$ & $\leq 5$ & $>5$ & $\leq 5$ & $>5$ \\
\hline Анкерная & & & & & & & & & & \\
\hline Набрызгбетонная & & & & & & & & & & \\
\hline Набрызгбетон с анкерами & & & & & & & & & & \\
\hline Набрызгбетон с анкерами и метал & & & & & & & & & & \\
\hline Металлическая рамная & & & & & & & & & & \\
\hline Сборная железобетонная & & & & & & & & & & \\
\hline Монолитная бетонная & & & & & & & & & & \\
\hline Металлическая рамная с анкерами & & & & & & & & & & \\
\hline
\end{tabular}

При учете влияния различных факторов можно надежно характеризовать состояние массива горных пород и на основании полученных результатов выбрать необходимые способы поддержания и крепления горных выработок для обеспечения безопасности горных работ. На основании анализа полученных результатов для месторождения «Олений ручей» рекомендуются: набрызг-бетон и набрызг-бетон с анкерами при сроке службы выработки до 5 лет и набрызг-бетон с анкерами и металлической сеткой и металлическая рамная крепь при сроке службы более 5 лет.

\subsubsection{2. Оиенка геомеханического состояния массива пород месторождений Мурманской области методом рейтинговых классификаичий с учетом новых данных}

Рейтинговые классификации скальных массивов (системы оценки качества геологической среды) являются основой эмпирического подхода к проектированию горных работ. Они создавались как средство обобщения результатов, накопленных в процессе натурных исследований. Рейтинговые классификации широко используются на предварительной стадии проектирования различных объектов.

Помимо рекомендаций по выбору конструктивных параметров подземных систем разработки, определению типа и параметров крепления горных выработок, А. Хайнсом и П. Тербрюгге [272] разработаны рекомендации по выбору ориентировочных значений углов откосов бортов карьеров на основе рассчитанного рейтинга по Д. Лобширу $\left(R_{L}\right)$.

Расчет рейтинга $R_{L}$ уточнен и дополнен для ряда месторождений Кольского региона: Куркенпахк и «Комсомольское» $\mathrm{AO}$ «Олкон», «Олений ручей» $\mathrm{AO}$ «СЗФК» $[264,273]$.

Полученные результаты для различных месторождений Кольского региона обобщены в таблице 6.15 .

В связи с появлением новых данных о зональности уровня напряженности массива пород и данных о трещиноватости, свидетельствующих о зависимости их от глубины, оценка рейтинга $R_{L}$ проведена для трех зон месторождения «Олений ручей»:

- для верхней части массива до глубины 100 м $R_{L} \approx 38$;

- для глубины $100-300$ м $R_{L} \approx 54 \div 65$;

- глубже 300 м $R_{L} \approx 60 \div 72$. 
Таблииа 6.15

Значения рейтинга $R_{L}$ по ряду месторождений Кольского региона

\begin{tabular}{|c|c|c|c|c|}
\hline \multirow[b]{2}{*}{ Месторождения } & \multicolumn{2}{|c|}{ Значение рейтинга MRMR } & \multirow{2}{*}{$\begin{array}{l}\text { Класс пород } \\
\text { по Лобширу }\end{array}$} & \multirow{2}{*}{$\begin{array}{l}\text { Рекомендуемый угол } \\
\text { откоса борта карьера }\end{array}$} \\
\hline & $\begin{array}{l}\text { диапазон } \\
\text { значений }\end{array}$ & $\begin{array}{l}\text { среднее } \\
\text { значение }\end{array}$ & & \\
\hline $\begin{array}{l}\text { Ковдорское } \\
(\mathrm{AO} \mathrm{«Ковдорский} \mathrm{ГОК»)}\end{array}$ & $72-80$ & 78 & II & $65^{\circ} \pm 5^{\circ}$ \\
\hline «Олений ручей» $(\mathrm{AO}$ «СЗФК») & $54-65$ & 60 & II-III & $\begin{array}{c}35 \div 50^{\circ} \\
\text { (для глубины до } 100 \mathrm{M}), \\
55 \pm 5^{\circ} \\
\text { (для глубины от } 100 \text { до } 300 \mathrm{M} \text { ) } \\
\leq 65^{\circ} \\
\text { (глубже } 300 \mathrm{M})\end{array}$ \\
\hline Ньоркпахкское («АО Апатит») & $62-68$ & 64 & II & $65 \pm 5^{\circ}$ \\
\hline $\begin{array}{l}\text { 《Плато Расвумчорр» } \\
\text { («ОАО Апатит») }\end{array}$ & $59-72$ & 65 & II & $65 \pm 5^{\circ}$ \\
\hline Кировогорское (АО «Олкон») & $43-79$ & 62 & II-III & $55 \pm 5^{\circ}$ \\
\hline Оленегорское (АО «Олкон») & $49-63$ & 54 & III & $5 \pm 5^{\circ}$ \\
\hline Куркенпахк (АО «Олкон») & $51-60$ & 55 & III & $55 \pm 5^{\circ}$ \\
\hline 〈Комсомольское» $(\mathrm{AO}$ «Олкон») & $43-57$ & 50 & III & $55 \pm 5^{\circ}$ \\
\hline
\end{tabular}

На основе рассчитанного рейтинга $R_{L}$ горных пород для карьера, отрабатывающего месторождение «Олений ручей», в первом приближении можно рекомендовать следующие углы откоса борта со стороны висячего бока рудной залежи:

- для глубины до $100 \mathrm{M}-35 \div 50^{\circ}$;

- для глубины от 100 до $300 \mathrm{M}-50 \div 60^{\circ}$;

- глубже $300 \mathrm{~m}$ - до $65^{\circ}$.

При этом угол откоса борта карьера со стороны лежачего бока рудной залежи определяется положением Главного разлома.

Результаты рейтинговой оценки по глубине районирования на разрезе $32+50$ м представлены на рисунке 6.60 .

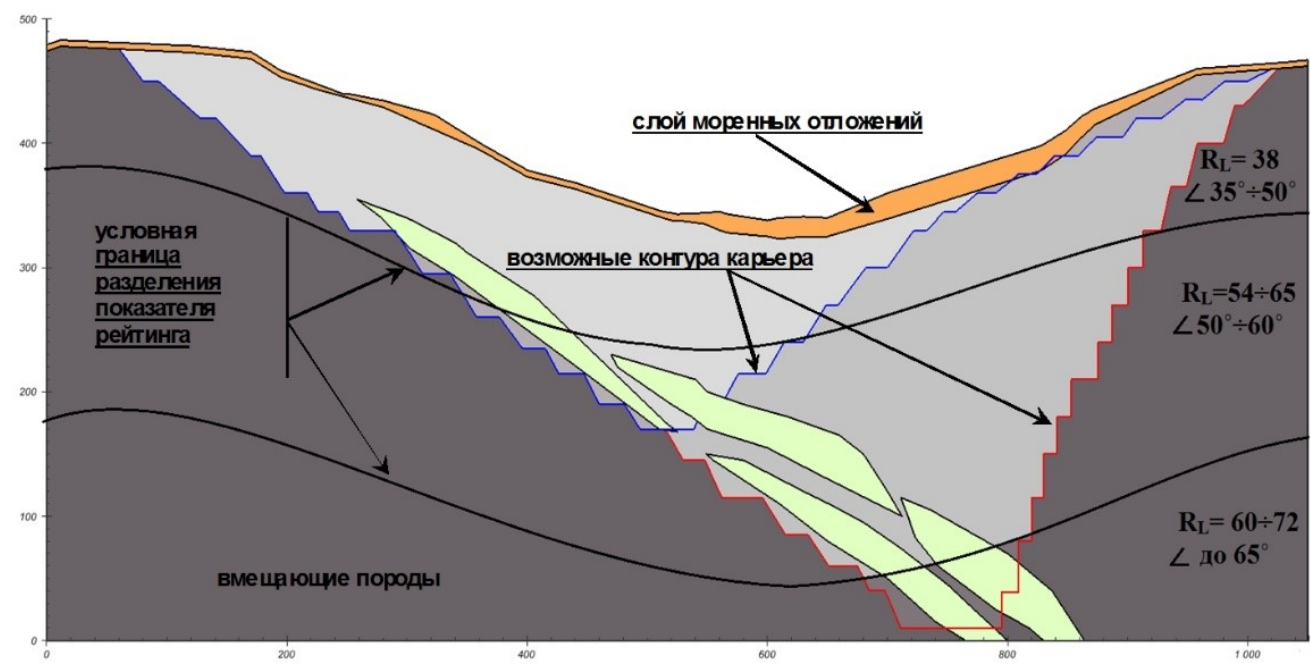

Рис. 6.60. Фрагмент геологического разреза $32+50$ м месторождения «Олений ручей» с положением условных границ различных значений рейтинга $R_{L}: \circlearrowright-$ слой мореных отложений; __ и __ возможные контура карьера; 2 - рудные тела; черный - условная граница разделения показателя рейтинга; - вмещающие породы 
Из данных таблицы 6.15 видно, что месторождения АО «Апатит», АО «СЗФК» и Кировогорское месторождение «АО Олкон» имеют примерно одинаковые значения рейтинга MRMR, что свидетельствует об идентичности геомеханической ситуации в этих массивах. Для Оленегорского и «Комсомольского» месторождений, а также для месторождения Куркенпахк значения рейтинга несколько ниже в силу высокой трещиноватости массива горных пород. Рейтинг MRMR для Ковдорского ГОКа выше, что говорит о более благоприятном геомеханическом состоянии массива горных пород относительно его устойчивости. Рекомендуемый угол откоса борта карьера для месторождений Ковдорское, Ньоркпахкское, «Плато Рассвумчорр» составляет $65 \pm 5^{\circ}$, для месторождения «Олений ручей» $-35-65^{\circ}$ в зависимости от глубины, а для остальных месторождений $-55 \pm 5^{\circ}$.

Расчет рейтинга MRMR наиболее целесообразно применять на предварительном этапе для оценки параметров карьерной выемки. Метод дает общую оценку геомеханической ситуации, однако с его помощью невозможно производить учет влияния крупных единичных поверхностей ослабления и крупных разломов, существенно влияющих на параметры откоса борта карьера.

Для определения возможных углов откосов бортов карьеров по рейтинговым оценкам необходимо, во-первых, доизучать прибортовой массив пород, получить необходимые данные о состоянии массива скальных пород: модуле трещиноватости, прочности породного блока, степени выветривания, ориентации трещин, напряженном состоянии массива, технологии проведения БВР, наличию подземных водопритоков; во-вторых, формировать конечный контур, минимально нарушая законтурный массив, а в случае необходимости производить крепление неустойчивых участков борта; и, в-третьих, осуществлять непрерывный мониторинг процессов деформирования и разрушения пород. Только при таких условиях можно достичь необходимого уровня безопасности при ведении открытых горных работ.

\subsection{5. Управление рисками при открытой геотехнологии}

\subsubsection{1.Методика расчета и результаты оценки устойчивости борта карьера «Железный» с учетом инженерно-геологических особенностей массива горных пород}

Управление риском при открытых горных работах сводится в основном к обеспечению устойчивости бортов карьеров, для чего разрабатываются соответствующие методики и создаются системы геомеханического мониторинга, о которых говорилось выше.

В соответствии с разработанными в ГоИ КНЦ РАН общими принципами и методикой обоснования параметров бортов карьеров в массивах скальных высоконапряженных пород, выполнена оценка устойчивости борта карьера по секторам с учетом инженерно-геологических особенностей строения массива горных пород [274]. Методика оценки устойчивости бортов карьеров в массивах скальных тектонически напряженных пород достаточно подробно изложена во многих публикациях [275-278].

Устойчивость борта характеризуется величиной коэффициента запаса устойчивости $n$. Если $n \geq 1,3$, борт считается устойчивым. Если $1,0 \leq n<1,3$, борт карьера считается недостаточно устойчивым. Если $n<1,0$, борт карьера считается неустойчивым. 
Для оценки устойчивости борта карьера необходима информация о физико-механических свойствах горных пород и напряженном состоянии вмещающего массива.

Определению подлежали плотностные, прочностные и упругие свойства пород основных петрографических разностей Ковдорского месторождения: плотность ( $\rho)$, прочность пород при одноосном сжатии $\left(\sigma_{c ж}\right)$ и растяжении $\left(\sigma_{\mathrm{p}}\right)$, статический и динамический модуль упругости $\left(E_{\mathrm{y}}, E_{\text {д}}\right)$, коэффициент Пуассона $(\mu)$ и коэффициент поперечных деформаций $(v)$, коэффициент крепости пород по шкале профессора М. М. Протодьяконова $(f)$, сцепление $(C)$, угол внутреннего трения $(\varphi)$, а также параметры паспорта прочности пород по результатам испытаний в условиях среза со сжатием и объемного сжатия. Все испытания проводились по методикам, описанным в монографии [279] в соответствии с действующими ГОСТами ${ }^{1}$.

Наиболее прочными породами являются ийолит и фенит $\left(\sigma_{\text {сж }}=144 \div 165 \mathrm{MПа;} f=14 \div 17\right)$. Наименее прочным по сравнению с другими петрографическими разностями является карбонатит $\left(\sigma_{\text {сж }}=55 \mathrm{MПа;} f=6\right)$. Исследуемые породы являются достаточно плотными и упругими. Их среднеарифметические значения плотности составляют $2,8 \div 3,17$ т/. $\mathrm{m}^{3}$, скорости прохождения продольных волн в образцах $V_{p}=4,5 \div 5,96$ км/с, коэффициент Пуассона $\mu=0,11 \div 0,24$ и модуль упругости $E_{\text {Д }}=(5,6 \div 9,4) \times 10^{4}$ МПа. Максимальные значения показателей упругости свойственны ийолитам и фенитам. Карбонатиты в этом комплексе пород являются наименее плотными и упругими ( $\left.\rho=2,8 \mathrm{~T} / \mathrm{M}^{3} ; E_{\text {д }}=5,6 \times 10^{4} \mathrm{MПа}\right)$.

Что касается пространственного расположения, то фениты и ийолиты слагают южную, западную и восточную части карьера (секторы III, IV, V, VI, VII и VIII). Тела карбонатитов распространены повсеместно, а пироксениты слагают северную часть карьера (секторы I и II) [280].

Также проведены дополнительные определения физико-механических свойств скальных трещиноватых пород Ковдорского месторождения на специальном срезном приборе ${ }^{2}$. Каждый контакт испытывали при нескольких ступенях нормальных и касательных нагрузок. В результате, определены сопротивления сдвигу по контактам поверхностей ослабления различных типов горных пород, построены паспорта прочности и вычислены сцепление и угол трения по контакту (соответственно $\mathrm{C}^{\prime}$ и $\varphi^{\prime}$ ).

Величина сцепления $\left(\mathrm{C}^{\prime}\right)$ в каждом секторе преимущественно лежит в диапазоне от 0,2 МПа и выше. При проведении дальнейших расчетов использованы следующие значения сцепления: $0,0,1$ и 0,2 МПа.

Что касается угла внутреннего трения, то анализ результатов определений показывает, что его величина лежит в диапазонах 26-35. С учетом общих представлений о массивах прочных скальных пород наиболее вероятное значение угла внутреннего трения по поверхностям ослабления составляет около $30^{\circ}$.

Для определения абсолютных значений действующих в массиве пород напряжений в основном использовали метод разгрузки, а в качестве дополнительного - метод дискования керна [281].

\footnotetext{
${ }^{1}$ ГОСТ 21153.0-75, 21153.2-84, 21153.3-85 и др.

2 Исследования физико-механических свойств контактов проведены в лаборатории физико-механических свойств и разрушения горных пород ВНИМИ.
} 
Несмотря на значительный разброс полученных результатов, зависимость между максимальной компонентой главных напряжений и глубиной расположения точек измерений можно в первом приближении представить в виде (при 400 м $>H>40 \div 50$ м):

$$
\sigma_{\max } \approx 0,1 \times H,
$$

где $\sigma_{\max }-$ максимальная компонента главных напряжений, МПа; $H$ - глубина расположения измерительной станции, м.

Учитывая общие закономерности распределения тектонических напряжений с глубиной, можно предположить, что на глубинах более $400 \div 500$ м зависимость $\sigma_{\max }=f(H)$ будет нелинейной, и возрастание напряжений с глубиной будет затухать.

В качестве дополнительного метода для оценки НДС массива пород использовали метод дискования керна, в основе которого лежат представления о том, что ствол скважины и извлекаемый керн являются по своей сути технологическими датчиками, с помощью которых можно оценить параметры поля напряжений массива пород. Эти определения основываются на использовании экспериментально устанавливаемых зависимостей характера разрушения выбуриваемого керна от степени напряженности массива пород. Характер разрушения керна в процессе бурения определяется соотношением величины и ориентации главных компонент естественного поля напряжений и прочностных характеристик пород. Деление керна на диски, толщина которых превышает его диаметр, в прочных скальных породах начинается при соотношении $\sigma_{\perp} / \sigma_{\text {сж }}=0,1-0,3$ ( $\sigma_{\perp}-$ напряжения, действующие

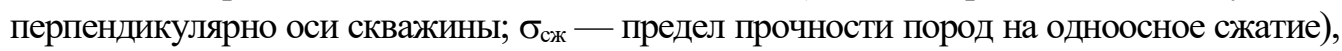
а при $\sigma_{\perp} / \sigma_{\text {сж }}=1-2$ керн может полностью превратиться в буровую мелочь.

Таким образом, этот метод обеспечивает получение информации о величине действующих напряжений практически на всем диапазоне нагрузок вплоть до разрушающих. Недостатком метода является качественный характер получаемых данных, однако в сопоставлении с реперными определениями НДС методом разгрузки реальная картина напряженного состояния исследуемого массива пород устанавливается с достаточной степенью надежности. Пример дискования керна приведен на рисунке 6.61 .

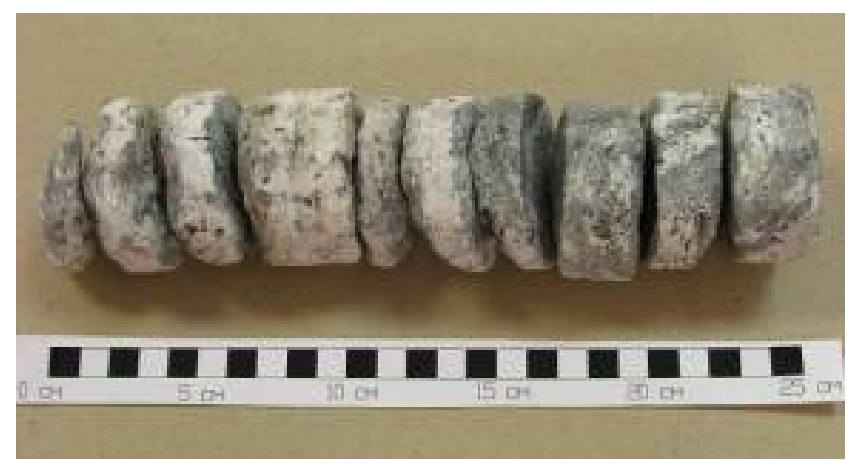

Рис. 6.61. Дискование керна в карбонатите (рудник «Железный»)

Дискование керна отмечено в большинстве скважин, что свидетельствует о действии в массиве пород повышенных тектонических субгоризонтальных напряжений по всему периметру карьера. 
Таблииа 6.16

Исходные данные для расчетов устойчивости борта карьера по выделенным инженерно-геологическим секторам (ИГС)*

\begin{tabular}{|c|c|c|c|c|c|c|c|c|}
\hline \begin{tabular}{|c|} 
№ \\
ИГС
\end{tabular} & $\begin{array}{c}\text { Основные литотипы } \\
\text { в пределах ИГС }\end{array}$ & \begin{tabular}{|} 
Объемный \\
вес, т/м ${ }^{3}$
\end{tabular} & $\begin{array}{c}\text { Сцепление } \\
\text { по структурным } \\
\text { ослаблениям С' } \\
\text { т/м }{ }^{2}\end{array}$ & $\begin{array}{c}\text { Угол } \\
\text { внутреннего } \\
\text { трения } \\
\text { по структурным } \\
\text { ослаблениям } \varphi^{\prime}, \\
\text { град }\end{array}$ & \begin{tabular}{|c} 
Абсолютные \\
значения \\
действующих \\
напряжений \\
в прибортовом \\
массиве пород $P_{\text {бок, }}$ \\
т/м² \\
\end{tabular} & $\mid \begin{array}{c}\text { Размер ИГС } \\
\text { по внешнему } \\
\text { контуру } \\
\text { карьера } b, \\
\text { м }\end{array}$ & \begin{tabular}{|c} 
Глубина \\
карьера \\
на конечном \\
контуре $H_{\mathrm{K}}$, \\
м
\end{tabular} & $\begin{array}{c}\text { Проверяемые } \\
\text { углы наклона } \\
\text { борта карьер } \\
\text { на конечном } \\
\text { контуре } \alpha, \\
\text { град }\end{array}$ \\
\hline I & Пироксенит, карбонатит, руда & 3 & $0 ; 10 ; 20$ & 30 & $0 ; 1000 ; 2000 ; 4000$ & 1000 & 1000 & $50,55,60$ \\
\hline II & Пироксенит, руда & 3 & $0 ; 10 ; 20$ & 30 & $0 ; 1000 ; 2000 ; 4000$ & 800 & 1000 & $50,55,60$ \\
\hline III & Оливинит, карбонатит, пироксенит, ийолит & 3 & $0 ; 10 ; 20$ & 30 & $0 ; 1000 ; 2000 ; 4000$ & 800 & 1000 & $50,55,60$ \\
\hline IV & Ийолит, фенит пироксенит & 3 & $0 ; 10 ; 20$ & 30 & $0 ; 500 ; 1000 ; 2000$ & 800 & 1000 & $45,50,55,60$ \\
\hline $\mathrm{V}$ & Фенит, ийолит, руда & 3 & $0 ; 10 ; 20$ & 30 & $0 ; 500 ; 1000 ; 2000$ & 1000 & 1000 & $45,50,55,60$ \\
\hline VI & Фенит, ийолит, карбонатит, руда & 3 & $0 ; 10 ; 20$ & 30 & $0 ; 500 ; 1000 ; 2000$ & 1000 & 1000 & $45,50,55,60$ \\
\hline VII & Фенит, ийолит, карбонатит, руда & 3 & $0 ; 10 ; 20$ & 30 & $0 ; 1000 ; 2000 ; 4000$ & 800 & 1000 & $50,55,60$ \\
\hline VIII & Фенит, ийолит, карбонатит & 3 & $0 ; 10 ; 20$ & 30 & $0 ; 1000 ; 2000 ; 4000$ & 800 & 1000 & $50,55,60$ \\
\hline
\end{tabular}

* Объемный вес горных пород, слагающих борта карьера, принимали равным 3 т/м³ для всех ИГС. 
Оценку устойчивости борта карьера выполняли по выделенным инженерно-геологическим секторам (ИГС). В таблице 6.16 приведены исходные данные для расчетов.

Сцепление по структурным ослаблениям $\mathrm{C}^{\prime}$ задавали равным 0,10 и $20 \mathrm{~T} / \mathrm{M}^{2}$. При этом наиболее вероятное значение $\mathrm{C}^{\prime}$ соответствует $10 \mathrm{~T} / \mathrm{M}^{2}$. Значение $\mathrm{C}^{\prime}=0$ соответствует случаю раскрытой гладкой трещины. Вариант, при котором $\mathrm{C}^{\prime} \approx 20 \mathrm{~T} / \mathrm{M}^{2}$, отражает возможность, при которой структурное нарушение заполнено и шероховато. Значение угла внутреннего трения по структурному нарушению во всех случаях принимали равным $30^{\circ}$.

Значения действующих в прибортовом массиве пород напряжений $\left(P_{\text {бок }}\right)$ принимали для I, II, III, VII, VIII ИГC равными 0, 1000, 2000 и $4000 \mathrm{~T} / \mathrm{m}^{2}$, а для IV, V, VI ИГC, учитывая вероятный относительно меньший уровень действующих напряжений в этих секторах, равными $0,500,1000$ и $2000 \mathrm{~T} / \mathrm{m}^{2}$. При этом необходимо учитывать следующее. Вариант расчета, при котором $P_{\text {бок }}=0$ и $\mathrm{C}^{\prime}=0$, соответствуют раздробленной горной массе с устойчивостью, полностью определяемой углом естественного откоса, равного в этом случае $30^{\circ}$. Значение $P_{\text {бок }}=1000 \mathrm{~T} / \mathrm{m}^{2}$ при глубине карьера $H_{\mathrm{\kappa}} \approx 1000$ м соответствует боковому отпору давления вышележащих пород (исходя из упругой модели среды, находящейся под действием напряжений только от собственного веса пород), то есть минимально возможному значению горизонтальных напряжений в прибортовом массиве пород. Для IV, V, VI ИГС в качестве промежуточного варианта было принято значение $P_{\text {бок }}=500$ т/м² , учитывая важность определения устойчивости в верхней части контура карьера.

Определяли коэффициент запаса устойчивости $\left(K_{\text {зап}}\right)$ в зависимости от входящих параметров и угла падения потенциальной трещины $(\beta)$, подсекающей борт карьера. Пример представления результата расчетов приведен в таблице 6.17. При $K_{\text {зап }} \geq 1,3$ борт карьера устойчив (выделено зеленым цветом), при $1,0 \leq K_{\text {зап }} \leq 1,3$ - недостаточно устойчив (желтый цвет), при $K_{\text {зап }}<1,0-$ неустойчив (красный цвет).

Таблища 6.17

Результаты расчета коэффициентов запаса устойчивости при различных условиях для I расчетной схемы

\begin{tabular}{|c|c|c|c|c|c|c|c|c|c|c|c|c|}
\hline \multirow{3}{*}{$\begin{array}{c}\text { Угол падения } \\
\text { структурного } \\
\text { нарушения }\end{array}$} & \multirow{2}{*}{\multicolumn{3}{|c|}{$\begin{array}{c}P_{\text {бок }}=0 \mathrm{~T} / \mathrm{M}^{2} \\
\mathrm{C}^{\prime}\end{array}$}} & \multirow{2}{*}{\multicolumn{3}{|c|}{$\begin{array}{c}P_{\text {бок }}=1000 \mathrm{~T} / \mathrm{M}^{2} \\
\mathrm{C}^{\prime}\end{array}$}} & \multirow{2}{*}{\multicolumn{3}{|c|}{$\begin{array}{c}P_{\text {бок }}=2000 \mathrm{~T} / \mathrm{M}^{2} \\
\mathrm{C}^{\prime}\end{array}$}} & \multirow{2}{*}{\multicolumn{3}{|c|}{$\begin{array}{c}P_{\text {бок }}=4000 \mathrm{~T} / \mathrm{M}^{2} \\
\mathrm{C}^{\prime}\end{array}$}} \\
\hline & & & & & & & & & & & & \\
\hline & 0 & 10 & 20 & 0 & 10 & 20 & 0 & 10 & 20 & 0 & 10 & 20 \\
\hline 20 & 1,59 & 1,62 & 1,64 & 2,71 & 2,74 & 2,77 & 3,84 & 3,87 & 3,89 & 6,09 & 6,12 & 6,15 \\
\hline 25 & 1,24 & 1,26 & 1,29 & 2,15 & 2,18 & 2,20 & 3,06 & 3,09 & 3,11 & 4,88 & 4,91 & 4,93 \\
\hline 30 & 1,00 & 1,03 & 1,05 & 1,77 & 1,80 & 1,82 & 2,54 & 2,57 & 2,59 & 4,08 & 4,10 & 4,13 \\
\hline 35 & 0,82 & 0,85 & 0,88 & 1,50 & 1,52 & 1,55 & 2,17 & 2,19 & 2,22 & 3,51 & 3,54 & 3,56 \\
\hline 40 & 0,69 & 0,72 & 0,75 & 1,29 & 1,32 & 1,35 & 1,89 & 1,92 & 1,95 & 3,08 & 3,11 & 3,15 \\
\hline 45 & 0,58 & 0,62 & 0,66 & 1,12 & 1,16 & 1,20 & 1,67 & 1,71 & 1,75 & 2,75 & 2,80 & 2,84 \\
\hline 50 & 0,48 & 0,56 & 0,63 & 0,99 & 1,06 & 1,13 & 1,49 & 1,56 & 1,63 & 2,49 & 2,57 & 2,64 \\
\hline 54 & 0,42 & 0,74 & 1,06 & 0,90 & 1,22 & 1,54 & 1,37 & 1,69 & 2,01 & 2,32 & 2,64 & 2,96 \\
\hline
\end{tabular}

Примечание. При $\alpha=55^{\circ} ; H=1000 \mathrm{м} ; b=1000 \mathrm{м} ; \varphi^{\prime}=30^{\circ}$.

Из таблицы 6.17 следует, что при наиболее вероятных значениях $P_{\text {бок }}=1000 \mathrm{~T} / \mathrm{M}^{2}$ и $\mathrm{C}^{\prime}=10 \mathrm{~T} / \mathrm{M}^{2}$ (выделено жирным) недостаточная устойчивость 
борта карьера $\left(1,0 \leq K_{\text {зап }} \leq 1,3\right)$ возможна в случае выявления в пределах данного ИГС подсекающей трещины с углом падения $\beta>40^{\circ}$.

Если предположить в дальнейшем выявление трещины, подсекающей борт карьера с гладкими границами $\left(\mathrm{C}^{\prime}=0\right)$, то недостаточная устойчивость борта карьера возможна при угле ее падения $\beta \geq 35^{\circ}$. В соответствии с имеющимися данными о структурной нарушенности массива пород в пределах I ИГС (разрез по профилю 12ИГ) таких протяженных трещин не выявлено. Варианты расчетов при $P_{\text {бок }}=2000$ и 4000 т/м² показывают высокую степень устойчивости борта карьера на больших глубинах. При этом следует иметь в виду, во-первых, что в пределах I ИГС к настоящему времени зафиксировано действие напряжений в прибортовом массиве пород порядка $2000 \mathrm{~T} / \mathrm{M}^{2}$, а во-вторых, большие значения действующих напряжений могут привести к разрушению участков массива пород в динамической форме, образованию техногенной трещиноватости, что возможно при формировании конечного контура карьера на глубинах $\geq 600-700$ м.

Этот способ оценки устойчивости применен для анализа результатов расчетов по всем выделенным инженерно-геологическим секторам. Сводные результаты оценки устойчивости бортов карьера на конечном контуре по ИГС и рекомендации по его формированию приведены в таблице 6.18 . Все оценки устойчивости выполнены исходя из значения коэффициента запаса устойчивости $K \geq 1,3$.

Таблица 6.18

Результаты оценки устойчивости бортов карьера на конечном контуре по выделенным инженерно-геологическим секторам (ИГС)

\begin{tabular}{|c|l|l|}
\hline \multirow{2}{*}{ ИГС } & \multicolumn{1}{|c|}{ Высотные отметки } & $\begin{array}{c}\text { Угол наклона борта карьера } \\
\text { на конечном контуре }\end{array}$ \\
\hline I & На всю глубину & Не более $60^{\circ}$ \\
\hline II & На всю глубину & Не болеe $55^{\circ}$ \\
\hline \multirow{2}{*}{ III } & От современного состояния карьера до гор. $-80 \mathrm{~m}$ & Не болеe $55^{\circ}$ \\
\cline { 2 - 3 } & От гор. -80 м до дна карьера & Не более $60^{\circ}$ \\
\hline IV, & От современного состояния карьера до гор. $-80 \mathrm{M}$ & Не более $45^{\circ}$ \\
\cline { 2 - 3 } V & От гор. -80 м до дна карьера & Не более $50^{\circ}$ \\
\hline \multirow{2}{*}{ VI } & От современного состояния карьера до гор. $+70 \mathrm{M}$ & Не более $45^{\circ}$ \\
\cline { 2 - 3 } & От гор. +70 м до дна карьера & Не более $50^{\circ}$ \\
\hline VII, & От современного состояния карьера до гор. $+40 \mathrm{M}$ & Не более $50^{\circ}$ \\
\cline { 2 - 3 } VIII & От гор. +40 м до дна карьера & Не более $60^{\circ}$ \\
\hline
\end{tabular}

Результаты оценки устойчивости позволяют повысить проектную глубину основного карьера, прирастить запасы полезного ископаемого, которые можно отработать открытым способом и, как следствие, продлить срок существования предприятия. При этом технико-экономический эффект достигается без увеличения площади горного отвода, что минимизирует экологическую нагрузку на окружающую среду.

\subsubsection{2. Оиенка устойчивости участка борта Оленегорского карьера со стороны лежачего бока рудного тела}

Выполнена оценка устойчивости участка борта Оленегорского карьера в районе геологического разреза 18 со стороны лежачего бока рудного тела c использованием лицензированных программных комплексов Galena 6.0, SVSlope 2D, а также в соответствии с методическим подходом, разработанным 
ГоИ КНЦ РАН и апробированным применительно к условиям горнодобывающих предприятий, отрабатывающих рудные месторождения открытым способом в массивах скальных пород.

Программы Galena 6.0 и SVSlope 2D представляют собой комплекс методов для решения задач по оценке устойчивости бортов карьеров при открытой разработке месторождений как в слабых грунтах, так и в скальных породах методом предельного равновесия. В программах иммитируется критическая поверхность скольжения, которая может представлять собой как круглоцилиндрическую, так и сложную поверхность. Для определения местоположения критической поверхности скольжения применяется метод последовательных приближений (рис. 6.62 и 6.63).

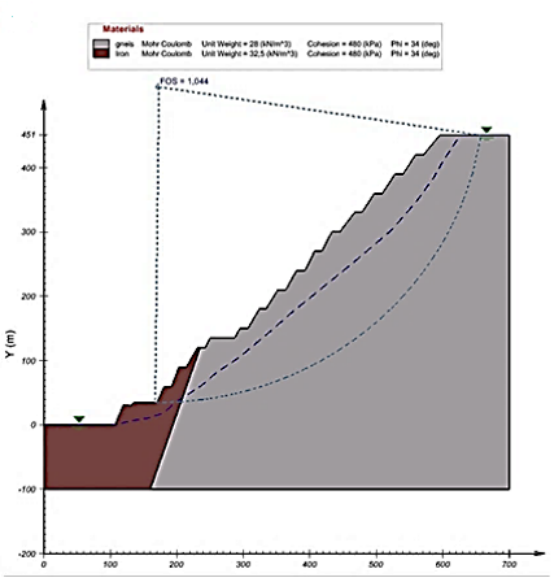

$a$

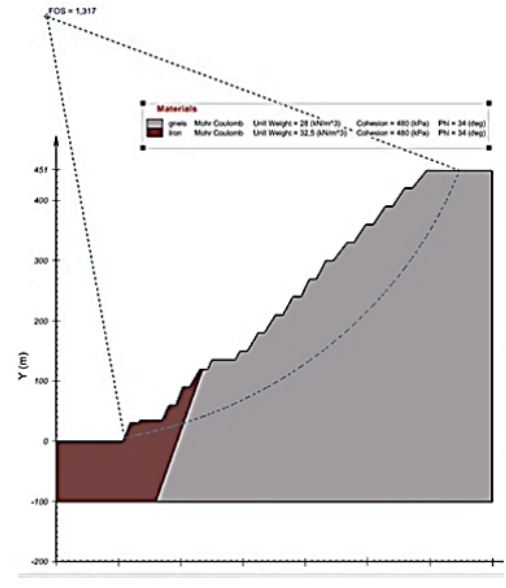

$\sigma$

Рис. 6.62. Оценка устойчивости программным комплексом SVSlope 2D: $a-$ обводненный массив пород (уровень грунтовых вод показан фиолетовой пунктирной линией); 6 - необводненный массив (уровень грунтовых вод расположен в глубине массива пород)

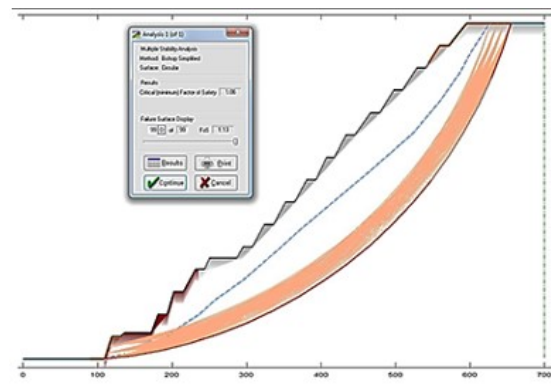

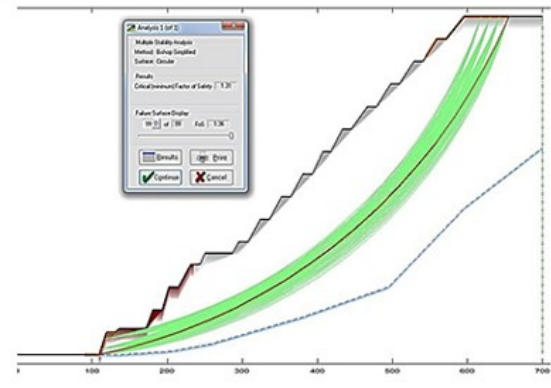

$\sigma$

Рис. 6.63. Расчет устойчивости программным комплексом Galena $6.0: a-$ обводненный массив пород (уровень грунтовых вод показан синей пунктирной линией); 6 - необводненный массив (уровень грунтовых вод расположен в глубине массива пород

По результатам расчета по программе SVSlope 2D при расчетных значениях коэффициента запаса устойчивости (КЗУ) меныше 1 участок борта карьера неустойчив, при значениях КЗУ больше или равном 1 , но меньше 1,3 - участок борта карьера недостаточно устойчив и при значениях КЗУ больше или равном 1,3 - участок борта карьера устойчив. 
В качестве исходных данных приняты следующие значения физико-механических свойств:

- $\quad$ средняя плотность гнейсов различного состава $\gamma=2,8$ т/м³

- средняя плотность железистых кварцитов $\gamma=3,25$ т/м ${ }^{3}$;

- сцепление в массиве $\mathrm{C}=0,48 \mathrm{MПа}$;

- угол внутреннего трения в массиве $\varphi=34^{\circ}$.

Расчеты выполнены для следующих технологических параметров:

- высота борта карьера $H=450$ м;

- угол откоса уступов $\alpha_{\mathrm{y}}=60^{\circ}$;

- генеральный угол $\alpha \approx 40^{\circ}$.

Гидрогеологические условия месторождения характеризуются тем, что подземные воды за время эксплуатации карьера полностью сдренированы. Это в свою очередь предполагает, что уровень грунтовых вод находится в глубине массива пород за пределами зоны возможного сдвижения, то есть гидрогеологические условия являются благоприятными. Однако подземные воды в карьере фиксируются, вскрыт водоносный горизонт. Это положение предполагает, что уровень грунтовых вод находится в пределах возможной зоны сдвижения. С учетом такой неопределенности оценку устойчивости выполняли в двух вариантах состояния массива - обводненном и необводненном.

В результате оценки устойчивости по заданным параметрам были получены КЗУ, приведенные в таблице 6.19 (желтым цветом выделены значения коэффициента запаса устойчивости, при которых участок борта карьера недостаточно устойчив); зеленым - при которых участок борта карьера устойчив).

Таблииа 6.19

Значения КЗУ, полученные с использованием программ Galena 6.0 и SVSlope 2D

\begin{tabular}{|c|c|c|}
\hline К3У & Galena 6.0 & SVSlope 2D \\
\hline Обводненный массив & 1,06 & 1,04 \\
\hline Необводненный массив & 1,31 & 1,32 \\
\hline
\end{tabular}

Оценку устойчивости этого участка карьера выполняли также с использованием методического подхода ГоИ КНЦ РАН.

В качестве исходных данных для оценки КЗУ использованы следующие параметры:

- объемный вес пород $\gamma=2,87 \mathrm{~T} / \mathrm{M}^{3}$;

- сцепление по поверхностям ослабления $\mathrm{C}^{\prime}=4 \mathrm{~T} / \mathrm{M}^{2}$ (дополнительно взяты значения 0 и 10 т/ $\left.\mathrm{M}^{2}\right)$;

- угол внутреннего трения по поверхностям ослабления $\varphi^{\prime}=22^{\circ}$;

- углы падения структурных нарушений $\beta$ от 5 до $39^{\circ}$ с шагом $5^{\circ}$;

- абсолютные значения горизонтальных напряжений $P_{\text {бок }}=270 \mathrm{~T} / \mathrm{M}^{2}$ (соответствует боковому отпору от веса вышележащих пород при высоте борта карьера 450 м). Дополнительно взяты значения $P_{\text {бок, }}$ равные 0 и 100 т/м².

Значения ширины выделяемого расчетного блока, то есть расстояние между структурными нарушениями со стороны висячего бока рудного тела $b=100$ м (значение устанавлено на основе инженерно-геологического районирования массива пород и взято из опыта оценки устойчивости бортов карьеров в аналогичных условиях).

Полученные значения КЗУ приведены в таблице 6.20 (жирным выделены значения КЗУ, полученные с использованием значения $\left.\mathrm{C}^{\prime}=4 \mathrm{~T} / \mathrm{M}^{2}\right)$. 
Таблица 6.20

Значения КЗУ, полученные с использованием методики ГоИ КНЦ РАН

\begin{tabular}{|c|c|c|c|c|c|c|c|c|c|}
\hline \multirow{3}{*}{$\begin{array}{c}\text { Угол падения } \\
\text { структурного нарушения ( } \beta), \\
\text { град }\end{array}$} & \multirow{2}{*}{\multicolumn{3}{|c|}{$\begin{array}{c}P_{\text {бок }}=0 \mathrm{~T} / \mathrm{M}^{2} \\
\mathrm{C}^{\prime}, \mathrm{T} / \mathrm{M}^{2}\end{array}$}} & \multirow{2}{*}{\multicolumn{3}{|c|}{$\begin{array}{c}P_{\text {бок }}=100 \mathrm{~T} / \mathrm{M}^{2} \\
\mathrm{C}^{\prime}, \mathrm{T} / \mathrm{M}^{2}\end{array}$}} & \multicolumn{3}{|c|}{$P_{\text {бок }}=270 \mathrm{~T} / \mathrm{M}^{2}$} \\
\hline & & & & & & & & $\mathrm{C}^{\prime}, \mathrm{T} / \mathrm{M}$ & \\
\hline & 0 & 4 & 10 & 0 & 4 & 10 & 0 & 4 & 10 \\
\hline 5 & 4,62 & 5,02 & 5,62 & 7,85 & 8,25 & 8,85 & 13,34 & 13,74 & 14,34 \\
\hline 10 & 2,29 & 2,50 & 2,81 & 3,91 & 4,12 & 4,43 & 6,67 & 6,88 & 7,19 \\
\hline 15 & 1,51 & 1,65 & 1,87 & 2,60 & 2,74 & 2,96 & 4,44 & 4,59 & 4,81 \\
\hline 20 & 1,11 & 1,23 & 1,40 & 1,93 & 2,05 & 2,23 & 3,33 & 3,45 & 3,63 \\
\hline 25 & 0,87 & 0,97 & 1,12 & 1,53 & 1,64 & 1,79 & 2,67 & 2,77 & 2,92 \\
\hline 30 & 0,70 & 0,81 & 0,96 & 1,26 & 1,37 & 1,53 & 2,22 & 2,33 & 2,48 \\
\hline 35 & 0,58 & 0,72 & 0,94 & 1,07 & 1,21 & 1,43 & 1,90 & 2,05 & 2,27 \\
\hline 39 & 0,50 & 1,18 & 2,19 & 0,95 & 1,62 & 2,64 & 1,71 & 2,38 & 3,40 \\
\hline
\end{tabular}

Оценка устойчивости с использованием программ Galena 6.0 и SVSlope 2D показала значительное влияние гидрогеологических условий на состояние рассматриваемого участка борта карьера. Так, в случае необводненного массива расчетный КЗУ составляет величину 1,31 (Galena 6.0) и 1,32 (SVSlope 2D), то есть участок борта карьера устойчив. В случае обводненного массива пород расчетный КЗУ составляет 1,06 и 1,04 соответственно, то есть участок борта карьера недостаточно устойчив.

Использование методики ГоИ КНЦ РАН показывает, что при значении сцепления по контактам $\mathrm{C}^{\prime}=4 \mathrm{~T} / \mathrm{m}^{2}$ устойчивость рассматриваемого участка борта карьера будет зависеть от уровня действующих в массиве

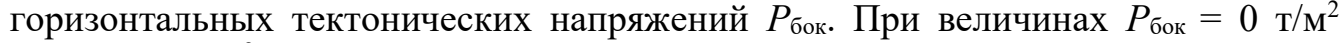
и $\mathrm{C}^{\prime}=0 \mathrm{~T} / \mathrm{M}^{2}$ рассматриваемый участок соответствует дезинтегрированной горной массе. В этом случае значения КЗУ меньше 1,3 при угле откоса более $20^{\circ}$ (табл. 6.20 , крайний левый столбец). При величине $P_{\text {бок }}>0$ (рассмотрены варианты $P_{\text {бок }}=100 \mathrm{~T} / \mathrm{M}^{2}$ и $P_{\text {бок }}=270 \mathrm{~T} / \mathrm{M}^{2}$ ) ситуация более благоприятна. Так, при $P_{\text {бок }}=100 \mathrm{~T} / \mathrm{M}^{2}$ и $\mathrm{C}^{\prime}=4 \mathrm{~T} / \mathrm{m}^{2}$ минимальное значение КЗУ составляет 1,21 . А при $P_{\text {бок }}=270 \mathrm{t} / \mathrm{M}^{2}$ и $\mathrm{C}^{\prime}=4 \mathrm{~T} / \mathrm{M}^{2}$ минимальное значение КЗУ $-2,05$.

К настоящему времени нет достоверных данных об уровне действующих напряжений в массиве пород Оленегорской группы месторождений. Этот вопрос требует дополнительных исследований. Можно сказать, что применение щадящей технологии постановки уступов на конечный контур сохраняет законтурный массив, что повышает его устойчивость [282].

Таким образом, установлено, что если массив пород не является обводненным, то участок борта карьера является устойчивым с КЗУ, ориентировочно равным 1,31. Если же рассматриваемый участок массива обводнен, то участок борта карьера недостаточно устойчив (значение КЗУ ориентировочно равно 1,04). Если в пределах прибортового участка массива пород действуют горизонтальные тектонические напряжения, соответствующие боковому отпору от веса вышележащих пород $\left(P_{\text {бок }}=270 \mathrm{~T} / \mathrm{M}^{2}\right)$, то при $\mathrm{C}^{\prime}=4 \mathrm{~T} / \mathrm{M}^{2}$ рассматриваемый участок борта карьера должен быть устойчивым.

Поэтому необходимо дополнительное изучение, с одной стороны, гидрогеологических условий месторождения, а с другой, - параметров напряженного состояния массива пород, так как, в конечном счете, эти факторы определяют устойчивость участков борта карьера. В качестве первоочередных мер, повышающих устойчивость борта карьера, следует выполнить осушение массива пород либо предотвратить его обводнение и применять щадящие 
технологии ведения взрывных работ. При этих условиях массив пород будет осушен, а прибортовая зона сохранена.

\subsubsection{3. Подходы к оценке устойчивости борта и уступов карьера «Олений ручей»}

Карьер «Олений ручей» функционирует около 10 лет, и за это время добыто более 10 млн т апатит-нефелиновой руды.

Основным структурным элементом, влияющим на формирование борта этого карьера, является Главный разлом. Он залегает со стороны лежачего бока рудного тела с простиранием на северо-восток и падением на северо-запад под углами 40-45. Главный разлом является основным фактором, контролирующим изменчивость параметров структурных неоднородностей массива пород в пределах карьерного поля. Поэтому борт карьера со стороны лежачего бока рудного тела отстраивается под углом падения Главного разлома, не пересекая его. Со стороны висячего бока рудного тела крупных эффективных структурных элементов в настоящее время не выявлено, что представляет возможность коррекции конечного контура карьера и необходимость оценки устойчивости этого участка его борта.

Для оценки устойчивости борта карьера со стороны висячего бока рудного тела использовано несколько методик, применение каждой из которых имеет под собой определенное основание.

\section{Оиенка устойчивости борта карьера}

в соответствии с «Методическим указаниям...» [277]

Для оценки устойчивости конечного контура карьера «Олений ручей» (рис. 6.64) выделены вертикальные разрезы (I, II, III), проходящие максимально перпендикулярно направлению борта карьера со стороны висячего бока рудного тела. Разрез I проходит через уступы опытно-промышленного участка (ОПУ).

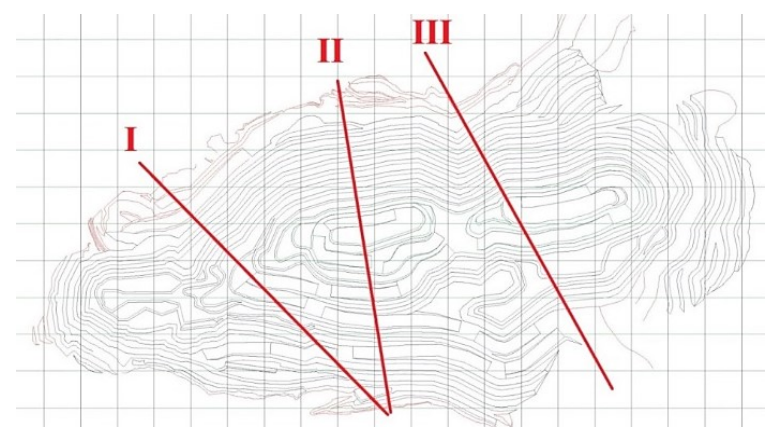

Рис. 6.64. Положение линии разреза (красная линия) на плане конечного контура карьера месторождения «Олений ручей»

В качестве исходных данных принимали:

- высота борта $H=150,270,330$ м (для I, II и III разрезов соответственно);

- угол откоса борта $\alpha=51,47$ и $49^{\circ}$ (для I, II и III разрезов соответственно);

- угол внутреннего трения $\varphi \approx 40^{\circ}$;

- сцепление $\mathrm{C}=1700 \mathrm{~T} / \mathrm{M}^{2}$;

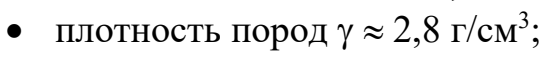

- коэффициент структурного ослабления $\lambda \approx 0,037$. 
На рисунке 6.65 показан пример расчетной схемы с потенциальной поверхностью скольжения круглоцилиндрической формы (для условий разреза I). Аналогичные расчетные схемы были построены для разрезов II и III.

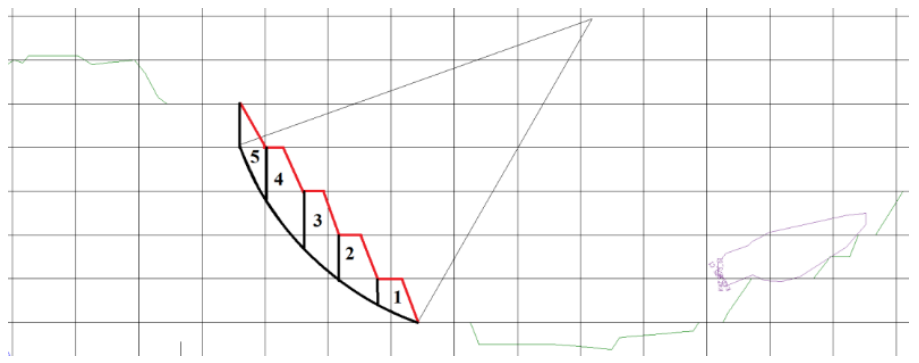

Рис. 6.65. Расчетная схема для разреза I

В результате, определены коэффициенты запаса для каждого разреза:

- разрез I; КЗУ разрез I $\approx 1,3$;

- разрез II; КЗУ разрез II $\approx 1,8$;

- разрез III; КЗУ разрез III $\approx 1,5$.

Таким образом, в результате расчетов, в соответствии с «Методическими указаниями...» [277], участок борта карьера «Олений ручей» является устойчивым.

Оиенка устойчивости борта карьера с использованием программного комплекса SVSlope $2 D$

Оценка проведена для того же участка борта карьера, находящегося со стороны висячего бока рудного тела в пределах ОПУ.

Исходные данные задавались такие же, как и при оценке устойчивости в соответствии с «Методическими указаниями...» [277].

На рисунке 6.66 приведена расчетная схема и результаты расчета устойчивости борта карьера применительно к условиям разреза I.

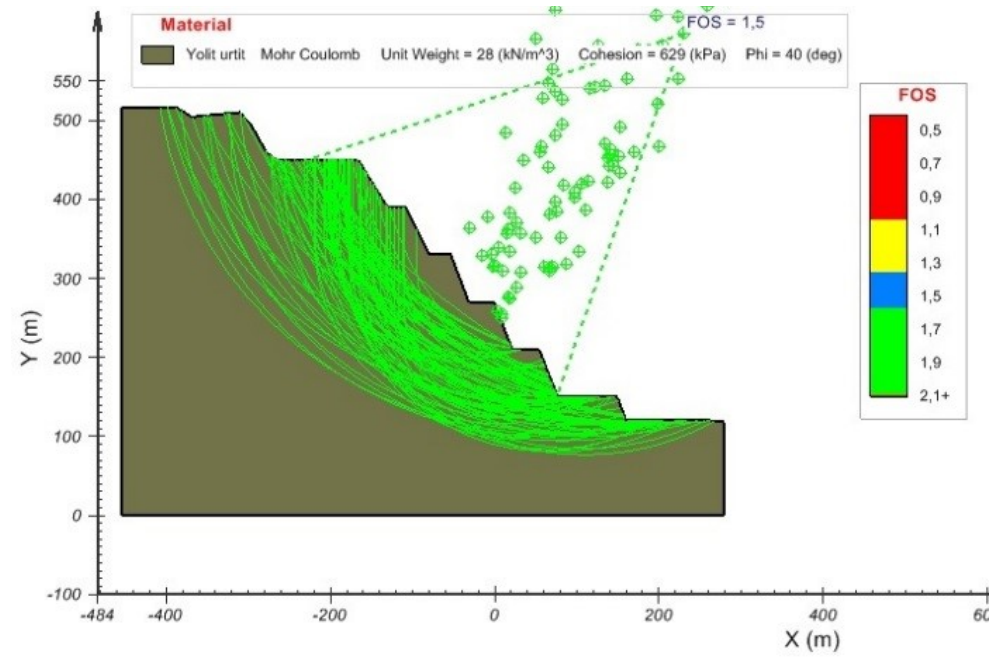

Рис. 6.66. Расчет устойчивости конечного контура борта карьера по разрезу I (участок со стороны лежачего бока рудного тела) с использованием программного комплекса SVSlope 2D: _ _ _ _ — плоскость ослабления; FOS — коэффициент запаса устойчивости 
В результате расчета по программе SVSlope 2D получено:

- Разрез I; КЗУ разрез I $\approx 1,5$;

- Разрез II; КЗУ разрез II $\approx 1,4$;

- Разрез III; КЗУ разрез III $\approx 1,3$.

Таким образом, по результатам расчетов по программе SVSlope 2D, участок борта карьера «Олений ручей» является устойчивым.

Оиенка устойчивости борта карьера в соответствии с методическим подходом ГоИ КНЦ РАН

В качестве исходных данных принимали:

- глубина карьера (высота борта) $H=300$ м;

- генеральный угол откоса карьерной выемки: 50, 55 и $60^{\circ}$ (три значения);

- объемный вес пород $\gamma=2,8$ т/м ${ }^{3}$;

- абсолютные значения горизонтальных напряжений $P_{\text {бок }}=0,3$ и 10 МПа (три значения);

- ширина выделяемого расчетного блока $b=500$ м;

- угол внутреннего трения по поверхностям ослабления $\varphi^{\prime}=24^{\circ}$;

- с сцепление по поверхностям ослабления $\mathrm{C}^{\prime}=0,0,1$ и 0,2 МПа (три значения).

Результаты оценки устойчивости борта карьера со стороны висячего бока залежи приведены в таблицах 6.21-6.23.

На основе выполненной оценки в соответствии с методическим подходом ГоИ КНЦ РАН можно сказать, что генеральный угол наклона борта карьера со стороны висячего бока рудной залежи может составить $55-60^{\circ}$ с КЗУ $\geq 1,3$ при условии отсутствия крупных структурных нарушений, подсекающих борт карьера.

Таким образом, в результате оценки устойчивости участка борта карьера со стороны висячего бока рудной залежи по различным методикам установлено следующее: во-первых, при генеральном угле наклона борта $\alpha \approx 51^{\circ} \mathrm{K} 3 \mathrm{~V}=1,3 \div 1,8$; во-вторых, при соблюдении необходимых условий существует резерв для повышения генерального угла наклона борта карьера в конечном положении до 55-60.

Таблица 6.21

Расчет коэффициентов запаса устойчивости при $\alpha=60^{\circ}, H=300 \mathrm{м} ; b=500 \mathrm{~m} ; \varphi^{\prime}=24^{\circ}$

\begin{tabular}{|c|c|c|c|c|c|c|c|c|c|}
\hline \multirow{3}{*}{$\begin{array}{c}\text { Угол падения структурного } \\
\text { нарушения ( } \beta), \text { град }\end{array}$} & \multicolumn{3}{|c|}{$P_{\text {бок }}=0 \mathrm{~T} / \mathrm{M}^{2}$} & \multicolumn{3}{|c|}{$P_{\text {бок }}=300 \mathrm{~T} / \mathrm{M}^{2}$} & \multicolumn{3}{|c|}{$P_{\text {бок }}=1000 \mathrm{~T} / \mathrm{M}^{2}$} \\
\hline & \multicolumn{3}{|c|}{$\mathrm{C}^{\prime}, \mathrm{T} / \mathrm{M}^{2}$} & \multicolumn{3}{|c|}{$\mathrm{C}^{\prime}, \mathrm{T} / \mathrm{M}^{2}$} & \multicolumn{3}{|c|}{$\mathrm{C}^{\prime}, \mathrm{T} / \mathrm{M}^{2}$} \\
\hline & 0 & 10 & 20 & 0 & 10 & 20 & 0 & 10 & 20 \\
\hline 1 & 25,51 & 27,70 & 29,90 & 36,44 & 38,64 & 40,83 & 61,95 & 64,15 & 66,34 \\
\hline 5 & 5,09 & 5,54 & 5,99 & 7,28 & 7,73 & 8,18 & 12,39 & 12,84 & 13,29 \\
\hline 10 & 2,52 & 2,76 & 3,00 & 3,62 & 3,86 & 4,10 & 6,19 & 6,42 & 6,66 \\
\hline 15 & 1,66 & 1,83 & 2,00 & 2,40 & 2,57 & 2,73 & 4,12 & 4,29 & 4,45 \\
\hline 20 & 1,22 & 1,36 & 1,49 & 1,78 & 1,92 & 2,05 & 3,08 & 3,22 & 3,35 \\
\hline 25 & 0,95 & 1,07 & 1,19 & 1,41 & 1,53 & 1,64 & 2,46 & 2,58 & 2,70 \\
\hline 30 & 0,77 & 0,88 & 0,99 & 1,15 & 1,26 & 1,38 & 2,04 & 2,15 & 2,27 \\
\hline 35 & 0,64 & 0,75 & 0,86 & 0,97 & 1,08 & 1,19 & 1,74 & 1,85 & 1,96 \\
\hline 40 & 0,53 & 0,65 & 0,76 & 0,83 & 0,94 & 1,06 & 1,52 & 1,64 & 1,75 \\
\hline 45 & 0,45 & 0,58 & 0,71 & 0,72 & 0,85 & 0,98 & 1,34 & 1,48 & 1,61 \\
\hline 50 & 0,37 & 0,55 & 0,72 & 0,62 & 0,80 & 0,97 & 1,20 & 1,38 & 1,55 \\
\hline 55 & 0,31 & 0,62 & 0,92 & 0,54 & 0,85 & 1,16 & 1,09 & 1,39 & 1,70 \\
\hline 59 & 0,27 & 1,66 & 3,06 & 0,80 & 1,13 & 1,47 & 1,24 & 1,58 & 1,92 \\
\hline
\end{tabular}


Таблица 6.22

Расчет коэффициентов запаса устойчивости при $\alpha=55^{\circ}, H=300 \mathrm{M}, b=500 \mathrm{M}, \varphi^{\prime}=24^{\circ}$

\begin{tabular}{|c|c|c|c|c|c|c|c|c|c|}
\hline \multirow{3}{*}{$\begin{array}{c}\text { Угол падения структурного } \\
\text { нарушения }(\beta), \text { град }\end{array}$} & \multirow{2}{*}{\multicolumn{3}{|c|}{$\begin{array}{c}P_{\text {бок }}=0 \mathrm{~T} / \mathrm{M}^{2} \\
\mathrm{C}^{\prime}, \mathrm{T} / \mathrm{M}^{2}\end{array}$}} & \multirow{2}{*}{\multicolumn{3}{|c|}{$\begin{array}{c}P_{\text {бок }}=30 \mathrm{~T} / \mathrm{M}^{2} \\
\mathrm{C}^{\prime}, \mathrm{T} / \mathrm{M}^{2}\end{array}$}} & \multirow{2}{*}{\multicolumn{3}{|c|}{$\begin{array}{c}P_{\text {бок }}=100 \mathrm{~T} / \mathrm{M}^{2} \\
\mathrm{C}^{\prime}, \mathrm{T} / \mathrm{M}^{2}\end{array}$}} \\
\hline & & & & & & & & & \\
\hline & 0 & 10 & 20 & 0 & 10 & 20 & 0 & 10 & 20 \\
\hline 1 & 25,51 & 27,71 & 29,91 & 36,44 & 38,64 & 40,84 & 61,95 & 64,15 & 66,35 \\
\hline 5 & 5,09 & 5,54 & 6,00 & 7,28 & 7,73 & 8,19 & 12,39 & 12,84 & 13,30 \\
\hline 10 & 2,52 & 2,77 & 3,01 & 3,62 & 3,86 & 4,11 & 6,19 & 6,43 & 6,67 \\
\hline 15 & 1,66 & 1,83 & 2,01 & 2,40 & 2,57 & 2,74 & 4,12 & 4,29 & $\overline{4,46}$ \\
\hline 20 & 1,22 & 1,36 & 1,51 & 1,78 & 1,92 & 2,06 & 3,08 & 3,22 & 3,37 \\
\hline 25 & 0,95 & 1,08 & 1,21 & 1,41 & 1,53 & 1,66 & 2,46 & 2,59 & 2,71 \\
\hline 30 & 0,77 & 0,89 & 1,01 & 1,15 & 1,27 & 1,39 & 2,04 & 2,16 & 2,29 \\
\hline 35 & 0,64 & 0,76 & 0,88 & 0,97 & 1,09 & 1,22 & 1,74 & 1,87 & 1,99 \\
\hline 40 & 0,53 & 0,67 & 0,81 & 0,83 & 0,97 & 1,11 & 1,52 & 1,66 & 1,80 \\
\hline 45 & 0,45 & 0,62 & 0,80 & 0,72 & 0,89 & 1,07 & 1,34 & 1,52 & 1,70 \\
\hline 50 & 0,37 & 0,68 & 1,00 & 0,62 & 0,93 & 1,24 & 1,20 & 1,51 & 1,83 \\
\hline 54 & 0,32 & 1,72 & 3,12 & 0,56 & 1,96 & 3,36 & 1,11 & 2,51 & 3,91 \\
\hline
\end{tabular}

Таблица 6.23

Расчет коэффициентов запаса устойчивости при $\alpha=50^{\circ}, H=300 \mathrm{M}, b=500 \mathrm{м} ; \varphi^{\prime}=24^{\circ}$

\begin{tabular}{|c|r|r|r|r|r|r|r|r|r|}
\hline \multirow{2}{*}{$\begin{array}{c}\text { Угл падения структурного } \\
\text { нарушения ( } \beta \text { ), град }\end{array}$} & \multicolumn{3}{|c|}{$P_{\text {бок }}=0 \mathrm{~T} / \mathrm{M}^{2}$} & \multicolumn{3}{c|}{$P_{\text {бок }}=300 \mathrm{~T} / \mathrm{M}^{2}$} & \multicolumn{3}{c|}{$P_{\text {бок }}=1000 \mathrm{~T} / \mathrm{M}^{2}$} \\
\cline { 2 - 11 } & \multicolumn{3}{|c|}{$\mathrm{C}^{\prime}, \mathrm{T} / \mathrm{M}^{2}$} & \multicolumn{3}{c|}{$\mathrm{C}^{\prime}, \mathrm{T} / \mathrm{M}^{2}$} & \multicolumn{3}{c|}{$\mathrm{C}^{2}$} \\
\cline { 2 - 10 } & \multicolumn{1}{|c|}{0} & 10 & 20 & 0 & 10 & 20 & 0 & 10 & 20 \\
\hline 1 & 25,51 & 27,71 & 29,91 & 36,44 & 38,64 & 40,85 & 61,95 & 64,15 & 66,36 \\
\hline 5 & 5,09 & 5,55 & 6,01 & 7,28 & 7,74 & 8,20 & 12,39 & 12,85 & 13,31 \\
\hline 10 & 2,52 & 2,77 & 3,02 & 3,62 & 3,87 & 4,12 & 6,19 & 6,43 & 6,68 \\
\hline 15 & 1,66 & 1,84 & 2,02 & 2,40 & 2,58 & 2,76 & 4,12 & 4,30 & 4,48 \\
\hline 20 & 1,22 & 1,37 & 1,52 & 1,78 & 1,93 & 2,08 & 3,08 & 3,23 & 3,38 \\
\hline 25 & 0,95 & 1,09 & 1,23 & 1,41 & 1,54 & 1,68 & 2,46 & 2,60 & 2,73 \\
\hline 30 & 0,77 & 0,91 & 1,04 & 1,15 & 1,29 & 1,42 & 2,04 & 2,18 & 2,31 \\
\hline 35 & 0,64 & 0,78 & 0,93 & 0,97 & 1,12 & 1,26 & 1,74 & 1,89 & 2,04 \\
\hline 40 & 0,53 & 0,72 & 0,90 & 0,83 & 1,01 & 1,20 & 1,52 & 1,71 & 1,89 \\
\hline 45 & 0,45 & 0,76 & 1,08 & 0,72 & 1,03 & 1,35 & 1,34 & 1,66 & 1,98 \\
\hline 49 & 0,39 & 1,79 & 3,20 & 0,64 & 2,04 & 3,45 & 1,23 & 2,63 & 4,04 \\
\hline
\end{tabular}

Подход к оиенке устойчивости карьерных уступов

исходя из объемов возможных вывалов (на примере карьера «Олений ручей»)

Оценку устойчивости карьерных уступов можно проводить исходя из анализа мощности нарушенной зоны и данных о естественной трещиноватости массива.

На основе натурных исследований геомеханического состояния прибортового массива прочных скальных пород в районе опытно-промышленного участка карьера «Олений ручей» выделены три зоны его техногенной деструкции и определены их количественные характеристики: первая зона - сильно разрушенные породы (массив полностью разбит); вторая зона - слабо- и средненарушенный массив (2-6 трещин на метр); третья зона - ненарушенный массив (0-2 трещины на метр) (рис. 6.67). 


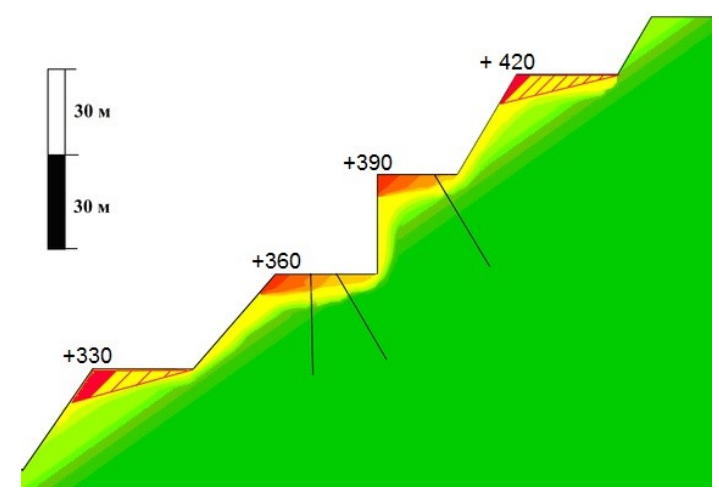

Рис. 6.67. Степени техногенной деструкции борта на опытно-промышленном участке карьера «Олений ручей». Красный цвет - первая зона техногенной деструкции (красным заштриховано вероятное положение данной зоны на гор. +330 и +420 м); желтый — слабая и средняя зона техногенной деструкции; зеленый — ненарушенный массив

Исходя из определенных зон техногенной деструкции можно сделать вывод о том, что мощность нарушенной зоны (нарушенная зона закрашена красным и желтым цветами на рис. 6.67) составляет ориентировочно 3 м.

Предложена схема формирования потенциальных вывалов (рис. 6.68).

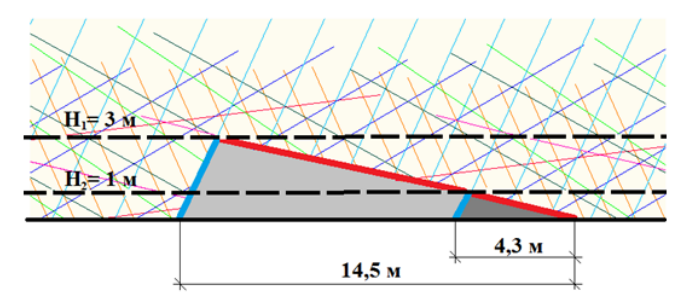

$a$

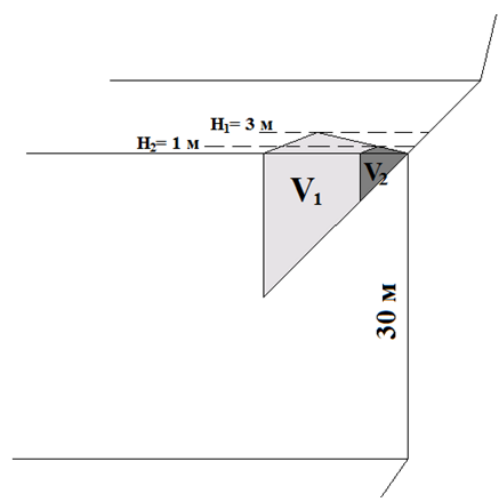

$\sigma$

Рис. 6.68. Схема формирования потенциальных вывалов при различной мощности нарушенной зоны (для условий ОПУ карьера «Олений ручей»): $a-$ план уступа с нанесенными системами трещин; $\sigma$ - объемная схема формирования потенциального вывала; - системы трещин; $H_{1}$ и $H_{2}$ - мощность нарушенной зоны 1 и 3 м соответственно; $V_{1}$ и $V_{2}$ - объем возможного вывала при мощности нарушенной зоны 1 и 3 м соответственно

Установлена эмпирическая зависимость между объемом потенциального вывала и мощностью нарушенной зоны в виде:

$$
V=k \times H^{3},
$$

где $V$ - объем потенциального вывала, ${ }^{3} ; H$ - мощность нарушенной зоны, м; $k$ - эмпирический коэффициент (для условий ОПУ карьера «Олений ручей» $k \approx 3,84$ ). 
Задокументированный вывал (рис. 6.69), произошедший в середине октября 2015 г. после взрыва строчки из 30 скважин в пределах ОПУ, имеет объем $V \approx 150 \div 300 \mathrm{~m}^{3}$, что в первом приближении говорит о сходимости полученной схемы формирования вывалов и эмпирической зависимости. Например, если принять мощность нарушенной зоны для участка, на котором произошел вывал, равной 4 м, то объем вывала, в соответствии с представленной эмпирической зависимостью, составит около $250 \mathrm{~m}^{3}$.

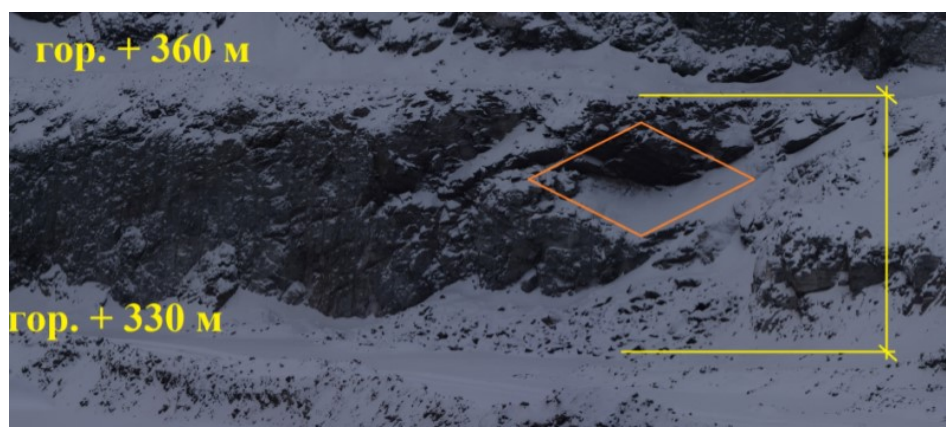

Рис. 6.69. Вид вертикального уступа на ОПУ карьера «Олений ручей» от 23.11 .2015 г.: $>$ - вывал

Необходимо отметить, что вывал произошел на участке, где поверхность уступа находилась в достаточно нарушенном состоянии, а его форма напоминает пирамиду с ромбовидным основанием. Это говорит о том, что он образован не только по существующей природной системе трещин, но и по техногенной трещине, образованной, скорее всего, в результате проведения БВР.

Таким образом, для предотвращения крупных вывалов с поверхности уступа необходимо тщательно соблюдать и постоянно совершенствовать методы БВР. Уменьшение мощности нарушенной зоны до 1 м исключит вывалы объемом более первых кубометров, что в свою очередь позволит устранить их путем механизированной зачистки и обеспечить устойчивость карьерных уступов и надлежащий уровень безопасности открытых горных работ.

\subsubsection{4. Развитие комплексной методики прогноза устойчивости бортов карьеров}

По результатам выполненных исследований предложена комплексная методика прогноза устойчивости борта глубокого карьера, в соответствии с которой оценка устойчивости борта начинается с анализа инженерно-геологической модели прибортового массива пород и формирования расчетной геомеханической схемы потери устойчивости участка борта. На этом этапе основным является определение того, подсечен участок борта карьера эффективным структурным нарушением или не подсечен. Если борт карьера подсечен эффективным структурным нарушением, то в этом случае оценка его устойчивости выполняется по методике с учетом действия горизонтальных тектонических напряжений. В случае, если коэффициент запаса устойчивости участка борта карьера меньше, чем его нормативно заданное значение, возможна потеря устойчивости участка борта путем сдвига блоков пород по эффективному структурному нарушению, подсекающему борт. Если критерий устойчивости выполняется, тогда проводят расчеты НДС прибортового массива пород в окрестности карьерной выемки. 
Сущность предложенной методики состоит в анализе получаемой с использованием численного моделирования картины распределения напряжений и деформаций в прибортовом массиве пород. При этом используются три критерия опасной ситуации в соответствии с тремя рассматриваемыми компонентами напряжений - максимальной и минимальной компонентами главных напряжений $\left(\sigma_{\max }, \sigma_{\min }\right)$ и максимальными касательными напряжениями $\left(\tau_{\max }\right)$. Полагается, что потеря устойчивости участком прибортового массива пород возможна при реализации одного из следующих критериев.

При ревышении минимальной компонентой главных напряжений $\left(\sigma_{\min }\right)$ предела прочности при растяжении $\left(\sigma_{\min }>\sigma_{p}\right)$ возможно раскрытие природных или формирование техногенных трещин.

При превышении максимальными касательными напряжениями $\left(\tau_{\max }\right)$ предела прочности на сдвиг с учетом нормативно заданного коэффициента запаса устойчивости вероятен сдвиг блоков пород по природным и техногенным трещинам.

При превышении максимальной компонентой главных напряжений $\left(\sigma_{\max }\right)$ $50 \%$ предела прочности на одноосное сжатие пород $\left(\sigma_{\text {сж }}\right)$, слагающий рассматриваемый участок борта $\left(\sigma_{\max } \geq 0,5 \sigma_{\text {сж }}\right)$ вероятно разрушение участка массива пород в динамической форме.

Эта методика удовлетворительно описывает возможность формирования в борту карьера ситуации, опасной с точки зрения потери устойчивости участками массива пород, и с ее помощью можно достаточно надежно выявить потенциально опасные участки возможных обрушений.

Блок-схема методики прогноза устойчивости участков борта карьера показана на рисунке 6.70 .

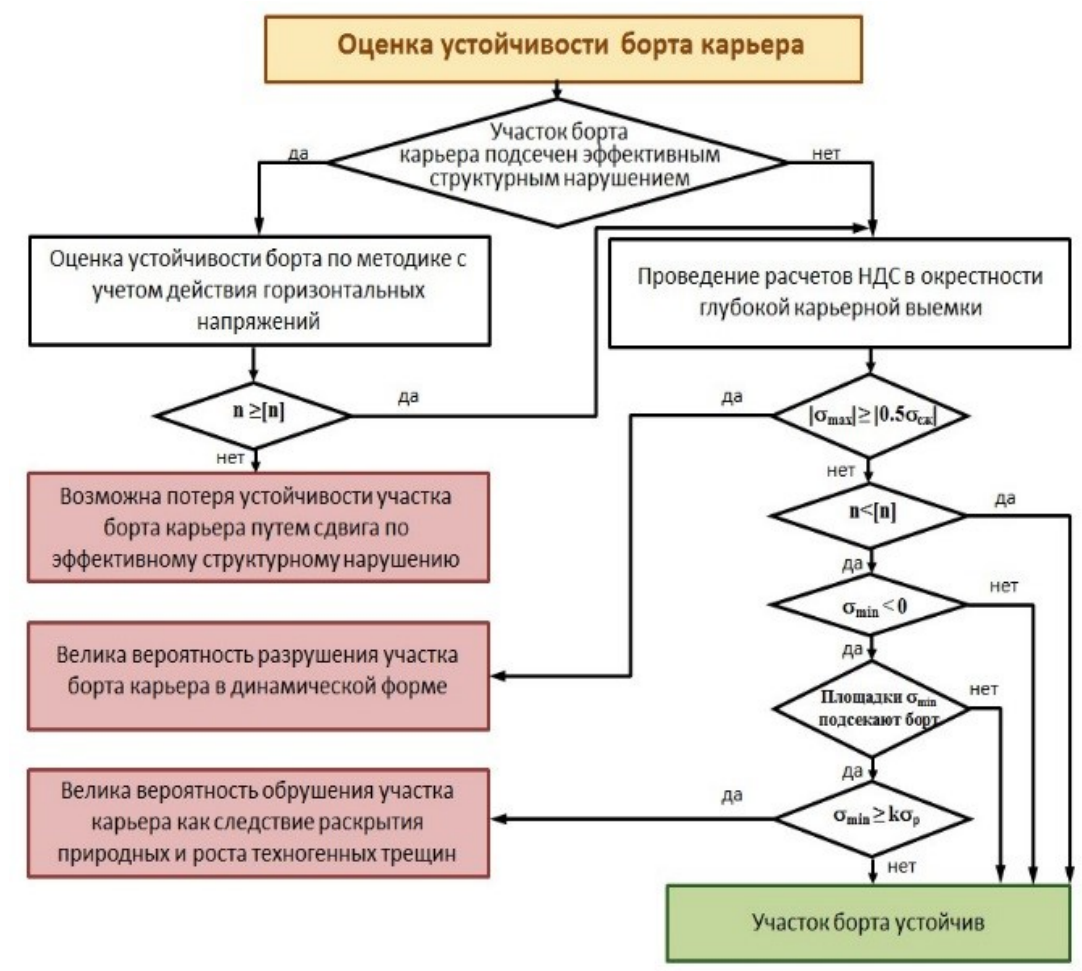

Рис. 6.70. Блок-схема комплексной методики прогноза устойчивости участков борта карьера 
Мы радуемся, постигая истину. Если же радости нет, это означает, что мы только знакомы с истиной, но не сумели постичь ее.

P. Tагор

\section{ЗАКЛЮЧЕНИЕ}

Обеспечение геодинамической безопасности при ведении горных работ в высоконапряженных массивах скальных пород по-прежнему остается одной из актуальных проблем современной горной науки и практики. Ощутимые результаты в решении этой проблемы могут быть достигнуты только комплексом аналитических и экспериментальных методов, некоторые результаты использования которых приведены в настоящей монографии.

Общесистемные законы и закономерности детерминируют методологию решения этой проблемы: создание инженерно-геологических моделей объектов недропользования - геомеханический мониторинг геологической среды горно-технических систем - изучение процессов трансформации напряженно-деформированного состояния пород в массиве на всех стадиях освоения месторождения методами численного моделирования и верификация этих моделей натурными определениями - выявление основных опасностей и оценка рисков - разработка мероприятий по управлению геодинамическими рисками.

На основе многолетних исследований разработана концепция организации комплексного геодинамического мониторинга геологической среды в горнотехнических системах, основанная на иерархично-блочной модели среды и решении основных методических и технических вопросов. Концепция имеет универсальный характер и может быть использована в горнотехнических условиях других месторождений, где геологическая среда представлена высокопрочными породами с широко развитыми структурными неоднородностями различного порядка.

Впервые в России создана и функционирует сейсмоакустическая система контроля устойчивости бортов карьера. На основе анализа параметров сейсмичности в прибортовом массиве карьера «Железный» Ковдорского ГОКа предложены методические подходы к оценке устойчивости бортов по параметрам сейсмической эмиссии, наиболее интересным в которых представляется выявление «фантомных» структур и оценка уровня их последующей реализации и соответствующей активности.

Получила дальнейшее развитие система сбора и анализа разнородной геофизической информации, апробация которой выполнена в наклономерно-деформометрическом комплексе на Кировском руднике КФ АО «Апатит».

Получена новая информация о параметрах полей напряжений в геологической среде горнотехнических систем апатитовых рудников: в горнотехнической системе «Олений ручей» величина напряжений на глубине от дневной поверхности около 400 м составляет 30-40 МПа, что подтверждает ранее выполненный прогноз на стадии разведки этого месторождения в 1985 г.; в горнотехнической системе Кировского рудника КФ АО «Апатит» на глубине 550 м величина наибольшего напряжения составляет около 20-30 МПа, а на глубине 550 м - около 40 МПа. Результаты этих измерений использованы при составлении методических руководств для рудников по вопросам крепления выработок и обеспечению безопасности горных работ. 
Выявлены сейсмические индикаторы геодинамического риска, на основе которых разработана методика оперативного пространственно-временного прогноза критических участков геологической среды, опасных по динамическим проявлениям горного давления типа горных ударов и техногенных землетрясений. Методика в настоящее время проходит апробацию на апатитовых рудниках.

На основе выявленных закономерностей увеличения на порядок и более суммарной сейсмической энергии от объема водопритоков в весенний и осенний периоды в горных выработках Кировского и Расвумчоррского рудников КФ АО «Апатит» и установленных критических значений предвестников (уровень водопритоков и высота снежного покрова) сильных сейсмических событий $(\geq 106$ Дж) разработана методика прогноза опасных периодов сейсмоактивности массива горных пород, заключающаяся в учете степени влияния метеорологических и гидрогеологических факторов на его сейсмический режим, разработана программная система, реализующая методику и применяемая в настоящее время в КФ АО «Апатит».

Многолетний геомеханический мониторинг, главным образом методами традиционной и спутниковой геодезии и регистрации параметров сейсмической эмиссии, показал, что в геологической среде горнотехнических систем КФ АО «Апатит» и АО «Ковдорский ГОК» идут активные процессы геомеханической самоорганизации, определяемые эволюцией ее напряженно-деформированного состояния под влиянием техногенных (крупномасштабные горные работы), эндогенных (неотектонические процессы) и экзогенных (метеорологические явления) факторов.

Наблюдаемыми отражениями этой самоорганизации являются техногенные деформации и достаточно мощные потоки сейсмической эмиссии, на фоне которой периодически происходят сильные динамические явления типа горных ударов и техногенных землетрясений.

Впервые определены основные количественные параметры самоорганизации иерархично-блочной геологической среды: дополнительных напряжений и деформаций, удельной энергии деформирования и некоторые характеристики переупаковки (вращения) структурных блоков.

Разработаны аналитические объяснительные модели эволюции иерархично-блочной геологической среды, которые показывают, что разрушение горных пород начинается в наиболее энергонасьщенных блоках, то есть на уровне более мелких и менее жестких блоков, что объясняет тот факт, что динамические события в геологической среде приурочены преимущественно к разломным зонам, представленным раздробленными и шпреуштейнизированными породами.

Предложен механизм разрушения трещиноватой геологической среды, который заключается в том, что в условиях действия сжимающих усилий в массиве пород по плоскостям ослабления (трещины различной степени заполнения, границы контактирующих блоков, разломы и т. п.) происходят значительные тангенциальные перемещения берегов разрывов друг относительно друга, при этом в концевых областях трещин возникают зоны растягивающих напряжений, ориентированных, как правило, перпендикулярно границам трещин (разломов), в результате действия которых при превышении ими предела прочности на разрыв возникают вторичные трещины, направленные ортогонально исходным, что приводит к «вспарыванию» барьерных перемычек между трещинами с образованием новых блоков различных масштабов. При этом наличие в массиве чисто сдвиговых напряжений является 
наиболее неблагоприятным в смысле устойчивости трещиноватых пород, так как предельные величины сдвигающих усилий на границе массива с трещинами, приводящие к его разрушению, составляют $(0,25-0,3)$ б разрушения пород в массиве при сдвиге наступают при действующих напряжениях в 2 раза меньших, чем при сжатии.

Разработаны новые математические модели закономерностей разрушения горных пород на границах раздела блоков с различными трещинами, которые могут быть полезными для оценки возможности обрушения подработанных толщ пород и для объяснения форшоковых явлений при подготовке сильных землетрясений.

Создана геомеханическая модель Хибинского массива, позволяющая рассматривать отработку комплекса сближенных месторождений и определять порядок и направление развития горных работ в удароопасных условиях с учетом вложенной кольцевой структуры массива, направления тектонического сжатия, основных радиальных разломов, рельефа дневной поверхности, параметров рудных тел. Установлены особенности напряженно-деформированного состояния Хибинского массива, подтверждающие гипотезу трансформации типа НДС с глубиной и переориентировку главных напряжений в блоках массива между радиальными разломами. Определены абсолютные высотные отметки $-1000 \div-1200$ м, ниже которых вертикальные напряжения превалируют над горизонтальными.

Таким образом, можно утверждать, что все разведанные запасы Хибинской апатитовой дуги будут отрабатываться в условиях выраженного тектонического сжатия пород. Полученные результаты могут быть использованы при проектировании отработки аналогичных сближенных месторождений.

Численным моделированием установлена квадратичная зависимость размеров зоны разрушения вокруг выработки от глубины ее заложения в тектонически напряженном массиве с минимумом на глубине около 1500 м.

Разработаны прогностические модели напряженно-деформированного состояния геологической среды природно-техногенных систем «Ловозеро» и «Хибины», на основе которых для рудника «Карнасурт» Ловозерского ГОКа показана возможность увеличения ширины очистных выработок по простиранию рудной залежи для системы разработки с регулярными внутриблоковыми циклами до величины 120 м, а также дано геомеханическое обоснование параметров камерно-целиковой системы разработки перспективного апатит-нефелинового месторождения «Партомчорр».

Обоснованы с применением комплекса натурных и численных методов параметры опережающей разгрузочной зоны для глубоких горизонтов Кукисвумчоррского месторождения при их отработке системами этажного обрушения с траншейным днищем и подэтажного обрушения. Показаны преимущества системы с подэтажным обрушением, обеспечивающей больший эффект защиты массива пород от действия высоких тектонических напряжений при меньшей пригрузке пород висячего бока за счет ступенчатого фронта опережающей выемки и меньшей изрезанности днища.

Выполнено обоснование технологии, технико-экономическая и геомеханическая оценка возможности рентабельной и безопасной отработки фланговой части месторождения «Суолуайв», принадлежащего КФ АО «Апатит», горными работами со стороны месторождения «Олений ручей» с увеличением прибыли от разработки на $220 \%$ при сокращении продолжительности отработки на $18 \div 23$ лет. 
Как известно, наиболее мощным триггером для техногенной сейсмичности являются взрывные работы, особенно массовые взрывы при очистной отбойке. Однако этот триггерный эффект по-разному проявляется на различных участках массива. Установлено, что после массового взрыва общее количество сейсмических событий увеличивается, но их суммарная энергия уменьшается, что свидетельствует об активном трещинообразовании и соответствующей релаксации напряжений в массиве горных пород.

Выявлены некоторые закономерности проявления сейсмичности в окрестности самого взрыва и очистного пространства, очередность и временные интервалы их реализации. Непосредственно в зоне действия массового взрыва формируется несколько очаговых зон сейсмичности с определенной последовательностью и цикличностью их проявления. Наиболее интенсивно сейсмические события проявляются, как правило, в границах наиболее ослабленных структурных блоков - в консоли необрушенных пород и в разломных зонах, а также вблизи границ отбиваемых секций. Параметры цикличности триггерной сейсмичности в различные периоды отработки месторождения могут быть использованы для среднесрочного прогноза мощных динамических явлений.

Установлена четкая зависимость геодинамической опасности от режима ведения взрывных работ при очистной выемке. Практически доказано, что изменением режима взрывных работ можно уменьшить уровень техногенной сейсмичности, что подтверждается фактами роста числа событий с меньшими энергиями. Такой эффект является экспериментальным подтверждением предлагаемому в сейсмологии способу предупреждения мощного землетрясения серией наведенных маломощных событий. В этом контексте можно рассматривать положительное влияние взрывных работ, а также процессов снеготаяния и водопритоков на активизацию релаксационных процессов в массиве горных пород, которые нивелируют геодинамическую ситуацию известным эффектом «потряхивания».

Впервые в условиях горнотехнических систем апатитовых рудников определена величина индивидуального геодинамического риска, которая оказалась существенно ниже самых строгих международных норм, что является объективным свидетельством эффективности профилактических противоударных мероприятий и достаточно высокой культурой производства. Показано, что в этих условиях геодинамический риск имеет характер технологического риска, поэтому наиболее актуальной является задача управления риском, а не оценка его величины, которая может быть представлена вербальными характеристиками.

На основе результатов исследований разработан ряд инструктивно-методических документов, например:

«Указания по безопасному ведению горных работ на месторождениях, склонных и опасных по горным ударам (Хибинские апатит-нефелиновые месторождения)», Апатиты-Кировск, 2015 г.;

«Указания по безопасному ведению горных работ на месторождениях, склонных и опасных по горным ударам (месторождение “Олений ручей”)», Апатиты-Кировск, 2015 г.;

«Указания по безопасному ведению горных работ на месторождении, склонном и опасном по горным ударам (Ловозерское месторождение, ООО “Ловозерский ГОК”)», 2015 г.; 
«Инструкция по креплению горных выработок на месторождении апатит-нефелиновых руд “Олений ручей”», Апатиты - Кировск, 2015 г.

Вышеупомянутые документы периодически обновляются по мере получения новой информации о состоянии геологической среды и последними достижениями в методологии геомеханического обеспечения технологии разработки месторождений.

Однако, несмотря на интенсивные и широкомасштабные исследования, актуальность проблемы обеспечения геодинамической безопасности не уменьшается, о чем свидетельствуют периодически происходящие мощные динамические события в геомеханических пространствах рудников. И эти угрозы будут нарастать по мере увеличения машстабов горных работ, роста их глубины и соответствующего усложнения горно-геологических условий. Поэтому исследования по развитию методологии управления геодинамическими рисками продолжаются. При этом основное внимание следует уделить энергонасыщенности - важнейшему геомеханическому параметру геологической среды в горнотехнических системах. Выявление новых закономерностей формирования и миграции энергонасыщенных зон в геологической среде горнотехнических систем под влиянием техногенных и экзогенных факторов, определение условий достижения ими критических параметров и разработка способов их нейтрализации будут основными задачами в целях геомеханического обеспечения безопасной и экономически эффективной разработки полезных ископаемых в любых горно-геологических условиях. 


\section{ЛИТЕРАТУРА}

1. Родионов В. Н., Шемякин Е. И. Горное производство: фундаментальные проблемы сохранения среды обитания // Вестник АН СССР. 1990. № 2. С. 26-33.

2. Мельников Н. Н. Экологические проблемы XXI века и освоение недр // Освоение недр и экологические проблемы XXI века - взгляд в XXI век. М.: Академия горных наук, 2001. С. 26-45.

3. Козырев А. А., Панин В. И. Эволюция геомеханических исследований в Горном институте КНЦ РАН в период 1961-2011 гг. // Вестник КНЦ РАН. 2012. № 4. С. 83-95.

4. Гзовский М. В. Основы тектонофизики. М.: Наука, 1975. С. 536.

5. Турчанинов И. А., Панин В. И. Геофизические методы определения и контроля напряжений в массиве. Л.: Наука, 1976. С. 164.

6. Марков Г. А. Тектонические напряжения и горное давление в рудниках Хибинского массива. Л.: Наука, 1977. С. 231.

7. Турчанинов И. А., Марков Г. А., Иванов В. И., Козырев А. А. Тектонические напряжения в земной коре и устойчивость горных выработок. Л.: Наука, 1978. C. 256.

8. Марков Г. А., Савченко С. Н. Напряженное состояние пород и горное давление в структурах гористого рельефа. Л.: Наука, 1984. С. 140.

9. Zoback Mary Lou, Zobark Mark D., Amadei Y. et al. Global patterns of tectonic stress // Nuture. 1989. Vol. 341, no. 6240. P. 291-298.

10.Козырев А. А., Панин В. И., Иванов В. И. и др. Управление горным давлением в тектонически напряженных массивах. Апатиты: КНЦ РАН, 1996. Ч. 1. С. 159. Ч. 2. С. 162.

11.Козырев А. А., Панин В. И., Савченко С. Н. и др. Сейсмичность при горных работах. Апатиты: КНЦ РАН, 2002. С. 325.

12.Техногенная сейсмичность при горных работах: модели очагов, прогноз, профилактика. Апатиты: КНЦ РАН, 2004. Ч. 1. С. 225. Ч. 2. С. 197.

13. Kozyrev A. A., Maltsev V. A., Panin V. I., Rybin V. V., Svinin V. S. Dynamical manifestations of rock pressure and mining-induced seismicity at Khibiny apatite mines in the Kola Peninsula // Controlling seismic risk: proceedings of the $6^{\text {th }}$ International Symposium on Rockburst and Seismicity in Mines. Australia: CSIRO, 2005. P. 567-573.

14. Kozyrev A. A., Panin V. I., Fedotova Iu. V., Pugachev S. S., Korchak P. A. Kola Peninsula mines induced seismicity and secure development of rockburst hazardous deposits // Proceeding of the $8^{\text {th }}$ International Symposium on Rockbursts and Seismicity in Mines (RaSiM 8). Geophysical Survey of RAS, Mining Institute UB RAS. Moscow-Perm, 2013. P. 495-500.

15.Шахраманьян М. А. Оценка сейсмического риска и прогноз последствий землетрясений в задачах спасения населения (теория и практика). М.: ВНИИ ГОЧС, 2000. С. 190;

16.Niroo Kanamori Earthquake Prediction: On Overview // International Handbook of Earthquake and Engineering Seismology. London: Academic Press, 2003. Part B. P. $1205-1216$.

17.Кондратьев О. К. Прогноз землетрясений. Причины неудач и пути решения проблемы // Оценка и управление природными рисками. Сб. материалов Всероссийской конференции «Риск-2003». М.: РУДН, 2003. Т. 1. С. 148-152. 
18. Любушин А. А. Геодинамический мониторинг: шумы, сигналы, предвестники // Проблемы геофизики XXI века. М.: Наука, 2003. Кн. 2. С. 70-94.

19.Соболев Г. А. Концепция предсказуемости землетрясений на основе динамики сейсмичности при триггерном воздействии. М.: ИФЗ РАН, 2011.

20.Эбелинг В. Образование структур при необратимых процессах. Введение в теорию диссипативных структур. М.: Мир, 1979. С. 279.

21.Мельников Н. Н., Козырев А. А., Савченко С. Н., Панин В. И., Мальцев В. А. Прогноз и профилактика горно-тектонических ударов и техногенных землетрясений с позиций нелинейной геодинамики // ФТПРПИ. 2001. № 4. С. 17-30.

22.Соболев Г. А. Методология, результаты и проблемы прогноза землетрясений // Вестник РАН. 2015. Т. 85, № 3. С. 203-208.

23. Соболев Г. А. Сейсмический шум. М.: ООО «Наука и образование», 2014. С. 272.

24.Шуман В. Н. О прогнозе и прогнозируемости сейсмического процесса // Геофизический журнал. 2014. Т. 36, № 3. С. 48-68.

25.Шерман С. И. Сейсмический процесс и прогноз землетрясений: тектонофизическая концепция. Новосибирск: ГЕО, 2014. С. 359.

26.Панин В. И. К прогнозу сейсмической опасности при разработке удароопасных месторождений // Геомеханика при ведении горных работ в высоконапряженных массивах. Апатиты: КНЦ РАН, 1998. С. 66-73.

27.Козырев А. А., Панин В. И., Мальцев В. А., Федотова Ю. В. Управление геодинамическими рисками в высоконапряженных массивах скальных пород // Горное дело в Арктике. СПб.: Изд. «Иван Федоров», 2005. С. 62-69.

28.Гольдин С. В. Дилатансия, переупаковка и землетрясения // Физика Земли. 2004. № 10. С. 37-54.

29. Чиков Б. М. Введение в физические основы статической и динамической геотектоники. Новосибирск: Гео, 2011. С. 299.

30.Пономарев В. С. Энергонасыщенность геологической среды. М.: Наука, 2008. C. 379.

31.Селье Г. На уровне целого организма. М.: Наука, 1972. С. 122.

32.Моисеев Н. Н. Расставание с простотой. М.: Аграф, 1998. С. 480.

33.Козырев А. А., Панин В. И., Свинин В. С. Геодинамическая безопасность при разработке рудных месторождений в высоконапряженных массивах // Горный журнал. 2010. № 9. С. 40-43.

34.Перламуттер Д. Зарядите свой мозг. М.: Эксмо, 2012. С. 320.

35.Арнольд В. И. Теория катастроф. 3-е изд. М.: Наука, 1990. С. 128.

36.Ломакин Е. В., Полилов А. Н. Наследственность в науке и в жизни // Вестник PAH. 2014. T. 84. № 4. C. 360-364.

37.Бехман В. Г. Современное общество как общество риска // Вопросы философии. 2007. № 1. С. 22-46.

38. Бернстайн П. Л. Против богов. Укрощение риска. М.: Олимп-Бизнес, 2000. С. 380.

39.Козырев А. А., Панин В. И., Мальцев В. А., Федотова Ю. В. Управление геодинамическими рисками при ведении горных работ в высоконапряженных массивах скальных пород // Оценка и управление природными рисками. Сб. материалов Всероссийской конференции «Риск - 2006». М.: РУДН, 2006. T. 2. C. $306-308$.

40.Козырев А. А., Панин В. И., Семенова И. Э. Практика управления геодинамическими рисками на Хибинских рудниках Кольского полуострова // Проблемы снижения природных опасностей и рисков / «Геориск - 2009»: сб. научн. тр. М.: РУДН, 2009. Т. 2. С. 270-276. 
41.Козырев А. А., Панин В. И., Федотова Ю. В., Семенова И. Э. Журавлева О. Г. Управление геодинамическими рисками в горнотехнических системах // Проблемы снижения природных опасностей и рисков: матер. Междунар. науч.-практ. конф. «Геориск - 2012». М.: РУДН, 2012. Т. 2. С. 161-166.

42. Козырев А. А., Панин В. И., Семенова И. Э. Геомеханическое моделирование для оценки и управления геодинамическими рисками при разработке удароопасных месторождений // Анализ, прогноз и управление природными рисками в современном мире. Материалы IX Междунар. науч.-практич. конф. «Геориск - 2015» М.: РУДН, 2015. Т. 2 С. 203-209.

43.Федотова Ю. В., Панин В. И. Структура геодинамического риска при разработке опасных по горным ударам месторождений (на примере Хибинских апатитовых рудников) // Анализ, прогноз и управление природными рисками с учетом глобального изменения климата. Материалы X Междунар. науч.-практич. конф. «Геориск - 2018». М.: РУДН, 2018. Т. 2. С. 136-140.

44.Мельников Н. Н., Козырев А. А., Панин В. И. и др. Разработка научных основ оценки риска геодинамических явлений при крупномасштабной отработке месторождений полезных ископаемых на больших глубинах // Комплексное освоение недр: перспективы расширения минерально-сырьевой базы России (программа ОНЗ-3). М.: ИПКОН РАН, 2009. Р. 2.2. С. 156-184.

45.Шокин Ю. И., Махутов Н. А. Москвичев В. В., Шабанов В. Ф. Проблемы природно-техногенной безопасности регионов Сибири // Всероссийский экономический журнал (ЭКО). 2003. № 8. С. 31-48.

46.Арсентьев А. И. Шпанский О. В., Константинов Г. П., Бложе В. Л. Определение главных параметров карьера. М.: Недра, 1976. С. 213.

47. Козырев А. А., Панин В. И., Савченко С. Н. и др. Определение закономерностей эволюции напряженно-деформированного состояния геологической среды в горнотехнических системах для повышения безопасности горных работ // Комплексное освоение недр Земли: новые методы разработки и обогащения многокомпонентных руд и углей в условиях кризиса. М.: УРАН ИПКОН РАН, 2011. Г. 6. Р. 6.2. С. 195-206.

48. Мельников Н. Н., Козырев А. А., Панин В. И. и др. Разработка геомеханических основ эффективного освоения месторождений полезных ископаемых открытым способом с учетом природных и техногенных факторов в горнотехнических системах // Развитие ресурсосберегающих и ресурсовоспроизводящих геотехнологий комплексного освоения месторождений полезных ископаемых. М.: ИПКОН РАН, 2012. Г. 3. Р. 3.2. С. 138-150.

49.Козырев С. А., Власова Е. А., Соколов А. В., Браунштейн А. А., Сакерин А. С. Разработка и научное обоснование эффективных взрывных технологий при освоении месторождений минерального сырья на больших глубинах с использованием эмульсионных взрывчатых веществ // Развитие ресурсосберегающих и ресурсовоспроизводящих геотехнологий комплексного освоения месторождений полезных ископаемых. М.: ИПКОН РАН, 2014. Г. 2. Р. 2.2. С. 87-107.

50.Козырев А. А., Савченко С. Н., Панин В. И. и др. Разработка способов управления напряженно-деформированным состоянием иерархично-блочных массивов горных пород для обеспечения безопасности и эффективности горных работ // Развитие ресурсосберегающих и ресурсовоспроизводящих геотехнологий комплексного освоения месторождений полезных ископаемых. М.: ИПКОН РАН, 2014. Г. 3. Р. 3.2. С. 125-133. 
51.Козырев А. А., Панин В. И., Савченко С. Н. и др. Методологические основы мониторинга геологической среды и управление геодинамическими рисками на рудниках Кольского полуострова // Методы и системы сейсмодеформационного мониторинга техногенных землетрясений и горных ударов. Новосибирск: СО РАН, 2009. Вып. 24, т. 1. Гл. 5. Р. 5.3. С. 234-290.

52.Козырев А. А., Панин В. И., Савченко С. Н. и др. Деструкция и процессы самоорганизации геологической среды в горнотехнических системах Хибин // Деструкция земной коры и процессы самоорганизации в областях сильного техногенного воздействия. Новосибирск: СО РАН, 2012. Т. 1. Р. 1. С. 19-117.

53. Козырев А. А., Семенова И. Э., Рыбин В. В. и др. Фенноскандия, Кольский полуостров. Управление геомеханическими процессами при разработке рудных месторождений в Евроарктическом регионе РФ // Геомеханические поля и процессы: экспериментально-аналитические исследования формирования и развития очаговых зон катастрофических событий в горнотехнических и природных системах. Новосибирск: СО РАН, 2018. Т. 1. С. 30-67.

54.Козырев А. А., Жиров Д. В., Климов С. А., Семенова И. Э., Аветисян И. М., Савченко С. H. 3D-моделирование структурных неоднородностей породных массивов центрального типа фенноскандинавского кристаллического щита // Геомеханические поля и процессы: экспериментально-аналитическое исследование формирования и развития очаговых зон катастрофических событий в горнотехнических и природных системах. Новосибирск: ИГД СО РАН, 2019. Т. 2. С. 117-145;

55.Федотова Ю. В., Журавлева О. Г., Каган М. М., Панасенко И. Г. Системы ГоИ КНЦ РАН автоматизированного анализа данных геомеханического мониторинга. Новосибирск: ИГД СО РАН, 2019. Т. 2. С. 282-291.

56. Прангишвили И. В., Пащенко Ф. Ф., Бусыгин Б. П. Системные законы и закономерности в электродинамике, природе и обществе. М.: Наука, 2001. С. 525.

57. Тахтаджян А. Л. Principia tectologica. Принципы организации и трансформации сложных систем: эволюционный подход. СПб.: СПХФА, 2001. С. 121.

58.Гамбурцев А. Г., Александров С. И., Олейник О. В. Общие и частные черты динамики современных геодинамических и других природных процессов // Геофизика XXI столетия: 2002 год. М.: Научный Мир, 2003. С. 188-194.

59.Смирнов В. Б., Пономарев А. В., Qian Jiadong, Черепанцев А. С. Ритмы и детерминированный хаос в геофизиченских временных рядах // Физика Земли. 2005. № 6. С.6-28.

60.Панжин А. А. Исследование деформирования породных массивов на больших пространственно-временных базах с использованием постоянно действующих GPS-станций // Известия высших учебных заведений. Горный журнал. 2008. № 8. С. 59-66.

61.Малинецкий Г. Г., Подлазов А. В., Кузнецов И. В. О национальной системе научного мониторинга // Новое в синергетике. Новая реальность. Новые проблемы. Новое поколение. М.: Наука, 2007. С. 40-78.

62.Кочарян Г. Г., Спивак А. А. Динамика деформирования блочных массивов. М.: ИКЦ «Академкнига», 2003. С. 423.

63.Каплунов Д. Р., Рыльникова М. В. Принципы проектирования комплексного освоения рудных месторождений комбинированной технологией // ФТПРПИ. 2008. № 6. С. 58-66. 
64.Рыльникова М. В., Корнеев С. А. Конструирование и типизация горнотехнических систем при комбинированной разработке рудных месторождений // Недропользование - XXI век. 2008. № 5. С. 75-85.

65.Урманцев Ю. А. Девять плюс один этюд о системной философии. Синтез мировоззрений. М.: Институт Холодинамики, 2001. С. 160.

66.Пуанкаре Анри. О науке. М.: Наука, 1983. С. 560.

67.Садовский М. А., Писаренко В. Ф. Случайность и неустойчивость в геофизических процессах // Изв. АН СССР. Физика Земли. 1989. С. 3-12.

68.Хакен Г. Информация и самоорганизация: макроскопический подход к сложным системам. М.: Мир, 1991. С. 240.

69.Указания по управлению обрушением покрывающих пород, охране сооружений и природных объектов от вредного влияния подземных разработок на рудниках открытого акционерного общества «Апатит» / коллектив авторов. Апатиты: КНЦ РАН, 2002. С. 52.

70.Городниченко В. И., Дмитриев А. П. Основы горного дела: учебник для вузов. М.: Горная книга, МГГУ, 2008. С. 464.

71.Садовский М. А., Писаренко В. Ф. Сейсмический процесс в блоковой среде // М.: Наука, 1991. С. 96.

72.Садовский М. А., Болховитинов Л. Г. Писаренко В. Ф. Деформирование геофизической среды и сейсмический процесс. М.: Наука, 1987. С. 100.

73.Николаев А. В. Черты геофизики XXI века // Проблемы геофизики XXI века. М.: Наука, 2003. Кн.1. С. 7-16.

74.Гольдин С. В. Физика «живой» Земли // Проблемы геофизики XXI века. М.: Наука, 2003. Кн. 1. С. 17-36.

75.Трубицин В. П., Рыков В. В. Мантийная конвекция с плавающими континентами // Проблемы глобальной геодинамики: мат-лы теоретического семинара ОГГГГН РАН, 1998-1999. М.: ГЕОС, 2000. С. 7-28.

76.Неуймин Ч. Г. Модели в науке и технике. Л.: Наука, 1984.

77.Морис Алле. Математика и экономика // Экология и жизнь. 2005. № 2 (43).

78.Мельников Н. Н., Козырев А. А., Савченко С. Н. Нелинейные эффекты в геологической среде и прогноз динамических событий при ведении горных работ // Неклассические задачи геомеханики. Якутск, 2008. С. 156-160.

79.Хакен Г. Синергетика. М.: Мир, 1980.

80. Степанов В. В. Курс дифференциальных уравнений. М.: Физматгиз, 1958. С. 468.

81.Эльсгольц Л. Э. Дифференциальные уравнения и вариационное исчисление. М.: Наука, 1969. С. 424.

82.Соболев Г. А., Пономарев А. В. Физика землетрясений и предвестники. М.: Наука, 2003. С. 270.

83.Ризниченко Ю. В. Размеры очага землетрясения и сейсмический момент // Исследования по физике землетрясений. М.: Наука, 1976. С. 9-27.

84.Улубиева Т. Р., Михайлова Р. С. Афтершоки землетрясений 2002 г.: 25,27 марта и 12 апреля южнее Таджикистана с $\mathrm{Mw}=6,1,5,6$ и 5,9. Дополнительные данные к каталогу землетрясений Северной Евразии на CD. Землетрясения Северной Евразии 2002. Обнинск, 2008. С. 45-62.

85.Кошечкин Б. И. Голоценовая тектоника восточной части Балтийского щита. Л.: Наука. Ленинградское отделение. 1979. С. 160.

86.Пожиленко В. И., Гавриленко Б. В., Жиров Д. В., Жабин С. В. Геология рудных районов Мурманской области. Апатиты: КНЦ РАН, 2002. С. 359. 
87.Балаганский В. В., Глазнев В. Н., Осипенко Л. Г. Раннепротерозойская эволюция северо-востока Балтийского щита: террейновый анализ // Геотектоника. 1998. № 2. С. 16-28.

88.Глазнев В. Н., Жирова А. М., Раевский А. Б. Новые данные о глубинном строении Хибинского и Ловозерского массивов, Кольский полуостров // Доклады Академии наук. 2008. Т. 422, № 3. С. 391-393.

89. Галахов А. В. Петрология Хибинского щелочного массива. Л.: Наука, 1975. 256 с.

90. Онохин Ф. М. Особенности структуры Хибинского массива. Л.: Наука, 1975. С. 105.

91.Савченко С. Н., Козырев А. А., Горбунов Ю. Г. Влияние кольцевых геологических структур Хибинской интрузии на напряженное состояние массивов горных пород // ФТПРПИ. 1989. № 3. С. 3-10.

92.Kozyrev A. A., Savchenko S. N. The Eurasia lithospheric plate horizontal tectonic stresses modelling // Geoecology and Computers, edited by S. A. Yufin, A. A. Balkema/ Rotterdam/Brookfield. 2000. P. 431-435.

93.Müller B., Zoback M.L., Fuchs K. et al. Regional patterns of tectonic stress in Europe // Journal of Geophysical Research. 1992. Vol. 97, no. B 8. PP. 11.783-11.803.

94.Савченко С. Н. Оценка величины горизонтальных тектонических напряжений по данным кернового бурения Кольской сверхглубокой скважины СГ-3 // ФТПРПИ. 2003. № 4. С. 19-26.

95.Савченко С. Н. Оценка напряженного состояния горных пород в районе бурения Кольской сверхглубокой скважины //ФТПРПИ. 2004. № 1. С. 27-34.

96.Справочник (кадастр) физических свойств горных пород / под ред. Н. В. Мельникова, В. В. Ржевского, М. М. Протодьяконова. М.: Недра,1975. С. 277.

97. Савченко С. Н., Ловчиков А. В., Козырев А. А. On tectonic stresses occurrent in rock masses near the day surface // Сб. докл. Междунар. конф. «Роль геомеханики в устойчивом развитии горной промышленности и гражданского строительства» (Несебыр (Болгария), 11-15 июня 2007 г.). C IV.11-IV.19.

98. Savchenko S. N., Kozyrev A. A. An investigation of the state of stress of rock composing the Fennoscandia and Kola pensula block structures using the numerical modelling data // Mining in the Arctic. Ed. John E Udd and Gertjan Bekkers, Montreal, Quebek, 2003. P. 303-312.

99. Gregorsen S. Crustal stress regime in Fennoscandia from focal mechanisms // Journal of Geophysical Research. 1992. Vol. 97, no. B8. P. 11.821-11.827.

100. Лурье А. И. Теория упругости. М.: Наука, 1970. С. 939.

101. Козырев А. А., Ловчиков А. В., Пернацкий С. И., Шершеневич В. А. Сильнейшее техногенное землетрясение на руднике «Умбозеро»: горнотехнические аспекты // Горный журнал. 2002. № 1. С. 43-49.

102. Савченко С. Н., Ловчиков А. В., Козырев А. А. Ретроспективный анализ очага техногенного землетрясения на руднике «Умбозеро» 17.08.1999 г. // Техногенная сейсмичность при горных работах: модели очагов, прогноз, профилактика. Апатиты: КНЦ РАН, 2004. Ч. 1. С. 170-179.

103. Савченко С. Н., Козырев А. А. Закономерности распределения напряжений в окрестности трещин при сдвиге // Физические основы прогнозирования разрушения горных пород. СПб.: ИФЗ РАН, 2010. С. 73-74.

104. Козырев А. А., Каспарьян Э. В., Рыбин В. В. Геомеханическое обоснование устойчивости бортов глубоких карьеров в массивах иерархично-блочной структуры // Всерос. науч.-технич. конф. с международным участием «Глубокие карьеры». Апатиты-СПб., 2012. С. 307-316. 
105. Аветисян И. М. Исследование напряженно-деформированного состояния пород в бортах глубокого карьера при действии тектонических напряжений (на примере карьера «Ковдорского ГОКа»): автореф. дис. ... канд. техн. наук. Апатиты, 2013. С. 20.

106. Козырев А. А. Геомеханика глубоких карьеров, средства и методы контроля устойчивости прибортового массива // Bсерос. науч.-технич. конф. с международным участием «Глубокие карьеры». Апатиты-СПб., 2012. С. $52-67$.

107. Беляев Н. М. Сопротивление материалов. М.-Л.: ГИТТЛ, 1949. С. 772.

108. Смирнов И. В. Трещина на границе раздела в однородном поле напряжений // Механика композитных материалов. 1985. С. 969-976.

109. Смирнов И. В. Взаимодействие системы ослабленных зон на границе раздела упругих сред в поле растягивающих напряжений // ПММ. 2011. Вып. І, т. 75. С. 140-151.

110. Фольдштейн Р. В., Перельмутер М. Н. Трещина на границе соединения материалов со связями между берегами // Изв. РАН, МТТ. 2001. № 1. С. 94-112.

111. Перельмутер М. Н. Трещина на границе раздела материалов с нелинейными связями в концевой области // ПММ. 2011. Вып. І, т. 75. С. 152-173.

112. Молчанов Е. В., Сильвестров В. В. Задача взаимодействия тонких жестких остроконечных включений, расположенных между разными упругими материалами // Изв. РАН, МТТ. 2011. № 5. С. 99-117.

113. Savchenko S. N., Kozyrev A. A. Investigations on stress state near the neighbouring fractures by boundary elements method // Computer Methods and Advences in Geomechanics, edited by G. Beer, J. R. Booker \& J. P. Carter // A. a. Balkema/Rotterdam/Brookfield. 1991. P. 1725-1730.

114. Савченко С. Н., Козырев А. А. Исследование напряженного состояния плоскости в процессе разрушения барьера между двумя параллельными разрывами // ФТПРПИ. 1991. № 4. С. 11-16.

115. Griffith A. A. The phenomenon of rupture and flow in solids // Philosophical Transactions of Royal Society. 1920. P. 221.

116. Баренблатт Г. И. Математическая теория равновесных трещин, образующихся при хрупком разрушении // Журнал прикладной механики и технической физики. 1961. № 4.

117. Панасюк В. В. Предельное равновесие хрупких тел с трещинами. Киев: Наукова думка, 1968.

118. Кит Г. С., Хай М. В. Метод потенциалов трехмерных задач термоупругости тел с трещинами. Киев: Наукова думка, 1989.

119. Савченко С. Н, Козырев А. А. Напряженное состояние пород в окрестности трещины на границе раздела геологических блоков // Proceedings of the V International Geomechanics Conference (Varna (Bulgaria), June 18-21, 2012).

120. Партон В. 3., Борисковский В. Г. Динамика хрупкого разрушения. М.: Машиностроение, 1988. С. 240.

121. Савченко С. Н. Система случайно ориентированных трещин в поле сжимающих сил // ФТПРПИ. 1993. № 1. С. 50-56.

122. Эйби Дж. А. Землетрясения / пер. с англ. Б. Г. Слепцова, Н. М. Хайме. М.: Недра, 1982. С. 264.

123. Мусхелишвили Н. И. Некоторые основные задачи математической теории упругости. М.: Наука, 1966. С. 708.

124. Стрельцов М. И. Нефтегорское землетрясение 27 (28) мая 1995 года на Сахалине. М.: Янус-К, 2005. 
125. Савченко С. Н., Козырев А. А. Разрушение барьерных зон между разрывами // Деформирование и разрушение материалов с дефектами и динамические явления в горных породах и выработках: мат-лы XIX Международной школы им. академика С. А. Христиановича, Крым, Симферополь. 2009.

126. Тарасов Л. В. Природа землетрясений и вулканизма. Долгопрудный: Интеллект, 2010.

127. Осокина Д. Н., Цветкова Н. Ю. Метод моделирования локальных полей напряжений в окрестности тектонических разрывов и в очагах землетрясений // Поля напряжений и деформаций в литосфере. М.: Наука, 1979. С. 139-226.

128. Бокун А. Н. Результаты тектонофизического моделирования зон горизонтального сдвига и использование их при поисках углеводородов // Тектонофизика и актуальные вопросы наук о Земле. М., 2008. Т. 1.

129. Ребецкий Ю. Л. Напряженное состояние слоя при продольном сдвиге // Известия АН СССР. Серия: Физика Земли. 1988. № 9.

130. Григорьев А. С., Михайлова А. В., Шахмуралова 3. Е. О кинематических характеристиках движения дневной поверхности и напряженном состоянии осадочного чехла в зонах над разломами фундамента // Известия АН СССР. Физика Земли. 1979. № 1.

131. Завьялов А. Д. Среднесрочный прогноз землетрясений: основы, методика, реализация. М.: Наука, 2006. С. 254.

132. Мячкин В. И., Костров Б. В., Соболев Г. А., Шамина О. Г. Основы физики очага и предвестники землетрясений // Физика очага землетрясения. М.: Наука, 1975. C. 6-29.

133. Stuart W. D. Diffusionless dilatancy model for earthquake precursors // Geophys. Res. Lett. 1974. Vol. 2, no. 6. P. 261-264.

134. Добровольский И. П. Теория подготовки тектонического землетрясения. М.: ИФЗ АН СССР, 1991. С. 224.

135. Bott M. N., Waghorn W. and Whittaker A. Plate boundary forces at subduction zones and trench-arc compression // Tectonophysics. 170 (1989). P. 1-15.

136. Whittaker A. A Numerical study of the dynamics of subduction. Ph. D. thesis. Univ. of Durham. Durham, 130, 1988.

137. Kusznir N. J. and Bott M. H. P. Stress concentration in the upper lithosphere caused by underlying visco-elastic creep // Tectonophysics. 1977. 43. P. 247-256.

138. Землетрясение в Японии (2011) // Википедия. URL: https://clck.ru/FsenT

139. Козырев А. А., Каспарьян Э. В., Федотова Ю. В. Мониторинг природных и техногенных процессов при ведении горных работ в высоконапряженных скальных массивах. Германия: LAP Lambert Academic Publishing, 2016. С. 152.

140. Козырев А. А., Семенова И. Э., Земцовский А. В. Геомеханическое обоснование безопасных параметров системы разработки и последовательности ведения подземных горных работ на перспективном месторождении «Олений ручей» // Горный информационно-аналитический бюллетень. 2010. № 9. С. 289-296.

141. Козырев А. А., Горбунов Ю. Г., Ширяев А. А., Панин В. И. Способ определения направлений главных тектонических напряжений в массиве горных пород. А.С. СССР № 1208238, Бюллетень изобретений, 1986. № 4. С. 56.

142. Curran J. H., and Corkum B. T. Examine 2D - A 2D boundary element program for calculating stresses around underground excavations in rock. Version 5. Rock Engineering Group, University of Toronto, Toronto, Canada. 1995. 
143. Мор О. Х. Чем обусловлен предел упругости и временное сопротивление материала // Новые идеи в технике. 1915. № 1. С. 50.

144. Hoek E., Carranza-Torres C. T., Corkum B. (2002). Hoek-Brown failure criterion - 2002 edition // Proceedings of the Fifth North American Rock Mechanics Symposium. Toronto, 2002. 1. P. 267-273.

145. Martin C. D., Kaiser P. K., McCreath D. Hoek-Brown parameters for predicting the depth of brittle failure around tunnels // Canadian Geotechnical Journal. 1999. Vol. 36. P. 136-151.

146. Адушкин В.В. Актуальные проблемы геомеханики земной коры // Вестник ОГГГГН РАН. 2001. № 1(16).

147. Николаев А. В. Проблемы искусственной разрядки тектонических напряжений и снижения сейсмической опасности // Геоэкология. Инженерная геология, гидрогеология, геокриология. 1999. № 5. С. 387.

148. Козырев С. А., Усачев Е. А. Реакция массива горных пород на мощные динамические воздействия // Вестник КНЦ РАН. 2011. № 3. С. 21-29.

149. Акопян С. Ц. Количественное описание сейсмических процессов на основе сейсмической энтропии // Физика Земли. 1988. № 1. С.11-26.

150. Томилин Н. Г., Воинов К. А. Контроль состояния породного массива на основе анализа вариации временных интервалов (ВВИ) между сейсмическими событиями // Методические основы контроля состояния породного массива и прогноза динамических явлений. Национальный геофизический комитет. M.: PAH, 1994. C. 7-24.

151. Xie H. P., Pariseau W. G. Fractal character and mechanism of rock bursts // Int. J. Rock Mech. and Min. Sci. 1993. Vol. 30, no. 4. P. 343-350.

152. Спивак А. А. Дифференциальные движения блочных структур при внешних воздействиях // Геоэкология, инженерная геология, гидргеология, геокриология. 1999. № 1. С. 62-76.

153. Шустер Г. Детерминированный хаос. Введение. М.: Мир, 1988.

154. Packard N. H., Crutchfield J. P., Farmer J. D. and Shaw R. S. Geometry from a time series // Physical Review Letters. 1980. Vol. 45, no. 9. P. 712-716.

155. Маловичко Д. А., Линч Р. Э. Микросейсмический мониторинг бортов карьеров // Горное эхо. 2006. № 2.

156. Nakamura Y. A Method for dynamic characteristic estimation of subsurface using microtremor on the ground surface // Quarterly Report of Railway Technical Research Institute. 1989. Vol. 30, no. 1. P. 25-33.

157. Аносов Г. И., Дробиз М. В., Коновалова О. А., Сотников Д. С., Чугаевич В. Я. Оценка сейсмической устойчивости учебного корпуса № 3 Российского государственного университета им. И. Канта с применением методики Накамуры // Вестник КРАУНЦ. Науки о земле. 2010. Вып 15, № 1. С. 223-231.

158. Кузьмин Ю. О., Жуков В. С. Современная геодинамика и вариации физических свойств горных пород. М.: МГГУ, 2004.

159. Хайтун С. Д. Феномен человека на фоне универсальной эволюции. М.: КомКнига, 2005.

160. Писаренко В. Ф., Родкин М. В. Распределения с тяжелыми хвостами: приложения к анализу катастроф // Вычислительная сейсмология. М.: ГЕОС, 2007. Вып. 38.

161. Haimson B. C. The hydrofracturing stress measurement method and recent field results // International Journal of Rock Mechanics and Mining Sciences \& Geomechanical Abstracts. 1978. Vol. 15, no. 4. 
162. Правила безопасности при ведении горных работ и переработке твердых полезных ископаемых. Вступили в силу 03.10.2014. М.: ООО НИИЦ «Недра ХХІ», 2015.

163. Mining-induced seismicity in underground, mechanized, hardrock mines // Results of a World Wide Survey. Australia: Australian Centre for Geomechanics, 2004.

164. Малинецкий Г. Г., Курдюмов С. П. Нелинейная динамика и проблемы прогноза // Вестник РАН. 2001. Т. 71, № 3.

165. Ойзерман Т. И. Возможно ли предвидение отдаленного будущего? // Вестник РАН. 2005. Т. 75, № 8.

166. Каспарьян Э. В. и др. Особенности геодезического мониторинга деформирования массивов пород на рудниках АО «Апатит» // Геомеханика при ведении горных работ в высоконапряженных массивах: сб. научн. тр. Апатиты: КНЦ РАН, 1998. С. 83-94.

167. Козырев А. А. и др. Применение высокоточных геодезических методов для мониторинга деформационных процессов в зонах ведения крупномасштабных работ // Геодинамика и напряженное состояние недр Земли: сб. науч. тр. Новосибирск, 1999. С. 356-362.

168. Козырев А. А. и др. Опыт применения высокоточных геодезических наблюдений для контроля деформационных процессов в массиве горных пород при крупномасштабных техногенных воздействиях // Записки горного института. Маркшейдерское дело и геодезия: сб. науч. тр. СПб.: Санкт-Петербургский горный институт (Технический университет), 2001. Т. 146. С. 9-18.

169. Rybin Vadim V., Panin Viktor I., Kagan Mikhail M., Konstantinov Konstantin N. Geophisical monitoring as an inhernet part of the technological process in deep open pits // Proceedings of Symposium EUROCK - 2018. Geomechanics and Geodynamics of Rock Masses - Vladimir Litvinenko (ed.). Publ. Taylor \& Fransis Group, London, 2018. P.551-556 (ISBN 978-1-138-61645-5).

170. Кашников Ю. А., Ашихмин С. Г., Букин В. Г., Гришко С. В., Гетманов И. В., Одинцов С. Л., Горбатиков А. В. Деформационные предвестники техногенных землетрясений при разработке месторождений углеводородов // ФТПРПИ. 2011. № 4. С. 40-49.

171. Каган М. М., Панасенко И. Г. Система автоматизации геофизического мониторинга // Мониторинг природных и техногенных процессов при ведении горных работ. Апатиты-СПб., 2013. С. 214-221.

172. Балаганский В. В., Горбунов И. А., Мудрук С. В. Палеопротерозойские Лапландско-Кольский и Свекофеннский орогены (Балтийский щит) // Вестник КНЦ РАН. 2016. Вып. 3 (26). С. 5-11.

173. Arzamastsev A. A., Mitrofanov F. P. Paleozoic plume-lithospheric processes in Northeastern Fennoscandia: evaluation of the composition of the parental mantle melts and magma generation conditions // Petrology. 2009. Vol. 17, no. 3. P. 300-313.

174. Когарко Л. Н., Крамм У., Блаксланд А. и др. Возраст и происхождение щелочных пород Хибинского массива (изотопия рубидия и стронция) // Докл. АН СССР. 1981. Т. 260, № 4. С. 1001-1004.

175. Kramm U., Kogarko L. N., Kononova V. A., Vartiainen H. The Kola alkaline province of the CIS and Finland: precise $\mathrm{Rb}-\mathrm{Sr}$ ages define 380-360 age range for all magmatism // Lithos. 1993. Vol. 30. P. 33-44.

176. Кухаренко А. А. Щелочной магматизм восточной части Балтийского щита // Зап. Всес. минер. об-ва. 1967. Вып. 5. Ч. 96. С. 547-567. 
177. Zhirov D. Controlling structures of the palaeozoic plume in the Kola alkaline Large igneous province // Conference Proceedings SGEM - 2016 (Albena (Bulgaria), 30 June-06 July, 2016). Book 1: Science and Technologies in Geology, Exploration and Mining. Vol. 1: Hydrogeology, Engineering Geology and Geotechnics. P. 133-140.

178. Каменев Е. А. Поиски, разведка и геолого-промышленная оценка апатитовых месторождений хибинского типа (методические основы). Л.: Недра, 1987. 188 с.

179. Zhirov D. V., Glaznev V. N., Zhirova A. M. Structure of upper crust of the Khibiny area on the basis of the geological and geophysical data and the results of $3 \mathrm{D}$ seismic and density modeling // Abstract of $30^{\text {th }}$ International Conference on "Ore Potential of Alkaline, Kimberlite and Carbonatite Magmatism" (Antalya, 29 September-02 October, 2014). 2014. P. 245-249.

180. Гиммельфарб Б. М., Вировлянский Г. М., Шугин А. А. Хибинские апатитовые месторождения. Вопросы структуры, гидрогеологии и методики разведки. М. Недра. 1965.

181. Дудкин О. Б., Козырева Л. В., Померанцева Н. Г. Минералогия апатитовых месторождений Хибинских тундр. М.-Л.: Наука, 1964.

182. Козырева Л. В. К вопросу о составе хибинских шпреуштейнов // Материалы по минералогии Кольского полуострова. Апатиты: КолФАН СССР, 1962. Вып. II.

183. Арзамасцев А. А., Глазнев В. Н., Раевский А. Б. Глубинное строение карбонатитовых комплексов Кольского региона: геолого-геофизические данные // Докл. РАН. 1996. Т. 348, № 3. С. 349-352.

184. Туголуков А. В., Кампель Ф. Б., Быховей А. Н. и др. Интенсификация использования природных и техногенных минерально-сырьевых ресурсов // Горный журнал. 2007. № 9. С. 14-19.

185. Афанасьев Б. В. Минеральные ресурсы щелочно-ультраосновных массивов Кольского полуострова. СПб.: Роза ветров, 2011. 224 с.

186. Жиров Д. В., Рыбин В. В., Климов С. А., Мелихова Г. С., Завьялов А. А. Проведение комплексного инженерно-геологического районирования для обоснования объектов и видов работ по закреплению/стабилизации уступов карьера с целью обеспечения безопасности горных работ в руднике «Железный» ОАО «Ковдорский ГОК». Ч. 1. СПб.: ЛапинЪ. Инженерная Защита 02 (02). 2014 а. С. 22-31.

187. Жиров Д. В., Рыбин В. В., Климов С. А., Мелихова Г. С., Завьялов А. А. Проведение комплексного инженерно-геологического районирования для обоснования объектов и видов работ по закреплению/стабилизации уступов карьера с целью обеспечения безопасности горных работ в руднике «Железный» ОАО «Ковдорский ГОК». Ч. 2. СПб.: ЛапинЪ. Инженерная Защита 03 (03). 2014 б. С. 16-25.

188. Гущенко О. И. Метод кинематического анализа структур разрушения при реконструкции полей тектонических напряжений // Поля напряжений в литосфере. М.: Наука, 1979. С. 7-25;

189. Гущенко О. И., Сим Л. А. Обоснование метода реконструкции напряженного состояния земной коры по ориентировкам сдвиговых тектонических смещений (по геологическим и сейсмологическим данным) // Механика литосферы. Л.-М., 1974. С. 5-8.

190. Сим Л. А. Изучение тектонических напряжений по геологическим индикаторам (методы, результаты, рекомендации) // Изв. вузов. Геология и разведка. 1991. № 10. С. 3-22. 
191. Ребецкий Ю. Л. Тектонические напряжения и прочность природных массивов. М.: ИКЦ Академкнига, 2007. С. 406.

192. Данилович В. Н. Метод поясов в исследованиях трещиноватости, связанный с разрывными смещениями. Иркутск: Иркутский политехн. ин-т, 1961. С. 47.

193. Шерман С. И. О потенциальной способности глубинных разломов к магмоконтролирующей деятельности // Вестник научной информации Забайкал. отд. Геогр. о-ва СССР. Чита: 1966. № 5. С. 16-2.

194. Жиров Д. В., Климов С. А., Рыбин В. В., Мелихова Г. С. 3D инженерно-геологическое моделирование в целях обоснования проектных решений по реконструкции карьеров // Горнодобывающая промышленность Баренцева Евро-Арктического региона - взгляд в будущее. Современная техника и технологии в горнодобывающей и обрабатывающей промышленности. Развитие промышленного сервиса на предприятиях ГПК. МГПК БЕАР - 2013 (Кировск, 21-22 ноября 2013 г.). Мурманск: Северная ТПП, 2014. С. 99-100.

195. Сим Л. А., Жиров Д. В., Маринин А. В. Реконструкция напряженно-деформированного состояния восточной части Балтийского щита // Геодинамика и тектонофизика. 2011. Т. 2, № 3. С. 219-243.

196. Копылов И. С. Теоретические и прикладные аспекты учения о геодинамических активных зонах // Современные проблемы науки и образования: электрон. жур. 2011. № 4. URL: www.science-education.ru/98-4745 (дата обращения: 29.09.2011).

197. Васильев Н. Ю., Мострюков А. О., Сунцов В. А. Условия тектонического нагружения и прогноз перспективных участков месторождения Таловейс // Геология и полезные ископаемые Карелии. Петрозаводск: КНЦ РАН, 2012. Вып. 15. С. 77-93.

198. Галаганов О. Н., Журавлев В. И., Лукк А. А. Волновые возмущения геофизических полей, наблюдаемых на Гармском полигоне // Динамические процессы в геофизической среде. М.: Наука, 1994.

199. Геодинамическое районирование недр: метод. указания. (Министерство угольной промышленности СССР; ВНИИ горной геомеханики и маркшейдерского дела, Кузбасский политехн. ин-т). Л., 1990.

200. Батугина И. М., Петухов И. М. Геодинамическое районирование при проектировании и эксплуатации рудников.М.: Недра, 1988. С. 166.

201. Батугина И. М., Петухов И. М., Батугин А. С. Горное дело и окружающая среда. Геодинамика недр. М.: Горная книга, 2012. С. 120; Геодинамическое районирование недр: метод. указания. Л.: ВНИМИ, 1990. С. 129.

202. Изучение гидрогеологических и инженерно-геологических условий месторождений твердых полезных ископаемых: метод. указания и требования. ВСЕГИНГЕО. М.: Недра, 1986. С. 172.

203. П 55-90. Методика составления геоструктурных схем (моделей) скальных массивов в основаниях гидросооружений. ВНИИГ. Пособие к СНиП 2.02.02-85 / А. М. Гуреев, О. К. Воронков. Л., 1991. С. 95.

204. Руководство по геодинамическому районированию шахтных полей (проект). СПб.: ВНИМИ, 2012. С. 114.

205. Нивин В. А. Вариации газо-геохимических полей как индикаторы геомеханического состояния пород и потенциальные предвестники горных ударов в магматических комплексах (на примере месторождений Хибинского и Ловозерского щелочных массивов) // Техногенная сейсмичность при горных работах: модели очагов, прогноз, профилактика. Апатиты: КНЦ РАН, 2004. Ч. 1. 
206. Savchenko S., Kasparyan E. The theoretical principles in geomechanical monitoring data processing for a block medium // Proceeding of the International Geomechanics Conference (Nessebar (Bulgaria), June 11-15, 2007). V-1 V-8.

207. Козырев А. А., Каган М. М., Константинов К. Н., Панасенко И. Г. Результаты мониторинга напряжений и деформаций блоковых структур массива горных пород по данным деформационных измерений на полигоне Кировского рудника АО «Апатит» // Вестник КНЦ РАН. 2013. № 1 (12). С. 11-15.

208. Каспарьян Э. В., Козырев А. А., Иофис М. А., Макаров А. Б. Геомеханика. М.: Высшая школа, 2006. С. 503.

209. Каспарьян Э. В., Кожуховский А. В., Розанов И. Ю. Опыт организации мониторинга устойчивости бортов и уступов карьера // Горный журнал. Известия вузов. 2015. № 5. С. 67-74.

210. Виноградов А. Н., Виноградов Ю. А., Кременецкая Е. О., Петров С. И. Формирование системы сейсмологического и инфразвукового мониторинга в Западной Арктике в XX веке и перспективы ее дальнейшего развития // Вестник КНЦ РАН. 2012. № 4. С. 145-163.

211. Виноградов Ю. А., Асминг В. Э, Кременецкая Е. О., Жиров Д. В. Современная сейсмичность на территории Мурманской области и ее проявление в горнопромышленных зонах // Экологическая стратегия Горного института. 2015. Кн. 2.

212. Баранов С. В., Асминг В. Э., Виноградов А. Н., Виноградов Ю. А. Результаты инструментальных сейсмологических исследований на Кольском полуострове // Землетрясения и микросейсмичность в задачах современной геодинамики Восточно-Европейской платформы / Кн. 1: Землетрясения. Петрозаводск: Карельский научный центр РАН, 2007. С. 173-182.

213. Годзиковская А. А., Асминг В. Э., Виноградов Ю. А. Ретроспективный анализ первичных материалов по сейсмичности Кольского полуострова и прилегающих территорий в ХХ веке. М.: ГС РАН, 2010. С. 132.

214. Аккуратов М. В., Асминг В. Э., Виноградов Ю. А., Корчак П. А. Объединенная система контроля состояния Хибинского горного массива на базе сетей сейсмических станций Кольского филиала ГС РАН и ОАО «Апатит» // Современные методы обработки и интерпретации сейсмологических данных. Обнинск: ГС РАН, 2011. С. 7-10.

215. Ловчиков А. В. Горнотектонические удары на Ловозерском редкометальном месторождении // Вестник МГТУ. 2008. Т. 11, № 3. С. 385-39.

216. Asming V. E., Kozyrev A. A., Korchak P. A., Lovchikov A. V. Some issue of mining-induced seismicity in Khibiny and Lovozero mountain massifs // Book of Abstracts. The $33^{\text {rd }}$ General Assembly of the European Seismological Commission (GA ESC 2012) (Moscow, August 19-24, 2012) and Young Seismologist Training Course (YSTC 2012) (Obninsk, August 25-30, 2012). M., 2012. P. 47-48.

217. Zhirova A. M., Vinogradov A. N., Zhirov D. V., Vinogradov Yu. A., Baranov S. V. Seismicity of the natural-technical systems in mining areas of the Murmansk region (NW Russia) // Proceeding of Vienna Congress on Recent Advances in Earthquake Engineering and Structural Dynamics 2013 (VEESD 2013). Vienna, Austria, 2013. No. 324. P. 1-10.

218. Журавлева О. Г. Применение кластерного анализа для прогноза проявлений техногенной сейсмичности // Сбалансированное природопользование. Охрана природы Севера, современные вызовы и решения. Апатиты, 2010. С. 90-92. 
219. Козырев А. А., Федотова Ю. В., Журавлева О. Г. Методические положения и некоторые результаты прогноза тектонических землетрясений на рудниках Кольского полуострова // Геодинамика и напряженное состояние недр Земли. Новосибирск: ИГД СО РАН, 2008. С. 502-506.

220. Козырев А. А., Журавлева О. Г., Федотова Ю. В. О кластеризации сейсмических событий при отработке удароопасных месторождений Хибинского массива // Фундаментальные и прикладные вопросы горных наук. Новосибирск: ИГД СО РАН им. Н. А. Чинакала, 2015. № 2. С. 108-113.

221. Рубцов Г. И. Структурные неоднородности рудного массива, прогноз и предотвращение горных ударов // Безопасность труда в промышленности. 1979. № 7. C. 22-24.

222. Прогноз и предотвращение горных ударов на рудниках. М.: ЛГИ, 1997. С. 376.

223. Ермаков Н. И. Геомеханика и конкурентноспособность горных предприятий Урала. Екатеринбург: УрО РАН, 2004. С. 2-22.

224. Жирова А. М., Жиров Д. В. Анализ непрерывных рядов сейсмичности в массиве пород рудника «Расвумчорр» (Хибины): первые результаты // Геология и стратегические полезные ископаемые Кольского региона. Апатиты: КНЦ РАН, 2014. С. 132-136.

225. Жукова С. А., Федотова Ю. В. Использование данных метео- и гидромониторинга для выявления периодов активизации сейсмической активности на рудниках ОАО «Апатит» // Мониторинг природных и техногенных процессов при ведении горных работ. Апатиты-СПб., 2013. С. 273-280.

226. Коротина М. А., Федотова Ю. В. Оценка влияния горно-геологических факторов на проявления техногенной сейсмичности ОКР ОАО «Апатит» // Сб. науч. тр. КФ ПетрГУ. Апатиты: КФ ПетрГУ, 2013. Вып. 6. С. 63-66.

227. Федотова Ю. В., Журавлева О. Г. Выявление зон повышенной сейсмоактивности массива горных пород и их взаимосвязи с горно-геологическими условиями // Проблемы и тенденции рационального и безопасного освоения георесурсов. Апатиты-СПб., 2011. С. 380-385.

228. Козырев А. А., Аккуратов М. В., Федотова Ю. В., Жукова С. А. Влияние обводненности пород на сейсмичность // Комплексные геолого-геофизические модели древних щитов. Апатиты: ГИ КНЦ РАН. 2009. С. 243-247.

229. Федотова Ю. В., Жукова С. А. Влияние природных факторов на проявления техногенной сейсмичности // Современные методы обработки и интерпретации сейсмологических данных. Обнинск: ГС РАН, 2011. С. 340-343

230. Козырев А. А., Федотова Ю. В., Аккуратов М. В., Жукова С. А. Взаимосвязь обводненности пород и сейсмичности в зоне стыковки подземного рудника и карьера // Проблемы и тенденции рационального и безопасного освоения георесурсов: сб. докл. Всерос. науч.-техн. конф. с междунар. участием, посвященной 50-летию ГИ КНЦ РАН. Апатиты-СПб., 2011. С. 385-390.

231. Федотова Ю. В. Анализ сейсмичности зоны деформации на ОАО «Ковдорский ГОК» // Открытые горные работы в XXI веке. M, 2011. T. 2. C. 361-367.

232. Козырев А. А., Панин В. И., Федотова Ю. В. Техногенная сейсмичность как отражение самоорганизации геологической среды в природно-технических системах // Геодинамика и напряженное состояние недр Земли. Новосибирск: ИГД СО РАН, 2011. Т. 1. С. 227-231. 
233. Kozyrev A. A., Panin V. I., Semenova I. E., Fedotova Yu. V., Rybin V. V. Geomechanical support of geotechnical solutions in high stress mining // Journal of Mining Science. 2012. Vol. 48, issue 2. P. 241-248.

234. Kozyrev A., Panin V., Fedotova Iu. Mining-induced seismicity in the Kola Peninsula mines // Journal of Civil Engineering and Architecture, ISSN 1934-7359, USA. July. 2013. Vol. 7, no.7. (Serial No. 68). P. 897-906.

235. Reshetnyak S. P. Melikhova G. S., Fedotova Yu. V., Melikhov M. V. Problems of deep open pits closure in the Kola Peninsula // Mine Water and Environment: conference proceedings. Ostrava, Czech Republic, 2008. P. 171-174.

236. Нивин В. А. Геоэкологические следствия и приложения водородной дегазации недр (на примере щелочных массивов Кольского полуострова) // Экологические проблемы северных регионов и пути их решения. Апатиты: КНЦ РАН, 2010. Ч. 2. С. 121-125.

237. Федотова Ю. В., Жукова С. А. Влияние массовых взрывов на динамику выделения подпочвенного водорода и появление зон сейсмической активности // Проблемы безопасности и эффективности освоения георесурсов в современных условиях. Пермь: ГИ УрО РАН, 2014. С. 86-90.

238. Fedotova Iu., Zhukova S. Interrelation of subsoil hydrogen emanation during bulk blasting and higher seismicity of the Khibiny massif // Proceedings of the $6^{\text {th }}$ International Symposium on In-situ Rock Stress, ISRM Specialized Conference (Sendai (Japan), August 20-22, 2013). 2013. P. 623-632.

239. Fedotova Iu. V., Zhukova S. A. Natural and man-made factors influence on seismicity changing of hard rock // Proceedings of the $23^{\text {rd }}$ International Mining Congress of Turkey (Antalya (Turkey), April 16-19, 2013). Ed. Ilkay Celik \& Mehtap Kilic. Publ. TMMOD Maden Muhendisleri Odasi Selanic Cad. 19/14 Kizilay-Ankara. ISBN: 978-605-01-0467-7. P. 2111-2120.

240. Методические указания по проведению анализа риска опасных производственных объектов, РД 03-418-01, утверждено Постановлением Госгортехнадзора России от 10 июля 2001 г. № 30.

241. Козырев А. А., Мальцев В. А., Федотова Ю. В., Панин В. И., Рыбин В. В., Семенова И. Э., Константинов К. Н Указания по безопасному ведению горных работ на месторождениях, склонных и опасных по горным ударам (Хибинские апатит-нефелиновые месторождения). Апатиты-Кировск, 2010. С. 117.

242. Опарин В. Н. и др. Методы и системы сейсмодеформационного мониторинга техногенных землетрясений и горных ударов; РАН, Сиб. отделение, Ин-т горного дела. Новосибирск: СО РАН, 2009. Интеграционные проекты СО РАН. Вып. 24, т. 1. С. 304.

243. Schinzinger R., Martin M. W. Introduction to engineering ethics. McGraw-Hill. 2000.

244. Terbrugge P. J., Wesseloo J., Venter J, Steffen O. K. A risk consequence approach to open pit slope design // Journal of the South African Institute of Mining and Metallurgy. 2006. Vol. 106, no. 7. C. 503-511.

245. Мадера А. Г. Риски и шансы: неопределенность, прогнозирование и оценка. М.: КРАСАНД, 2014. С. 448.

246. Tweede Kamer. National environmental policy plan, the Hague: SDU Publishers (ISSN 0921-7371), 1988-1989.

247. To choose or to loose. National environmental policy plan. The Netherlands // The Netherlands SDU Publishers, 1988. 
248. Быков А. А., Мурзин Н. В. Проблемы анализа безопасности человека, общества и природы. СПб.: Наука, 1998.

249. Кузьмин И. И., Махутов Н. А., Хетагуров С. В. Безопасность и риск: эколого-экономические аспекты. СПб., 1997.

250. Елохин А. Н. Анализ и управление риском: теория и практика. 2-е изд., исправ. и доп. М.: ПолиМедиа, 2002. С. 191.

251. Быков А. А., Порфирьев Б. Н. Об анализе риска, концепциях и классификациях рисков // Проблемы анализа риска. 2006. Т. 3, № 4. С. 319-337.

252. Козырев А. А., Панин В. И., Федотова Ю. В. Проблемы безопасности при ведении горных работ в высоконапряженных массивах скальных пород // Записки Горного института. СПб., 2012. Т. 198. С. 150-156.

253. Воробьева А. Ф., Новосельцева Т. А. Бальная оценка количественного критерия риска в процессе акустико-эмиссионного контроля технических устройств нефтегазопродуктопроводов // Безопасность труда в промышленности. 2012. № 2. С. 66-70.

254. Маркова С. С. К вопросу оценки техногенных рисков // Геомеханические и геодинамические проблемы эффективного освоения месторождений твердых полезных ископаемых северных и северо-восточных регионов России. Якутск: ФГБУН Институт мерзловедения им. П. И. Мельникова CO PAH, 2014. C. 180-182.

255. Чефранов И. В., Любищенко Е. И. Оценка профессионального риска при буровзрывном способе проведения выработок // ГИАБ. 2015. № 3. С. 313-314.

256. ГОСТ Р 12.0.010-2009. Национальный стандарт РФ. Системы управления охраны труда. Определение опасностей и оценка рисков. Дата введения: 2011-01-01.

257. Eriksen H-J. Fires and explosions - causes, effects and prevention // Health and Safety in Norwegian Tunnelling Society. 2004. No. 13. P. 19-21.

258. Демидов, Ю. В., Козырев А. А., Мальцев В. А., Енютин А. Н. Семенова И. Э. Отработка горизонта с применением протяженных разгрузочных зон в удароопасном массиве // Геодинамика и напряженное состояние недр Земли: сб. науч. тр. междунар. конф. РАН, Сиб. отд., Ин-т горного дела. Новосибирск, 2004. С. 413-418.

259. Семенова И. Э., Земцовский А. В., Павлов Д. А. Комплексное геомеханическое исследование массива горных пород удароопасного месторождения «Олений ручей» при ведении подземных горных работ // Горный информационно-аналитический бюллетень. 2014. № 4. С. 78-89.

260. Федеральные нормы и правила в области промышленной безопасности «Положение по безопасному ведению горных работ на месторождениях, склонных и опасных по горным ударам». Приказ Ростехнадзора от 2 дек. 2013 г. № 576.

261. Методические указания по установлению размеров камер и целиков при камерных системах разработки руд цветных металлов. Л.: ВНИМИ, 1972. С. 82.

262. Методика прогноза обрушений по результатам численного моделирования деформированного состояния подработанных пород. М.: МГГУ, 2006. С. 14.

263. Козырев А. А., Демидов Ю. В., Мальцев В. А., Енютин А. Н., Аминов В. Н., Семенова И. Э., Доставалов Р. Н. Указания по управлению обрушением покрывающих пород, охране сооружений и природных объектов от вредного влияния подземных разработок на рудниках открытого акционерного общества «Апатит»; КНЦ Горный ин-т, ОАО «Апатит». Апатиты, 2002. С. 51. 
264. Рыбин В. В., Константинов К. Н., Потапов Д. А. Оценка рейтинга массивов горных пород по классификации проф. Д. Лобшира для месторождений Кольского полуострова, отрабатываемых открытым способом // Глубокие карьеры: сб. науч. тр. РАН, КНЦ, Горн. ин-т. СПб.: Реноме, 2012. С. 459-465.

265. Козырев А. А., Семенова И. Э., Аветисян И. М. Исследование изменений характера обрушений подработанной толщи с увеличением глубины горных работ на Кукисвумчоррском месторождении ОАО «Апатит» // ГИАБ. 2011. № 5. С. 11-20.

266. Козырев А. А., Панин В. И., Семенова И. Э. Опыт применения экспертных систем оценки напряженно-деформированного состояния массива горных пород для выбора безопасных способов отработки рудных месторождений // Записки Горного института 2012. Т. 198. С. 16-23.

267. Козырев А. А., Семенова И. Э., Шестов А. А. Методика экспертной оценки геомеханического состояния удароопасных участков рудных месторождений // Инновационные технологии и современные методы инженерного обеспечения горно-обогатительного производства. Апатиты, 2010. С.17-20.

268. Козырев А. А., Лукичев С. В., Наговицын О. В., Семенова И. Э. Геомеханическое и горнотехнологическое моделирование как средство повышения безопасности отработки месторождений твердых полезных ископаемых // Горный информационно-аналитический бюллетень (науч.-техн. жур.). 2015. № 4. С. 73-83.

269. Jacubec J., Laubscher D. H. The MRMR rock mass rating classification system in mining practice. Brisbane, 2000.

270. Булычев Н. С. Механика подземных сооружений: учебник для вузов. М., Недра, 1982. С. 270.

271. Козырев А. А., Смирнов Ю. Г., Орлов А. О., Семенова И. Э. и др. Инструкция по креплению горных выработок на месторождении апатитнефелиновых руд «Олений ручей». Апатиты-Кировск, 2013. С. 60.

272. Haines A., Terbrugge P. J. (1991). Preliminary estimation of rock slope stability using rock mass classification systems // Proc. $7^{\text {th }}$ Cong. on Rock Mechanics. ISRM. Aachen, Germany. 2 ed. Wittke W. publ. Balkema, Rotterdam. P. 887-892.

273. Рыбин В. В., Калюжный А. С., Потапов Д. А. Геомеханическое обоснование параметров борта карьера на месторождении «Олений ручей» и мониторинг его устойчивости // Мониторинг природных и техногенных процессов при ведении горных работ. Апатиты; СПб., 2013. С. 180-187.

274. Козырев А. А., Решетняк С. П., Каспарьян Э. В., Рыбин В. В., Свердленко Н. А. Обеспечение устойчивости бортов карьеров в предельном положении // Безопасность труда в промышленности. 2003. № 10. С. 41-44.

275. Козырев А. А., Рыбин В. В. Геомеханическое обоснование рациональных конструкций бортов карьеров в тектонически напряженных массивах // Фундаментальные и прикладные вопросы горных наук. 2015, № 2. Новосибирск: ИГД им. Н. А. Чинакала СО РАН, 2015. С. 245-250.

276. Рыбин В. В. Методика расчета и результаты оценки устойчивости борта карьера Ковдорского ГОКа по секторам с учетом инженерно-геологических особенностей строения массива горных пород // Экологическая стратегия развития горнодобывающей отрасли - формирование нового мировоззрения в освоении природных ресурсов: сб. докл. Всеросс. науч.-техн. конф. с участием иностранных специалистов (13-15 окт. 2014 г.); в 2 т. / РАН, Горный ин-т КНЦ РАН. Апатиты; СПб.: Реноме, 2014. Т. 1. С. 104-112. 
277. Методические указания по определению углов наклона бортов, откосов уступов и отвалов, строящихся и эксплуатируемых карьеров / ВНИМИ; Сост.: Г. Л. Фисенко, В. Т. Сапожников, А. М. Мочалов, В. И. Пушкарев, Ю. С. Козлов. Л.: ВНИМИ, 1972. С. 165.

278. Козырев А. А., Рыбин В. В., Каспарьян Э. В., Мелик-Гайказов И. В. Общие принципы обоснования параметров бортов карьеров в массивах скальных напряженных пород // Экологическая стратегия развития горнодобывающей отрасли - формирование нового мировоззрения в освоении природных ресурсов: сб. докл. Всеросс. науч.-техн. конф. с участием иностранных специалистов (13-15 окт. 2014 г.); в 2 т. / РАН, Горный ин-т КНЦ РАН. Апатиты; СПб.: Реноме, 2014. Т. 1. С. 146-152.

279. Турчанинов И. А., Медведев Р. В., Панин В. И. Современные методы комплексного определения физических свойств горных пород. Л.: Недра, 1967. C. 200.

280. Рыбин В. В., Константинов К. Н., Данилов И. В., Данилкин А. А. Геомеханическое состояние массивов горных пород в бортах карьеров по данным инструментальных определений // Глубокие карьеры. Апатиты-СПб., 2012. С. 282-287.

281. Методические рекомендации по изучению напряженно-деформированного состояния горных пород на различных стадиях геологического процесса: метод. рекомендации / ВНИИГеоинформсистем; научн. ред. Е. И. Шемякин; сост. от КФАН СССР: Н. И. Белов, Ю. Г. Горбунов, В. И. Иванов, А. А. Козырев и др. М., 1987. С. 116.

282. Фокин В. А., Тарасов Г. Е., Тогунов М. Б., Данилкин А. А., Шитов Ю. А. Совершенствование технологии буровзрывных работ на предельном контуре карьеров. Апатиты: КНЦ РАН, 2008. С. 224. 


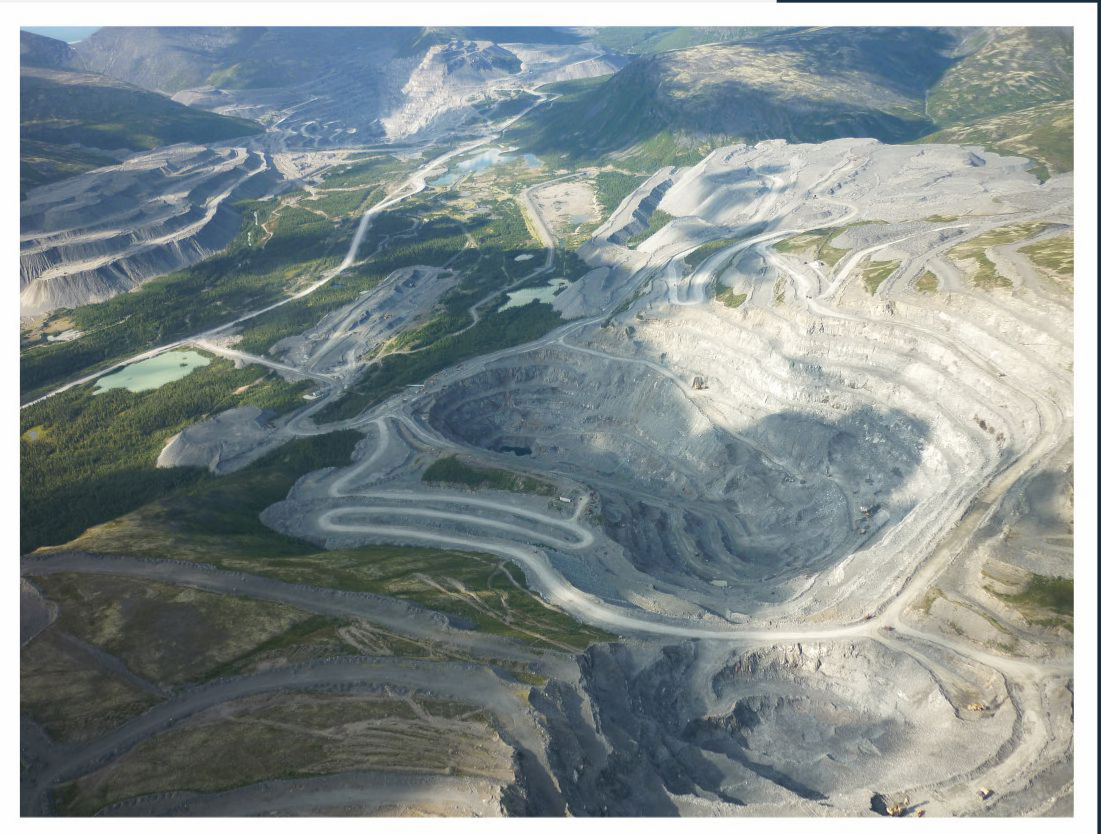

ISBN 978-5-91137-391-7
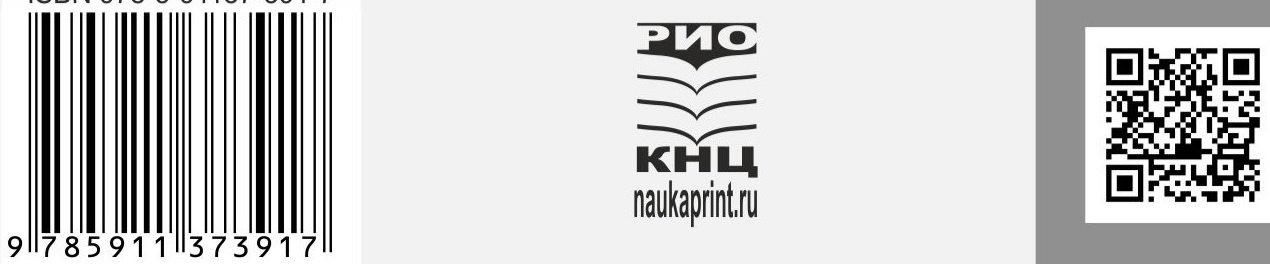